\title{
EXPERIMENT DATA REPORT FOR SEMISCALE MOD-1 TESTS S-05-6 AND S-05-7 (ALTERNATE ECC INJECTION TESTS)
}

EDGAR M. FELDMAN KENNETH E. SACKETT

\section{June 1977}

\section{EG\&G Idaho, Inc.}




\section{DISCLAIMER}

This report was prepared as an account of work sponsored by an agency of the United States Government. Neither the United States Government nor any agency Thereof, nor any of their employees, makes any warranty, express or implied, or assumes any legal liability or responsibility for the accuracy, completeness, or usefulness of any information, apparatus, product, or process disclosed, or represents that its use would not infringe privately owned rights. Reference herein to any specific commercial product, process, or service by trade name, trademark, manufacturer, or otherwise does not necessarily constitute or imply its endorsement, recommendation, or favoring by the United States Government or any agency thereof. The views and opinions of authors expressed herein do not necessarily state or reflect those of the United States Government or any agency thereof. 


\section{DISCLAIMER}

Portions of this document may be illegible in electronic image products. Images are produced from the best available original document. 
Printed in the United States of America Available from

National Technical Information Service

U.S. Department of Commerce 5285 Port Royal Road

Springfield, Virginia 22161

Price: Printed Copy $\$ 10.50$; Microfiche $\$ 3.00$

"The NRC will make available data tapes and operational computer codes on research programs dealing with postulated loss-ot-coolant accidents lin liylıl water reactors. Persons requesting this information must reimburse the NRC contractors for their expenses in preparing copies of the data tapes and the operational computer codes. Requests should be submitted to the Research Applications Branch, Office of Nuclear Regulatory Research, Nuclear Regulatory Commission, Washington, D.C. 20555."

\section{NOTICE}

This report was prepared as an account of work sponsored by the United States Government. Neither the United States nor the Energy Research and Development Administration, nor the Nuclear Regulatory Commission, nor any of their employees, nor any of their contractors, subcontractors, or their employees, makes any warranty, express or implied, or assumes any legal liability or responsibility for the accuracy, completeness or usefulness of any information, apparatus, product or process disclosed, or represents that its use would not infringe privately owned rights. 
Approved:
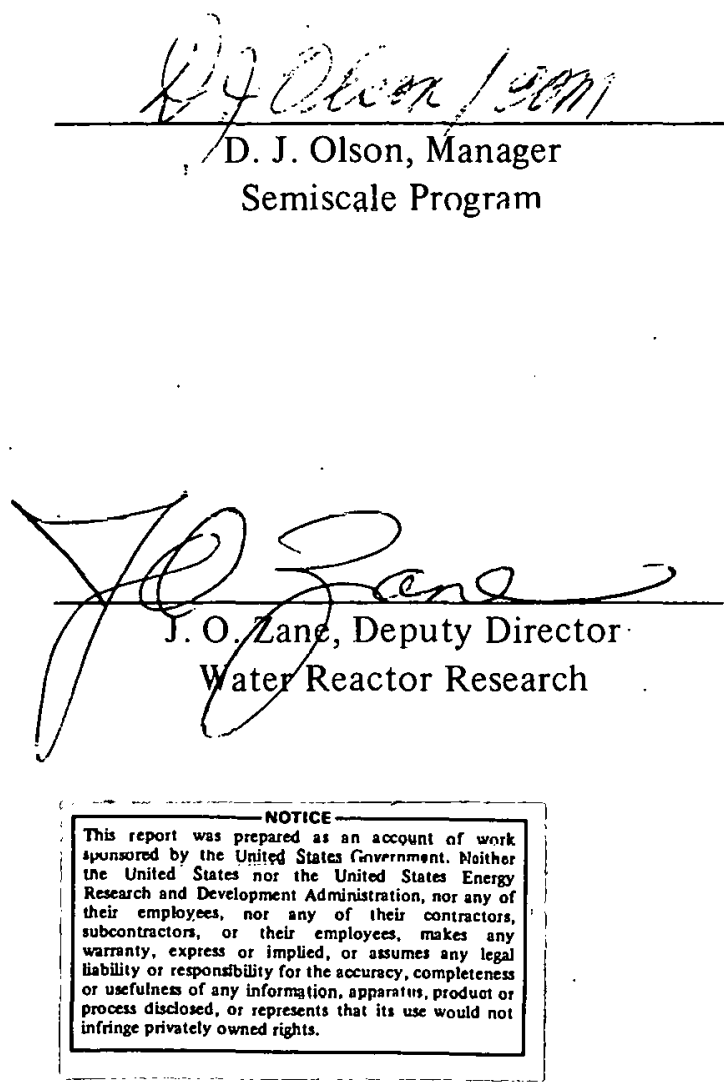


\section{EXPERIMFNT DATA REPORT FOR SEMISC.ALE MOD-1 \\ TESTS S-05-6 AND S-05-7 \\ (ALTERNATE ECC INJECTION TESTS)}

\section{By}

Edgar M. Feldman

Kenneth E. Sackett

EG\&G IDAHO, INC.

June 1977

PREPARED FOR THE

U.S. NUCLEAR REGULATORY COMMISSION

AND

ENERGY RESEARCH AND DEVELOPMENT ADMINISTRATION

IDAHO OPERATIONS OFFICE

UNDER CONTRACT NO. EY-76-C-07-1570 


\begin{abstract}
Recorded test data are presented for Tests S-05-6 and S- $05-7$ of the Semiscale Mod-1 alternate ECC injection test series. These tests are among several Semiscale Mod-1 experiments conducted to investigate the thermal and hydraulic phenomena accompanying a hypothesized loss-of-coolant accident in a pressurized water reactor (PWR) system.

I'ests S-US-6 and S-U5-7 were conducted trom initial conditions of 2263 psia and $550^{\circ} \mathrm{F}$ and $2253 \mathrm{psia}$ and $551^{\circ} \mathrm{F}$, respectively, to investigate the response of the Semiscale Mod-1 system to a depressurization and reflood transient following a simulated doubleended offset shear of the cold leg broken loop piping. 'The specific objective for these tests was to investigate the effectiveness of low pressure injection system (LPIS) coolant injection into the upper plenum when combined with cold leg intact loop injection. The Semiscale Mod-1 system was modified to represent more closely a two-loop PWR. However, Tests S-05-6 and S-05-7 were not expected to be a demonstration of a two-loop PWR system because of scaling distortions in the Semiscale Mod-1 system relative to a two-loop PWR. Test S-05-6 served as a baseline test for Test S-05-7. Both tests were conducted from similar initial conditions and system configuration with the primary exception that ECC was injected into the upper plenum by the LPIS for Test S-05-7 rather than into the intact and broken loop cold legs as was done for Test S-05-6:
\end{abstract}

The purpose of this report is to make available the uninterpreted data from Tests S-05-6 and S-05-7 for future data analysis and test results reporting activities. The data, presented in the form of graphs in engineering units, have been analyzed only to the extent necessary to ensure that they are reasonable and consistent. 


\section{SUMMARY}

Tests S-05-6 and S-05-7 were performed as part of the Semiscale Mod-1 portion of the Semiscale Program conducted by EG\&G Idaho, Inc. for the United States Government. These tests were part of the alternate ECC injection test series (Test Series 5), performed to investigate the response of the Semiscale Mod-1 system to specific variations in coolant injection location. The test objective specific to Tests S-05-6 and S-05-7 was to provide data which can be used to assess the influence on core and system response of injecting fluid directly into the upper plenum using the low pressure injection system (LPIS). Test S-05-6 was run with emergency core coolant (ECC) injected by the LPIS into the intact loop and broken loop cold legs to provide baseline data for Test S-05-7. Test S-05-7 differed from Test S-05-6 in that the ECC injection by the LPIS was only into the vessel upper plenum. Hardware configuration and test parameters were selected to simulate more closely the response of a two-loop pressurized water reactor (PWR) to a hypothesized loss-of-coolant accident (LOCA) with subsequent refill and reflood. However, Tests S-05-6 and S-05-7 were not expected to be a demonstration of a two-loop PWR system because of scaling distortions in the Semiscale Mod-1 system relative to a two-loop PWR.

Tests S-05-6 and S-05-7 utilized the Semiscale Mod-1 system, equipped with a pressure vessel with a 40-rod electrically heated core; an intact loop with pump, steam generator, and pressurizer; a broken loop with simulated pump, simulated steam generator, and rupture assemblies; and a pressure suppression system with header, pressure suppression tank, and steam supply system. A coolant injection accumulator was provided for each Semiscale Mod-1 system loop at the cold leg injection points. LPIS pumps were provided for coolant injection into the intact and broken loop cold legs for Test S-05-6 and for coolant injection into the vessel upper plenum for Test S-05-7. The ECC flow rates and total ECC accumulator nitrogen flow were volumetrically scaled to represent more closely a two-loop PWR. In addition, for Tests S-05-6 and S-05-7, four heater rods were intentionally unpowered to simulate the effects of control rod guide tubes, and the power in three heater rods was increased to produce a slightly peaked profile.

Tests S-05-6 and S-05-7 were conducted from initial conditions of 2263 psia and $550^{\circ} \mathrm{F}$ and $2253 \mathrm{psia}$ and $551^{\circ} \mathrm{F}$ (temperatures taken at the intact loop cold leg vessel inlet), respectively, by a simulated full-size (200\%), double-ended offset shear of the cold leg broken loop piping. The initial core power level was 1.45 MW for Tests S-05-6 and S-05-7 and the initial core inlet flow rate was $175 \mathrm{gpm}$ for both tests. The instantaneous offset shear of the broken loop cold leg piping was simulated by simultaneous (within $10 \mathrm{msec}$ ) actuation of the rupture assemblies. After initiation of blowdown, power to the heated core was reduced to simulate the predicted heat flux response of nuclear fuel rods during a LOCA. Blowdown was accompanied by simulated emergency core coolant injection in to the intact and broken loop cold legs. ECC was injected by the LPIS into the vessel upper plenum for Test S-05-7 rather than into the intact and broken loop cold legs as done for Test S-05-6. 
Tests S-05-6 and S-05-7 were generally conducted as specified. Conditions which did not conform to the specified test configuration were considered acceptable for analysis purposes within the test objectives. The instrumentation used generally functioned as intended. Of 215 measurements taken during Test S-05-6, 212 produced usable data. All 218 measurements taken during Test S-05-7 produced usable data. 


\section{CONTENTS}

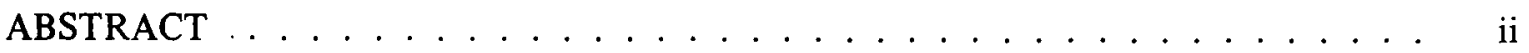

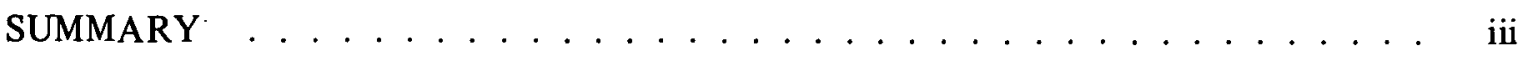

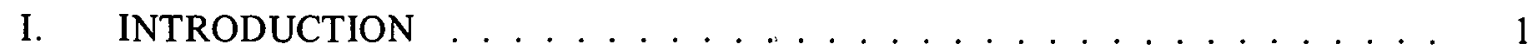

II. SYSTEM, PROCEDURES, CONDITIONS, AND EVENTS FOR

TESTS S-05-6 AND S-05-7 . . . . . . . . . . . . . . . . . 2

1. SYSTEM CONFIGURATION AND TEST PROCEDURES . . . . . . . 2

2. INITIAL TEST CONDITIONS AND SEQUENCE OF EVENTS . . . . . . 4

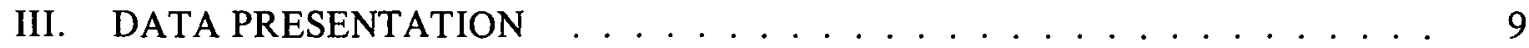

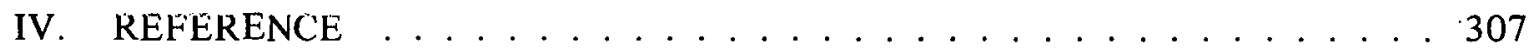

APPENDIX A - POSTTEST ADJUSTMENTS TO DATA FROM SEMISCALE MOD-1

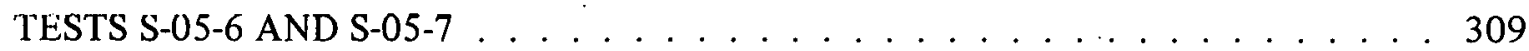

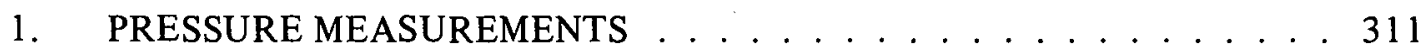

2. DIFFERENTIAL PRESSURE MEASUREMENTS . . . . . . . . 313

3. MOMENTUM FLIUX MFASUREMENTS . . . . . . . . . . 317

4. DENSITY MEASUREMENTS .................. . . 319

\section{FIGURES}

1. Semsicale Mod-1 system for cold leg break configuration schematic

2. Semiscale Mod-1 system and instrumentation for cold leg break

configuration - isometric

3. Semiscale Mod-1 system and instrumentation for cold leg break configuration - schematic

4. Semiscale Mod-1 pressure vessel - cross section showing instrumentation 
5. Semiscale Mod-1 pressure vessel - isometric showing instrumentation

6. Semiscale Mod-1 pressure vessel - penetrations and instrumentation 14

7. Semiscale Mod-1 heated core - plan view . . . . . . . . . . . . 15

8. Fluid temperatue in in tact loop hot leg (RBU-2), from -20 to $300 \mathrm{sec} \ldots \ldots \ldots \ldots \ldots$

9. Fluid temperature in intact loop hot leg (RBU-2), from -6 to 42 sec . . . . . . . . . . . . . . . . . . . .

10. Fluid temperature in intact loop cold leg (TFU-7), from -20 tó $3000 \mathrm{sec}$

11. Fluid temperature in intact loop cold leg (TFU-7), from -6 to $42 \mathrm{sec}$

12. Fluid temperature in intact loop cold leg (TFU-10), from -20

to $300 \mathrm{sec}$

13. Fluid temperature in intact loop cold leg (TFU-10), from -6 to $42 \mathrm{sec}$

14. Fluid temperature in intact loop cold leg (RBU-14A), from -20 to $300 \mathrm{sec}$

15. Fluid temperature in intact loop cold leg (RBU-14A), from -6 to $42 \mathrm{sec}$

16. Fluid temperature in intact loop cold leg (TFU-14B), from -20 to $300 \mathrm{sec}$

17. Fluid temperature in intact loop cold leg (TFU-14B), from -6 to $4 \underline{2 \mathrm{sec}}$

18. Fluid temperature in broken loop, vessel side (TFB-20), from -20 to $300 \mathrm{sec}$

19. Fluid temperature in broken loop, vessel side (TFB-20), from -6 to $42 \mathrm{sec}$

20. Fluid temperature in broken loop, vessel side (TFB-23), from -20 to $300 \mathrm{sec}$ 
21. Fluid temperature in broken loop, vessel side (TFB-23),

from -6 to $42 \mathrm{sec}$

22. Fluid temperature in broken loop, pump side (TFB-30), from -20

to $300 \mathrm{sec}$

23. Fluid temperature in broken loop, pump side (TFB-30), from -6

to $42 \mathrm{sec}$

24. Fluid temperature in broken loop, pump side (TFB-37), from -20

to $300 \mathrm{sec}$

25. Fluid temperature in broken loop, pump side (TFB-37), from -6

to $42 \mathrm{sec}$

26. Fluid temperature in broken loop, pump side (TFB-42), from -20

to $300 \mathrm{sec}$

27. Fluid temperature in broken loop, pump side (TFB-42), from -6

to $42 \mathrm{sec}$

28. Fluid temperature in inlet annulus (TFV-ANN-4A), from -20

to $300 \mathrm{sec}$

29. Fluid temperature in inlet annulus (TFV-ANN-4A), from -6

to $42 \mathrm{sec}$

30. Fluid temperature in inlet annulus (TFV-ANN-4M), from -20

to $300 \mathrm{sec}$

31. Fluid temperature in inlet annulus (TFV-ANN-4M), from -6

to $42 \mathrm{sec}$

32. Fluid temperature in downcomer annulus (TFV-ANN-35A), from -20

to $300 \mathrm{sec}$

33. Fluid temperature in downcomer annulus (TFV-ANN-35A), from -6

to $42 \mathrm{sec}$

34. Fluiv temprature in downomer annulus (TFV=ANN=70A), from -20

to $300 \mathrm{sec}$

35. Fluid temperature in downcomer annulus (TFV-ANN-70A), from -6

to $42 \mathrm{sec}$ 
36. Fluid temperature in downcomer annulus (TFV-ANN-115A), from -20 to $300 \mathrm{sec} \ldots \ldots \ldots \ldots$. . . . . . . . . . . . . . . . 4

37. Fluid temperature in downcomer annulus (TFV-ANN-1 15A), from -6 to $42 \mathrm{sec}$

38. Fluid temperature in downcomer annulus (TFV-ANN-156A), from -20 to $300 \mathrm{sec}$

39. Fluid temperature in downcomer annulus (TFV-ANN-156A), from -6 to $42 \mathrm{sec}$

40. Hluid temperature in upper plenum (TFV-UP+13), fruII -20

to $300 \mathrm{sec}$

41. Fluid temperature in upper plenum (TFV-UP+13), from - 6 to $42 \mathrm{sec}$

42. Fluid temperature in upper plenum (TFV-LP-2), from -20

to $300 \mathrm{sec}$

43. Fluid temperature in upper plenum (TFV-LP-2), from -6

to $42 \mathrm{sec}$

44. Fluid temperature in lower plenum (TFV-LP-7), from -20

to $300 \mathrm{sec}$

45. Fluid temperature in lower plenum (TFV-LP-7), frum - 6

to $42 \mathrm{sec}$

46. Fluid temperature in core insulation gap (TFV-CIG-70A),

from -20 to 30() $\mathrm{sec}$

47. Fluid temperature in core insulation gap (T.FV-CIG-70A); from -6 to $42 \mathrm{sec}$

48. Fluid temperature in vessel filler insulation gap (TFV-FIG-156A),

from -20 to $300 \mathrm{sec}$

49. Fluid temperature in vessel filler insulation gap (TFV-FIG-156A), from -6 to $42 \mathrm{sec}$

50. Fluid temperature in core, Grid Spacer 5 (TFG-5CD-45), from -20 to $300 \mathrm{sec}$ 
51. Fluid temperature in core, Grid Spacer 5 (TFG-5CD-45), from -6 to $42 \mathrm{sec}$

52. Fluid temperature in core, Grid Spacer 6 (TFG-6AB-45), from -20 to $300 \mathrm{sec}$

53. Fluid temperature in core, Grid Spacer 6 (TFG-6AB-45), from -6 to $42 \mathrm{sec}$

54. Fluid temperature in core, Grid Spacer 6 (TFG-6CD-45), from -20 to $300 \mathrm{sec}$

55. Fluid temperature in core, Grid Spacer 6 (TFG-6CD-45), from -6 to $42 \mathrm{sec}$

56. Fluid temperature in intact loop ECC injection line (TFU-ECC-14), from -20 to $300 \mathrm{sec}$

57. Fluid temperature in intact loop ECC injection line (TFU-ECC-14), from -6 to $42 \mathrm{sec}$

58. Fluid temperature in broken loop ECC injection line (TFB-ECC-42),

from -20 to $300 \mathrm{sec}$

59. Fluid temperature in broken loop ECC injection line (TFB-ECC-42), from -6 to $42 \mathrm{sec} \ldots \ldots \ldots \ldots \ldots$

60. Fluid temperature in vessel ECC injection line, Test S-05-7

(TFV-ECC+13), from -20 to 300 sec

61. Fluid temperature in vessel ECC injection line, Test S-05-7

(TFV-ECC+13), from -6 to $42 \mathrm{sec}$

62. Fluid temperature in steam generator (TFU-SGFW), from -20

to $300 \mathrm{sec}$

63. Fluid temperature in steam generator (TFU-SGFW), from -6 to $42 \mathrm{sec}$

64. Fluid tempcrature in steam generator, secondary side (TFU-SG1), from -20 to $300 \mathrm{sec}$

65. Fluid temperature in steam generator, sccondary side (TFU-SG1), from -6 to $42 \mathrm{sec}$ 
66. Fluid temperature in steam generator, secondary side, Test S-05-7 (TFU-SG2), from -20 to $300 \mathrm{sec} \ldots \ldots \ldots$. . . . . . . . . . 56

67. Fluid temperature in steam generator, secondary side, Test S-05-7 (TFU-SG2), from -6 to $42 \mathrm{sec} \ldots \ldots \ldots$. . . . . . . . . . 56

68. Fluid temperature in steam generator, secondary side (TFU-SG3), from -20 to $300 \mathrm{sec} \ldots \ldots \ldots . \ldots . \ldots 57$

69. Fluid temperature in steam generator, secondary side (TFU-SG3), from -6 to $42 \mathrm{sec} \ldots \ldots \ldots \ldots$. . . . . . . . . . . . . . 57

70. Fluid temperature in pressurizer surge line (TFU-PRIZE), from -20 to $3 n$ ser.

71. Fluid temperature in pressurizer surge line (TFU-PRIZE), from -6 to $42 \mathrm{sec}$

72. Fluid temperature in pressure suppression tank (TF-PSS-33), from -20 to $300 \mathrm{sec}$

73. Fluid temperature in pressure suppression tank.(TF-PSS-33), from -6 to $42 \mathrm{sec} \ldots \ldots \ldots \ldots \ldots \ldots \ldots \ldots$

74. Fluid temperature in pressure suppression tank (TF-PSS-130), from -20 to $300 \mathrm{sec}$.

75. Fluid temperature in pressure suppression tank (TF-PSS-130), from -6 to $42 \mathrm{sec}$

76. Material temperature in intact loop (TMU-1T.16), from -20 to $300 \mathrm{sec}$

77. Material temperature in intact loop (TMU-1T16), from -6 to $42 \mathrm{sec} . \ldots \ldots \ldots \ldots \ldots$

78. Material temperature in intact loop (TMU-15T16), from -20 to $300 \mathrm{sec}$

79. Material temperature in intact loop (TMU-1 5T16), from -6 to $42 \mathrm{sec}$

80. Material temperature in broken loop (TMB-20B16), from -20 to $300 \mathrm{sec}$ 
81. Material temperature in broken loop (TMB-20B 16), from -6 to $42 \mathrm{sec} \ldots \ldots \ldots \ldots \ldots$. . . . . . . . . . . . . . 63

82. Material temperature in vessel filler (TMV-FI-4M), from -20 to $300 \mathrm{sec}$

83. Material temperature in vessel filler (TMV-FI-4M), from -6

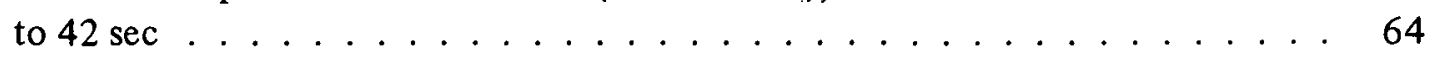

84. Material temperature in vessel filler (TMV-FI-15A), from -20

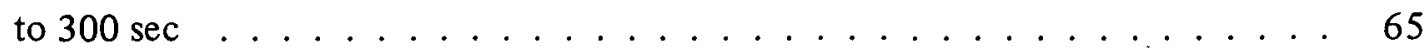

85. Material temperature in vessel filler (TMV-FI-15A), from -6 to $42 \mathrm{sec} \ldots \ldots \ldots \ldots \ldots$. . . . . . . . . . . . . . . . . . . . . .

86. Material temperature in vessel filler (TMV-FI-35A), from -20 to $300 \mathrm{sec}$

87. Material temperature in vessel filler (TMV-FI-35A), from -6 to $42 \mathrm{sec}$

88. Material temperature in vessel filler (TMV-FI-1 15A), from -20 to $300 \mathrm{sec}$

89. Material temperature in vessel filler (TMV-FI-1 15A), from -6 to $42 \mathrm{sec} \ldots \ldots \ldots \ldots \ldots$. . . . . . . . . . . . . . . . . . . .

90. Material temperature in vessel filler (TMV-FO-156A), from -20 to $300 \mathrm{sec}$

91. Material temperature in vessel filler (TMV-FO-156A), from -6 to 42 séc

92. Material temperature in vessel filler insulator (TIV-FO-35A), from -20 to $300 \mathrm{sec}$

93. Material temperature in vessel filler insulator (TIV-FO-35A), from -6 to $42 \mathrm{sec} \ldots \ldots \ldots \ldots \ldots$

94. Material temperature in vessel filler insulator (TIV-FO-35M), from -20 to $300 \mathrm{sec}$

95. Material temperature in vessel filler insulator (TIV-FO-35M), from -6 to $42 \mathrm{sec}$ 
96. Material temperature in vcssel filler insulator (TIV-FO-70A), from -20 to $300 \mathrm{sec}$

97. Material temperature in vessel filler insulator (TIV-FO-70A), from -6 to $42 \mathrm{sec}$

98. Material temperature in vessel filler insulator (TIV-FO-1 15A), from -20 to $300 \mathrm{sec}$

99. Material temperature in vessel filler insulätor (TIV-FO-115A), from -6 to $42 \mathrm{sec}$

100. Material tempcraturc in core barrel (TMV-CI-70A), from -20 to $300 \mathrm{sec}$

101. Material temperature in core barrel (TMV-CI-70A), from -6 to $42 \mathrm{sec}$

102. Material temperature in core barrel (TMV-CI-1 15A), from -20 to $300 \mathrm{scc}$

103. Material temperature in core barrel (TMV $-\mathrm{Cl}-1 \mathrm{I} 5 \mathrm{~A}$ ), from -6 to $42 \mathrm{sec}$

104. Material temperature in core barrel (TMV-CO-70A), from -20 to $300 \mathrm{sec}$

105. Material temperature in core barrel (TMV-CO-70A), from -6 to $42 \mathrm{sec}$

106. Material temperature in core barrel (TMV-CO-1 15A), from -20 to $300 \mathrm{sec}$

107. Material temperature in core barrel (TMV-CO-115A), from -6 to $42 \mathrm{sec}$ 76

108. Material tempcrature in core housing filler (TMV-HF-115W), from -20 to $300 \mathrm{sec}$

109. Material temperature in core housing filler (TMV-HF-115W), from -6 to $42 \mathrm{sec}$

110. Material temperature in core housing filler (TMV-HF-138W), from -20 to $300 \mathrm{sec}$ 
111. Material temperature in core housing filler (TMV-HF-138W), from -6 to $42 \mathrm{sec} \ldots \ldots \ldots \ldots 78$

112. Material temperature in steam generator, secondary side (TMÜ-SG1), from -20 to $300 \mathrm{sec}$

113. Material temperature in steam generator, secondary side (TMU-SG1), from -6 to $42 \mathrm{sec}$

114. Material temperature in steam generator, secondary side (TMU-SG2), from -20 to $300 \mathrm{sec}$

115. Material temperature in steam generator, secondary side (TMU-SG2), from -6 to 42 sec . . . . . . . . . . . . . . . . . . . . 80

116. Material temperature in steam generator, secondary side (TMU-SG3), from -20 to $300 \mathrm{sec}$

117. Material temperature in steam generalor, secondary side (TMU-SG3), from -6 to $42 \mathrm{sec}$

118. Core heater temperature, Rod D-4 (TH-D4-14), from -20 to $300 \mathrm{sec} \ldots . . .82$

119. Core heater temperature, Rod D-4 (TH-D4-14), from -6 to $42 \mathrm{sec} \ldots \ldots$

120. Core heater temperature, Rod D-4 (TH-D4-29), from -20 to $300 \mathrm{sec} \ldots . . .83$

121. Core heater temperature, Rod D-4 (TH-D4-29), from -6 to $42 \mathrm{sec} \ldots \ldots 3$

122. Core heater temperature, Rod D-5 (TH-D5-29), from -20 to $300 \mathrm{sec} \ldots$. . . 84

123. Core heater temperature, Rod D-5 (TH-D5-29), from -6 to $42 \mathrm{sec} \ldots \ldots 4$

124. Core heater temperature, Rod E-4 (TH-E4-09), from -20 to $300 \mathrm{sec} \ldots \ldots 5$

125. Core heater temperature, Rod E-4 (TH-E4-09), from -6 to $42 \mathrm{sec} \ldots \ldots 5$

126. Corc heater temperature, Rod E-4 (TH-E4-27), from -20 to $300 \mathrm{sec} \ldots \ldots 6$

127. Core heater temperature, Rod E-4 (TH-E4-27), from -6 to $42 \mathrm{sec} \ldots \ldots 6$

128. Core heater temperature, Rod E-4 (TH-E4-55), from -20 to $300 \mathrm{sec} \ldots \ldots 7$

129. Core heater temperature, Rod E-4 (TH-E4-55), from -6 to $42 \mathrm{sec} \ldots \ldots 7$ 
130. : Core heater temperature, Rod E-5 (TH-E5-25), from -20 to $300 \mathrm{sec} \ldots \ldots 8$

131. Core heater temperature, Rod E-5 (TH-E5-25), from -6 to $42 \mathrm{sec} \ldots \ldots 8$

132. Core heater temperature, Rod A-4 (TH-A4-09), from -20 to $300 \mathrm{sec} \ldots . . .89$

133. Core heater temperature, Rod A-4 (TH-A4-09), from -6 to $42 \mathrm{sec} \ldots . . . . \quad 89$

134. Core heater temperature, Rod A-4 (TH-A4-29), from -20 to $300 \mathrm{sec} \quad . . . .99$

135. Core heater temperature, Rod A-4 (TH-A4-29), from -6 to $42 \mathrm{sec} \ldots \ldots$. . . . 90

136. Core heater temperature, Rod A-4 (TH-A4-39), from -20 to $300 \mathrm{sec} \ldots . . .91$

137. Core heater temperature, Rod A-4 (TH-A4-39), from -6 to $42 \mathrm{sec} \ldots \ldots 1$

138. Core heater temperature, Rod A-5 (TH-A5-29), from -20 to $300 \mathrm{sec} \ldots \ldots 2$

139. Core heater temperature, Rod A-5 ('I'H-A5-29), from -6 lo $42 \mathrm{sec}$. . . . . . 92

140. Core heater temperature, Rod A-5 (TH-A5-45), from -20 to $300 \mathrm{sec} \ldots . . .93$

141. Core heater temperature, Rod A-5 (TH-A5-45), from -6 to $42 \mathrm{sec} \ldots \ldots 3$

142. Core heater temperature, Rod B-3 (TH-B3-32), from -20 to $300 \mathrm{sec} \ldots . . .94$

143 Cnre heater temperature, Rod B-3 (THH-B3-32), from -6 to $42 \mathrm{sec} \ldots \ldots$

144. Core heater temperature, Rod B-5 (TH-B5-29), from -20 to $300 \mathrm{sec} \ldots \ldots 5$

145. Core heater temperature, Rod B-5 (TH-B5-29), from -6 to $42 \mathrm{sec} \ldots \ldots$

146. Core heater temperature, Rud B-3 (TII=D5-33), from 20 to 300 sec . . . . . . 96

147. Core heater temperature, Rod B-5 (TH-B5-33), from -6 to $42 \mathrm{sec} \ldots \ldots 6$

148. Corc honter tomperature, Rod B-6 (TH-B6-29), from -20 to $300 \mathrm{sec}$. . . . . . 97

149. Core heater temperature, Rod B-6 (TH-B6-29), from -6 to $42 \mathrm{sec} \ldots \ldots 7$

15n. Core heater temperature, Rod C-2 (TH-C2-38), from -20 to $300 \mathrm{sec} \ldots \ldots 8$

151. Core heater temperature, Rod C-2 (TH-C2-38), from -6 to $42 \mathrm{sec} \ldots \ldots 8$

152. Core heater temperature, Rod C-4 (TH-C4-26), from -20 to $300 \mathrm{sec} \ldots . . . .99$ 
153. Core heater temperature, Rod C-4 (TH-C4-26), from -6 to $42 \mathrm{sec} \ldots . . . .999$

154. Core heater temperature, Rod C-4 (TH-C4-53), from -20 to $300 \mathrm{sec} \ldots \ldots 100$

155. Core heater temperature, Rod C-4 (TH-C4-53), from -6 to $42 \mathrm{sec} \ldots \ldots 0$

156. Core heater temperature, Rod C-5 (TH-C5-28), from -20 to $300 \mathrm{sec} \ldots \ldots 101$

157. Core heater temperature, Rod C-5 (TH-C5-28), from -6 to $42 \mathrm{sec} \ldots \ldots 101$

158. Core heater temperature, Rod C-7 (TH-C7-07), from -20 to $300 \mathrm{sec} \ldots \ldots 2$

159. Core heater temperature, Rod C-7 (TH-C7-07), from -6 to $42 \mathrm{sec} \ldots \ldots 2$

160. Core heater temperature, Rod C-7 (TH-C7-15), from -20 to $300 \mathrm{sec} \ldots \ldots 3$

161. Core heater temperature, Rod C-7 (TH-C7-1 5), from -6 to $42 \mathrm{sec} \ldots \ldots 103$

162. Core heater temperature, Rod D-1 (TH-D1-21), from -20 to $300 \mathrm{sec} \ldots . . .104$

163. Core heater temperature, Rod D-1 (TH-D1-21), from -6 to $42 \mathrm{sec} \ldots \ldots 4$

164. Core heater temperature, Rod D-2 (TH-D2-14), from -20 to $300 \mathrm{sec} \ldots \ldots 5$

165. Core heater temperature, Rod D-2 (TH-D2-14), from -6 to $42 \mathrm{sec} \ldots \ldots$

166. Core heatcr temperature, Rud D-2 (TH-D'2-61), from -20 to $300 \mathrm{sec} \ldots \ldots 6$

167. Core heater temperature, Rod D-2 (TH-D2-61), from -6 to $42 \mathrm{sec} \ldots \ldots 6$

168. Core heater temperature, Rod D-3 (TH-D3-29), from -20 to $300 \mathrm{sec} \ldots \ldots 7$

169. Core heater tempcrature, Rod D-3 (TH-D3-29), from -6 to $42 \mathrm{sec} \ldots \ldots . . . .107$

170. Core heater temperature, Rod D-3 (TH-D3-39), from -20 to $300 \mathrm{sec} \ldots \ldots$

171. Core heater temperature, Rod D-3 (TH-D3-39), from -6 to $42 \mathrm{sec} \ldots \ldots 108$

172. Core heater temperature, Rod D-6 (TH-D6-15), from -20 to $300 \mathrm{sec} \ldots 109$

173. Core heater temperature, Rod D-6 (TH-D6-15), from -6 to $42 \mathrm{sec} . \ldots 109$

174. Core heater temperature, Rod D-6 (TH-D6-25), from -20 to $300 \mathrm{sec} \ldots \ldots$

175. Core heater temperature, Rod D-6 (TH-D6-25), from -6 to $42 \mathrm{sec} \ldots \ldots$ 
176. Core heater temperature, Rod D-7 (TH-D7-20), from -20 to $300 \mathrm{sec} \ldots \ldots 11$

177. Core heater temperature, Rod D-7 (TH-D7-20), from -6 to $42 \mathrm{sec} \ldots \ldots$. . . . 111

178. Core heater temperature, Rod D-8 (TH-D8-27), from -20 to $300 \mathrm{sec} \ldots \ldots$

179. Core heater temperature, Rod D-8 (TH-D8-27), from -6 to $42 \mathrm{sec} \ldots \ldots 112$

180. Core heater temperature, Rod D-8 (TH-D8-57), from -20 to $300 \mathrm{sec} \ldots \ldots$

181. Core heater temperature, Rod D-8 (TH-D8-57), from -6 to $42 \mathrm{sec} \ldots \ldots 113$

182. Core heater temperature, Rod E-1 (TH-E1-33), from -20 to $300 \mathrm{sec} \ldots \ldots 114$

183. Core heater temperature, Rod E-1 (TH-E1-33), from -6 to $42 \mathrm{sec} \ldots \ldots . . .114$

184. Core heater temperature, Rod E-2 (TH-E2-20), from -20 to $300 \mathrm{sec} \ldots \ldots$. . 115

185. Corc heater temperature, Rod E-2 (TH-E2-20), from -6 to $42 \mathrm{sec} \ldots \ldots$

186. Core heater temperature, Rod E-2 (TH-E2-33), from -20 to $300 \mathrm{sec} \ldots \ldots 116$

187. Core heater temperature, Rod E-2 (TH-E2-33), from -6 to $42 \mathrm{sec} \ldots \ldots$. . . 116

188. Core heater temperature, Rod E-3 (TH-E3-05), from -20 to $300 \mathrm{sec} \ldots \ldots$. . . 117

189. Core heater temperature, Rod E-3 (TH-E3-05), from -6 to $42 \mathrm{sec} \ldots \ldots$. . . 117

190. Core heater temperature, Rod E-3 (TH-E3-20), from -20 to $300 \mathrm{sec} \ldots \ldots$

191. Core heater temperature, Rod E-3 (TH-E3-20), from -6 to $42 \mathrm{sec} \ldots \ldots 118$

192. Core heater temperature, Rod E-3 (TH-E3-24), from -20 to $300 \mathrm{sec} \ldots \ldots 119$

193. Core heater temperature, Rod E-3 (TH-E3-24), from -6 to $42 \mathrm{sec} . . . . . .119$

194. Core heater temperature, Rod E-6 (TH-E6-08), from $-20.10300 \mathrm{sec} \ldots \ldots 120$

195. Core heater temperature, Rod E-6 (TH-E6-08), from -6 to $42 \mathrm{sec} \ldots \ldots$

196. Core heater temperature, Rod E-6 (TH-E6-28), from -20 to $300 \mathrm{sec} \ldots \ldots 121$

197. Core heater temperature, Rod E-6 (TH-E6-28), from -6 to $42 \mathrm{sec} \ldots \ldots$. . . . 121

198. Core heater temperature, Rod E-6 (TH-E6-37), from -20 to $300 \mathrm{sec} \ldots \ldots . . .122$ 


\section{)}

199. Core heater temperature, Rod E-6 (TH-E6-37), from -6 to $42 \mathrm{sec} \ldots \ldots \ldots$

200. Core heater tempearture, Rod E-7 (TH-E7-44), from -20 to $300 \mathrm{sec} \ldots \ldots 123$

201. Core heater temperature, Rod E-7 (TH-E7-44), from -6 to $42 \mathrm{sec} \ldots \ldots$

202. Core heater temperature, Rod E-8 (TH-E8-14), from -20 to $300 \mathrm{sec} \ldots \ldots \ldots 124$

203. Core heater temperature, Rod E-8 (TH-E8-14), from -6 to $42 \mathrm{sec} \ldots \ldots$

204. Core heater temperature, Rod E-8 (TH-E8-29), from -20 to $300 \mathrm{sec} \ldots \ldots \ldots$

205. Core heater temperature, Rod E-8 (TH-E8-29), from -6 to $42 \mathrm{sec} \ldots \ldots \ldots$

206. Core heater temperature, Rod E-8 (TH-E8-45), from -20 to $300 \mathrm{sec} \ldots \ldots \ldots$

207. Core heater temperature, Rod E-8 (TH-E8-45), from -6 to $42 \mathrm{sec} \ldots \ldots \ldots$

208. Core heater temperature, Rod F-2 (TH-F2-07), from -20 to $300 \mathrm{sec} \ldots \ldots \ldots$

209. Core heater temperature, Rod F-2 (TH-F2-07), from -6 tn 42 sec . . . . . . 127

210. Core heater temperature, Rod F-2 (TH-F2-22), from -20 to $300 \mathrm{sec} \ldots \ldots \ldots 128$

211. Core heater temperature, Rod F-2 (TH-F2-22), from -6 to $42 \mathrm{sec} \ldots \ldots \ldots 128$

212. Core heater temperalure, Rod F-2 (TH-H2-25), from -20 to $300 \mathrm{sec} \ldots \ldots \ldots 129$

213. Core heater temperature, Rod F-2 (TH-F2-25), from -6 to $42 \mathrm{sec} \ldots \ldots$

214. Core heater temperature, Rod F-4 (TH-F4-14), from -20 to $300 \mathrm{sec} \ldots \ldots . .130$

215. Corc heater temperature, Rod F-4 (TH-F4-14), from -6 to $42 \mathrm{sec} \ldots \ldots . . .130$

216. Core heater temperature, Rod F-4 (TH-F4-29), from -20 to $300 \mathrm{sec} \ldots \ldots \ldots 131$

217. Core heater temperature, Rod F-4 (TH-F4-29), from -6 to $42 \mathrm{sec} \ldots \ldots . . .131$

218. Core heater temperature, Rod F-4 (TH-F4-44), from -20 to $300 \mathrm{sec} \ldots \ldots . .132$

219. Core heater temperature, Rod F-4 (TH-F4-44), from -6 to $42 \mathrm{sec} \ldots \ldots \ldots 132$

220. Core heater temperalure, Rod F-5 (TH-F5-20), from -20 to $300 \mathrm{sec} \ldots \ldots \ldots 133$

221. Core heater temperature, Rod F-5 (TH-F5-20), from -6 to $42 \mathrm{sec} \ldots \ldots . . .133$ 
222. Core heater temperature, Rod F-5 (TH-F5-26), from -20 to $300 \mathrm{sec} \ldots \ldots 134$

223. Core heater temperature, Rod F-5 (TH-F5-26), from -6 to $42 \mathrm{sec} \ldots \ldots 134$

224. Core heater temperature, Rod F-5 (TH-F5-33), from -20 to $300 \mathrm{sec} \ldots \ldots 135$

225. Core heater temperature, Rod F-5 (TH-F5-33), from -6 to $42 \mathrm{sec} \ldots \ldots 135$

226. Core heater temperature, Rod F-5 (TH-F5-53), from -20 to $300 \mathrm{sec} \ldots \ldots$

227. Core heater temperature, Rod F-5 (TH-F5-53), from -6 to $42 \mathrm{sec} \ldots \ldots 136$

2.28. Core heater temperature, Rod G-3 (TH-G3-13), from -20 to $300 \mathrm{sec} \ldots \ldots$

229. Core heater temperature, Rod G-3 (TH-G3-13), from-6 to $42 \mathrm{scc} \ldots \ldots . . . .137$

230. Core heater temperature, Rod G-4 (TH-G4-29), from -20 to 300 sec $\ldots \ldots$

231. Core heater temperature, Rod G-4 (TH-G4-29), from -6 to $42 \mathrm{sec} \ldots \ldots$

232. Core heater temperature, Rod G-4 (TH-G4-33), from -20 to $300 \mathrm{sec} \ldots 139$

233. Core heater temperature, Rod G-4 (TH-G4-33), from -6 to $42 \mathrm{sec} \ldots \ldots$

231. Core heater temperature, Rod G-4 (TH-G4-38), from -20 to $300 \mathrm{sec} \quad \ldots . . .140$

235. Core heater temperature, Rod G-4 (TH-G4-38), from -6 to $42 \mathrm{sec} \ldots \ldots . . .140$

236. Cure heatcr temperature, Rod r.-5 (TH-G5-14), from -20 to $300 \mathrm{scc}$. . . . . 141

237. Core heater temperature, Rod G-5 (TH-G5-14), from -6 to $42 \mathrm{sec} \ldots \ldots 141$

238. Core heater temperature, Rod G-5 (TH-G5-24), from -20 to 300 ser . . . . 142

239. Core heater temperature, Rod G-5 (TH-G5-24), from -6 to 42 sec . . . . . . . 142

240. Core heater temperature, Rod H-5 (TH-H5-32), from 20 to 300 sec . . . . 143

241. Core heater temperature, Rod H-5 (TH-H5-32), from -6 to $42 \mathrm{sec} \ldots \ldots$. . . 143

242. Pressure in intact loop, Spool 13, Test S-05-7 (PU-13),

from -20 to $300 \mathrm{sec} \ldots \ldots \ldots \ldots$. . . . . . . . . . . . . . . . . .

243. Pressure in intact loop, Spool 13, Test S-05-7 (PU-13), from -6 to $42 \mathrm{sec} \ldots \ldots \ldots \ldots . \ldots . \ldots . \ldots 144$ 
244. Pressure in intact loop, Spool 15 (PU-15L), from -20 to $300 \mathrm{sec}$

245. Pressure in intact loop, Spool 15 (PU-15L), from -6 to $42 \mathrm{sec}$

246. Pressure in broken loop, Spool 23, Test S-05-7 (PB-23), from -20 to $300 \mathrm{sec}$

247. Pressure in broken loop, Spool 23, Test S-05-7 (PB-23), from -6 to $42 \mathrm{sec}$

248. Pressure in broken loop, near break (PB-37), from -20 to $300 \mathrm{sec}$

249. Pressure in broken loop, near break (PB-37), from -6 to $42 \mathrm{sec}$

250. Pressure in broken loop, near break (PB-42), from -20 to $300 \mathrm{sec}$

251. Pressure in broken loop, near break (PB-42), from -6 to $42 \mathrm{sec}$

252. Pressure in broken loop, near break (PB-HN1), from -20 to 300 sec

253. Pressure in broken loop, near hreak (PB-HN1), from -6 to $42 \mathrm{scc}$

254. Pressure in broken loop, vessel-side nozzle (PB-CN1), from -20 to $300 \mathrm{sec}$

255. Pressure in broken loop, vessel-side nozzle (PB-CN1), from -6 to $42 \mathrm{sec}$

256. Pressure in broken loop, vessel-side nozzle (PB-CN2), from -20 to $300 \mathrm{sec}$

257. Pressure in broken loop, vessel side nozzle (PB-CN2), frum -6 tò $42 \mathrm{sec}$

258. Pressure in broken loop, vessel-side nozzle (PB-CN3), from -20 to $300 \mathrm{sec}$

259. Pressure in broken loop, vèssel-side nozzle (PB-CN3), from -6 to $42 \mathrm{sec}$

260. Pressure in broken loop, vessel-side nozzle (PB-CN4), from -20 to $300 \mathrm{se}$

261. Pressure in broken loop, vessel-side nozzle (PB-CN4), from -6 to $42 \mathrm{sec}$ 
262. Pressure in vessel (PV-UP+10), from -20 to $300 \mathrm{sec} \ldots \ldots \ldots$. . . . . . 154

263. Pressure in vessel (PV-UP+10), from -6 to $42 \mathrm{sec} \ldots \ldots . \ldots 154$

264. Pressure in vessel (PV-LP-1.66), from -20 to $300 \mathrm{sec} \ldots \ldots \ldots$

265. Pressure in vessel (PV-LP-166), from -6 to $42 \mathrm{sec} \ldots \ldots \ldots 5$

266. Pressure in intact loop accumulator (PU-ACC), from -20 to $300 \mathrm{sec} \ldots \ldots$

267. Pressure in intact loop accumulator (PU-ACC), from -6 to $42 \mathrm{sec} \ldots \ldots$

268. Pressure in broken loop accumulator (PB-ACC), from -20 to $300 \mathrm{sec} \ldots \ldots 157$

269. Pressure in broken loop accumulator (PB-ACC), from -6 to $42 \mathrm{sec} \ldots \ldots 7$

270. Pressure in steam generator, secondary side (PU-SGSD), from -20 to $300 \mathrm{sec} \ldots \ldots \ldots \ldots \ldots$

271. Pressure in steam generator, secondary side (PU-SGSD), from -6 to $42 \mathrm{sec} \ldots \ldots \ldots \ldots \ldots$

272. Pressure in pressurizer (PU-PRIZE), from -20 to $300 \mathrm{sec} \ldots \ldots . . . . .159$

273. Pressure in pressurizer (PU-PRIZE), from -6 to $42 \mathrm{sec} \ldots \ldots$. . . . . . . 159

274. Pressure in pressure suppression tank (P-PSS), from -20 to $300 \mathrm{sec} \ldots \ldots 0$

275. Pressure in pressure suppression lank (P-PSS), from -6 to 42 scc . . . . . 160

276. Differential pressure in intact loop (DPU-UP-3), from -20

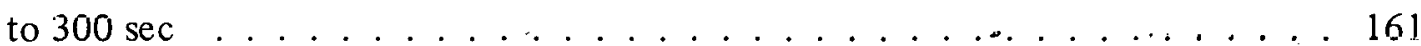

277. Differential pressure in intact loop (DPU-UP-3), from -6 to $42 \mathrm{sec} \ldots \ldots \ldots \ldots 16 \ldots \ldots$

278. Differential pressure in intact loop (DPU-3-7), from -20 to $300 \mathrm{sec}$

279. Differential pressure in in tact loop (DPU-3-7), from -6 to $42 \mathrm{sec}$

280. Differential pressure in intact loop, Test S-05-7 (DPU-6-SGIP), from -20 to $300 \mathrm{sec}$ 
281. Differential pressure in intact loop, Test S-05-7 (DPU-6-SGIP),

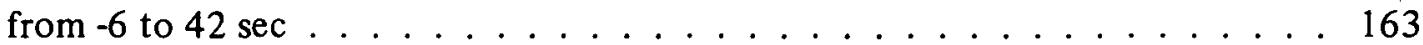

282. Differential pressure in intact loop, Test S-05-7 (DPU-SGOP-7), from -20 to $300 \mathrm{sec} \ldots \ldots \ldots \ldots \ldots$. . . . . . . . . . 164

283. Differential pressure in intact loop, Test S-05-7 (DPU-SGOP-7), from -6 to $42 \mathrm{sec} \ldots \ldots \ldots \ldots \ldots \ldots$. . . . . . . . . . . 164

284. Differential pressure in intact loop (DPU-7-10), from -20 to $300 \mathrm{sec}$

285. Differential pressure in intact loop (DPU-7-10), from -6 to $42 \mathrm{sec}$

286. Differential pressure in intact loop (DPU-12-10), from -20 to $300 \mathrm{sec}$ 166

287. Differential pressure in intact loop (DPU-12-10), from -6 to $42 \mathrm{sec}$ 166

288. Differential pressure in intact loop, low range (DPU-12-10L), from -20 to $300 \mathrm{sec}$

289. Differential pressure in intact loop, low range (DPU-12-10L), from -6 to $42 \mathrm{sec}$

290. Differential pressure in intact loop, Test S-05-6 (DPU-12-15), from -20 to $300 \mathrm{sec}$

291. Differential pressure in intact loop, Test S-05-6 (DPU-12-15), from -6 to $42 \mathrm{scc}$ 168

292. Differential pressure in intact loop, Test S-05-7 (DPU-12-15), from -20 to $300 \mathrm{sec}$ 169

293. Differential pressure in intact loop, Test S-05-7 (DPU-12-15), from -6 to $42 \mathrm{sec}$

294. Differential pressure in intact loop (DPU-15-1), from -20 to $300 \mathrm{sec}$

295. Differential pressure in intact loop (DPU-15-1), from -6 to $42 \mathrm{sec}$ 
296. Differential pressure in intact loop, low range, Test S-05-6

(DPU-15-1 L), from -20 to $300 \mathrm{sec}$

297. Differential pressure in intact loop, low range, Test S-05-6

(DPU-15-1 L), from -6 to $42 \mathrm{sec}$

298. Differential pressure in intact loop, low range, Test S-05-7

(DPU-15-1 L), from -20 to $300 \mathrm{sec}$

299. Differential pressure in intact loop; low range, Test S-05-7.

(DPU-15-1 L), from -6 to $42 \mathrm{sec}$

300. Differential pressure in intact loop, Test S-05-6 (DPU-15-IANN),

from -20 to $300 \mathrm{sec}$

301. Differential pressure in intact loop, Test S-05-6 (DPU-15-IANN),.

from -6 to $42 \mathrm{sec} \ldots \ldots \ldots \ldots \ldots \ldots$. . . . . . . . . . . . . . . . . . . . . . .

302. Differential pressure in intact loop, Test S-05-7 (DPU-15-IANN),

from -20 to $300 \mathrm{sec}$

303. Differential pressure in intact loop, Test S-05-7 (DPU-15-IANN),

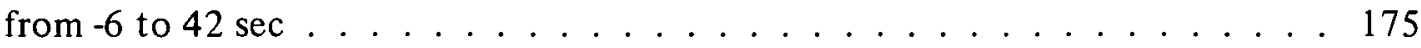

304. Differential pressure in intact loop (DPU-PRESLL), from -20

to $300 \mathrm{sec}$

305. Differential pressure in intact loop (DPU-PRESL.L.), from -6

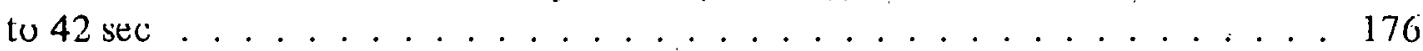

306. Differential pressure in intact loop (DPU-PR-4), from -20

to 300 scc

307. Differential pressure in intact loop (DPU-PR-4), from - 6

to $42 \mathrm{sec}$

308. Differential pressurc in brokcn loop, Test S-05-6 (DPB-UP-30),

from -20 to $300 \mathrm{sec}$

309. Differential pressure in broken loop, Test S-05-6 (DPB-UP-30),

from -6 to 42 sec

310. Differential pressure in broken loop, Test S-05-7 (DPB-UP-30), from -20 to $300 \mathrm{sec}$ 
311. Differential pressure in broken loop, Test S-05-7 (DPB-UP-30), from -6 to $42 \mathrm{sec}$

312. Differential pressure in broken loop, Test S-05-6 (DPB-21-IANN), from -20 to $300 \mathrm{sec}$

313. Differential pressure in broken loop, Test S-05-6 (DPB-21-IANN), from -6 to $42 \mathrm{sec}$

314. Differential pressure in broken loop, Test S-05-7 (DPB-21-IANN), from -20 to $300 \mathrm{sec}$

315. Differential pressure in broken loop, Test S-05-7 (DPB-21-IANN), from -6 to $42 \mathrm{sec}$

316. Differential pressure in broken loop (DPB-23-CN1), from -20 to $300 \mathrm{sec}$

317. Differential pressure in broken loop (DPB-23-CN1), from -6 to $42 \mathrm{sec}$

318. Differential pressure in broken loop (DPB-CN1-PSS-63), from -20 to $300 \mathrm{sec}$

319. Differential pressure in broken loop (DPB-CN1-PSS-63), from -6 to $42 \mathrm{sec}$

320. Differential pressure in broken loop (DPB-30-36L), from -20 to $300 \mathrm{sec}$

321. Differential pressure in broken loop (DPB-30-36L), from -6 to $42 \mathrm{sec}$

322. Differential pressure in broken loop (DPB-32U-36L), from -20 to $300 \mathrm{sec}$

323. Differential pressure in broken loop (DPB-32U-36L), from -6 to $42 \mathrm{sec}$

324. Differential pressure in broken loop (DPB-36L-37), from -20 to $300 \mathrm{sec}$ 186

325. Differential pressure in broken loop (DPB-36L-37), from -6 to $42 \mathrm{sec}$ 
326. Differential pressure in broken loop (DPB-37-38), from -20

to $300 \mathrm{sec}$

327. Differential pressure in broken loö (DPB-37-38), from -6

to $42 \mathrm{sec}$

328. Differential pressure in broken loop (DPB-38-40), from -20

to $300 \mathrm{sec}$

329. Differential pressure in broken loop (DPB-38-40), from -6 to $42 \mathrm{sec}$

330. Differential pressure in broken loop, Test S-05-6 (DPB-40-42),

from -20 to $300 \mathrm{sec}$

331. Differential pressure in broken loop, Test S-05-6 (DPB-40-42),

from -6 to $42 \mathrm{sec}$.

332. Differential pressure in broken loop, Test S-05-7 (DPB-40-42),

from -20 to $300 \mathrm{sec}$

333. Differential pressure in broken loop, Test S-05-7 (DPB-40-42),

from -6 to $42 \mathrm{sec}$

334. Differential pressure in vessel (DPV-UP-IANN), from -20

to $300 \mathrm{sec}$

335. Differential pressure in vessel (DPV-UP-IANN), from -6

to $42 \mathrm{sec}$

336. Differential pressure in vessèl, Test S-05-6 (DPV-0-9GQ),

from -20 to $300 \mathrm{sec}$

337. Differential pressure in vessel, Test S-05-6 (DPV-0-9GQ),

from -6 to $42 \mathrm{sec}$

338. Differential pressure in vessel, Test S-05-7 (DPV-0-9GQ),

from -20 to $300 \mathrm{sec}$

339. Differential pressure in vessel, Test S-05-7 (DPV-0-9GQ),

from -6 to $42 \mathrm{sec}$.

340. Differential pressure in vessel; Test S-05-6 (DPV-9-26QQ),

from -20 to $300 \mathrm{sec}$ 
341. Differential pressure in vessel, Test S-05-6 (DPV-9-26QQ), from -6 to $42 \mathrm{sec} \ldots \ldots \ldots \ldots . \ldots \ldots 6$

342. Differential pressure in vessel, Test S-05-7 (DPV-9-26QQ), from -20 to $300 \mathrm{sec} \ldots \ldots \ldots$. . . . . . . . . . . . . 197

343. Differential pressure in vessel, Test S-05-7 (DPV-9-26QQ), from -6 to $42 \mathrm{sec}$

344. Differential pressure in vessel, Test S-05-6 (DPV-9-166QQ), from -20 to $300 \mathrm{sec}$

345. Differential pressure in vessel, Test S-05-6 (DPV-9-166QQ), from -6 to $42 \mathrm{sec}$

346. Differential pressure in vessel, Test S-05-7 (DPV-9-166QQ), from -20 to $300 \mathrm{sec}$

347. Differential pressure in vessel, Test S-05-7 (DPV-9-166QQ), from -6 to $42 \mathrm{sec}$ 199

348. Differential pressure in vessel, Test S-05-6 (DPV-26-55QM), from -20 to $300 \mathrm{sec}$ 200

349. Differential pressure in vessel, Test S-05-6 (DPV-26-55QM), from -6 to $42 \mathrm{sec}$ 200

350. Differential pressure in vessel, Test S-05-7 (DPV-26-55QM), from -20 to $300 \mathrm{sec}$

351. Differential pressure in vessel, Test S-05-7 (DPV-26-5.5QM), from -6 to $42 \mathrm{sec}$ 201

352. Differential pressure in vessel, Test S-05-6 (DPV-55-110MM), from -20 to $300 \mathrm{sec}$ 202

353. Differential pressure in vessel, Test S-05-6 (DPV-55-1 10MM), from -6 to $42 \mathrm{sec}$ 202

354. Differential pressure in vessel, Test S-05-7 (DPV-55-110MM), from -20 to $300 \mathrm{sec}$ 203

355. Differential pressure in vessel, Test S-05-7 (DPV-55-110MM), from -6 to $42 \mathrm{sec}$ 
356. Differential pressure.in vessel, Test S-05-6 (DPV-1 10-156MQ), from -20 to $300 \mathrm{sec} \ldots \ldots \ldots \ldots \ldots \ldots . \ldots \ldots 20 \ldots \ldots$

357. Differential pressure in vessel, Test S-05-6 (DPV-1 10-156MQ), from -6 to $42 \mathrm{sec} \ldots \ldots \ldots \ldots \ldots \ldots . \ldots \ldots$

358. Differential pressure in vessel, Test S-05-7 (DPV-110-156MQ), from -20 to $300 \mathrm{sec}$ 205

359. Differential pressure in vessel, Test S-05-7 (DPV-1 10-156MQ), from -6 to $42 \mathrm{sec}$.

360. Differential preššüre in véšsel (DPV-166-173QQ), from -20 to $300 \mathrm{sec}$ 206

361. Differential pressure in vessel (DPV-166-173QQ), from -6 to $42 \mathrm{scc}$ 206

362. Differential pressure in vessel (DPV-166Q-UP), from -20 to $300 \mathrm{sec}$

363. Differential pressure in vessel (DPV-166Q-UP), from -6 to $42 \mathrm{sec}$

364. Differential pressure in intact loop accumulator (DPU-ACC-TB), from -20 to $300 \mathrm{sec} \ldots \ldots \ldots \ldots \ldots$

365. Differential pressure in intact loop accumulator (DPU-ACC-TB), from -6 to $42 \mathrm{sec} \ldots \ldots \ldots \ldots \ldots \ldots \ldots$

366. Differential pressure in broken loop accumulator (DPB-ACC-TB), from -20 to $300 \mathrm{sec}$ 209

$36 \%$ Difterential pressure in broken loop accumulator (DPB-ACC-TB), from -6 to $42 \mathrm{sec}$. . . . . . . . . . . . . . . . . . . . . . . . 209

368. Differential pressüure in šteàm generător secondàry (DPU-SG-SEC), from -20 to $300 \mathrm{sec}$

369. Differential pressure in steam generator secondary (DPU-SG-SEC), from -6 to 42 sec

370. Differential pressure across steam generator outlet orifice (DPU-SG-DISC), from -20 to $300 \mathrm{sec}$ 
371. Differential pressure across steam generator outlet orifice (DPU-SG-DISC), from -6 to $42 \mathrm{sec}$

372. Volumetric flow in intact loop, Test S-05-6 (FTU-1), from -20 to $300 \mathrm{sec}$

373. Volumetric flow in intact loop, Test S-05-6 (FTU-1), from -6 to $42 \mathrm{sec}$

374. Volumetric flow in intact loop, Test S-05-7 (FTU-1), from -20 to $300 \mathrm{sec}$

375. Volumetric flow in intact loop, Test S-05-7 (FTU-1), from -6 to 42 sec.

376. Volumetric flow in intact loop, Test S-05-6 (FTU-9), from -20 to $300 \mathrm{sec}$

377. Volumetric flow in intact loop, Test S-05-6 (FTU-9), from -6 to $42 \mathrm{sec}$

378. Volumetric flow in intact loop, Test S-05-7 (FTU-9), from -20 to $300 \mathrm{sec}$

379. Volumetric flow in intact loop, Test S-05-7 (FTU-9), from -6 to $42 \mathrm{sec}$

380. Volumetric flow in intact loop, Test S-05-6 (FTU-13), from -20 to $300 \mathrm{sec}$

381. Volumetric flow in intact loop, Test S-05-6 (FTU-13), from -6 to $42 \mathrm{sec}$

382. Volumetric flow in intact loop, Test S-05-7 (FTU-13), from -20 to $300 \mathrm{sec}$

383. Volumetric flow in intact loop, Test S-05-7 (FTU-13), from -6 to $42 \mathrm{sec}$

384. Volumetric flow in intact loop, Test S-05-6 (FTU-15), from -20 to $300 \mathrm{sec}$ 218

385. Volumetric flow in intact loop, Test S-05-6 (FTU-15), from -6 to $42 \mathrm{sec}$ 
386. Volumetric flow in intact loop, Test.S-05-7 (FTU-15), from -20. to $300 \mathrm{sec} \ldots \ldots \ldots \ldots \ldots \ldots . \ldots \ldots \ldots$

387. Volumetric flow in intact loop, Test S-05-7 (FTU-15), from -6 to $42 \mathrm{sec} \ldots \ldots \ldots \ldots . \ldots \ldots 219$

388. Volumetric flow in broken loop (FTB-21), from -20 to $300 \mathrm{sec} \ldots \ldots . . .220$

389. Volumetric flow in broken loop (FTB-21), from -6 to $42 \mathrm{sec} \ldots \ldots . . . .220$

390. Volumetric flow in broken loop (FTB-30), from -20 to $300 \mathrm{sec} \ldots \ldots . . . .221$

391. Volumetric flow in broken loop (FTB-30), from -6 to $42 \mathrm{sec} \ldots \ldots 22$

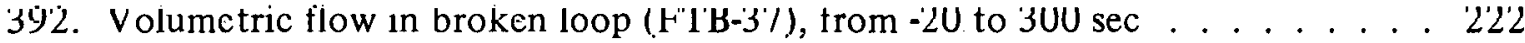

393. Volumetric flow in broken loop (FTB-37), from -6 to $42 \mathrm{sec} \ldots \ldots . . . .222$

394. Volumetric flow in core entrance (FTV-CORE-IN), from -20 to $300 \mathrm{sec} \ldots \ldots \ldots \ldots . \ldots \ldots \ldots$

395. Volumetric flow in core entrance (FTV-CORE-IN), from -6

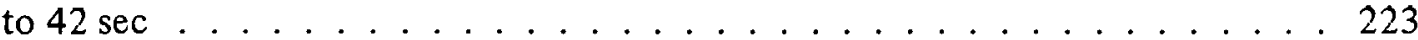

396. Volumetric flow in intact loop low pressure injection line, Test S-05-6 (FTU-LPIS), from -20 to $300 \mathrm{sec} \ldots \ldots . . . . . . . .224$

397. Volumetric flow in intact loop low pressure injection line, Test S-05-6 (FTU-LPIS), from -6 to $42 \mathrm{sec} \ldots \ldots . \ldots . . \ldots 224$

398. Volumetric flow in vessel low-pressure injection line, Test S-05-7 (FTV-LPIS), from -20 to $300 \mathrm{sec} \ldots \ldots . \ldots 225$

399. Volumetric flow in vessel low pressure injection line, Test S-05-7 (FTV-LPIS), from -6 to $42 \mathrm{sec}$

400. Volumetric flow in broken loop low pressure injection line, Test S-05-6 (FTB-LPIS), from -20 to $300 \mathrm{sec}$ 226

401. Volumetric flow in broken loop low pressure injection line, 'lest S-U5-6 (FTB-LPIS), from -6 to $42 \mathrm{sec}$ 226

402. Volumetric flow in intact loop accumulator discharge line (FTU-ACC), from -20 to $300 \mathrm{sec} \ldots \ldots \ldots \ldots . \ldots . \ldots . \ldots 227$ 
403. Volumetric flow in intact loop accumulator discharge line (FTU-ACC), from -6 to $42 \mathrm{sec} \ldots \ldots \ldots \ldots 227$

404. Volumetric flow in broken loop accumulator discharge line (FTB-ACC), from -20 to $300 \mathrm{sec} \ldots \ldots \ldots \ldots . \ldots \ldots 28$

405. Volumetric flow in broken loop accumulator discharge line (FTB-ACC), from -6 to $42 \mathrm{sec} \ldots \ldots \ldots \ldots . \ldots \ldots 28$

406. Volumetric flow from pressurizer (FTU-PRIZE), from -20 to $300 \mathrm{sec} \ldots$. . . . 229

407. Volumetric flow from pressurizer (FTU-PRIZE), from -6 to 42 séc . . . . . . 229

408. Fluid velocity in vessel, Test S-05-6 (FTV-40A), from -20 to $300 \mathrm{sec} \ldots \ldots \ldots \ldots \ldots \ldots$

409. Fluid velocity in vessel, Test S-05-6 (FTV-40A), from -6 to $42 \mathrm{sec} \ldots \ldots \ldots \ldots \ldots$. . . . . . . . . . . . . . . . . . . 30

410. Fluid velocity in vessel, Test S-05-7 (FTV-40A), from -20 to $300 \mathrm{sec}$

411. Fluid velocity in vessel, Test S-05-7 (FTV-40A), from -6 to $42 \mathrm{sec}$

412. Fluid velocity in vessel, Test S-05-6 (FTV-40M), from -20 to $300 \mathrm{sec}$

413. Fluid velocity in vessel, Test S-05-6 (FTV-40M), from -6 to $42 \mathrm{sec}$

414. Fluid velocity in vessel, Test S-05-7 (FTV-40M), from -20 to $300 \mathrm{sec}$ 233

415. Fluid velocity in vessel, Test S-05-7 (FTV-40M), from -6 to $42 \mathrm{sec}$ 233

416. Momentum flux in intact loop (FDU-1), from -20 to $300 \mathrm{sec}$ 234

417. Momentum flux in intact loop (FDU்-1), from -6 to $42 \mathrm{sec}$ 234

418. Momentum flux in intact loop (FDU-5), from -20 to $300 \mathrm{sec} \ldots . . . .235$

419. Momentum flux in intact loop (FDU-5), from -6 to 42 ses. 235

420. Momentum flux in intact loop (FDU-10), from -20 to $300 \mathrm{sec}$ 236 
42.1. Momentum flux in intact loop (FDU-10), from -6 to $42 \mathrm{sec} \ldots \ldots . . . . .236$

422. Momentum flux in intact loop, Test S-05-6 (FDU-13), from -20 to $300 \mathrm{sec} \ldots \ldots \ldots \ldots . \ldots \ldots \ldots$

423. Momentum flux in intact loop, Test S-05-6 (FDU-13), from -6 to $42 \mathrm{sec} \ldots \ldots \ldots \ldots \ldots \ldots \ldots$

424. Momentum flux in intact loop, Test S-05-7 (FDU-13), from -20 to $300 \mathrm{sec} \ldots \ldots \ldots \ldots . \ldots \ldots$. . . . . . . . . . . . . . . . . . . . . . . .

425. Momentum flux in intact loop, Test S-05-7 (FDU-13), from -6

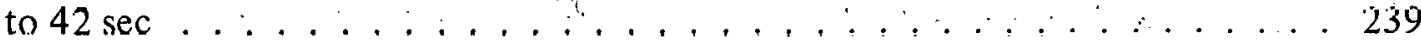

426. Momentum flux in intact loop, Test S-05-6 (FDU-15), from -20

to $300 \mathrm{sec}$

427. Momentum flux in intact loop, Test S-05-6 (FDU-15), from -6 to $42 \mathrm{sec} \ldots \ldots \ldots \ldots \ldots \ldots$. . . . . . . . . . . . . . . . . . . . . . . . .

428. Momentum flux in intact loop, Test S-05-7 (FDU-15), from -20

429. Momentum flux in intact loop, Test S-05-7 (FDU-15), from -6 to $42 \mathrm{sec}$

430. Momentum flux in broken loop (FDB-21); from -20 to $300 \mathrm{sec}$. . . . . . . 242

431. Momentum flux in broken loop (FDB-21), from -6 to $42 \mathrm{sec} \ldots \ldots 242$

432. Momentum flux in broken loop (FDB-23), from -20 to $300 \mathrm{sec} \ldots \ldots 243$

433. Momentum flux in broken loop (FDB-23), from -6 to 42 sec $\ldots \ldots \ldots . . .243$

434. Momentum flux in broken loop (FDB-30), from -20 to $300 \mathrm{sec} \ldots \ldots 244$

435. Momentum flux in broken loop (FDB-30), from -6 to $42 \mathrm{sec} \ldots \ldots . . . . .244$

436. Momentum flux in broken loop (FDB-37), from -20 to $300 \mathrm{sec}$. . . . . . 245

437. Momentum flux in broken loop (FDB-37), from -6 to $42 \mathrm{sec} \ldots \ldots . \ldots 245$

438. Momentum flux in broken loop (FDB-42), from -20 to $300 \mathrm{sec} \ldots \ldots 246$

439. Momentum flux in broken loop (FDB-42), from -6 to $42 \mathrm{sec} \ldots \ldots . . . . .246$ 
440. Momentum flux in core entrance (FDV-CORE-IN), from -20 to $300 \mathrm{sec}$

441. Momentum flux in core entrance (FDV-CORE-IN), from -6 to $42 \mathrm{sec} \ldots \ldots 24$

442. Density in intact loop (GU-1 VR), from -20 to $300 \mathrm{sec} \ldots \ldots 248$

443. Density in intact loop (GU-1VR), from -6 to $42 \mathrm{sec} \ldots \ldots . \ldots 248$

444. Density in intact loop (GU-1 HZ), from -20 to $300 \mathrm{sec} \ldots \ldots 249$

445. Density in intact loop (GU-1 HZ), from -6 to $42 \mathrm{sec} \ldots \ldots 249$

446. Density in intact loop (GU-5VR), from -20 to $300^{t} \mathrm{sec} \ldots \ldots 250$

447. Density in intact loop (GU-5VR), from -6 to $42 \mathrm{sec} \ldots \ldots . \ldots 250$

448. Density in intact loop (GU-10VR), from -20 to $300 \mathrm{sec} \ldots \ldots . \ldots 251$

449. Density in intact loop (GU-10VR), from -6 to $42 \mathrm{sec} \ldots \ldots \ldots 251$

450. Density in intact loop, Test S-05-6 (GU-13VR), from -20

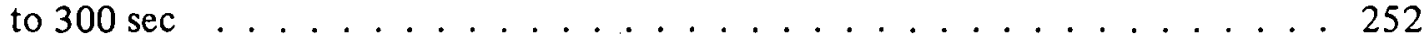

451. Density in intact loop, Test S-05-6 (GU-13VR), from -6 to $42 \mathrm{sec} \ldots \ldots \ldots \ldots 252$

452. Density in intact loop, Test S-05-7 (GU-13VR), from -20

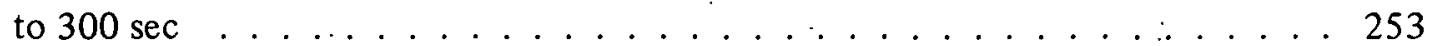

453. Density in intact loop, Test S-05-7 (GU-13VR), from -6 to $42 \mathrm{sec} \ldots \ldots \ldots \ldots \ldots \ldots$

454. Density in intact loop, Test S-05-6 (GU-15VR), from -20 to $300 \mathrm{sec}$

455. Density in intact loop, Test S-05-6 (GU-15VR), from -6 to $42 \mathrm{sec} \ldots \ldots \ldots \ldots \ldots \ldots . \ldots \ldots \ldots$

456. Density in inlacl loup, Test S-05-7 (GU-1 JVR), fiom $=20$

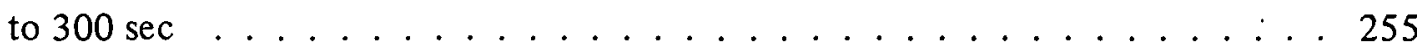

457. Density in intact loop, Test S-05-7 (GU-15VR), from -6

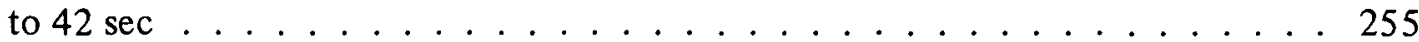


458. Density in intact loop, Test S-05-6 (GU-15HZ), from -20 to $300 \mathrm{sec} \ldots \ldots \ldots \ldots \ldots \ldots$

459. Density in intact loop, Test S-05-6 (GU-15HZ), from -6

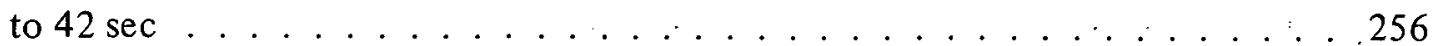

460. Density in intact loop, Test S-05-7 (GU-15HZ), from -20 to $300 \mathrm{sec}$

461. Density in intact loop, Test S-05-7 (GU-15HZ), from -6 to $42 \mathrm{scc}$

462. Density in broken loop. Test S-05-6 (GB-2iT), from -20 to $300 \mathrm{sec}$

463. Density in broken loop, Test S-05-6 (GB-21T), from -6 to $42 \mathrm{sec}$ 258

464. Density in broken loop, Test S-05-7 (GB-21T), from -20 to $300 \mathrm{sec}$ 259

465. Density in broken loop, Test S-05-7 (GB-21T), from -6 to $42 \mathrm{sec}$

466. Density in broken loop, Test S-05-6 (GB-21B), from -20 to $300 \mathrm{sec}$

467. Density in broken loop, Test S-05-6 (GB-21B), from -6 to $42 \mathrm{sec}$

468. Density in broken loop, Test S-05-7 (GB-21B), from -20 to $300 \mathrm{sec}$ 261

469. Density in broken loop, Test S-05-7 (GB-21B), from -6 to $42 \mathrm{sec}$

470. Density in broken loop, Test S-05-6 (GB-21C), from -20 to $300 \mathrm{sec}$

471. Density in broken loop, Test S-05-6 (GB-21C), from -6 to $42 \mathrm{sec}$

472. Density in broken loop, Test S-05-7 (GB-21C), from -20 to $300 \mathrm{sec}$ 
473. Density in broken loop, Test S-05-7 (GB-21C), from -6 to $42 \mathrm{sec} \ldots \ldots \ldots \ldots 263$

474. Density in broken loop, Test S-05-6 (GB-23VR), from -20 to $300 \mathrm{sec}$

475. Density in broken loop, Test S-05-6 (GB-23VR), from -6 to $42 \mathrm{sec} \ldots \ldots \ldots \ldots \ldots$. . . . . . . . . . . . . . . . . . . . . . . . .

476. Density in broken loop, Test S-05-7 (GB-23VR), from -20 to $300 \mathrm{sec}$ 265

477. Density in broken loop, Test S-05-7 (GB-23VR), from -6 265

478. Density in broken loop (GB-30T), from -20 to $300 \mathrm{sec} \ldots \ldots 6$

479. Density in broken loop (GB-30T), from -6 to $42 \mathrm{sec} \ldots \ldots \ldots 6$.

480. Density in broken loop (GB-30B), from -20 to $300 \mathrm{sec} \ldots \ldots 267$

481. Density in broken loop (GB-30B), from -6 to $42 \mathrm{sec} \ldots \ldots . \ldots 267$

482. Density in broken loop (GB-30C), from -20 to $300 \mathrm{sec} \ldots \ldots 268$

483. Density in broken loop (GB-30C), from -6 to $42 \mathrm{sec} \ldots \ldots . \ldots 268$

484. Density in broken loop (GB-42VR), from -20 to $300 \mathrm{sec} \ldots \ldots 9$

485. Density in broken loop (GB-42VR), from -6 to $42 \mathrm{sec} \ldots \ldots 269$

486. Density in vessel (GV-COR-1 50HZ), from -20 to $300 \mathrm{sec} \ldots \ldots$. . . . . . 270

487. Density in vessel (GV-COR-150HZ), from -6 to $42 \mathrm{sec} \ldots \ldots . \ldots . . . . .270$

488. Density in vessel (GVLP-165HZ), from -20 to $300 \mathrm{sec} \ldots \ldots$. . . . . . . 271

489. Density in vessel (GVLP-165HZ), from -6 to $42 \mathrm{sec} \ldots \ldots . \ldots 271$

490. Density in vessel (GVLP-172HZ), from -20 to $300 \mathrm{sec} \ldots \ldots . \ldots 272$

491. Density in vessel (GVLP-172HZ), from -6 to $42 \mathrm{sec} \ldots \ldots . \ldots 272$

492. Density in pressurizer (GU-PRIZE), from -20 to $300 \mathrm{sec} \ldots \ldots 273$ 
493. Density in pressurizer (GU-PRIZE), from -6 to $42 \mathrm{sec} \ldots \ldots . \ldots 273$

494. Mass flow in in tact loop (FDU-1, GU-1VR), from -20 to $300 \mathrm{sec} \ldots . . . . .274$

495. Mass flow in intact loop (FDU-1, GU-1VR), from -6 to $42 \mathrm{sec} \ldots \ldots 274$

496. Mass flow in in tact loop, Test S-05-6 (FTU-1, GU-1VR), from -20

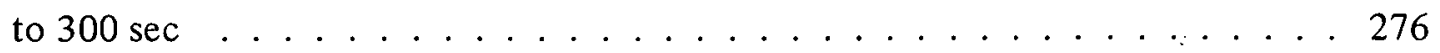

497. Mass flow in intact loop, Test S-05-6 (FTU-1, GU-1 VR), from -6 to $42 \mathrm{sec} \ldots \ldots \ldots \ldots$. . . . . . . . . . . . . . . . . . . . . . . .

498. Mass flow in intact loop, Test S-05-7 (FTU-1, GU-1VR), from -20 . to $300 \mathrm{sec}$

499. Mass flow in intact loop, Test S-05-7 (FTU-1, GU-1VR), from -6 to $42 \mathrm{sec}$

500. Mass flow in in tact loop, Test S-05-6 (FDU-5, GU-5VR), from -20 to $300 \mathrm{sec}$ 278

501. Mass flow in intact loop, Test S-05-6 (FDU-5, GU-5VR), from -6 to $42 \mathrm{sec}$ 278

502. Mass flow in intact loop, Test S-05-7 (FDU-5, GU-5VR), from -20 to $300 \mathrm{sec}$ 279

503. Mass flow in intact loop, Test S-05-7 (FDU-5, GU-5VR), from -6. to $42 \mathrm{sec}$ 279

504. Mass flow in intact loop, Test S-05-6 (FTU-9, GU-10VR), from -20 to $300 \mathrm{sec}$ 280

505. Mass flow in intact loop, Test S-05-6 (FTU-9, GU-10VR), from -6 to $42 \mathrm{sec}$ 280

506. Mass flow in intact loop, 'lest S-US-'/ (F'IU-Y, GU-1UVR), from -20 to $300 \mathrm{sec}$ 281

507. Mass flow in intact loop, Test S-05-7 (FTU-9, GU-10VR), from -6. to $42 \mathrm{sec}$ 281

508. Mass flow in intact loop (FDU-10, GU-10VR), from -20 to $300 \mathrm{sec} \ldots . . . .282$ 509. Mass flow in intact loop (FDU-10, GU-10VR), from -6 to $42 \mathrm{sec}$ 282 
510. Mass flow in intact loop, Test S-05-6 (FDU-13, GU-13VR), from -20 to $300 \mathrm{sec}$

511. Mass flow in intact loop, Test S-05-6 (FDU-13, GU-13VR), from -6 to $42 \mathrm{sec}$

512. Mass flow in intact loop, Test S-05-7 (FDU-13, GU-13VR), from -20 to $300 \mathrm{sec}$

513. Mass flow in intact loop, Test S-05-7 (FDU-13, GU-13VR), from -6 to $42 \mathrm{sec}$ 285

514. Mass flow in intact loop, Test S-05-6 (FTU-13, GU-13VR), from -20 to $300 \mathrm{sec}$. 286

515. Mass flow in intact loop, Test S-05-6 (FTU-13, GU-13VR), from -6 to $42 \mathrm{sec}$ 286

516. Mass flow in intact loop, Test S-05-7 (FTU-13, GU-13VR), from -20 to $300 \mathrm{sec}$

517. Mass flow in intact loop, Test S-05-7 (FTU-13, GU-13VR), from -6 to $42 \mathrm{sec}$

518. Mass flow in intact loop, Test S-05-6 (FDU-15, GU-15VR), from -20 to $300 \mathrm{sec}$

519. Mass flow in intact loop, Test S-05-6 (FDU-1 5, GU-15VR), from -6 to $42 \mathrm{sec}$

520. Mass flow in intact loop, Test S-05-7 (FDU-1 5, GU-1 5VR), from -20 to $300 \mathrm{sec}$

521. Mass flow in intact loop, Test S-05-7 (FDU-1 5, GU-15VR), from -6 to $42 \mathrm{sec}$

522. Mass flow in intact loop, Test S-05-6 (FTU-15, GU-15VR), from -20 to $300 \mathrm{sec}$ 290

523. Mass flow in intact loop, Test S-05-6 (FTU-15, GU-15VR), from -6 to $42 \mathrm{sec}$

524. Mass flow in intact loop, Test S-05-7 (FTU-1 5, GU-15VR), from -20 to $300 \mathrm{sec}$ 
525. Mass flow in intact loop, Test S-05-7 (FTU-1 5, GU-15VR), from -6 to $42 \mathrm{sec} \ldots \ldots \ldots \ldots 2 . \ldots \ldots 2 \ldots \ldots . \ldots \ldots$

526. Mass flow in broken loop (FDB-21, GB-21C), from -20 to $300 \mathrm{sec} \ldots 292$

527. Mass flow in broken loop (FDB-21, GB-21C), from -6 to $42 \mathrm{sec}$. . . . . . . . 292

528. Mass flow in broken loop (FTB-21, GB-21C), from -20 to $300 \mathrm{sec} \ldots 293$

529. Mass flow in broken loop (FTB-21, GB-21C), from -6 to $42 \mathrm{sec} \ldots \ldots 293$

530. Mass flow in broken loop (FDB-23, GB-23VR), from -20 to $300 \mathrm{sec} \quad \ldots . . .94$

531. Mass flow in broken loop (FDB-23, GB-23VR), from -6 to $42 \mathrm{sec} \ldots \ldots 294$

532. Mass flow in broken loop (FDB-30, GB-30C), from -20 to $300 \mathrm{sec} \ldots 295$

533. Mass flow in broken loop (FDB-30, GB-30C), from -6 to $42 \mathrm{sec} \ldots \ldots 295$

534. Mass flow in broken loop (FTB-30, GB-30C), from -20 to $300 \mathrm{sec} \ldots 296$

535. Mass flow in broken loop (FTB-30, GB-30C), from -6 to $42 \mathrm{sec} \ldots . . . .296$

536. Mass flow in broken loop (FDB-42, GB-42VR), from -20 to $300 \mathrm{sec} \ldots 297$

537. Mass flow in broken loop (FDB-42, GB-42VR), from -6 to $42 \mathrm{sec} . \ldots 297$

538. Mass flow in vessel (FDV-CORE-IN, GV-COR-1 50HZ), from -20 to $300 \mathrm{sec} \ldots \ldots \ldots \ldots . \ldots \ldots$

539. Mass flow in vessel (FDV-CORE-IN, GV-COR-150HZ), from -6 . to $42 \mathrm{sec} \ldots \ldots \ldots \ldots . \ldots \ldots 29 . \ldots \ldots$

540. Mass flow in vessel (FTV-CORE-IN, GV-COR-150HZ), from -20 to $300 \mathrm{sec} \ldots \ldots \ldots . \ldots . \ldots . \ldots 299$

541. Mass flow in vesscl (FTV-CORE-IN, GV-COR-15011'L), frön -G to $42 \mathrm{sec} \ldots \ldots \ldots \ldots$. . . . . . . . . . . . . . . . 299

542. Mass flow in pressurizer surge line (FTU-PRIZE, GU-PRIZE), from -20 to $300 \mathrm{sec} \ldots \ldots \ldots \ldots$. . . . . . . . . . . . . . . . . . . . . . . .

543. Mass flow in pressurizer surge line (FTU-PRIZE, GU-PRIZE), from -6 to $42 \mathrm{sec}$ 300 
544. Core heater rod total power (PWRCOR T-1), from -20 to $300 \mathrm{sec} \ldots \ldots 301$

545. Core heater rod total power (PWRCOR T-1), from -6 to $42 \mathrm{sec} \ldots \ldots 301$

546. Core heater rod total power (PWRCOR T-2), from -20 to $300 \mathrm{sec} \ldots \ldots 302$

547. Core heater rod total power (PWRCOR T-2), from -6 to $42 \mathrm{sec} \ldots \ldots 302$

548. Core heater voltage (VOLTCOR-T), from -20 to $300 \mathrm{sec} \ldots \ldots 303$

549. Core heater voltage (VOLTCOR-T), from -6 to $42 \mathrm{sec} \ldots \ldots$. . . . . . . . . 303

550. Core heater current (AMPCOR-T), from -20 to $300 \mathrm{sec} \ldots \ldots 304$

551. Core heater current (AMPCOR-T), from -6 to $42 \mathrm{sec} \ldots \ldots . . . . . . . .304$

552. Primary pump current (PUMPU-CUR), from -20 to $300 \mathrm{sec} \ldots \ldots 305$

553. Primary pump current (PUMPU-CUR), from -6 to $42 \mathrm{sec} \ldots \ldots 305$

554. Primary pump speed (PUMPU-RPM), from -20 to $300 \mathrm{sec} \ldots \ldots$. . . . . . . 306

555. Primary pump speed (PUMPU-RPM), from -6 to $42 \mathrm{sec} \ldots \ldots$. . . . . . . 306

A-1. Geometry used for processing of density data obtained from two-beam gamma densitometers . . . . . . . . . . . . . . 322

\section{TABLES}

1. Conditions at Blowdown Initiation . . . . . . . . . . . . 5

II. Primary Coolant Temperature Distribution Prior to Rupture . . . . . . . 6

III. Water Chemistry Prior to Blowdown ... . . . . . . . . . . 7

IV. Sequence of Events Dưring Test ................ 8

V. Data Presentation for Semiscale Mod-1 Tests S-05-6 and S-05-7 . . . . . 16

A-I. Constants for Pressure Measurement Corrections . . . . . . . . . . . . 312

A-II. Constants for Differential Pressure Measurement Corrections _ . . . . . . . . 314

A-III. Constants for Irregular Differential Pressure Measurement Corrections _ . . . 316 
A-IV. Constants for Momentum Flux Measurement Corrections . . . . . . . . 318

$\mathrm{A}: \mathrm{V}$. Constants for Density Measurement Conversions to Engineering Units . . . . . 320

A-VI. Constants for Density Measurement Conversions to Engineering

Units for Detectors Using Log Amplifiers . . . . . . . . . . . . . . . . 322 


\section{EXPERIMENT DATA REPORT FOR SEMISCALE MOD-1 TESTS S-05-6 AND S-05-7 (ALTERNATE ECC INJECTION TESTS)}

\section{INTRODUCTION}

The Semiscale Mod-1 experiments represent the current phase of the Semiscale Program conducted by EG\&G Idaho, Inc. for the United States Government. The program, which is sponsored by the Nuclear Regulatory Commission through the Energy Research and Development Administration, is part of the overall program designed to investigate the response of a pressurized water reactor (PWR) system to a hypothesized loss-of-coolant accident (LOCA). The underlying objectives of the Semiscale project are to quantify the physical processes controlling system behavior during a LOCA and to provide an expcrimental data base for assessing reactor safety evaluation models. The Semiscale Mod-1 program has the further objective of providing support to other experimental programs in the form of instrumentation assessment, optimization of test series, selection of test parameters, and evaluation of tcst results.

Tests S-05-6 and S-05-7 were conducted March 1st and 10th, 1977, respectively, in the Semiscale Mod-1 system as part of the alternate ECC injection tests series, which was designed to obtain thermal-hydraulic response data from blowdown, refill, and reflood transients in a simulated nuclear reactor with a heated core, to study system response to changes in emergency core coolant (ECC) injection location. The test objective specific to Tests S-05-6 and S-05-7 was to investigate the effectiveness of low pressure injection system (LPIS) coolant injection into the upper plenum when combined with cold leg intact loop coolant injection. The Semiscale Mod-1 system and ECC injection parameters were modified to represent more closely those of a two-loop PWR. However, Tests S-05-6 and S-05-7 were not expected to be a complete demonstration of a two-loop PWR system because of scaling distortions in the Semiscale Mod-1 system relative to a two-loop PWR. Both tests were conducted from similar initial conditions and system configuration with the primary exception that ECC was injected into the upper plenum by the LPIS for Test S-05-7 rather than into the intact loop and broken loop cold legs as was done for Test S-05-6. Test S-05-6 served as a baseline test for Test S-05-7.

The purpose of this report is to present the test data in an uninterpreted but readily usable form for use by the nuclear community in advance of detailed analysis and interpretation. Section II briefly describes the system configuration, procedures, initial test conditions, and events that are applicable to Tests S-05-6 and S-05-7; Section III presents the data graphs and provides comments and supporting information necessary for interpretation of the data. A description of the overall Semiscale program and test series, a more detailed description of the Semiscale Mod-1 system, and a description of the measurement and data processing techniques and uncertainties can be found in Reference 1 . 


\section{SYSTEM, PROCEDURES, CONDITIONS, AND EVENTS FOR TESTS S-05-6 AND S-05-7}

The following system configuration, procedures, initial test conditions, and events are specific to Tests S-05-6 and S-05-7 as indicated.

\section{SYSTEM CONFIGURATION AND TEST PROCEDURES}

The Semiscale Mod-1 system used for these tests consisted of a pressure vessel with in ternals, including a 40-rod core with 36 electrically heated rods; an intact loop with steam generator, pump, and pressurizer; a broken loop with simulated stean gentrator, simulatcd pump, and two rupture assemblies; coolant injection accumulators for both the intact and broken loops; low pressure injection pumps for the intact and broken loops for Test S-05-6, low pressure injection pump for the vessel upper plenum for Test S-05-7; and a pressurc suppression system with a suppression tank, header, and heated steam supply system. The Semiscale Mod-1 experimental system configuration is provided in Reference 1. Figure 1 provides the system configuration for Tests S-05-6 and S-05-7.

For Tests S-05-6 and S-05-7, 33 rods of the 40-rod electrically heated core wcrc operated at a peak power density of approximately $11.5 \mathrm{~kW} / \mathrm{ft}$, three rods (Rods D-4, E-4, and E-5) were operated at a peak power density of approximately $12.1 \mathrm{~kW} / \mathrm{ft}$ to yield d slightly peaked power profile, and four rods (Rods C-3, D-5, F-3, and F-6) were unpowered to simulate the effect of control rod guide tubes. The resulting total corc power wais aijiriximately $1.15 \mathrm{MW}$.

In preparation for the tests, the intact and broken lonp accumulators were tilled with treated demineralized water, drained to the specified initial levels, and pressurized with nitrogen to $700 \mathrm{psig}$. The system was filled with treated demineralized water and vented at strategic points to ensure a liquid rull system. Prior to warmup the system was pressurized to check for leakage, system instrümentation was cliecked, and transducer reidings wert initialized. Warmup to initial test conditions was accomplished with the heaters in the vessel core. Heatup of the broken loop piping was accomplished with by pass lines which served to allow circulation through the bruken luup. During warmup, the purification and sampling systems were valved into the primary system to main tain watcr chemistry requirements and to provide a water sample at system conditions for subsequent analysis. At $100-{ }^{\circ} \mathrm{F}$ temperature intervals during warmup, detector readings were sampled to allow the integrity of the measurement instrumentation and the operability of the data acquisition system to be checked.

Prior to the initial core power level being established, the pressure suppression system was pressurized to 35 psia with saturated steam from the steam supply system. After the core power was increased to the initial test value (1.45 MW for both Tests S-05-6 and 


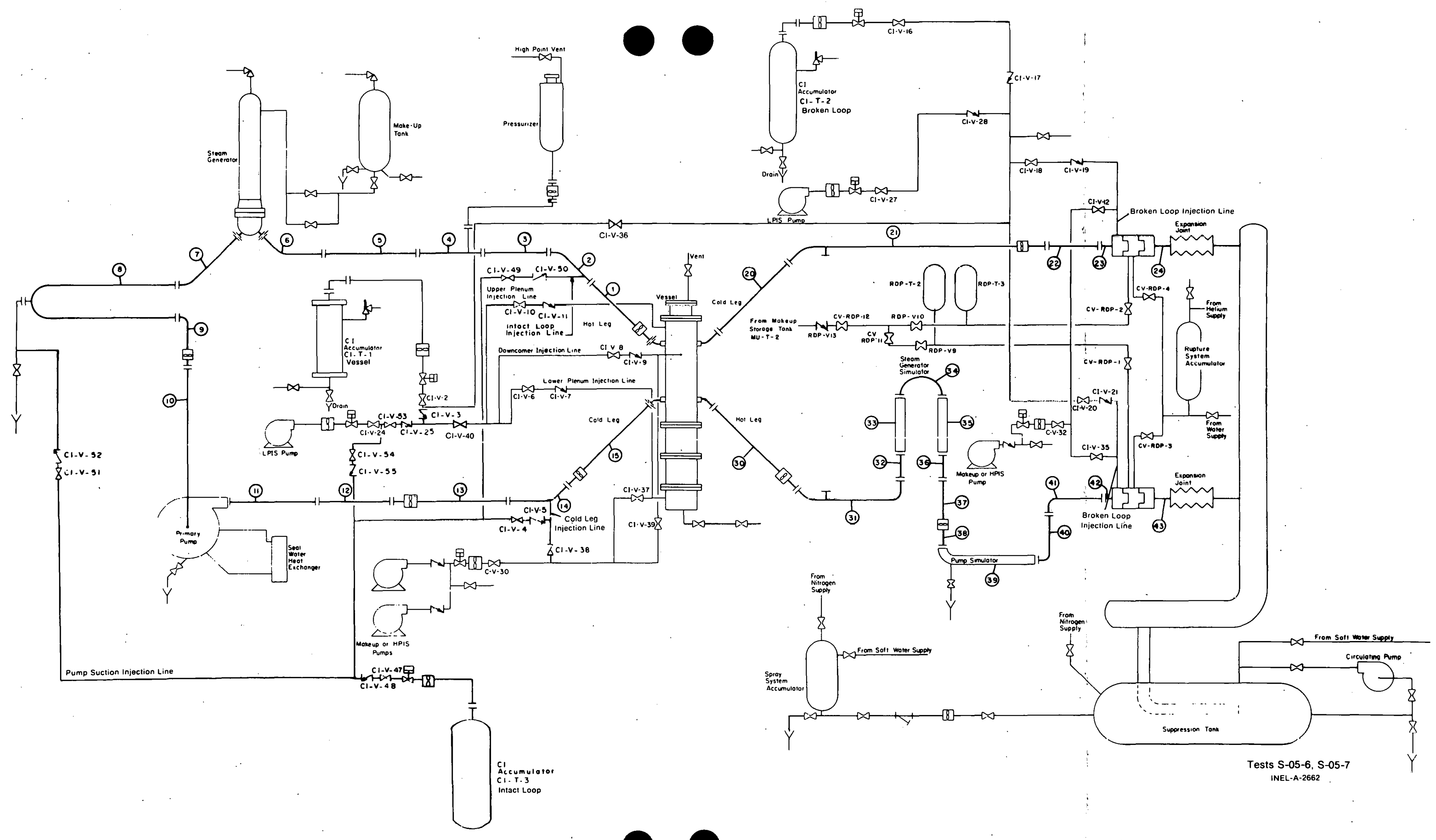

Fig. 1 Semiscale Mod-1 syst for col break configuration -- schematic. 
S-05-7), initial test conditions were held for 17 minutes and 10 minutes for Test S-05-6 and. Test S-05-7, respectively, to establish equilibrium in the system. At the end of this period, all auxiliary systems including the bypass lines were isolated to prevent blowdown through those systems.

During each test, the system was successfully subjected to a simulated $200 \%$ double-ended cold leg break through two rupture assemblies and two blowdown nozzles, each having a break area of $0.00508 \mathrm{ft}^{2}$. Pressure to operate the rupture assemblies and initiate blowdown was taken from an accumulator system filled with water and pressurized to $2250 \mathrm{psig}$ with gaseous nitrogen. Immediately (within $0.02 \mathrm{sec}$ ) after initiation of blowdown, the lines to the accumulator were again isolated. The effluent from the primary system was ejected into the pressure suppression system which was vented to maintain a constant pressure of $35 \mathrm{psia}$. At blowdown, power to the primary coolant circulation pump was reduced and the punp was alluwed lo cuast duwn lo speeds of 1530 i pin and 1540 ipm for Tests S-05-6 and S-05-7, respectively. These respective speeds were maintained for the duration of the tests. During the blowdown transient, power to the electrically heated core was automatically controlled to simulate the thermal response of the nuclear-heated fuel rods.

For Tests S-05-6 and S-05-7, coolant injection was initiated from the intact and broken loop accumulators into Spools 14 and 42, respectively, after the system depressurized to 700 psig; injection continued until the accumulators were depleted. Nitrogen flow from the intact loop accumulator was terminated at $100 \mathrm{sec}$ and $103 \mathrm{sec}$ after blowdown initiation for Tests S-05-6 and S-05-7, respectively. Nitrogen tlow from the broken loop accumulator continued until depletion for both tests. At approximately $150 \mathrm{psig}$. the low pressure injection punips were also slarted. Low pressure injection for the intact loop was into Spool 14, and In the broken loop it was into Spool 42 for Test S-05-6. Tow pressure injection was only made into the vessel upper plenum for Test S-05-7. Coolant injection from the low prcssurc injcction pumps continued until the tests were terminated 300 sec after initiation of blowdown.

\section{INITIAL TEST CONDITIONS AND SEQUENCE OF EVENTS}

Conditions in the Semiscale Mod-1 system at initiation of blowdown are given in Tables I and II; the primary system water chemistry prior to blowdown is given in Table III; and the sequence of events relative to rupture is given in Table IV. 


\section{TABLE I}

\begin{tabular}{|c|c|c|c|}
\hline \multirow[b]{2}{*}{, } & \multicolumn{2}{|c|}{ Measured $[\mathrm{a}]$} & \multirow[b]{2}{*}{ Specified } \\
\hline & Test S-05-6 & Test $5-05-7$ & \\
\hline Core power (MW) & 1.454 & 1.448 & $1.444 \pm 0.03$ \\
\hline $\begin{array}{l}\text { Intact loop cold leg fluid } \\
\text { temperature }\left({ }^{\circ} \mathrm{F}\right)\end{array}$ & 550 & 551 & 552 \\
\hline $\begin{array}{l}\text { Hot leg to cold leg temperature } \\
\left.\text { differential ( }{ }^{\circ} \mathrm{F}\right)\end{array}$ & 59 & 58 & $66 \pm 1$ \\
\hline Pressurizer pressure (psia) & 2263 & 2253 & $2263 \pm 25$ \\
\hline $\begin{array}{l}\text { Pressurizer water leve] } \\
\quad \text { (in.)[b] }\end{array}$ & $19.2^{[c]}$ & $20.5^{[c]}$ & 21.13 \\
\hline $\begin{array}{l}\text { Steam generator feedwater } \\
\text { temperature }\left({ }^{\circ} \mathrm{F}\right)\end{array}$ & 400 & .400 & $400 \pm 10$ \\
\hline $\begin{array}{l}\text { Steam generator liquid leve? } \\
\text { (from bottom of tube sheet) } \\
\text { (in.) }\end{array}$ & 106 & 109 & $116 \pm 2$ \\
\hline $\begin{array}{l}\text { Fluid temperature in broken } \\
\text { loop (pump side) }\left({ }^{\circ} \mathrm{F}\right)\end{array}$ & 599 & 599 & $605 \pm 5$ \\
\hline $\begin{array}{l}\text { Fluid temperature in broken } \\
\left.\text { loop (vessel side) }{ }^{\circ} \mathrm{F}\right)\end{array}$ & 548 & 550 & $\begin{array}{l}\text { Not } \\
\text { Specified }\end{array}$ \\
\hline Intact loop cold leg flow (gpm) & 175 & 175 & [d] \\
\hline $\begin{array}{l}\text { Pressure suppression tank } \\
\text { water level (in.) }\end{array}$ & 47.5 & 47.5 & $47.5 \pm 0.5$ \\
\hline $\begin{array}{l}\text { Pressure suppression tank } \\
\text { pressure (psia) }\end{array}$ & 34.75 & 35 & $35.5 \pm 1$ \\
\hline $\begin{array}{l}\text { Pressure suppression tank } \\
\text { water temperature }\left({ }^{\circ} \mathrm{F}\right)\end{array}$ & 60 & 62 & Ambient \\
\hline
\end{tabular}

[a] Measured initial conditions are taken from process instrumentation read just prior to blowdown. Those measured conditions which did not meet the specified initial conditions were considered acceptable for analysis purposes within the test objectives.

[b] Pressurizer water levels measured down from inside of top head. Levels were specified in terms of differential pressure in the liquid level measuring system.

[c] Levels shown correspond to pressurizer system volumes of 0.74 and $0.71 \mathrm{ft}^{3}$ (including surge line) for Tests $S-05-6$ and $S-05-7$, respectively.

[d] Flow is not specified, since it must be adjusted to achieve the required differential temperature across the core. 
TABLE II

PRIMARY COOLANT TEMPERATURE DISTRIBUT.ION PR.IOR TO RUPTURE[a]

\begin{tabular}{|c|c|c|c|c|}
\hline \multirow{2}{*}{\multicolumn{2}{|c|}{$\therefore \quad$ Detector }} & \multicolumn{3}{|c|}{ Temperature $\left({ }^{\circ} \mathrm{F}\right)$} \\
\hline & & Test S-05-6 & Test & t $S-05-7$ \\
\hline $\begin{array}{l}\text { Vessel lower plenum (upper } \\
\text { portion above filler block) }\end{array}$ & TFV-LP-7 & 553 & & 554 \\
\hline $\begin{array}{l}\text { Intact loop hot leg (near } \\
\text { vessel) }\end{array}$ & RBIJ-2 & 608 & & $6 \cap 9$ \\
\hline $\begin{array}{l}\text { Inldcl loup culd ley (lledr } \\
\text { pump inlet) }\end{array}$ & TFU $-10^{\circ}$ & 551 & & 553 \\
\hline $\begin{array}{l}\text { Intact loop cold leg (near } \\
\text { vessel) }\end{array}$ & RBU-14A & 550 & & 551 \\
\hline $\begin{array}{l}\text { Broken loop cold leg (near } \\
\text { nozzle) }\end{array}$ & TFB-23 & 548 & & 550 \\
\hline $\begin{array}{l}\text { Broken loop hot leg (near } \\
\text { vessel) }\end{array}$ & TFB-30 & 605 & & 606 \\
\hline $\begin{array}{l}\text { Broken loop cold leg (near } \\
\text { nozzle) }\end{array}$ & TFB-12 & 699 & & 599 \\
\hline $\begin{array}{l}\text { [a] Data taken from final dig } \\
\text { for Tests } S-05-6 \text { and } S-0\end{array}$ & $\begin{array}{l}\text { al scan } \\
\text { respec }\end{array}$ & $\begin{array}{l}\text { nd } 172 \mathrm{sec} \\
y .\end{array}$ & & rupture \\
\hline
\end{tabular}


TABLE II I

WATER CHEMISTRY PRIOR TO BLOWDOWN ${ }^{\text {[a] }}$

\begin{tabular}{|c|c|c|}
\hline & Test S-05-6 & Test $\mathrm{S}-05-7$ \\
\hline $\mathrm{pH}$ & 10.80 & 10.80 \\
\hline Conductivity $(\mu \mathrm{mho} / \mathrm{cm})$ & 196 & 139 \\
\hline Lithium (ppm) & 4.9 & 3.8 \\
\hline Chlorides (ppm) & $<0.1$ & 3.7 \\
\hline Fluorides $(\mathrm{ppm})^{[\mathrm{b}]}$ & $<0.5$ & $<0.4^{[b]}$ \\
\hline Oxygen $(\mathrm{cc} / 1)$ & $<0.1$ & 0.65 \\
\hline Total gas $(\mathrm{cc} / 1)$ & 192.0 & $259.8^{[\mathrm{C}]}$ \\
\hline Susperided solids (ppm) & 0.99 & $0.41^{\circ}$ \\
\hline \multicolumn{3}{|c|}{$\begin{array}{l}\text { [a] Water samples taken at a system pressure of about } 2250 \text { psia and a } \\
\text { system temperature of about } 540^{\circ} \mathrm{F} \text { (cold leg). }\end{array}$} \\
\hline \multicolumn{3}{|c|}{$\begin{array}{l}\text { [b] Present analytical methods prevent accurate determination of } \\
\text { fluorides at concentrations of less than } 0.4 \mathrm{ppm} \text {. }\end{array}$} \\
\hline \multicolumn{3}{|l|}{$\begin{array}{ll}\text { [c] Tot } \\
\text { dur }\end{array}$} \\
\hline
\end{tabular}




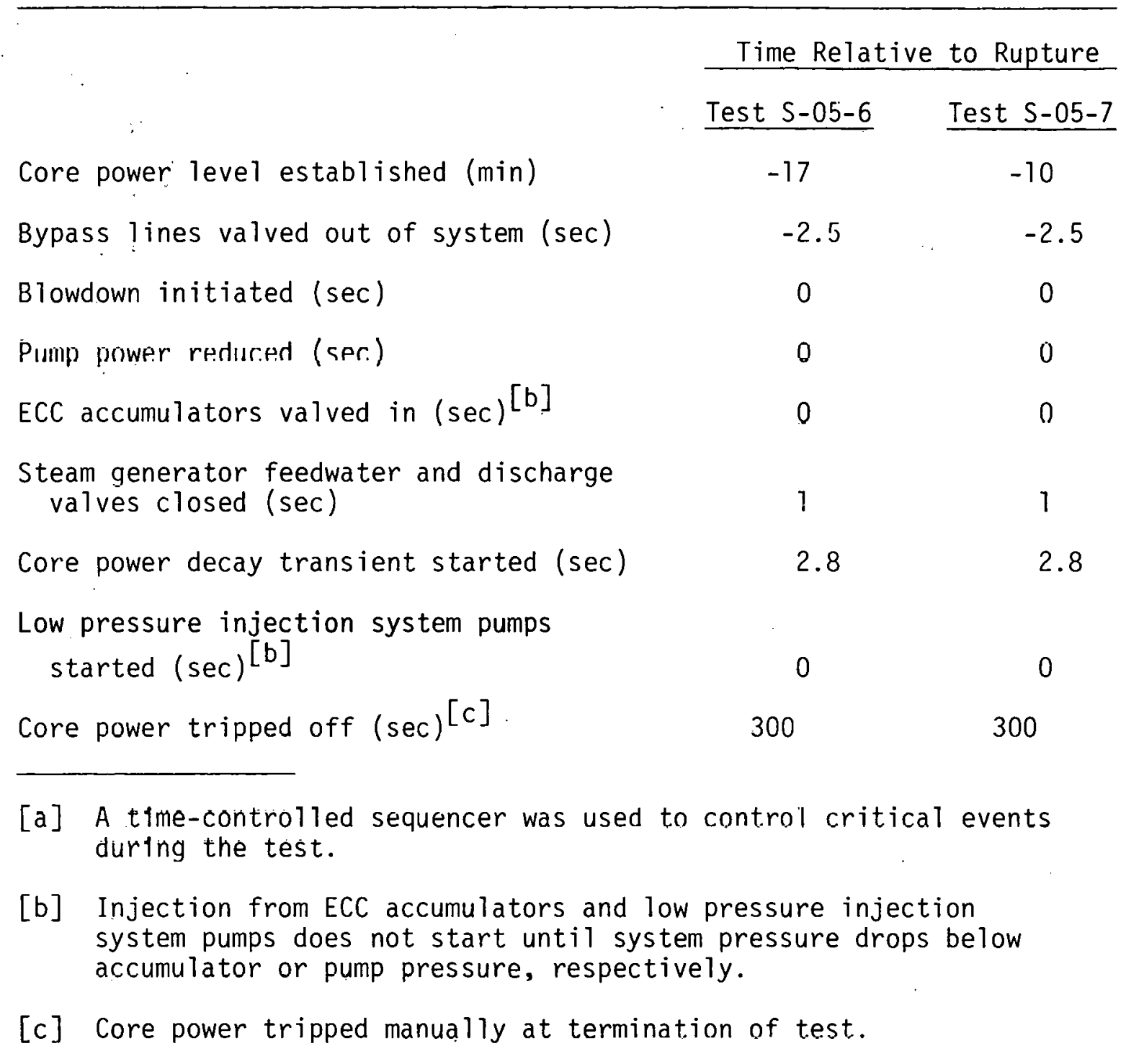




\section{DATA PRESENTATION}

The data from Semiscale Mod-1 Tests S-05-6 and S-05-7 are presented with brief comment. Processing analysis has been performed only to the extent necessary to obtain appropriate engineering units and to ensure that the data are reasonable and consistent. In all cases, in converting transducer output to engineering units, a homogeneous fluid was assumed. Further interpretation and analysis should consider that sudden decompression processes, such as those occurring during blowdown, may have subjected the measurement devices to nonhomogeneous fluid conditions.

The performance of the system during Test S-05-6 was monitored by 215 detectors and for Test S-05-7 by 218 detectors. The data obtained were recorded on both digital and analog data acquisition systems. The digital data were recorded at a sample rate of 57.5 points per sec. Long term plots $(-20$ to $300 \mathrm{sec})$ were compressed at a 20 to 1 ratio giving an effective sample rate of 2.875 points per sec. Short term plots $(-6$ to $42 \mathrm{sec})$ were compressed at a 3 to 1 ratio giving an effective sample rate of 19.17 points per sec. The analog systcm was used to provide better resolution capability (needed as input to various data analysis codes) and to provide redundancy.

The data are presented, in most instances, in the form of composite graphs to facilitate comparison of the values of given variables between the two tests. The scales selected for the graphs do not reflect the obtainable resolution of the data (the data processing techniques are described further in Reference 1).

Figurcs 2 through 7 and Table $\mathrm{V}$ provide supporting information for interpretation of the data graphs shown in Figures 8 through 555 and provide relative locations of all detectors used during Tests S-05-6 and S-05-7. Table V groups the measurements according to measurement type; identifies the specific measurement location and the range of the detector and actual recording range of the data acquisition system; provides brief comments regarding the data; and references the measurements and comments to the corresponding figure. Figures 8 through 555 present all the blowdown and rcflood data obtained. Time zero on the graphs is the time of rupture initiation. Appendix A provides information explaining data adjustments and posttest data processing for data conversion into engineering units. 


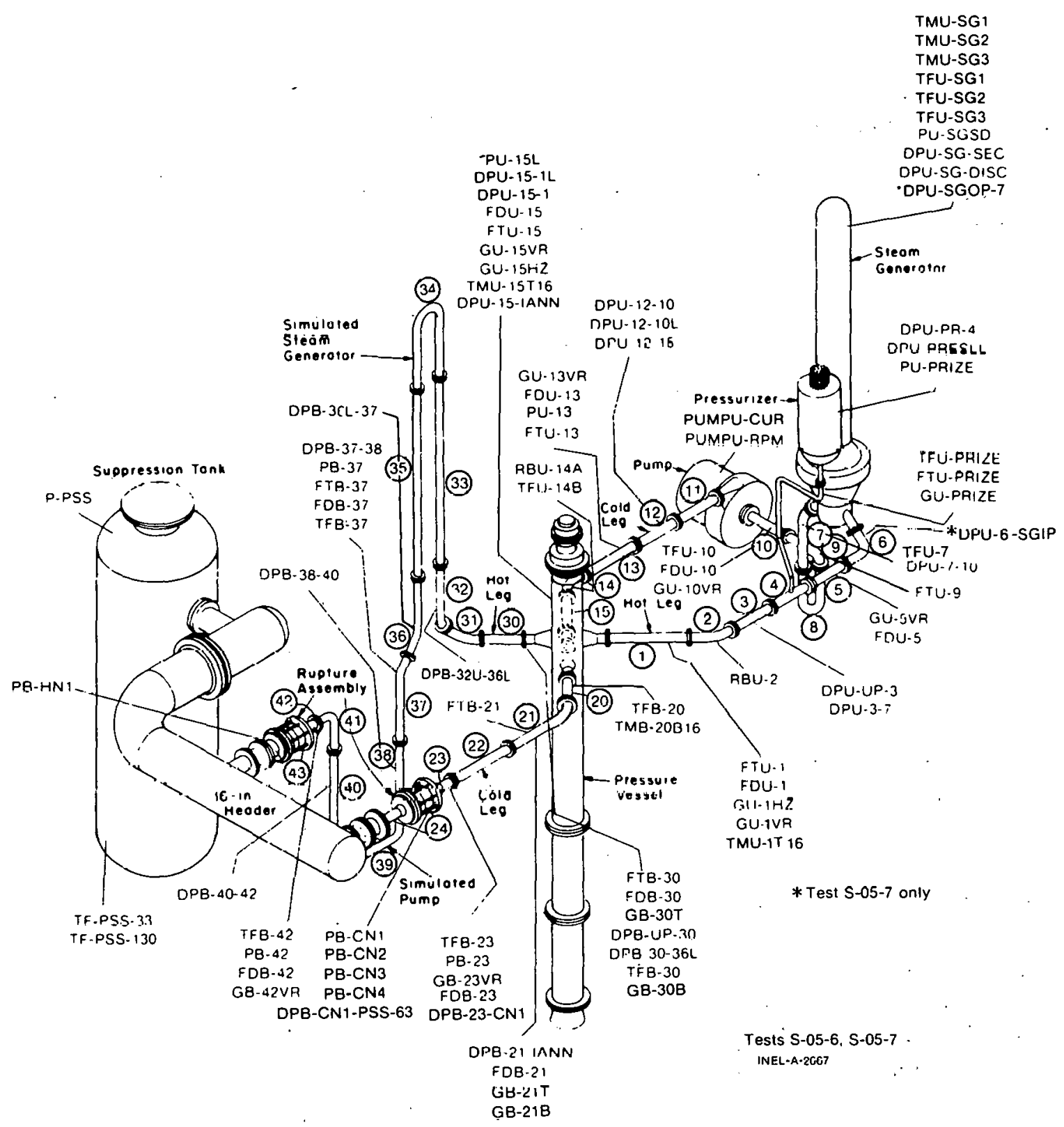

Fig. 2 Semiscale Mod-1 system and instrumentation for cold leg break configuration -- isometric. 


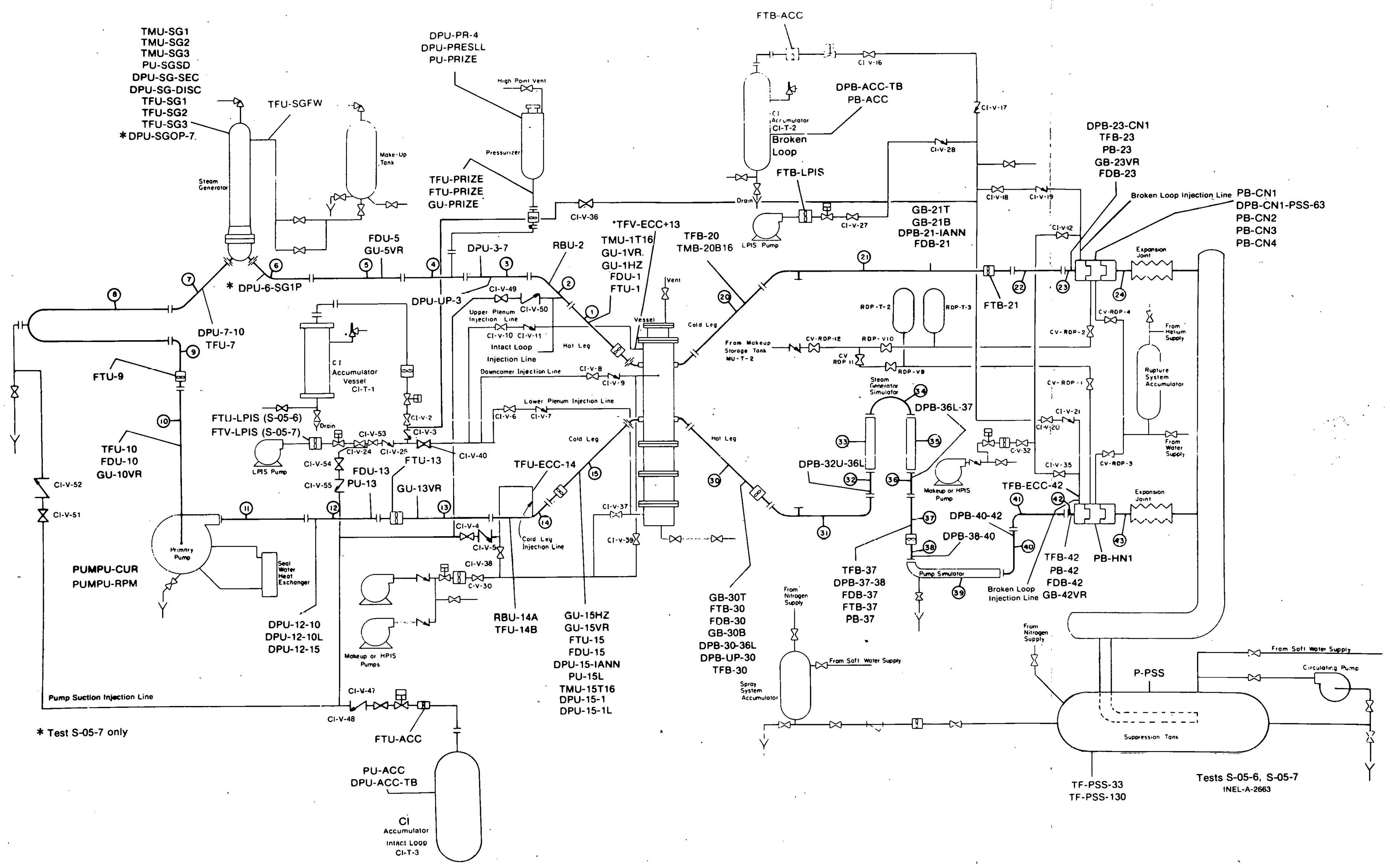

Fig. 3 Semiscale Mod- 1 system and instrumentation for cold leg break configuration -- schematic. 


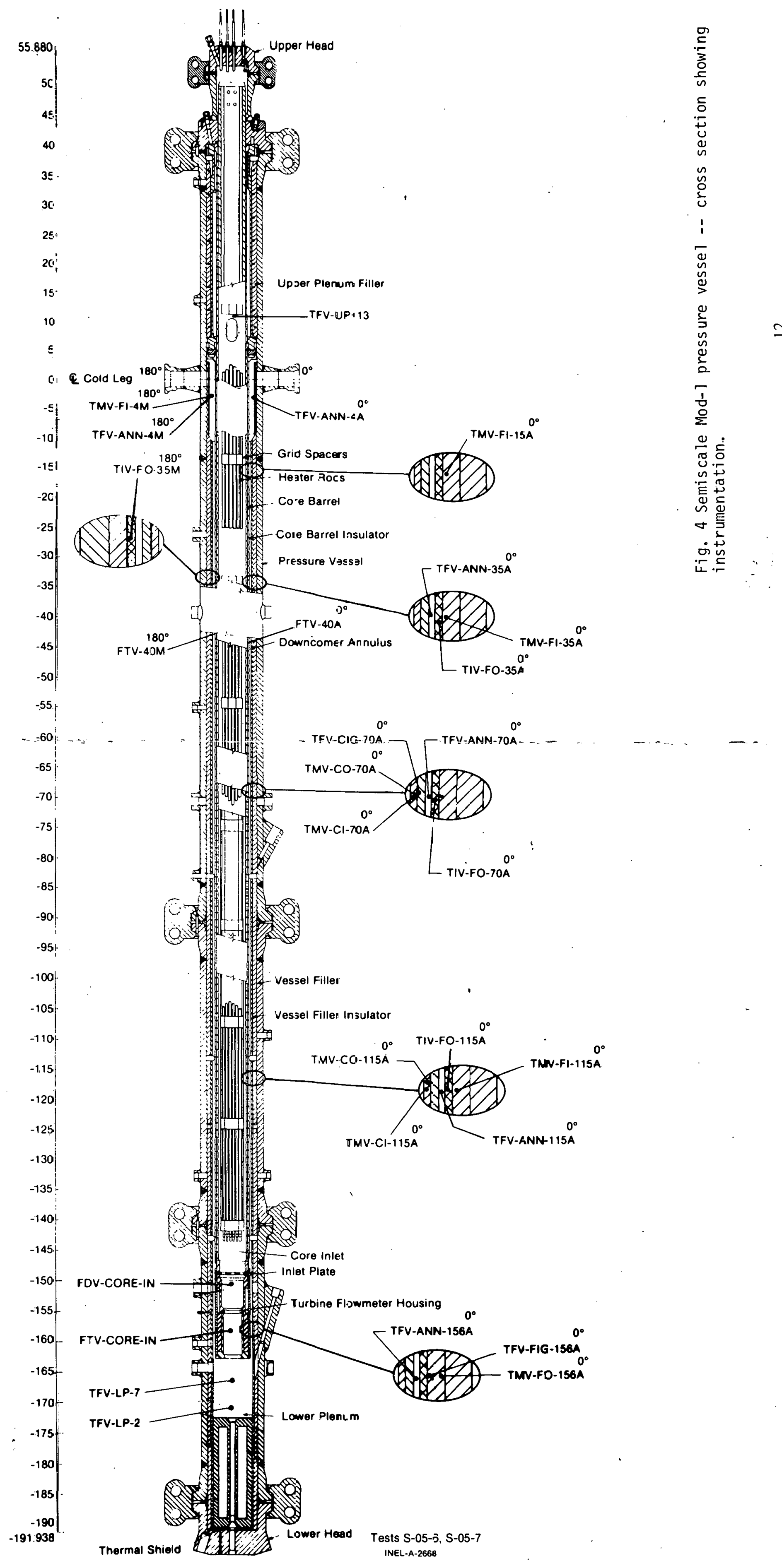




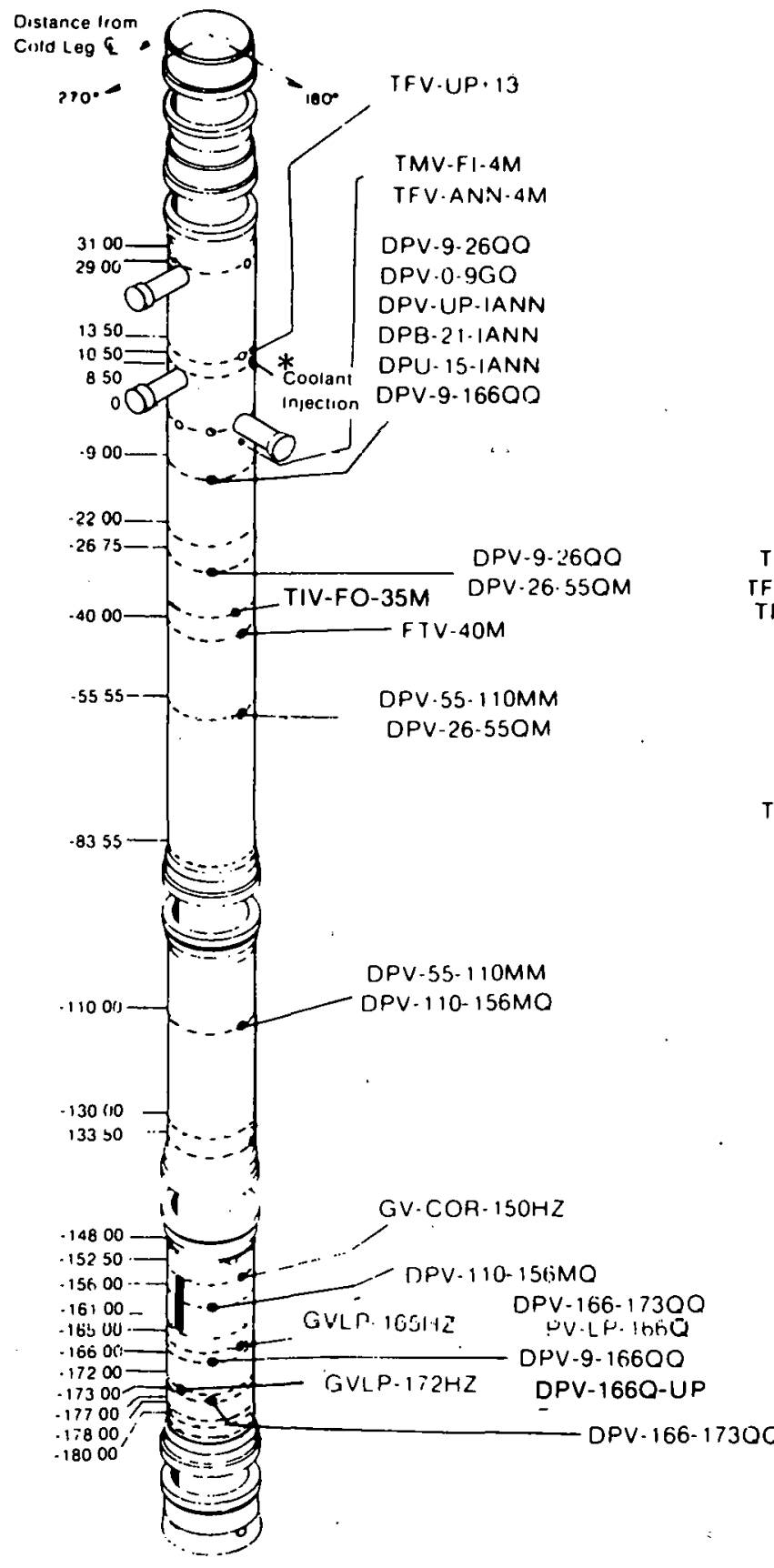

*Test S-05-7 only

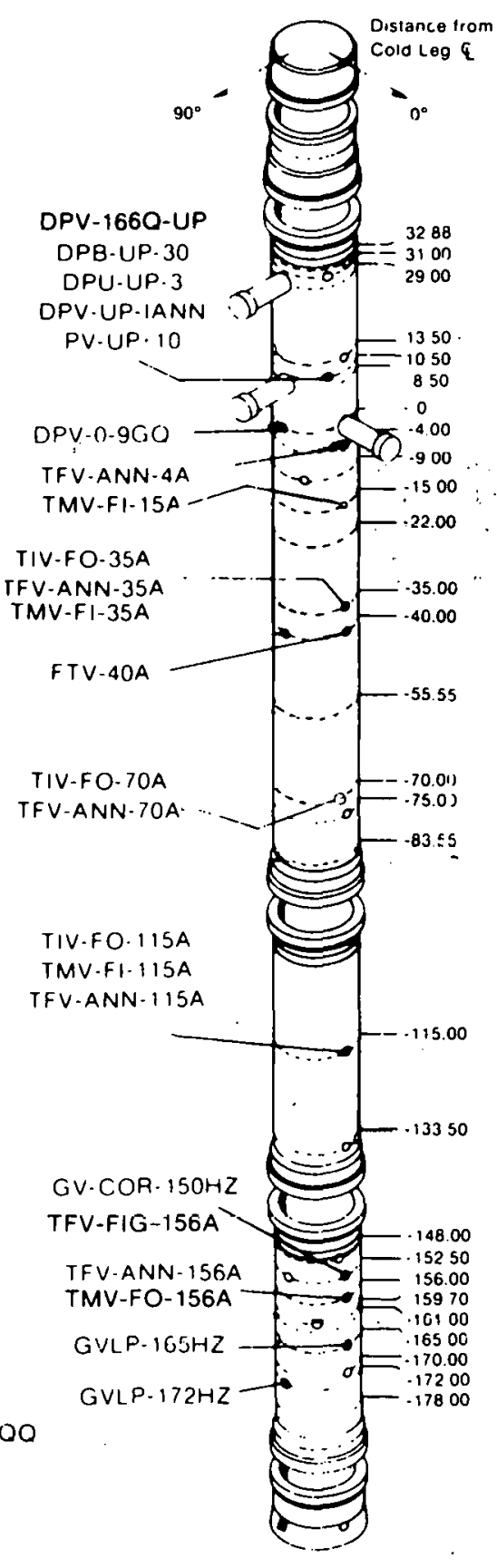

Tests S-05-6, S-05-7 INEL-A-2665

Fi.g. 5 Semiscale Mod-1 pressure vessel -- isometric showing instrumentation. 


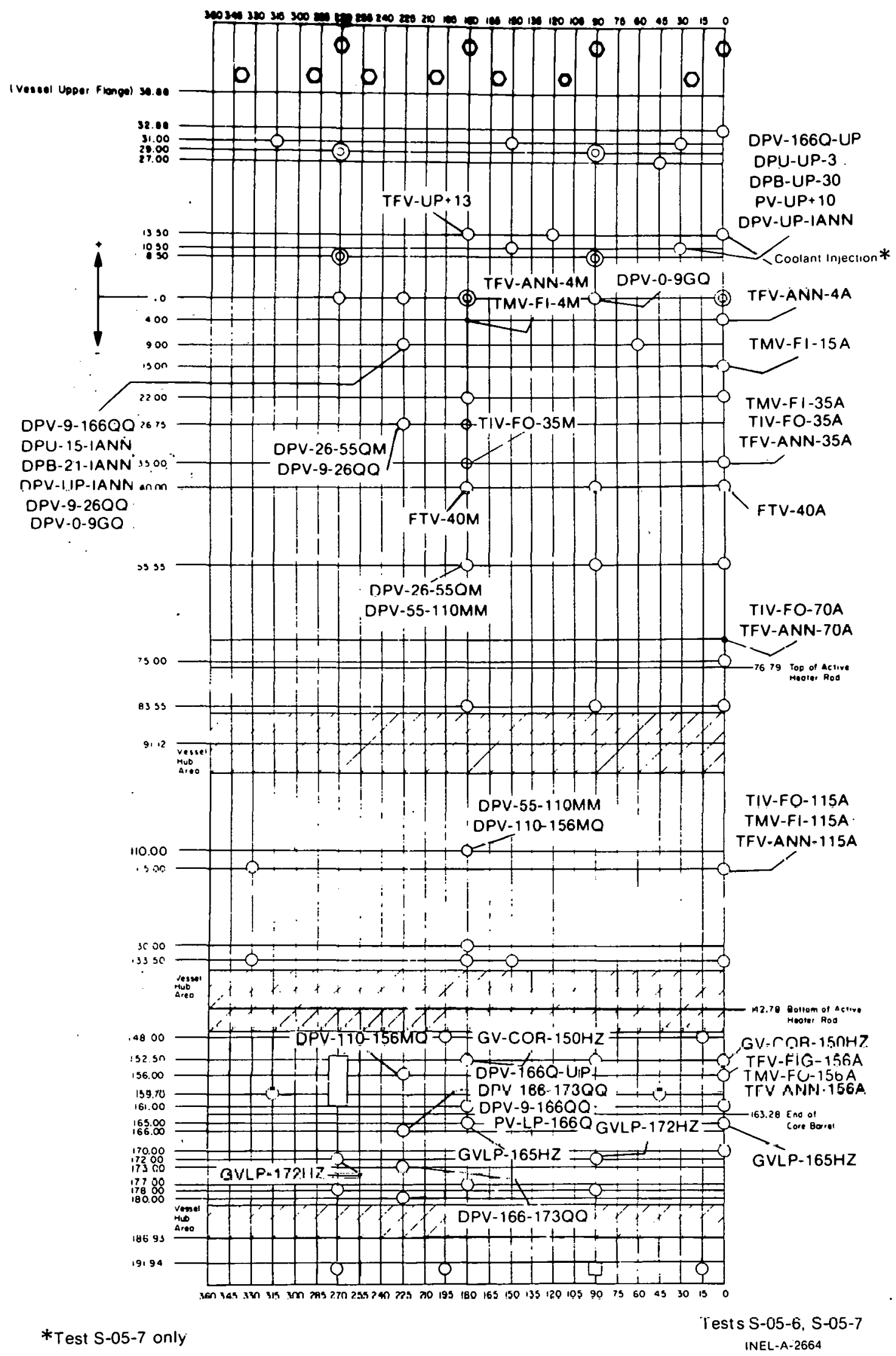

Fig. 6 Semiscale Mod-1 pressure vessel -- penetrations and instrumentation. 


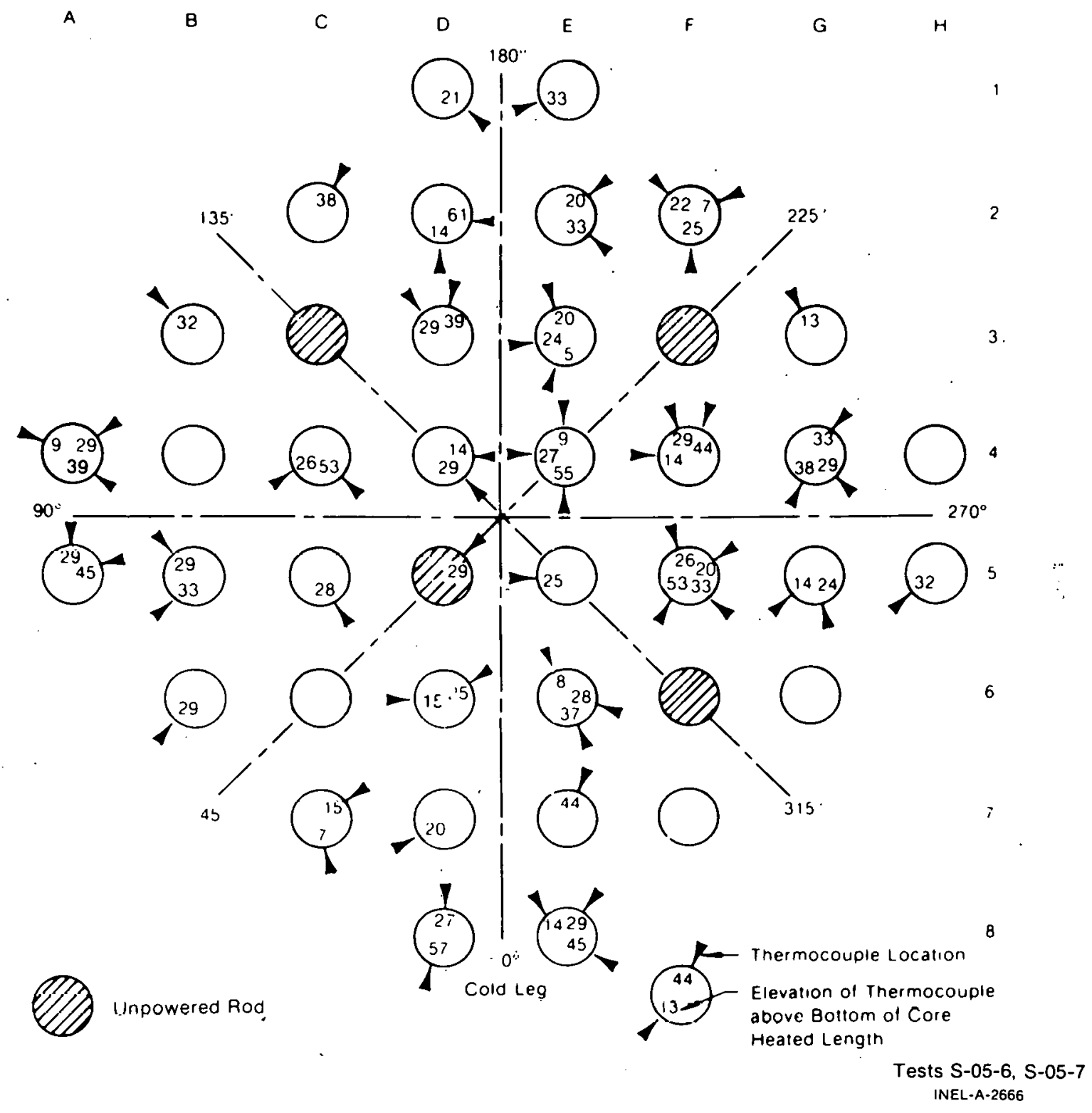

Fig. 7 Semiscale Mod-1 heated core -- plan view. 


\section{TABLE $V$}

DATA PRESENTATION FOR SEMISCALE MOD- 1 TESTS S-05-6 and S-05-7

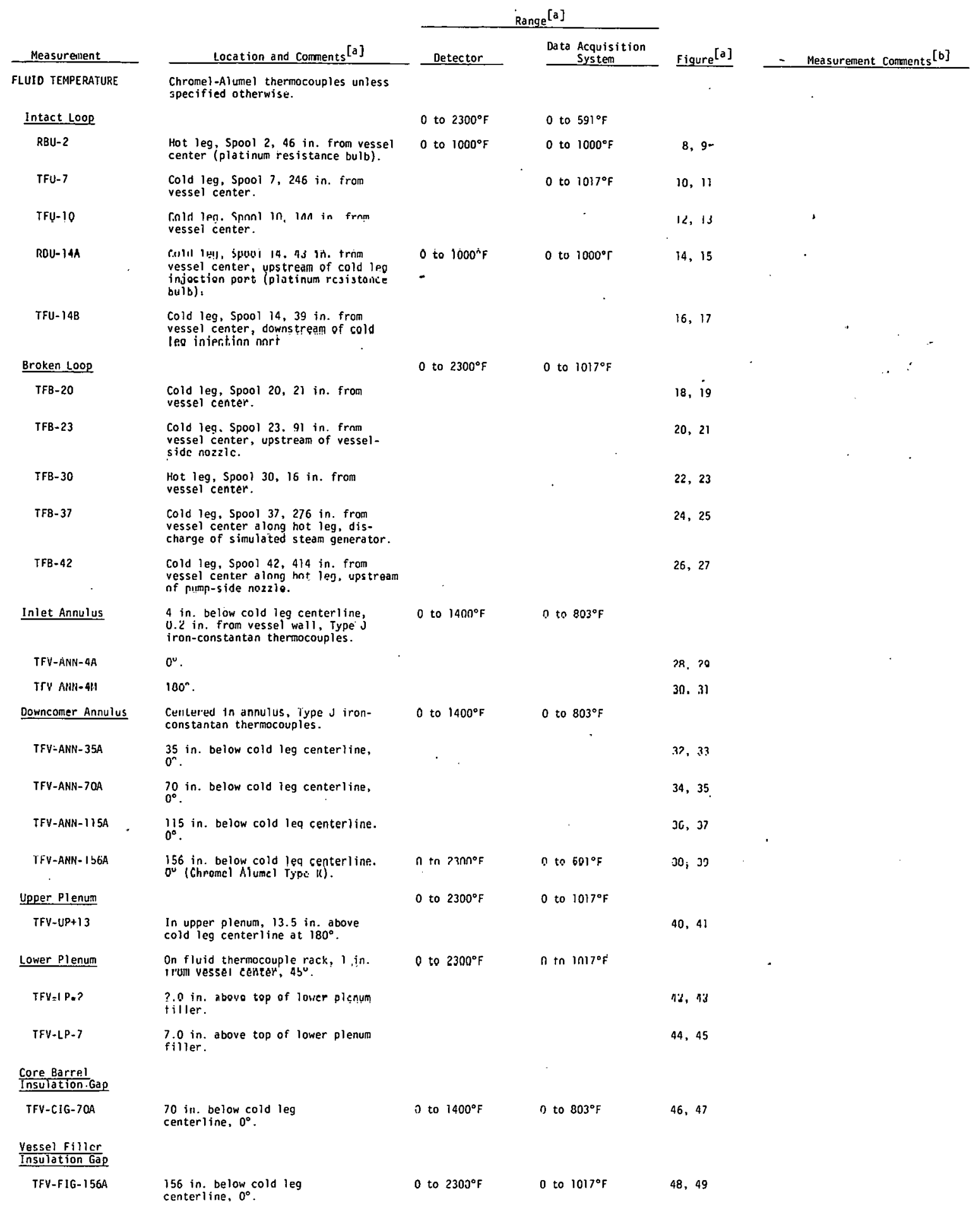




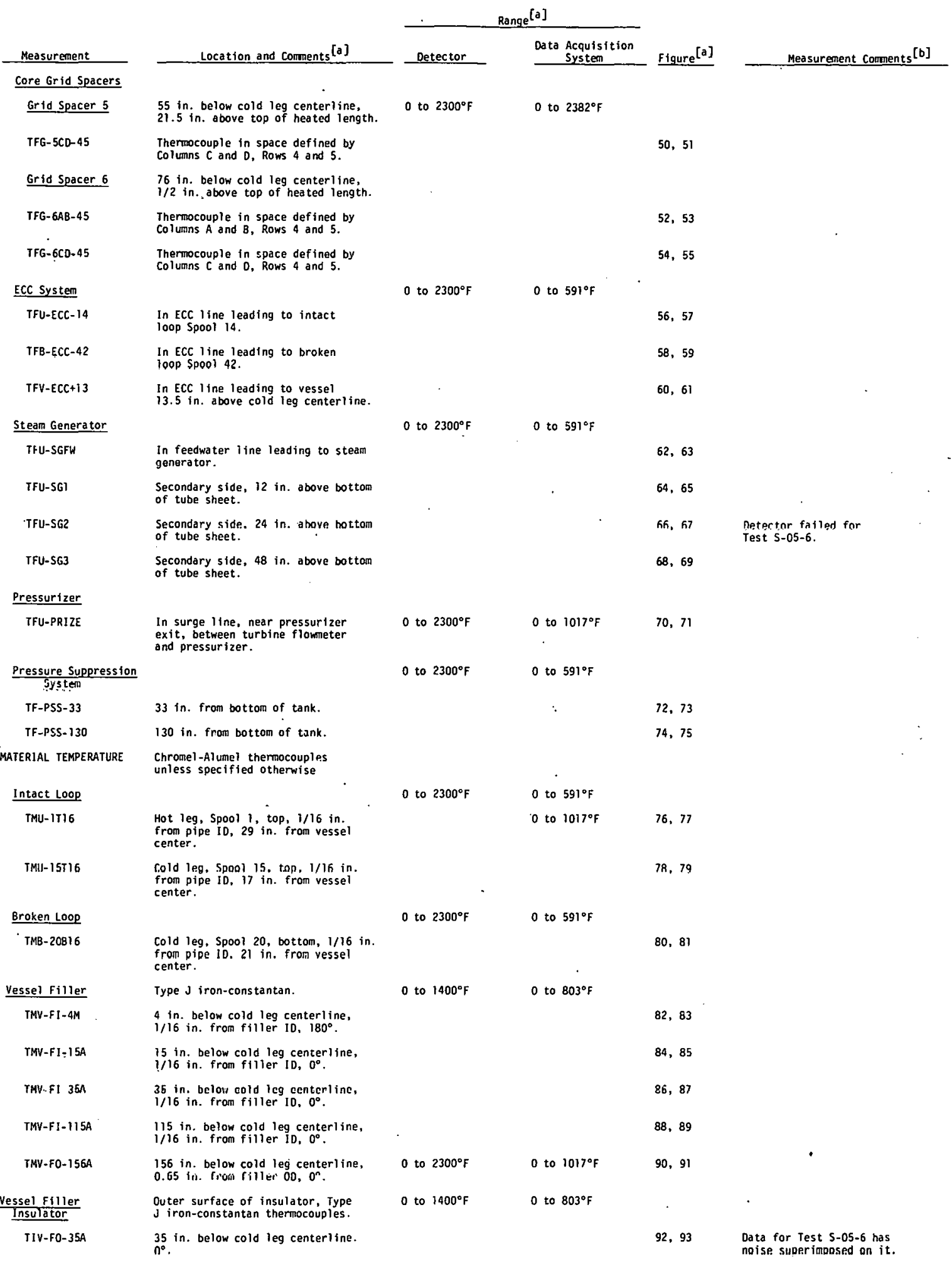


TABLE V (continued)

\begin{tabular}{|c|c|c|c|c|c|}
\hline \multirow[b]{2}{*}{ Measurement } & \multirow[b]{2}{*}{ Location and Comments ${ }^{[a]}$} & \multicolumn{2}{|c|}{ Range $^{[a]}$} & \multirow{2}{*}{ Figure $^{[a]}$} & \multirow[b]{2}{*}{ Measurement Comments ${ }^{[\mathrm{b}]}$} \\
\hline & & Detector & $\begin{array}{c}\text { Data Acquisition } \\
\text { System } \\
\end{array}$ & & \\
\hline \multicolumn{6}{|l|}{$\begin{array}{l}\text { Vessel Filler } \\
\text { Insulator. (continued) }\end{array}$} \\
\hline TIV-F0-35M & & & & 94,95 & \\
\hline TIV-FO-70A & $\begin{array}{l}70 \text { in. below cold leg centerline, } \\
0^{\circ} \text {. }\end{array}$ & & & 96.97 & \\
\hline TIV-F0-115A & $\begin{array}{l}115 \text { in. below cold leg centerline, } \\
0^{\circ} \text {. }\end{array}$ & & . & 98,99 & \\
\hline Core Barrel & Type $\mathrm{J}$ iron-constantan therriocouples & 0 to $1400^{\circ} \mathrm{F}$ & 0 to $803^{\circ} \mathrm{F}$ & . & \\
\hline TMV-CI-70A & $\begin{array}{l}70 \text { in. below cold leg centerline, } \\
1 / 16 \text { in. from core barrel } 10,0^{\circ} .\end{array}$ & & & 100,101 & \\
\hline TMV-CI-115A & $\begin{array}{l}115 \text { in. below cold leg centerline, } \\
1 / 16 \text { in. from core barrel } 10,0^{\circ} .\end{array}$ & . & & 102,103 & \\
\hline TMV-CO-7OA & $\begin{array}{l}70 \text { in below cold leg centerline, } \\
1 / 16 \text { in. from core barrel } 00,0^{\circ} \text {. }\end{array}$ & & & 104, 105 & \\
\hline TMV-CO-115A & $\begin{array}{l}115 \text { in. below cold leg centerline, } \\
1 / 16 \text { in. from core barrel on, } 0^{\circ} \text {. }\end{array}$ & & & 106,107 & \\
\hline Core Housing Filler & & 0 to $2300^{\circ} \mathrm{F}$ & 0 to $1017^{\circ} \mathrm{F}$ & & \\
\hline TMV-HF-115W & $\begin{array}{l}\text { On core housing filler, } 115 \text { in. } \\
\text { below cold leg centerline, } 0.20 \mathrm{mn} \text {. } \\
\text { rrium untur surface, } 315^{\circ} \text {. }\end{array}$ & & & 108,109 & \\
\hline TMV-HF-138W & $\begin{array}{l}\text { On core housing filler, } 138 \text { in. } \\
\text { below cold leg centerline, } 0.20 \text { in. } \\
\text { trom outer surface, } 315^{\circ} \text {. }\end{array}$ & & & 110,111 & \\
\hline steam Generator & & 0 to $2300^{\circ} \mathrm{F}$ & 0 to $591^{\circ} \mathrm{F}$ & & \\
\hline TMU-SGI & $\begin{array}{l}\text { On a steam generator tube, } 12 \text { in. } \\
\text { above bottom of tube sheet, on } \\
\text { tube } 00 \text {. }\end{array}$ & & & 112,113 & \\
\hline TMU-SG2 & $\begin{array}{l}\text { On a steam gencrator tubc, } 24 \text { in. } \\
\text { above bott tom of tube sheet, on } \\
\text { tube } 00 \text {. }\end{array}$ & & & 114,115 & \\
\hline TMU. $5 G 3$ & $\begin{array}{l}\text { On a sledill yenerator tube, } 48 \mathrm{in} \text {. } \\
\text { above Dott of of tube sheet, on } \\
\text { tube } 00 \text {. }\end{array}$ & & & 116,117 & \\
\hline $\begin{array}{l}\text { CORE HEATER } \\
\text { GLADOING TCINERATUNCS }\end{array}$ & Chromel-Alumel thermocouples. & & & & \\
\hline High Power Heaters & & 0 to $2300^{\circ} \mathrm{F}$ & 0 to $2382^{\circ} \mathrm{F}$ & & \\
\hline $\begin{array}{l}T H-04-14 \\
1 H-04-29\end{array}$ & 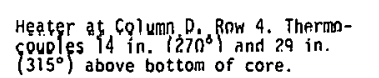 & & & $\begin{array}{l}118,110 \\
130,131\end{array}$ & \\
\hline$T H-05-29$ & $\begin{array}{l}\text { Heater at Column D, Row } 5 \text {. Thermo- } \\
\text { couple } 29 \text { in. }\left(275^{\circ}\right) \text { andove battom } \\
\text { of core. }\end{array}$ & . & & 122,123 & \\
\hline $\begin{array}{l}T H-E 4-09 \\
T H-E 4-27 \\
T H-E 4-55\end{array}$ & $\begin{array}{l}\text { Heater at column E, Row } 4 \text {. Thermo- } \\
\text { couples } 9 \text { in. }\left(180^{\circ}\right), 27 \text { in. }\left(90^{\circ}\right) \text {, } \\
\text { and } 55 \text { in. }\left(0^{\circ}\right) \text { above bottom of } \\
\text { core. }\end{array}$ & & & $\begin{array}{l}124,125 \\
126,127 \\
128,129\end{array}$ & \\
\hline TH-E5-25 & $\begin{array}{l}\text { Heater at column E, Row 5. Thermo- } \\
\text { couple } 25 \text { in. }\left(90^{\circ}\right) \text { above bottom } \\
\text { of core. }\end{array}$ & & & 130,131 & \\
\hline Low Power Heaters & & 0 to $2300^{\circ} \mathrm{F}$ & 0 to $2382^{\circ} \mathrm{F}$ & & \\
\hline $\begin{array}{l}\text { TH-A4-09 } \\
T H-A 4-29 \\
T H-A 4-39\end{array}$ & $\begin{array}{l}\text { Heater at column A, Row } 4 \text { Thermo- } \\
\text { couples } 9 \text { in. }\left(100^{\circ}\right), 29 \text { in } \\
\left(240^{\circ}\right) \text { and } 39 \text { in. }\left(300^{\circ}\right) \text { above } \\
\text { mint thm of rnn?. }\end{array}$ & & $:$ & $\begin{array}{l}132,133 \\
134,135 \\
136,137\end{array}$ & \\
\hline 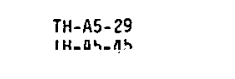 & 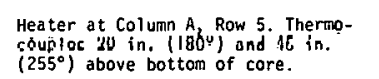 & & & $\begin{array}{l}138,139 \\
140,141\end{array}$ & \\
\hline TH-B3-32 & $\begin{array}{l}\text { Heater at column B. Row } 3 . \text { Thermo- } \\
\text { couple } 32 \text { in. }\left(135^{\circ}\right) \text { above bottom } \\
\text { of corre. }\end{array}$ & & & 142,143 & \\
\hline $\begin{array}{l}\text { TH- } 85-2 y \\
\text { TH- } 85-33\end{array}$ & $\begin{array}{l}\text { Heater at column } 8 \text {. Row } 5 \text {. Thermo- } \\
\text { couples } 29 \text { in. }\left(150^{\circ}\right) \text { and } 33 \text { in. } \\
\left(45^{\circ}\right) \text { above bottom of core. }\end{array}$ & & & $\begin{array}{l}144,145 \\
146,147\end{array}$ & \\
\hline TH-B6-29 & $\begin{array}{l}\text { Heater at column B, Row 6. Thermo- } \\
\text { couple } 29 \text { in. }\left(45^{\circ}\right) \text { above bottom } \\
\text { of core. }\end{array}$ & . & & 148,149 & \\
\hline TH-C2-38 & $\begin{array}{l}\text { Heater at Column C, Row 2. Thermo- } \\
\text { couple } 38 \text { in. }\left(225^{\circ}\right) \text { above bottom } \\
\text { of core. }\end{array}$ & & & 150,151 & \\
\hline
\end{tabular}




\section{TABLE V (continued)}

\begin{tabular}{|c|c|c|c|c|c|}
\hline \multirow[b]{2}{*}{ Measurement } & \multirow[b]{2}{*}{ Location and Comments ${ }^{[a]}$} & \multicolumn{2}{|c|}{ Range $^{[\mathrm{a}]}$} & \multirow[b]{2}{*}{ Figure $^{[a]}$} & \multirow[b]{2}{*}{ Measurement Comments $[\mathrm{b}]$} \\
\hline & & Detector & $\begin{array}{l}\text { Data Acquisition } \\
\text { System }\end{array}$ & & \\
\hline \multicolumn{6}{|c|}{ Low Power Heaters (continued) } \\
\hline $\begin{array}{l}\mathrm{TH}-\mathrm{C} 4-26 \\
\mathrm{TH}-\mathrm{C} 4-53\end{array}$ & $\begin{array}{l}\text { Heater at colutnn } C \text {, Row } 4 \text {. Therno- } \\
\text { couples } 26 \text { in. }\left(75^{\circ}\right) \text { and } 53 \text { in. } \\
\left(300^{\circ}\right) \text { above bot tom of core. }\end{array}$ & & & $\begin{array}{l}\text { 152, } 153 \\
154,155\end{array}$ & \\
\hline TH-C5-28 & $\begin{array}{l}\text { Heater at column C, Row 5. Therno- } \\
\text { couple } 28 \text { in. }\left(315^{\circ}\right) \text { above bottom } \\
\text { of core. }\end{array}$ & & & 156,157 & \\
\hline $\begin{array}{l}\text { TH-C7-07 } \\
T H=C 7=15\end{array}$ & $\begin{array}{l}\text { Heater at Column } c \text {, Row } 7 \text { Thermo- } \\
\text { couples } 7 \text { in. }\left(345^{\circ}\right) \text { and is in. } \\
\left(255^{\circ}\right) \text { above bottom of core. }\end{array}$ & & & $\begin{array}{l}158,159 \\
160,161\end{array}$ & \\
\hline$T H-01-21$ & $\begin{array}{l}\text { Heater at column } 0 \text {, Row } 1 \text {. Therno- } \\
\text { couple } 21 \text { in. }\left(330^{\circ}\right) \text { above bottom } \\
\text { of core. }\end{array}$ & & & 162,163 & \\
\hline $\begin{array}{l}T H-02-14 \\
T H=02=61\end{array}$ & $\begin{array}{l}\text { Heater at Column } D \text {, Row } 2 \text {. Thermo- } \\
\text { coupl I in. } 14 \text { in ond } 61 \text { in. } \\
\left(270^{\circ}\right) \text { above bottom of core. }\end{array}$ & & & $\begin{array}{l}164,165 \\
166,167\end{array}$ & \\
\hline $\begin{array}{l}\text { TH-D3-29 } \\
\text { TH-03-39 }\end{array}$ & $\begin{array}{l}\text { Heater at column D, Row } 3 \text {. Thermo- } \\
\text { couples } 29 \text { in. (150) and } 39 \text { in. } \\
\left(20^{\circ}\right) \text { abave bot tom of core. }\end{array}$ & & & $\begin{array}{l}168,169 \\
170,171\end{array}$ & \\
\hline $\begin{array}{l}\text { TH-06-15 } \\
\text { TH-06-25 }\end{array}$ & $\begin{array}{l}\text { Heater at Column o, Row } 6 \text {. Thermo- } \\
\text { couples } 15 \text { in }\left(90^{\circ}\right) \text { and } 25 \text { in. }\left(255^{\circ}\right) \\
\text { above bottom of core. }\end{array}$ & & & $\begin{array}{l}172,173 \\
174,175\end{array}$ & . \\
\hline TII- $07-20$ & $\begin{array}{l}\text { Healer al Colwing D, Ruw } 7 \text {. Therran- } \\
\text { couple } 20 \text { in. }\left(60^{\circ}\right) \text { above bottom } \\
\text { of core. }\end{array}$ & & & 176,177 & \\
\hline $\begin{array}{l}\text { TH-08-27 } \\
\text { TH-D8-57 }\end{array}$ & $\begin{array}{l}\text { Heater at column } 0 \text {, Row 8. Thermo- } \\
\text { couples } 27 \text { in. }\left(180^{\circ}\right) \text {, and } 57 \text { in. }\left(15^{\circ}\right) \\
\text { above oot tom of core. }\end{array}$ & & & $\begin{array}{l}178,179 \\
180.18 i\end{array}$ & $\because$ \\
\hline TH-E1-33 & $\begin{array}{l}\text { Heater at column E, Row 1. Therno- } \\
\text { couple } 33 \text { in. }\left(60^{\circ}\right) \text { above bottom of } \\
\text { core. }\end{array}$ & & & 182,183 & . \\
\hline $\begin{array}{l}\text { TH- } 22-20 \\
T H-\varepsilon 2-33\end{array}$ & $\begin{array}{l}\text { Heater at column E, Row } 2 \text {. Thermo- } \\
\text { couples } 20 \text { in. }\left(210^{\circ}\right) \text { and } 33 \text { in. } \\
\left(315^{\circ}\right) \text { obove bot tom of core. }\end{array}$ & & & $\begin{array}{l}184,185 \\
186,187\end{array}$ & \\
\hline $\begin{array}{l}\text { TH-E3-05 } \\
T H-E 3-20 \\
T H-E 3-24\end{array}$ & $\begin{array}{l}\text { Heater at column E, Row } 3 \text {. Therno- } \\
\text { couples } 5 \text { in }\left(15^{\circ}\right), 20 \text { in. }\left(165^{\circ}\right) \text {, } \\
\text { and } 24 \text { in. }\left(75^{\circ}\right) \text { above bottom of } \\
\text { core. }\end{array}$ & & & $\begin{array}{l}188,189 \\
190, \\
192, \\
193\end{array}$ & . \\
\hline $\begin{array}{l}\text { TH-E6-08 } \\
\text { TH-E6-28 } \\
\text { TH-F }-6-37\end{array}$ & 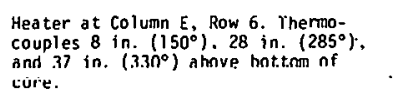 & & & $\begin{array}{l}194,195 \\
196,197 \\
198,199\end{array}$ & $\therefore$ \\
\hline$T H-E 7-44$ & $\begin{array}{l}\text { Heater at Column } E \text {, Row } 7 \text {. Thermo- } \\
\text { couple } 44 \text { in. }\left(195^{\circ}\right) \text { above bottom } \\
\text { of corc. }\end{array}$ & & & 200.201 & \\
\hline $\begin{array}{l}\text { TH-E8-14 } \\
\text { TH-E8-29 } \\
\text { TH-E8-45 }\end{array}$ & $\begin{array}{l}\text { Heater at column E, Row 8. Thermo- } \\
\text { couples } 14 \text { in. }\left(150^{\circ}\right), 29 \text { in. }\left(225^{\circ}\right) \text {. } \\
\text { and } 45 \text { in. }\left(300^{\circ}\right) \text { above bottom of } \\
\text { core. }\end{array}$ & & & $\begin{array}{l}\text { 202, } 203 \\
204,205 \\
206,207\end{array}$ & \\
\hline $\begin{array}{l}\text { TH-FY-07 } \\
\text { TH-F2-22 } \\
T H-F 2-25\end{array}$ & $\begin{array}{l}\text { Heater at (n) unn F, Row } 2 \text {. Thermo- } \\
\text { couples } 7 \text { in }\left(255^{\circ}\right) .22 \text { in. }\left(105^{\circ}\right) \text {. } \\
\text { and } 25 \text { in. }\left(0^{\circ}\right) \text { above bottom of core. }\end{array}$ & & & $\begin{array}{l}208,209 \\
210,211 \\
212,213\end{array}$ & \\
\hline $\begin{array}{l}\text { TH-F4-14 } \\
\text { TH-F4-29 } \\
\text { TH-F4-44 }\end{array}$ & 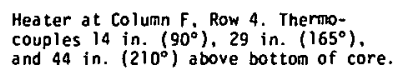 & & & $\begin{array}{l}214,215 \\
216,217 \\
218,219\end{array}$ & " \\
\hline $\begin{array}{l}T H-F 5-20 \\
T H-F 5-26 \\
T H-F 5-33 \\
T H-F 5-53\end{array}$ & $\begin{array}{l}\text { Heater at columin } F \text {, Row } 5 . \text { Thermo- } \\
\text { couples } 20 \text { in. }\left(255^{\circ}\right), 26 \text { in. }\left(115^{\circ}\right) \text {, } \\
33 \text { in. }\left(315^{\circ}\right) \text {, and } 53^{\circ} \text { in. }\left(30^{\circ}\right) \text { above } \\
\text { bot tom of core. }\end{array}$ & & & $\begin{array}{l}220,221 \\
222,223 \\
224,225 \\
226,227\end{array}$ & \\
\hline$T H-63-13$ & $\begin{array}{l}\text { Heater at column G, Row 3. Thermo- } \\
\text { couple } 13 \text { in. }\left(150^{\circ}\right) \text { above bot tom } \\
\text { of core. }\end{array}$ & & & 228,229 & \\
\hline $\begin{array}{l}T H-64-29 \\
T H 1-64-3 J \\
T H-64-38\end{array}$ & 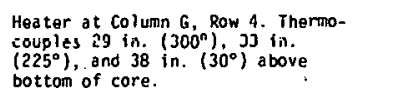 & & & $\begin{array}{l}230,231 \\
239,233 \\
234,235\end{array}$ & \\
\hline $\begin{array}{l}\text { TH-65-14 } \\
\text { TH-65-24 }\end{array}$ & $\begin{array}{l}\text { Heater at column } G \text {, Row } 5 \text {. Thermo- } \\
\text { couples } 14 \text { in. }\left(45^{\circ}\right) \text { and } 24 \text { in. } \\
\left(330^{\circ}\right) \text { above bottom of core. }\end{array}$ & & & $\begin{array}{l}236,237 \\
238,239\end{array}$ & \\
\hline TH-H5-32 & $\begin{array}{l}\text { Heater at Column H, Row 5. Thermo- } \\
\text { couple } 32 \mathrm{in} .\left(45^{\circ}\right) \text { above bottom } \\
\text { of core. }\end{array}$ & & & 240,241 & \\
\hline
\end{tabular}


TABLE V (continued)

\begin{tabular}{|c|c|c|c|c|c|}
\hline \multirow[b]{2}{*}{ Measurenient } & \multirow[b]{2}{*}{ Location and Comments ${ }^{[a]}$} & \multicolumn{2}{|c|}{ Range $^{[a]}$} & \multirow[b]{2}{*}{ Figure[a] } & \multirow[b]{2}{*}{ Measurement comments $[\mathrm{b}]$} \\
\hline & & Detector & $\begin{array}{l}\text { Data Acquisition } \\
\text { System }\end{array}$ & & \\
\hline \multicolumn{6}{|l|}{ PRESSURE } \\
\hline Intact Loop & $\cdot$ & $\begin{array}{l}0 \text { to } 3000 \\
\text { psi }\end{array}$ & $\cdot \quad \cdot$ & & . \\
\hline PU-13 & $\begin{array}{l}\text { cold leg, spool 13,54 in. from } \\
\text { vessel center. }\end{array}$ & & 0 to 4600 psia & 242,243 & Failed on Test S-05-6. \\
\hline PU-15L & $\begin{array}{l}\text { Cold leg, Spool } 15,16 \text { in. from } \\
\text { vessel center, to a tmosphere } \\
\text { (low range). }\end{array}$ & 0 to $500 \mathrm{psi}$ & 0 to 500 psia & 244,245 & 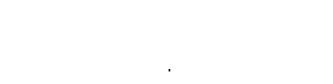 \\
\hline Broken Loop & & $\begin{array}{l}0 \text { to } 3000 \\
\text { psi }\end{array}$ & & & \\
\hline$P 8-23$ & $\begin{array}{l}\text { Cold lcg, Spool } 23,92 \text { in. from } \\
\text { vessel center, upstream of nozzle } \\
\text { (tee off oP taol. }\end{array}$ & & 0 to 4400 psia & 246,247 & Fasled on Test $5-05-6$ \\
\hline op 77 & $\begin{array}{l}\text { Gold log, \{pogl } 37, \text { goa in. from } \\
\text { vessel center along hot leg. }\end{array}$ & & O ló $+700 \mu$ s lu & 240,249 & $=\quad:$ \\
\hline$\Gamma D-42$ & $\begin{array}{l}\text { Cold leg, spool } 42,415 \text { in. from } \\
\text { vessel center a long hot leg, up- } \\
\text { stream of pumn-side nnmle too } \\
\text { off or tap). }\end{array}$ & & 0 to 4800 psia & 250,231 &. \\
\hline P8-HNI & $\begin{array}{l}\text { Pump-side nozzle, nozzle throat, } \\
419 \text { in. from vessel center olong } \\
\text { hot leg (tee off op tap). }\end{array}$ & & 0 to 4600 psia & 252,253 &. \\
\hline$P B-C N 1$ & $\begin{array}{l}\text { Cold leg, Spool } 23 \text {, vessel-side } \\
\text { nozzlc, nozzlc throat, } 96 \text { in. } \\
\text { from vessel center along cold } \\
\text { leg. } 45^{\circ} \text {. }\end{array}$ & 0 to $2500 \mathrm{psi}$ & 0 to 3100 psia & 254,255 & . \\
\hline $\mathrm{PB}-\mathrm{CH} 2$ & $\begin{array}{l}\text { Cold leg, spool } 23 \text {, vessel-side } \\
\text { nozzle, nozzle throat, } 96 \text { in. } \\
\text { from vesssel center alona cold } \\
\text { ?eg, } 315^{\circ} \text {. }\end{array}$ & o to 2500 psi & 0 to 4500 psia & 256,257 & . \\
\hline $\mathrm{PB}-\mathrm{CN} 3$ & $\begin{array}{l}\text { Cold leg, Spooi } 23 \text {, vessel-side } \\
\text { nozzle at begining of nozzle } \\
\text { divergent section, } 97 \text { in. from } \\
\text { vessel center olong cold leg, } 0^{\circ} \text {. }\end{array}$ & & 0 to 4700 psia & 258,259 & \\
\hline PB-CN4 & 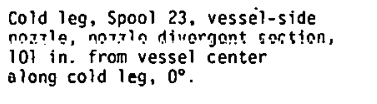 & & 0 to 4800 psia & 260,261 & \\
\hline \multicolumn{6}{|l|}{ Vessel } \\
\hline$P V-U P+10$ & $\begin{array}{l}\text { In upper plenum, } 10 \text { in. above cold } \\
\text { leg center line, mounted on standoff, } \\
30^{8} \text {. }\end{array}$ & 0 to 3000 psi & 0 to 4900 psía & 262,263 & . \\
\hline PV-LP-166 & $\begin{array}{l}\text { In upper part of lower plenum, } 166 \\
\text { in. below coid leg centerline, } \\
\text { mounted on } 3 \text { tandoff, } 225^{\circ} \text {. }\end{array}$ & & O to 4900 psia & 264,265 & . \\
\hline ECC System. & & 0 to $1000 \mathrm{psi}$ & & & . \\
\hline PU-ACC & In intact loop accumulator. & & 0 to 1200 psia & 266,267 & \\
\hline \multicolumn{6}{|l|}{ Steam Generator } \\
\hline PU-56SO & Secondary side steam dome. & $\begin{array}{l}0 \text { to } 3000 \\
\text { psi }\end{array}$ & 0 to 2000 psia & 270.271 & \\
\hline Pressurizer & & & : & & . \\
\hline PU-PRIZE & Pressurizer steam dome. & $\begin{array}{l}0 \text { to } 2500 \\
\text { nsi }\end{array}$ & 0 to 3200 psia & 272,273 & . . \\
\hline$\frac{\text { Pressure Suporession }}{\underline{\text { yustwut }}}$ & & & & & . \\
\hline P-PSS & Suppression tank top. & 0 to 250 psi & 0 to $340 \mathrm{ps} i a$ & 274,275 & $\cdot$ \\
\hline DIFFERENTIAL PRESSURE & $\begin{array}{l}\text { Elevation difference between } \\
\text { transducer taps is zcro unlcss } \\
\text { ullierwise suecified. }\end{array}$ & & & . & 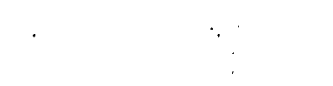 \\
\hline Intact Loop & & & & & \\
\hline nPII=1IP-3 & $\begin{array}{l}\text { lippor planum in } 5 \text { in amuse } \\
\text { cold leg centerline at } 30^{\circ} \text { to } \\
\text { hot ley, Spuul } 3,62 \text { in. ruull } \\
\text { vessel center. Upper plenum tap } \\
\text { is approximately } 2 \text { in. above Spool } \\
3 \text { tap. }\end{array}$ & $\begin{array}{l} \pm 5 n \text { in } \\
\text { water }\end{array}$ & \pm 25 prid & 276; 277 & $\begin{array}{l}\text { sats arquicition syctem } \\
\text { saturated prior to } t=0 \text { sec } \\
\text { and intemittently until } \\
t=1 \text { sec. }\end{array}$ \\
\hline
\end{tabular}


TABLE $\vee$ (continued)

\begin{tabular}{|c|c|c|c|c|c|}
\hline \multirow[b]{2}{*}{ Measurement } & \multirow[b]{2}{*}{ Location and Comments $[\mathrm{a}]$} & \multicolumn{2}{|c|}{ Range $^{[a]}$} & \multirow[b]{2}{*}{ Figure $^{[a]}$} & \multirow[b]{2}{*}{ Measurement Comments $[\mathrm{b}]$} \\
\hline & & Detector & $\begin{array}{l}\text { Data Acquisition } \\
\text { System }\end{array}$ & & \\
\hline \multicolumn{6}{|c|}{ Intact Logg (cont inued) } \\
\hline DPU-3-7 & $\begin{array}{l}\text { Across stean generator, hot leg } \\
\text { Spool } 3 \text {, 62 in. from vessel center } \\
\text { to cold leg Spool } 7,231 \text { in. from } \\
\text { vessel center. Spool } 3 \text { tap is } \\
\text { approximately } 18 \text { in. above Spool } \\
7 \text { tap. }\end{array}$ & $\begin{array}{l} \pm 500 \text { in. } \\
\text { water. }\end{array}$ & \pm 25 psid & 278.279 & $\begin{array}{l}\text { Data acquisition system } \\
\text { saturated prior to } \\
t=2.5 \text { sec. }\end{array}$ \\
\hline DPU-6-SGIP & $\begin{array}{l}\text { Hot leg, Spool } 6,114 \text { in. from } \\
\text { vessel center to steam generator } \\
\text { inlet plenum } 145 \text { in. from } \\
\text { vessel center. Spool } 6 \text { tap is } \\
16 \text { in. below SGIP tap. }\end{array}$ & $\begin{array}{l} \pm 500 \mathrm{in} . \\
\text { water }\end{array}$ & \pm 24.6 psid & 280,281 & Test S-05-7 only. \\
\hline $\begin{array}{c}\text { DPU-SGOP-7 } \\
.\end{array}$ & $\begin{array}{l}\text { From steam generator outlet plenum, } \\
269 \text { in. from vessel center along } \\
\text { cold leg to cold leg Spool } 7,231 \text { in. } \\
\text { from vessel center. including orifice, } \\
\text { Spool } 7 \text { tap is } 35 \text { in. below SGOP tap. }\end{array}$ & $\underset{\text { water }}{ \pm 500 \text { in. }}$ & \pm 24.5 psid & 282,283 & $\begin{array}{l}\text { Test } 5-05-7 \text { oniy. Data } \\
\text { acquisition system saturated. } \\
\text { prior to } t=4 \text { sec. }\end{array}$ \\
\hline DPU-7-10 & $\begin{array}{l}\text { Steam generator outlet to pump } \\
\text { inlet, cold leg Spool } 7,231 \text { in. } \\
\text { from vessel center, to cold leg } \\
\text { Spool 10, } 141 \text { in. from vessel } \\
\text { center. }\end{array}$ & $\begin{array}{l}+50 \text { in. } \\
\text { water }\end{array}$ & $\pm 2.5 \mathrm{psid}-$ & 284,285 & $\begin{array}{l}\text { Data acquisition system } \\
\text { saturated intermittently } \\
\text { between } t=0 \text { and } t=1.5 \mathrm{sec} \text {. }\end{array}$ \\
\hline DPU-12-10 & $\begin{array}{l}\text { Pump outlet to pump inlet, cold } \\
\text { leg Spool } 12,75 \text { in. from vessel } \\
\text { center, to cold leg Spool } 10,141 \\
\text { in. from vessel center. Spool } 10 \\
\text { tap is } 10 \text { in. below Spool } 12 \text { tap. }\end{array}$ & \pm 50 psi & \pm 50 psid & 286,287 & $\begin{array}{l}\text { Data acquisition system } \\
\text { saturated prior to } t=2.5 \\
\text { sec for Test } S-05.6 \text {. }\end{array}$ \\
\hline UPU-12-1UL & $\begin{array}{l}\text { Pump out let to pump inlet, cold } \\
\text { leg Spool } 12,75 \text { in. from vessel } \\
\text { center, to cold leg Spool } 10,141 \\
\text { in. from vessel center. Spool } 10 \\
\text { tap is } 10 \text { in. below Spool } 12 \text { tap } \\
\text { (luw range). }\end{array}$ & $\frac{+100 \text { in. }}{\text { water }}$ & $\pm 4.9 \mathrm{psid}$ & 288,289 & $\begin{array}{l}\text { Data acquisition system } \\
\text { saturated prior to } \\
5 \text { sec. }\end{array}$ \\
\hline DPU- $12-15$ & $\begin{array}{l}\text { Across cold leg injection point, } \\
\text { cold leg Spool } 12,75 \text { in. from vessel } \\
\text { center, to cold leg Spool } 15,16 \text { in. } \\
\text { from vessel center. }\end{array}$ & $\begin{array}{l} \pm 100 \mathrm{in} . \\
\text { water }\end{array}$ & \pm 4.9 psid & $\begin{array}{l}290,291 \\
292,293\end{array}$ & $\begin{array}{l}\text { Data acquisition system } \\
\text { saturated intermittently } \\
\text { between } t=0 \text { and } t=4 \text { sec for } \\
\text { Test } 5-05-6 \text { and between } t=0 \\
\text { and } t=5 \text { sec for Test } S-05-7 \text {. }\end{array}$ \\
\hline OPU-15-1 & $\begin{array}{l}\text { Cold leg to hot leg; cold leg Spool } \\
15,16 \text { in. from vessel center. to } \\
\text { hot leg Spool } 1,31 \text { in. from vessel } \\
\text { center. Spool is tap is } 8.5 \text { in. } \\
\text { below Spool } 1 \text { țap. }\end{array}$ & $\begin{array}{l} \pm 500 \text { in. } \\
\text { water }\end{array}$ & \pm 25 psid & 294,295 & \\
\hline DPU-15-1L & $\begin{array}{l}\text { cold leg to hot leg, cold leg Spool } \\
15, \text { in in. from vessel center, to } \\
\text { hot leg spool i, 31 fil. fruili vessel } \\
\text { center. Spool is tap is } 8.5 \text { in. below } \\
\text { spool i tap (low range). } \\
\text {, }\end{array}$ & $\begin{array}{l}+100 \mathrm{in} . \\
\text { water }\end{array}$ & \pm 4.9 psid & $\begin{array}{l}296,297 \\
298,299\end{array}$ & 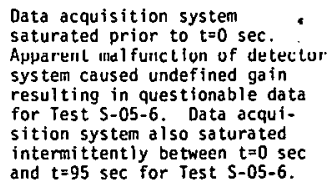 \\
\hline DPU-15-IANN & $\begin{array}{l}\text { Cold leg Spool } 15,16 \text { in. from } \\
\text { vessel center, to inlet annulus, } 9 \\
\text { in below cold leg centerline ot } \\
225^{\circ} \text {. spool is tap is } 9 \text { in. above } \\
\text { inlet annulus tap. }\end{array}$ & \pm 100 in. & \pm 4.9 psid & $\begin{array}{l}300,301 \\
302,303\end{array}$ & $\begin{array}{l}\text { Data acquisition system } \\
\text { saturated between } t=0 \\
t=0.5 \text { ser. }\end{array}$ \\
\hline DPU-PRESLL & $\begin{array}{l}\text { Pressurizer water level. Eleva- } \\
\text { tion difference between taps is } \\
53 \text { in. Lower tap is } 3.5 \text { in. above } \\
\text { pressurizer exit. }\end{array}$ & $\begin{array}{l} \pm 50 \text { in. } \\
\text { water }\end{array}$ & \pm 2.5 psid & 304,305 & \\
\hline DPU-PR-4 & $\begin{array}{l}\text { Pressurizer bottoni to spool } 4 \text {. Eleva. } \\
\text { tion difference between taps is } \\
62 \text { in. Spool } 4 \text { tap is } 55 \text { in. below } \\
\text { pressurizer exit. }\end{array}$ & $\pm 1000 \mu \mathrm{si}$ & \pm 1300 psid & 306,307 & \\
\hline \multicolumn{6}{|l|}{ Broken loop } \\
\hline DPB-UP-30 & $\begin{array}{l}\text { Vessel upper plenum, } .10 .5 \text { in, above } \\
\text { cold leg centerline at } 30^{\circ} \text {, to hot } \\
\text { leg Spool } 30 \text {, } 18 \text { in. from vessel } \\
\text { center. Upper plenum tap is } 2 \text { in. } \\
\text { above Spool } 30 \text { tap. }\end{array}$ & $\underset{\text { water }}{+100 \text { in. }}$ & \pm 4.8 psid & $\begin{array}{l}308,309 \\
310,311\end{array}$ & • \\
\hline DPB-21-IANN & $\begin{array}{l}\text { Cold leg Spool } 21,49 \text { in. from } \\
\text { vessel center, to vessel inlet } \\
\text { annulus, } 9 \text { in. below cold leg } \\
\text { centerifne at } 225^{\circ} \text {. Inlet annulus } \\
\text { tap is } 9 \text { in, below Spool } 21 \text { tap. }\end{array}$ & $\begin{array}{l} \pm 100 \text { in. } \\
\text { water }\end{array}$ & \pm 4.8 psid & $\begin{array}{l}312,313 \\
314,315\end{array}$ & $\bullet$ \\
\hline $\mathrm{DPB}-23-\mathrm{CN} 3$ & $\begin{array}{l}\text { Cold leg, } 5 \text { pool } 23,92 \text { in. from } \\
\text { vessel center to vessel-side } \\
\text { nozzle throat, } 95 \text { in. from vessel } \\
\text { center. }\end{array}$ & \pm 1500 ps 1 & \pm 2000 psid & 316,317 & \\
\hline
\end{tabular}




\begin{tabular}{|c|c|c|c|c|c|}
\hline \multirow[b]{2}{*}{ Measurement } & \multirow[b]{2}{*}{ Location and Comments ${ }^{[a]}$} & \multicolumn{2}{|c|}{ Range [a] $^{[a]}$} & \multirow[b]{2}{*}{ Figure $^{[a]}$} & \multirow[b]{2}{*}{ Measurement Comments [ $\mathrm{b}]$} \\
\hline & & Detector & $\begin{array}{l}\text { Data Acquisition } \\
\text { System }\end{array}$ & & \\
\hline \multicolumn{6}{|c|}{ Broken Loog (continued) } \\
\hline OPB-CN1-PSS- 63 & $\begin{array}{l}\text { From vessel-side nozzle throat, } \\
96 \text { in. from vessel center to } \\
\text { pressure suppression tank, } 353 \\
\text { in. from vessel center a long } \\
\text { cold leg. Tap is } 63 \text { in. above } \\
\text { suppression tank bottom. }\end{array}$ & \pm 1500 psi & \pm 2000 psid & 318,319 & . \\
\hline$D P B-30-36 \mathrm{~L}$ & $\begin{array}{l}\text { Across entire simulated steam gen- } \\
\text { erator assembly, hot leg Spool } 30, \\
18 \text { in. from vessel center, to cold } \\
\text { leg Spool } 36 \text { lower tap, } 242 \text { in. } \\
\text { from vessel center. Spool } 30 \text { tap is } \\
19 \text { in. below Spool } 36 \text { lower tap. }\end{array}$ & $\pm 500 \mathrm{psi}$ & \pm 500 psid & 320,321 & - \\
\hline $\begin{array}{l}\text { DPB-32U-36L } \\
\cdot\end{array}$ & 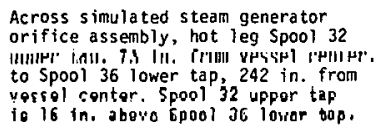 & \pm 500 psi & $\pm 500 \mathrm{psid}$ & 322,323 & \\
\hline DPB-36L-37 & $\begin{array}{l}\text { Across nozzle assembly, Spool } 36 \\
\text { lower tap, } 242 \text { in. from vessel } \\
\text { center a long hot ieg, to Spool } 37 \text {. } \\
282 \text { in. from vessel center a long } \\
\text { hot leg. Spool } 37 \text { tap is } 40 \text { in. } \\
\text { below Spool } 36 \text { lower tap. }\end{array}$ & \pm 50 psi & \pm 50 psid & 324,325 & \\
\hline $\mathrm{DPB}-37-38$ & $\begin{array}{l}\text { Across turbine flowmeter and drag } \\
\text { disc, coid leg Spool } 37,282 \text { in. } \\
\text { from vessel center along hot leg. to } \\
\text { cold leg Spool } 38,305 \text { in. from } \\
\text { vessel center along hot leg. Spool } \\
37 \text { tap is } 23 \text { in. above Spool } 38 \text { tap. }\end{array}$ & $\begin{array}{l} \pm 50 \mathrm{in} . \\
\text { water }\end{array}$ & $\pm 2.5 \mathrm{psid}$ & 326,321 & \\
\hline$U P H-38-4 V$ & $\begin{array}{l}\text { Across simulated pump, cold leg } \\
\text { Spool } 38,305 \text { in. from vessel center } \\
\text { along hot leg, to cold leg } 5 p o o l ~ 40, \\
365 \text { in. from vessel center along hot } \\
\text { leg. }\end{array}$ & $\pm 1000 \mathrm{psi}$ & $\pm 1300 \mathrm{psid}$ & 328,329 & \\
\hline DPB-40-42 & $\begin{array}{l}\text { Across elbow leading to spool up- } \\
\text { stream of pump-side nozzle. Cold } \\
\text { leg Spmol } 40.365 \text { in. frnm vessel } \\
\text { center along hot leg, to Spool } 42 \text {, } \\
415 \text { in. from vessel center along } \\
\text { hot leg. Spool } 40 \text { top is } 40 \text { in. } \\
\text { below Spool } 42 \text { tap. }\end{array}$ & $\begin{array}{l}+50 \text { in. } \\
\text { water }\end{array}$ & \pm 2.4 psid & $\begin{array}{l}330,331 \\
332,333\end{array}$ & $\begin{array}{l}\text { Data acquisition system } \\
\text { saturated between } t=0 \text { and } \\
t=10.5 \text { sec for Tes } t=05-6 \\
\text { and saturated intermittently } \\
\text { petween } t=0 \text { and } t=23.5 \mathrm{sec} \\
\text { for Test } S-05-7 \text {. }\end{array}$ \\
\hline \multicolumn{6}{|l|}{ Vessel } \\
\hline$B Q V=U P=I A N H$ & 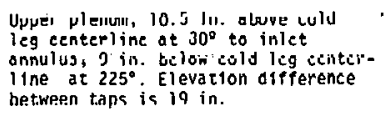 & Tiater" & $I 14.7 \mu \mathrm{s} / \mathrm{d}$ & $334, j 35$ & $\begin{array}{l}\text { yata acquisiciun system } \\
\text { satul a led letween l=0 and } \\
\text { l=1 sel. }\end{array}$ \\
\hline$D P V-0.96 Q$ & $\begin{array}{l}\text { Inlet annulus cold leg centerline at } \\
90^{\circ} \text {, to } 9 \text { in. below cold leg center- } \\
\text { line at } 225^{\circ} \text {. Elevation difference } \\
\text { between taps is } 9 \text { in. }\end{array}$ & $\begin{array}{l} \pm 50 \text { in. } \\
\text { water }\end{array}$ & $\pm 2.6 \mathrm{psid}$ & $\begin{array}{l}336,337 \\
338,339\end{array}$ & \\
\hline DPV-9-26QQ & $\begin{array}{l}\text { Inlet annulus, } 9 \text { in. below cold leg } \\
\text { centerline at } 225^{\circ} \text {, to downcomer gap. } \\
28 \text { in. below cold ieg centerisne at } \\
225^{\circ} \text {. El evation difference between. } \\
\text { taps is } 17 \text { in. }\end{array}$ & $\begin{array}{l}+50 \text { in. } \\
\text { wa ter }\end{array}$ & +2.4 psid & $\begin{array}{l}340,341 \\
342,343\end{array}$ & \\
\hline DPV-9-1660Q & $\begin{array}{l}\text { Inlet annulus, } 9 \text { in. below cold leg } \\
\text { centerline at } 225^{\circ} \text {, to lower plenum, } \\
166^{2} \text { in. below cold leg centerline } \\
\text { at } 225^{\circ} \text {. Elevation difference be- } \\
\text { tween taps is } 157 \text { in. }\end{array}$ & $\begin{array}{l} \pm 300 \text { in. } \\
\text { noter. }\end{array}$ & \pm 14.5 psid : & $\begin{array}{l}344,345 \\
346,347\end{array}$ & \\
\hline$U P V-\angle B-53 U M$ & 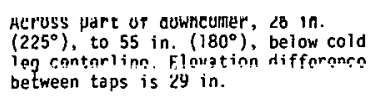 & $\begin{array}{l}+50 \text { in. } \\
\text { water }\end{array}$ & \pm 3.0 psso & $\begin{array}{l}348,349 \\
350,351\end{array}$ & . \\
\hline OPV-55-110444 & $\begin{array}{l}\text { Across part of downcomer, } 55 \text { in. } \\
\left(180^{\circ}\right) \text {, to } 10 \text { in. }\left(180^{\circ}\right) \text {, below } \\
\text { cold leg centerline. Elevation } \\
\text { differenre het,ween taps is } 55 \text { in. }\end{array}$ & $\begin{array}{l}+100 \text { in. } \\
\text { water }\end{array}$ & \pm 4.9 psid & $\begin{array}{l}352,353 \\
354,355\end{array}$ & . \\
\hline DPV-110-156MQ & $\begin{array}{l}\text { Across part of downcomer, } 110 \text { in. } \\
\left(180^{\circ}\right) \text {, to } 156 \text { in. }\left(225^{\circ}\right) \text {, below cold } \\
\text { leg centerline. Elevation difference } \\
\text { between taps is } 46 \text { in. }\end{array}$ & \pm 100 in. & \pm 4.9 psid & $\begin{array}{l}356,357 \\
358,359\end{array}$ & \\
\hline DPV- $166-17300$ & $\begin{array}{l}\text { Across part of lower plenum, } 166 \text { in. } \\
\left(225^{\circ}\right) \text {, to } 173 \text { in. }\left(225^{\circ}\right) \text {, below cold } \\
\text { leg centerline. Elevation difference } \\
\text { between taps is } 7 \text { in. }\end{array}$ & $\begin{array}{l}+20 \mathrm{in} . \\
\text { water }\end{array}$ & \pm 0.98 psid & 360,361 & . \\
\hline
\end{tabular}




\begin{tabular}{|c|c|c|c|c|c|}
\hline \multirow[b]{2}{*}{ Measurement } & \multirow[b]{2}{*}{ Location and Comments ${ }^{[\mathrm{a}]}$} & \multicolumn{2}{|c|}{ Range $[\mathrm{a}]$} & \multirow{2}{*}{ Figure $^{[a]}$} & \multirow[b]{2}{*}{ Measurement Comments $[\mathrm{b}]$} \\
\hline & & Detector & $\begin{array}{l}\text { Data Acquisition } \\
\text { System }\end{array}$ & & \\
\hline \multicolumn{6}{|l|}{ Vessel (continued) } \\
\hline OPV-1660-UP & $\begin{array}{l}\text { Lower plenum, } 166 \text { in. below cold } \\
\text { leg centerline at } 225^{\circ} \text {, to upper } \\
\text { plenum, } 10.5 \text { in. above cold } 1 \mathrm{eg} \\
\text { centerline at } 30^{\circ} \text {. Elevation dif- } \\
\text { ference between taps is } 177 \text { in. }\end{array}$ & $\begin{array}{l} \pm 300 \text { in. } \\
\text { water }\end{array}$ & \pm 14.7 psid & 362,363 & $\begin{array}{l}\text { Data acquisition system } \\
\text { saturated betrreen } t=0 \\
\text { and } t=1 \text { sec. }\end{array}$ \\
\hline \multicolumn{6}{|l|}{ ECC SYSTEM } \\
\hline DPU-ACC-TB & $\begin{array}{l}\text { Top to bottom of intact loop } \\
\text { accumulator. Elevation difference } \\
\text { between taps is } 108 \text { in. }\end{array}$ & $\begin{array}{l}+500 \text { in. } \\
\text { water }\end{array}$ & \pm 16.0 psid & 364,365 & . \\
\hline $\mathrm{DPB}-\mathrm{ACC}-\mathrm{TB}$ & $\begin{array}{l}\text { Top to bottom of broken loop accumu- } \\
\text { lator tank. Elevation difference be- } \\
\text { twcen taps is } 84 \text { in. }\end{array}$ & $\begin{array}{l}+300 \text { in. } \\
\text { water }\end{array}$ & $\pm 15: 0$ psid & 366,367 & \\
\hline \multicolumn{6}{|l|}{ Steam Generator } \\
\hline DPU-SG-SEC & $\begin{array}{l}\text { Secondary side, differential pressure } \\
\text { taps at } 45 \text { in. and } 126 \text { in. above } \\
\text { botton of tube sheet. Elevation } \\
\text { difference between taps is } 81 \text { in. }\end{array}$ & $\begin{array}{l}\$ 100 \text { in. } \\
\text { wa ter }\end{array}$ & $\pm 5.0 \mathrm{psid}$ & 368,369 & \\
\hline DPU-5G-DISC & $\begin{array}{l}\text { Across venturi tube, } 65 \text { in. down- } \\
\text { stream from steam generator dis- } \\
\text { charge. }\end{array}$ & $\begin{array}{l}\text { too in. } \\
\text { water }\end{array}$ & $\pm 4.9 \mathrm{psid}$ & 370,371 & . \\
\hline VOLUMETRIC FLOW RATE & Turbine flowneter, bidirectional. & & . & & $\begin{array}{l}\text { Data acquisition system } \\
\text { range may exceed rated } \\
\text { detector range; however, } \\
\text { turbine response is } \\
\text { linear lu flow rates } \\
\text { well beyond the rated range. }\end{array}$ \\
\hline Intact Loop & 3-in. Schedule 160 pipe. & & & & \\
\hline FTII-1 & $\begin{array}{l}\text { Hnt leg, Snnn1 } 1,18 \mathrm{in} \text {, from } \\
\text { vessel center. }\end{array}$ & $\frac{+20}{\mathrm{~g} p m}$ to \pm 400 & $\pm 1800 \mathrm{gpm}$ & $\begin{array}{l}372,373 \\
374,375\end{array}$ & \\
\hline FTU-9 & $\begin{array}{l}\text { Cold leg. Spool 9, } 154 \text { in. from } \\
\text { vessel center. }\end{array}$ & $\frac{+80}{9 p m}$ to \pm 800 & $\pm 1800 \mathrm{gpm}$ & $\begin{array}{l}376,377 \\
378,379\end{array}$ & · \\
\hline FTU-13 & $\begin{array}{l}\text { Cold leg, Spool 13, } 64 \text { in. from } \\
\text { vessel center. }\end{array}$ & $\pm \frac{20}{9 \mathrm{pm}}$ to \pm 800 & $\pm 1800 \mathrm{gpm}$ & $\begin{array}{l}380,381 \\
382,383\end{array}$ & \\
\hline FTU-15 & $\begin{array}{l}\text { Cold leg, Spool } 15,29 \text { in. from } \\
\text { vessel center. }\end{array}$ & $\frac{ \pm 20}{\mathrm{gpm}}$ to \pm 800 & $\pm 1500 \mathrm{gpm}$ & $\begin{array}{l}384,385 \\
386,387\end{array}$ & \\
\hline Broken Loop & Schedule 160 pipe. & . & & & \\
\hline FTB-21 & $\begin{array}{l}\text { Cold leg, Spool } 21,58 \text { in. from } \\
\text { vessel center; } 3-\mathrm{in} \text {. pipe. }\end{array}$ & $\frac{+20}{9 p m}$ to \pm 400 & $\pm 1800 \mathrm{gpm}$ & 388,389 & $\begin{array}{l}\text { Positive flow indications in } \\
\text { the Test } S-05-6 \text { data prior to } \\
t=0 \text { scc arc attributed to noise } \\
\text { pickup by the detector system. }\end{array}$ \\
\hline FTB -30 & $\begin{array}{l}\text { Hot leg, Spool } 30,25 \text { in. from } \\
\text { vessel center; } 3-i n \text {. pipe. }\end{array}$ & $\frac{ \pm 20}{9 p m}$ to \pm 400 & $\pm 1200 \mathrm{gpm}$ & 390,391 & $\begin{array}{l}\text { Positive flow indications prior } \\
\text { to } t=0 \text { sec are attributed to noise } \\
\text { pickup by tle delectur system. }\end{array}$ \\
\hline FT8-37 & $\begin{array}{l}\text { Cold leg, Spool } 37,290 \text { in. from } \\
\text { vessel center along hot leg; } 2-\mathrm{in} \text {. } \\
\text { pipe. }\end{array}$ & $\frac{+20}{9 p m}$ to \pm 800 & $\pm 800 \mathrm{gpm}$ & 392,393 & $\begin{array}{l}\text { Flow prior to } t=0 \text { should not be } \\
\text { negative. There was no negative } \\
\text { flow prior to } t=0 \text { sec in the } \\
\text { broken loop. }\end{array}$ \\
\hline \multicolumn{6}{|l|}{ Conre } \\
\hline FTV-CORE-IN & $\begin{array}{l}\text { Entrance to core, } 2158 \text { in. below } \\
\text { cold leg centerline. }\end{array}$ & $\frac{ \pm 20}{9 p m}$ to \pm 200 & $\pm 1200 \mathrm{gpm}$ & 394,395 & $\begin{array}{l}\text { Detectors saturated at }-1000 \mathrm{gpm} \\
\text { and }-1200 \mathrm{gpm} \text { for Tests } 5-05-6 \\
\text { and } 5-05-7 \text { respectively. }\end{array}$ \\
\hline \multicolumn{6}{|l|}{ ECC System } \\
\hline FTU-LPIS & $\begin{array}{l}\text { In line leading from LPIS pump } \\
\text { for intact loop, } 1 / 2-i n \text {. line. }\end{array}$ & \pm 0.75 to \pm 7.5 & $\pm 10 \mathrm{gpm}$ & 396,397 & $\begin{array}{l}\text { 5-05-6 only. Positive flow } \\
\text { indicated prior to t=0 sec is } \\
\text { attributed to noise pickup by } \\
\text { the detector system, Data } \\
\text { acquisition system saturated } \\
\text { mnmorntarily when flnw first } \\
\text { started. }\end{array}$ \\
\hline FTV-LPIS & $\begin{array}{l}\text { In line leading from LPIS pump } \\
\text { for vessel upper plenum, } 1 / 2-i n \text {. } \\
\text { line. }\end{array}$ & $\frac{ \pm 0.75}{9 \mathrm{pm}}$ to \pm 7.5 & $\pm 10 \mathrm{gpm}$ & 398,399 & $\begin{array}{l}\text { S-05-7 only. Data acquisition } \\
\text { system saturated munieitalitily } \\
\text { when flow iirst startea. }\end{array}$ \\
\hline FTB-LPIS & $\begin{array}{l}\text { In line leading from LPIS pump } \\
\text { for broken loop, } 3 / 4-i n \text {. line }\end{array}$ & $\frac{ \pm 0.75 \text { to } \pm 7.5}{9 \mathrm{pm}}$ & $\pm 4 \mathrm{gpm}$ & 400,401 & $\begin{array}{l}\text { S-05-6 only. Broken loop LPIS } \\
\text { was not used during Test S-05-7. }\end{array}$ \\
\hline FTU-ACC & $\begin{array}{l}\text { In line leading from intact loop } \\
\text { accumulator, l-in. line. }\end{array}$ & $\frac{ \pm 5}{9 \mathrm{pm}}$ to \pm 50 & $\pm 70 \mathrm{gpm}$ & 402,403 & \\
\hline FTB-ACC & $\begin{array}{l}\text { In line leading from broken } 100 p \\
\text { accumulator, l-in. line. }\end{array}$ & $\frac{+5 \text { to }}{9 \mathrm{p} m} \pm 50$ & $\pm 70 \mathrm{gpm}$ & 404,405 & $\begin{array}{l}\text { The data acquisition system } \\
\text { mal functioned for flow rates } \\
\text { greater than wa gpm causing } \\
\text { invalid data measurements from } \\
t=92 \text { to } 116 \text { sec for Test } 5-05-6 \\
\text { and from to- to } 129 \text { sec for } \\
\text { Test. } \$-05-7 \text {. }\end{array}$ \\
\hline
\end{tabular}




\begin{tabular}{|c|c|c|c|c|c|}
\hline \multirow{2}{*}{ Measurement } & \multirow[b]{2}{*}{ Location and Comments [a] } & \multicolumn{2}{|c|}{$\operatorname{Range}^{[a]}$} & \multirow[b]{2}{*}{ Figure $^{[a]}$} & \multirow[b]{2}{*}{ Measurement Comments ${ }^{[\mathrm{b}]}$} \\
\hline & & Detector & $\begin{array}{c}\text { Data Acquisition } \\
\text { System }\end{array}$ & & \\
\hline Pressurizer & 1-1/2-in. turbine. & & & & \\
\hline FTU-PRIZE & Surge line. & $\frac{+5}{9 p m}$ to \pm 50 & $\pm 100 \mathrm{gpm}$ & 406,407 & $\begin{array}{l}\text { Positive flow indicated prior } \\
\text { to } t=0 \text { sec is attributed to noise } \\
\text { pickup by the detector system. }\end{array}$ \\
\hline FLUID VELOCITY & Turbine flowmeter, bidirectional. & & & & $\begin{array}{l}\text { Detectors saturated for neg- } \\
\text { ative flow velocities greater } \\
\text { than } 60 \mathrm{ft} / \mathrm{sec} \text {. }\end{array}$ \\
\hline \multicolumn{6}{|l|}{ Downcomer } \\
\hline FTV-40A & $\begin{array}{l}40 \text { in, below cold leg centerline, } \\
0^{\circ} \text {. }\end{array}$ & $\begin{array}{l}+2.5 \text { to } 50 \\
\mathrm{ft} t / \mathrm{sec}\end{array}$ & $\pm 60 \mathrm{ft} / \mathrm{sec}$ & $\begin{array}{l}408,409 \\
410,411\end{array}$ & \\
\hline FTV-40M & $\begin{array}{l}40 \text { in. below cold leg centerline. } \\
180^{\circ} .\end{array}$ & $\begin{array}{l}\frac{1 \cdot 2.5}{f} \text { to } 50 \\
\text { t } / \mathrm{sec}\end{array}$ & $160 \mathrm{ft} / \mathrm{sec}$ & $\begin{array}{l}412,413 \\
414,415\end{array}$ & ; \\
\hline MUMENTUM FLUX & Urag disc, bidirectional. & & & . & $\begin{array}{l}\text { Urag oisc ada may. exhiblt } \\
\text { significant temperature } \\
\text { dependence. Drag disc data } \\
\text { should be used only for short- } \\
\text { term trans fent resporse. }\end{array}$ \\
\hline Intact Loop & 3-in. pipe. & & & & \\
\hline FDU-1 & $\begin{array}{l}\text { Hot leg, Spool } 1,29 \text { in. from } \\
\text { vessel center; target size } \\
0.875 \text { ill. }\end{array}$ & $\begin{array}{l} \pm 200 \text { to } \pm 11,500 \\
1 \text { linl/rb-stes }\end{array}$ & $\begin{array}{l} \pm 17,800 \\
1 \mathrm{Ln1} / \mathrm{rL}-\mathrm{sex} \mathrm{s}^{2}\end{array}$ & 416,417 & \\
\hline FDU-5 & $\begin{array}{l}\text { Hot leg, Spool } 5,100 \text { in. from } \\
\text { vessel center; target size } \\
\text { l.0 in. }\end{array}$ & $\begin{array}{l} \pm 1 \text { to } \pm 2000 \\
1 \mathrm{tm} / \mathrm{tt}-\sec ^{2}\end{array}$ & $\begin{array}{l} \pm 4700 \\
1 \mathrm{bm} / \mathrm{ft}-\sec ^{2}\end{array}$ & 418,419 & $\begin{array}{l}\text { Detector saturated prior to } \\
t=1 \text { sec. }\end{array}$ \\
\hline FDU- 10 & $\begin{array}{l}\text { Cold leg. Spool } 10,137 \text { in. from } \\
\text { vessel center; target size } 0.875 \text { in. }\end{array}$ & $\begin{array}{l} \pm 200 \text { to } \pm 104,000 \\
1 \mathrm{bm} / \mathrm{ft}-\sec ^{2}\end{array}$ & $\begin{array}{l} \pm 23,750 \\
7 \mathrm{bm} / \mathrm{ft}-\sec ^{2}\end{array}$ & 420,421 & \\
\hline FDU-13 & $\begin{array}{l}\text { Cold leg, Spool } 13,54 \text { in. from } \\
\text { vessel center; target size } 0.875 \mathrm{in.}\end{array}$ & $\begin{array}{l} \pm 200 \text { to } \pm 14,800 \\
1 \mathrm{bm} / \mathrm{ft}-\mathrm{sec}^{2}\end{array}$ & $\begin{array}{l} \pm 19,170 \\
1 \mathrm{bm} / \mathrm{ft}-\mathrm{sec}^{2}\end{array}$ & $\begin{array}{l}422,423 \\
424,425\end{array}$ & \\
\hline FDU- 15 & $\begin{array}{l}\text { Cold leg, Spooi } 15,19 \text { in. from } \\
\text { vessel center; target size } 0.875 \text { in. }\end{array}$ & $\begin{array}{l} \pm 200 \text { to } \pm 14,500 \\
\text { Itom/fl-sec }\end{array}$ & $\begin{array}{l} \pm 20,700 \\
1 \mathrm{lnn} / \mathrm{rl}-\mathrm{sec} \mathrm{c}^{2}\end{array}$ & $\begin{array}{c}426,427 \\
428,429 \\
.\end{array}$ & \\
\hline \multicolumn{6}{|l|}{ Broken Loop } \\
\hline FDB-21 & $\begin{array}{l}\text { Cold leg, Spool } 21,53 \text { in. from } \\
\text { vessel center, } 3-\text { in. plpe; ldryet } \\
\text { size } 0.186 \text { in. }\end{array}$ & $\begin{array}{l} \pm 200 \text { to } \pm 70,500 \\
1 \mathrm{bm} / \mathrm{ft} \mathrm{cec}^{2}\end{array}$ & $\begin{array}{l} \pm 72,912 \\
1 \mathrm{bm} / \mathrm{ft}-\mathrm{ces}^{2}\end{array}$ & 430,431 & $\begin{array}{l}\text { Detector has a nonlinear output } \\
\text { rur tulumentunt flux vdlues above } \\
15,000 \mathrm{bm} / \mathrm{ft}-\mathrm{scc} \text { ? }\end{array}$ \\
\hline FnR-7.3 & $\begin{array}{l}\text { r.nld leg. Snonl } 2.3 .9 .9 \text { in. from } \\
\text { vessel center, upstream of vessel } \\
\text { side nozle, t-in, pipe; tarqet } \\
\text { size } 0.406 \text { in. }\end{array}$ & $\begin{array}{l} \pm 7 n n \text { t.n } \pm 121 . n n n \\
1 \mathrm{bm} / \mathrm{ft}-\mathrm{ssec}^{2}\end{array}$ & 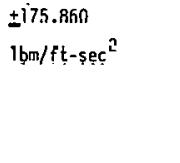 & 4.33. 4.33 & 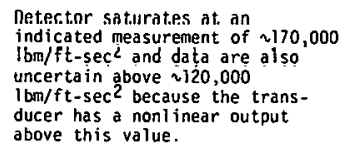 \\
\hline FDB- 30 & $\begin{array}{l}\text { Hot leg, spool } 30,21 \text { in. from } \\
\text { vessel center, } 3-\text { in. pipe; target }_{\text {size } 0.406 \text { in. }}\end{array}$ & $\begin{array}{l} \pm 200 \text { tu } \pm 60,000 \\
1 \mathrm{~b} \pi / \mathrm{ft}-\sec ^{2}\end{array}$ & $\begin{array}{l} \pm 90, \hat{2} 20 \\
1 \mathrm{bm} / \mathrm{ft}-\sec ^{2}\end{array}$ & 434,435 & \\
\hline FDB- 37 & $\begin{array}{l}\text { Cold leg, spool } 37,284 \text { in. from } \\
\text { vessel center along hot lepg. stearn } \\
\text { gcnerator outlet, vertical pipe, } \\
2 \text { in. pipo, targot cias } 0.106 \text { in. }\end{array}$ & $\begin{array}{l} \pm 200 \text { to } \pm 121,000 \\
1 \mathrm{bm} / \mathrm{ft} \sec ^{2}\end{array}$ & $\begin{array}{l} \pm 203,210 \\
1 \mathrm{bm} / f \mathrm{t} \mathrm{sec}^{\mathrm{L}}\end{array}$ & 436,437 & \\
\hline FDB-42 & $\begin{array}{l}\text { Cold leg, Spool } 42,416 \text { in. from } \\
\text { vessel center along hot leg, up- } \\
\text { stream of pump-side nozzle, down- } \\
\text { stream of injection point, } 2-\text { in. } 14 . \\
\text { pipe; target size } 0.406 \text { in. }\end{array}$ & $\begin{array}{l} \pm 200 \text { to } \pm 116,000 \\
1 \mathrm{bm} / \mathrm{ft}-\mathrm{sec}^{2}\end{array}$ & $\begin{array}{l} \pm 128,850 \\
1 \mathrm{bm} / \mathrm{ft}-\mathrm{sec}^{2}\end{array}$ & 438,439 & \\
\hline Verfol & & & & & $\cdot$ \\
\hline FDV-CORE-IN & $\begin{array}{l}\text { In core flow mixer box } 150 \text { in. } \\
\text { belore sold loj contarline, tangot } \\
\text { size } 0.656 \text { in. }\end{array}$ & $\begin{array}{l} \pm 200 \text { to } \pm 131,000 \\
1 \mathrm{bm} / \mathrm{ft}-\sec ^{2}\end{array}$ & $\begin{array}{l} \pm 14,160 \\
1 \mathrm{bm} / \mathrm{ft}_{-\mathrm{sec}^{2}}\end{array}$ & 440,441 & \\
\hline \multicolumn{6}{|l|}{ OENSITY } \\
\hline Intail Loup & & $\begin{array}{l}0.1 \text { lu } 100 \\
1 \mathrm{bm} / \mathrm{tt}^{3}\end{array}$ & $\begin{array}{l}0 \text { to } 100 \\
10 \mathrm{~m} / \mathrm{tt} \mathrm{t}^{3}\end{array}$ & & $\cdot$ \\
\hline GU-IVR & $\begin{array}{l}\text { Hot leg, Spool } 1,24 \text { in. from } \\
\text { vossal conter, vertical. }\end{array}$ & . & & 442,443 & 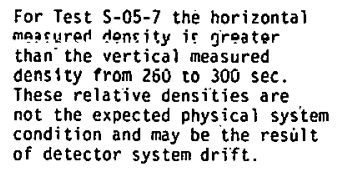 \\
\hline
\end{tabular}




\begin{tabular}{|c|c|c|c|c|c|}
\hline \multirow[b]{2}{*}{ Measurement } & \multirow[b]{2}{*}{ Location and Comments ${ }^{[a]}$} & \multicolumn{2}{|c|}{ Range $^{[a]}$} & \multirow{3}{*}{ Figure $^{[a]}$} & \multirow[b]{2}{*}{ Measurement Comments ${ }^{[b]}$} \\
\hline & & \multirow[t]{2}{*}{ Detector } & $\begin{array}{l}\text { Data Acquisition } \\
\text { System } \\
\end{array}$ & & \\
\hline \multicolumn{4}{|c|}{ Intact Loop (continued) } & & \\
\hline GU-1HZ & $\begin{array}{l}\text { Hot leg, Spool 1, } 26 \text { in. from } \\
\text { vessel center, horizontal. }\end{array}$ & - & . & 444. 445 & $\begin{array}{l}\text { For Test } 5-05-7 \text { the horizontal } \\
\text { measured density is greater } \\
\text { than the vertical measured } \\
\text { density from } 260 \text { to } 300 \text { sec. } \\
\text { These relative densities are } \\
\text { not the expected physical system } \\
\text { condition and may be the result } \\
\text { of detector system drift. }\end{array}$ \\
\hline GU-5VR & $\begin{array}{l}\text { Hot leg, Spool } 5,96 \text { in. from } \\
\text { vessel center, vertical. }\end{array}$ & & & 446,447 & \\
\hline GU-10VR & $\begin{array}{l}\text { Cold leg, Spool } 10,141 \text { in. from } \\
\text { vessel center, vertical. }\end{array}$ & & & 448,449 & \\
\hline GU-13VR & $\begin{array}{l}\text { Cold leg, Spool } 13,59 \text { in. from } \\
\text { vessel center, vertical. }\end{array}$ & & , & $\begin{array}{l}450,451 \\
452,453\end{array}$ & \\
\hline GU-15VR & $\begin{array}{l}\text { Cold leg, Spool } 15,23 \text { in. from } \\
\text { vessel center, vertical. }\end{array}$ & & & $\begin{array}{l}454,455 \\
456,457\end{array}$ & $\begin{array}{l}\text { Data values above } 62.4 \quad \mathrm{lom} / \mathrm{ft}^{3} \\
\text { for Test } 5-05-6 \text { do not reflect } \\
\text { actual system density rand were } \\
\text { the result of detector system } \\
\text { nonlinearity. }\end{array}$ \\
\hline GU-15HZ & $\begin{array}{l}\text { Cold leg, Spool 15, } 20 \text { in. from } \\
\text { vessel center, horizontal. }\end{array}$ & & & $\begin{array}{l}458,459 \\
460,461\end{array}$ & $\begin{array}{l}\text { Oata values above } 62.4 \quad 1 \mathrm{bm} / \mathrm{ft}^{3} \\
\text { for rest } 5-05-7 \text { do not reflect } \\
\text { actual system density and were } \\
\text { the result of detector system } \\
\text { nonlinearity. }\end{array}$ \\
\hline \multirow[t]{2}{*}{ Broken I nחp } & & 0.1 to 100 & 0 to 100 & & - \\
\hline & & $1 \mathrm{bm} / \mathrm{ft}^{3}$ & $\mathrm{~b} \mathrm{bm} / \mathrm{ft}^{3}$ & & \\
\hline GB-2IT & $\begin{array}{l}\text { Cold leg, Spool 21, } 49 \text { in. from } \\
\text { vessel center. T(top) ranges }\end{array}$ & & & $\begin{array}{l}462,463 \\
464,465\end{array}$ & \\
\hline GB-21B & $\begin{array}{l}270 \text { to } 360 \text { egrees. } B \text { (bottom) } \\
\text { ranges } 30 \text { to } 330 \text { degrees. } C \text {. }\end{array}$ & & & $\begin{array}{l}466,467 \\
468,459\end{array}$ & \\
\hline $6 B-21 C$ & $\begin{array}{l}\text { mathematical composite of } \\
T \text { and } B \text {. }\end{array}$ & & & $\begin{array}{l}470,471 \\
472,473\end{array}$ & \\
\hline GB-23VR & $\begin{array}{l}\text { Cold leg, Spool 23, 92 in. from } \\
\text { vessel center, vertical. }\end{array}$ & & & $\begin{array}{l}474,475 \\
476,477\end{array}$ & \\
\hline $\begin{array}{l}G B-30 T \\
G B-30 B \\
G B-30 C\end{array}$ & $\begin{array}{l}\text { Hot leg, Spool } 30,18 \text { in. from } \\
\text { vessel center. T(top) ranges } \\
270 \text { to } 360 \text { degrees. B(bottom) } \\
\text { ranges } 30 \text { to } 330 \text { degrees. C, } \\
\text { mathematical compusite uf. T and B. }\end{array}$ & & & $\begin{array}{l}478,479 \\
480,481 \\
482,483\end{array}$ & 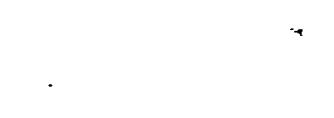 \\
\hline GB-42VR & $\begin{array}{l}\text { Cold leg, Spool } 42,415 \mathrm{in} \text {. from } \\
\text { vessel center along hot leg. } \\
\text { vertical. }\end{array}$ & , & & 484,485 & \\
\hline \multirow[t]{2}{*}{ Vessel } & & 0.1 to 100 & 0 to 100 . & & \\
\hline & & $i \mathrm{bm} / \mathrm{ft}^{3}$ & $\mathrm{bm} / \mathrm{ft}^{3}$ & & - \\
\hline GV-COR- $150 \mathrm{HZ}$ & $\begin{array}{l}\text { Core flow mixer box, } 152 \text { in. } \\
\text { below cold leg centerl ine, } \\
\text { horizontal, o to } 180^{\circ} \text {. }\end{array}$ & & & 486,487 & \\
\hline EVLR-165HZ & $\begin{array}{l}\text { Upper part of lower pleciluin, } 165 \text { in. } \\
\text { below cold leg centeritine, } 7.72 .4 \\
\text { in below downocomer exit, horizon- } \\
\text { tai, } 0 \text { to } 180^{\circ} \text {. }\end{array}$ & & & $488,48 y$ & \\
\hline GVLP-172HZ & $\begin{array}{l}\text { Lower plenum, } 172 \text { in. below cold leg } \\
\text { centerline, } 8.729 \text { in. below downcomer } \\
\text { exit. horizontal, } 90 \text { to } 270^{\circ} \text {. }\end{array}$ & & & 490,491 & : \\
\hline \multicolumn{6}{|l|}{ Pressurizer } \\
\hline \multirow[t]{2}{*}{ GU-PRIZZE } & Surge line. & 0.1 to 100 & 0 to 100 & 492,493 & \\
\hline & & $1 \mathrm{bm} / \mathrm{ft}^{3}$ & $\mathrm{bm} / \mathrm{ft}^{3}$ & & \\
\hline MASS r̈LUW KAIL & $\begin{array}{l}\text { Mass tlow rate obtained by com- } \\
\text { bining density (gama attenua- } \\
\text { tion technique) with volumetric } \\
\text { fin rate (turhine flowmeter) or } \\
\text { momenturi flum (drag dise). }\end{array}$ & $\begin{array}{l}\text { Range for mas } \\
\text { determined } f r \\
\text { individual de } \\
\text { in calculatio }\end{array}$ & $\begin{array}{l}\text { is } \\
\text { ige of } \\
\text { ss used }\end{array}$ & & \\
\hline \multicolumn{6}{|l|}{ Intact Loop } \\
\hline $\begin{array}{l}\text { FOU-1, GU-1VR } \\
\text { FTU-1, GU-1VR }\end{array}$ & Hot leg, Spool 1. & & & $\begin{array}{l}494,495 \\
496,497 \\
498,499\end{array}$ & \\
\hline FOU-5, GU-5VR & Hot leg, Spool 5. & & & $\begin{array}{l}500,501 \\
502,503\end{array}$ & $\begin{array}{l}\text { The drag disc transducer } \\
\text { saturated prior to } t=1 \mathrm{sec} \text {. }\end{array}$ \\
\hline FTU-9, GU- 1OVR & coidd leg, Spool 9. & & & $\begin{array}{l}504,505 \\
506,507\end{array}$ & \\
\hline
\end{tabular}




\section{TABLE V (continued)}

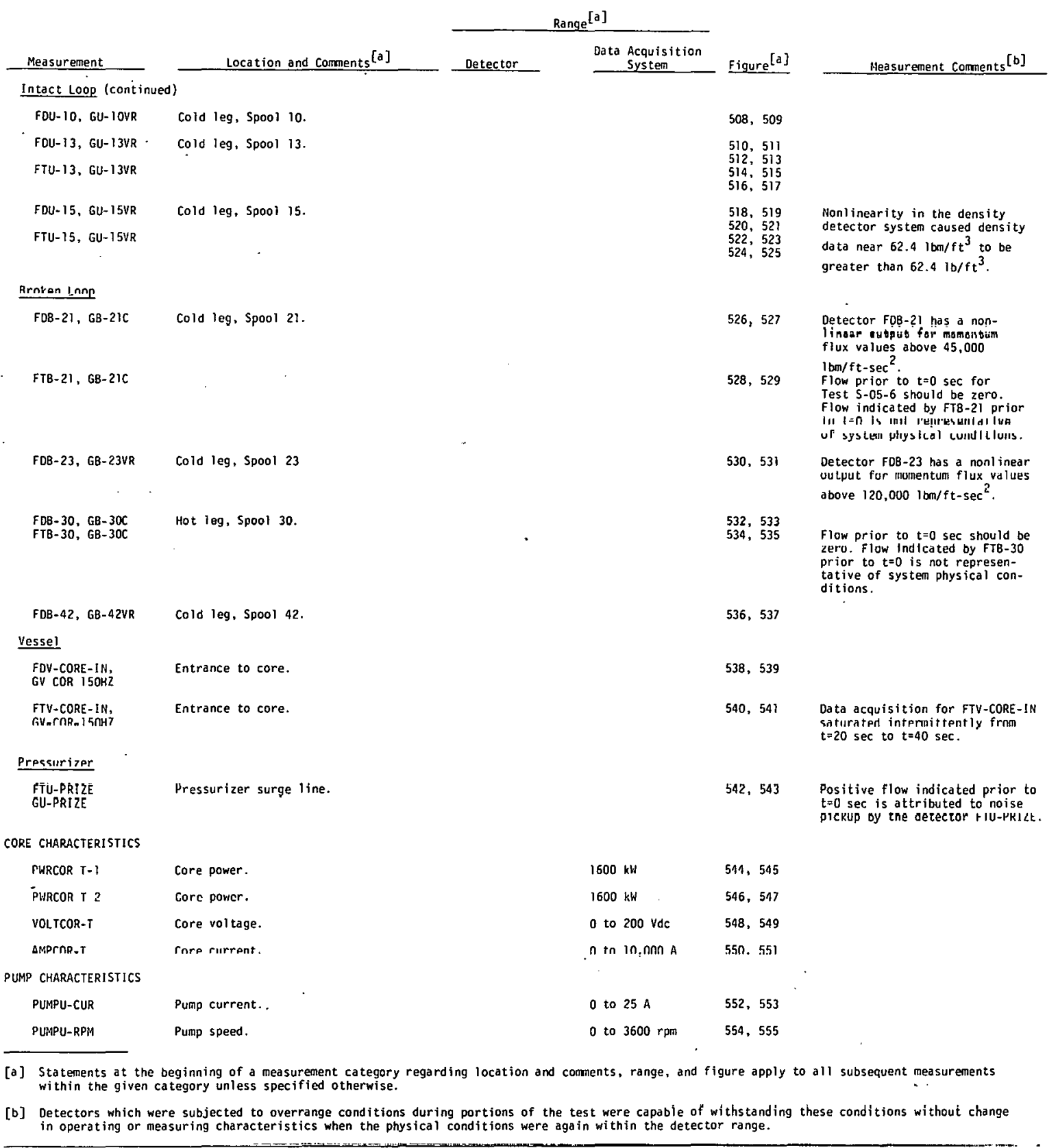




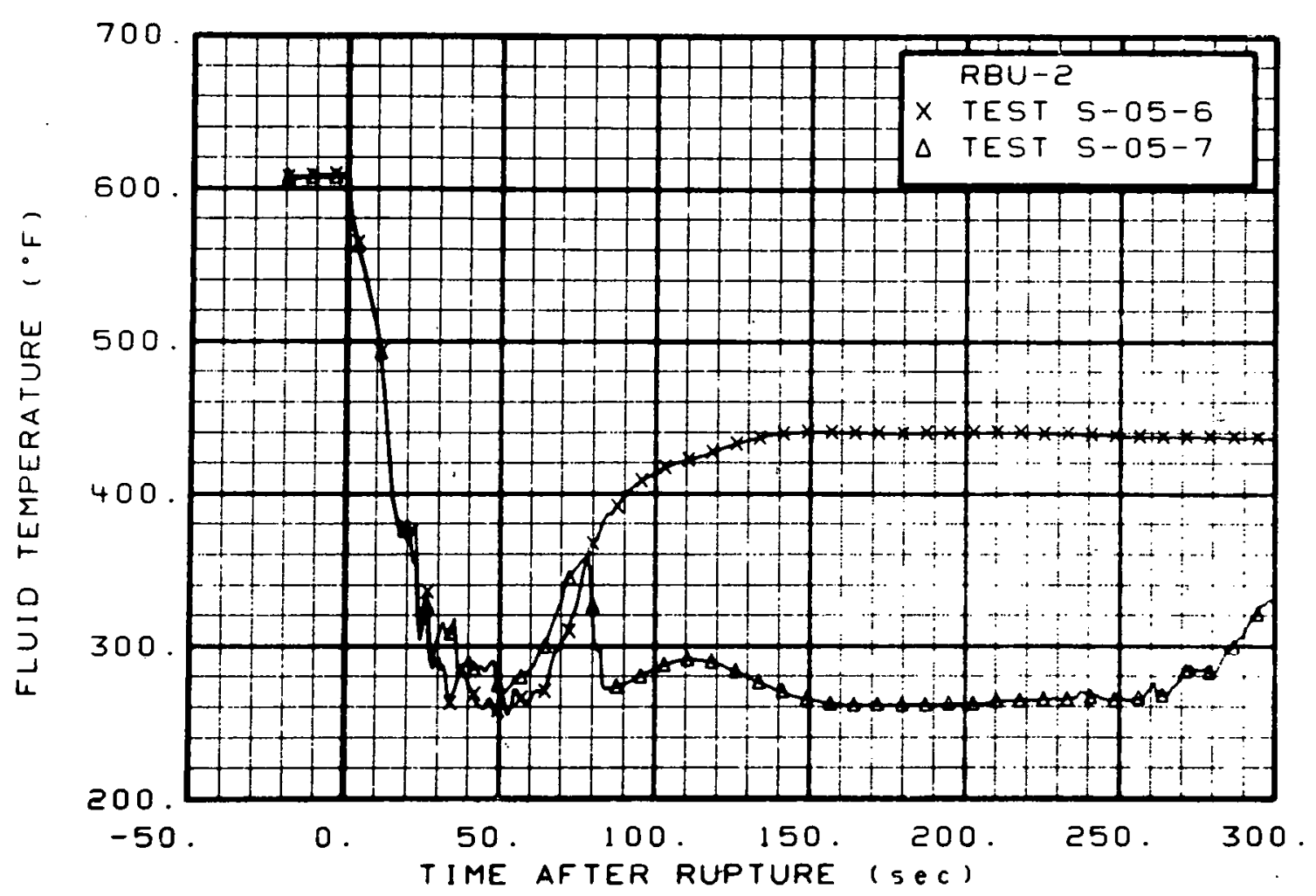

Fig. 8 Fluid temperature in intact loop hot leg (RBU-2), from -20 to $300 \mathrm{sec}$.

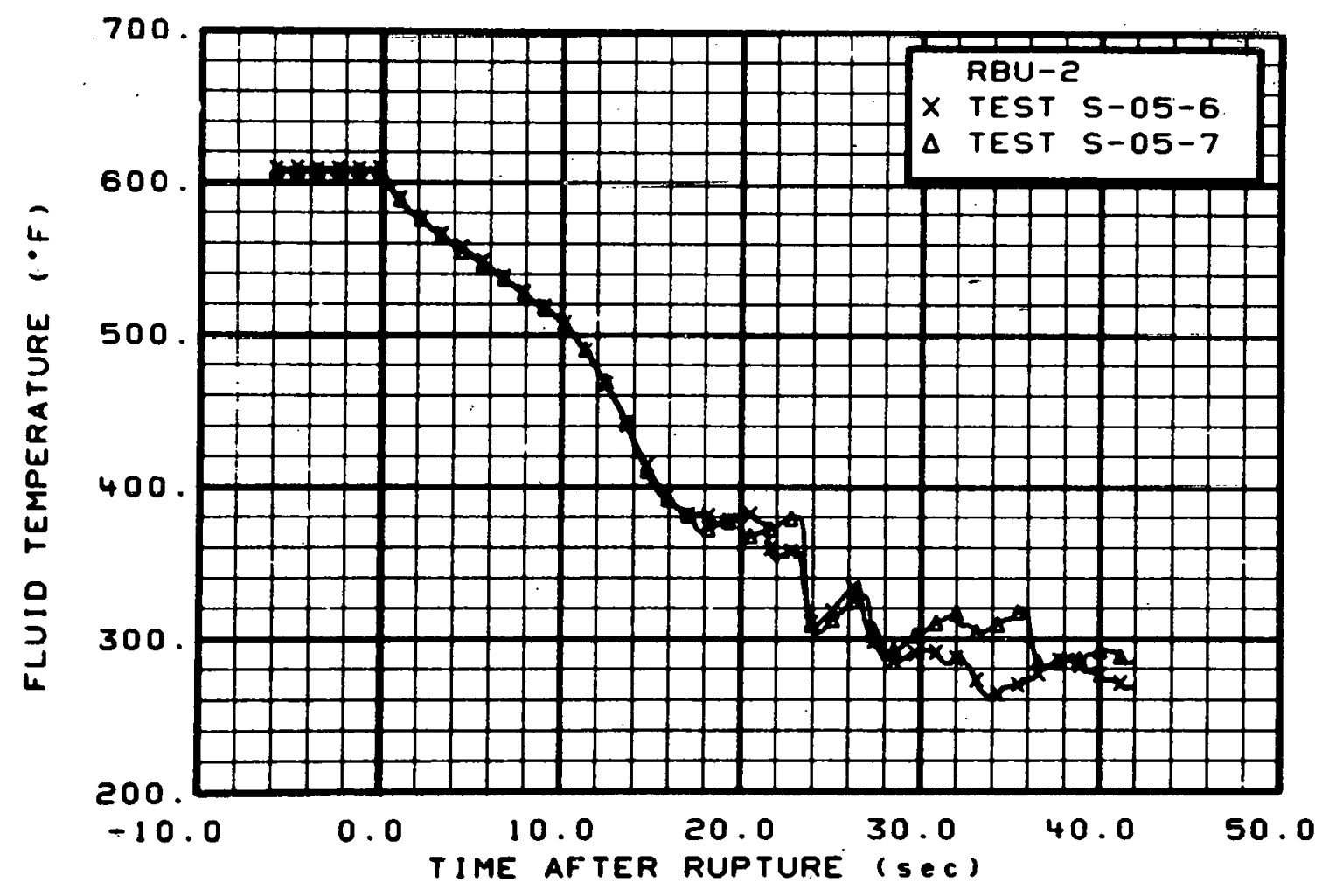

Fig. 9 Fluid temperature in intact loop hot leg (RBU-2), from -6 to 42 sec. 




Fig. 10 Fluid temperature in intact loop cold leg (TFU-7), from -20 to $300 \mathrm{sec}$.

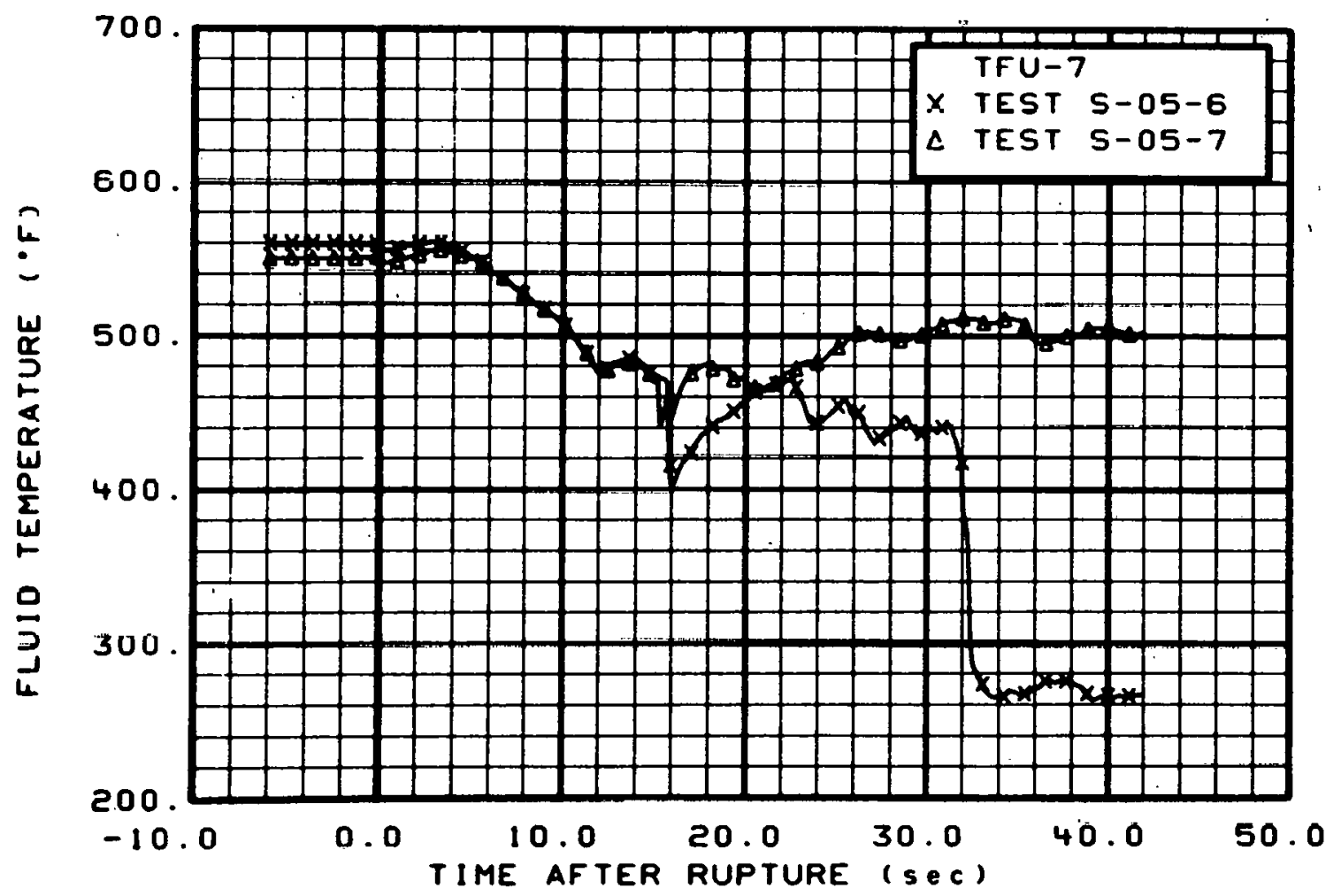

Fig. 11 Fluid temperature in intact loop cold leg (TFU-7), from -6 to $42 \mathrm{sec}$. 


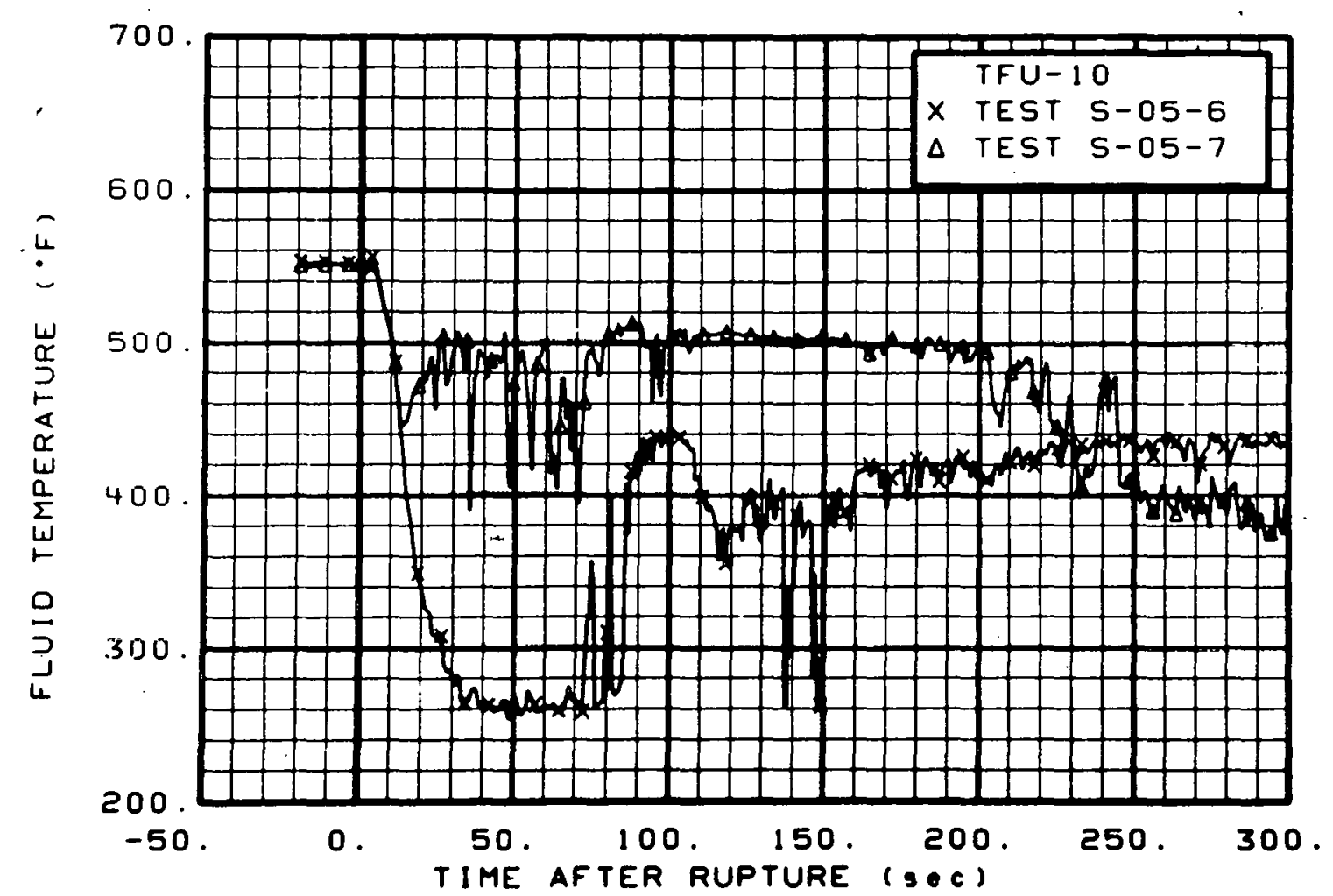

Fig. 12 Fluid temperature in intact loop cold leg (TFU-10), from -20 to 300 sec.

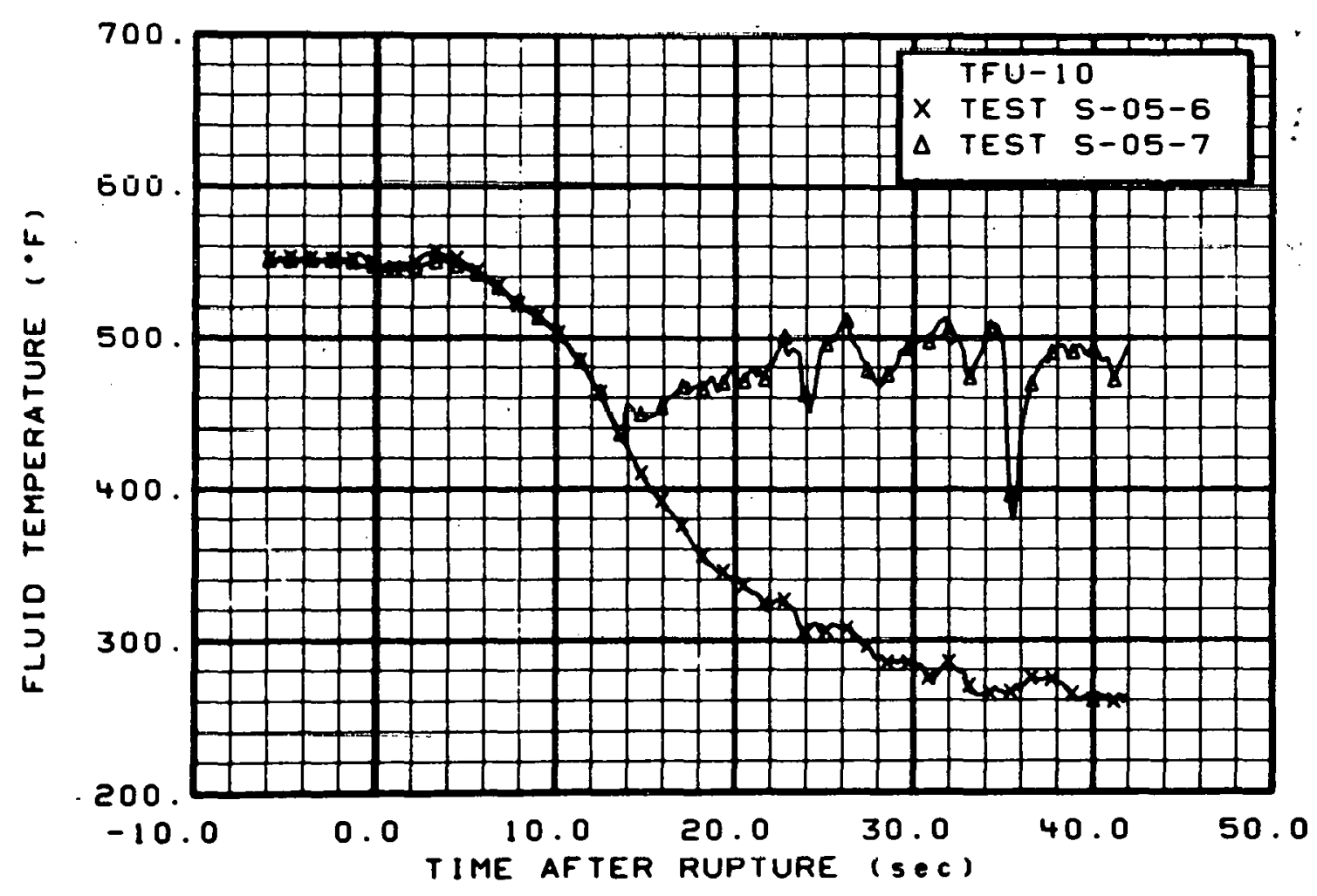

Fig. 13 Fluid temperature in intact loop cold leg (TFU-10), from -6 to 42 sec. 


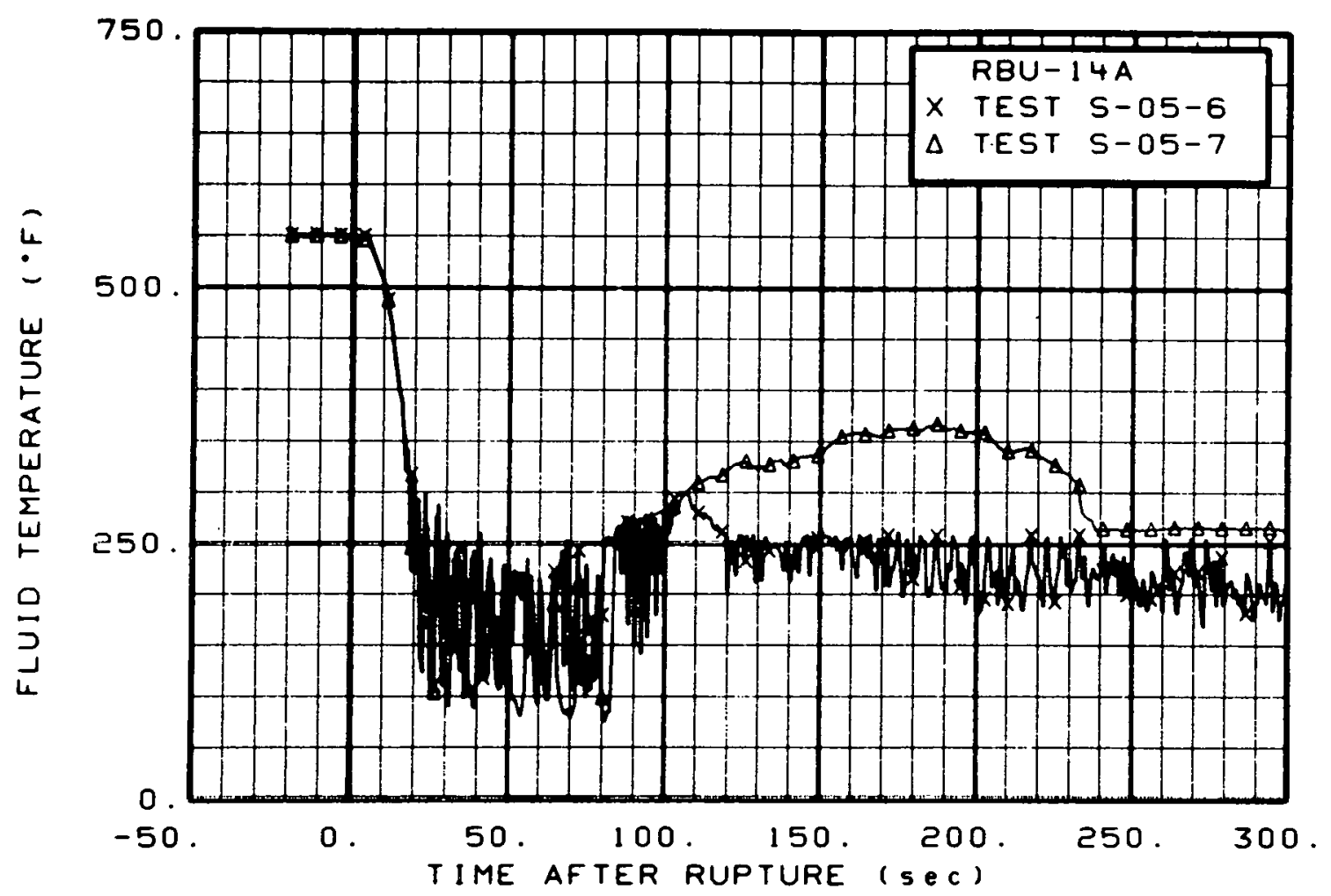

Fig. 14 Fluid temperature in intact loop cold leg (RBU-14A), from -20 to $300 \mathrm{sec}$.

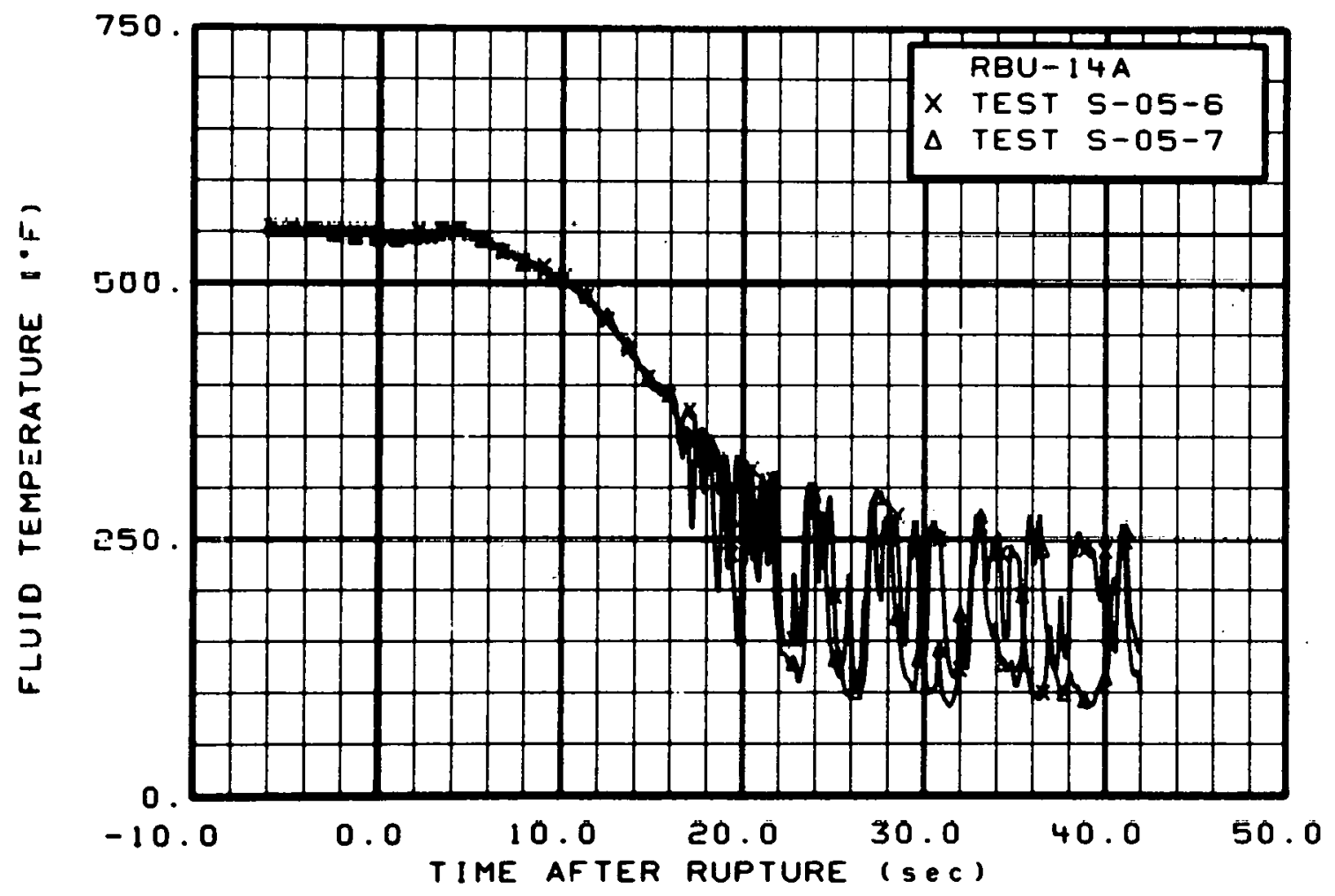

Fig. 15 Fluid temperature in intact loop cold leg (RBU-14A), from -6 to $42 \mathrm{sec}$. 


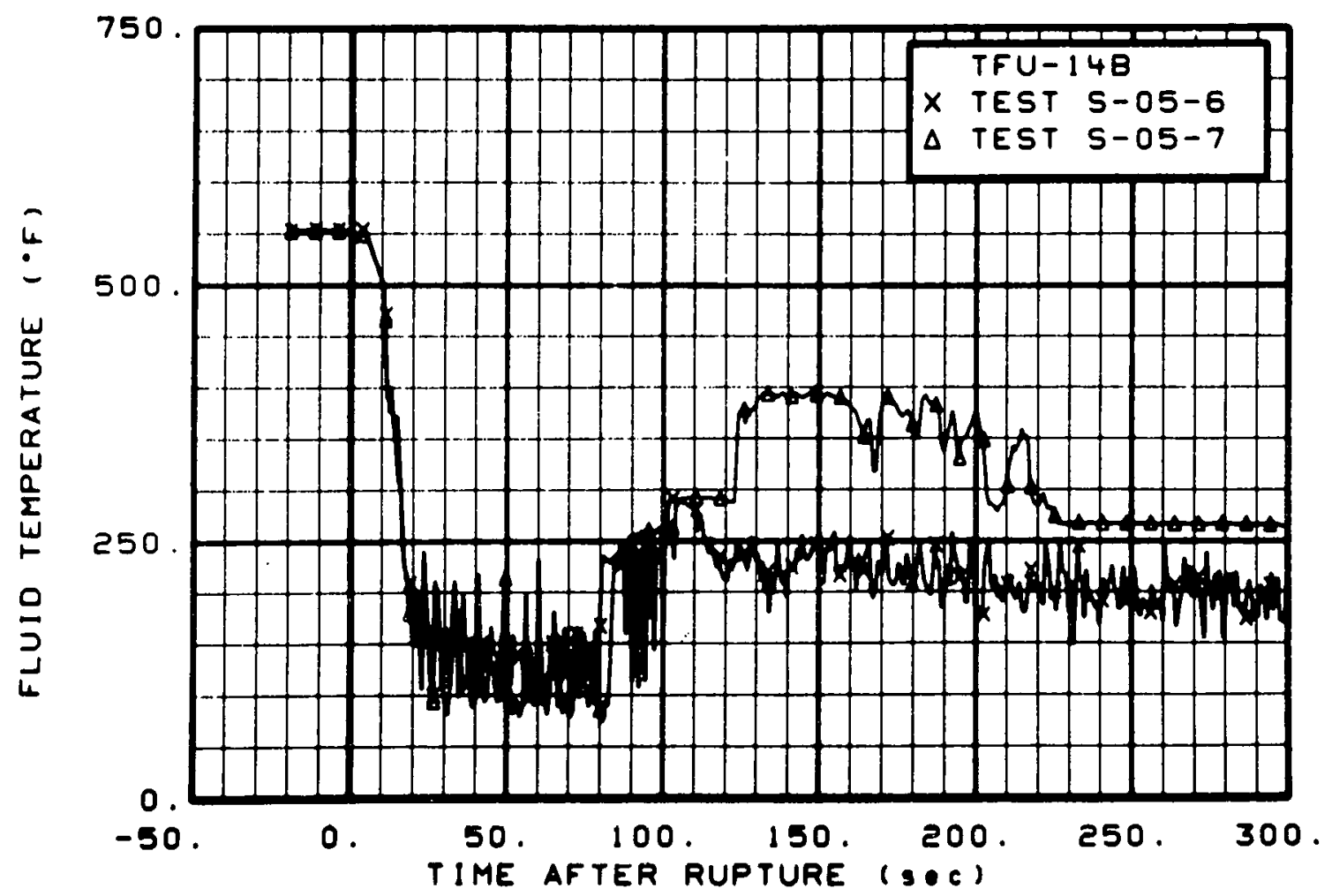

Fig. 16 Fluid temperature in intact loop cold leg (TFU-14B), from -20 to 300 sec.

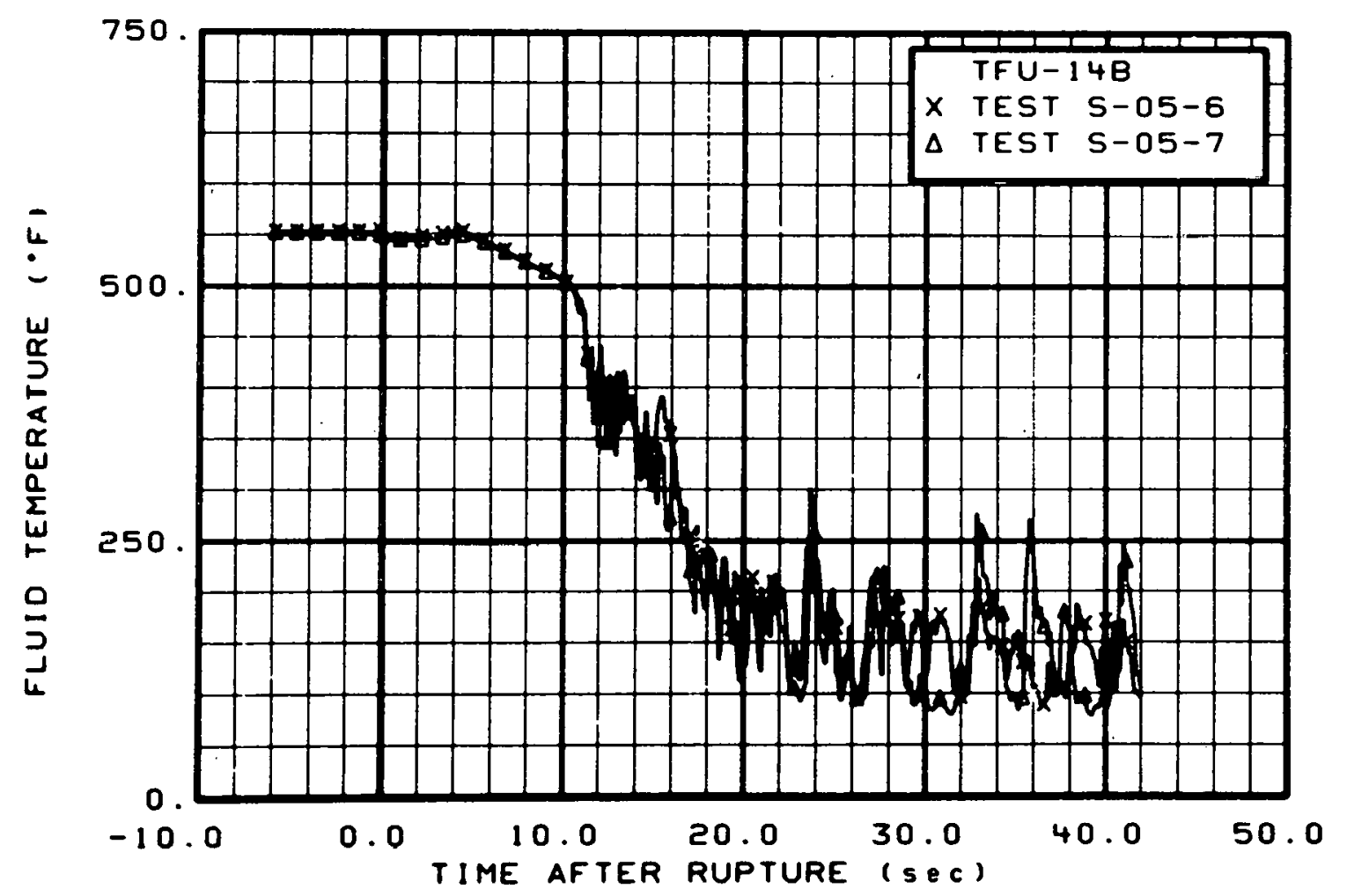

Fig. 17 Fluid temperature in intact loop cold leg (TFU-14B), from -6 to, 42 sec. 


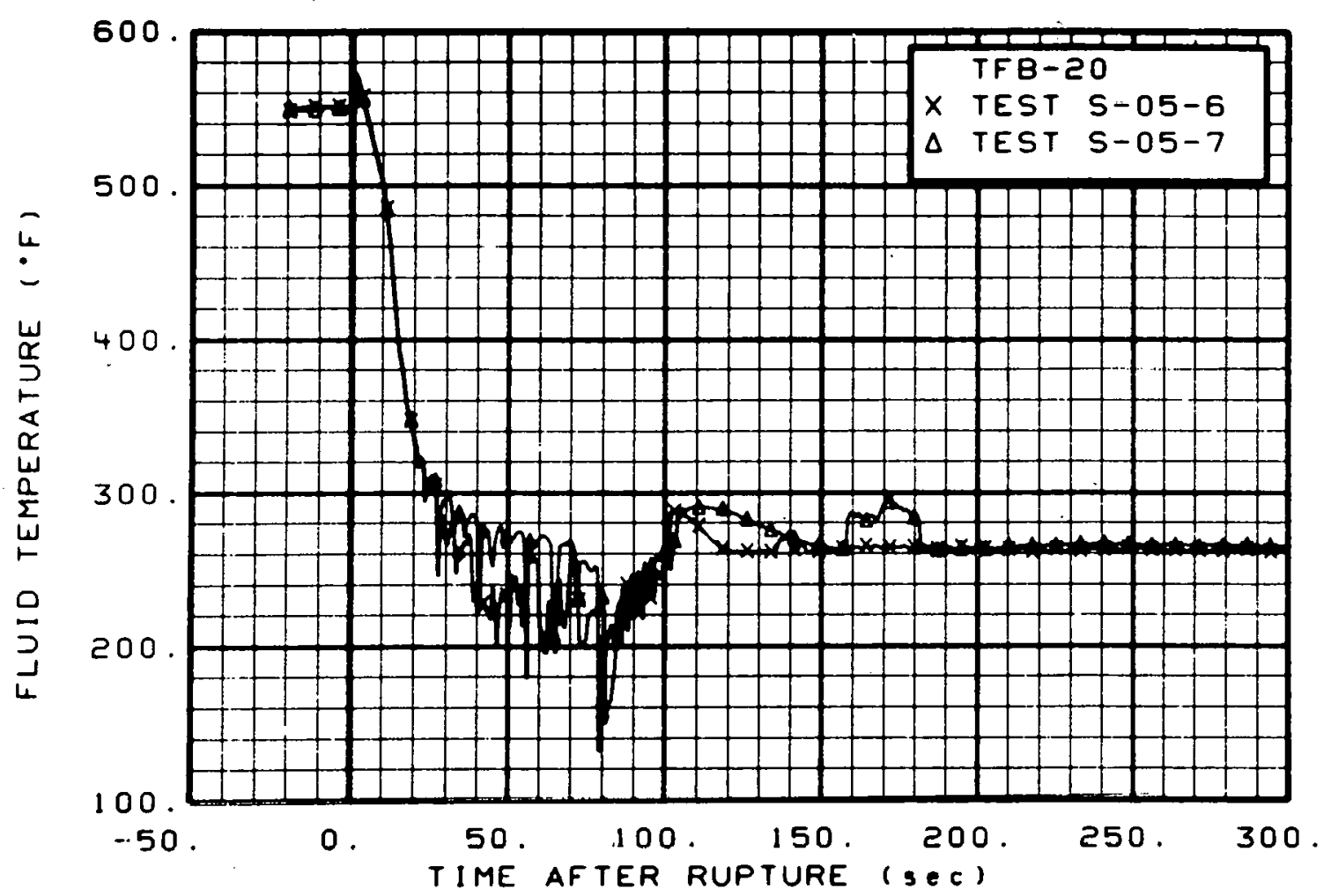

Fig. 18 Fluid temperature in broken loop, vessel side (TFB-20), from -20 to $300 \mathrm{sec}$.

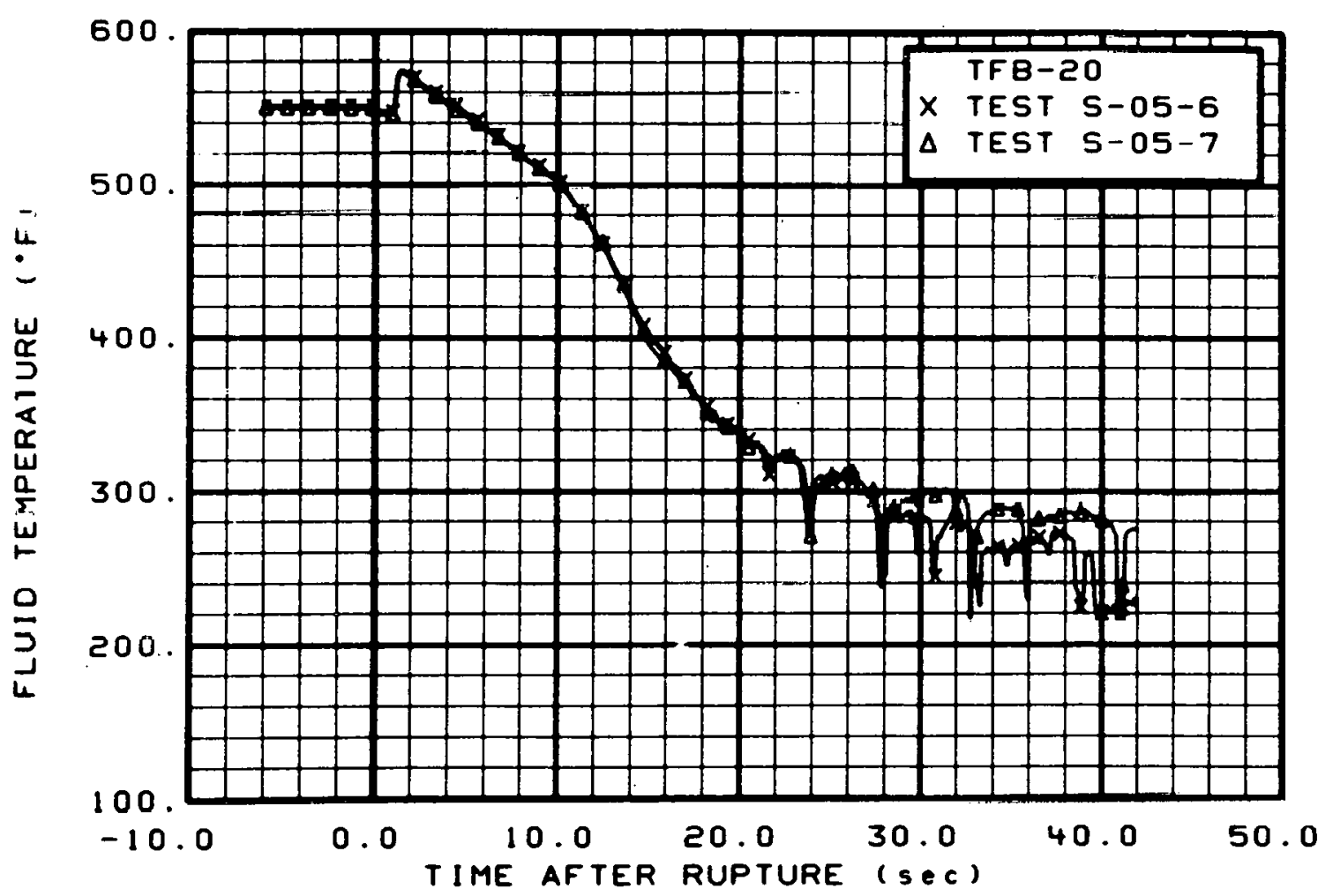

Fig. 19 Fluid temperature in broken loop, vessel side (TFB-20), from -6 to $42 \mathrm{sec}$. 


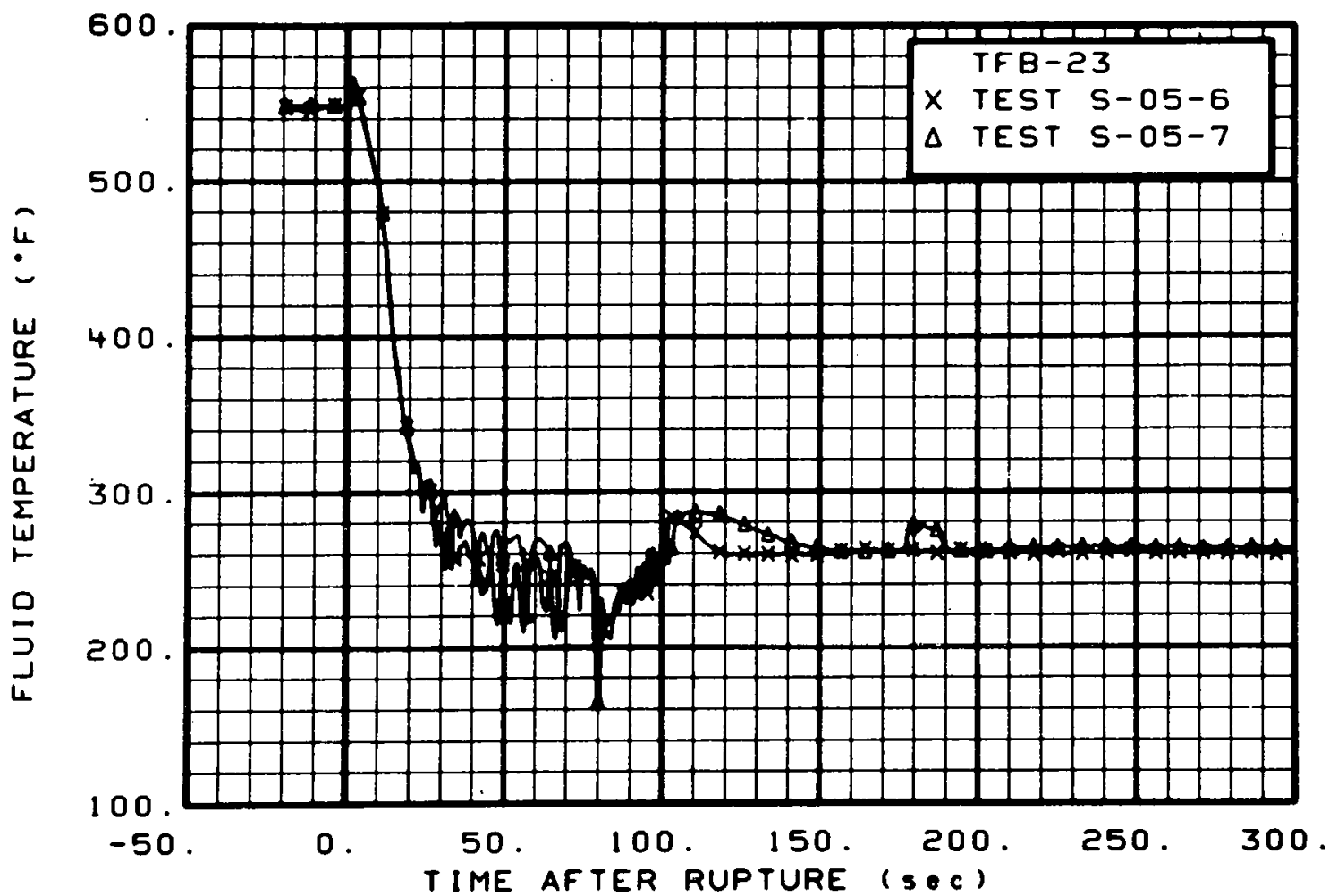

Fig. 20 Fluid temperature in broken 10op, vessel side (TFB-23), from -20 to $300 \mathrm{sec}$.

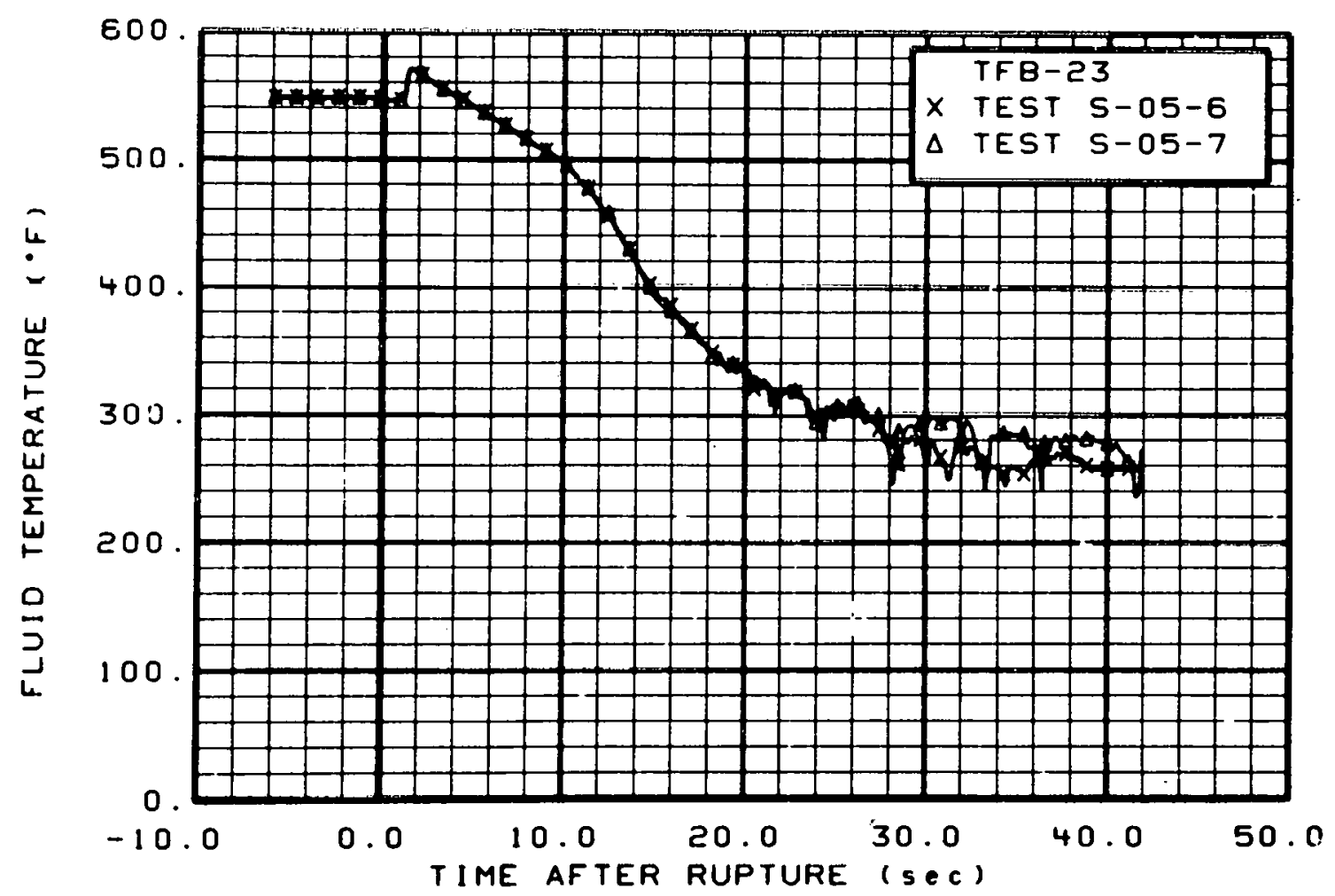

Fig. 21 Fluid temperature in broken loop, vessel side (TFB-23), from -6 to 42 sec. 


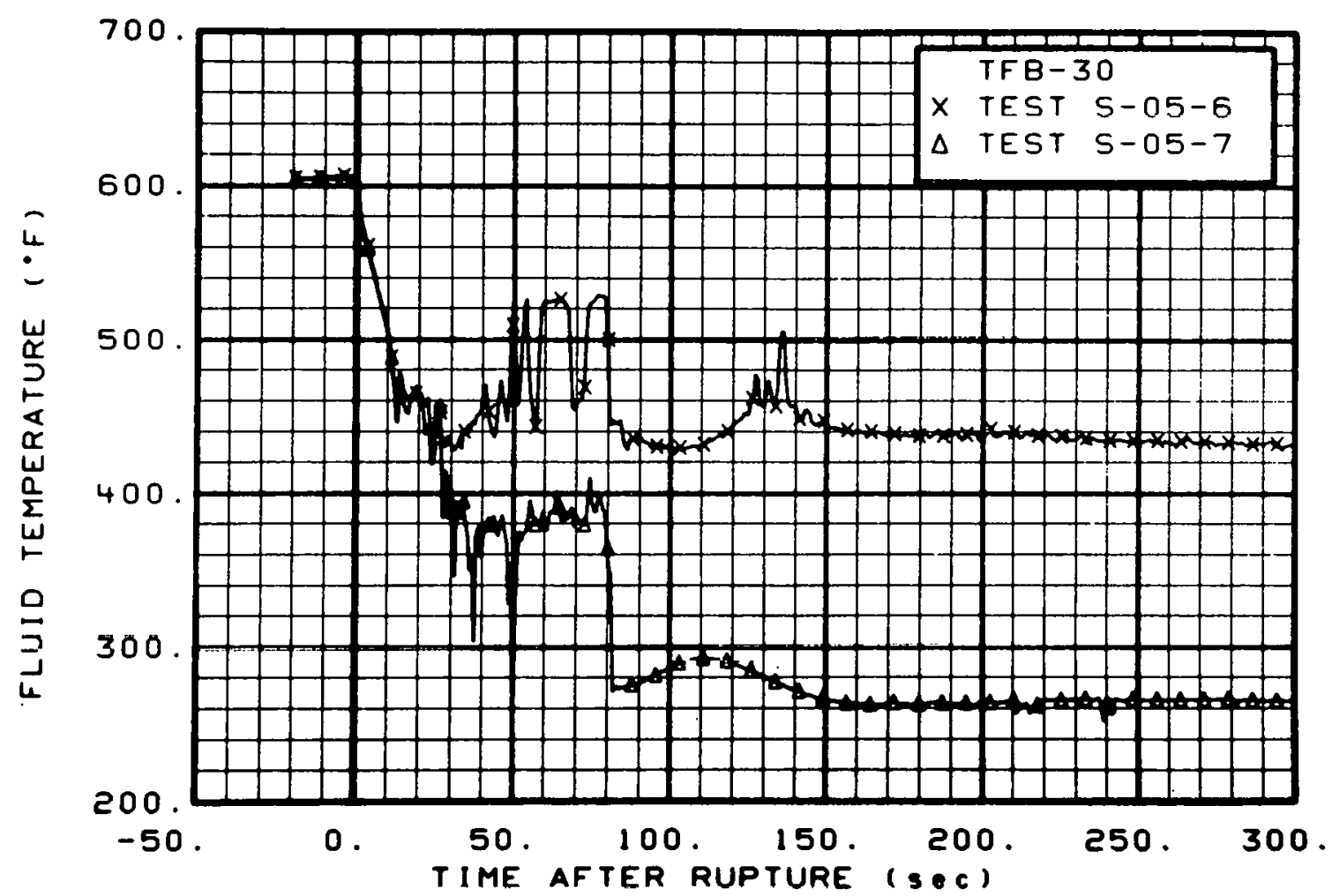

Fig. 22 Fluid temperature in broken loop, pump side (TFB-30), from -20 to $300 \mathrm{sec}$.

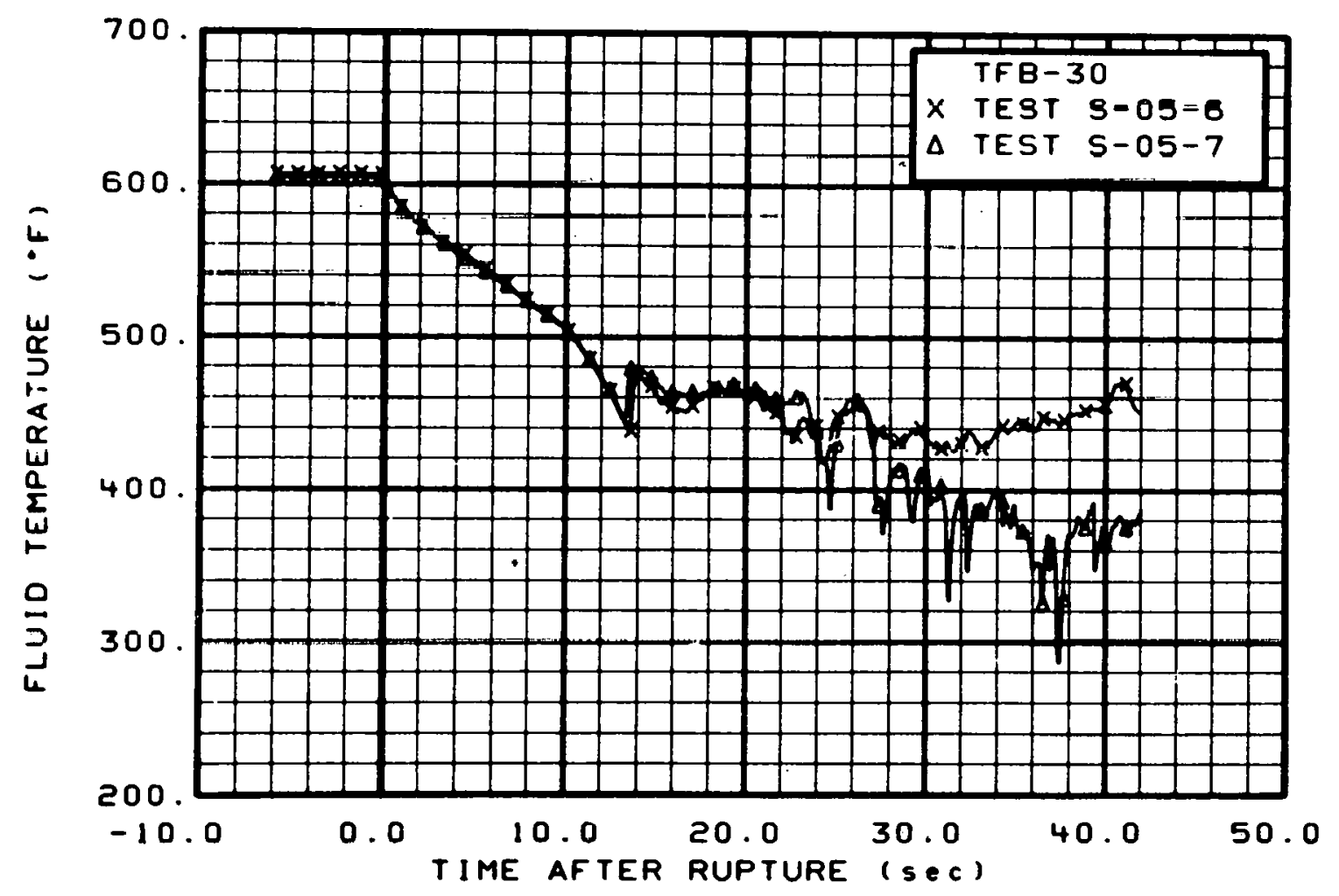

Fig. 23 Fluid temperature in broken loop, pump side (TFB-30), from -6 to $42 \mathrm{sec}$. 


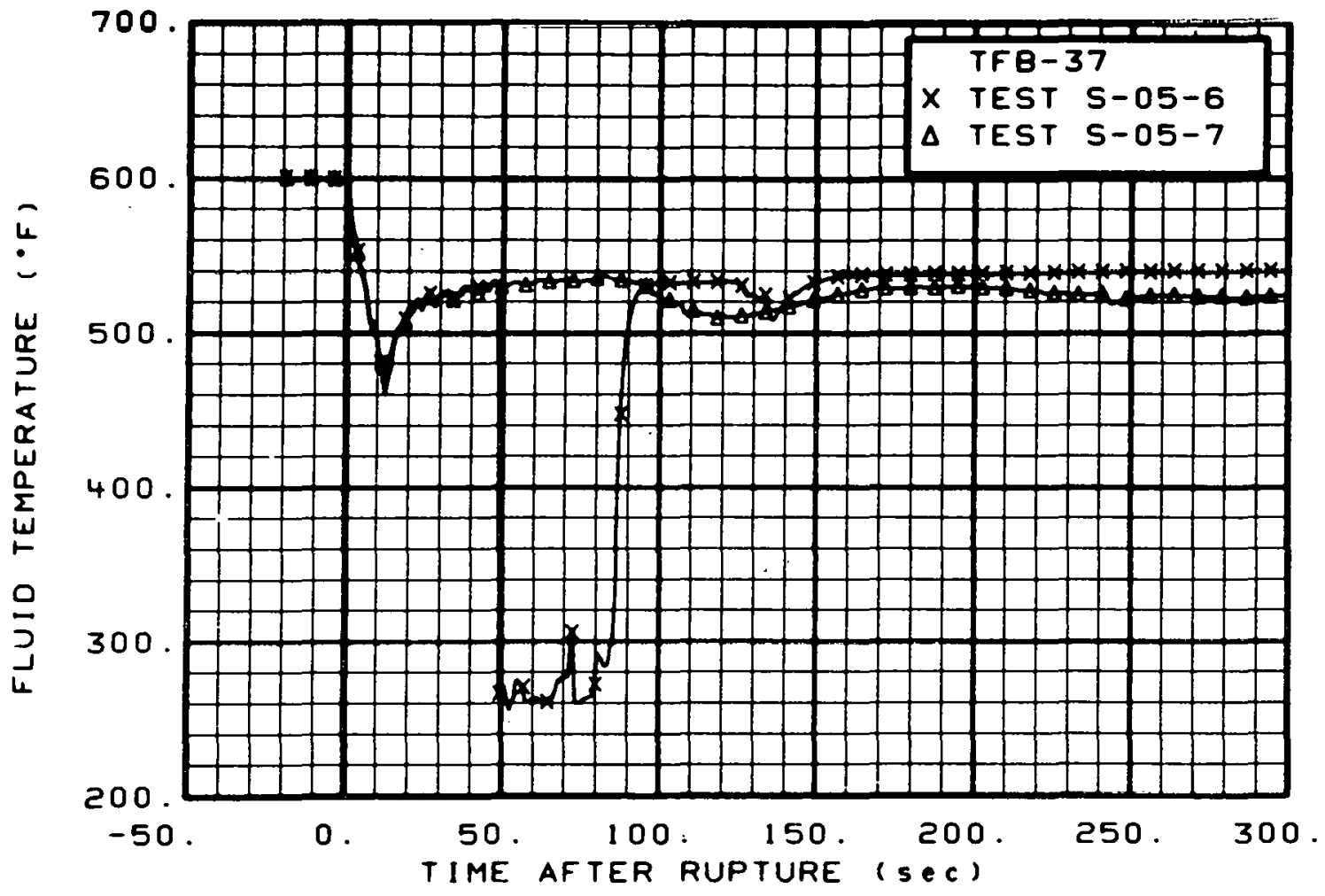

Fig. 24 Fluid temperature in broken loop, pump side (TFB-37), from -20 to $300 \mathrm{sec}$.

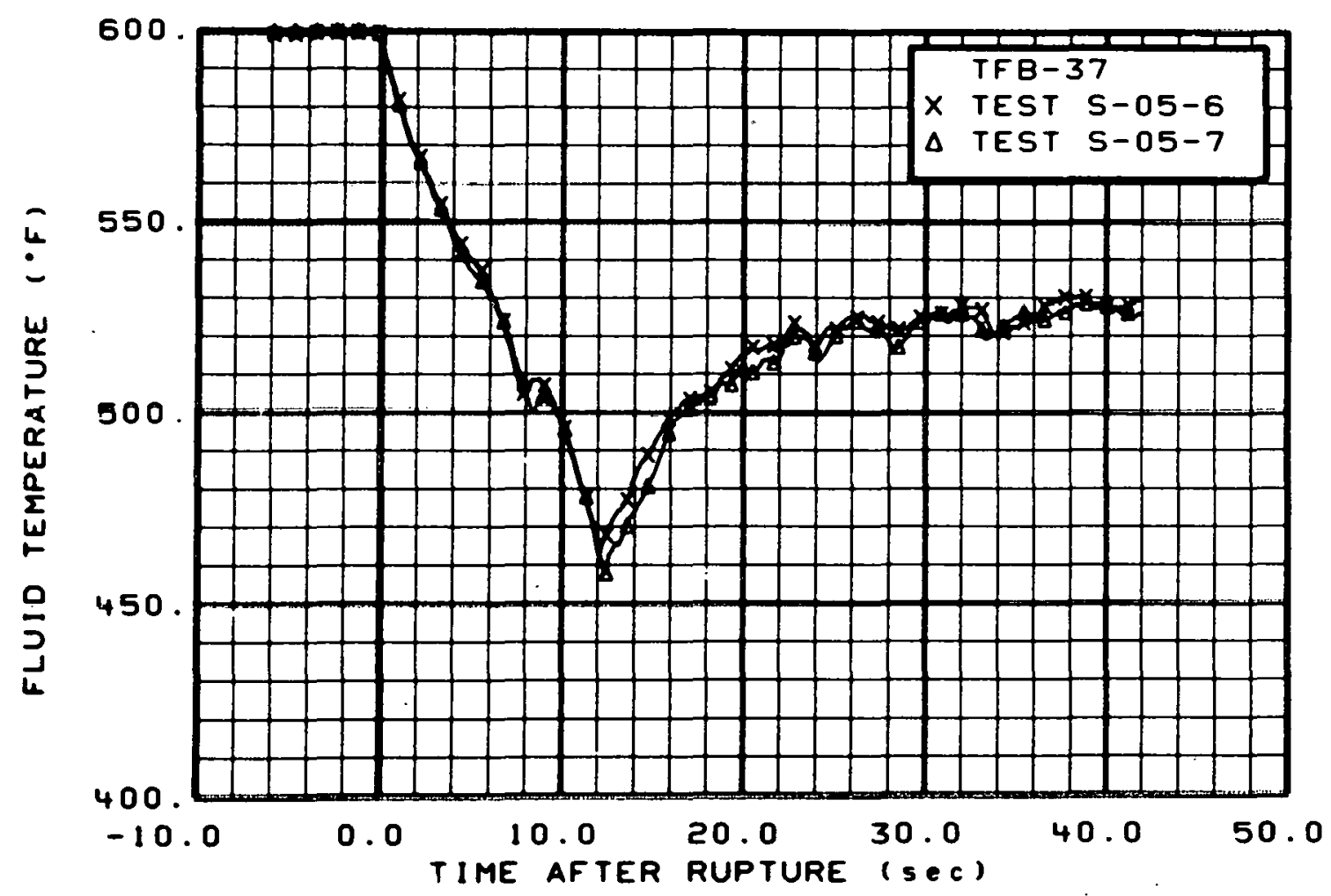

Fig. 25 Fluid temperature in broken loop, pump side (TFB-37), from -6 to $42 \mathrm{sec}$. 


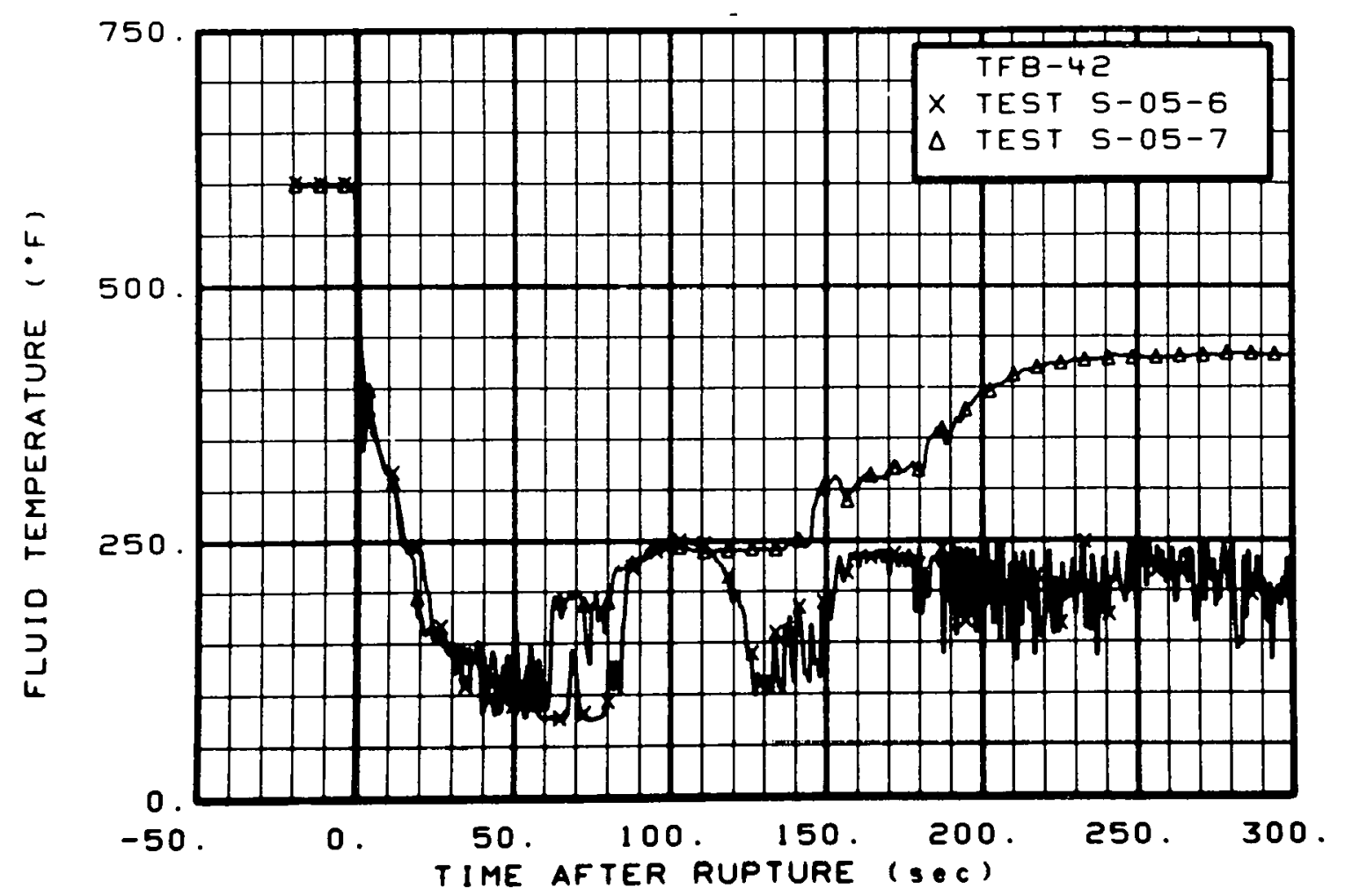

Fig. 26 Fluid temperature in broken 10op, pump side (TFB-42), from -20 to $300 \mathrm{sec}$.

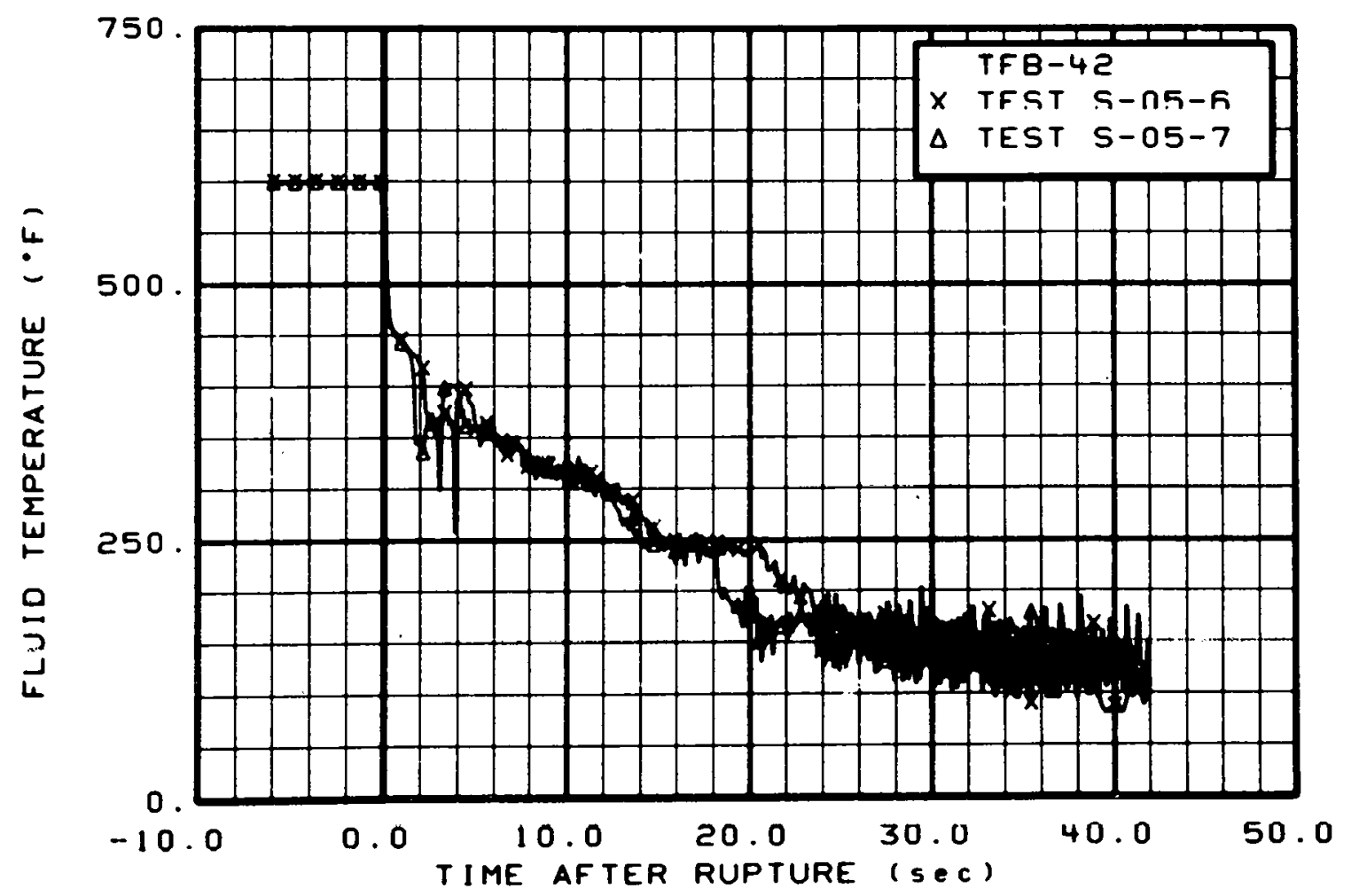

Fig. 27 Fluid temperature in broken loop, pump side $(T F B-42)$, from -6 to $42 \mathrm{sec}$. 


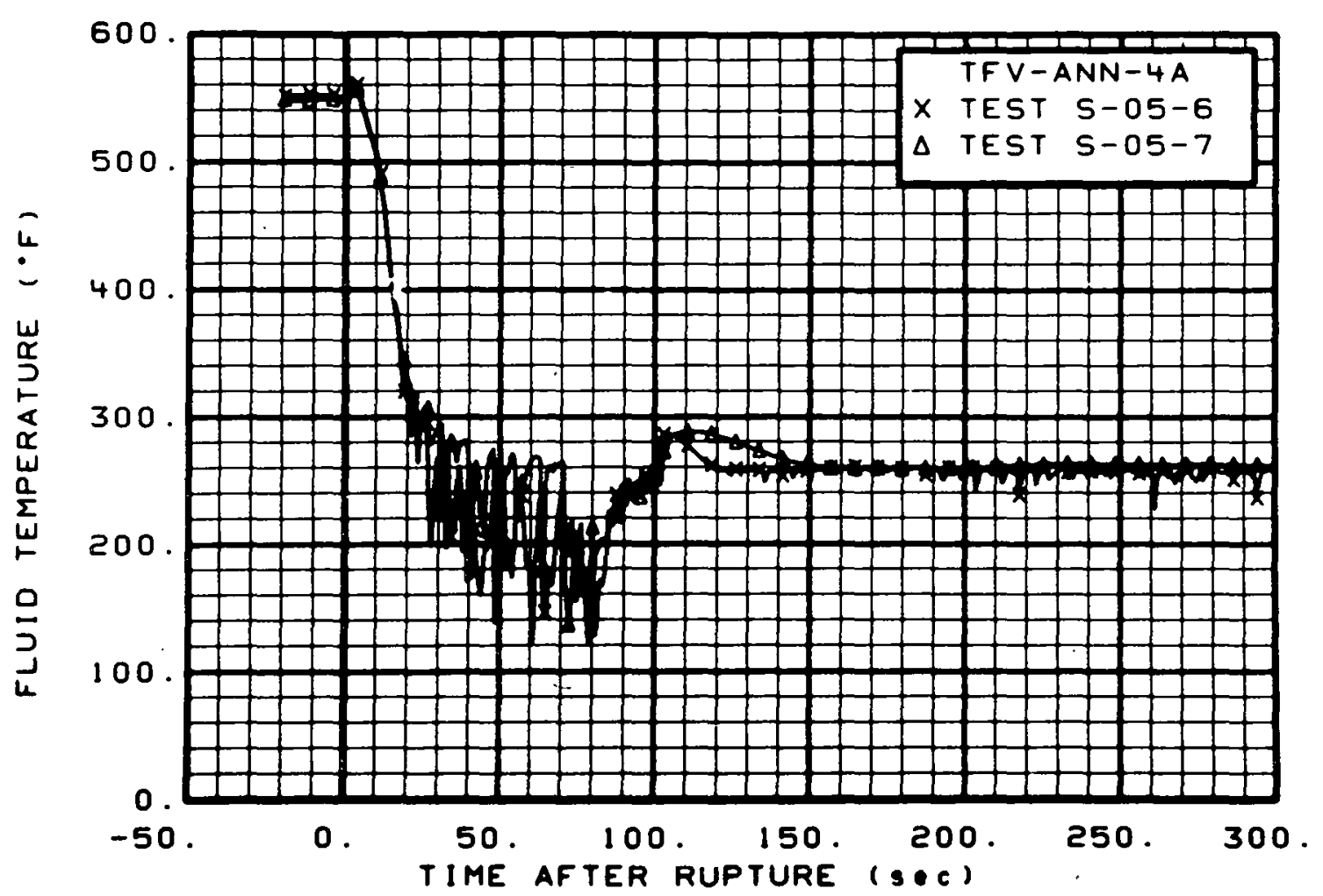

Fig. 28 Fluid temperature in in let annulus (TFV-ANN-4A), from -20 to $300 \mathrm{sec}$.

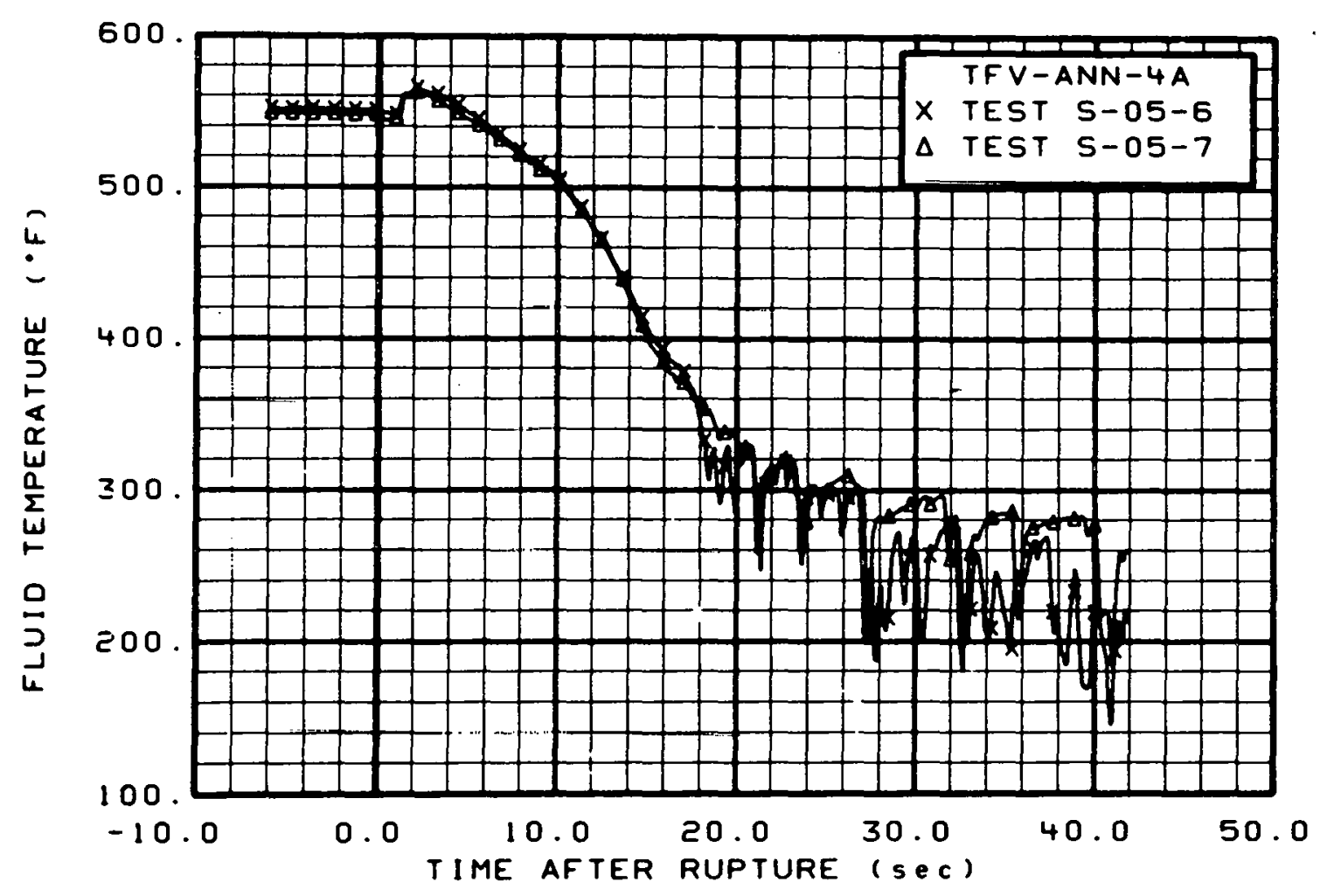

Fig. 29 Fluid temperature in inlet annulus (TFV-ANN-4A), from -6 to $42 \mathrm{sec}$. 


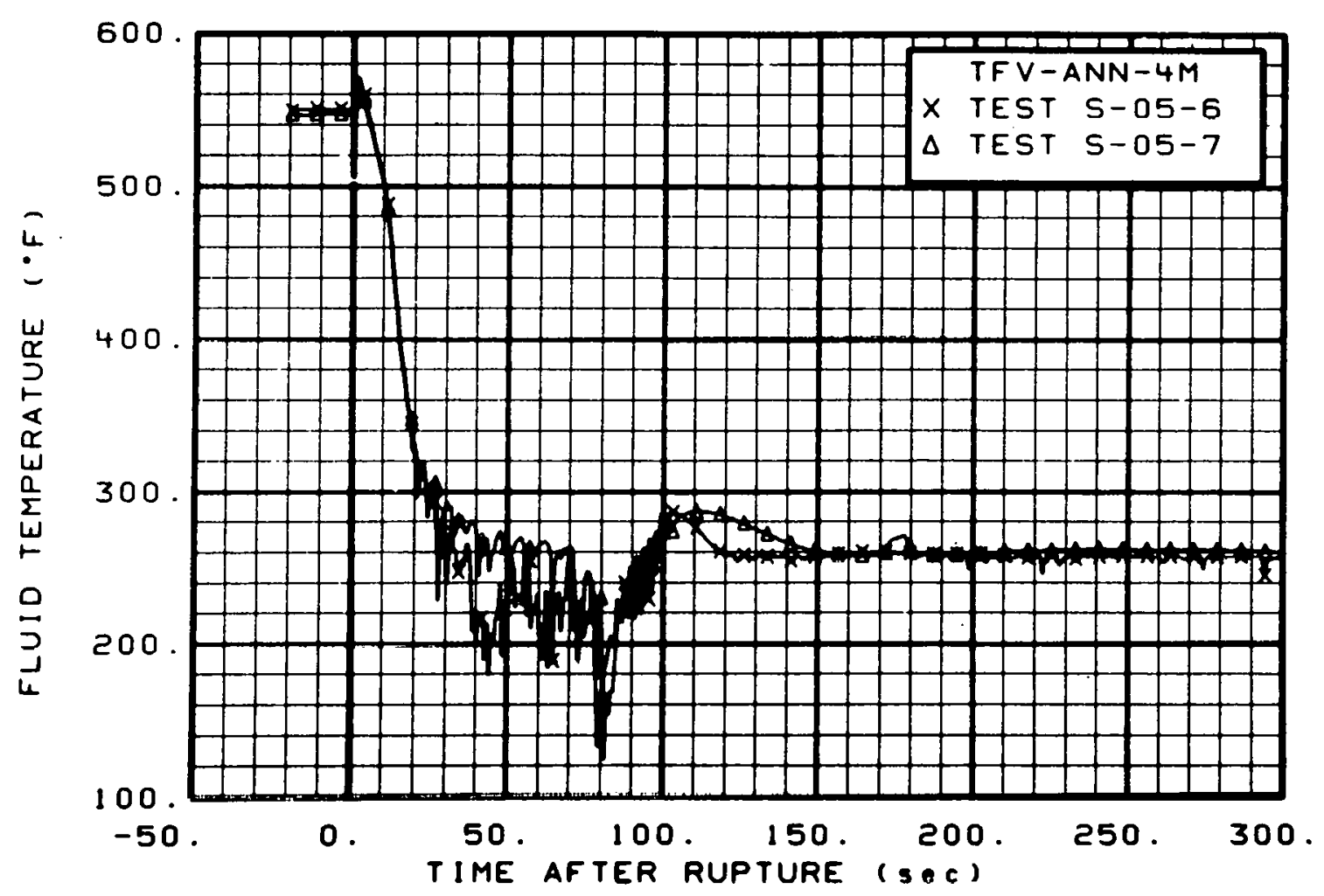

Fig. 30 Fluid temperature in inlet annulus (TFV-ANN-4M), from -20 to $300 \mathrm{sec}$.

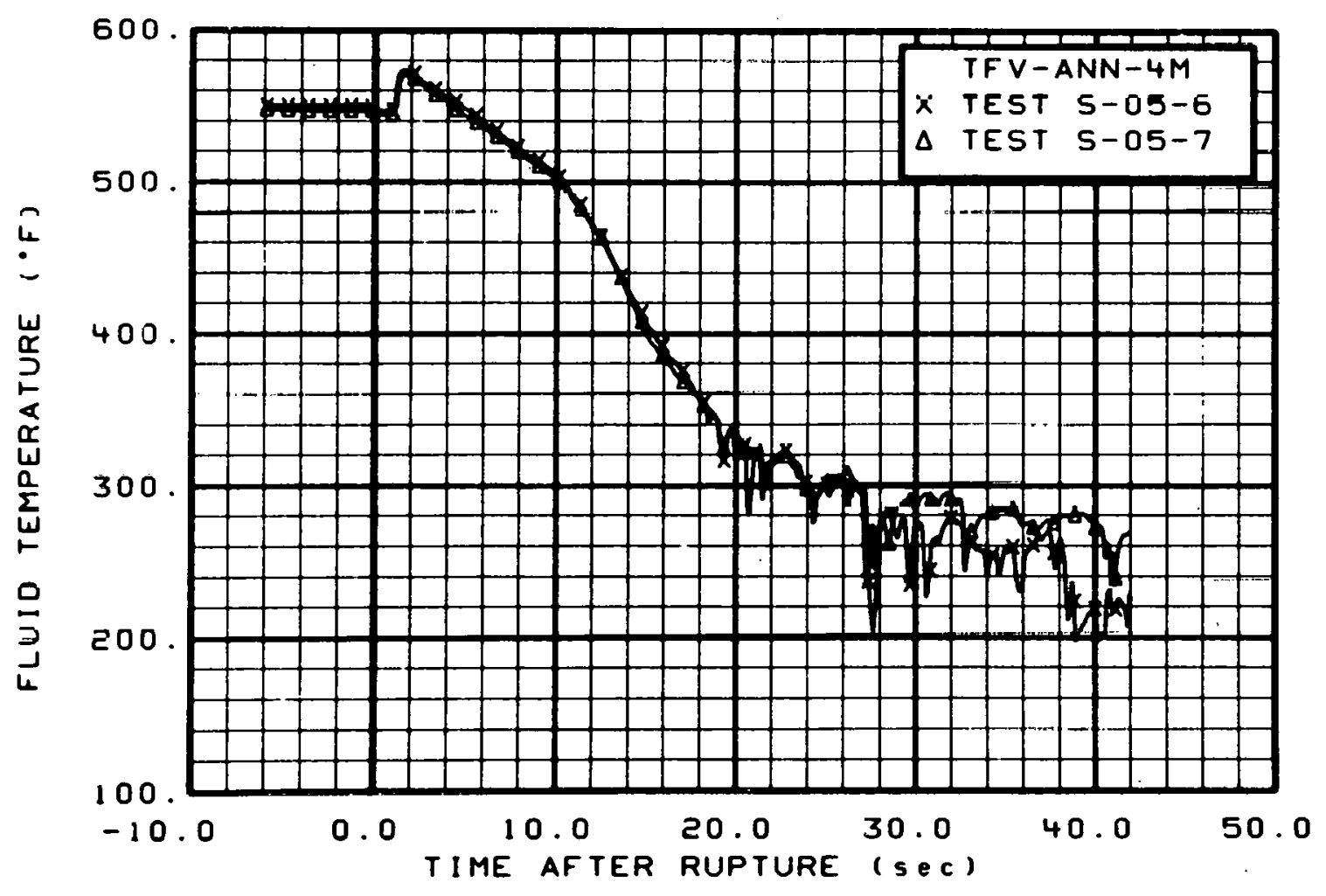

Fig. 31 Fluid temperature in inlet annulus (TFV-ANN-4M), from -6 to $42 \mathrm{sec}$. 


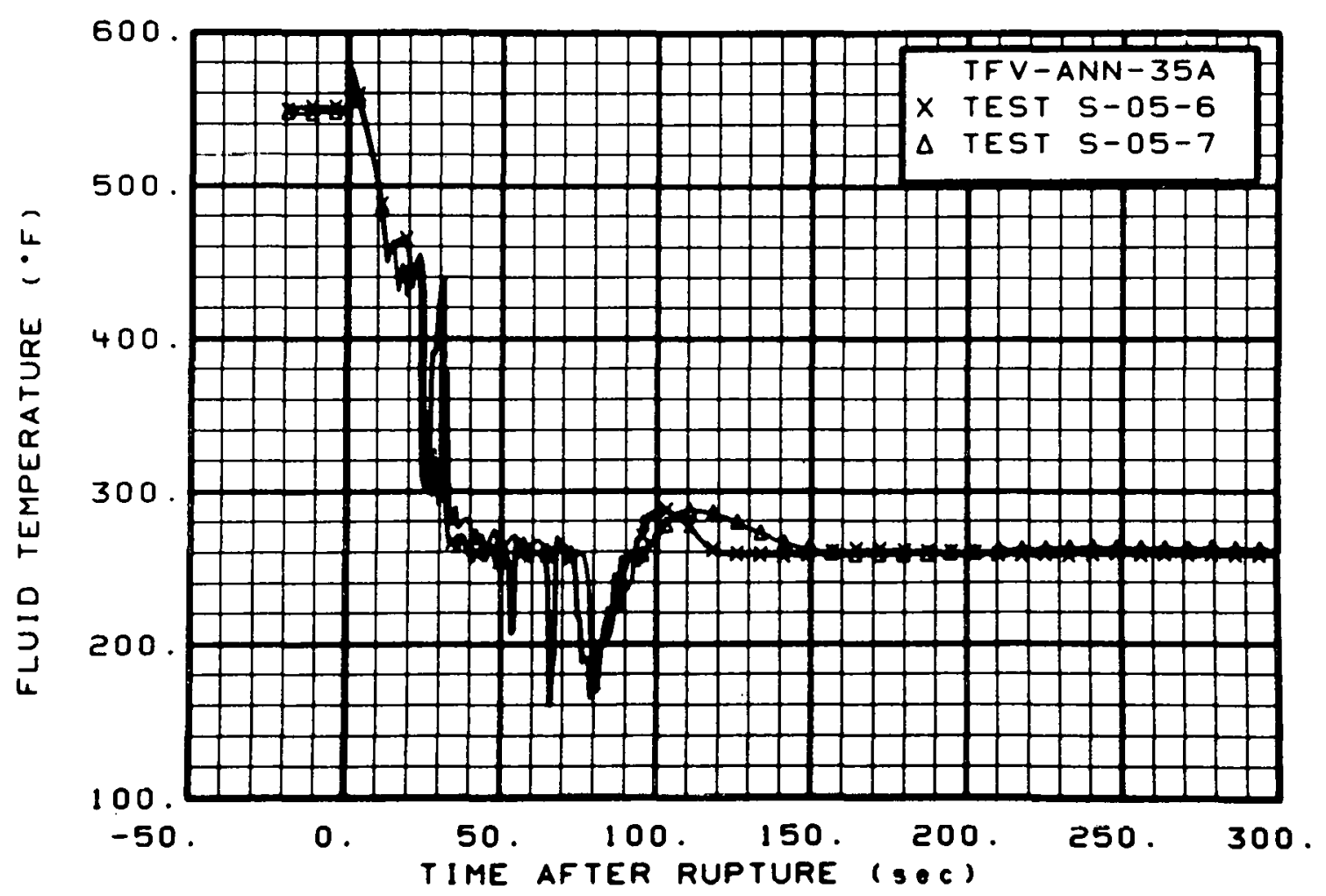

Fig. 32 Fluid temperature in downcomer annulus (TFV-ANi- $35 \mathrm{~A}$ ), from -20 to $300 \mathrm{sec}$.

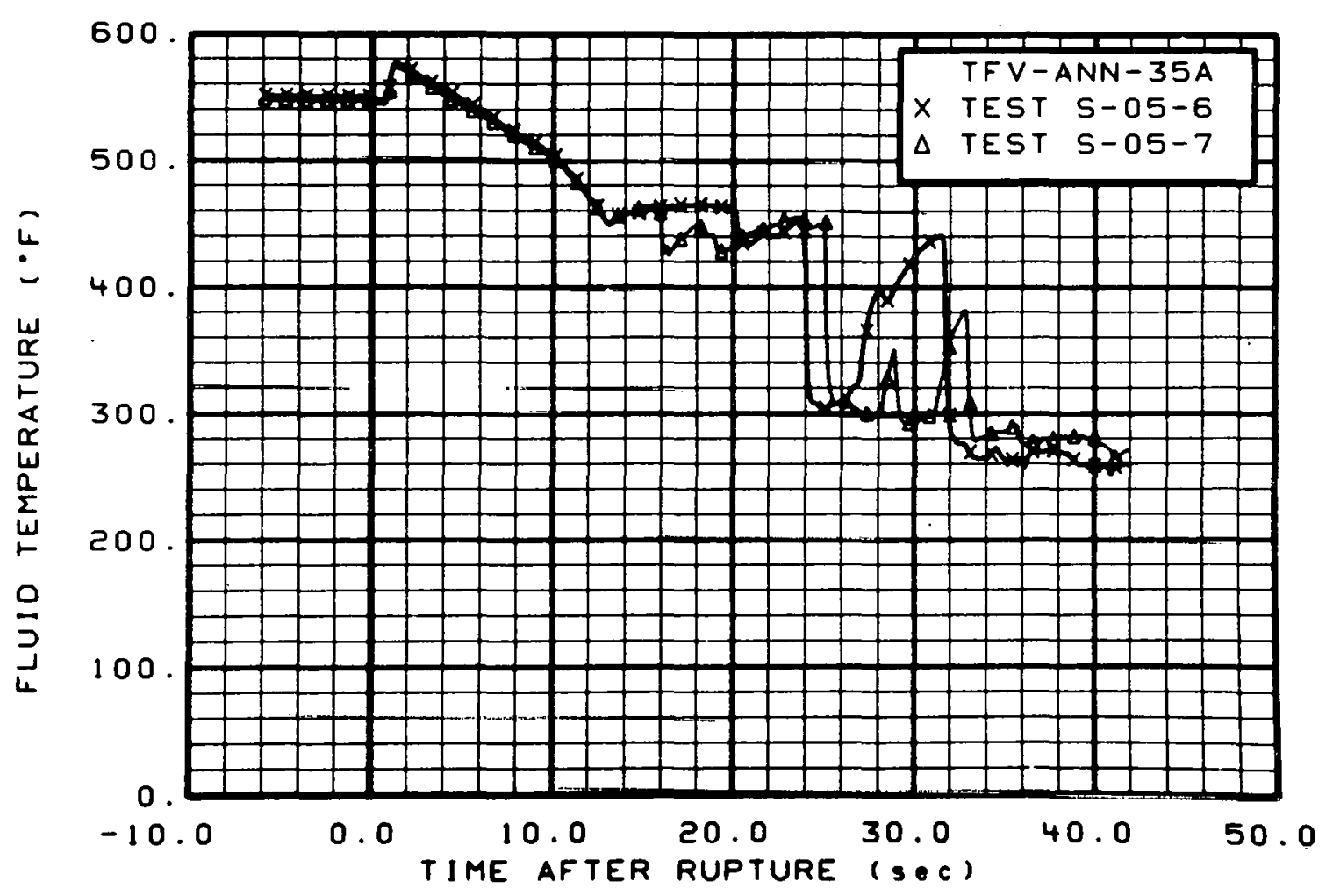

Fig. 33 Fluid temperature in downcomer annulus (TFV-ANN-35A), from -6 to $42 \mathrm{sec}$. 


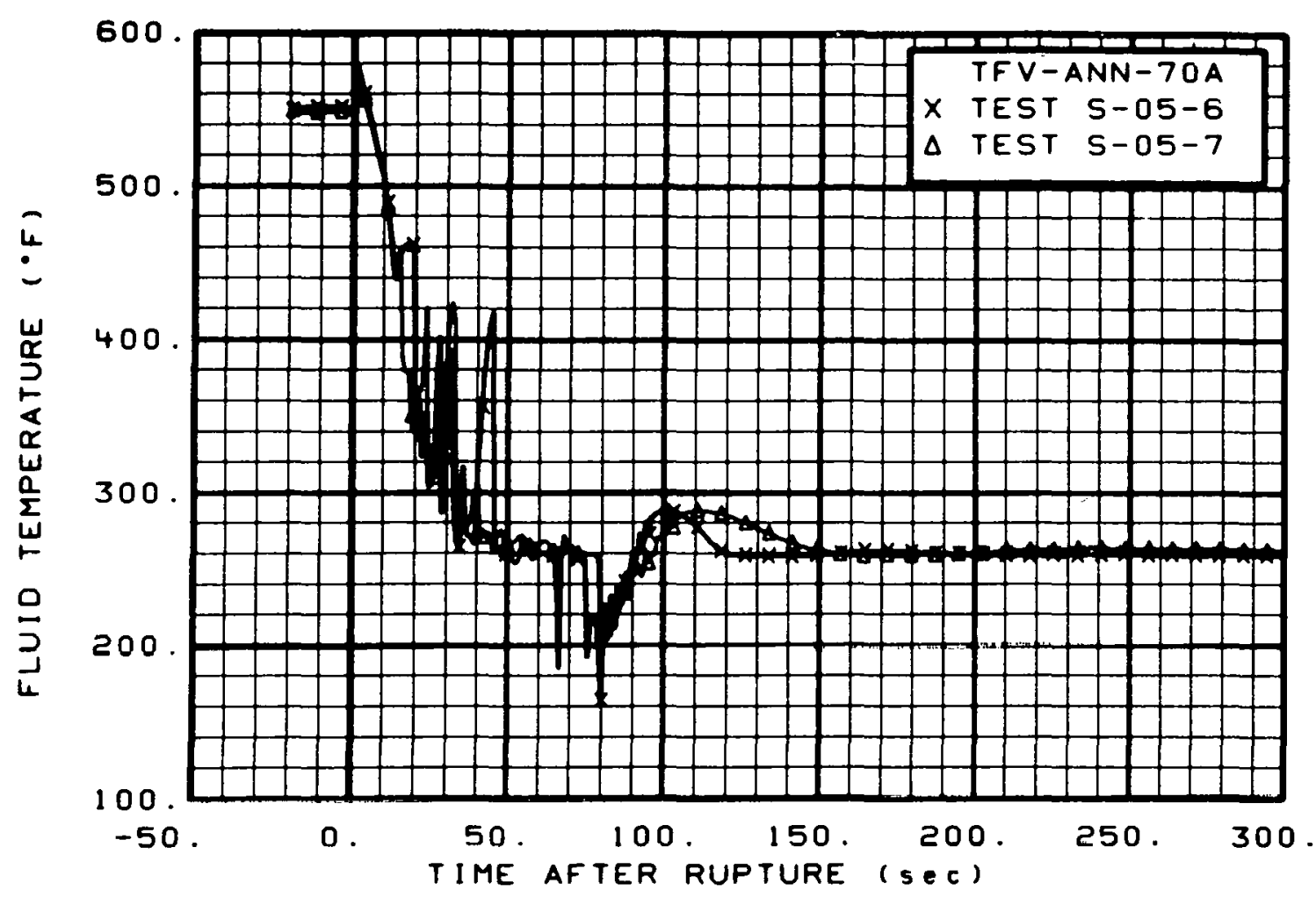

Fig. 34 Fluid temperature in downcomer annulus (TFV-ANN-70A), from -20 to $300 \mathrm{sec}$.

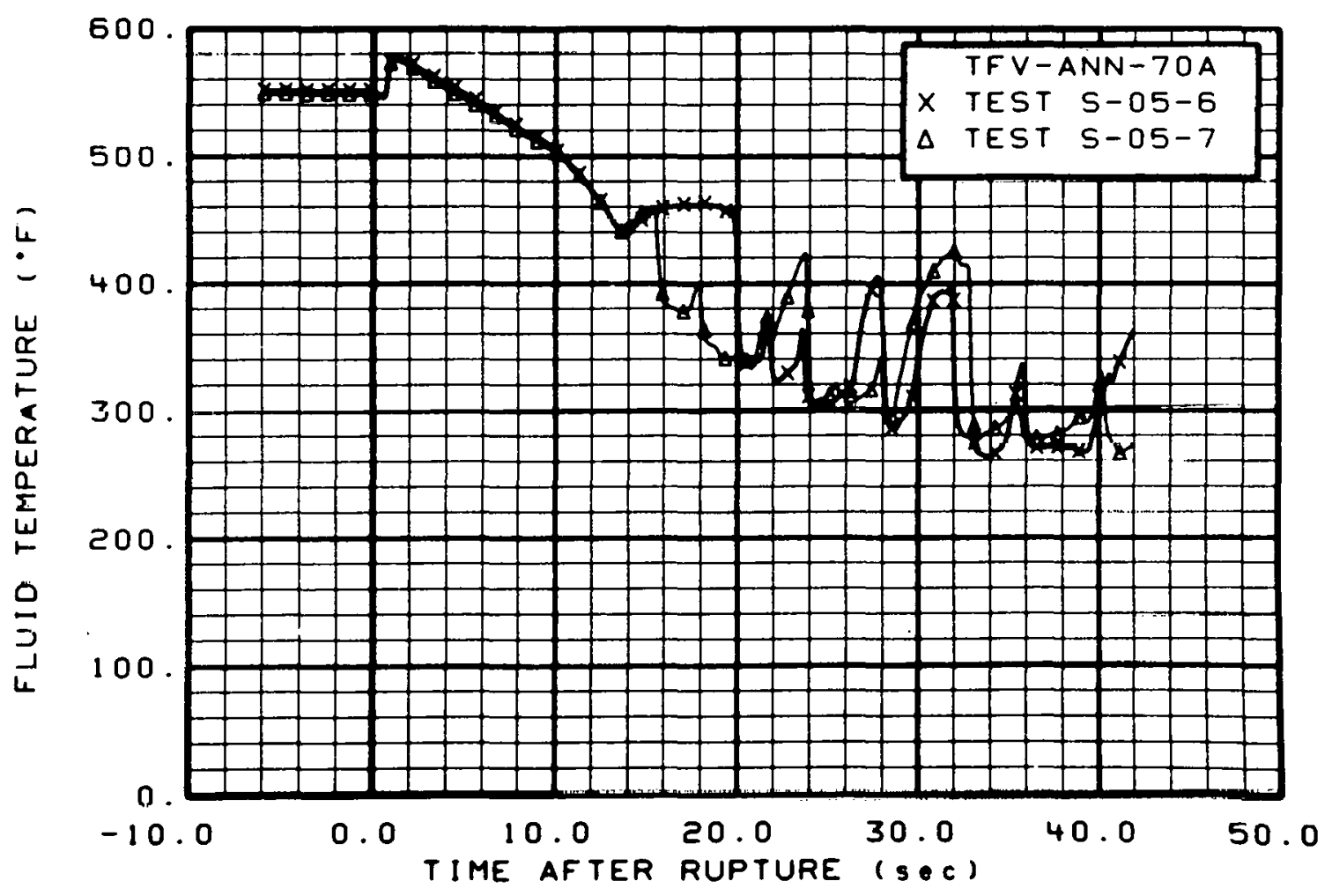

Fig. 35 Fluid temperature in downcomer annulus (TFV-ANN-70A), from -6 to $42 \mathrm{sec}$. 


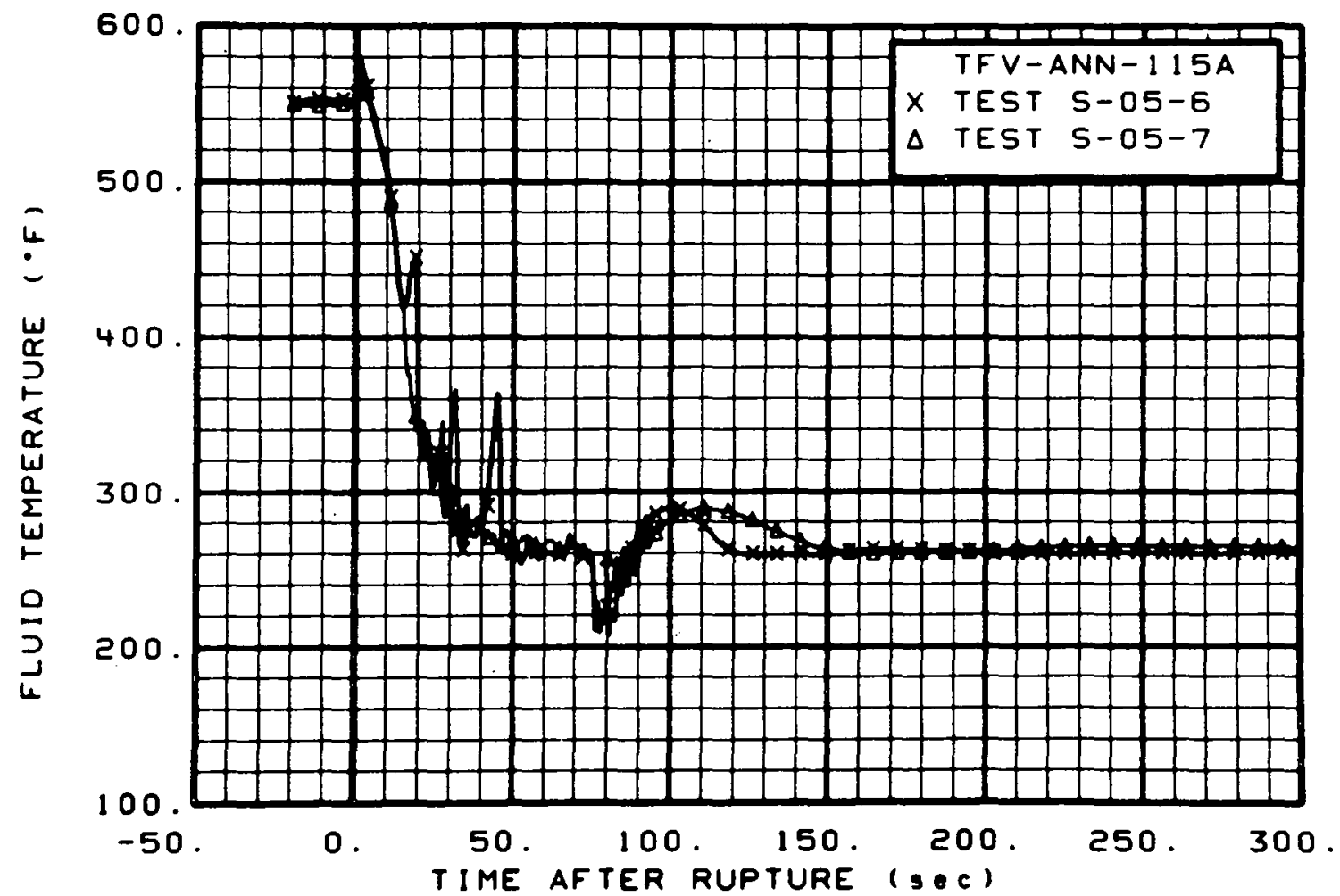

Fig. 36 Fluid temperature in downcomer annulus (TFV-ANN-115A), from -20 to $300 \mathrm{sec}$.

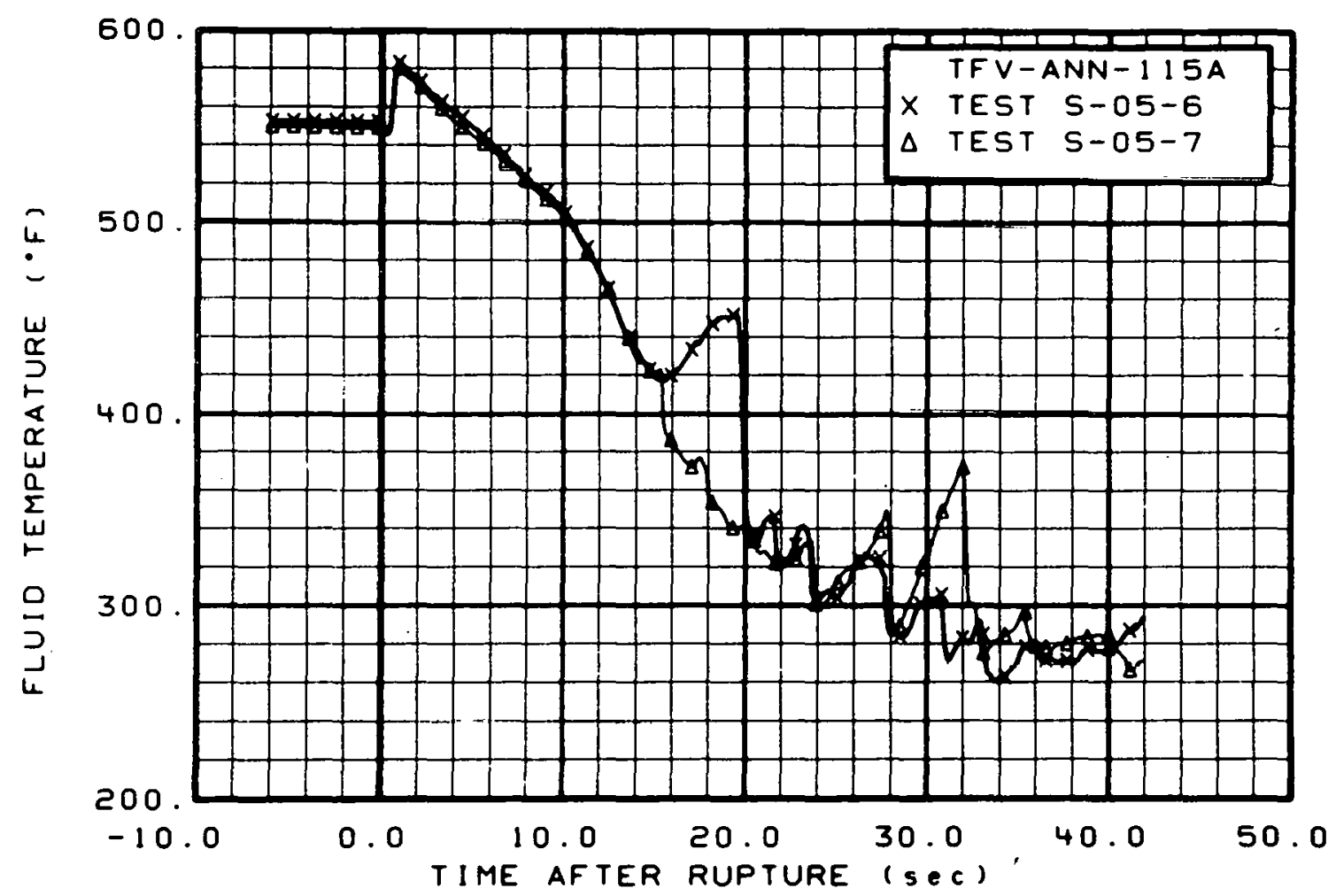

Fig. 37 Fluid temperature in downcomer annulus (TFV-ANN-115A), from -6 to $42 \mathrm{sec}$. 


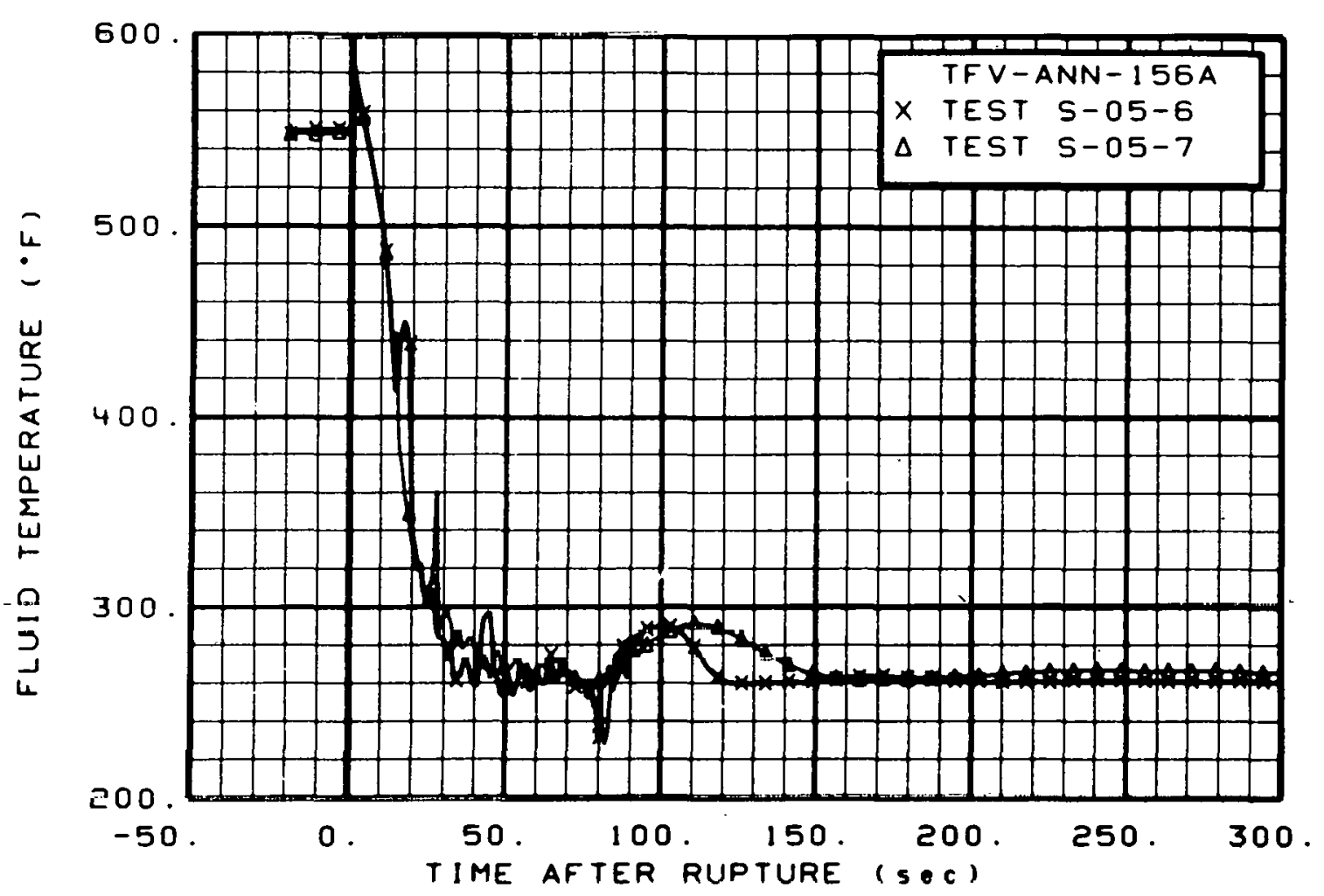

Fig. 38 Fluid temperature in downcomer annulus (TFV-ANN-156A), from -20 to $300 \mathrm{sec}$.

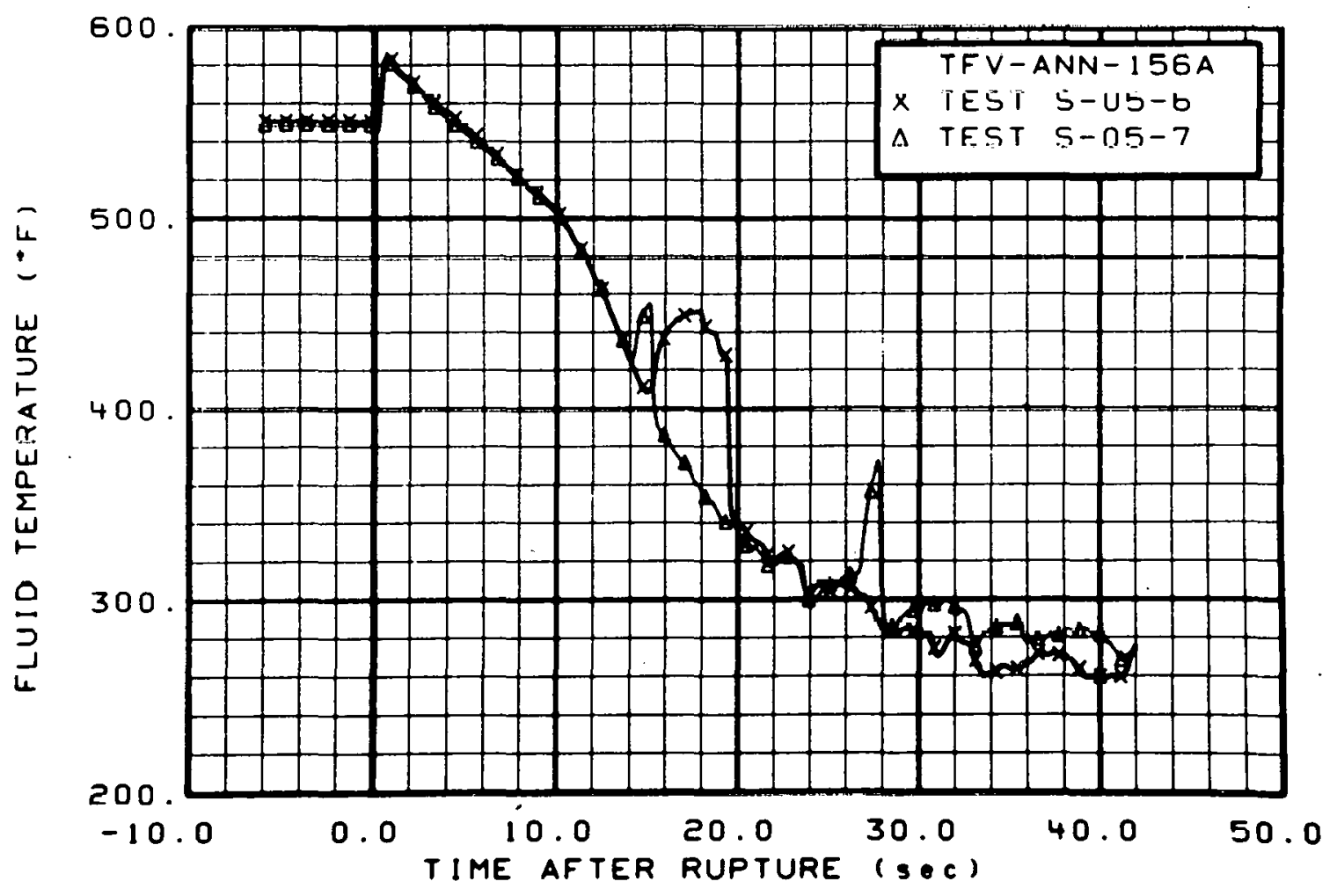

Fig. 39 Fluid temperature in downcomer annulus (TFV-ANN-156A), from -6 to $42 \mathrm{sec}$. 


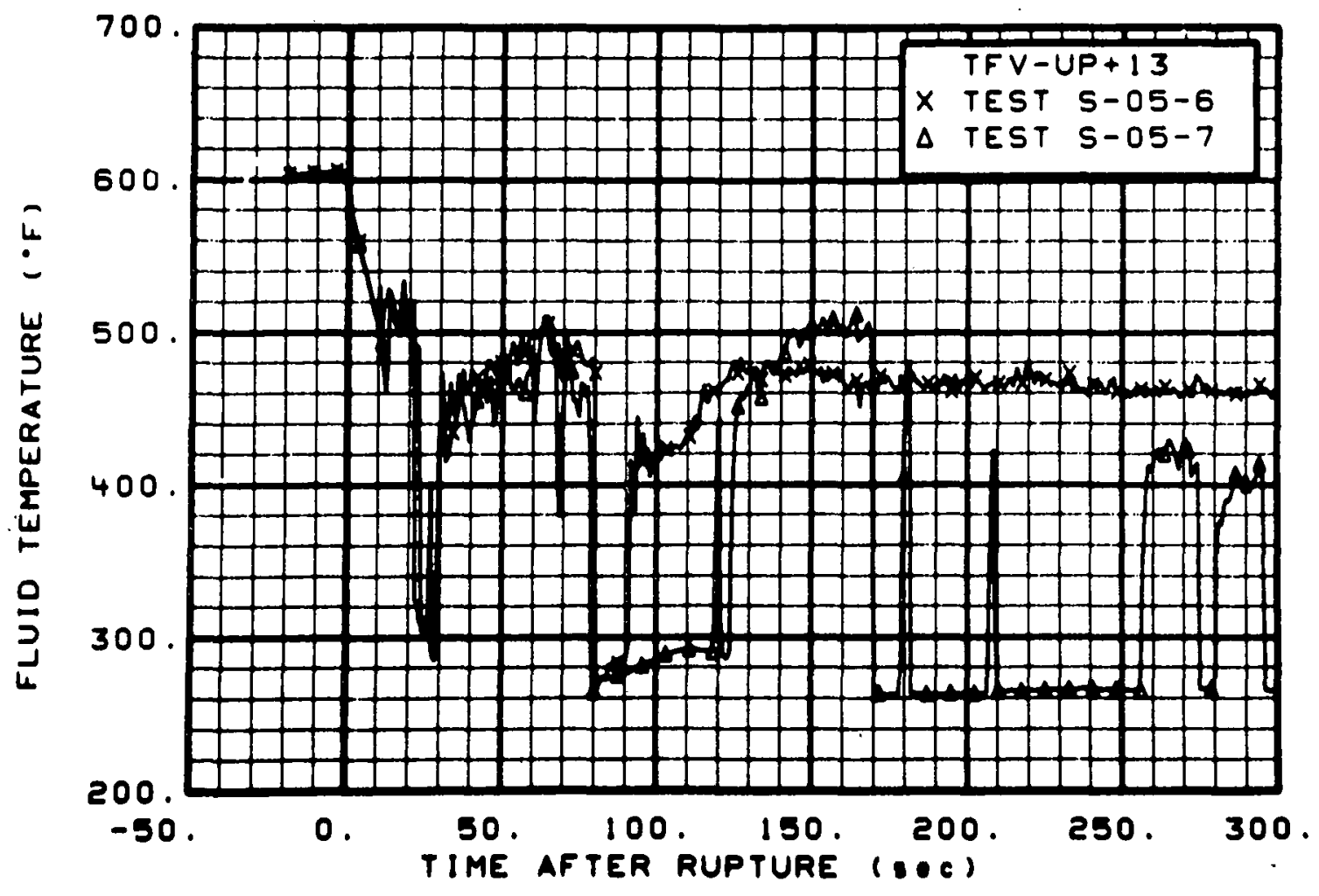

Fig. 40 Fluid temperature in upper plenum (TFV-UP+13), from -20 to $300 \mathrm{sec}$.

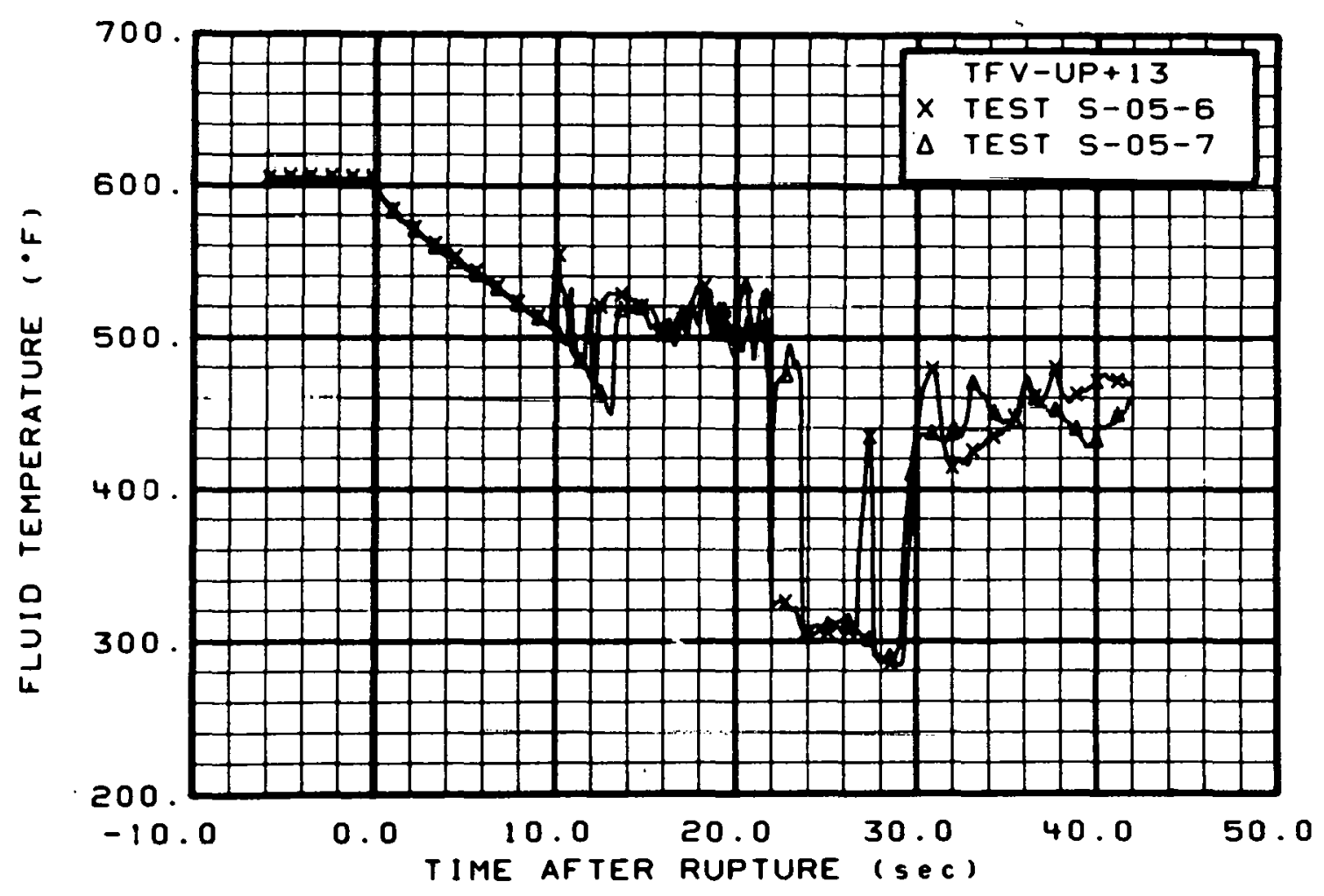

Fig. 41 Fluid temperature in upper plenum (TFV-UP+13), from -6 to $42 \mathrm{sec}$. 


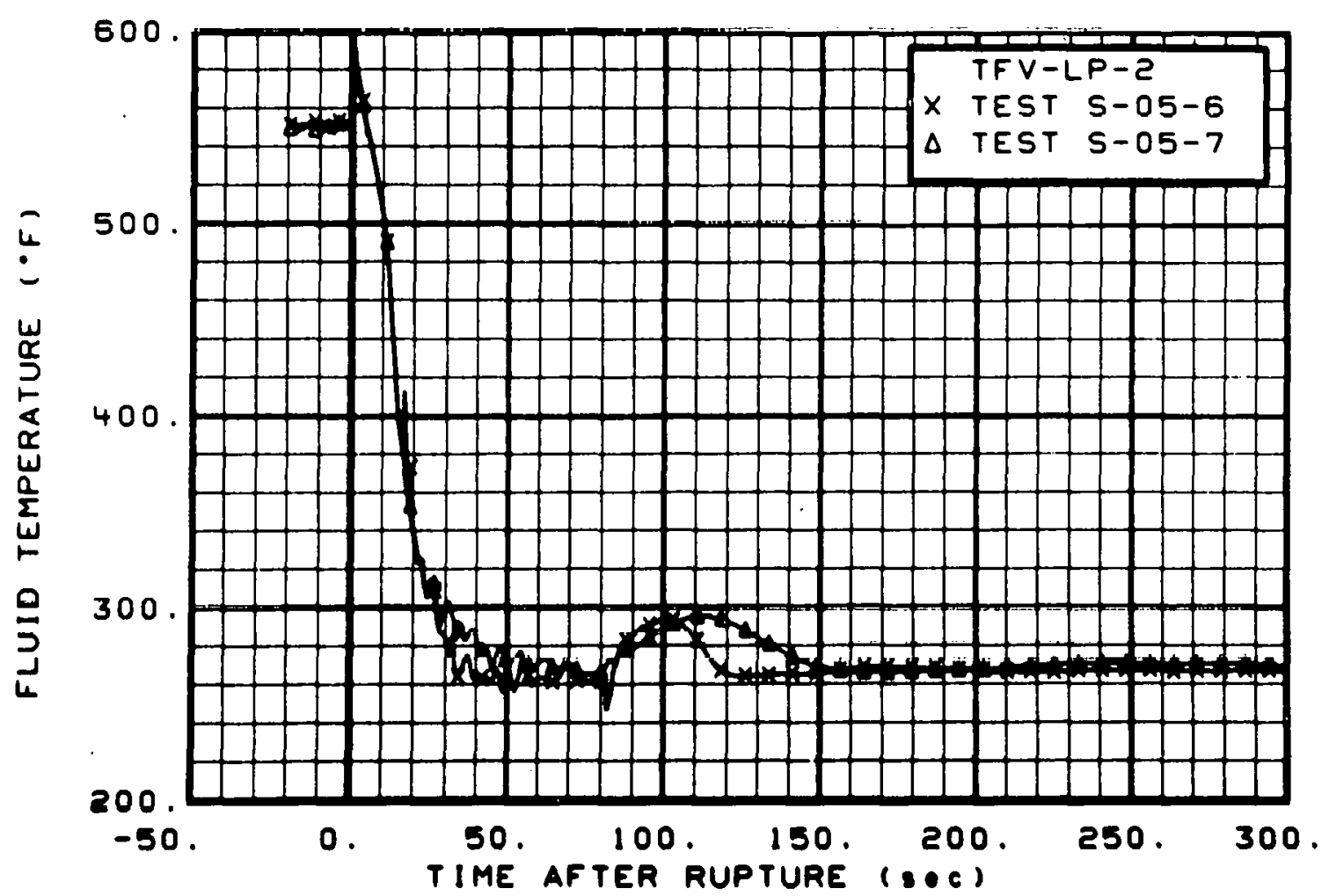

Fig. 42 Fluid temperature in upper plenum (TFV-LP-2), from -20 to $300 \mathrm{sec}$.

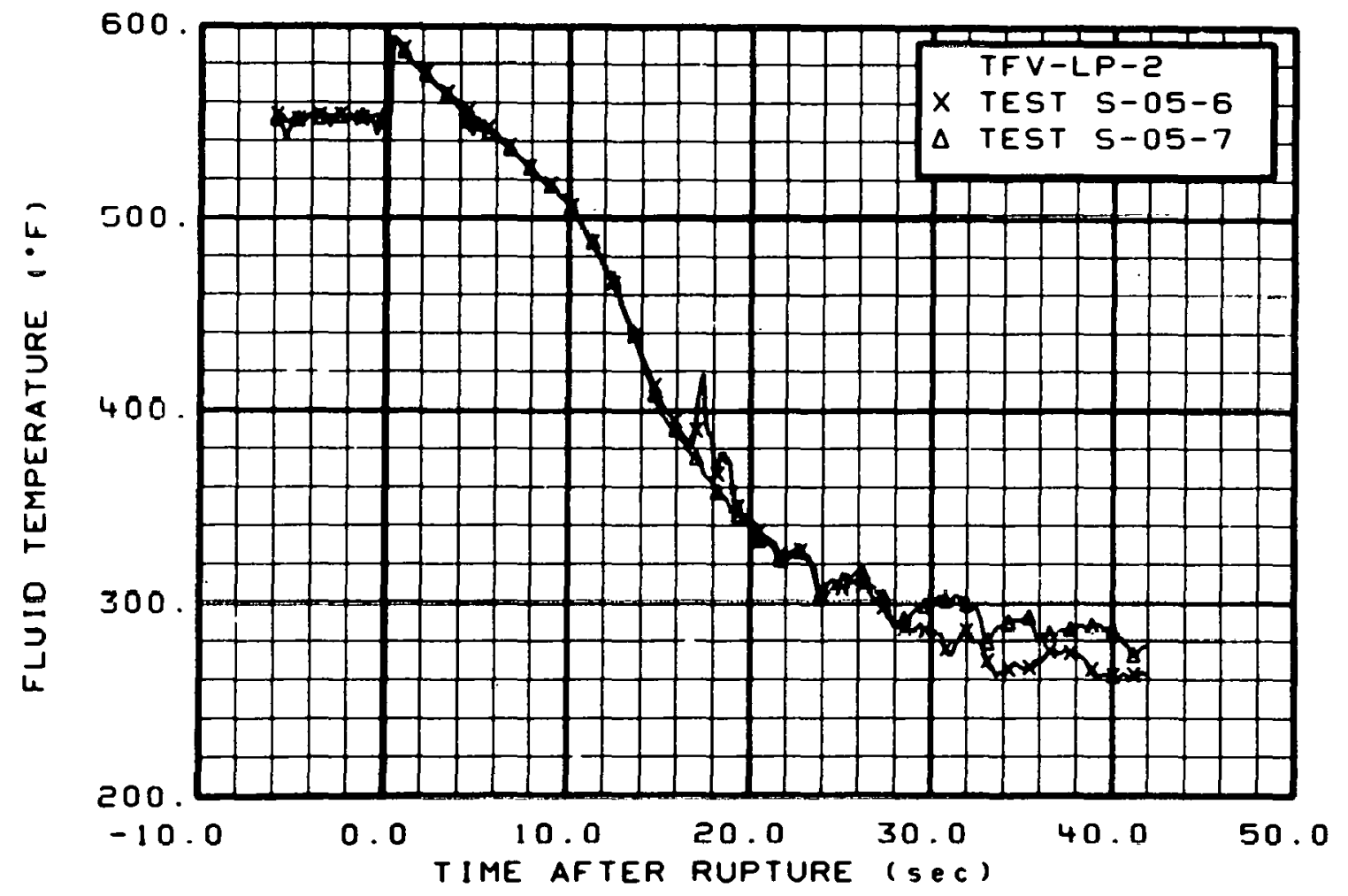

Fig. 43 Fluid temperature in upper plenum (TFV-LP-2), from -6 to 42 sec. 


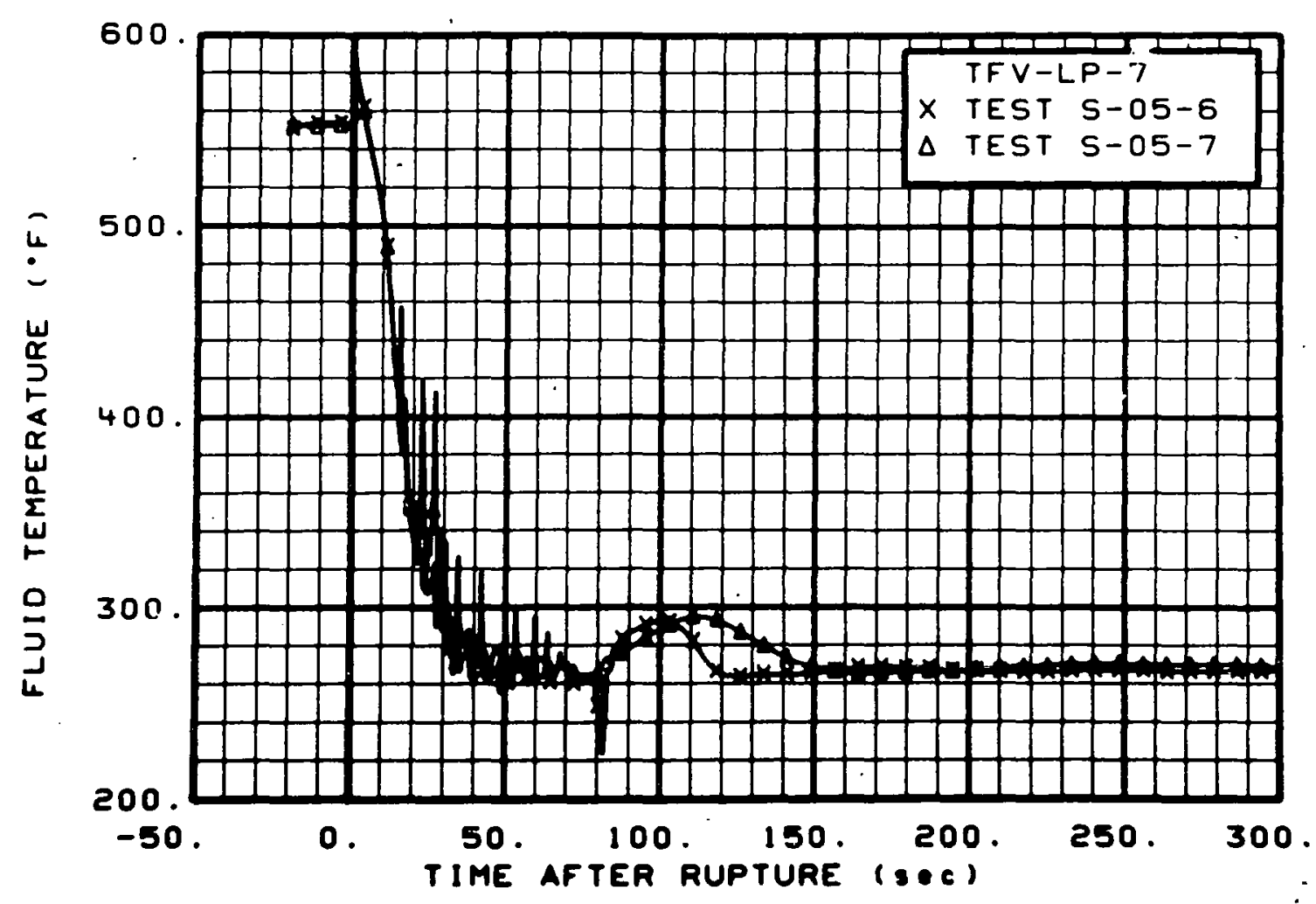

Fig. 44 Fluid temperature in lower plenum (TFV-LP-7), from -20 to ,. 300 sec.

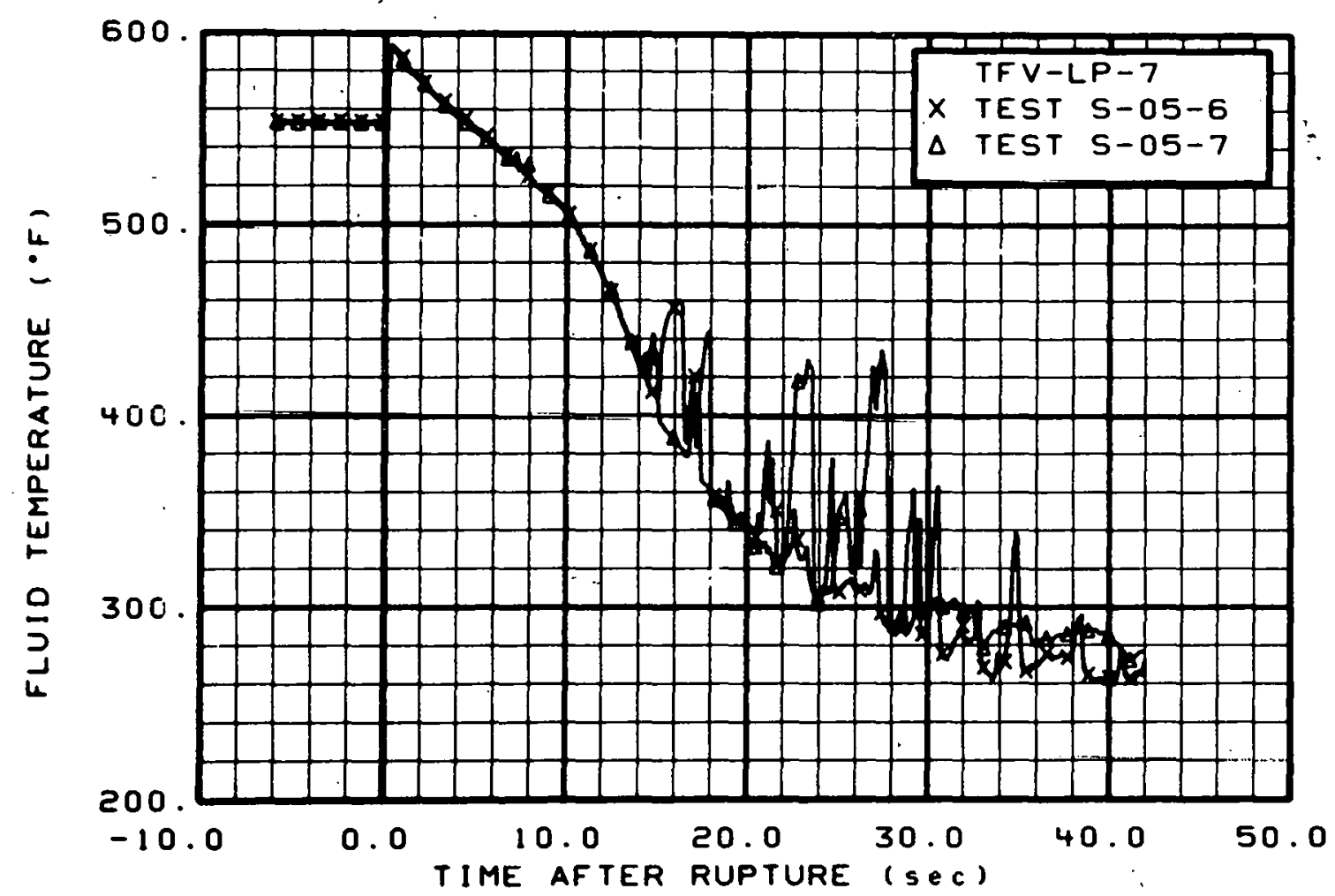

Fig. 45 Fluid temperature in lower plenum (TFV-LP-7), from -6 to 42 sec. 


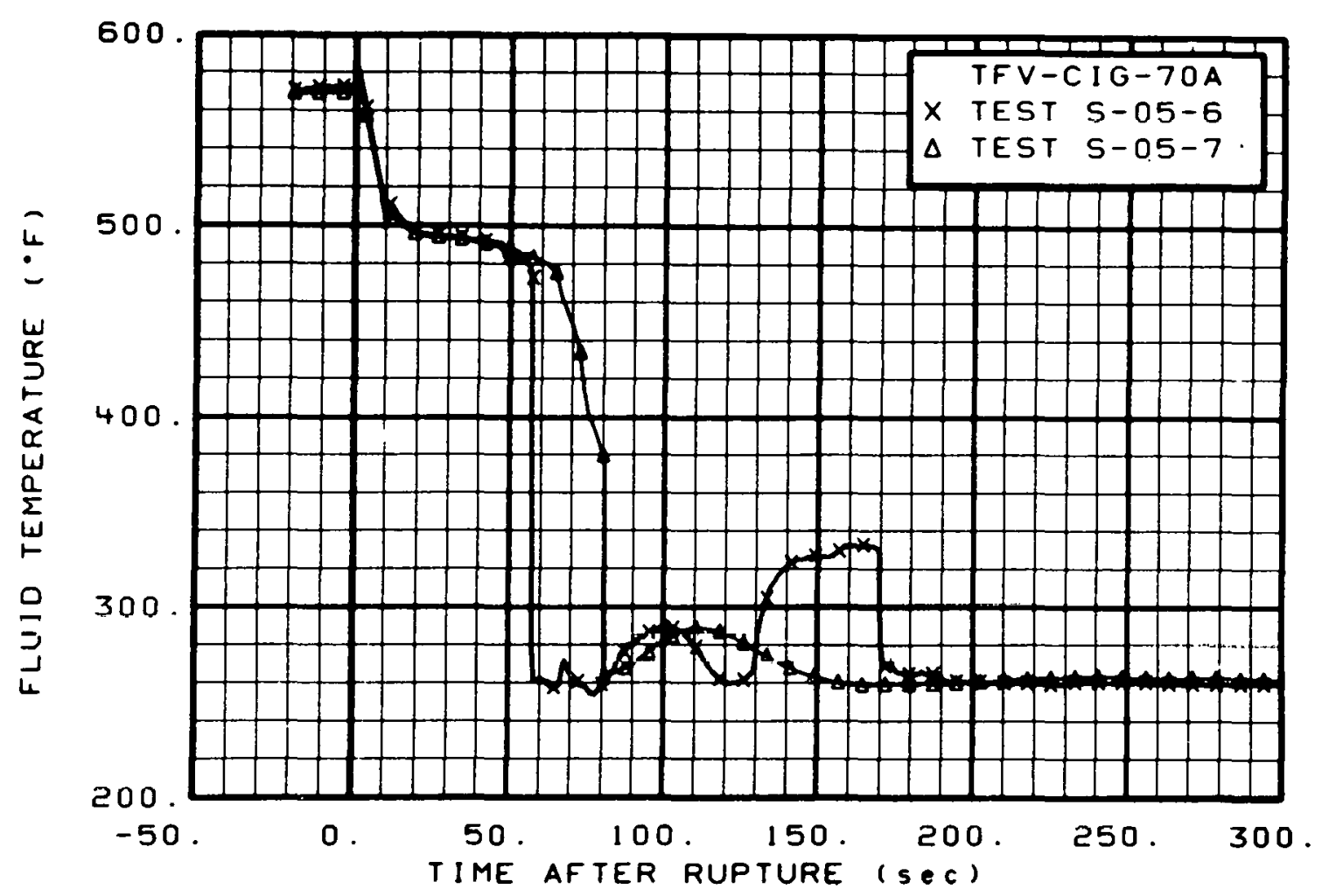

Fig. 46 Fluid temperature in core insulation gap (TFV-CIG-70A), from -20 to $300 \mathrm{sec}$.

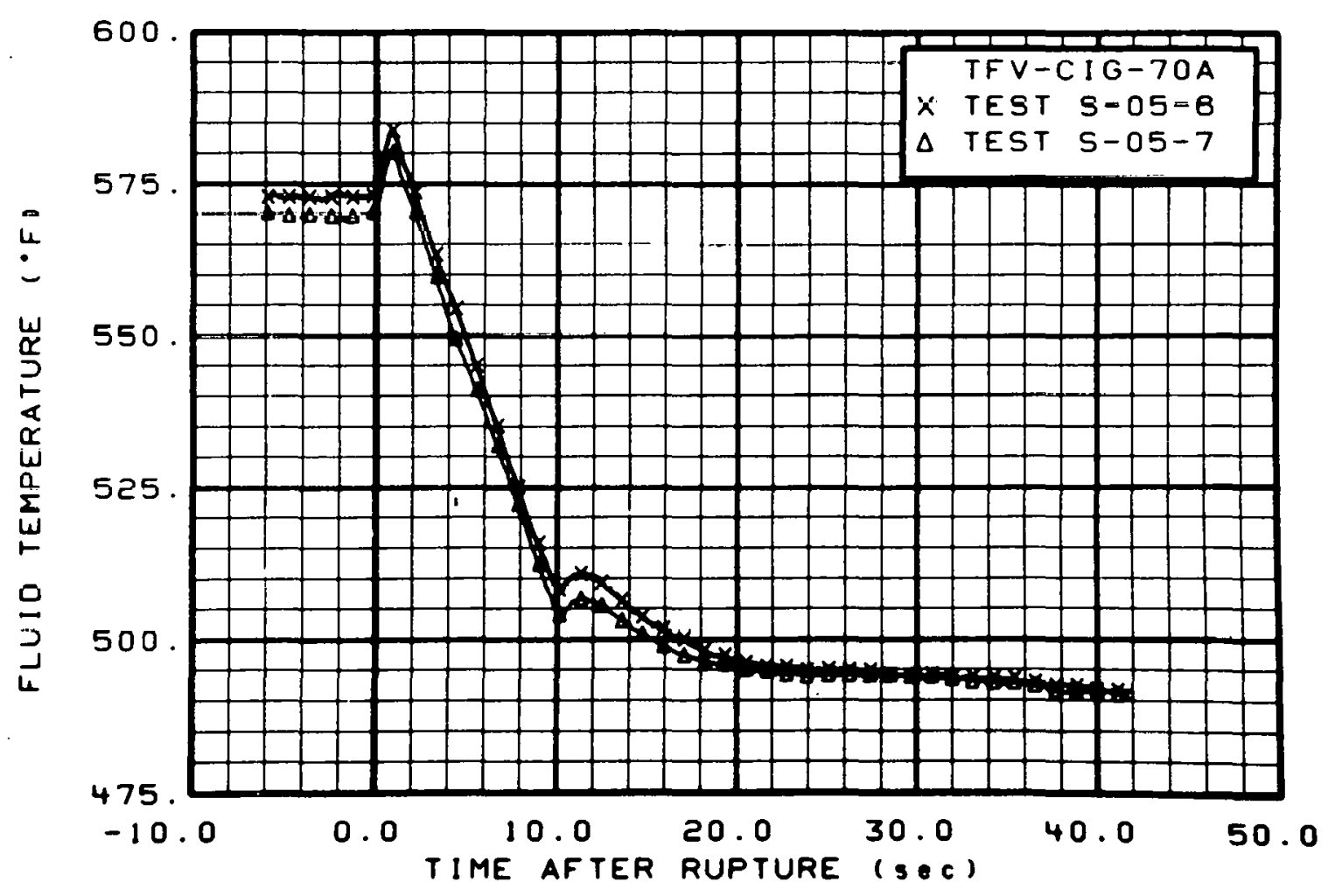

Fig. 47 Fluid temperature in core insulation gap (TFV-CIG-70A), from -6 to $42 \mathrm{sec}$. 


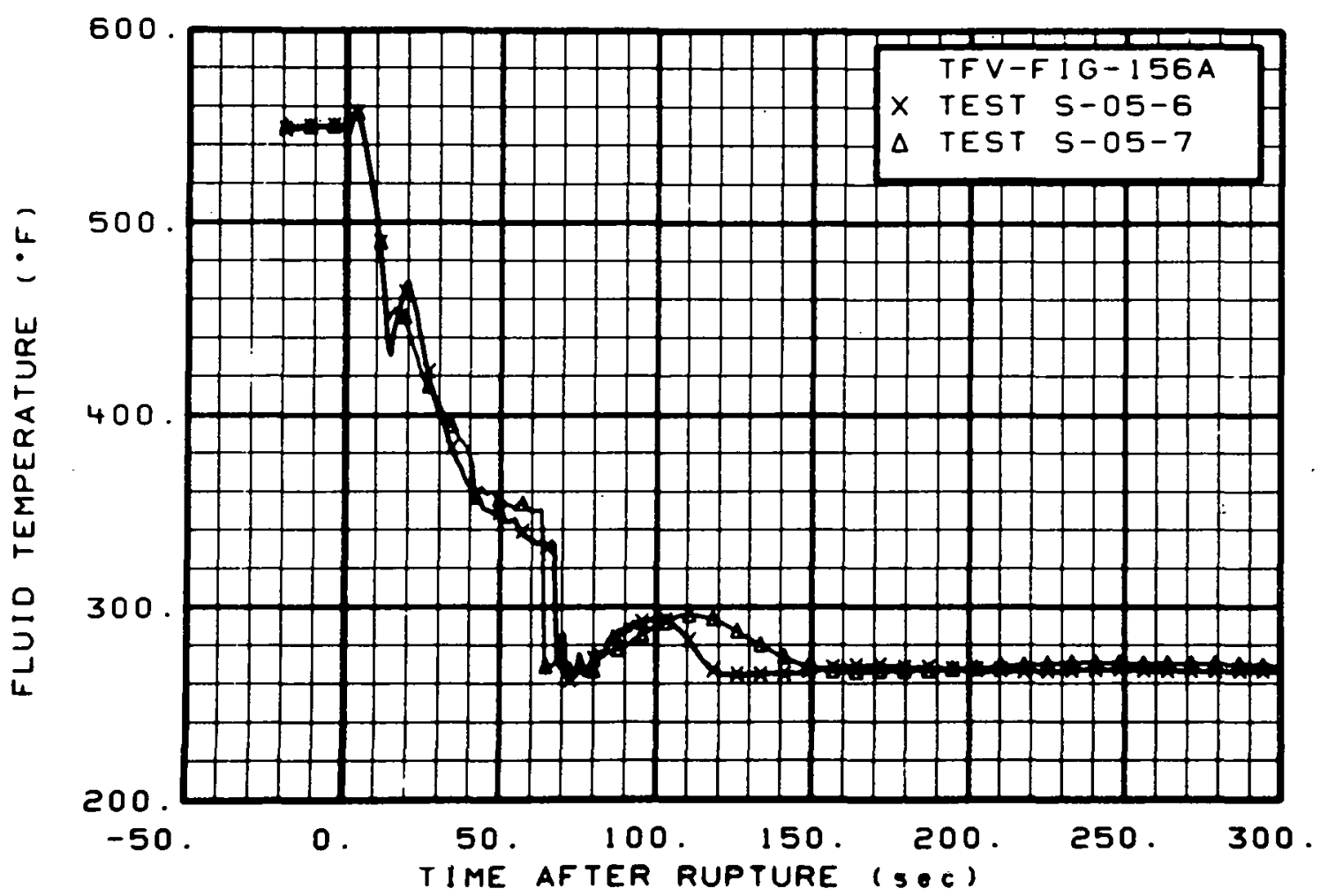

Fig. 48 Fluid temperature in vessel filler insulation gap (TFV-FIG-156A), from -20 to $300 \mathrm{sec}$.

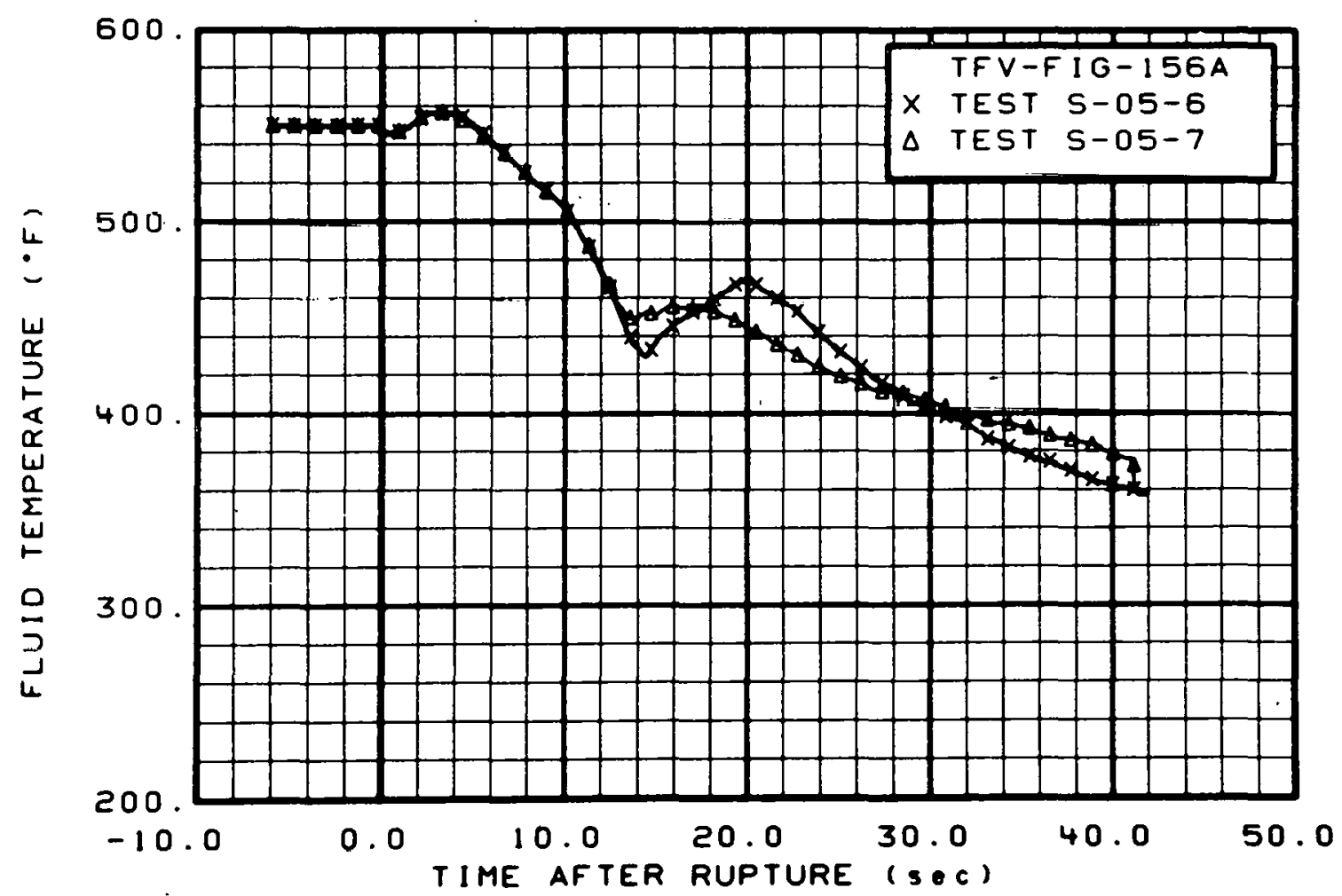

Fig. 49 Fluid temperature in vessel filler insulation gap (TFV-FIG-156A), from . 6 to 12 sec. 


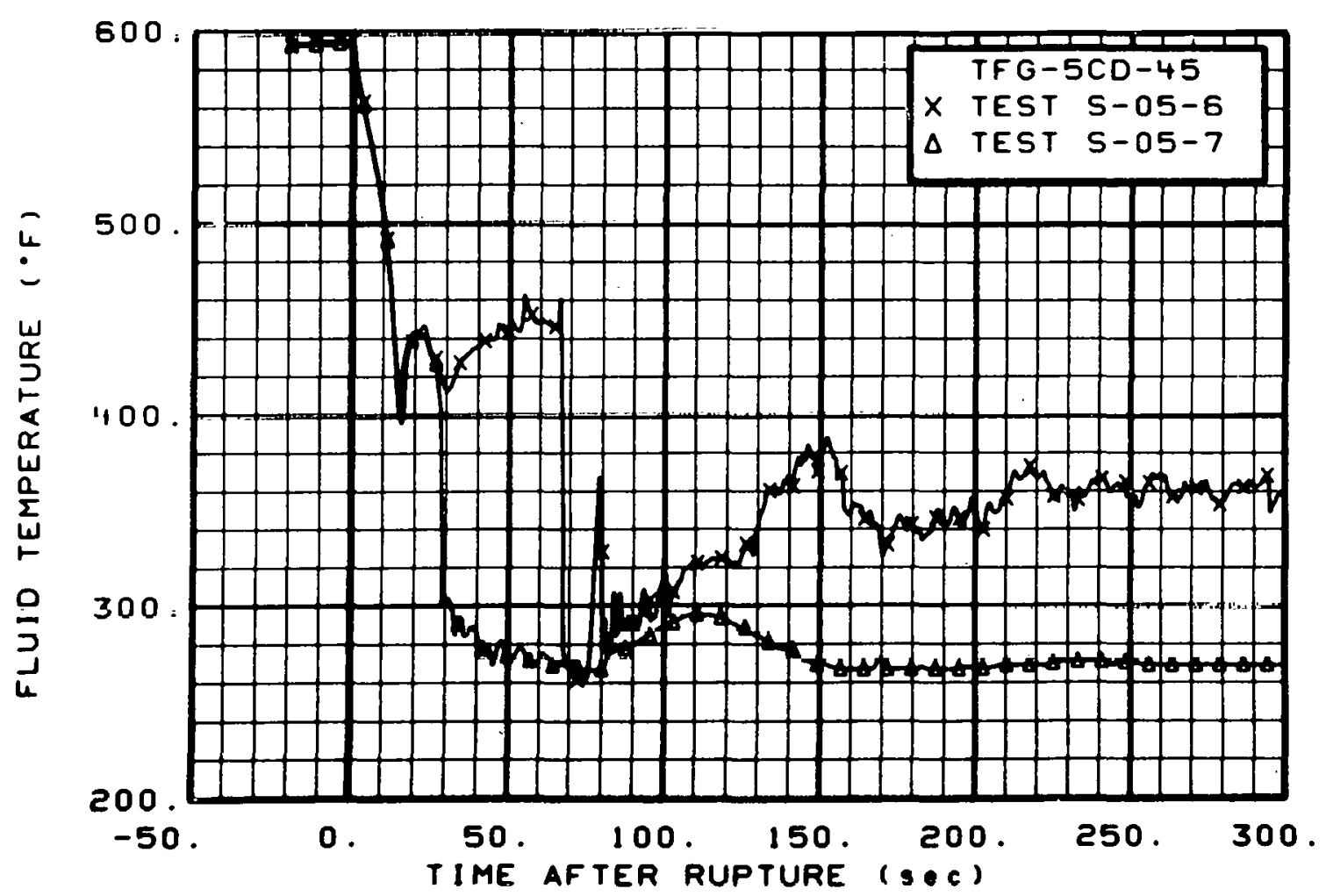

Fig. 50 Fluid temperature in core, Grid Spacer 5 (TFG-5CD-45), from -20 to $300 \mathrm{sec}$.

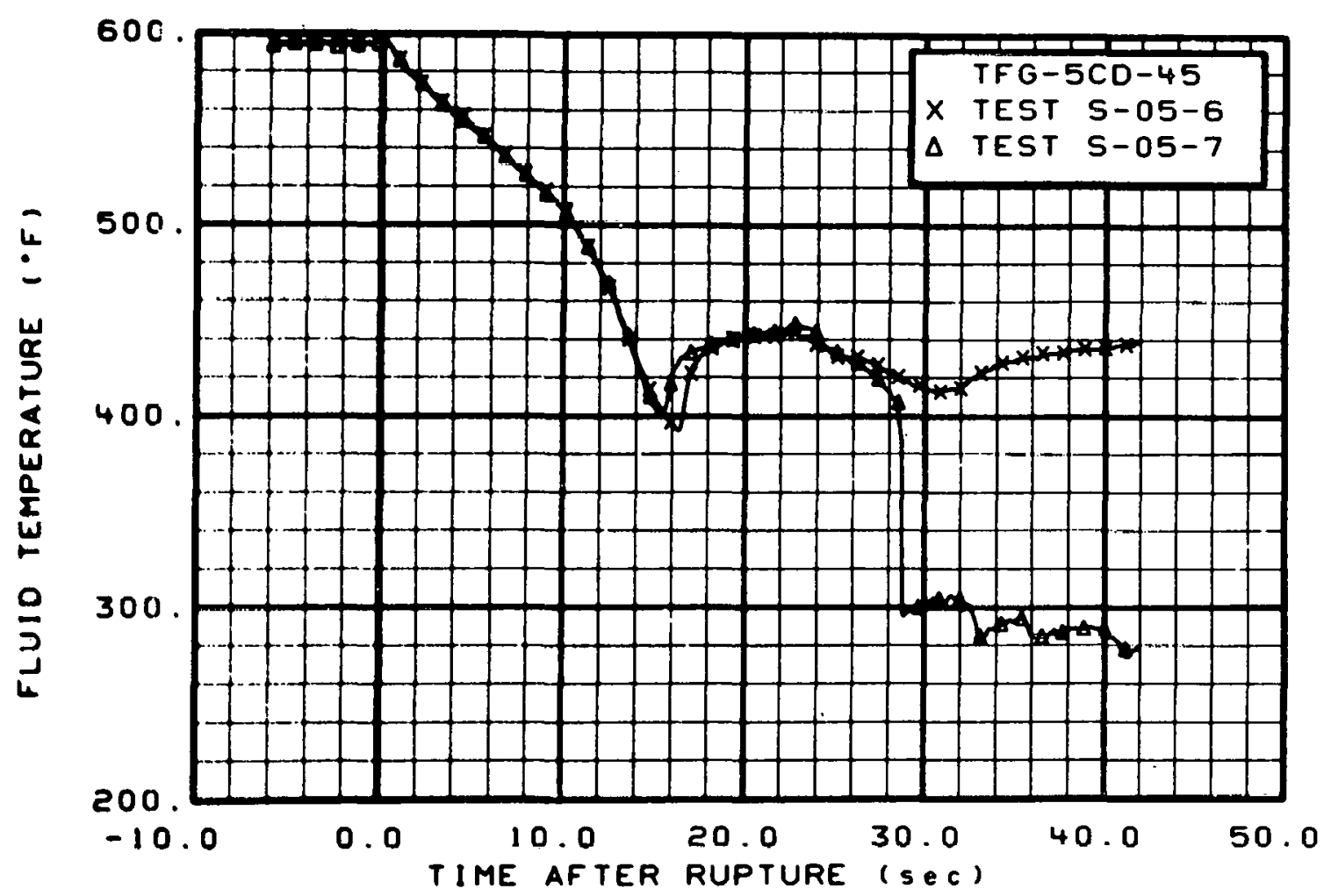

Fig. 51 Fluid temperature in core, Grid Spacer 5 (TFG-5CD-45), from -6 to $42 \mathrm{sec}$. 


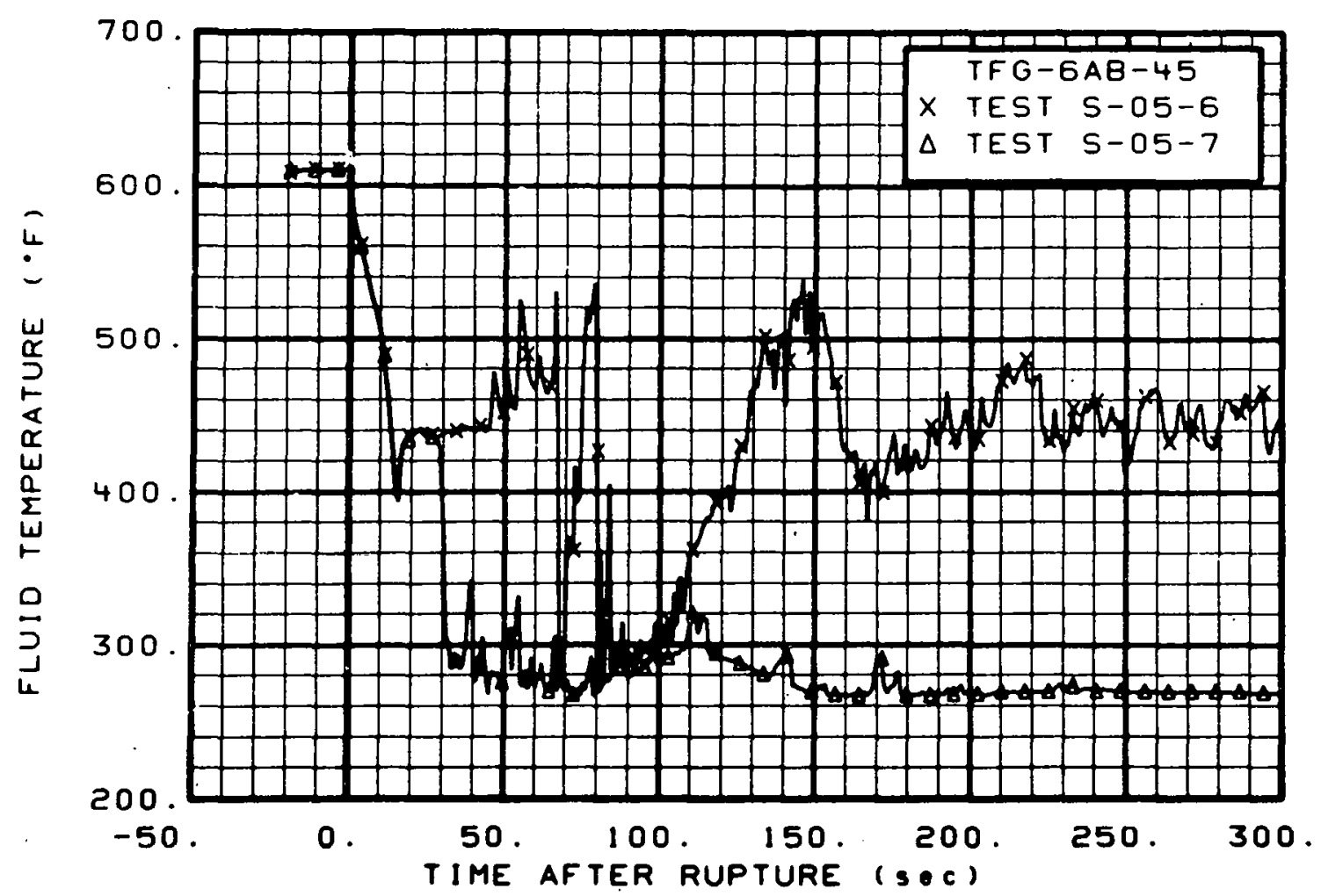

Fig. 52 Fluid temperature in core, Grid Spacer $6(T F G-6 A B-45)$, from -20 to $300 \mathrm{sec}$.

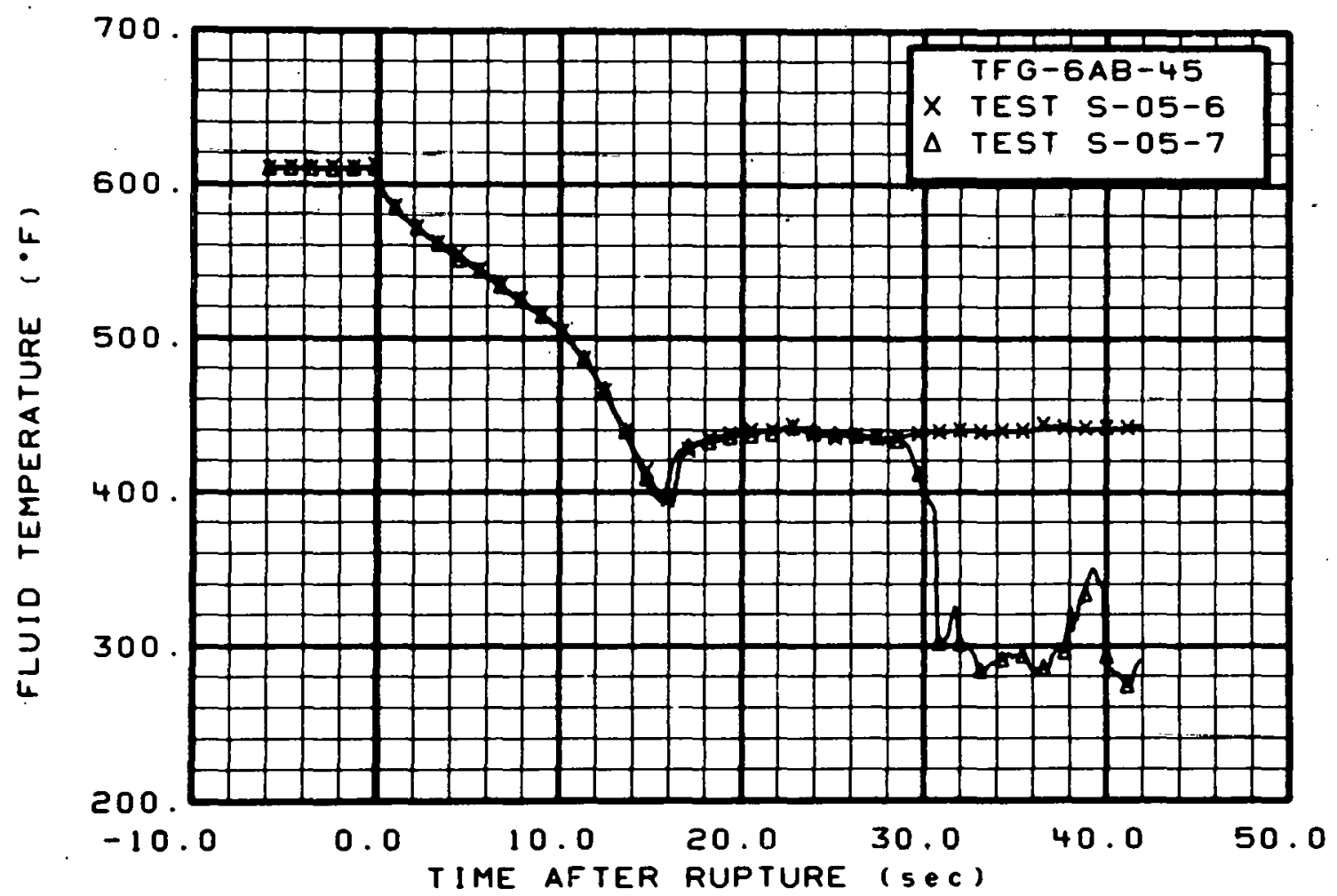

Fig. 53 Fluid temperature in core, Grid Spacer 6 (TFG-6AB-45), from -6 to $42 \mathrm{sec}$. 


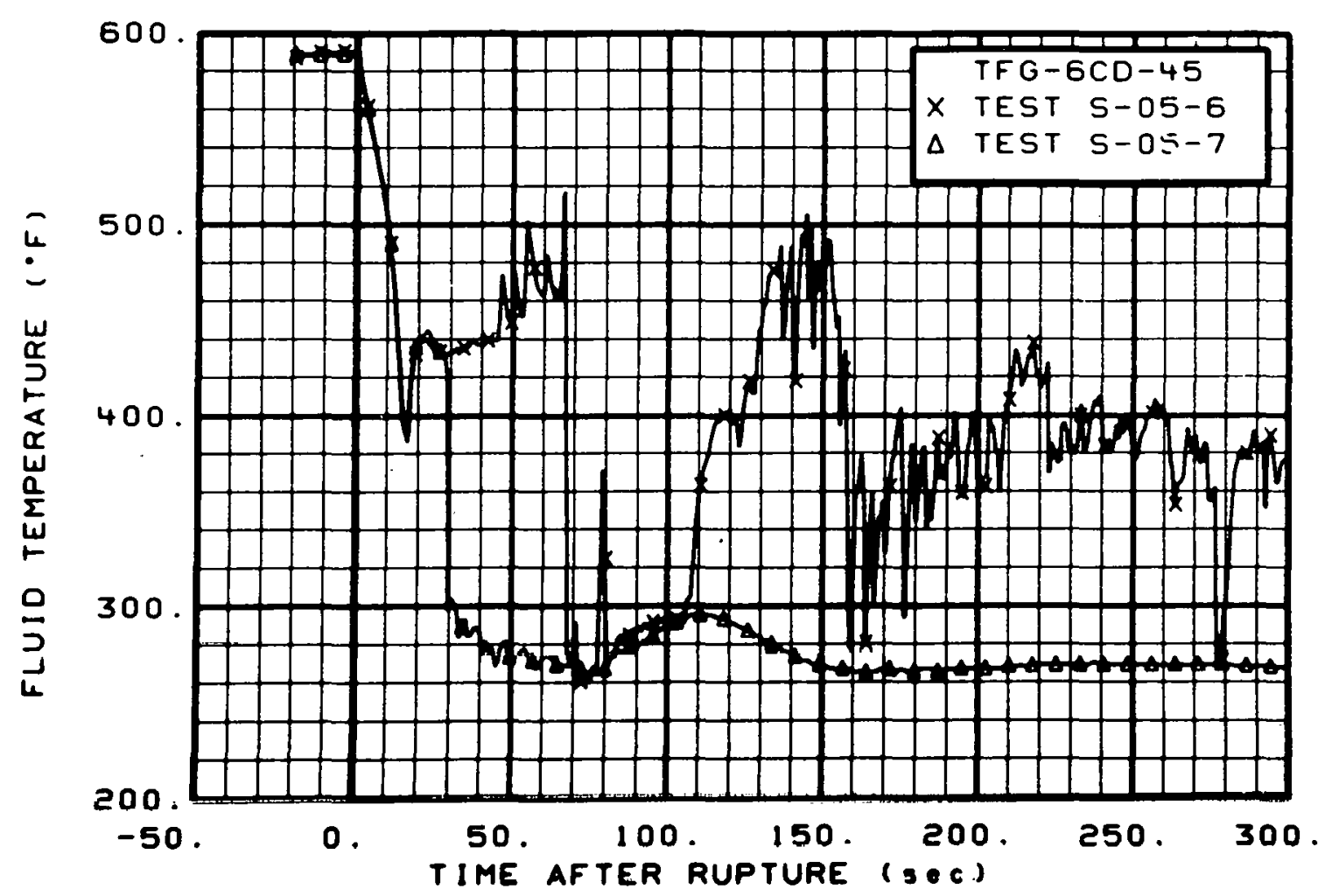

Fig. 54 Fluid temperature in core, Grid Spacer 6 (TFG-6CD-45), from -20 to $300 \mathrm{sec}$.

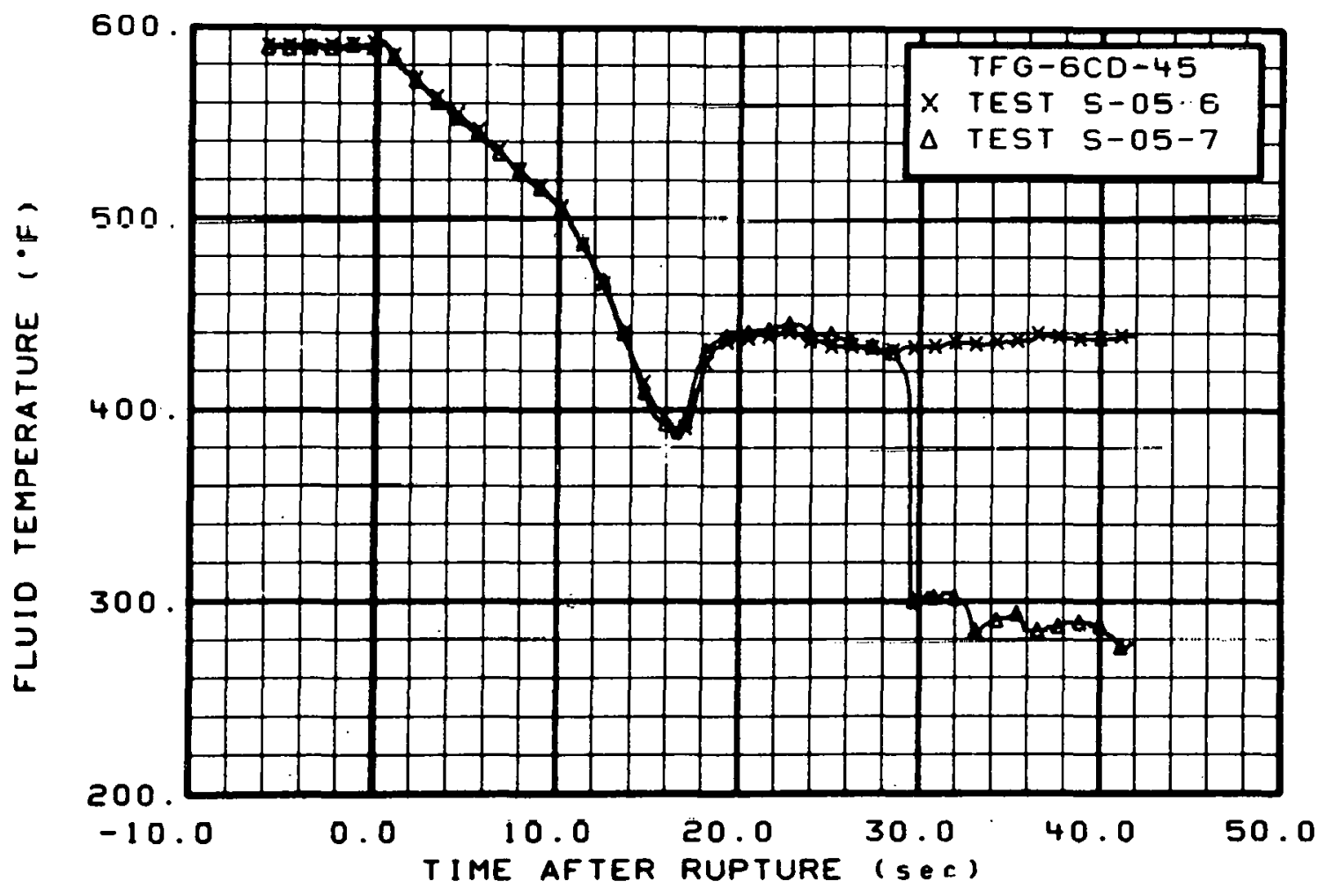

Fig. 55 Fluid temperature in core, Grid Spacer 6 (TFG-6CD-45), from -6 to $42 \mathrm{sec}$. 


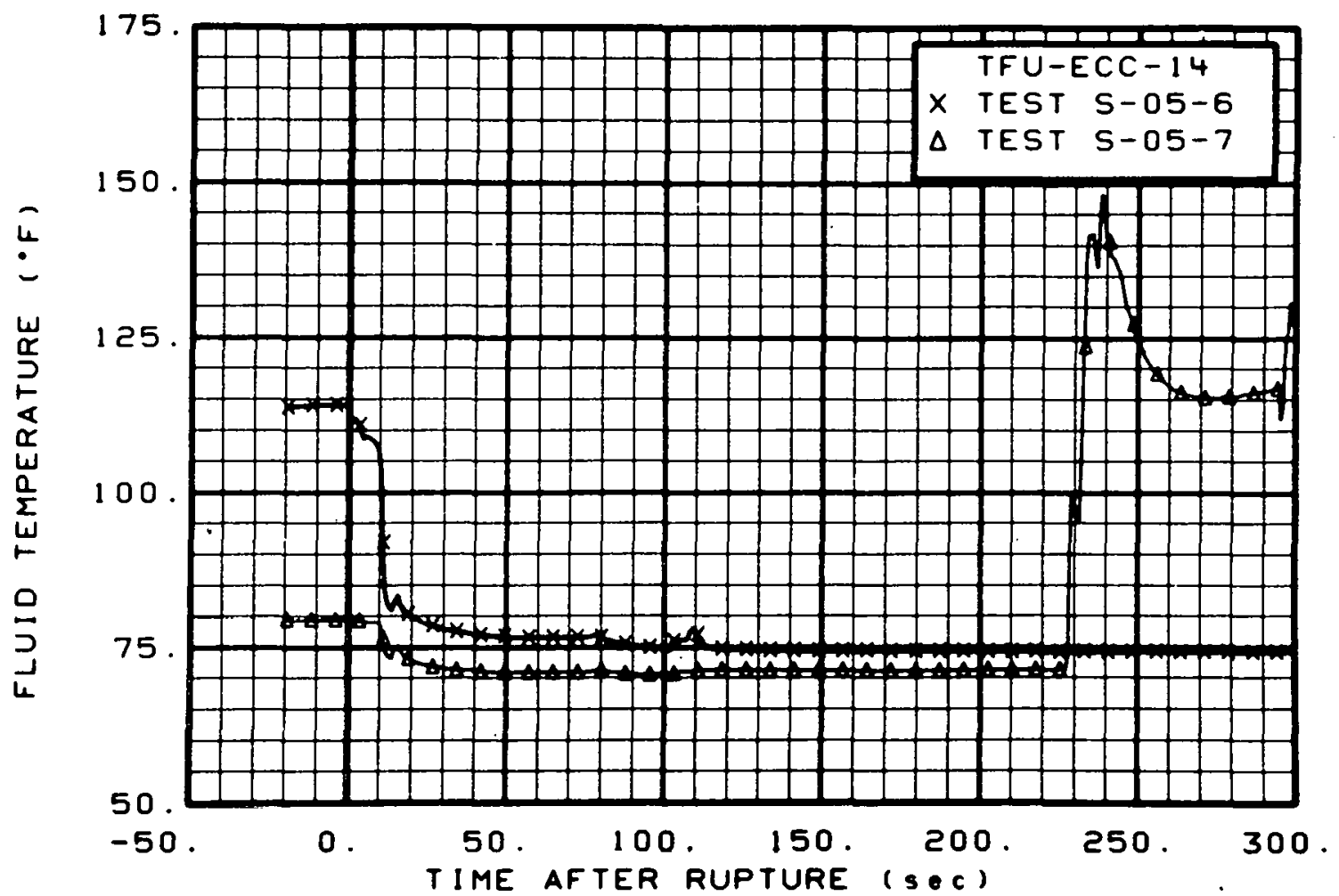

Fig. 56 Fluid temperature in intact loop ECC injection line (TFU-ECC-i4), from -20 to $300 \mathrm{sec}$.

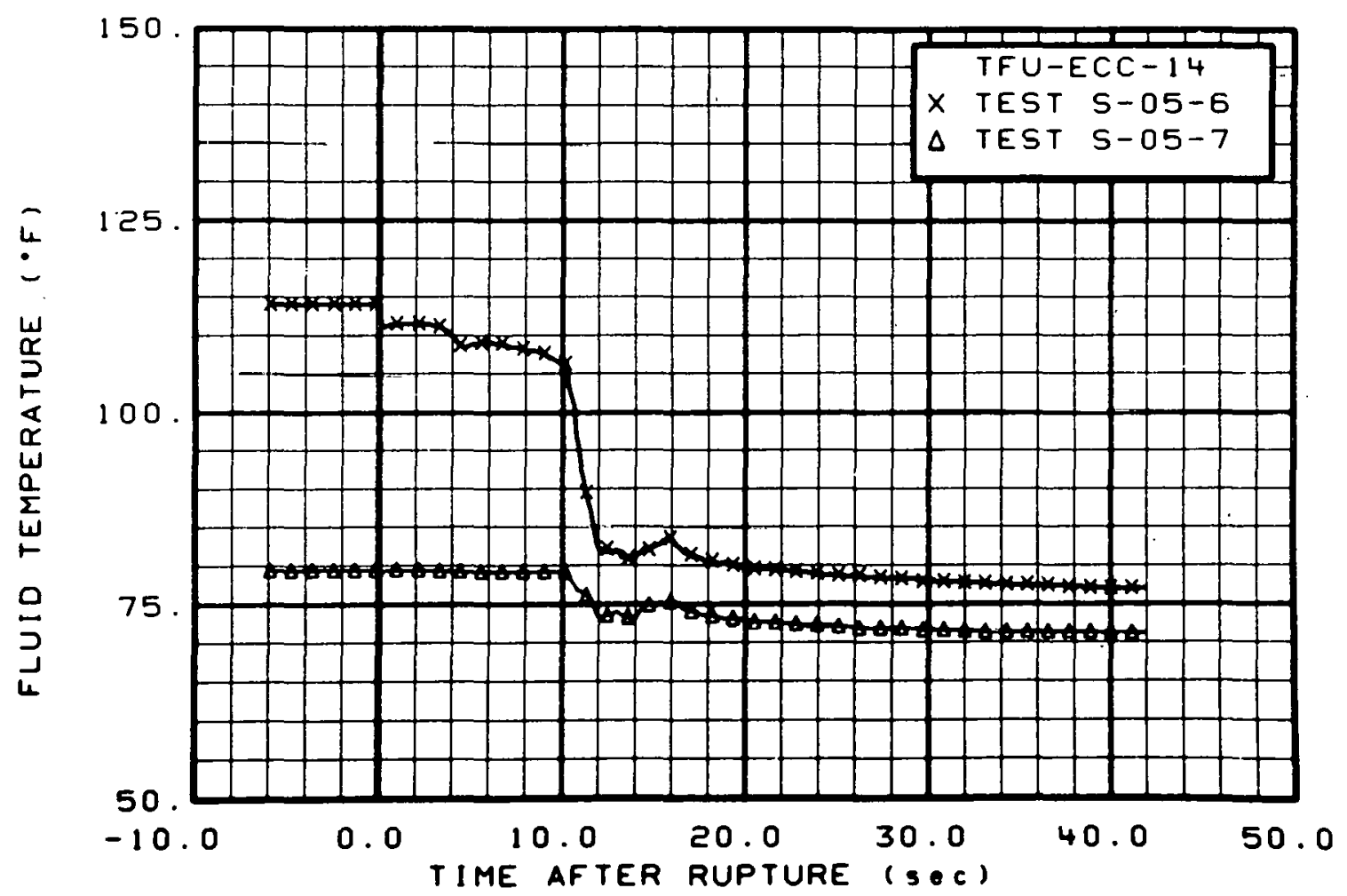

Fig. 57 Fluid temperature in intact loop ECC injection line (TFU-ECC-14), from -6 to $42 \mathrm{sec}$. 


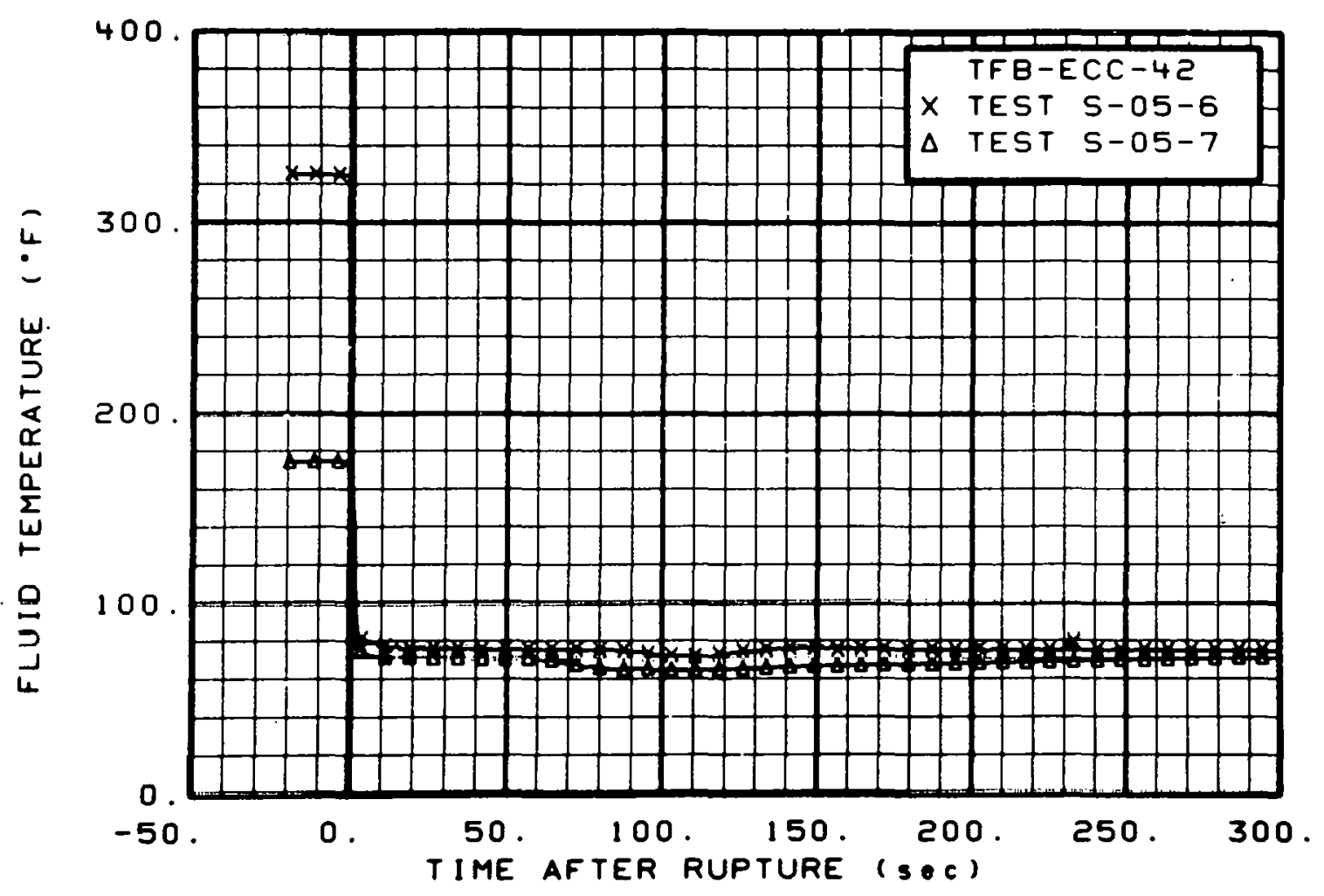

Fig. 58 Fluid temperature in broken loop ECC injection line (TFB-ECC-42), from -20 to $300 \mathrm{sec}$.

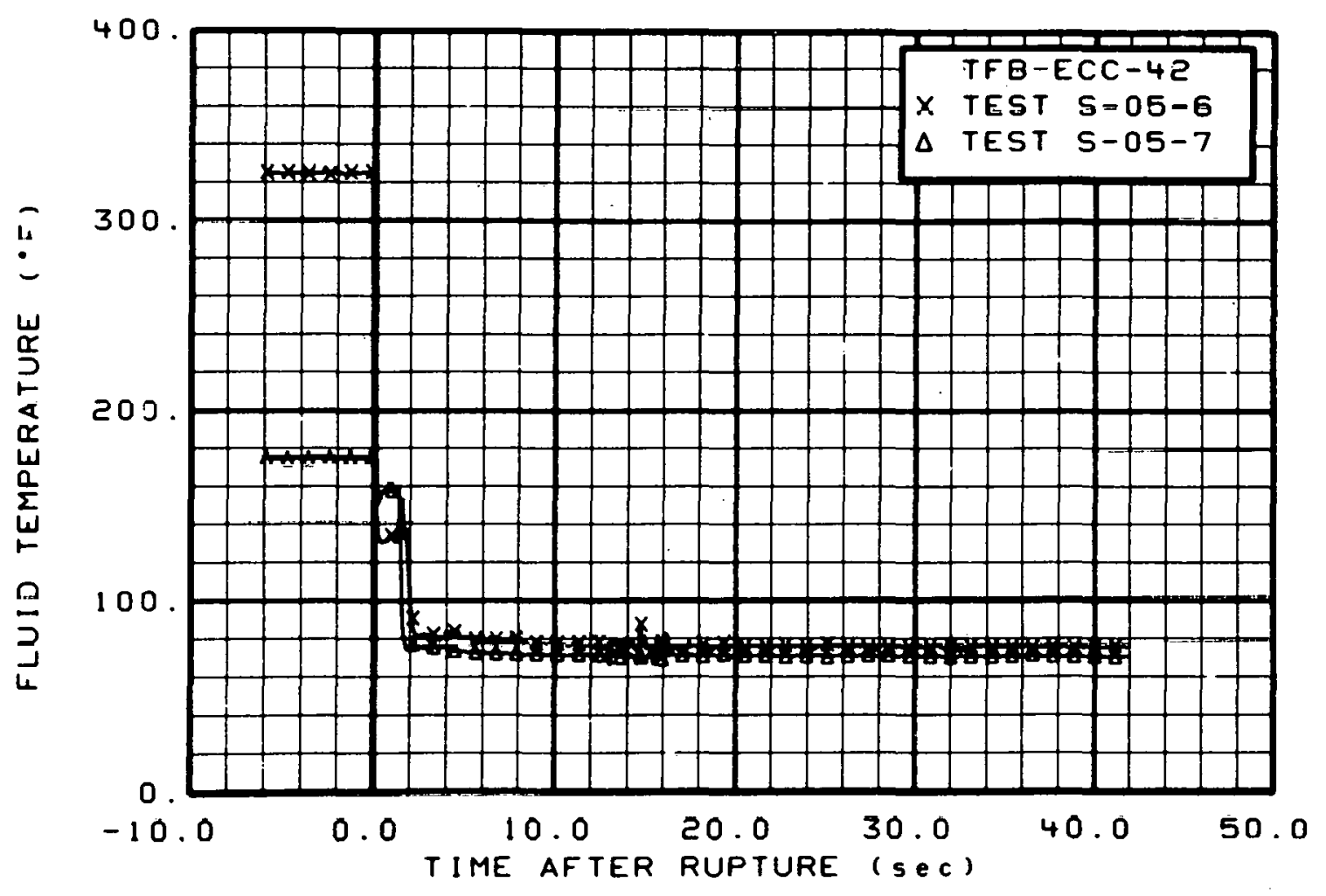

Fig. 59 Fluid temperature in broken loop ECC injection line (TFB-ECC-42), from -6 to $42 \mathrm{sec}$. 


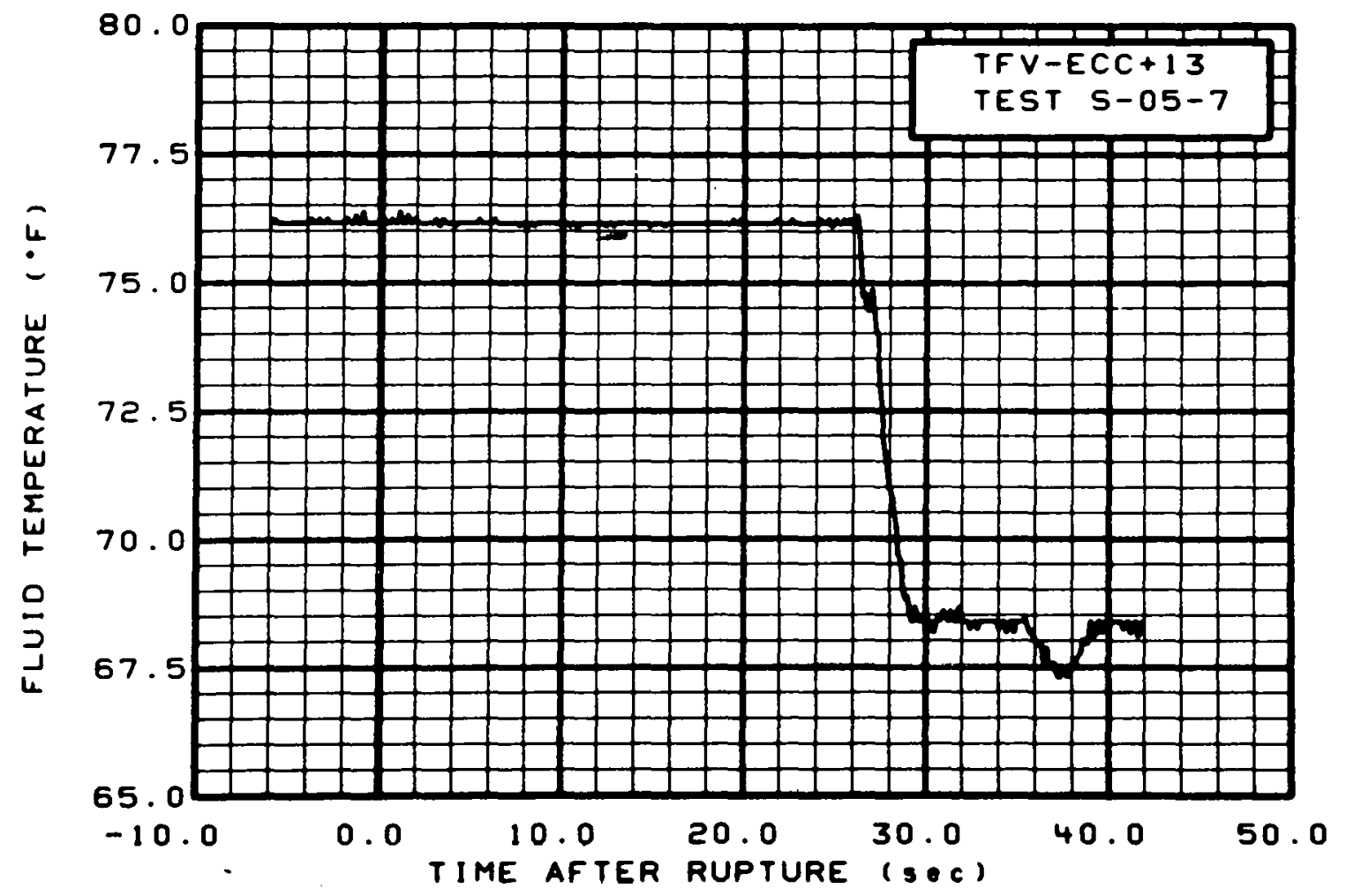

Fig. 60 Fluid temperature in vessel ECC injection line, Test S-05-7 (TFV-ECC+13), from -20 to $300 \mathrm{sec}$.

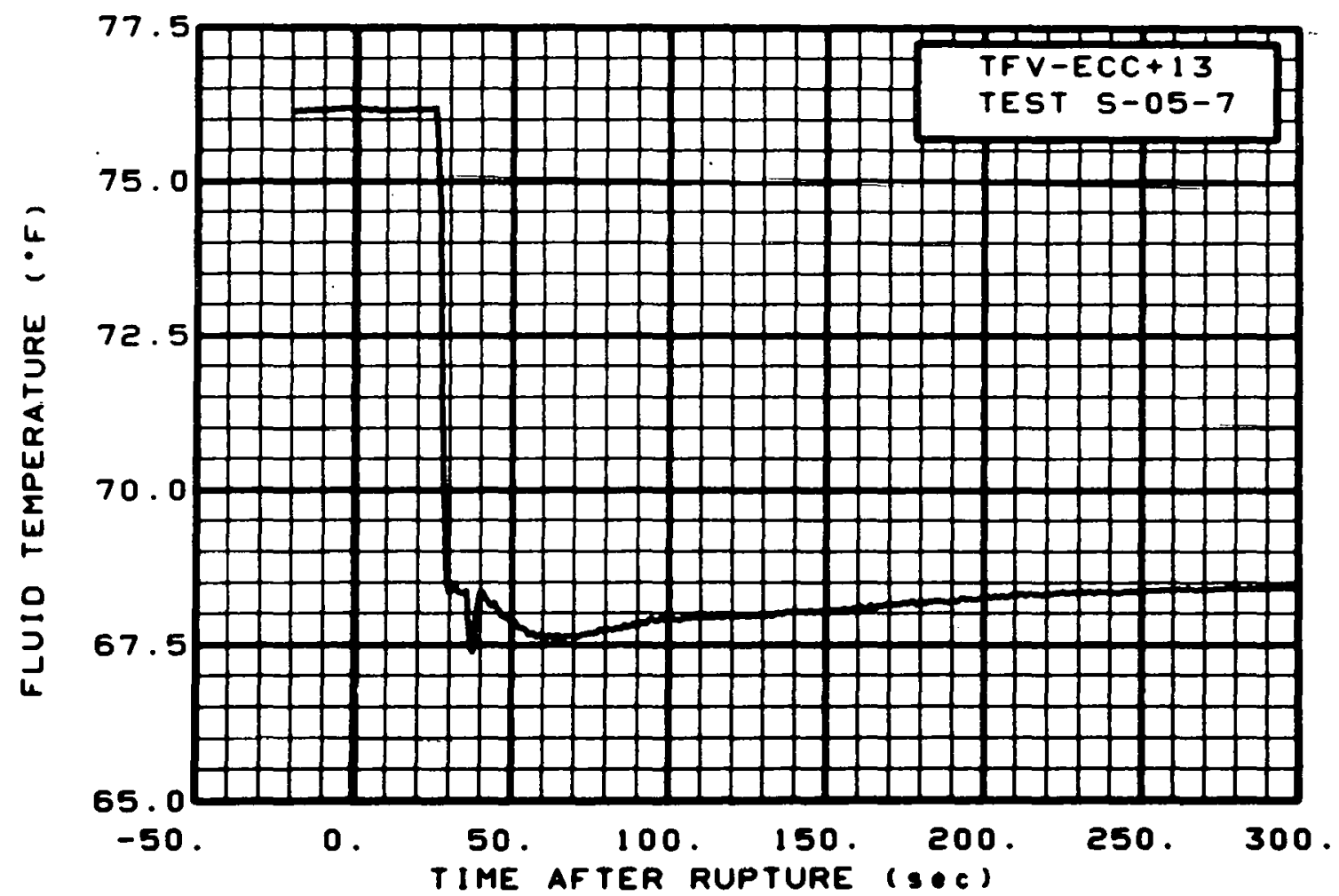

Fig. 61 Fluid temperature in vessel ECC injection line, Test S-05-7 (TFV-ECC+13), from -6 to 42 ser. 


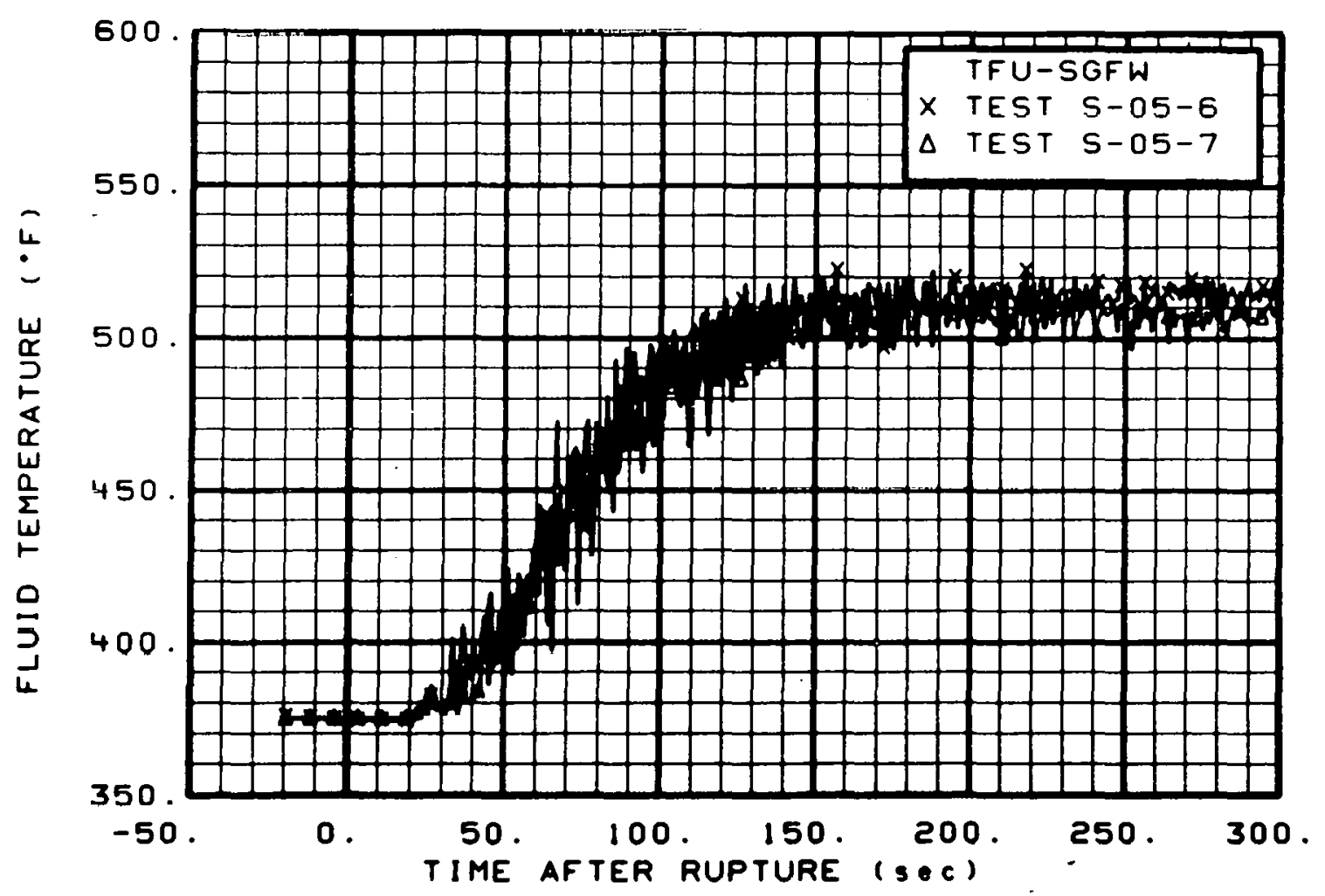

Fig. 62 Fluid temperature in steam generator (TFU-SGFW), from -20 to $300 \mathrm{sec}$.

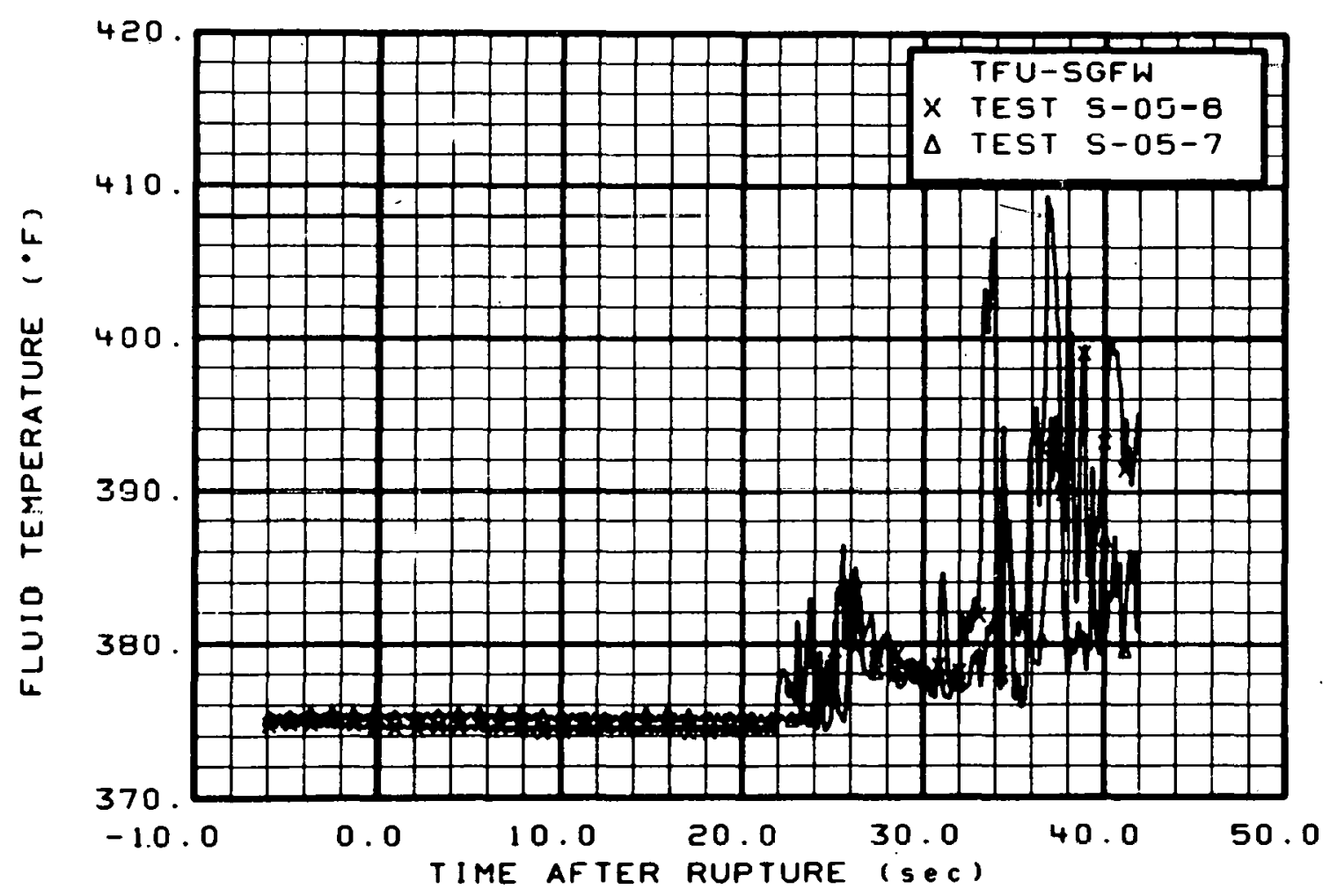

Fig. 63 Fluid temperature in steam generator (TFU-SGFW), from -6 to $42 \mathrm{sec}$. 


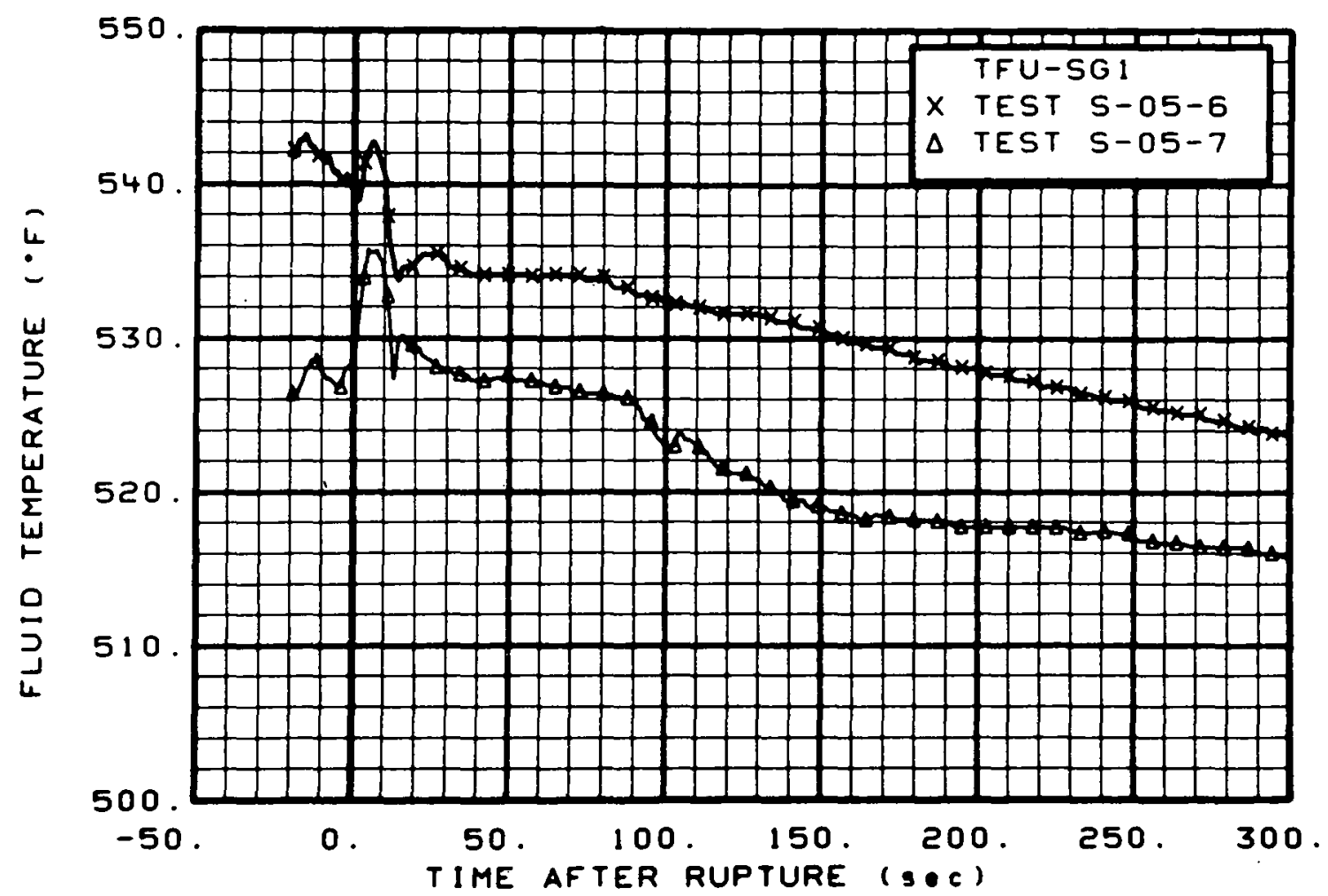

Fig. 64 Fluid temperature in steam generator, secondary side (TFU-SGT), from -20 to $300 \mathrm{sec}$.

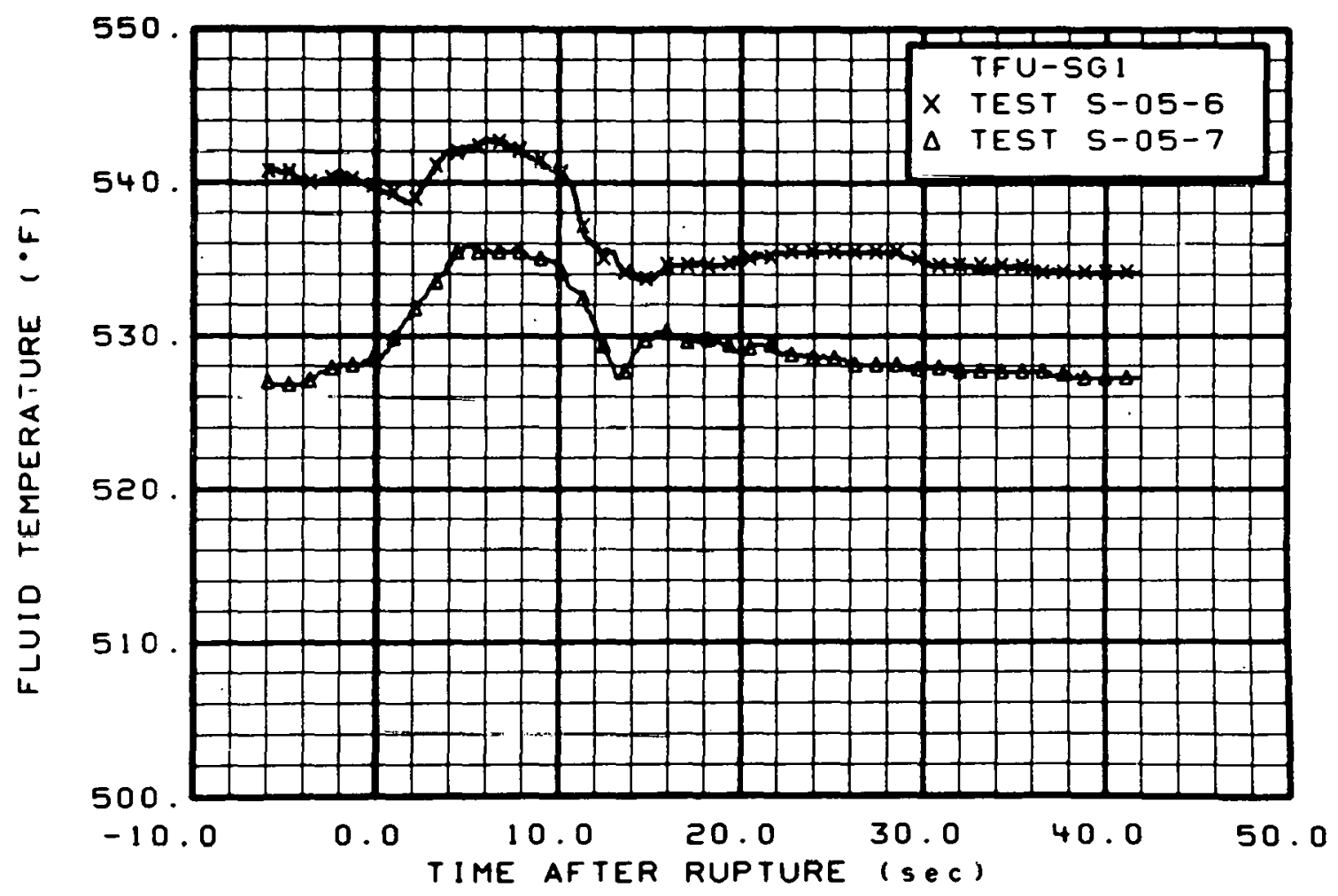

Fig. 65 Fluid temperature in steam generator, secondary side (TFU-SGI), from -6 to 42 sec. 


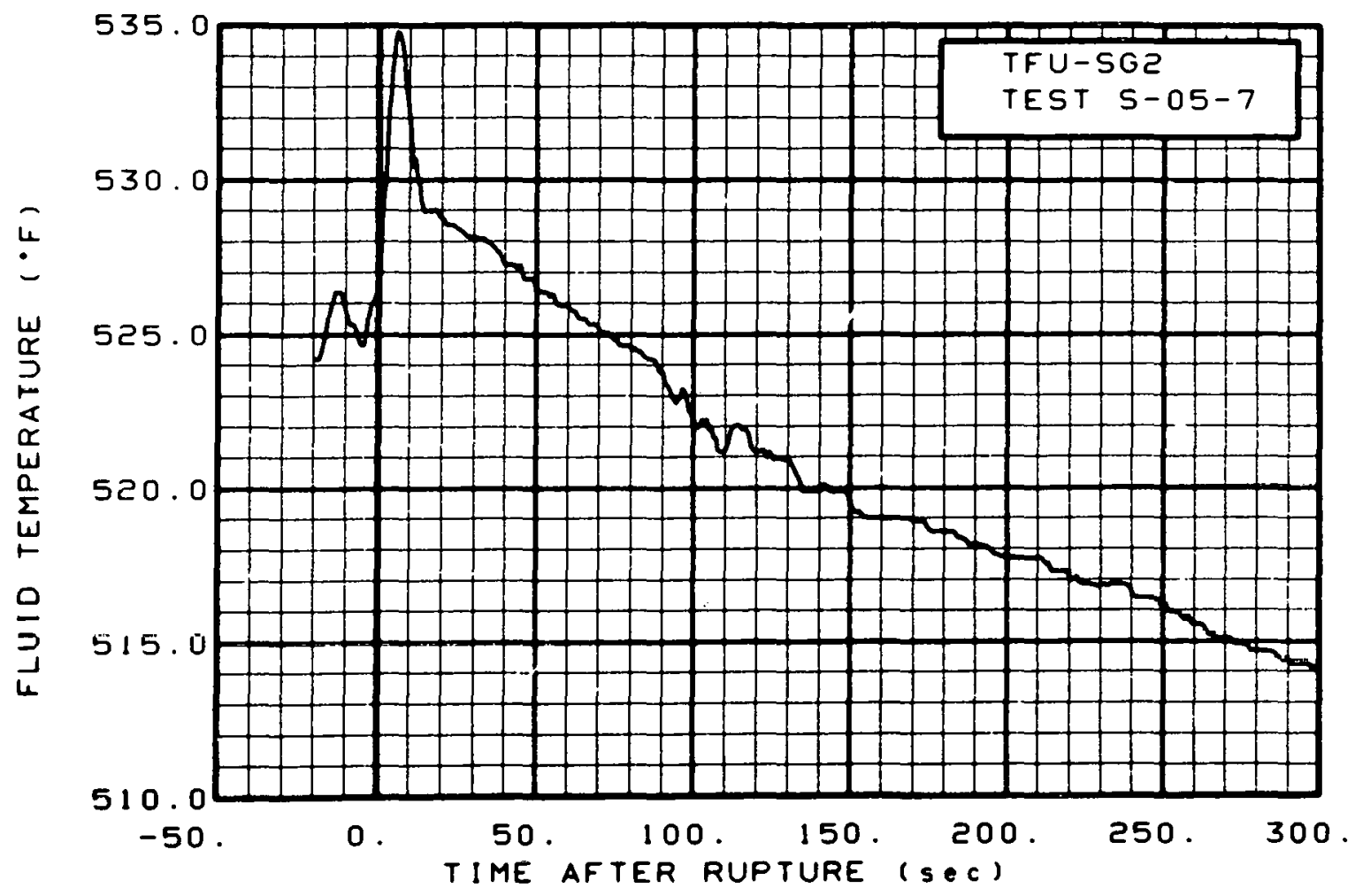

Fig. 66 Fluid temperature in steam generator, secondary side, Test S-05-7 (TFU-SG2), from -20 to 300 sec.

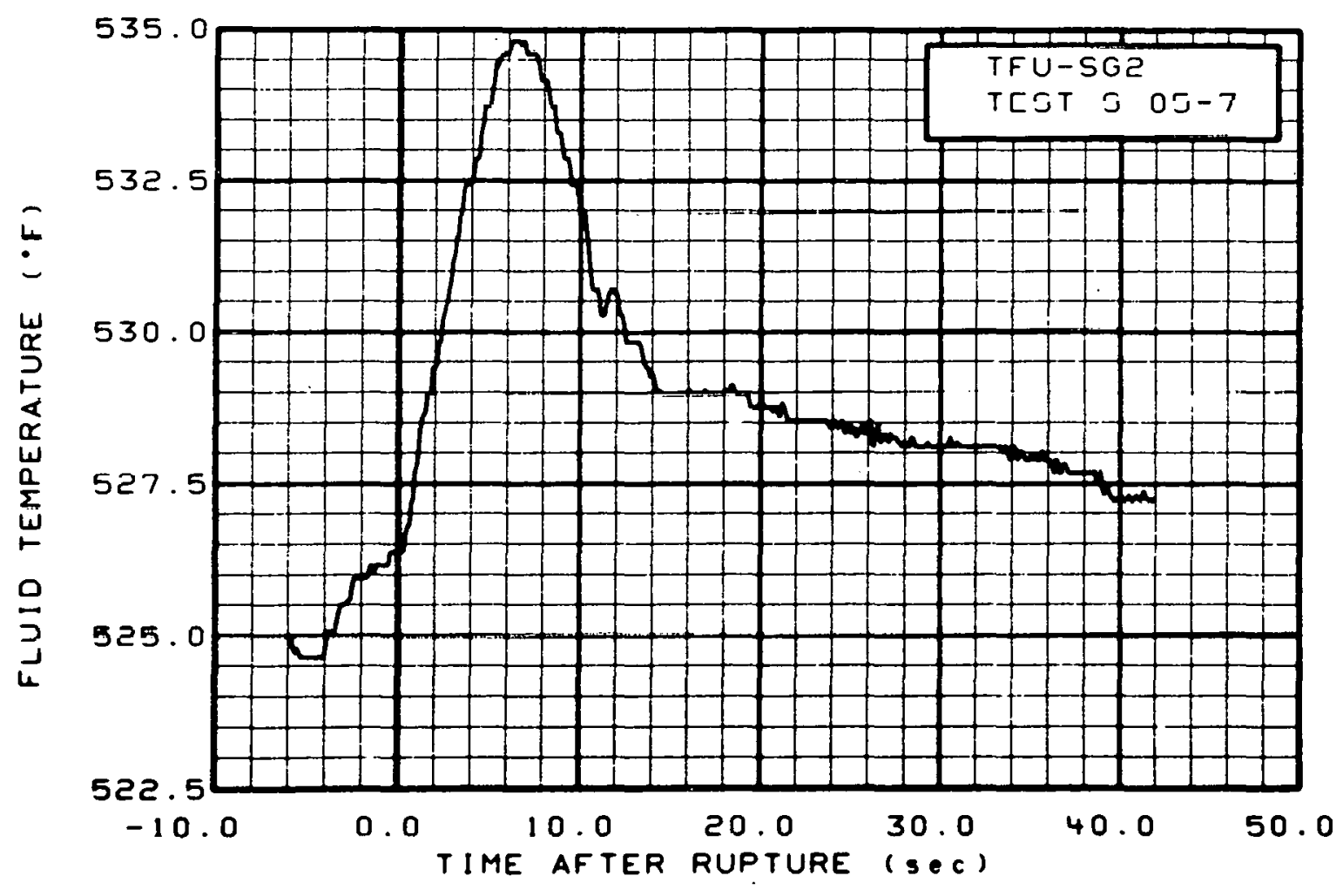

Fig. 67 Fluid temperature in steam generator, secondary side, Test S-05-7 (TFU-SG2), from -6 to $42 \mathrm{sec}$. 


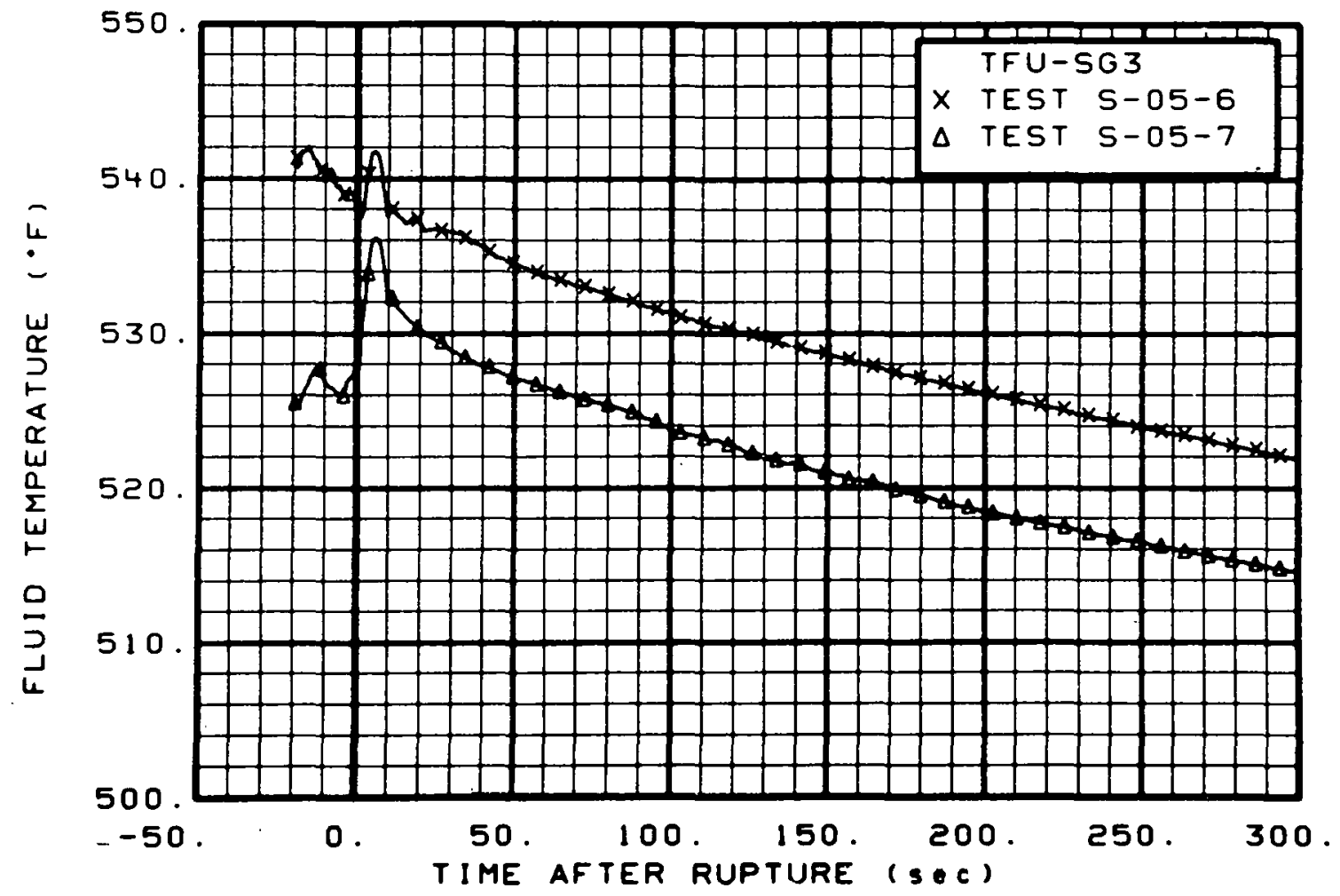

Fig. 68 Fluid temperature in steam generator, secondary side (TFU-SG3), from -20 to $300 \mathrm{sec}$.

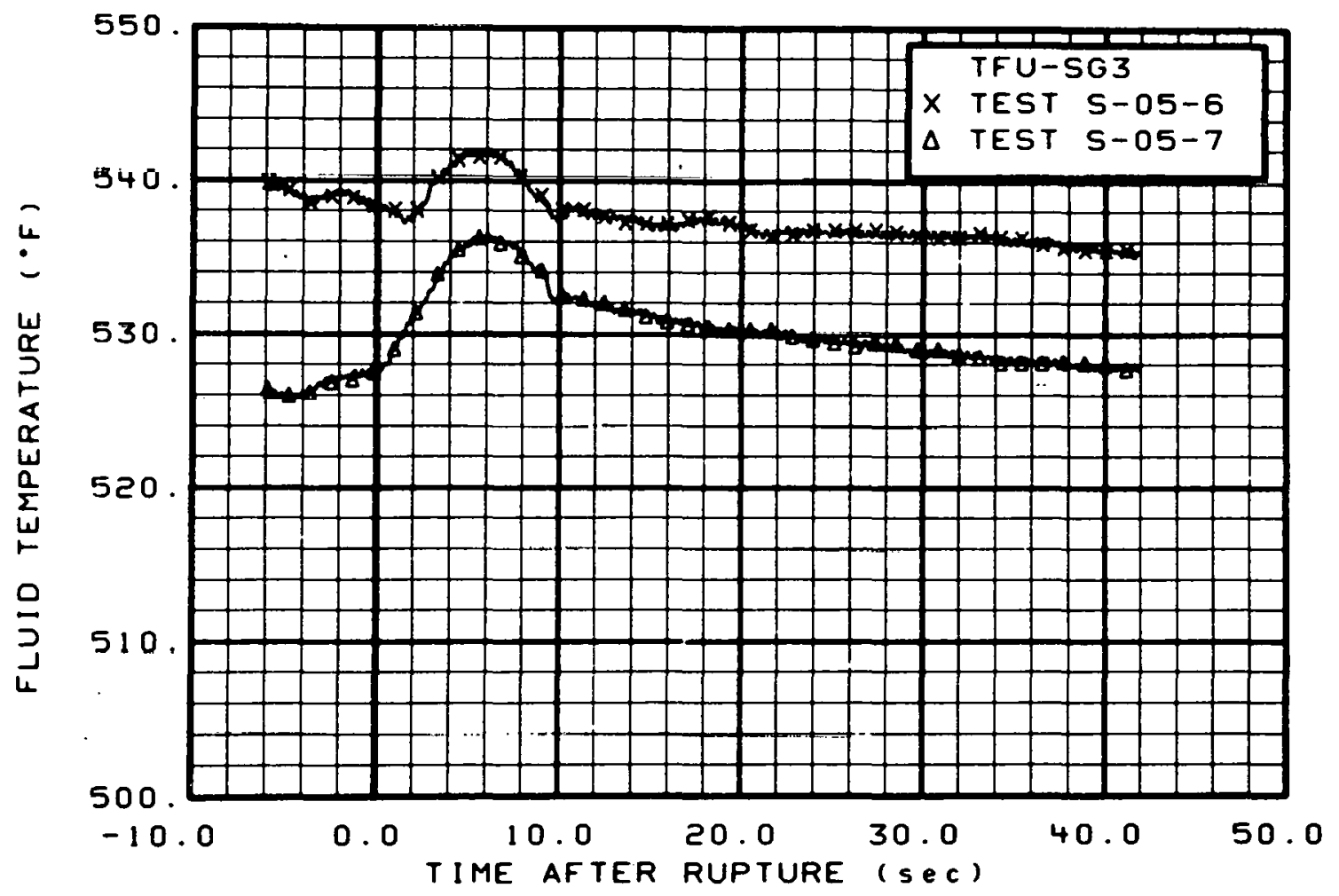

Fig. 69 Fluid temperature in steam generator, secondary side (TFU-SG3), from -6 to $42 \mathrm{sec}$. 


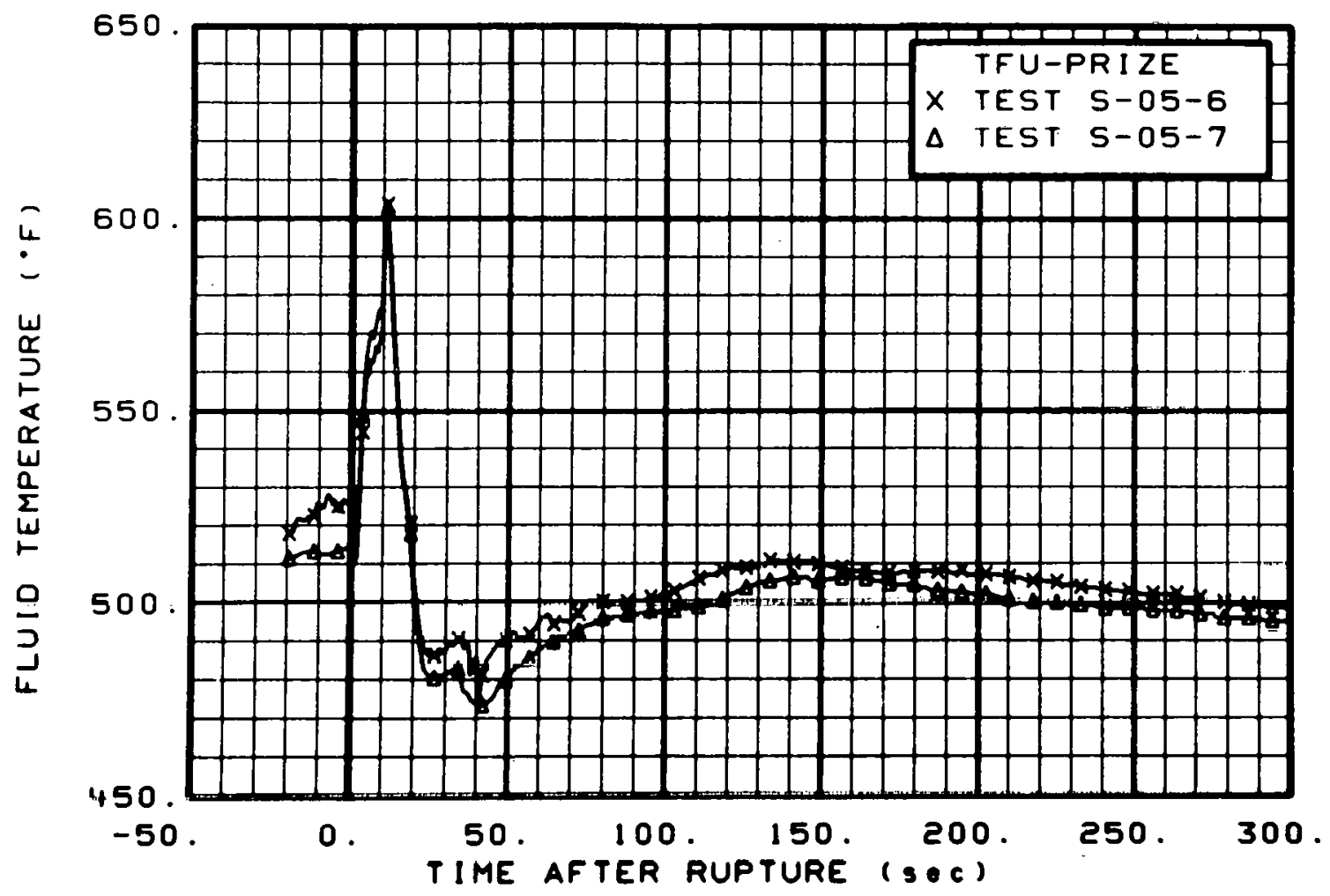

Fig. 70 Fluid temperature in pressurizer surge line (TFU-PRIZE), from -20 to $300 \mathrm{sec}$.

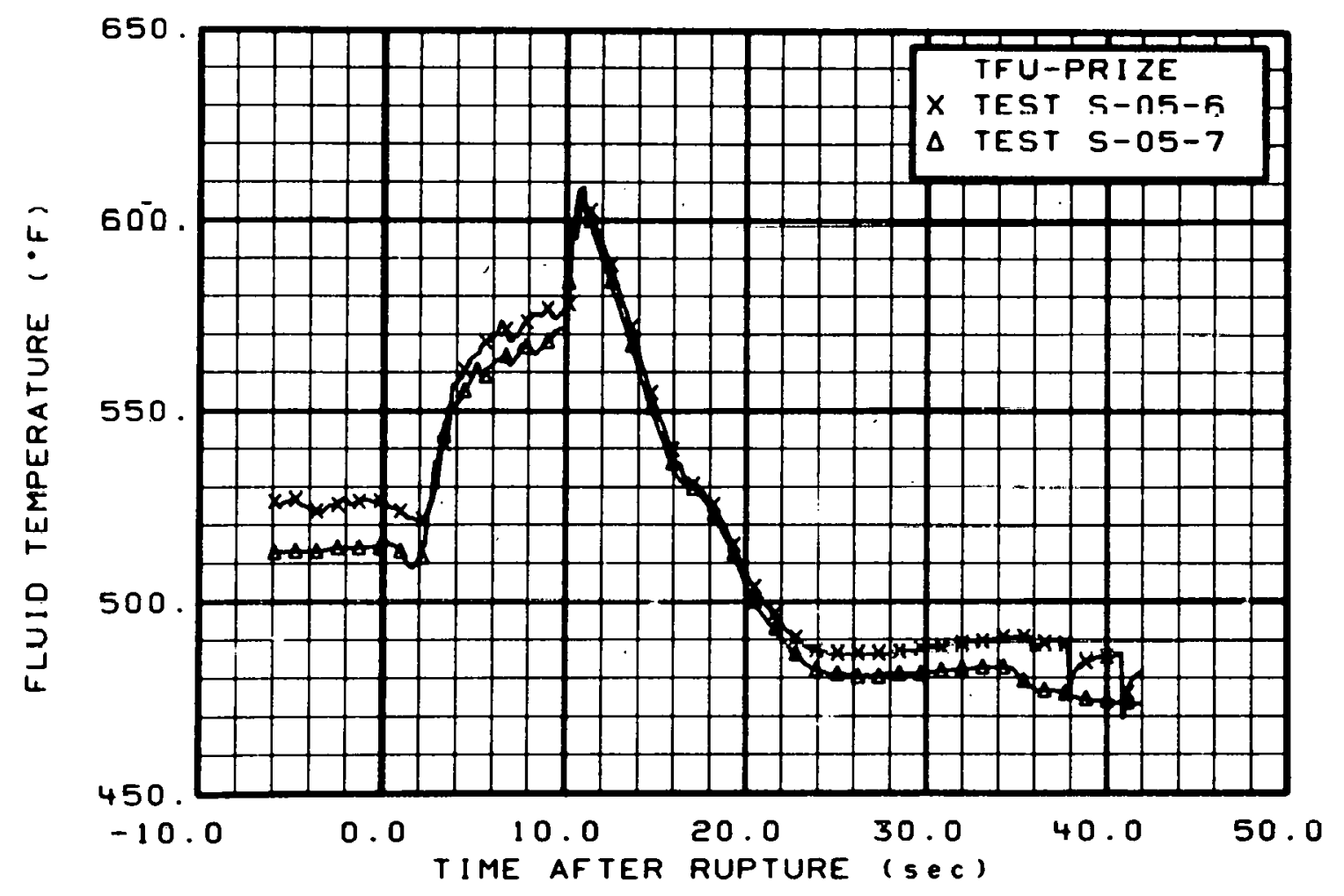

Fig. 71 Fluid temperature in pressurizer surge line (TFU-PRIZE), from -6 to $42 \mathrm{sec}$. 


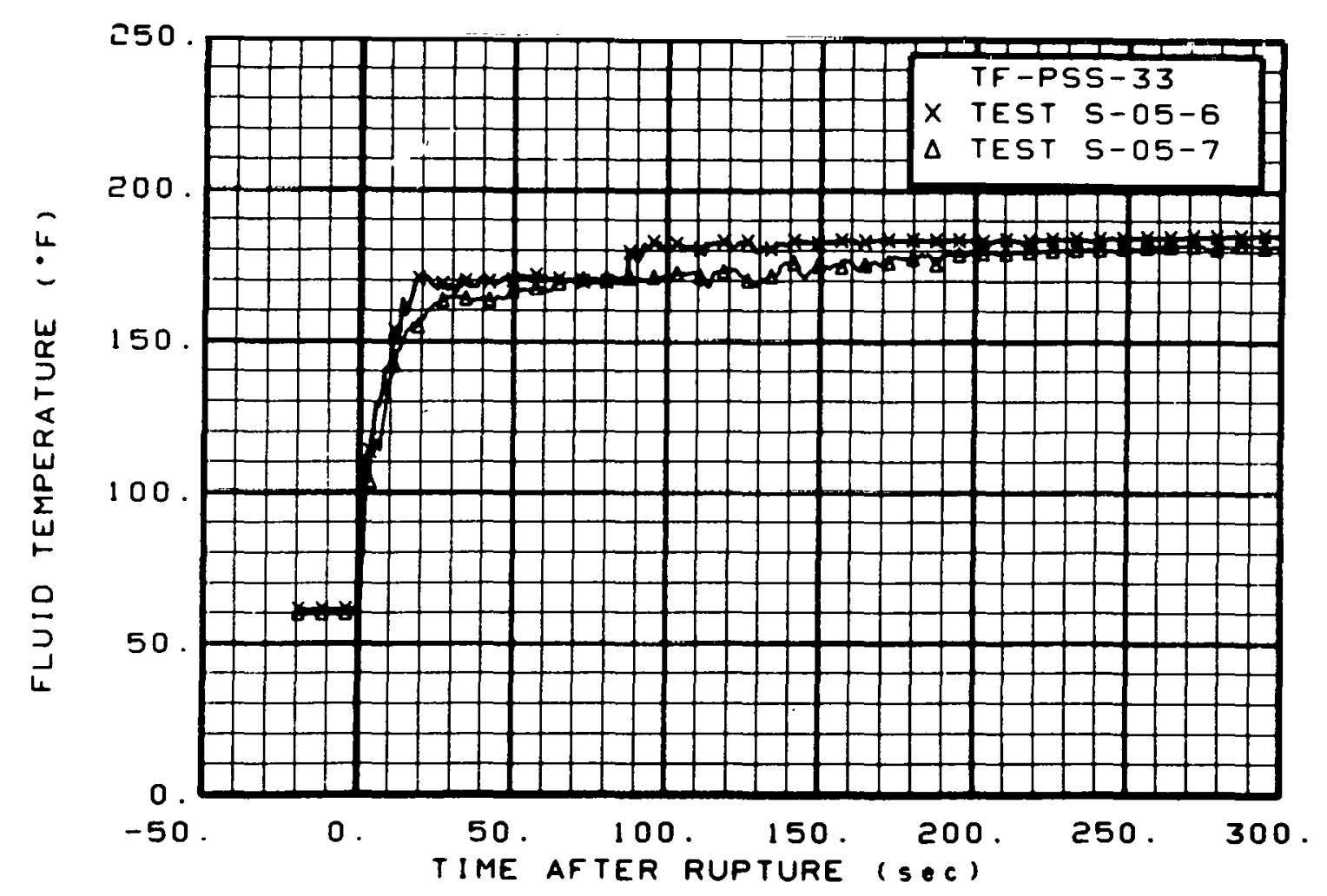

Fig. 72 Fluid temperature in pressure suppression tank (TF-PSS-33), from -20 to $300 \mathrm{sec}$.

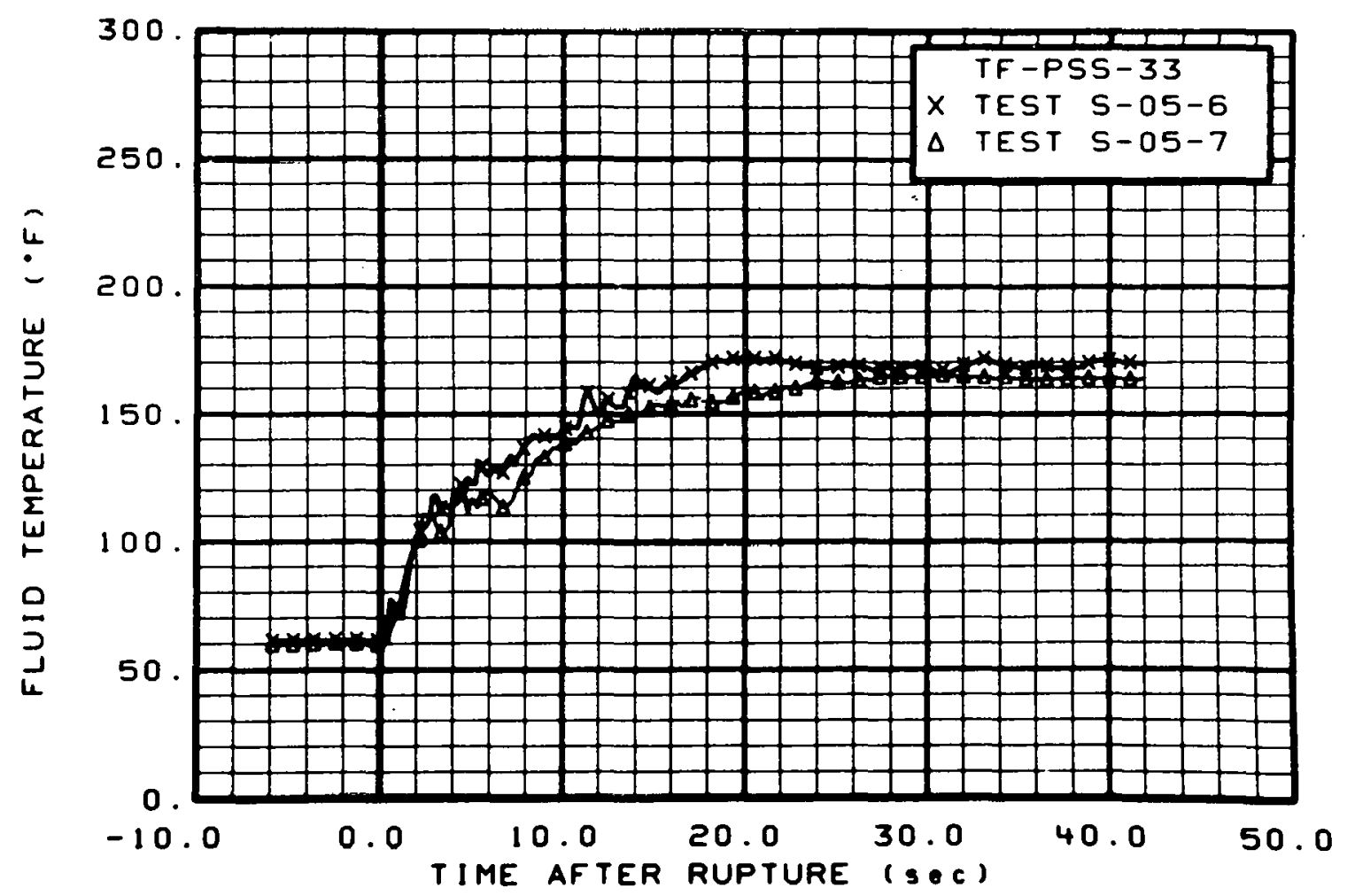

Fig. 73 Fluid temperature in pressure suppression tank (TF-PSS-33), from -6 to $42 \mathrm{sec}$. 


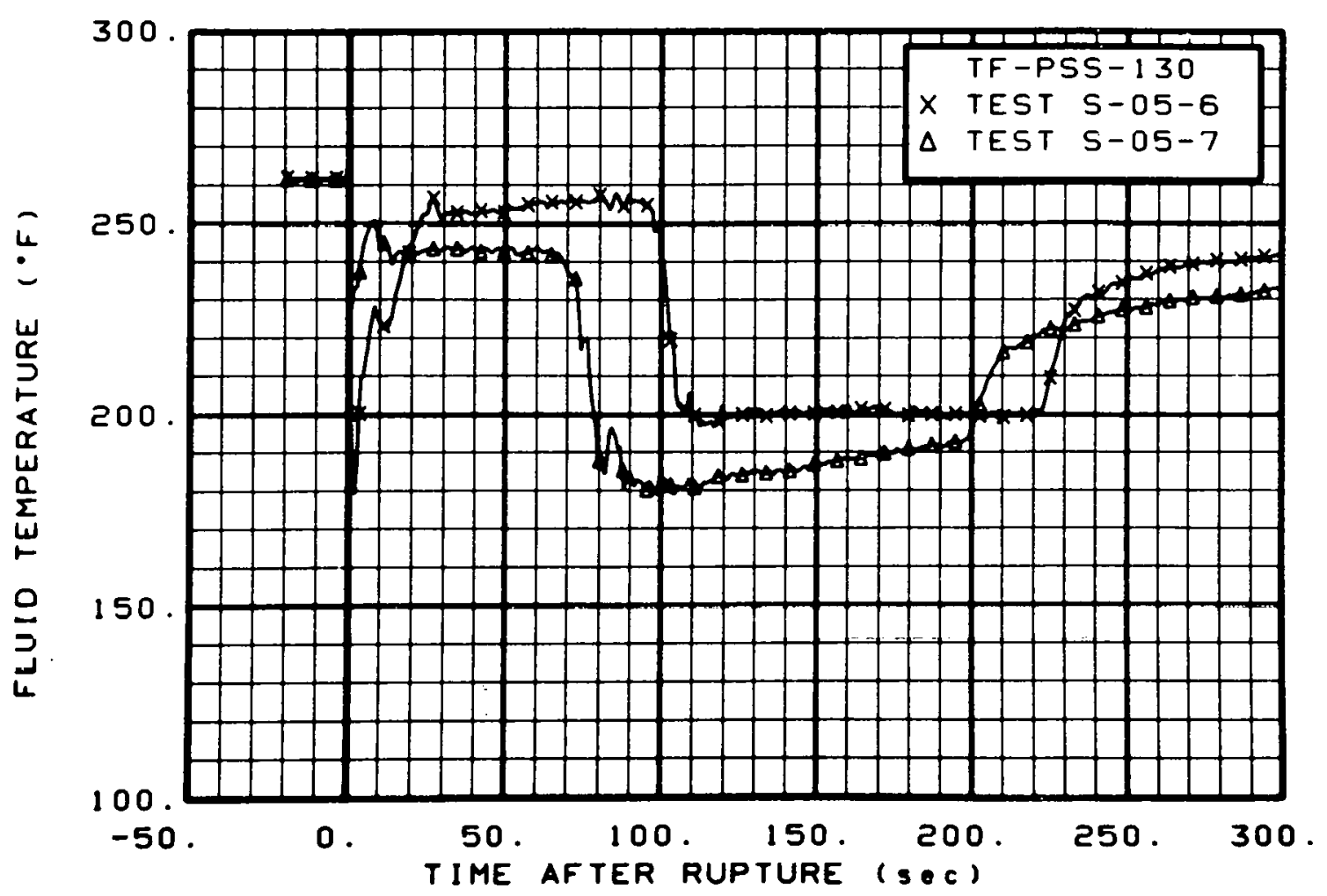

Fig. 74 Fluid temperature in pressure suppression tank (TF-PSS-130), from -20 to $300 \mathrm{sec}$.

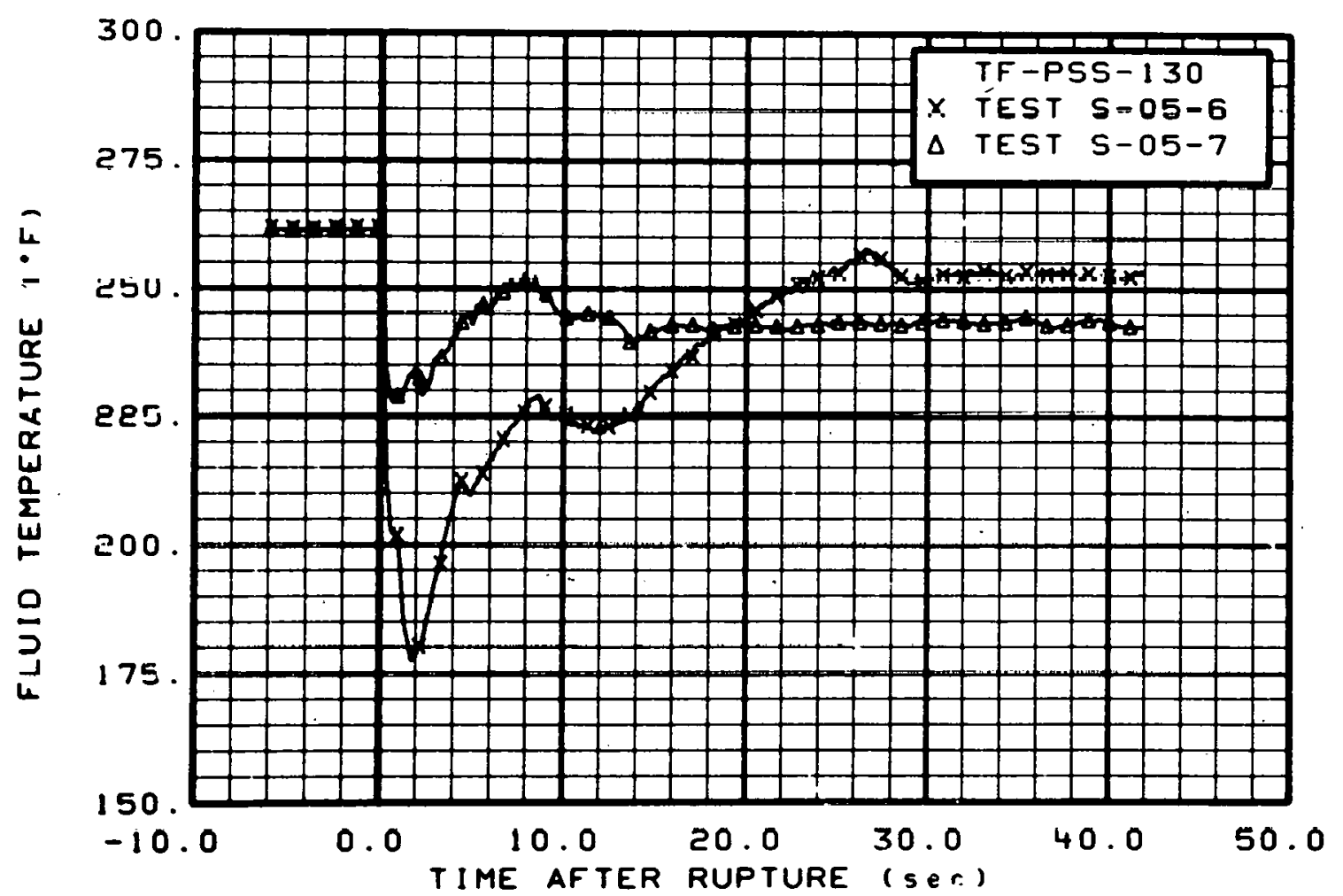

Fig. 75 Fluid temperature in pressure suppression tank (TF-PSS-130), from -6 to $42 \mathrm{sec}$. 


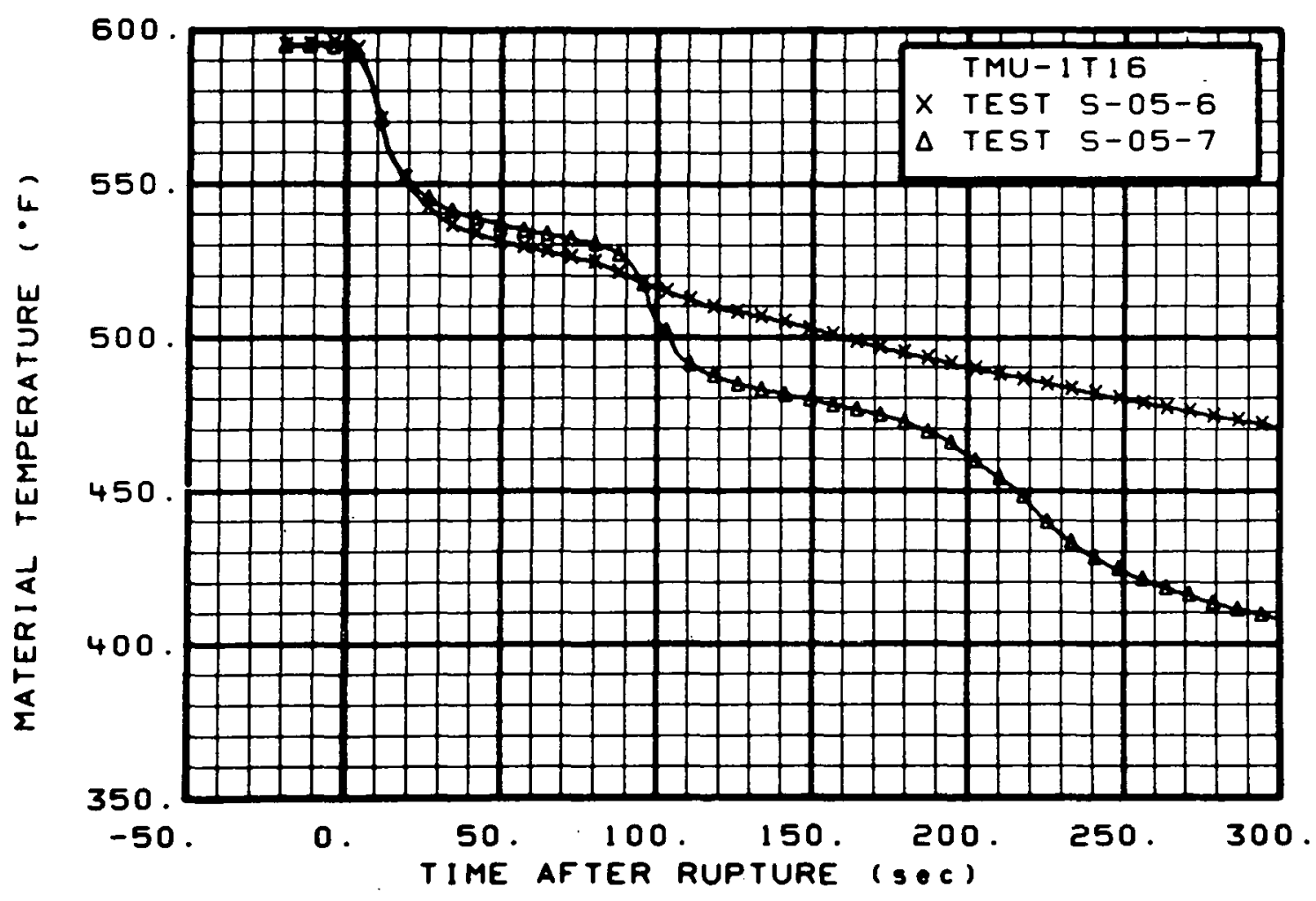

Fig. 76 Material temperature in intact loop (TMU-1T16), from -20 to $300 \mathrm{sec}$.

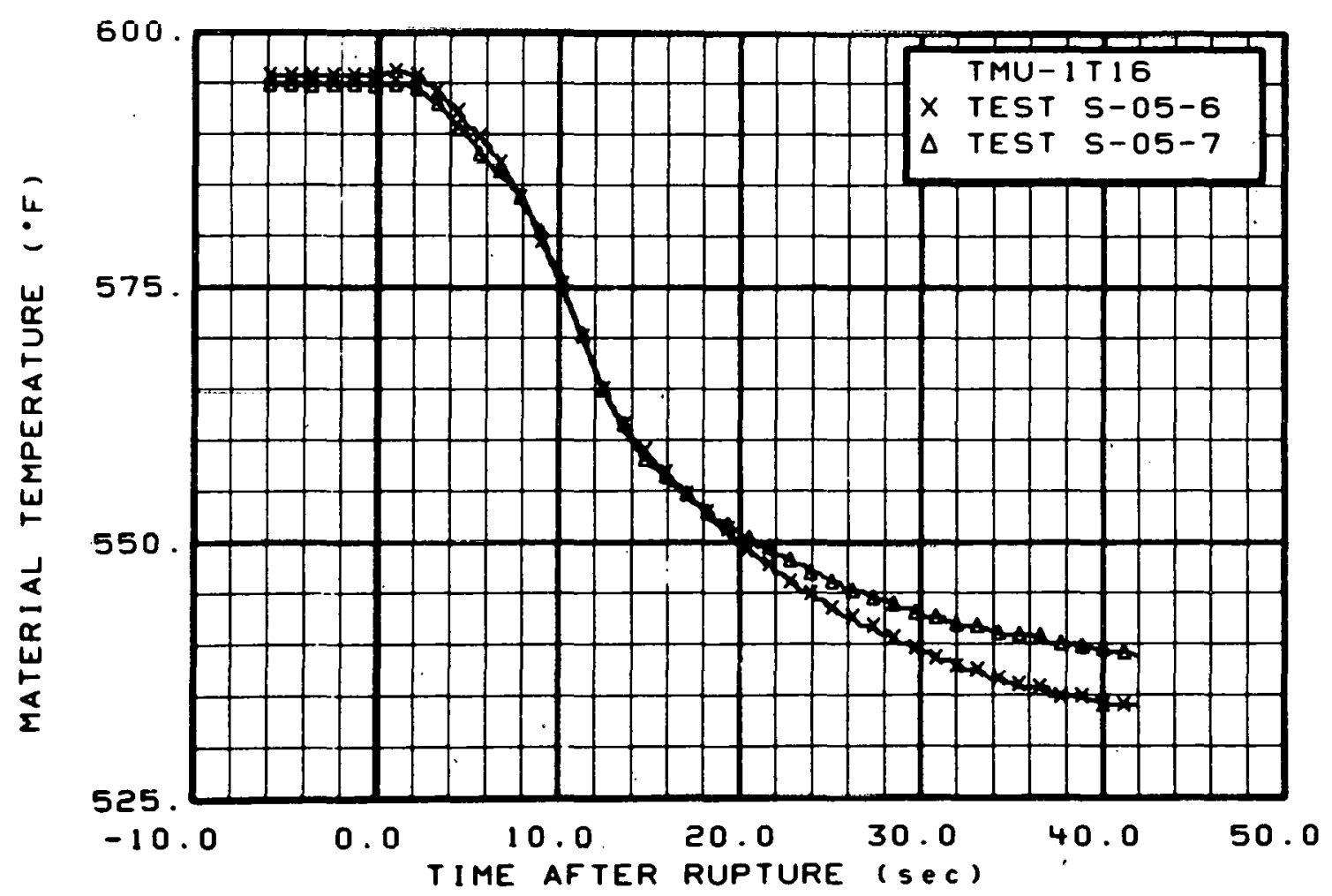

Fig. 77 Material temperature in intact loop (TMU-1T16), from -6 to $42 \mathrm{sec}$. 


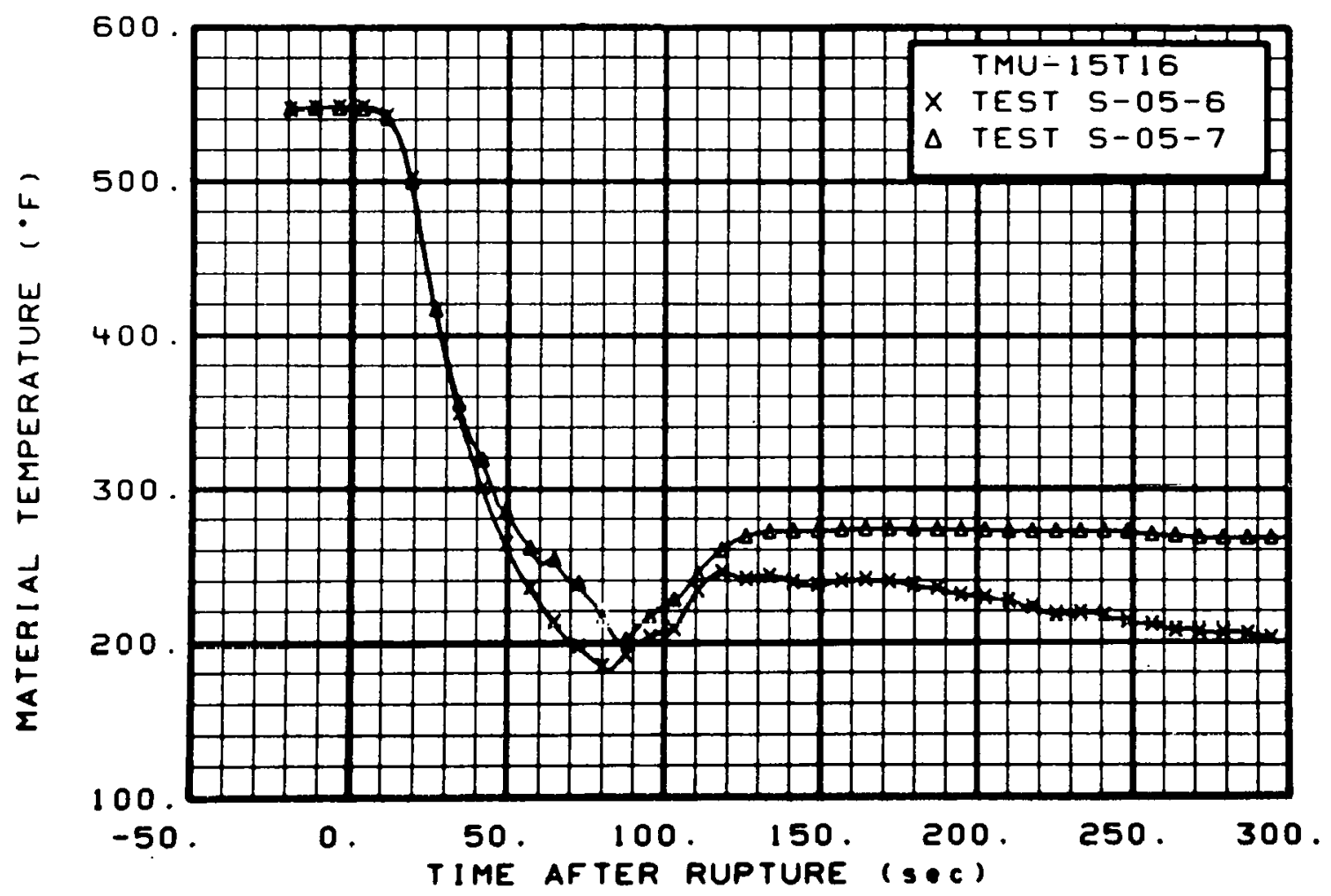

Fig. 78 Material temperature in intact loop (TMU-15T16), from -20 to $300 \mathrm{sec}$.

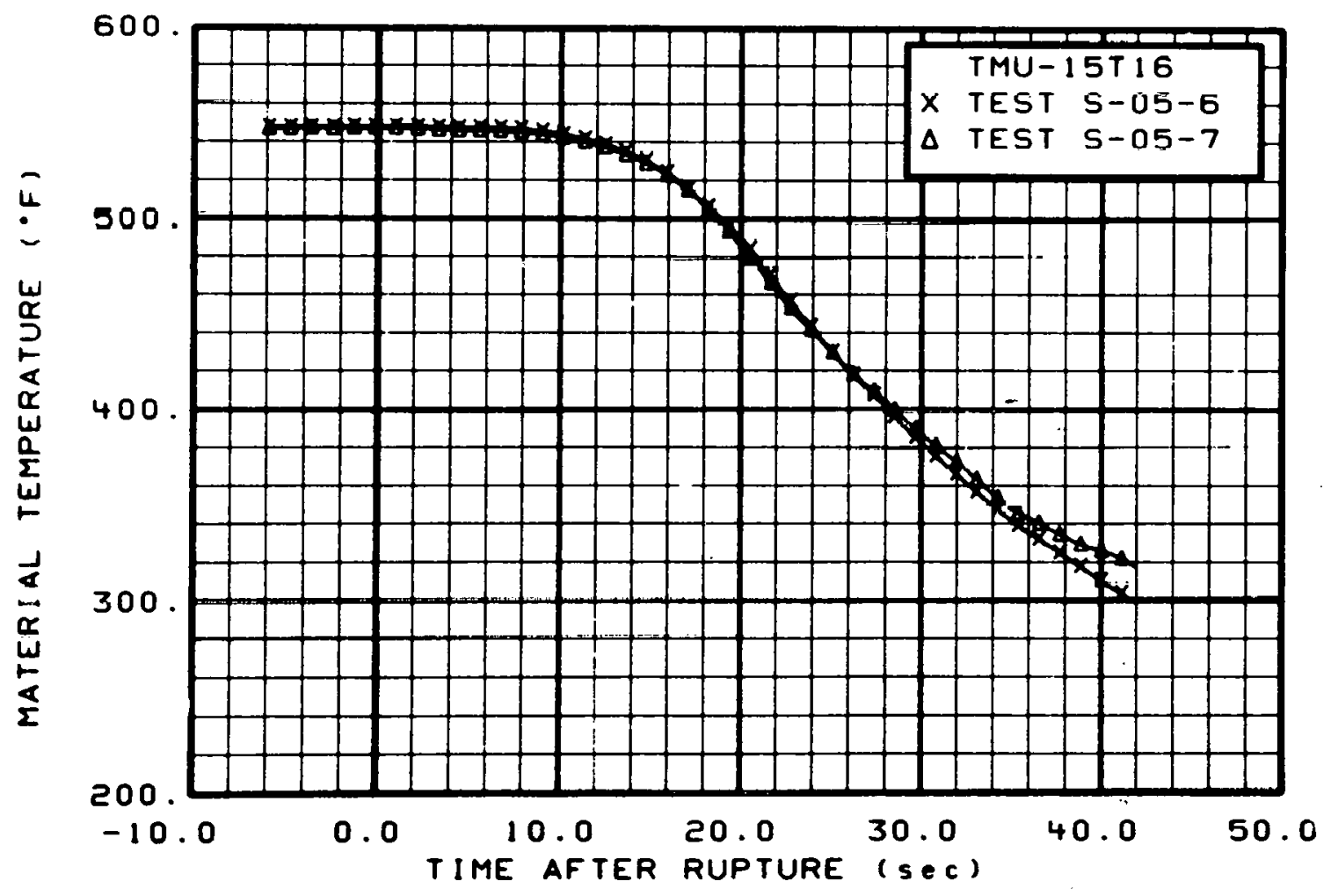

Fig. 79 Material temperature in intact loop (TMU-15T16), from -6 to $42 \mathrm{sec}$. 


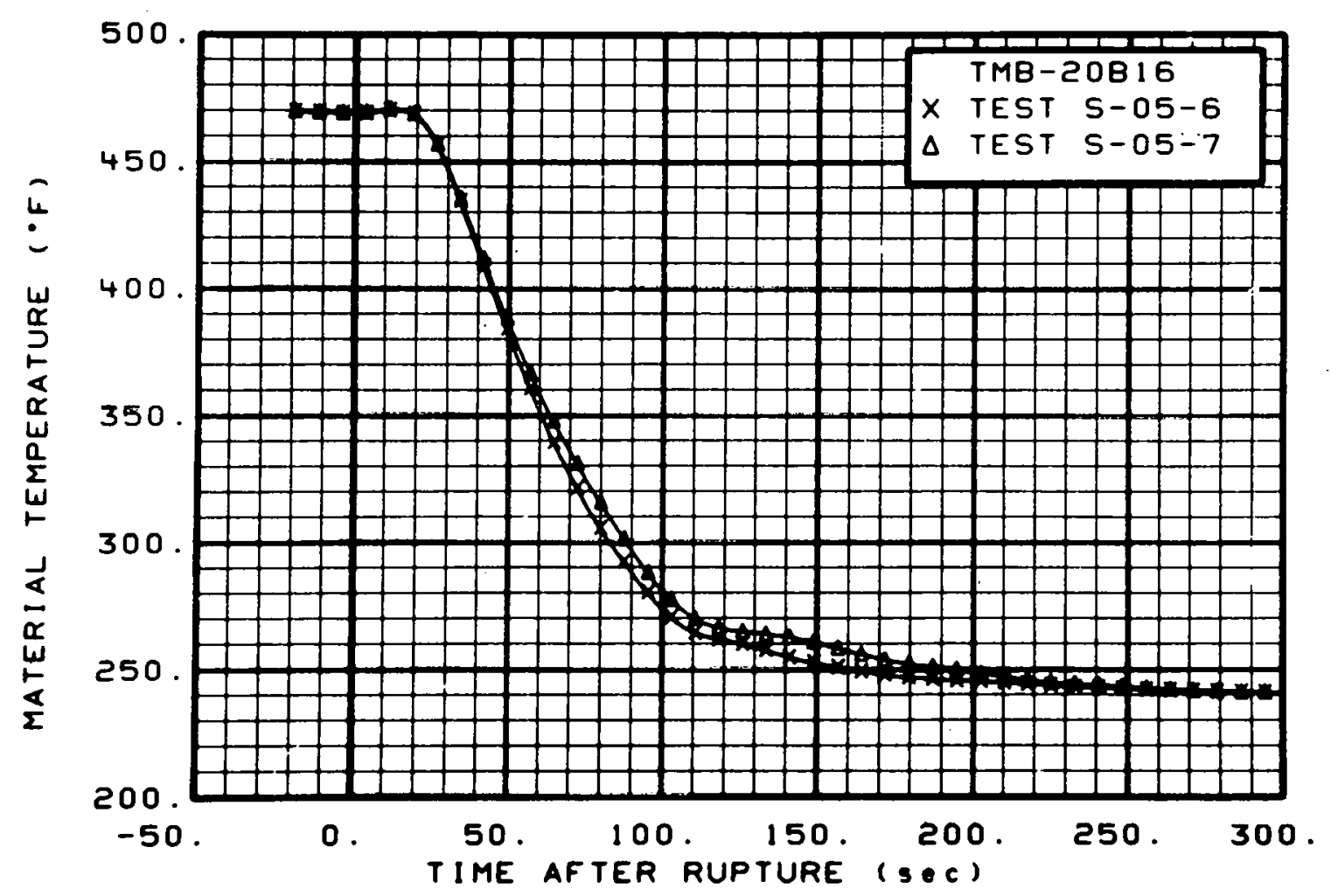

Fig. 80 Material temperature in broken loop (TMB-20B16), from -20 to $300 \mathrm{sec}$.

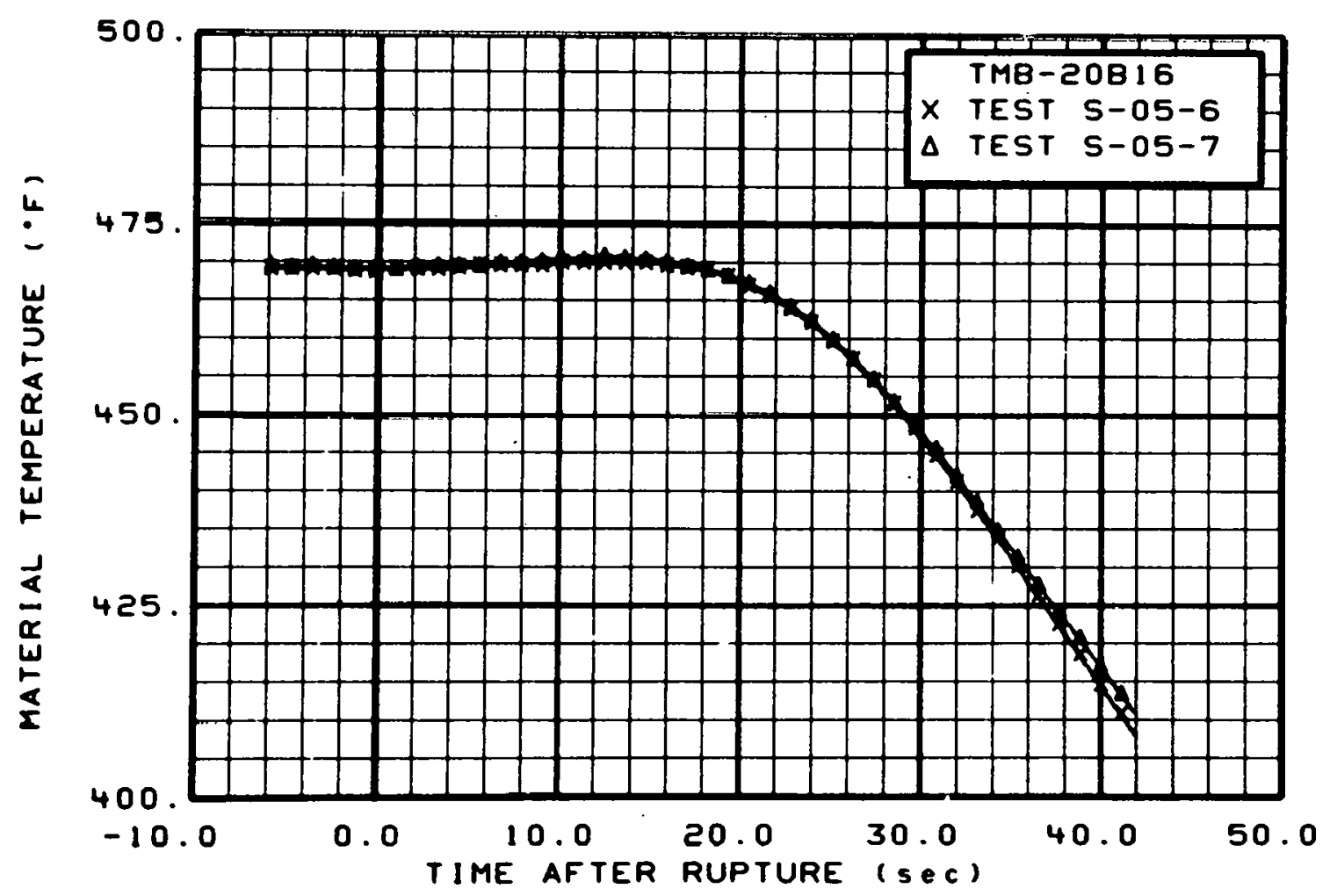

Fig. 81 Material temperature in broken loop (TMB-20B16), from -6 to $42 \mathrm{sec}$. 


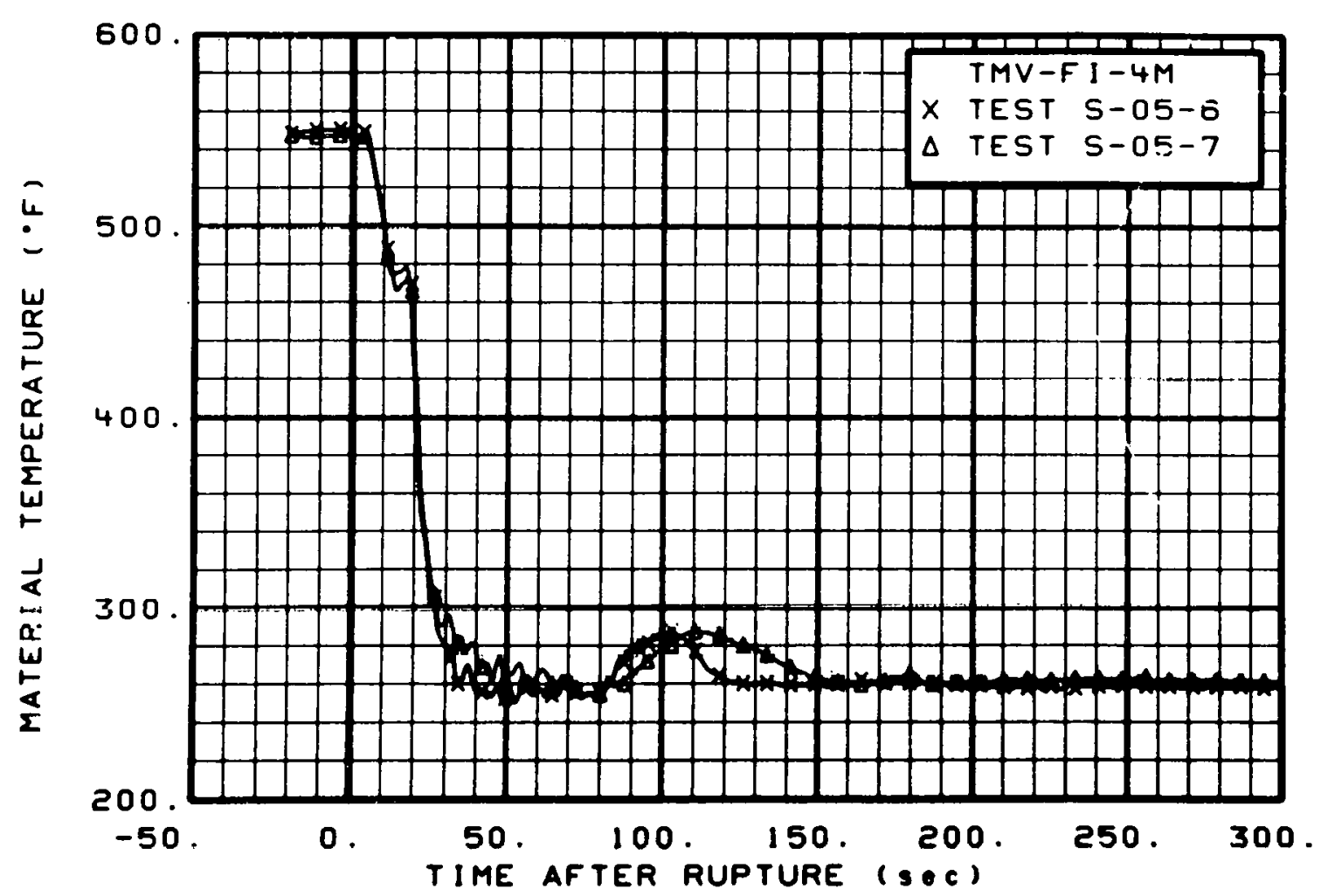

Fig. 82 Material temperature in vessel filler (TMV-FI-4M), from -20 to 300 seC.

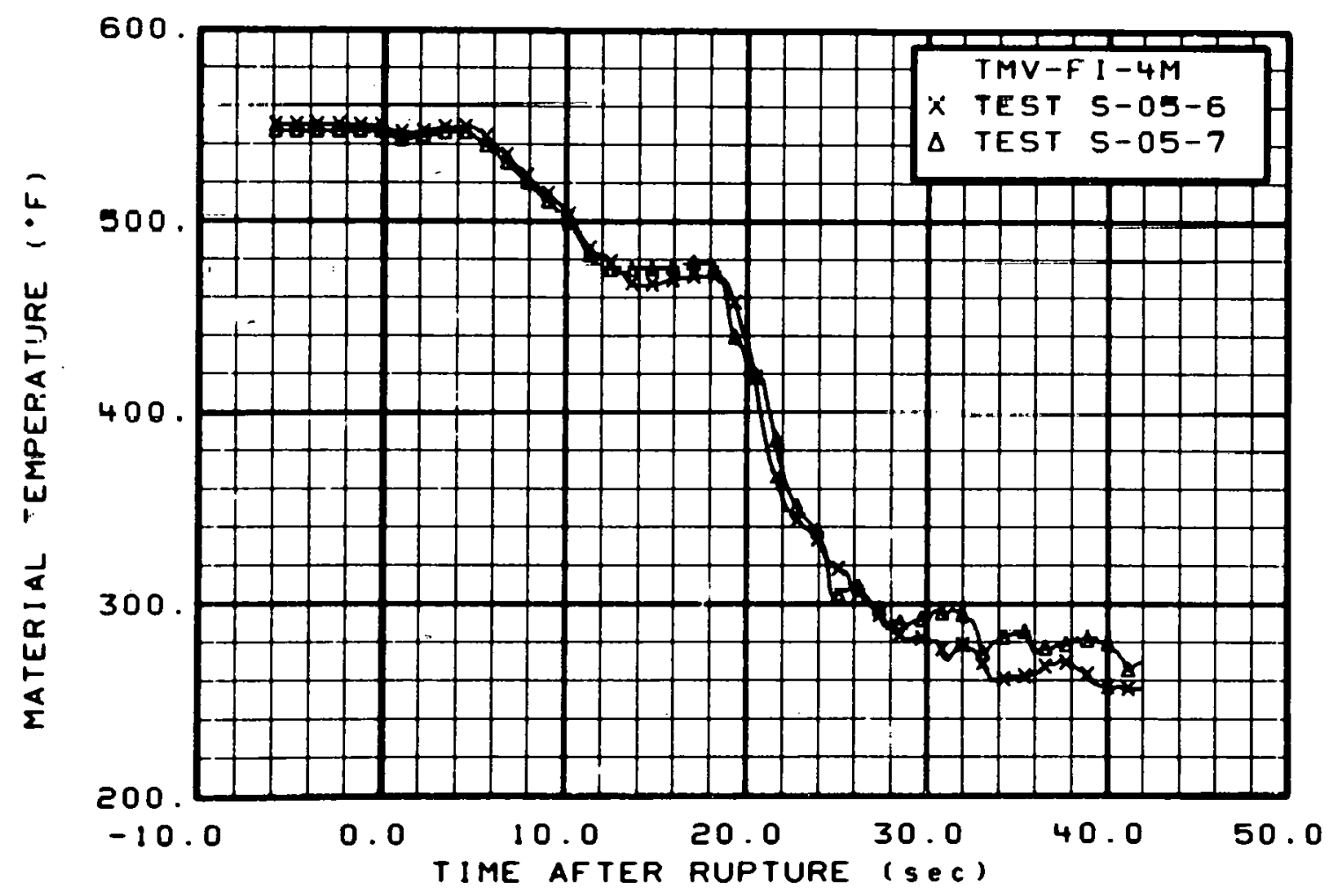

Fig. 83 Material temperature in vessel filler (TMV-FI-4M), from -6 to 42 sec. 


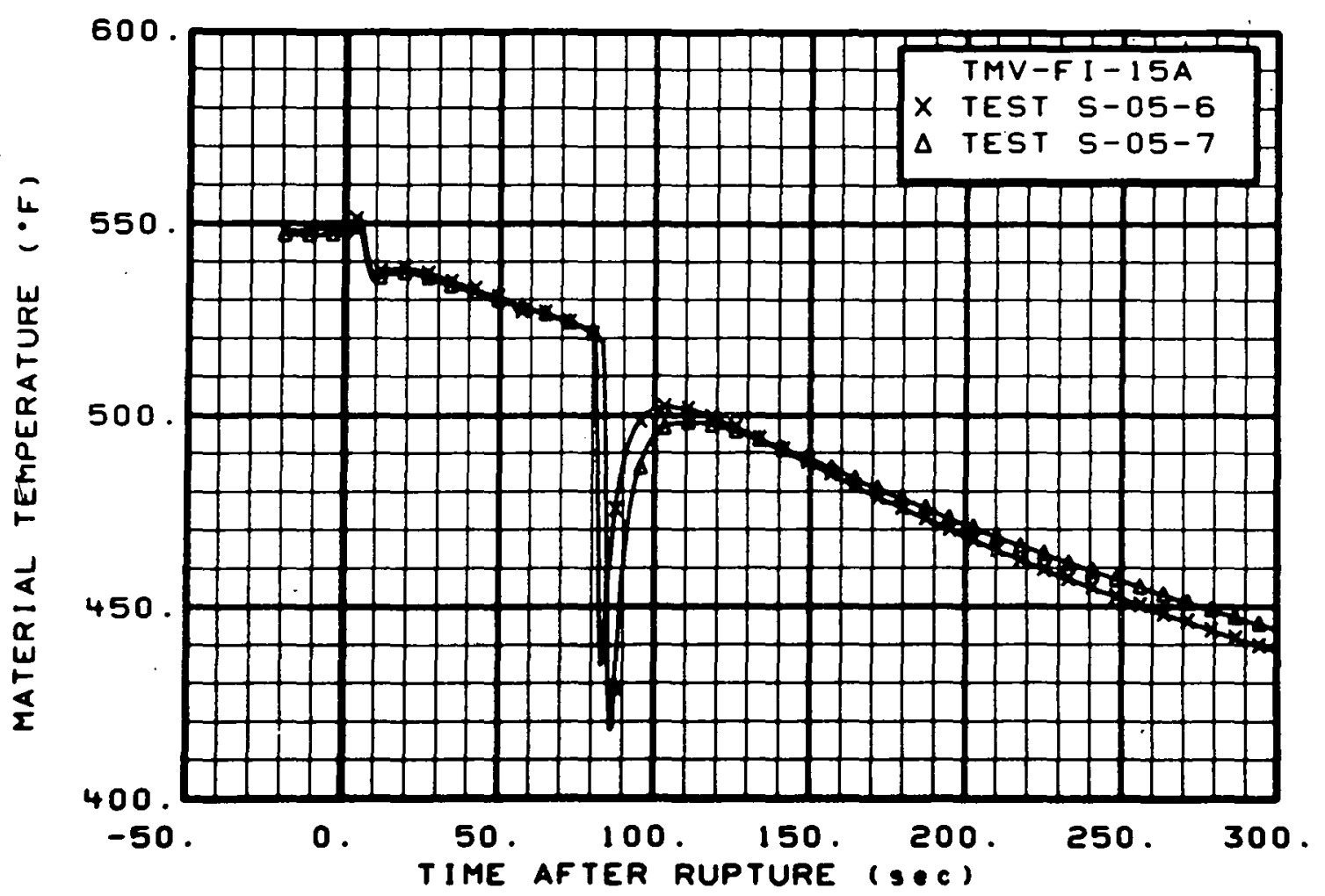

Fig. 84 Material temperature in vessel filler (TMV-FI-15A), from -20 , to 300 sec.

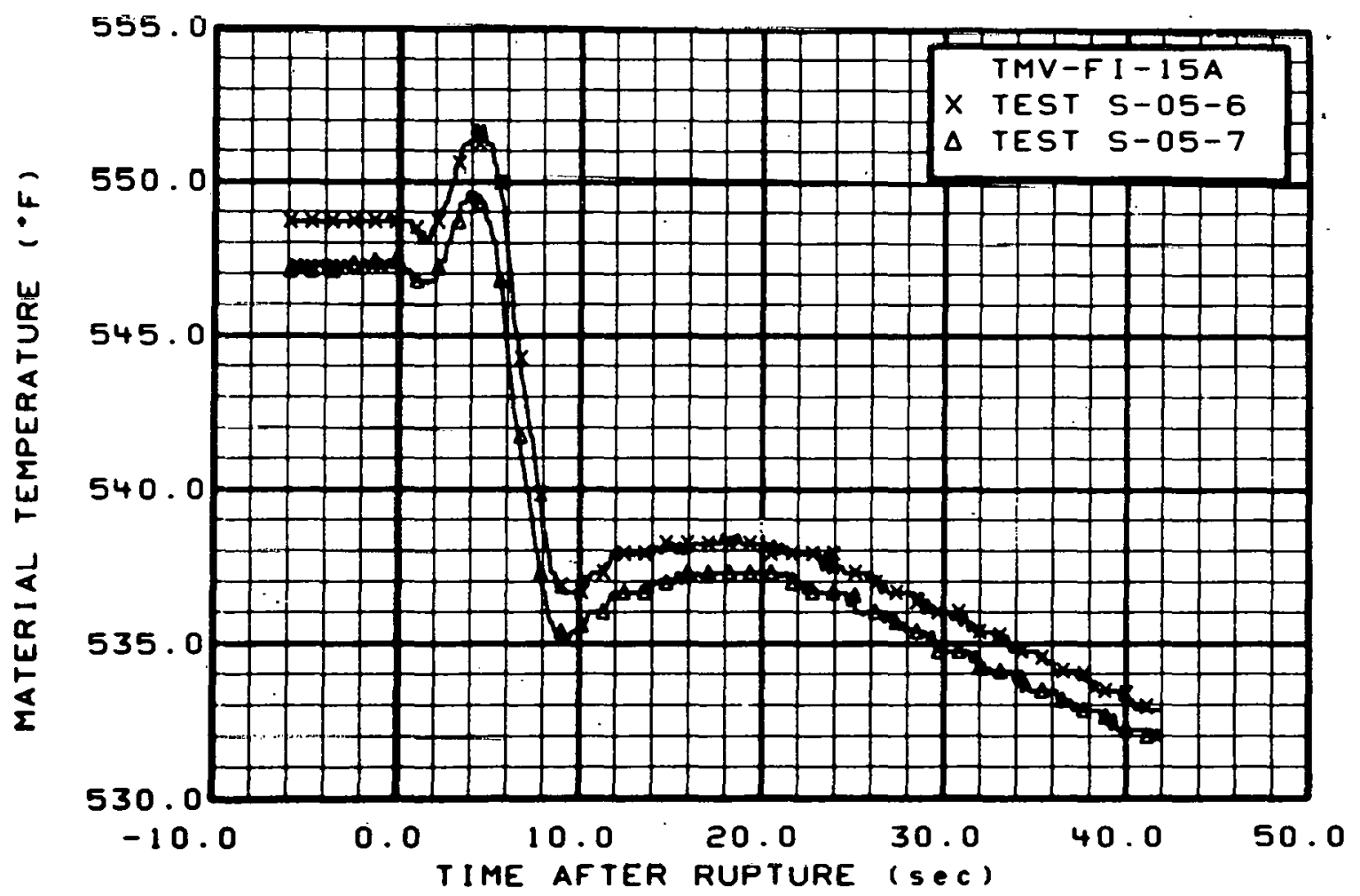

Fig. 85 Material temperature in vessel filler (TMV-FI-15A), from -6 to 42 sec. 


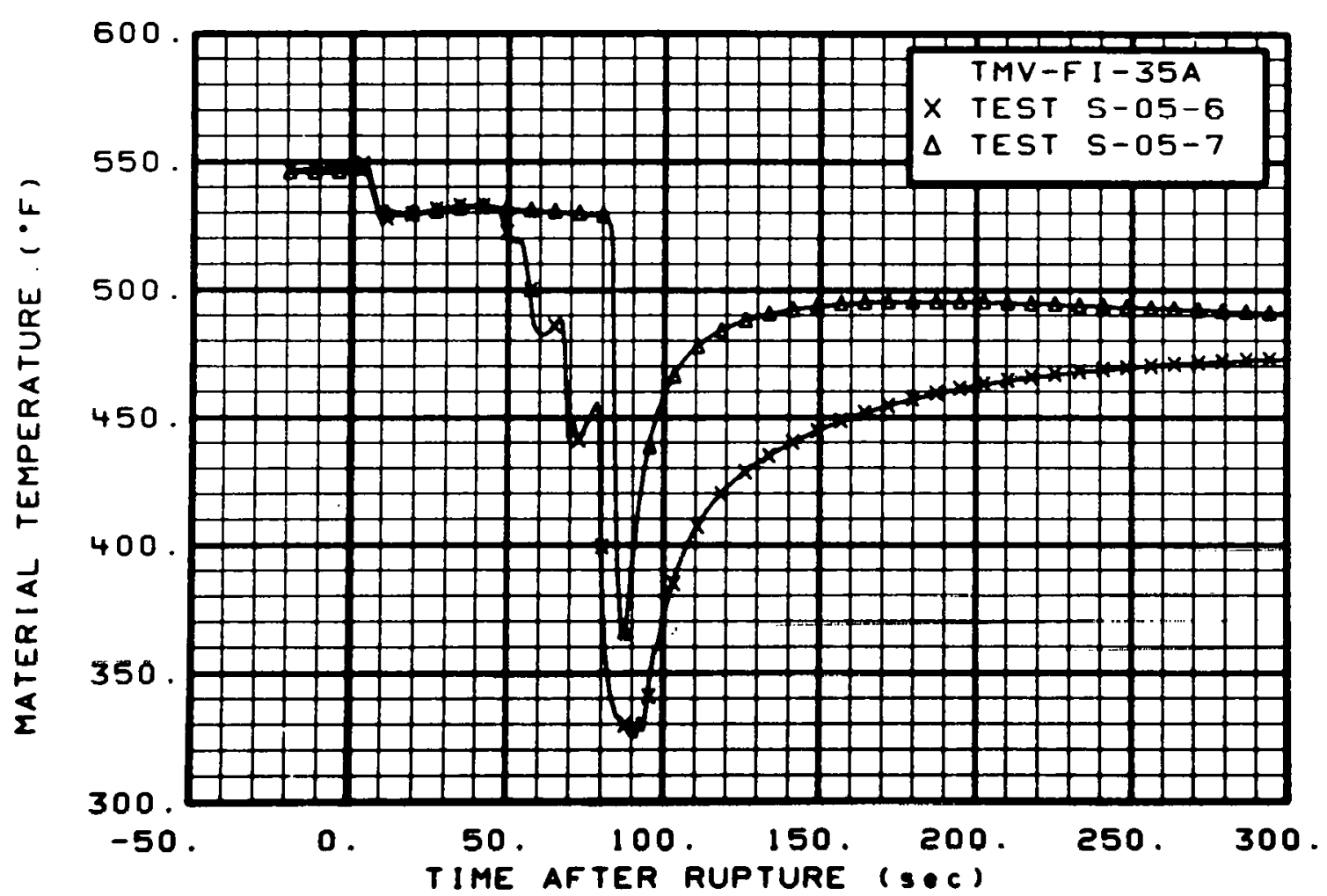

Fig. 86 Material temperature in vessel filler (TMV-FI-35A), from -20 to $300 \mathrm{sec}$.

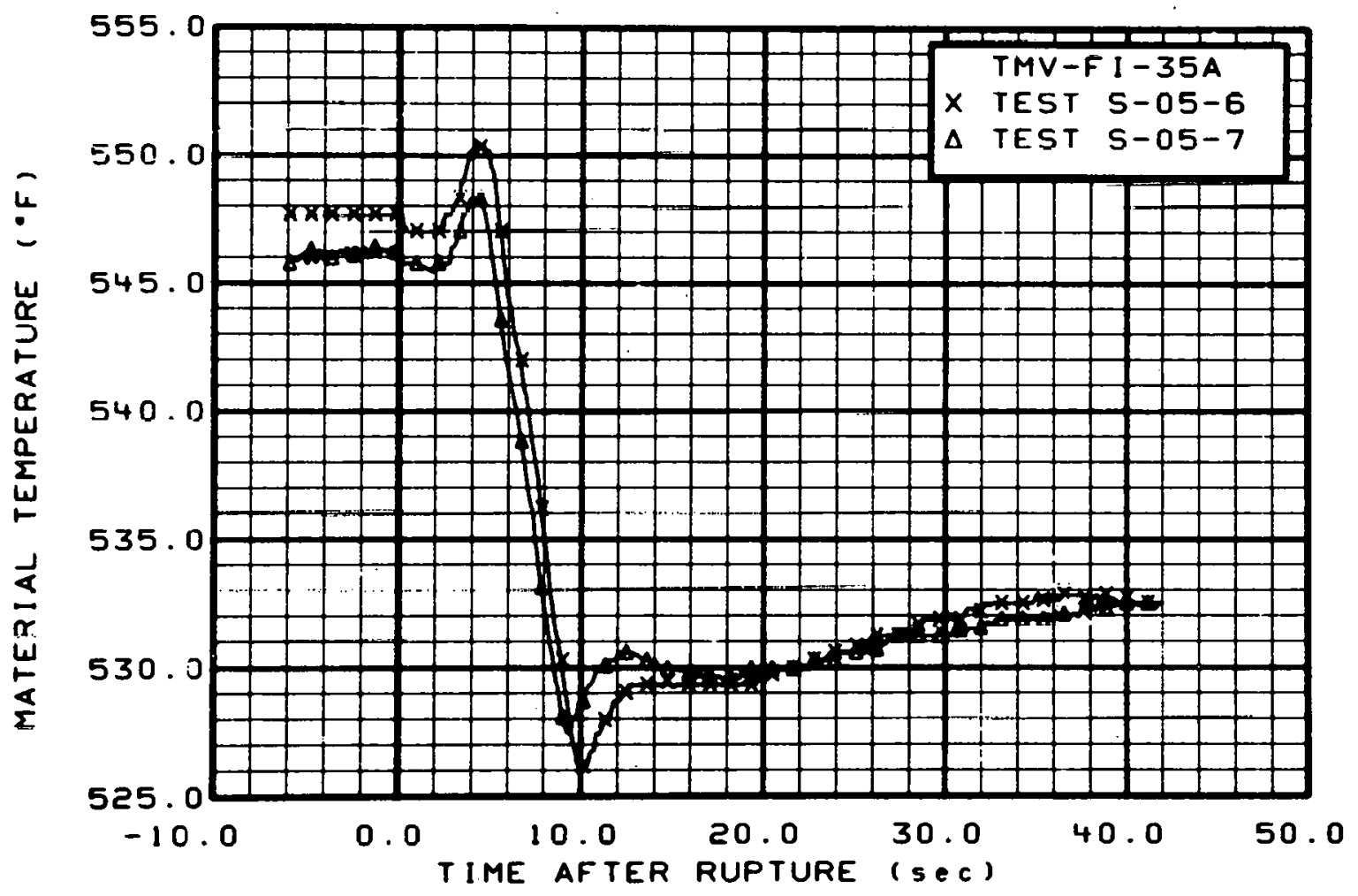

Fig. 87 Material temperature in vessel filler (TMV-FI-35A), from -6 to $42 \mathrm{sec}$. 


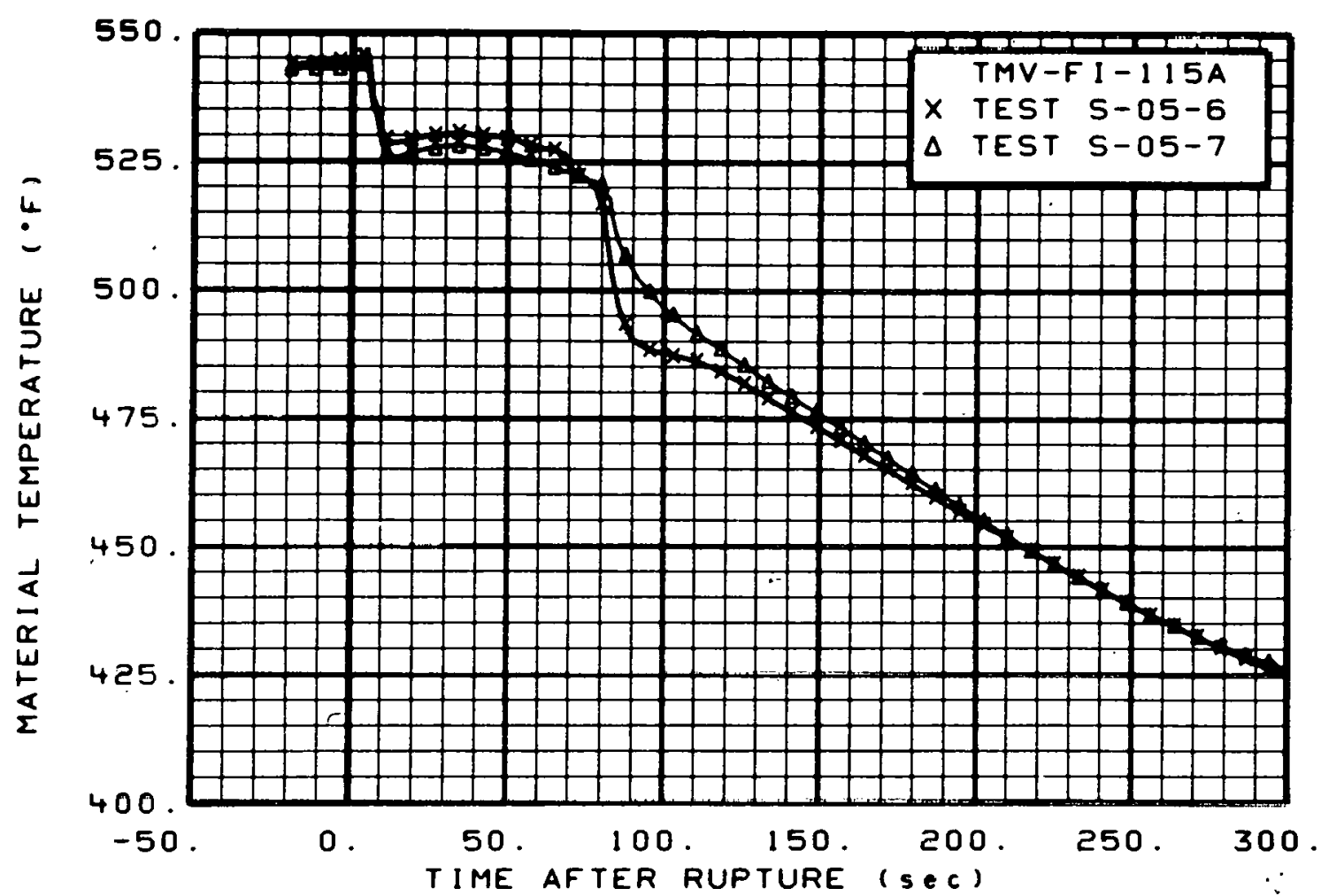

Fig. 88 Material temperature in vessel filler (TMV-FI-115A), from -20 to $300 \mathrm{sec}$.

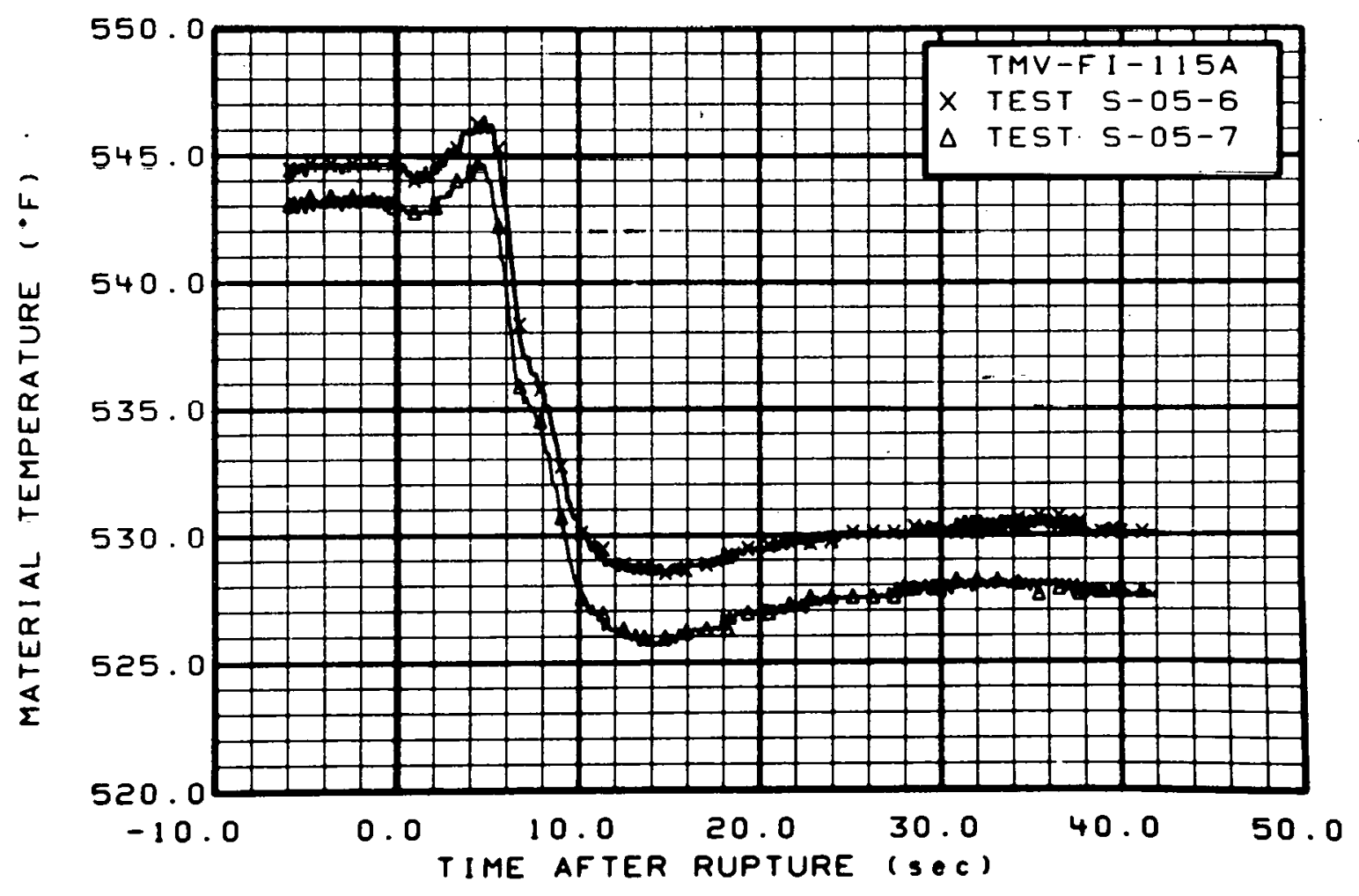

Fig. 89 Material temperature in vessel filler (TMV-FI-115A), from -6 to 42 sec. 


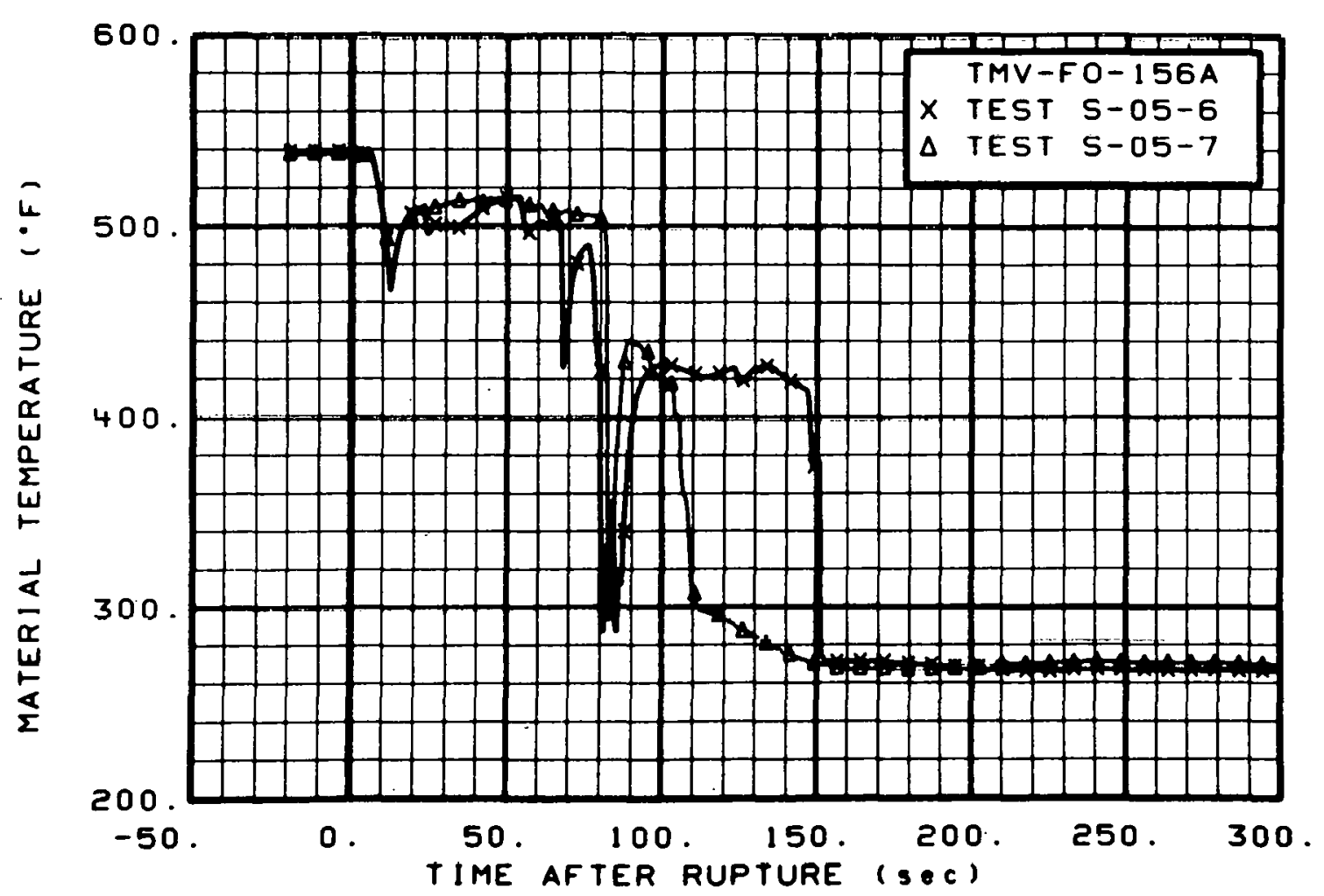

Fig. 90 Material temperature in vessel filler. (TMV-F0-156A), from -20 to $300 \mathrm{sec}$.

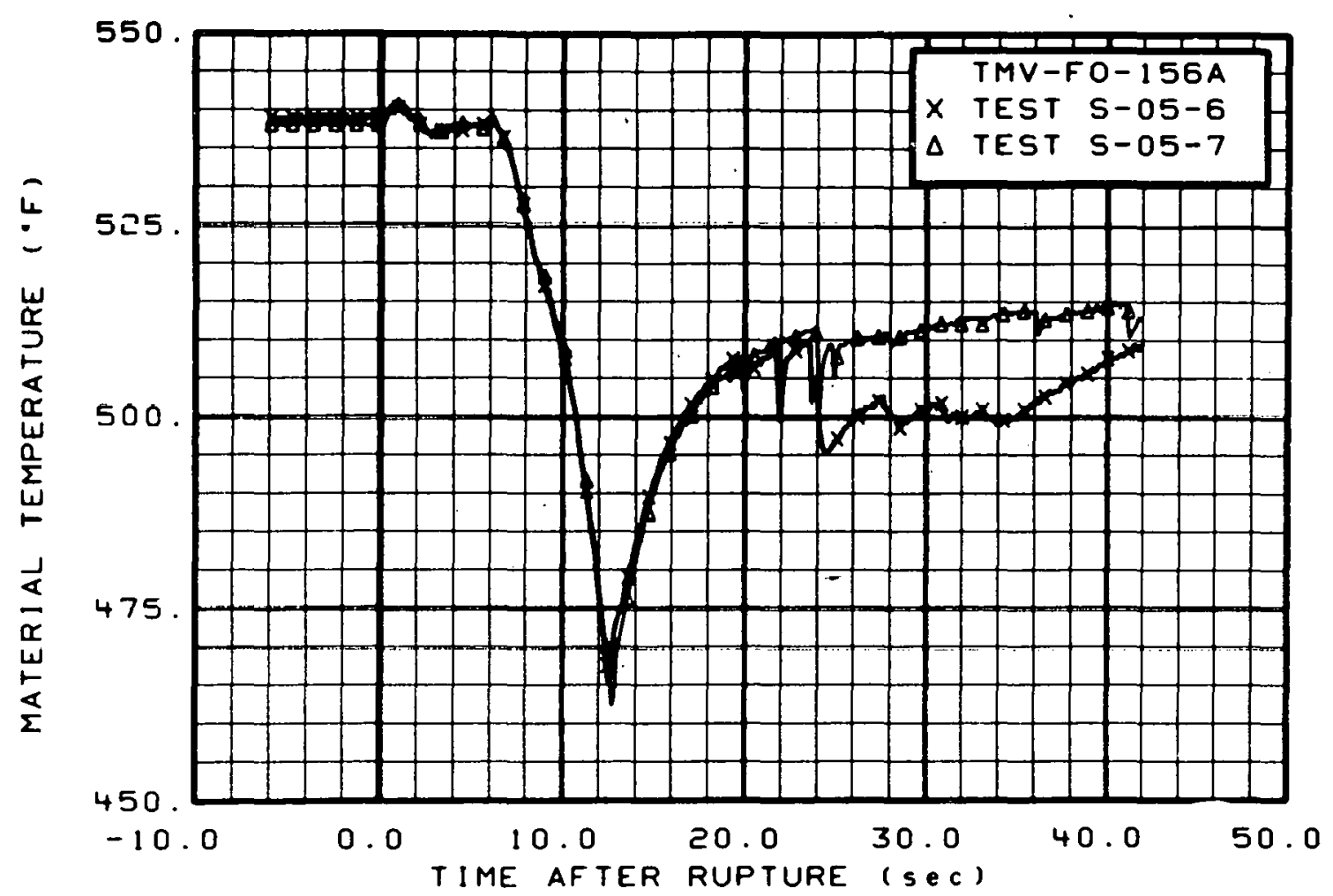

Fig. 91 Material temperature in vessel filler (TMV-F0-156A), from -6 to $42 \mathrm{sec}$. 


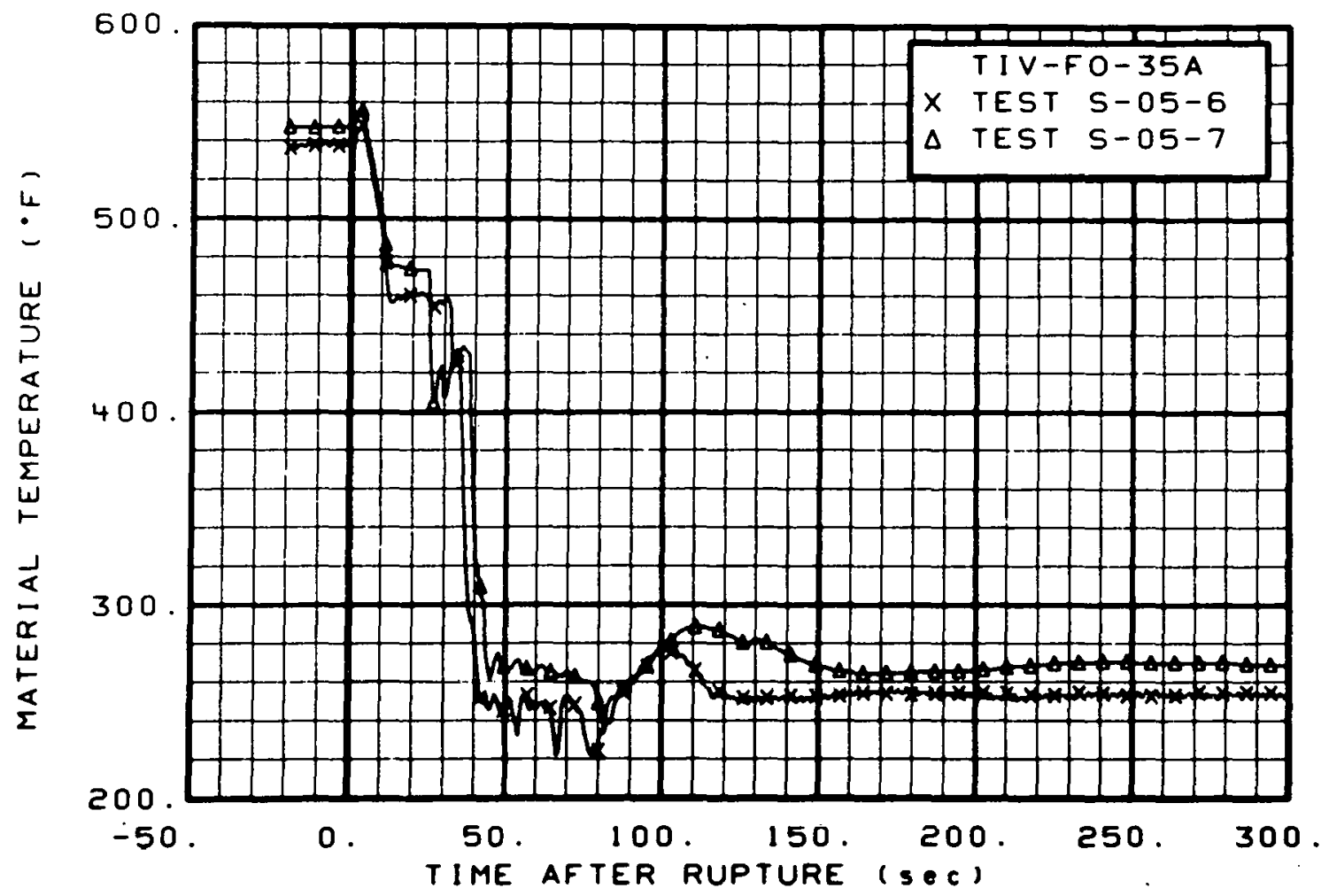

Fig. 92 Material temperature in vessel filler insulator (TIV-F0-35A); from -20 to $300 \mathrm{sec}$.

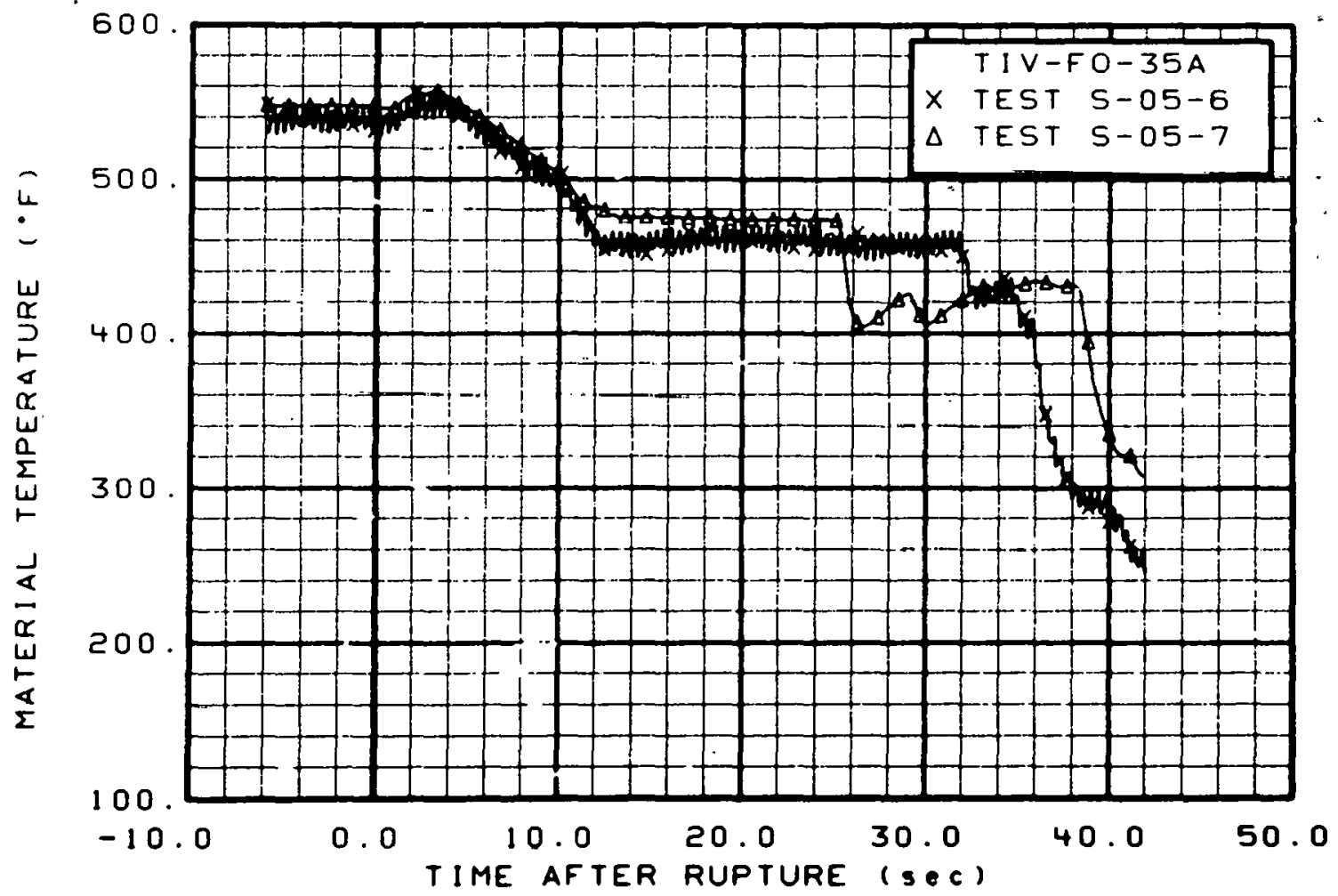

Fig. 93. Material tempcrature in vessel filler insulator (TIV-F0-35A), from -6 to $42 \mathrm{sec}$. 


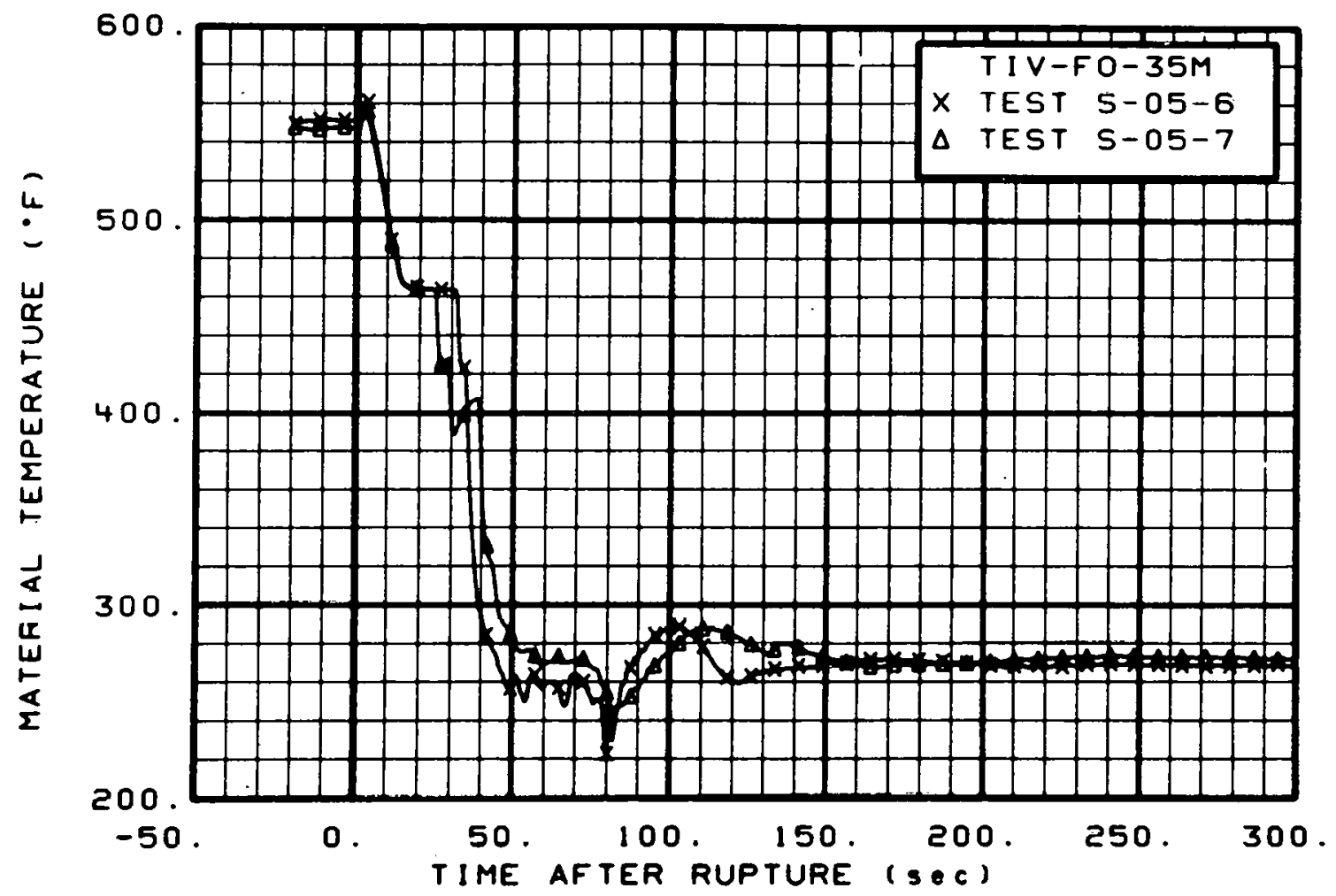

Fig. 94 Material temperature in vessel filler insulator (TIV-F0-35M), from -20 to $300 \mathrm{sec}$.

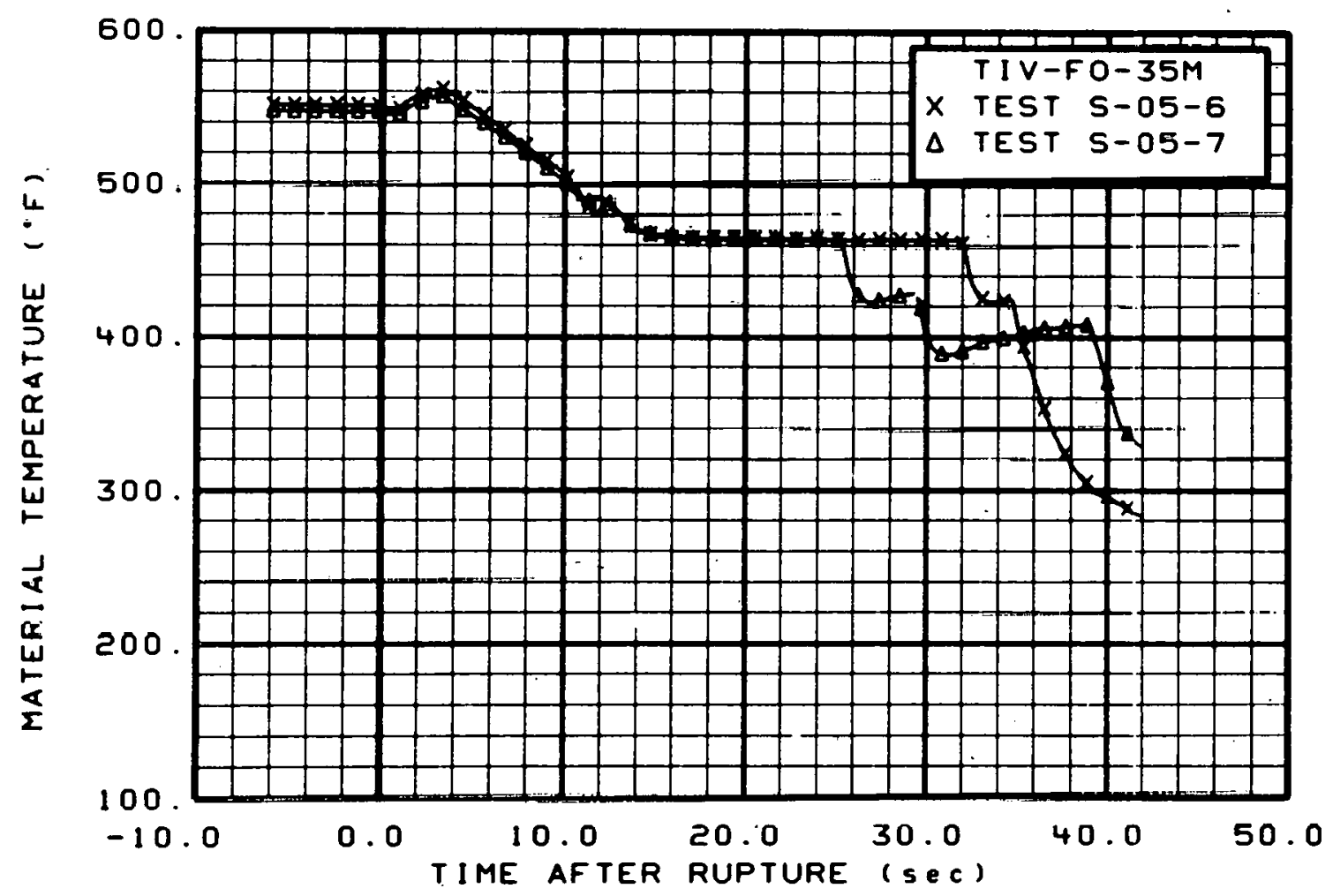

Fig. 95 Material temperature in vessel filler insulator (TIV-F0-35M), from -6 to $42 \mathrm{sec}$. 


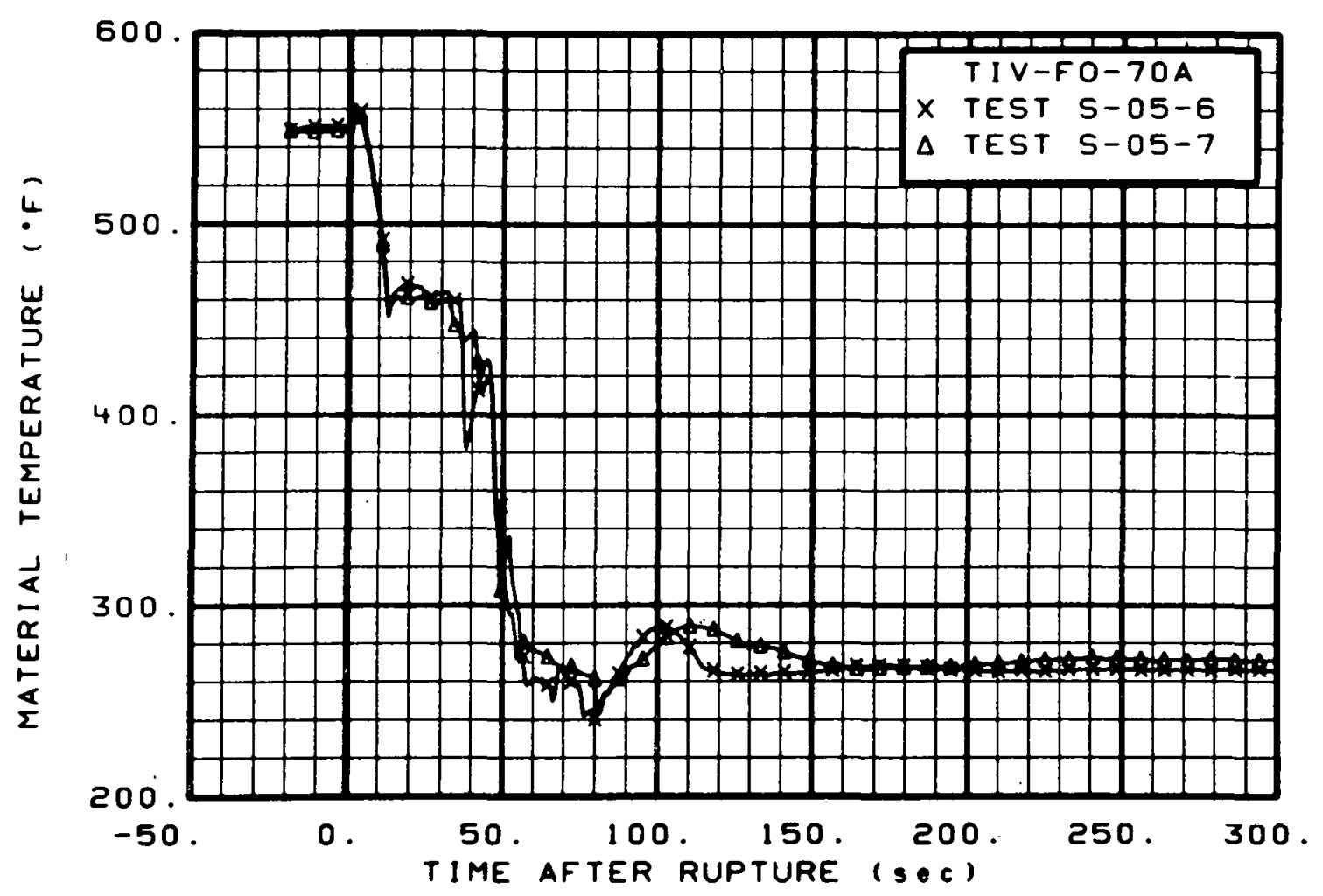

Fig. 96 Material temperature' in vessel filler insulator (TIV-FO-70A); from -20 to $300 \mathrm{sec}$.

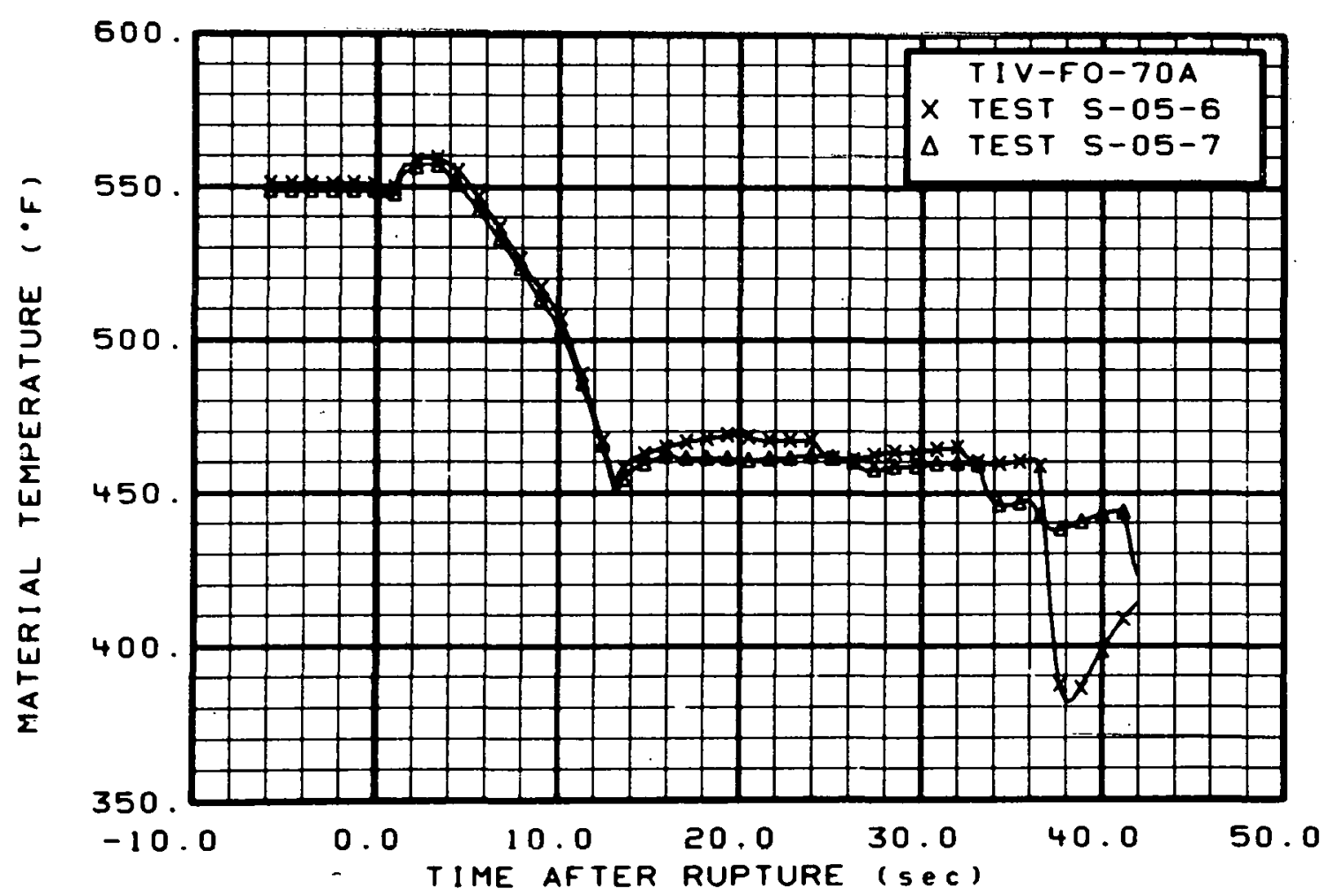

Fig, 97 Material temperature in vessel filler insulator (TIV-F0-70A), from -6 to $42 \mathrm{sec}$. 


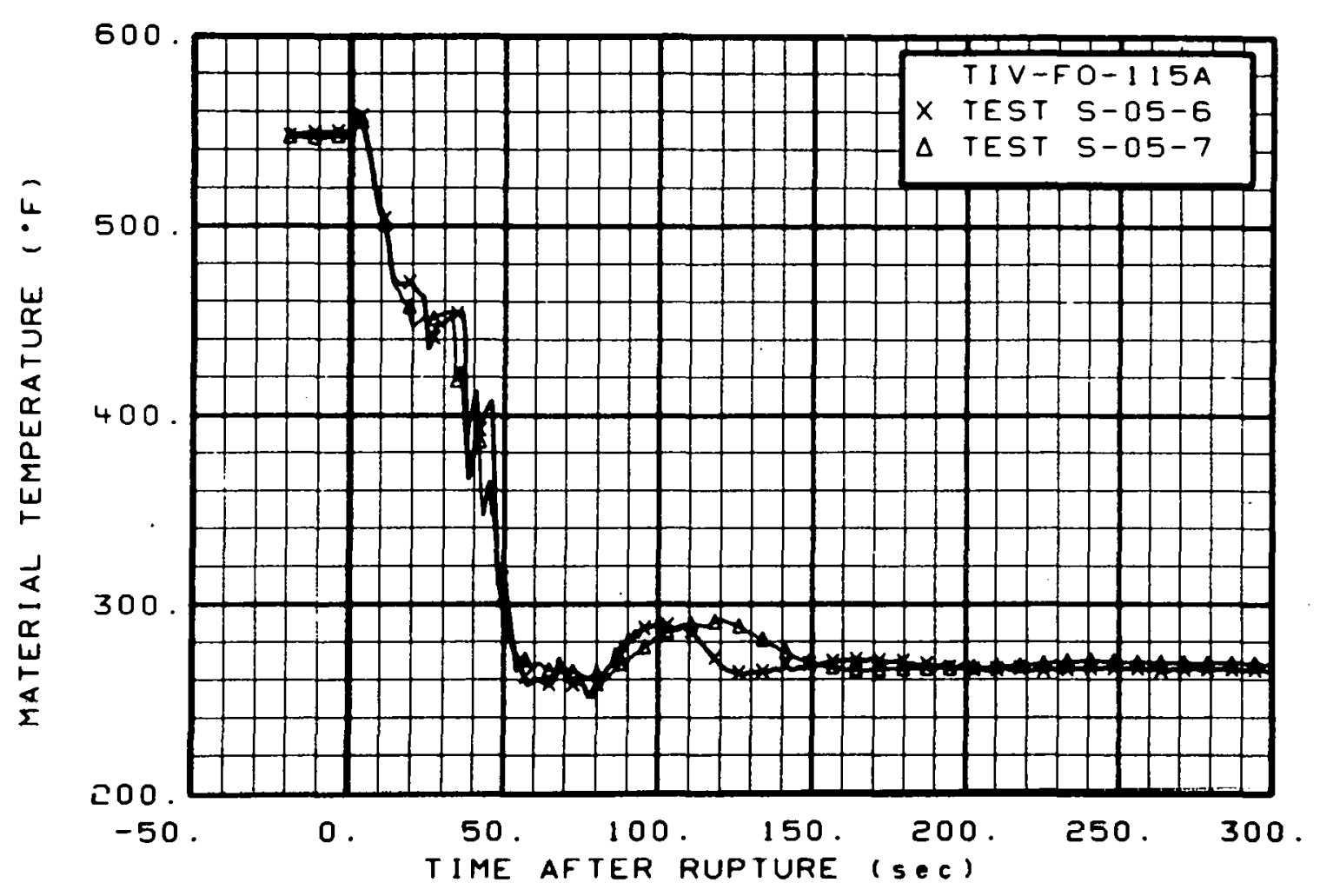

Fig. 98 Material temperature in vessel filler insulator (TIV-F0-115A), from -20 to 300 sec.

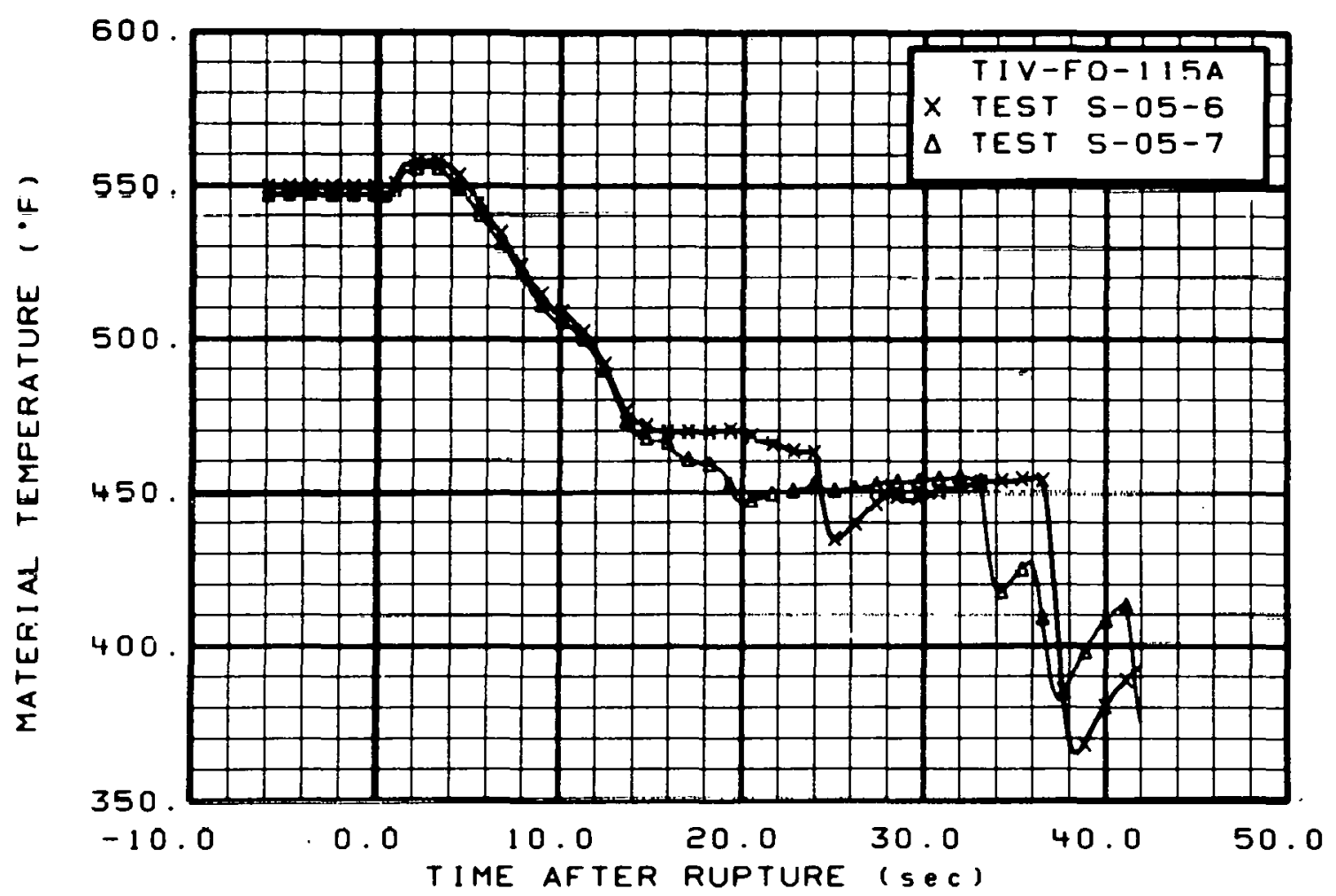

Fig. 99 Material temperature in vessel filler insulator (TIV-F0-115A), from -6 to $42 \mathrm{sec}$. 


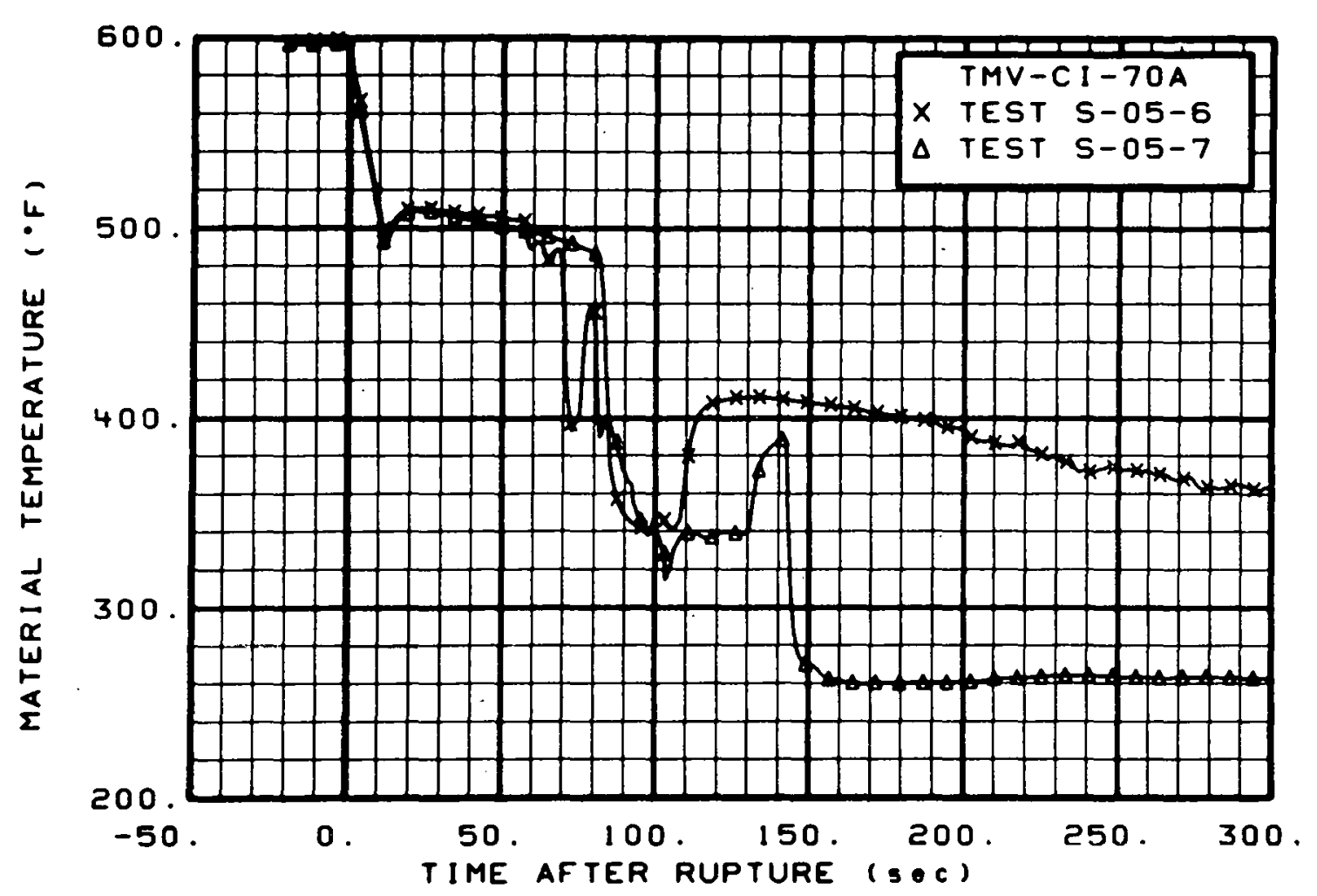

Fig. 100 Material temperature in core barrel (TMV-CI-70A), from -20 to $300 \mathrm{sec}$.

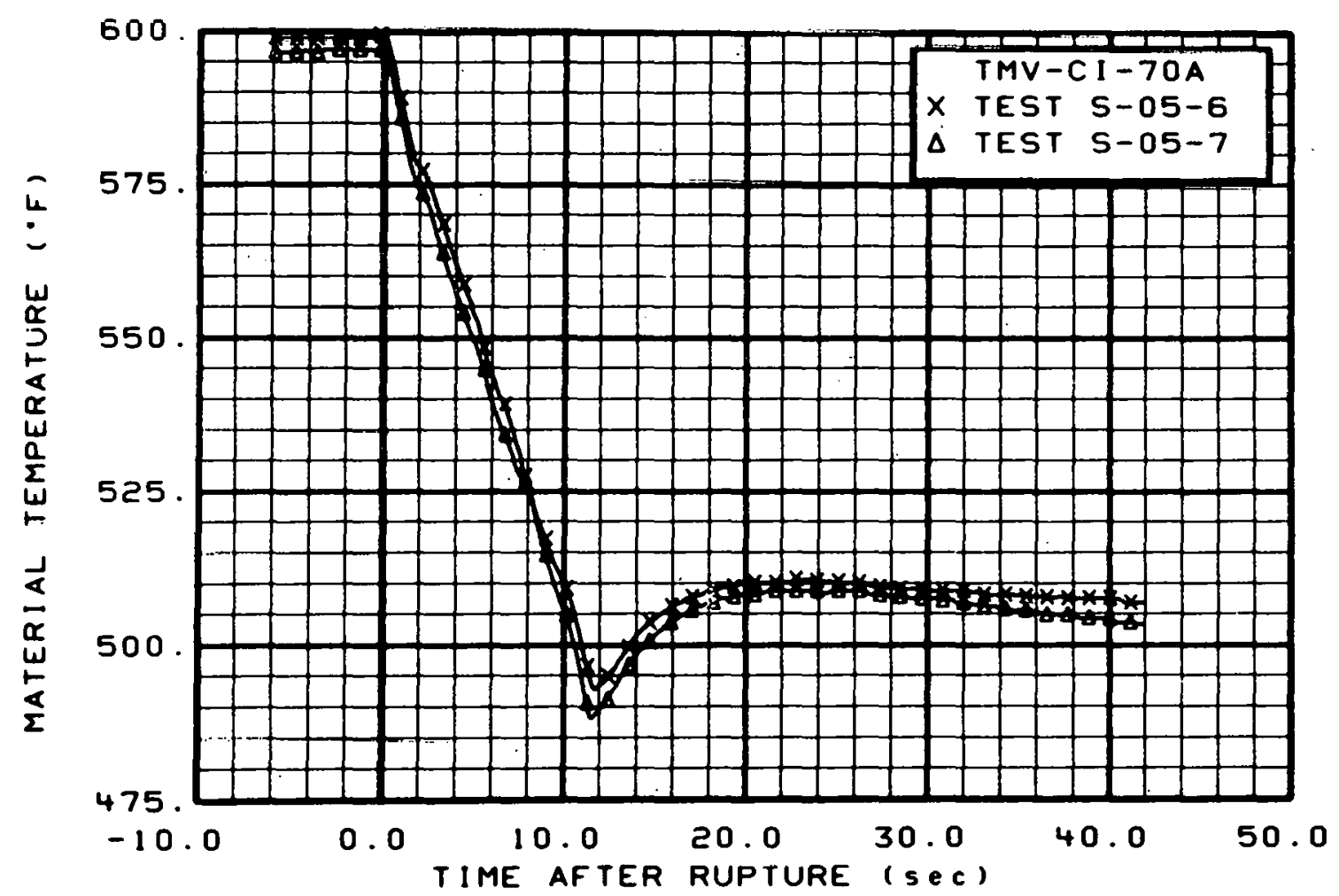

Fig. 101 Material temperature in core barrel (TMV-CI-70A), from -6 to $42 \mathrm{sec}$. 


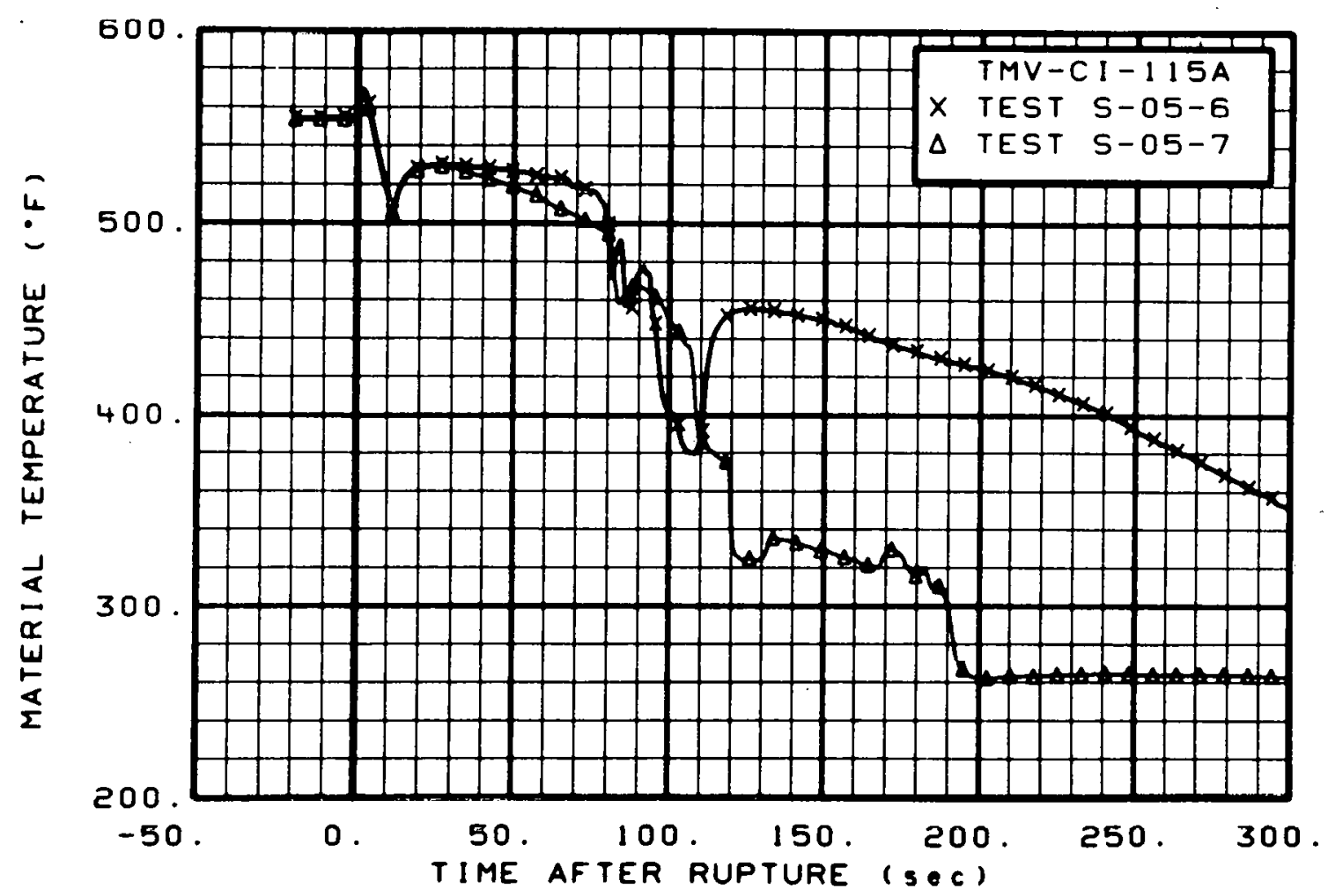

Fig. 102 Material temperature in core barrel (TMV-CI-115A), from -20 to $300 \mathrm{sec}$.

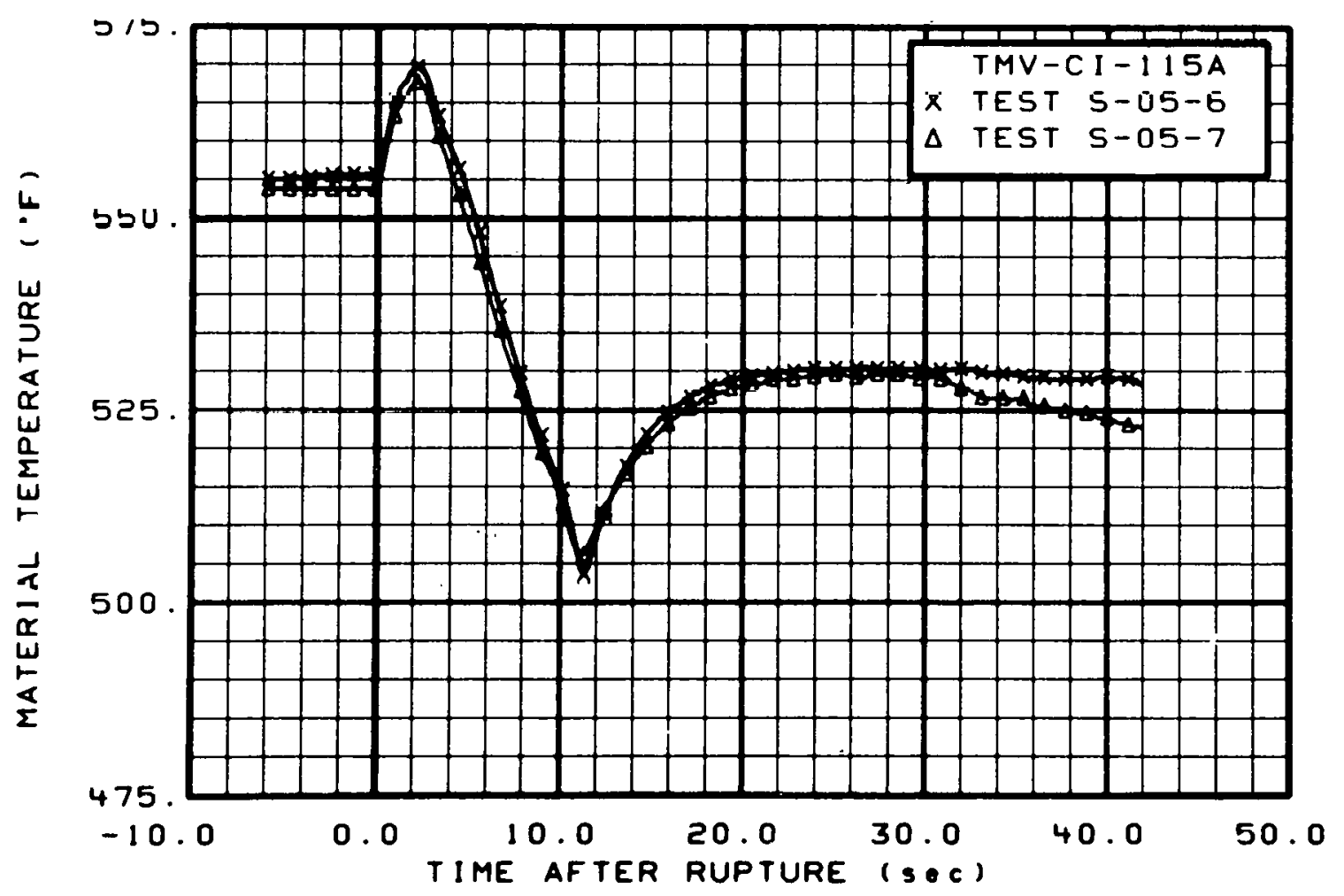

Fig. 103 Material temperature in core barrel (TMV-CI-115A), from -6 to $42 \mathrm{sec}$. 


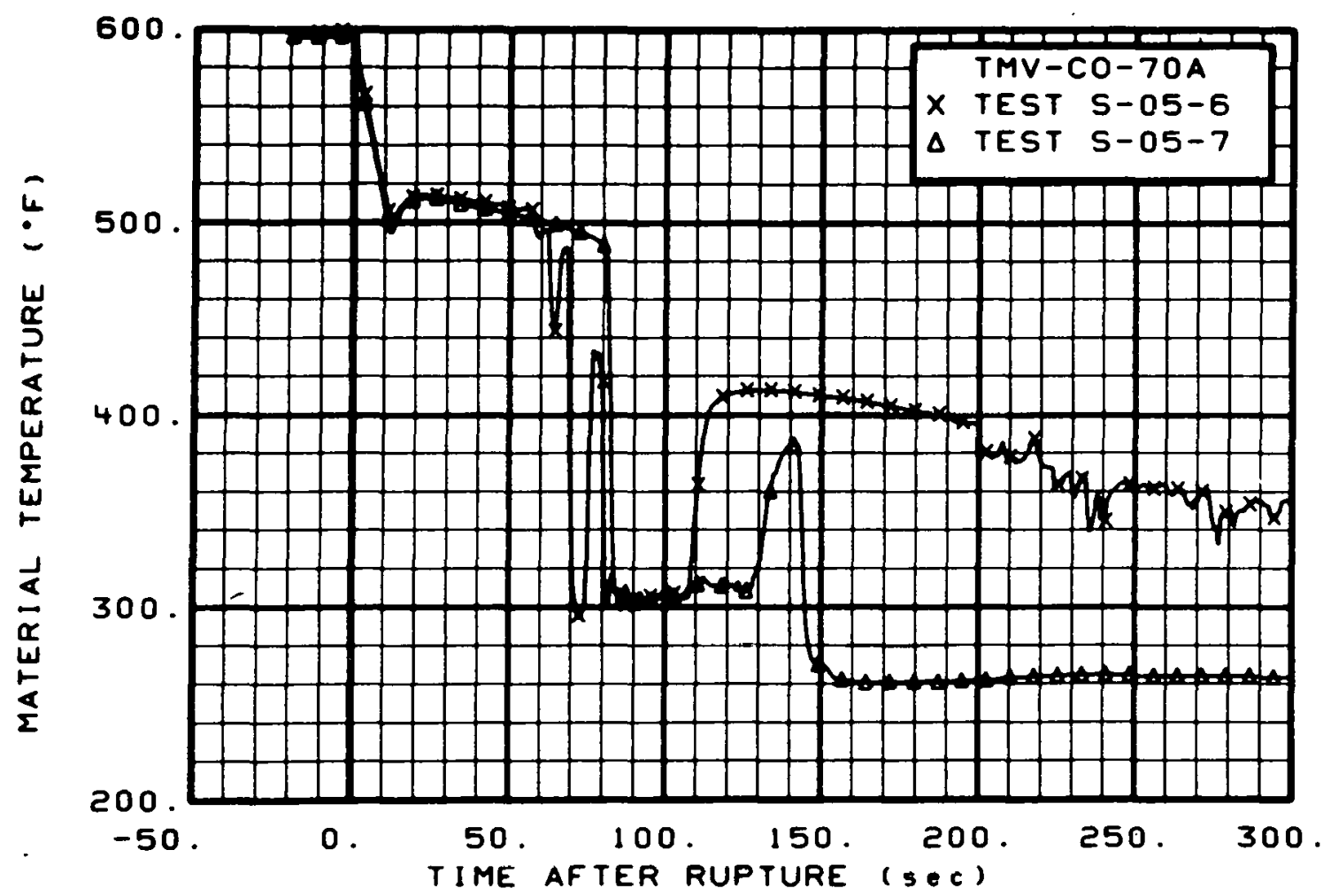

Fig. 104 Material temperature in core barrel (TMV-CO-70A), from -20 to $300 \mathrm{sec}$.

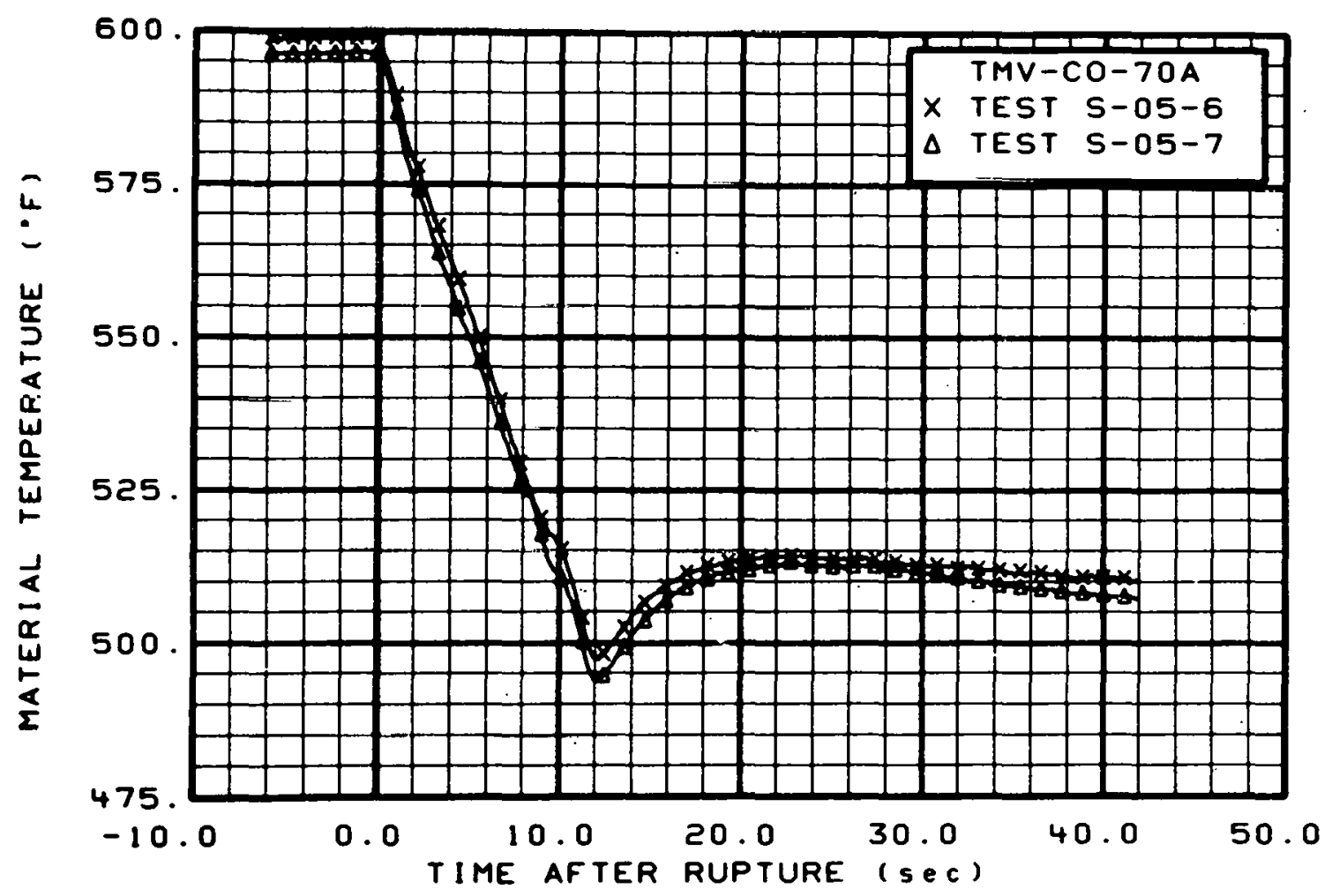

Fig. 105 Material temperature in core barrel (TMV-CO-70A), from -6 to 47 ser. 


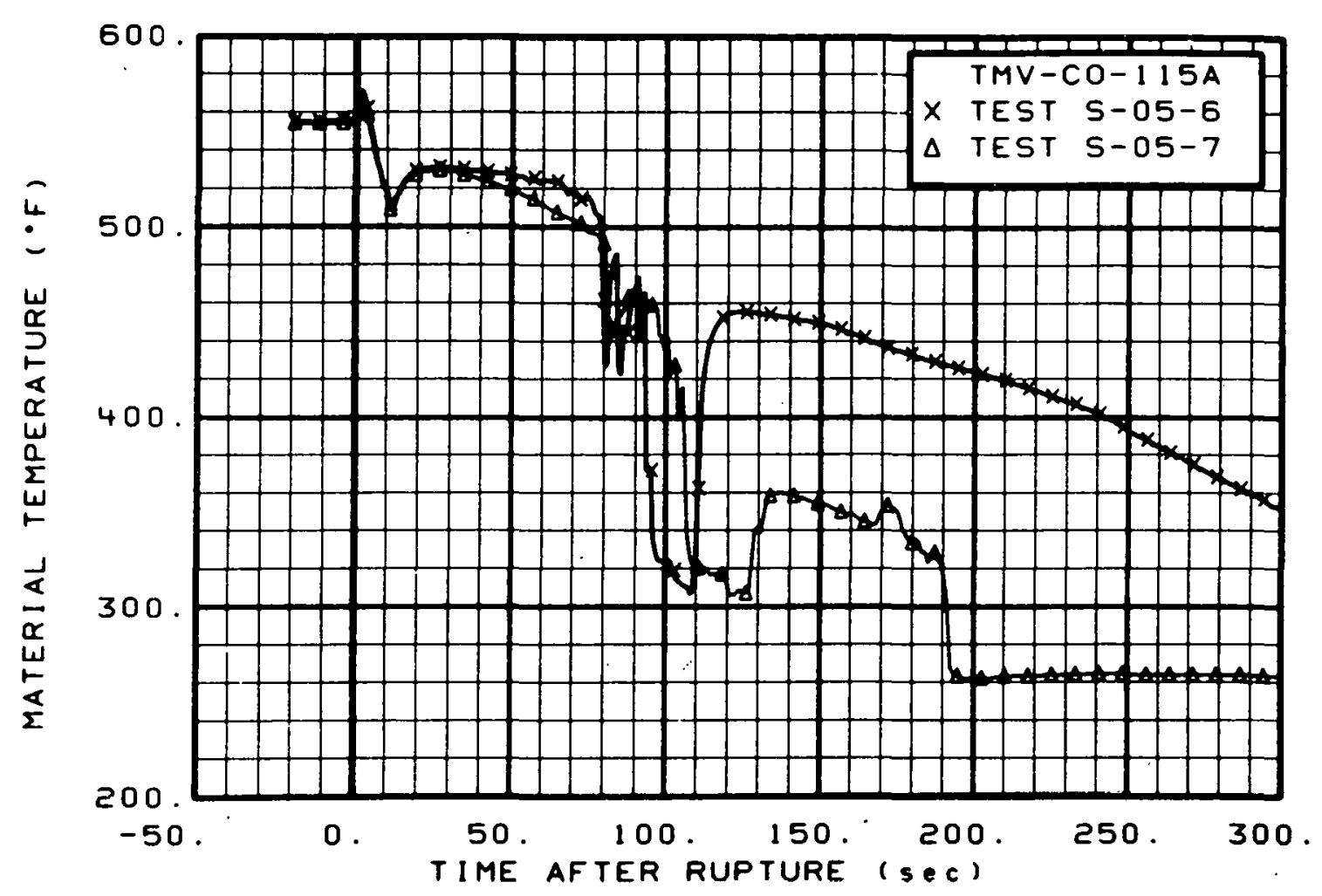

Fig. 106 Material temperature in core barrel (TMV-C0-115A), from -20 to $300 \mathrm{sec}$.

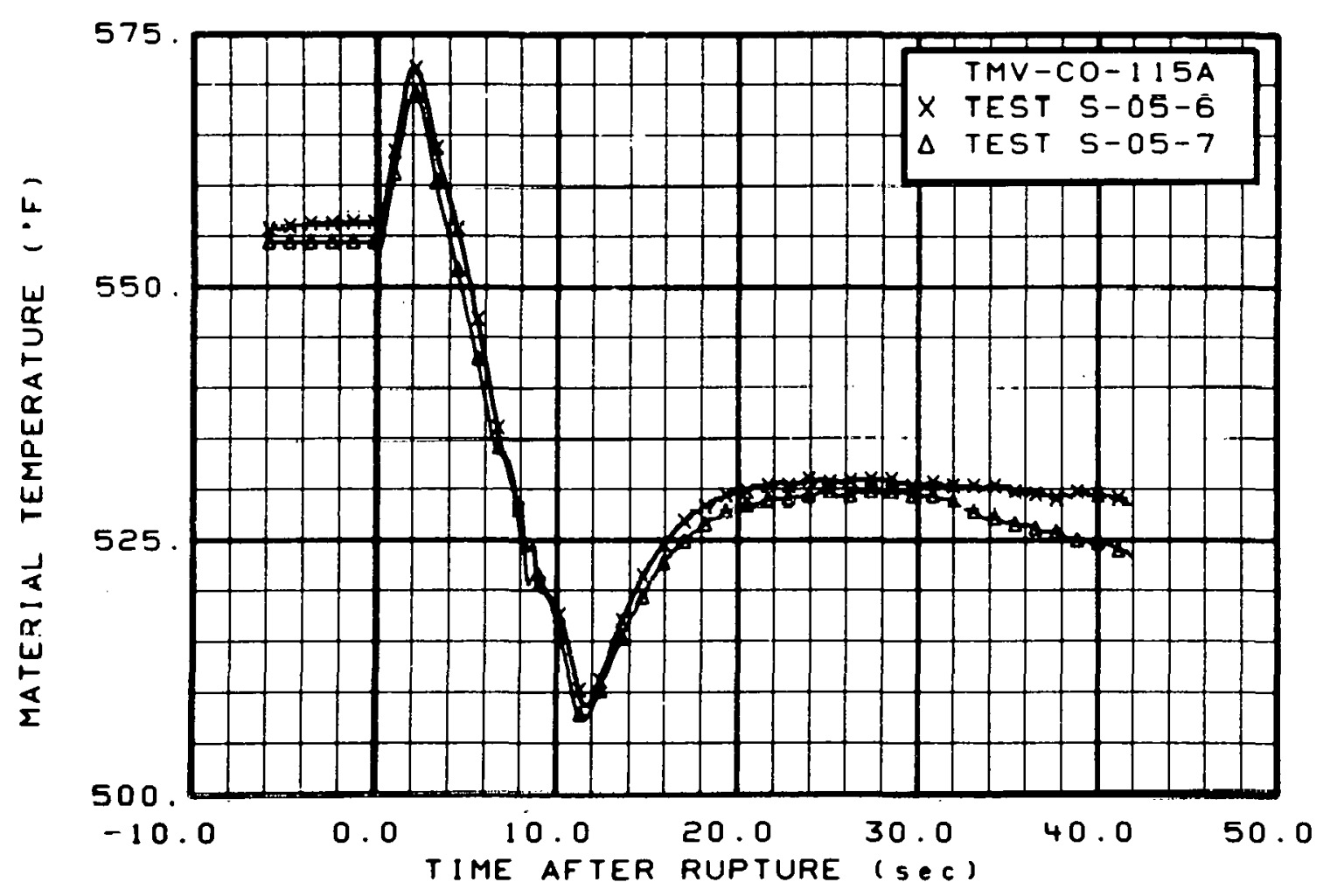

Fig. 107 Material temperature in core barrel (TMV-C0-115A), from -6 to $42 \mathrm{sec}$. 


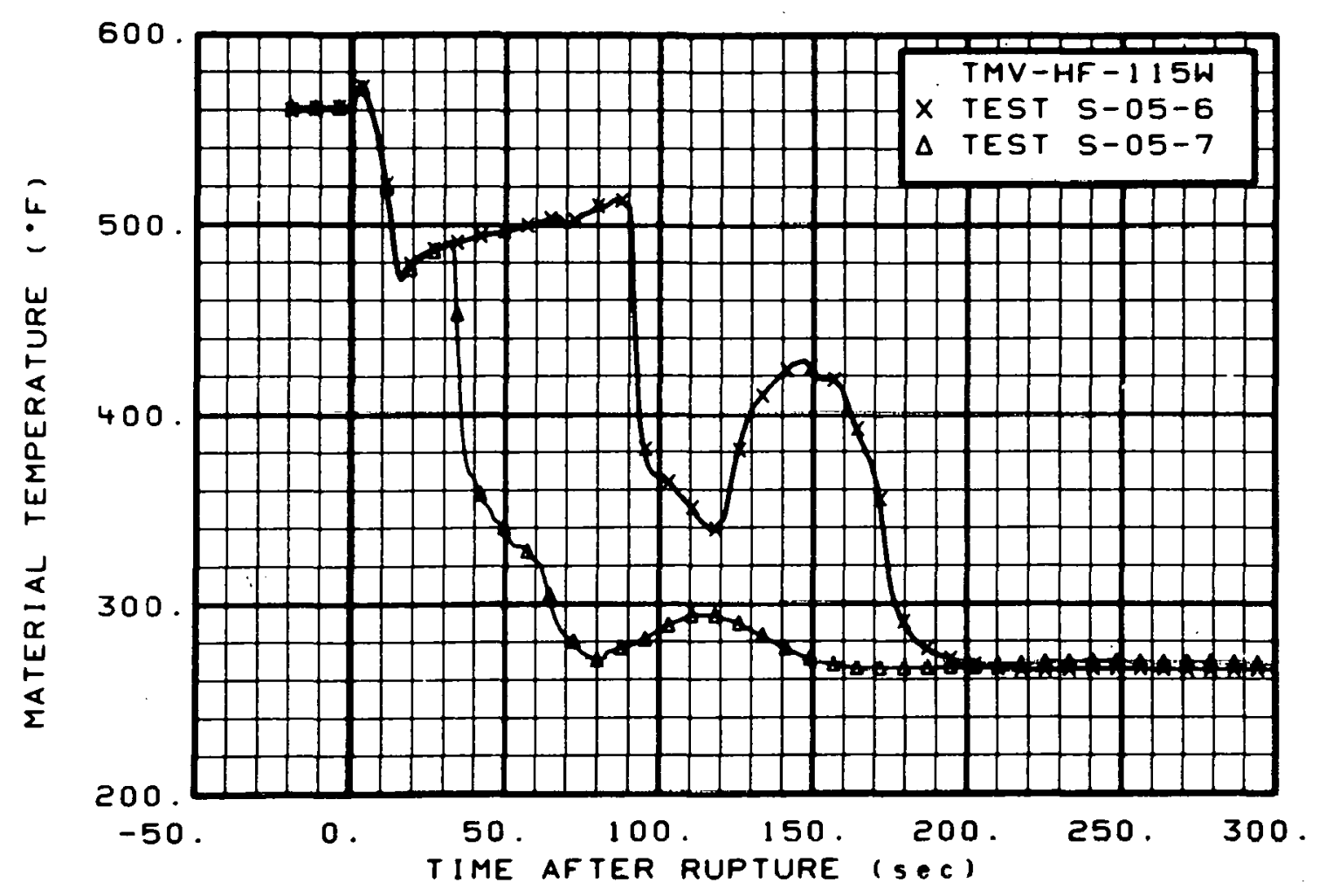

Fig. 108 Material temperature in core housing filler (TMV-HF-115W),from -20 to $300 \mathrm{sec}$.

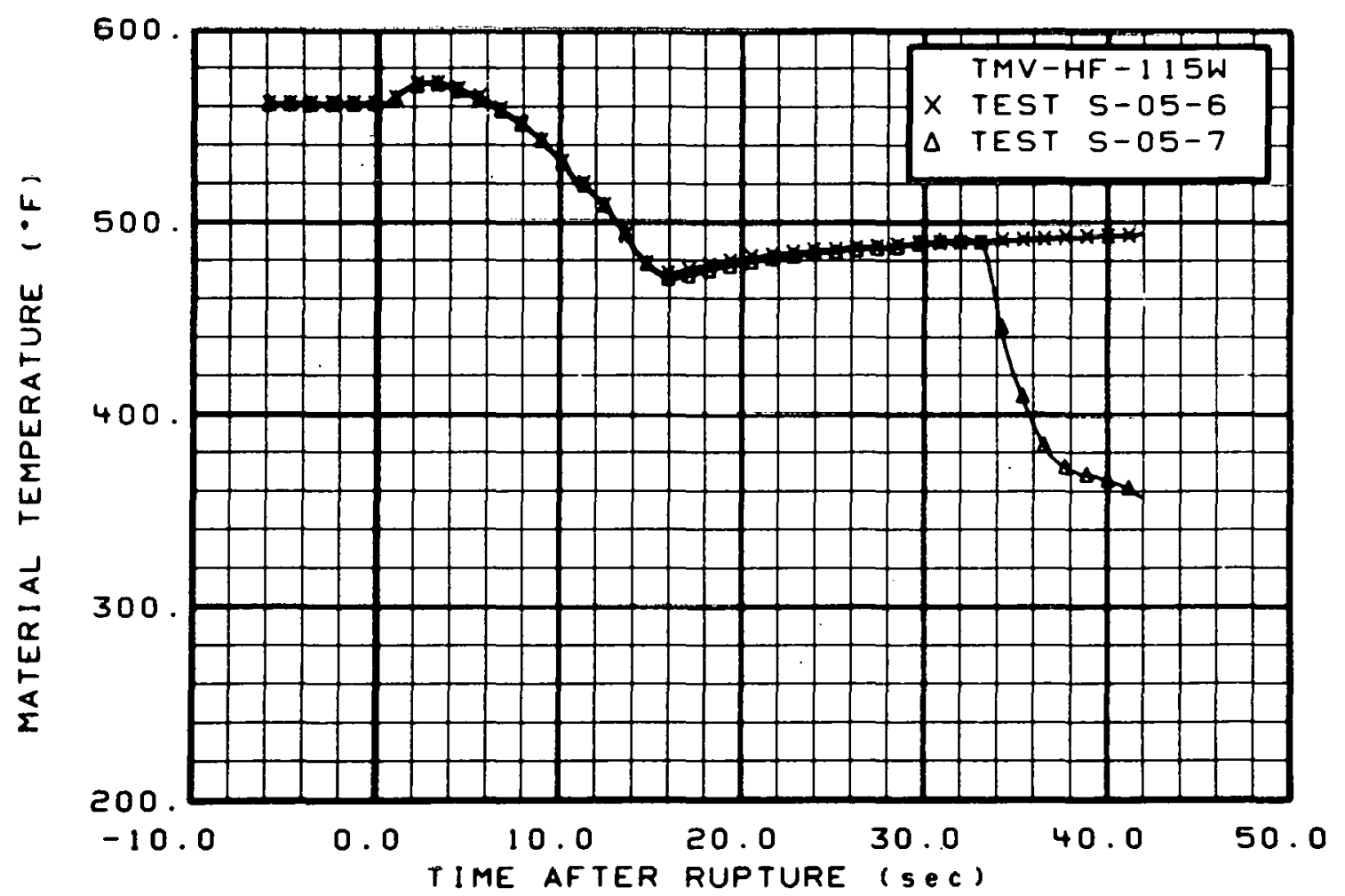

Fig. 109 Material temperature in core housing filler (TMV-HF-115W), from -6 to $42 \mathrm{scc}$. 


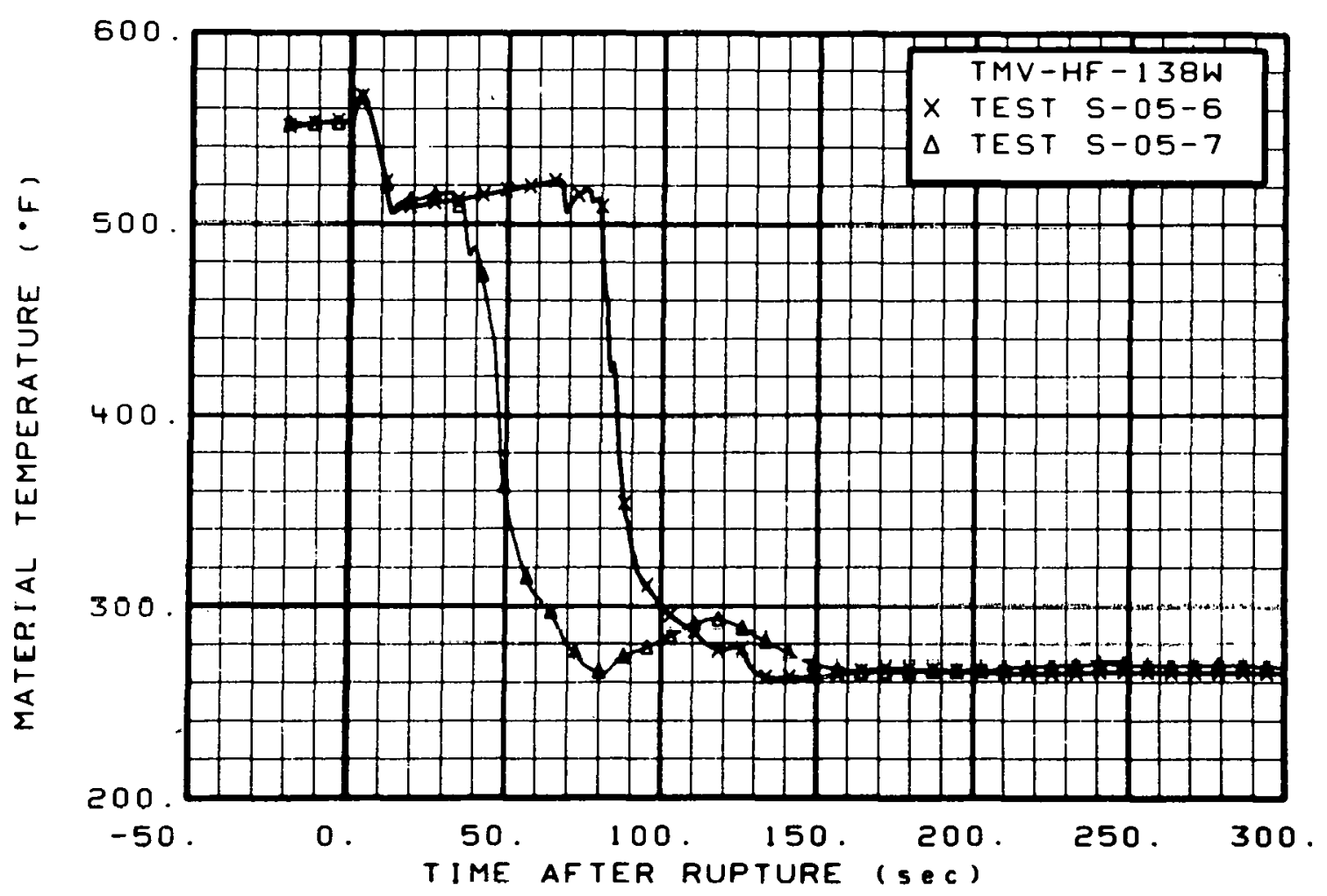

Fig. 110 Material temperature in core housing filler (TMV-HF-138W), from -20 to $300 \mathrm{sec}$.

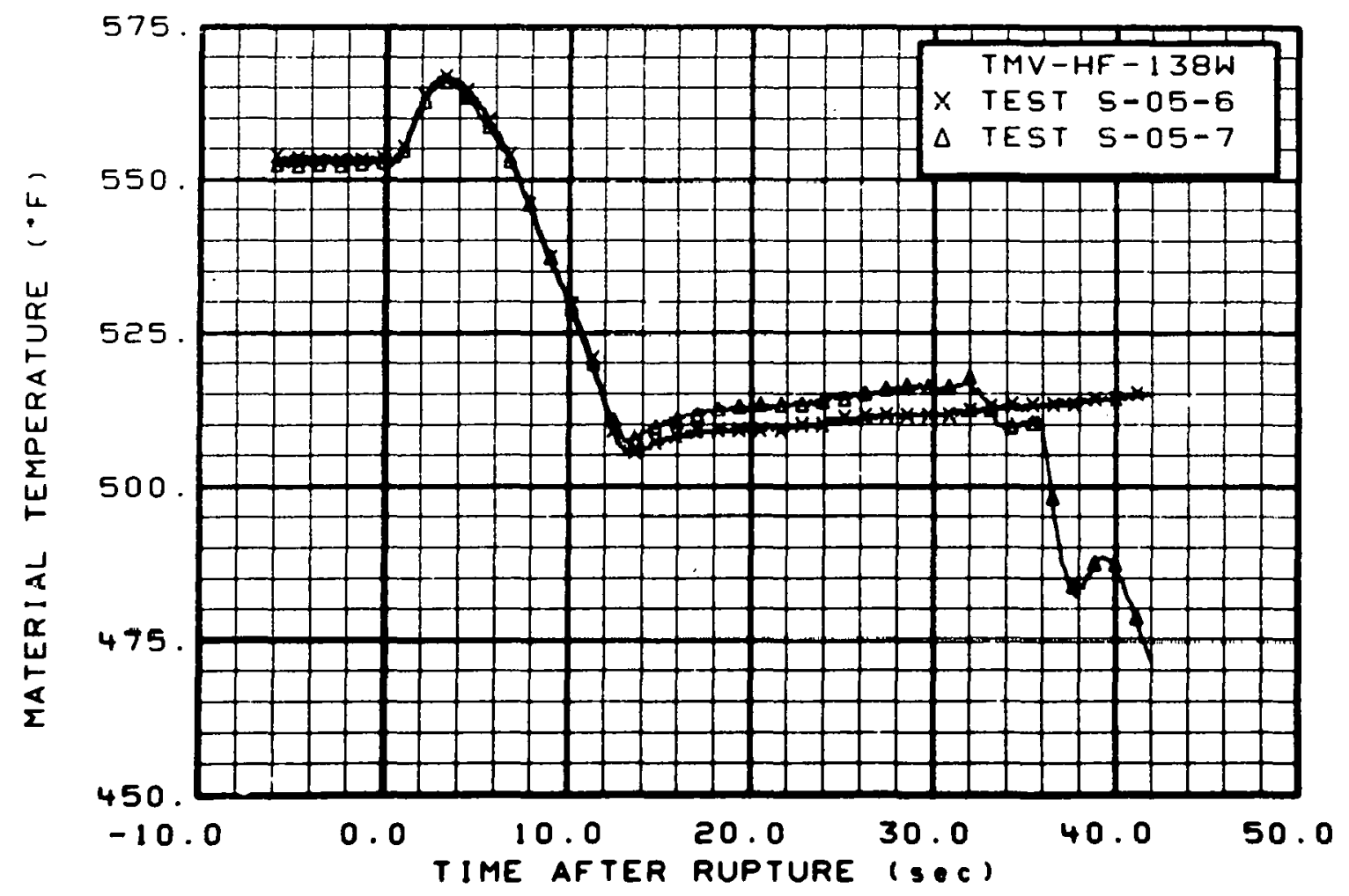

Fig. 111 Material temperature in core housing filler (TMV-HF-138W), from -6 to $42 \mathrm{sec}$. 


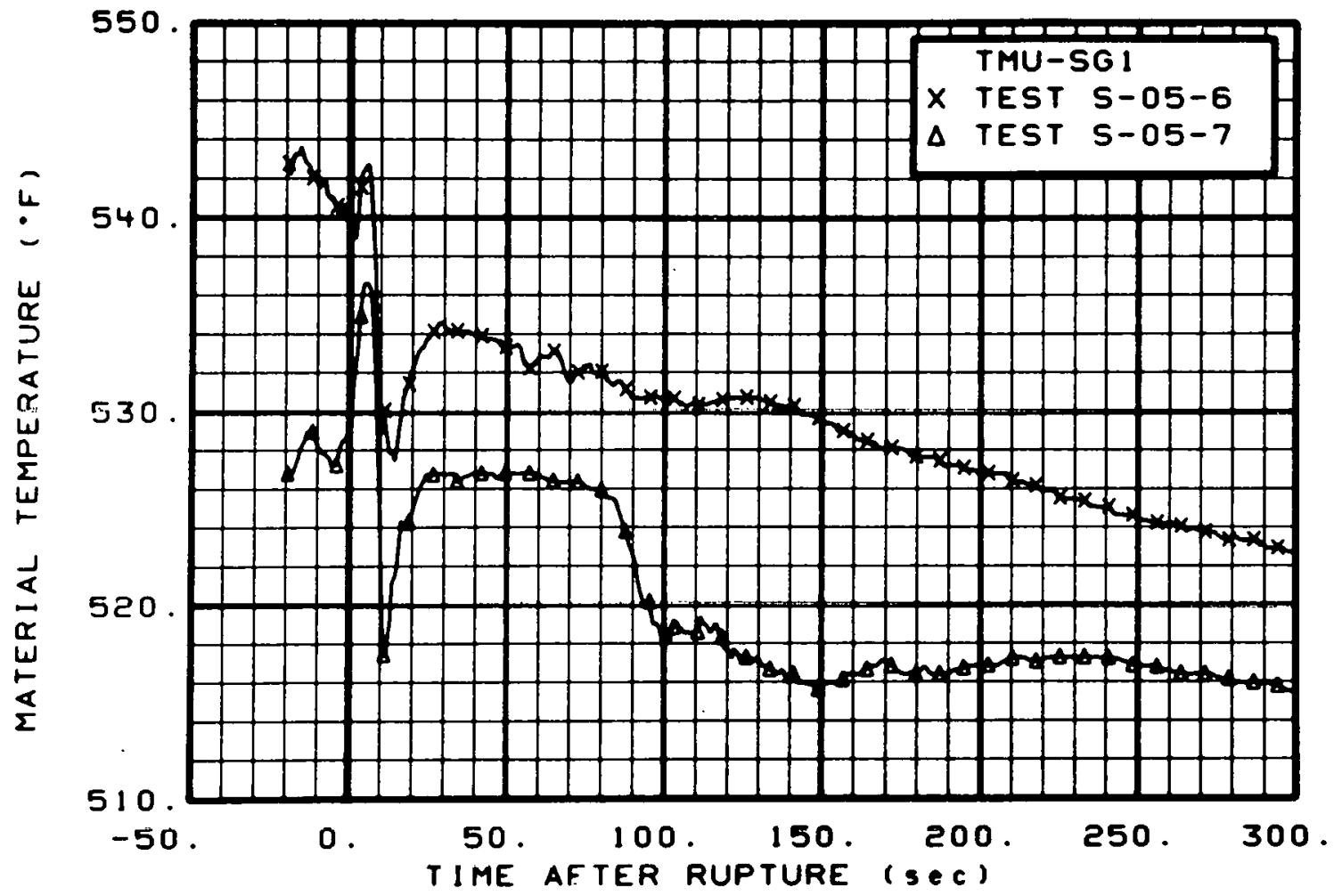

Fig. 112 Material temperature in steam generator, secondary side (TMU-SG1), from -20 to $300 \mathrm{sec}$.

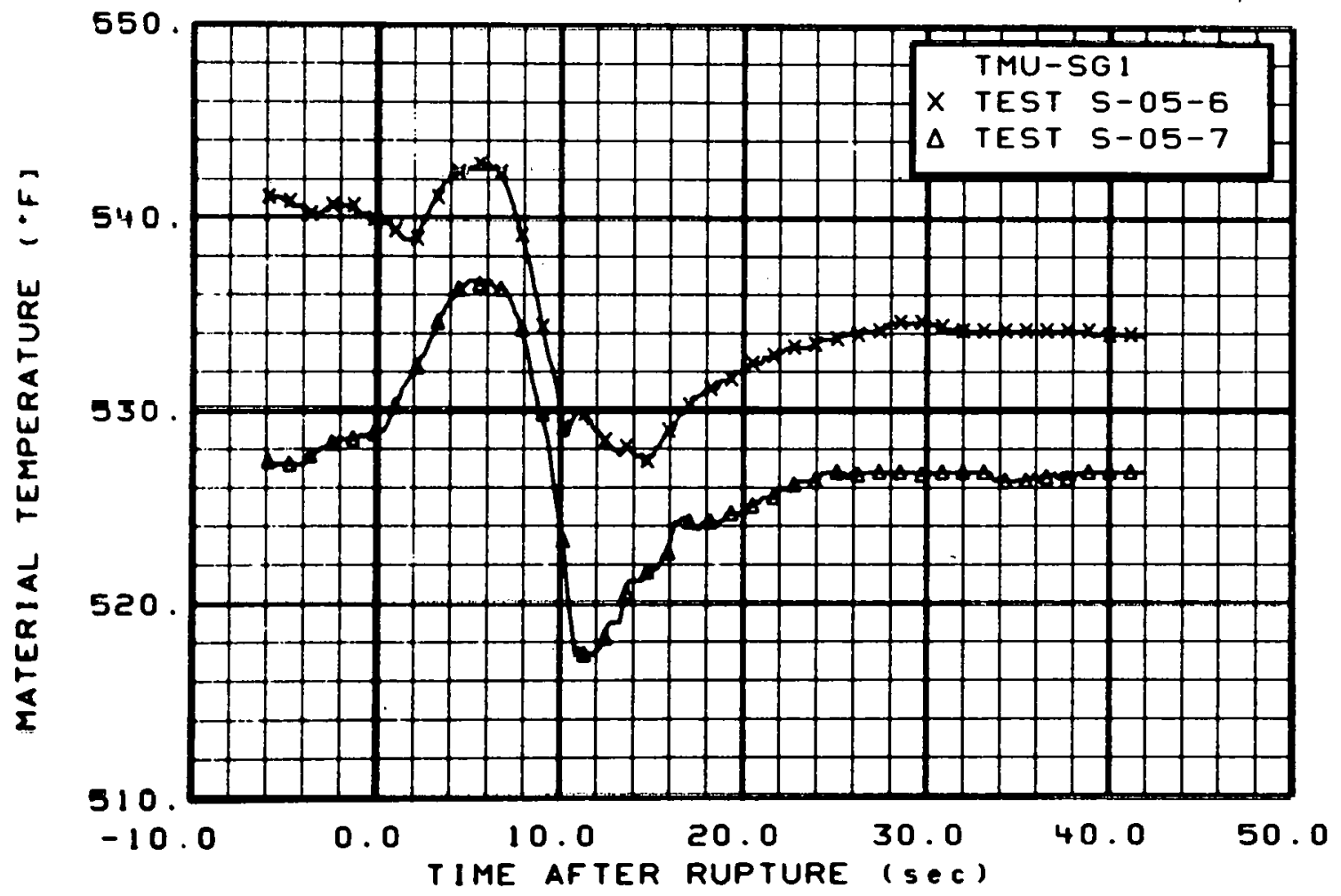

Fig. 113 Material temperature in steam generator, secondary side (TMU-SGI), from -6 to $42 \mathrm{sec}$. 


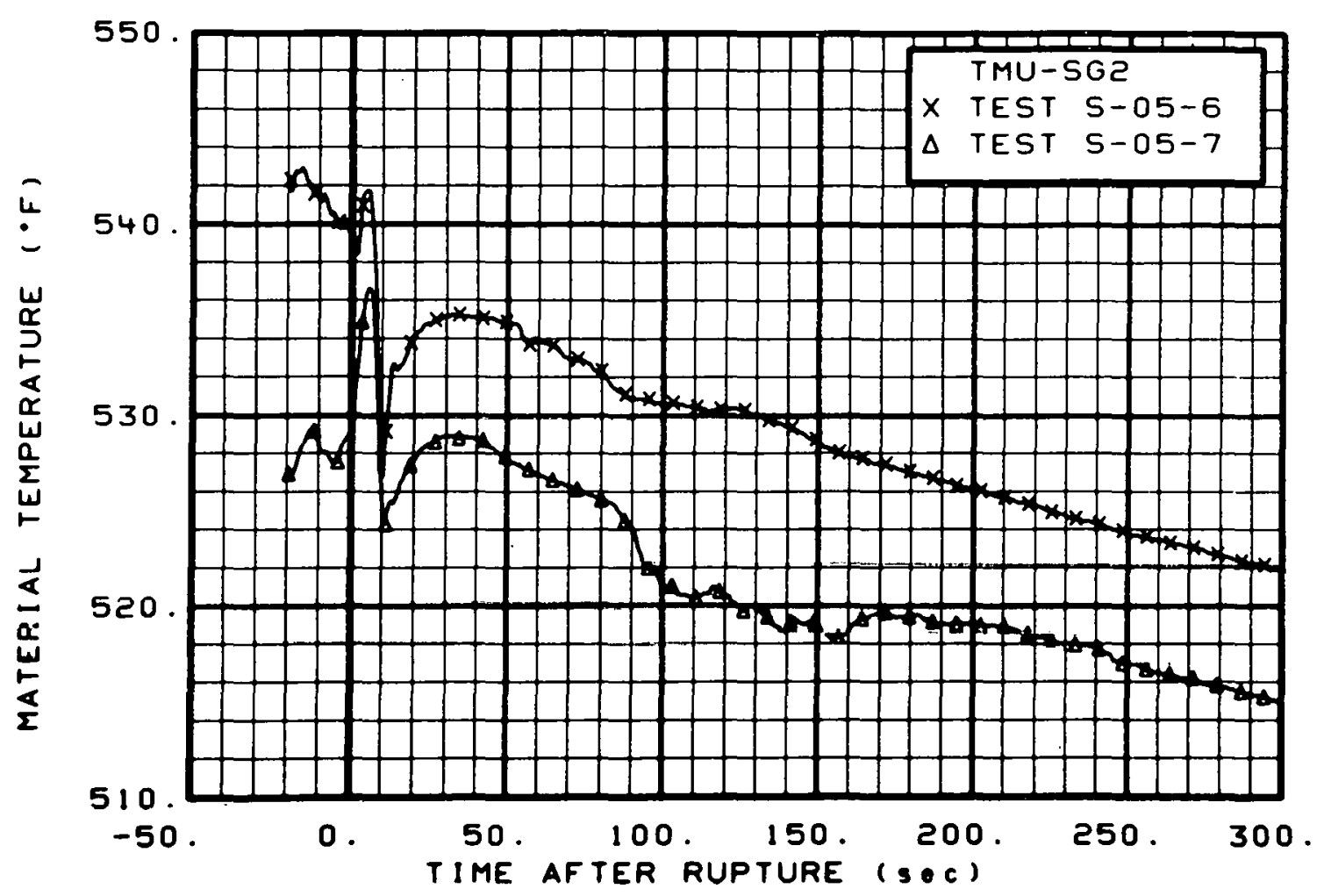

Fig. 114 Material temperature in steam generator, secondary side (TMU-SG2), from -20 to $300 \mathrm{sec}$.



Fig. 115 Material temperature in steam generator, secondary side (TMU-SG2), from -6 to $42 \mathrm{sec}$. 


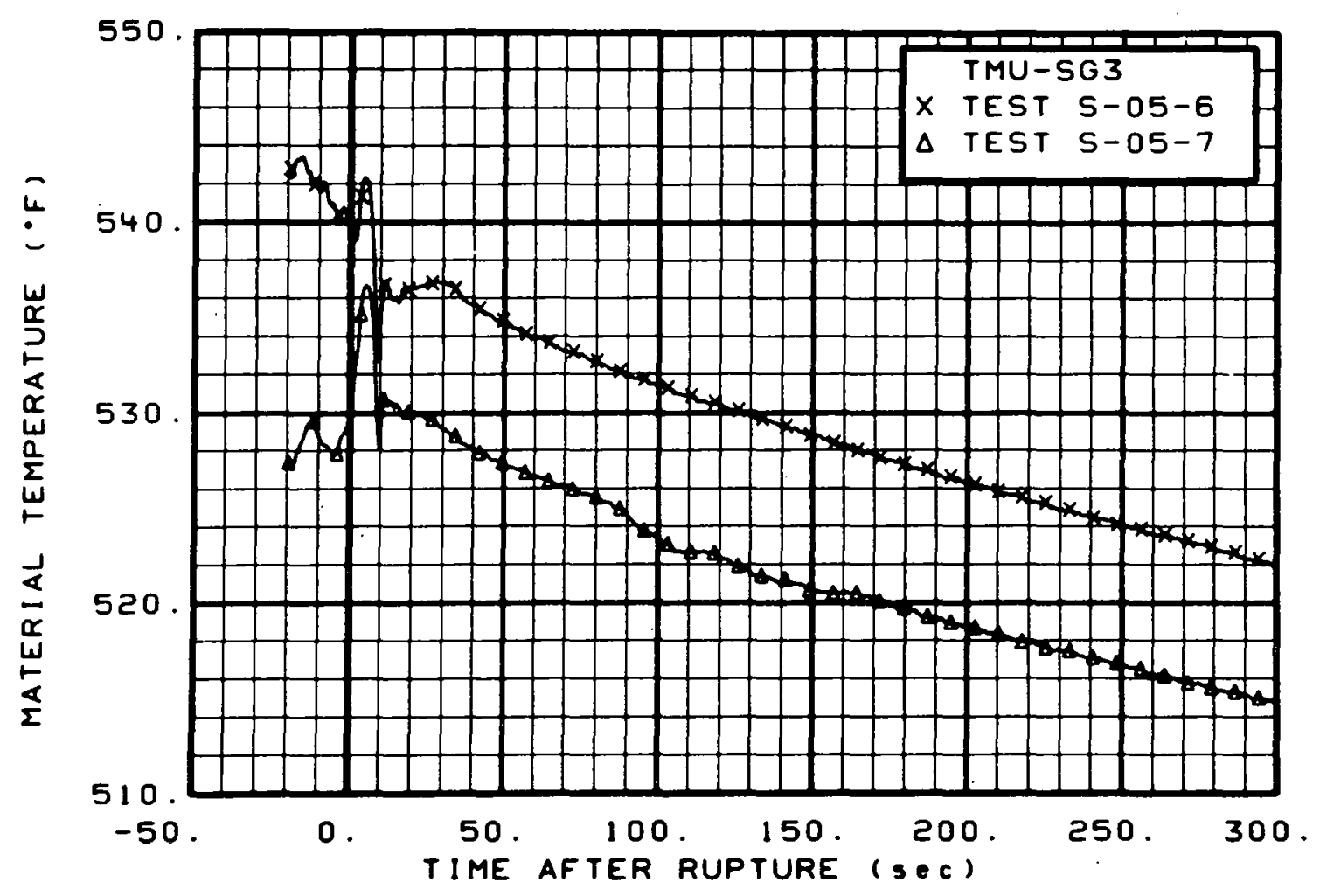

Fig. 116 Material temperature in steam generator, secondary side (TMU-SG3), from -20 to $300 \mathrm{sec}$.

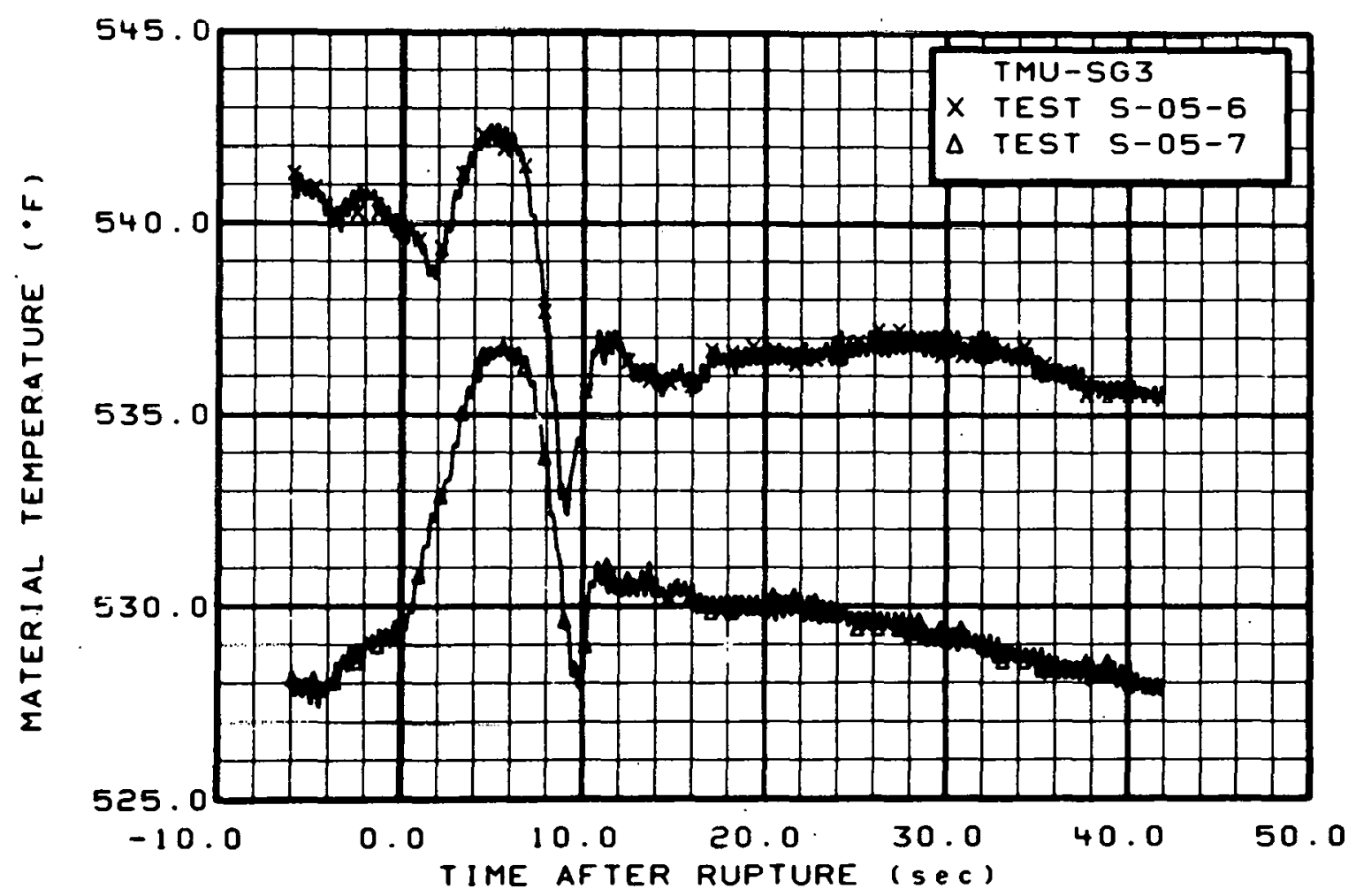

Fig. 117 Material temperature in steam generator, secondary side (TMU-SG3), from -6 to 42 sec. 


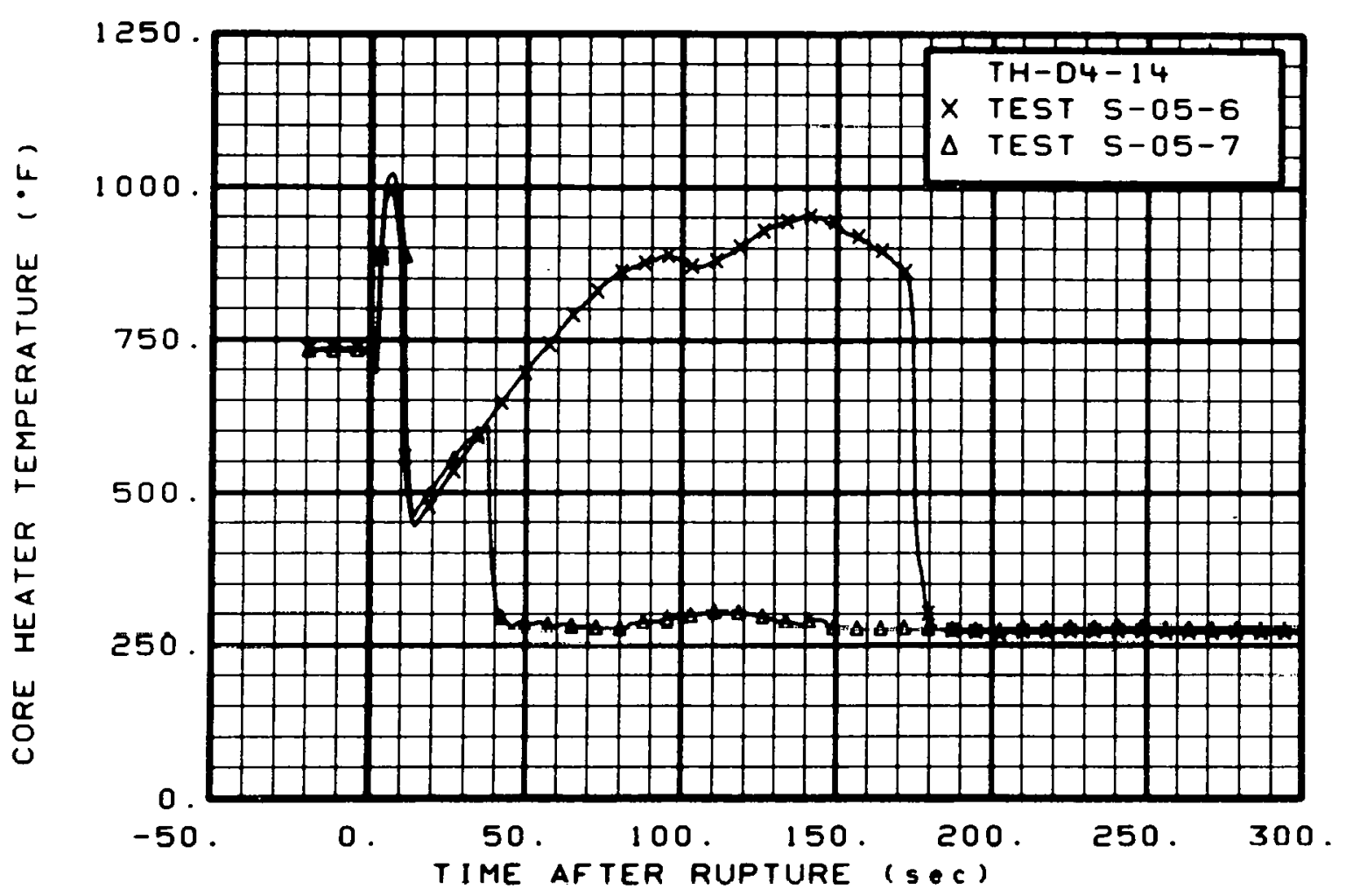

Fig. 118 Core heater temperature, Rod D-4 (TH-D4-14), from -20 to $300 \mathrm{sec}$.

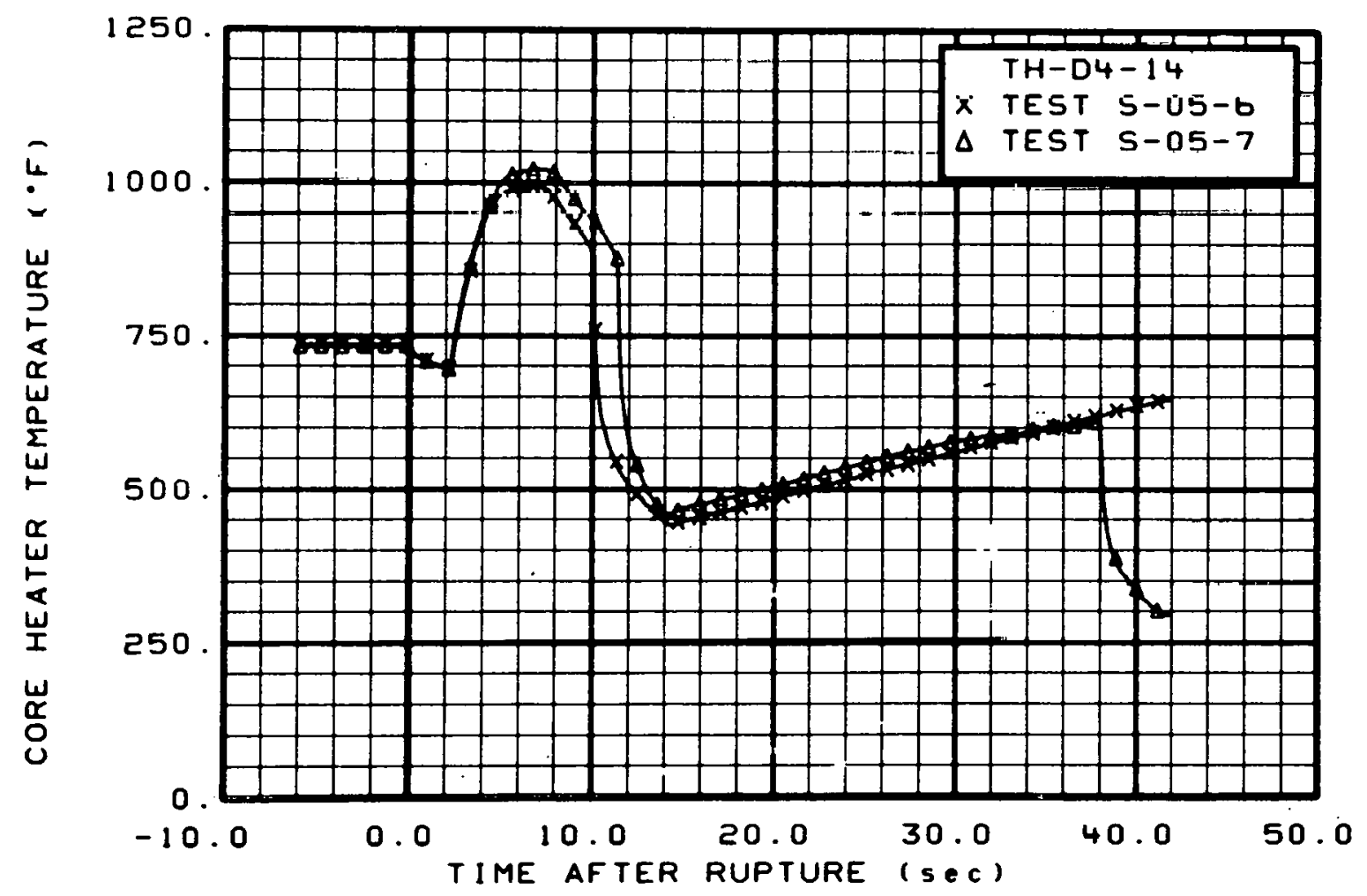

Fig. 119 Core heater temperature, Rod D-4 (TH-D4-14), from -6 to $42 \mathrm{sec}$. 


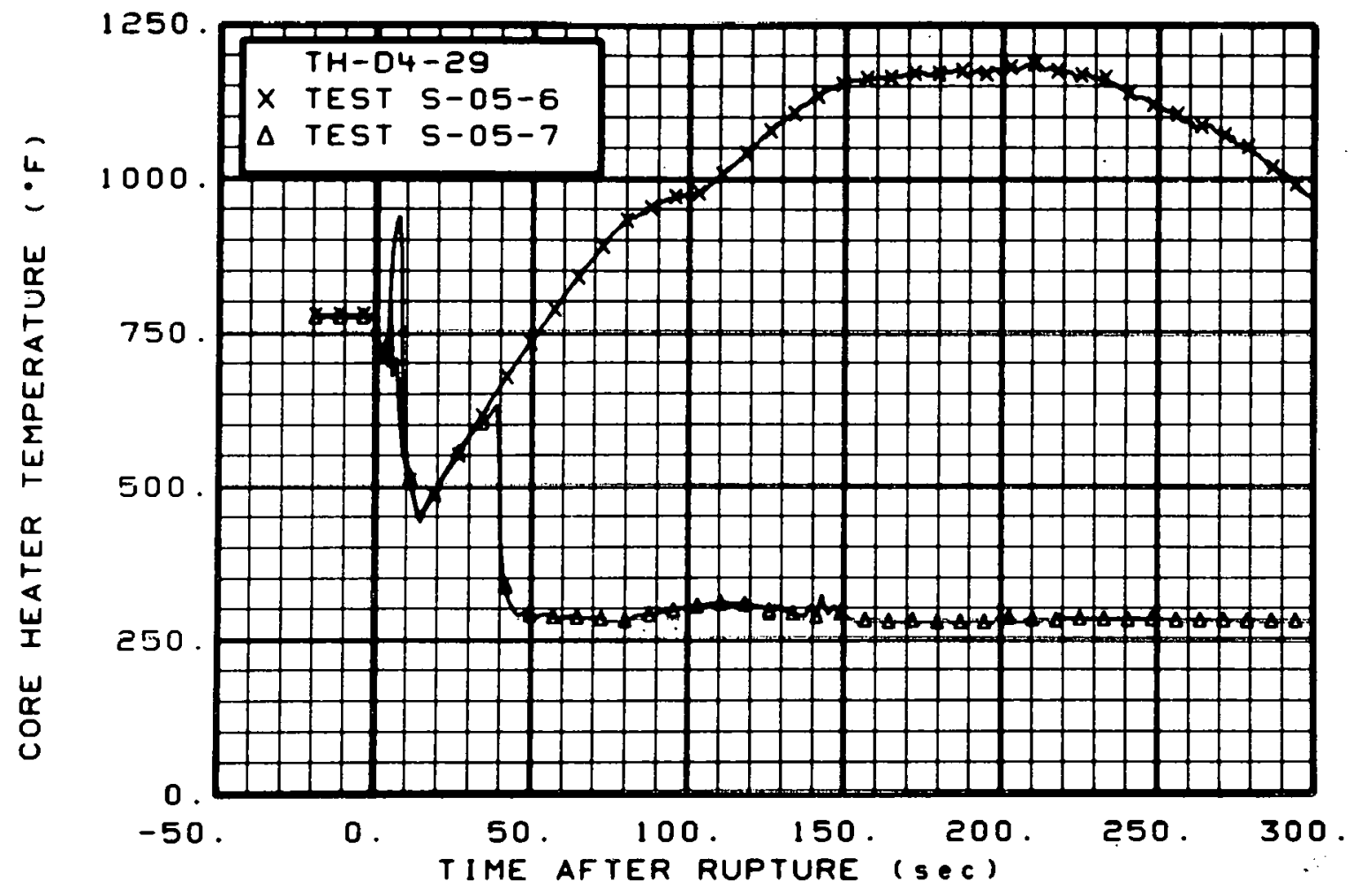

Fig. 120 Core heater temperature, Rod D-4 (TH-D4-29), from -20 to $300 \mathrm{sec}$.

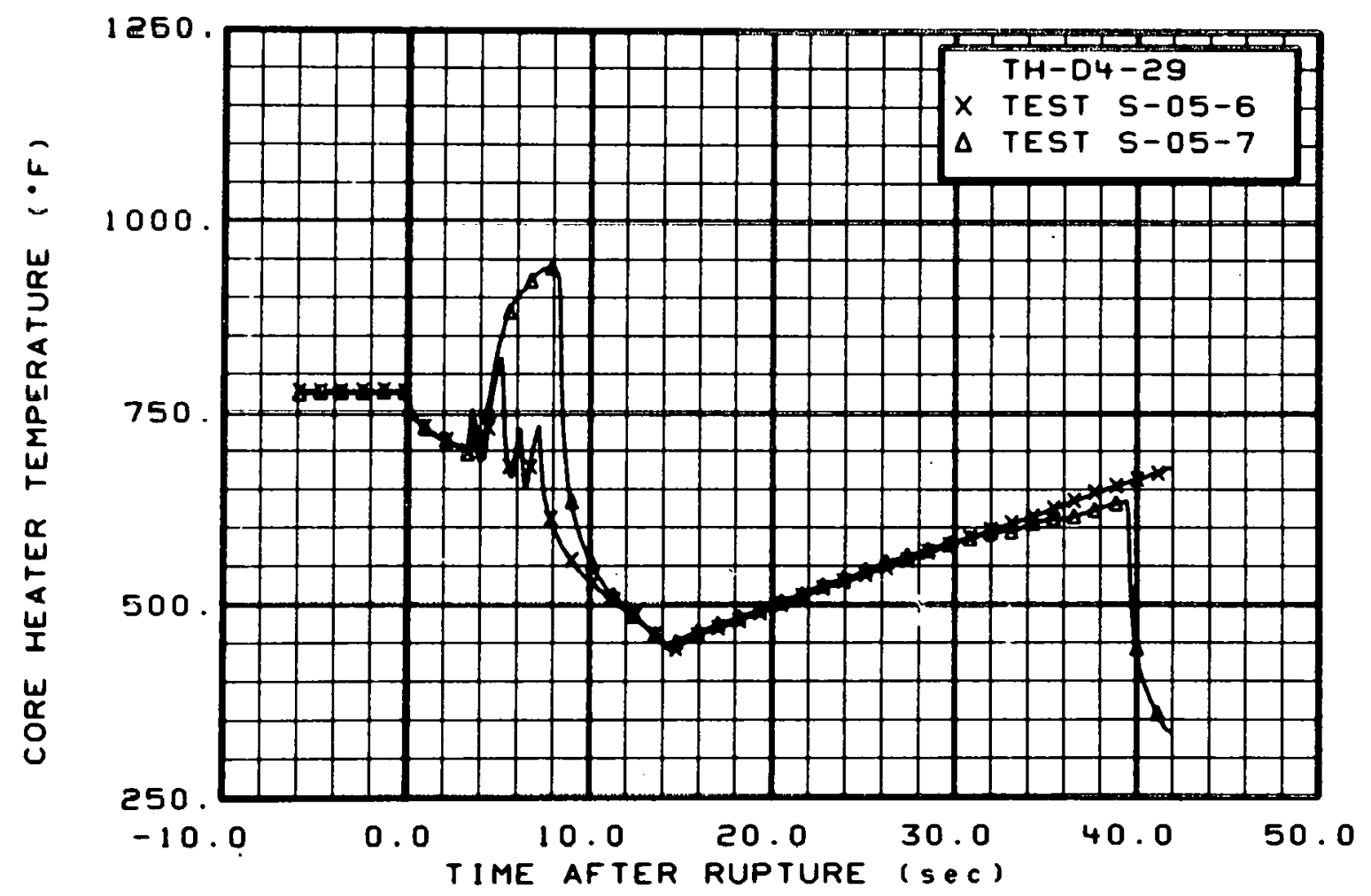

Fig. 121 Core heater temperature, Rod D-4 (TH-D4-29), from -6 to $42 \mathrm{sec}$. 


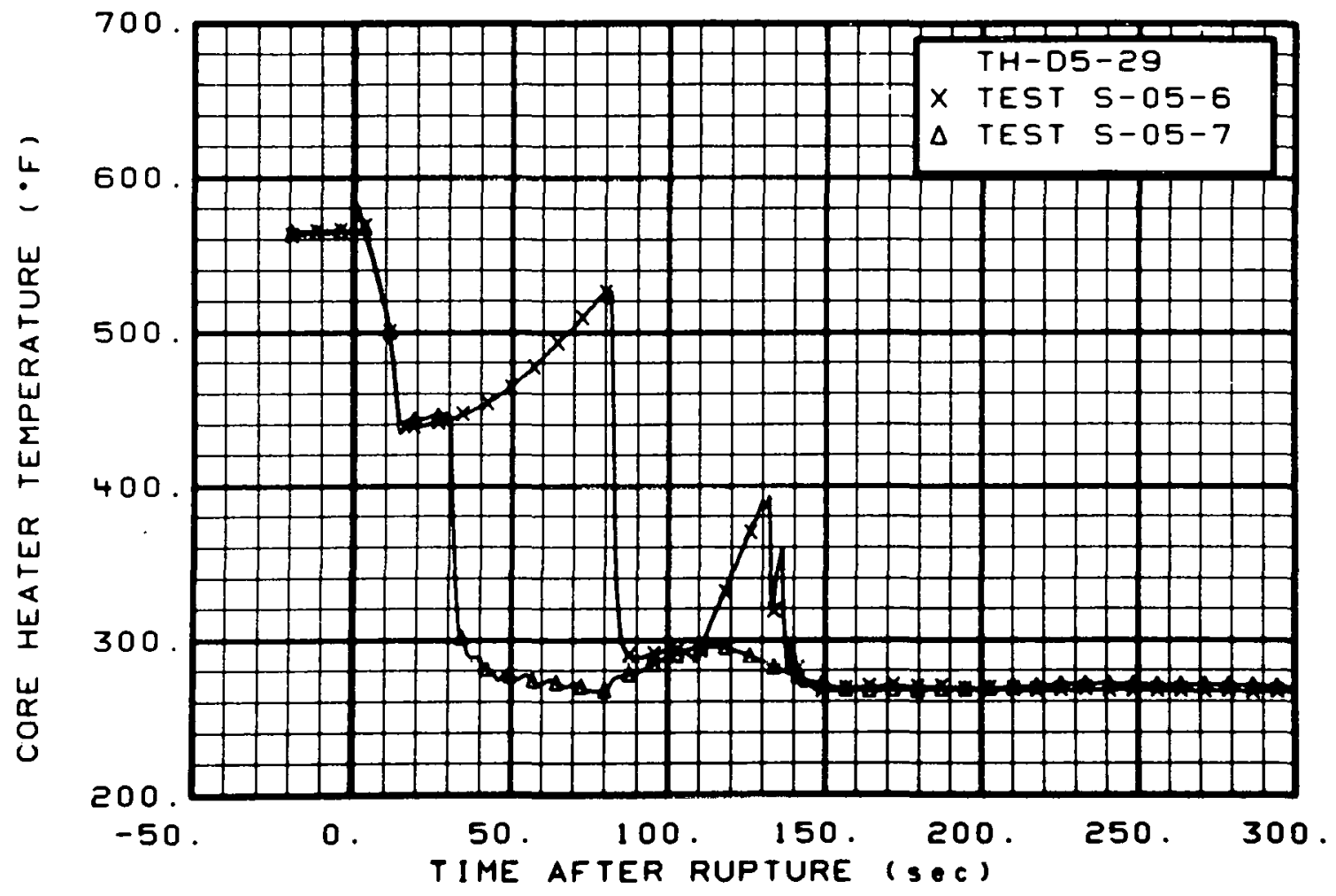

Fig. 122 Core heater temperature, Rod D-5 (TH-D5-29), from -20 to $300 \mathrm{sec}$.

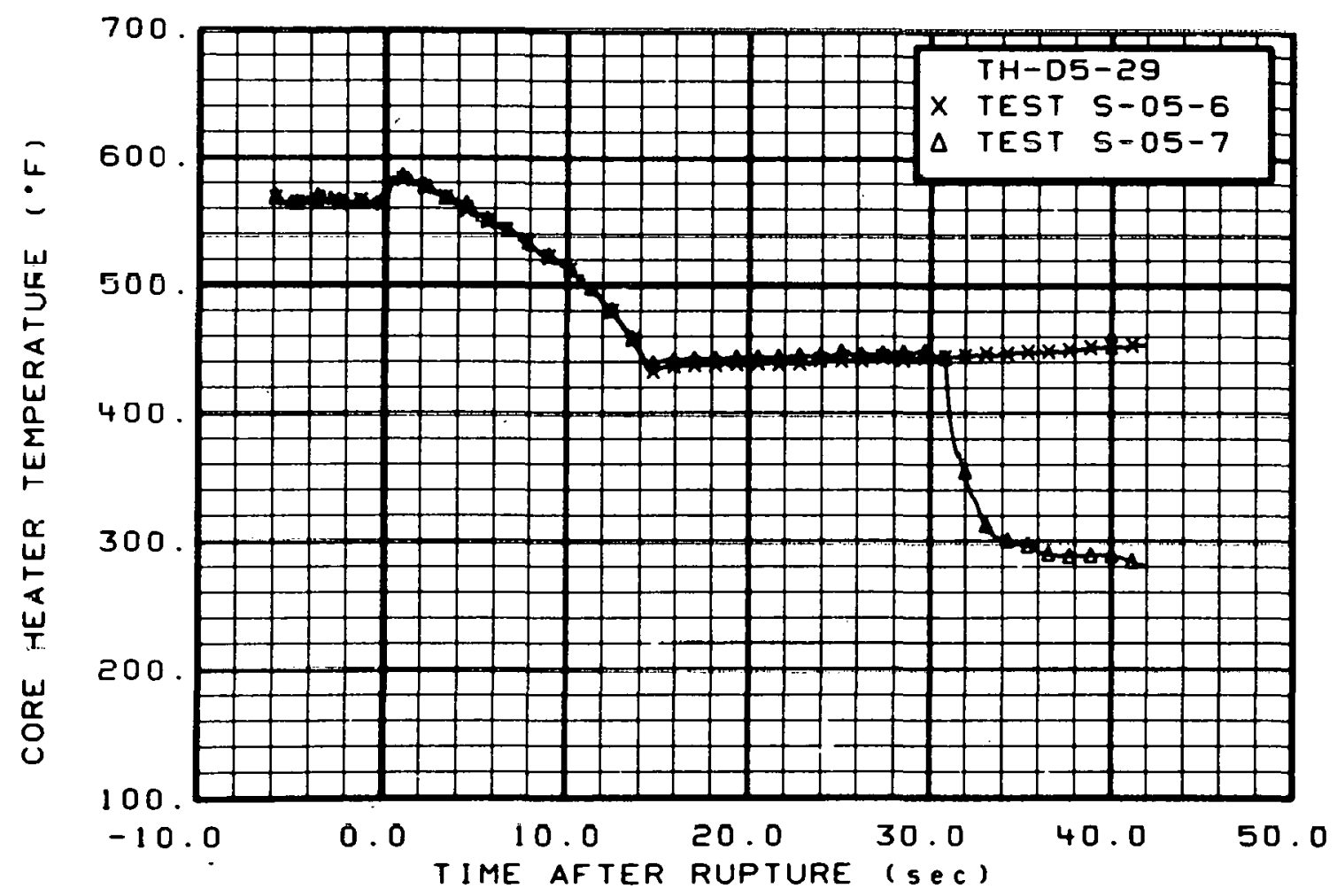

Fig. 123 Core heater temperature, Rod D-5 (TH-D5-29), from -6 to $42 \mathrm{sec}$. 


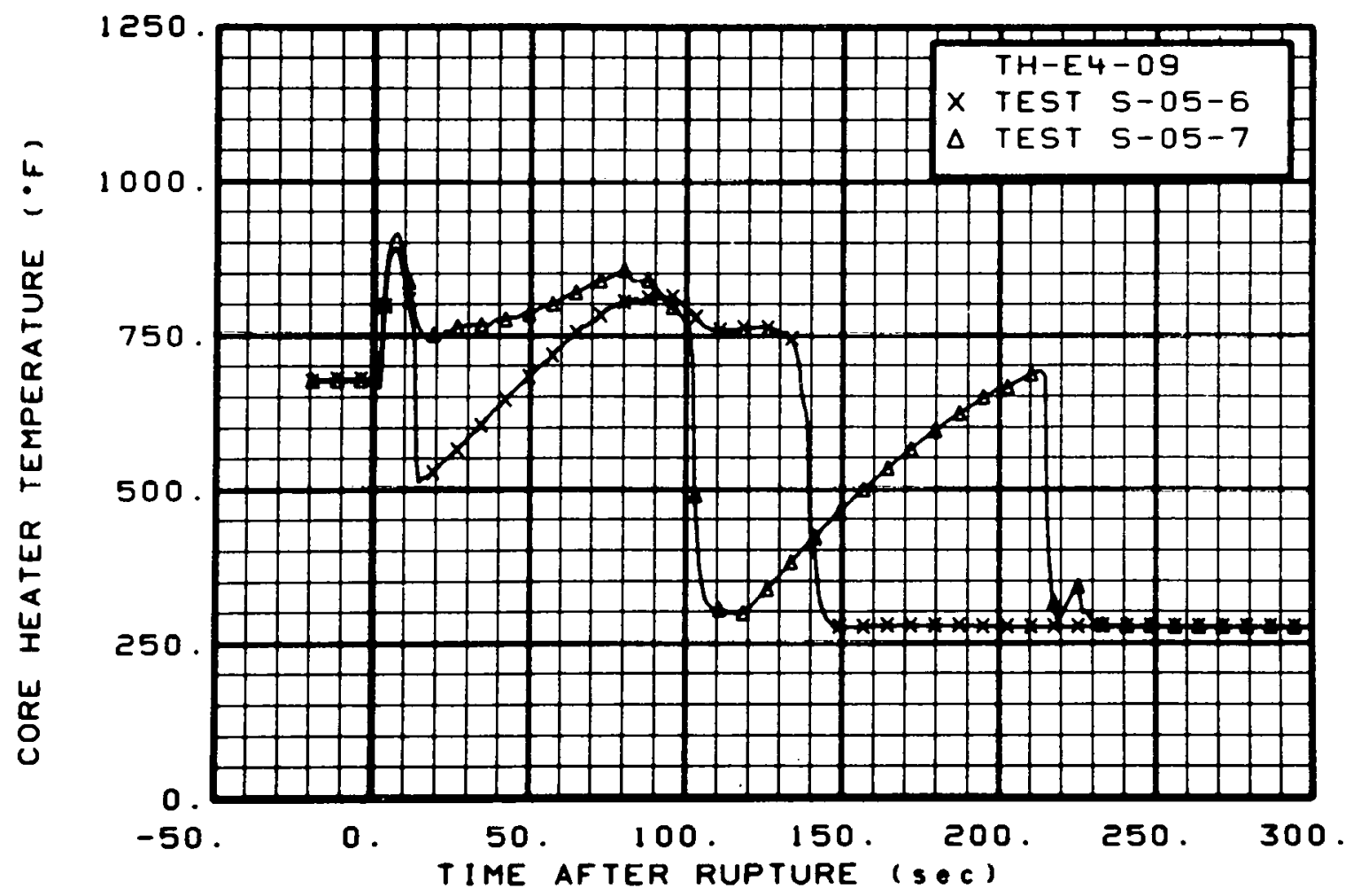

Fig. 124 Core heater temperature, Rod E-4 (TH-E4-09), from -20 to $300 \mathrm{sec}$.

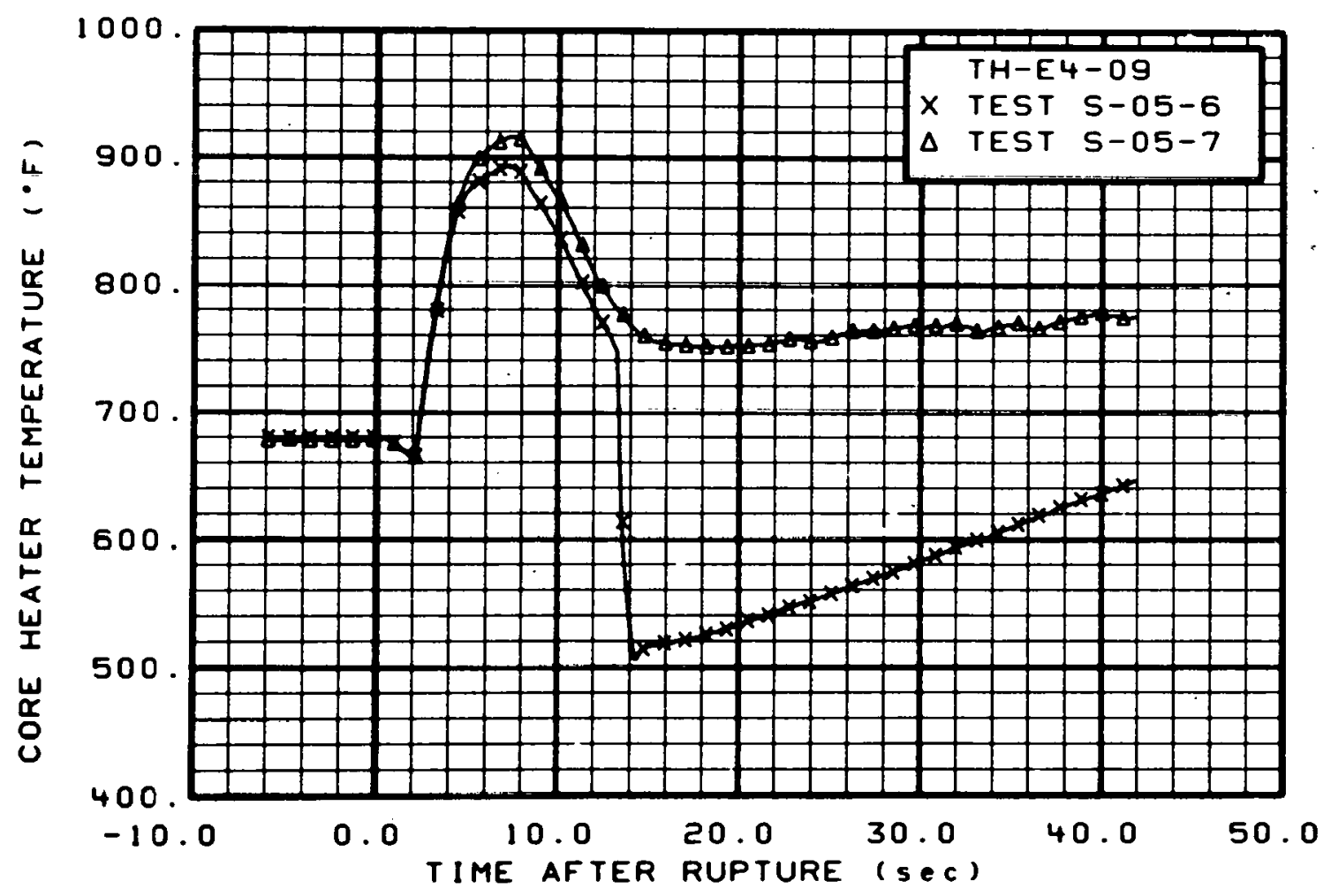

Fig. 125 Core heater temperature, Rod E-4 (TH-E4-09), from -6 to $42 \mathrm{sec}$. 


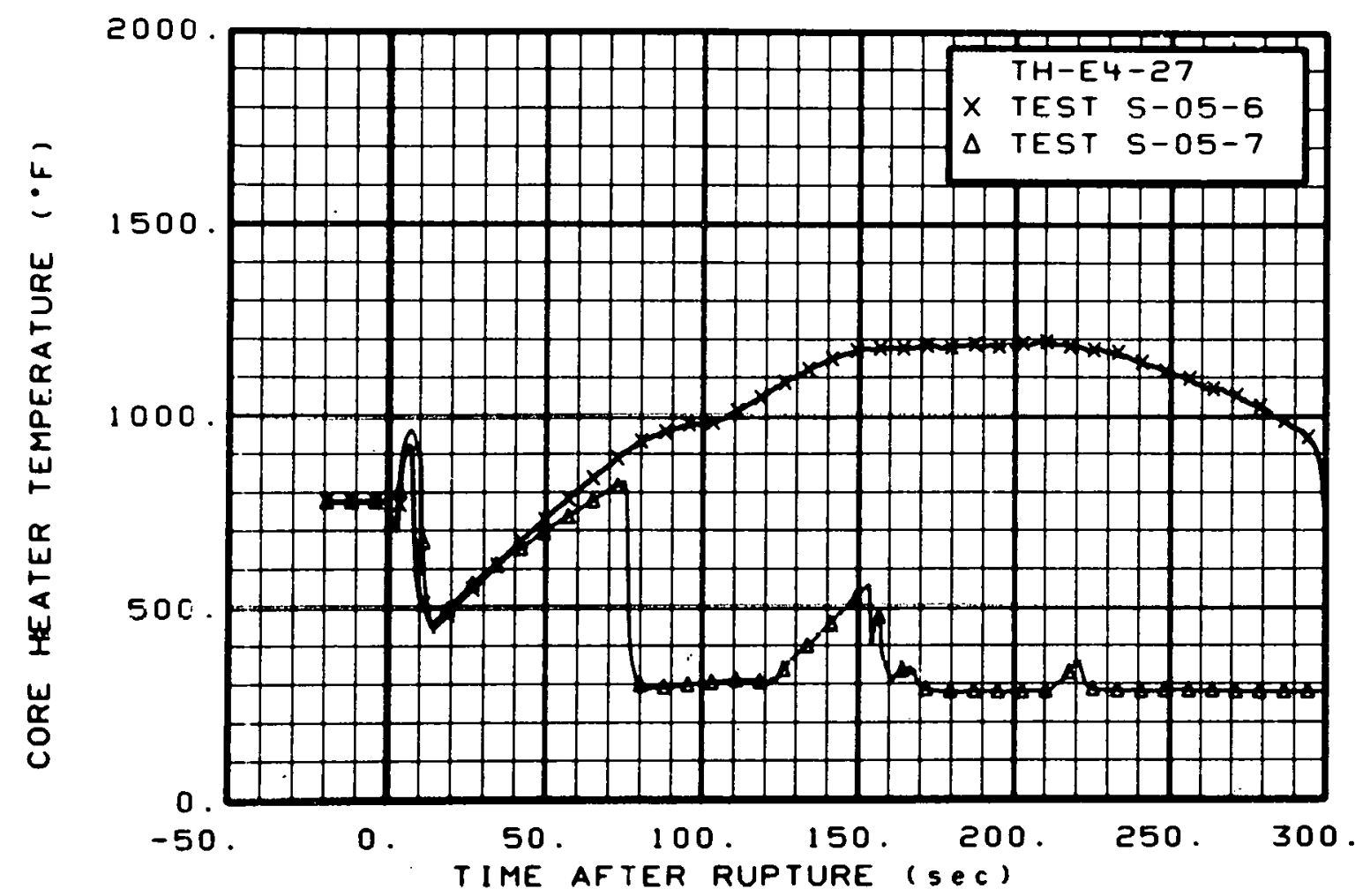

Fig. 126 Cort leater temperature, Rod E-4 (TH-E4-27), from -20 to $300 \mathrm{sec}$.

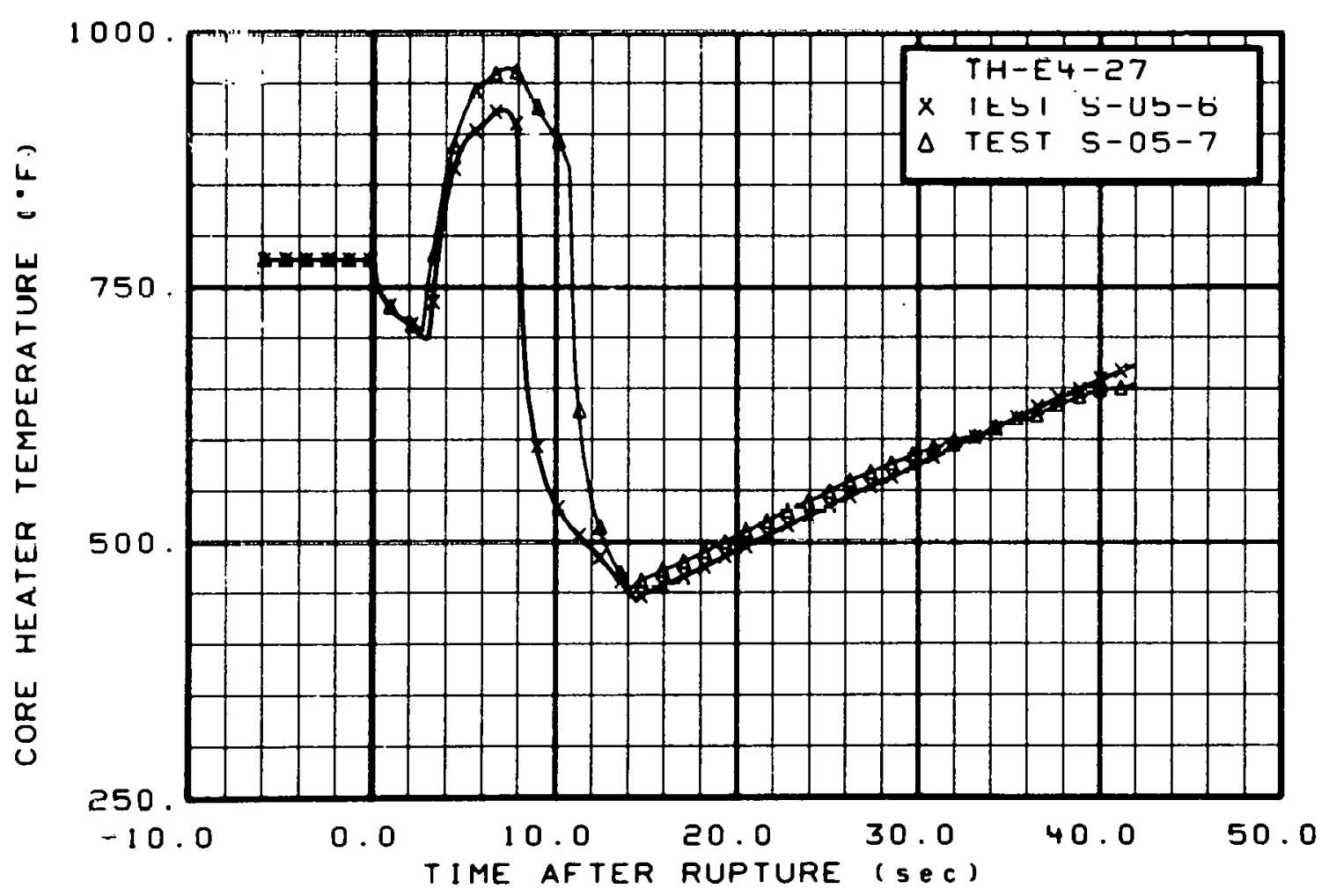

Fig. 127 Core heater temperature, Rod E-4 (TH-E4-27), from -6 to $42 \mathrm{sec}$. 


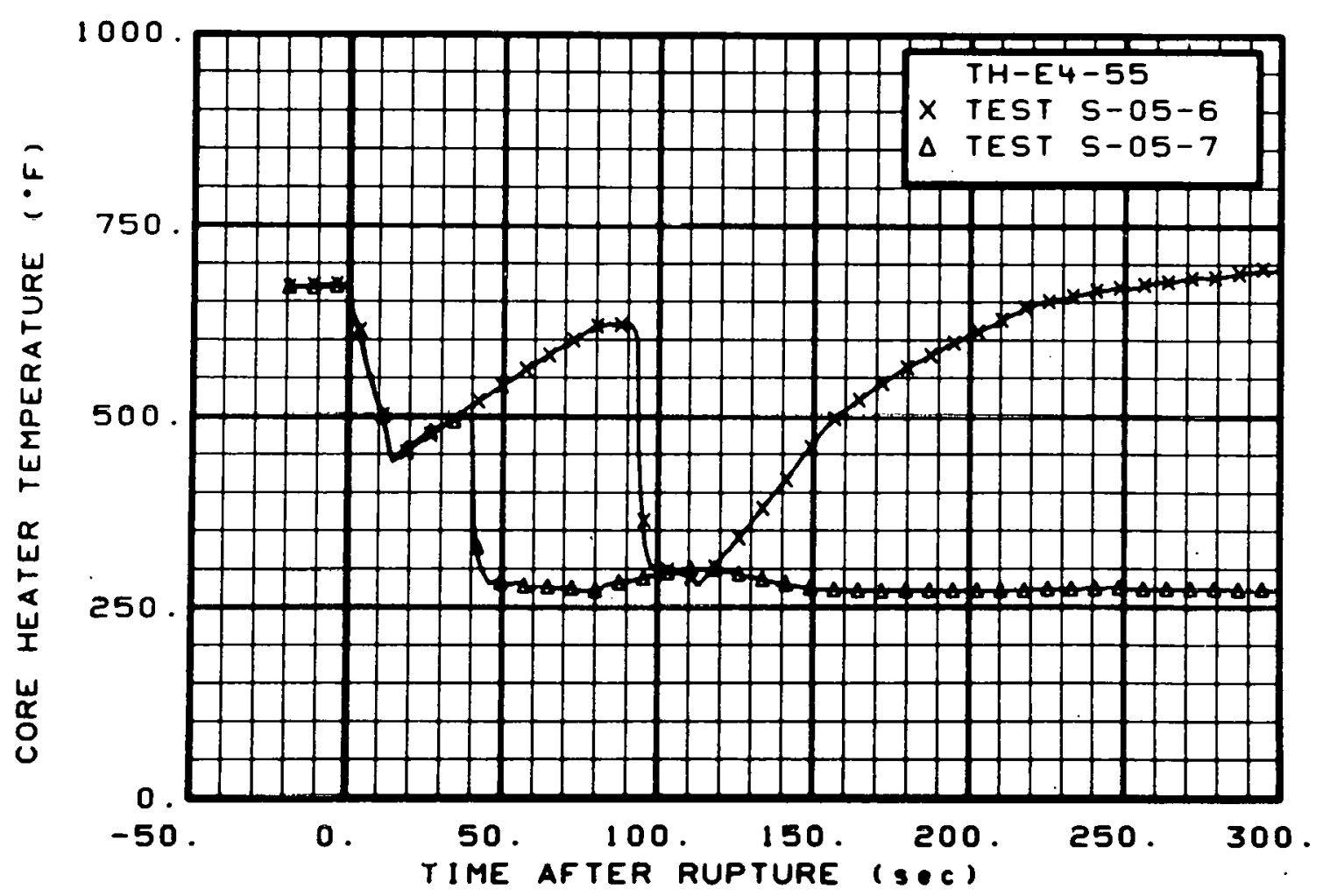

Fig. 128 Core heater temperature, Rod E-4 (TH-E4-55), from -20 to $300 \mathrm{sec}$.

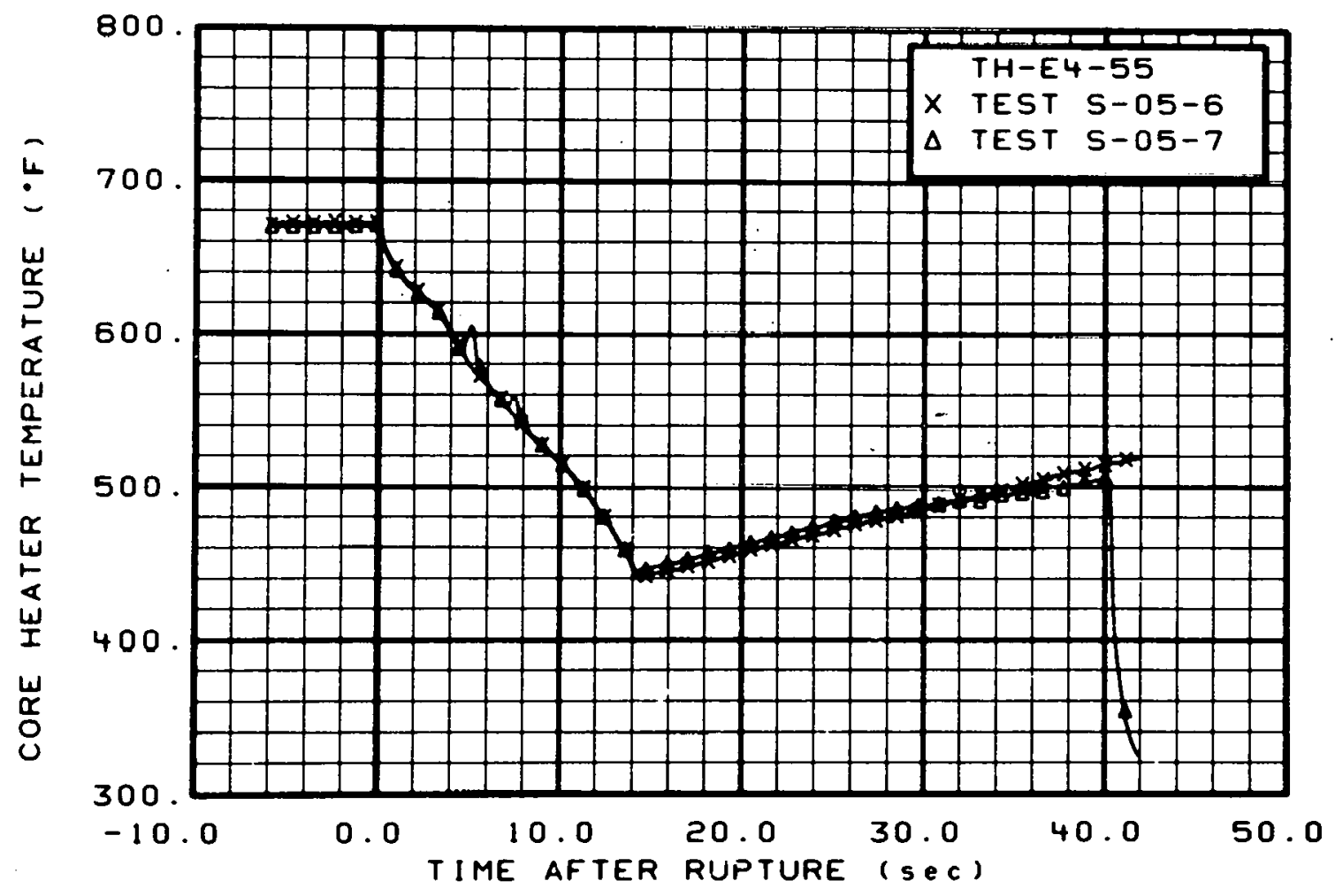

Fig. 129 Core heater temperature, Rod E-4 (TH-E4-55), from -6 to $42 \mathrm{sec}$. 


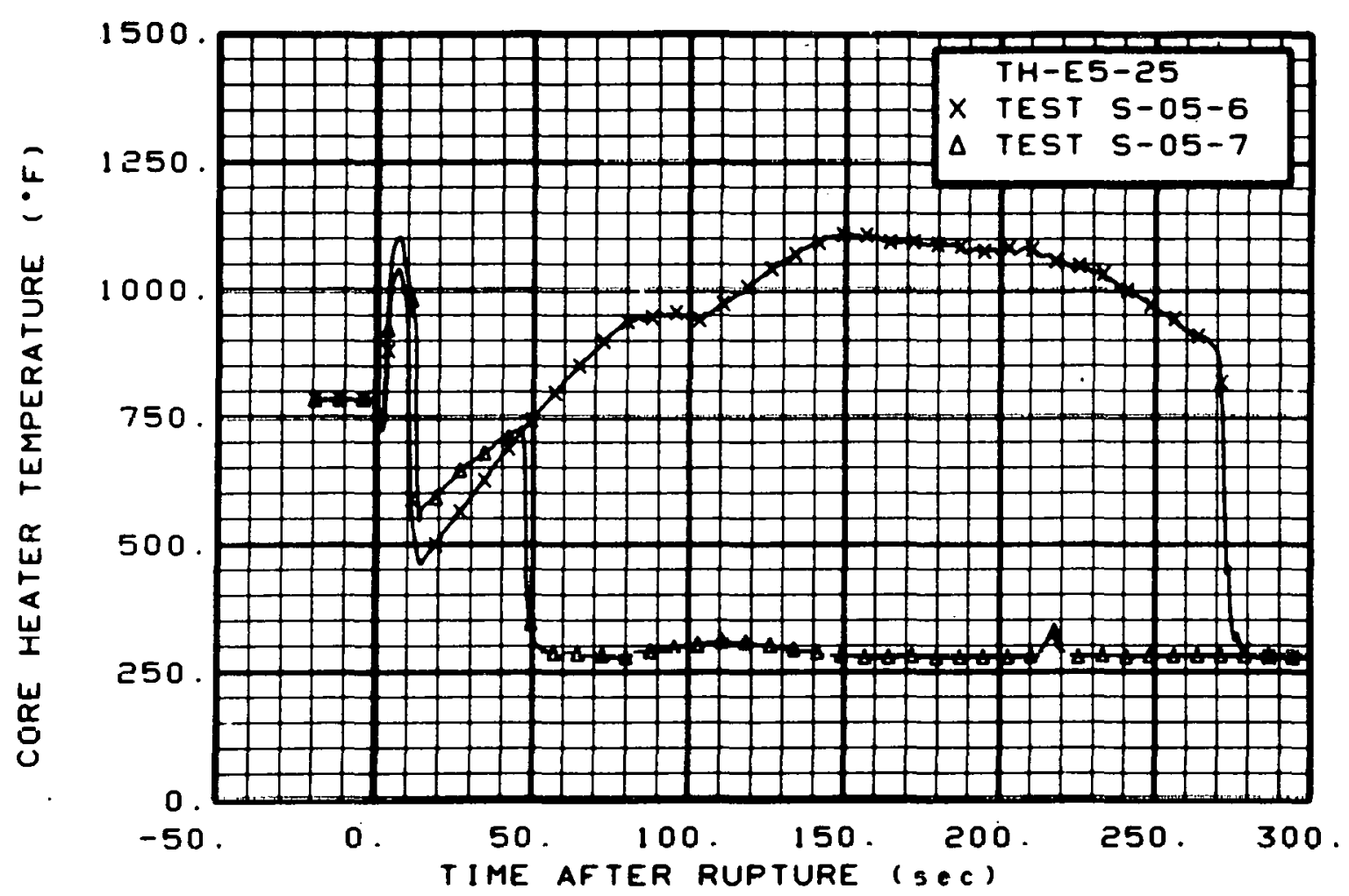

Fig. 130 Core heater temperature, Rod E-5 (TH-E5-25), from -20 to $300 \mathrm{sec}$.

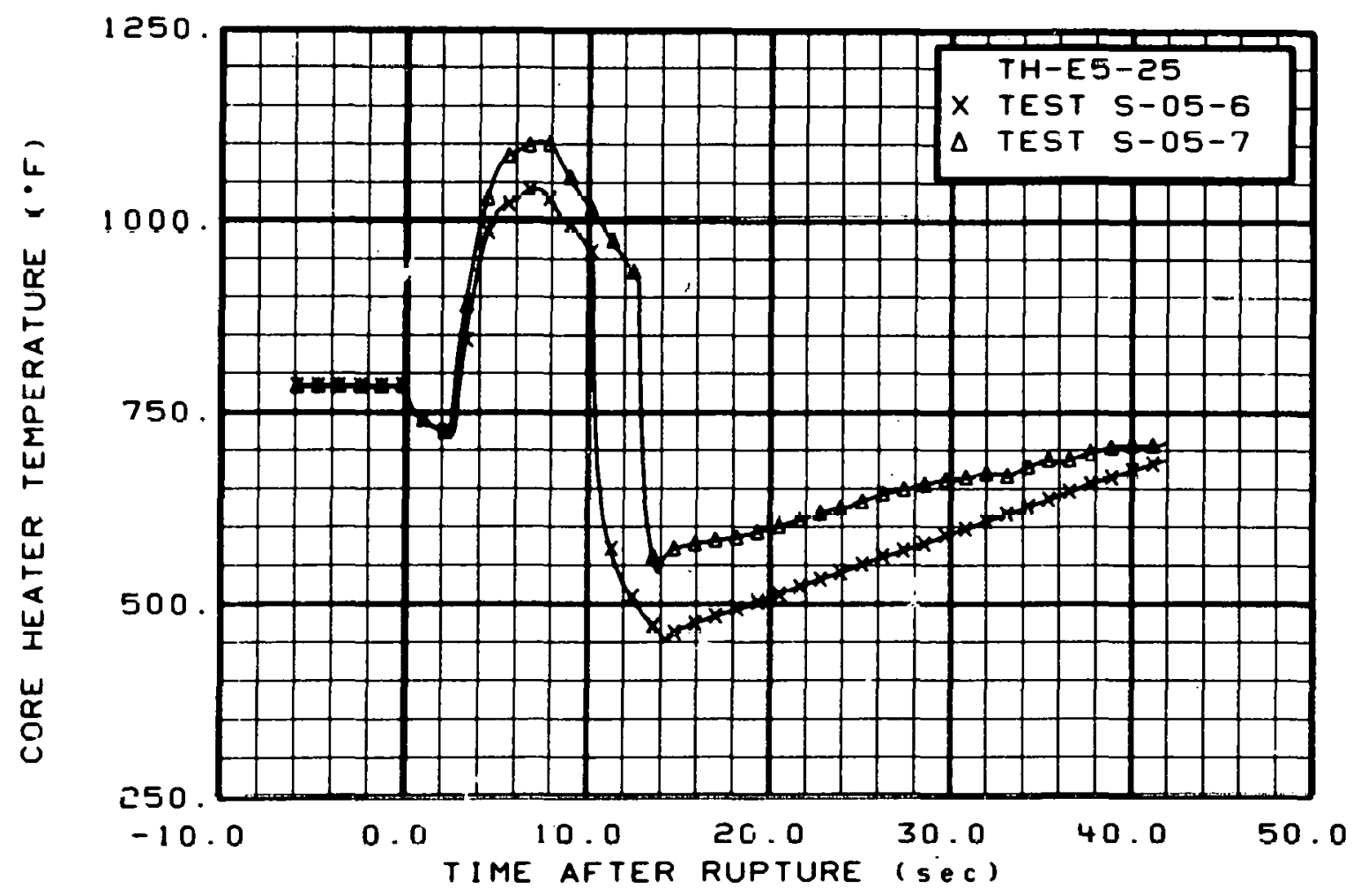

Fig. 131 Core heater temperature, Rod E-5 (TH-E5-25), from -6 to $42 \mathrm{sec}$. 


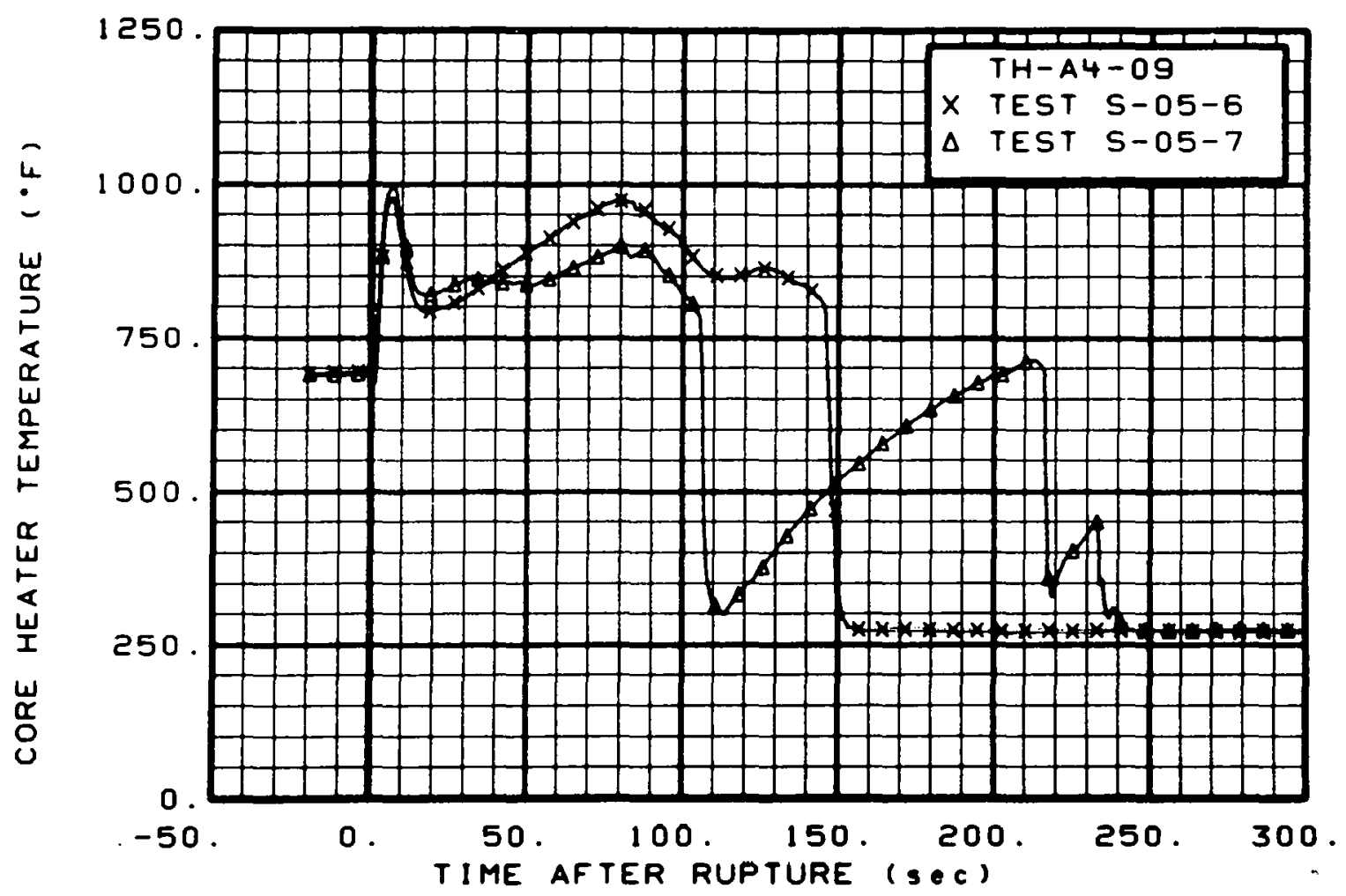

Fig. 132 Core heater temperature, Rod A-4 (TH-A4-09), from -20 to $300 \mathrm{sec}$.

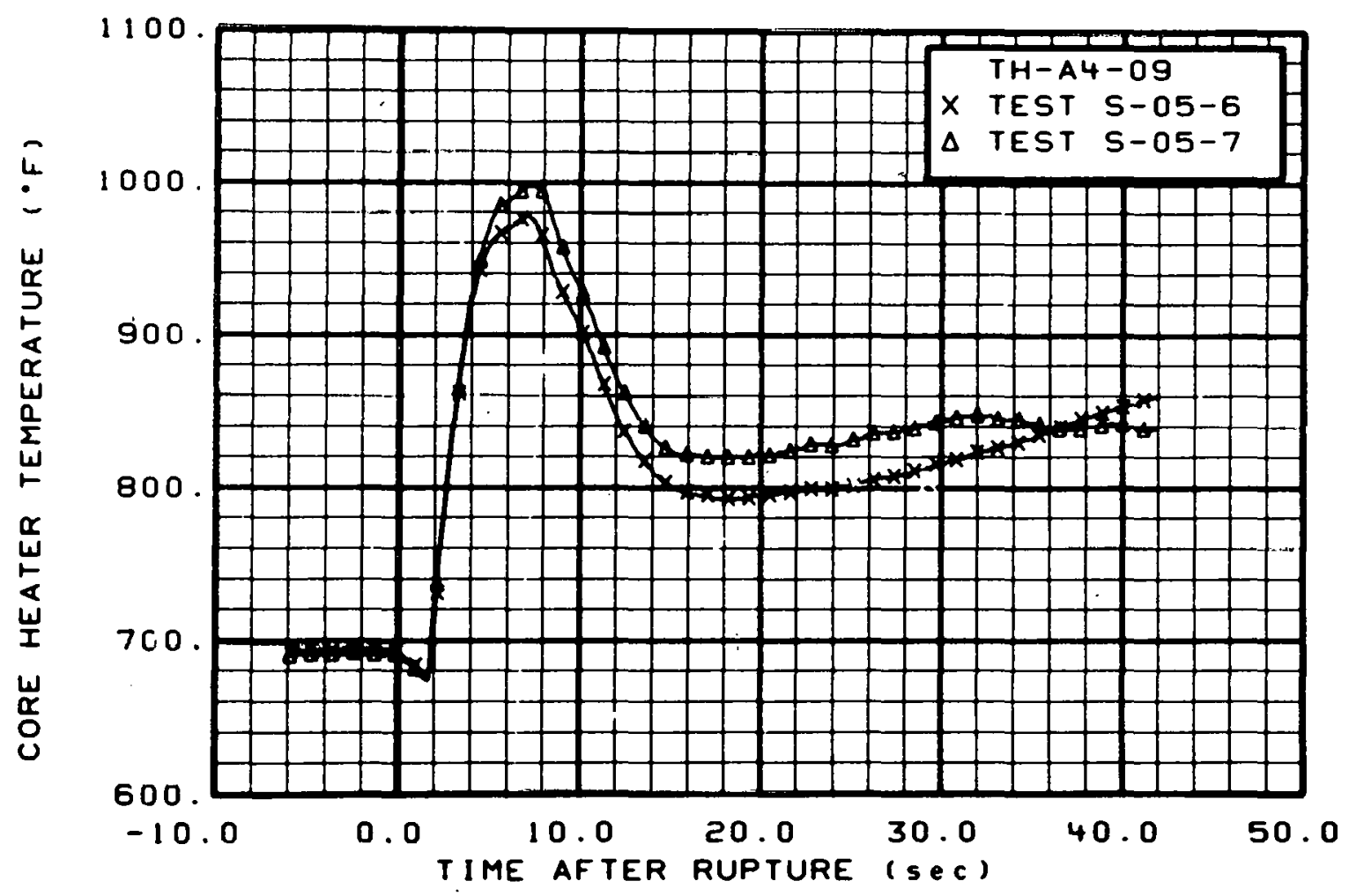

Fig. 133 Core heater temperature, Rod A-4 (TH-A4-09), from -6 to $42 \mathrm{sec}$. 


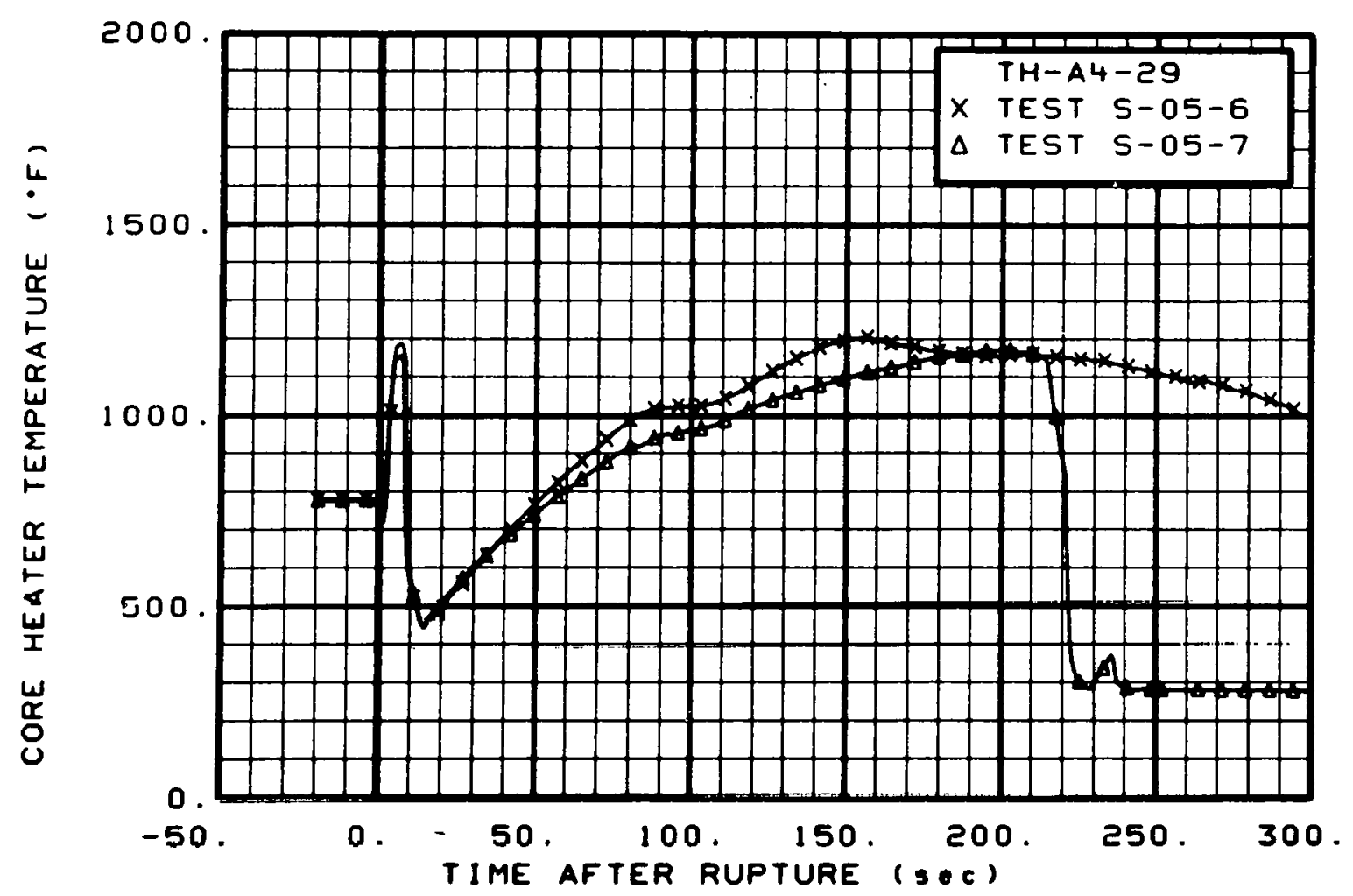

Fig. 134 Core heater temperature, Rod A-4 (TH-A4-29), from -20 to $300 \mathrm{sec}$.

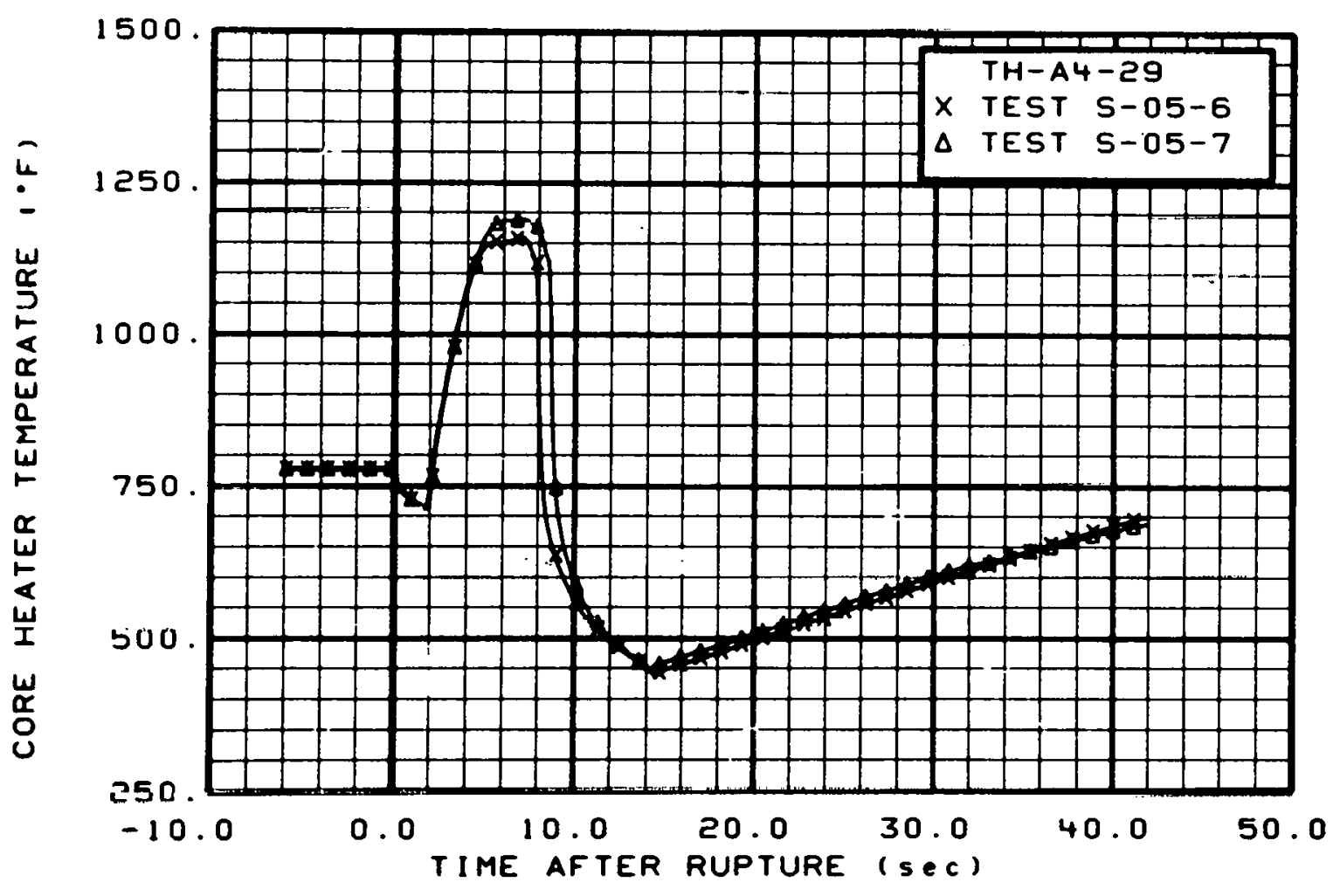

Fig. 135 Core heater temperature, Rod A-4 (TH-A4-29), from -6 to $42 \mathrm{sec}$. 


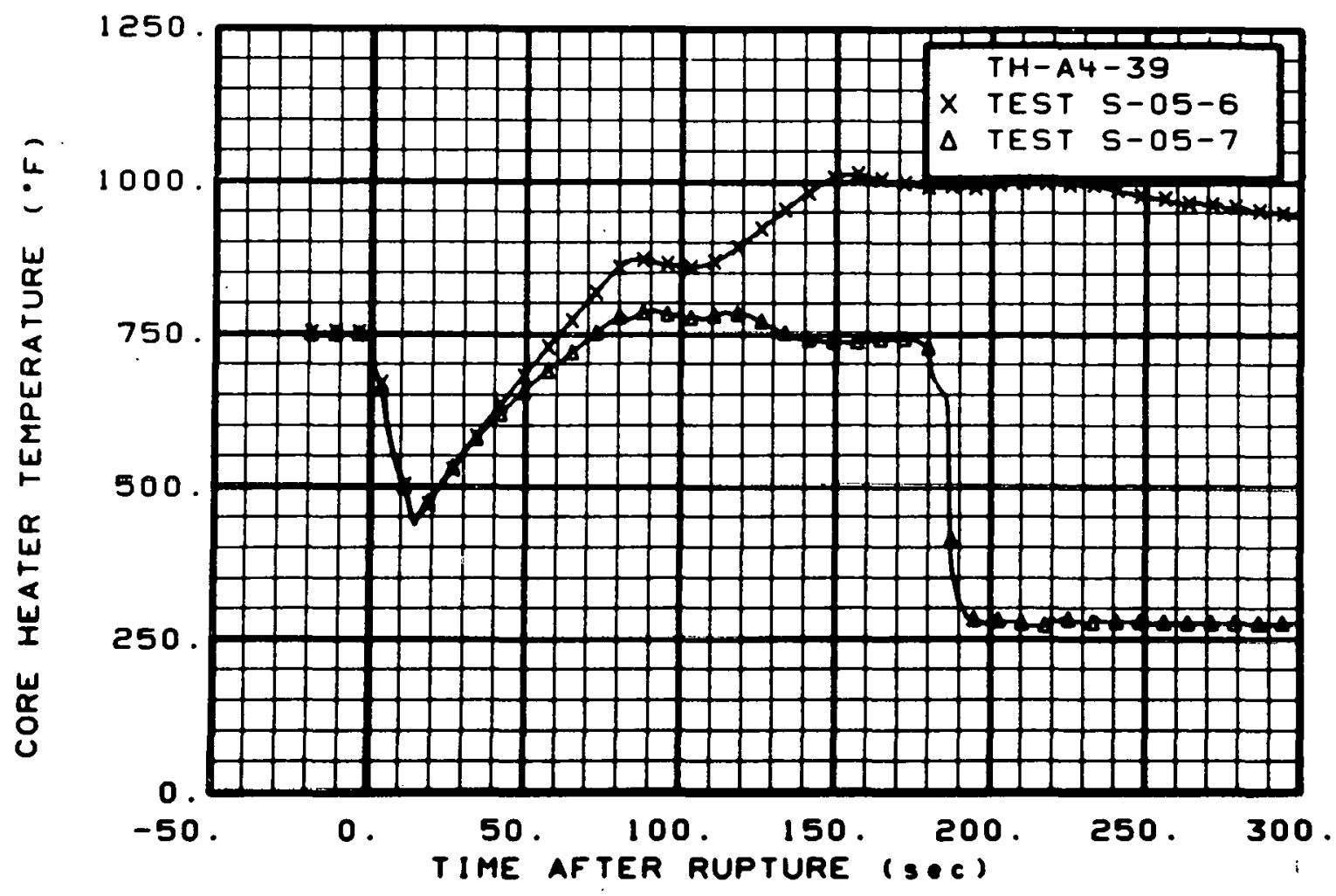

Fig. 136 Core heater temperature, Rod A-4 (TH-A4-39), from -20 to $300 \mathrm{sec}$.

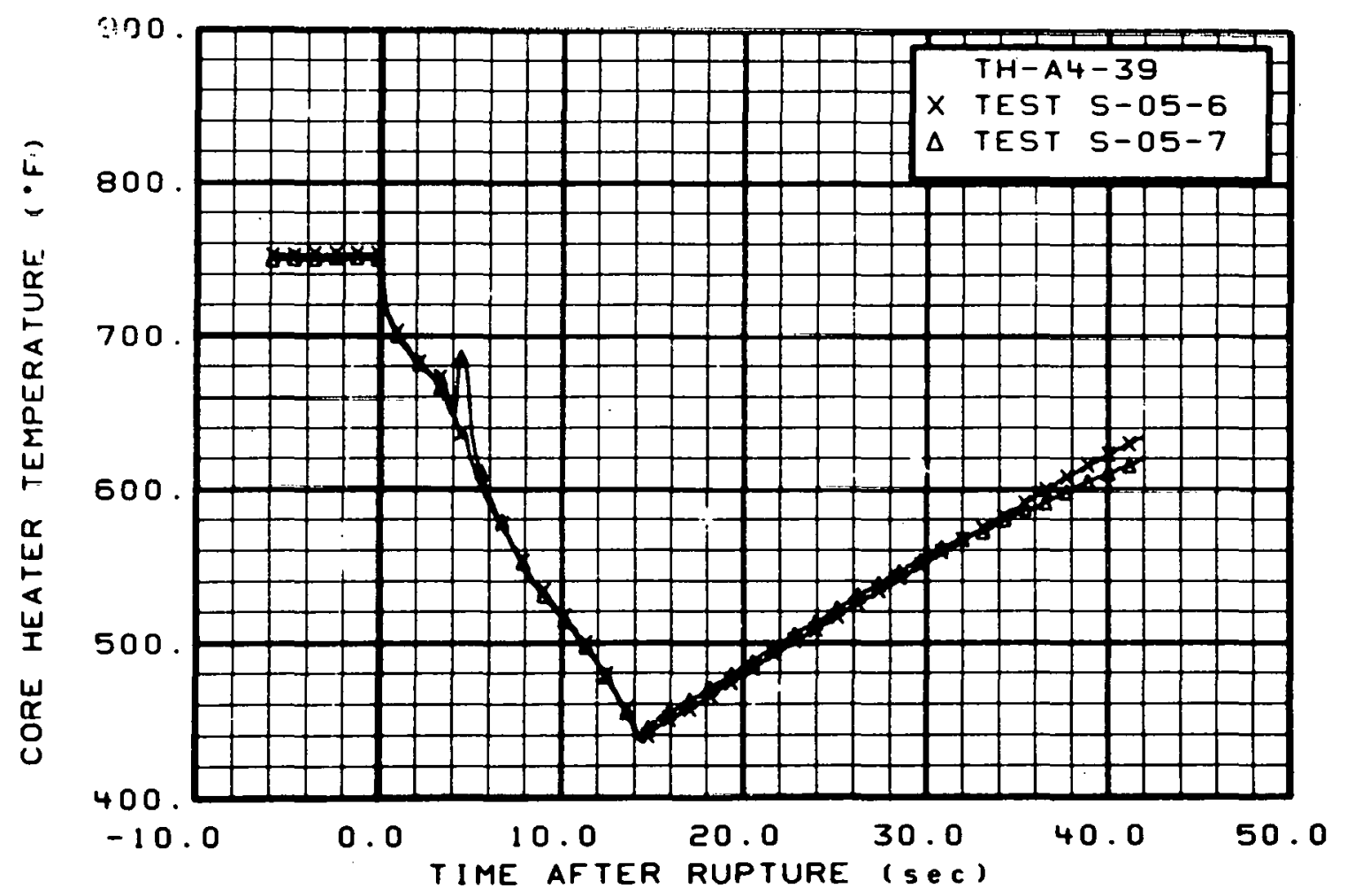

Fig. 137 Core heater temperature, Rod A-4 (TH-A4-39), from -6 to $42 \mathrm{sec}$. 


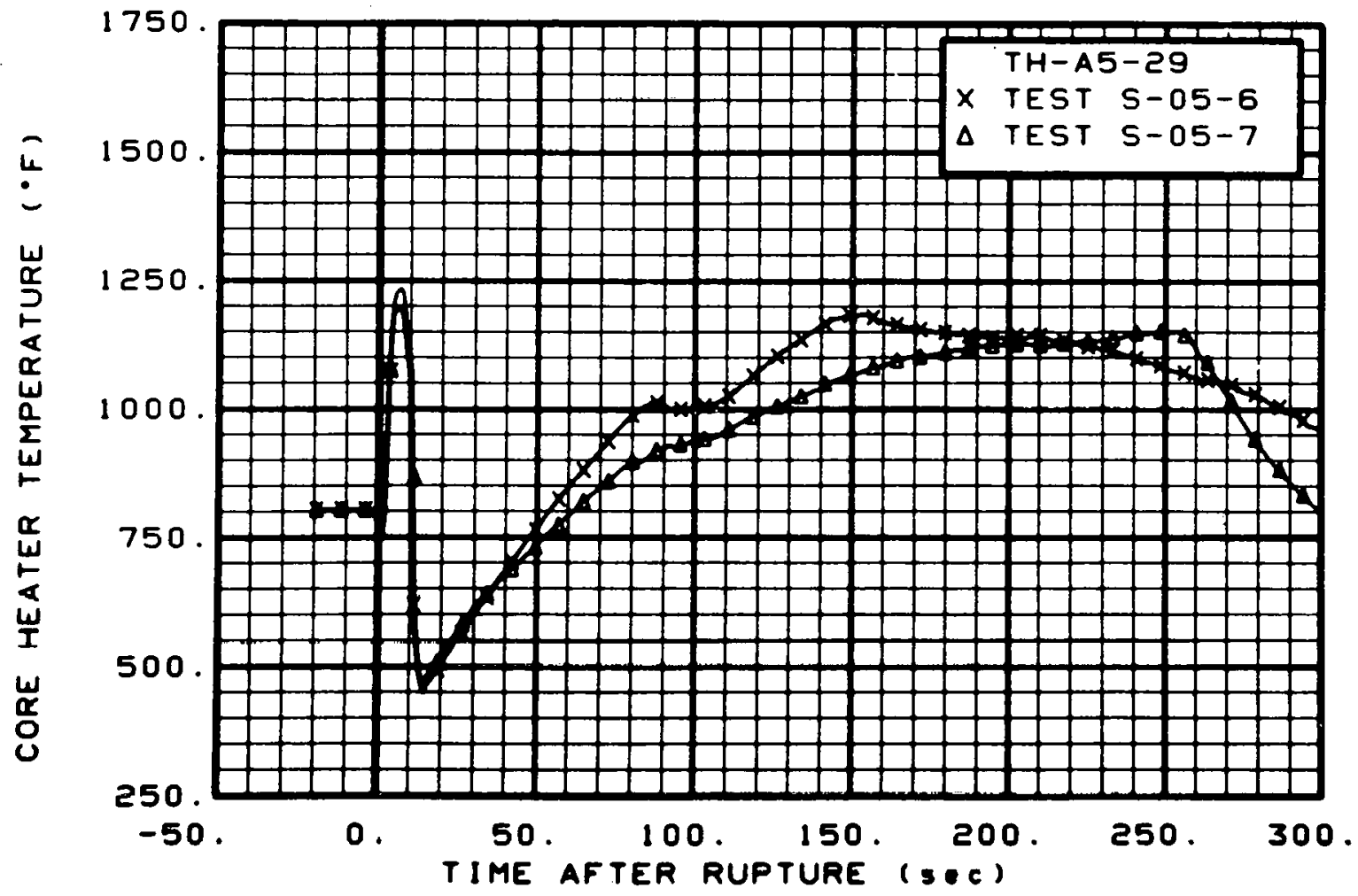

Fig. 138 Core heater temperature, Rod A-5 (TH-A5-29), from -20 to $300 \mathrm{sec}$.

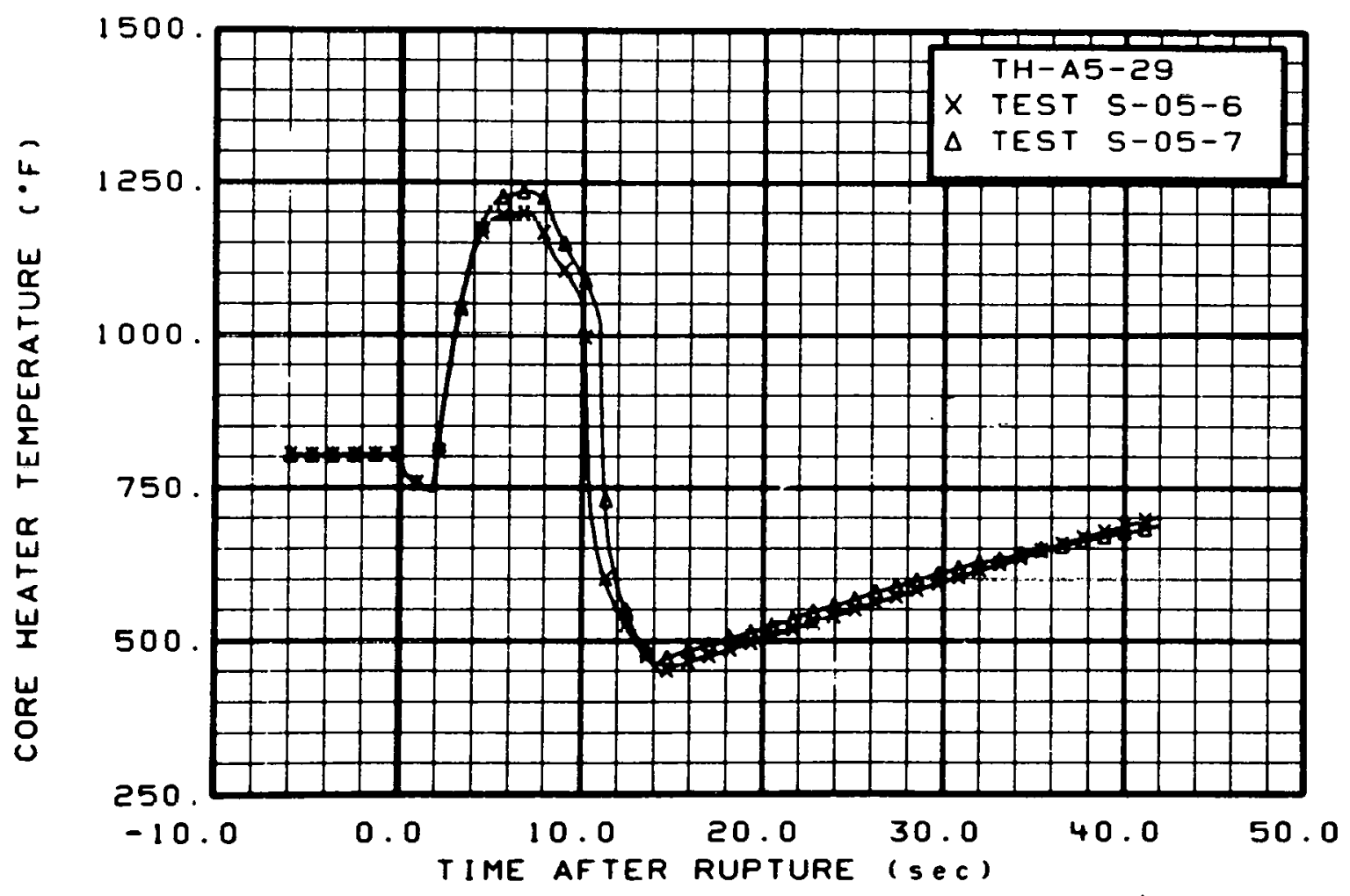

Fig. 139 Core heater temperature, Rod A-5 (TH-A5-29), from -6 to 42 sec. 


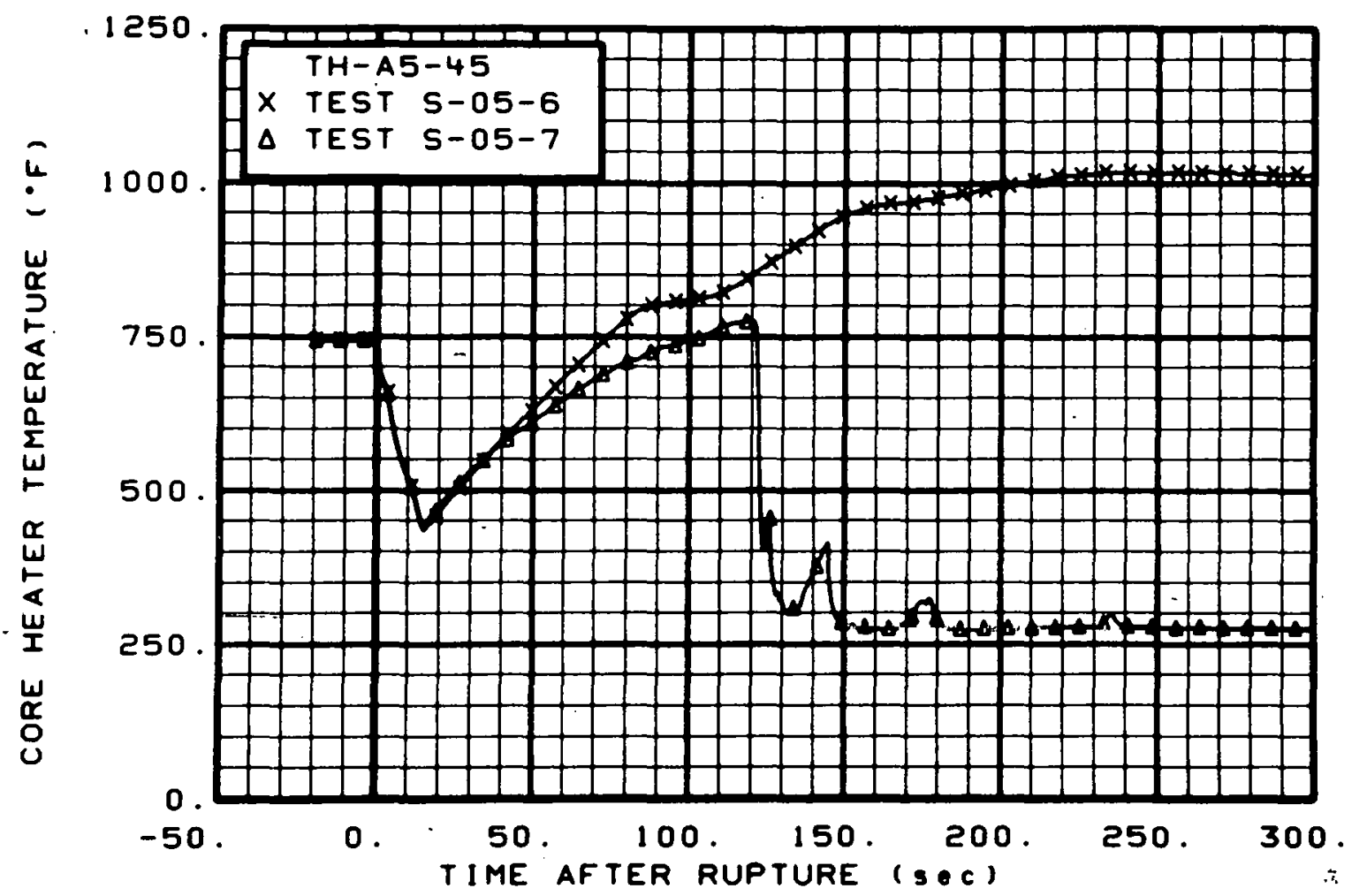

Fig. 140 Core heater temperature, Rod A-5 (TH-A5-45), from -20 to 300 sec.

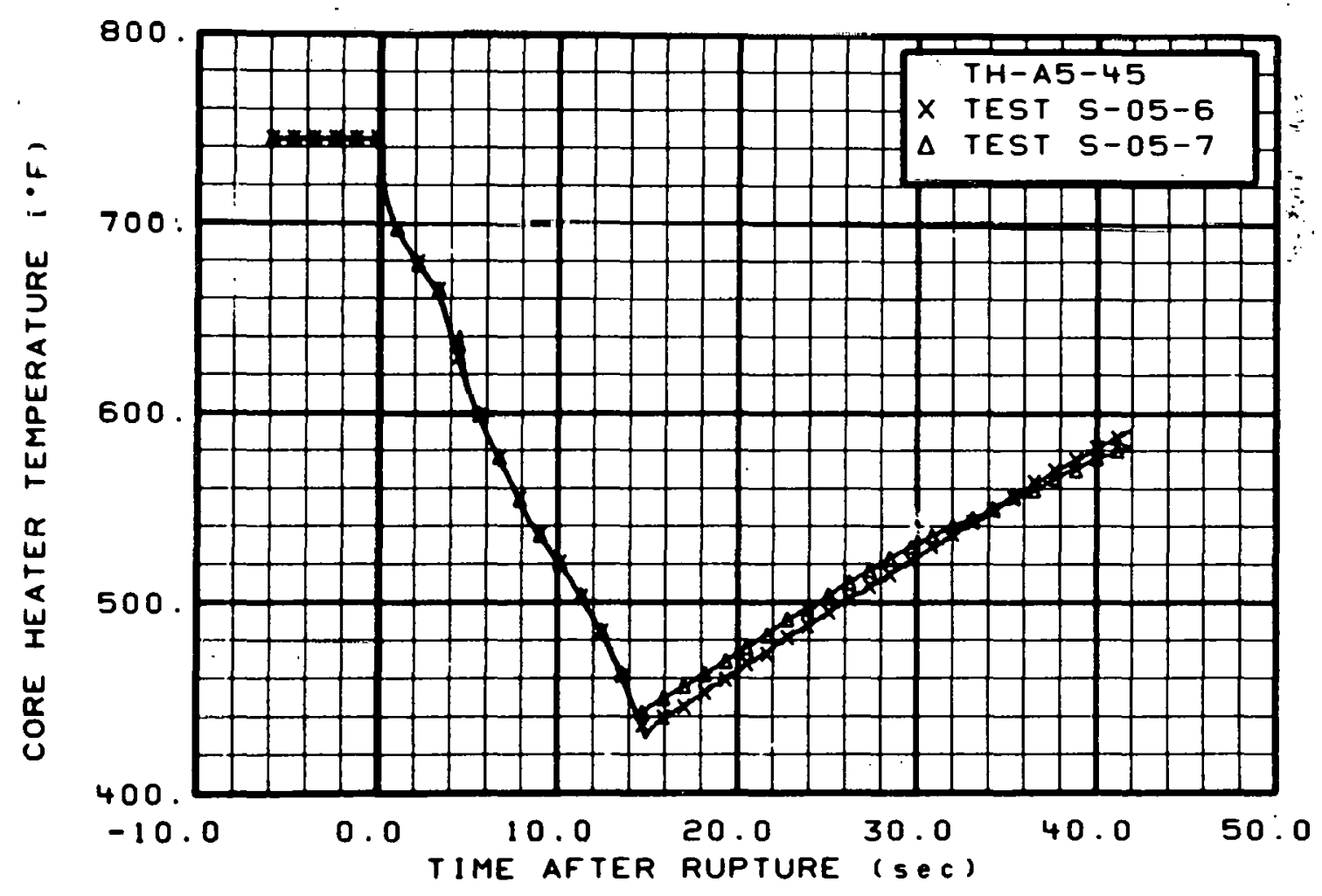

Fig. 141 Core heater temperature, Rod A-5 (TH-A5-45), from -6 to 42 sec. 


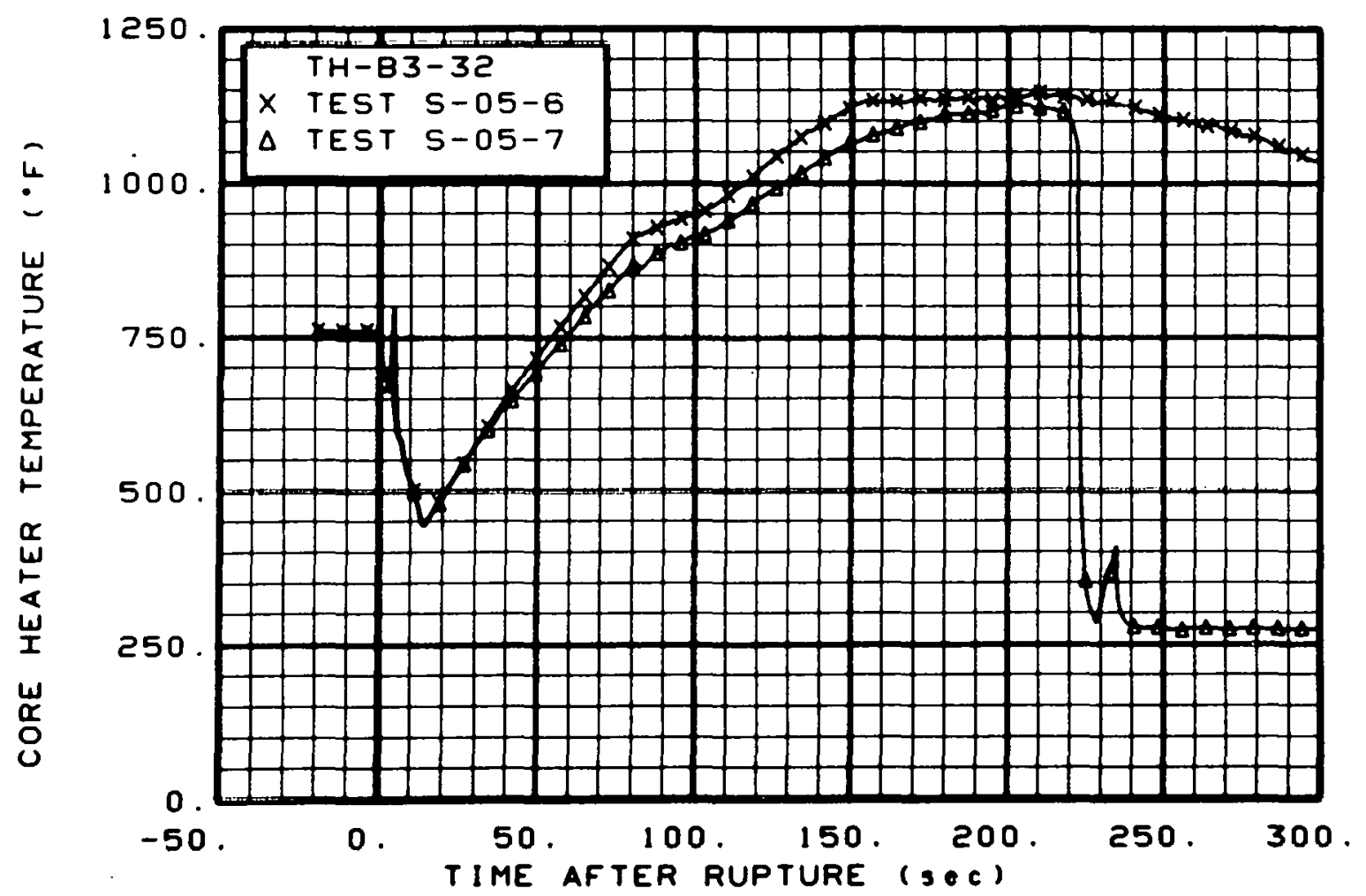

Fig. 142 Core heater temperature, Rod B-3 (TH-B3-32), from -20 to $300 \mathrm{sec}$.

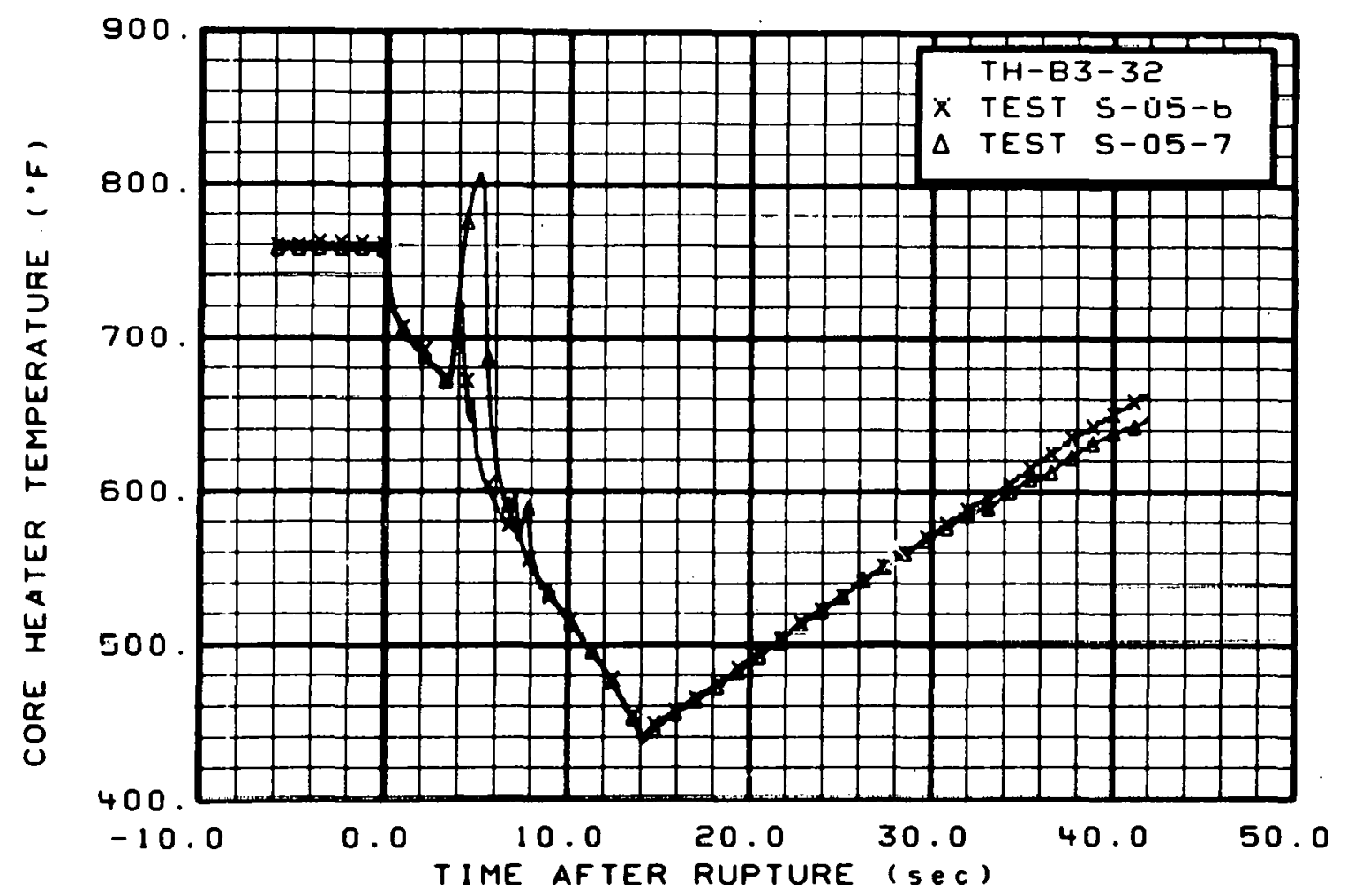

Fig. 143 Core heater temperature, Rod B-3 (TH-B3-32), from -6 to $42 \mathrm{sec}$. 


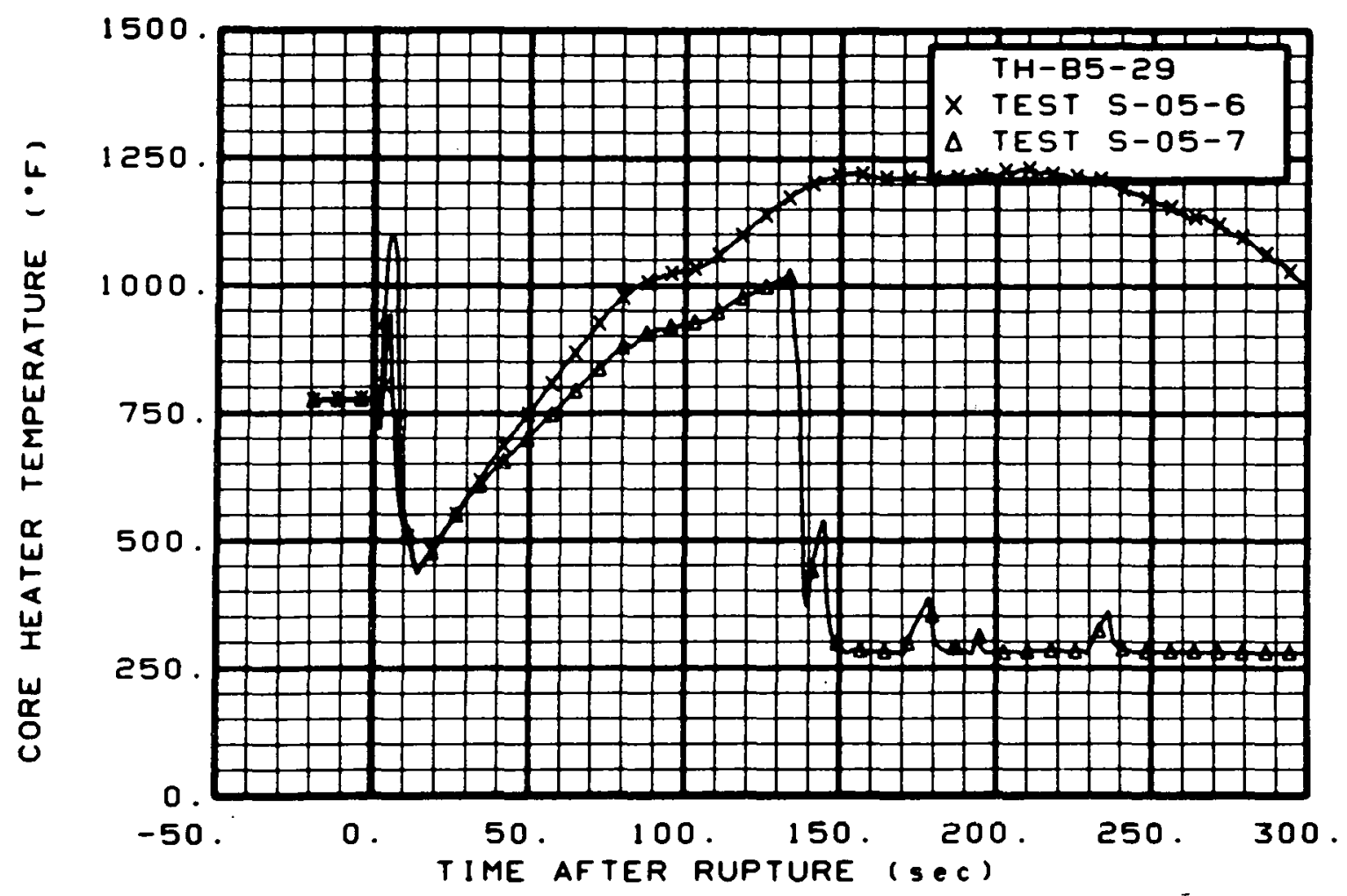

Fig. 141 Core heater temperature, Rod B-5 (TH-B5-29), from -20 to $300 \mathrm{sec}$.

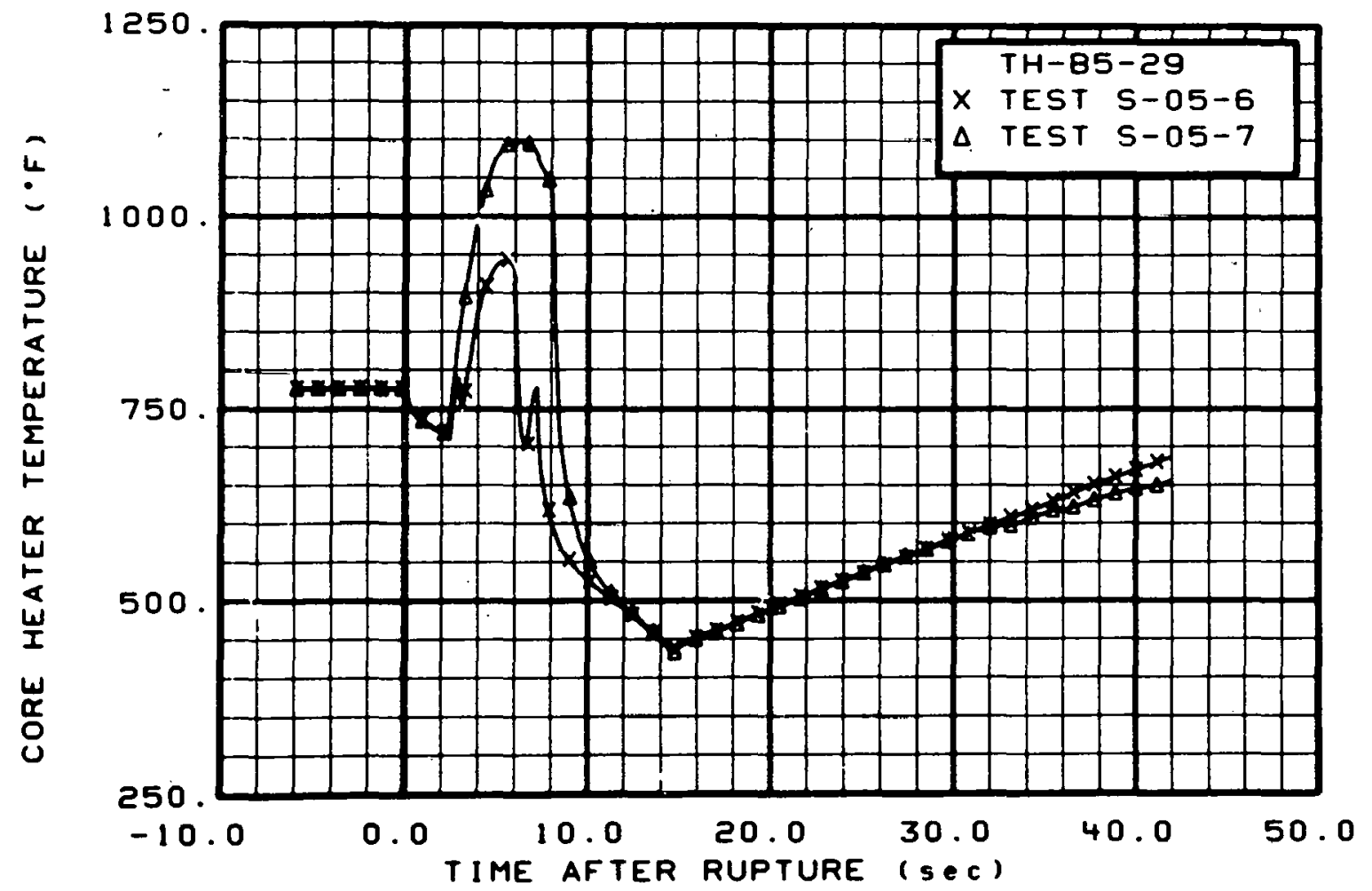

Fig. 145 Core heater temperature, Rod B-5 (TH-B5-29), from -6 to $42 \mathrm{sec}$. 


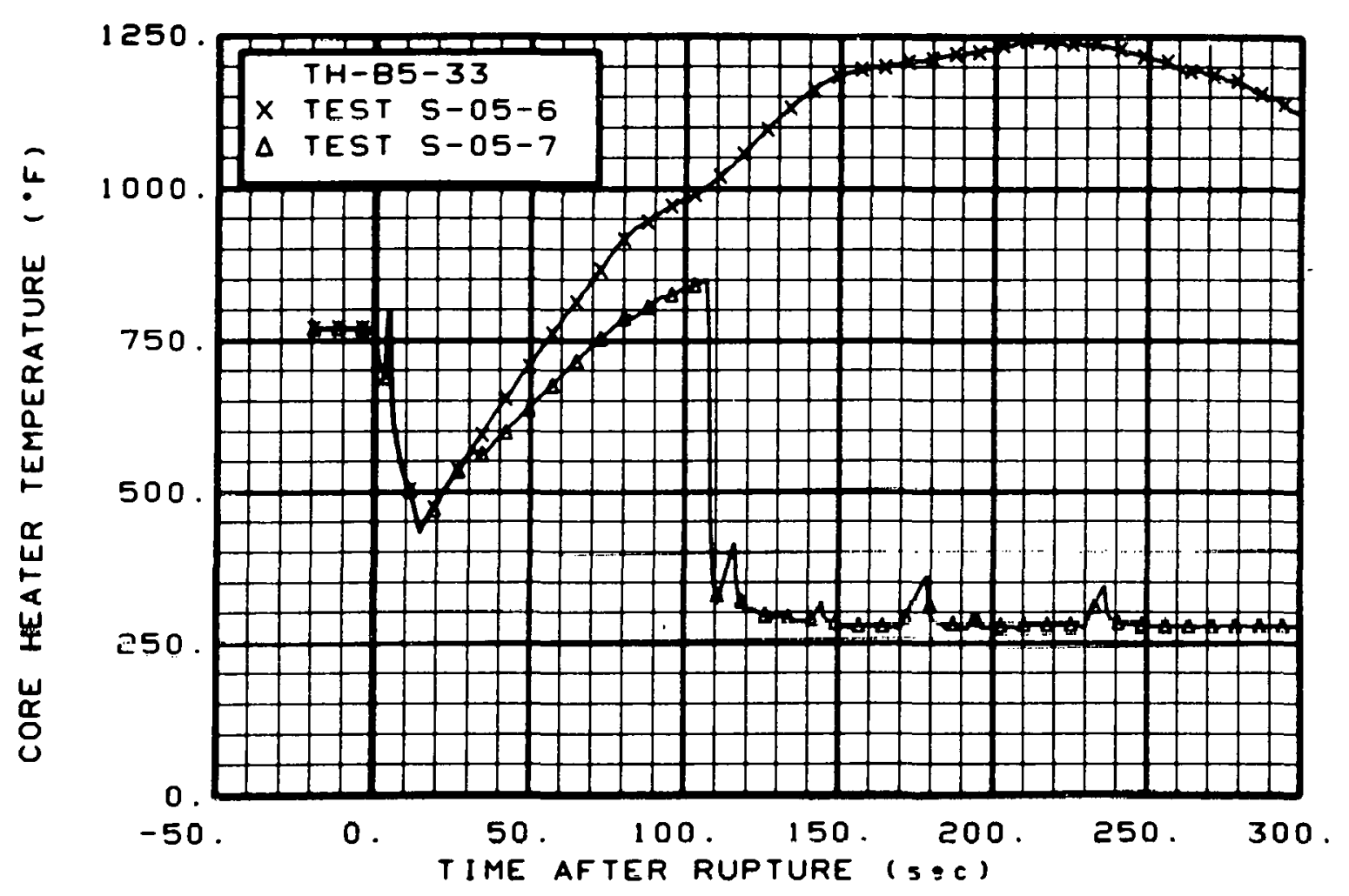

Fig. 146 Core heater temperature, Rod B-5 (TH-B5-33), from -20 to $300 \mathrm{sec}$.

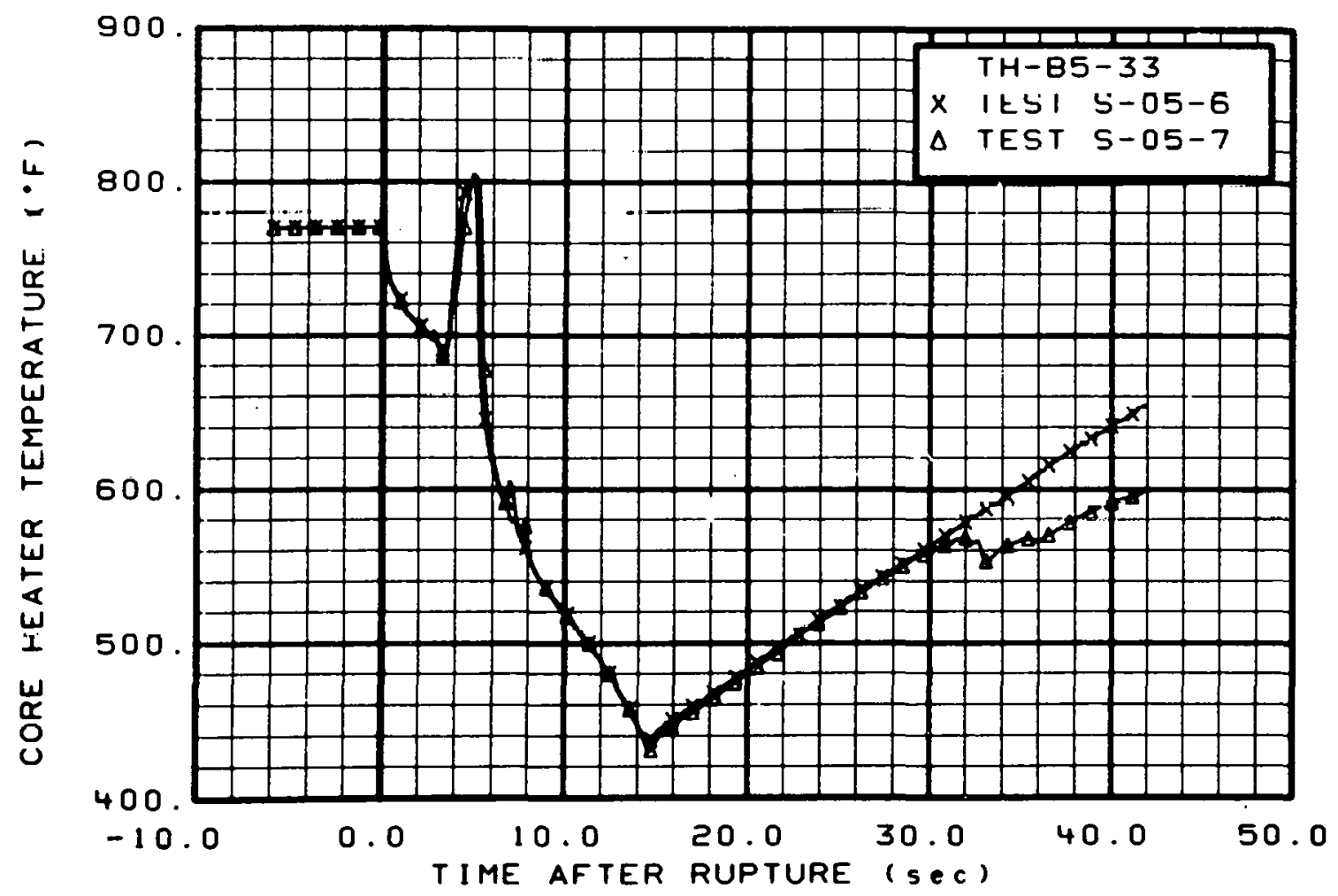

Fig. 147 Core heater temperature, Rod B-5 (TH-B5-33), from -6 to $42 \mathrm{sec}$. 


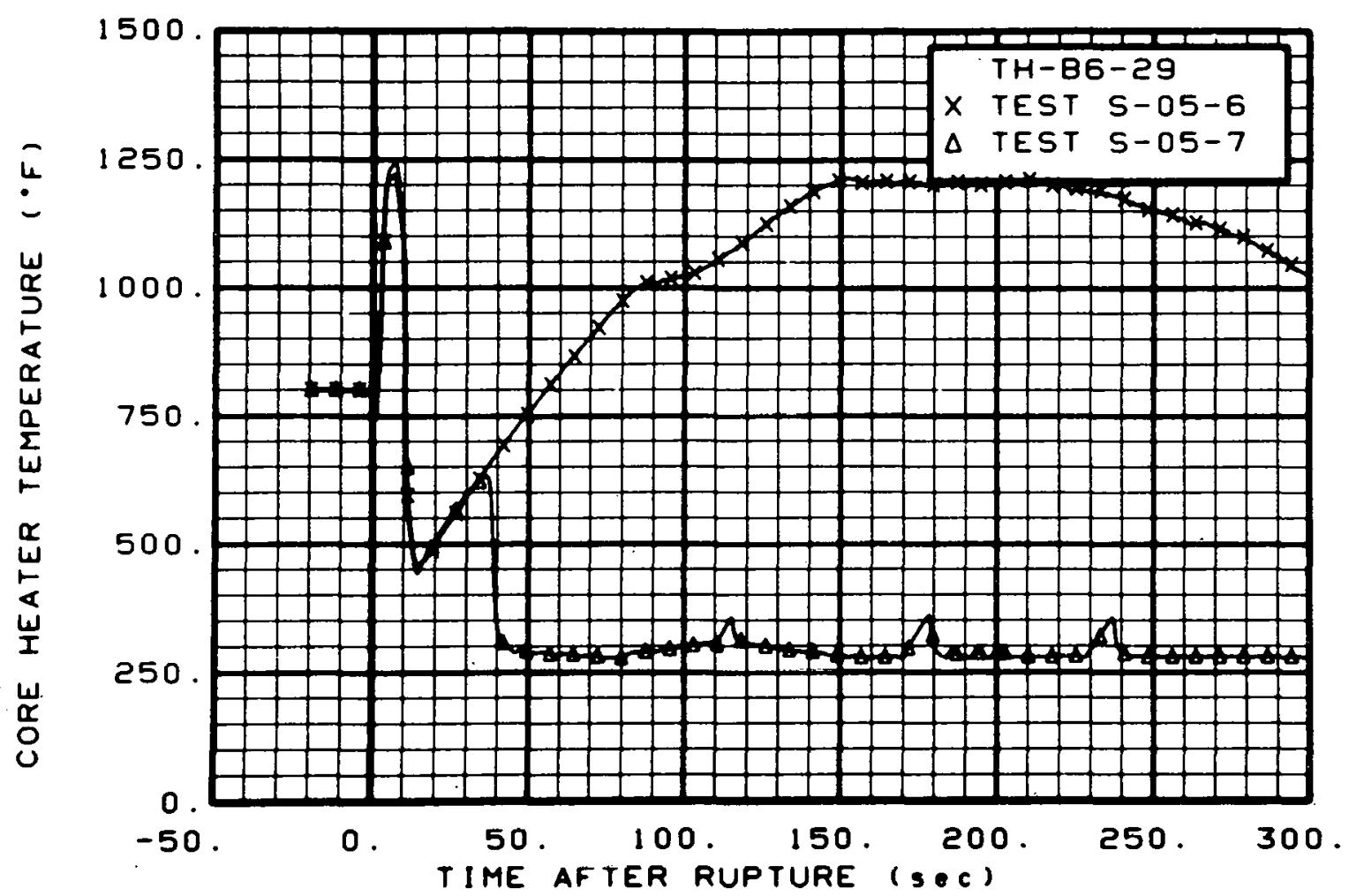

Fig. 148 Core heater temperature, Rod B-6 (TH-B6-29), from -20 to $300 \mathrm{sec}$.

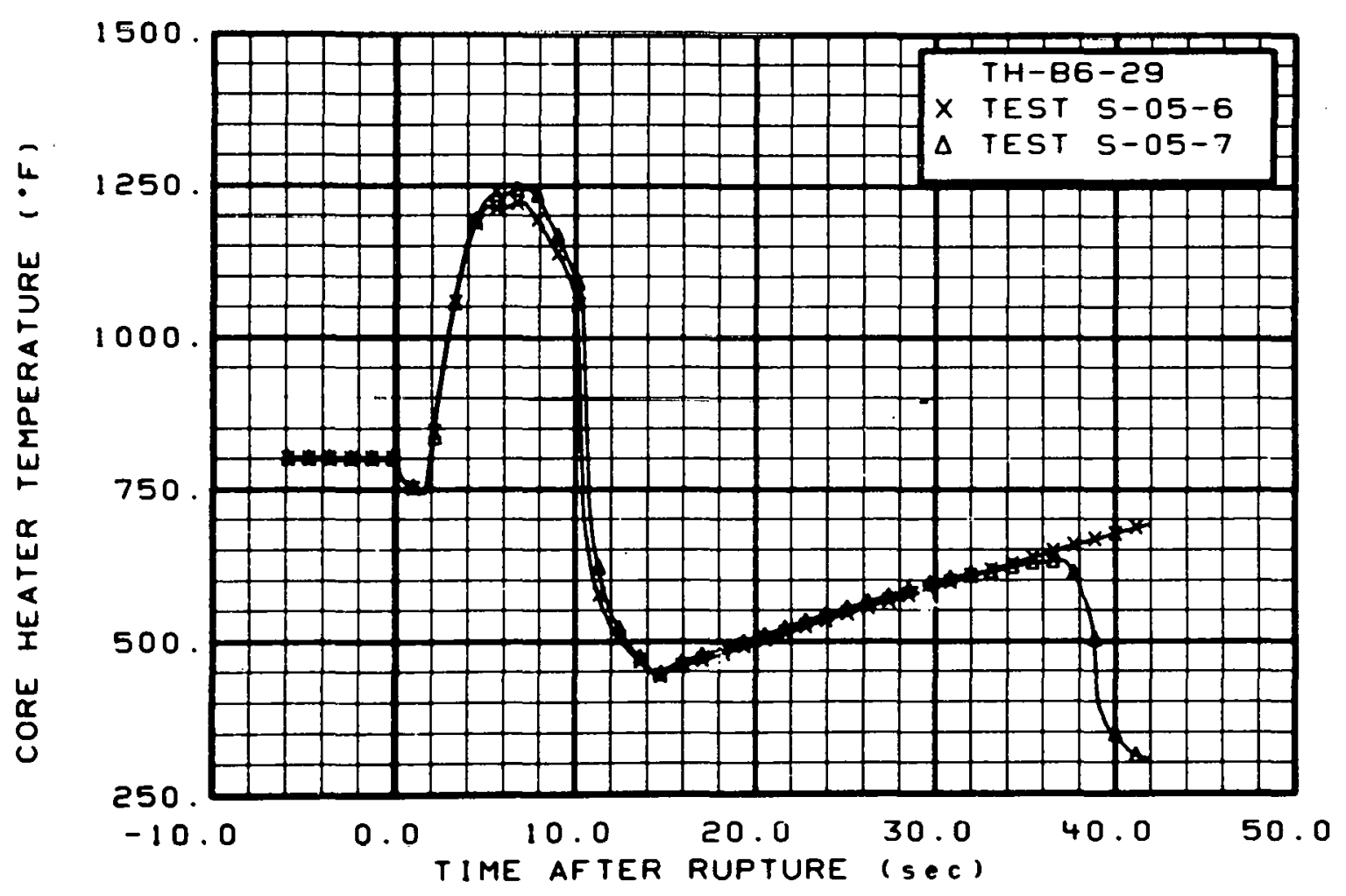

Fig. 149 Core heater temperature, Rod B-6 (TH-B6-29), from -6 to $42 \mathrm{sec}$. 


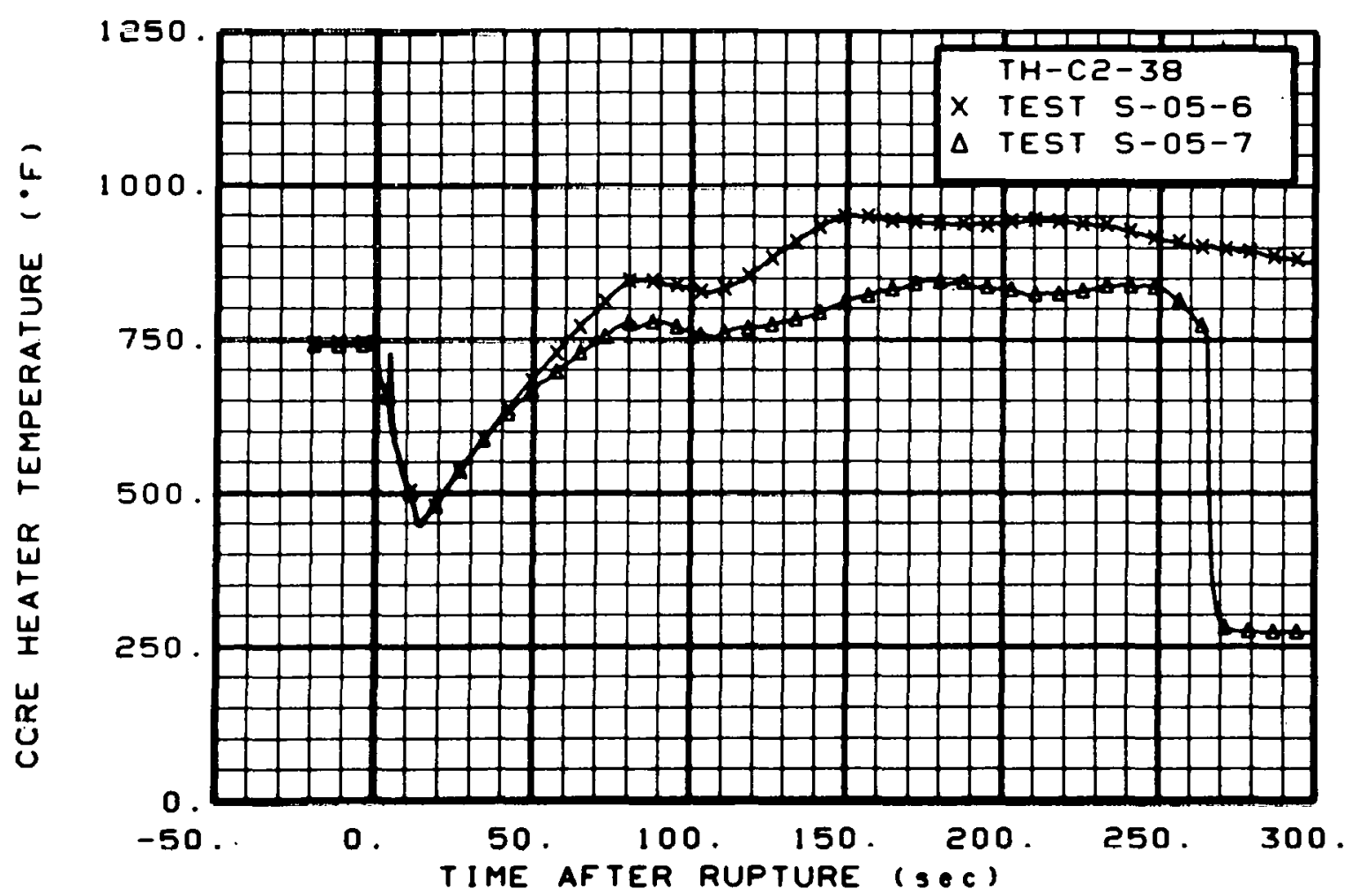

Fig. 150 Core heater temperature, Rod C-2 ( $\mathrm{TH}-\mathrm{C} 2-38$ ), from -20 to $300 \mathrm{sec}$.

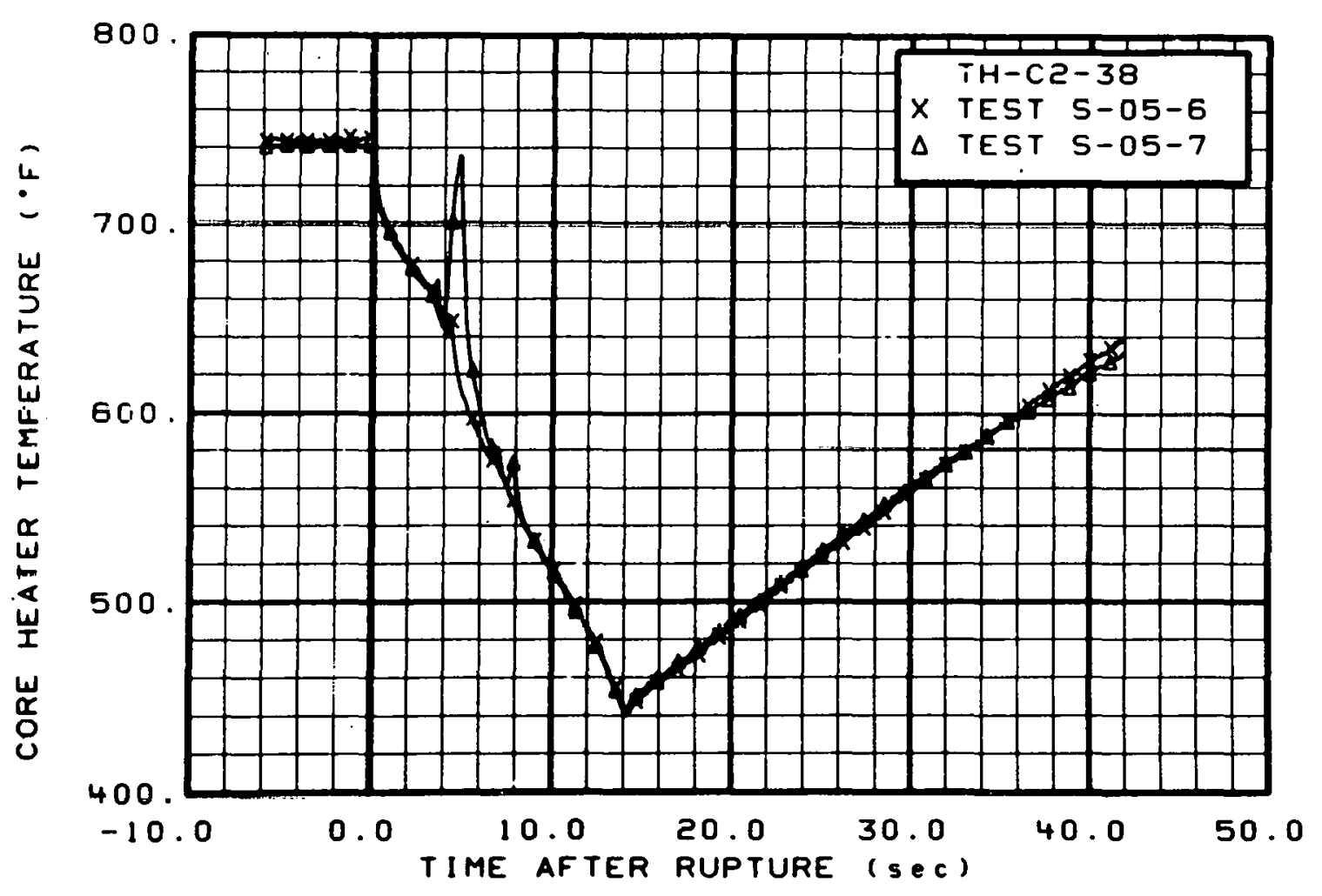

Fig. 151 Core heater temperature, Rod C-2 (TH-C2-38), from -6 to $42 \mathrm{sec}$. 


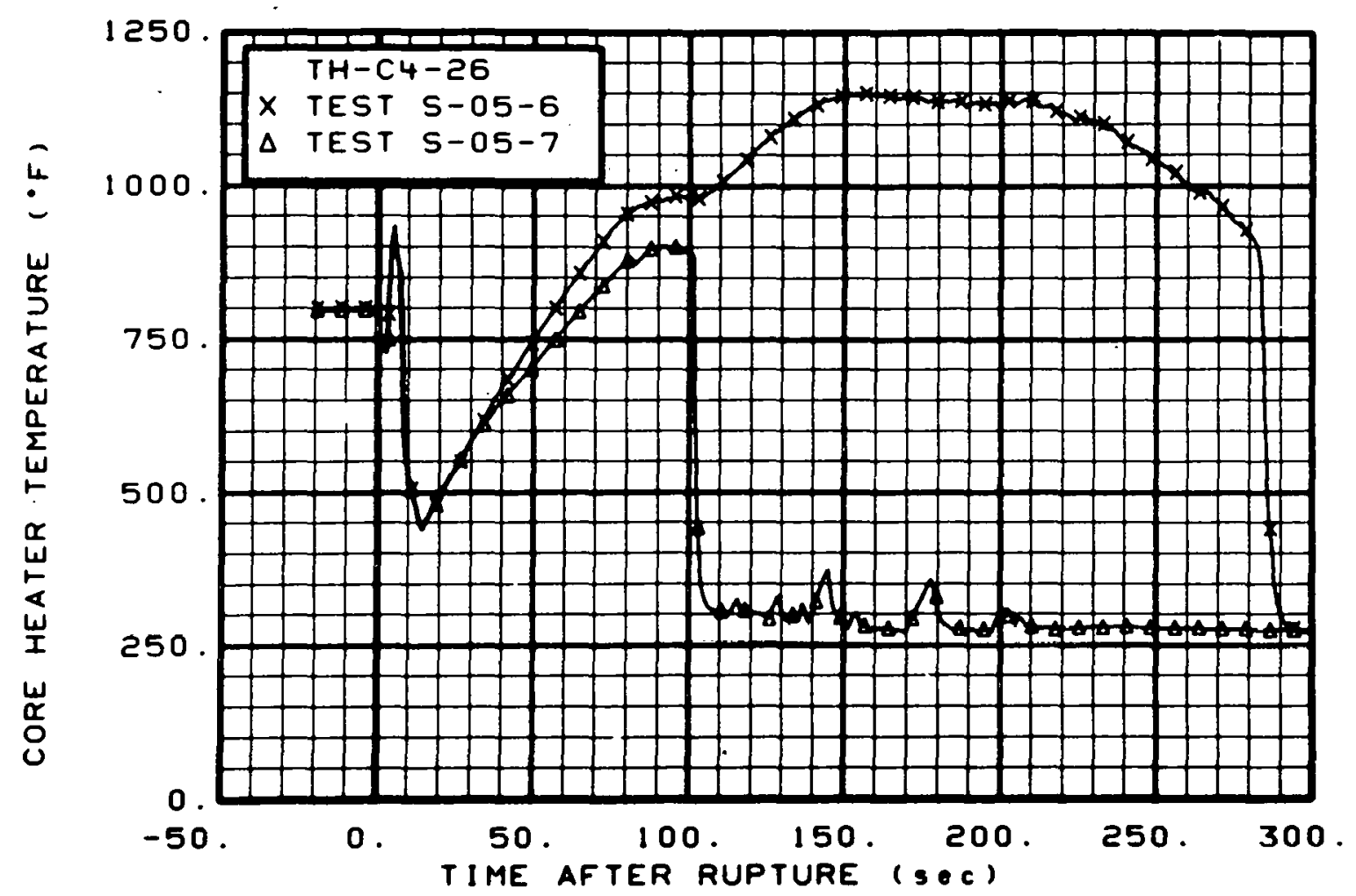

Fig. 152 Core heater temperature, Rod C-4. (TH-C4-26), from -20 to 300 sec.

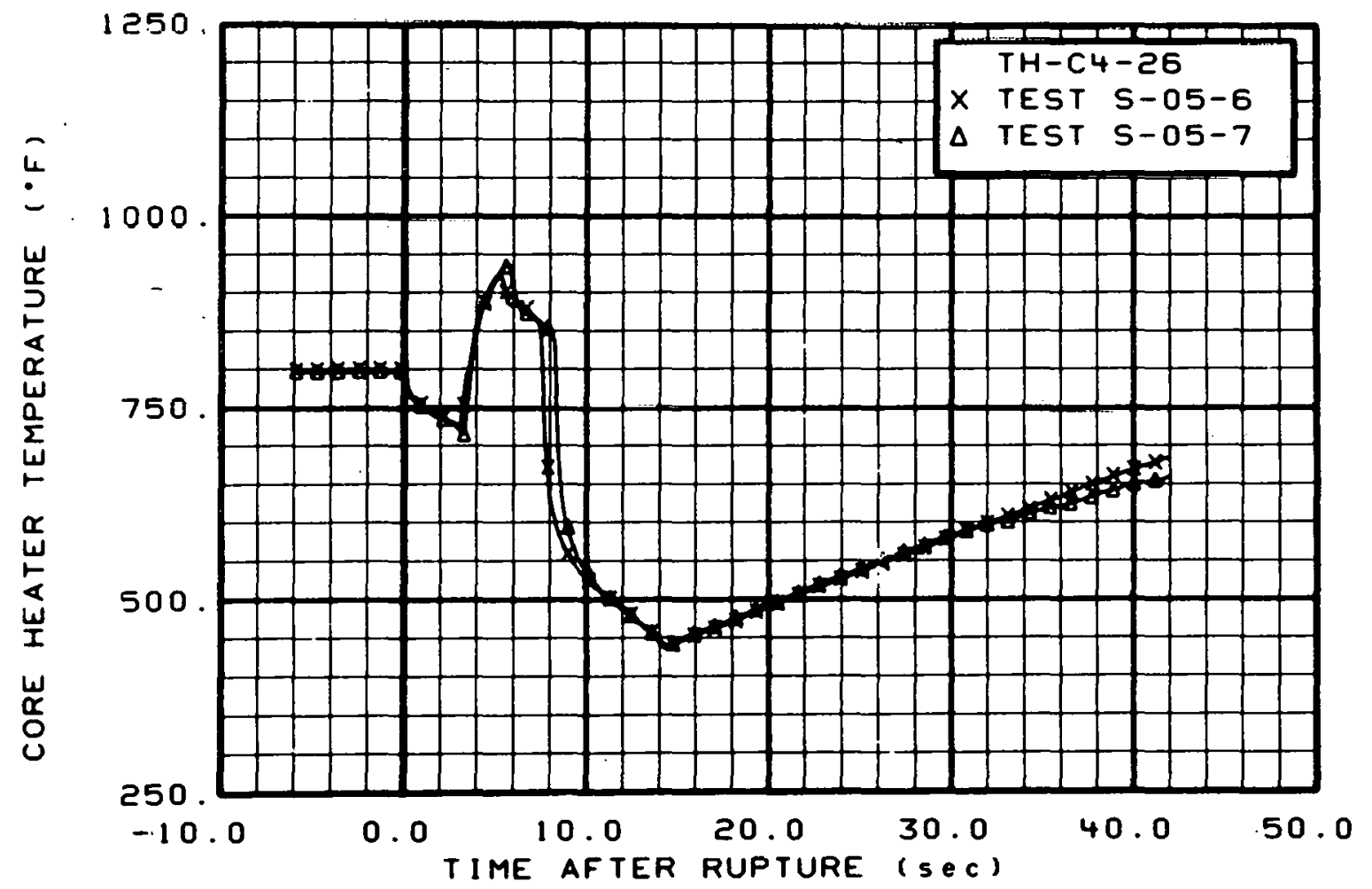

Fig. 153 Core heater temperature, Rod $\mathrm{C}-4(\mathrm{TH}-\mathrm{C} 4-26)$, from -6 to $42 \mathrm{sec}$. 


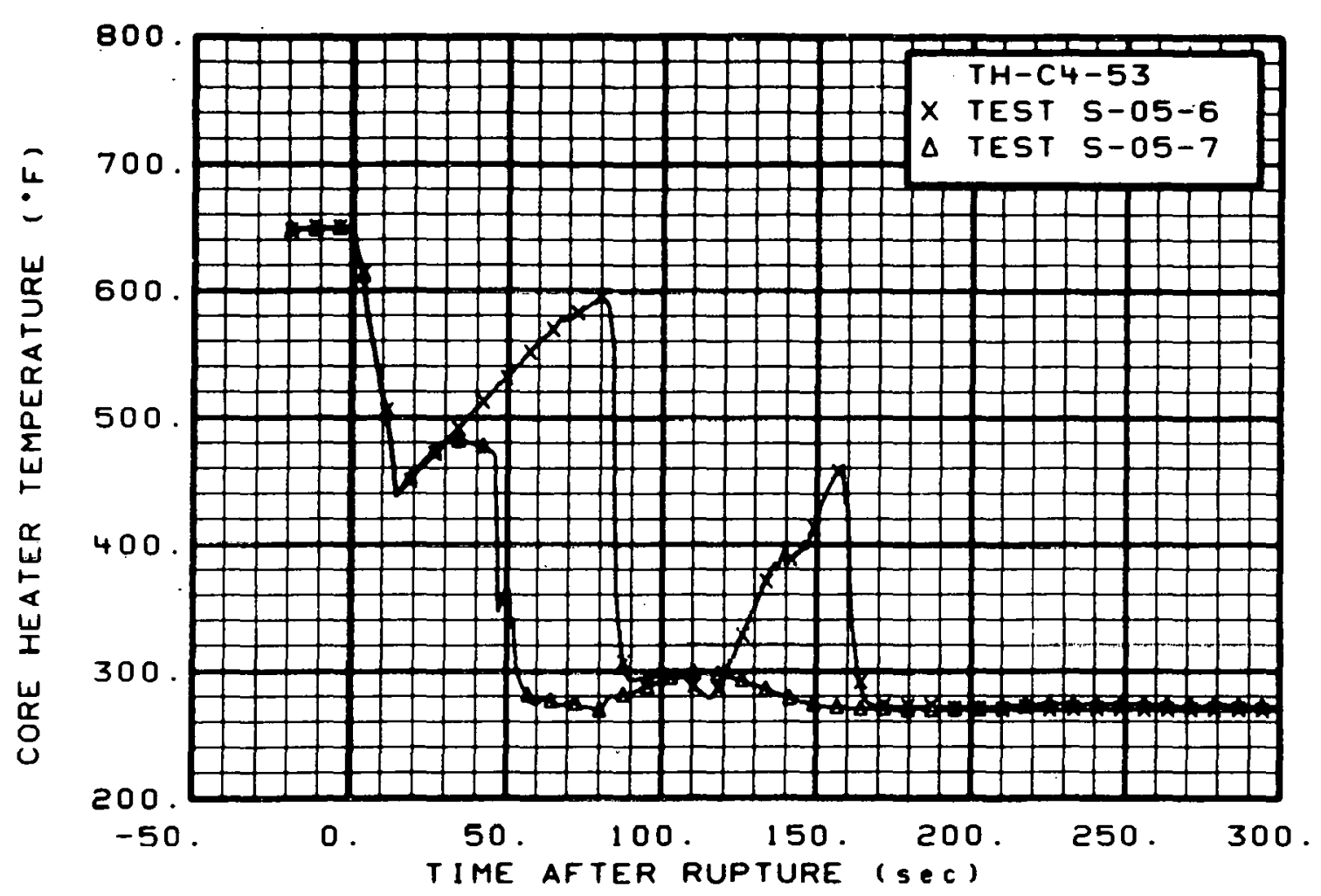

Fig. 154 Core heater temperature, Rod C-4 (TH-C4-53), from -20 to $300 \mathrm{sec}$.

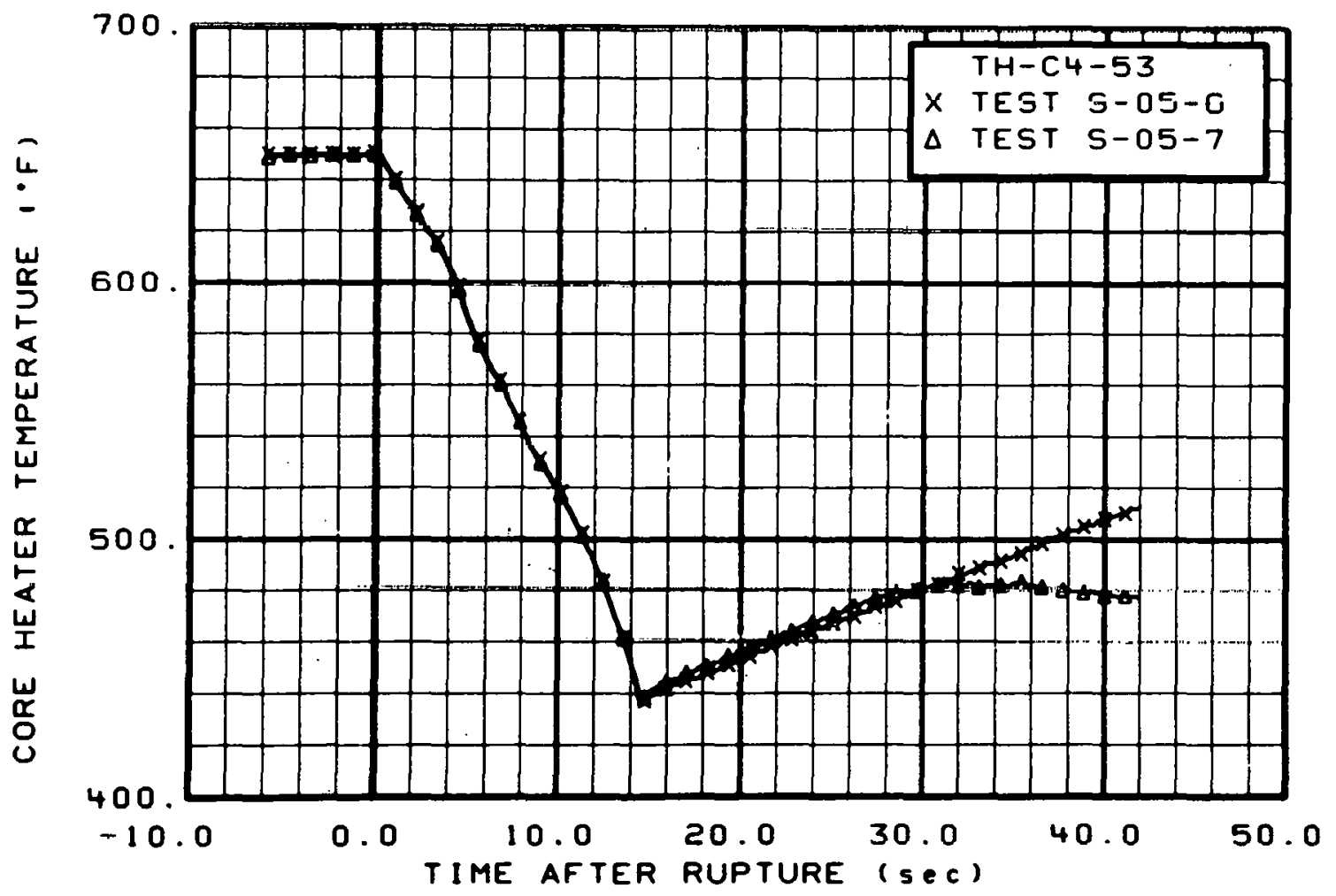

Fig. 155 Core heater temperature, Rod C-4 (TH-C4-53), from -6 to $42 \mathrm{sec}$. 


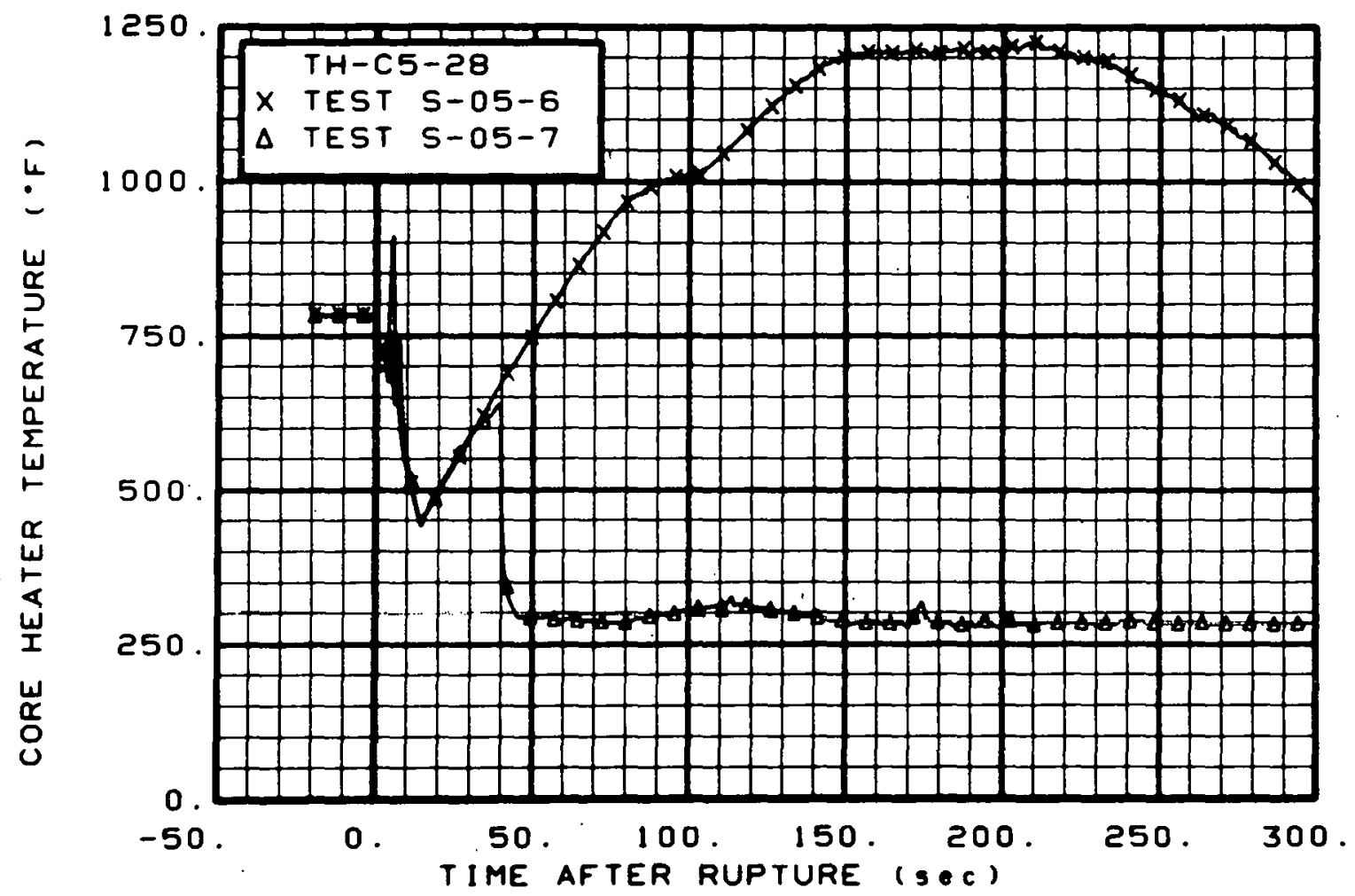

Fig. 156 Core heater temperature, Rod C-5 (TH-C5-28), from -20 to 300 sec.

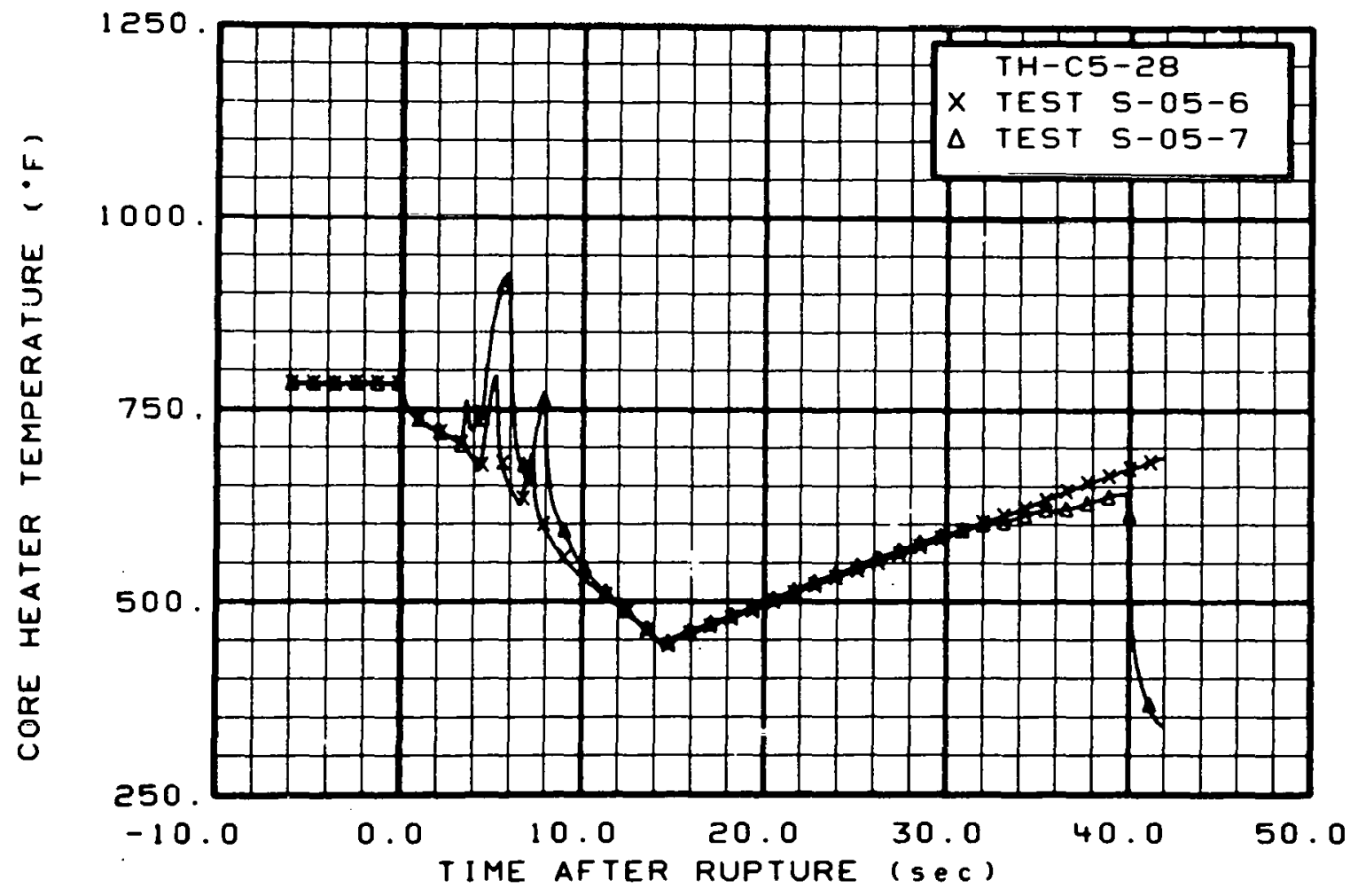

Fig. 157 Core heater temperature, Rod C-5 (TH-C5-28), from -6 to 42 sec. 


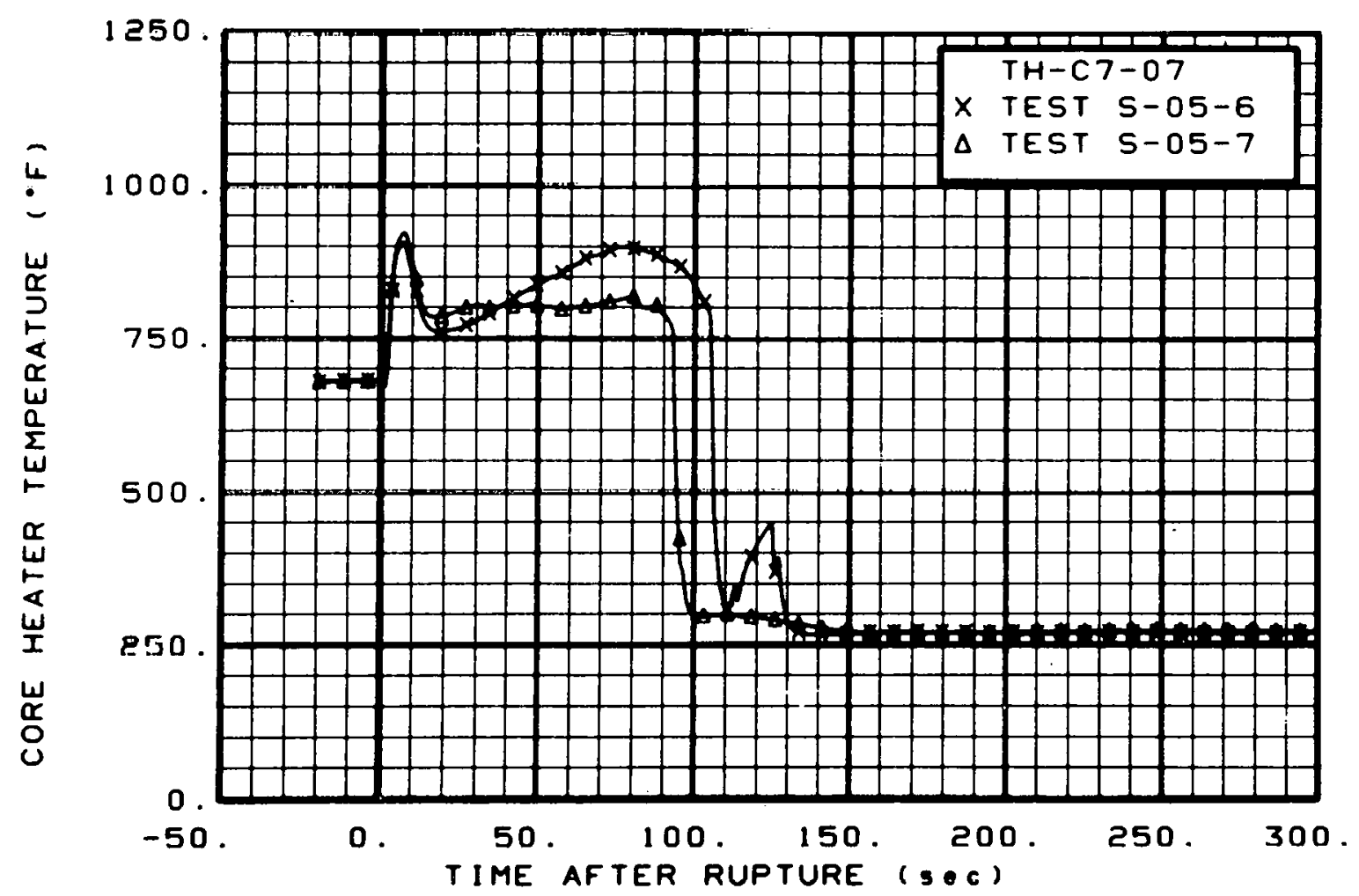

Fig. 158 Core heater temperature, Rod C-7 (TH-C7-07), from -20 to $300 \mathrm{sec}$.

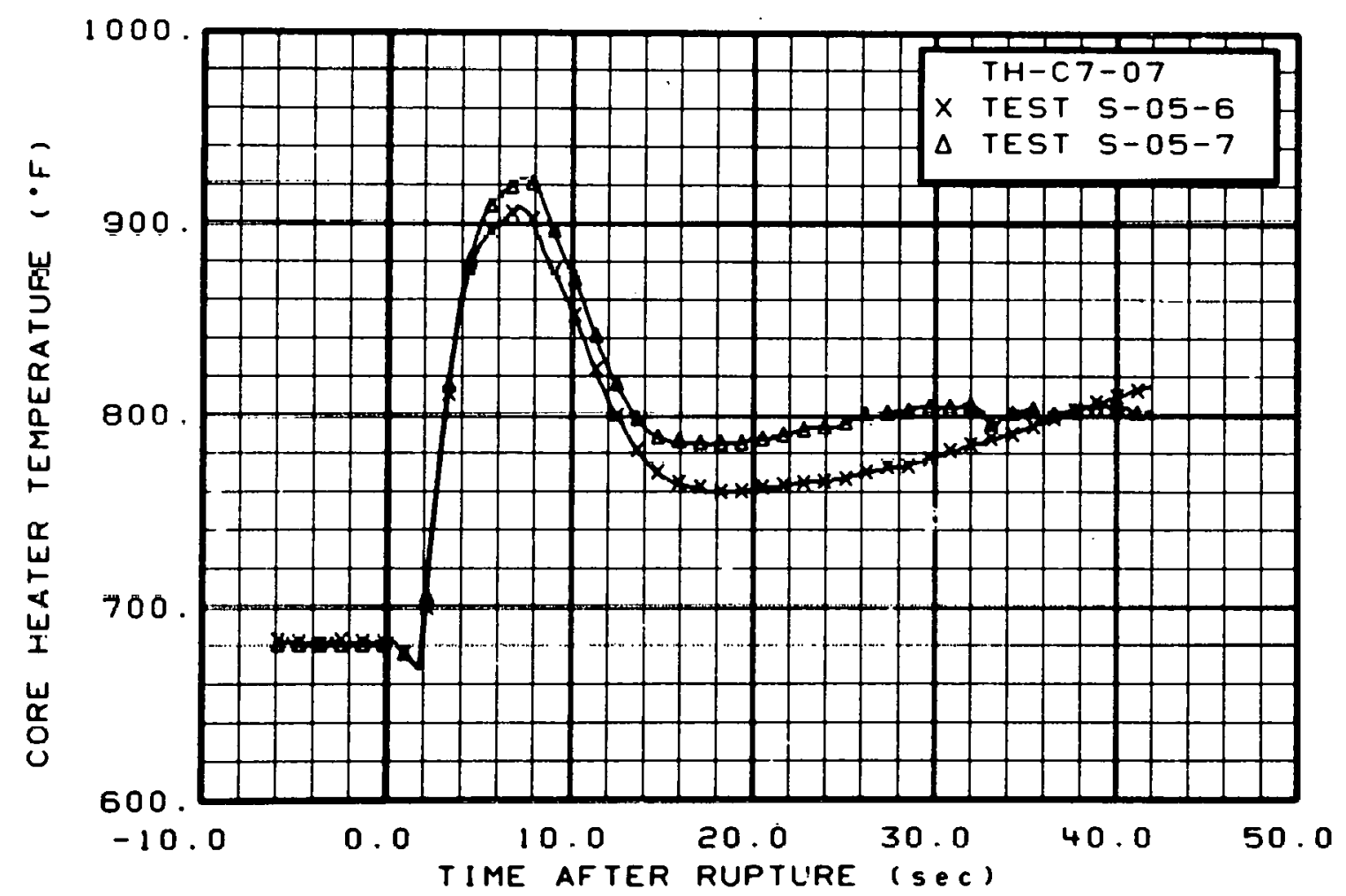

Fig. 159 Core heater temperature, Rod C-7 (TH-C7-07), from -6 to $42 \mathrm{sec}$. 


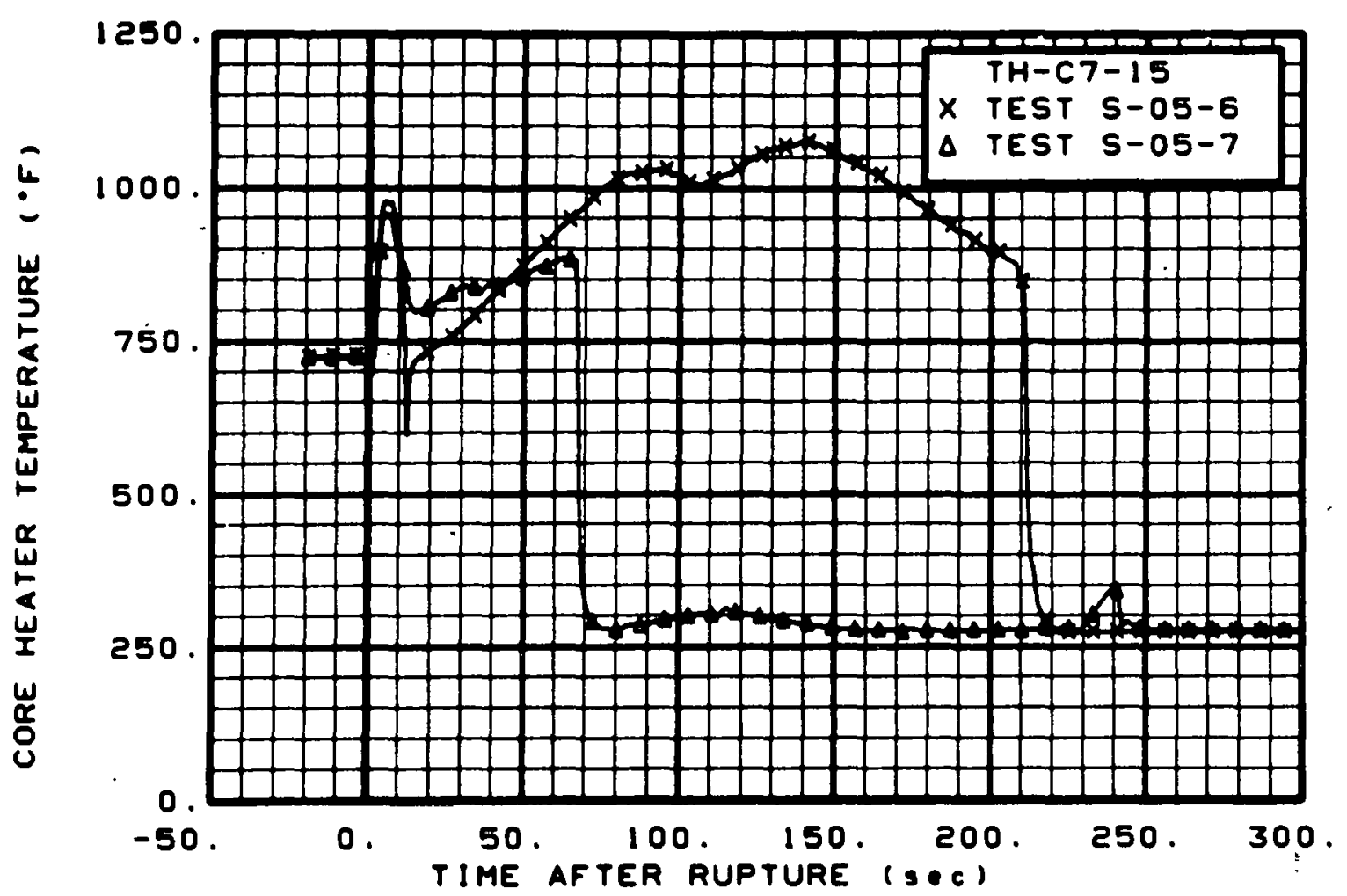

Fig. 160 Core heater temperature, Rod $\mathrm{C}-7$ ( TH-C.7-15), from -20 to $300 \%$ sec.

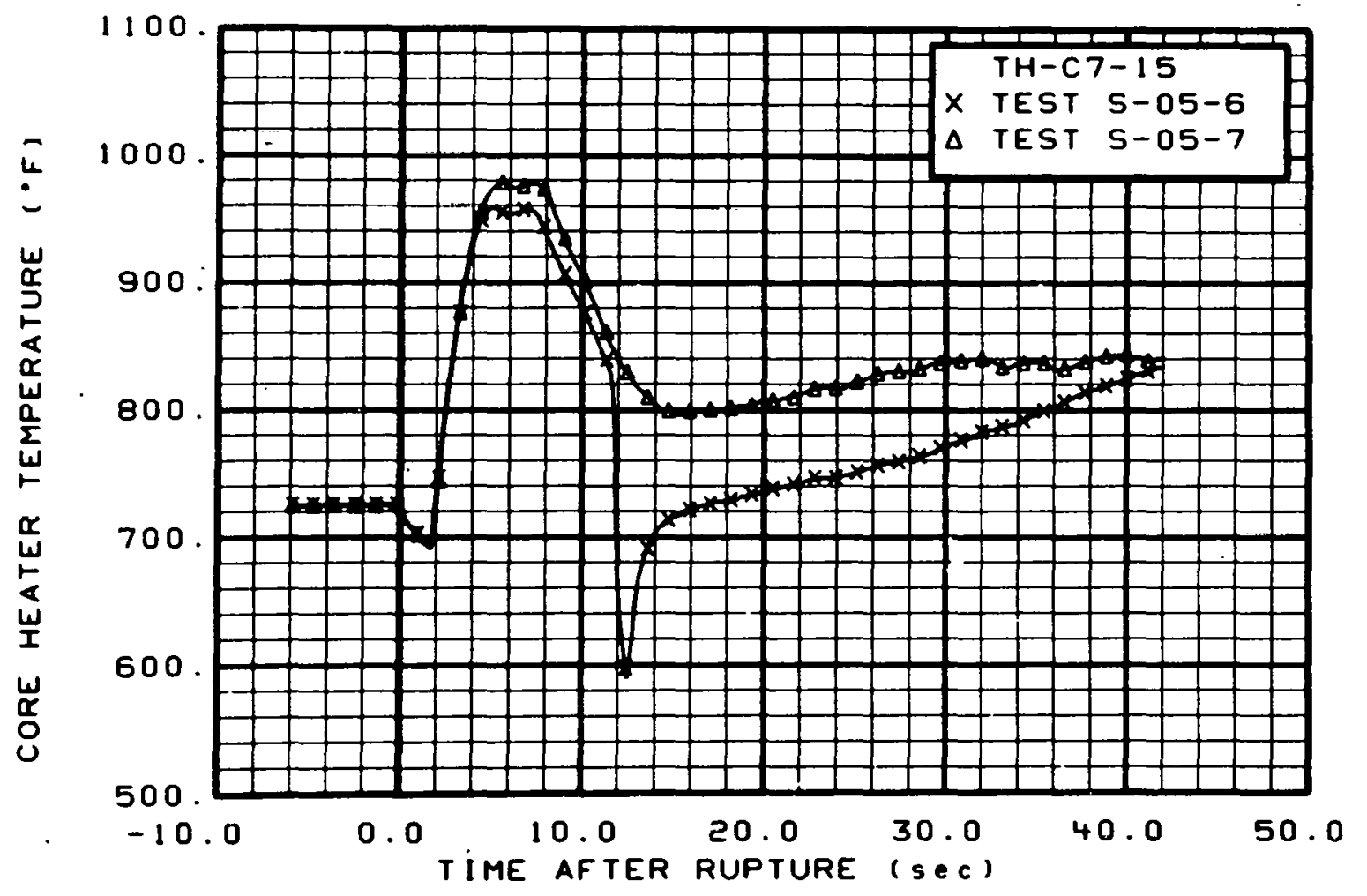

Fig. 161 Core heater temperature, Rod C-7 (TH-C7-15), from -6 to $42 \mathrm{sec}$. 


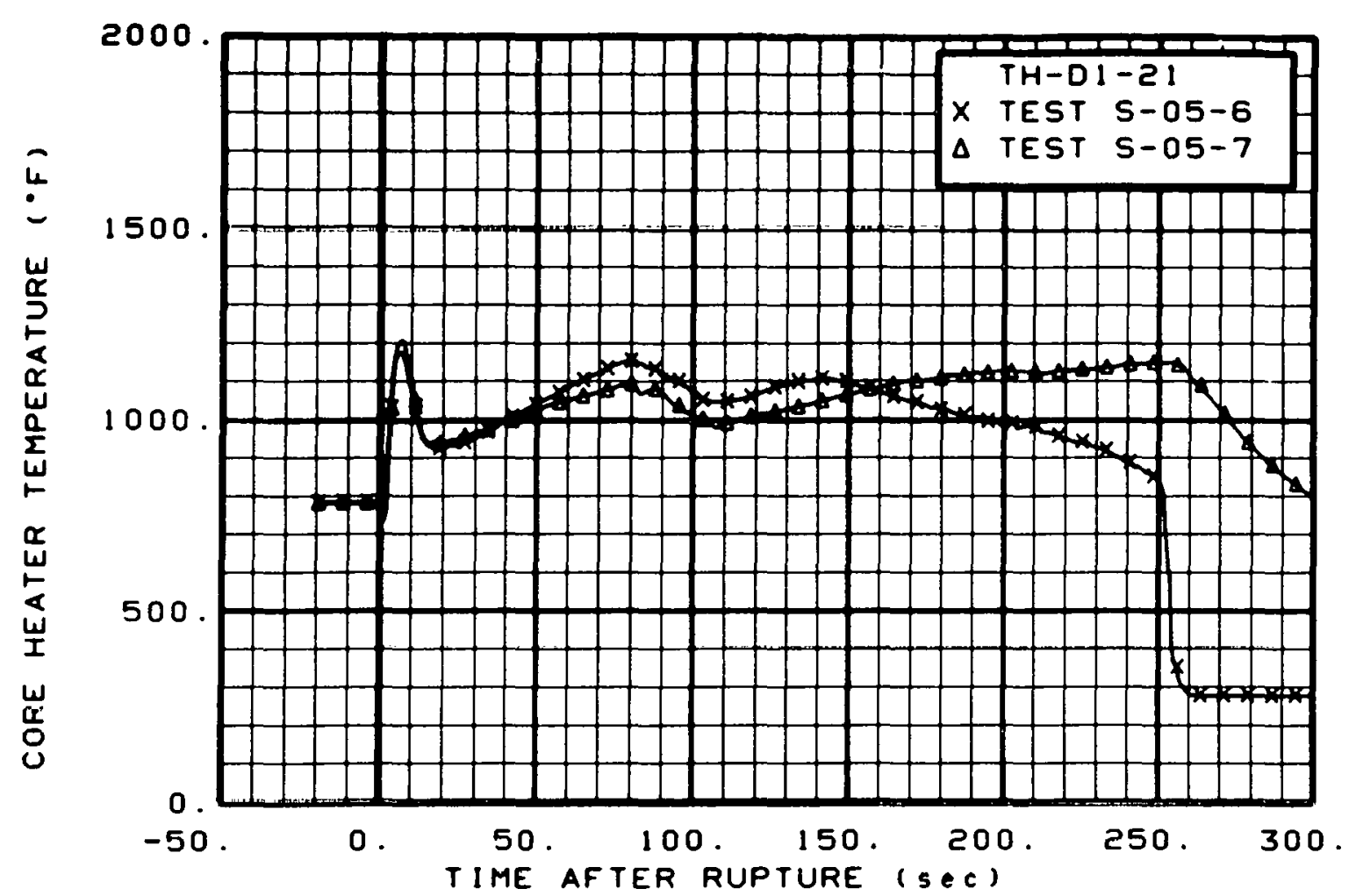

Fig. 162 Core heater temperature, Rod D-1 (TH-DI-2T), from -20 to $300 \mathrm{sec}$.

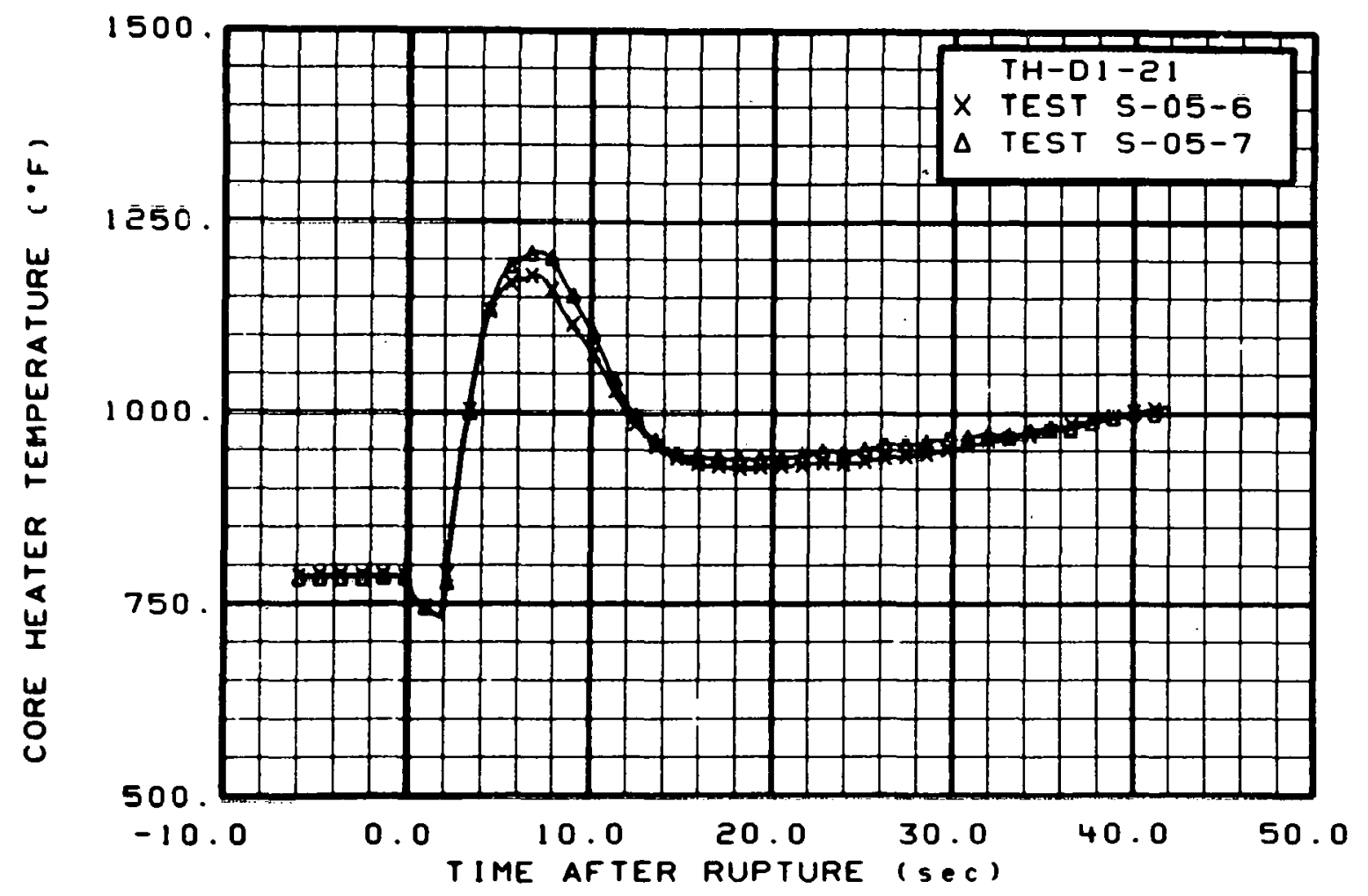

Fig. 163 Core heater temperature, Rod D-1 (TH-D1-21), from -6 to $42 \mathrm{sec}$. 


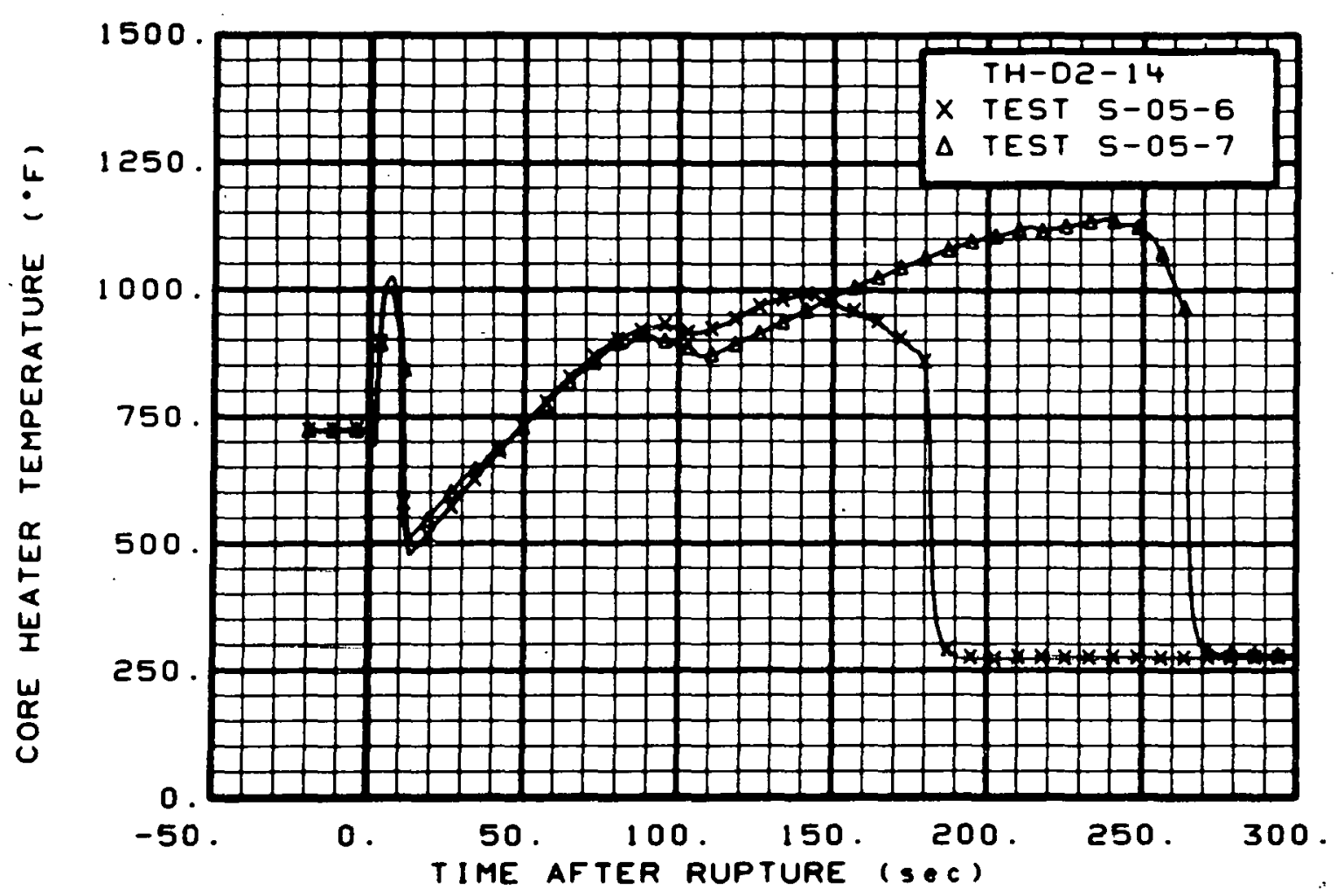

Fig. 164 Core heater temperature, Rod D-2 (TH-D2-14), from -20 to $300 \mathrm{sec}$.

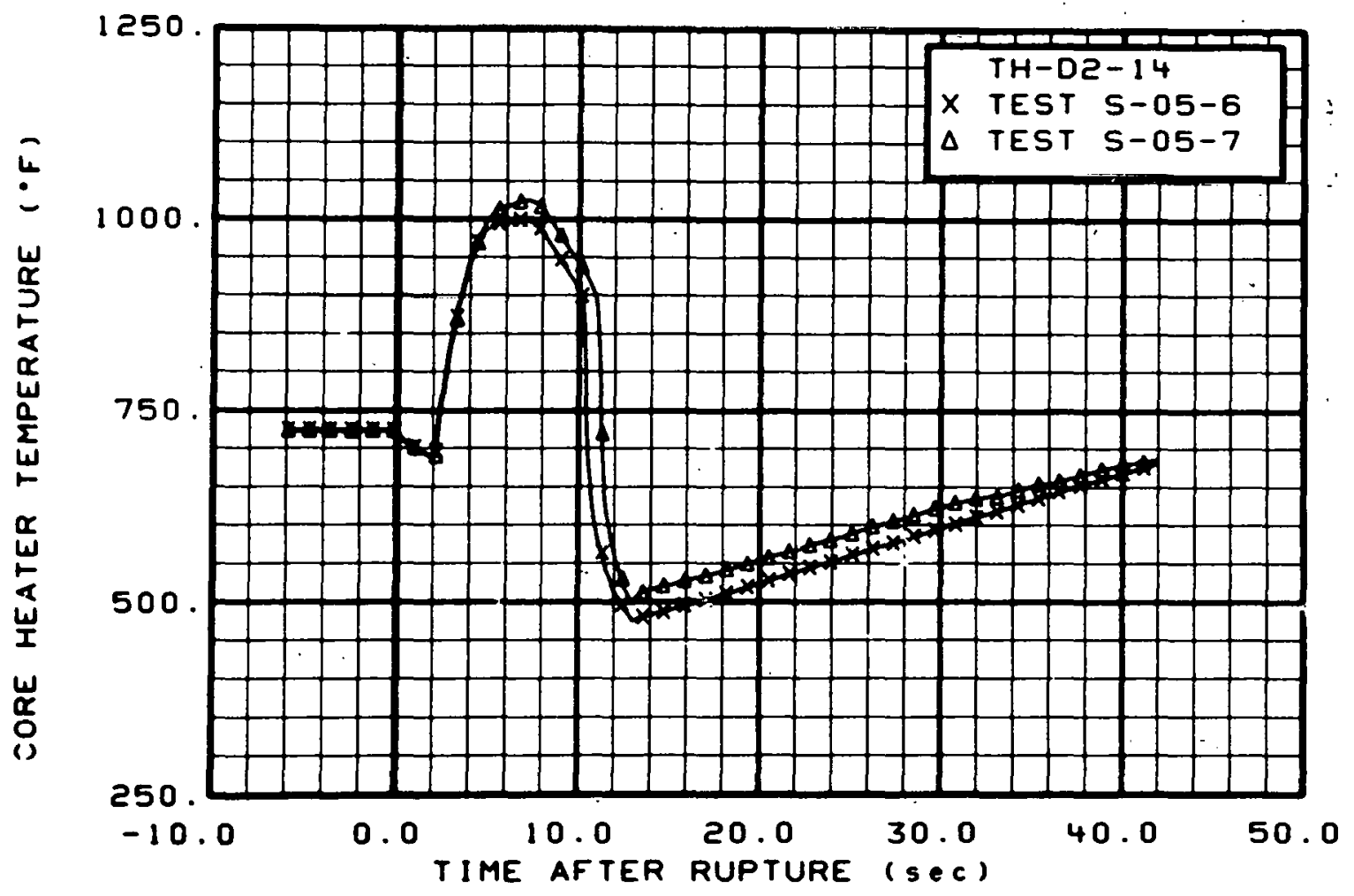

Fig. 165 Core heater temperature, Rod D-2 (TH-D2-14), from -6 to $42 \mathrm{sec}$. 


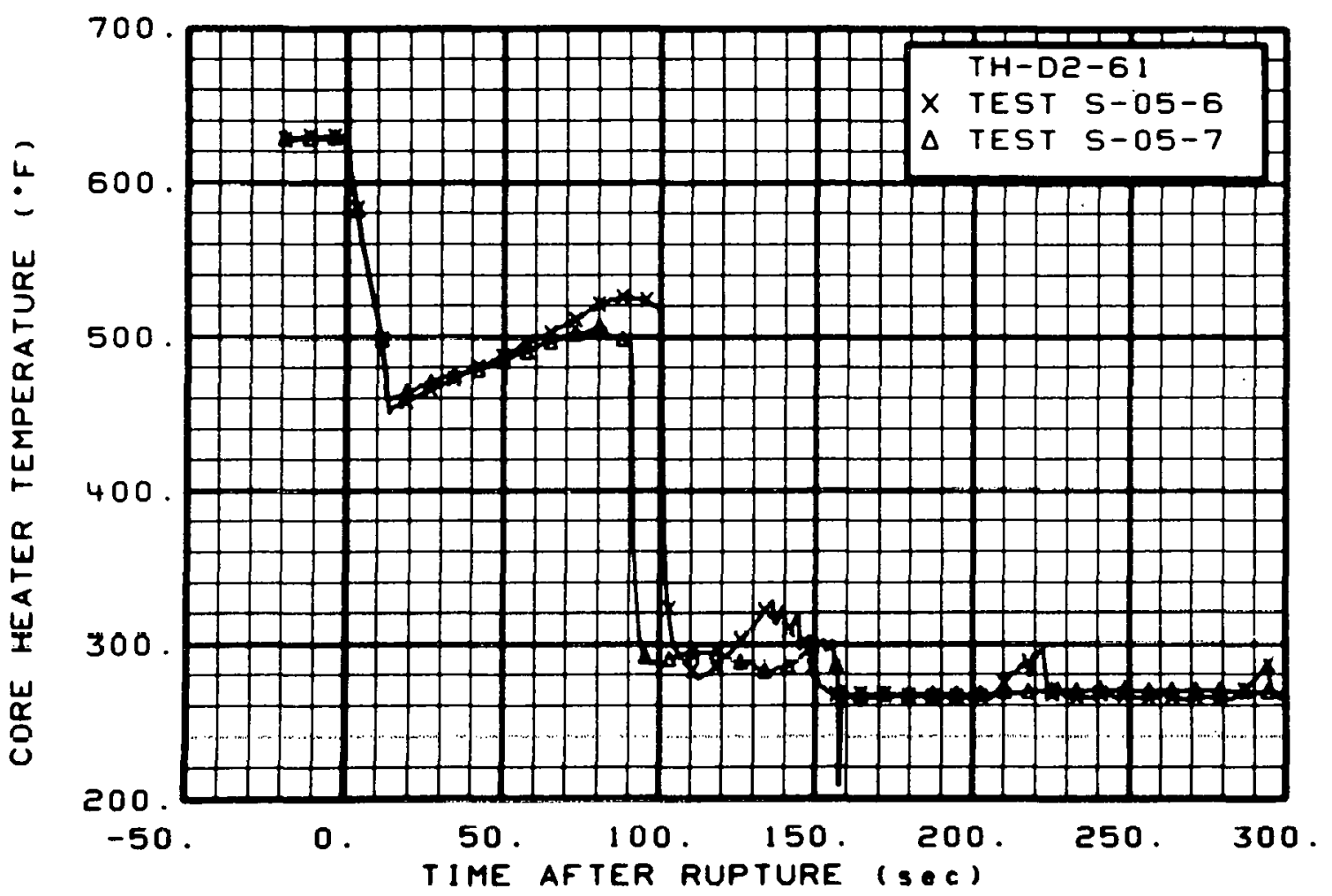

Fig. 166 Core heater temperature, Rod D-2 (TH-D2-61), from -20 to $300 \mathrm{sec}$.

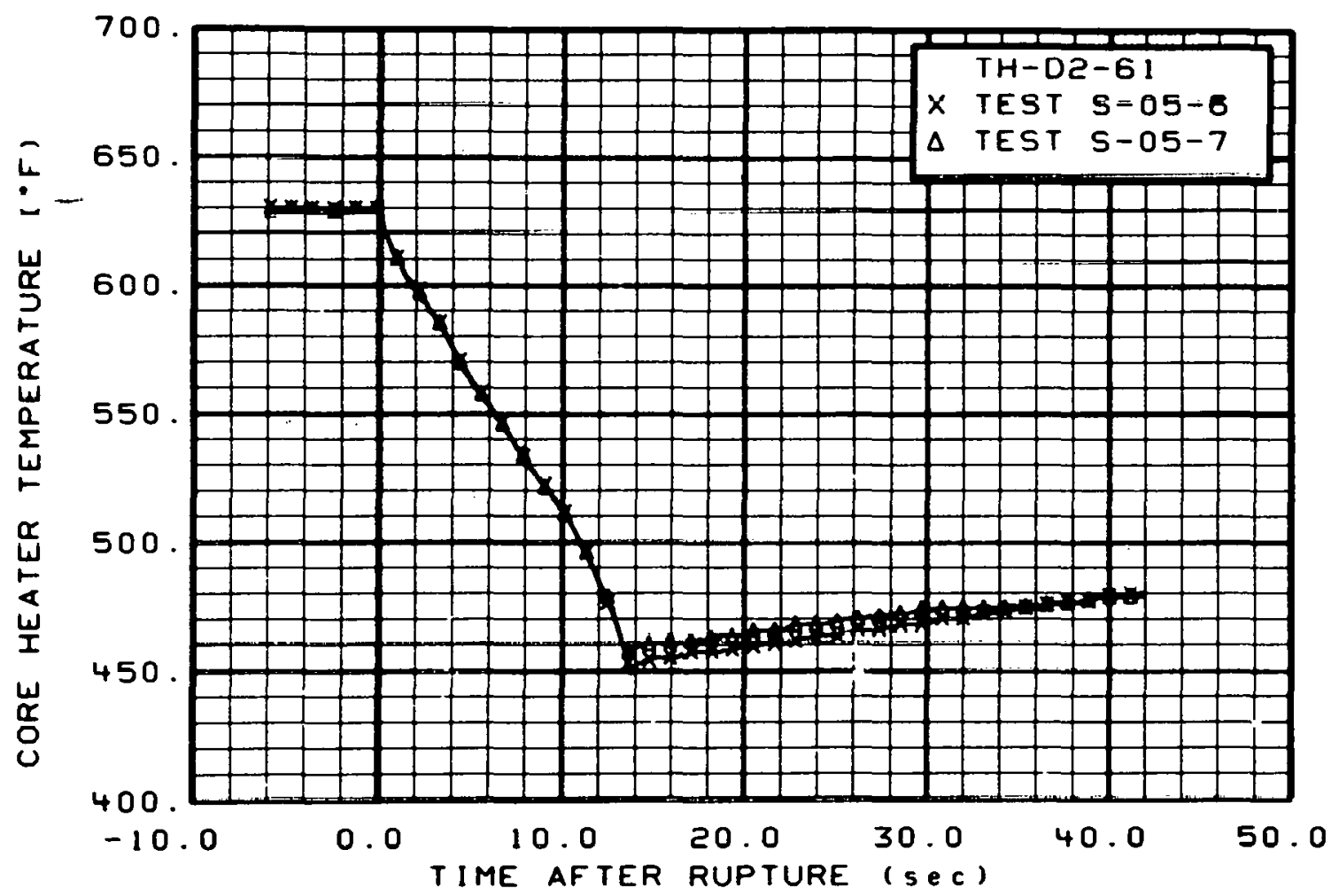

Fig. 167 Core heater temperature, Rod D-2 (TH-D2-61), from -6 to $42 \mathrm{sec}$. 


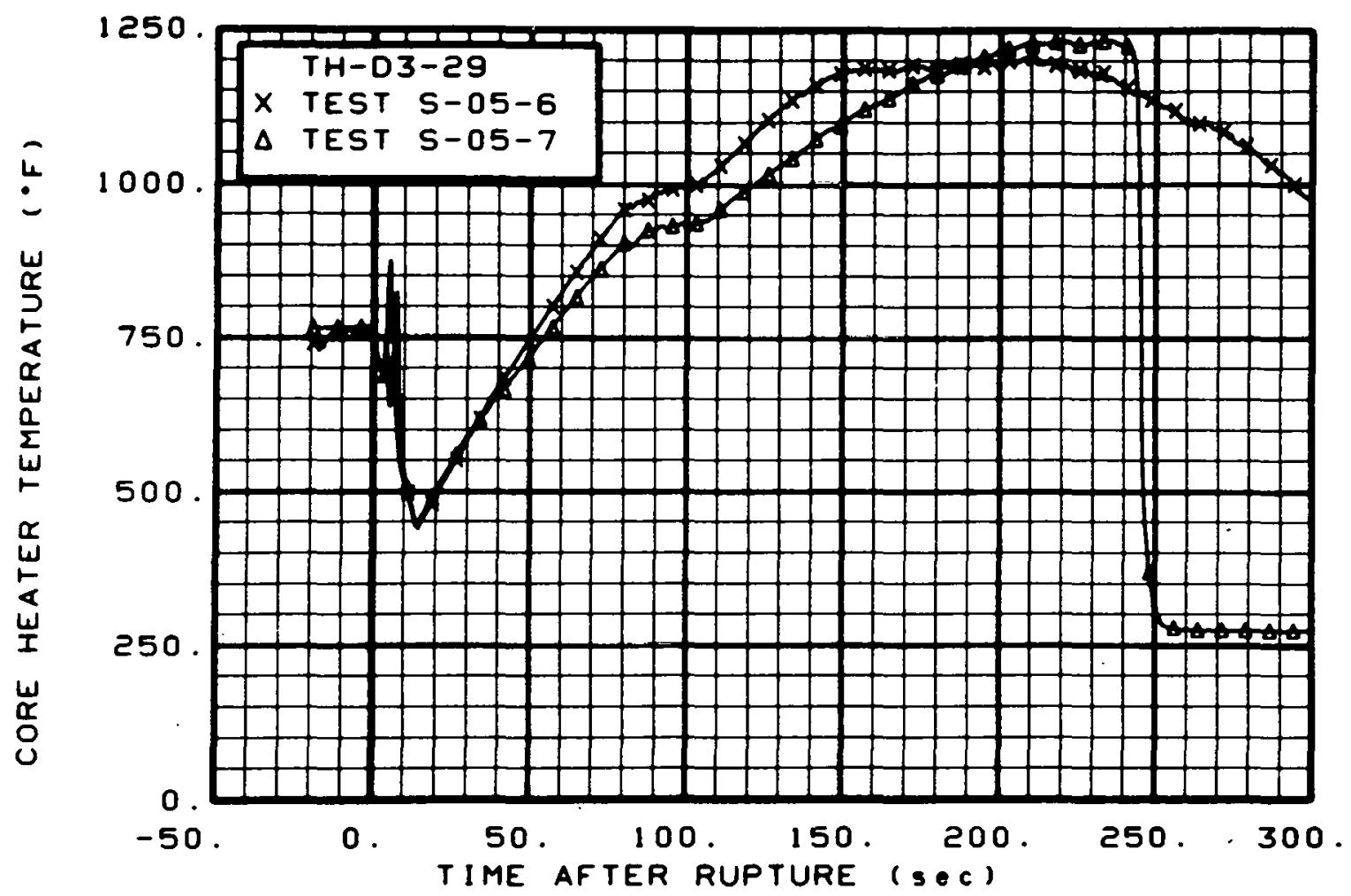

Fig. 168 Core heater temperature, Rod D-3 (TH-D3-29), from -20 to 300 sec.

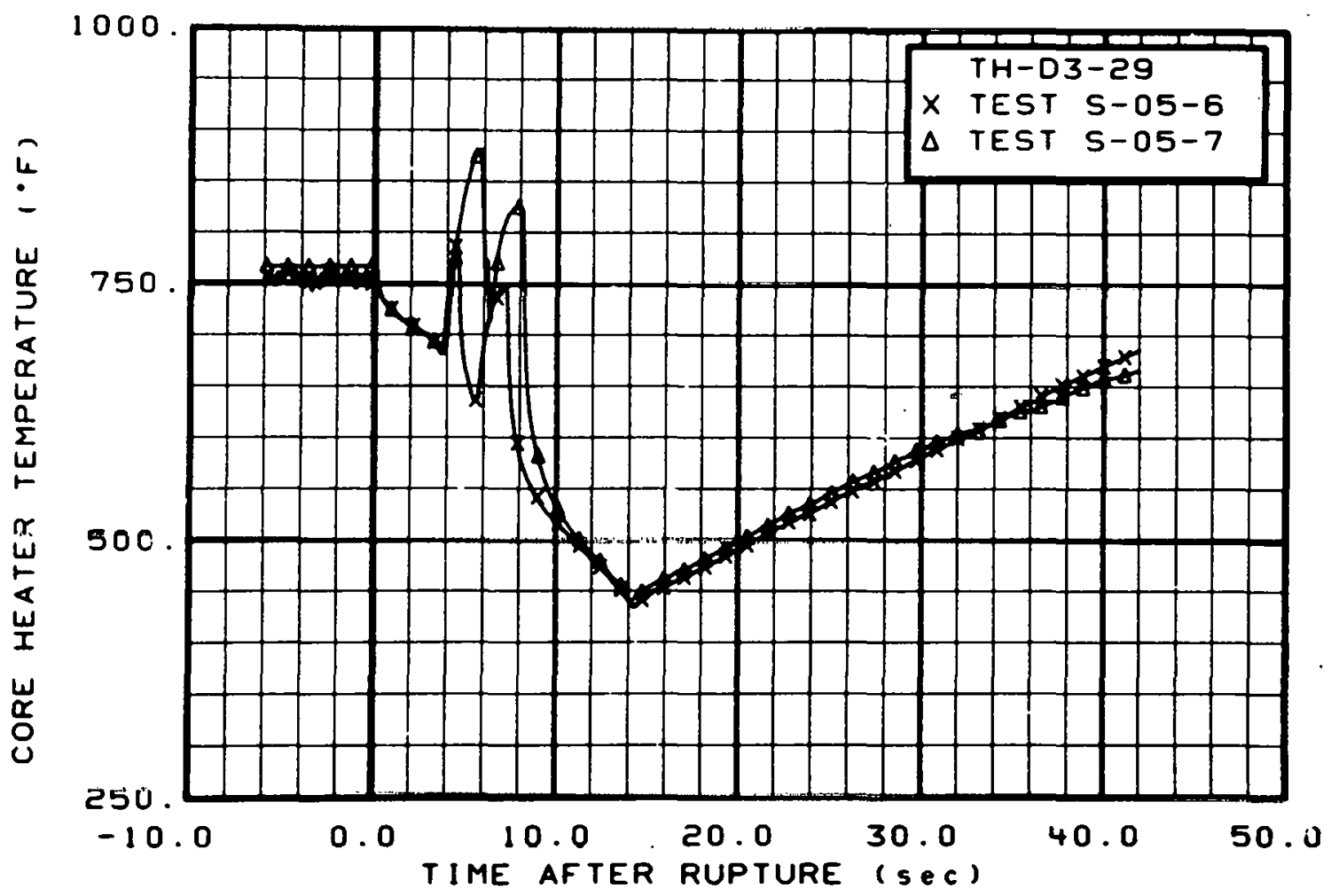

Fig. 169 Core heater temperature, Rod D-3 (TH-D3-29), from -6 to $42 \mathrm{sec}$. 


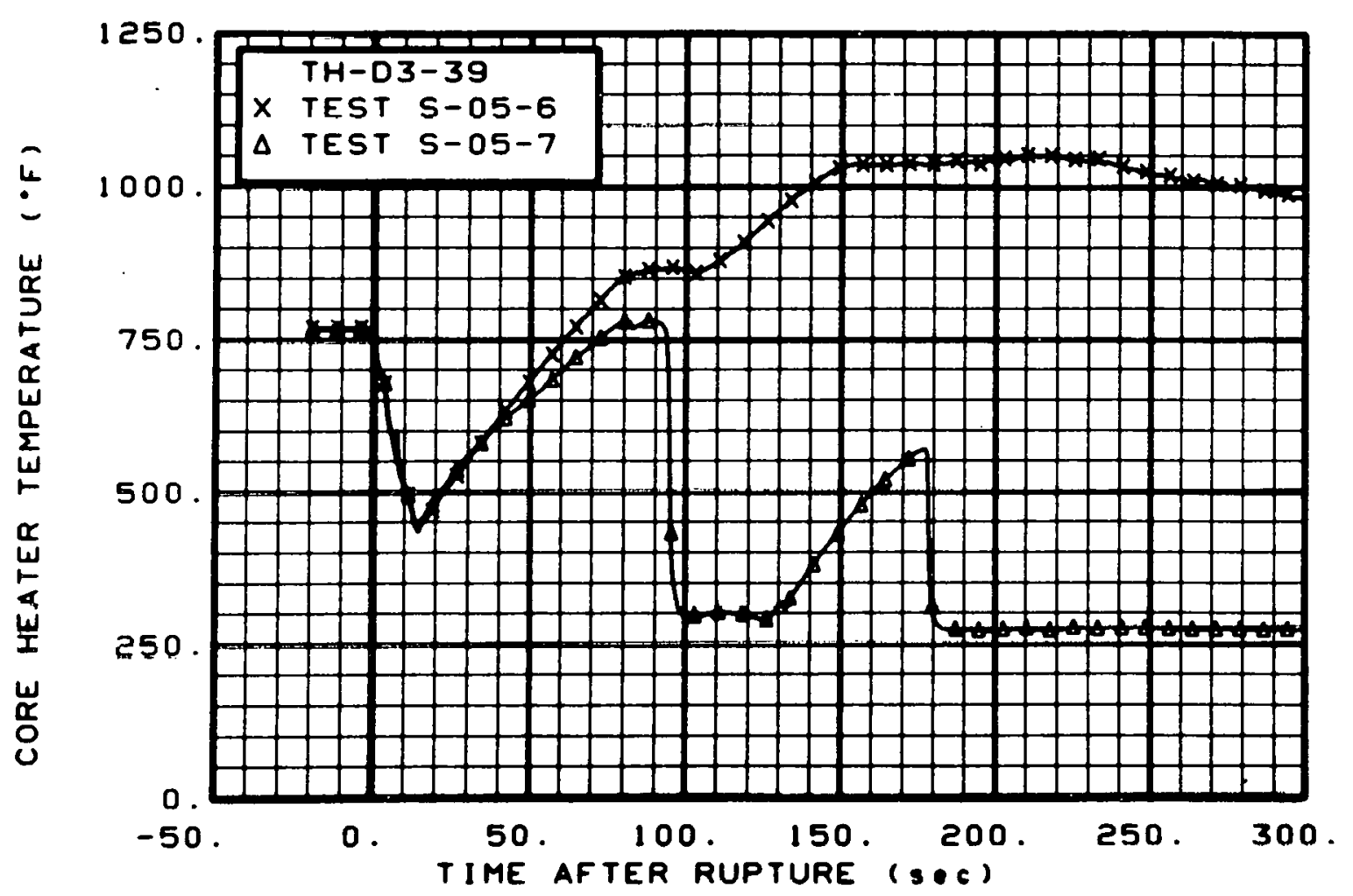

Fig. 170 Core heater temperature, Rod D-3 (TH-D3-39), from -20 to $300 \mathrm{sec}$.

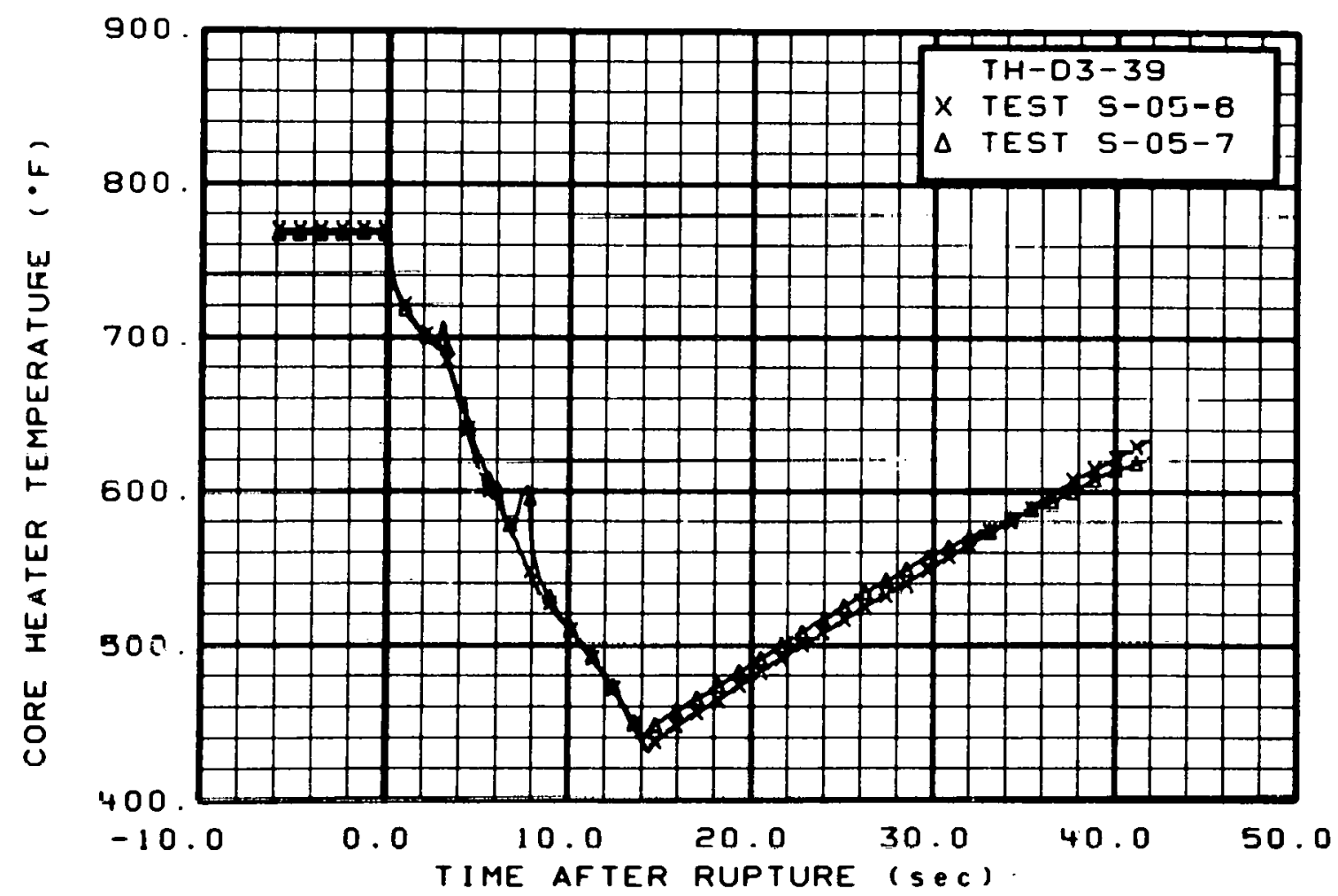

Fig. 171 Core heater temperature, Rod D-3 (TH-D3-39), from -6 to $42 \mathrm{sec}$. 


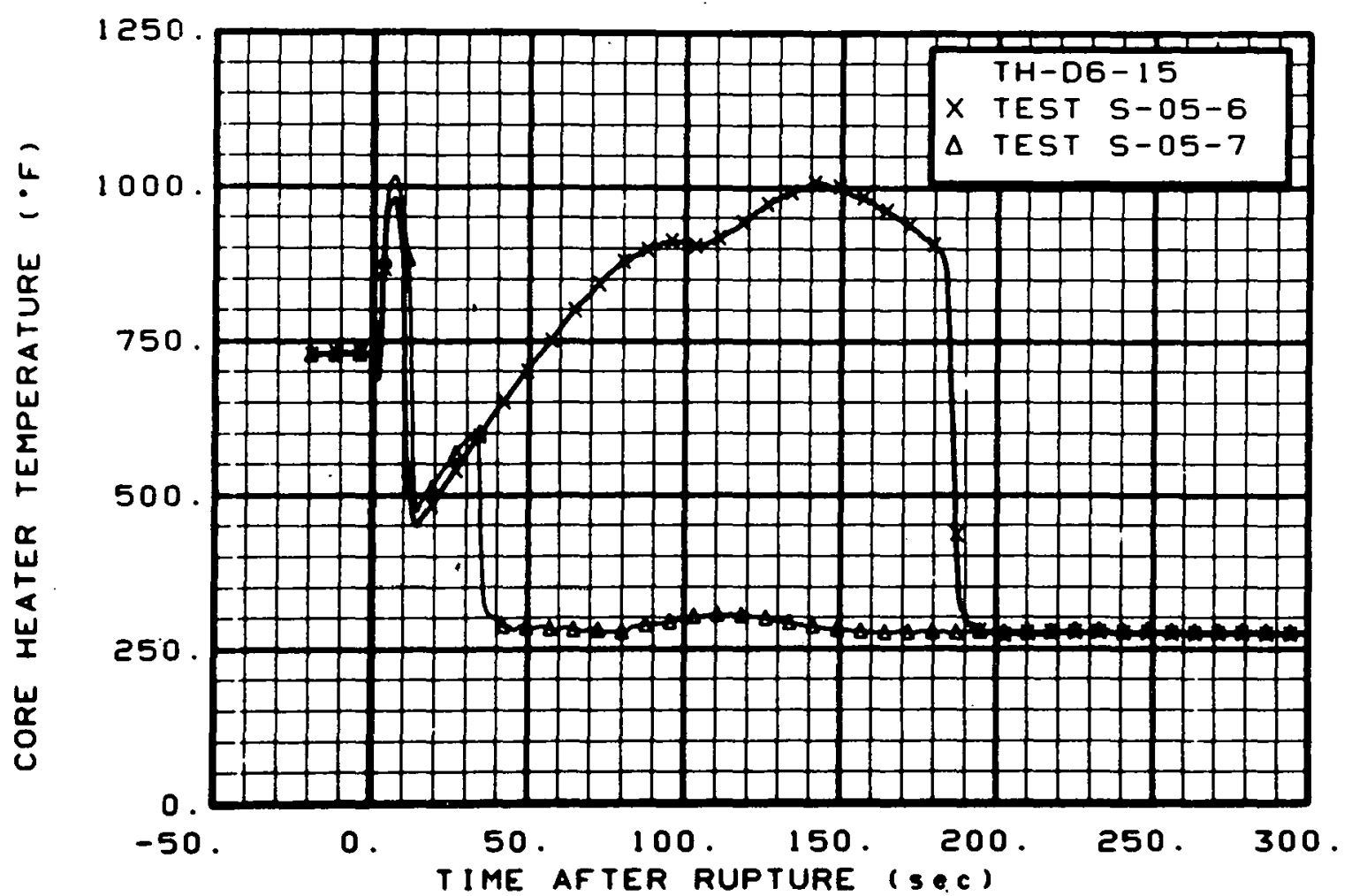

Fig. 172 Core heater temperature, Rod D-6 (TH-D6-15), from -20 to $300 \mathrm{sec}$.

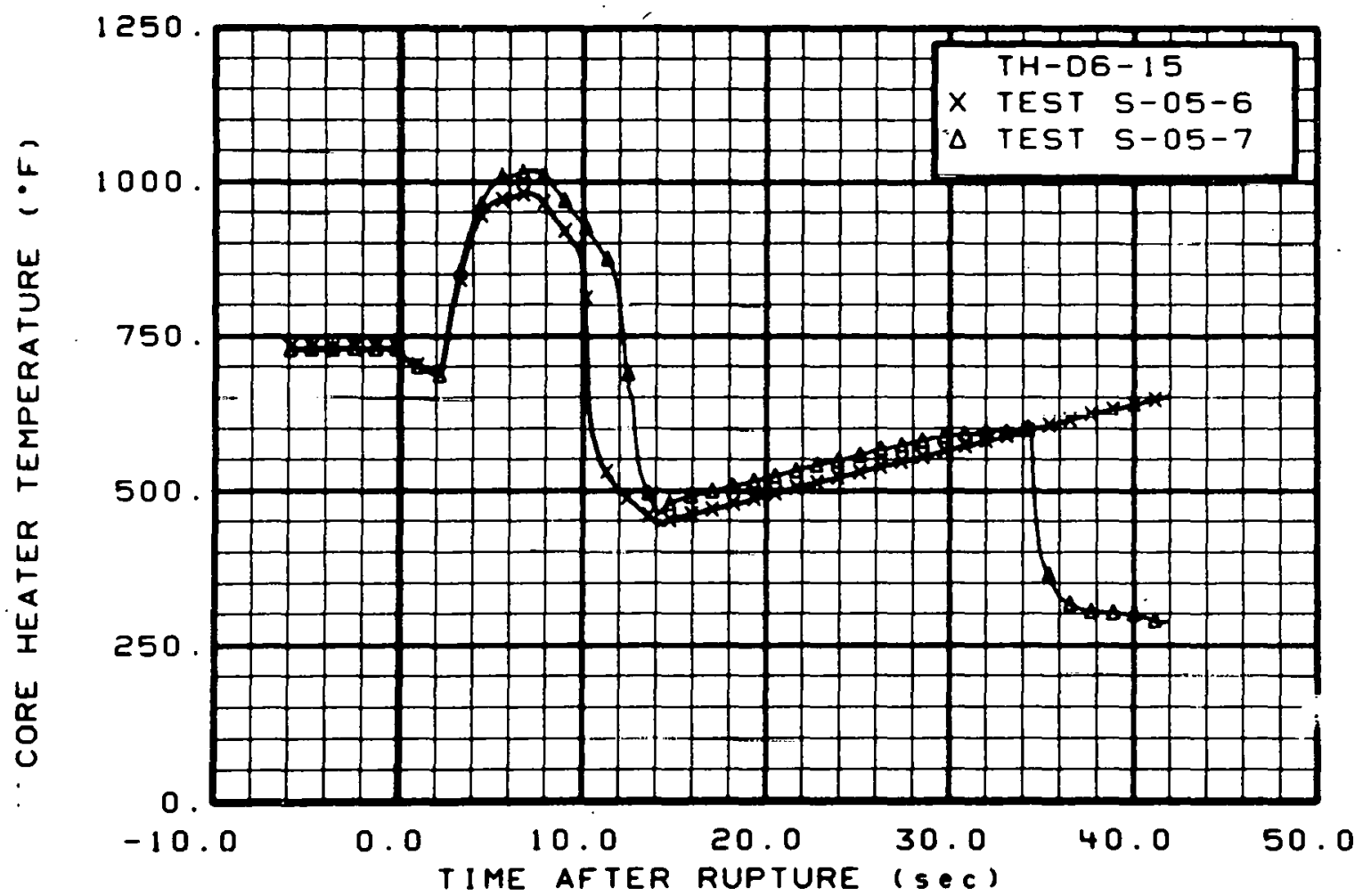

Fig. 173 Core heater temperature, Rod D-6 (TH-D6-15), from -6 to 42 sec. 


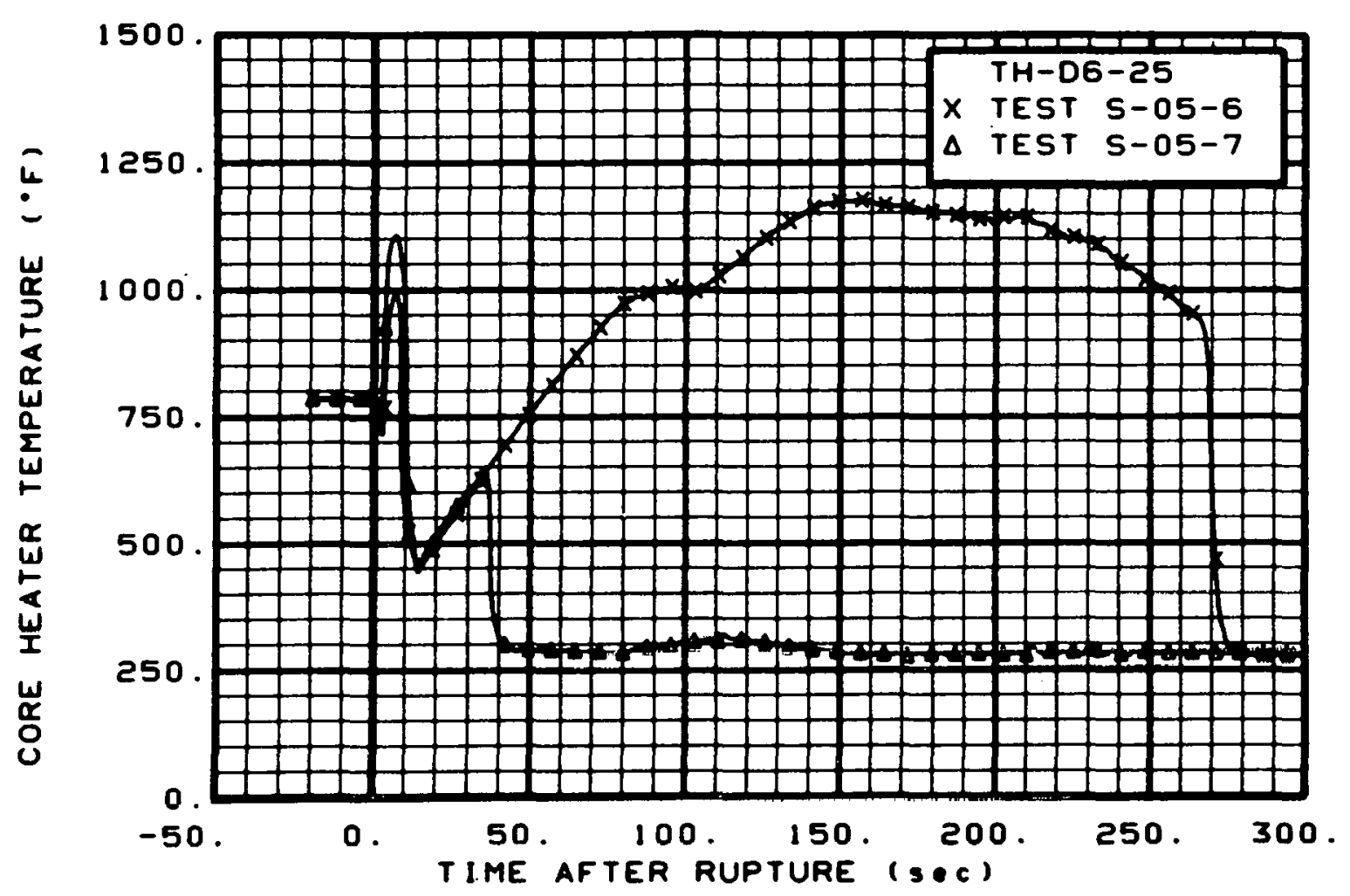

Fig. 174 Core heater temperature, Rod D-6 (TH-D6-25), from -20 to $300 \mathrm{sec}$.

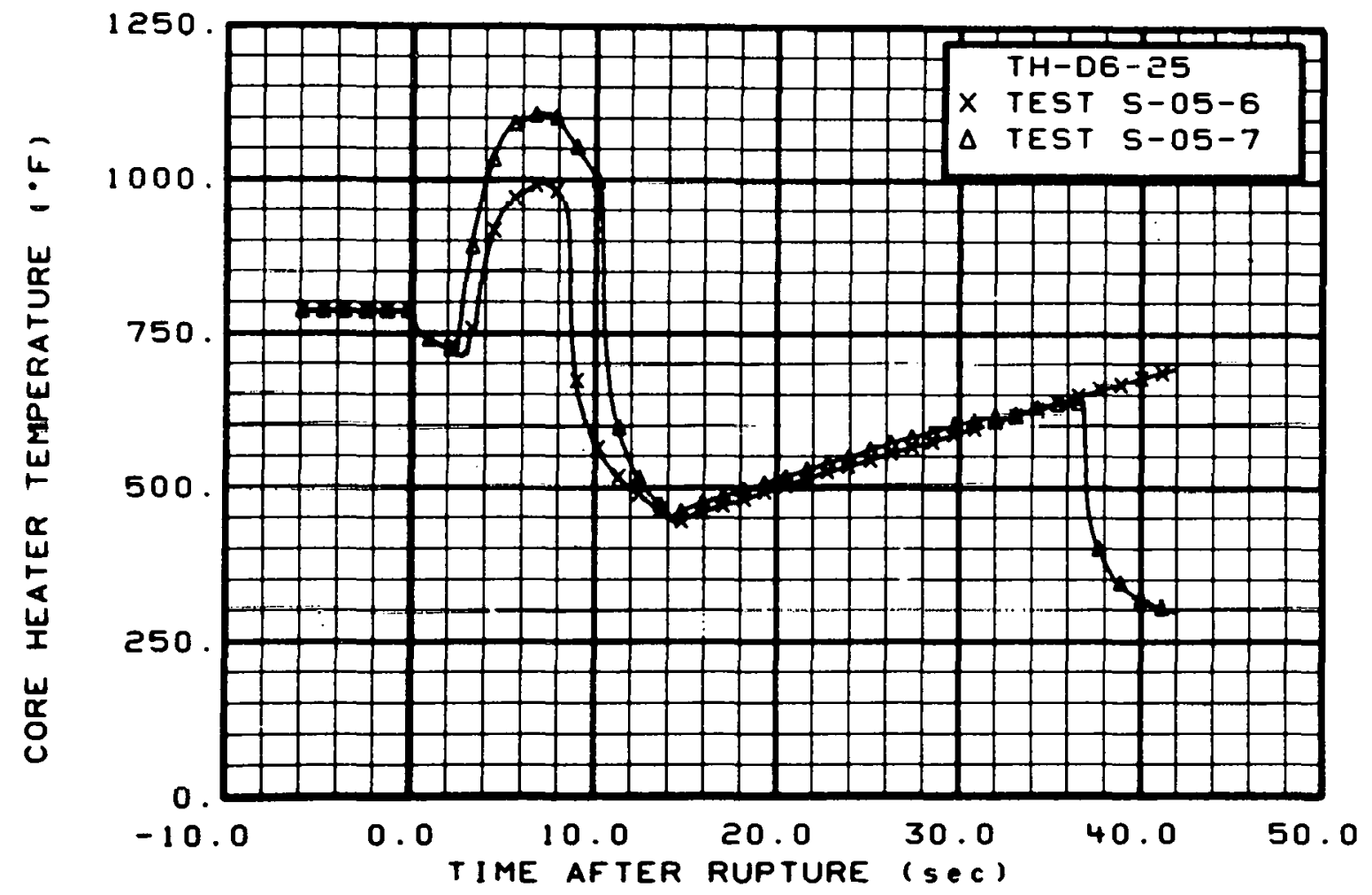

Fig. 175 Core heater temperature, Rod D-6 (TH-D6-25), from -6 to $42 \mathrm{sec}$. 


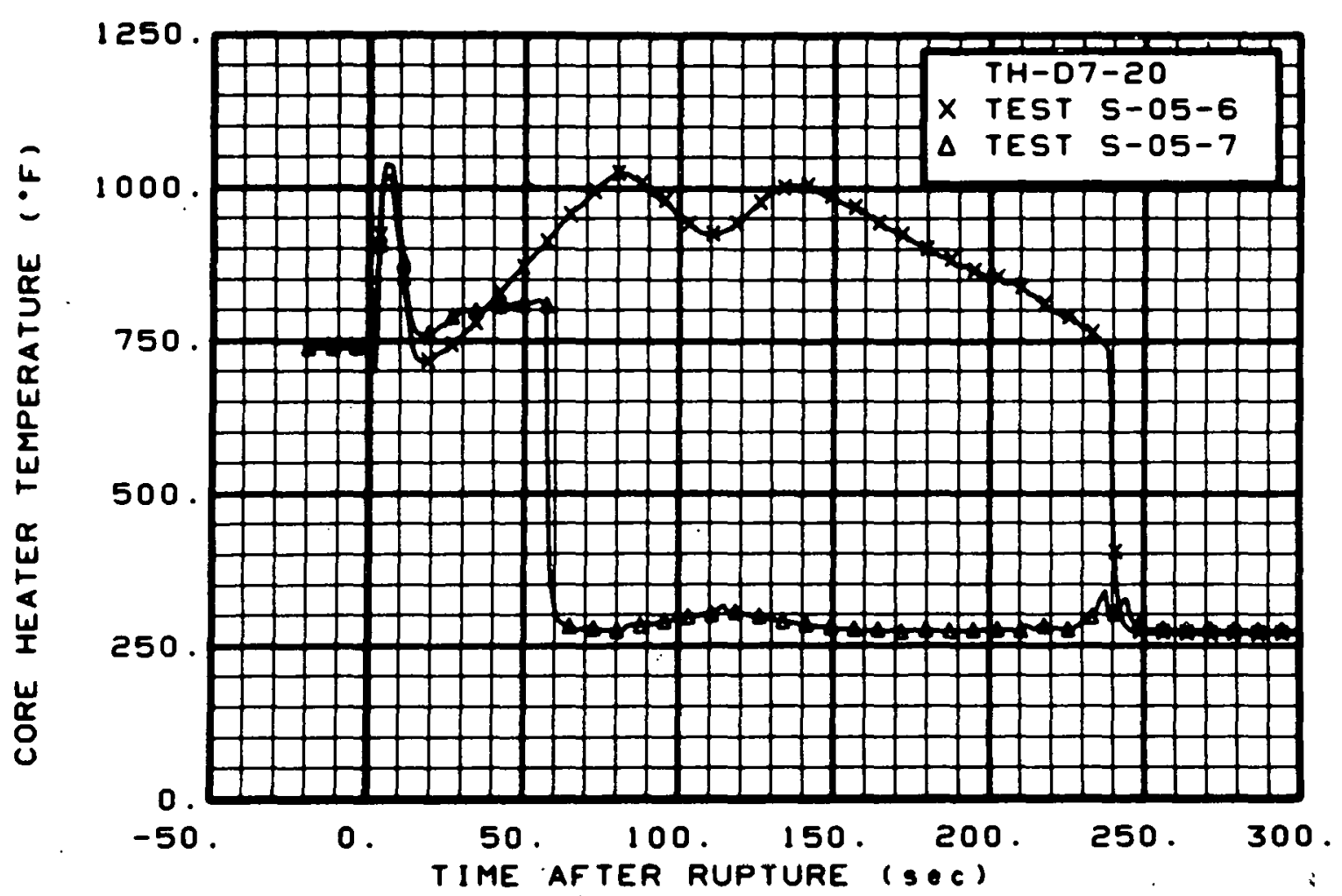

Fig. 176 Core heater temperature, Rod D-7 (TH-D7-20), from -20 to $300 \mathrm{sec}$.

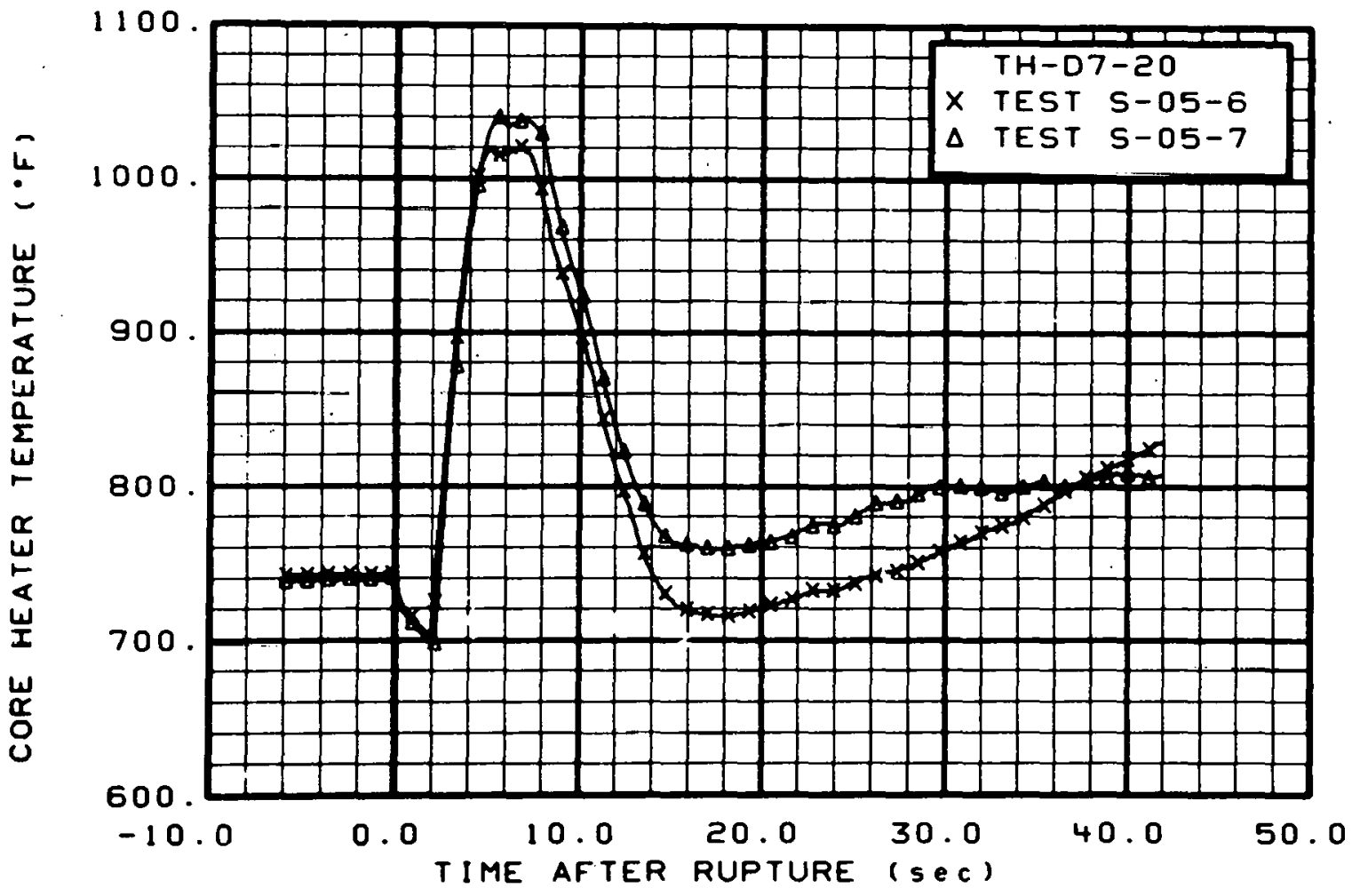

Fig. 177 Core heater temperature, Rod D-7 (TH-D7-20), from -6 to $42 \mathrm{sec}$. 


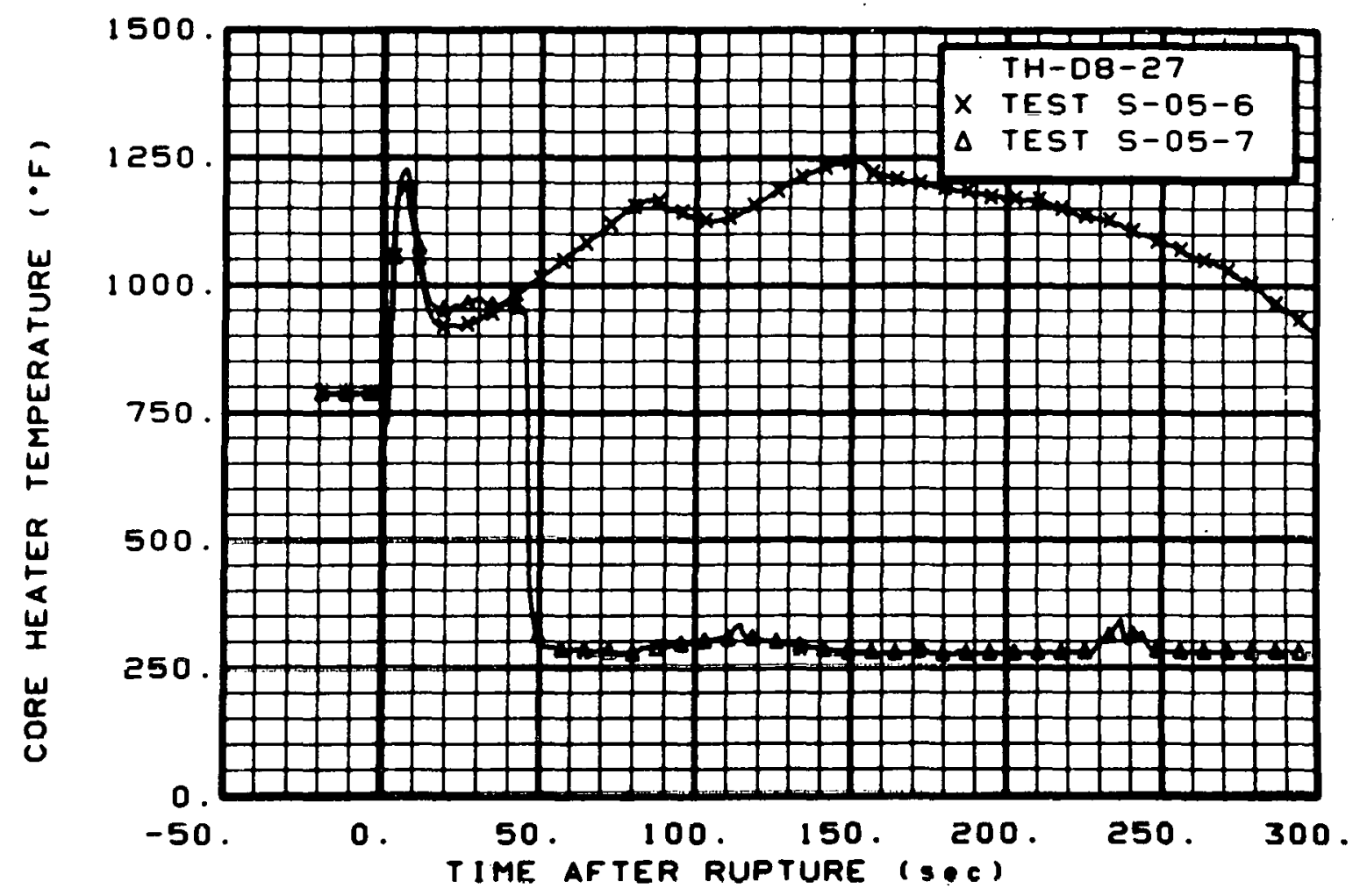

Fig. 178 Core heater temperature, Rod D-8 (TH-D8-27), from -20 to $300 \mathrm{sec}$.

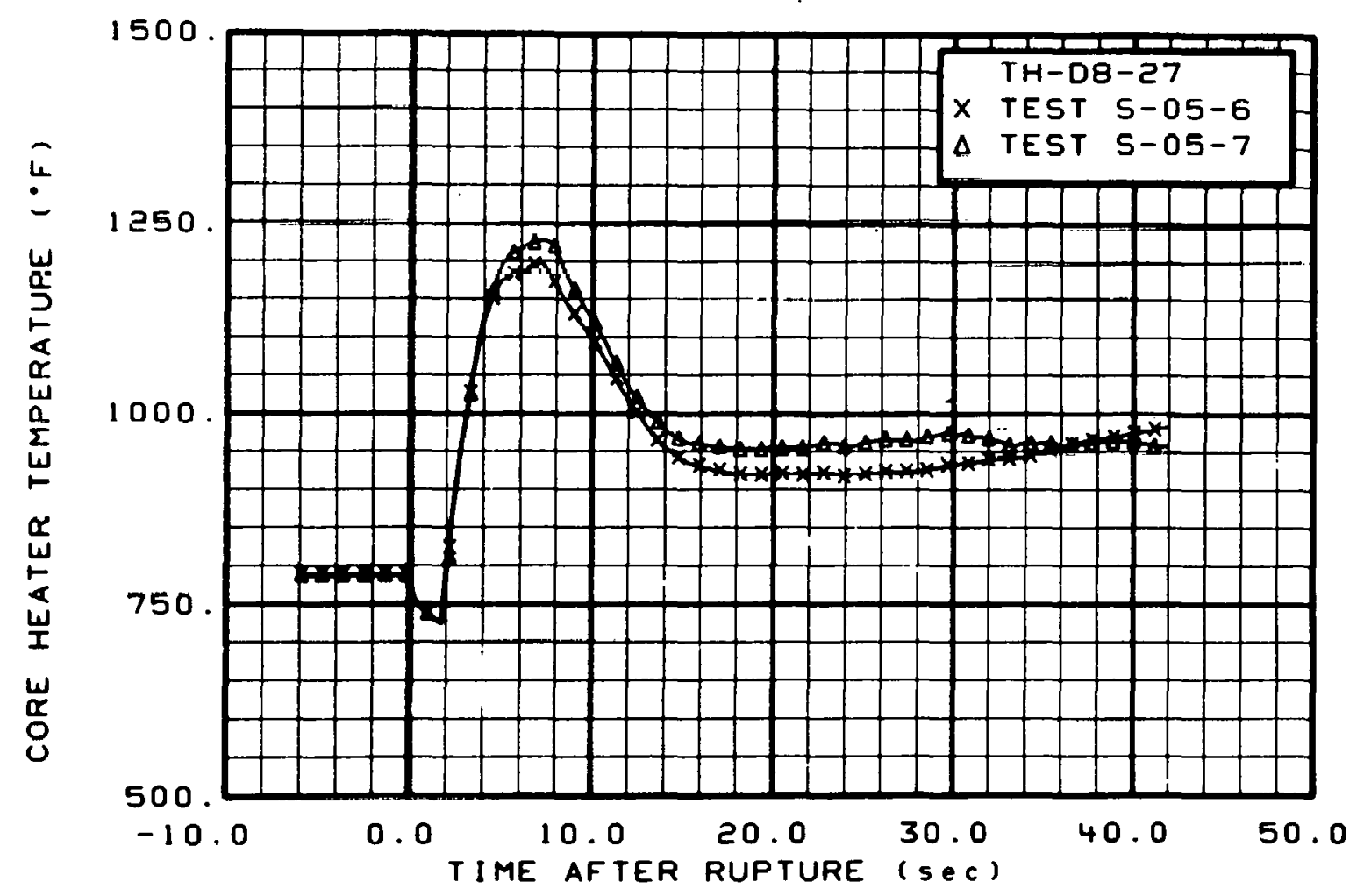

Fig. 179 Core heater temperature, Rod D-8 (TH-D8-27), from -6 to $42 \mathrm{sec}$. 


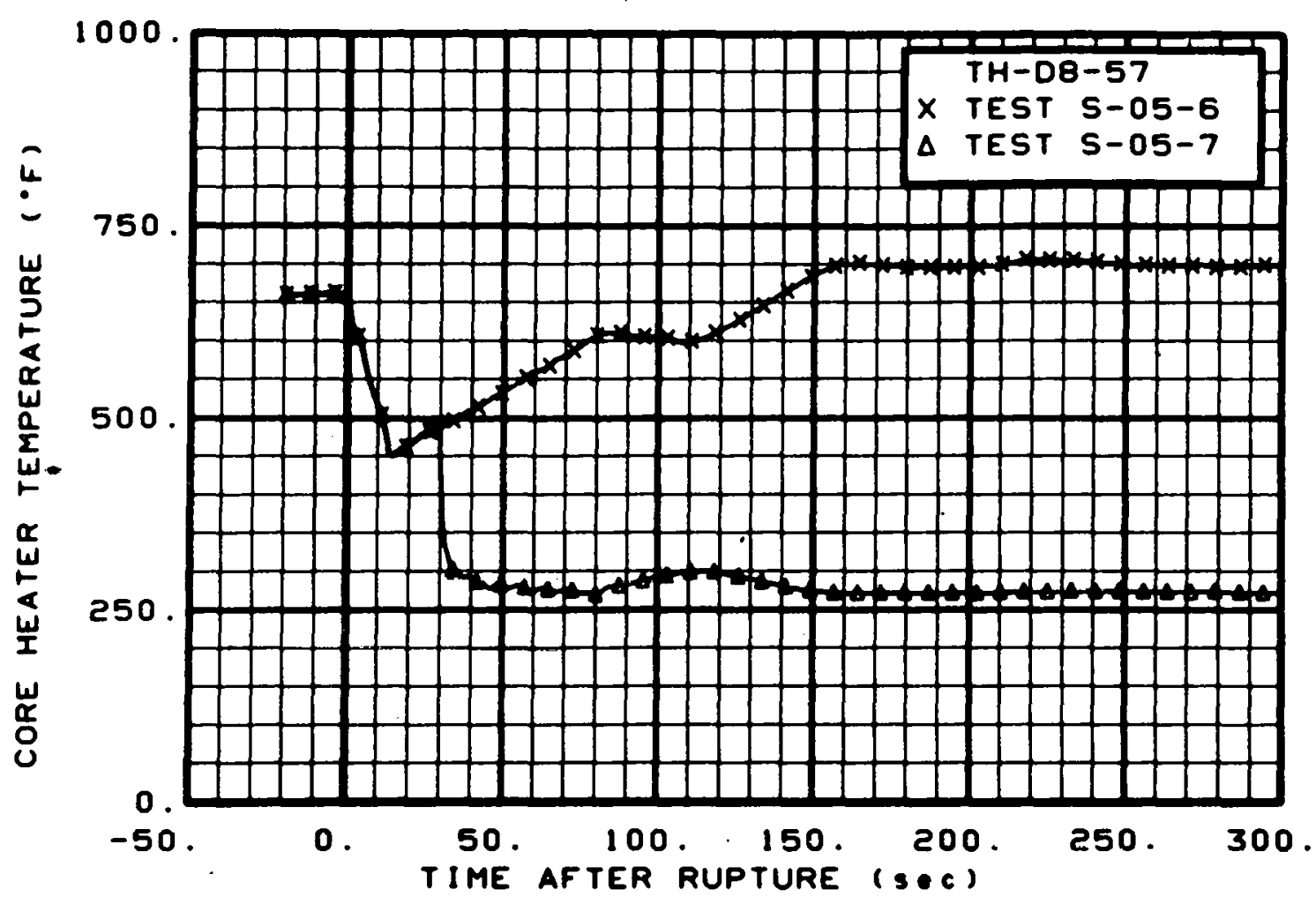

Fig. 180 Core heater temperature, Rod D-8 (TH-D8-57), from -20 to 300 sec. $\because$

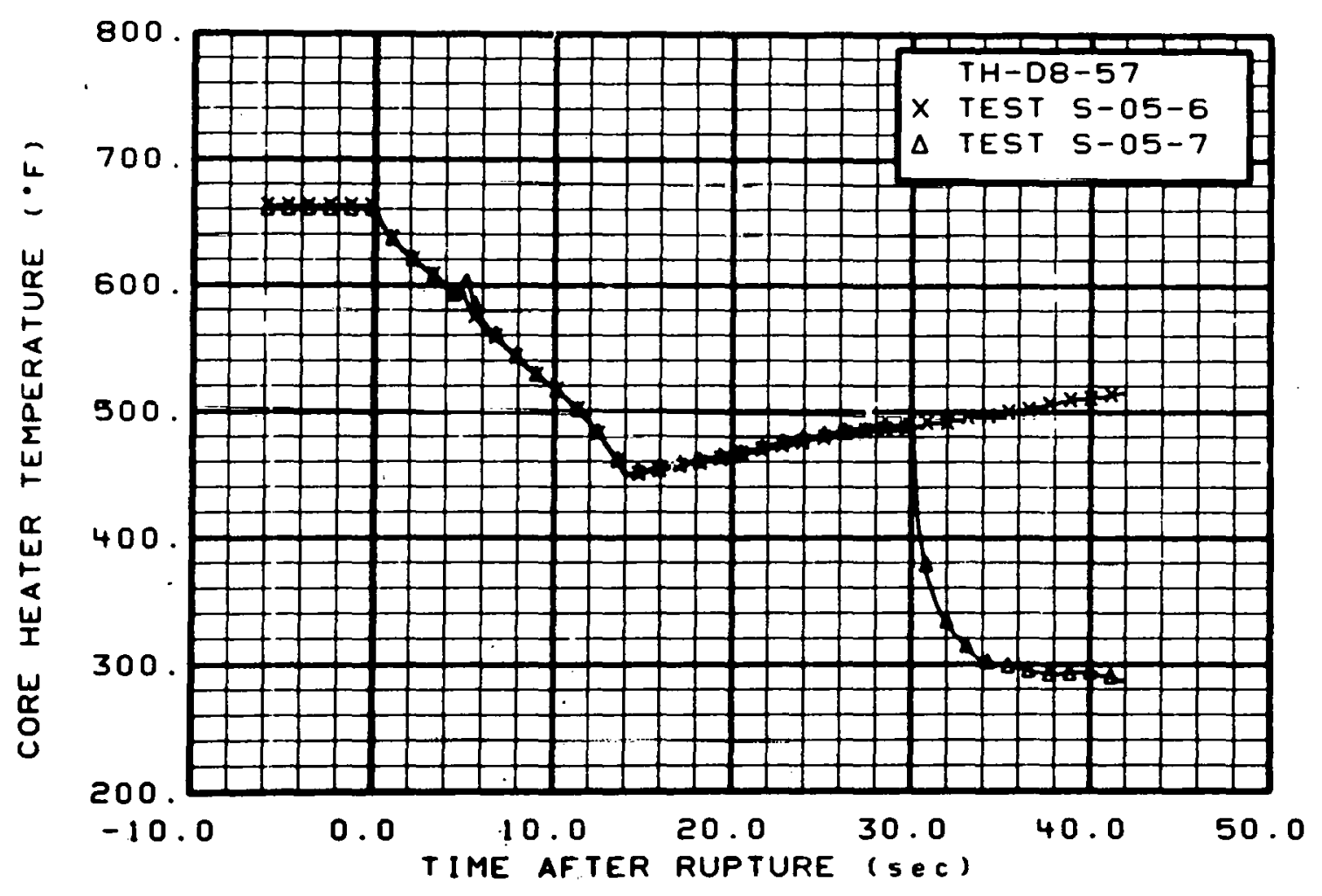

Fig. 181 Core heater temperature, Rod D-8 (TH-D8-57), from -6 to 42 sec. 


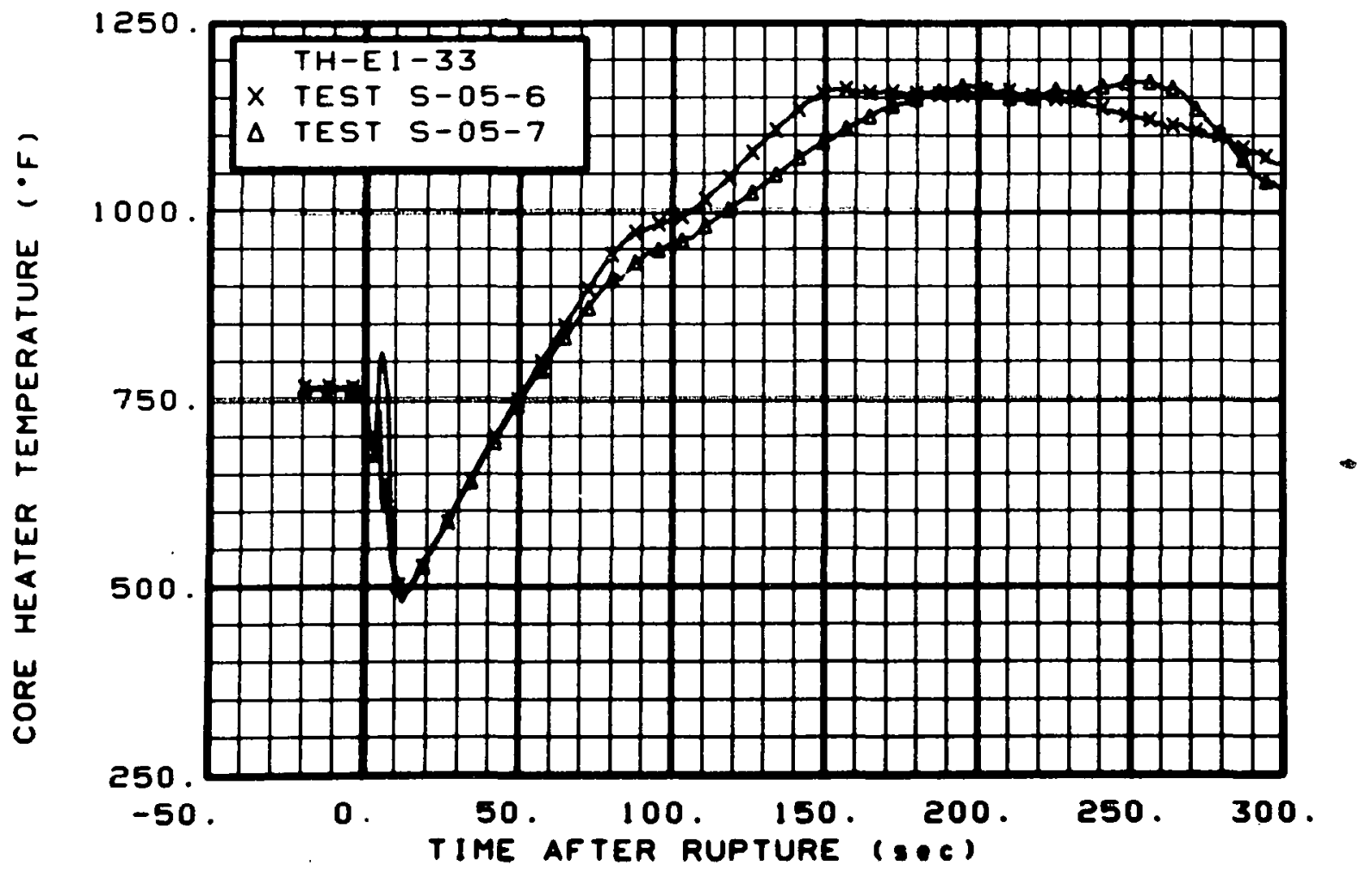

Fig. 182 Core heater temperature, Rod E-1 (TH-ET-33), from -20 to $300 \mathrm{sec}$.

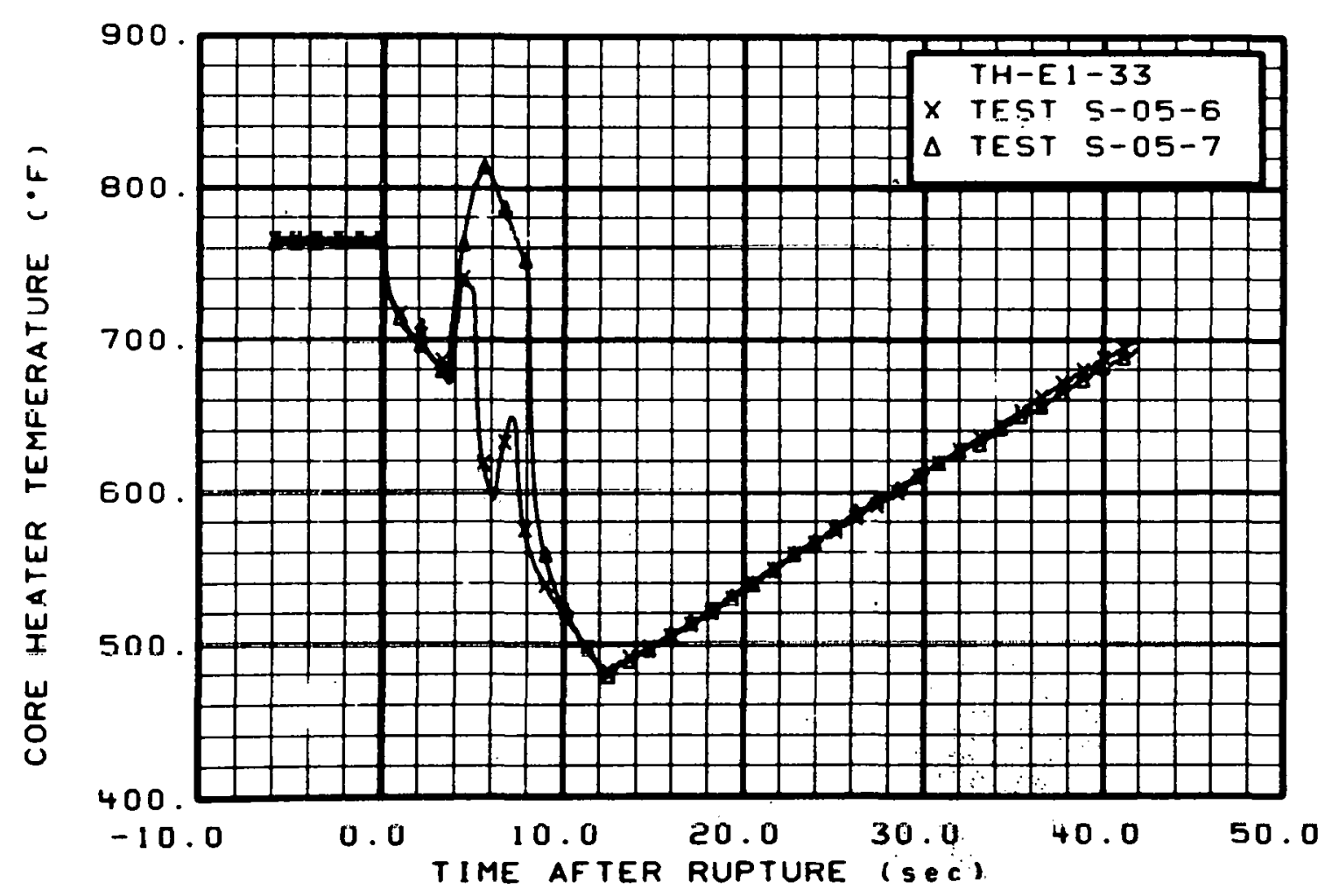

Fig. 183 Core heater temperature, Rod E-1 (TH-E 1-33), from -6 to $42 \mathrm{sec}$. 


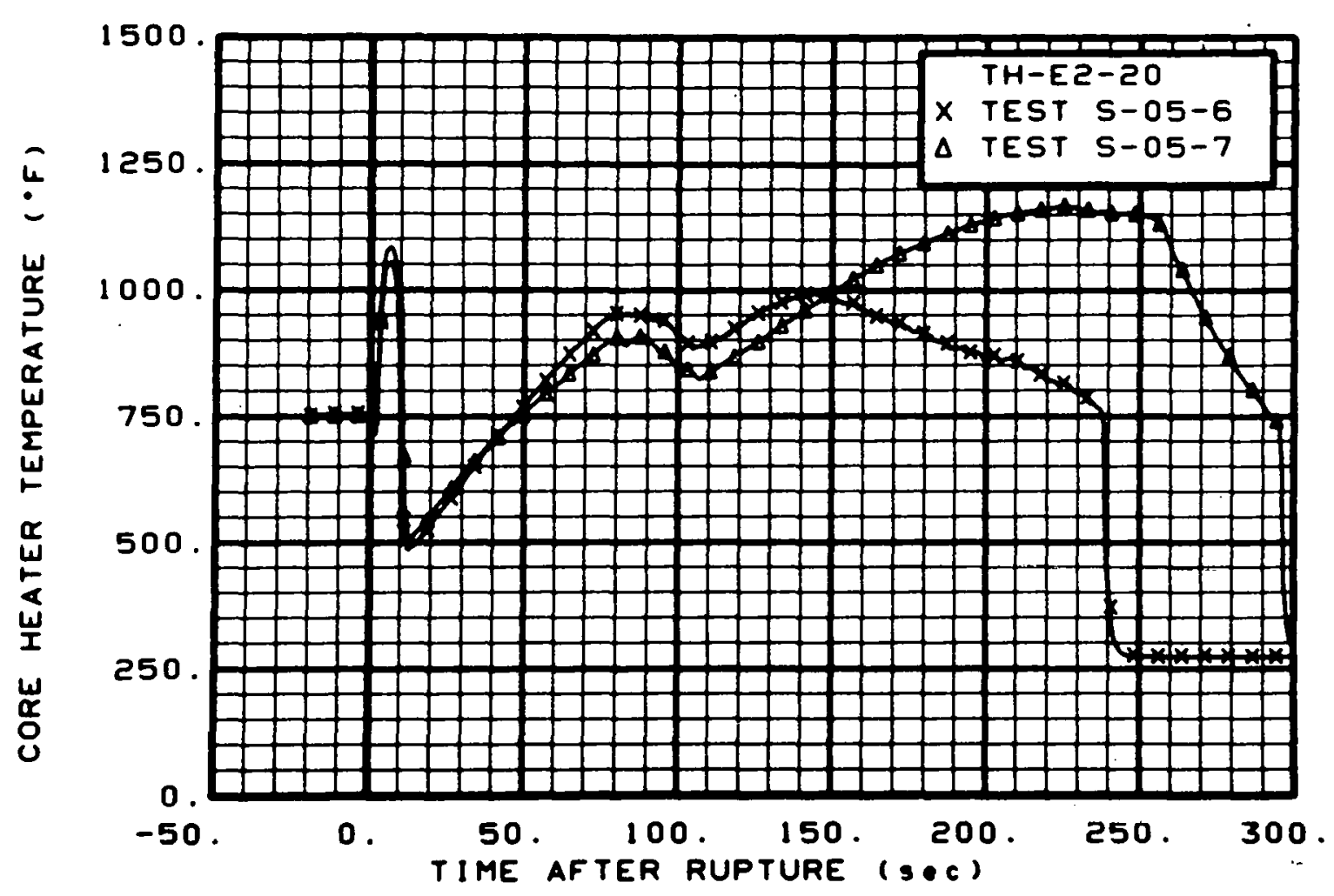

Fig. 184 Core heater temperature, Rod $F_{-}-2(T H-E 2-20)$, from -20 to 300 sec.

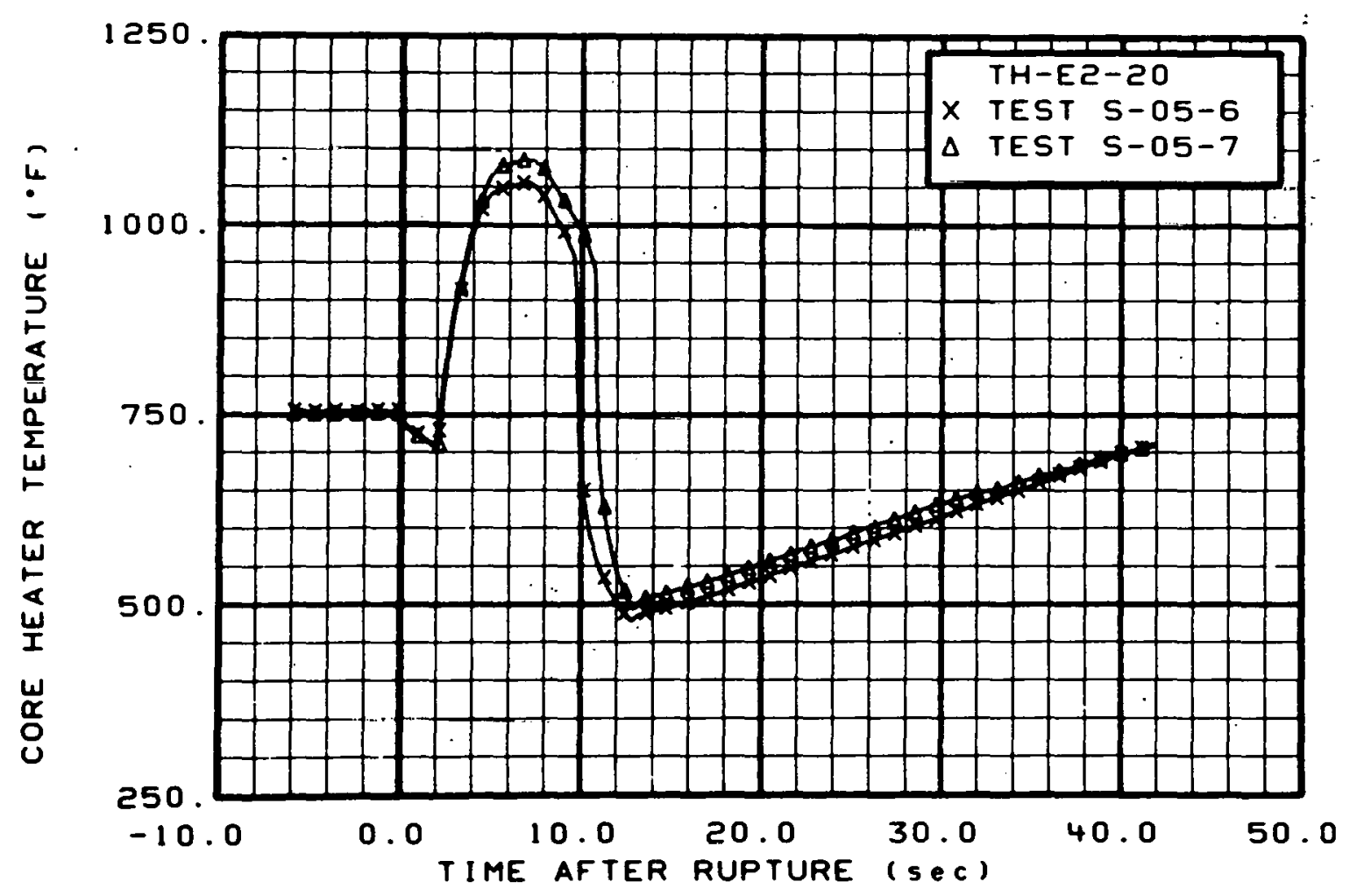

Fig. 185 Core heater temperature, Rod E-2 (TH-E2-20), from -6 to 42 sec. 


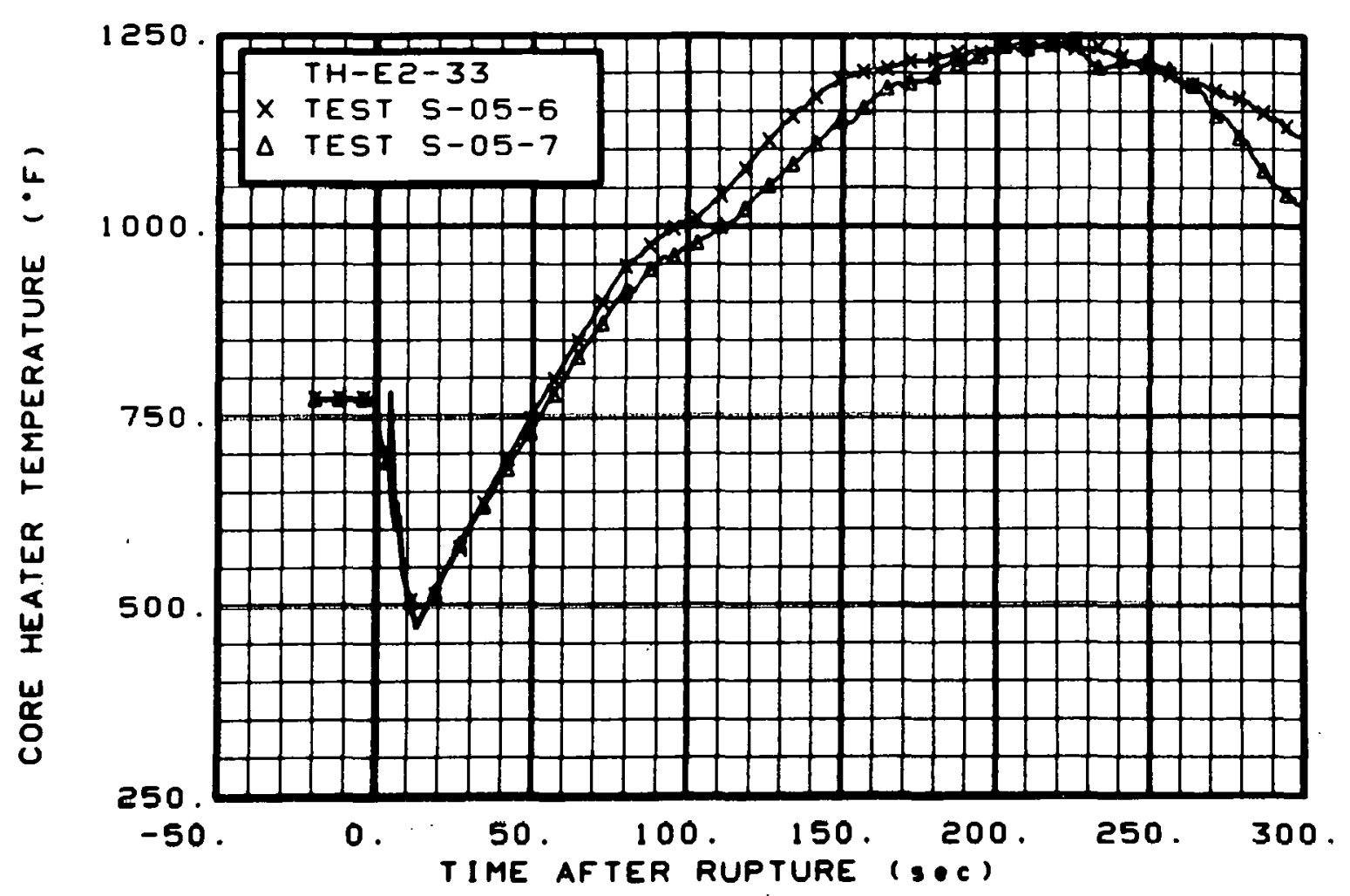

Fig. 186 Core heater temperature, Rod E-2 (TH-E2-33), from -20 to $300 \mathrm{sec}$.

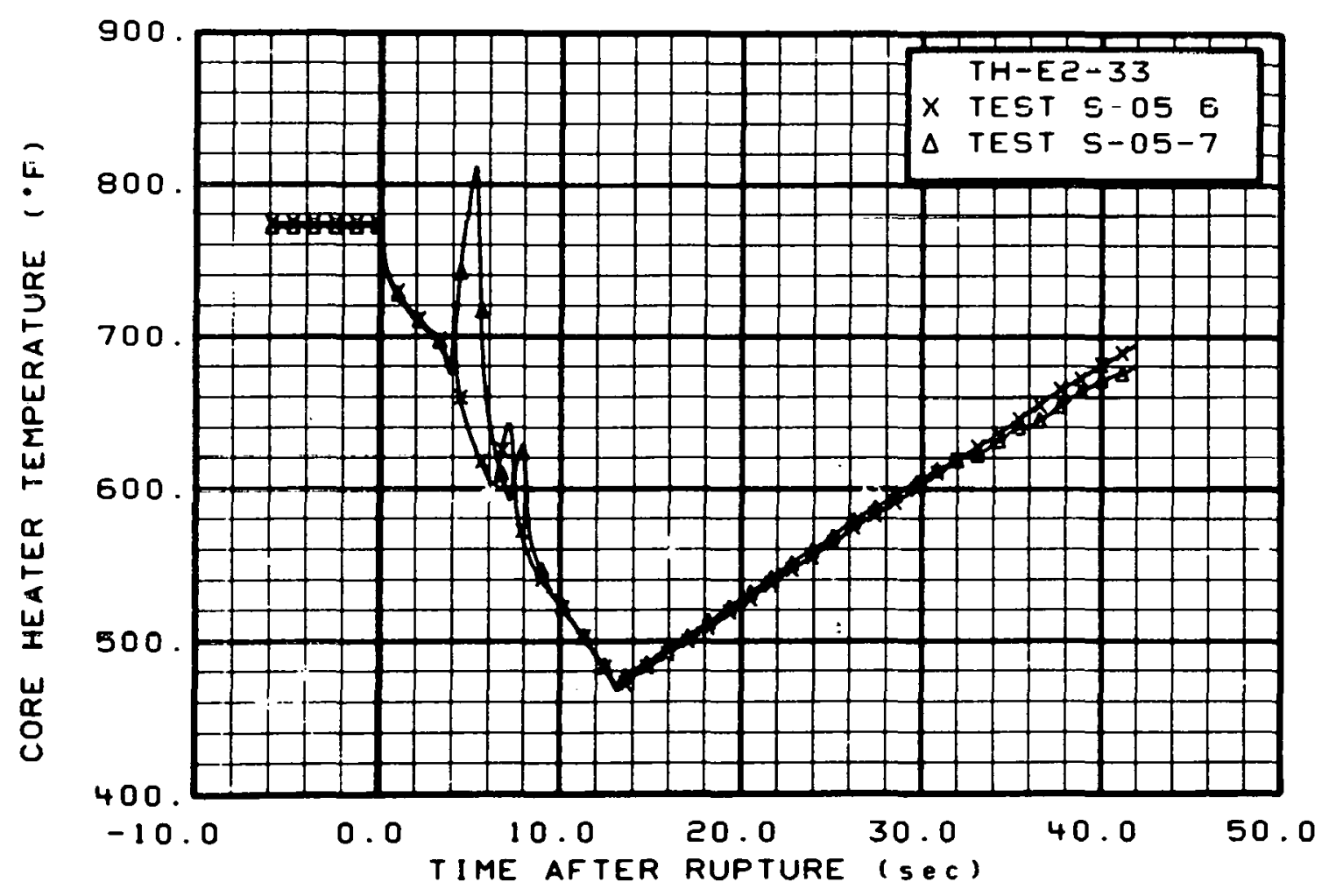

Fig. 187 Core heater temperature, Rod E-2 (TH-E2-33), from -6 to $42 \mathrm{sec}$. 


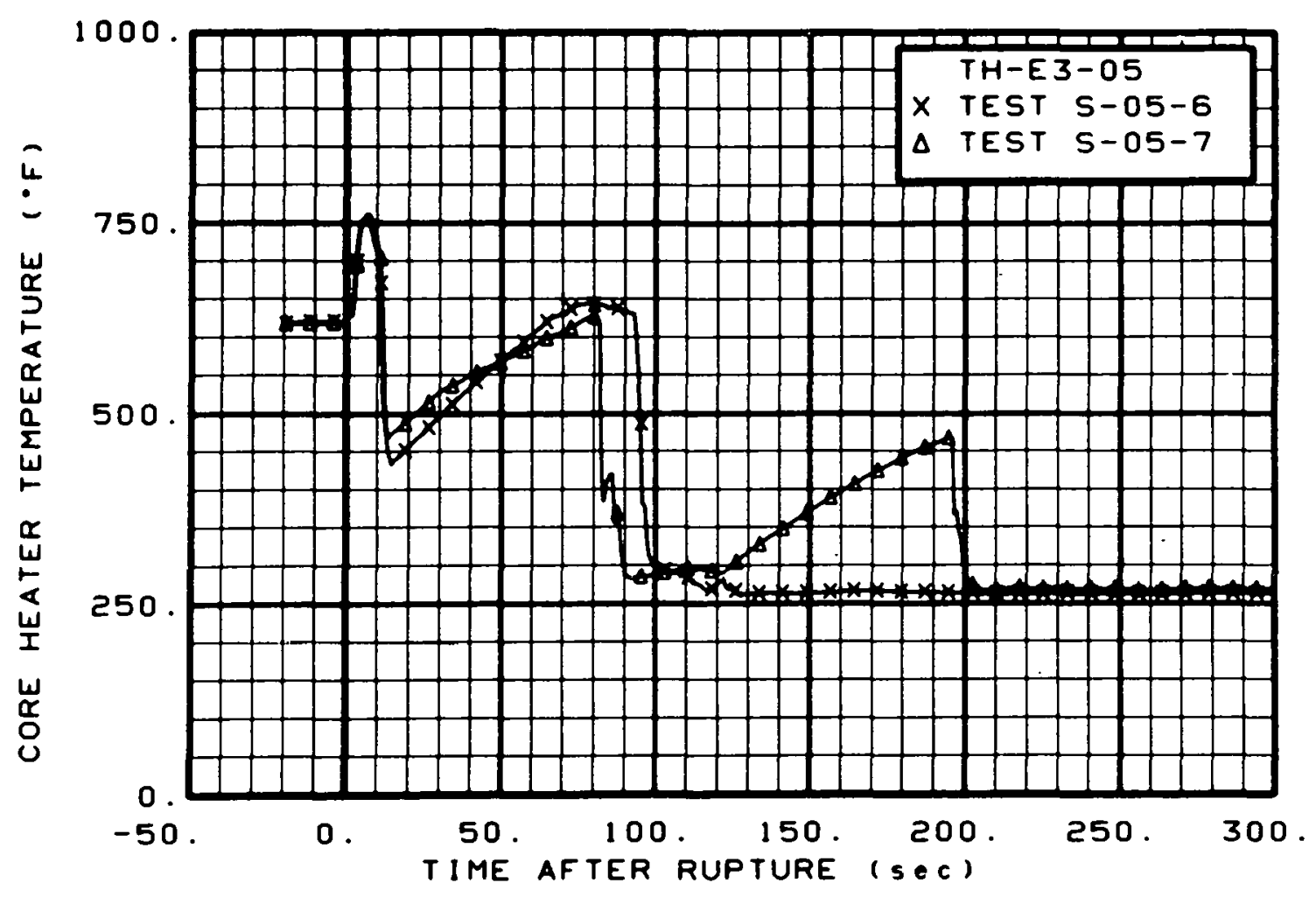

Fig. 188 Core heater temperature, Rod E-3 (TH-E3-05), from -20 to $300 \mathrm{sec}$.

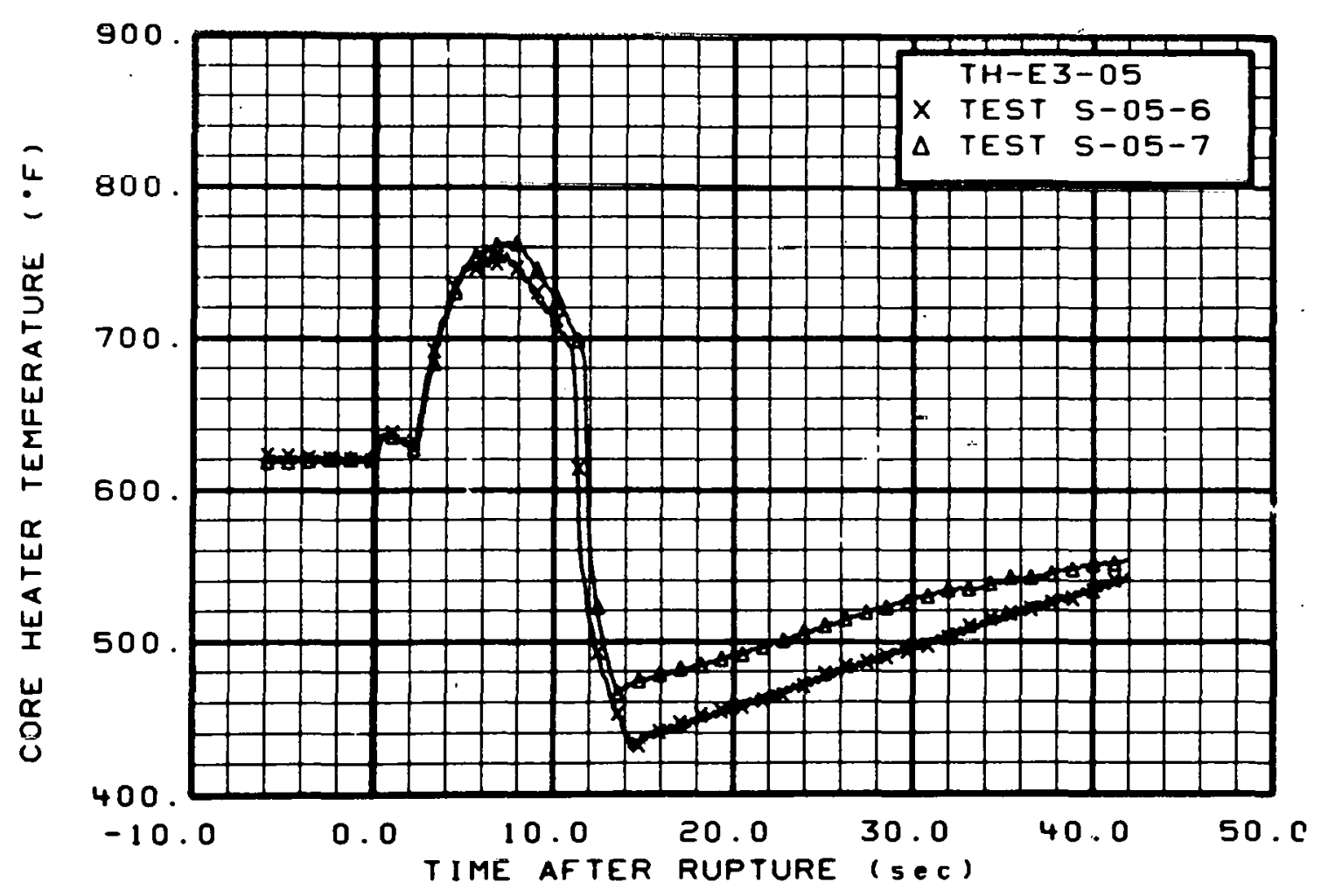

Fig. 189 Core heater temperature, Rod E-3 (TH-E3-05), from -6 to $42 \mathrm{sec}$. 


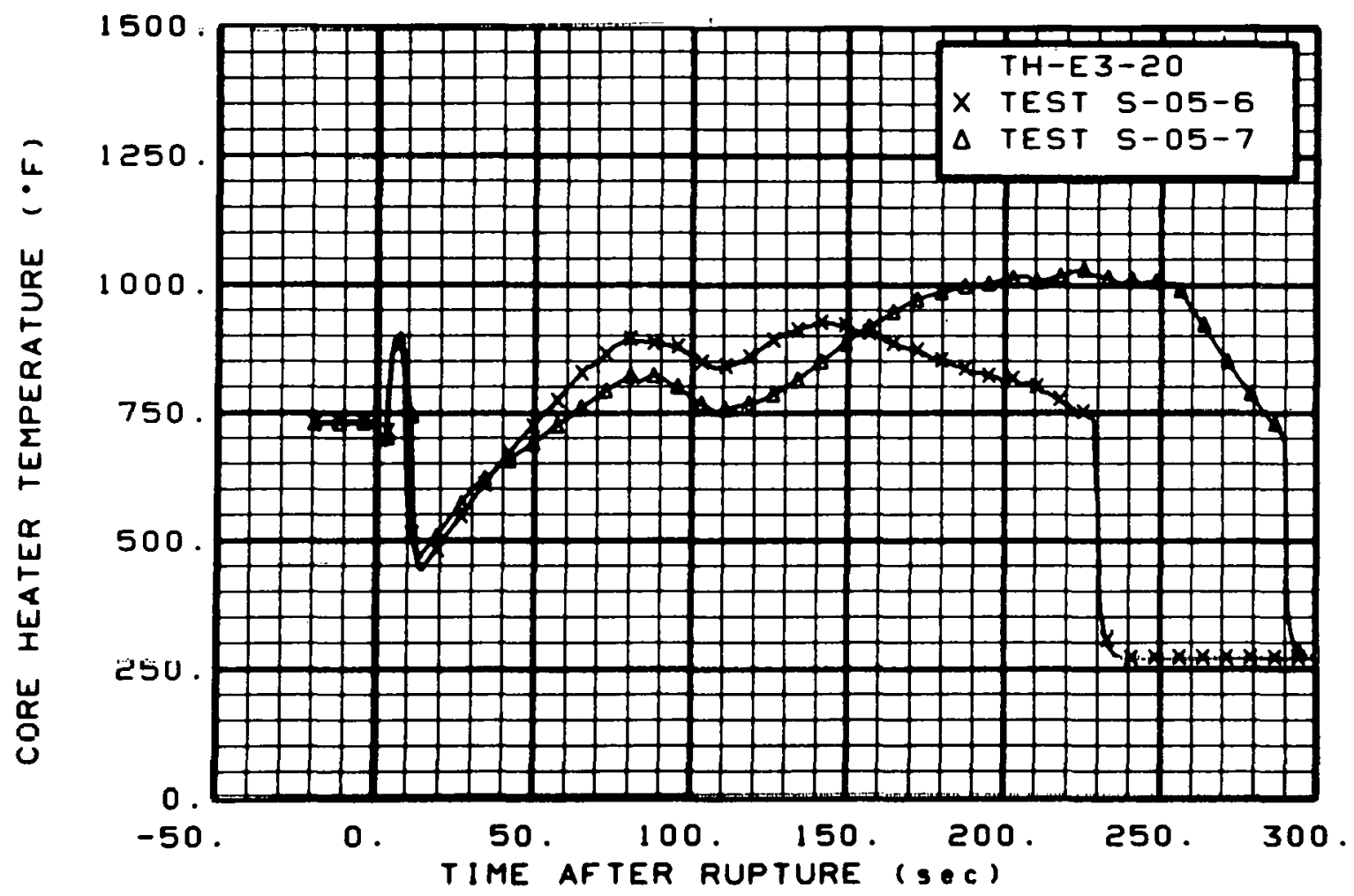

Fig. 190 Core heater temperature, Rod E-3 (TH-E3-20), from -20 to $300 \mathrm{sec}$.

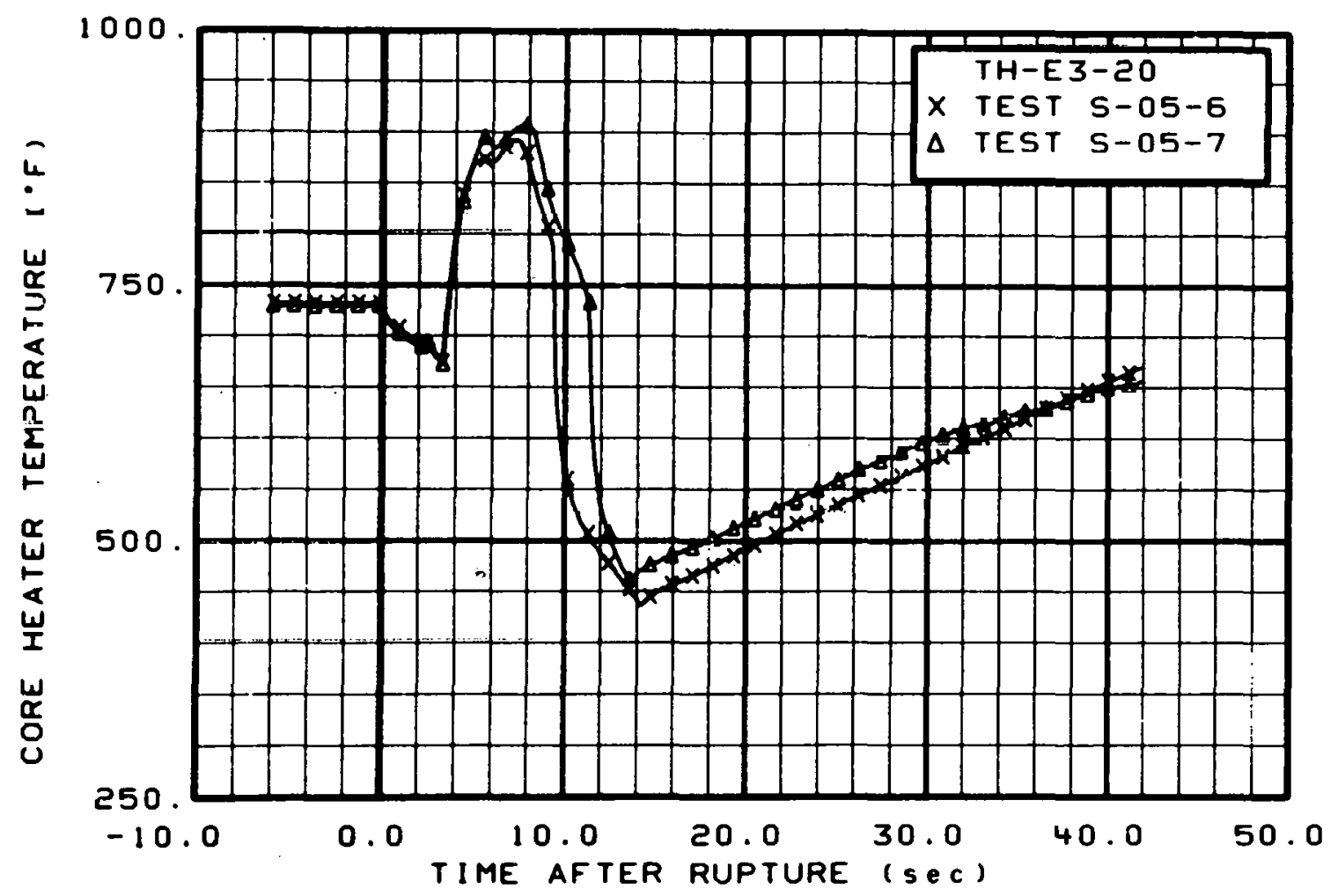

Fig. 191 Core heater temperature, Rod E-3 (TH-E3-20), from -6 to $42 \mathrm{sec}$. 


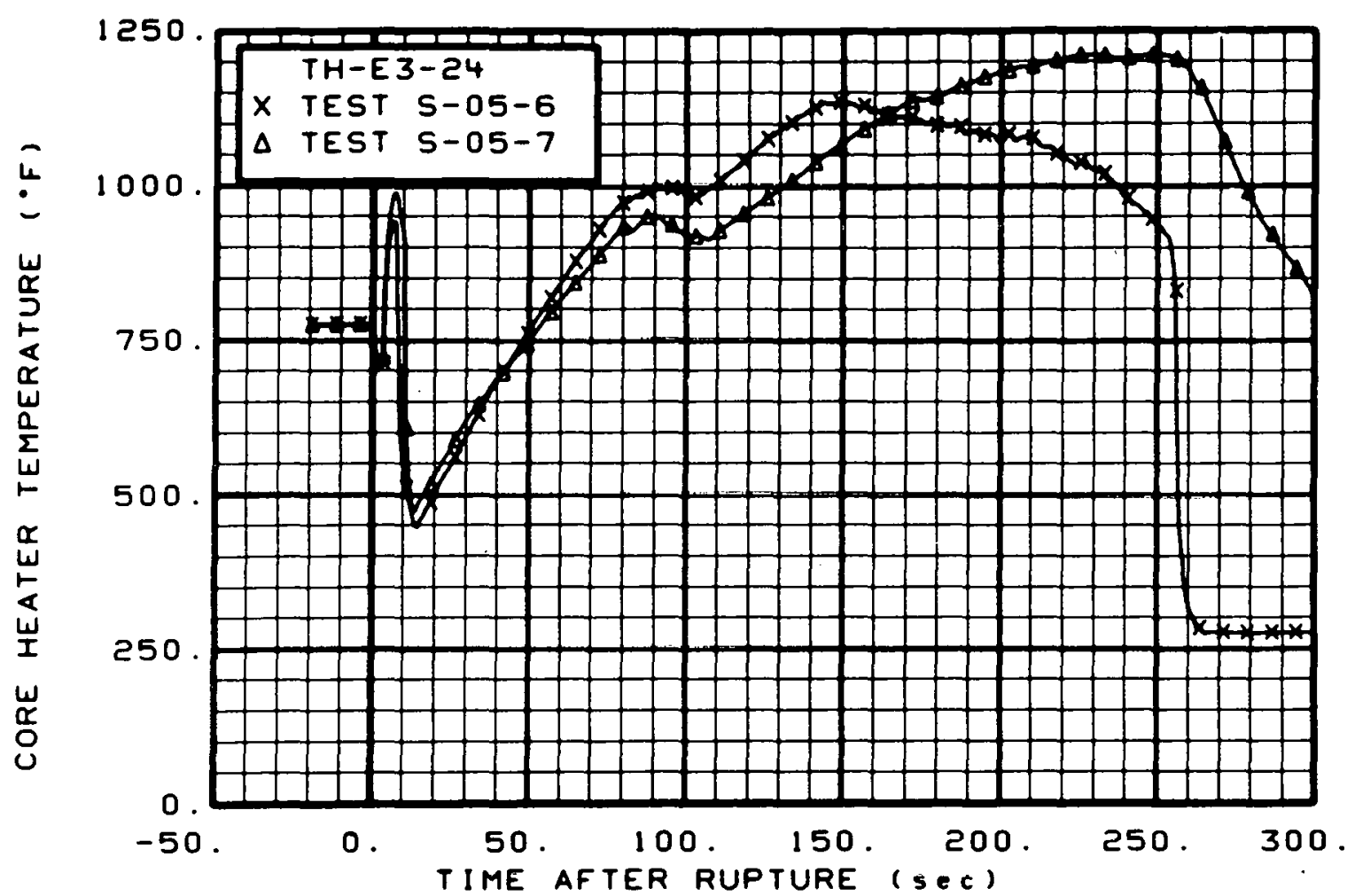

Fig. 192 Core heater temperature, Rod E-3 (TH-E3-24), from -20 to $300 \mathrm{sec}$.

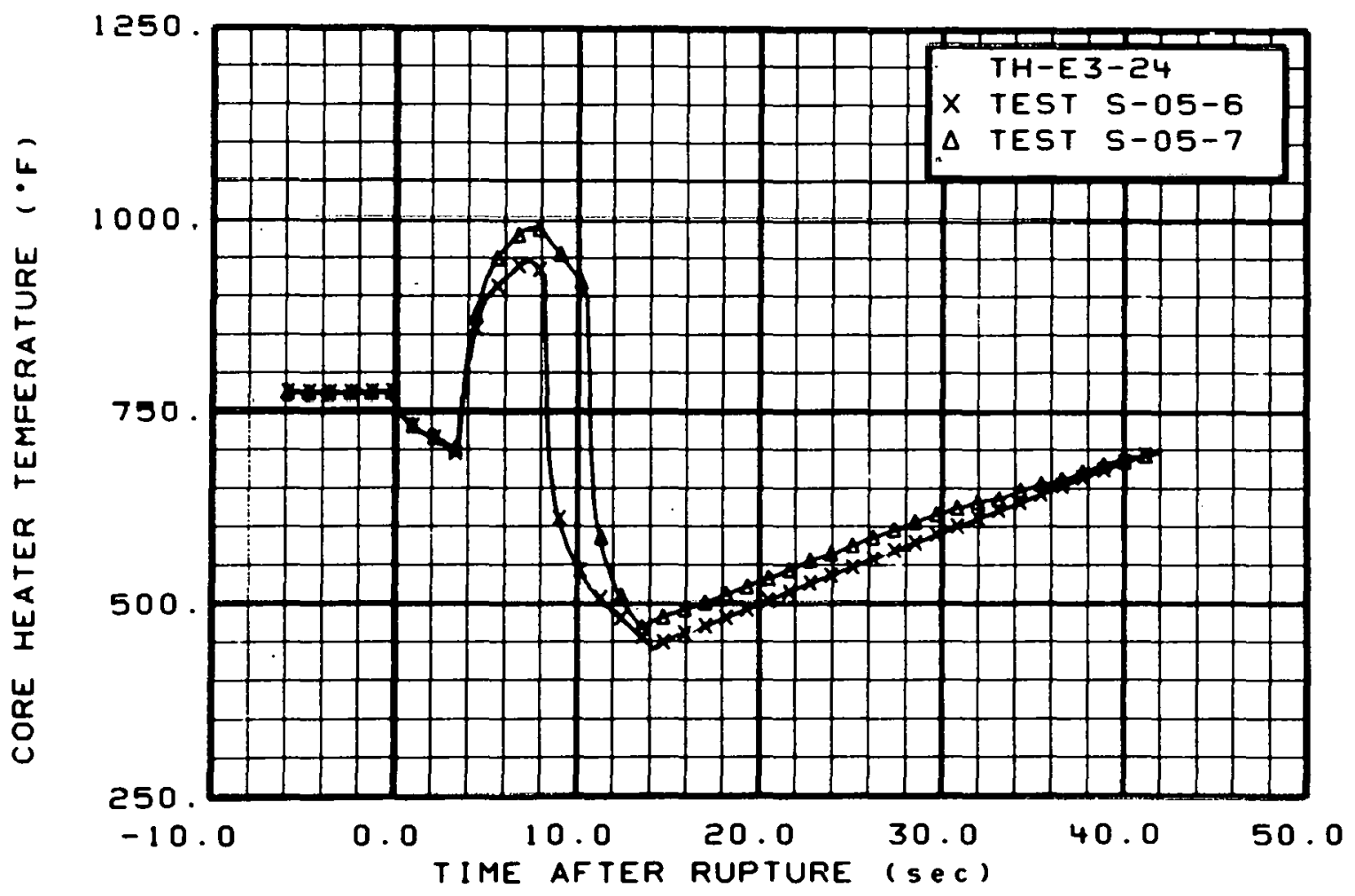

Fig. 193 Core heater temperature, Rod E-3 (TH-E3-24), from -6 to $42 \mathrm{sec}$. 


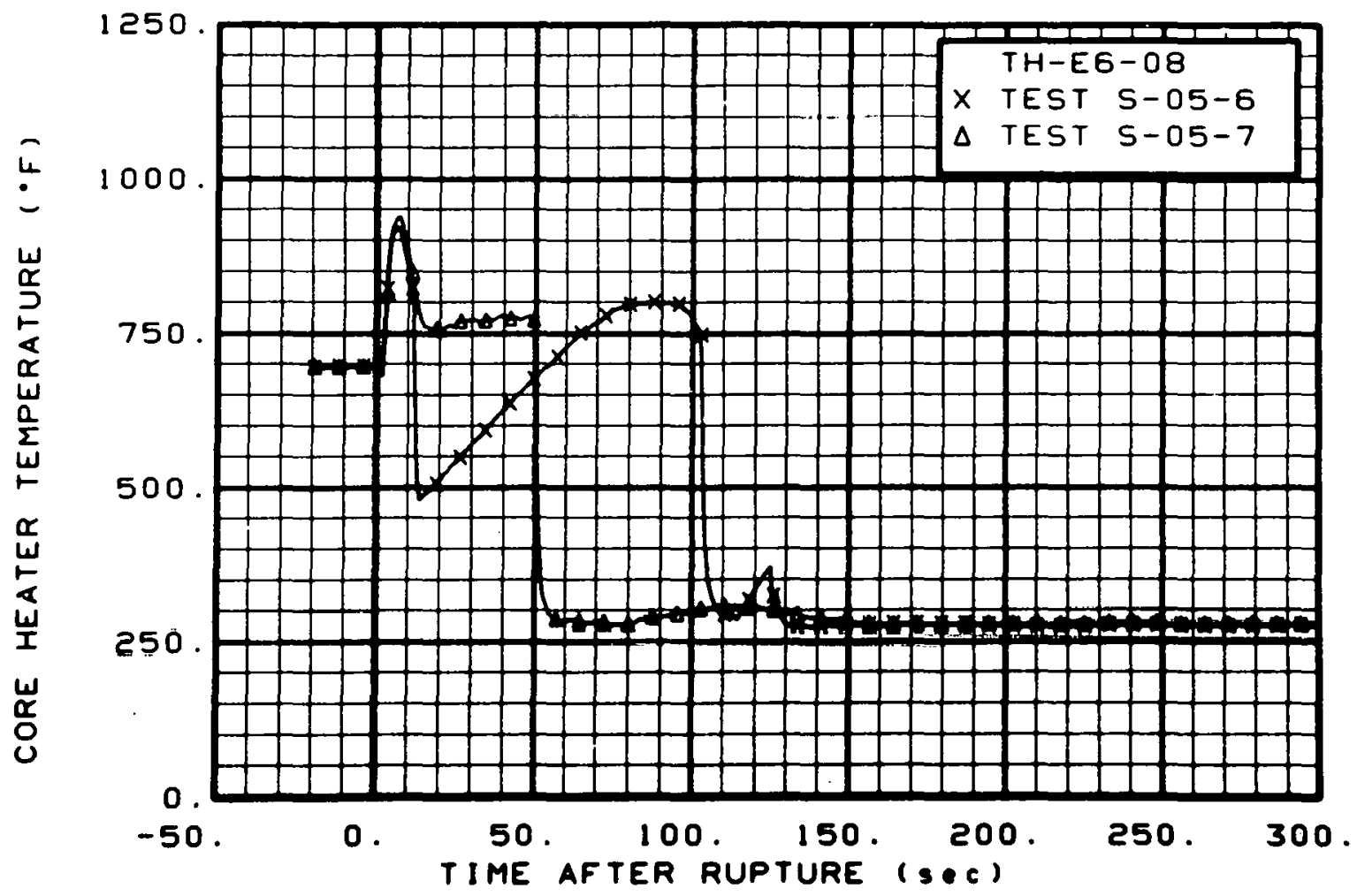

Fig. 194 Core heater temperature, Rod E-6 (TH-E6-08), from -20 to $300 \mathrm{sec}$.

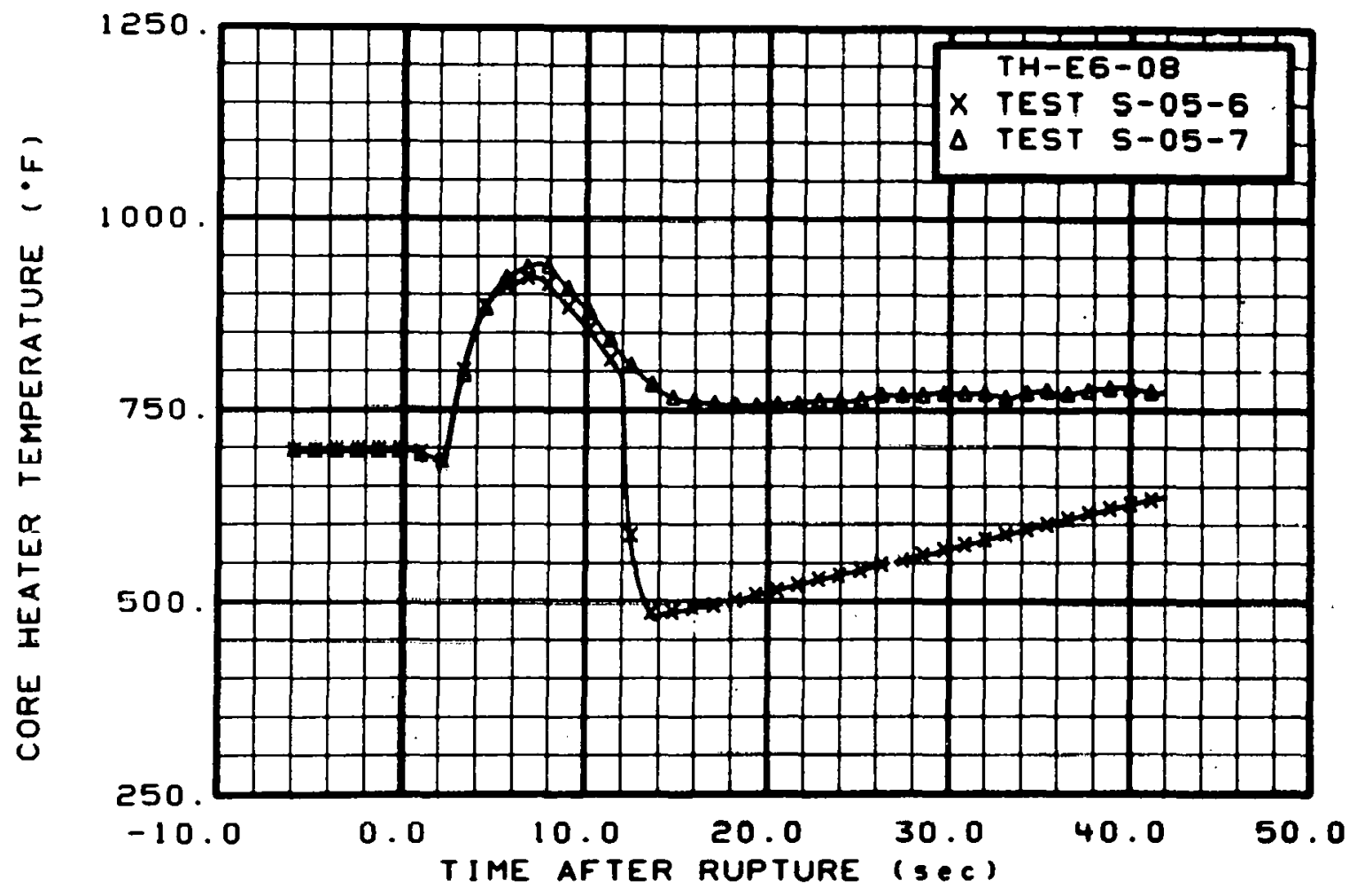

Fig. 195 Core heater temperature, Rod E-6 (TH-E6-08), from -6 to $42 \mathrm{sec}$. 


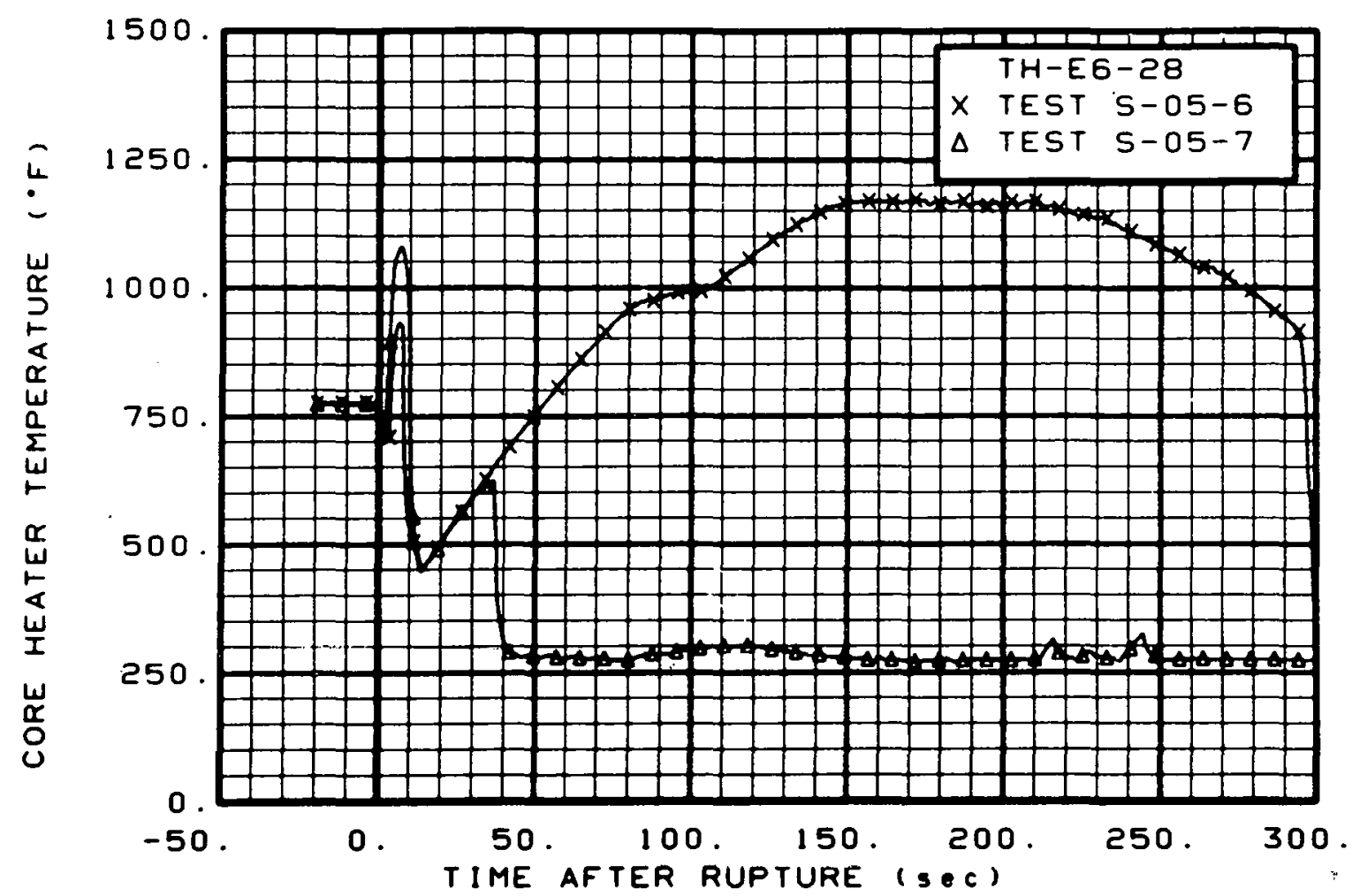

Fig. 196 Core heater temperature, Rod E-6 (TH-E6-28), from -20 to 300 séc.

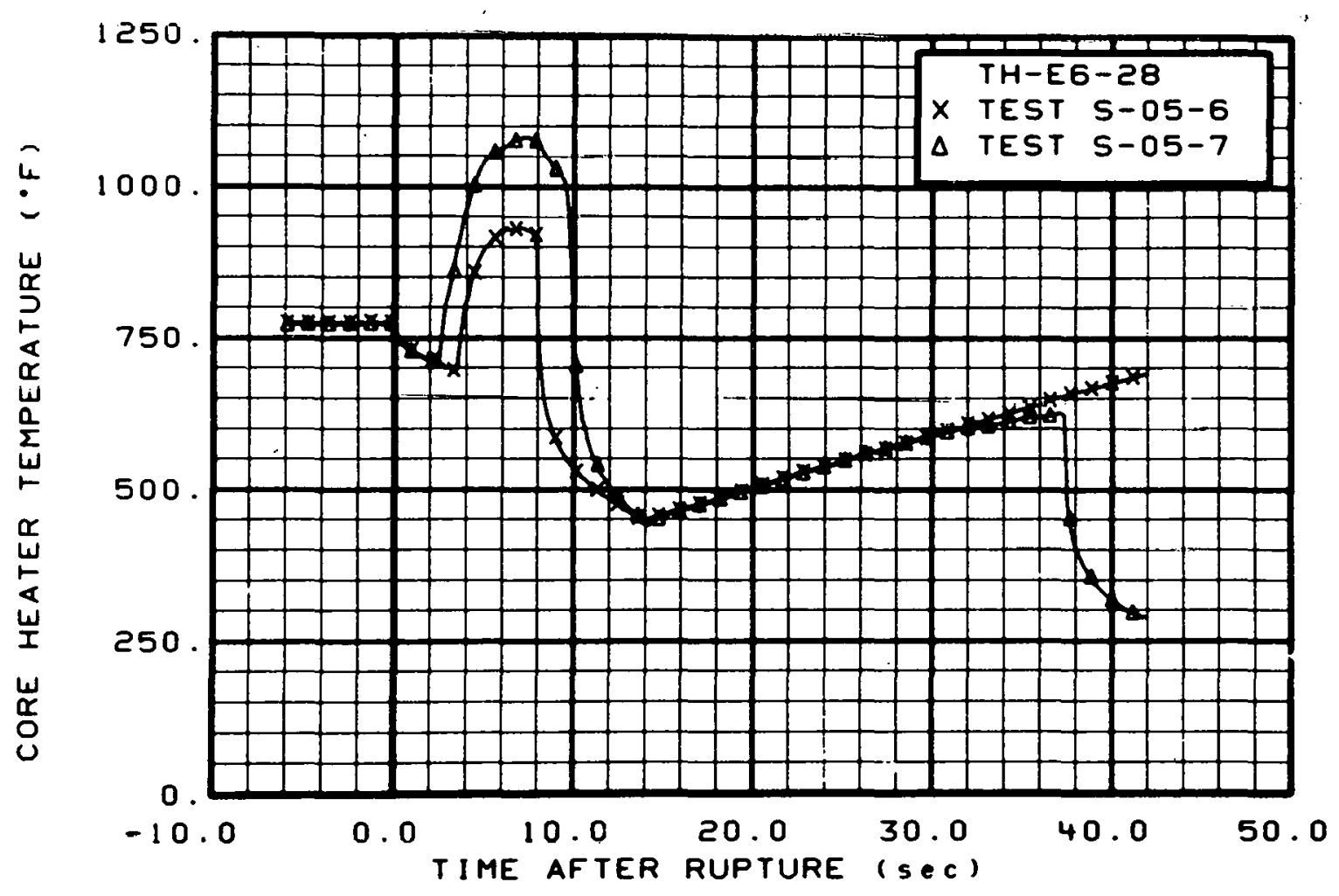

Fig. 197 Core heater temperature, Rod E-6 (TH-E6-28), from -6 to $42 \mathrm{sec}$. 


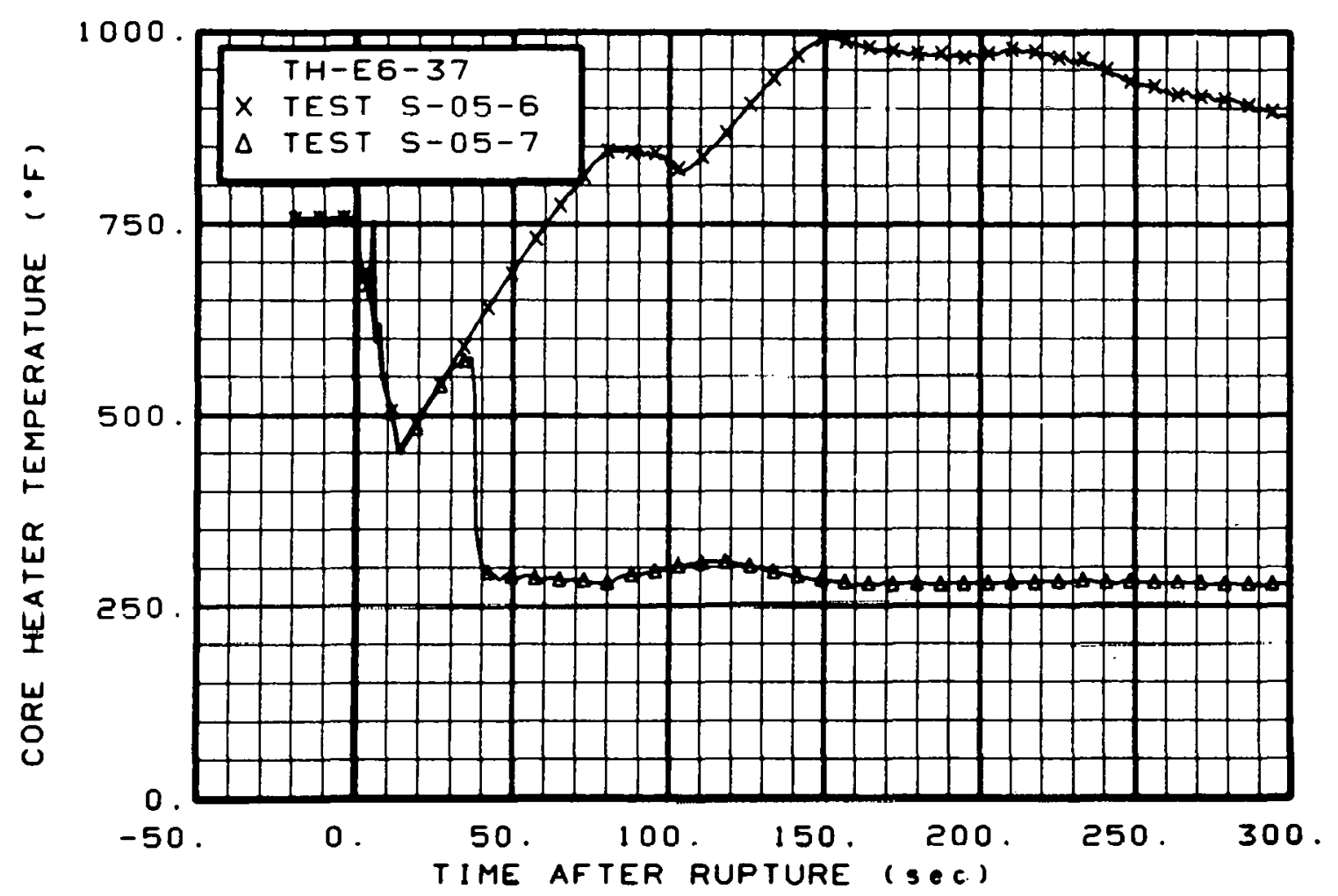

Fig. 198 Core heater temperature, Rod E-6 (TH-E6-37), from -20 to $300 \mathrm{sec}$.

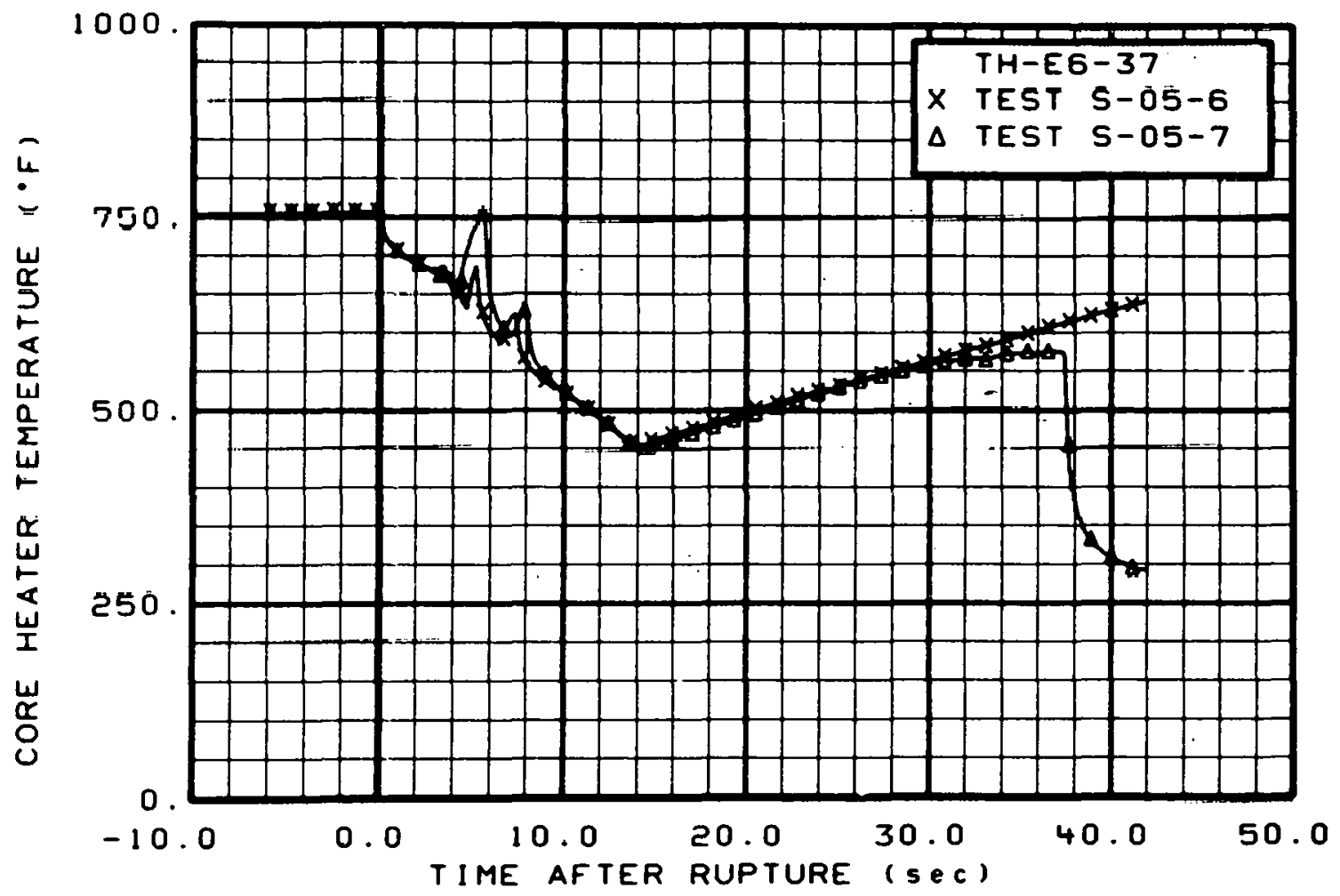

Fig. 199 Core heater temperature, Rod E-6 (TH-E6-37), from -6 to $42 \mathrm{sec}$. 


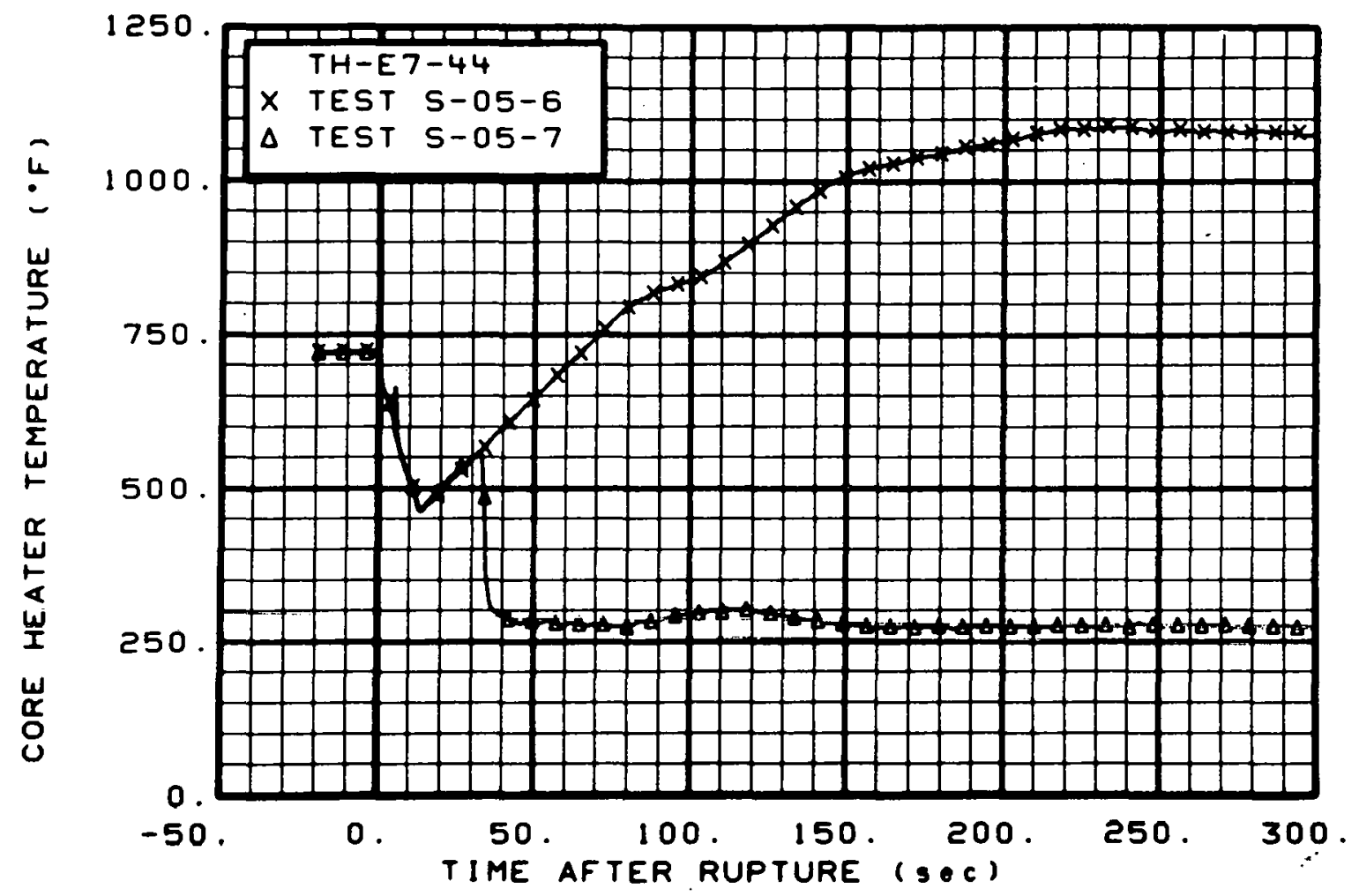

Fig. 200 Core heater temperature, Rod E-7 (TH-E7-44), from -20 to $300 \mathrm{sec}$.

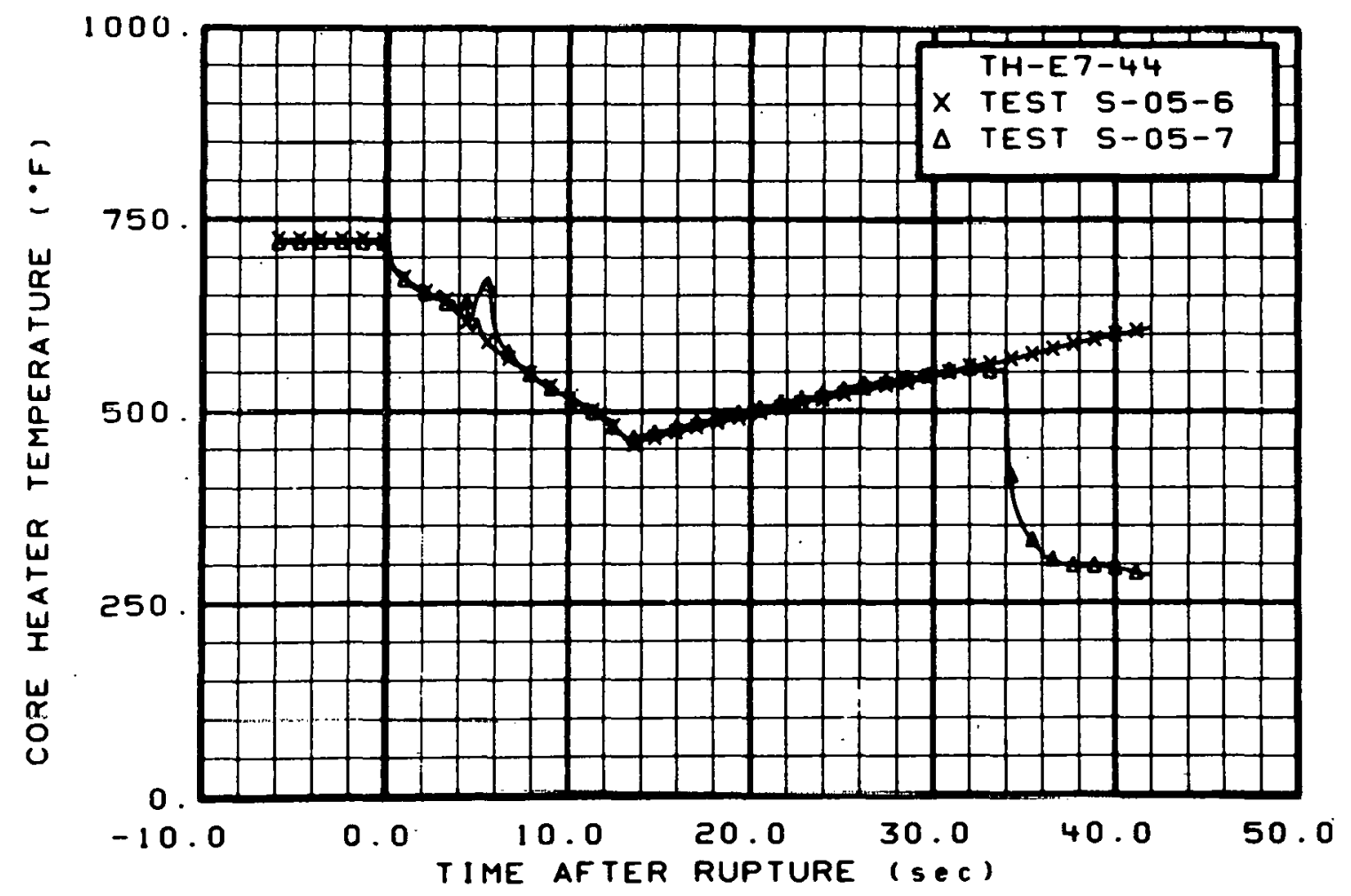

Fig. 201 Core heater temperature, Rod E-7 (TH-E7-44), from -6 to $42 \mathrm{sec}$. 


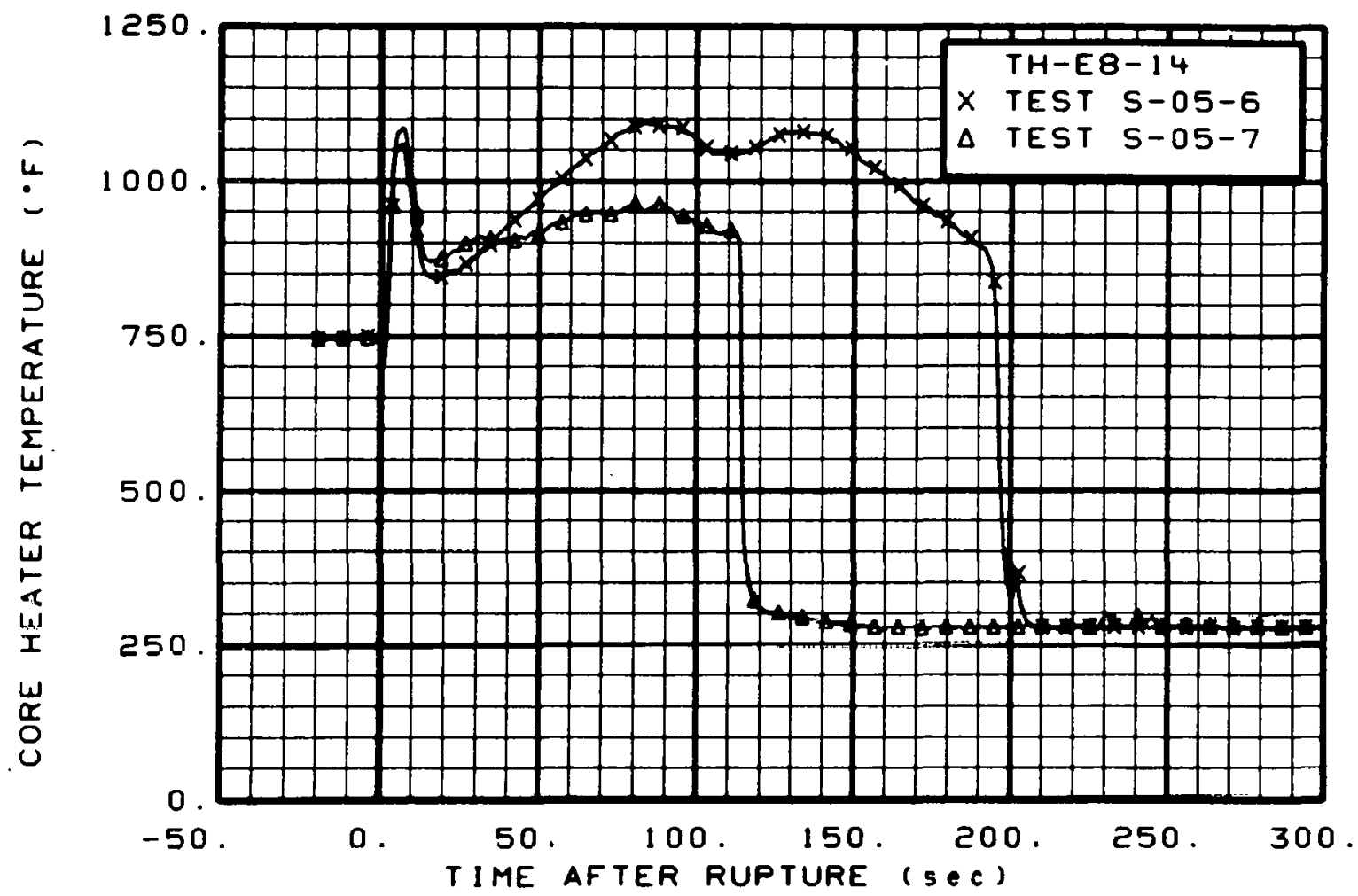

Fig. 202 Core heater temperature, Rod E-8 (TH-E8-14), from -20 to $300 \mathrm{sec}$.

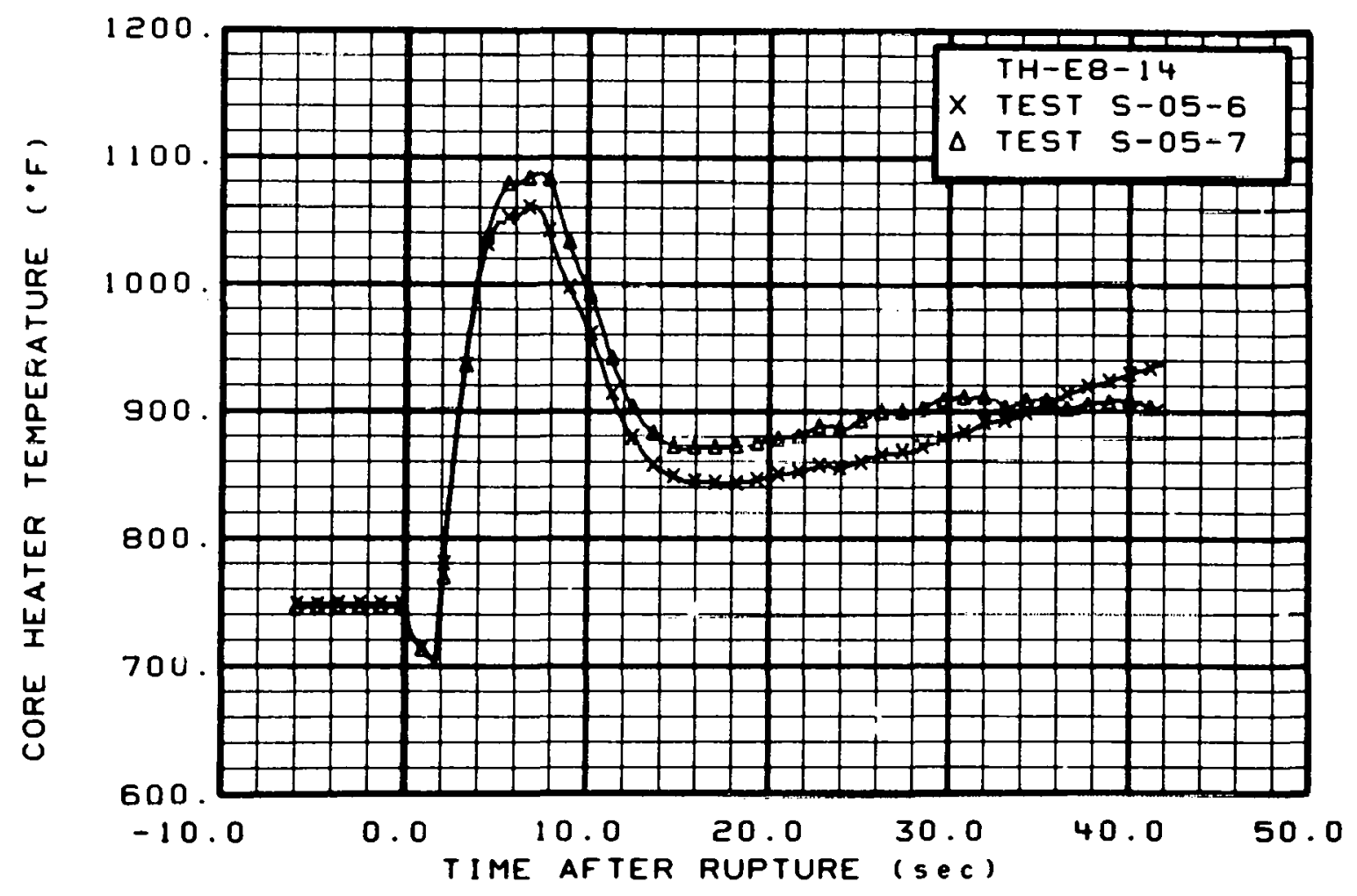

Fig. 203 Core heater temperature, Rod E-8 (TH-E8-14), from -6 to $42 \mathrm{sec}$. 


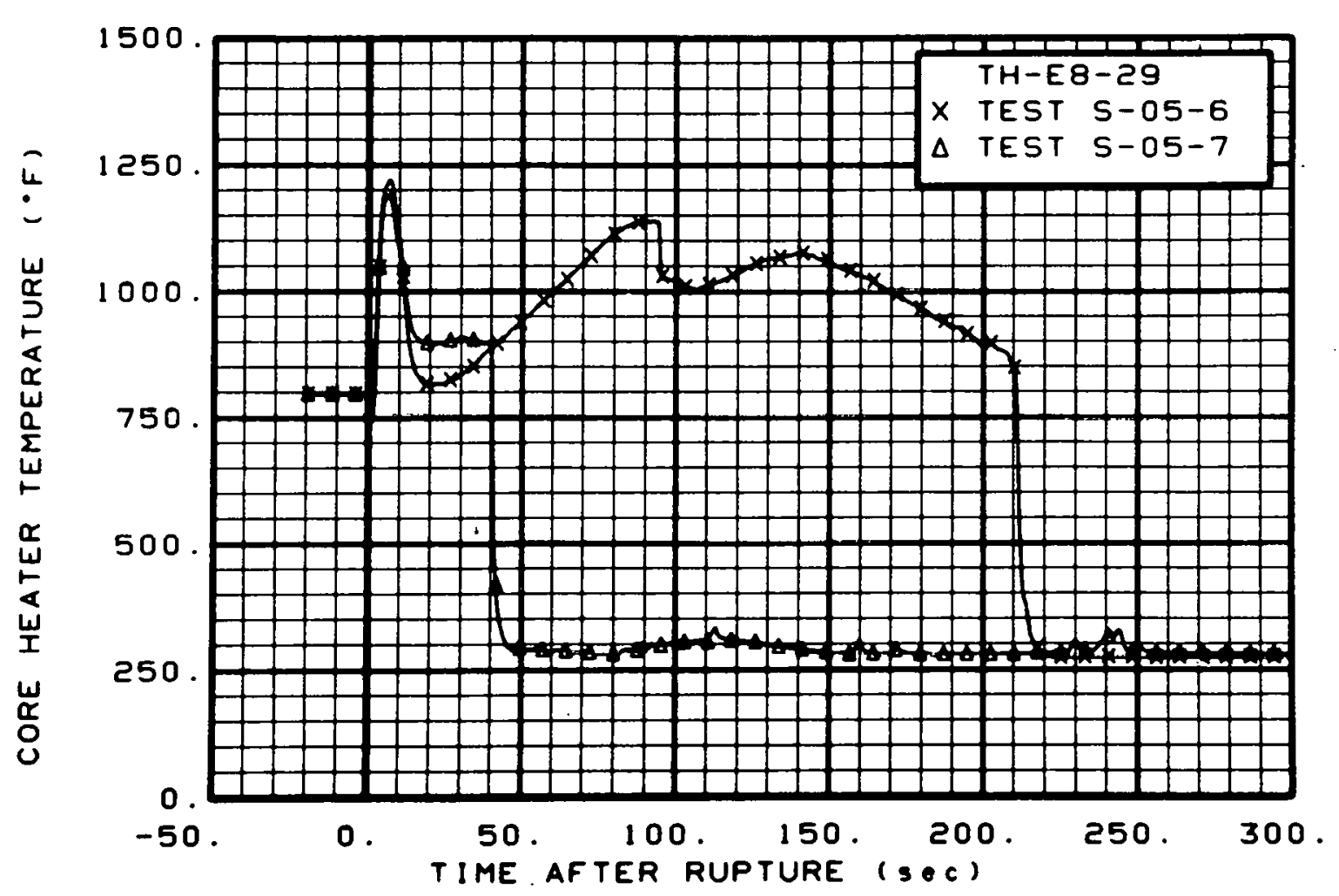

Fig. 204 Core heater temperature, Rod E-8 (TH-E8-29), from -20 to $300 \mathrm{sec}$.

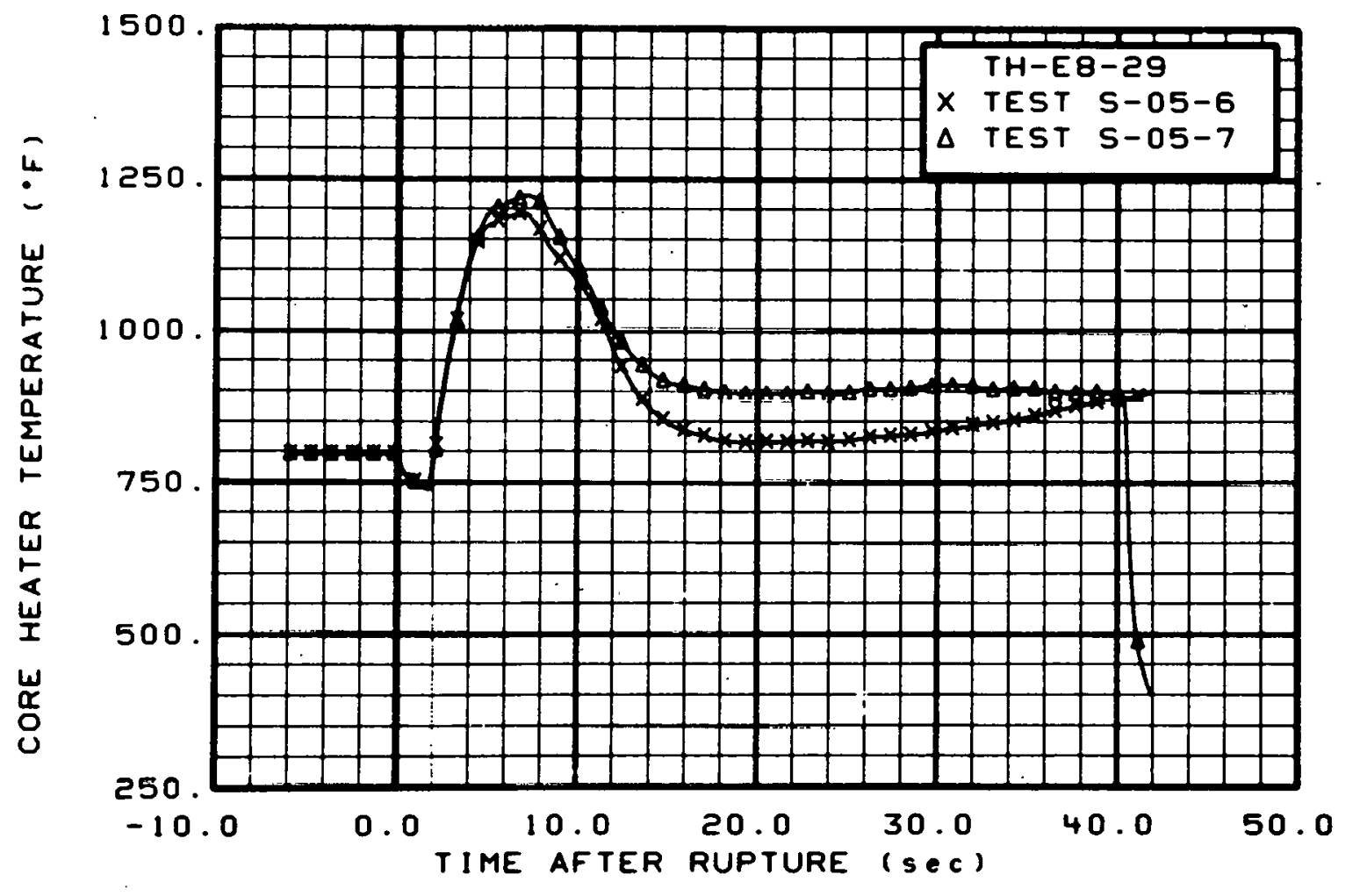

Fig. 205 Core heater temperature, Rod E-8 (TH-E8-29), from -6 to $42 \mathrm{sec}$. 


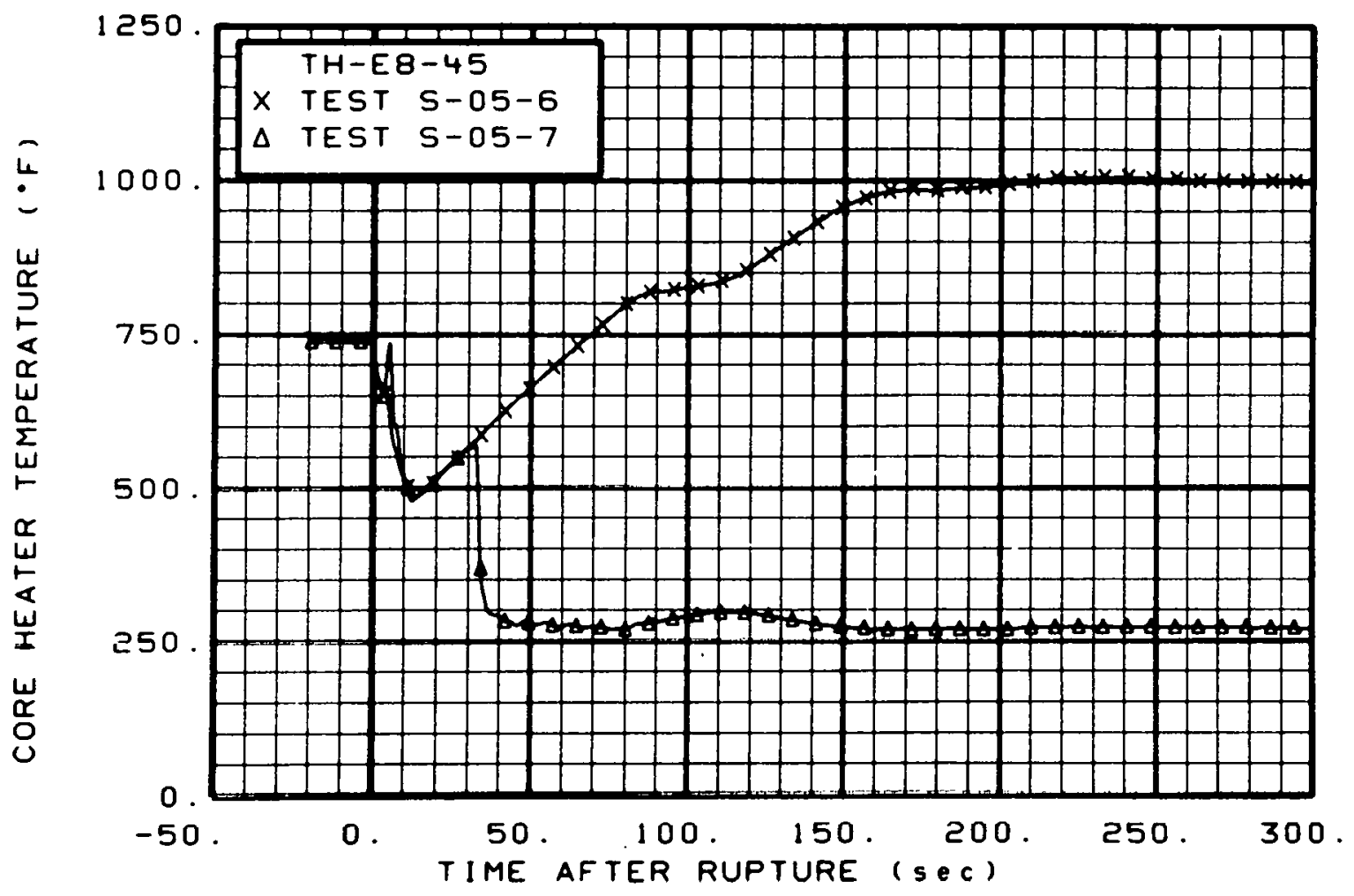

Fig. 206 Core heater temperature, Rod E-8 (TH-E8-45), from -20 to $300 \mathrm{sec}$.

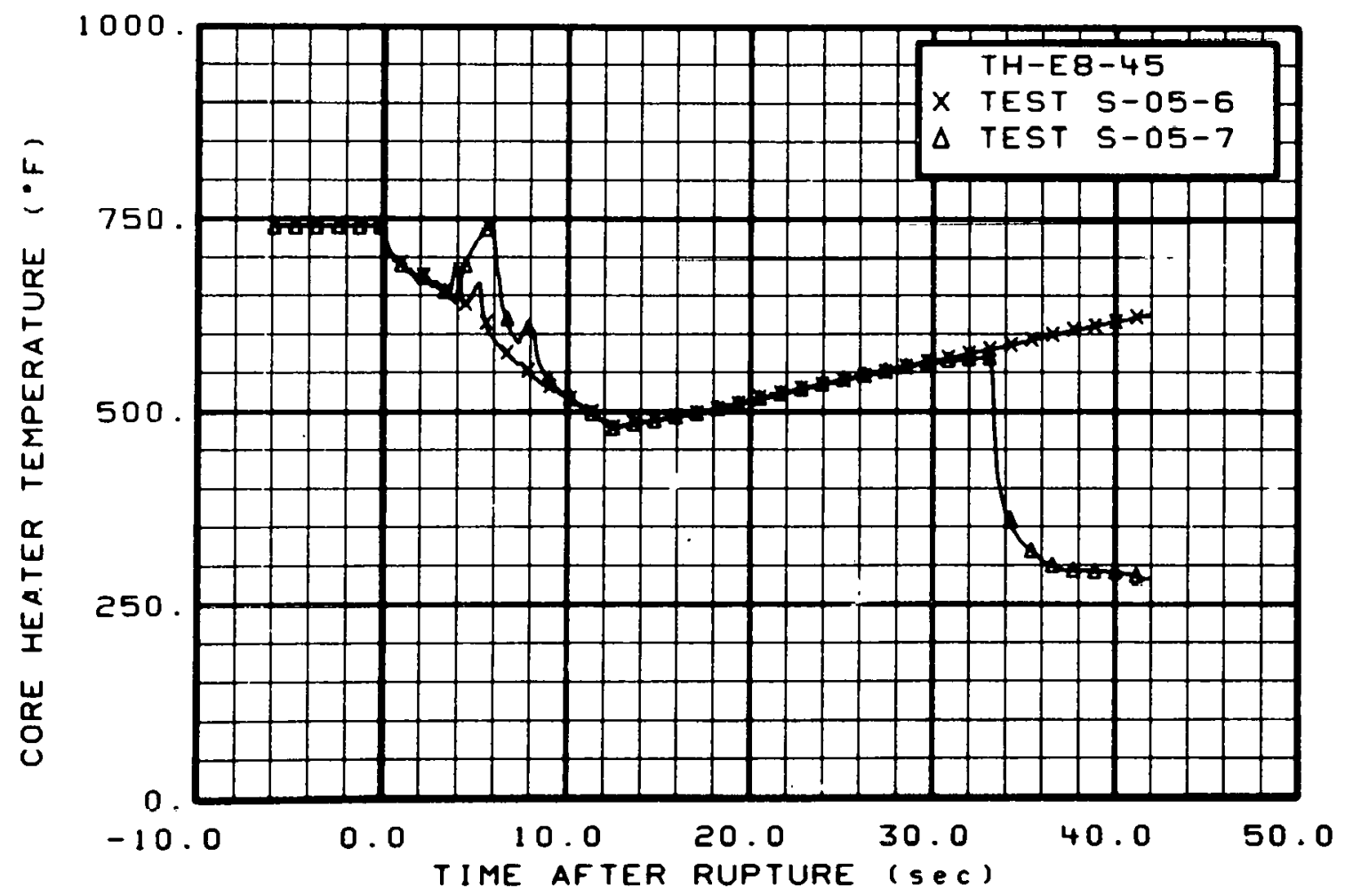

Fig. 207 Core heater temperature, Rod E-8 (TH-E8-45), from -6 to $42 \mathrm{sec}$. 


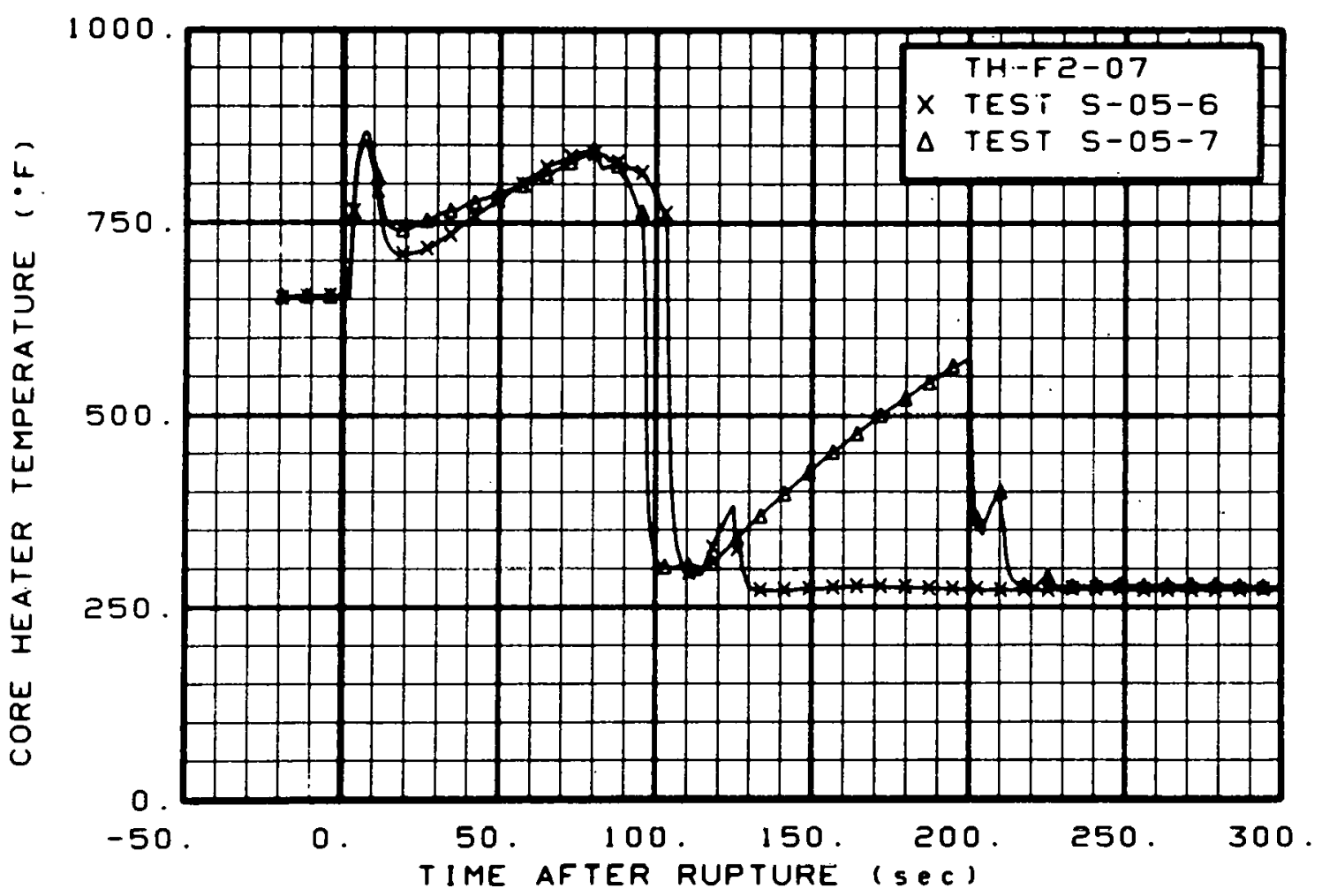

Fig. 208 Core heater temperature, Rod F-2 (TH-F2-07), from -20 to $300 \mathrm{sec}$.

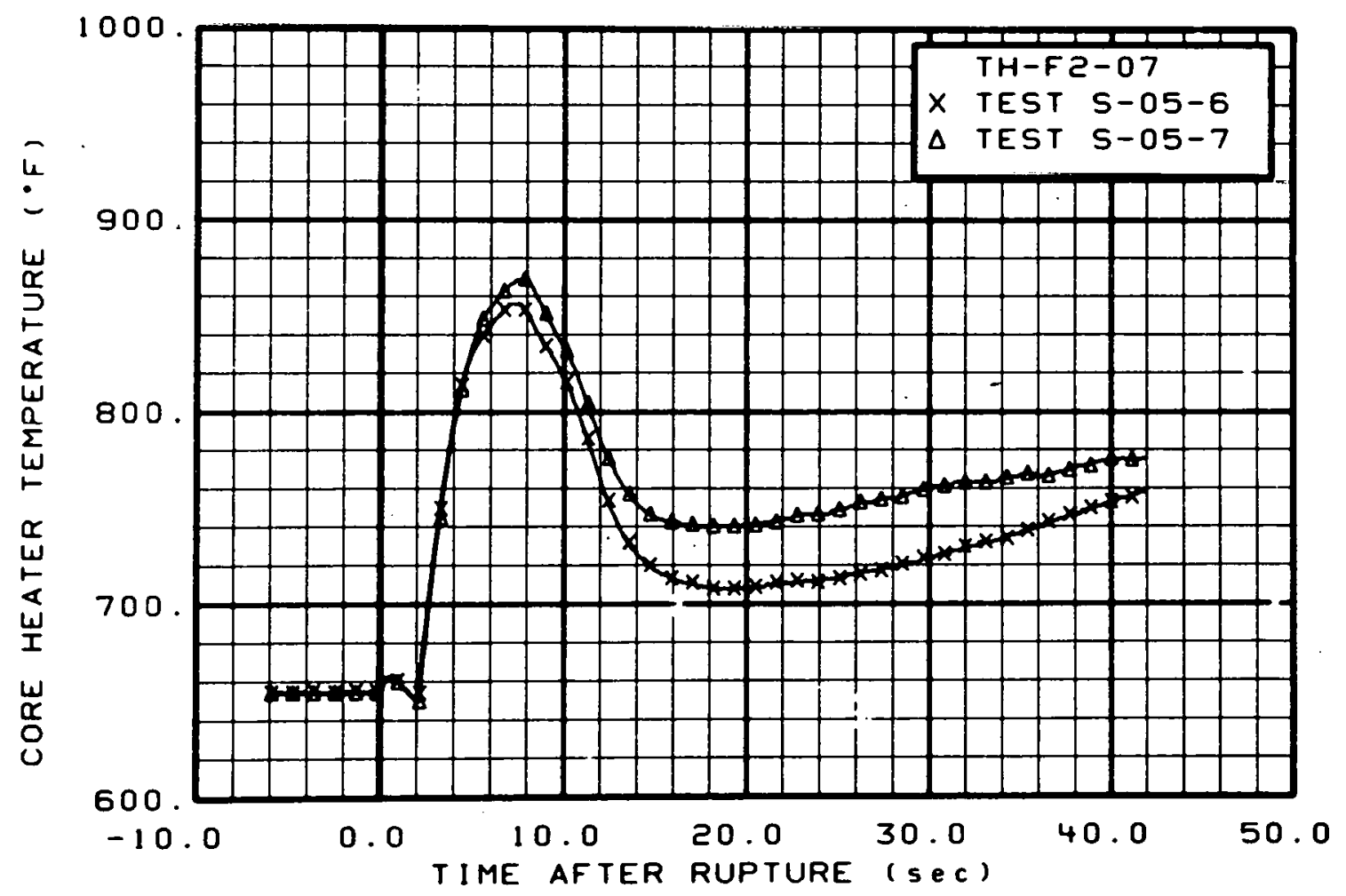

Fig. 209 Core heater temperature, Rod F-2 (TH-F2-07), from -6 to $42 \mathrm{sec}$. 


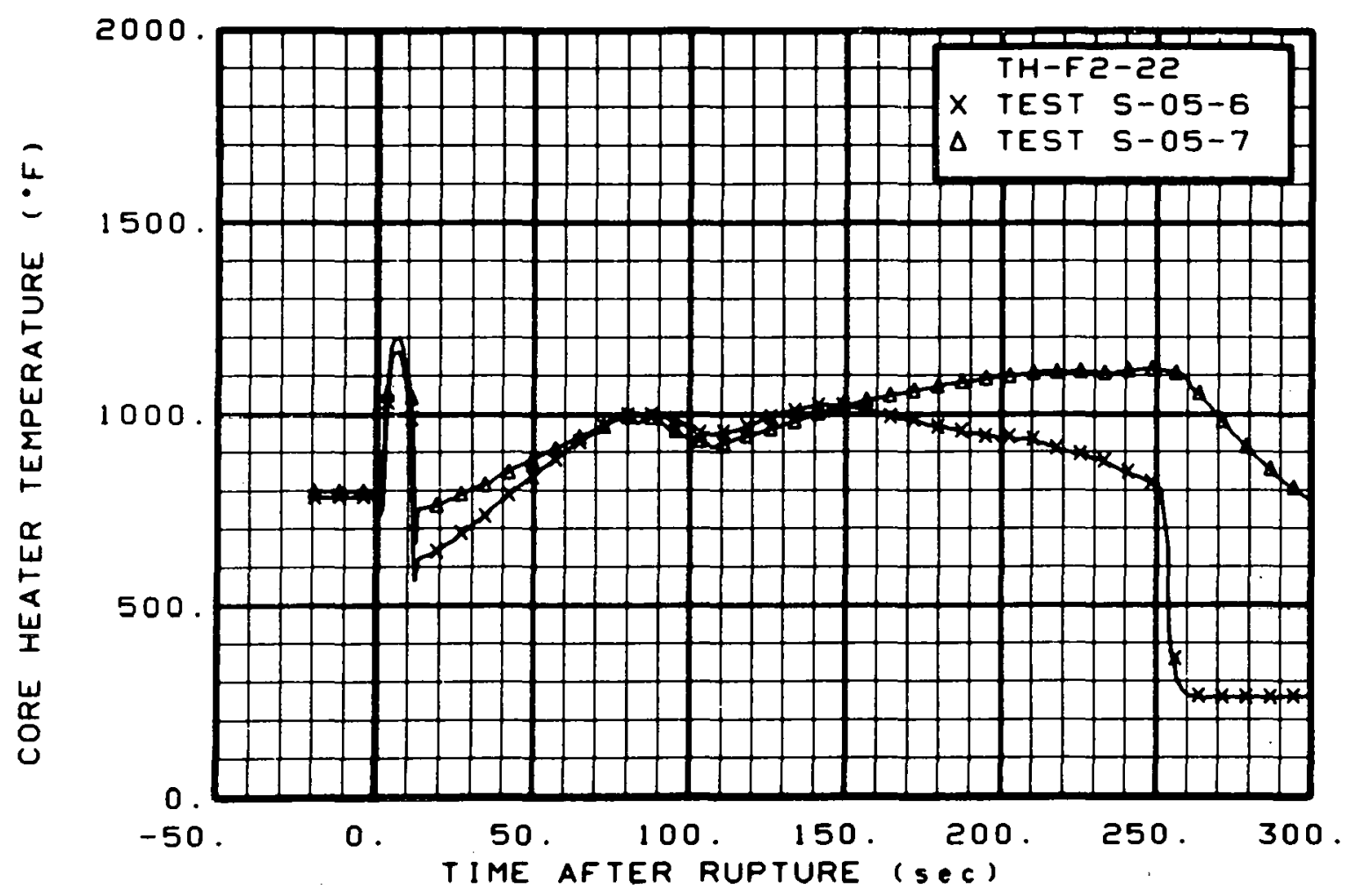

Fig. 210 Core heater temperature, Rod F-2 (TH-F2-22), from -20 to $300 \mathrm{sec}$.

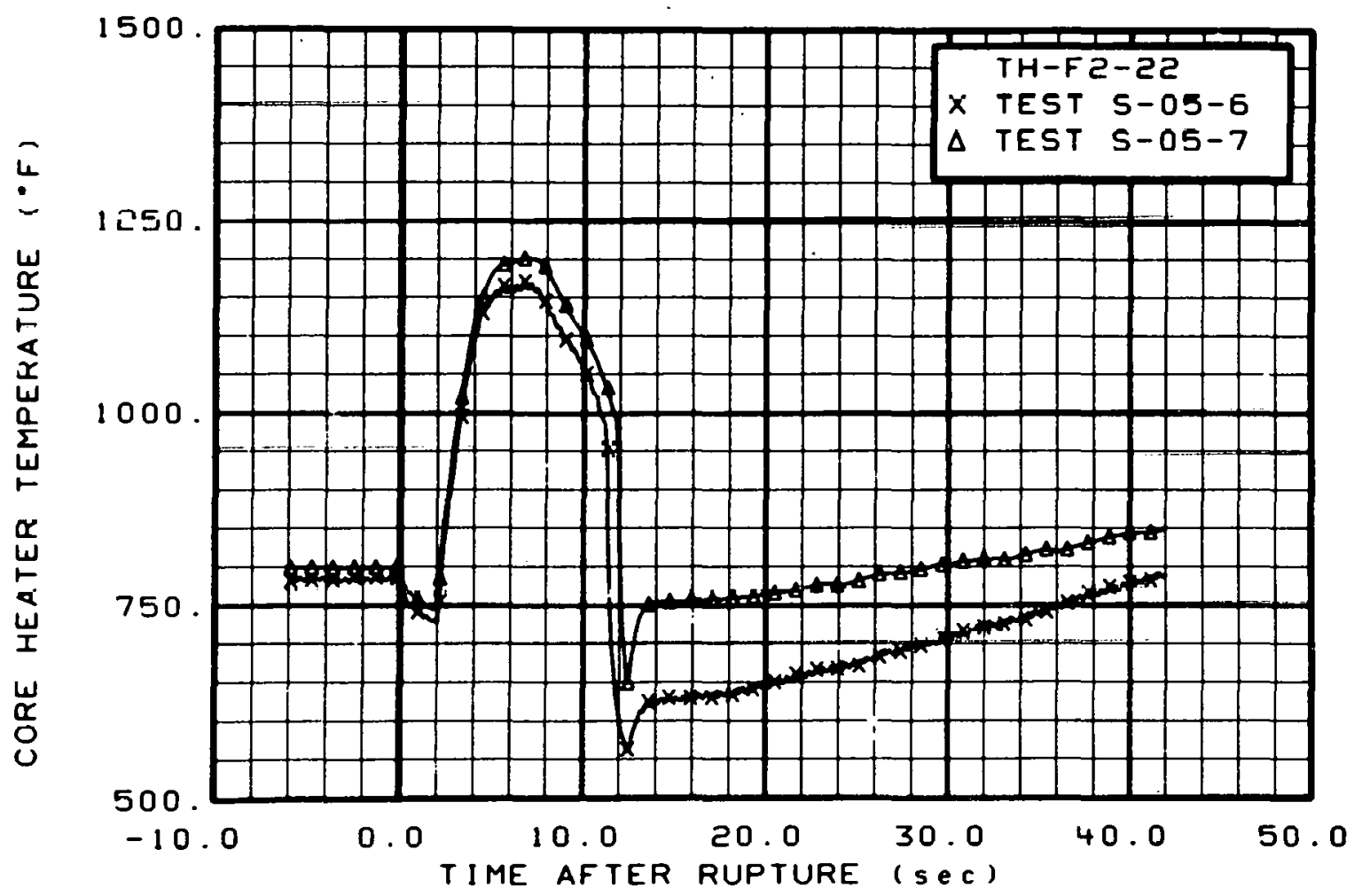

Fig. 211 Core heater temperature, Rod F-2 (TH-F2-22), from -6 to $42 \mathrm{sec}$. 


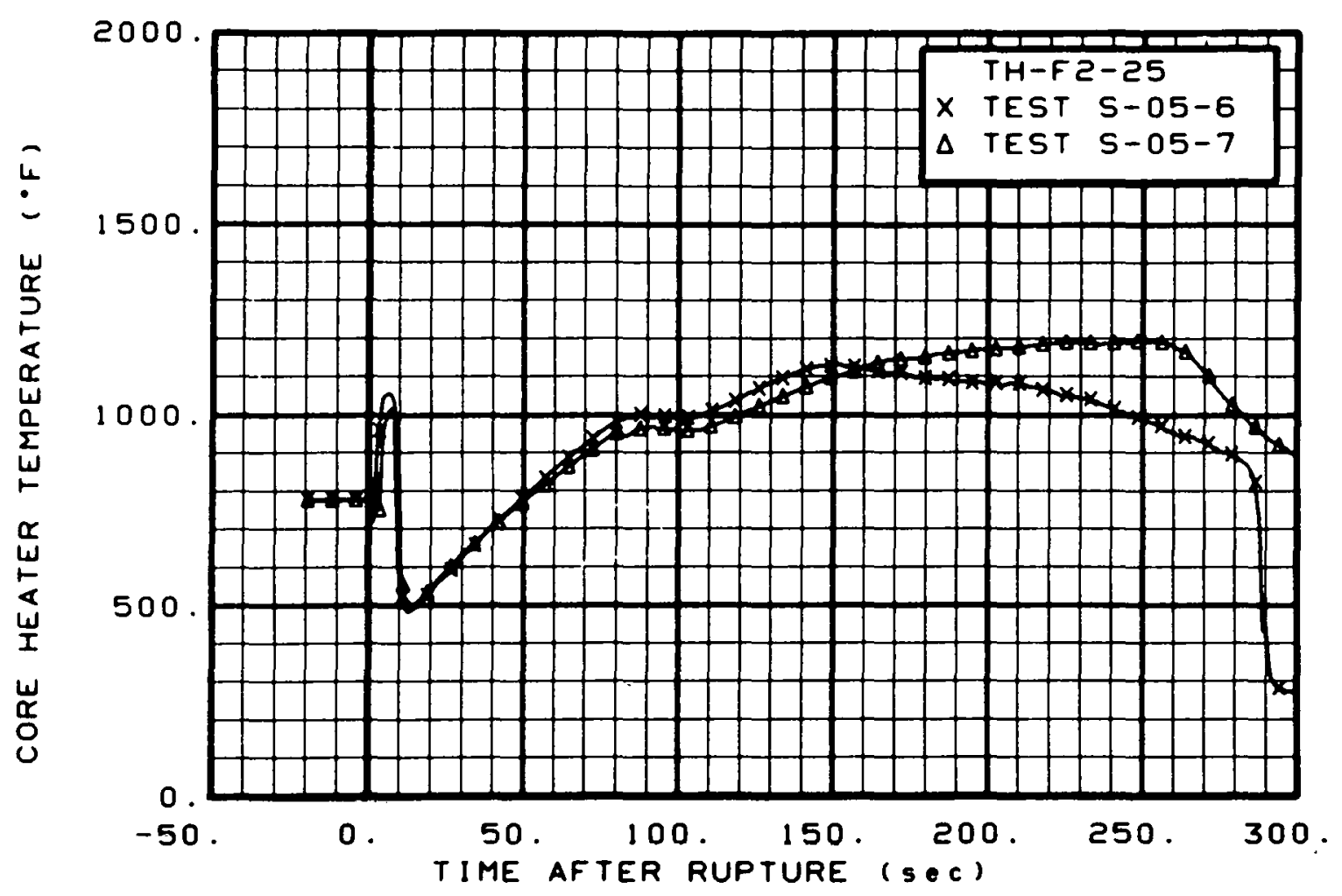

Fig. 212 Core heater temperature, Rod F-2 (TH-F2-25), from -20 to $300 \mathrm{sec}$.

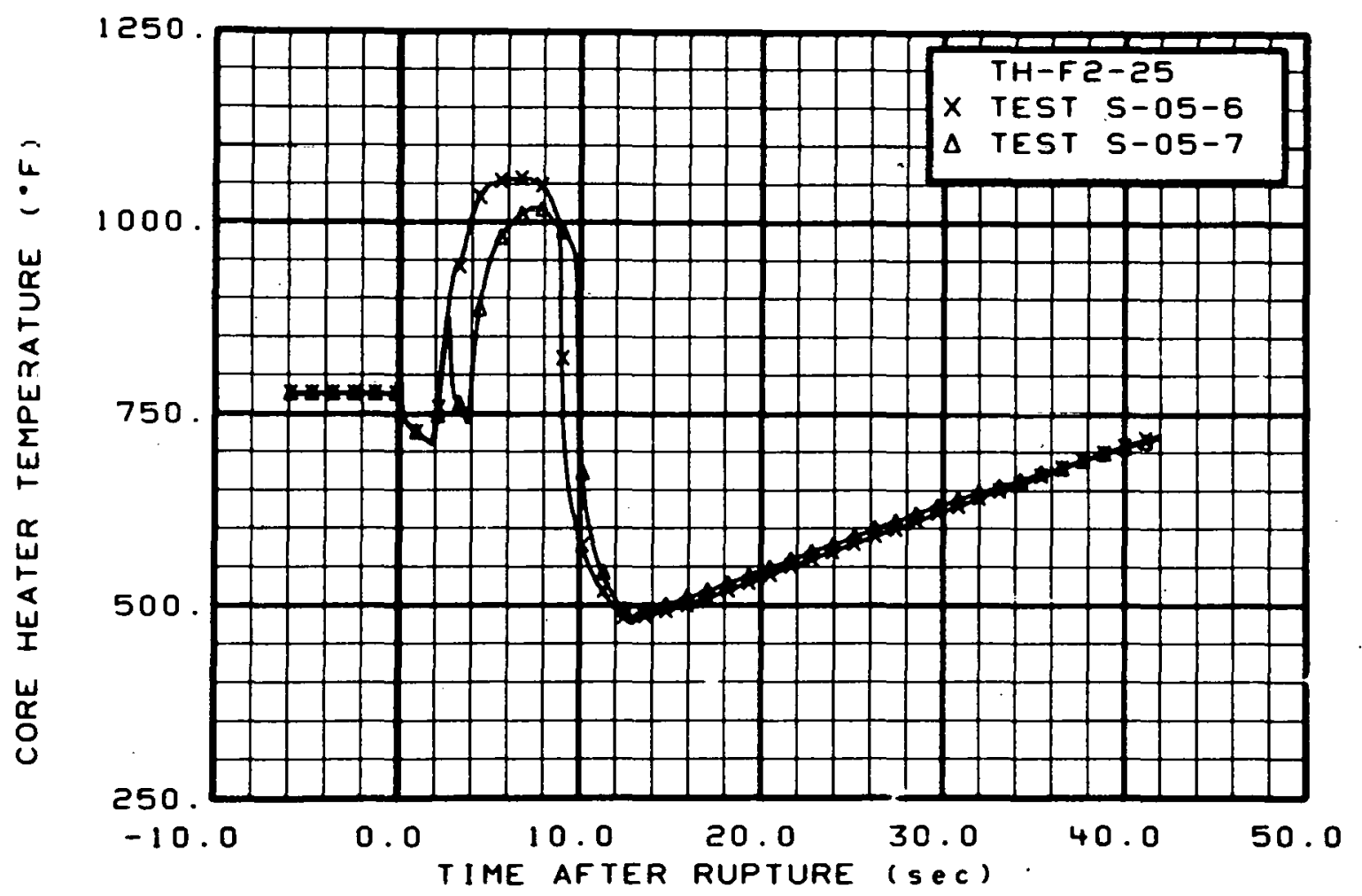

Fig. 213 Core heater temperature, Rod F-2 (TH-F2-25), from -6 to 42 sec. 


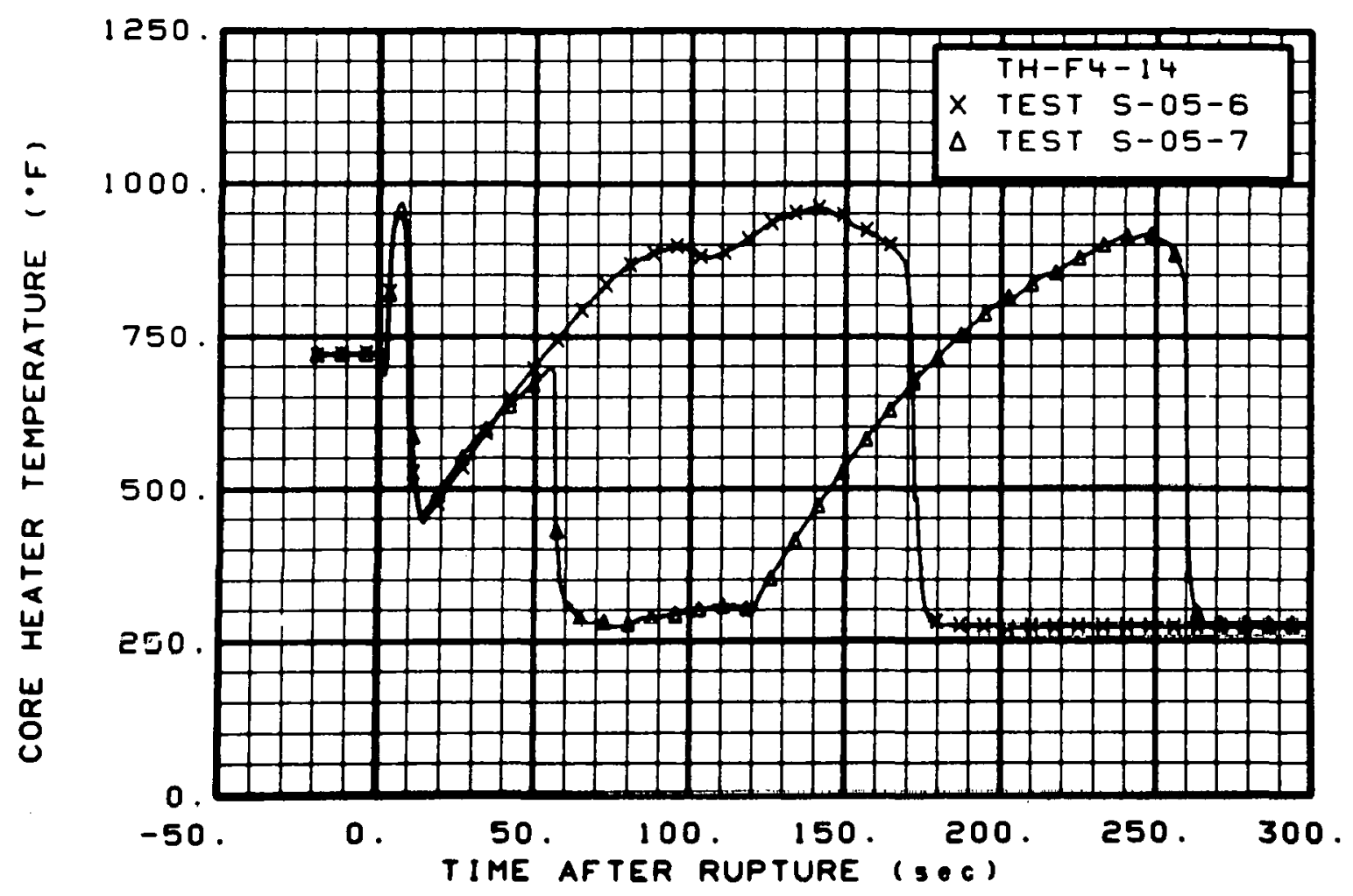

Fig. 214 Core heater temperature, Rod F-4 (TH-F4-14), from -20 to $300 \mathrm{sec}$.

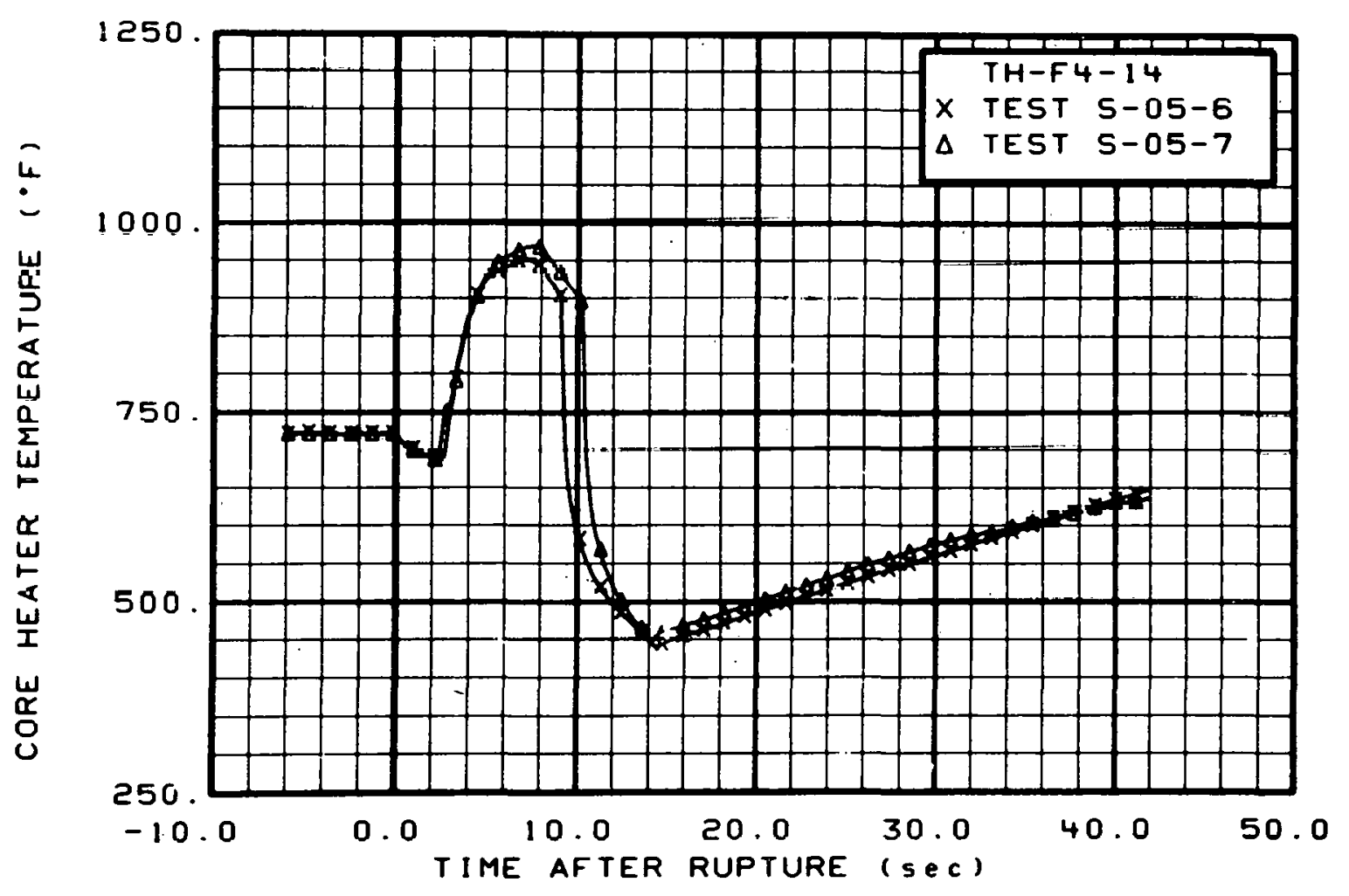

Fig. 215 Core heater temperature, Rod F-4 (TH-F4-14), from -6 to 42 sec. 


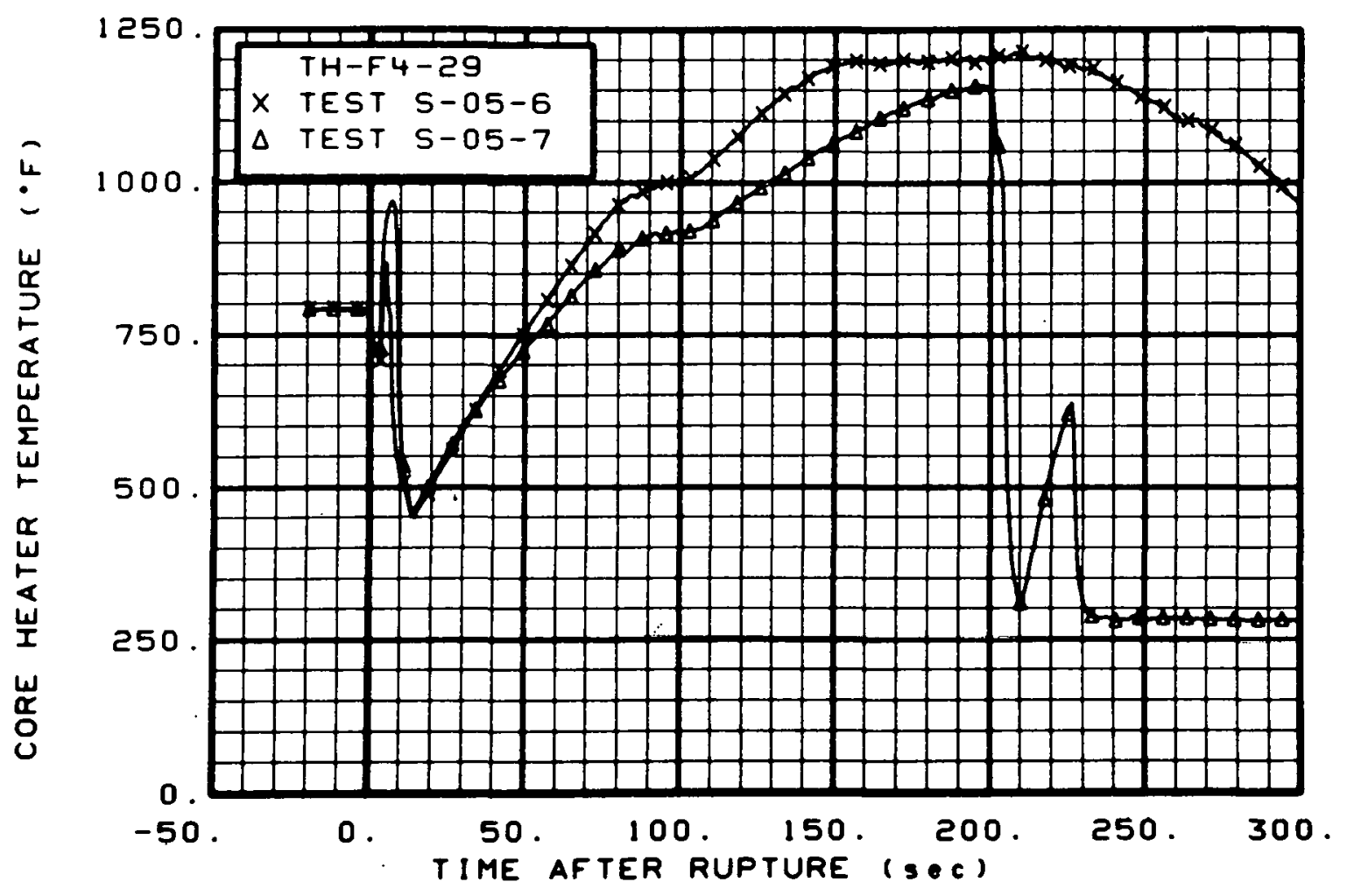

Fig. 216 Core heater temperature, Rod F-4 (TH-F4-29), from -20 to $300 \mathrm{sec}$.

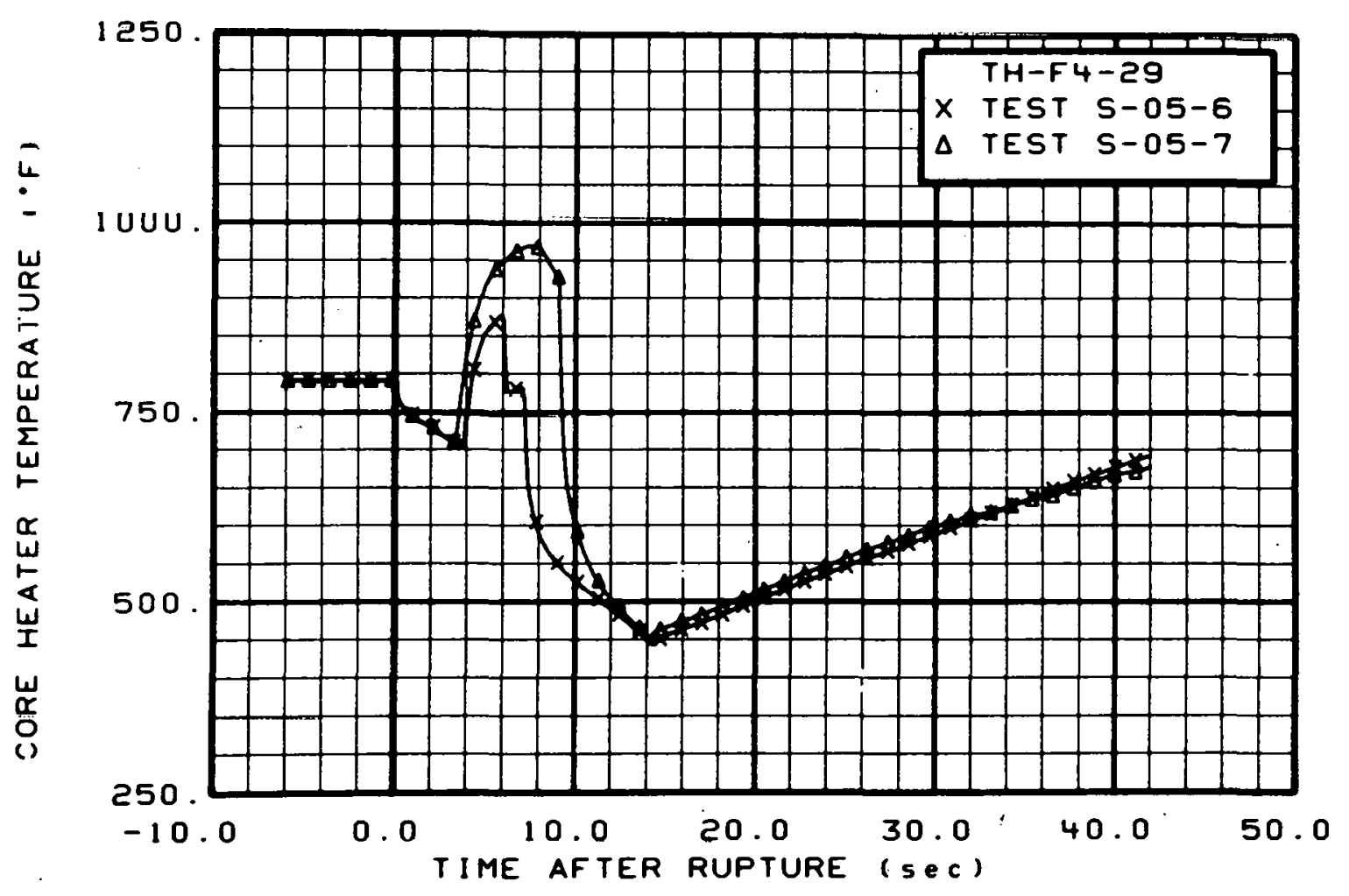

Fig. 217 Core heater temperature, Rod F-4 (TH-F4-29), from -6 to $42 \mathrm{sec}$. 


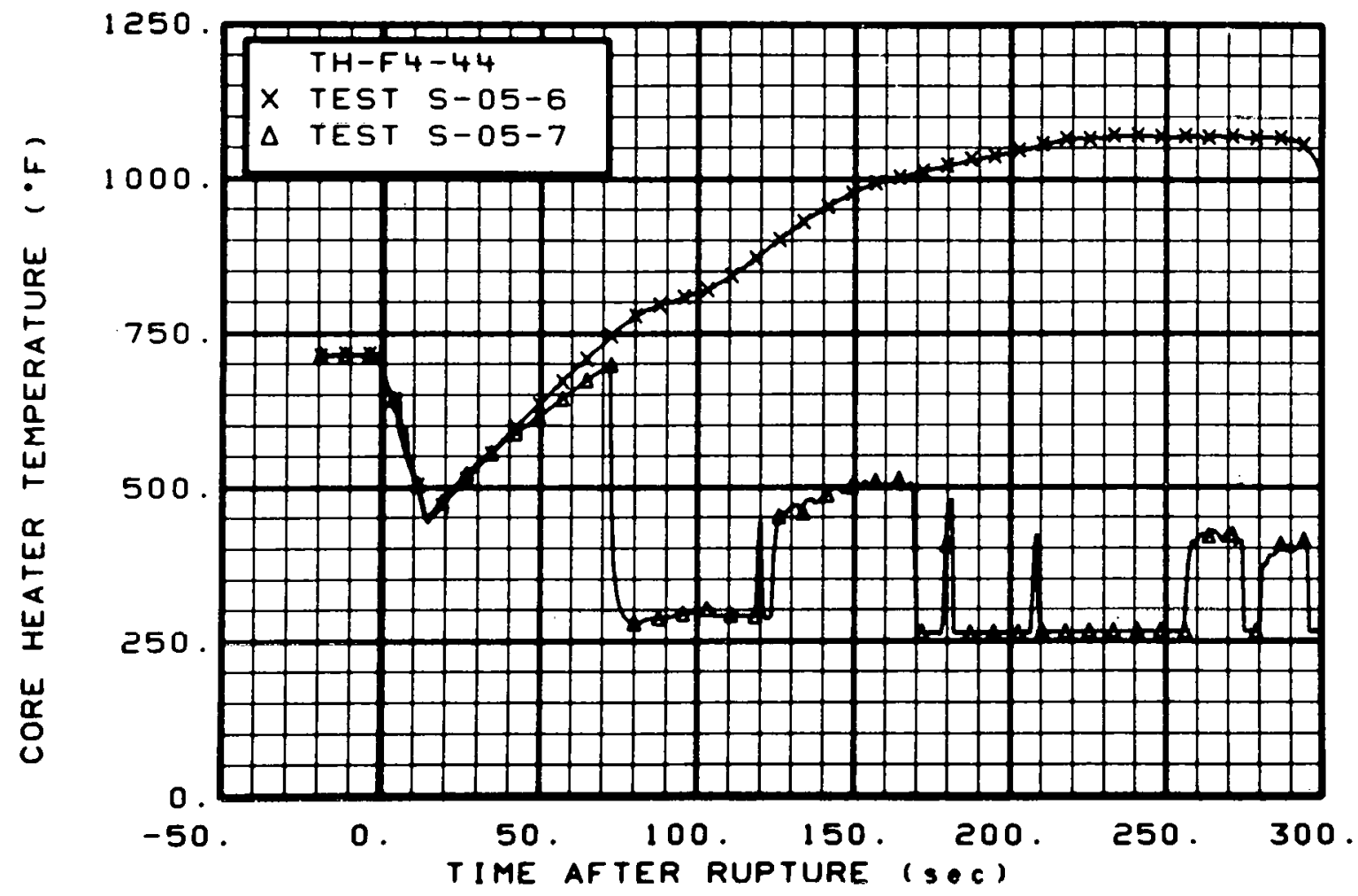

Fig. 218 Core heater temperature, Rod F-4 (TH-F4-44), from -20 to $300 \mathrm{sec}$.

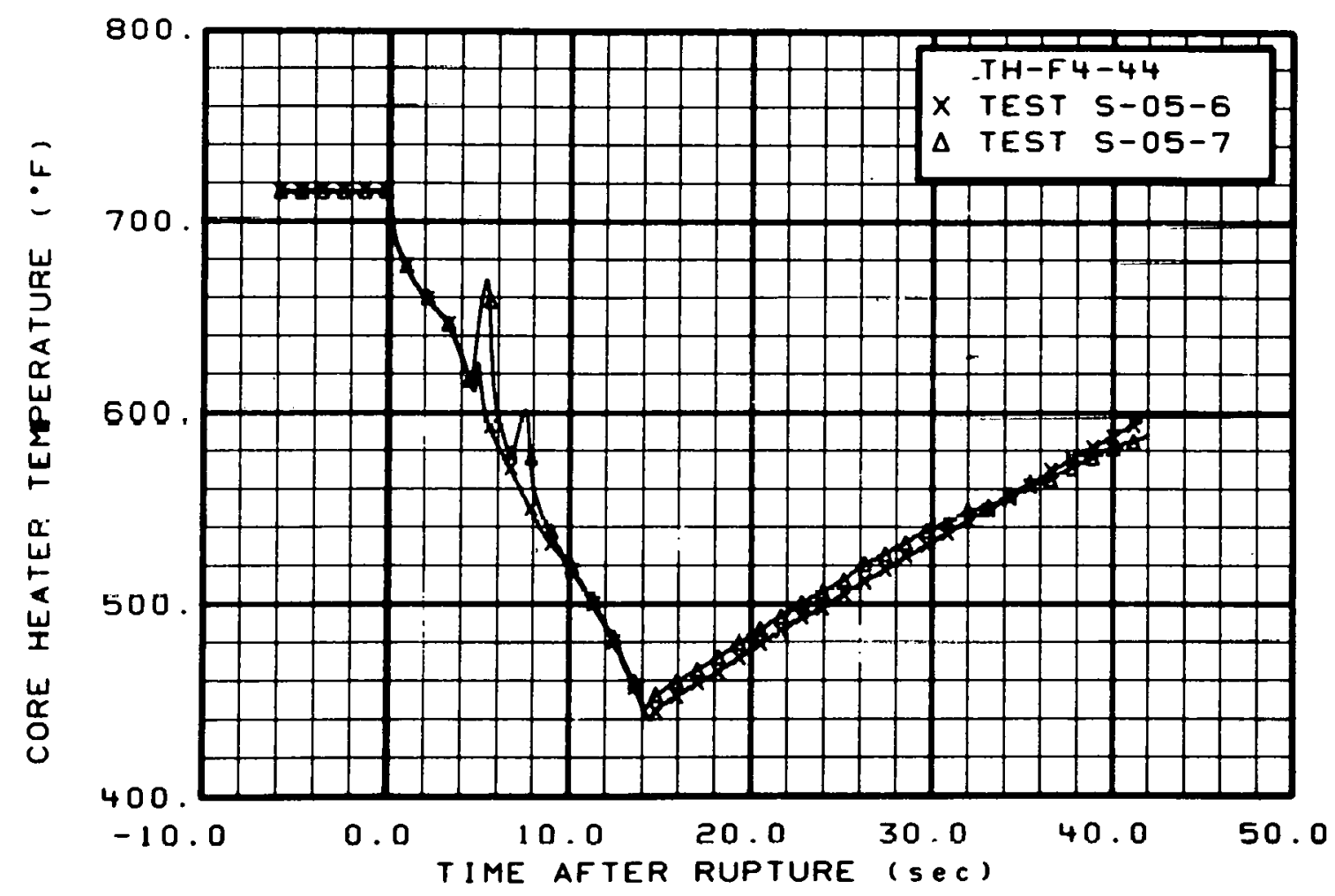

Fig. 219 Core heater temperature, Rod F-4 (TH-F4-44), from -6 to $42 \mathrm{sec}$. 


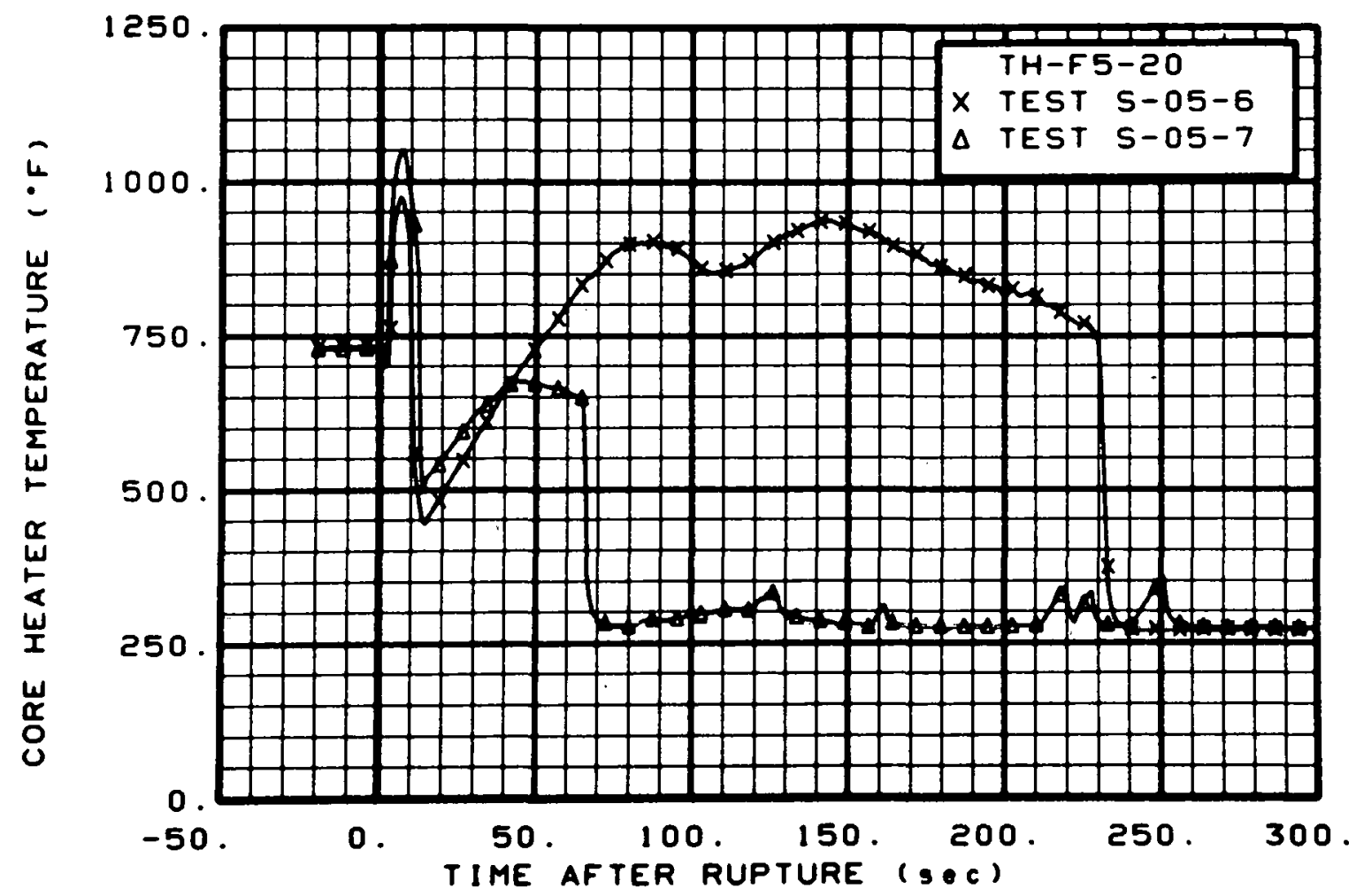

Fig. 220 Core heater temperature, Rod F-5 (TH-F5-20), from -20 to $300 \mathrm{sec}$.

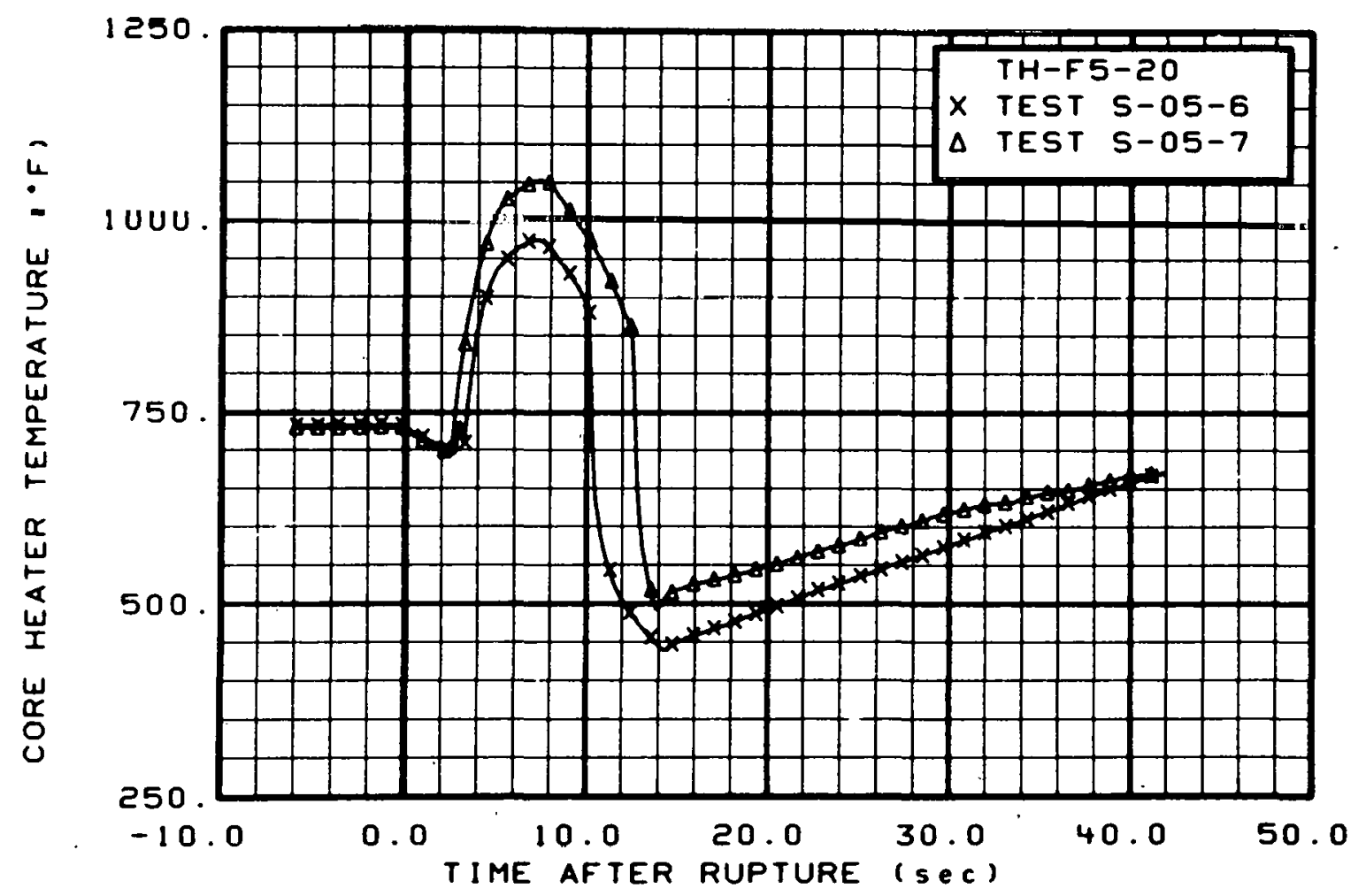

Fig. 221 Core heater temperature, Rod F-5 (TH-F5-20), from -6 to $42 \mathrm{sec}$. 


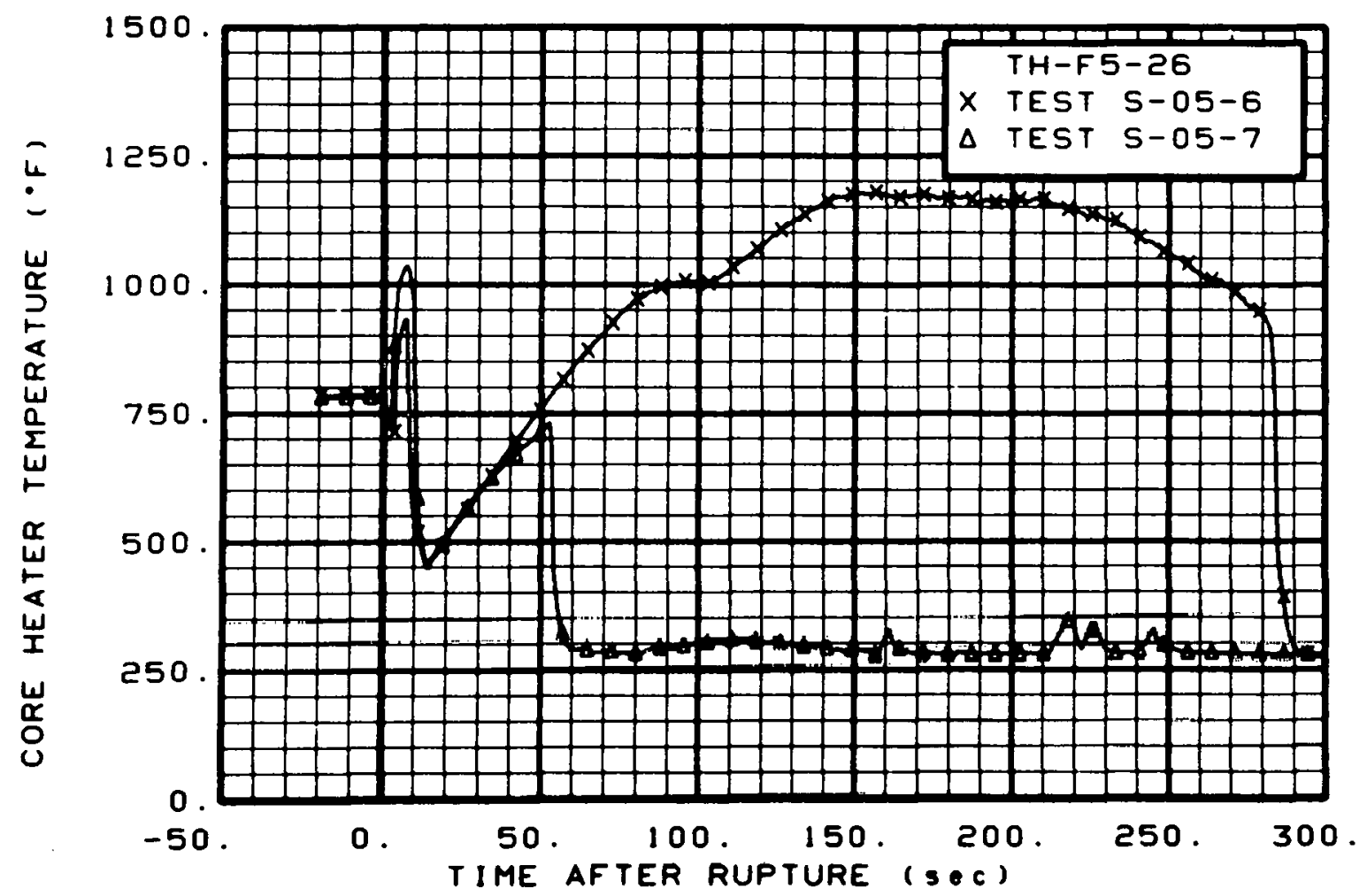

Fig. 222 Core heater temperature, Rod F-5 (TH-F5-26), from -20 to $300 \mathrm{sec}$.

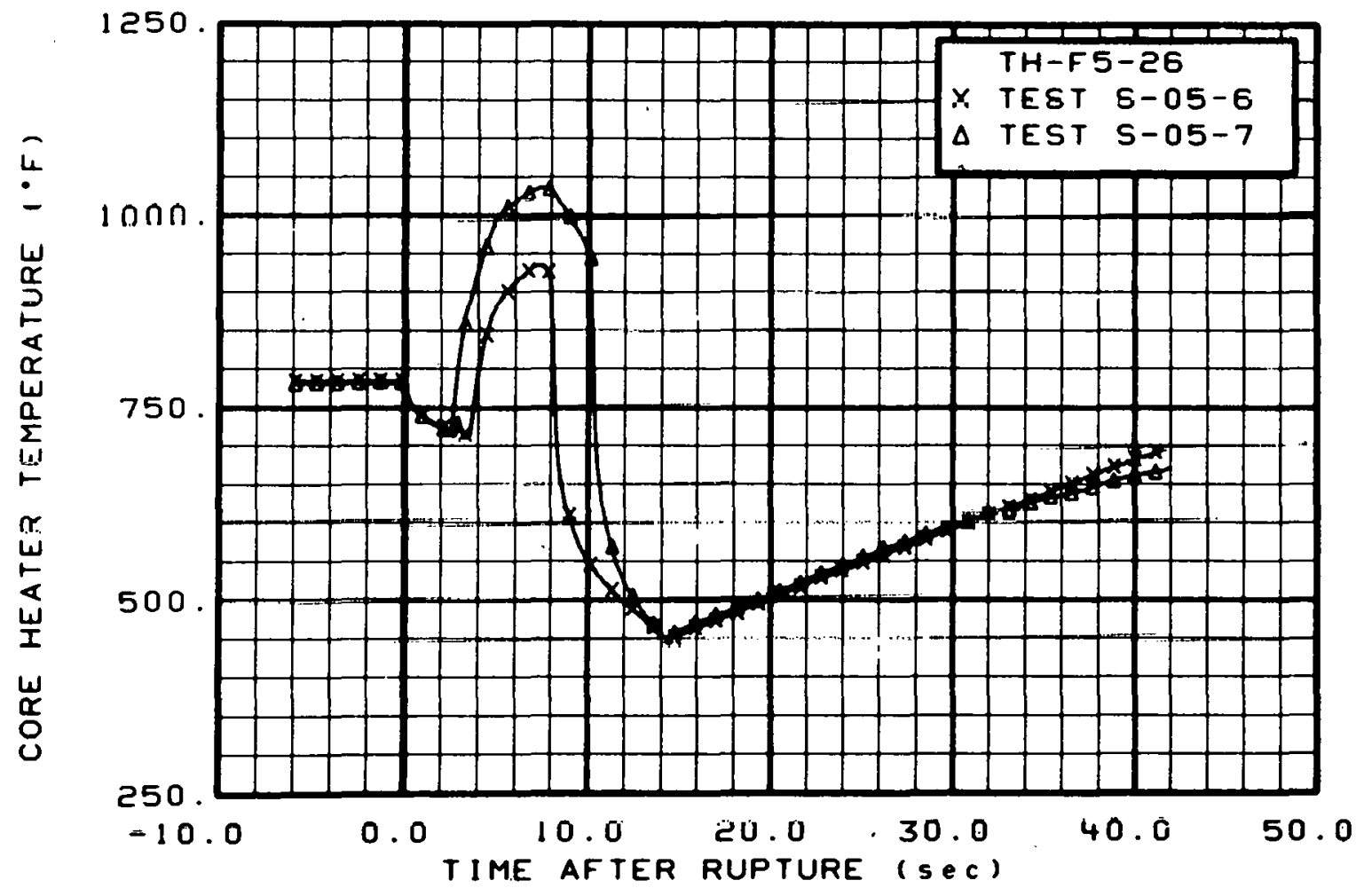

Fig. 223 Core heater temperature, Rod F-5 (TH-F5-26), from -6 to $42 \mathrm{sec}$. 


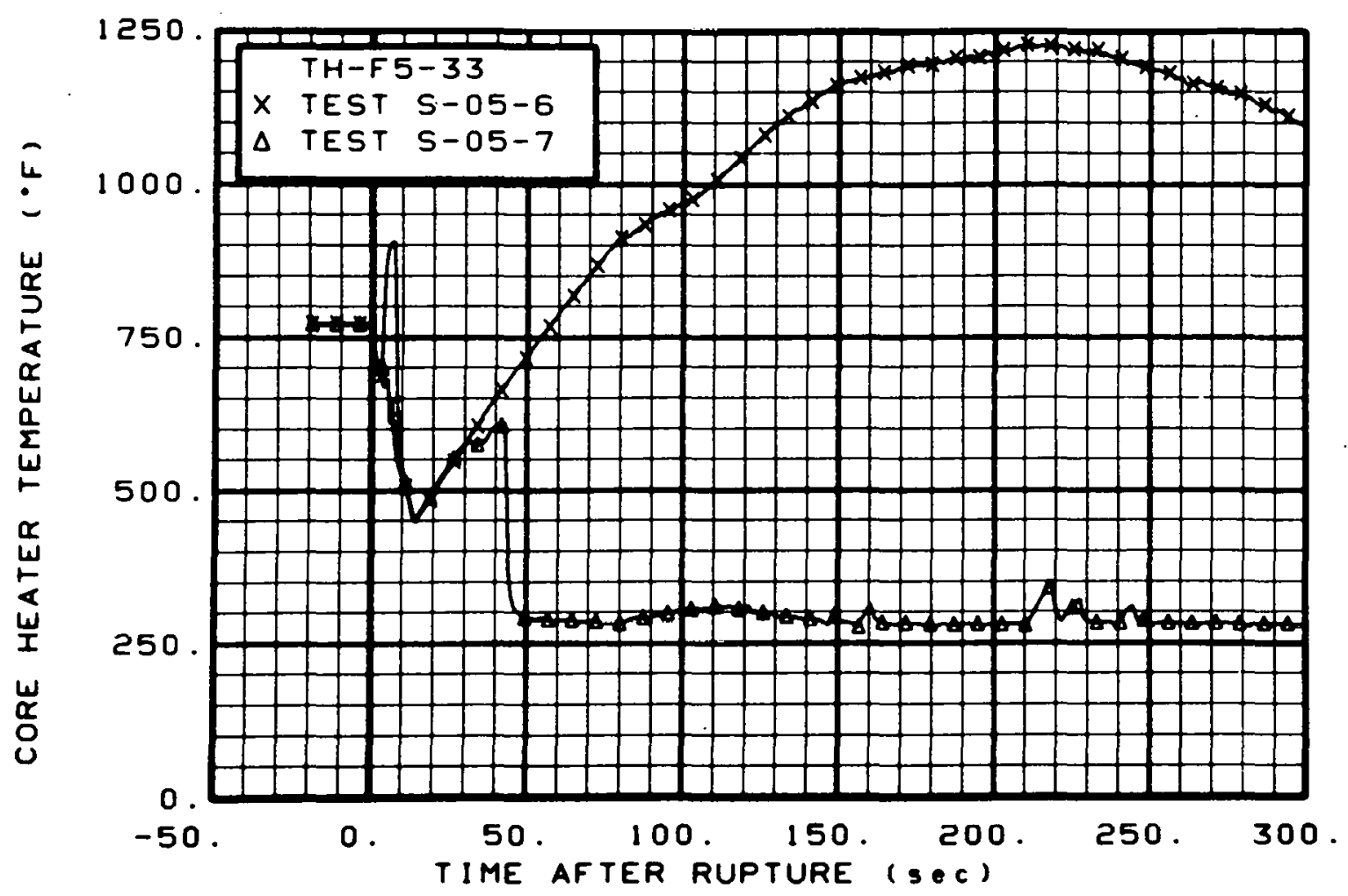

Fig. 224 Core heater temperature, Rod F-5 (TH-F5-33), from -20 to $300 \mathrm{sec}$.

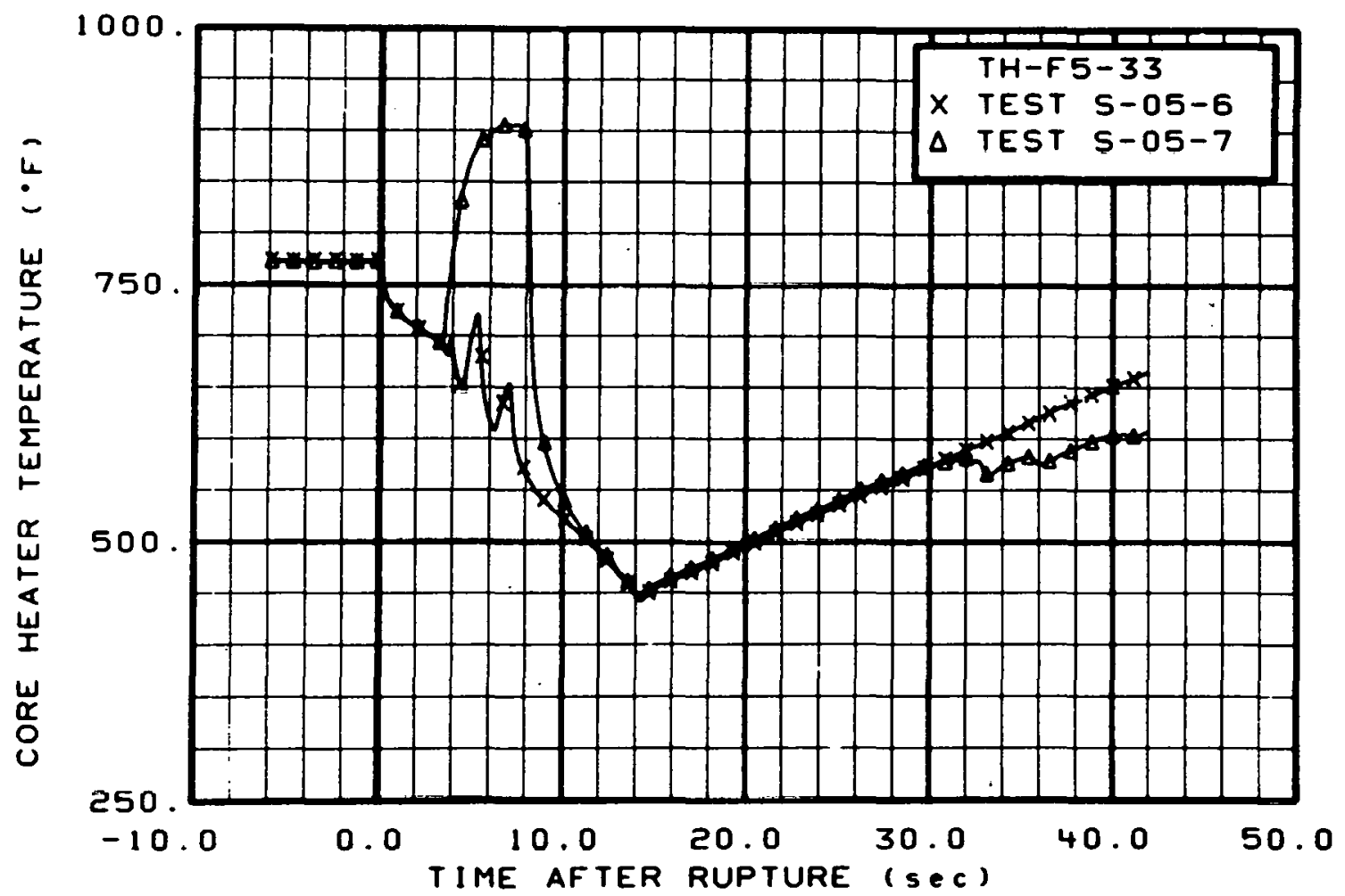

Fig. 225 Core heater temperature, Rod F-5 (TH-F5-33), from -6 to $42 \mathrm{sec}$. 


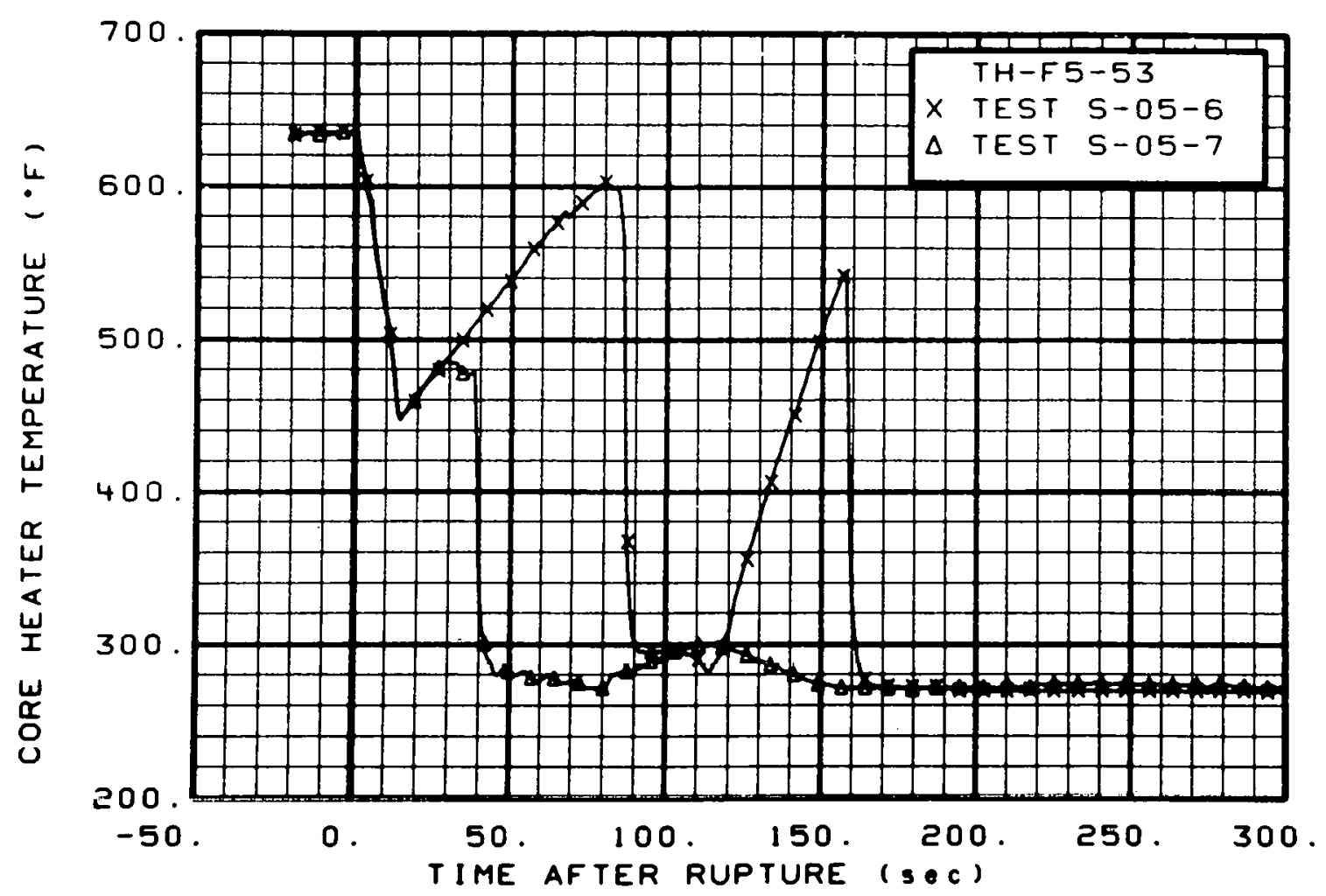

Fig. 226 Core heater temperature, Rod F-5 (TH-F5-53), from -20 to $300 \mathrm{sec}$.

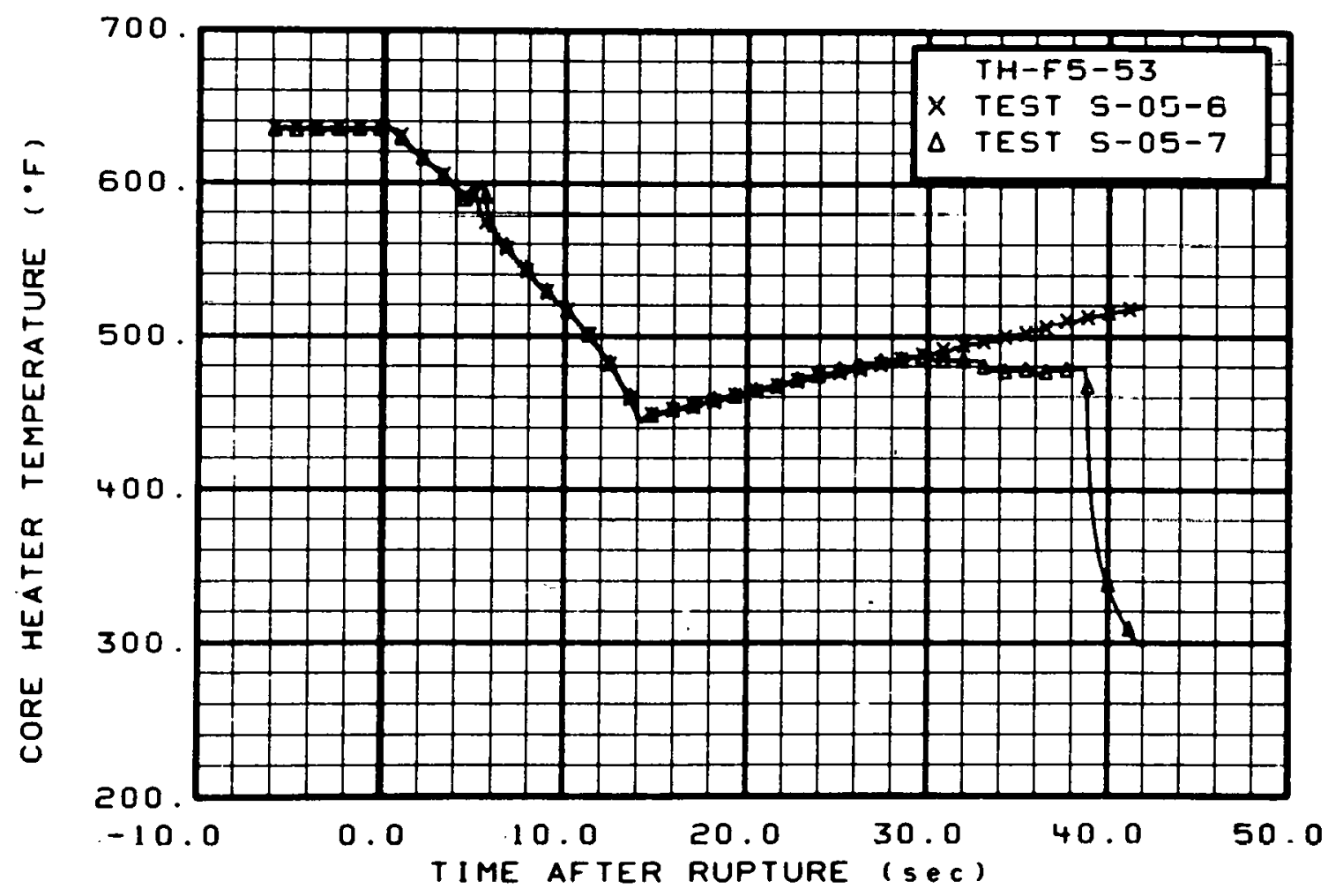

Fig. 227 Core heater temperature, Rod F-5 (TH-F5-53), from -6 to $42 \mathrm{sec}$. 


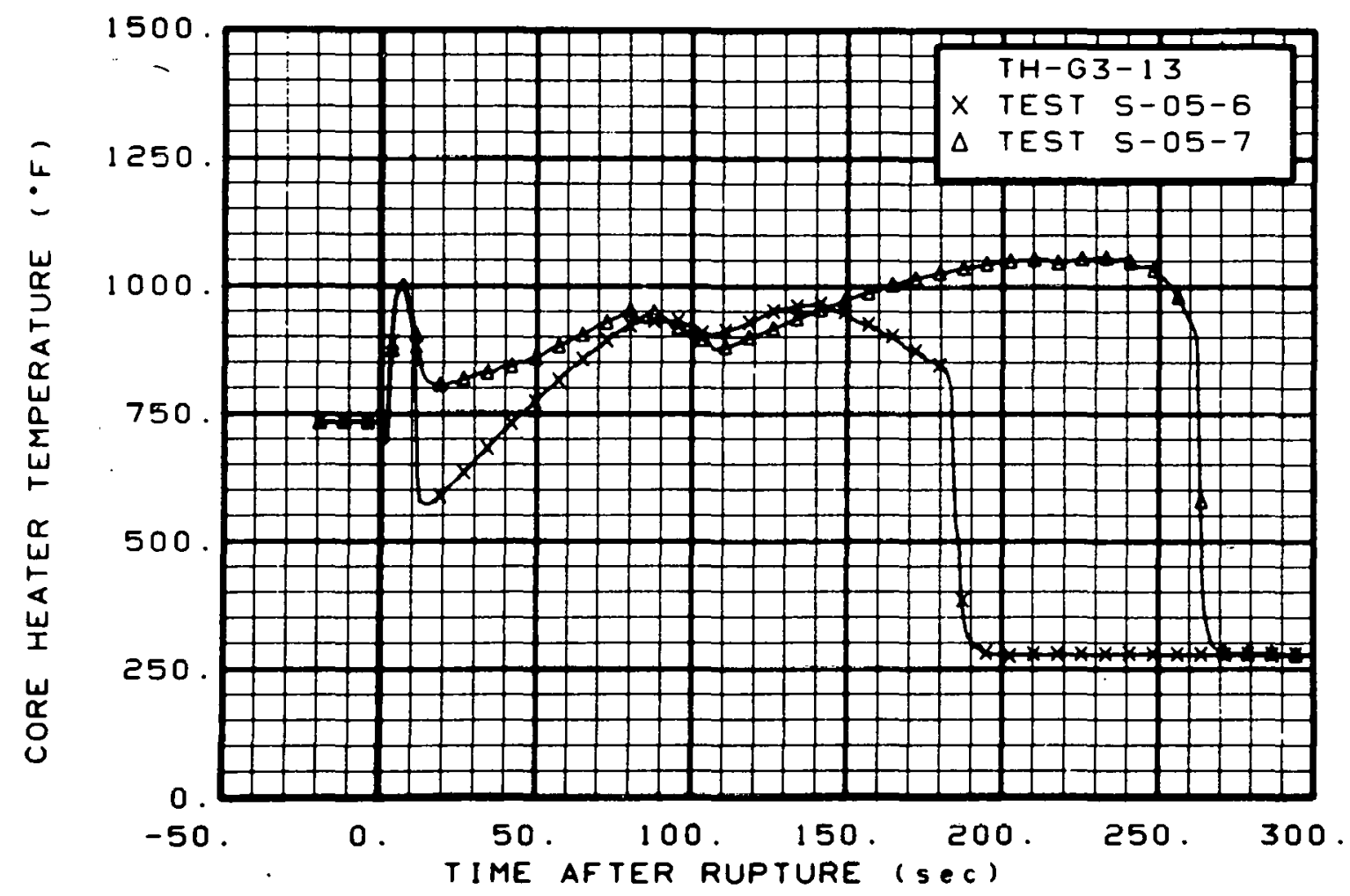

Fig, 228 Core heater temperature, Rod G-3 (TH-G3-13), from -20 to $300 \mathrm{sec}$.

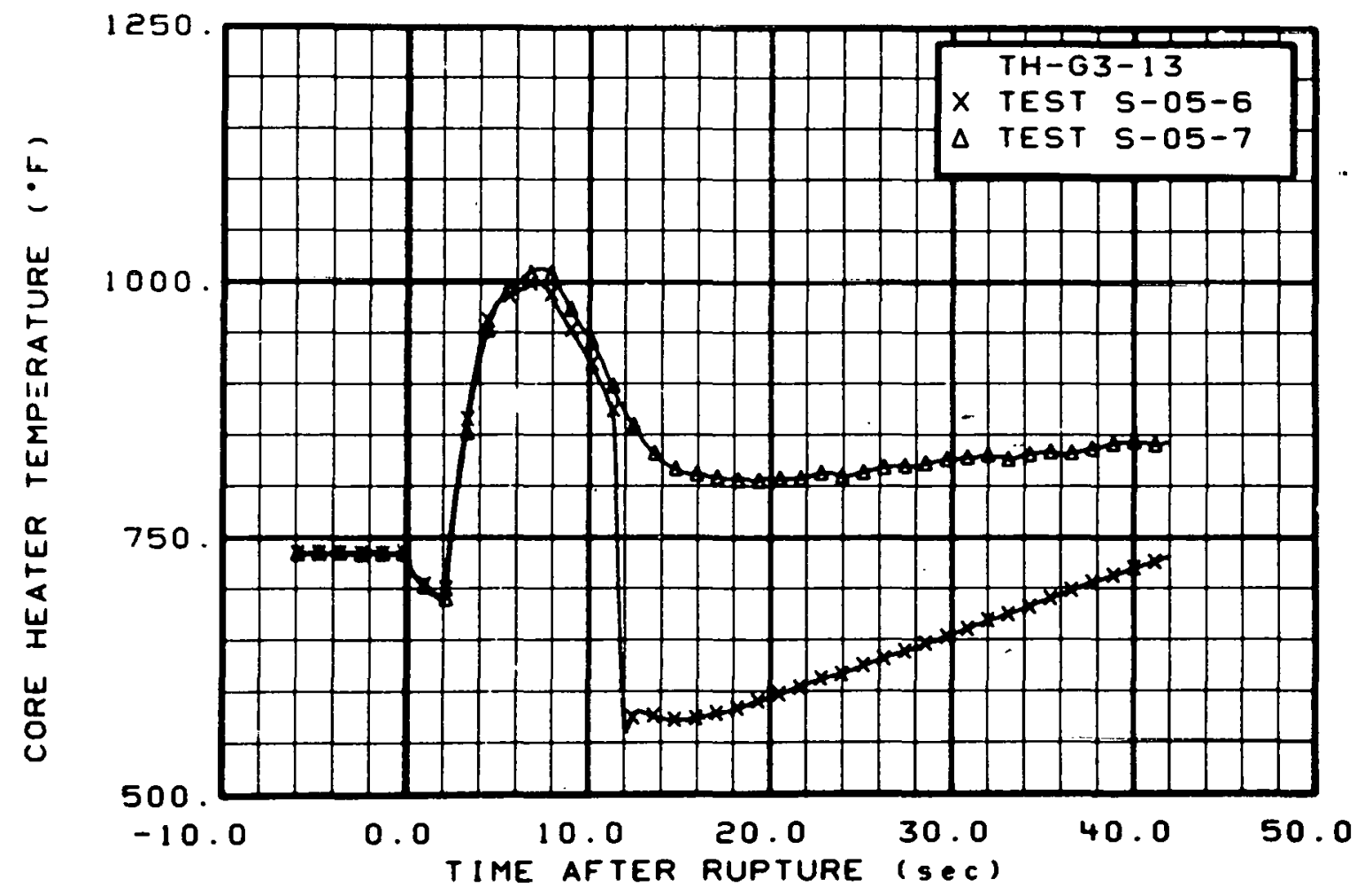

Fig. 229 Core heater temperature, Rod G-3 (TH-G3-13), from -6 to $42 \mathrm{sec}$. 


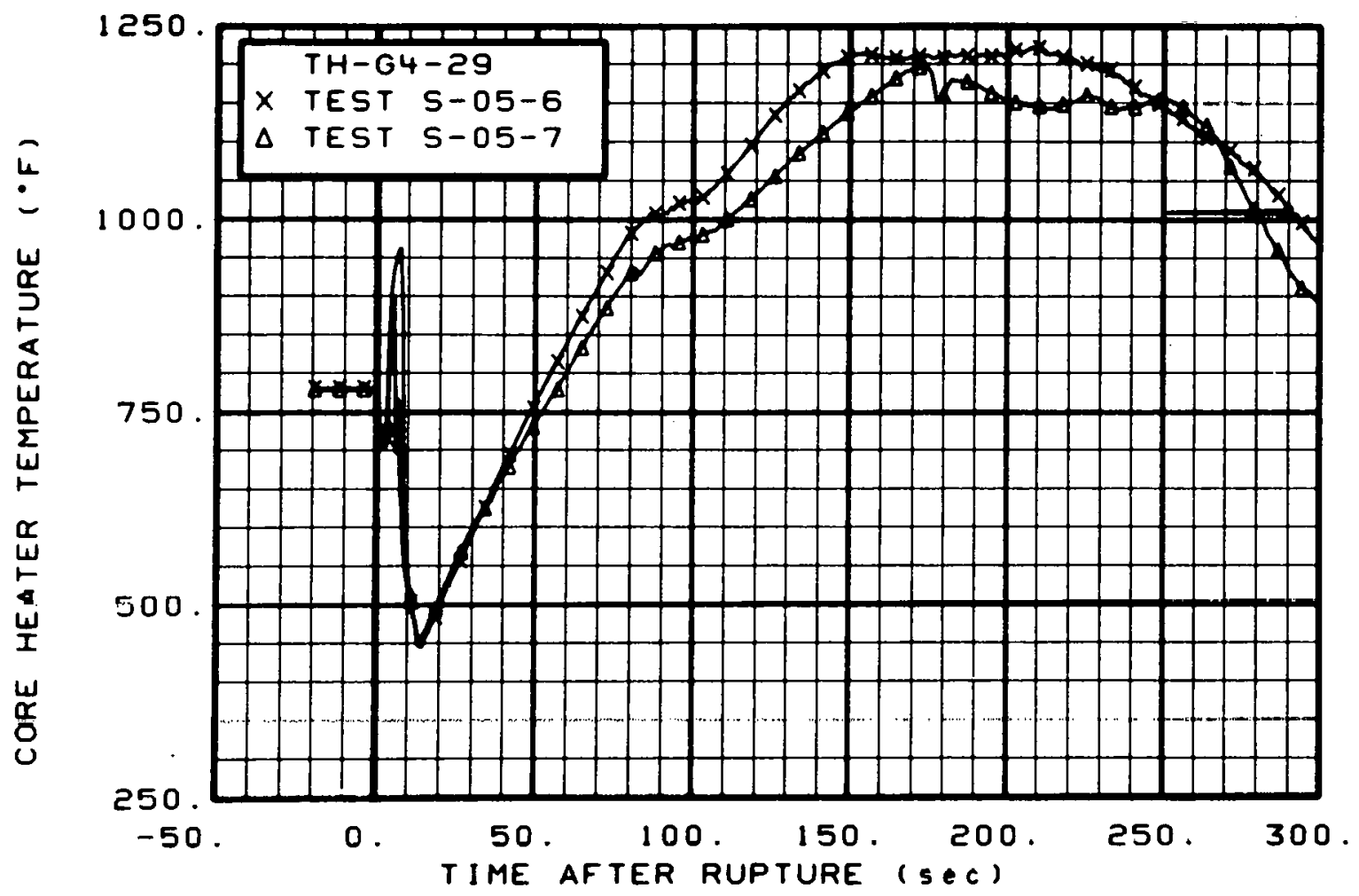

Fig. 230 Core heater temperature, Rod G-4 (TH-G4-29), from -20 to $300 \mathrm{sec}$.

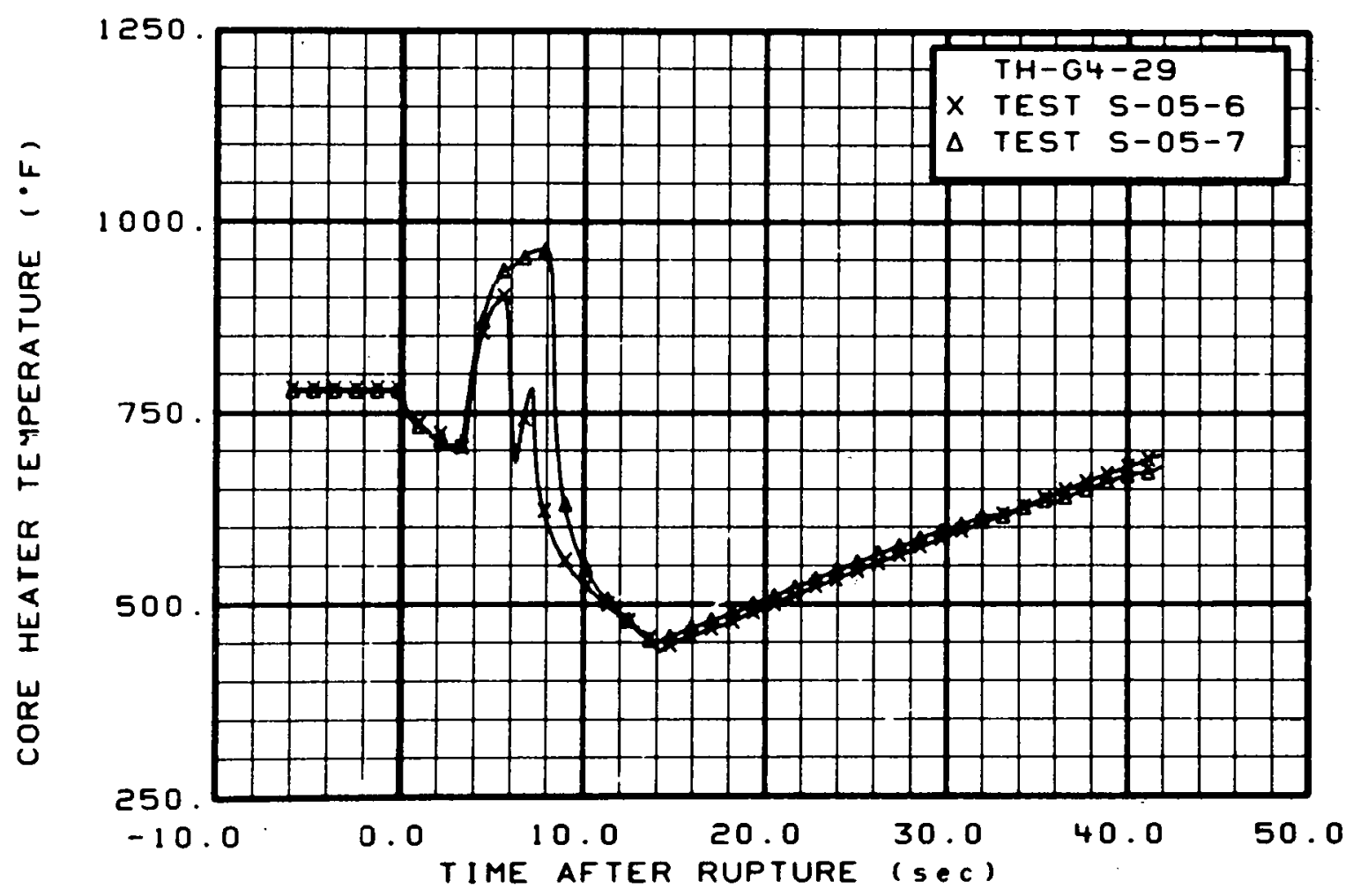

Fig. 231 Core heater temperature, Rod G=4 (TH-G4-29), from -6 to $42 \mathrm{sec}$. 


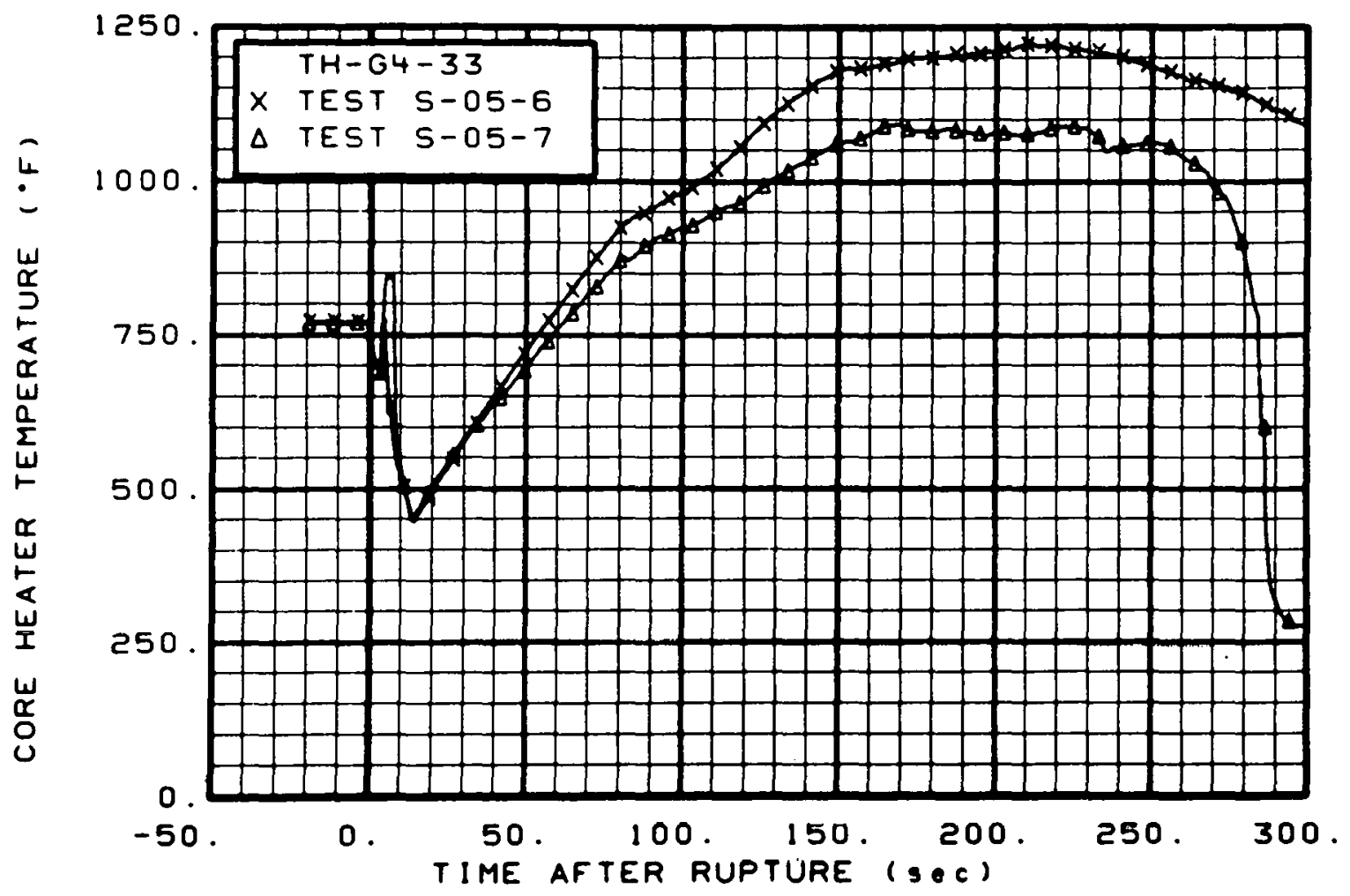

Fig. 232 Core heater temperature, Rod G-4 (TH-G4-33), from -20 to $300 \mathrm{sec}$.

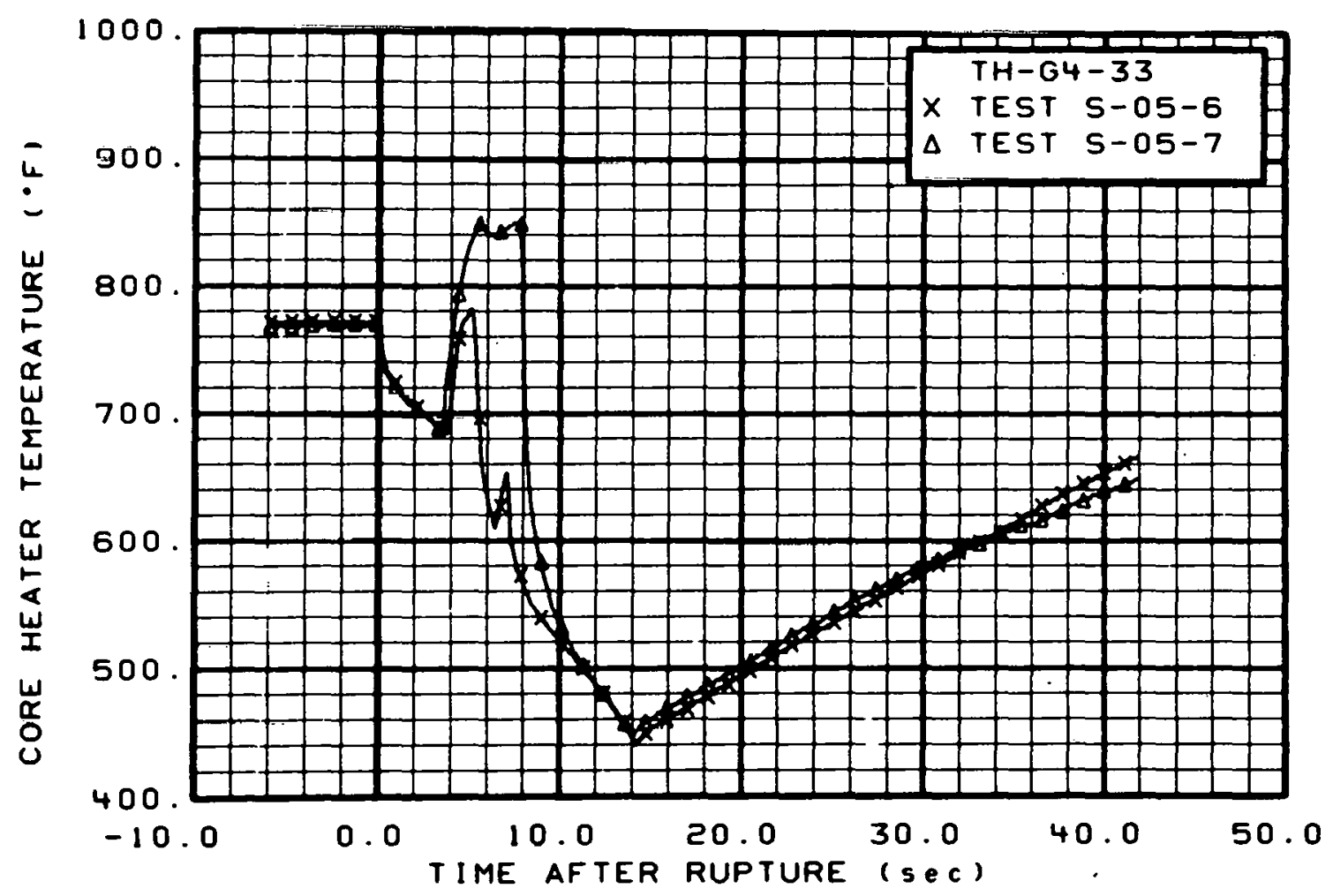

Fig. 233 Core heater temperature, Rod G-4 (TH-G4-33), from -6 to $42 \mathrm{sec}$. 


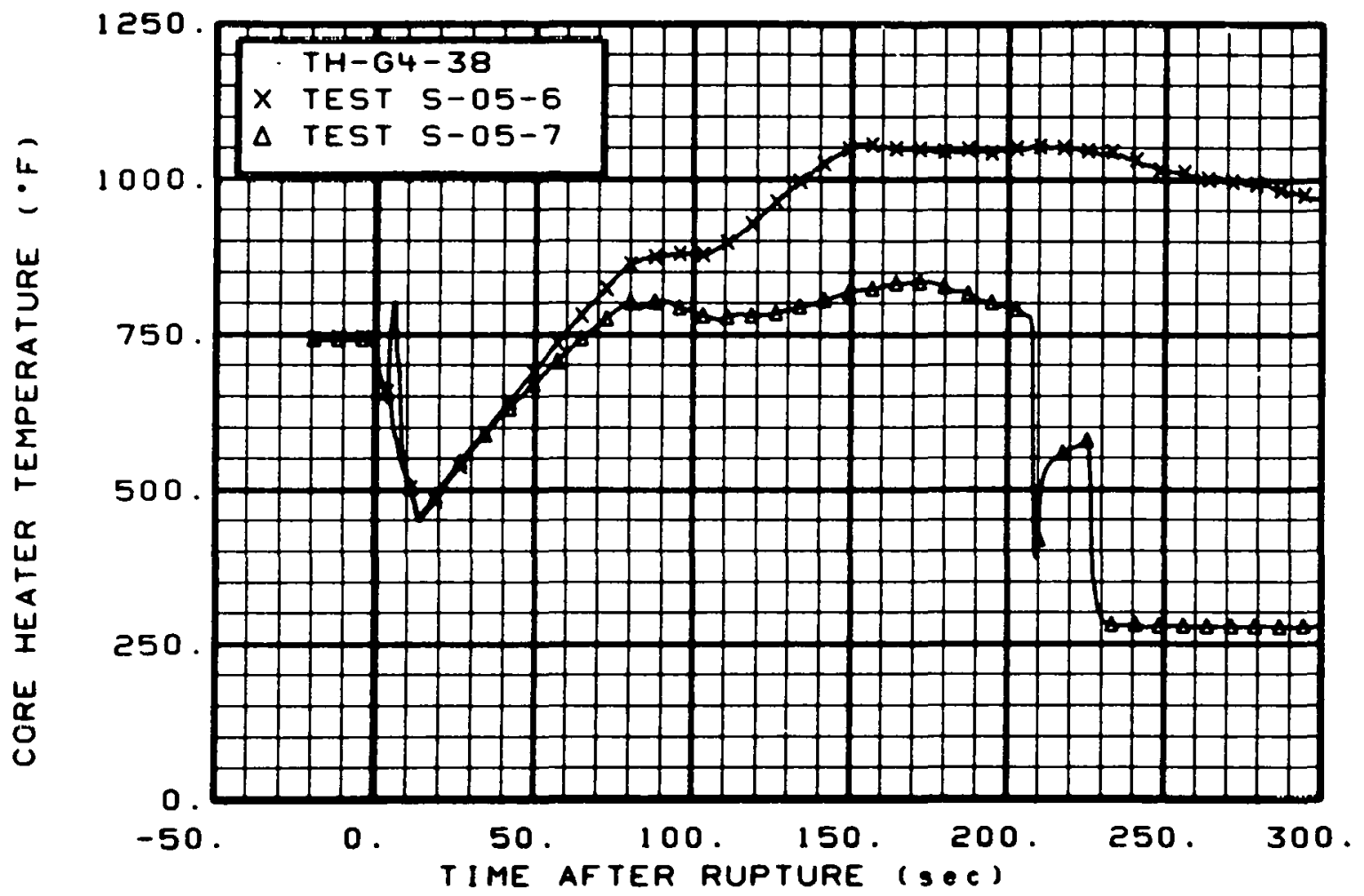

Fig. 234 Core heater temperature, Rod G-4 (TH-G4-38), from -20 to $300 \mathrm{sec}$.

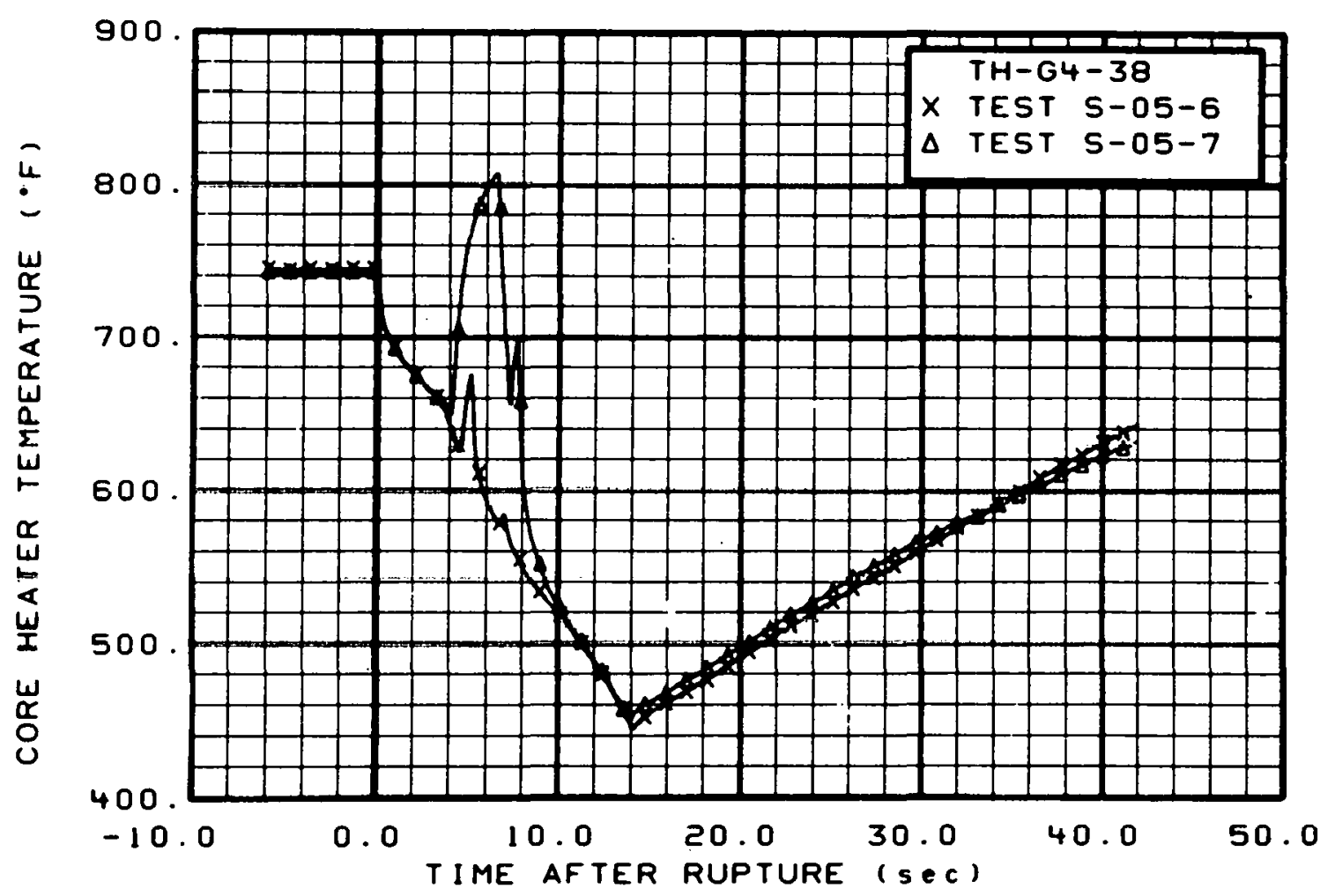

Fig. 235 Core heater temperature, Rod G-4 (TH-G4-38), from -6 to 42 sec. 


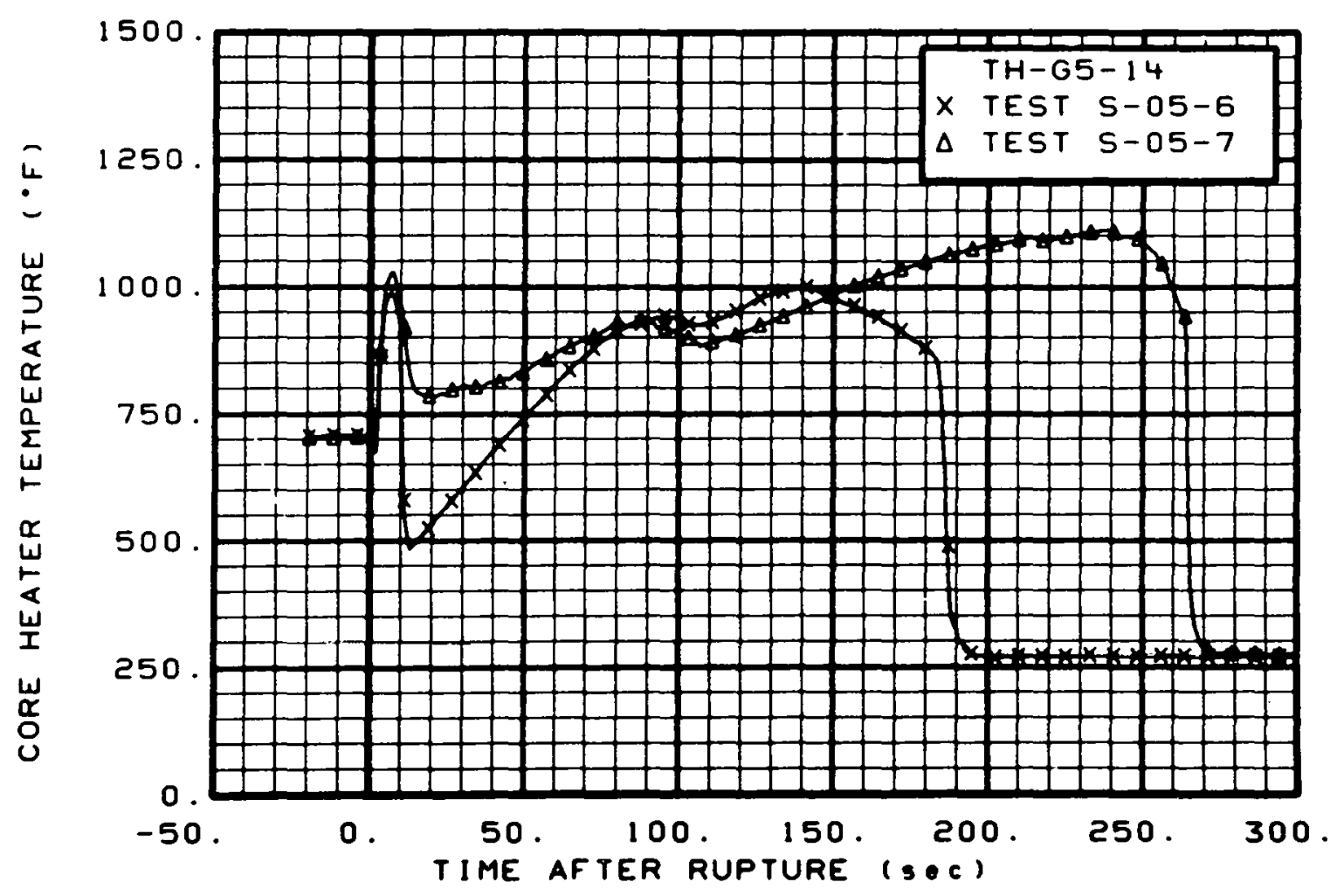

Fig. 236 Core heater temperature, Rod G-5 (TH-G5-14), from -20 to $300 \mathrm{sec}$.

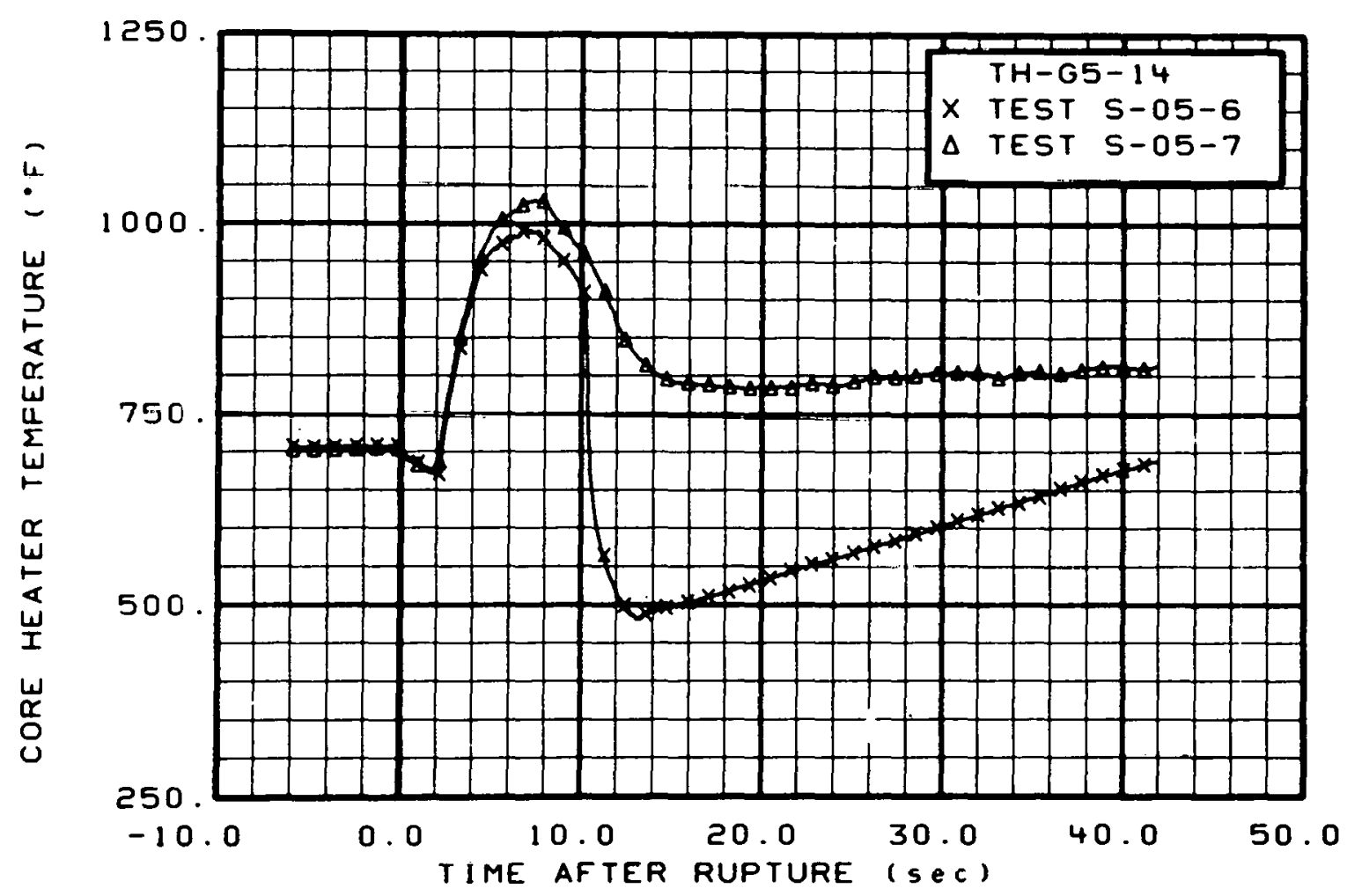

Fig. 237 Core heater temperature, Rod G-5 (TH-G5-14), from -6 to $42 \mathrm{sec}$. 


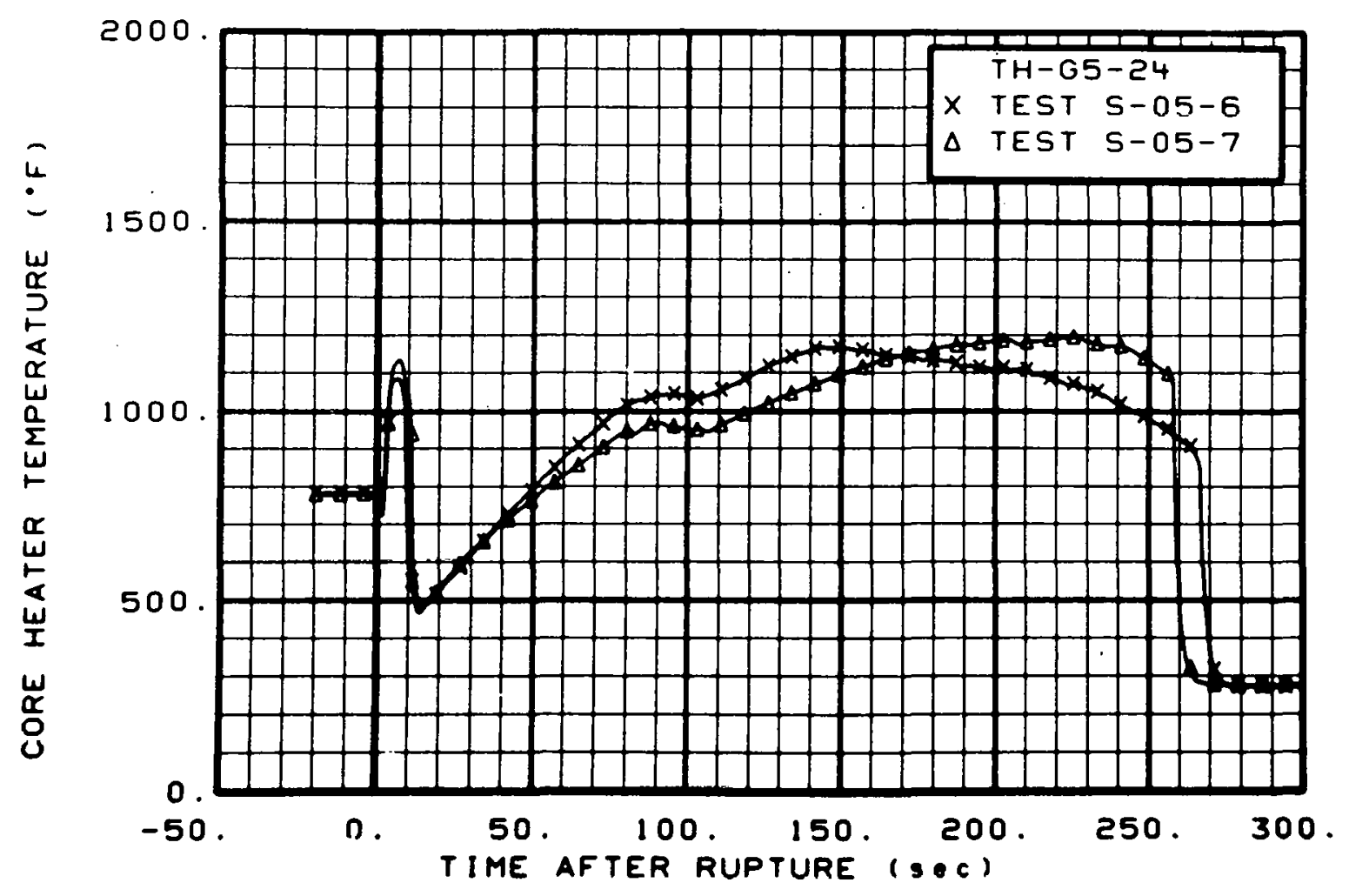

Fig. 238 Core heater temperature, Rod G-5 (TH-G5-24), from -20 to $300 \mathrm{sec}$.

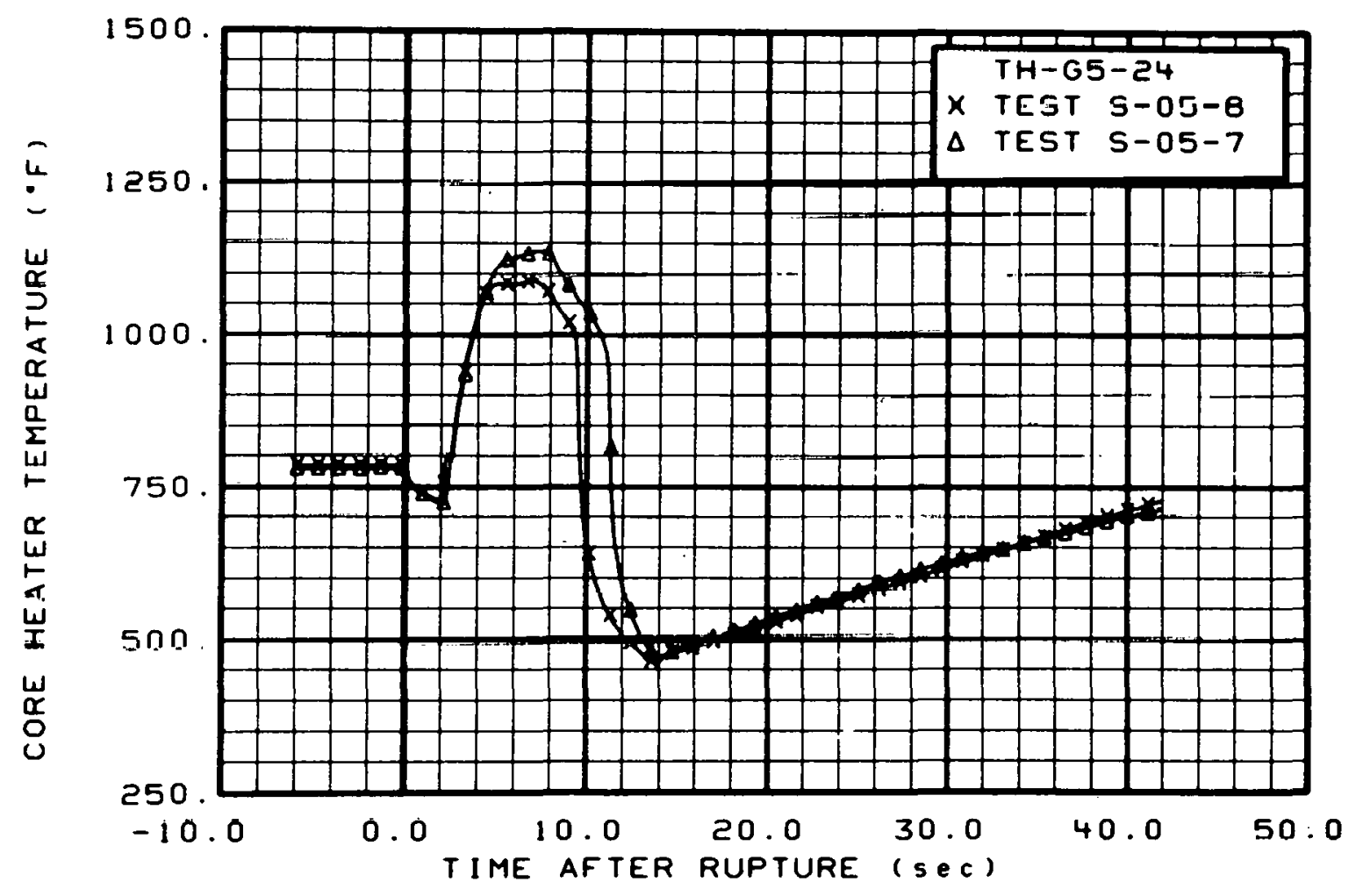

Fig. 239 Core heater temperature, Rod G-5 (TH-G5-24), from -6 to $42 \mathrm{sec}$. 


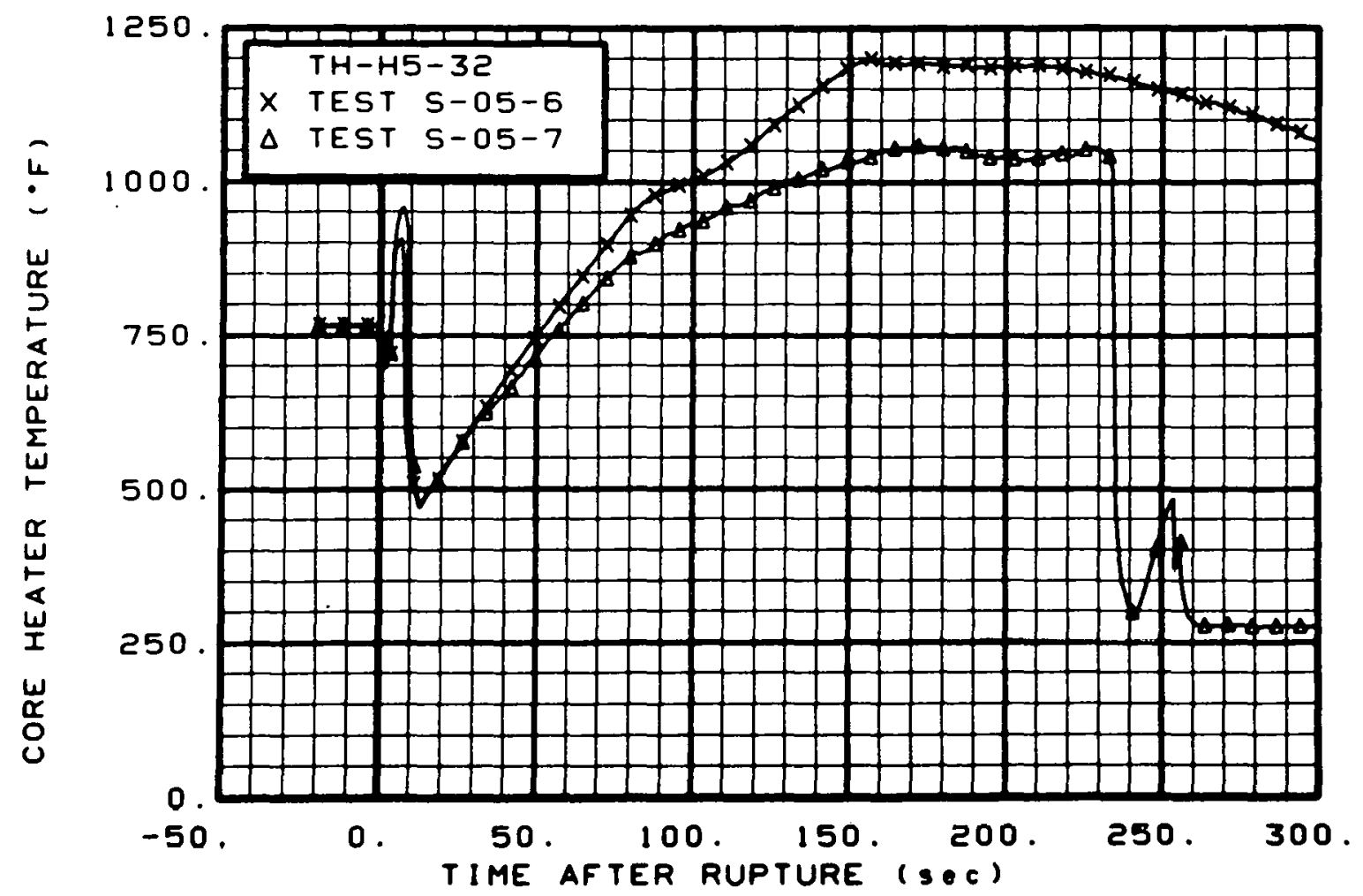

Fig. 240 Core heater temperature, Rod H-5 (TH-H5-32), from -20 to $300 \mathrm{sec}$.

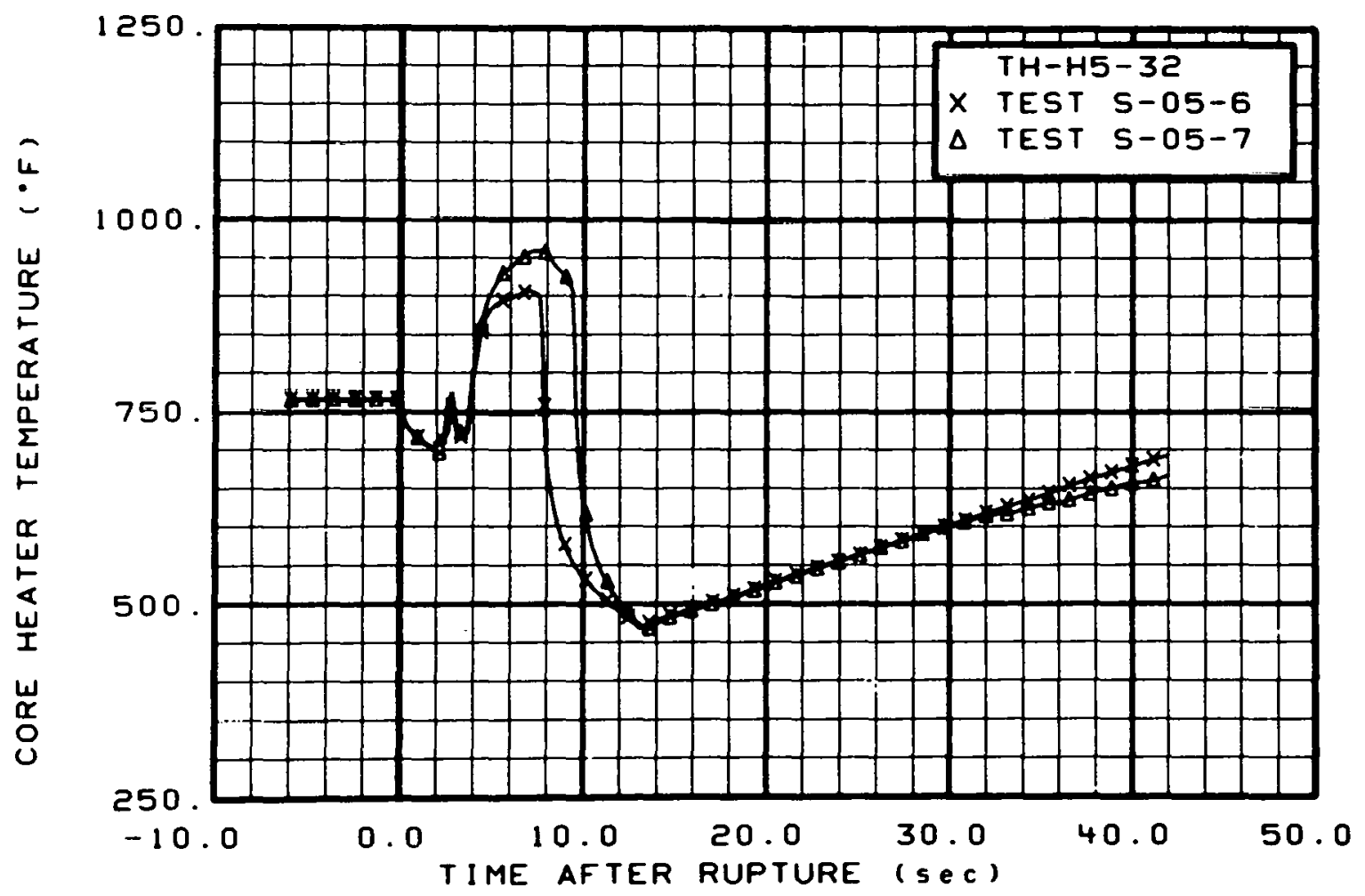

Fig. 241 Core heater temperature, Rod H-5 (TH-H5-32), from -6 to $42 \mathrm{sec}$. 


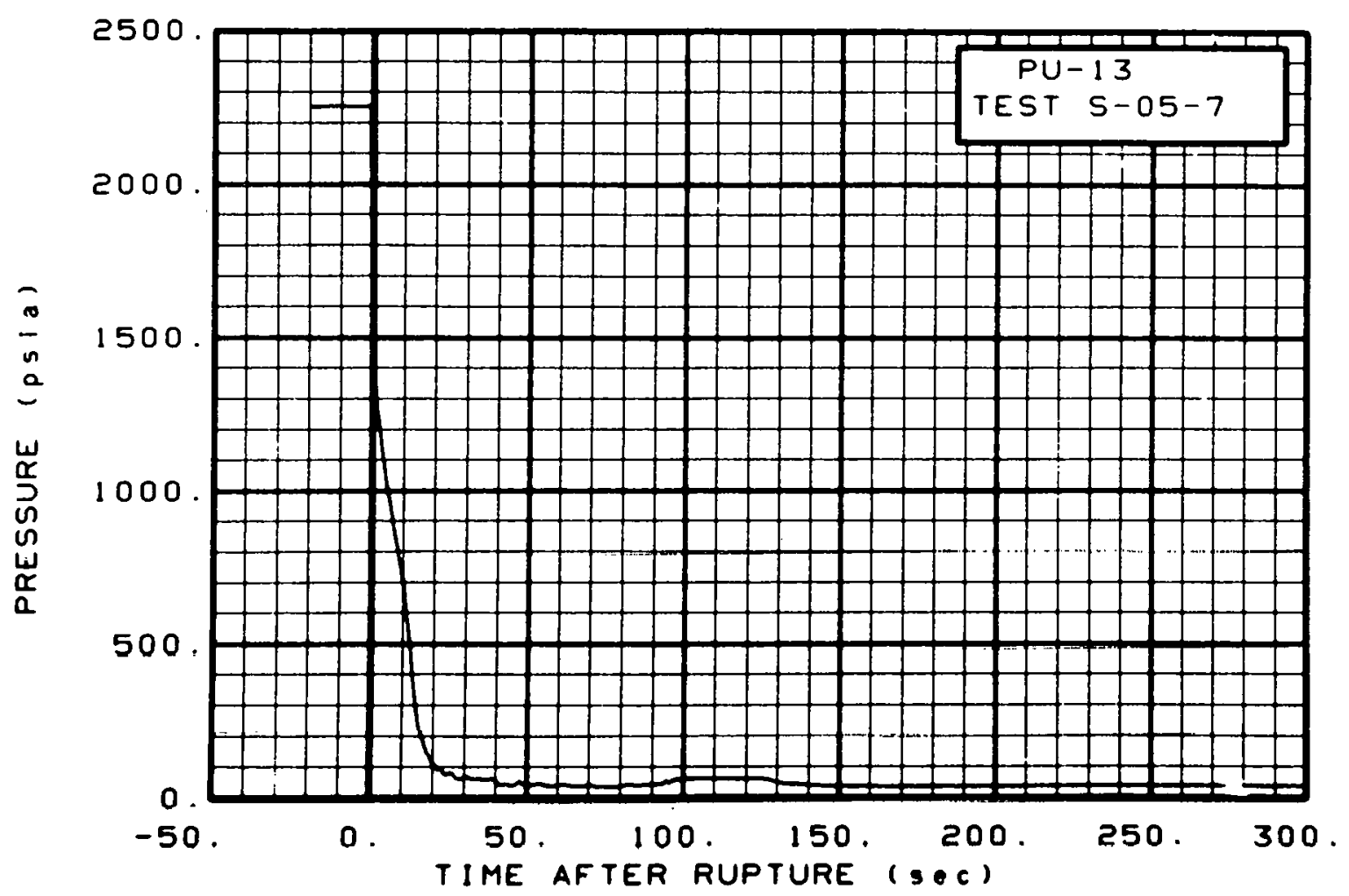

Fig. 242 Pressure in intact loop, Spool 13, Test S-05-7 (PU-13), from -20 to $300 \mathrm{sec}$.

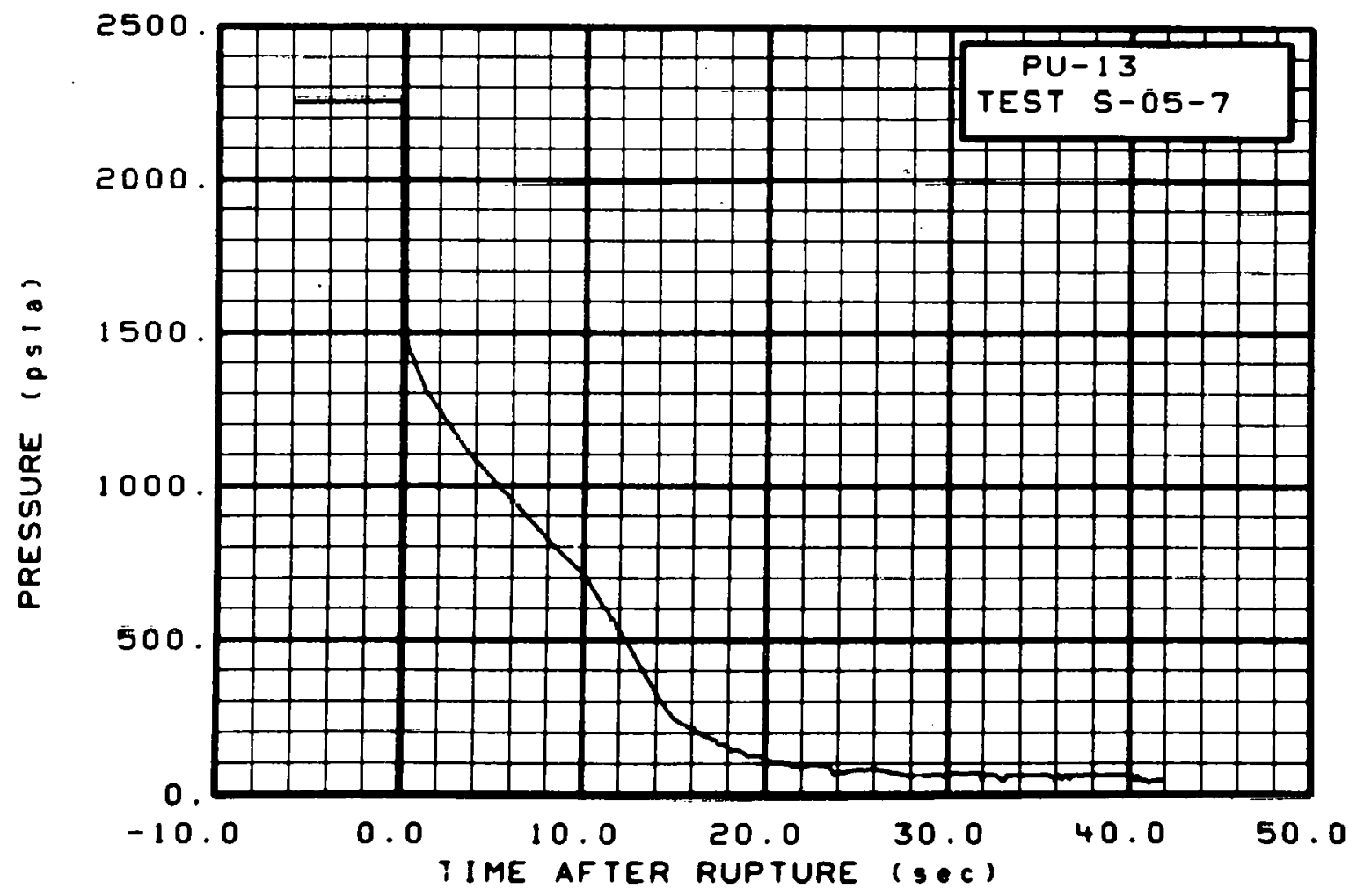

Fig. 243 Pressure in intact loop, Spool 13, Test S-05-7 (PU-13), from -6 to $42 \mathrm{sec}$. 


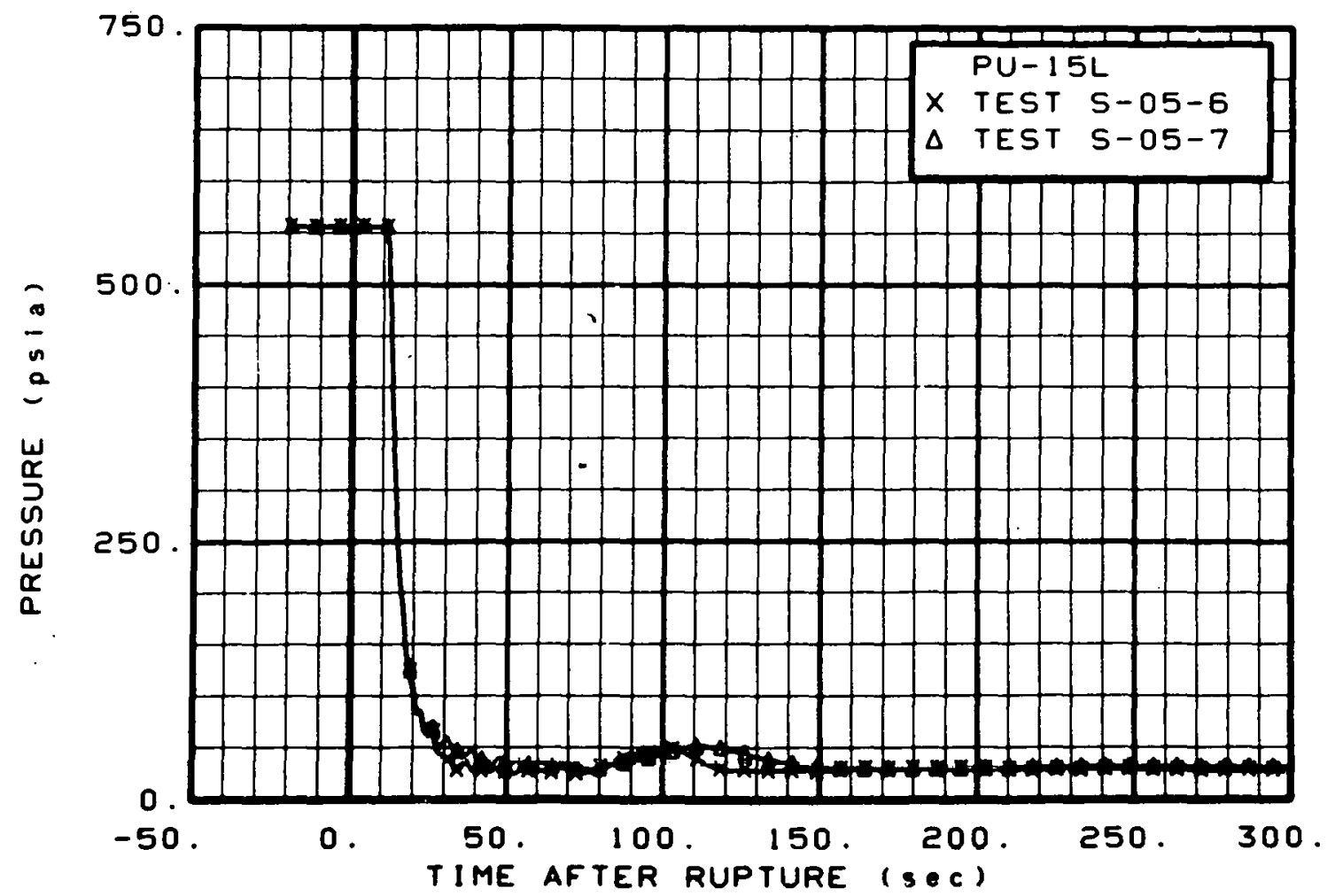

Fig. 244 Pressure in intact loop, Spool 15 (PU-15L), from -20 to $300 \mathrm{sec}$.

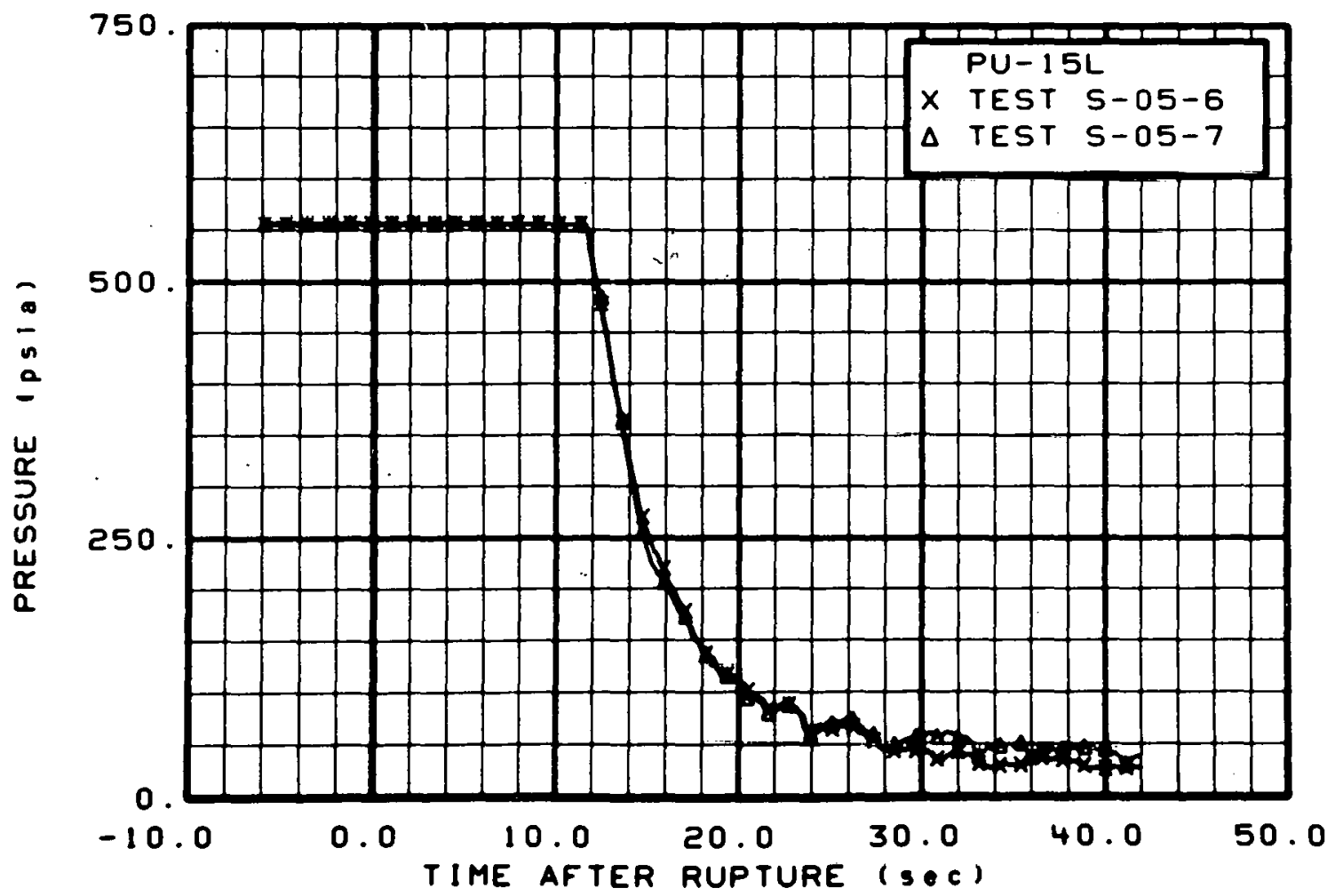

Fig. 245 Pressure in intact loop, Spool 15 (PU-15L), from -6 to $42 \mathrm{sec}$. 


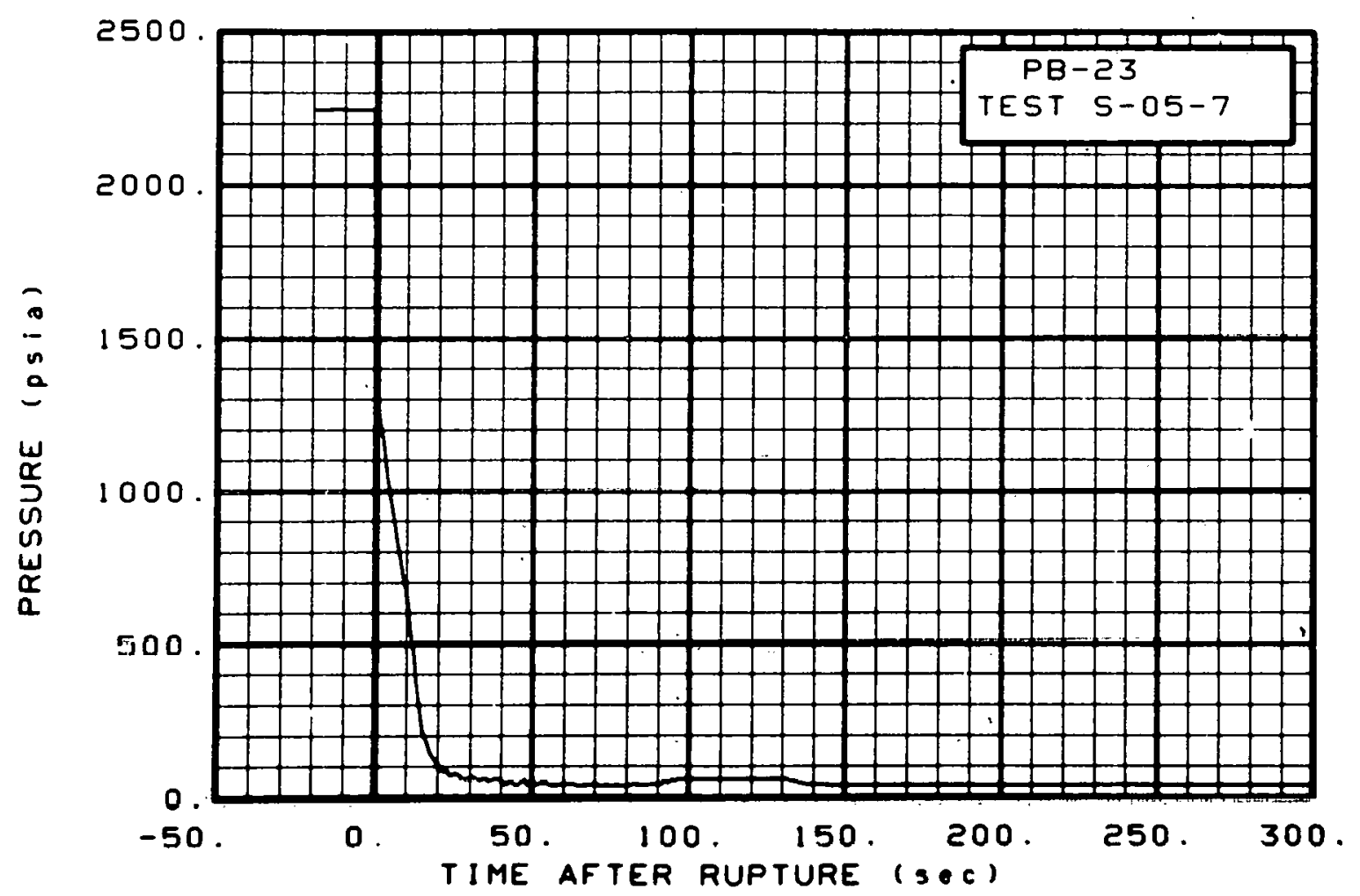

Fig. 246 Pressure in broken loop, Spool 23, Test S-05-7'(PB-23), from -20 to $300 \mathrm{sec}$.

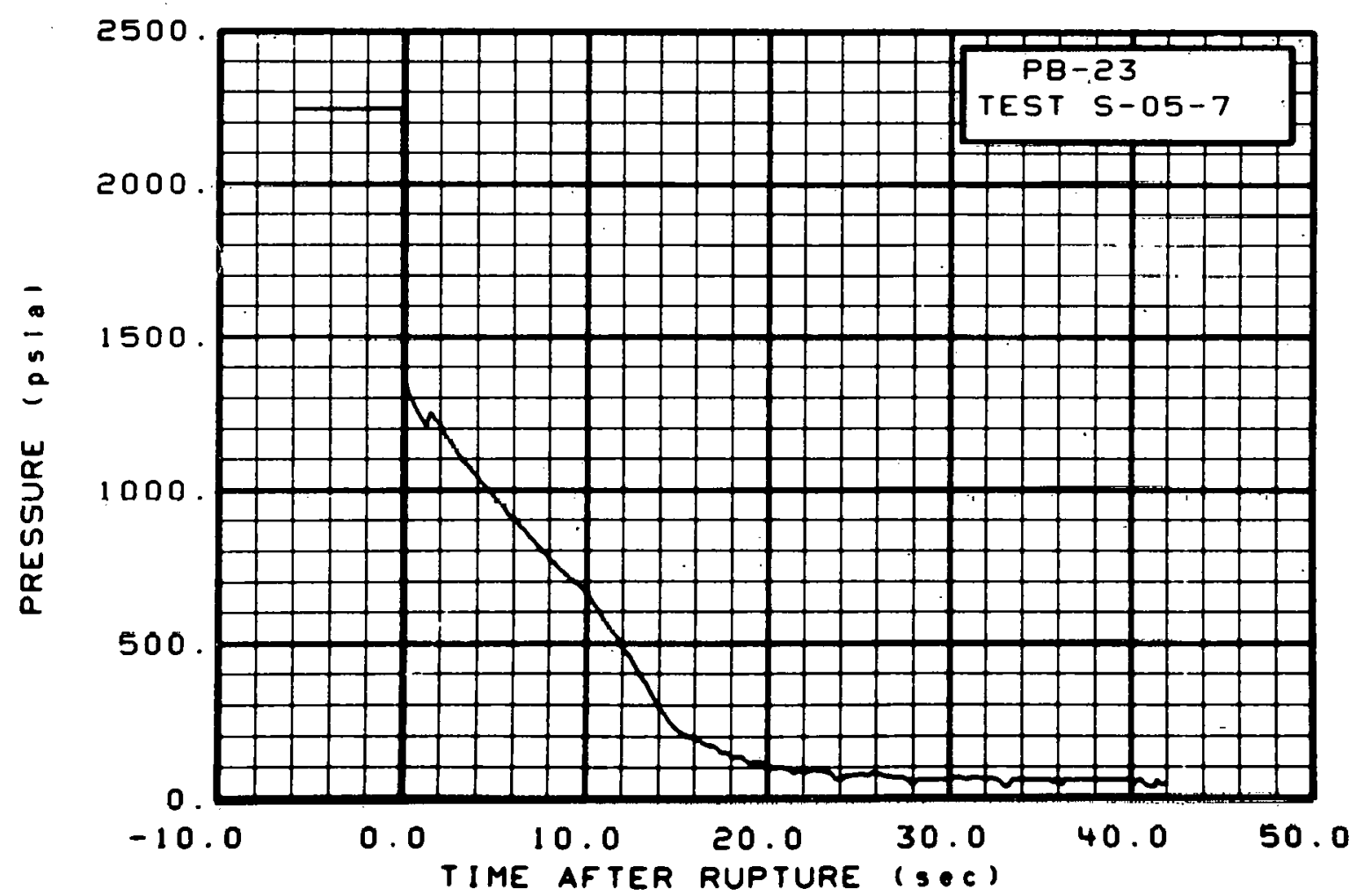

Fig. 247 Pressure in broken loop, Spool 23, Test S-05-7 (PB-23), from -6 to $42 \mathrm{sec}$. 


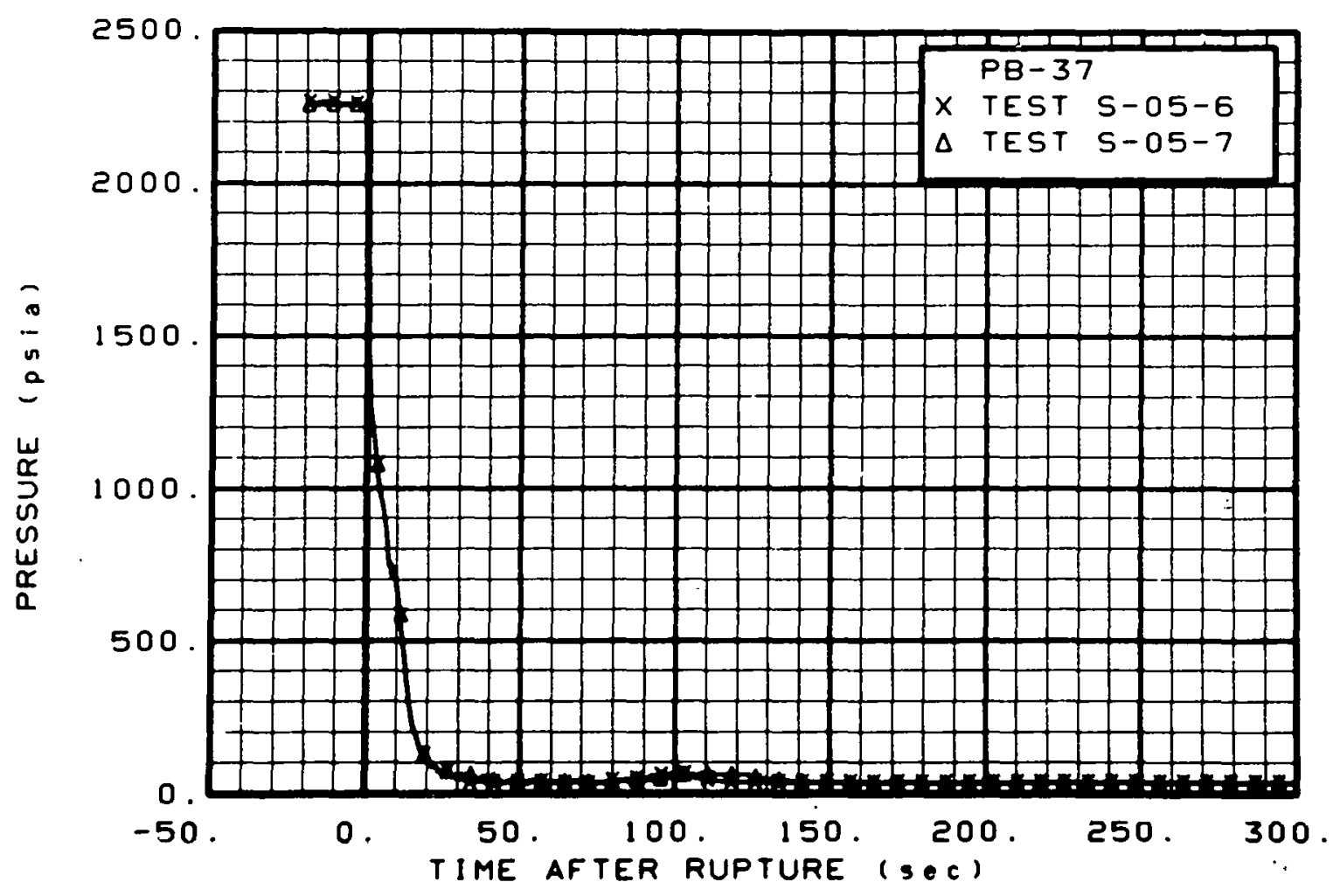

Fig. 248 Pressure in broken loop, near break (PB-37), from -20 to $300 \mathrm{sec}$.

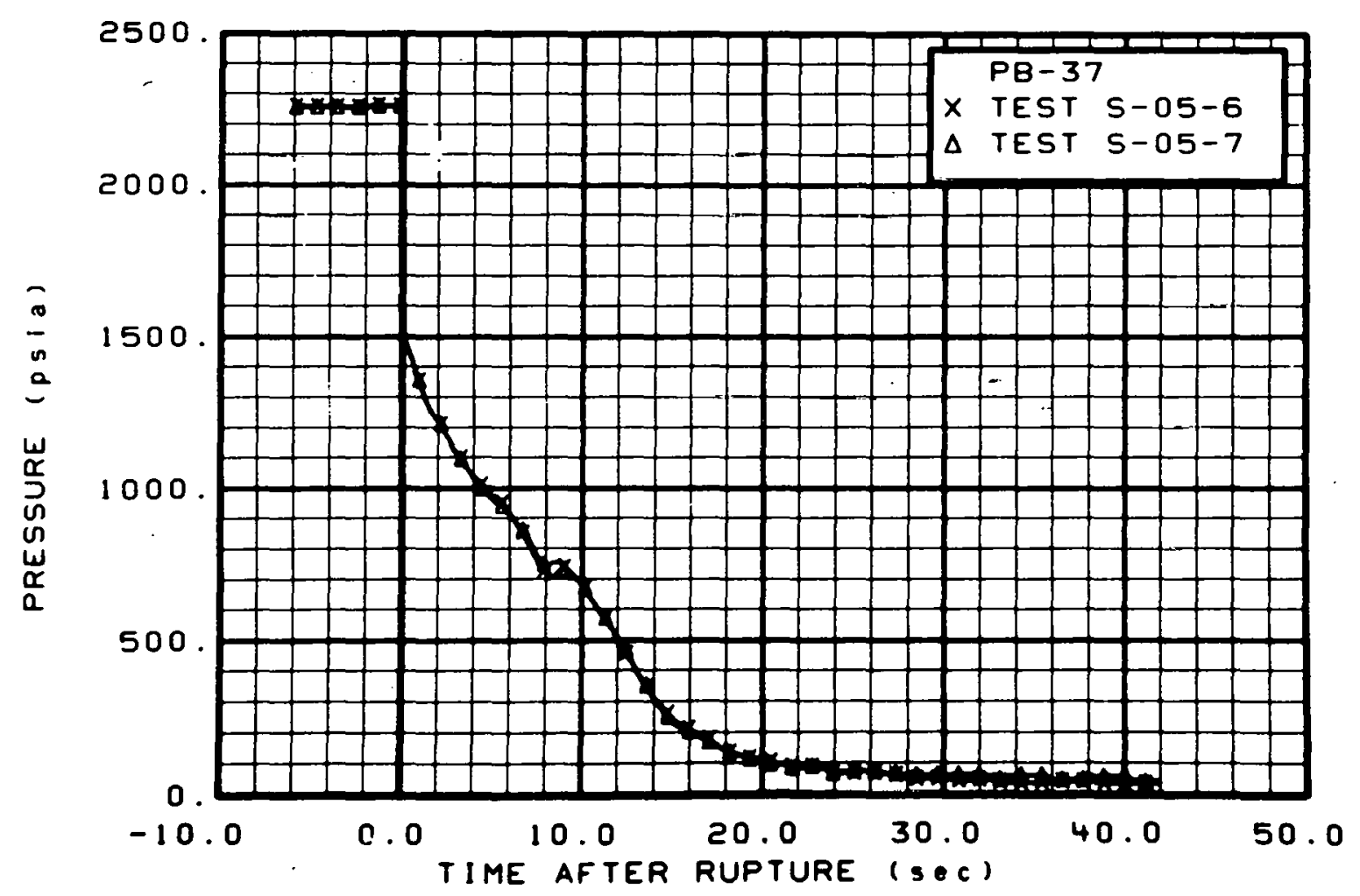

Fig. 249 Pressure in broken 10op, near break (PB-37), from -6 to $42 \mathrm{sec}$. 


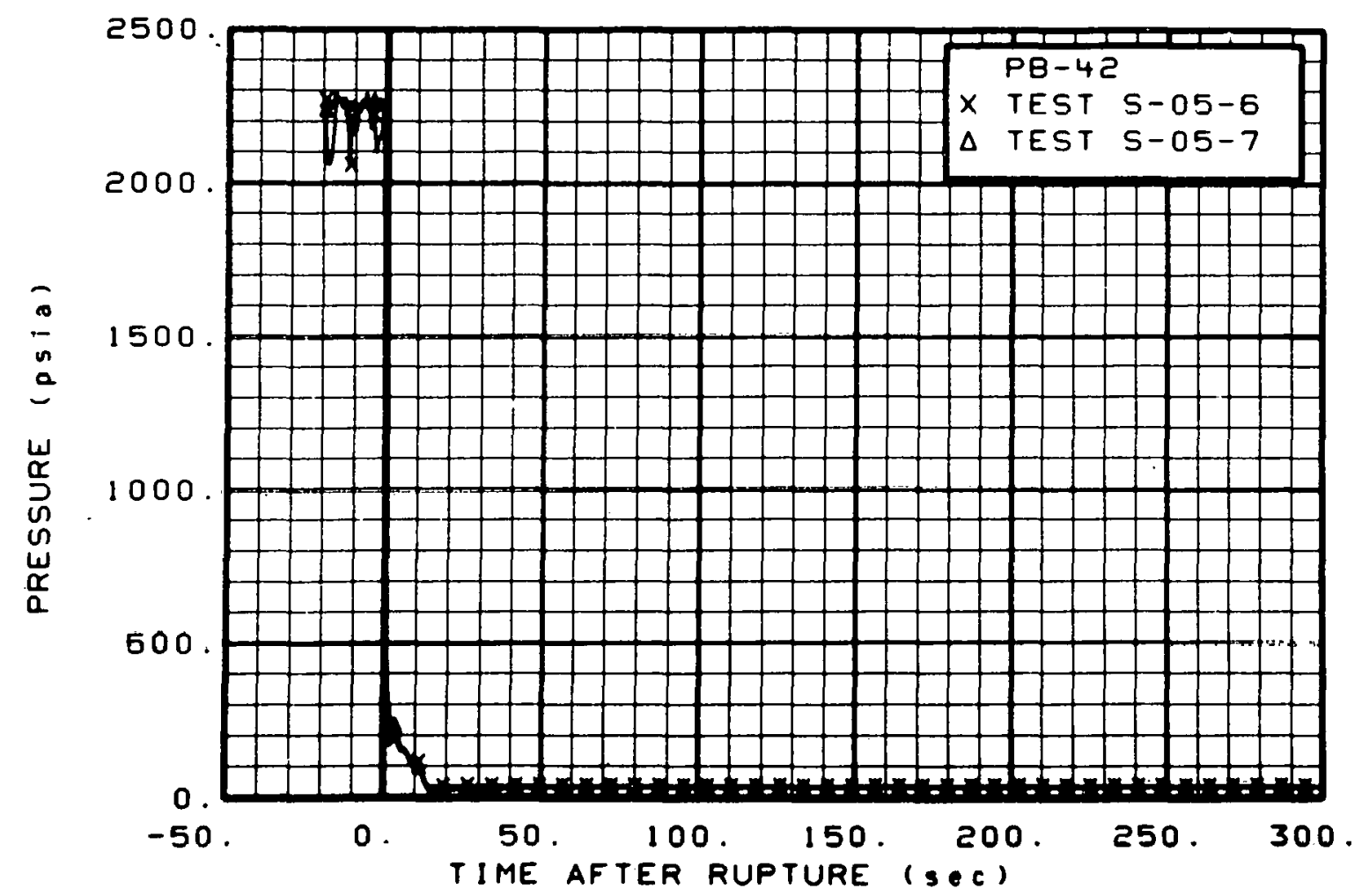

Fig. 250 Pressure in broken loop, near break (PB-42), from -20 to $300 \mathrm{sec}$.

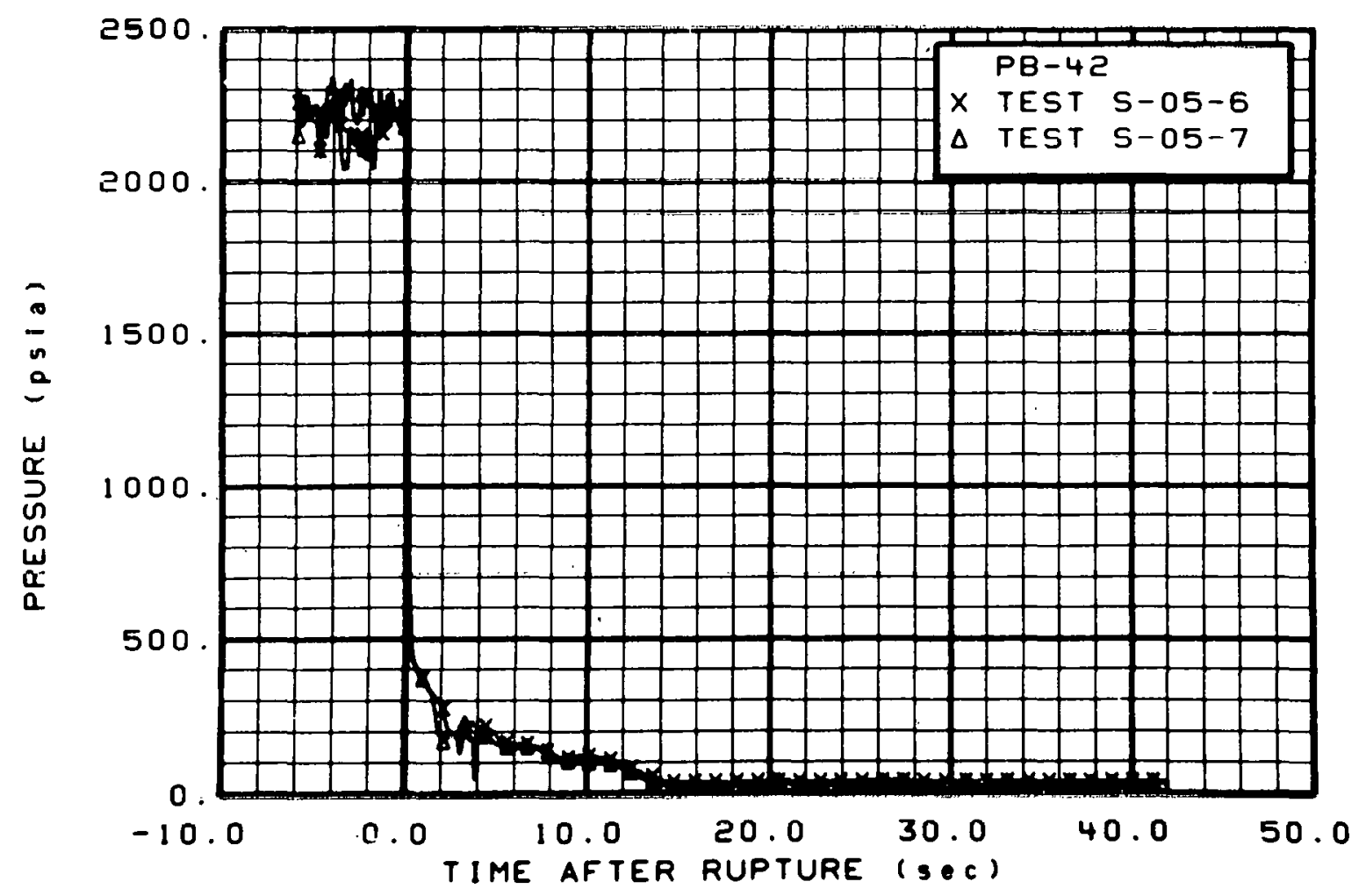

Fig. 251 Pressure in broken loop, near break (PB-42), from -6 to $42 \mathrm{sec}$. 


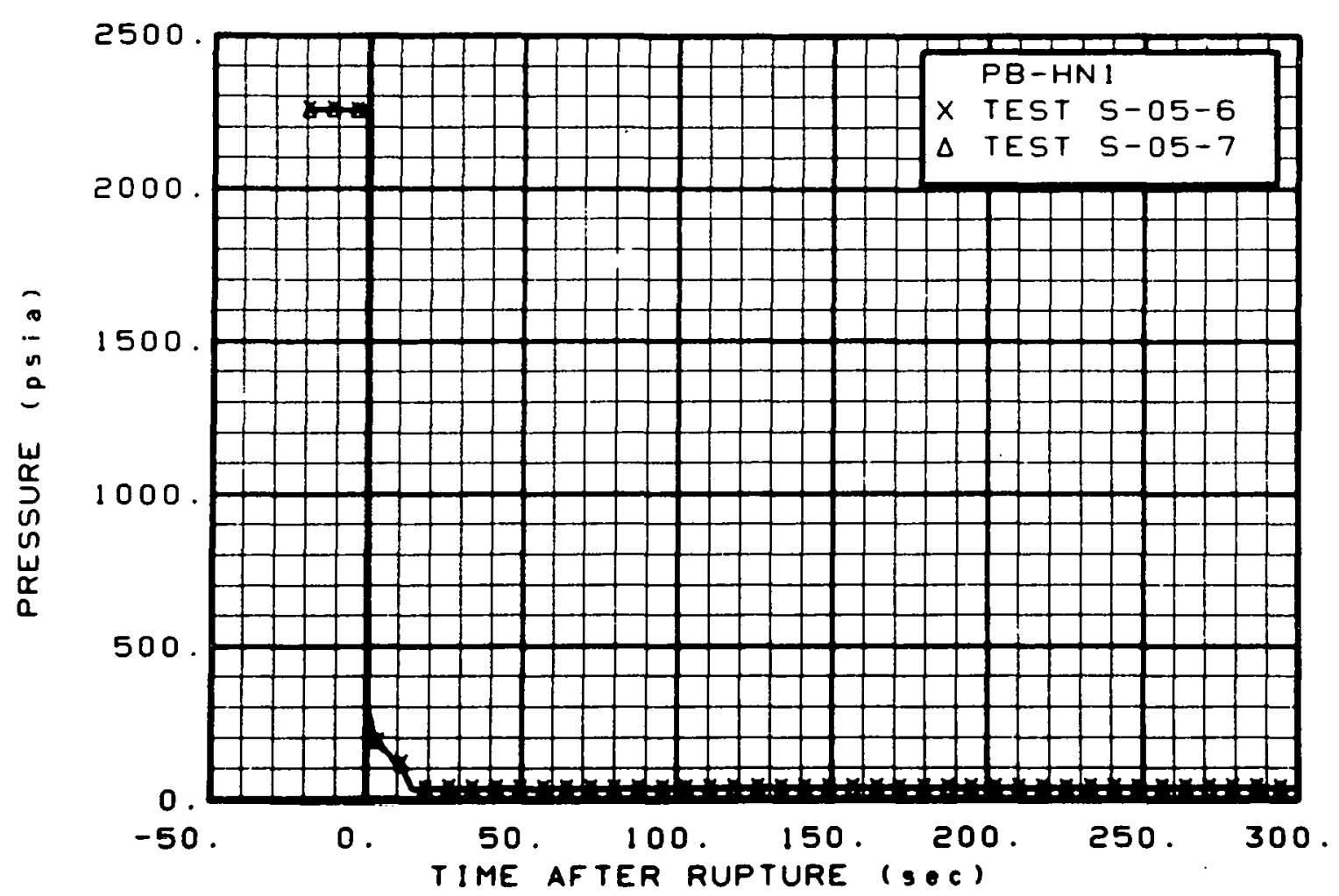

Fig. 252 Pressure in broken loop, near break (PB-HN1), from -20 to $300 \mathrm{sec}$.

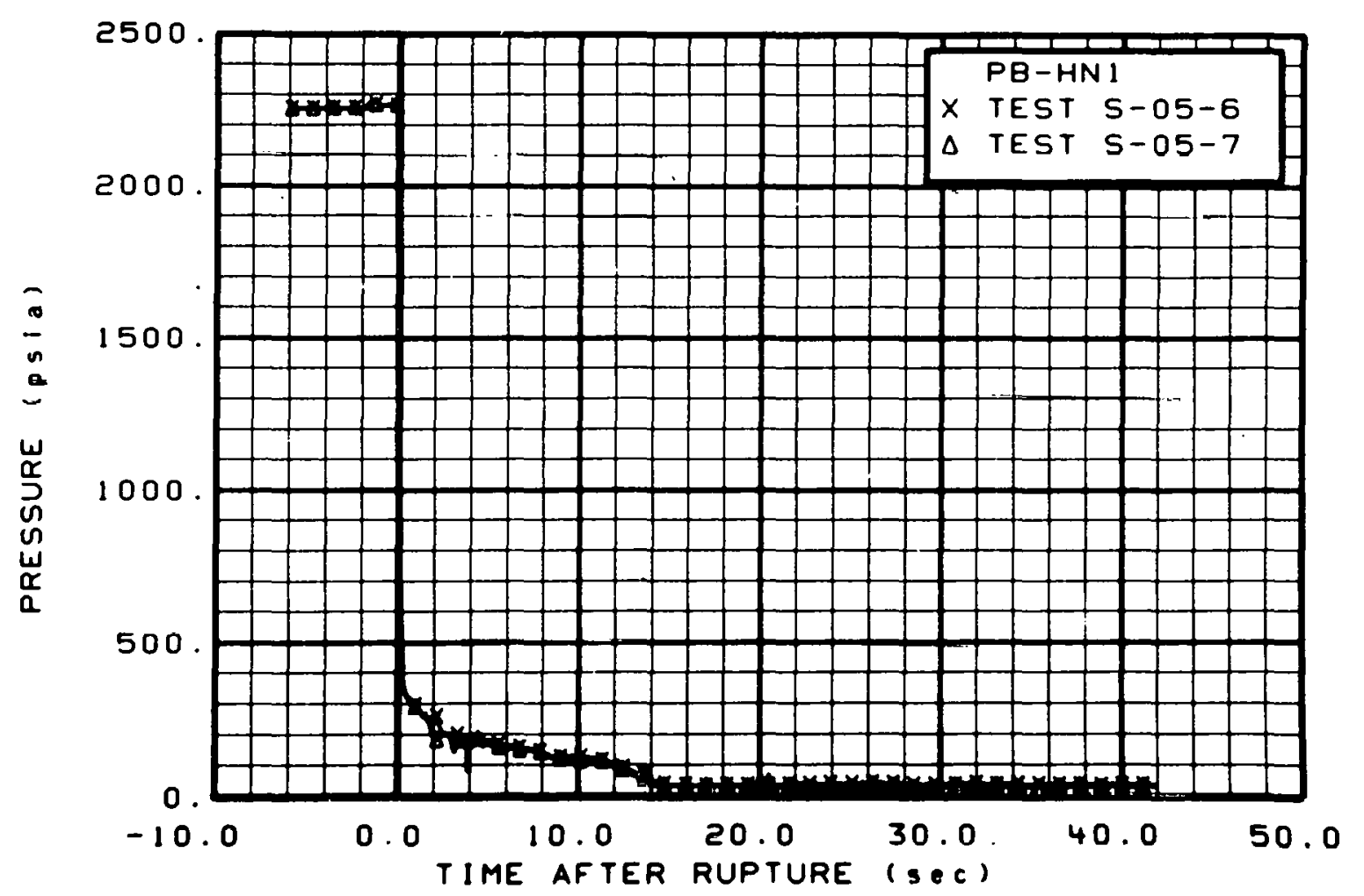

Fig. 253 Pressure in broken 1oop, near break (PB-HN1), from -6 to 42 sec. 


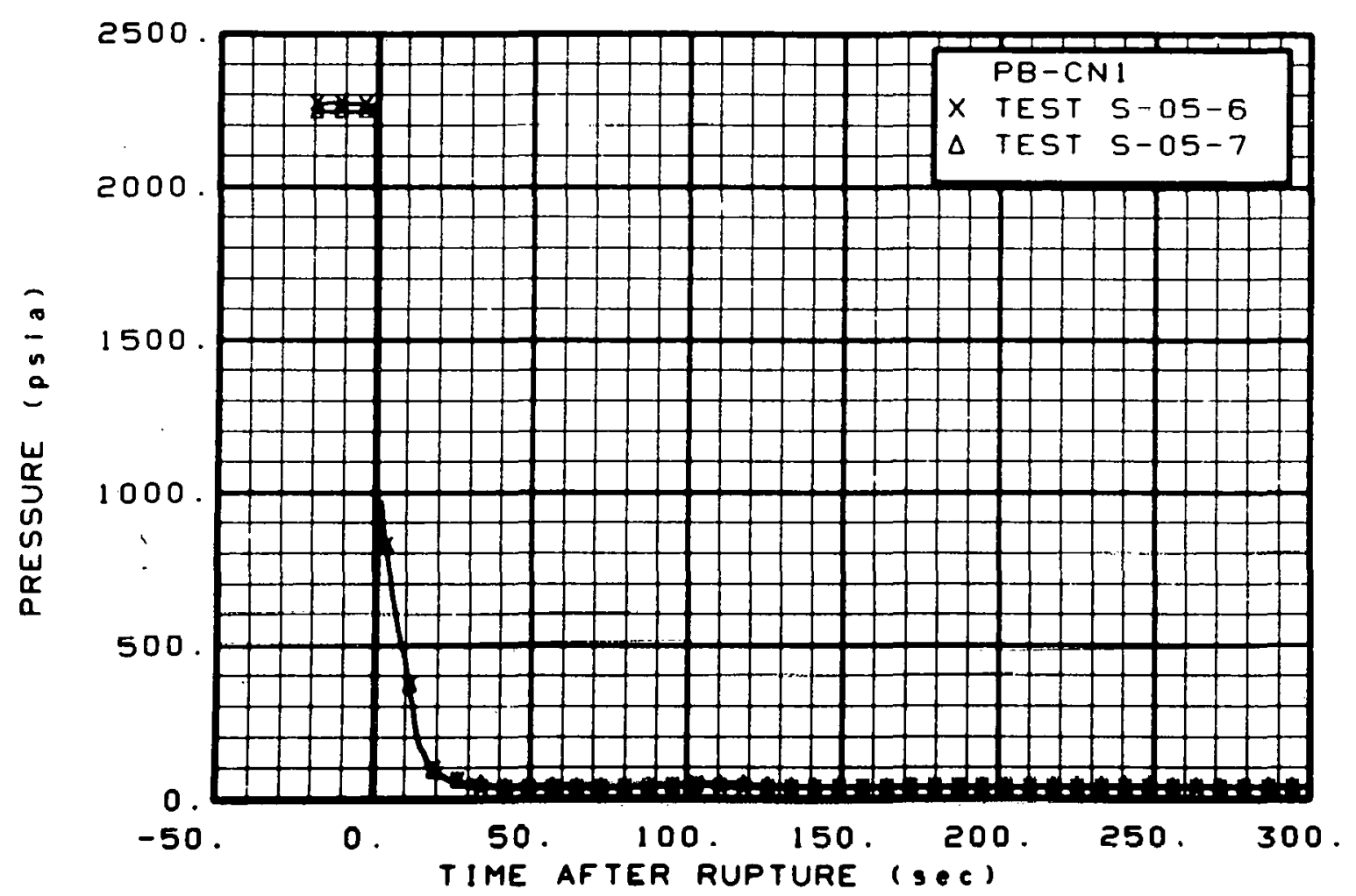

Fig. 254 Pressure in broken loop, vessel-side nozzle (PB-CN1), from -20 to 300 sec.

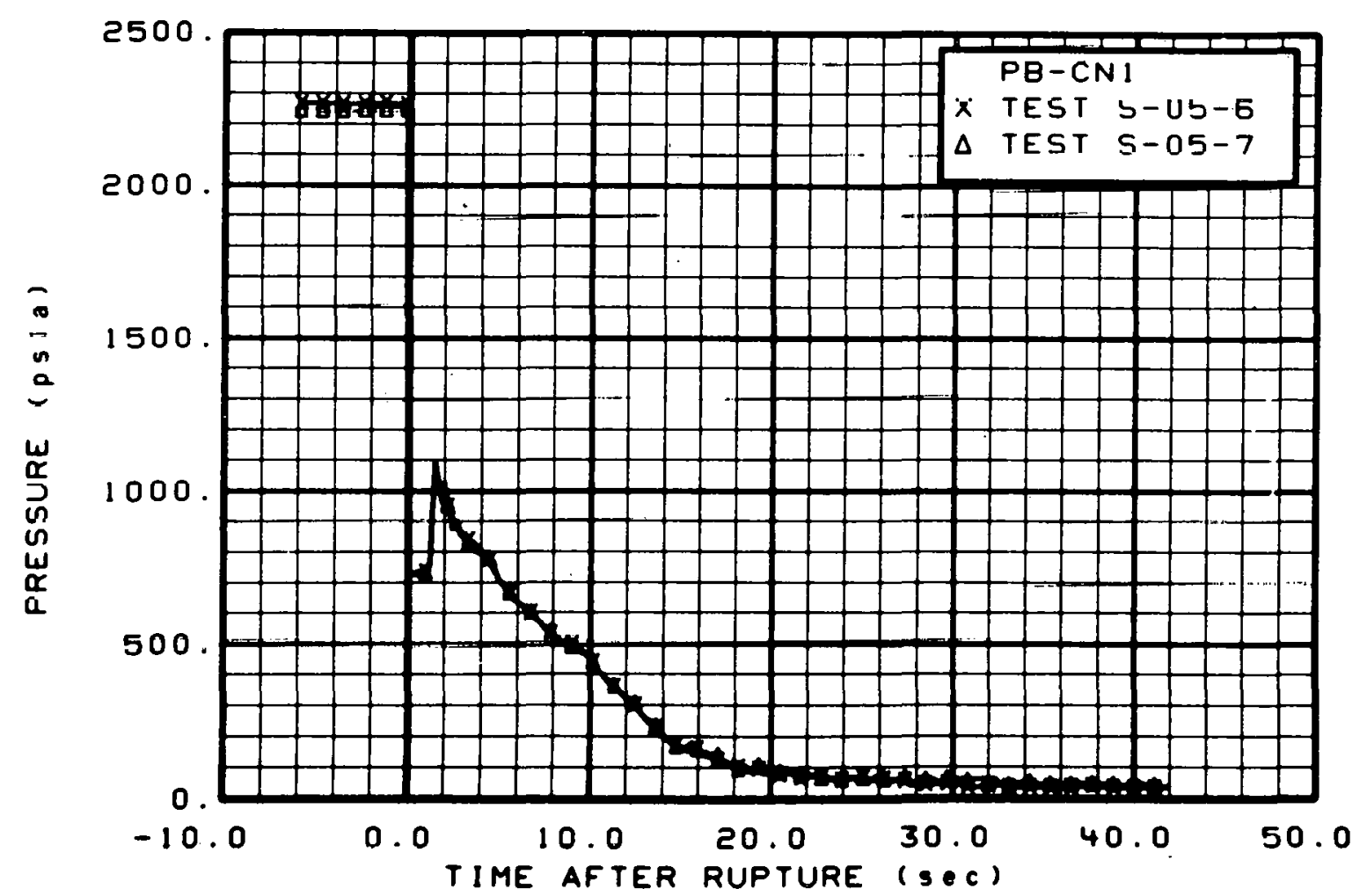

Fig. 255 Pressure in broken loop, vessel-side nozzle (PB-CN1), from -6 to $42 \mathrm{sec}$. 


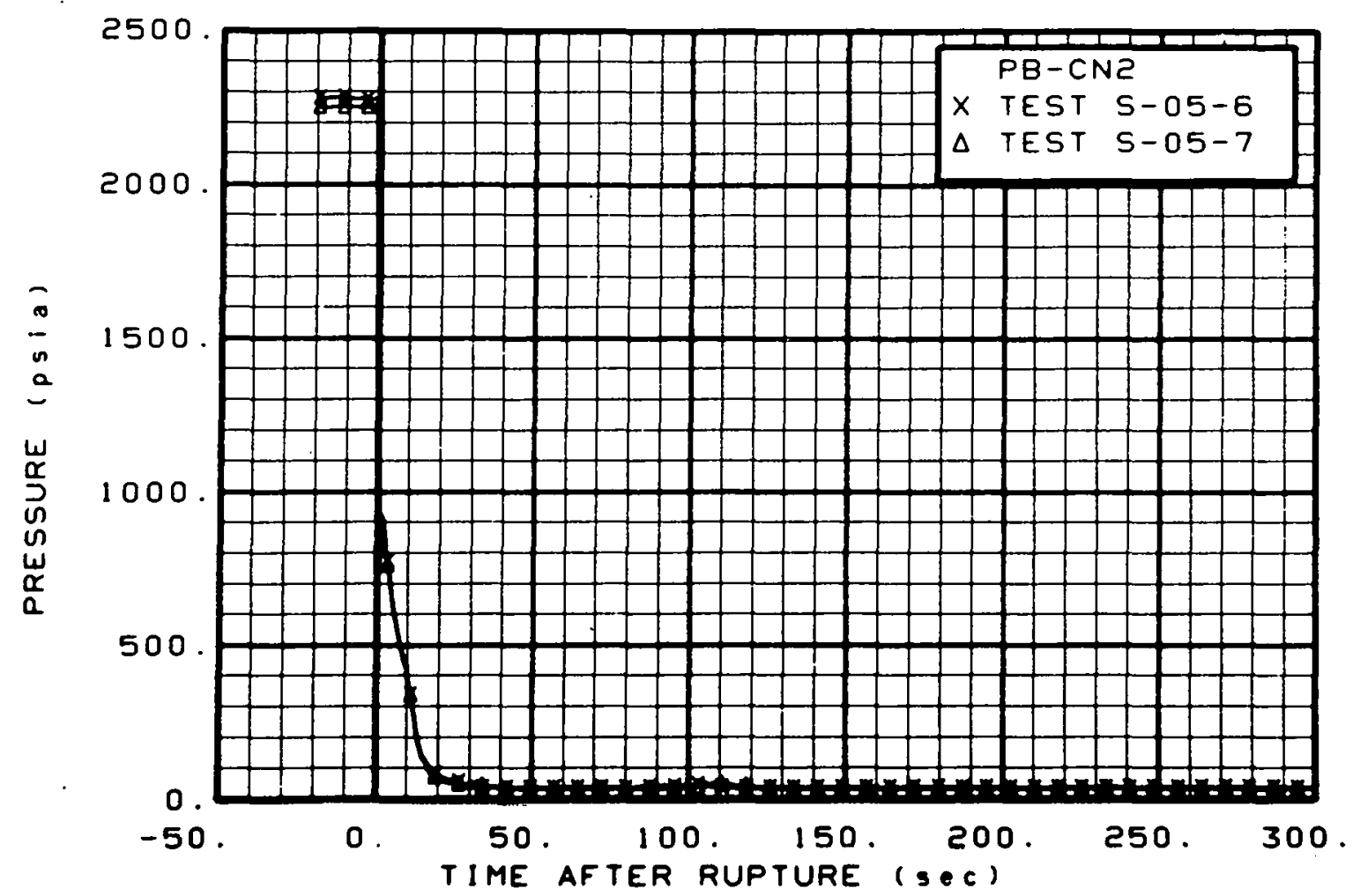

Fig. 256 Pressure in broken loop, vessel-side nozzle (PB-CN2), from -20 to $300 \mathrm{sec}$.

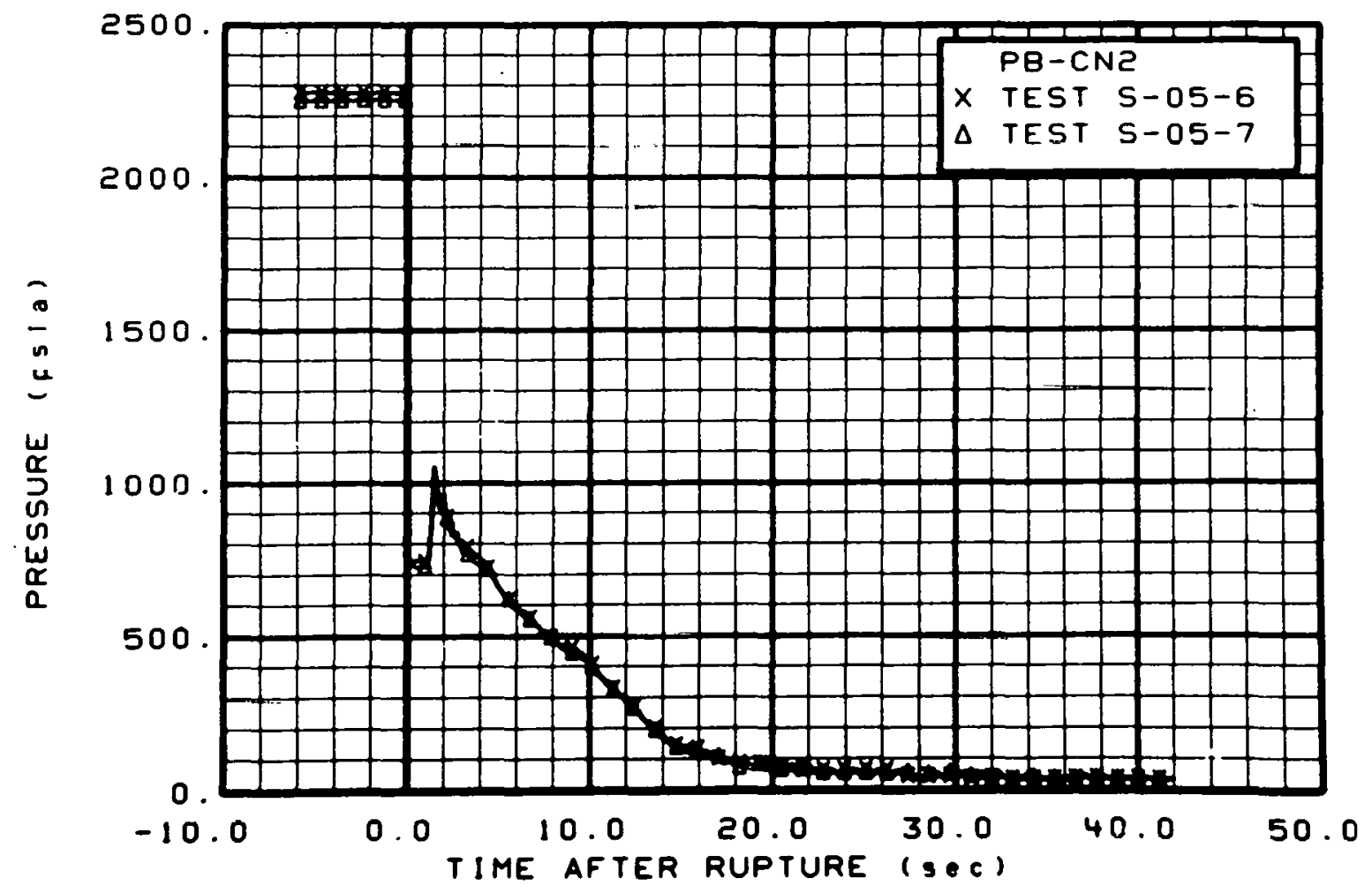

Fig. 257 pressure in broken loop, vesse1-side nozzle (PB-CN2), from -6 to $42 \mathrm{sec}$. 


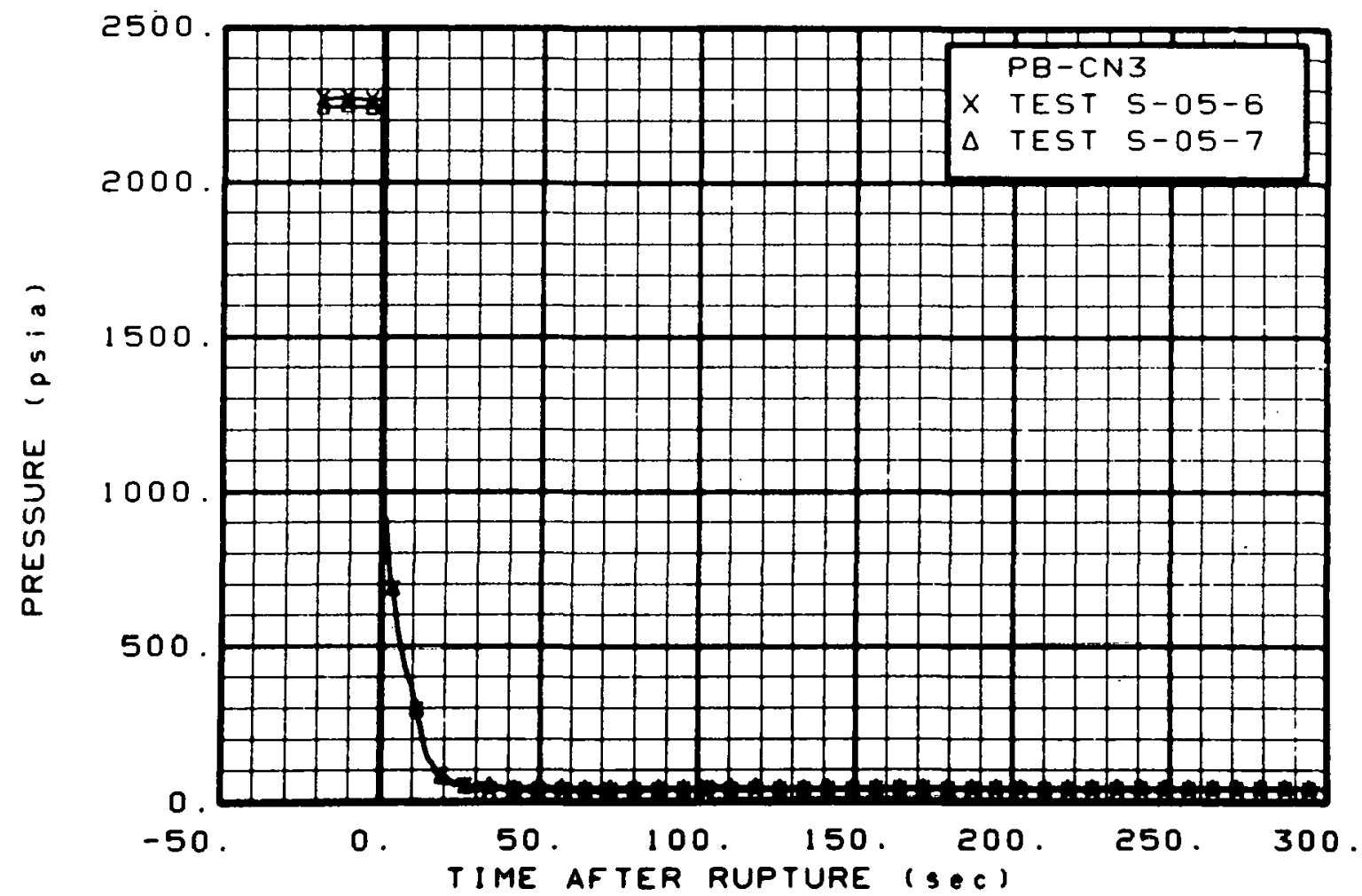

Fig. 258 Pressure in broken 10op, vessel-side nozzle (PB-CN3), from -20 to 300 sec.

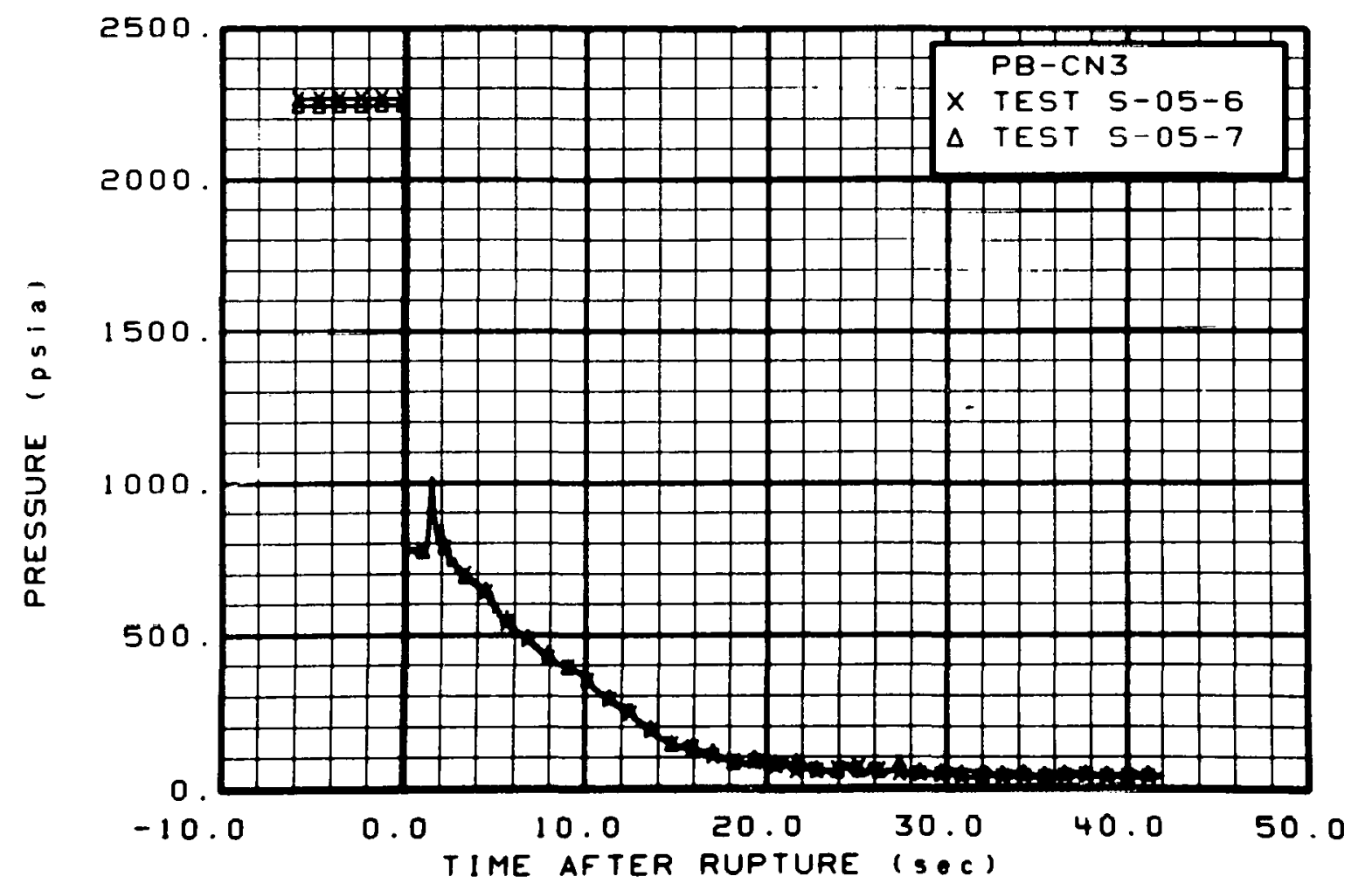

Fig. 259 Pressure in broken loop, vessel-side nozzle (PB-CN3), from -6 to $42 \mathrm{sec}$. 


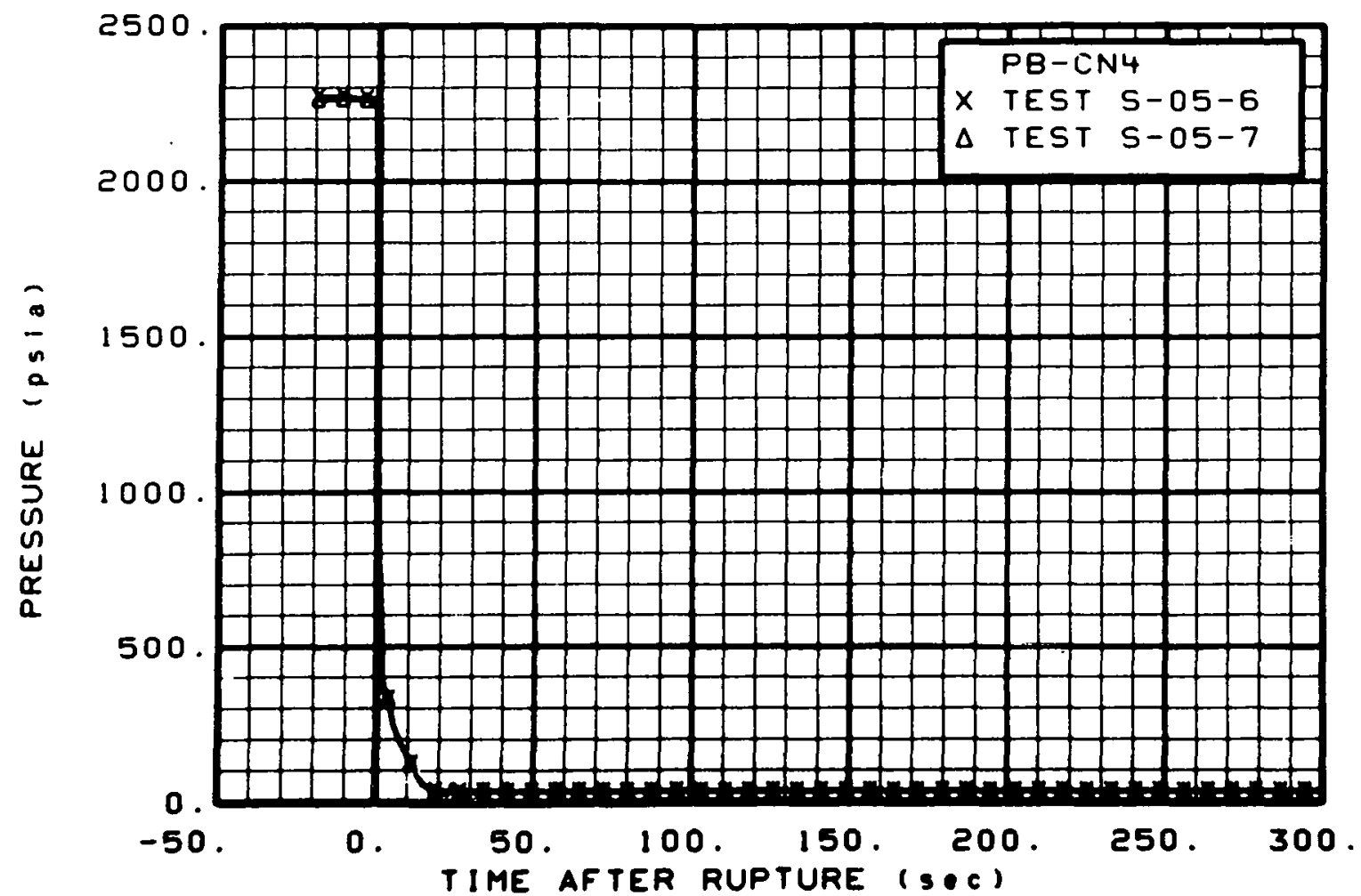

Fig. 260 Pressure in broken 10op, vessel-side nozzle (PB-CN4), from -20 to $300 \mathrm{sec}$.

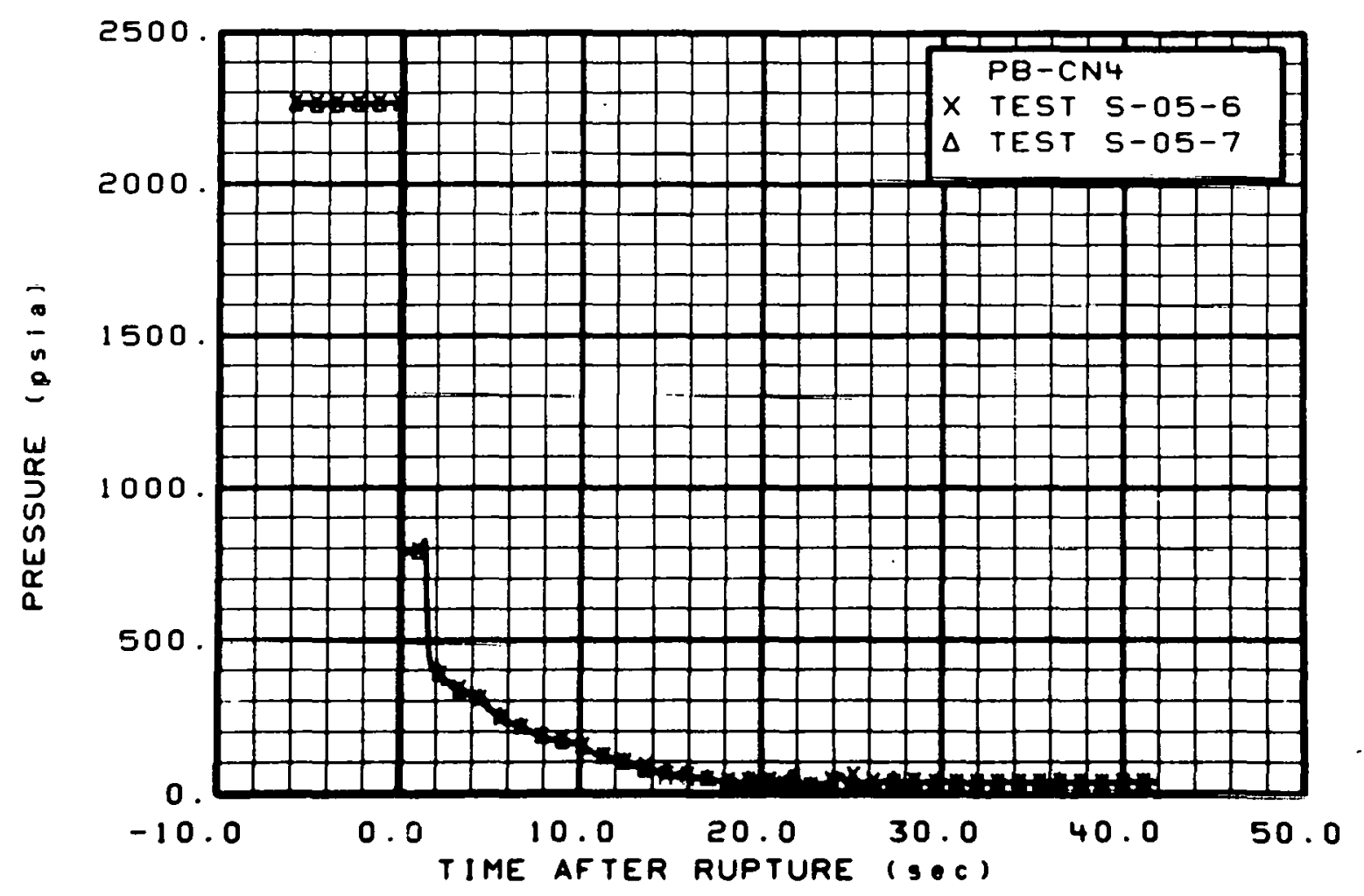

Fig, 261 Pressure in broken loop, vessel-side nozzle (PB-CN4), from -6 to 42 sei. 


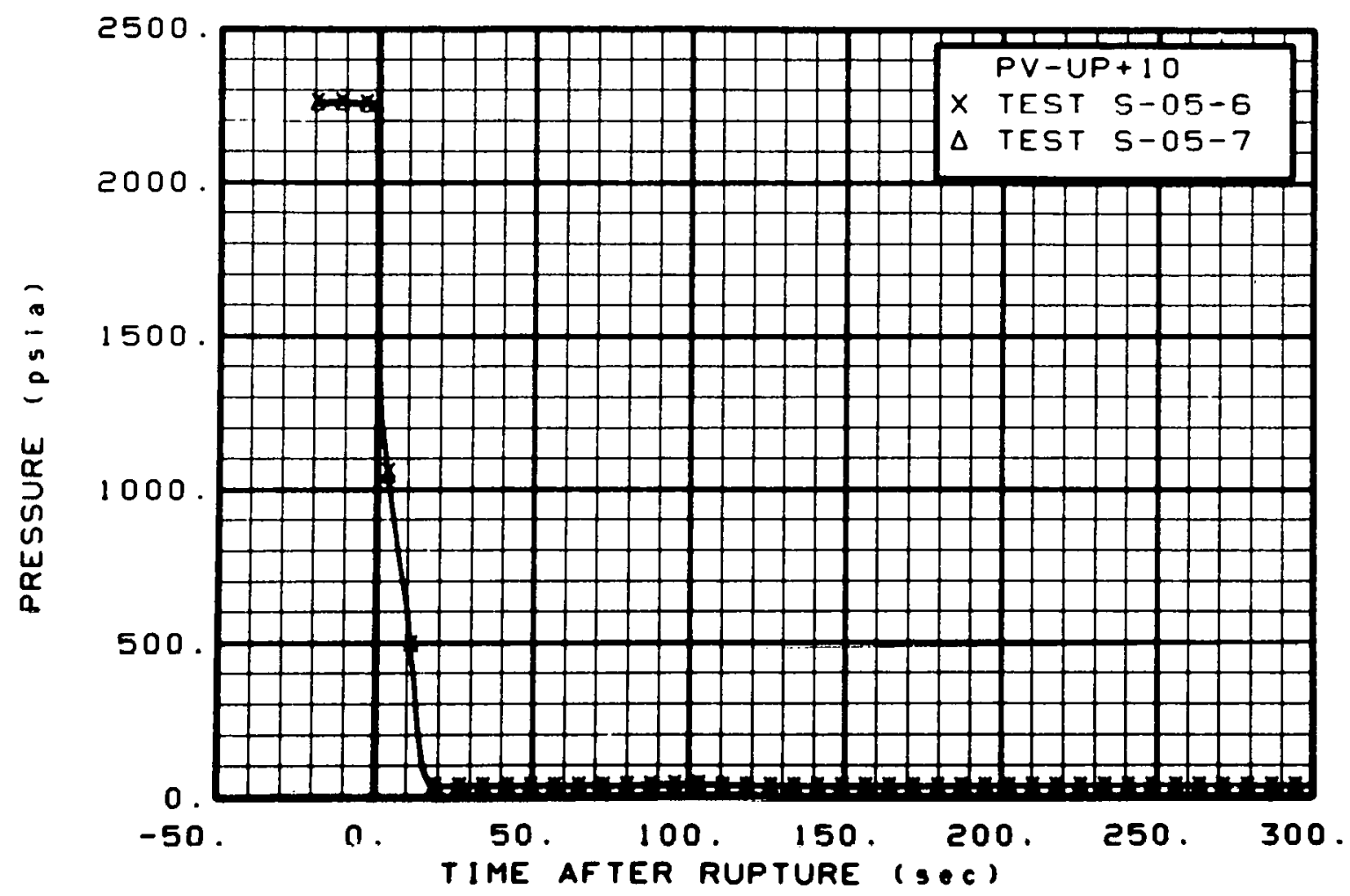

Fig. 262 Pressure in vessel (PV-UP+10), from -20 to $300 \mathrm{sec}$.

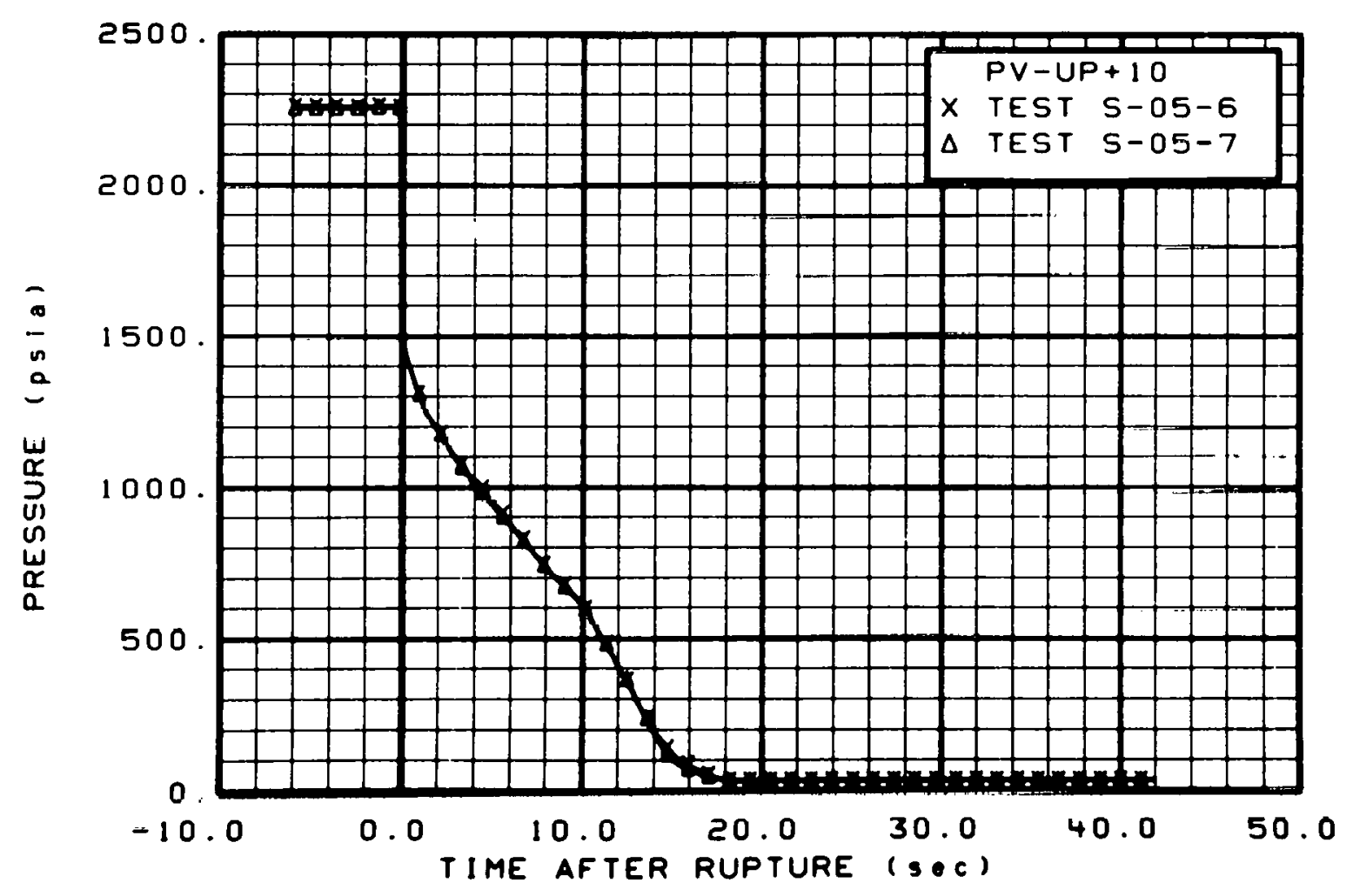

Fig. 263 Pressure in vessel (PV-UP+10), from -6 to $42 \mathrm{sec}$. 


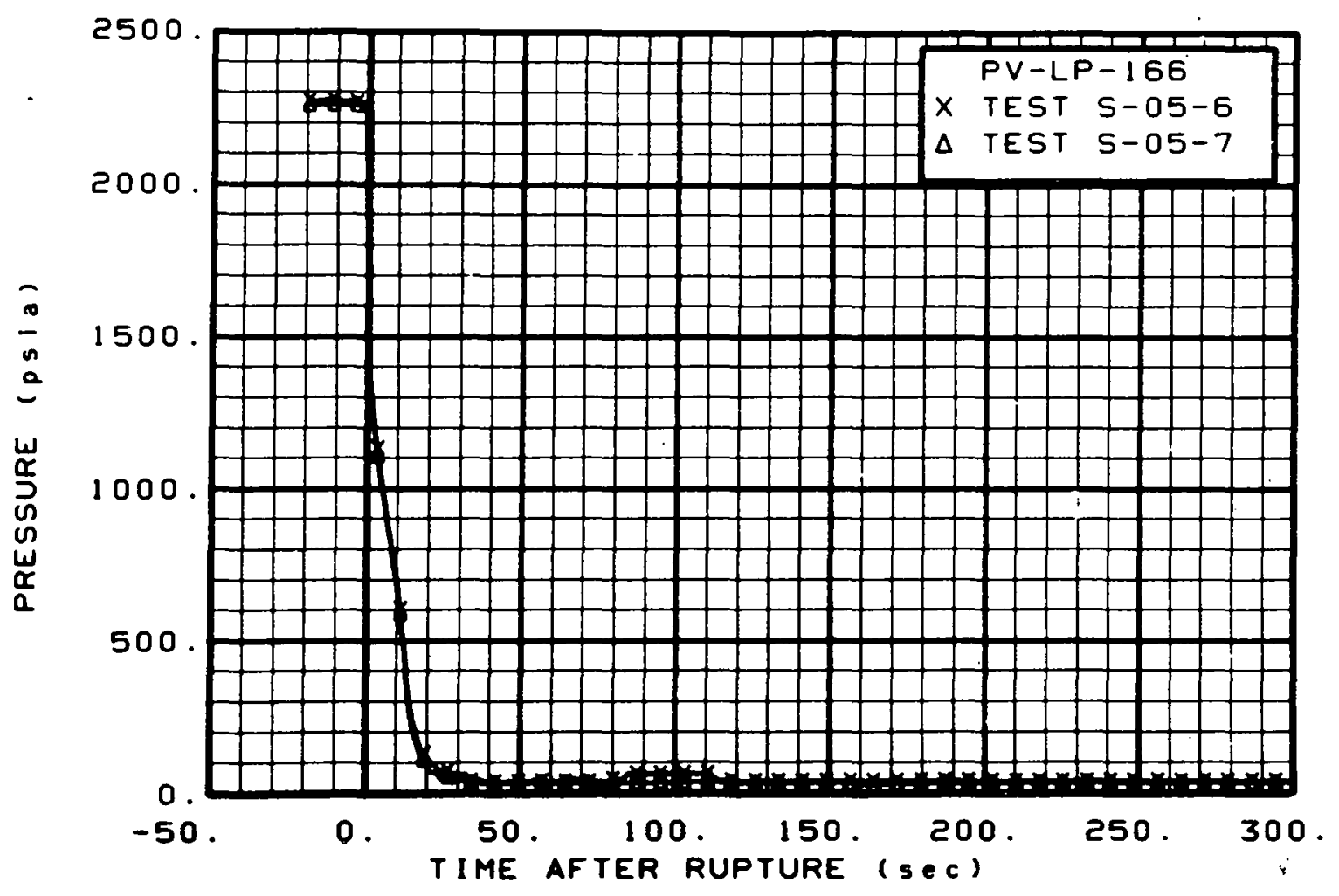

Fig. 264 Pressure in vessel (PV-LP-166), from -20 to $300 \mathrm{sec}$.

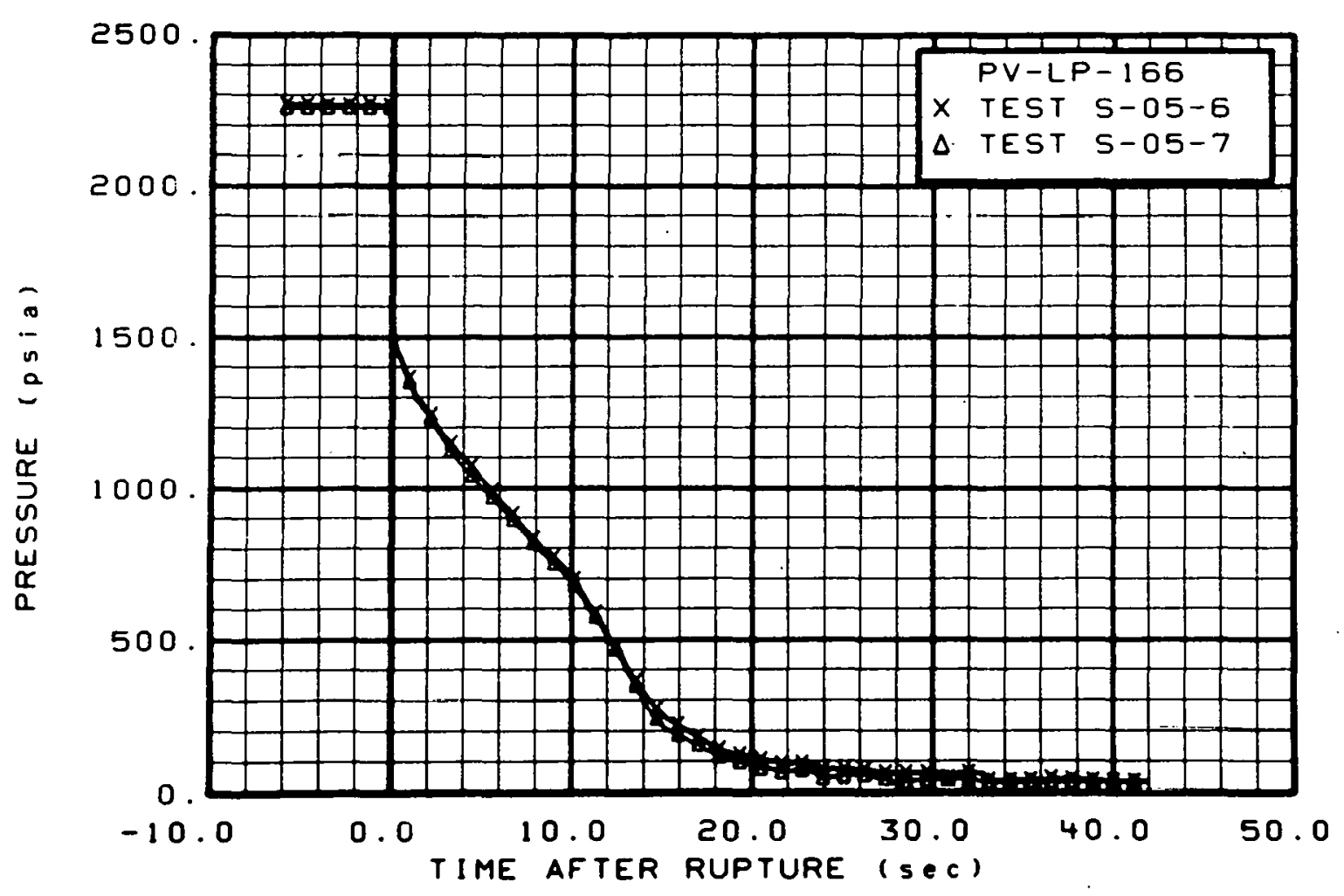

Fig. 265 Pressure in vesse1 (PV-LP-166), from -6 to $42 \mathrm{sec}$. 


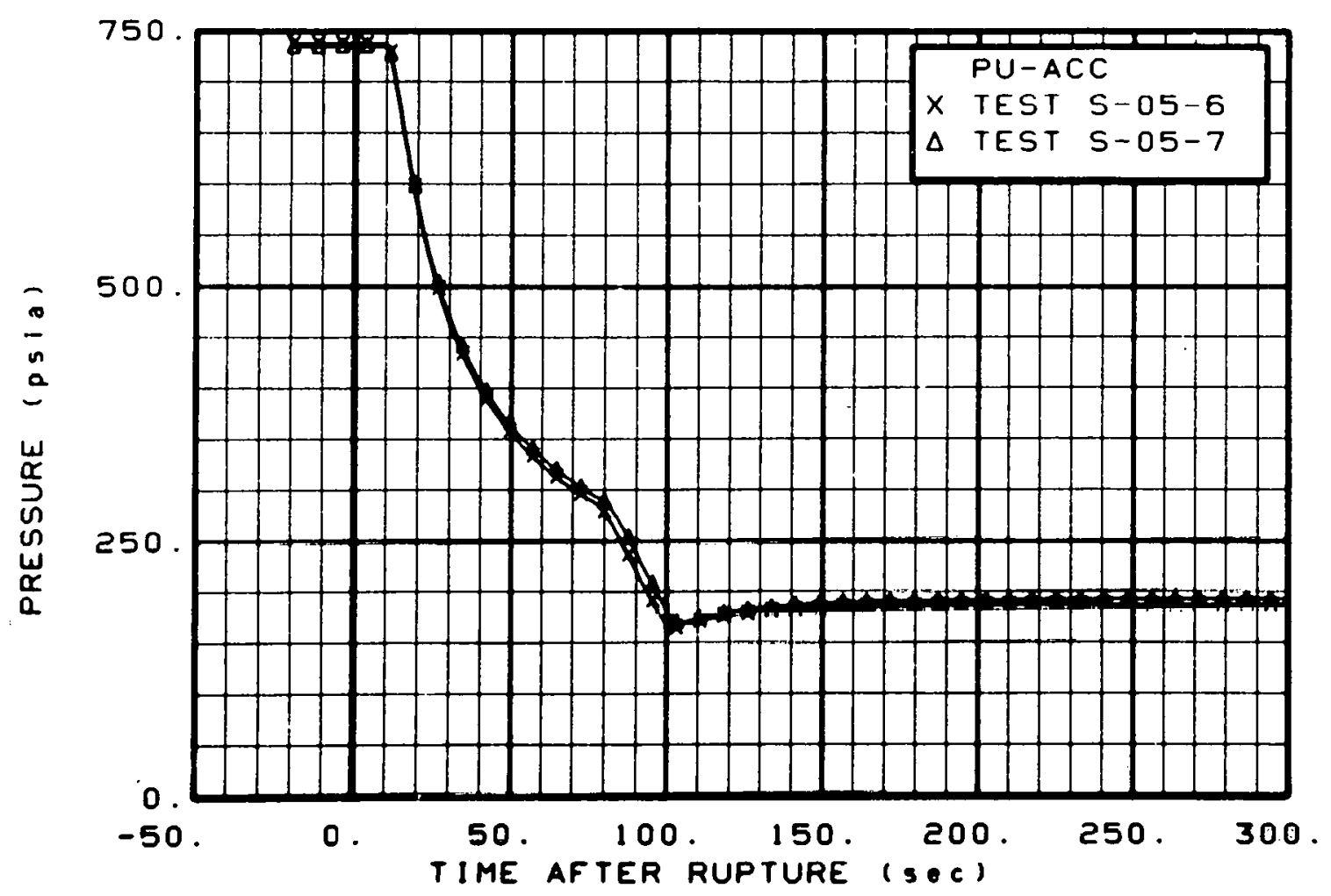

Fig. 266 Pressure in intact 100 accumulator (PU-ACC), from -20 to $300 \mathrm{sec}$.

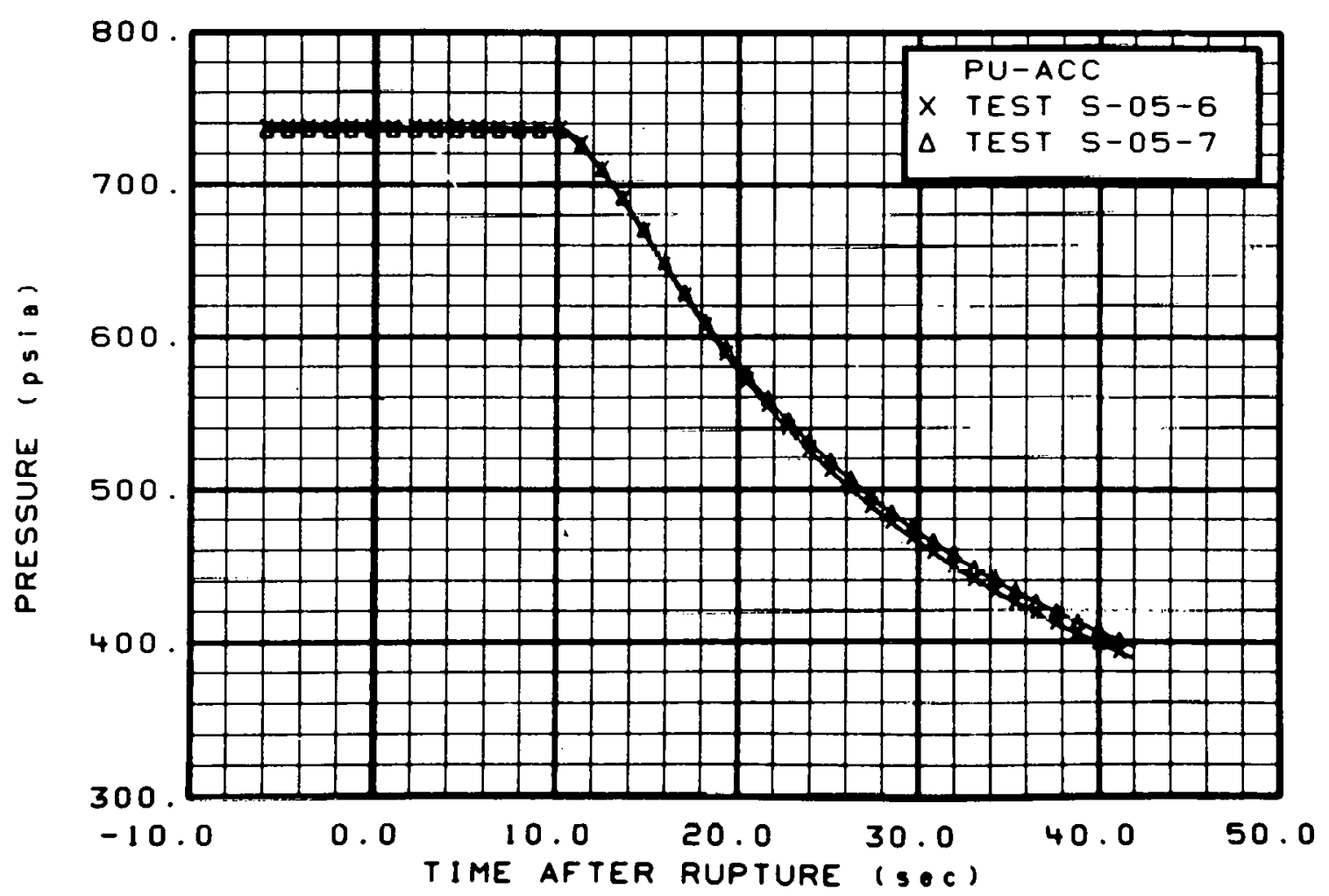

Fig. 267 Pressure in intact loop accumulator (PU-ACC), from -6 to $42 \mathrm{sec}$. 


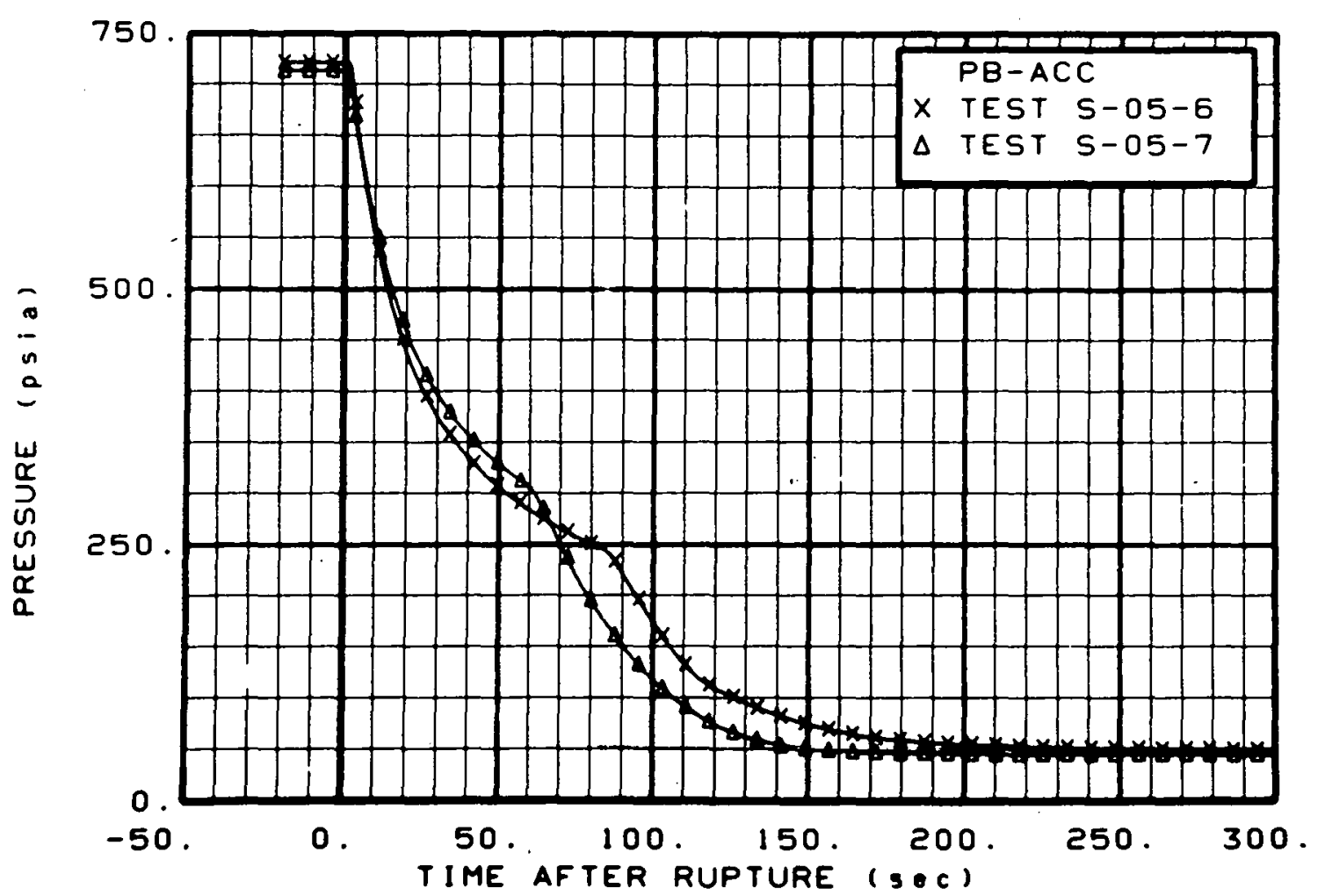

Fig. 268 Pressure in broken loop accumulator (PB-ACC), from -20 to $300 \mathrm{sec}$.

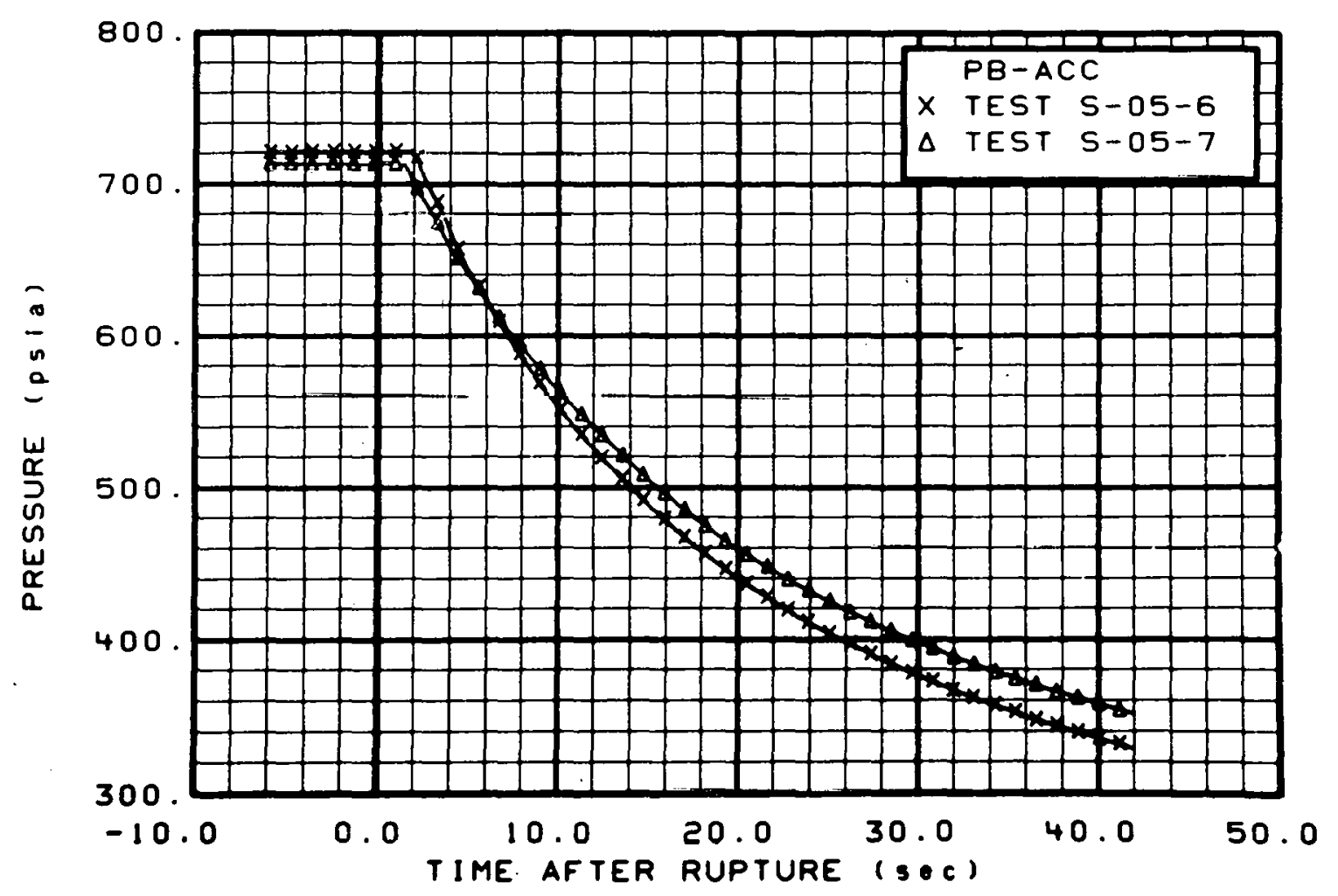

Fig. 269 Pressure in broken loop accumulator (PB-ACC), from -6 to $42 \mathrm{sec}$. 


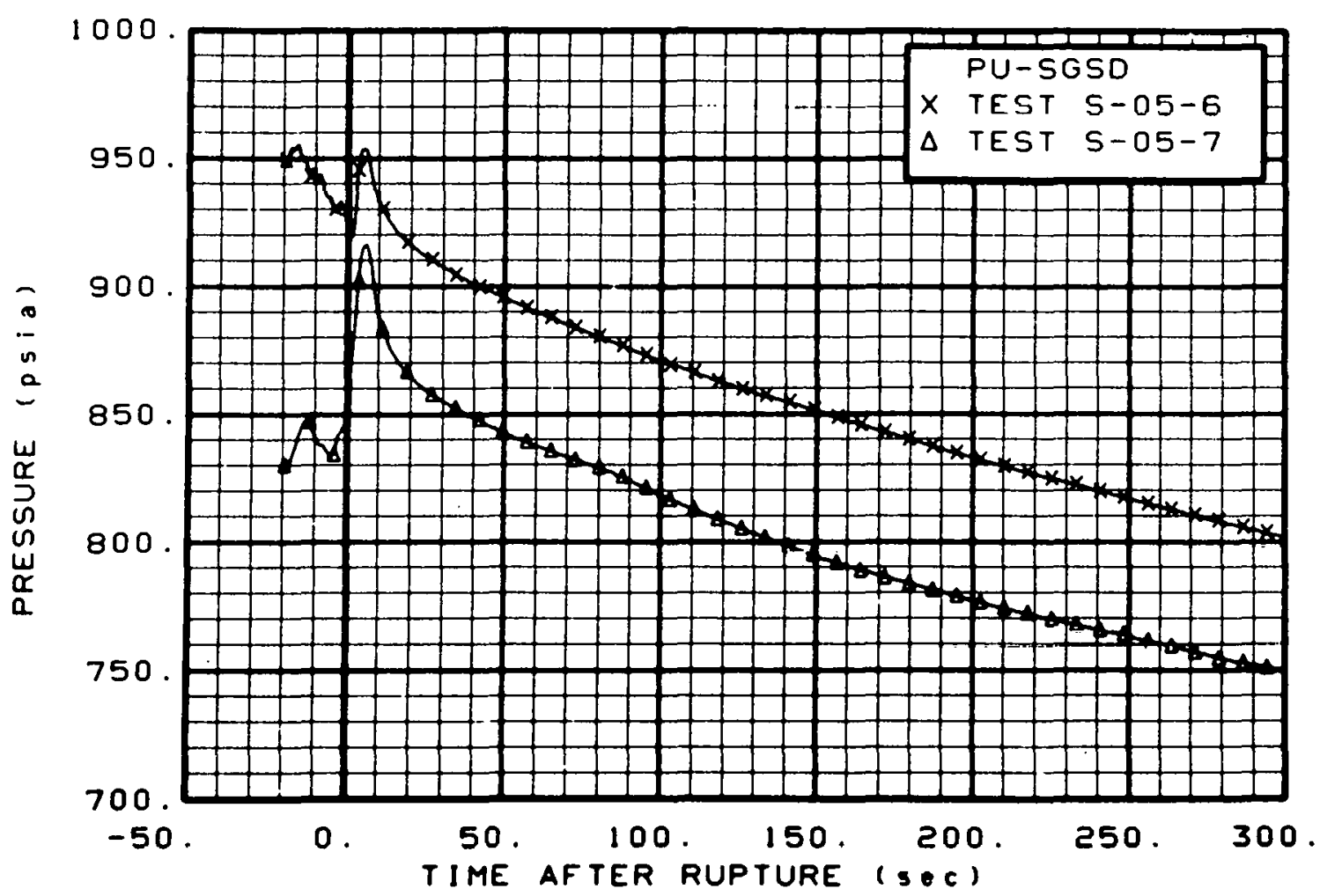

Fig. 270 Pressure in steam generator, secondary side (PU-SGSD), from -20 to $300 \mathrm{sec}$.

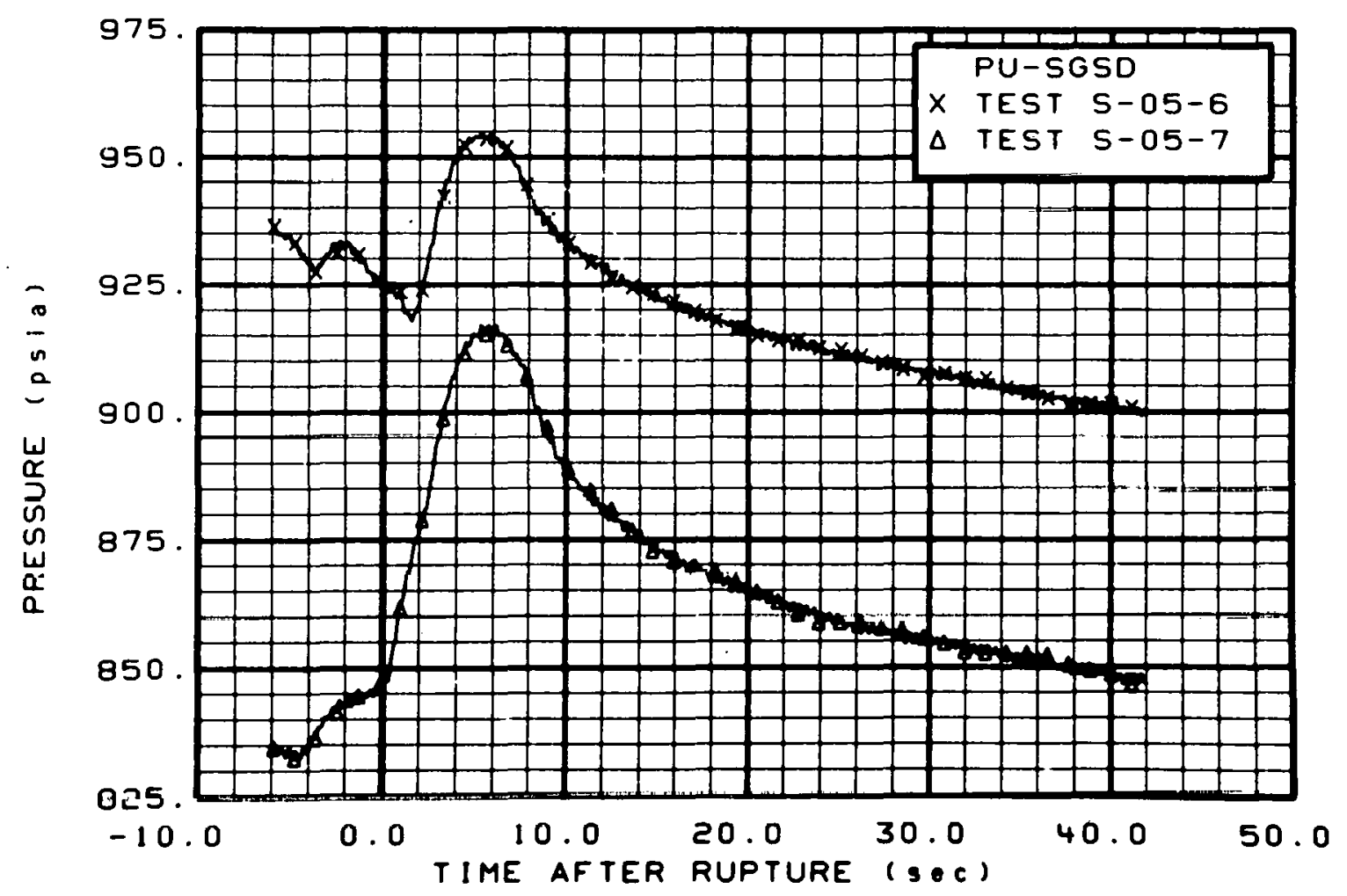

Fig. 271 Pressure in steam generator, secondary side (PU-SGSD), from -6 to $42 \mathrm{sec}$. 


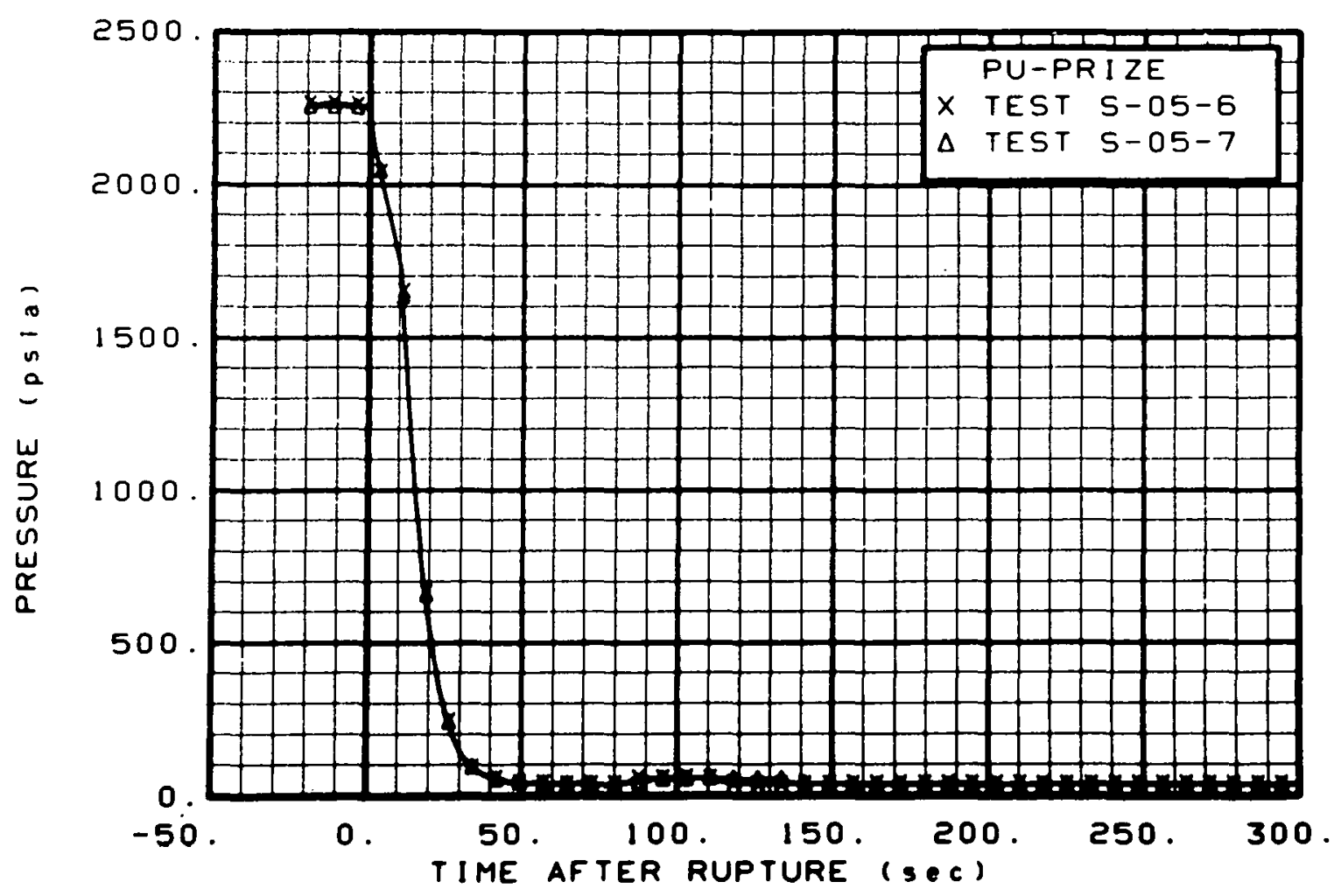

Fig. 272 Pressure in pressurizer (PU-PRIZE), from -20 to $300 \mathrm{sec}$.

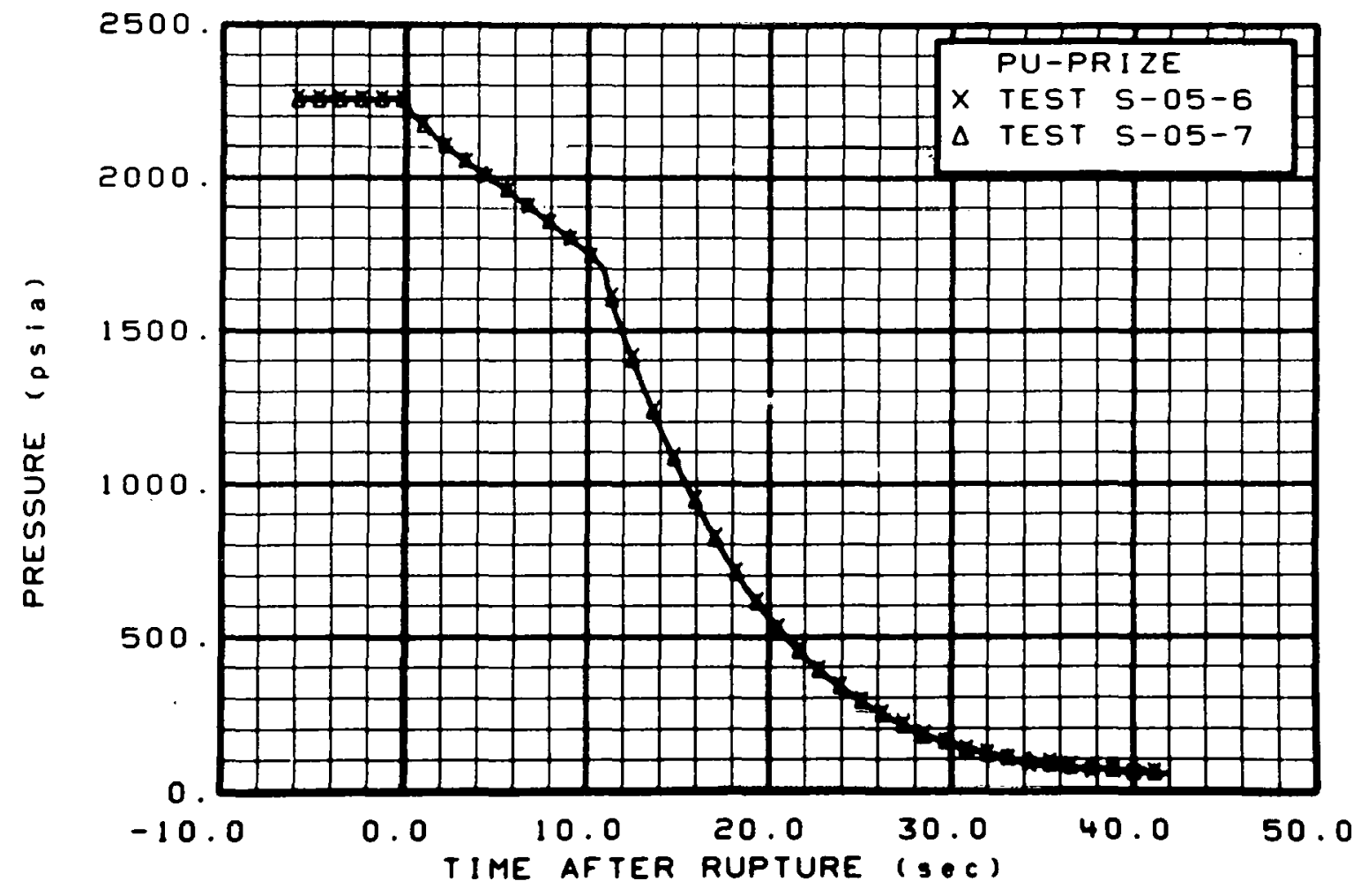

Fig. 273 Pressure in pressurizer (PU-PRIZE), from -6 to $42 \mathrm{sec}$. 


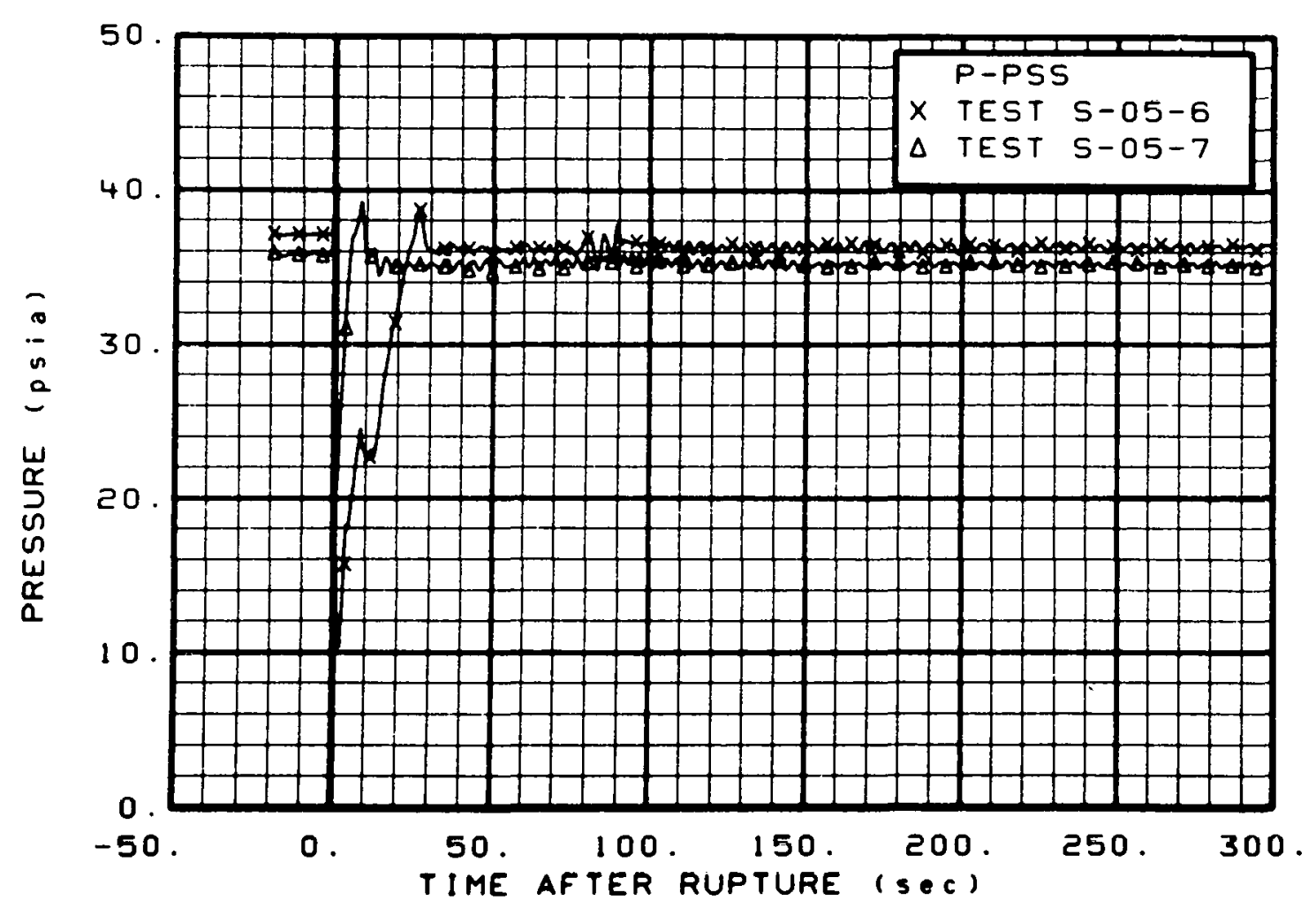

Fig. 274 Pressure in pressure suppression tank (P-PSS), from -20 to $300 \mathrm{sec}$.

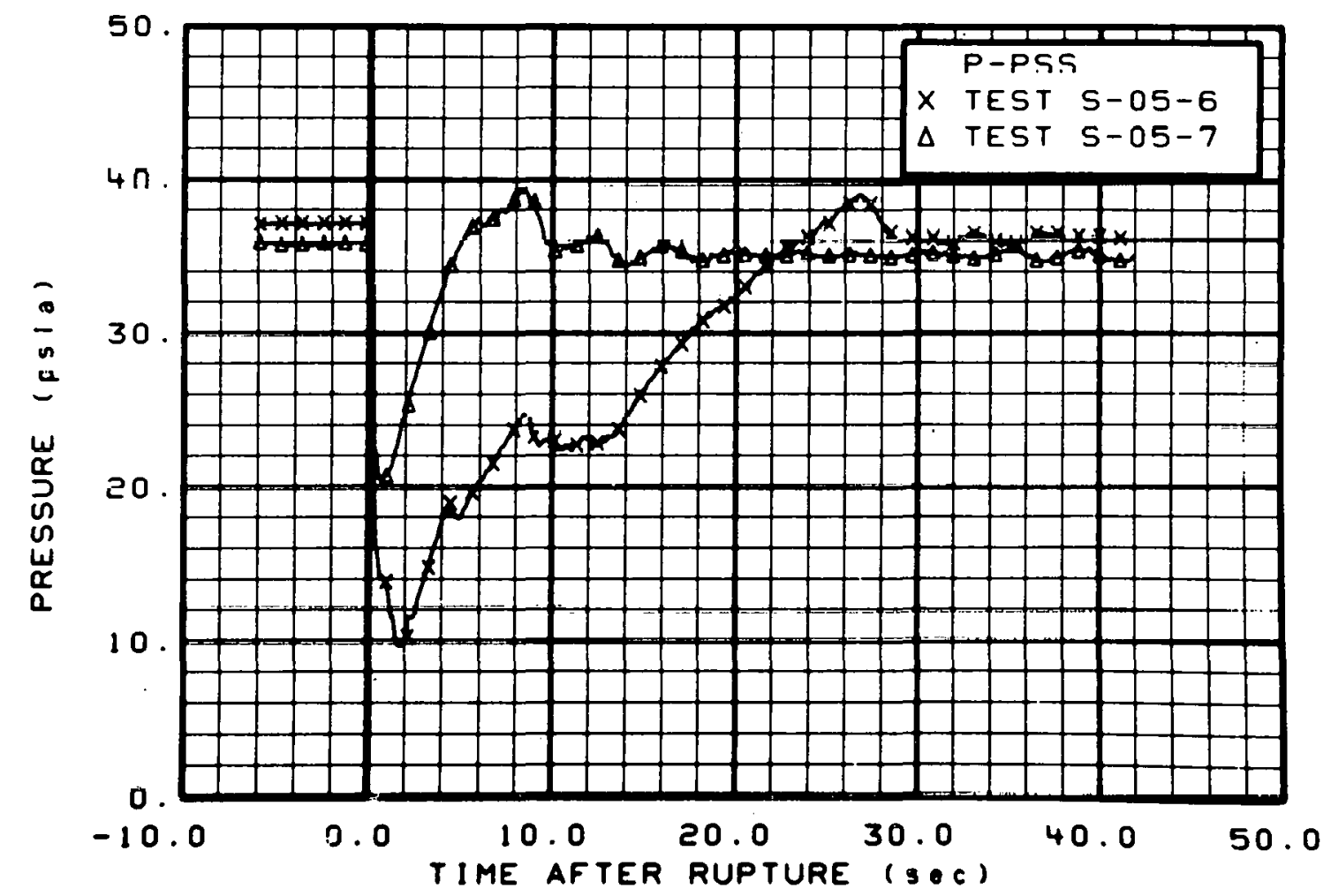

Fig. 275 Pressure in pressure suppression tank (P-PSS), from -6 to $42 \mathrm{sec}$. 


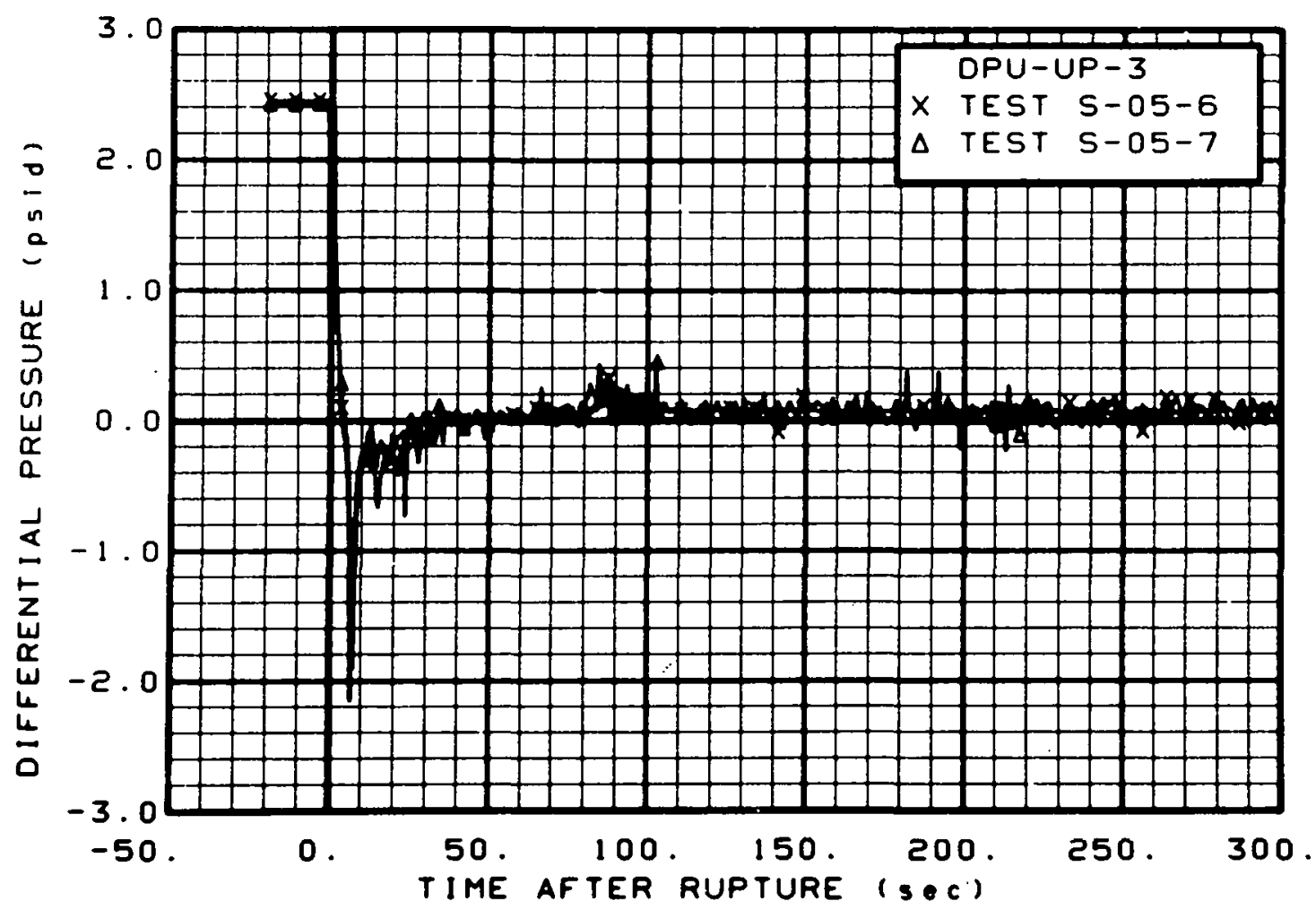

Fig. 276 Differential pressure in intact loop (DPU-UP-3), from -20 to $300 \mathrm{sec}$.

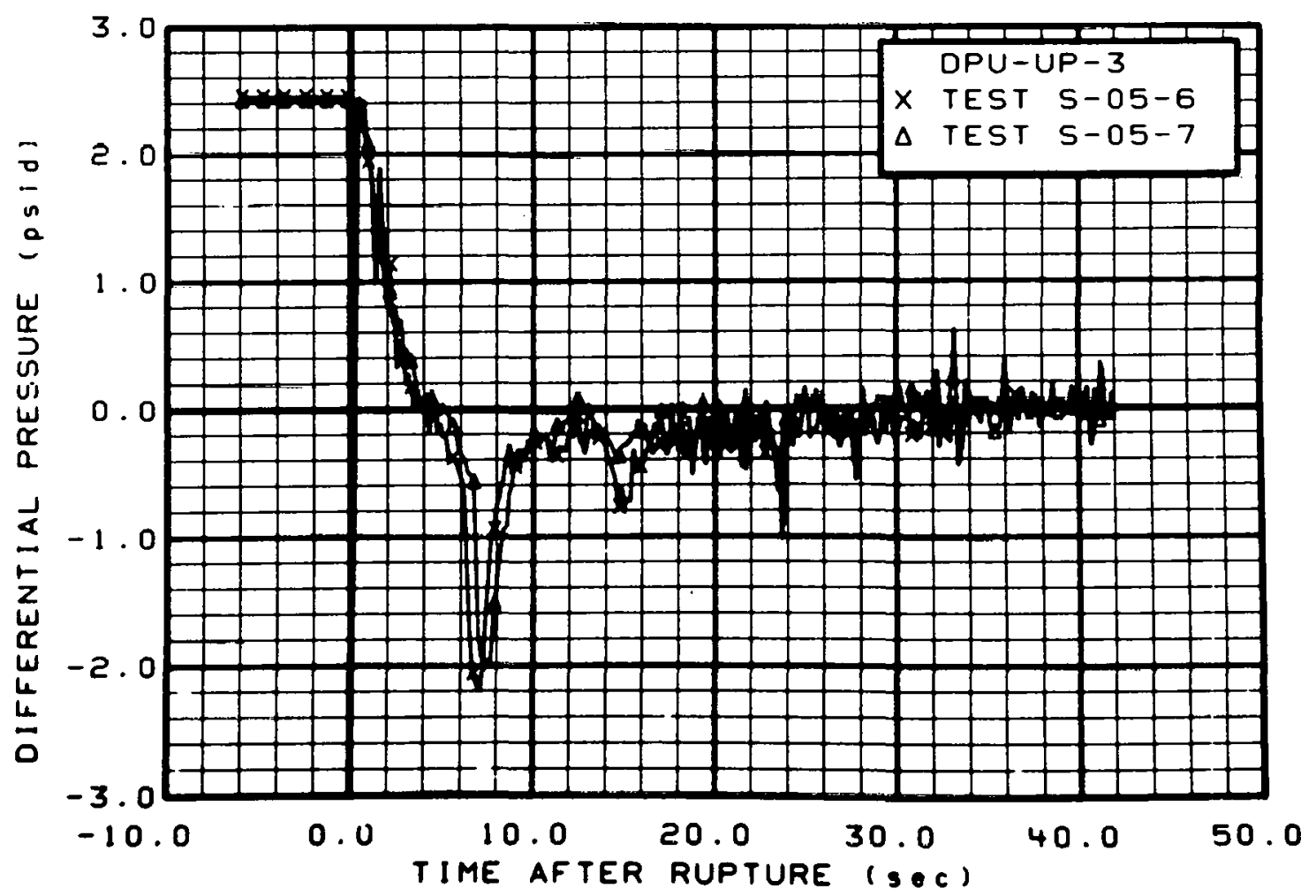

Fig. 277 Differential pressure in int.act. 10op (DPU-UP-3), from -6 to $42 \mathrm{sec}$. 


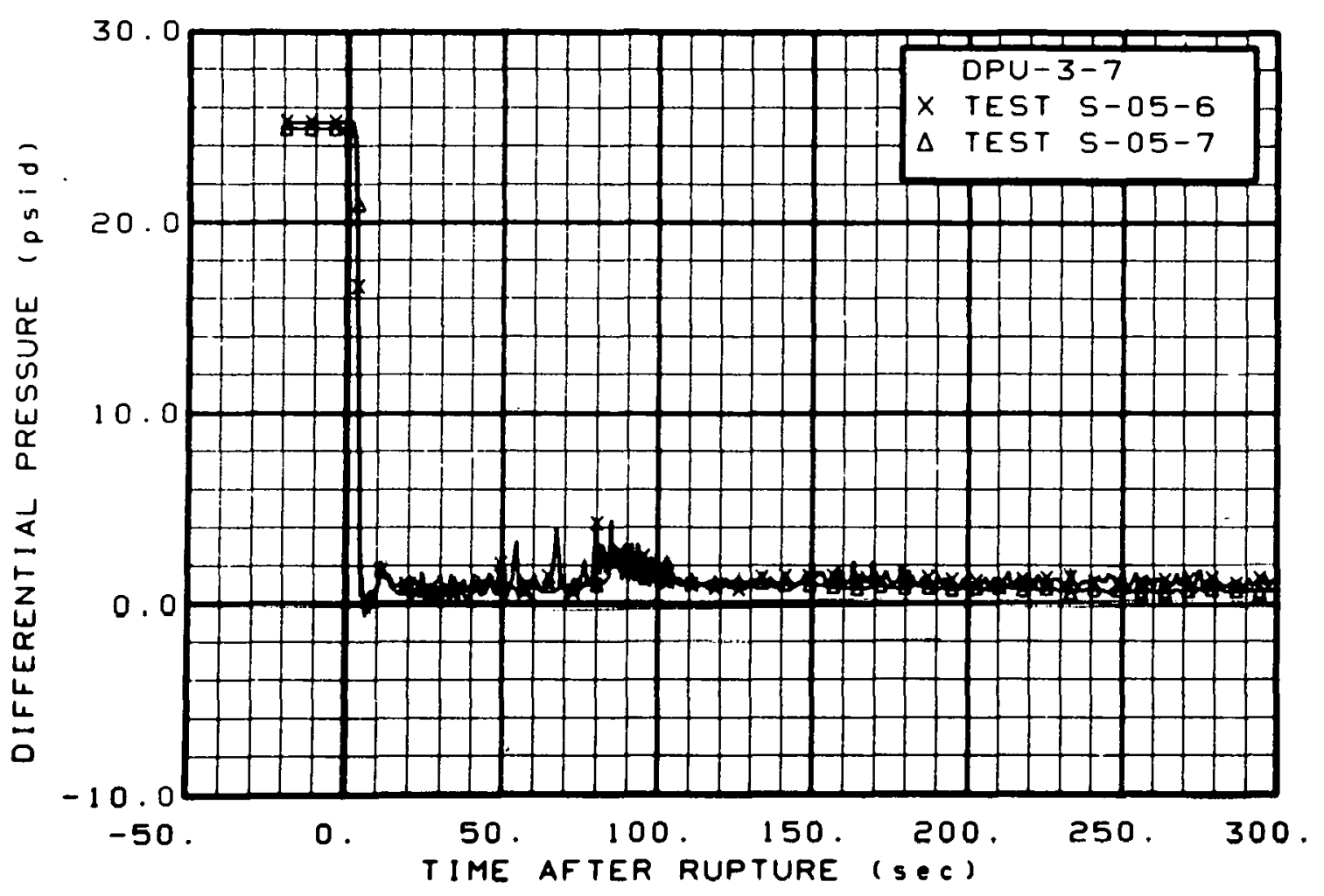

Fig. 278 Differential pressure in intact 1oop (DPU-3-7), from -20 to $300 \mathrm{sec}$.

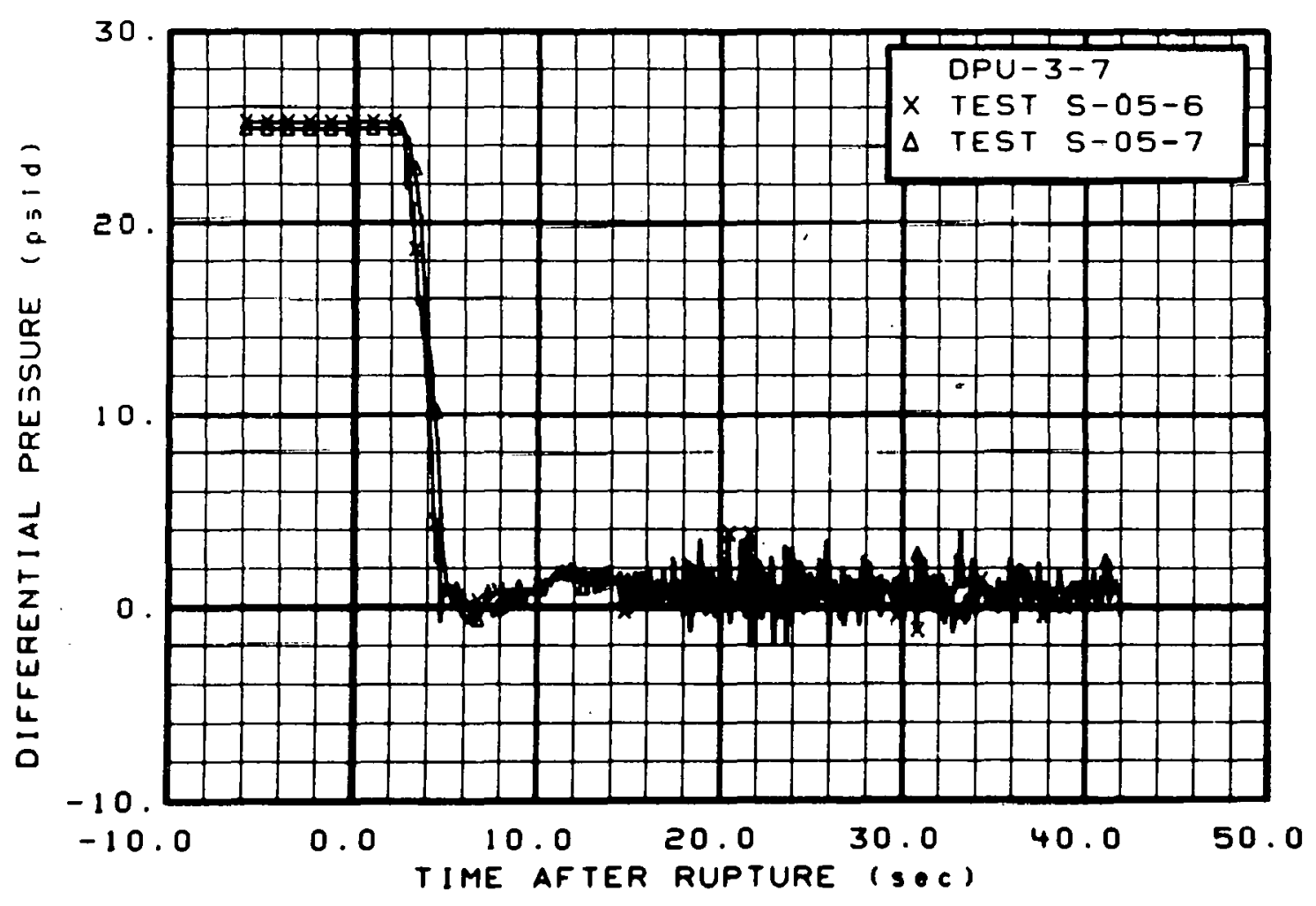

Fig. 279 Differential pressure in intact loop (DPU-3-7), from -6 to $42 \mathrm{sec}$. 


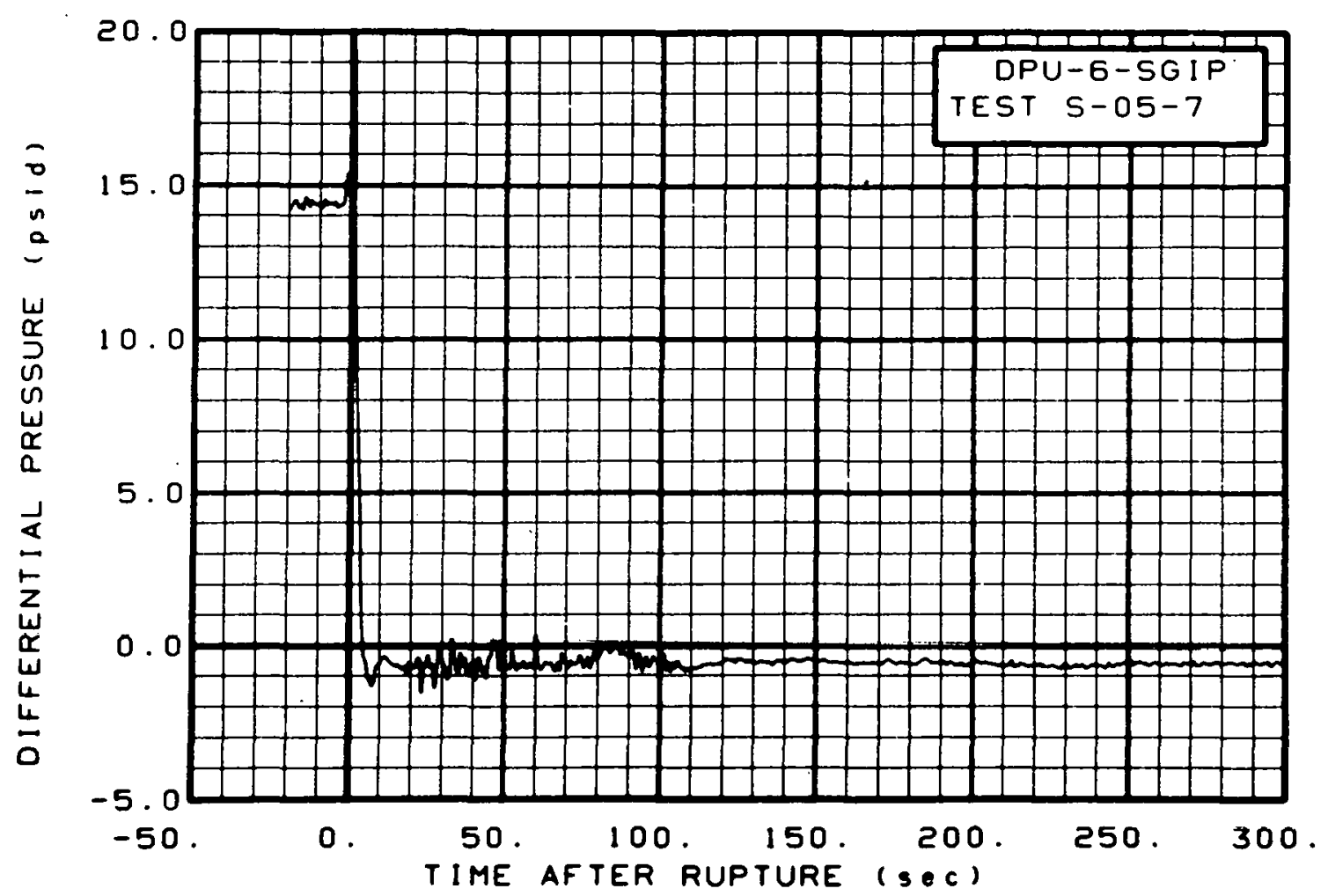

Fig. 280 Differential pressure in intact loop, Test S-05-7 (DPU-6-SGIP), from -20 to $300 \mathrm{sec}$.

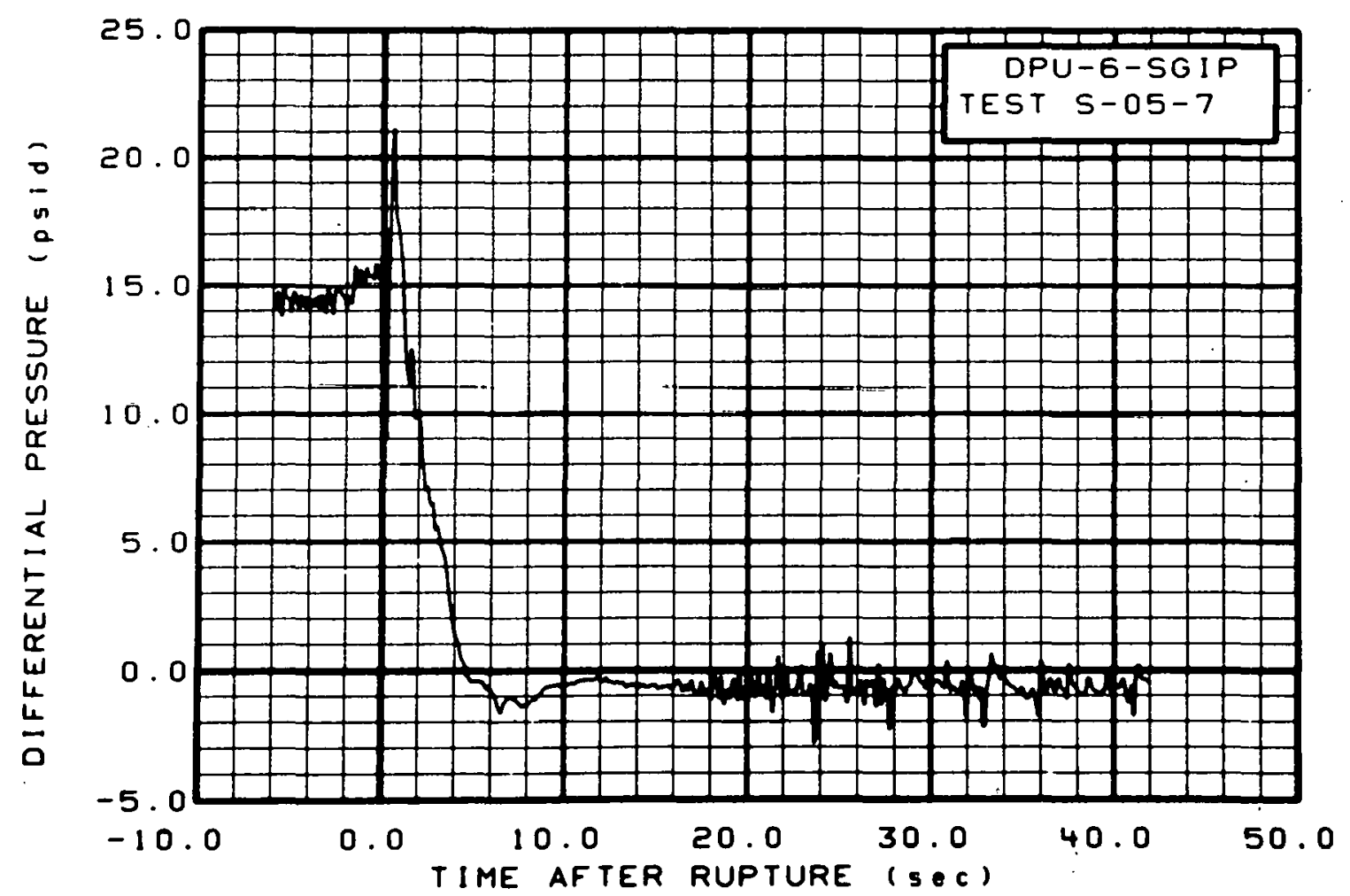

Fig. 281 Differential pressure in intact 10op, Test S-05-7 (DPU-6-SGIP), from -6 to $42 \mathrm{sec}$. 


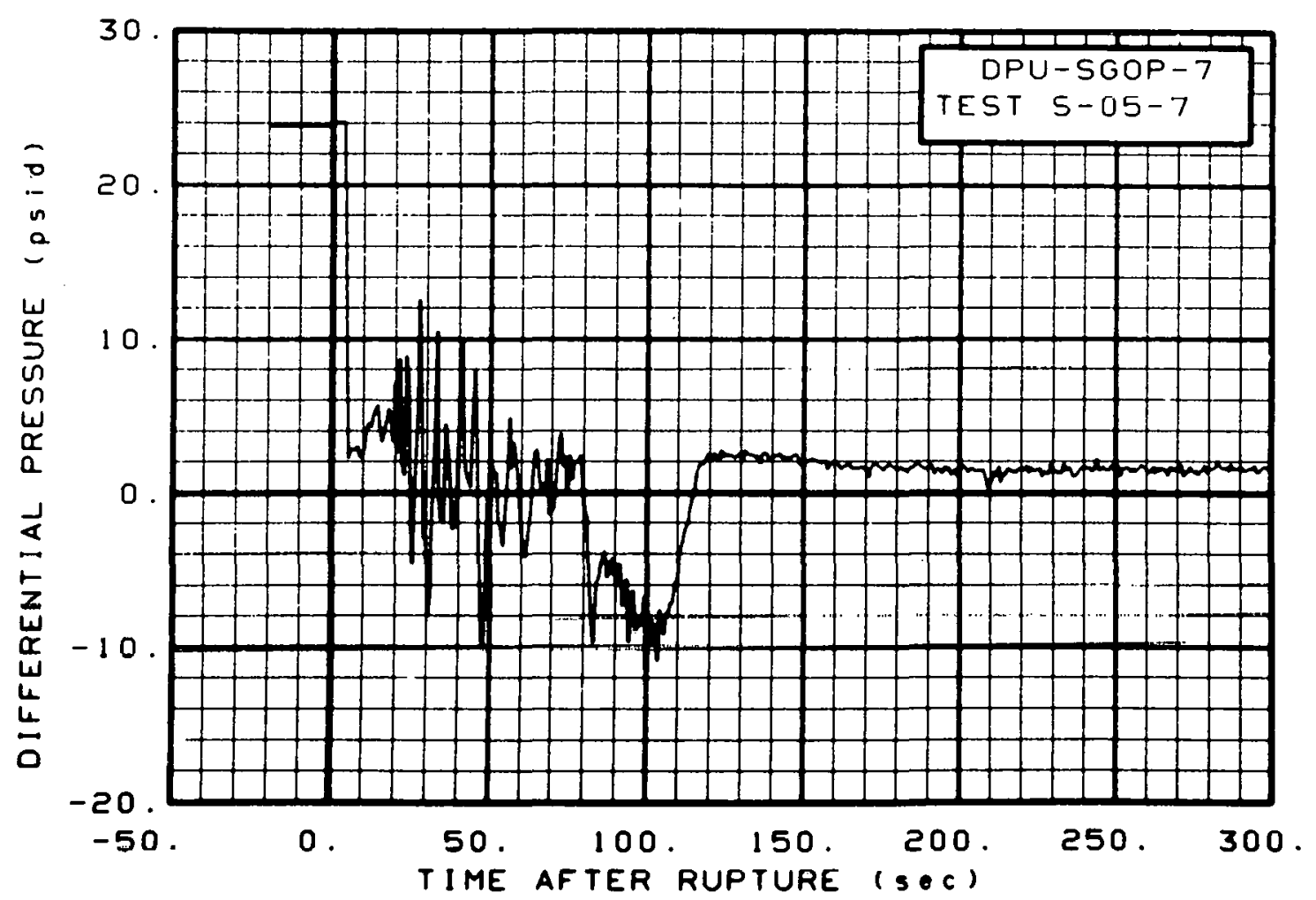

Fig. 282 Differential pressure in intact loop, Test S-05-7 (DPU-SGOP-7), from -20 to $300 \mathrm{sec}$.

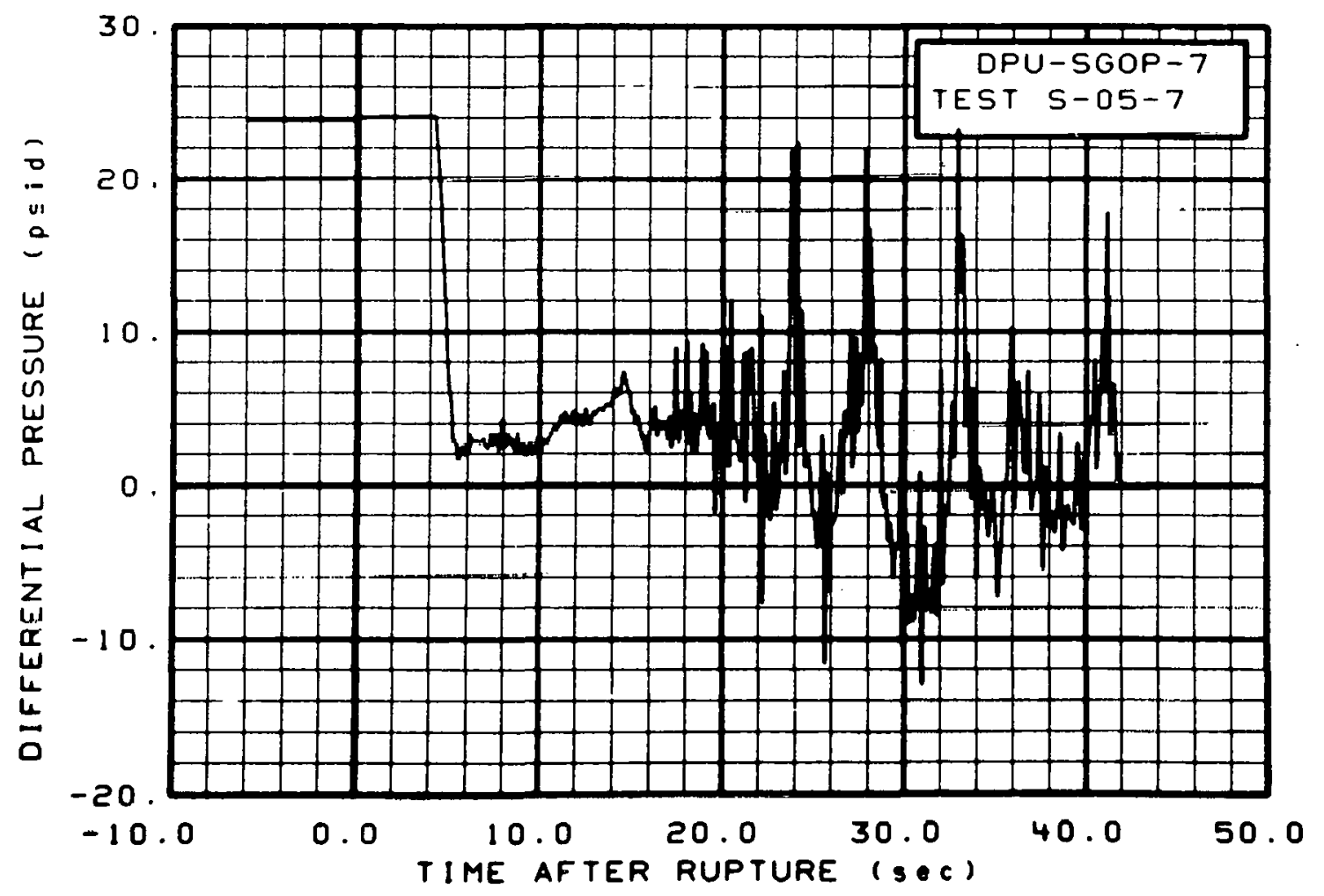

Fig. 283 Differential pressure in intact 1oop, Test S-05-7 (DPU-SGOP-7), from -6 to $42 \mathrm{sec}$. 


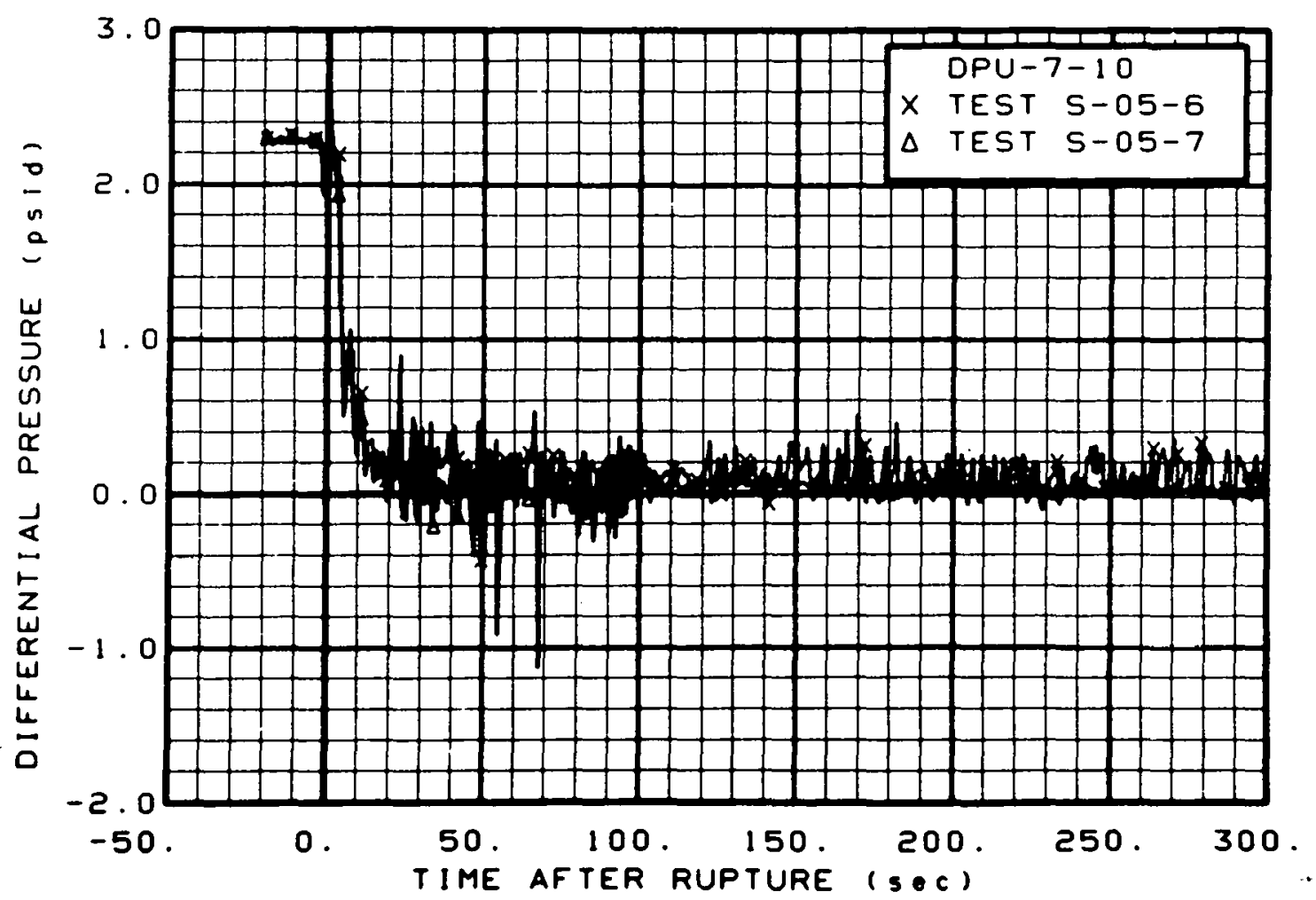

Fig. 284 Differential pressure in intact loop (DPU-7-10), from -20 to: 300 sec.

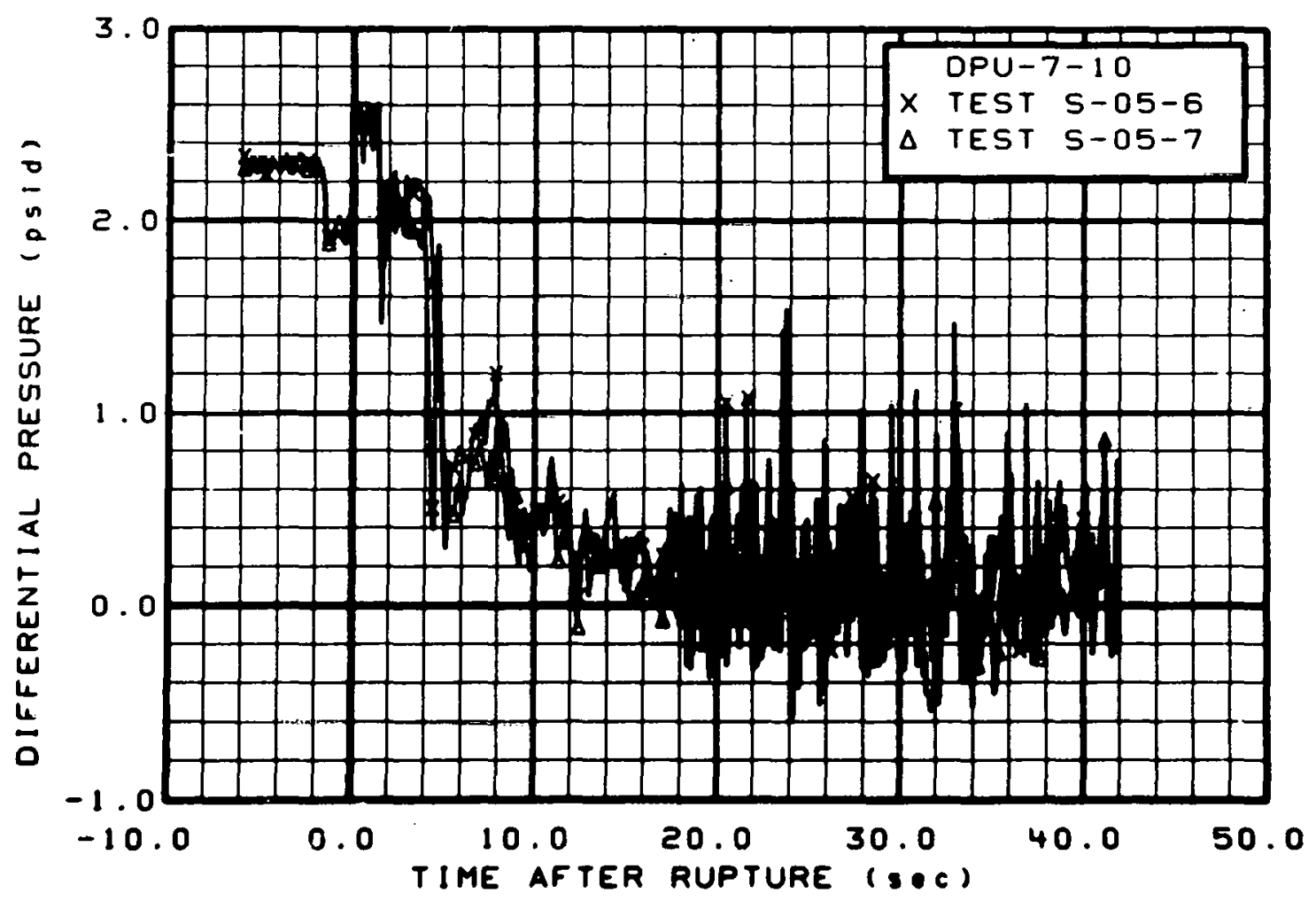

Fig. 285 Differential pressure in intact loop (DPU-7-10), from -6 to 42 sec. 


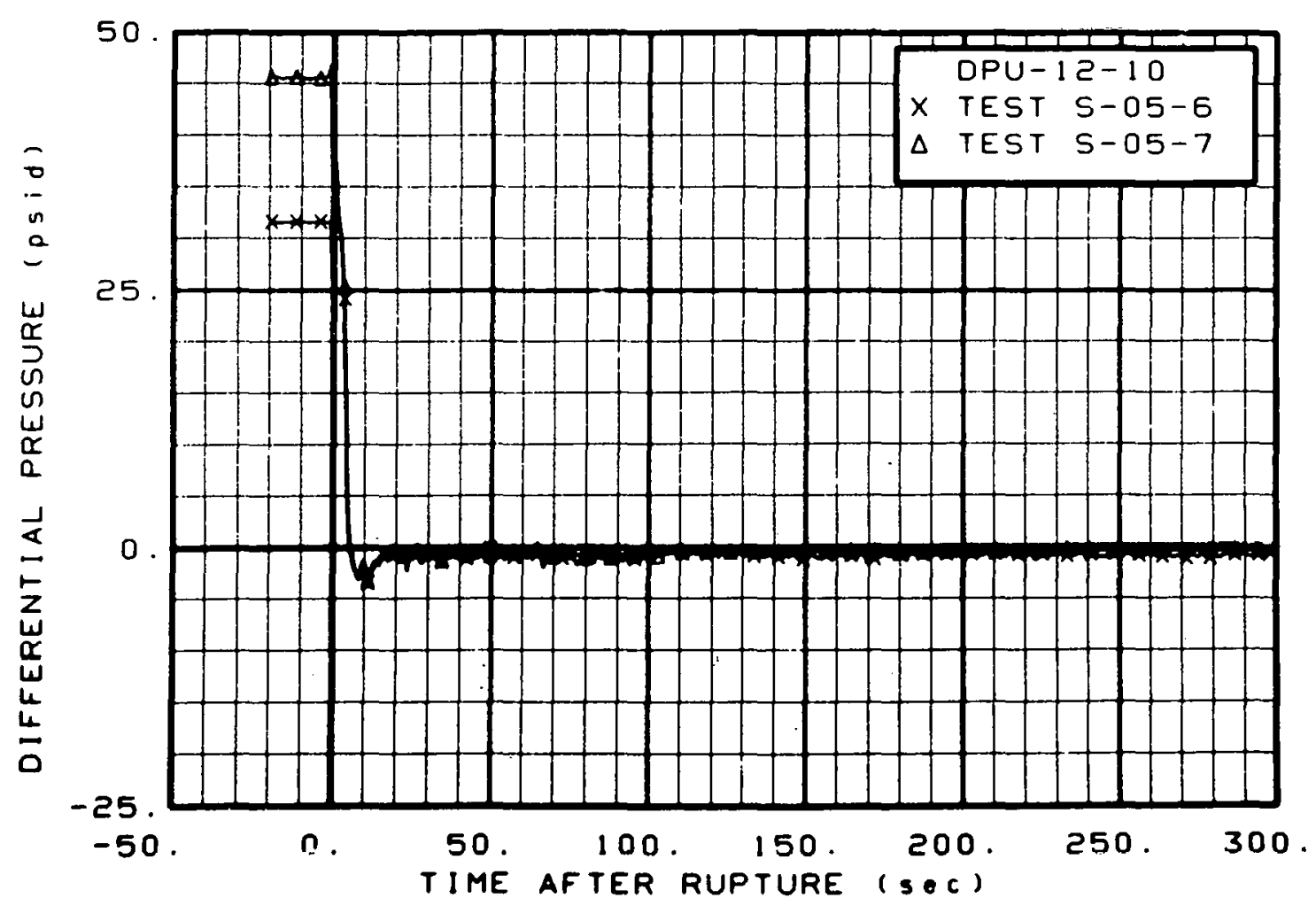

Fig. 286 Differential pressure in intact loop (DPU-12-10), from -20 to $300 \mathrm{sec}$.

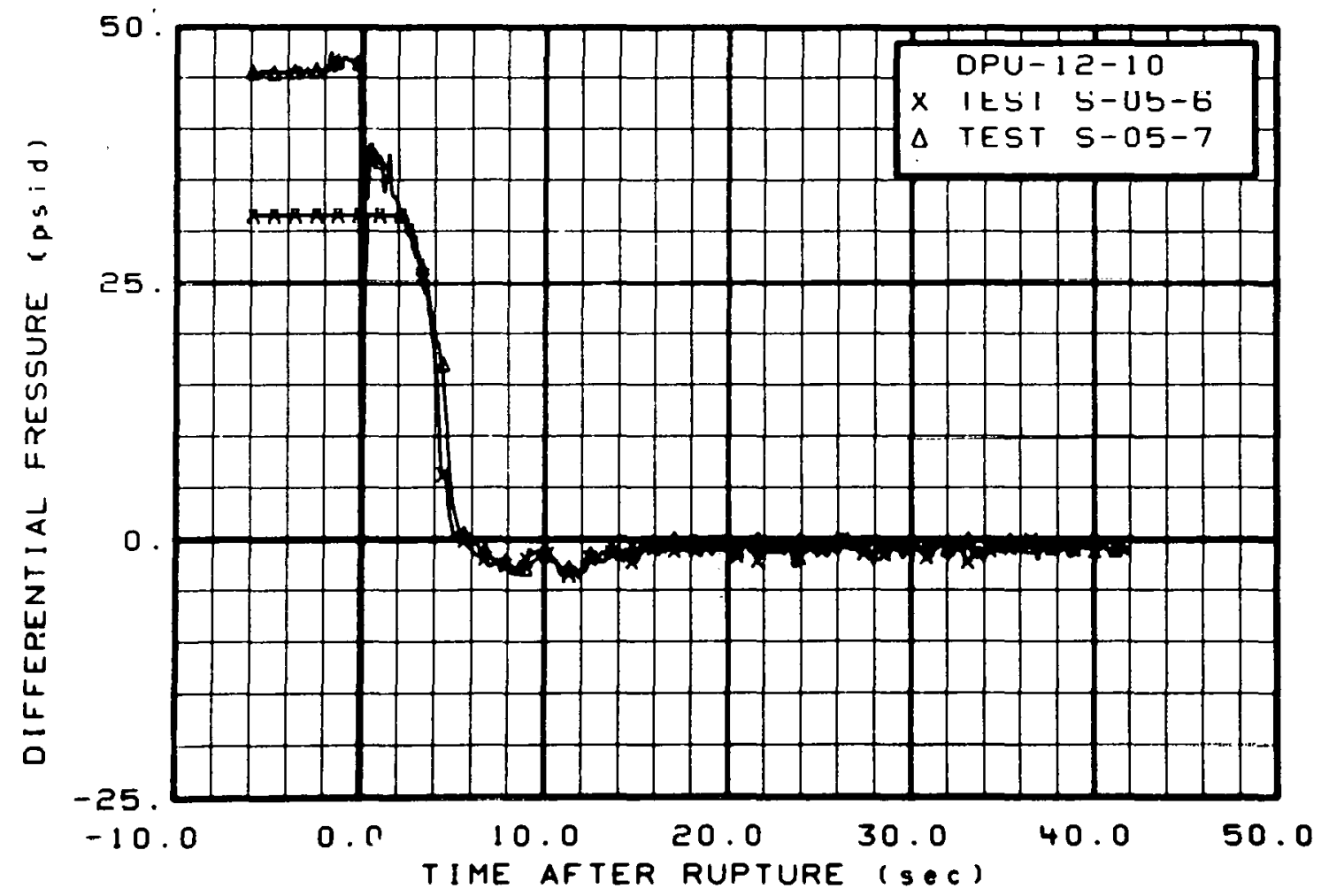

Fig. 287 Differential pressure in intact 10op (DPU-12-10), from -6 to $42 \mathrm{sec}$. 


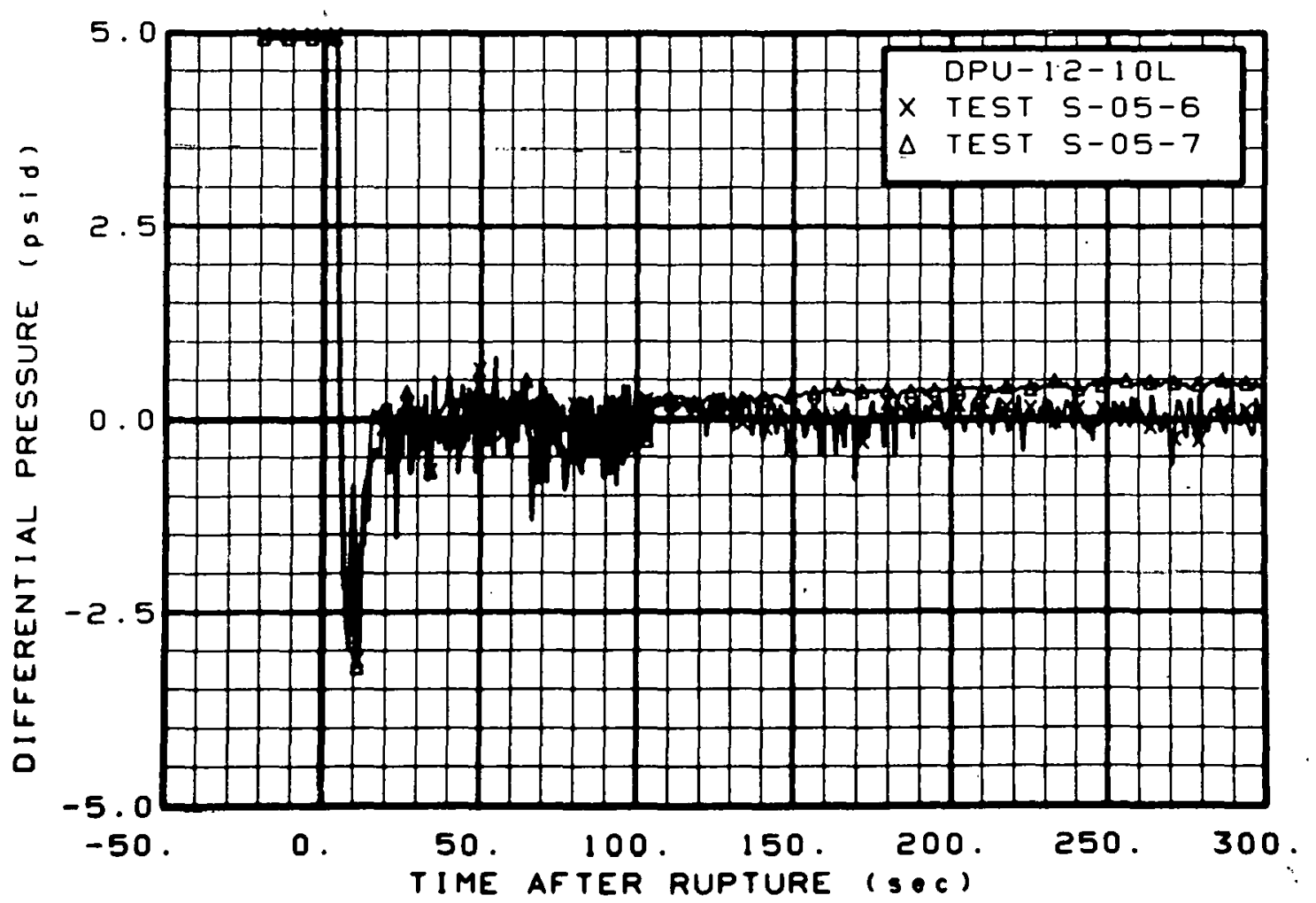

Fig. 288 Differential pressure in intact loop, low range (DPU-12-10L), from -20 to $300 \mathrm{sec}$.

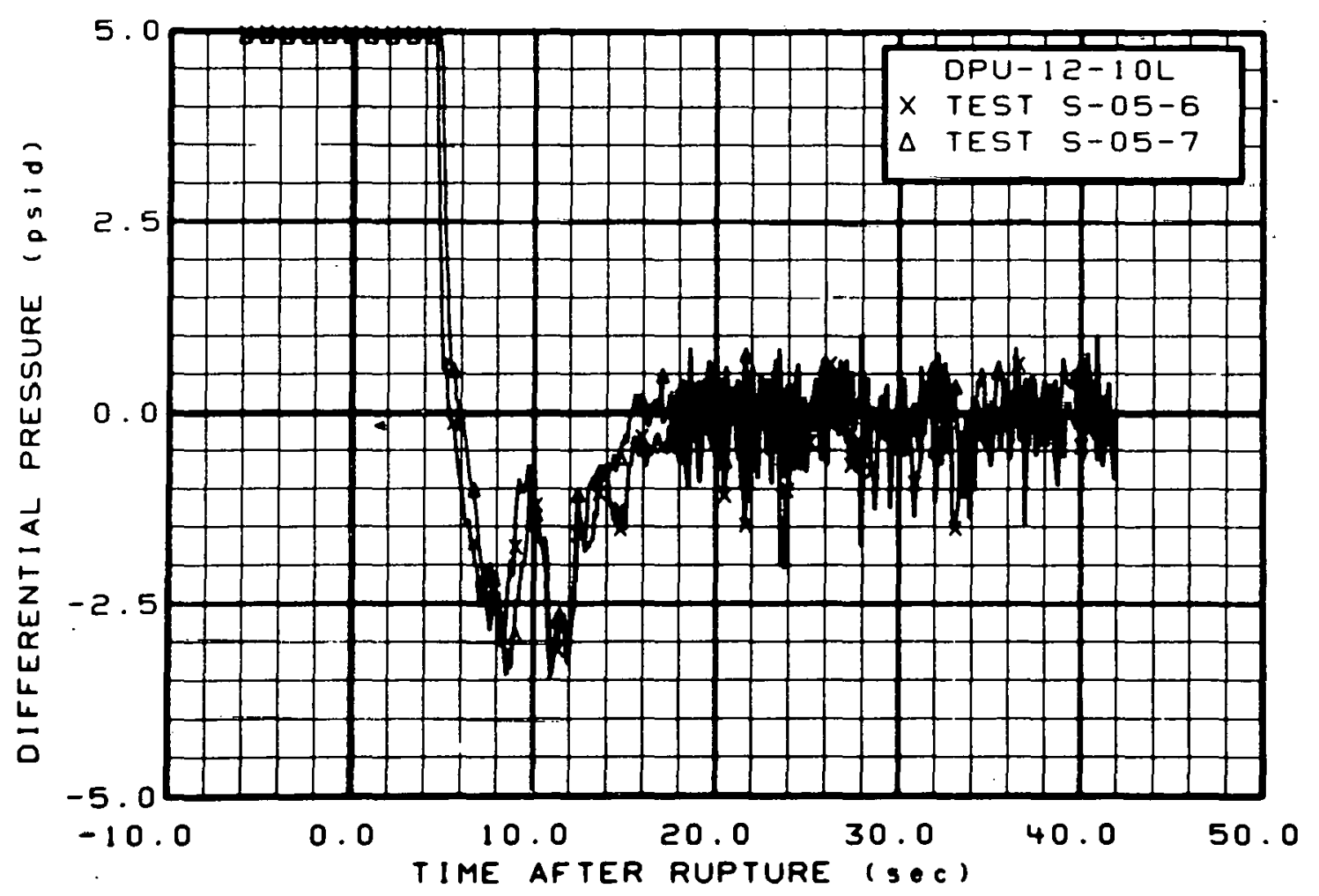

Fig. 289 Differential pressure in intact loop, low range (DPU-12-10L), from -6 to $42 \mathrm{sec}$. 


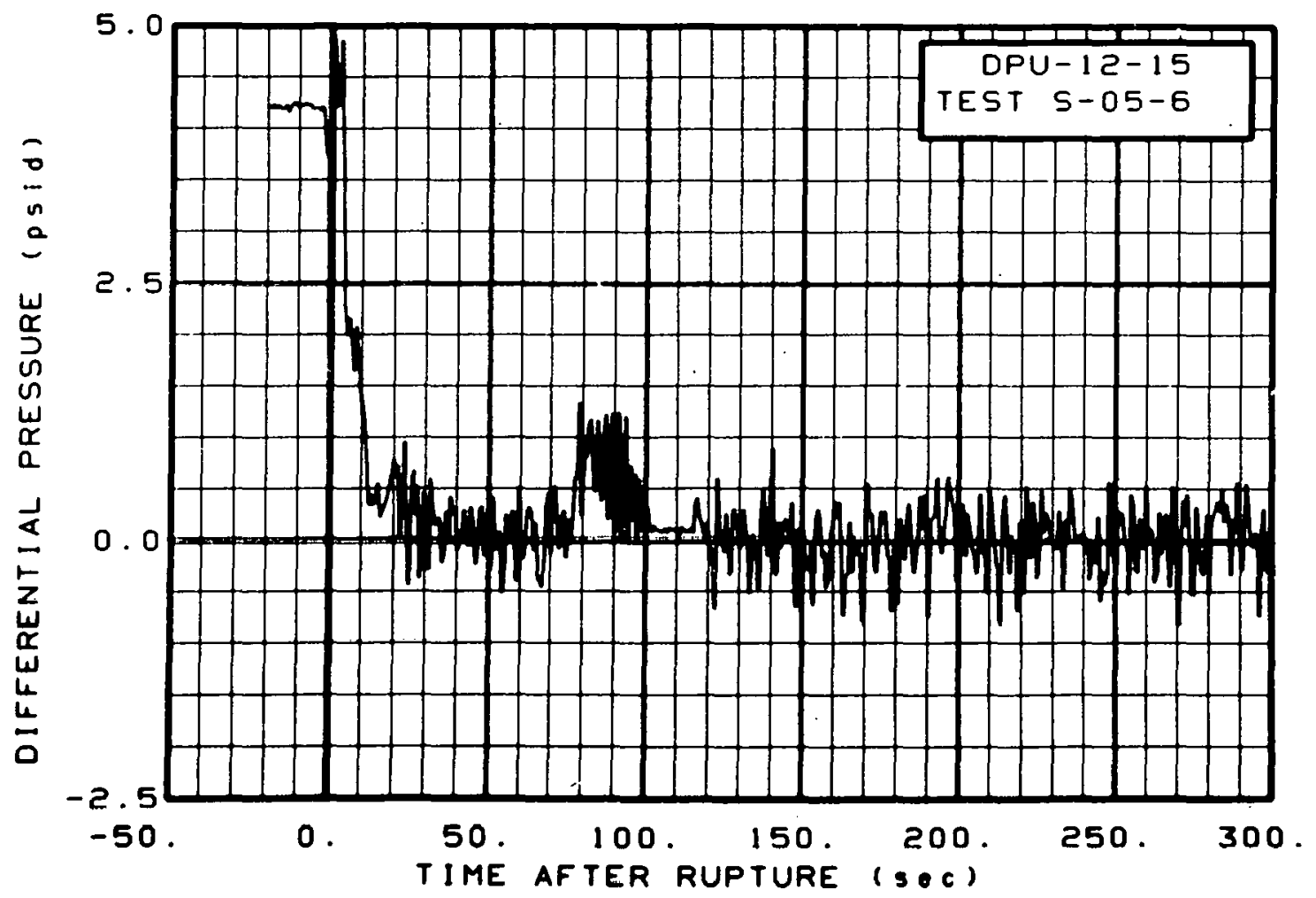

Fig. 290 Differential pressure in intact 10op, Jest S-05-6 (DPU-12-15), from -20 to $300 \mathrm{sec}$.

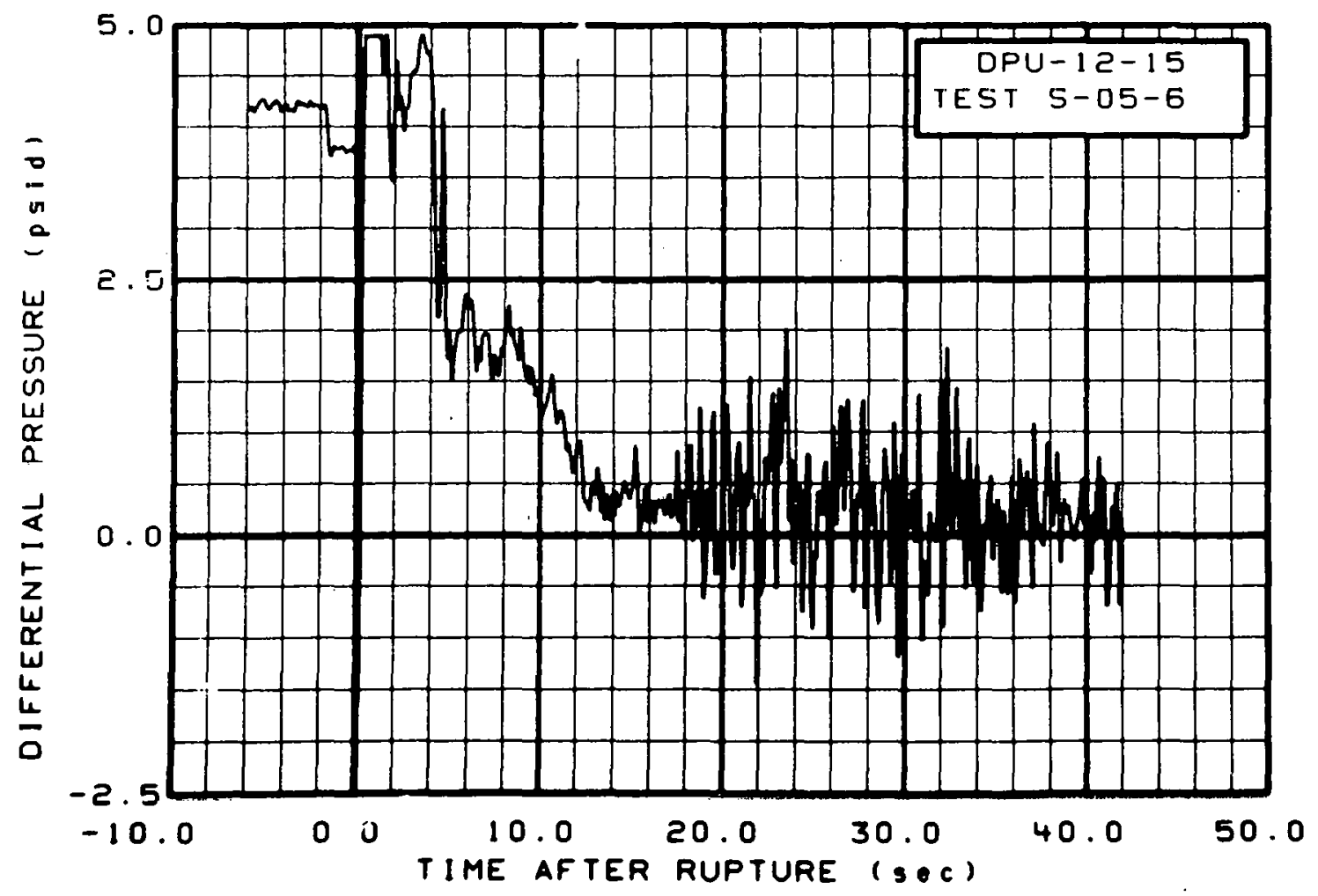

Fig. 291 Differential pressure in intact loop, Test S-05-6 (DPU-12-15), from -6 to $42 \mathrm{sec}$. 


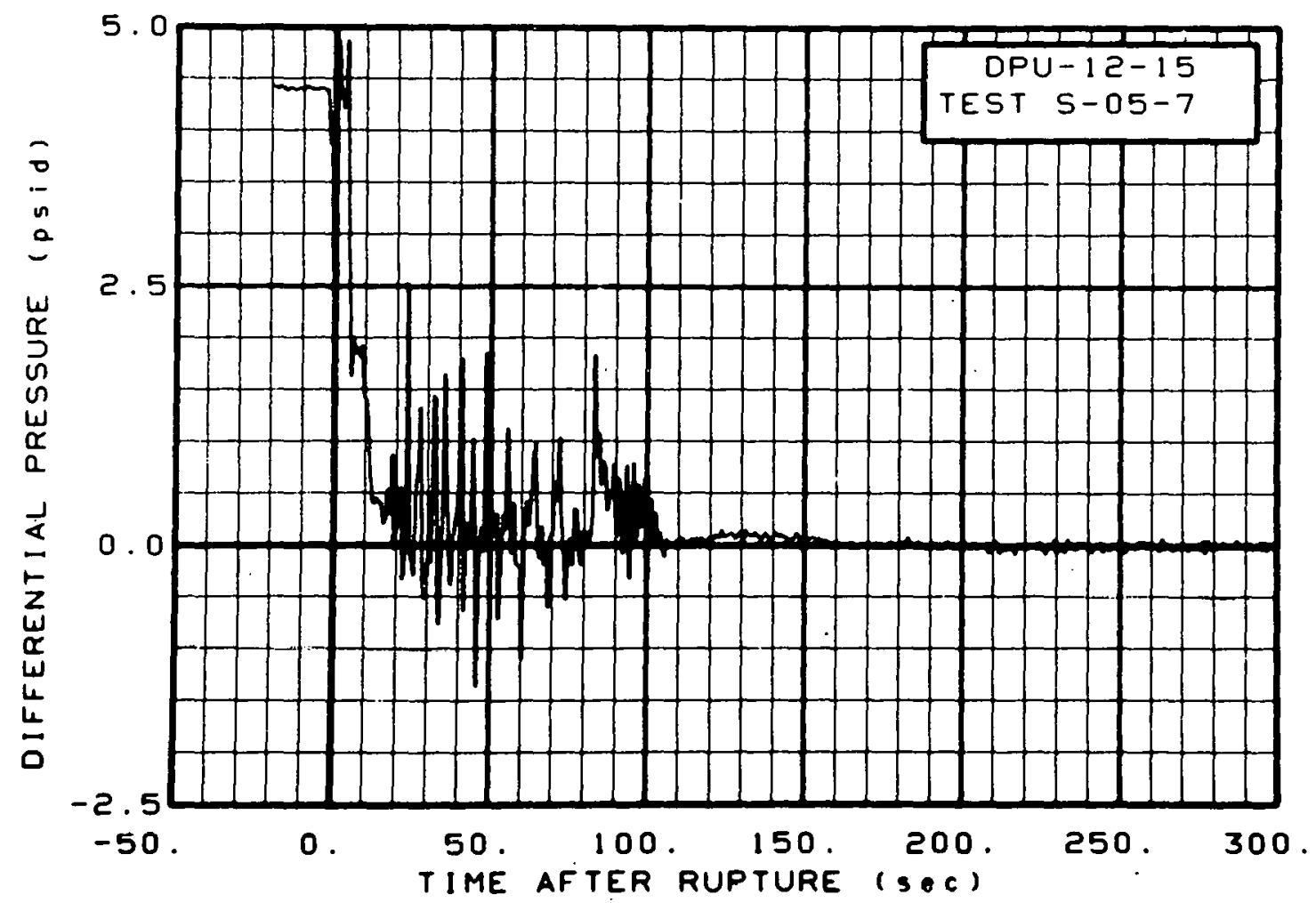

Fig. 292 Differential pressure in intact loop, Test S-05-7 (DPU-12-15), from -20 to $300 \mathrm{sec}$.

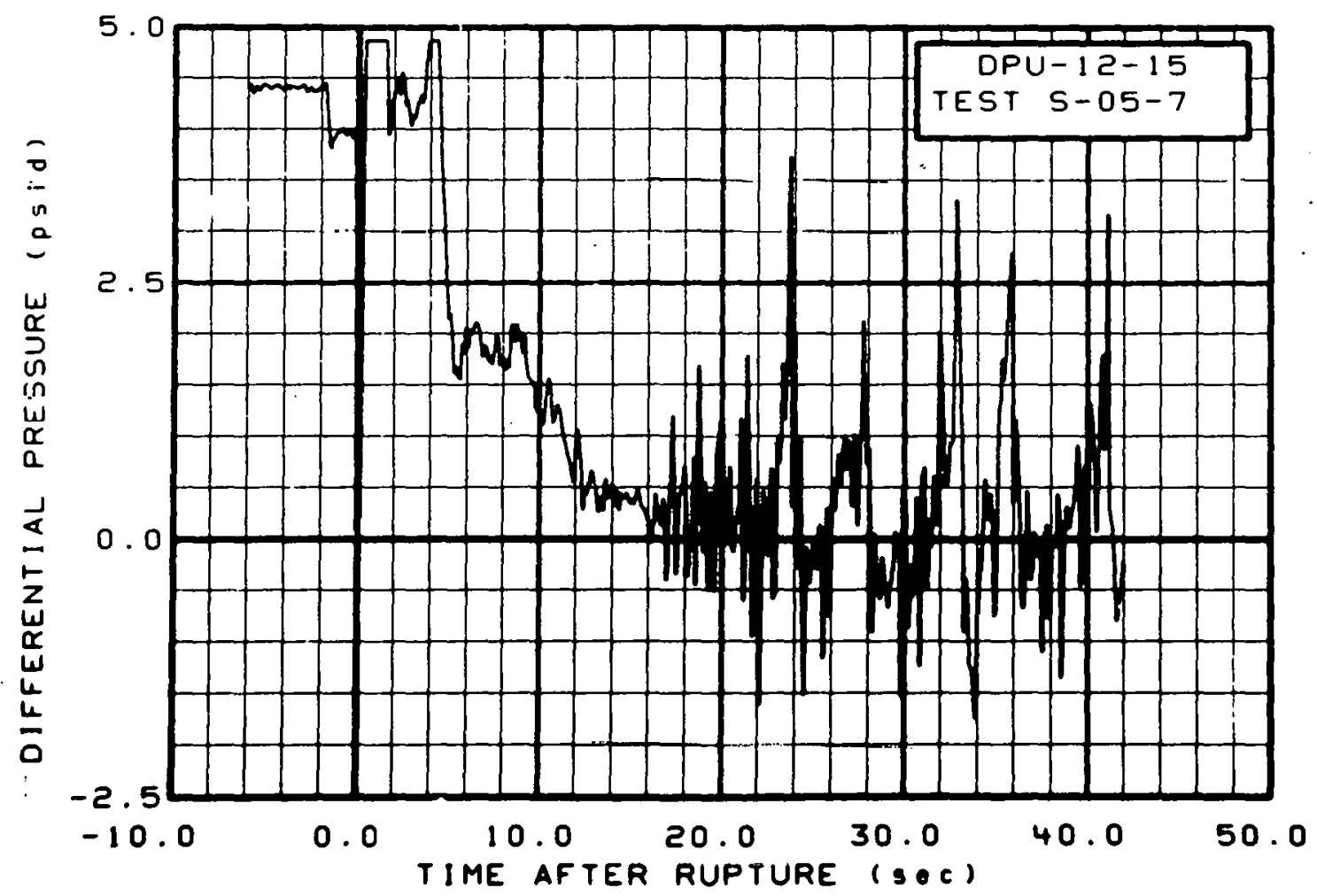

Fig. 293 Differential pressure in intact loop, Test S-05-7 (DPU-12-15), from -6 to $42 \mathrm{sec}$. 


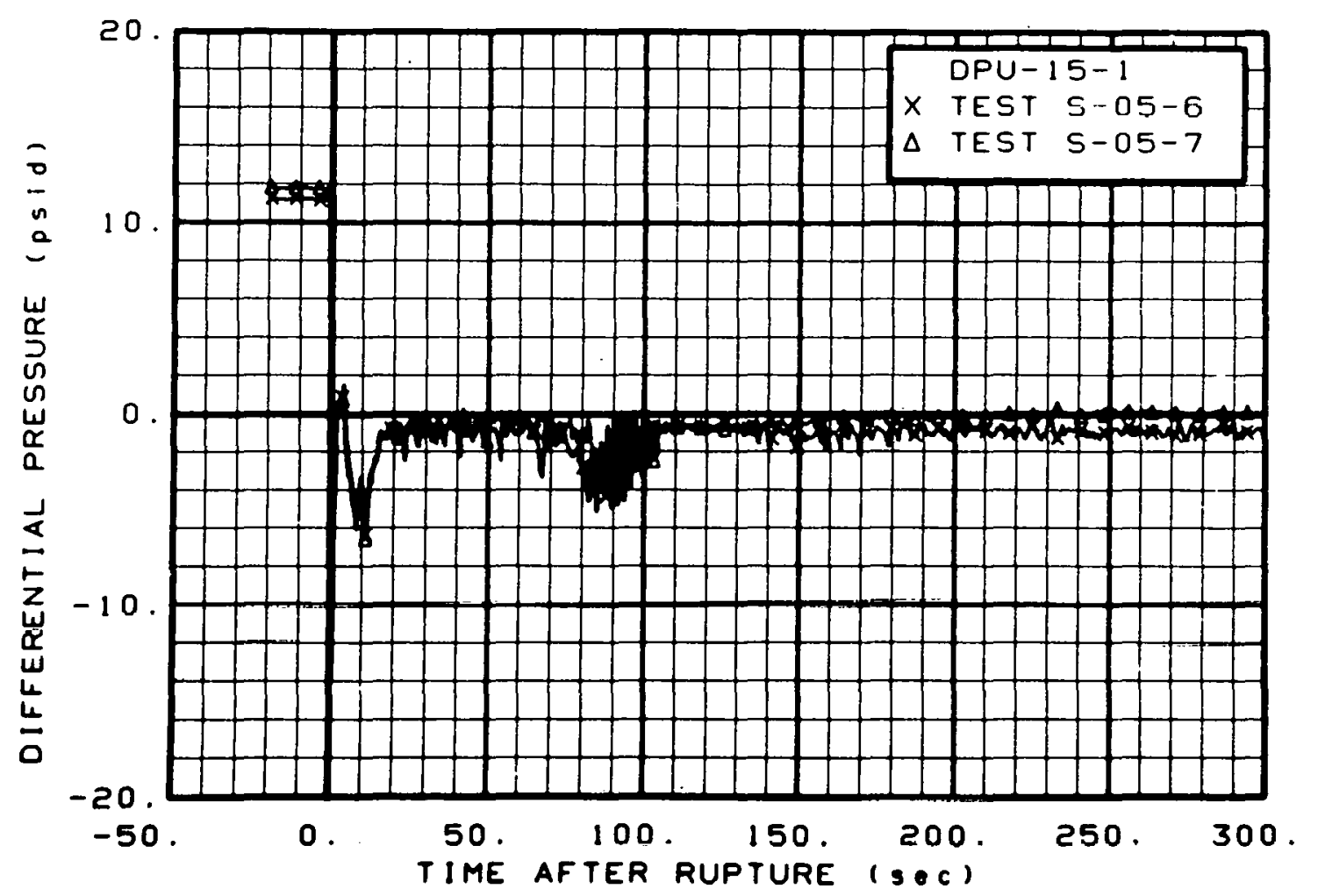

Fig. 294 Differential pressure in intact loop (DPU-15-1), from -20 to $300 \mathrm{sec}$.

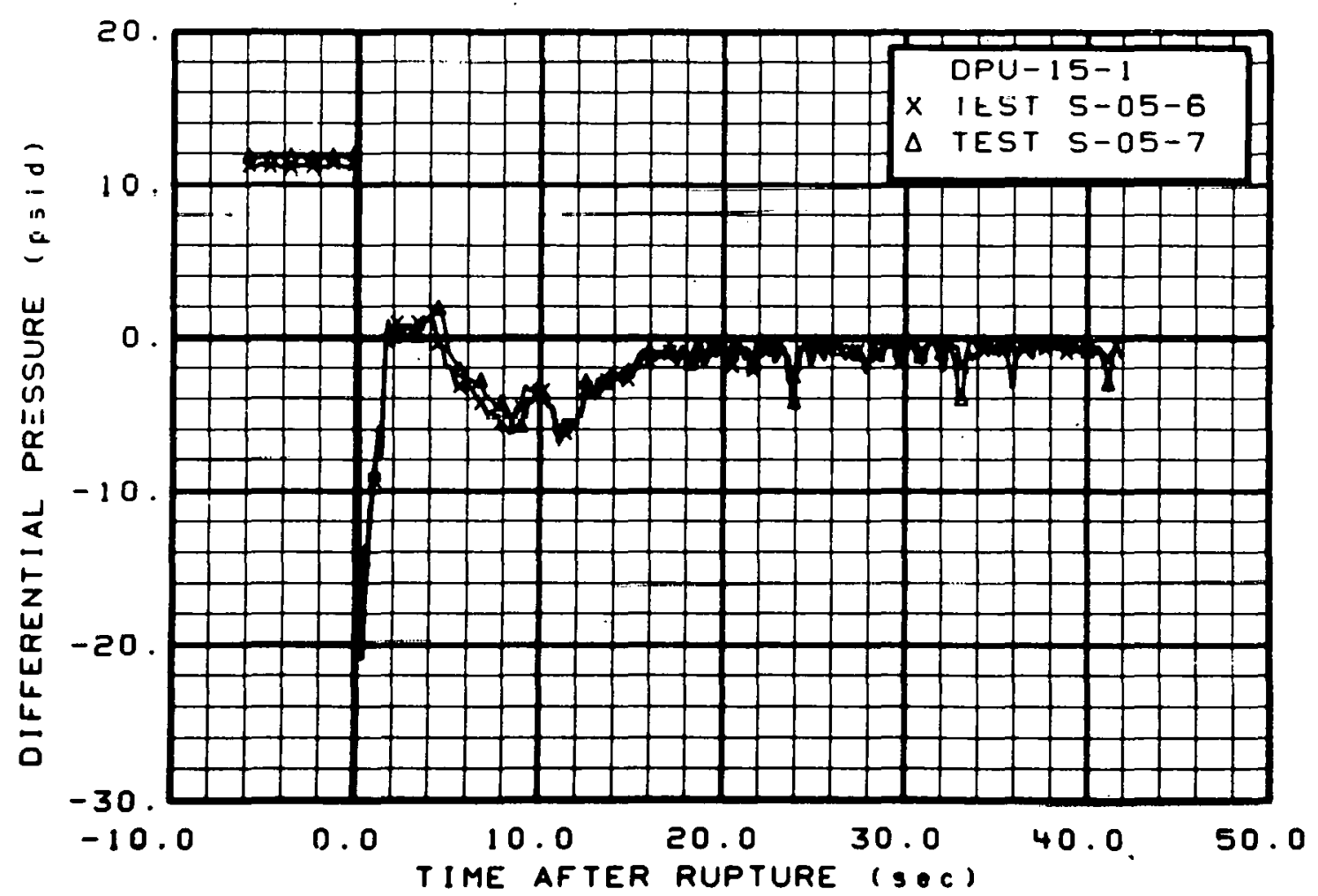

Fig. 295 Differential pressure in intact loop (DPU-15-1), from -6 to $42 \mathrm{sec}$. 
THIS PAGE

\section{WAS INTENTIONALLY \\ LEFT BLANK}




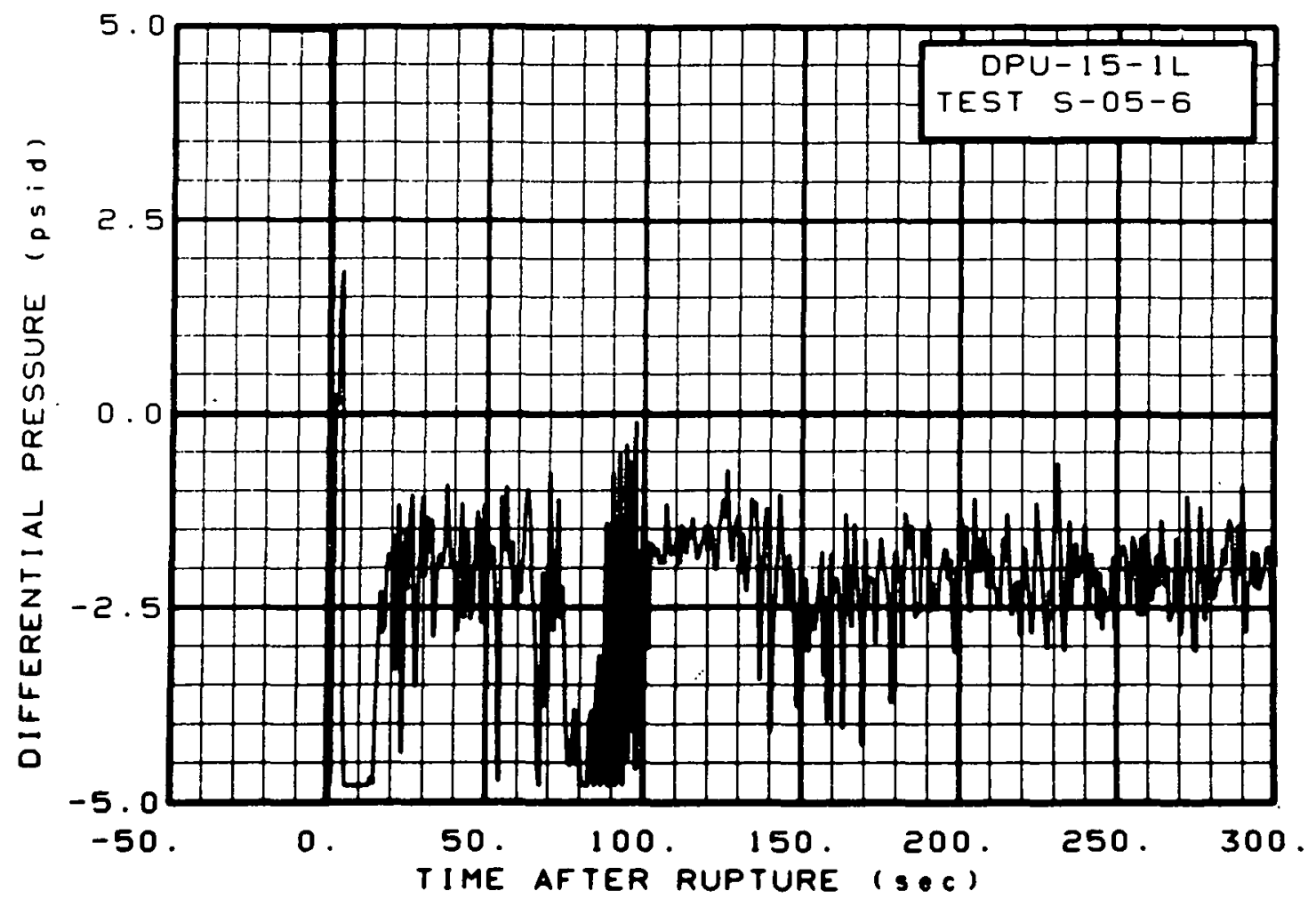

Fig. 296 Differential pressure in intact loop, low range, Test S-05-6 (DPU-15-1L), from -20 to $300 \mathrm{sec}$.

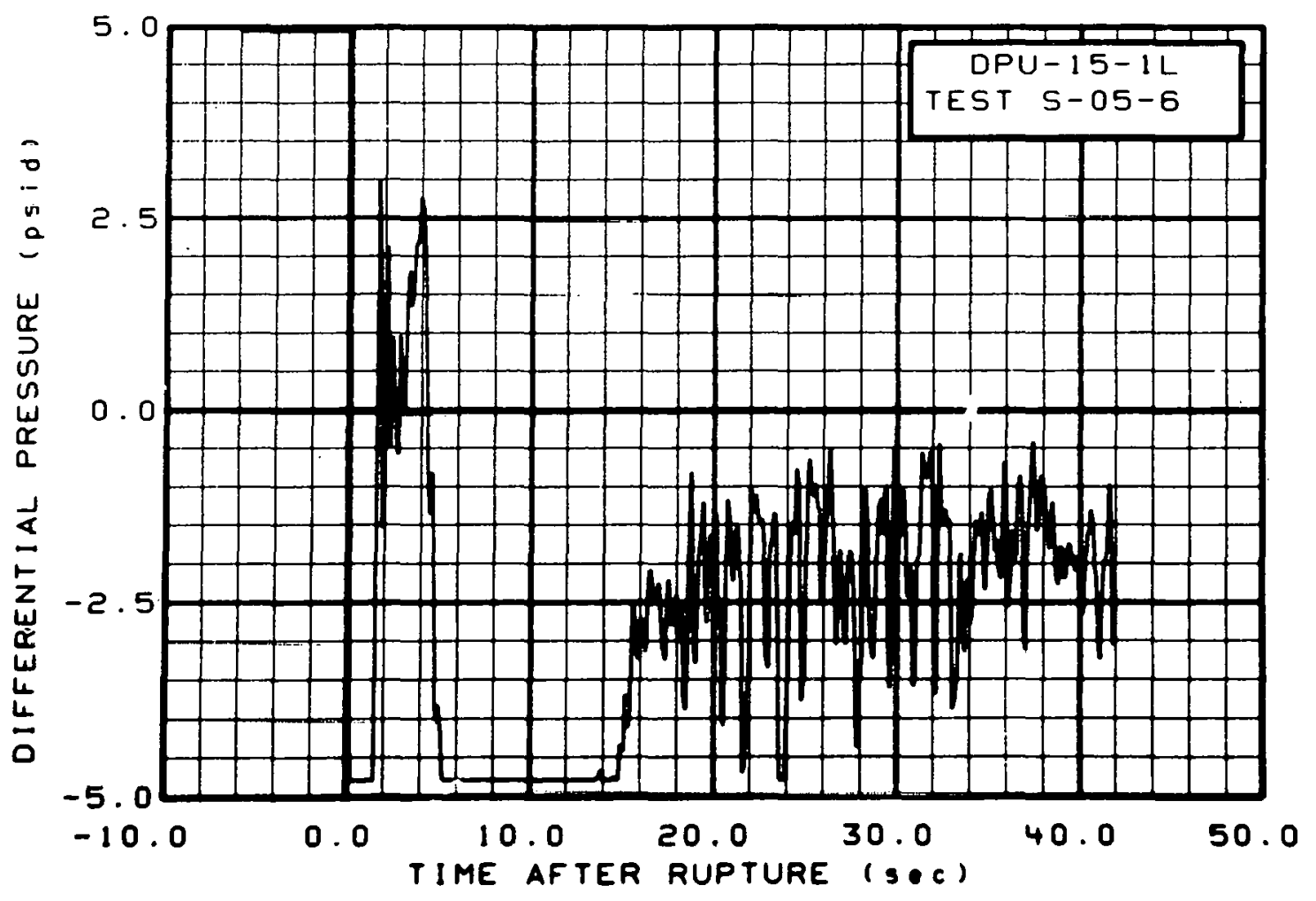

Fiq. 297 Differential pressure in intact loop, low range, Test S-05-6 (DPU-15-1L), from -6 to $42 \mathrm{sec}$. 


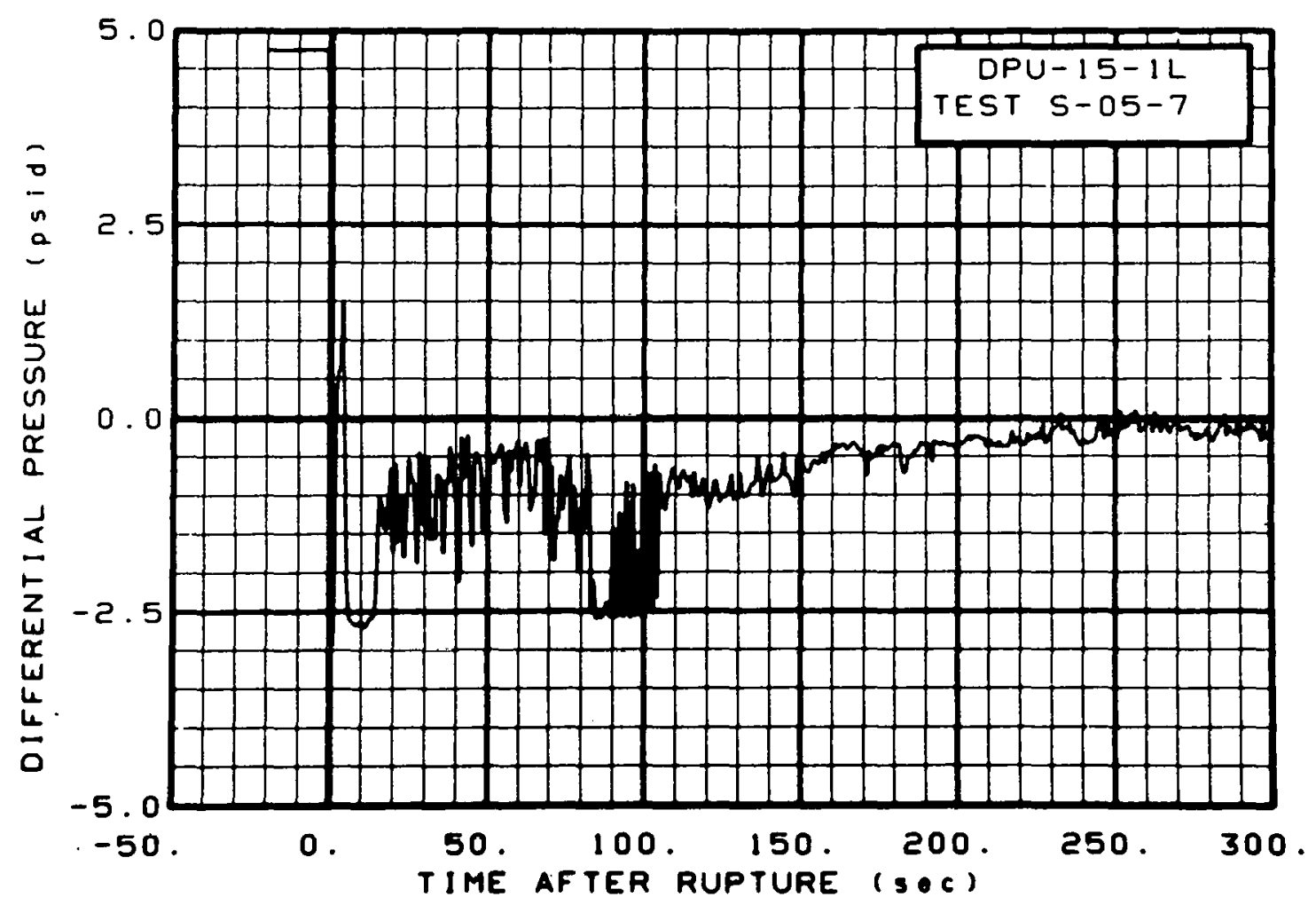

Fig. 298 Differential pressure in intact loop, low range, Test S-05-7 (UPU-15-1L), from -20 to $300 \mathrm{sec}$.

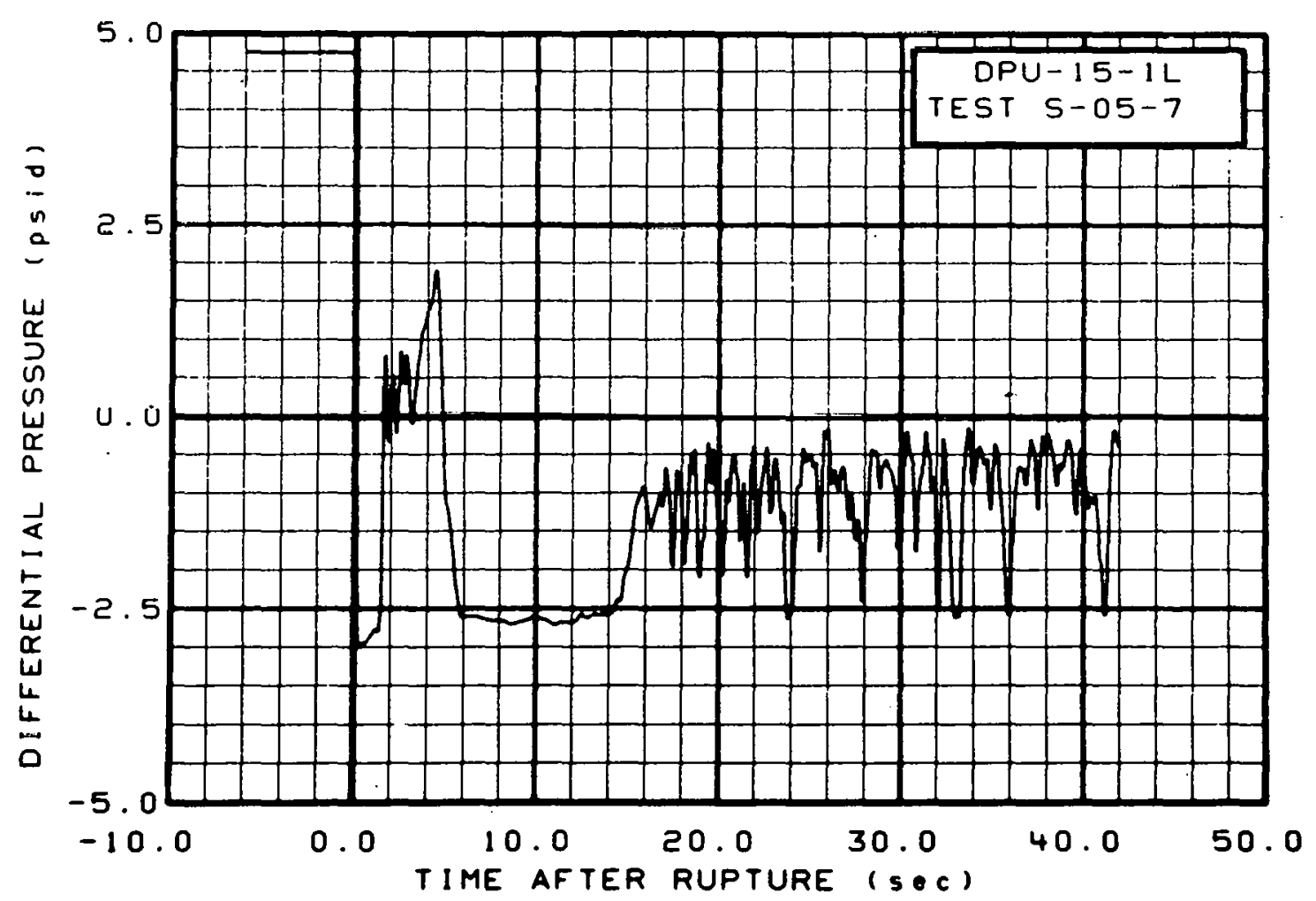

Fig. 299 Differential pressure in intact 10op, low range, Test S-05-7 (DPU-15-iL), frnm -6 to 42 sec. 


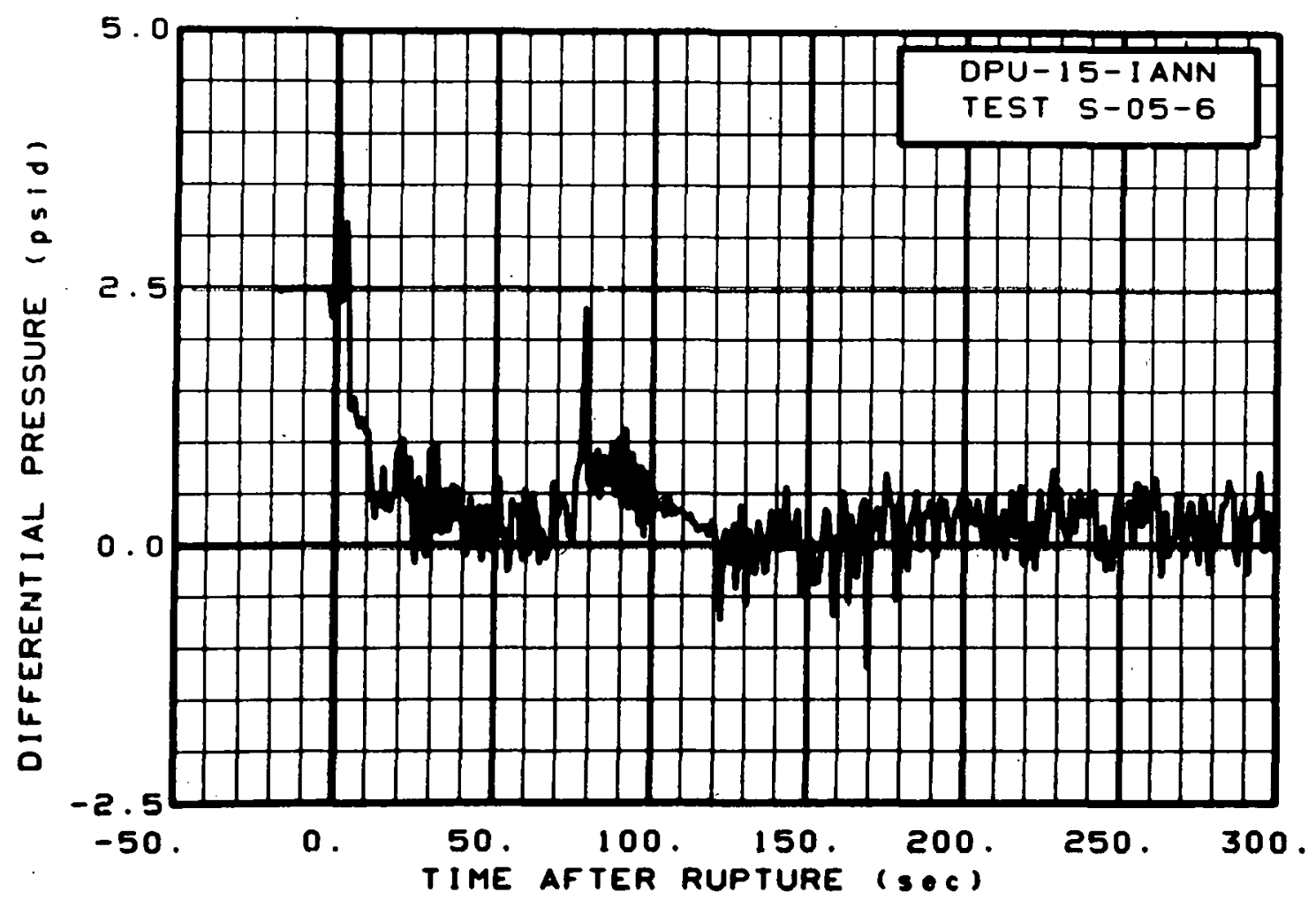

Fig. 300 Differential pressure in intact loop, Test S-05-6 (DPU-15-IANN), from -20 to $300 \mathrm{sec}$.

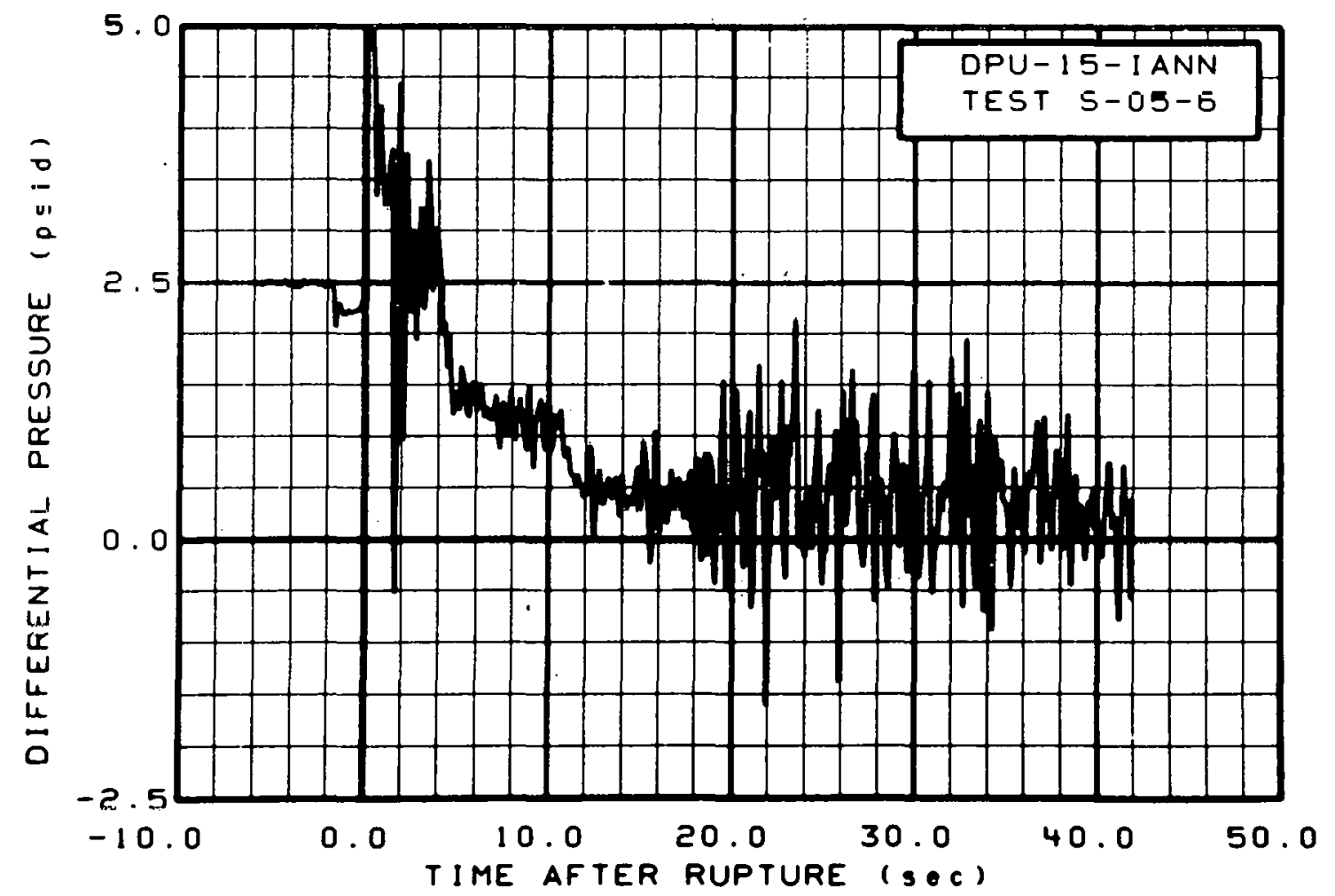

Fig. 301 Differential pressure in intact 1oop, Test S-05-6 (DPU-15-IANN), from -6 to $42 \mathrm{sec}$. 


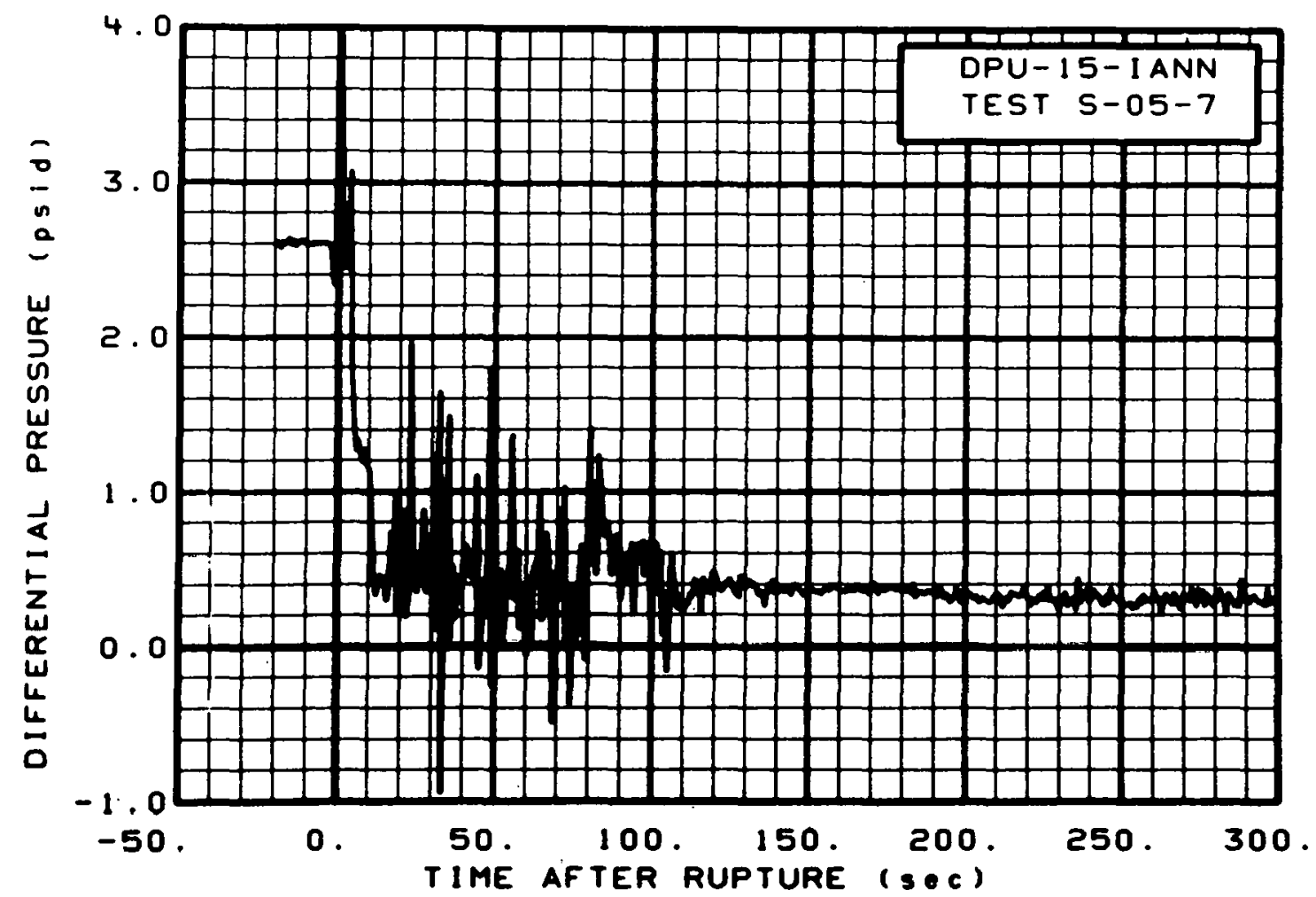

Fig. 302 Differential pressure in intact loop, Test S-05-7 (DPU-15-IANN), from -20 to $300 \mathrm{sec}$.

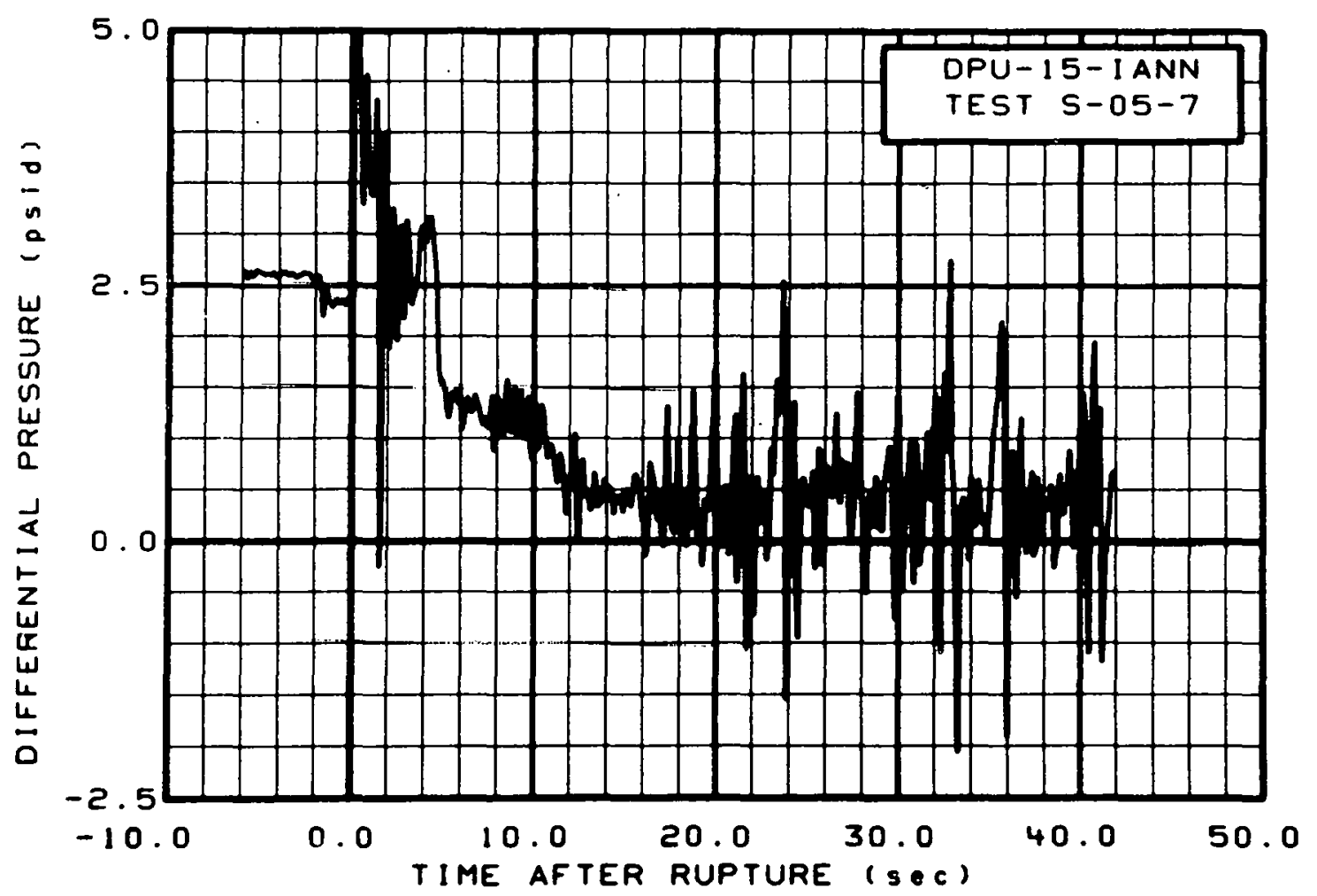

Fig. 303 Differential pressure in intact loop, Test S-05-7 (DPU-15-IANN), from -6 to $42 \mathrm{sec}$. 


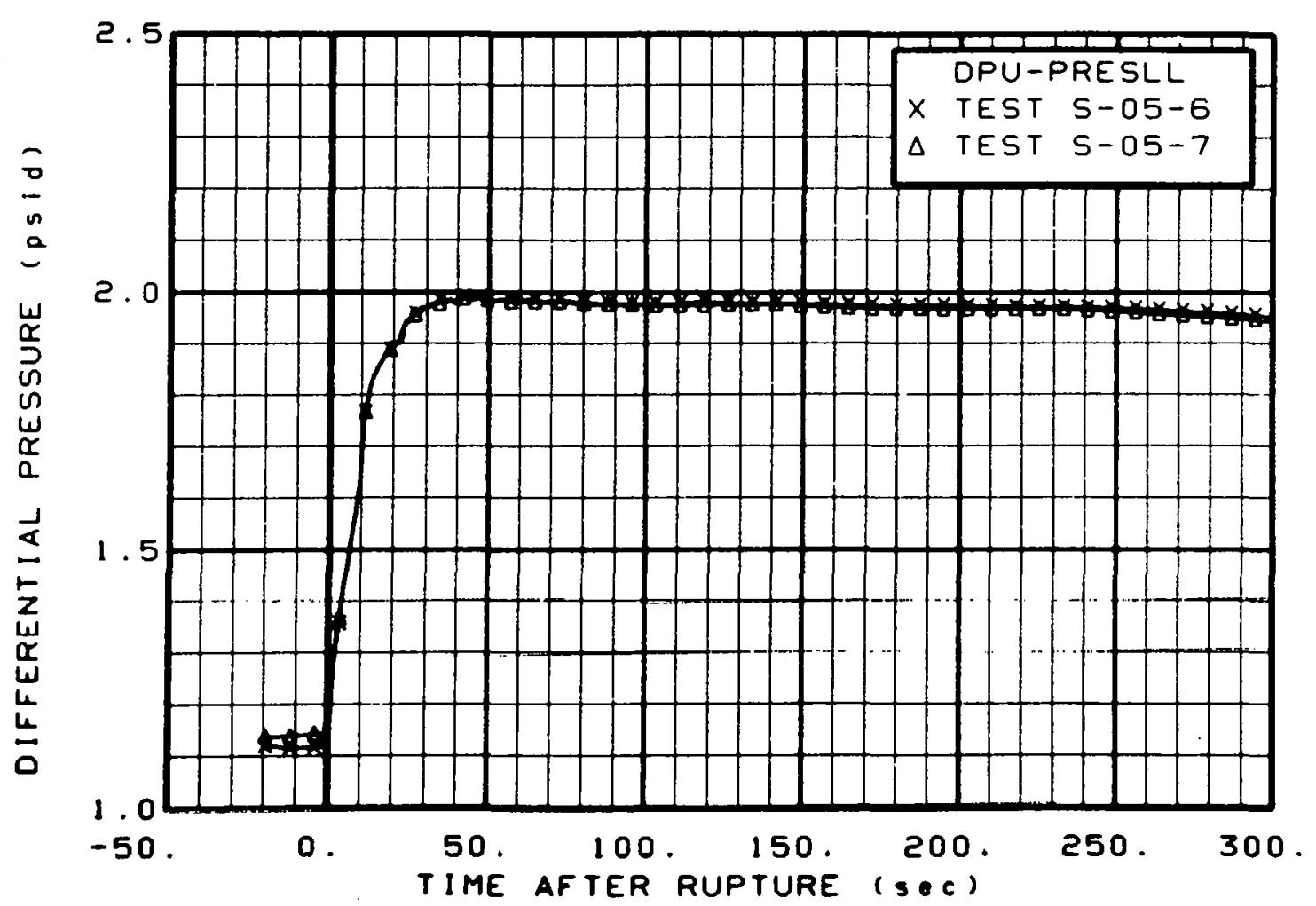

Fig. 304 Differential pressure in intact loop (DPU-PRESLL), from -20 to $300 \mathrm{sec}$.

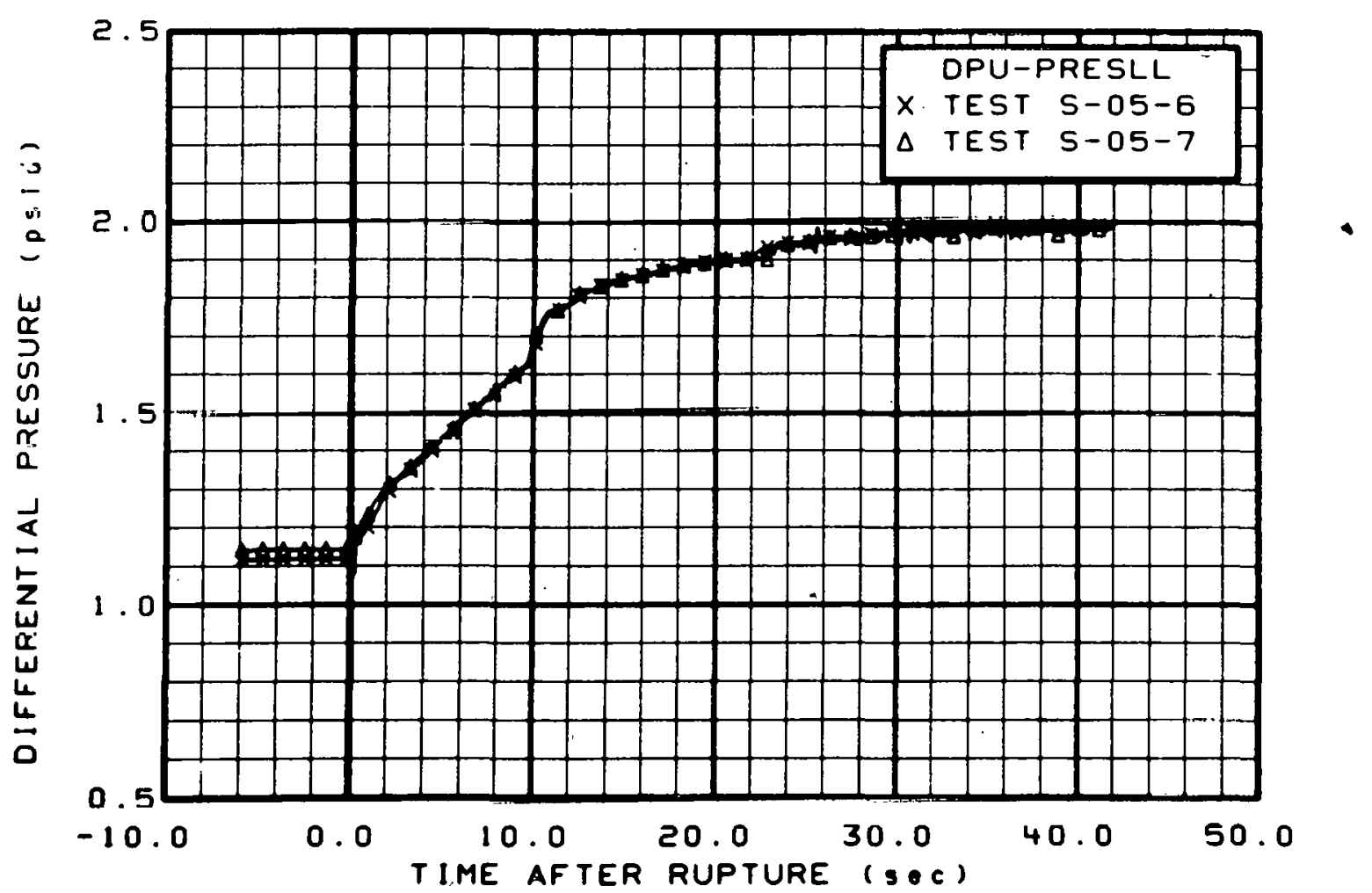

Fig. 305 Differential pressure in intact loop (DPU-PRESLL), from -6 to 42 se.c. 


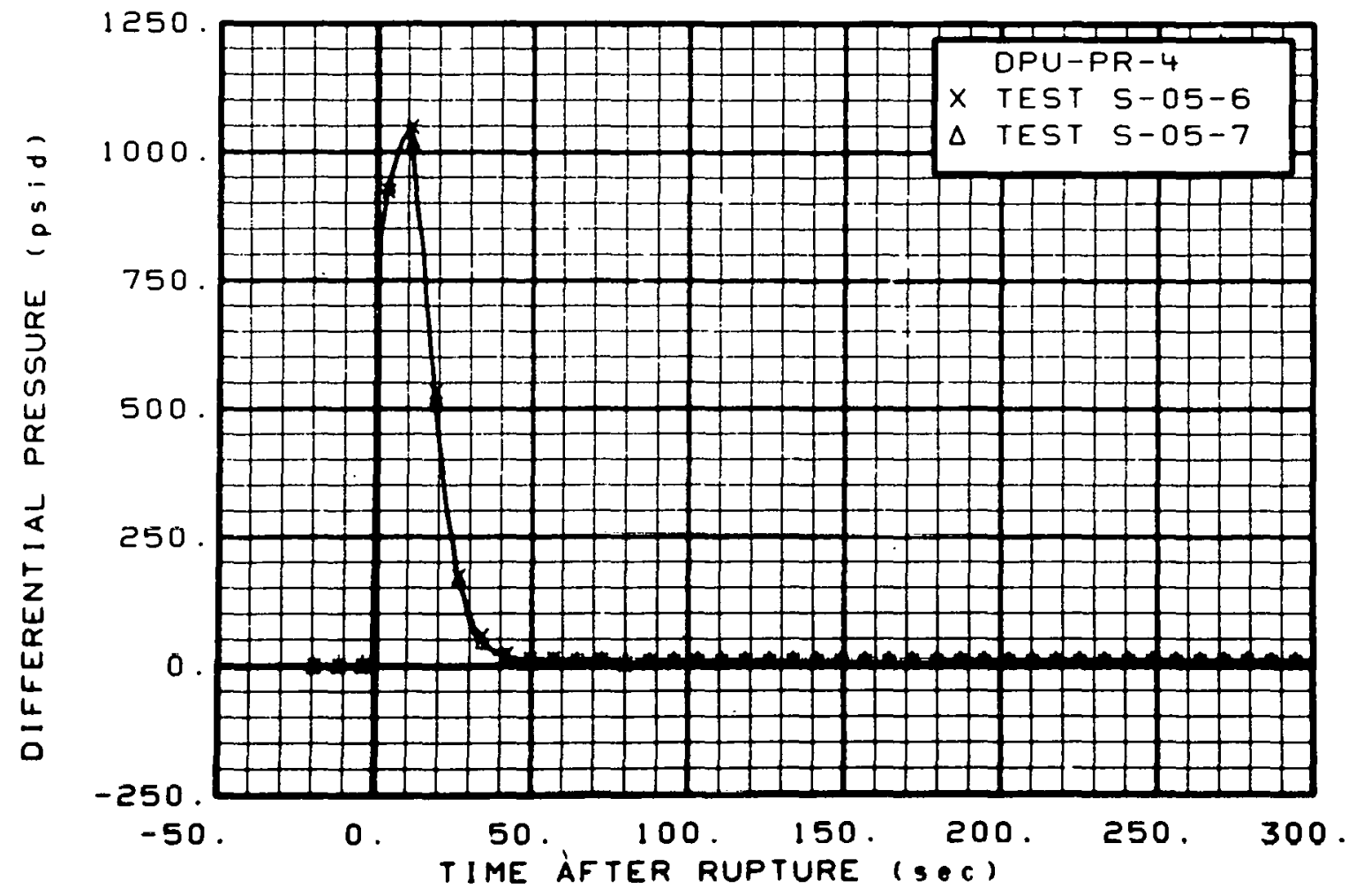

Fig. 306 Differential pressure in intact 10op (DPU-PR-4), from -20 to $300 \mathrm{sec}$.

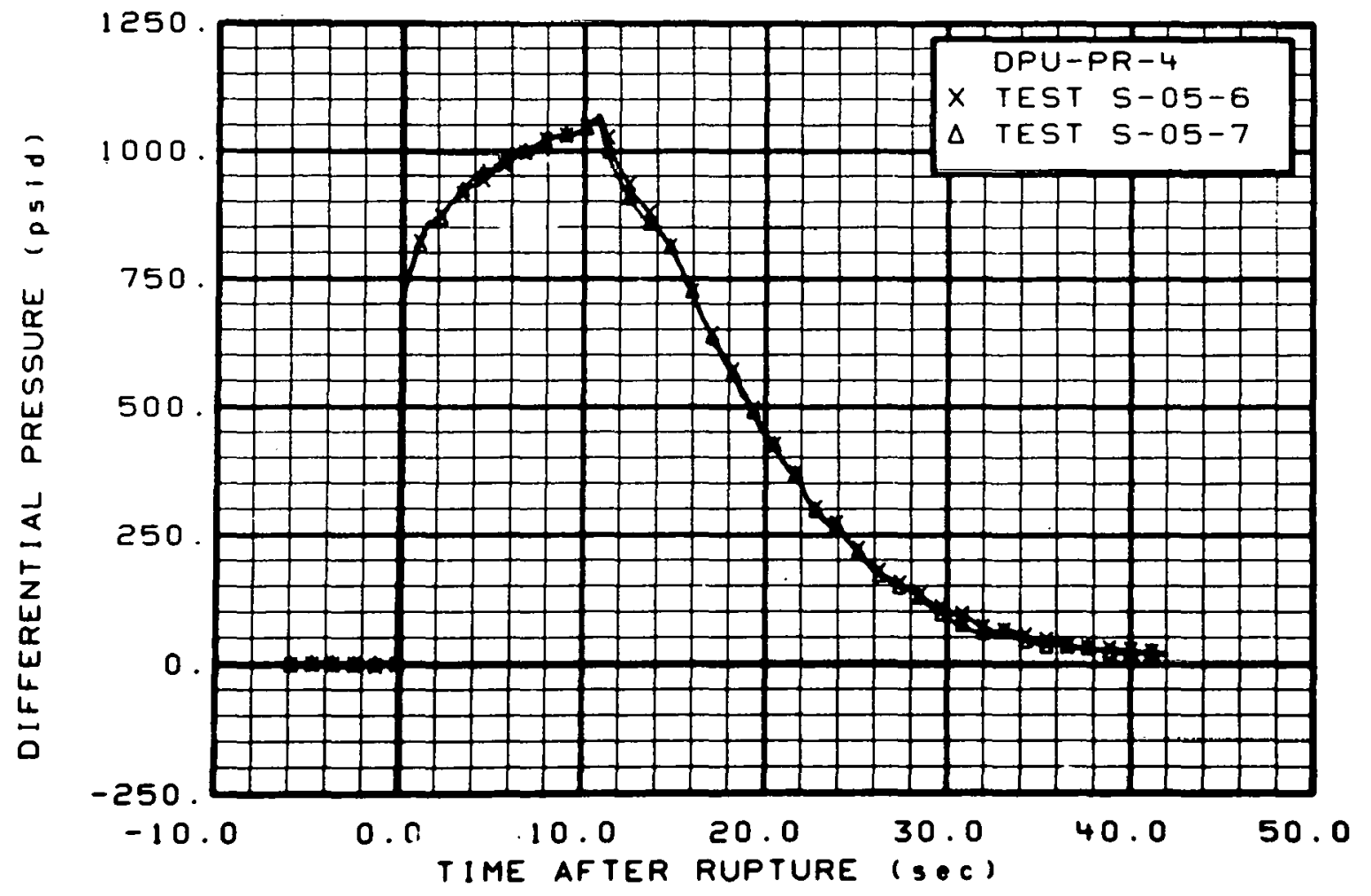

Fig. 307 Differential pressure in intact loop (DPU-PR-4), from -6 to $42 \mathrm{sec}$. 


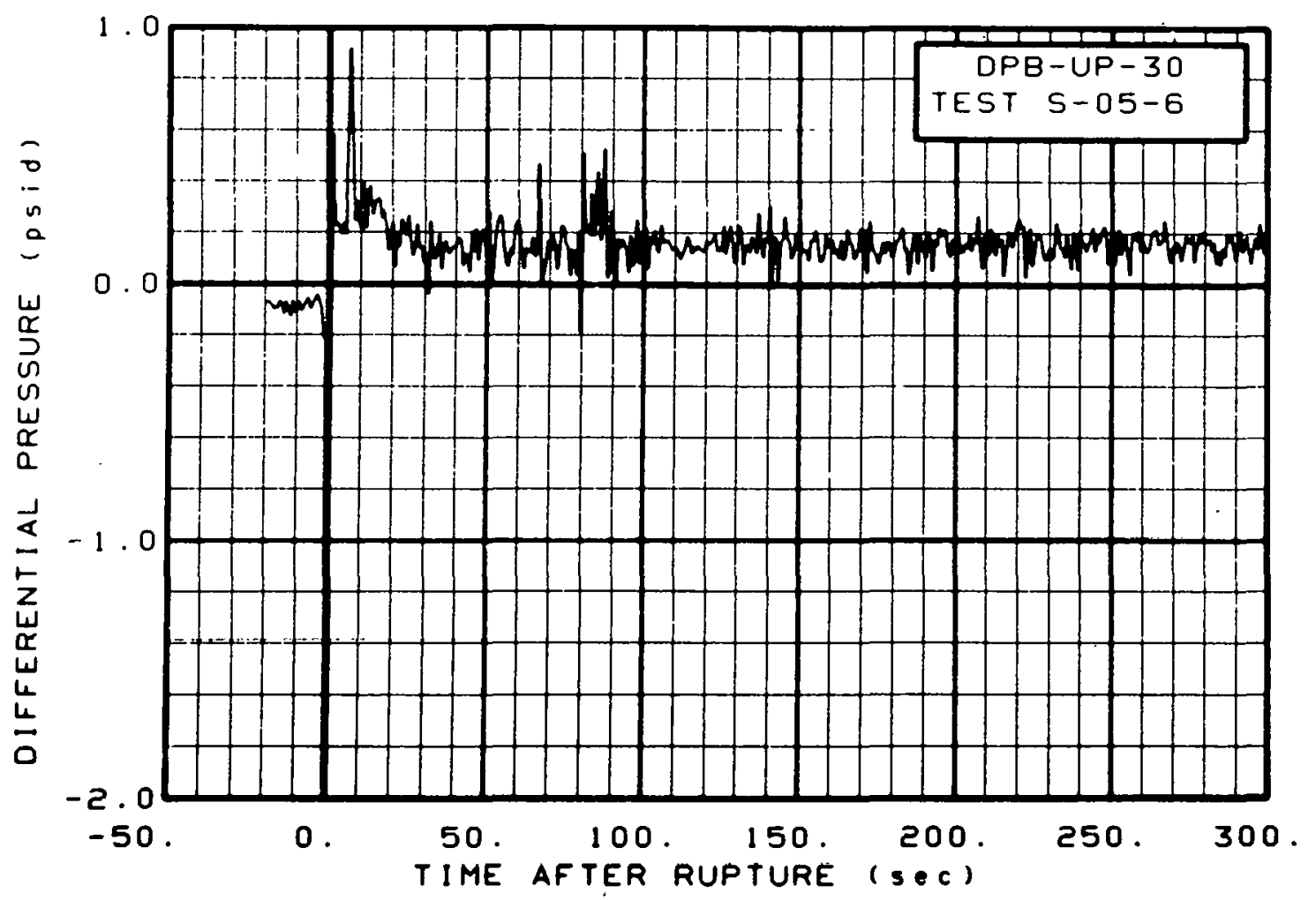

Fig. 308 Differential pressure in broken loop, Test S-05-6 (DPB-UP-30), from -20 to $300 \mathrm{sec}$.

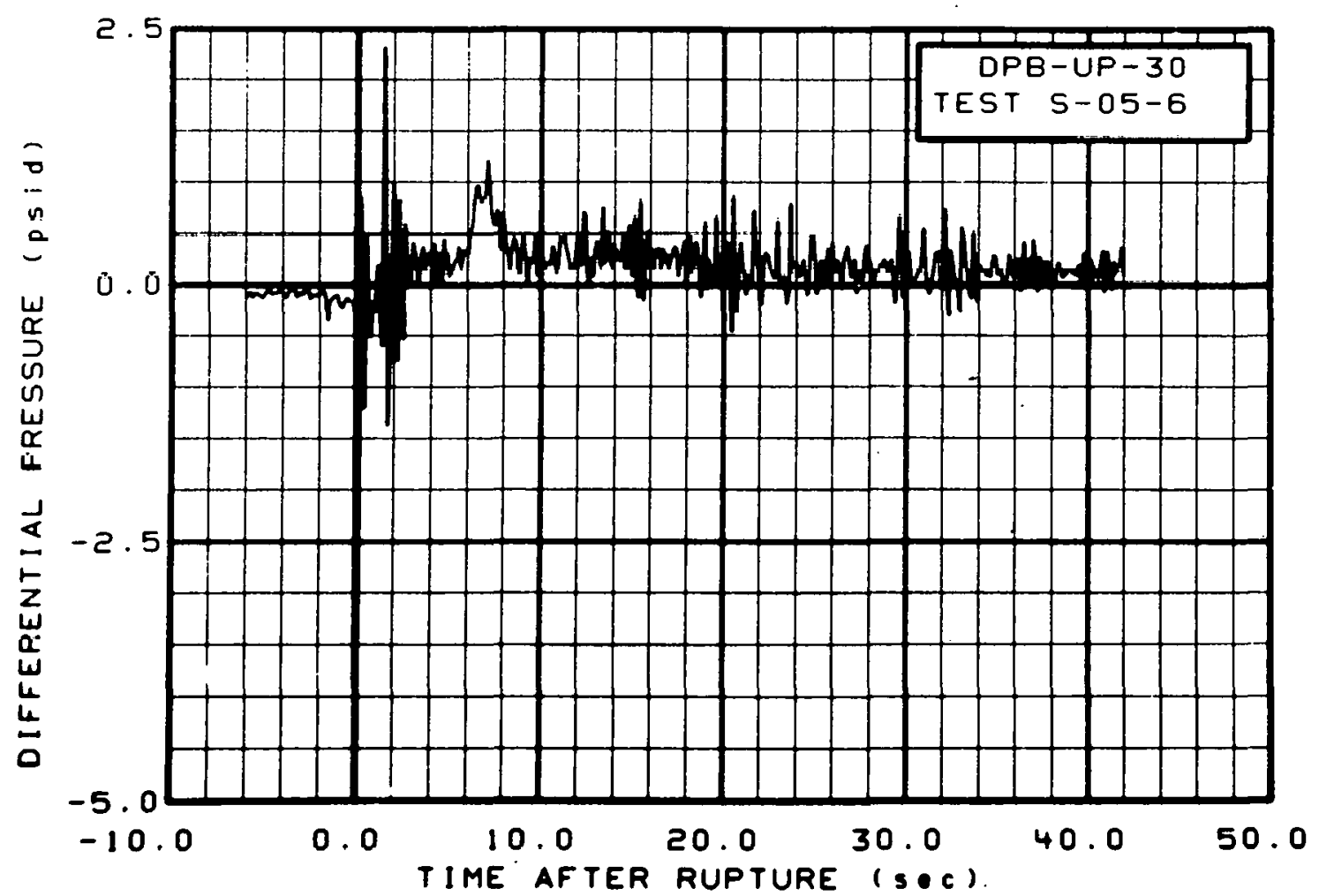

Fig. 309 Differential pressure in broken 10op, Test S-05-6 (DPB-UP-30), from -6 to $42 \mathrm{sec}$. 


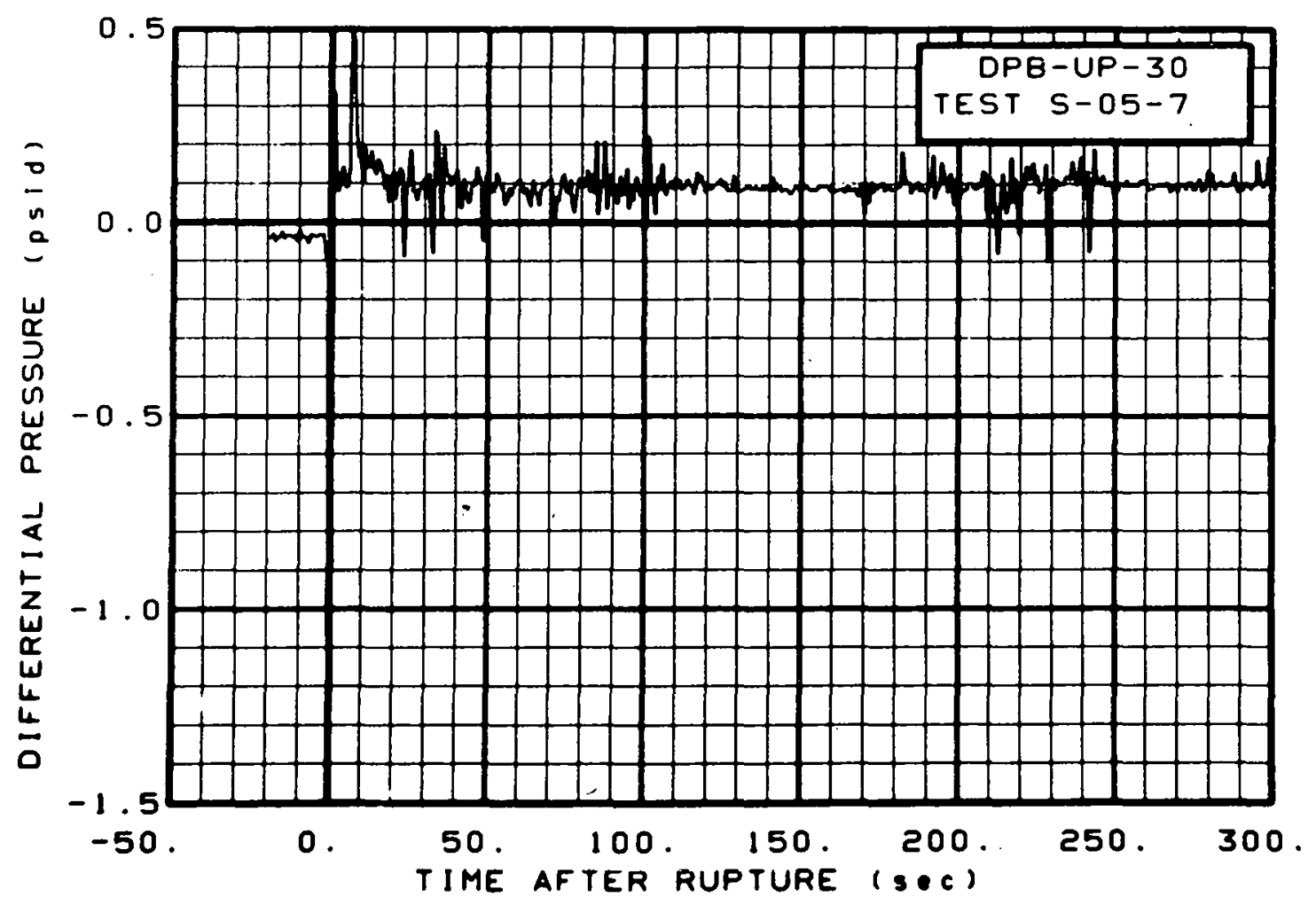

Fig. 310 Differential pressure in broken 1oop, Test S-05-7 (DPB-UP-30), from -20 to $300 \mathrm{sec}$.

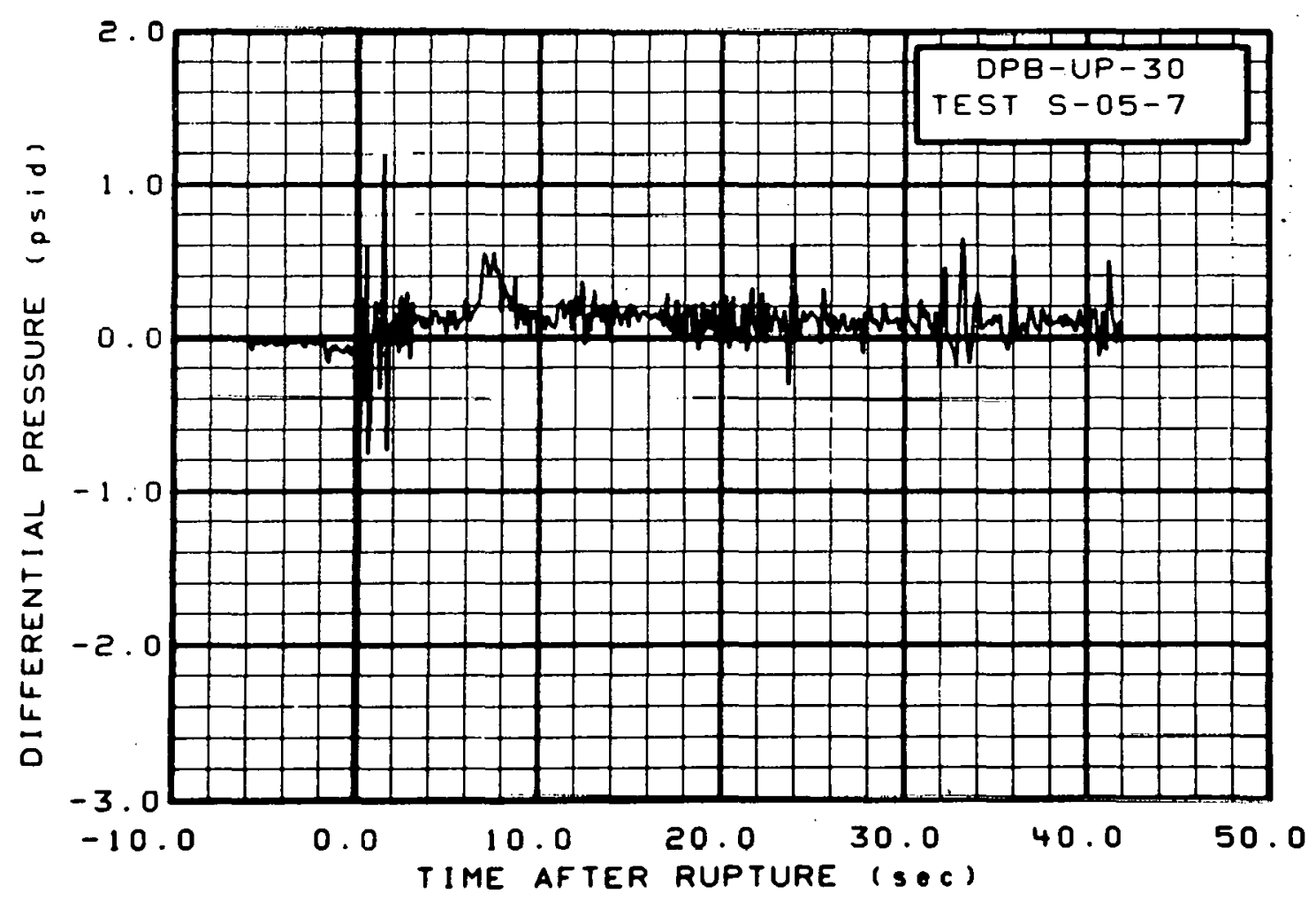

Fig. 311 Differential pressure in broken 10op, Test S-05-7 (DPB-UP-30), from -6 to $42 \mathrm{sec}$. 


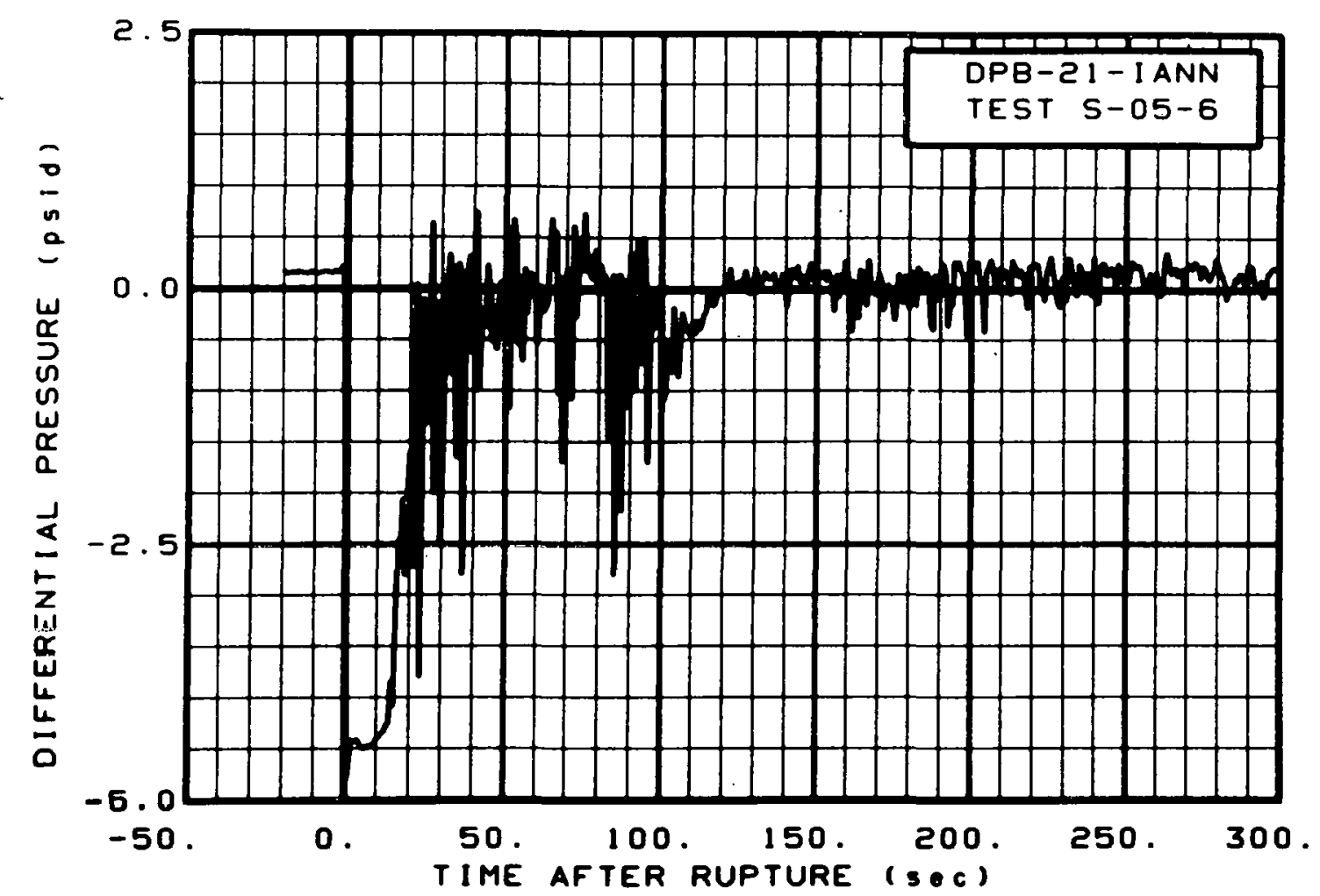

Fig. 312 Differential pressure in broken 10op, Test S-05-6 (DPB-21-IANN), from -20 to $300 \mathrm{sec}$.

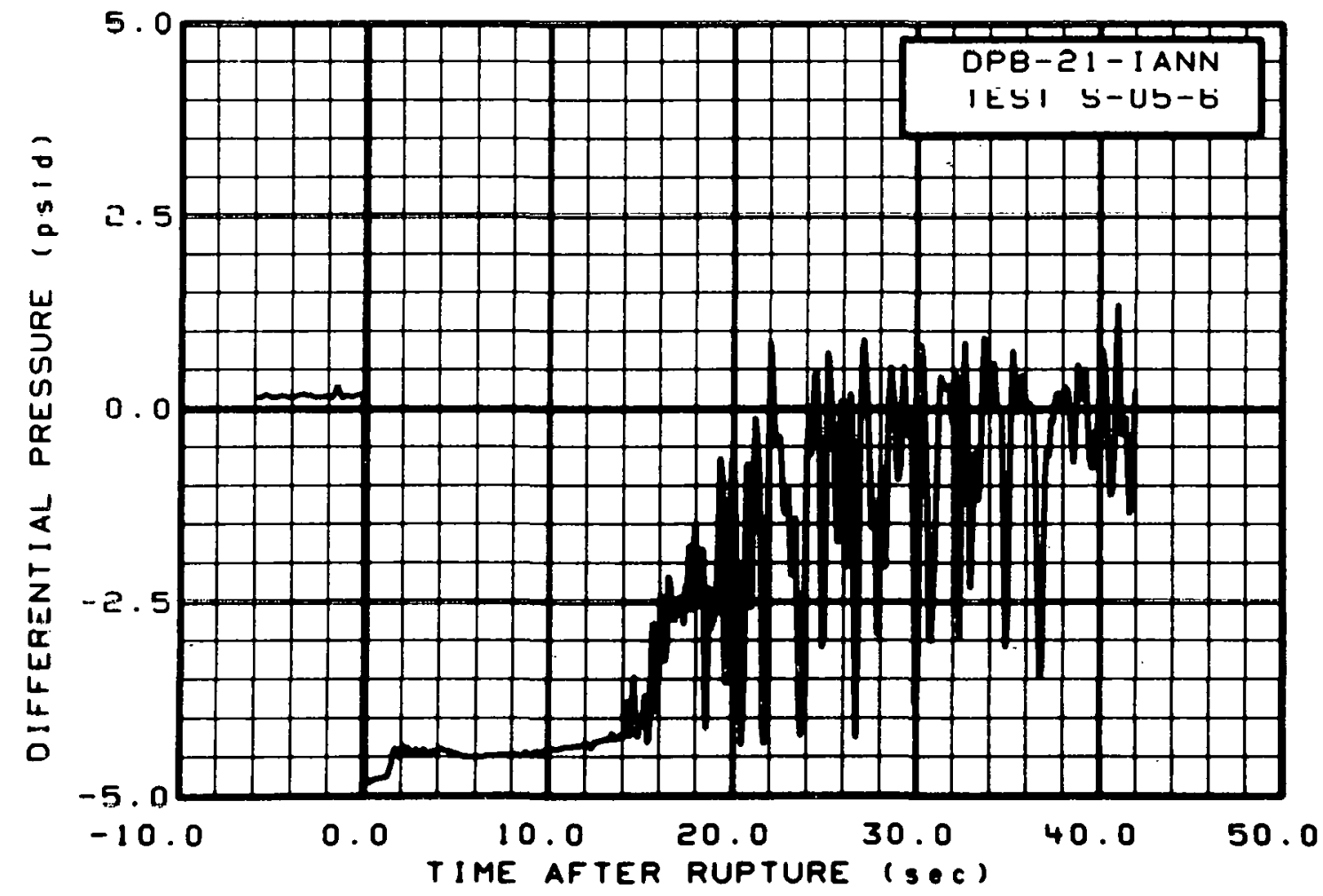

Fig. 313 Differential pressure in broken 10op, Test S-05-6 (DPB-21-IANN), from -6 to $42 \mathrm{sec}$. 


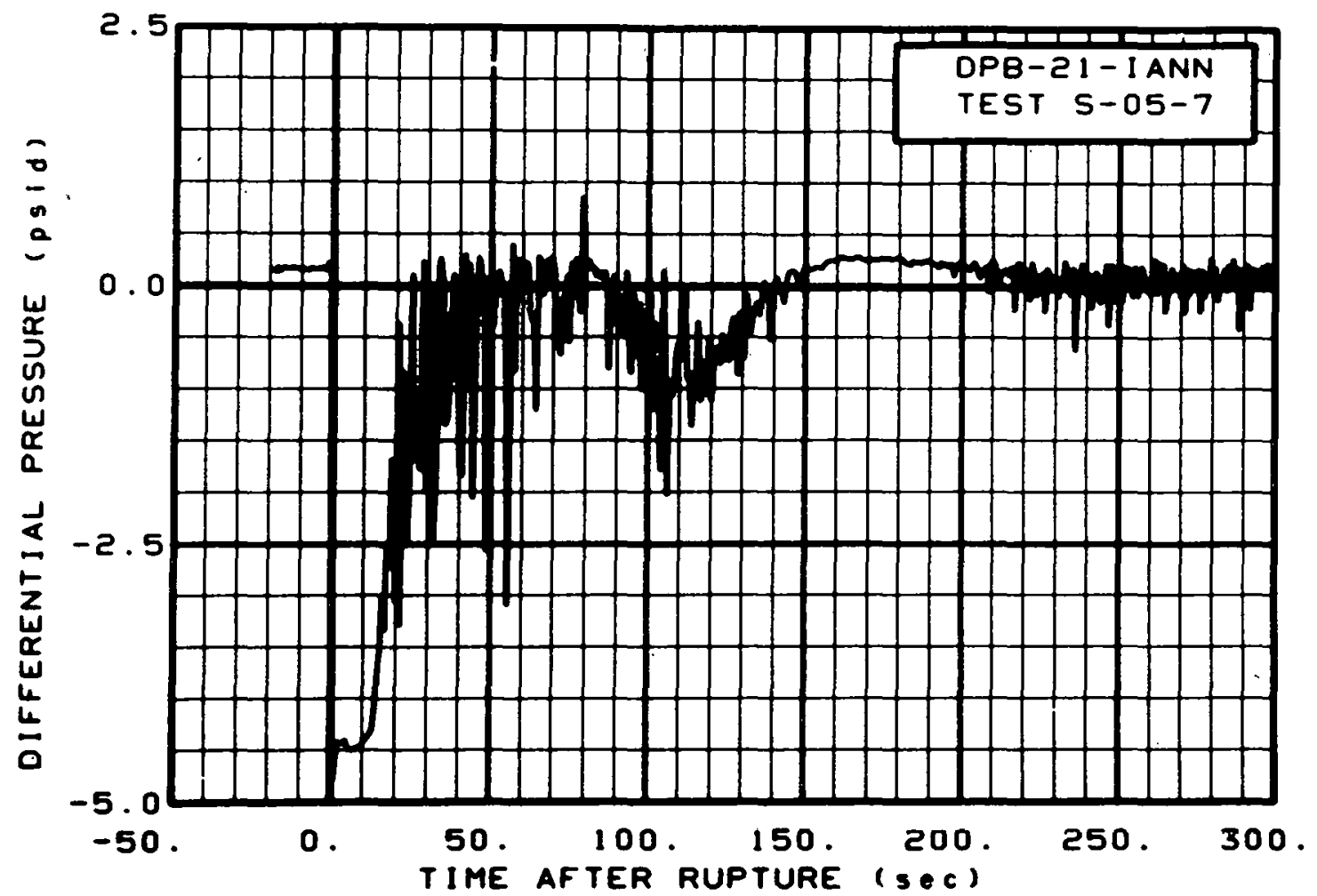

Fig. 314 Differential pressure in broken 1oop, Test S-05-7 (DPB-21-IANN), from -20 to $300 \mathrm{sec}$.

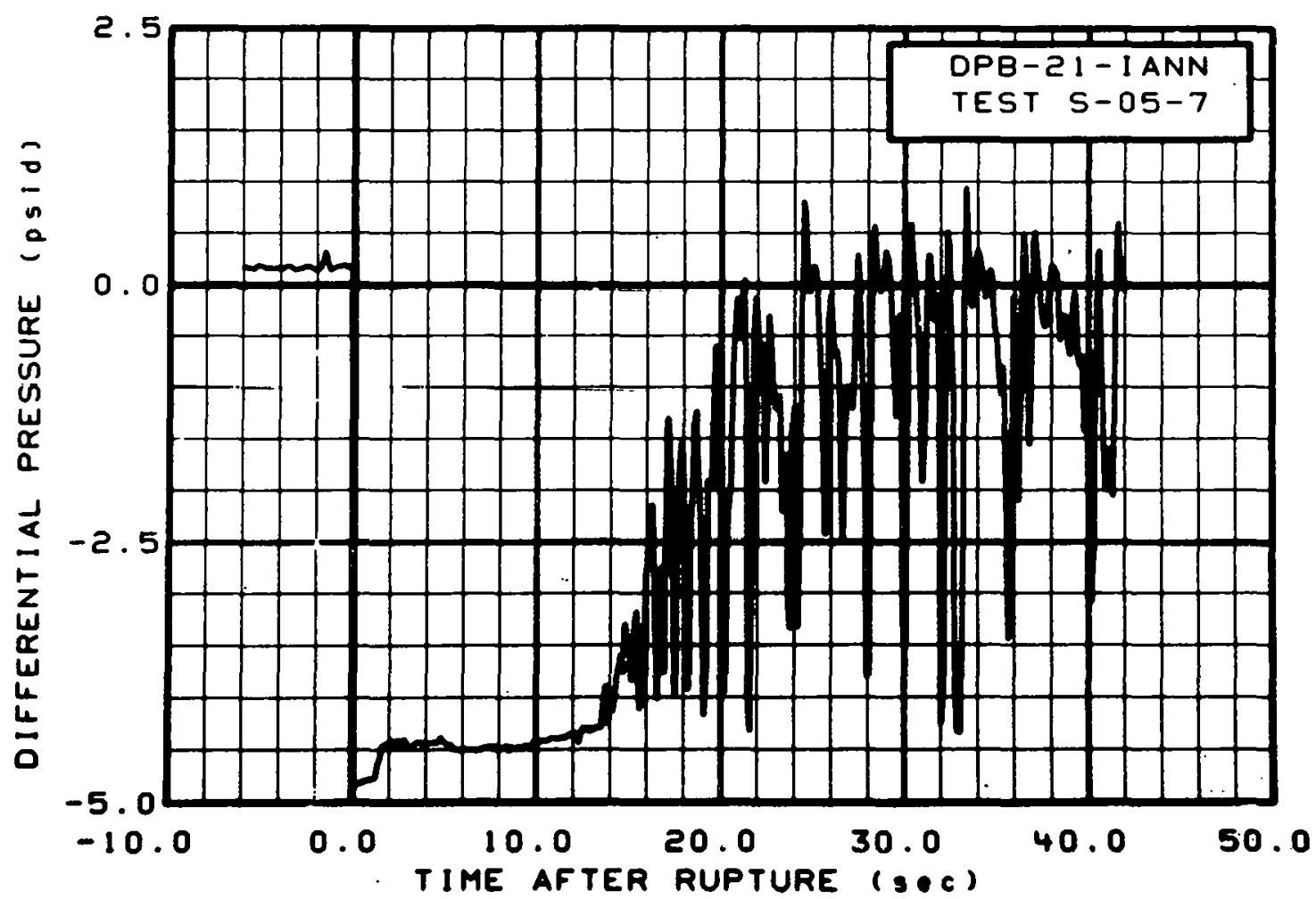

Fig. 315 Differential pressure in broken loop, Test S-05-7 (DPB-21-IANN), from -6 to $42 \mathrm{sec}$. 


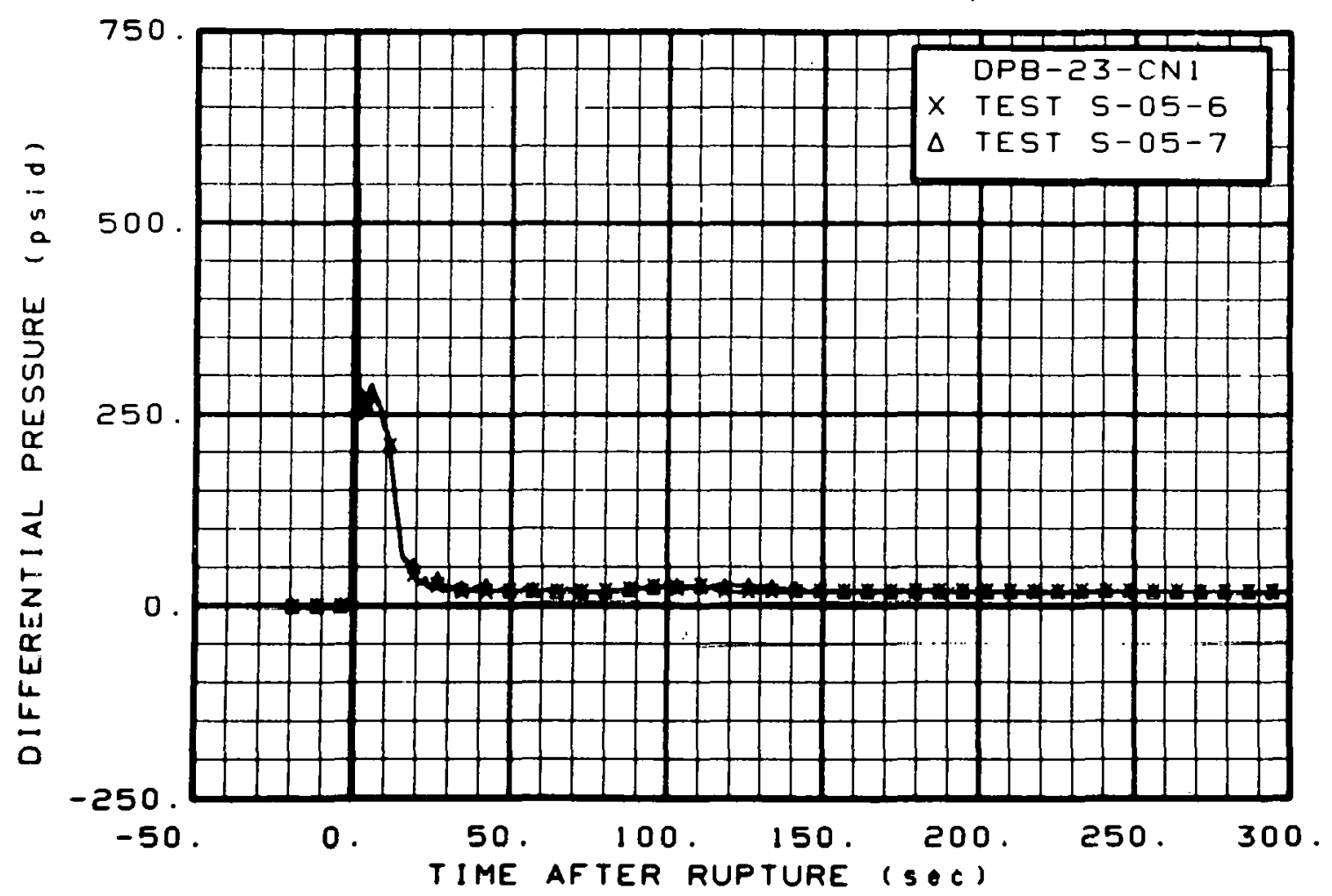

Fig. 316 Differential pressure in broken loop (DPB-23-CN1), from -20 to $300 \mathrm{sec}$.

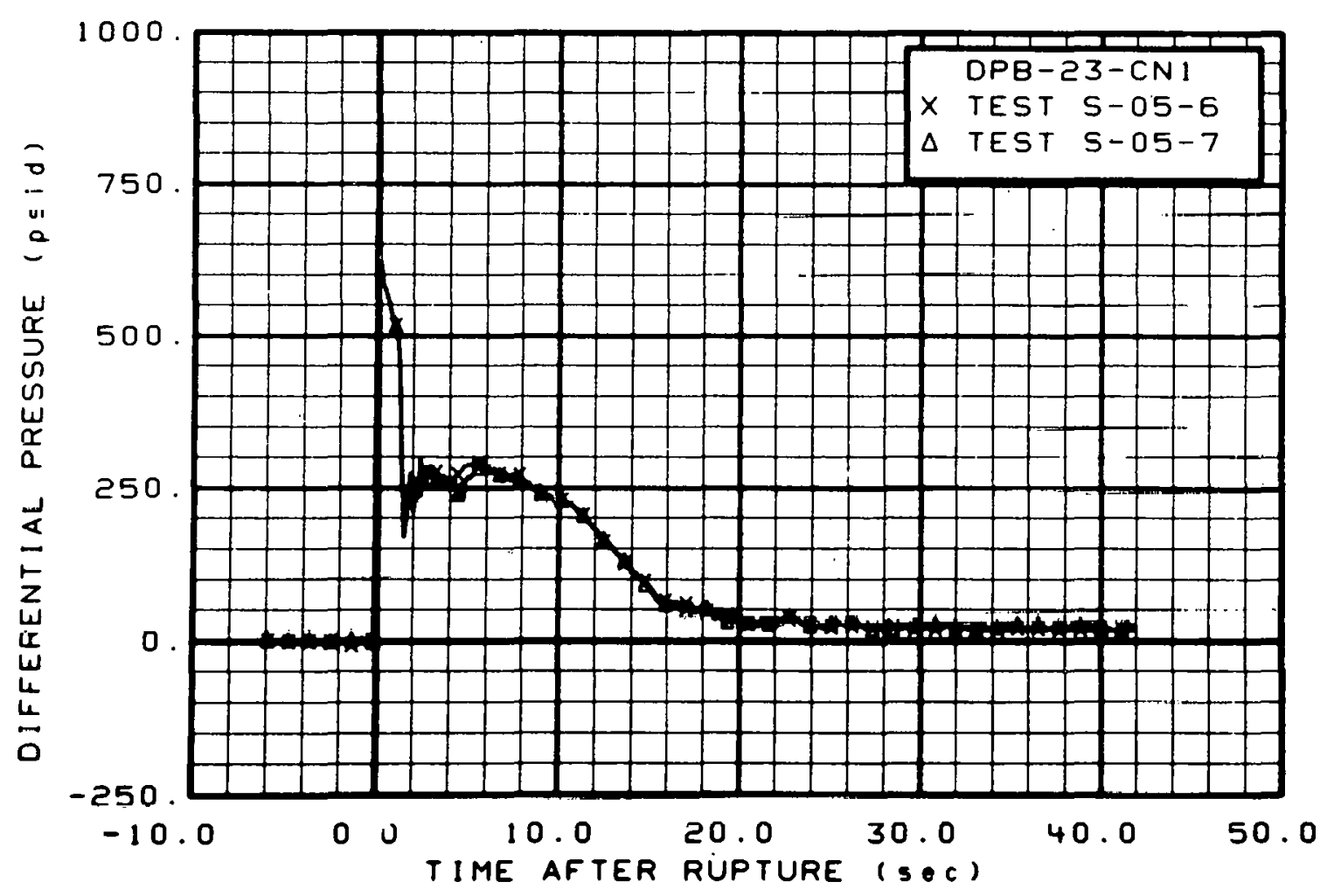

Fig. 317 Differential pressure in broken loop (DPB-23-CN1), from -6 to $42 \mathrm{sec}$. 


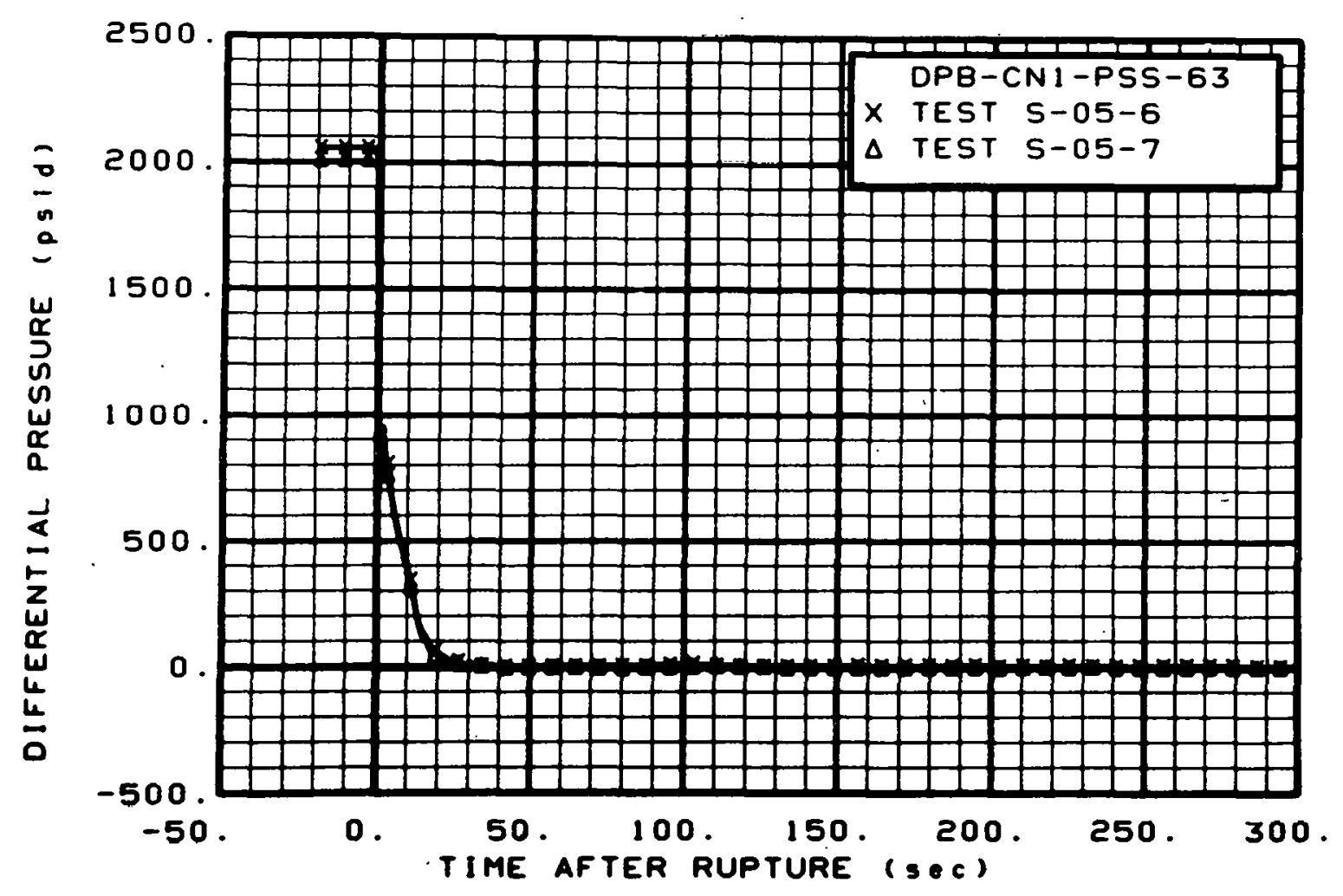

Fig. 318 Differential pressure in broken loop (DPB-CN1-PSS-63), from -20 to $300 \mathrm{sec}$.

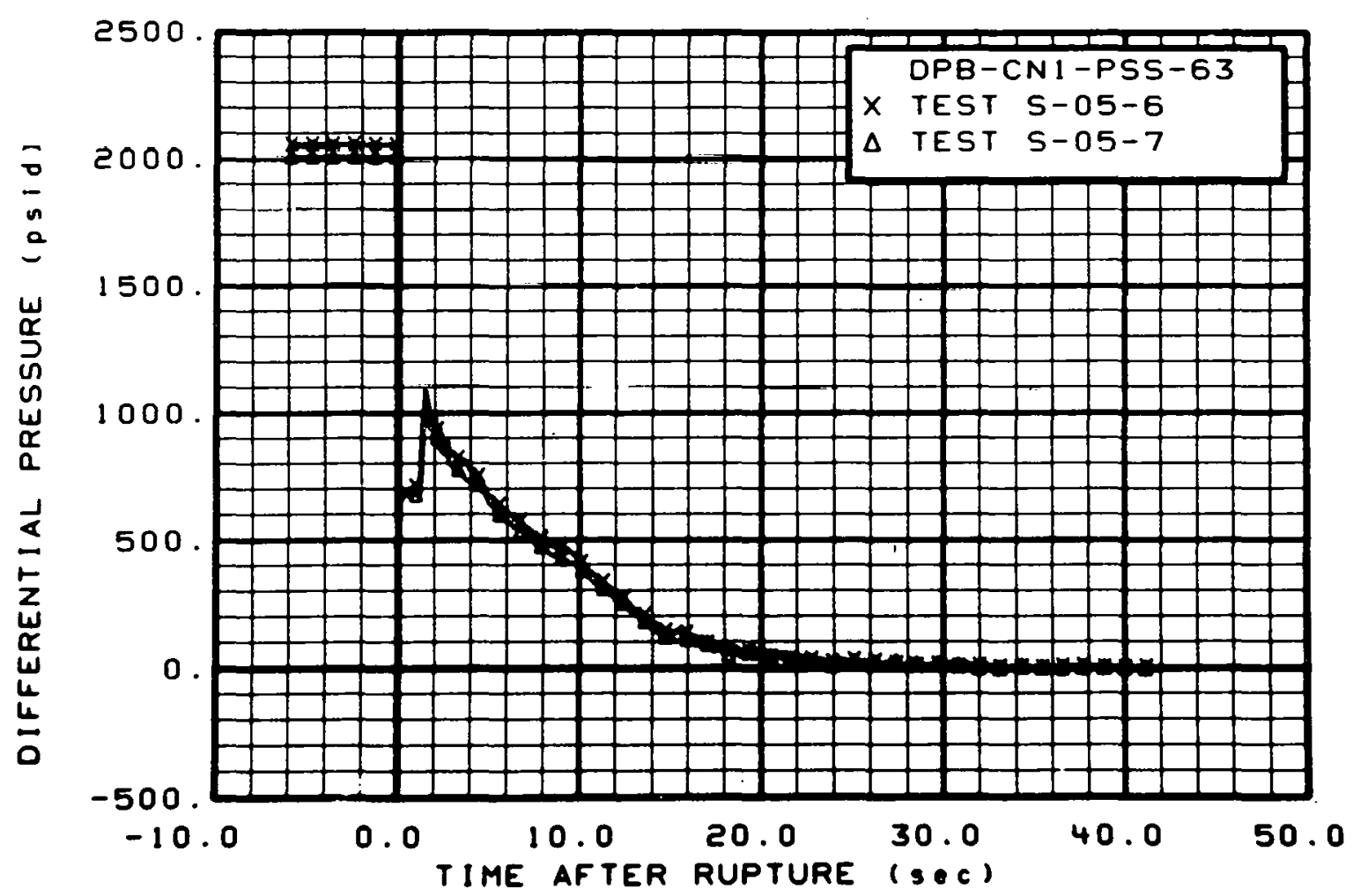

Fig. 319 Differential pressure in broken loop (DPB-CN1-PSS-63), from -6 to $42 \mathrm{sec}$. 


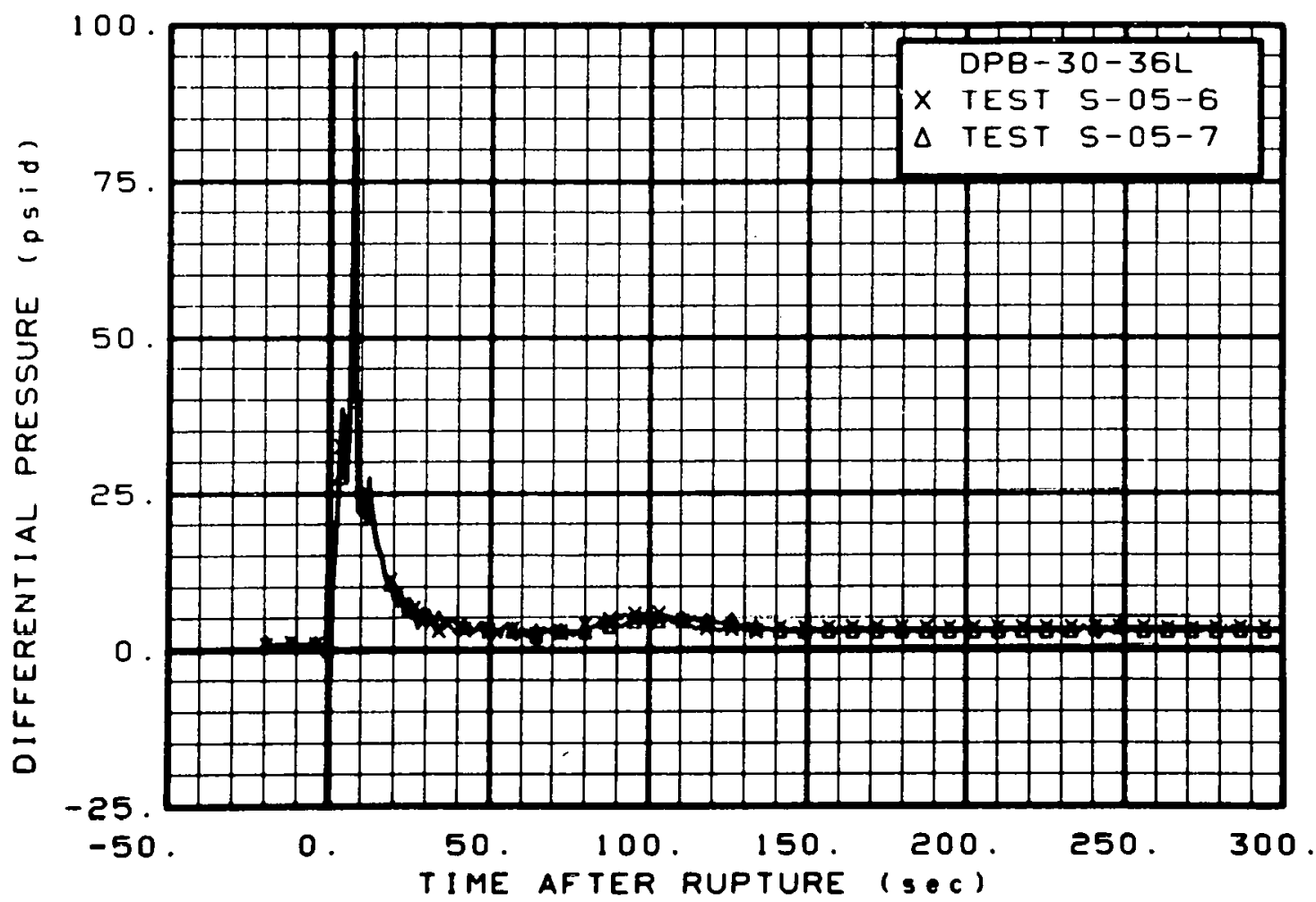

Fig. 320 Differential pressure in broken loop (DPB-30-36L), from -20 to $300 \mathrm{sec}$.

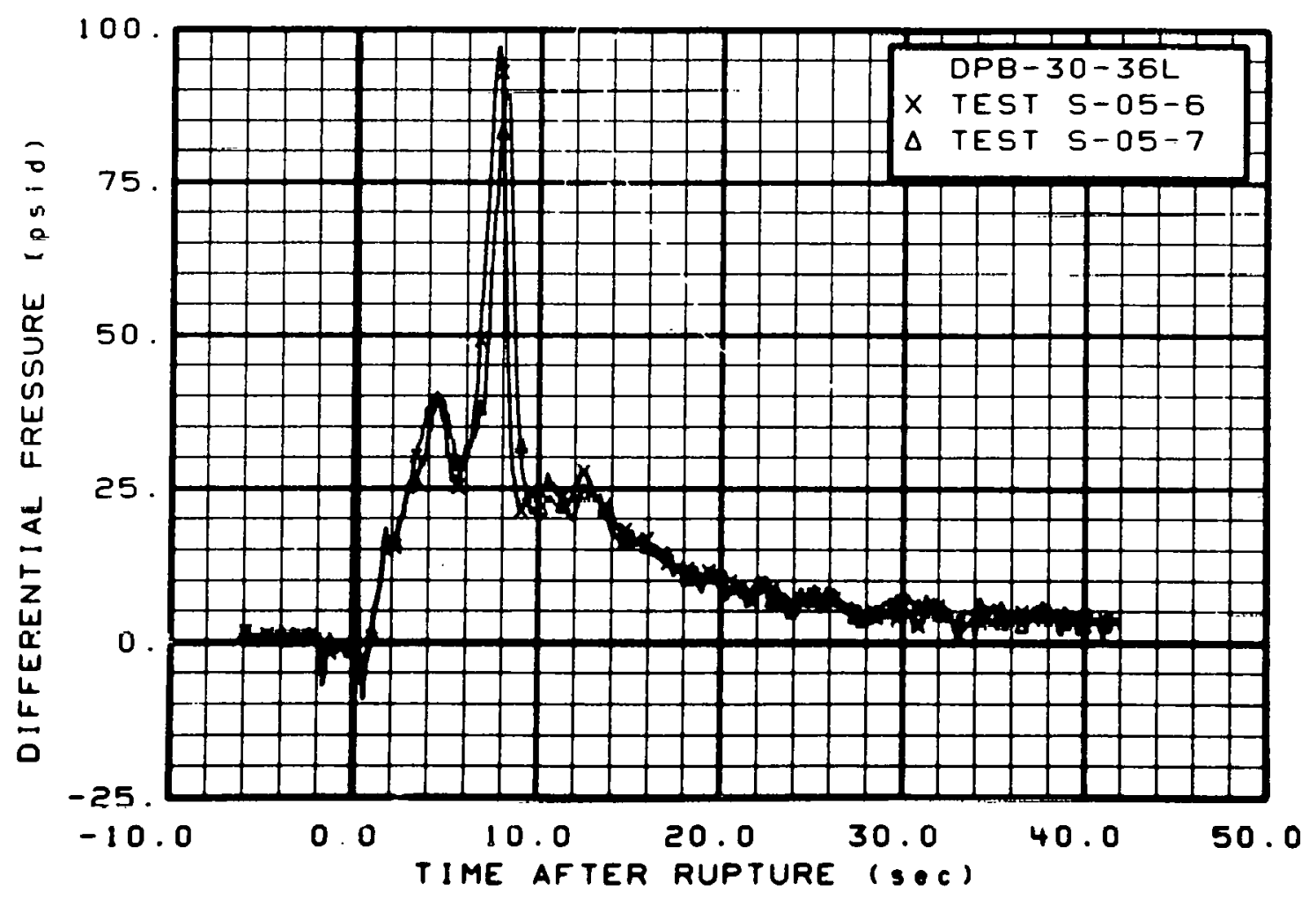

Fig. 321 Differential pressure in broken 10op (DPB-30-36L), from -6 to $42 \mathrm{sec}$. 


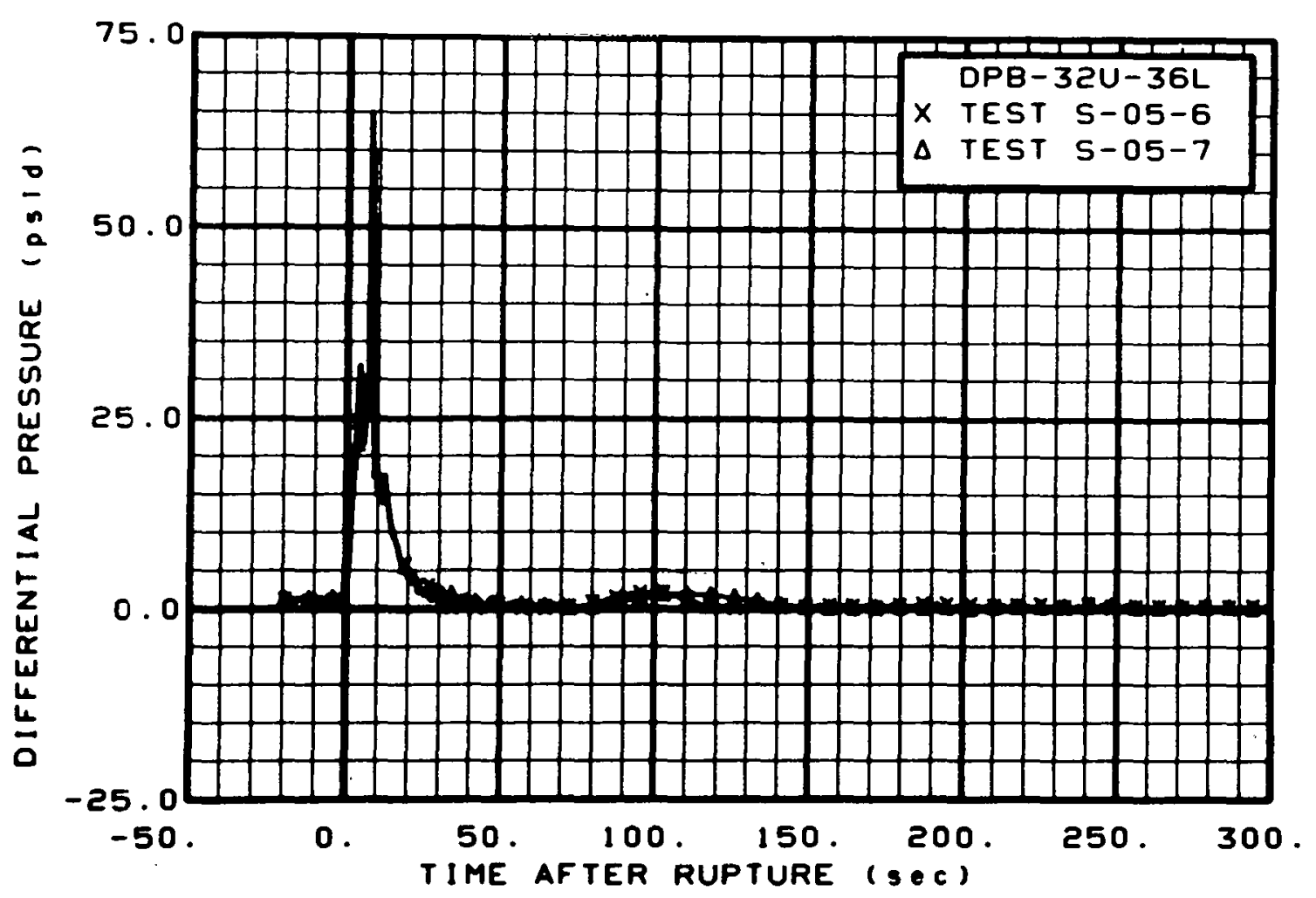

Fig. 322 Differential pressure in broken 10op (DPB-32U-36L), from -20 to $300 \mathrm{sec}$.

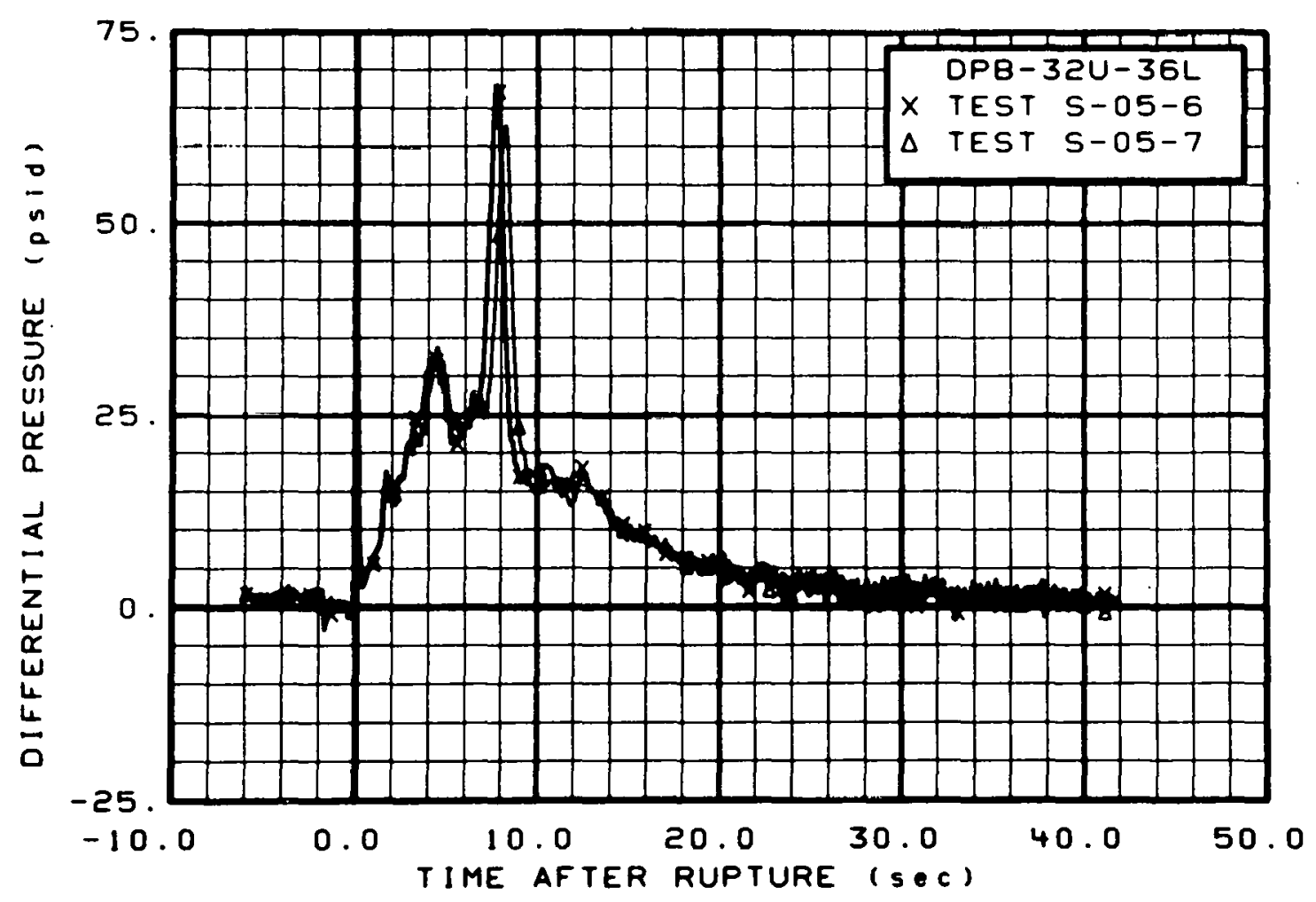

Fig, 323 Differential pressure in broken loop (DPB-32U-36L), from -6 to $42 \mathrm{sec}$. 


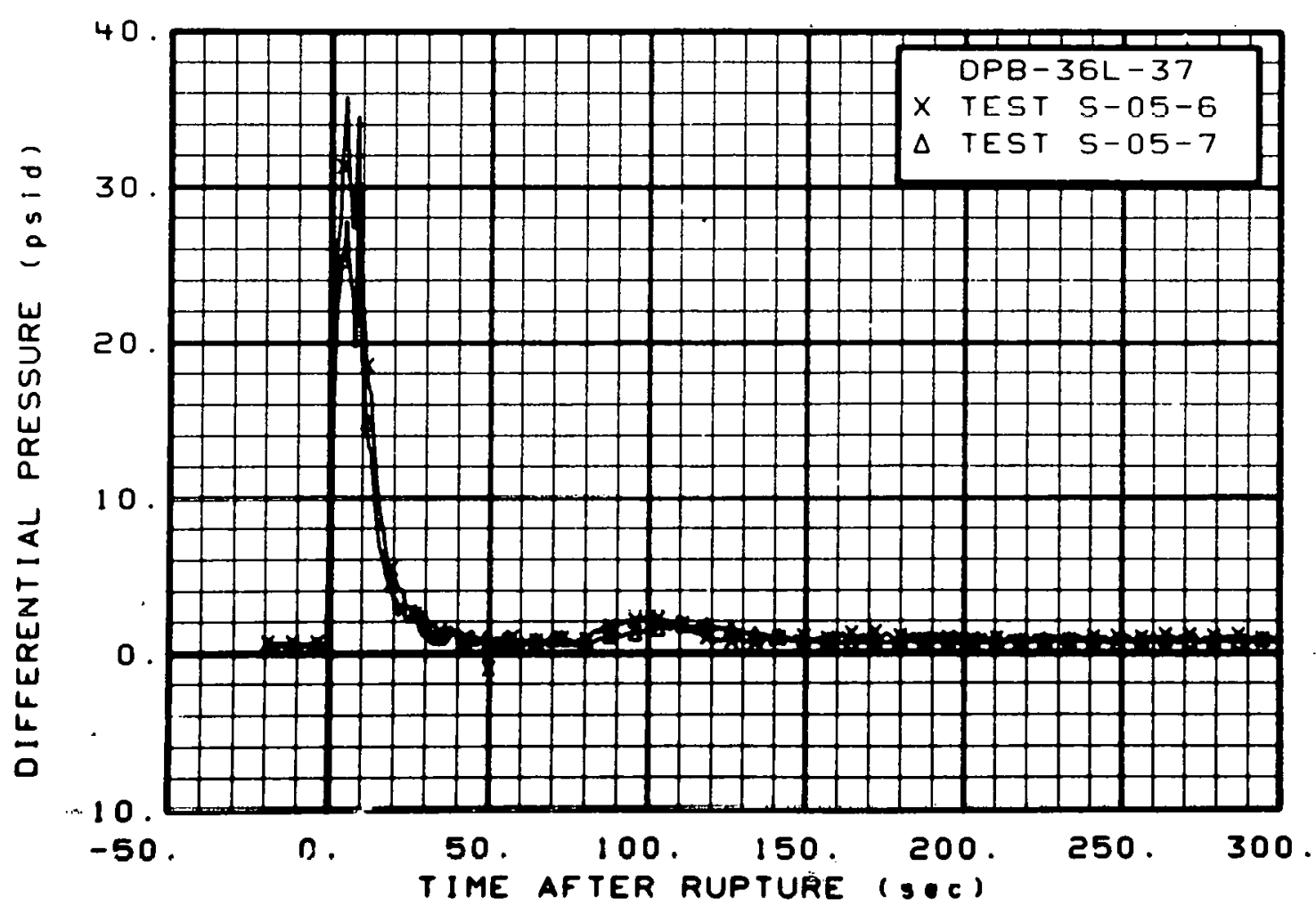

Fig. 324 Differential pressure in broken 10op (DPB-36L-37), from -20 to $300 \mathrm{sec}$.

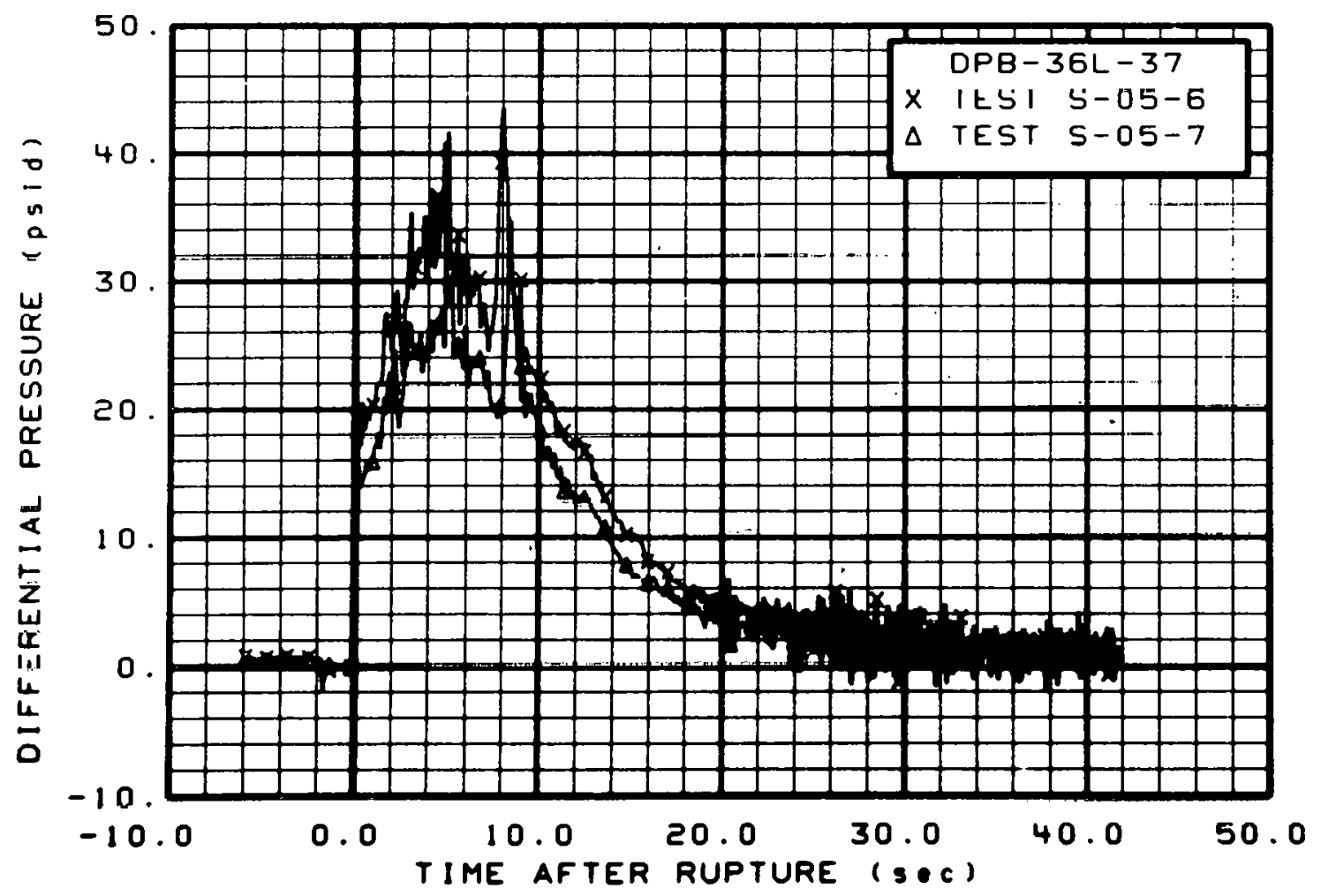

Fig. 325 Differential pressure in broken loop (DPB-36L-37), from -6 to $42 \mathrm{sec}$. 


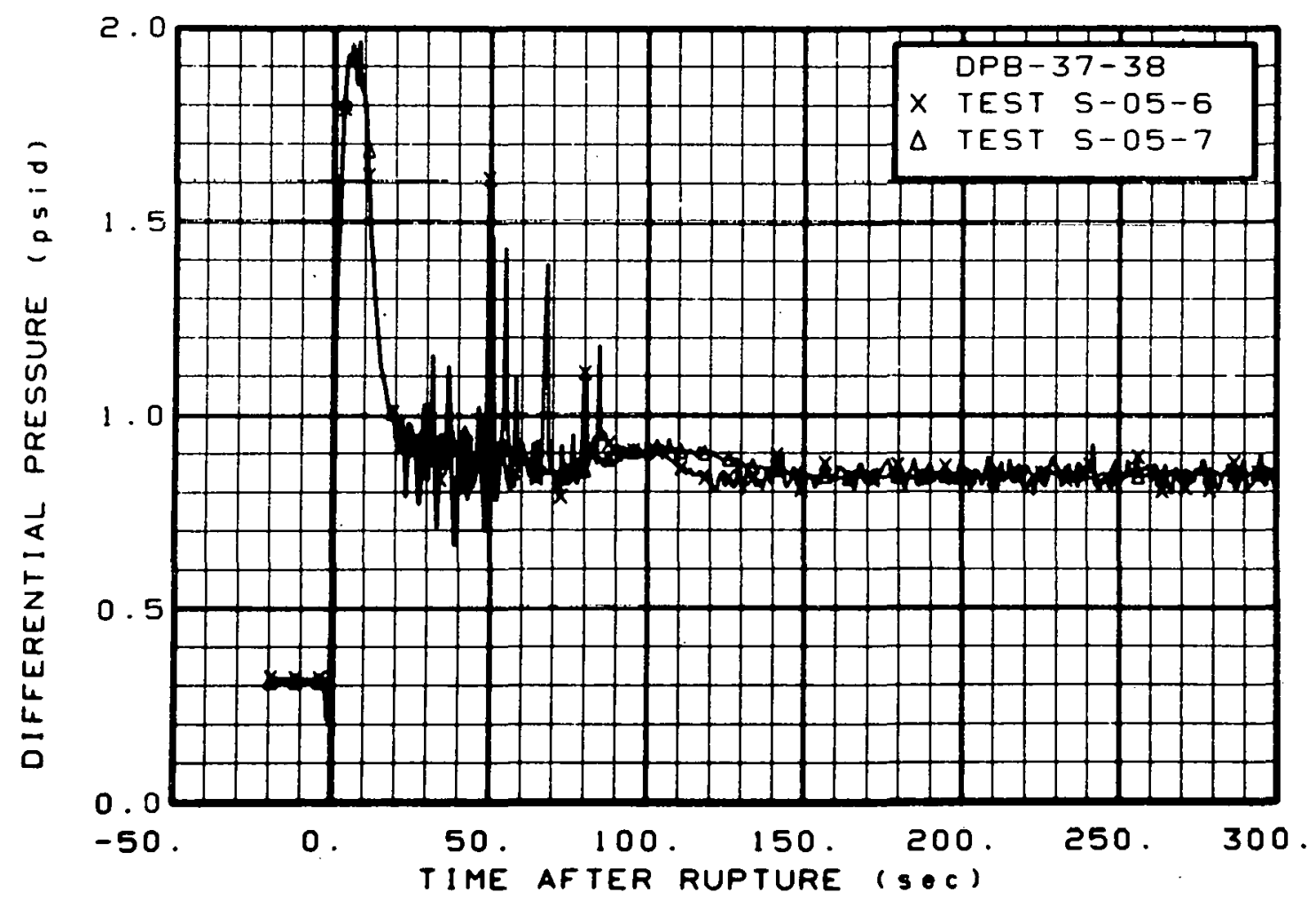

Fig. 326 Differential pressure in broken loop (DPB-37-38), from -20 to 300 sec.

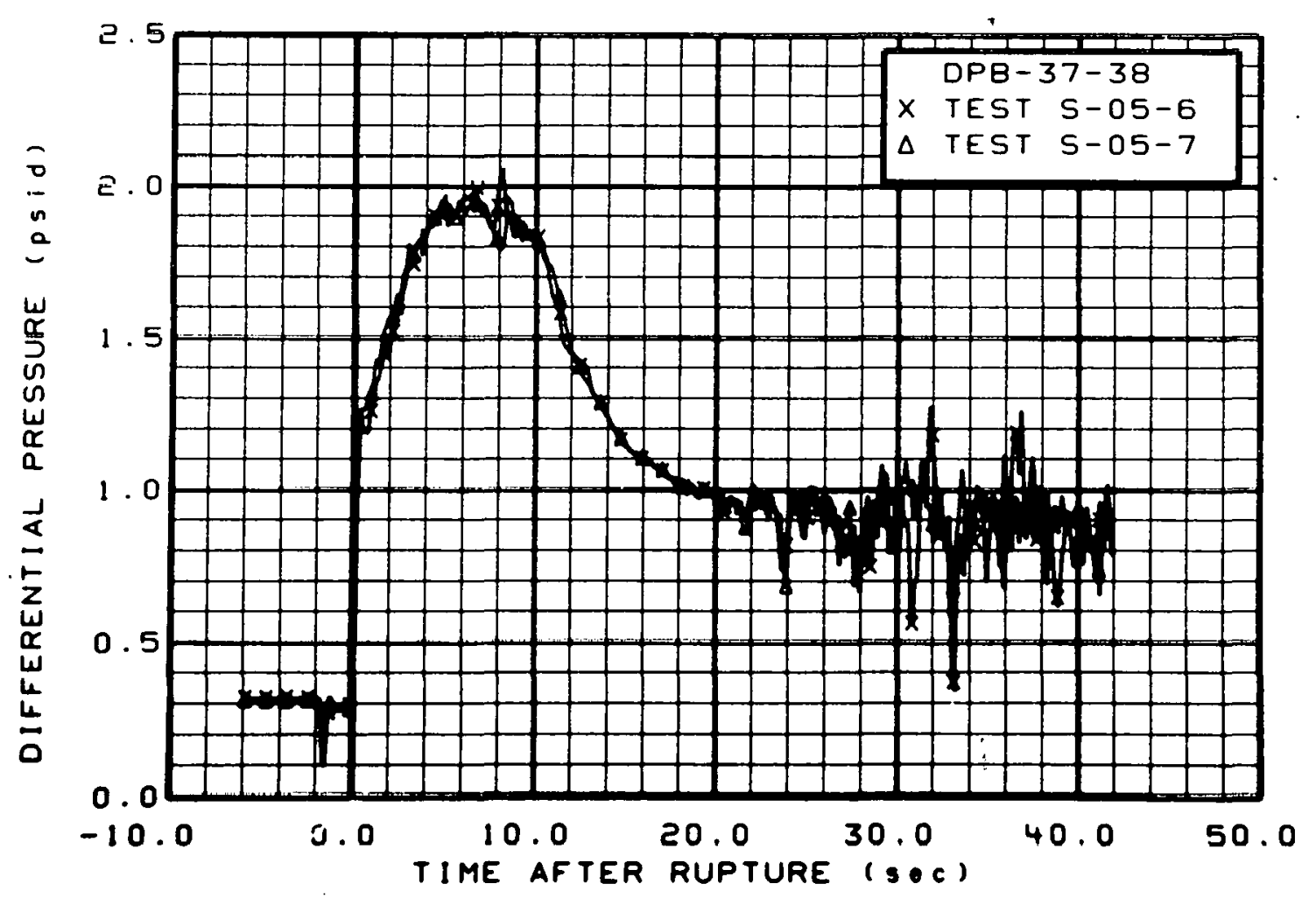

Fig. 327 Differential pressure in broken loop (DPB-37-38), from -6 to $42 \mathrm{sec}$. 


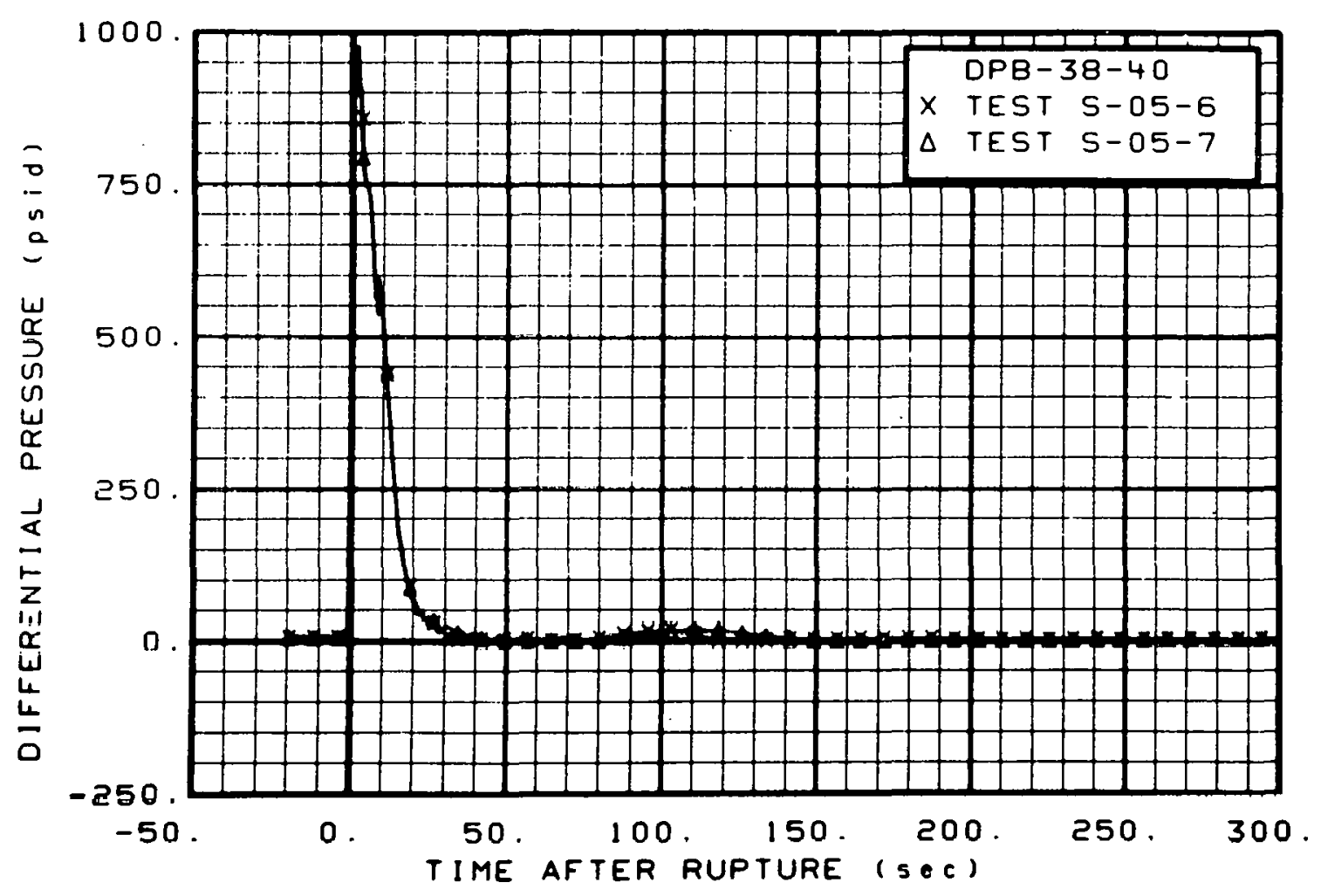

Fig. 328 Differential pressure in broken loop (DPB-38-40), from -20 to $300 \mathrm{sec}$.

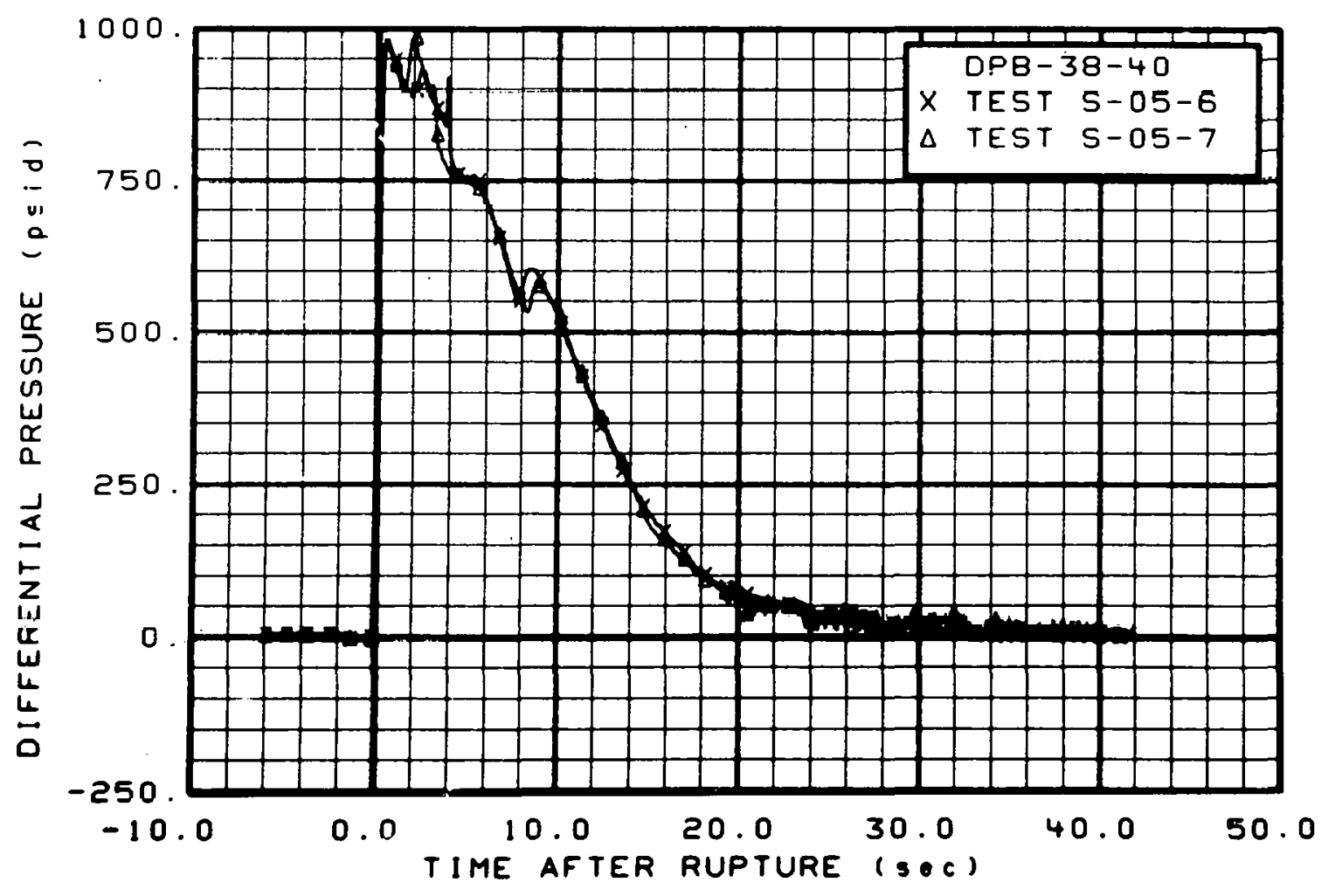

Fig. 329 Differential pressure in broken 1oop (DPB-38-40), from -6 to $42 \mathrm{sec}$. 


\section{THIS PAGE \\ WAS INTENTIONALLY \\ LEFT BLANK}




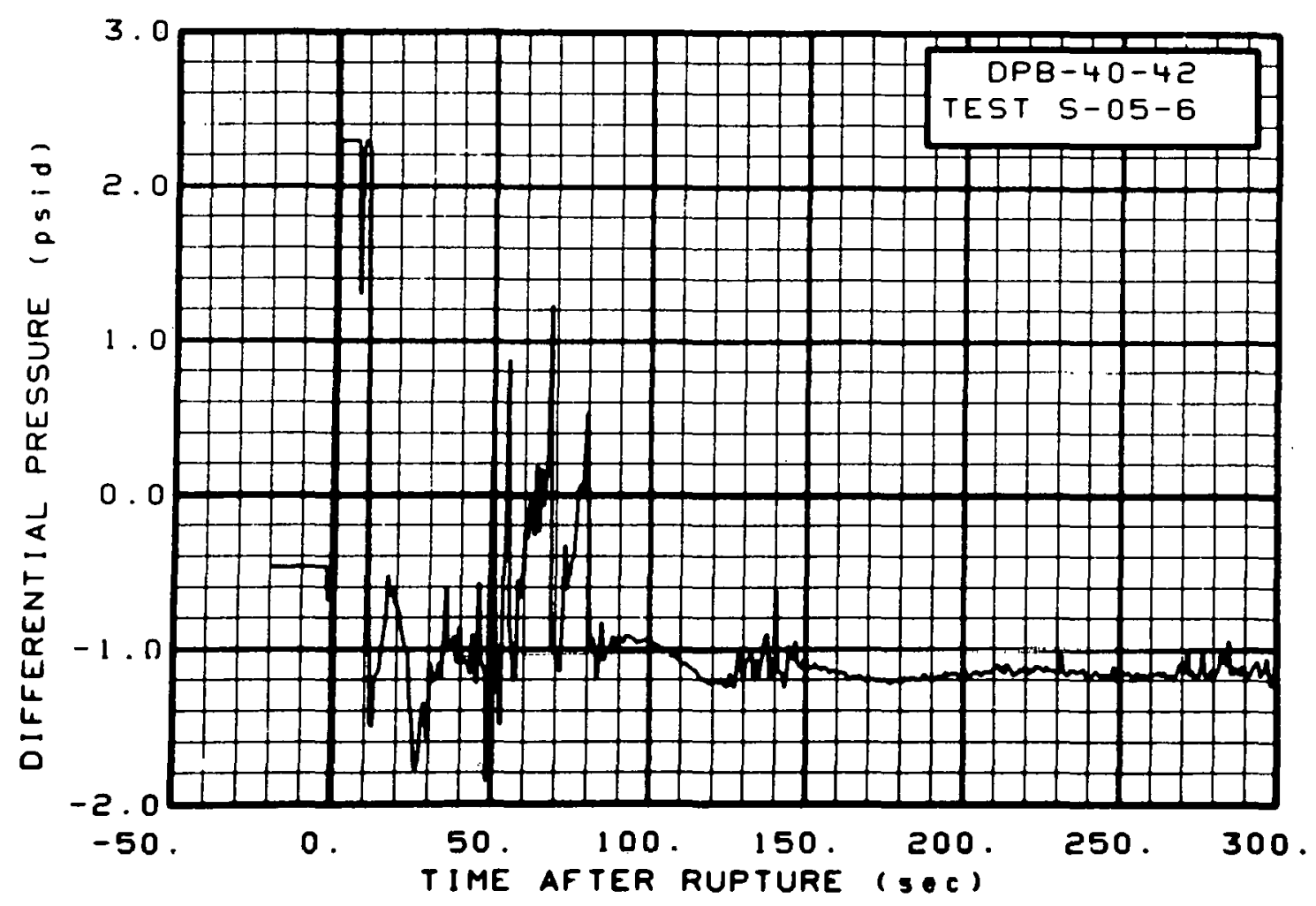

Fig. 330 Differential pressure in broken loop, Test S-05-6 (DPB-40-42), from -20 to $300 \mathrm{sec}$.

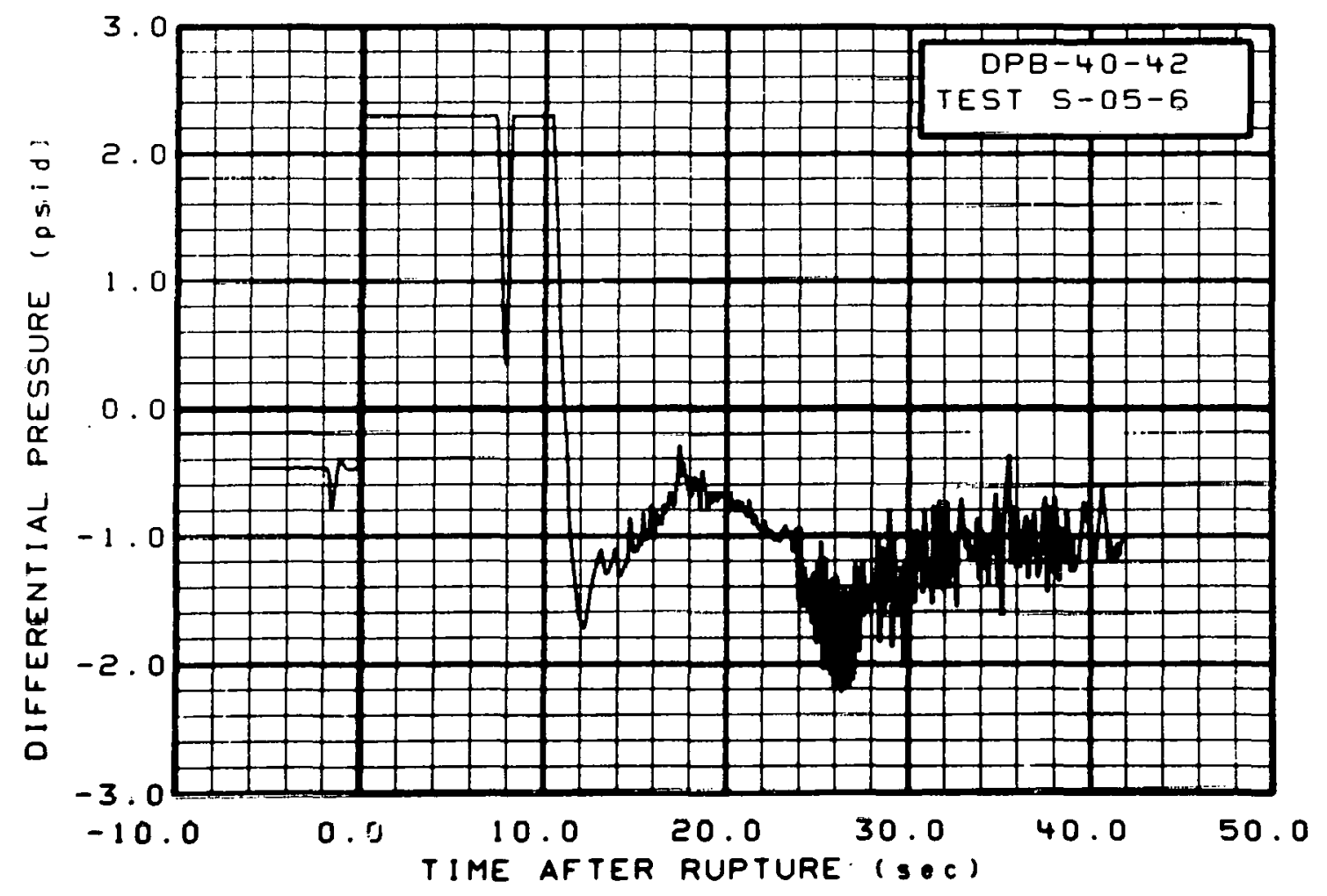

Fig. 331 Differential pressure in broken loop, Test S-05-6 (DPB-40-42), from -6 to $42 \mathrm{sec}$. 


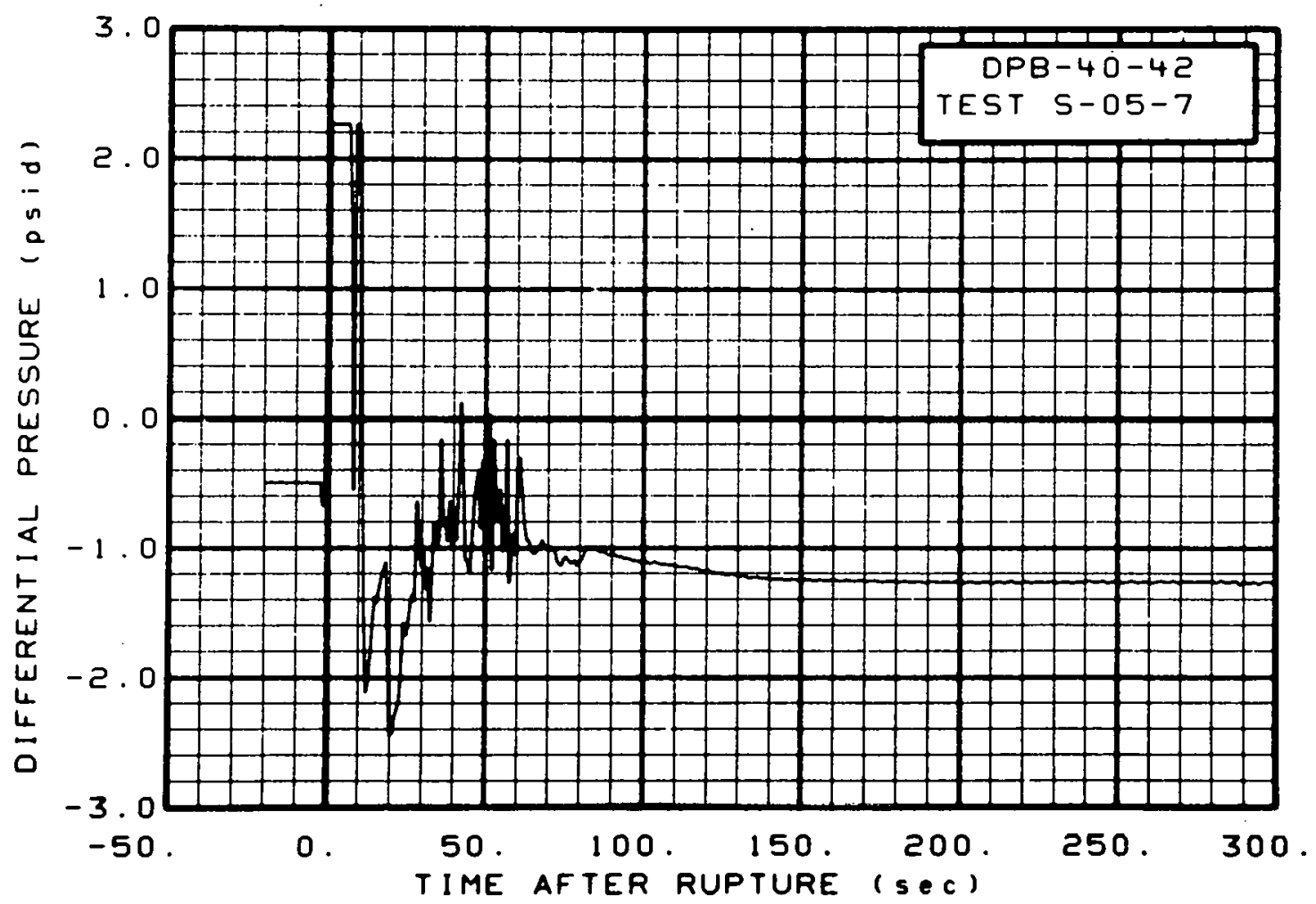

Fig. 332 Differential pressure in broken loop, Test S-05-7 (DPB-40-42), from -20 to $300 \mathrm{sec}$.

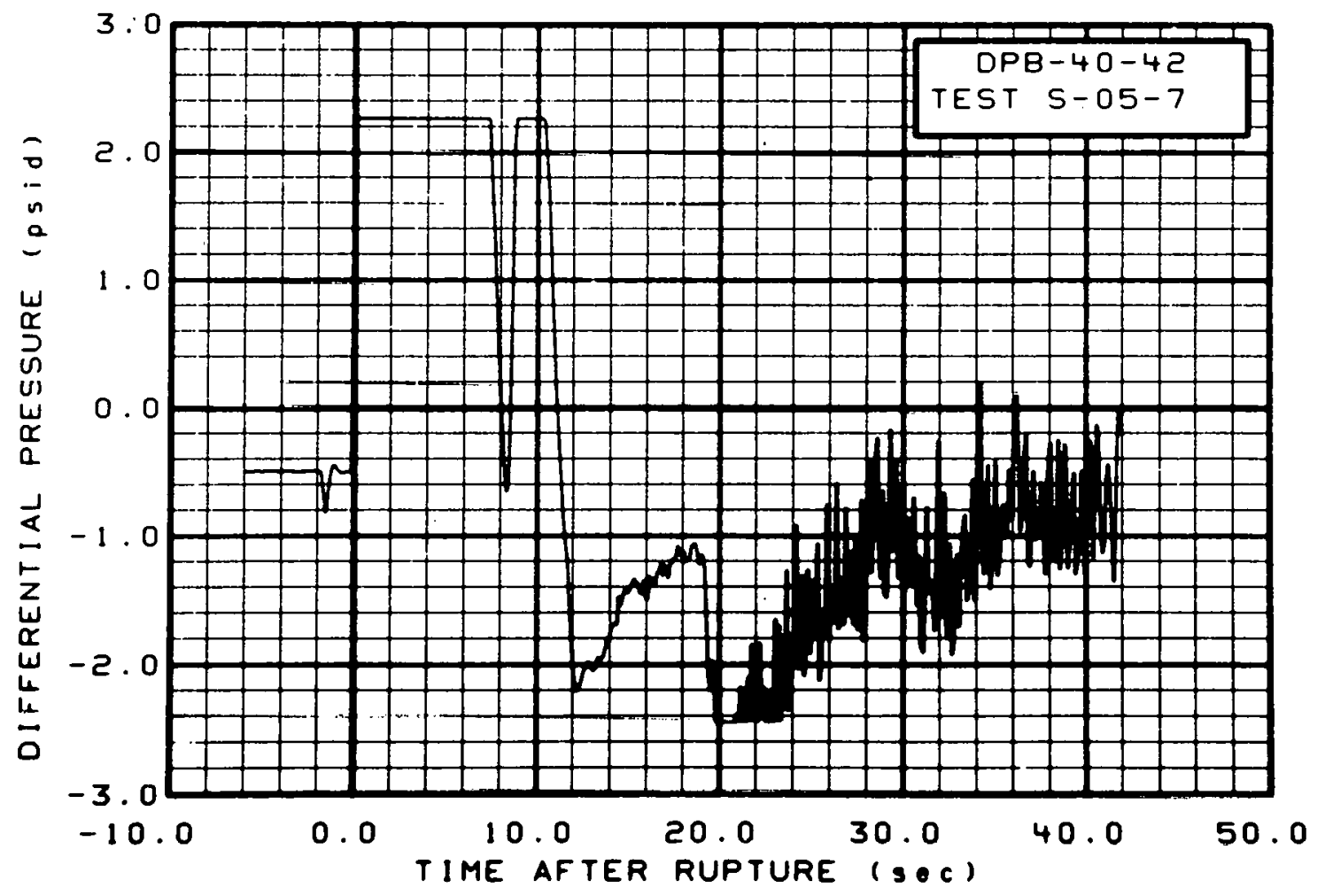

Fig. 333 Differential pressure in broken 1oop, Test S-05-7 (DPB-40-42), rioin $-G$ to 42 sec. 


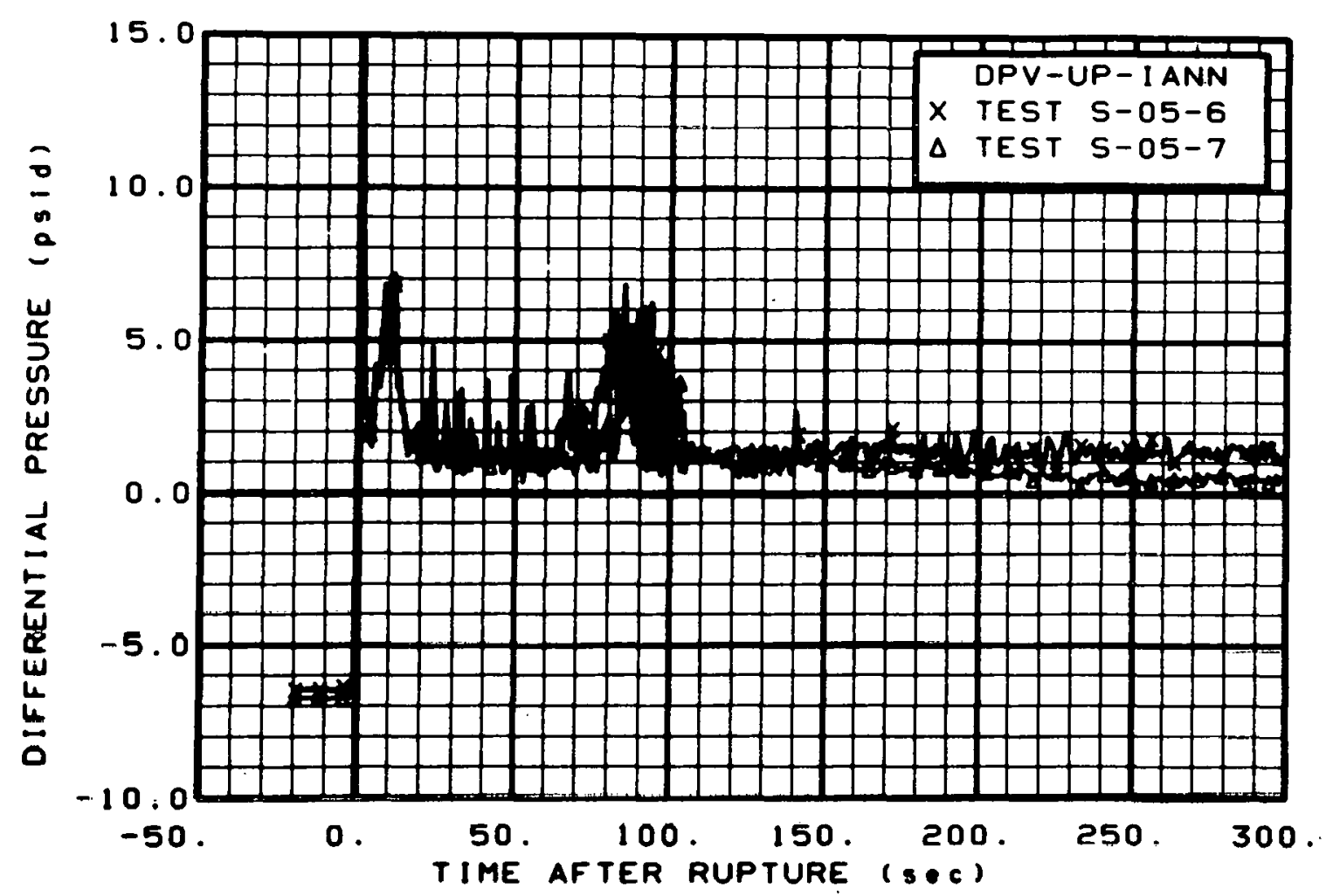

Fig. 334 Differential pressure in vessel (DPV-UP-IANN), from -20 to $300 \mathrm{sec}$.

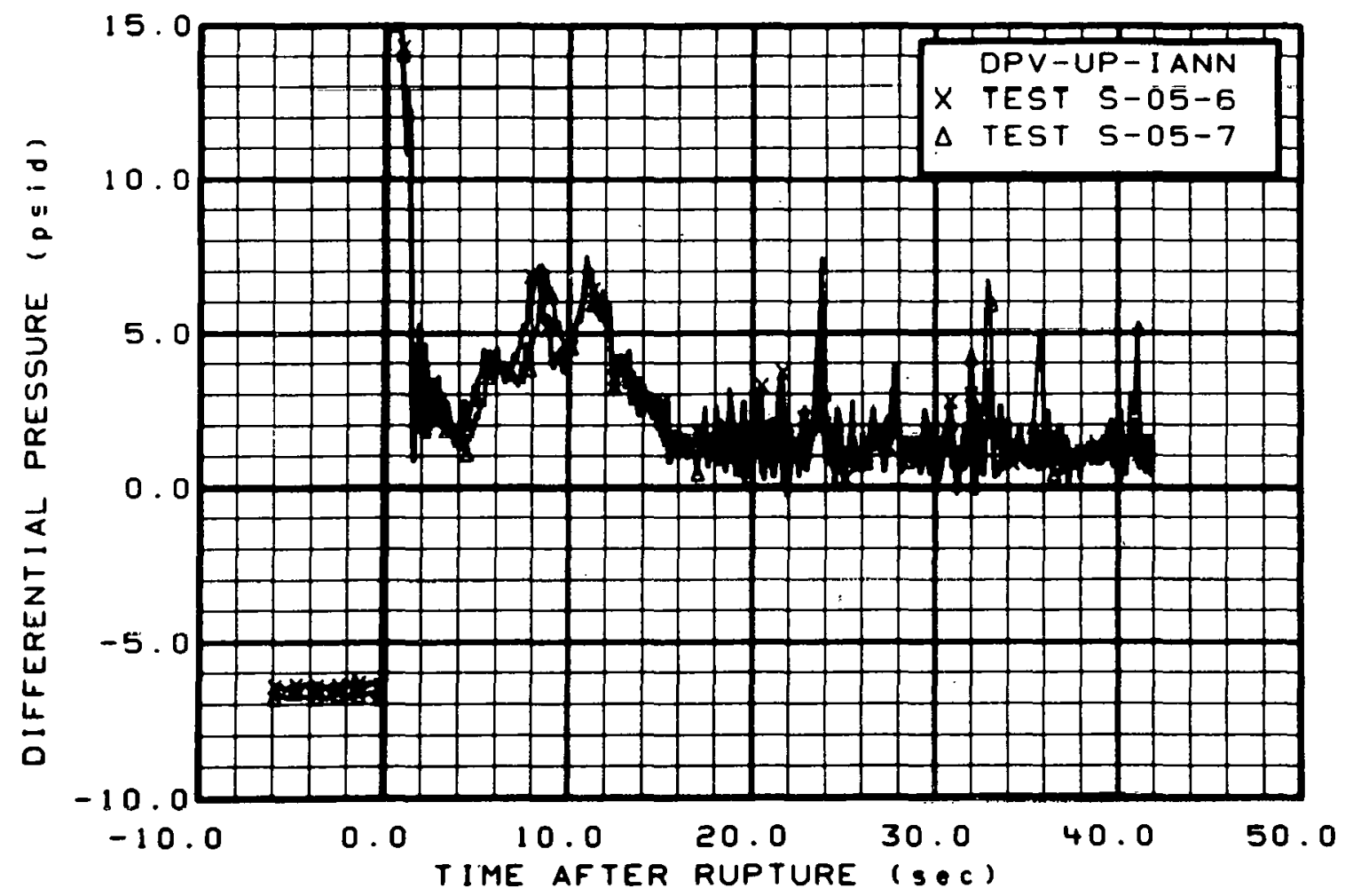

Fig. 335 Differential pressure in vesse1 (DPV-UP-IANN), from -6 to $42 \mathrm{sec}$. 


\section{THIS PAGE}

\section{WAS INTENTIONALLY LEFT BLANK}




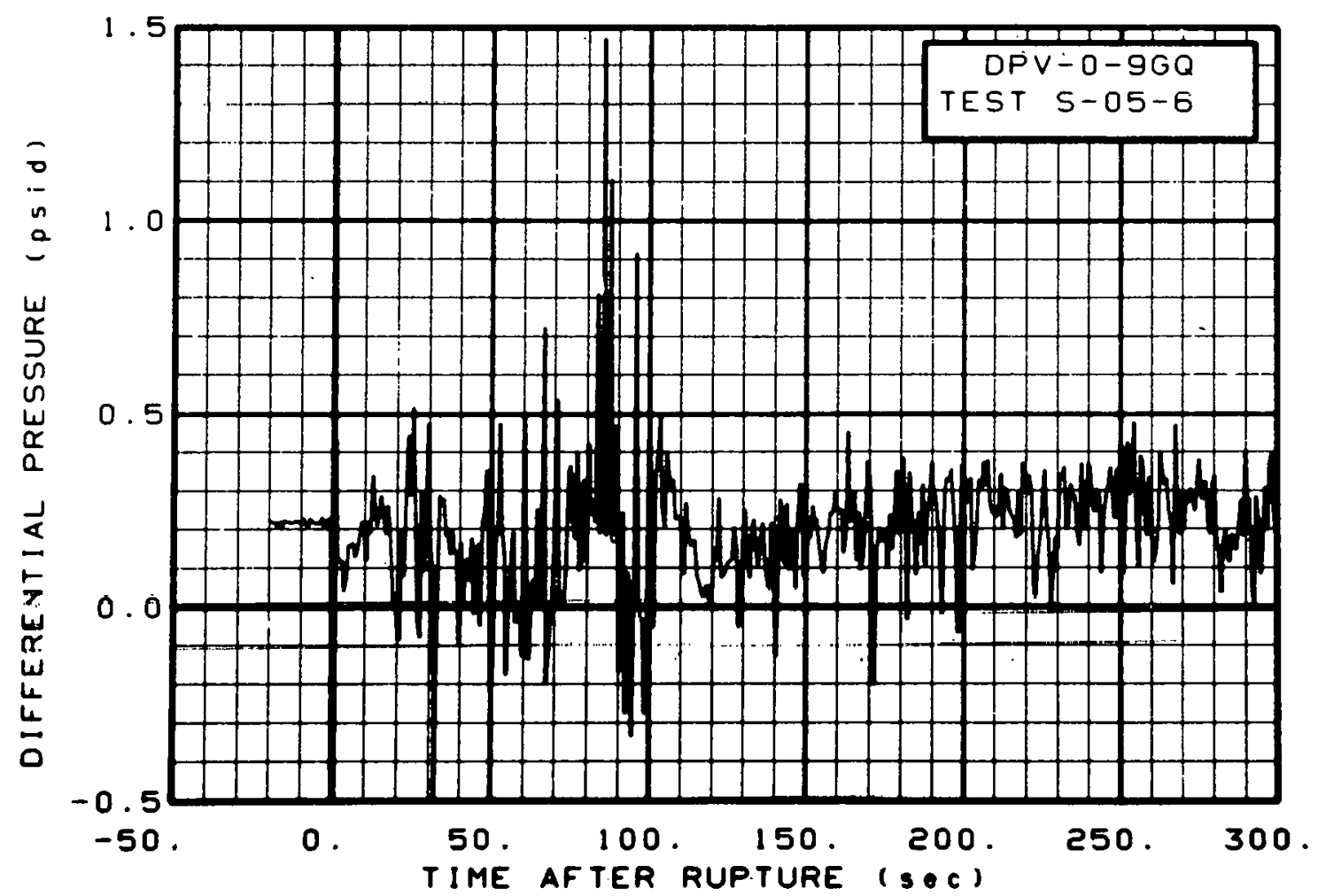

Fig. 336 Differential pressure in vessel, Test S-05-6 (DPV-0-9GQ), from -20 to $300 \mathrm{sec}$.

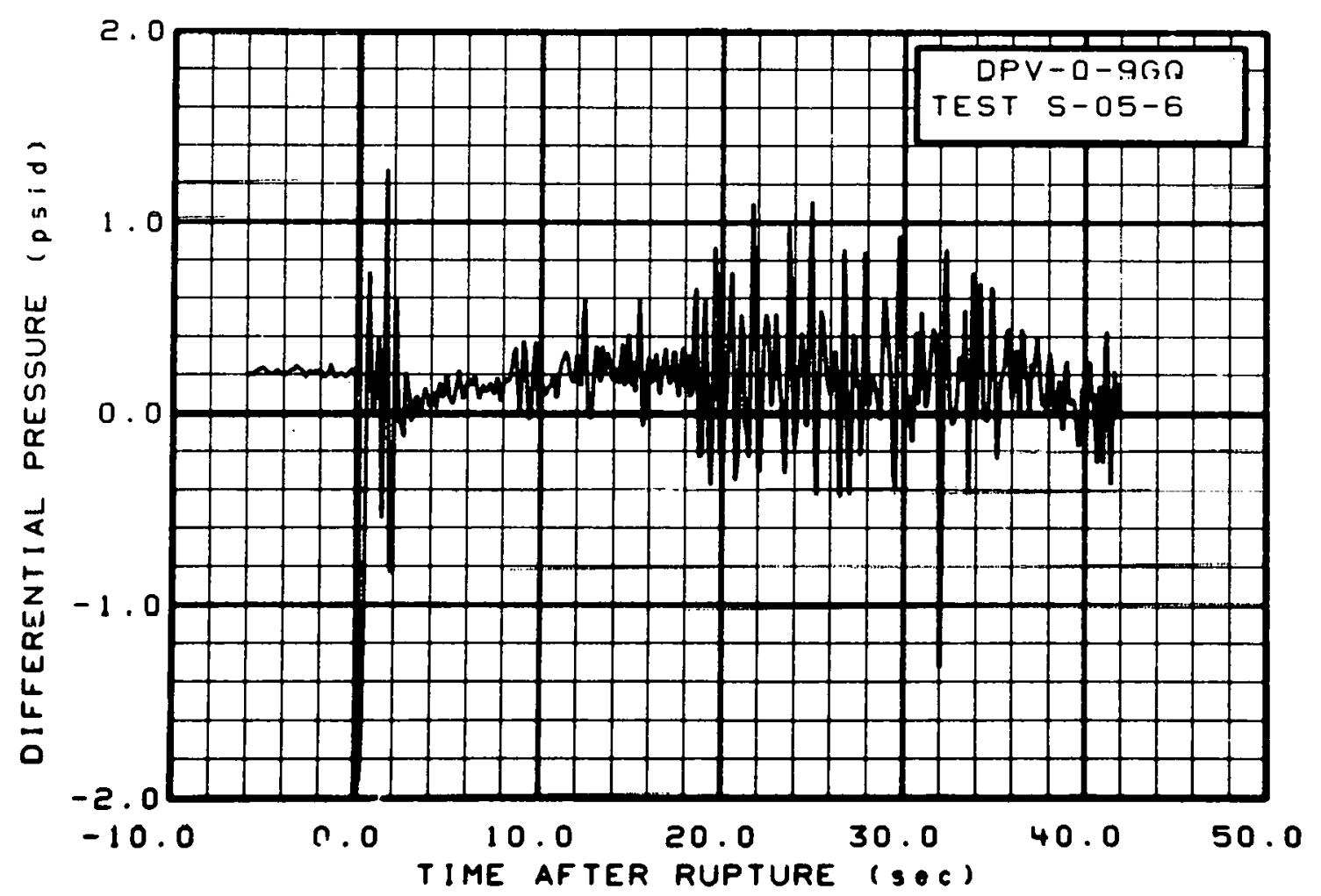

Fig. 337 Differential pressure in vessel, Test S-05-6 (DPV-0-9GQ), from -6 to $42 \mathrm{sec}$. 


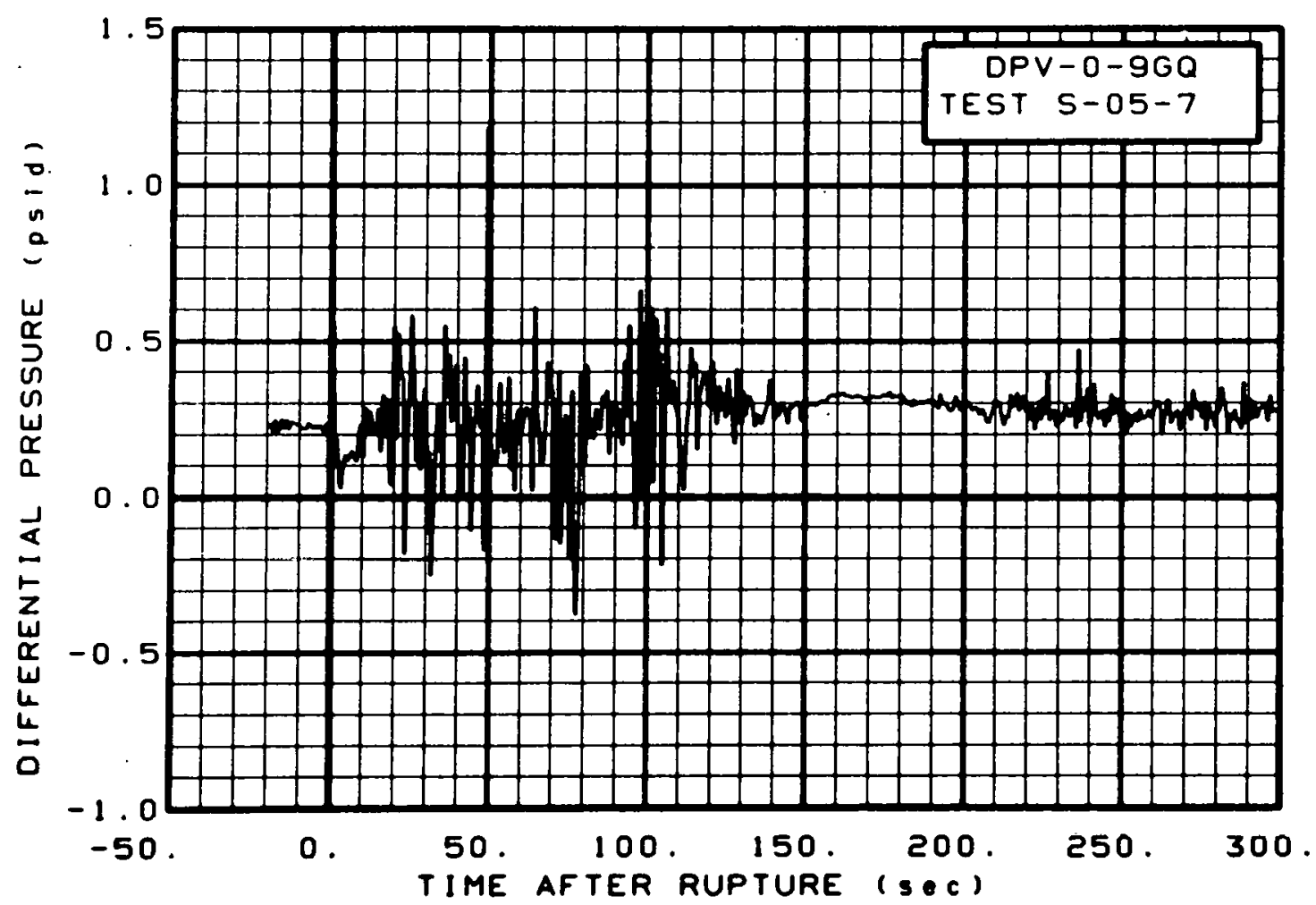

Fig. 338 Differential pressure in vessel, Test S-05-7 (DPV-0-9GQ), from -20 to 300 sec.

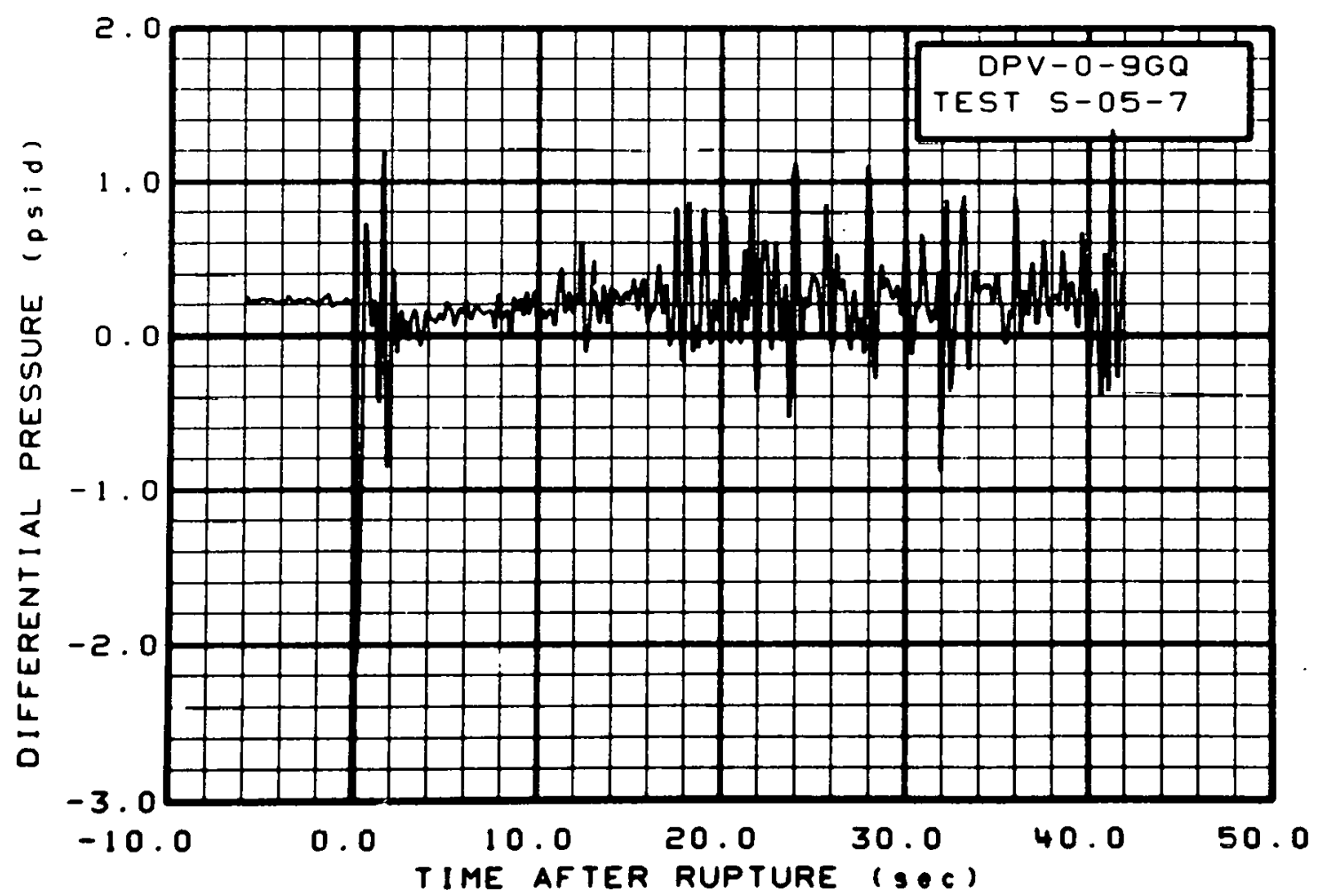

Fig. 339 Differential pressure in vessel, Test S-05-7 (DPV-0-9GQ), from -6 to $42 \mathrm{sec}$. 


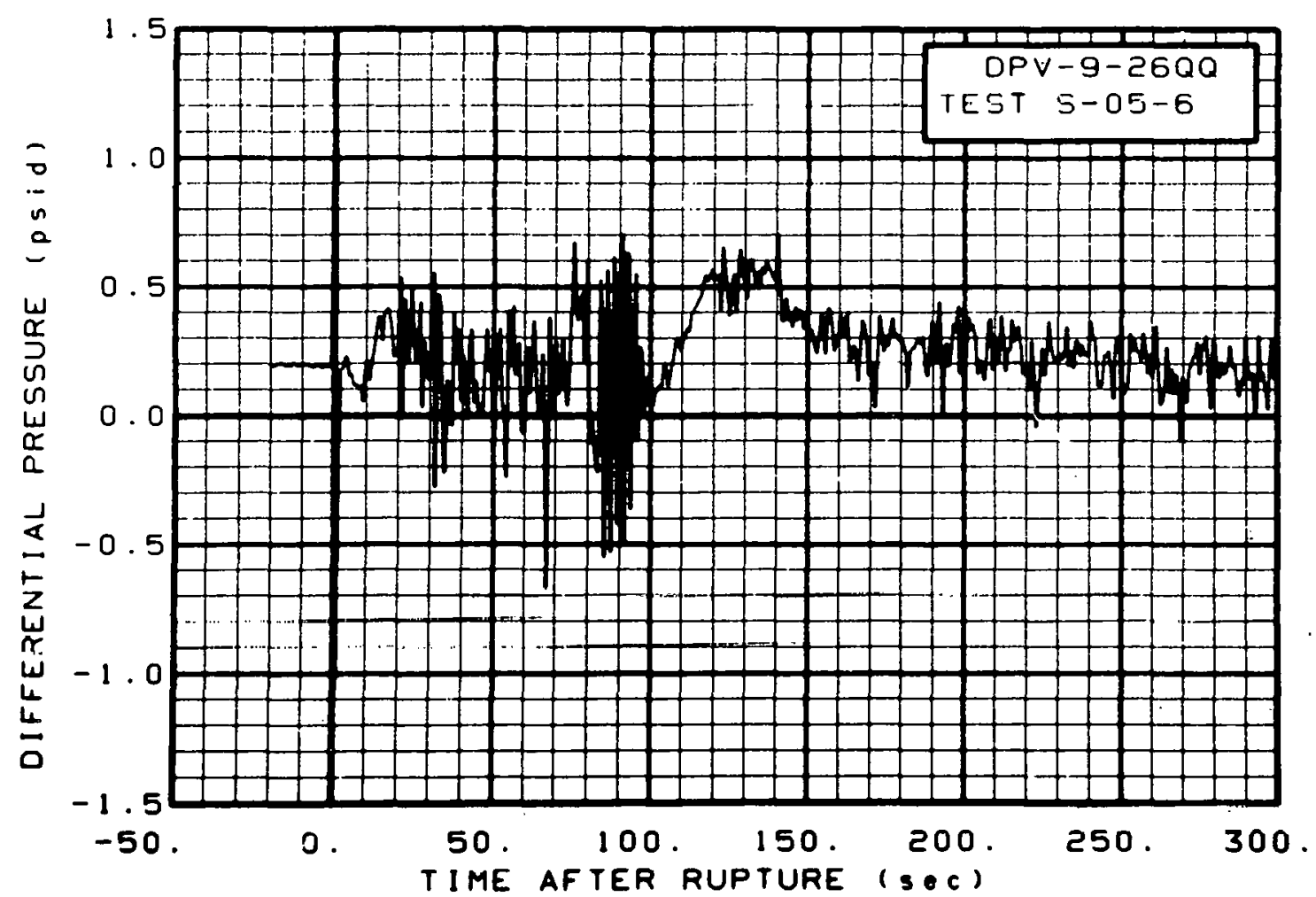

Fig. 340 Differential pressure in vessel, Test S-05-6 (DPV-9-26QQ), from -20 to $300 \mathrm{sec}$.

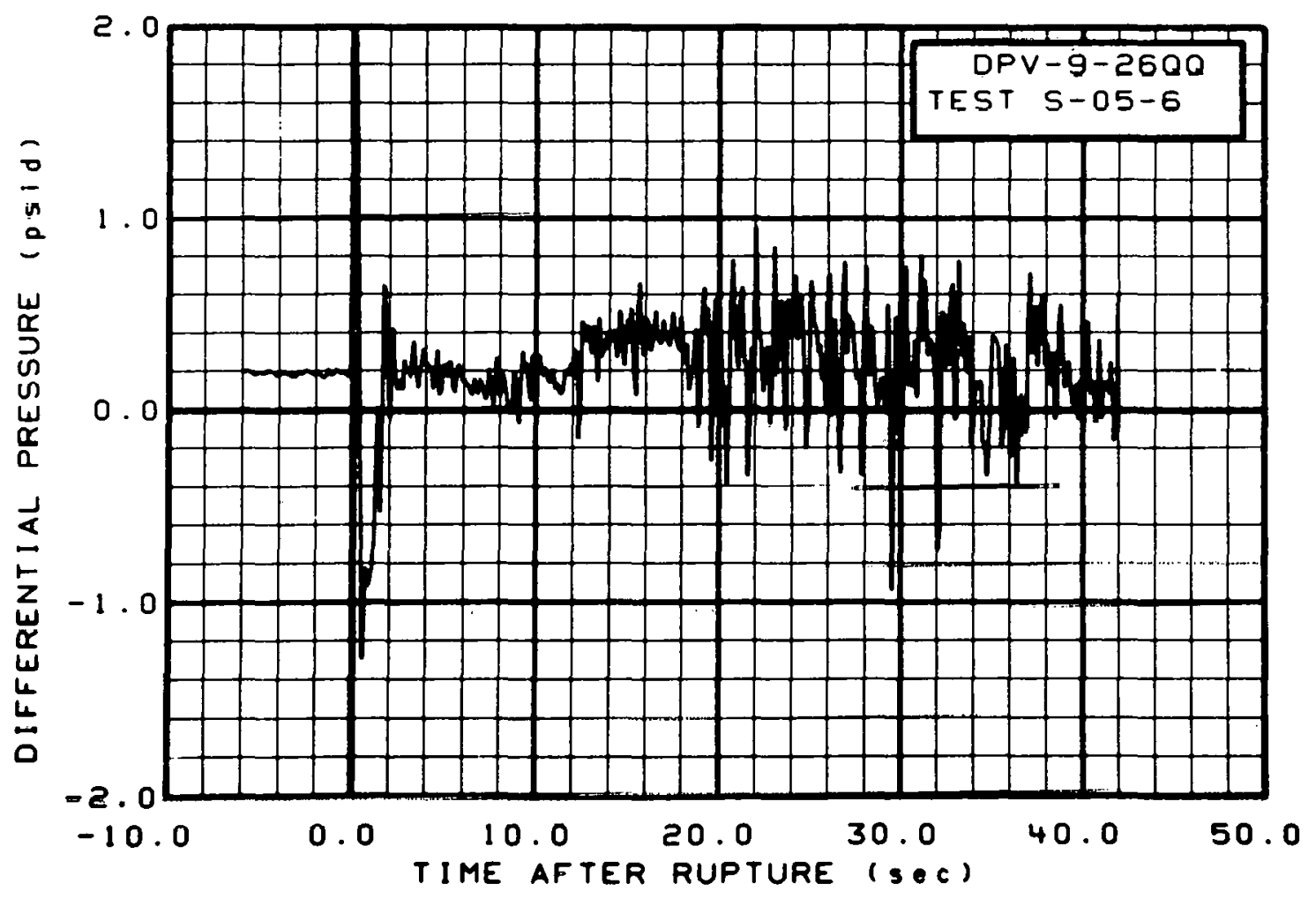

Fig. 341 Differential pressure in vesse1, Test S-05-6 (DPV-9-260Q), from -6 to $42 \mathrm{sec}$. 


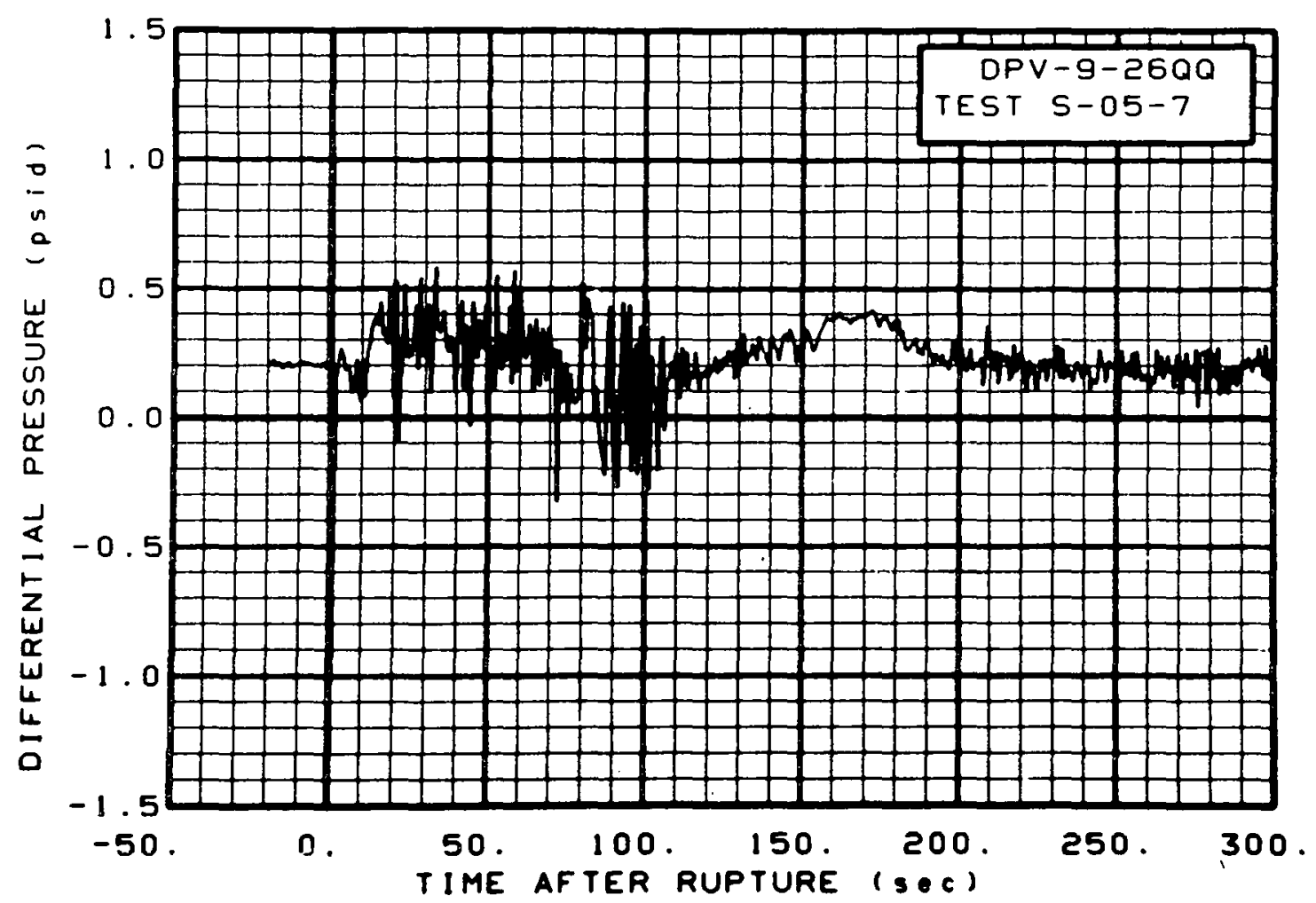

Fig. 342 Differential pressure in vesse1, Test S-05-7 (DPV-9-26QQ), from -20 to $300 \mathrm{sec}$.



Fig. 343 Differential pressure in vessel, Test S-05-7 (DPV-9-260Q), from -6 to $42 \mathrm{sec}$. 


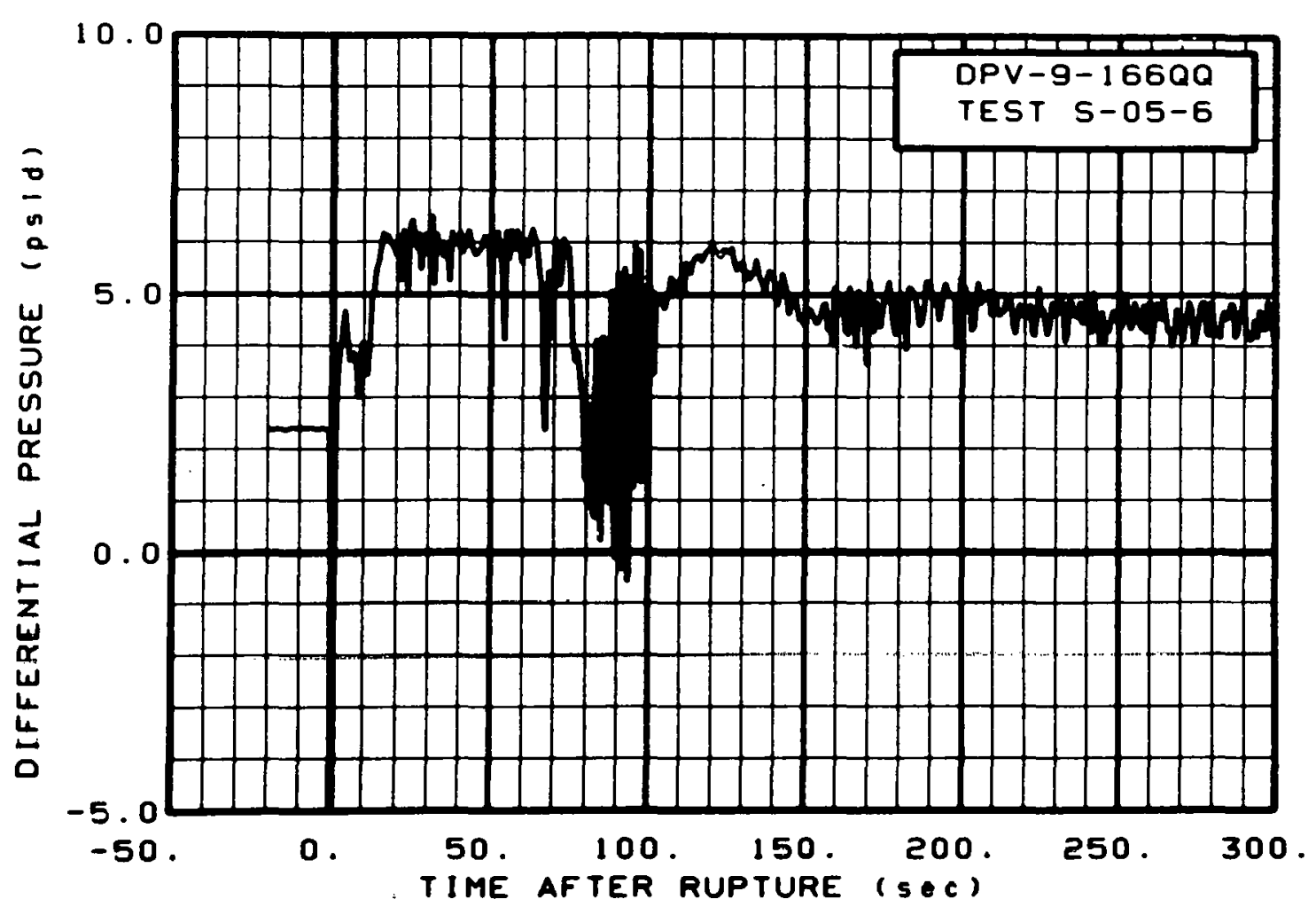

Fig. 344 Differential pressure in vesse1, Test S-05-6 (DPV-9-166QQ), from -20 to $300 \mathrm{sec}$.

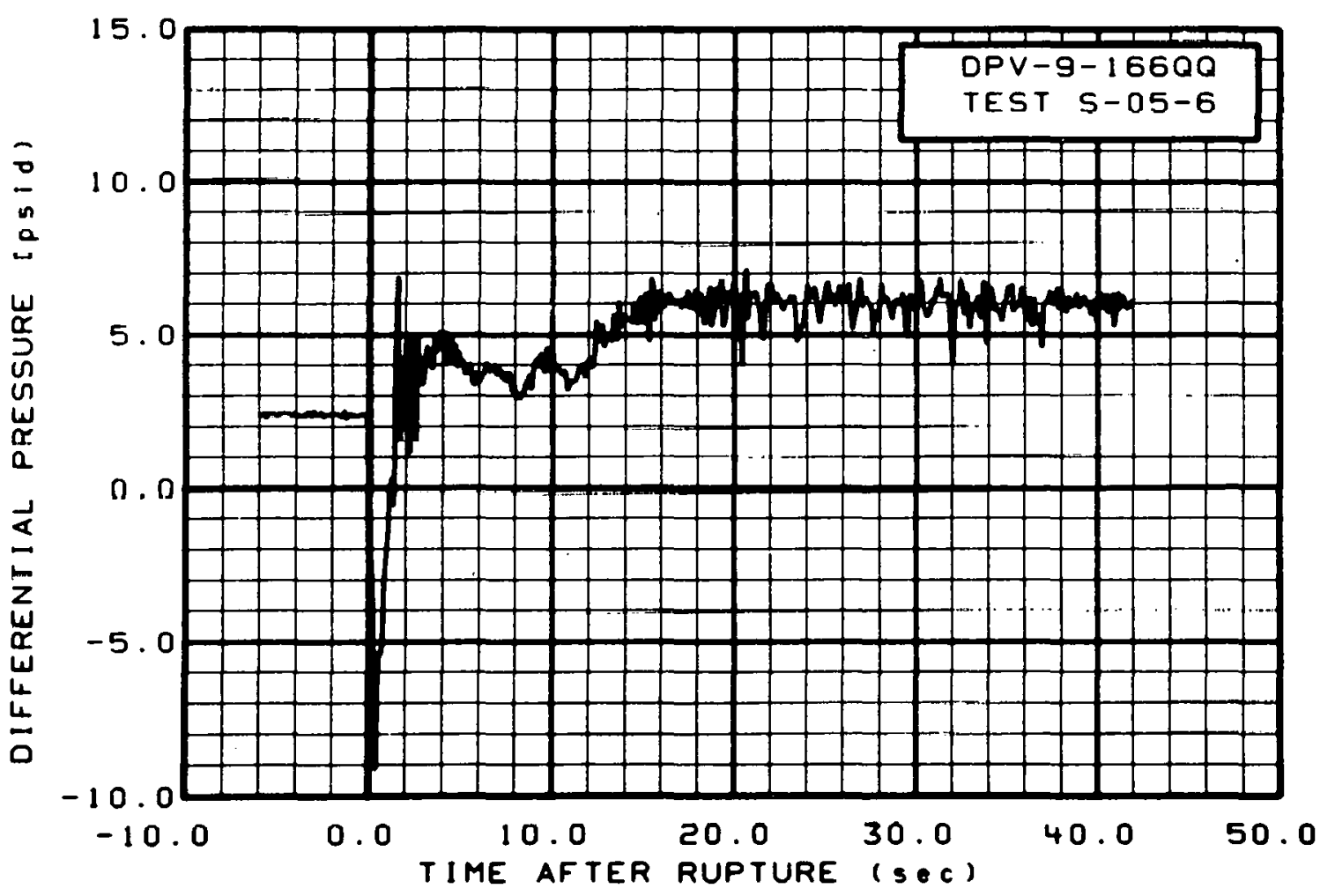

Fig. 345 Differential pressure in vessel, Test S-05-6 (DPV-9-166QQ), from -6 to $42 \mathrm{sec}$. 


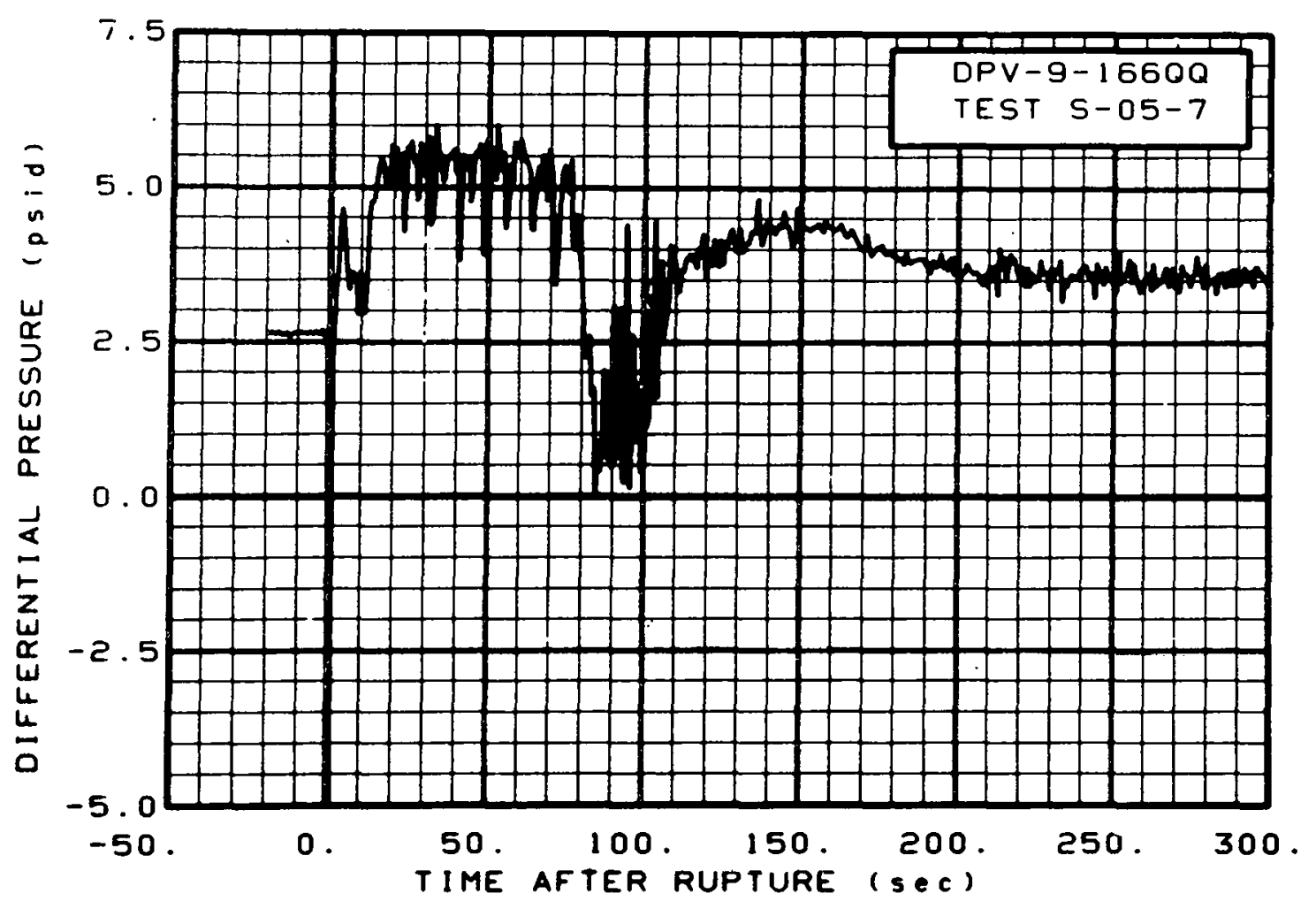

Fig. 346 Differential pressure in vessel, Test S-05-7 (DPV-9-166QQ), from -20 to $300 \mathrm{sec}$.

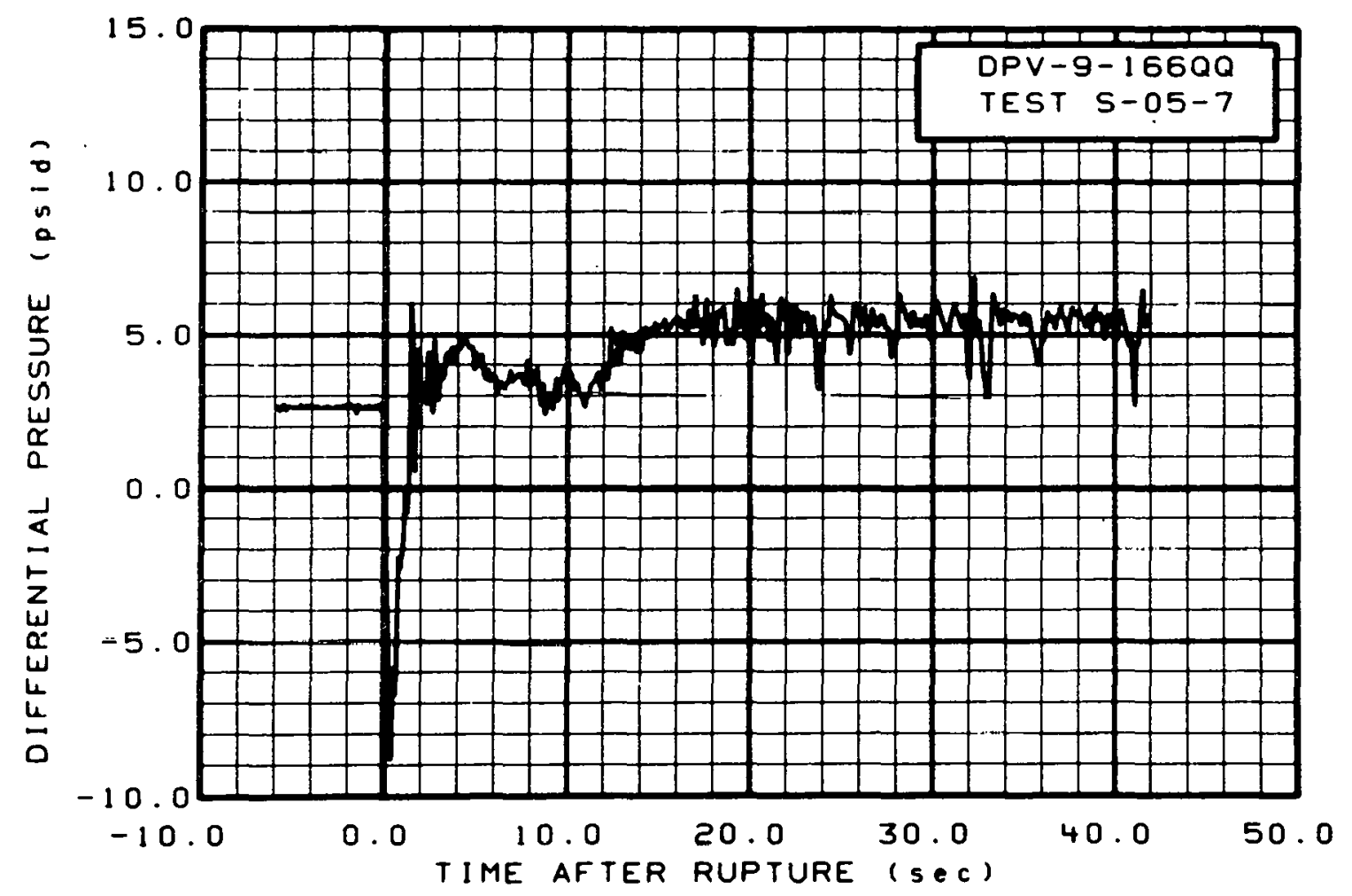

Fig. 347 Differential pressure in vessel, Test S-05-7 (DPV-9-1660Q), from -6 to 42 sec. 


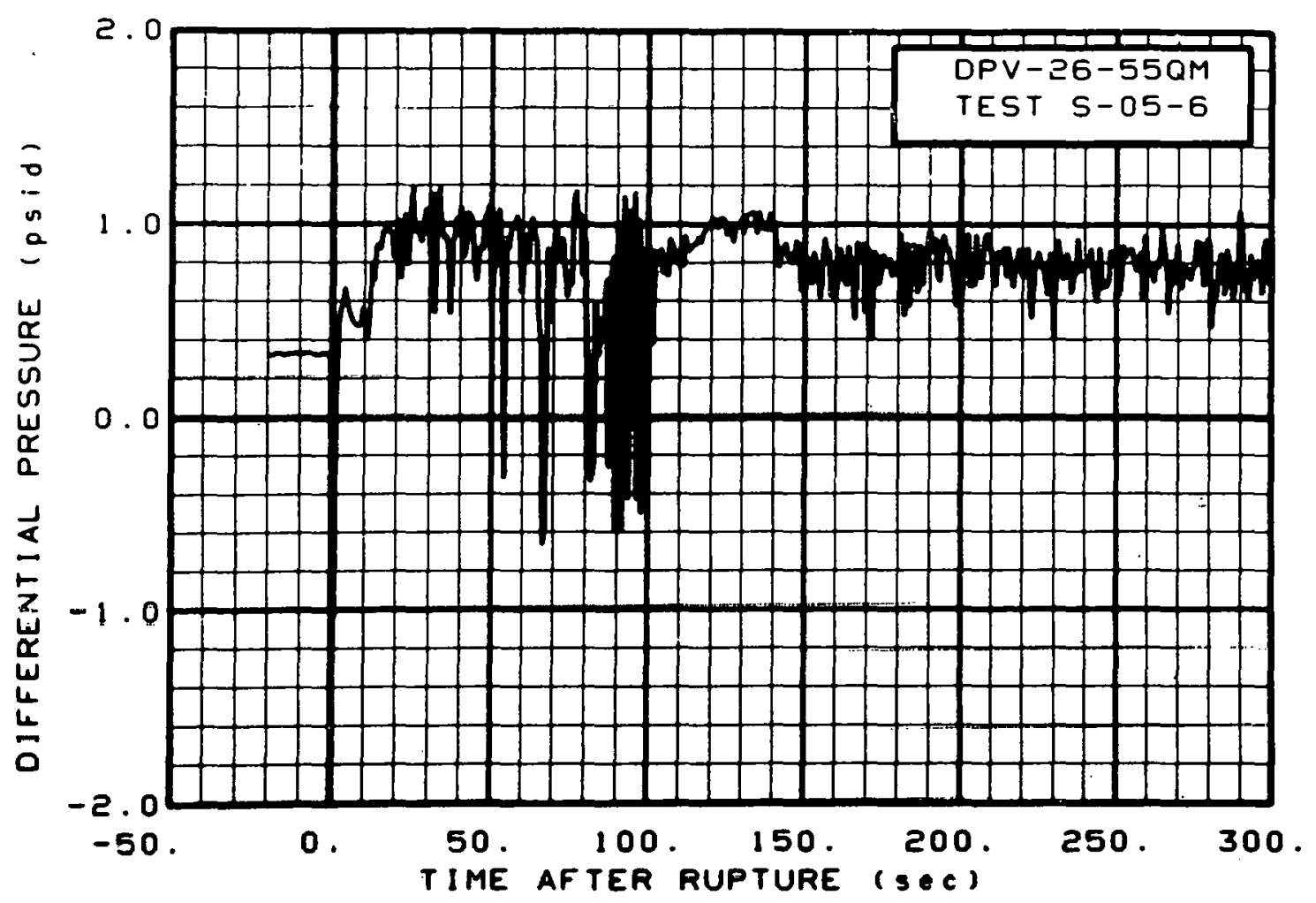

Fig. 348 Differential pressure in vessel, Test S-05-6 (DPV-26-55QM), from -20 to $300 \mathrm{sec}$.

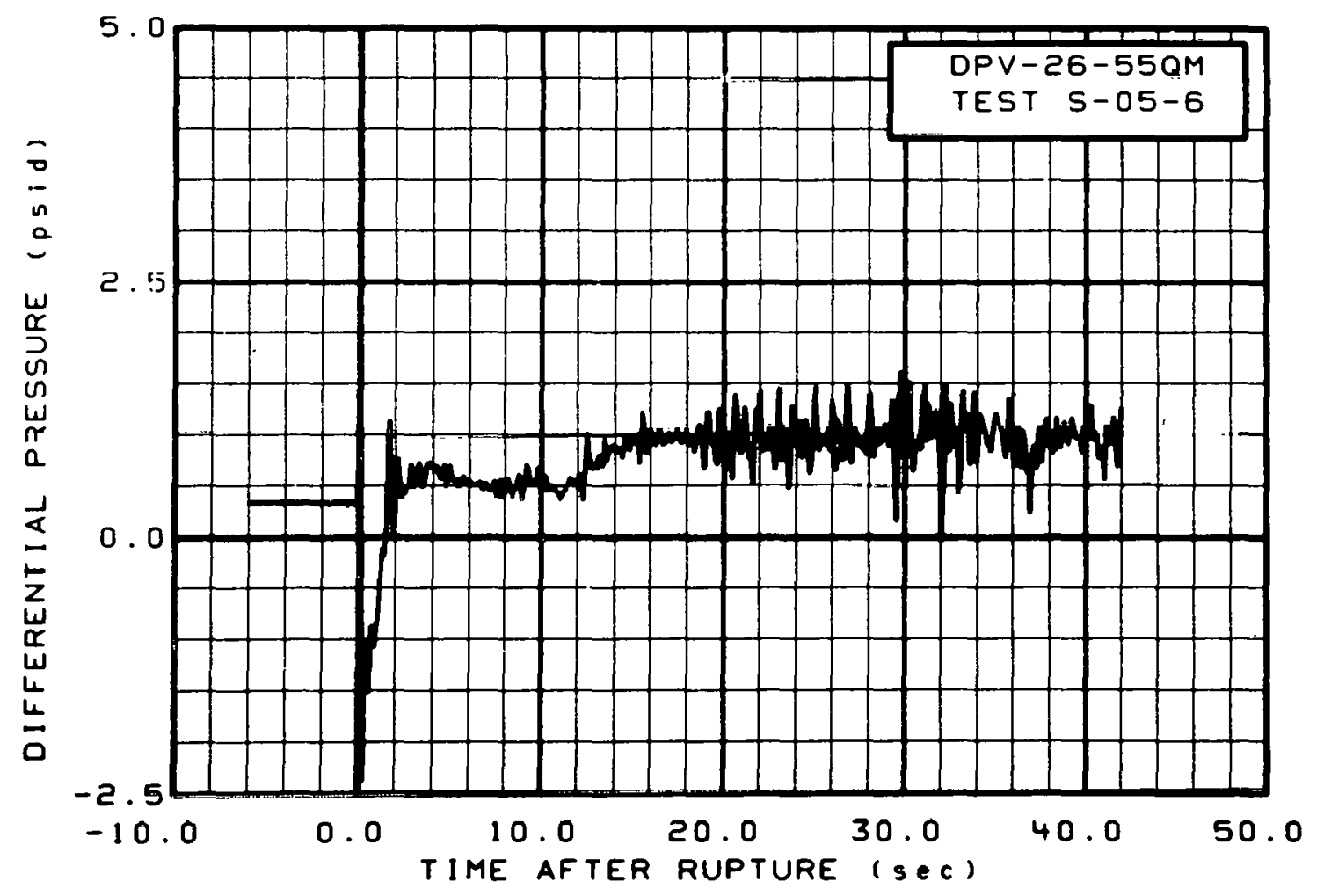

Fig. 349 Differential pressure in vessel, Test S-05-6 (DPV-26-55QM), from -6 to $42 \mathrm{sec}$. 


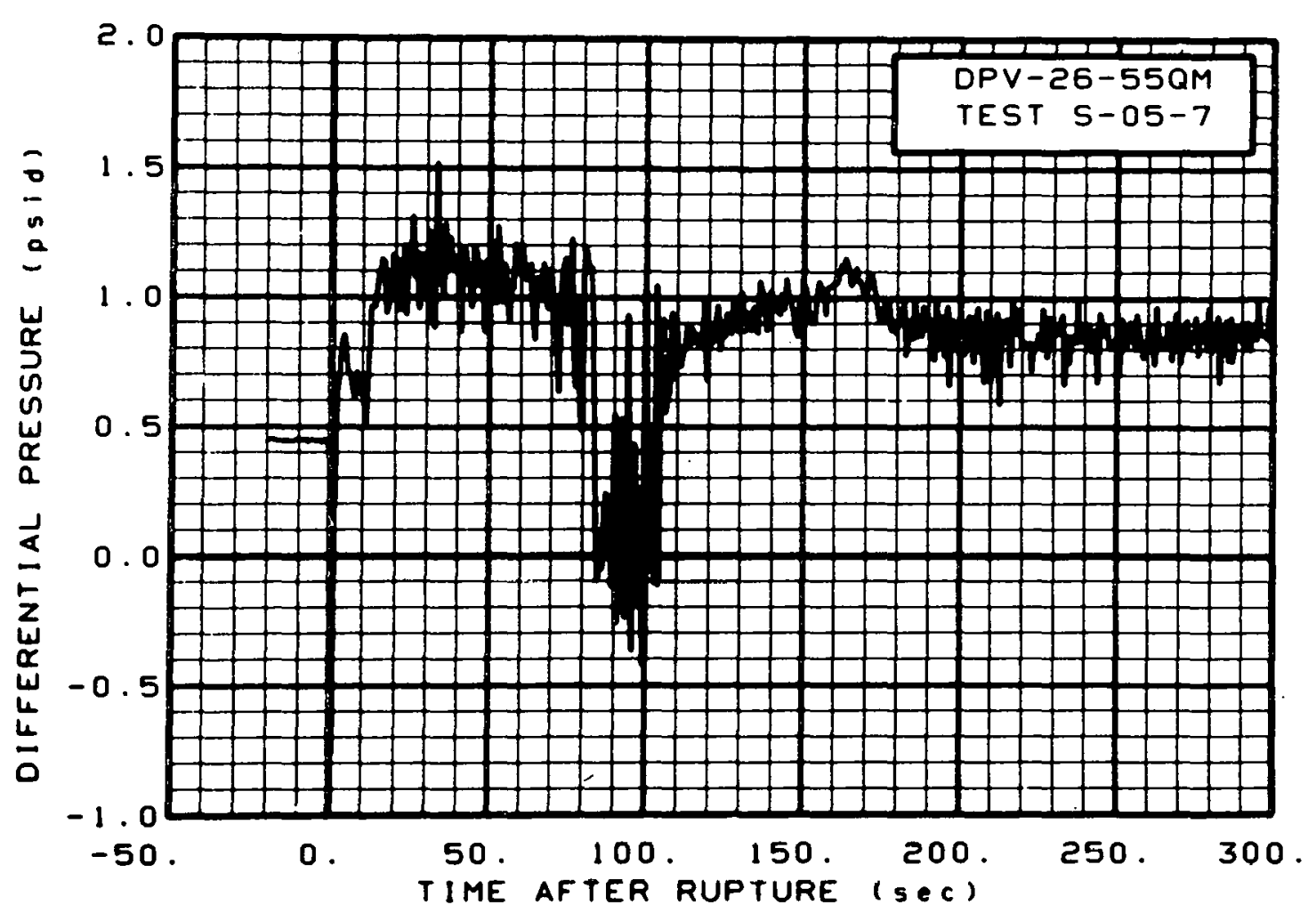

Fig. 350 Differential pressure in vessel, Test S-05-7 (DPV-26-55QM), from -20 to $300 \mathrm{sec}$.

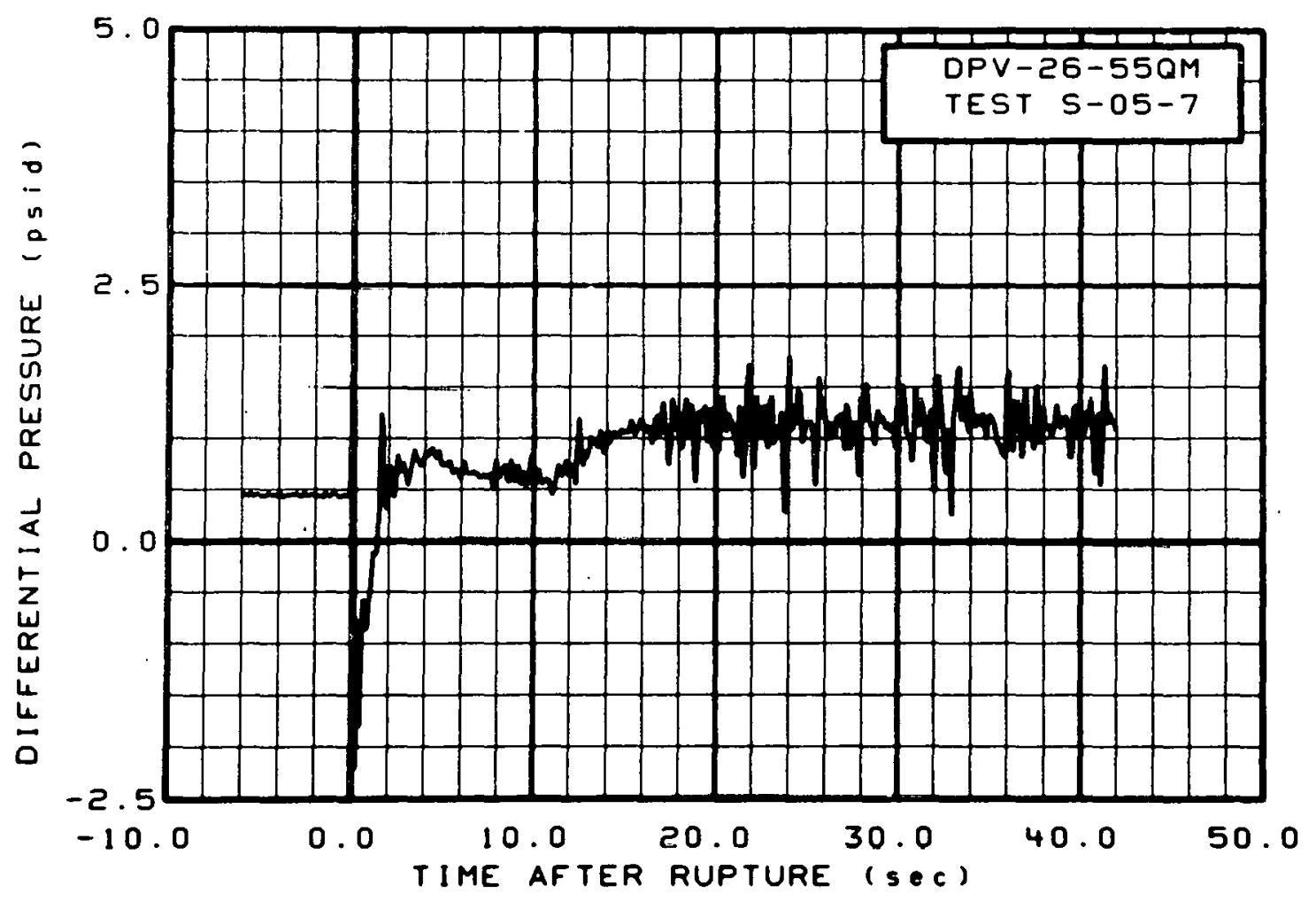

Fig. 351 Differential pressure in vesse1, Test S-05-7 (DPV-26-55QM), from -6 to 42 sec. 


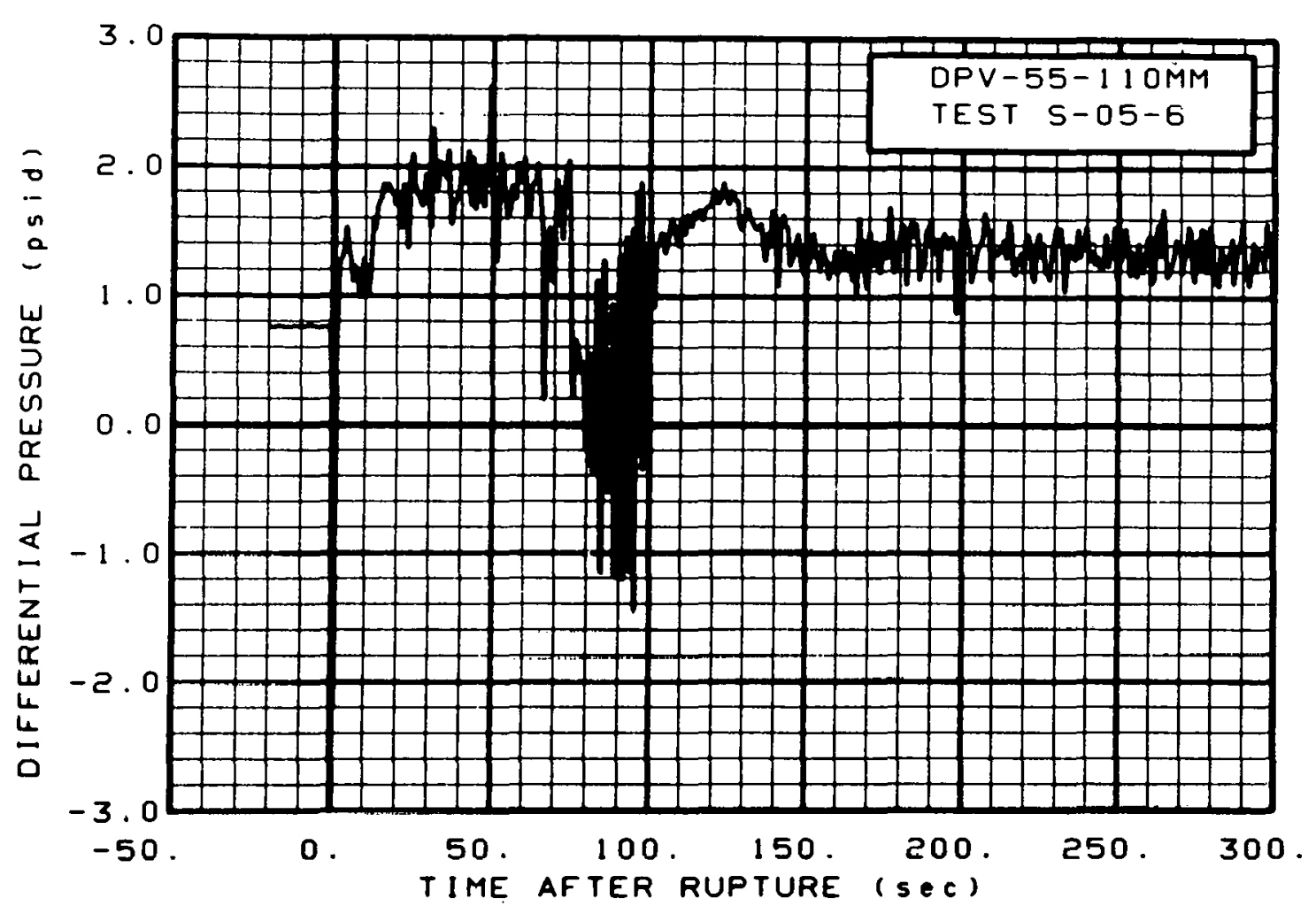

Fig. 352 Differential pressure in vesse1, Test S-05-6 (DPV-55-110MM), from -20 to $300 \mathrm{sec}$.

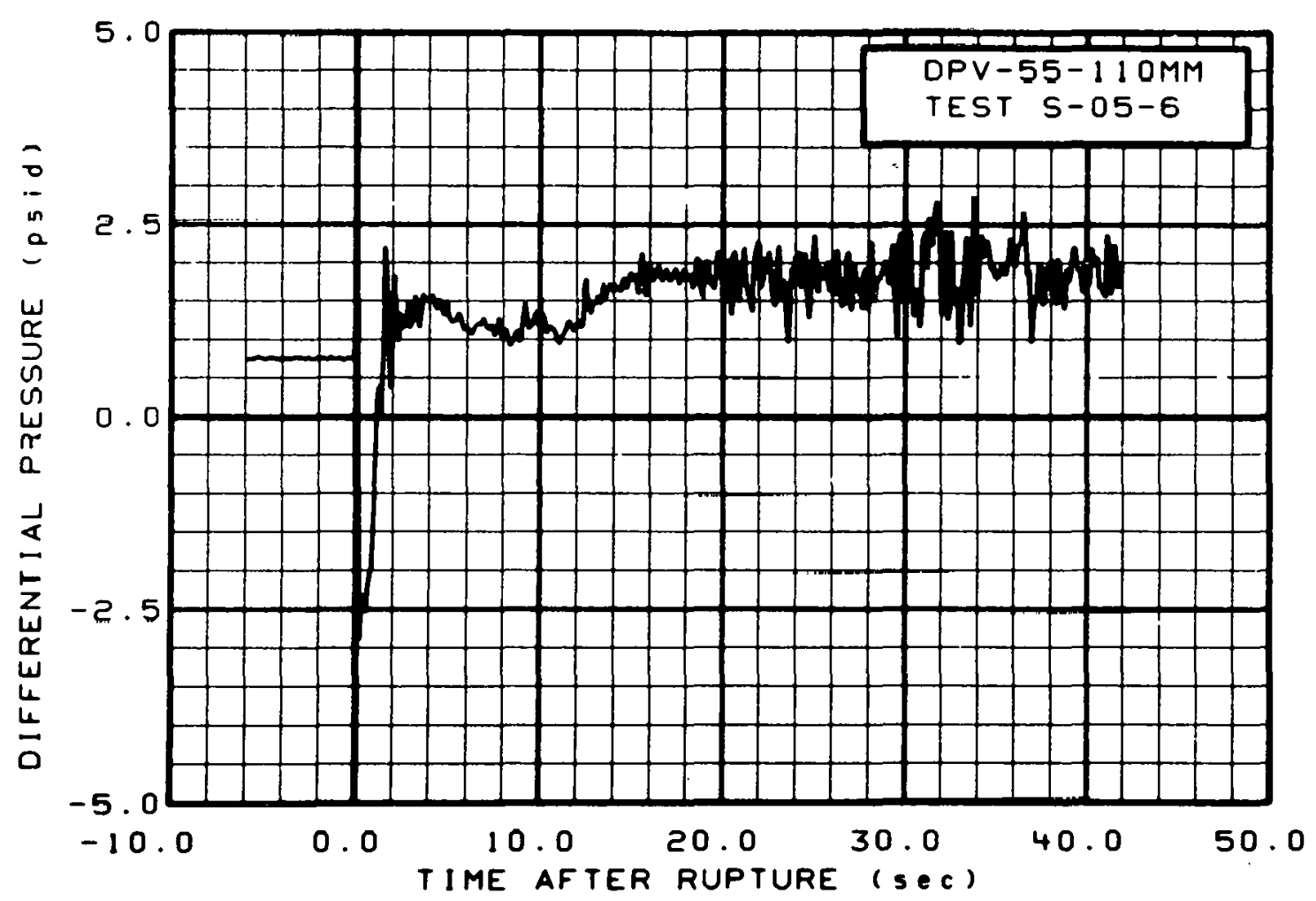

Fig. 353 Differential pressure in vessel, Test S-05-6 (DPV-55-110MM), from -6 to $42 \mathrm{sec}$. 


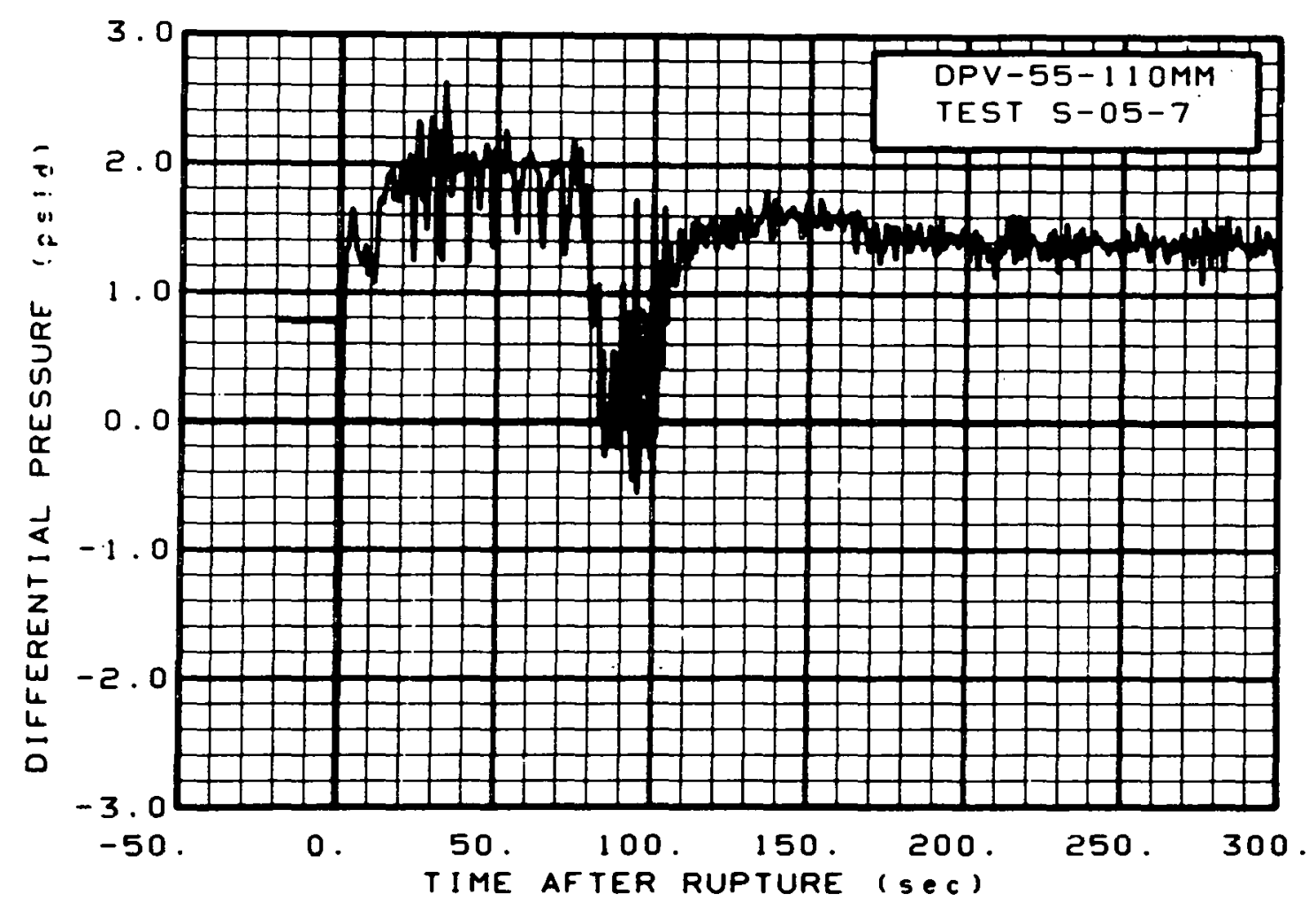

Fig. 354 Differential pressure in vessel, Test S-05-7 (DPV-55-110MM), from: -20 to $300 \mathrm{sec}$.

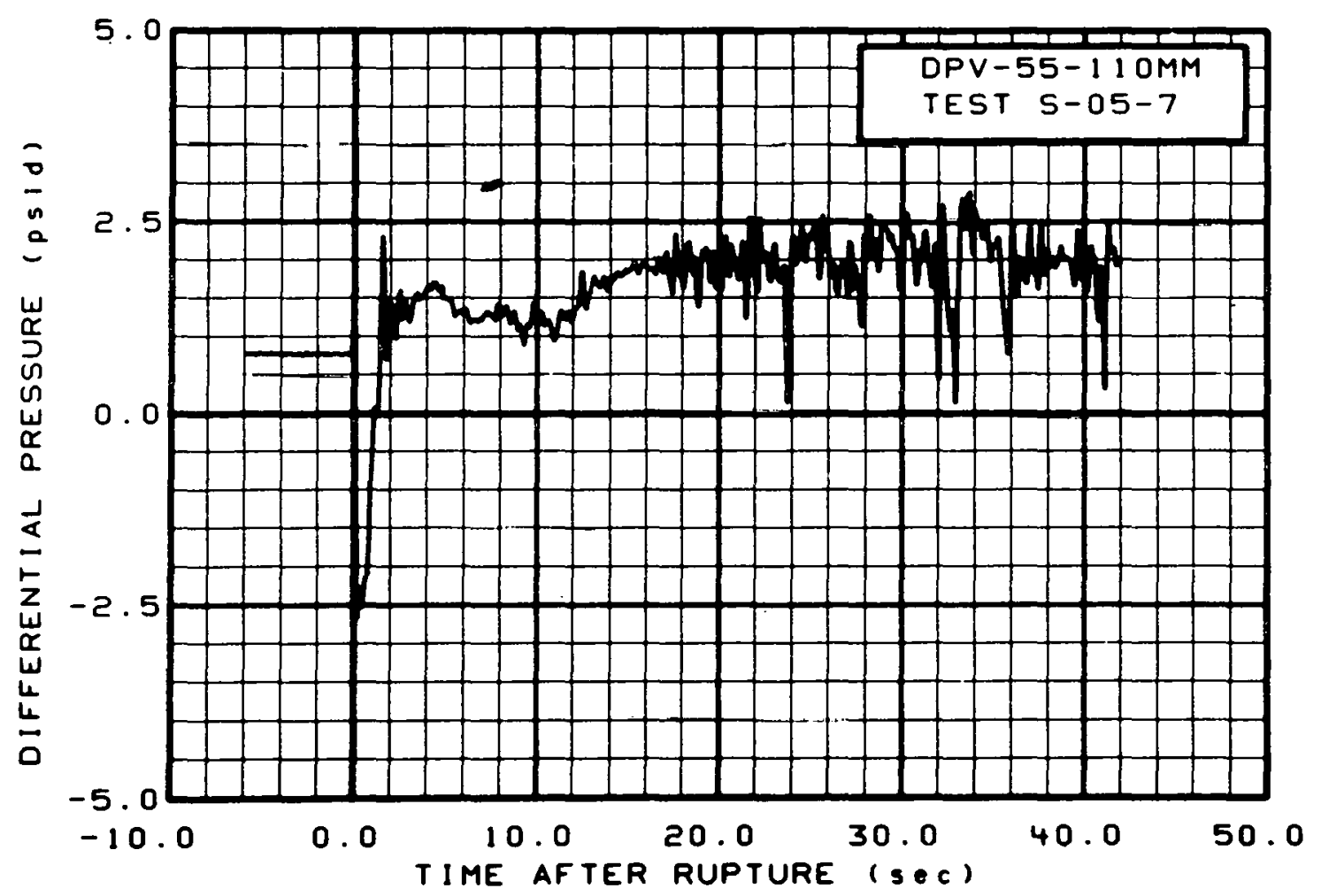

Fig. 355 Differential pressure in vessel, Test S-05-7 (DPV-55-110MM), from -6 to $42 \mathrm{sec}$. 


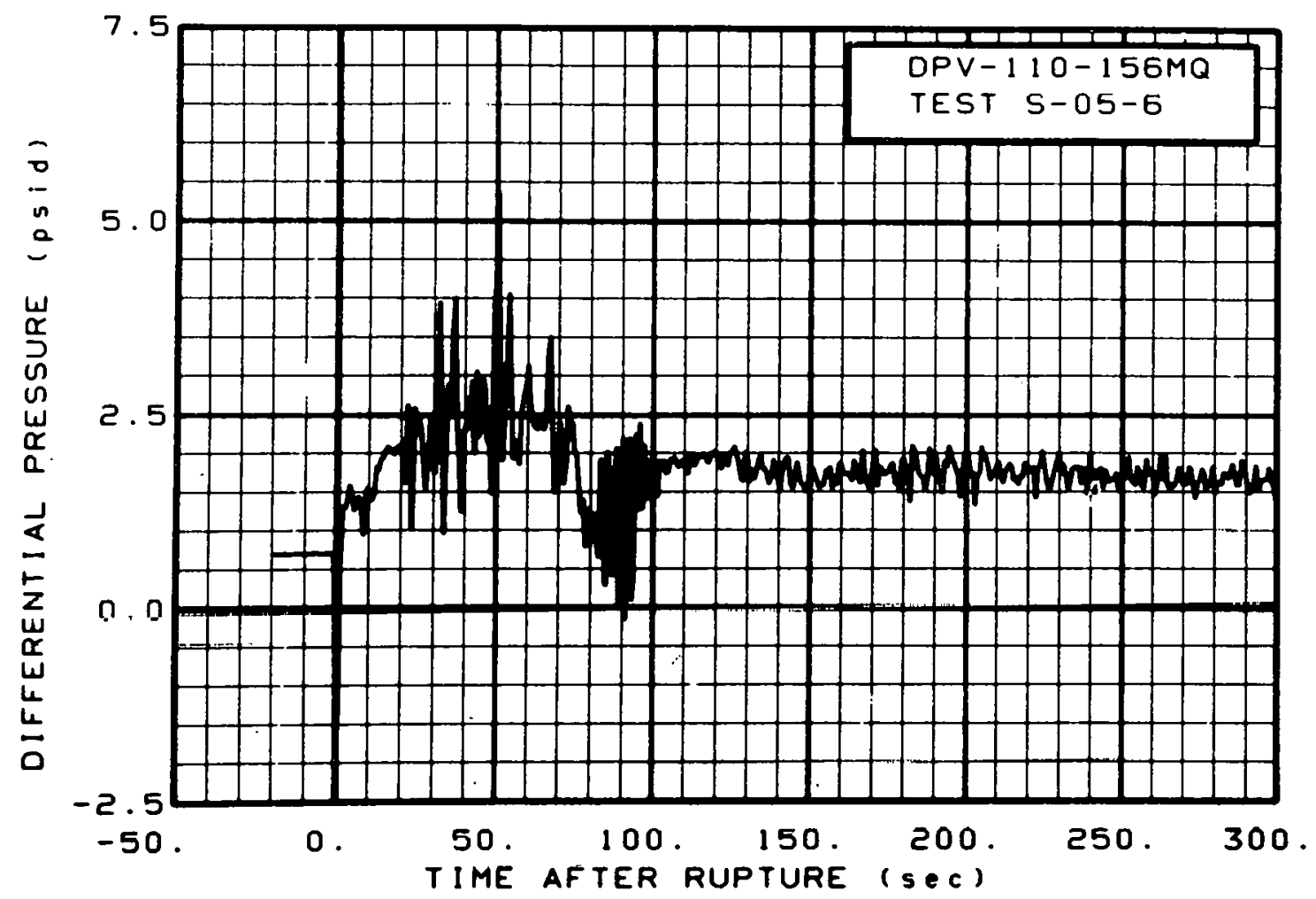

Fig. 356 Differential pressure in vessel, Test S-05-6 (DPV-110-156MQ), from -20 to $300 \mathrm{sec}$.

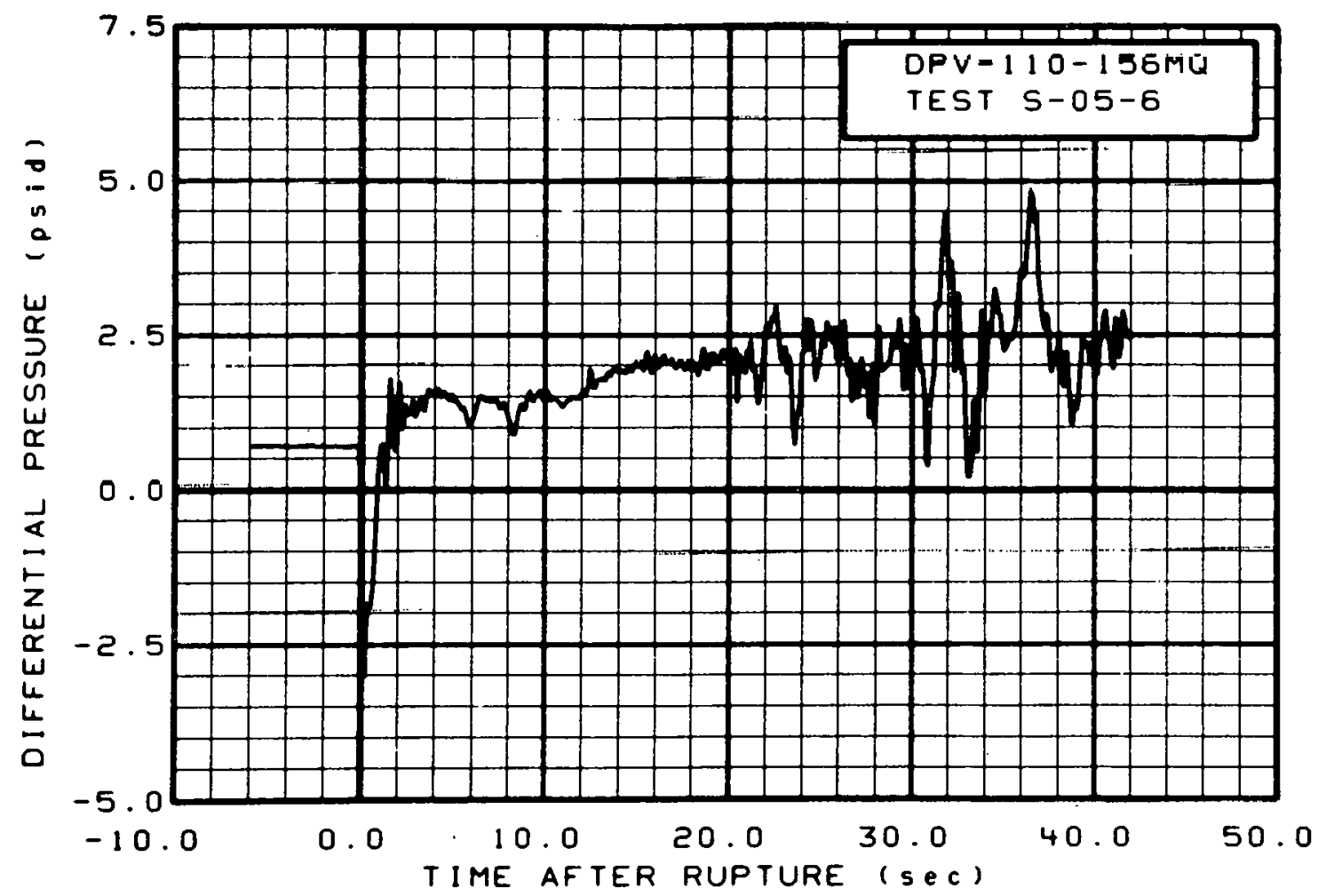

Fig. 357 Differential pressure in vessel, Test S-05-6 (DPV-110-156MQ), from -6 to 42 sec. 


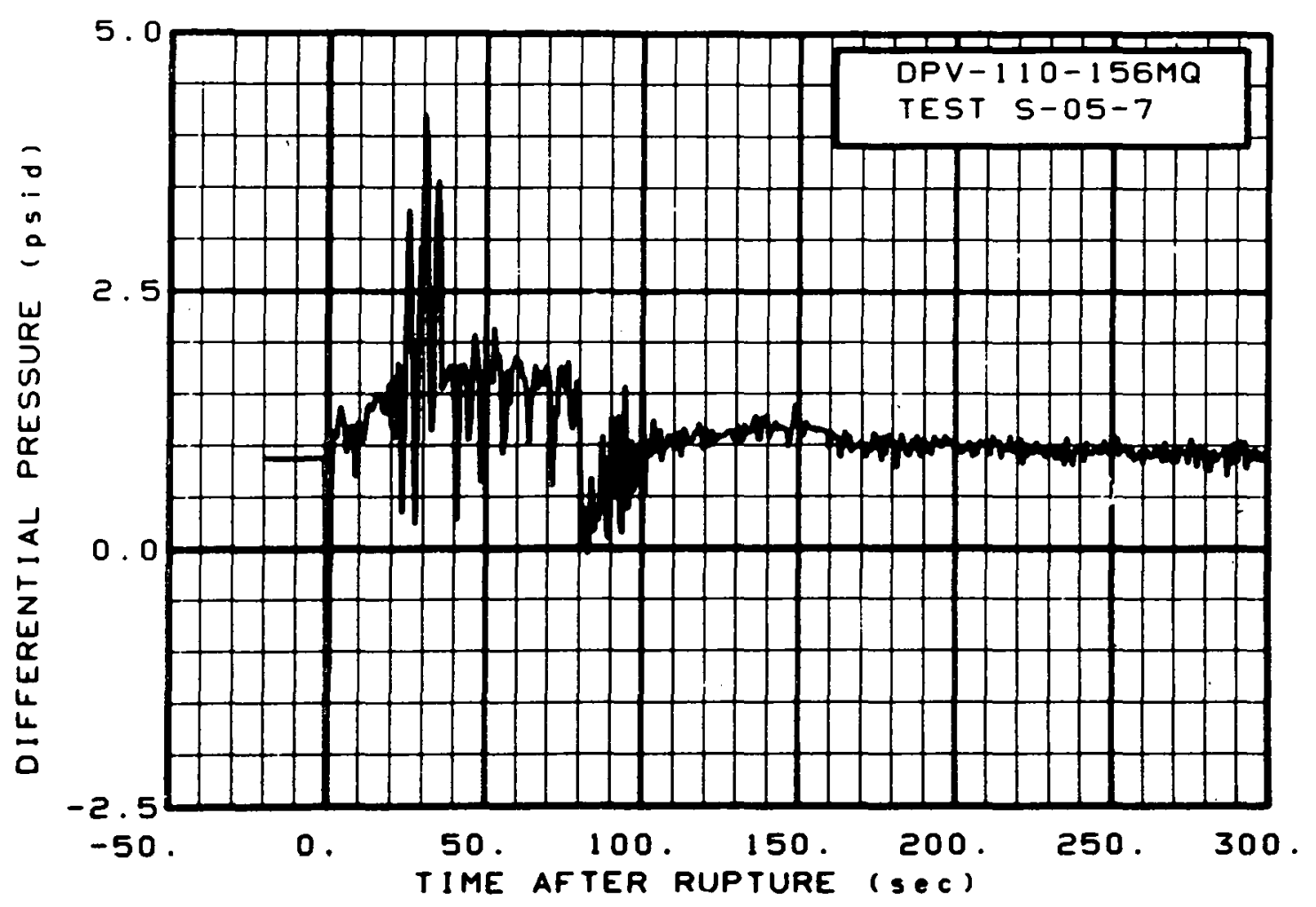

Fig. 358 Differential pressure in vessel, Test S-05-7 (DPV-110-156MQ), from -20 to 300 sec.

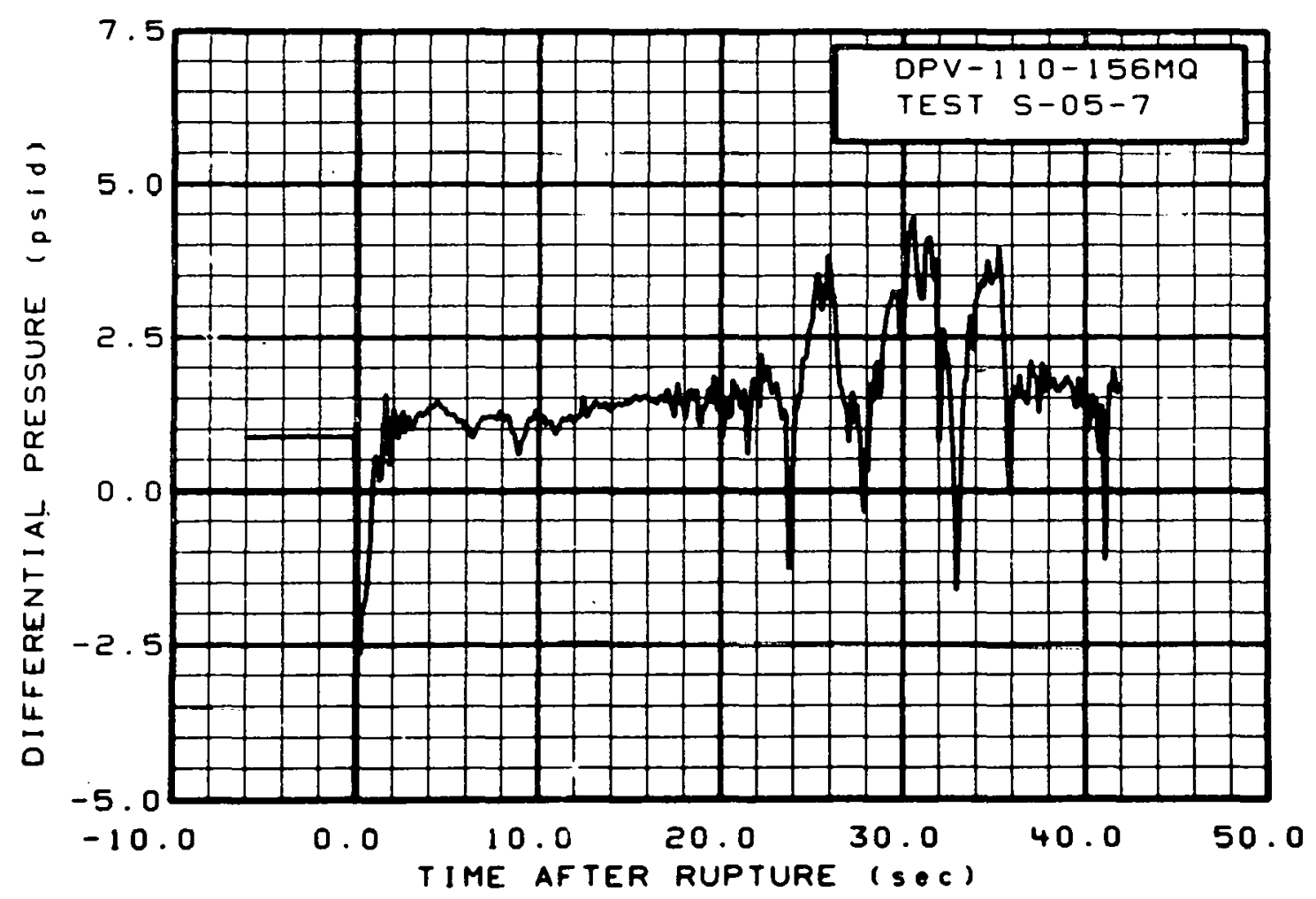

Fig. 359 Differential pressure in vesse1, Test S-05-7 (DPV-110-156MQ), from -6 to $42 \mathrm{sec}$. 


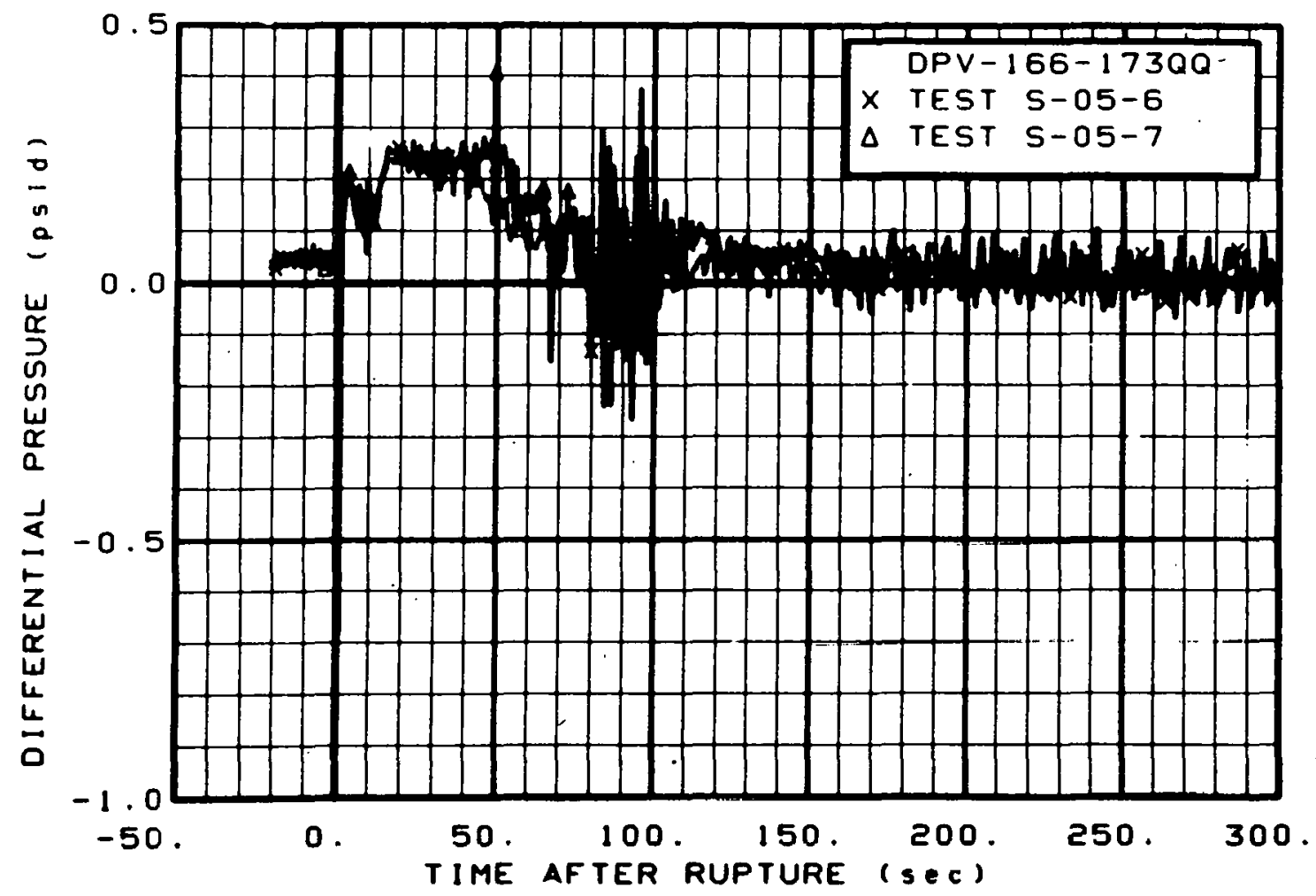

Fig. 360 Differential pressure in vessel (DPV-166-173QQ), from -20 to $300 \mathrm{sec}$.

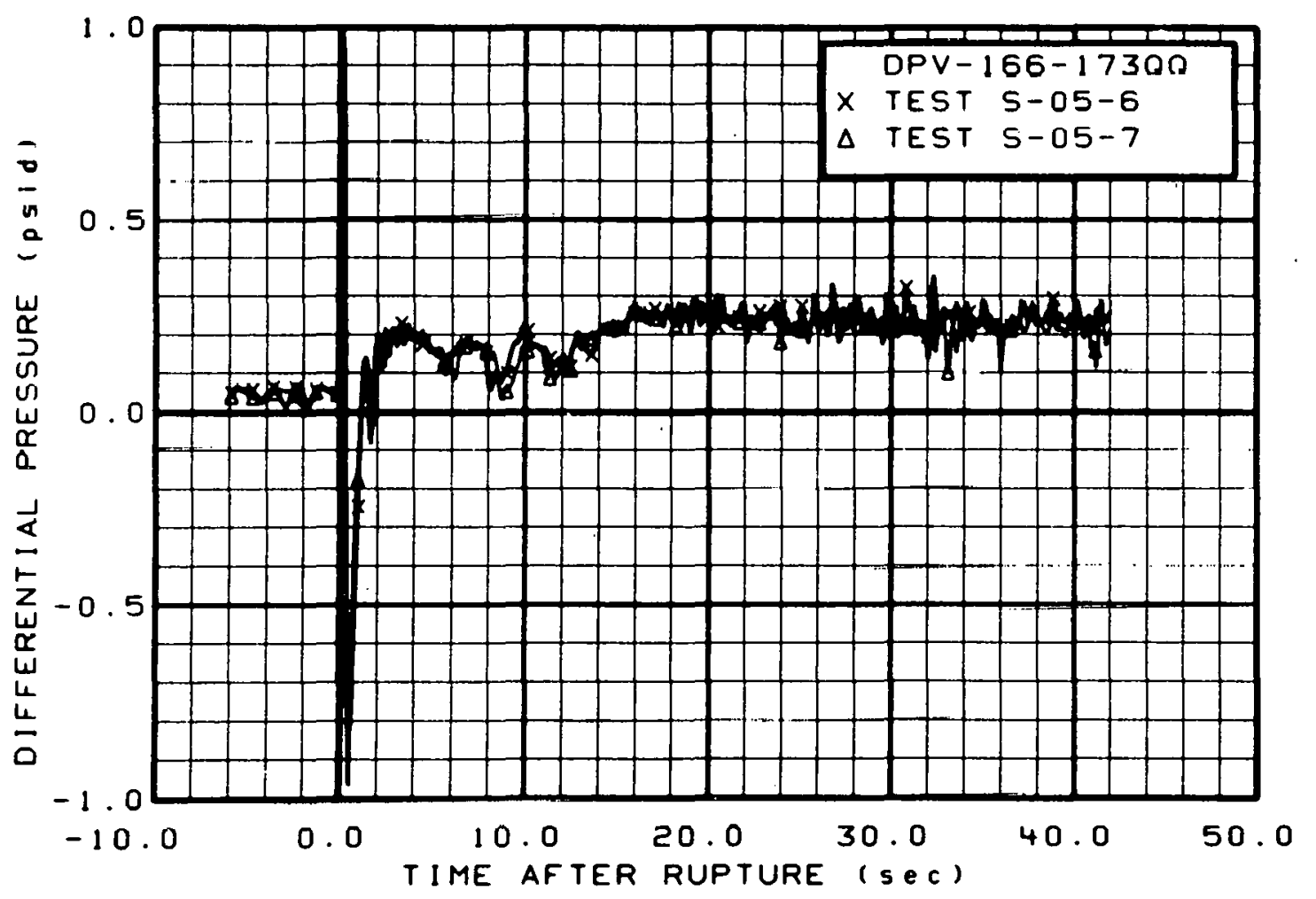

Fig. 361 Differential pressure in vessel (DPV-166-1730Q), from -6 to 42 sec. 


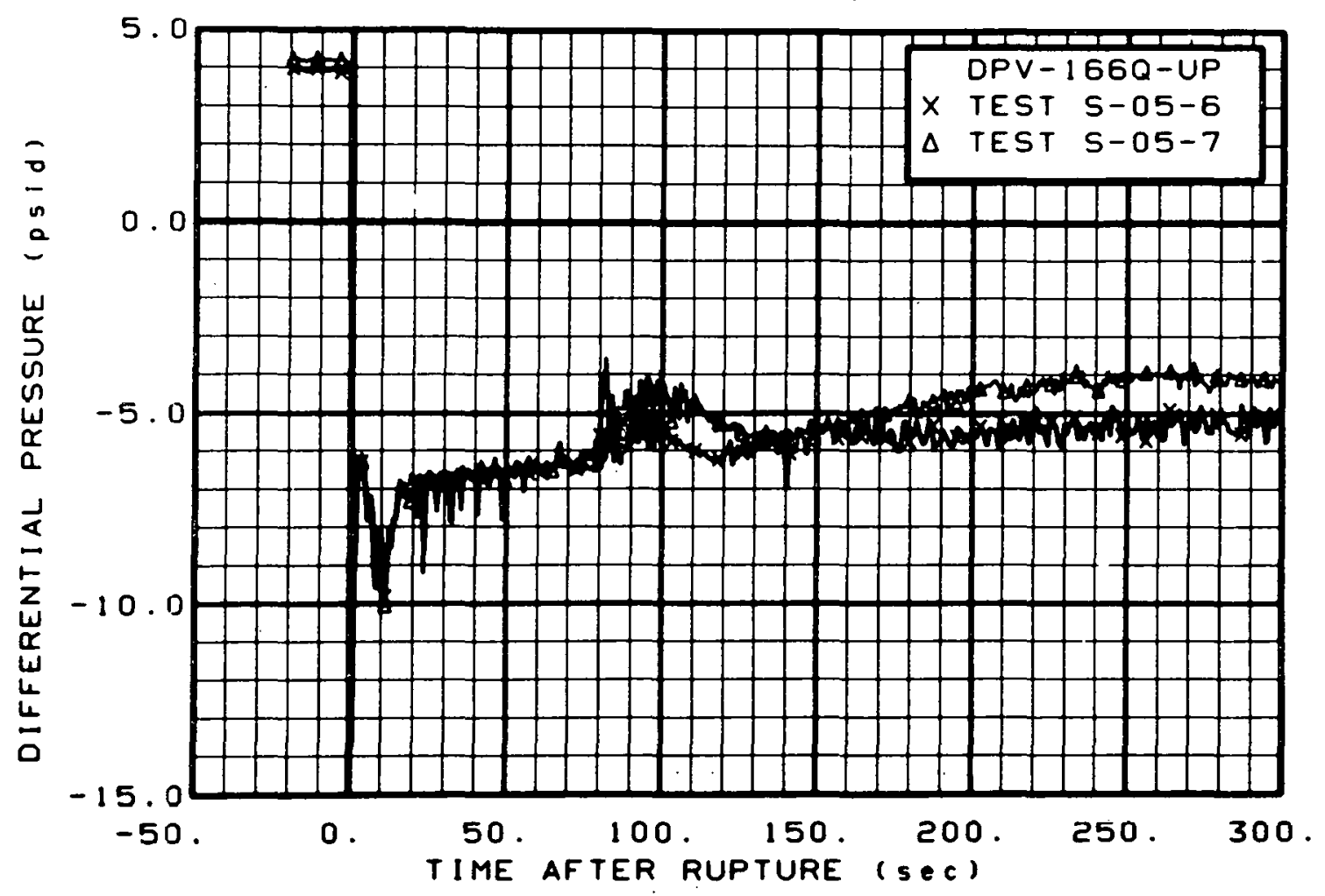

Fig. 362 Differential pressure in vessel (DPV-166Q-UP), from -20 to $300 \mathrm{sec}$.

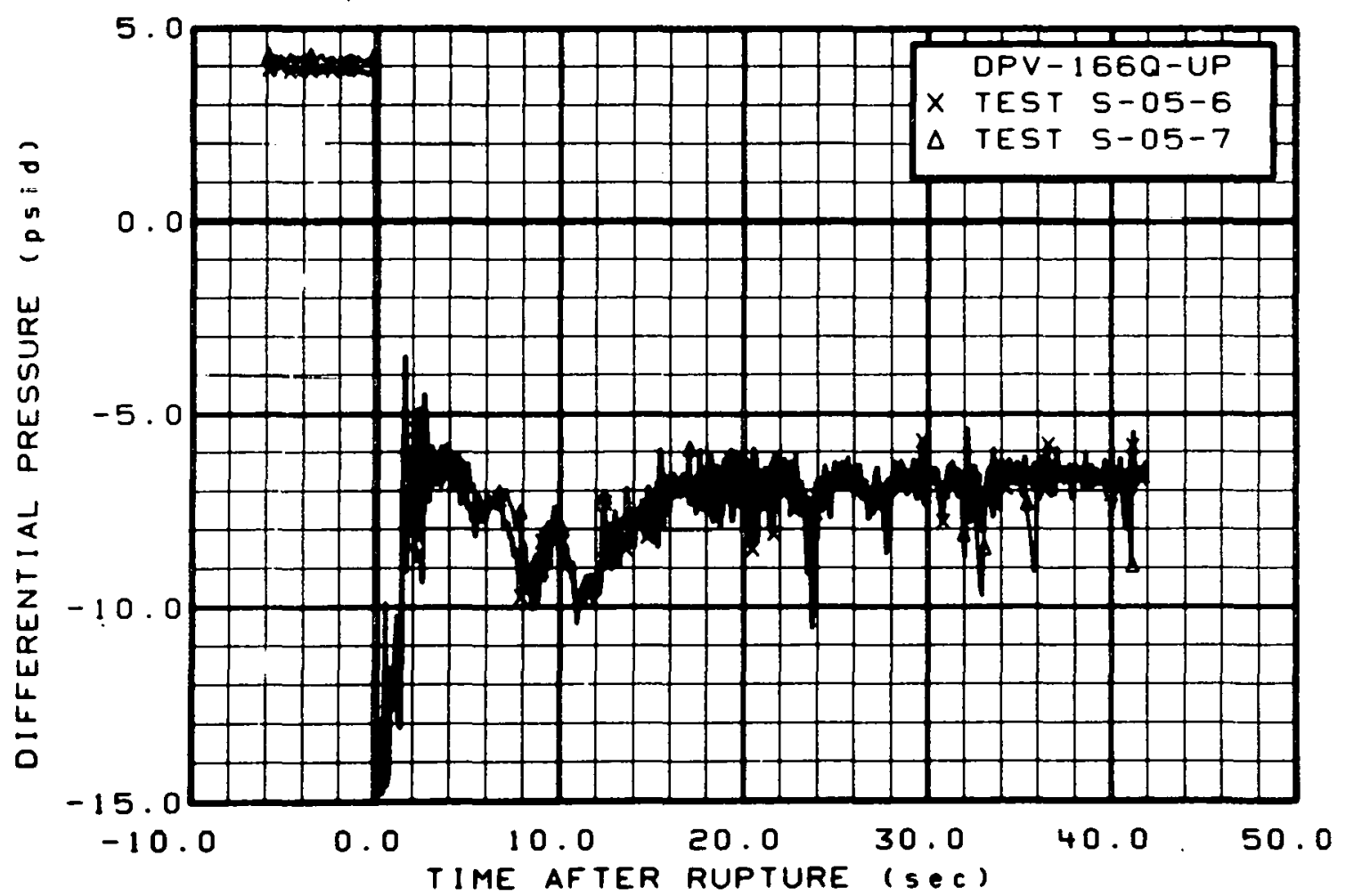

Fig. 363 Differential pressure in vessel (DPV-166Q-UP), from -6 to 42 sec. 


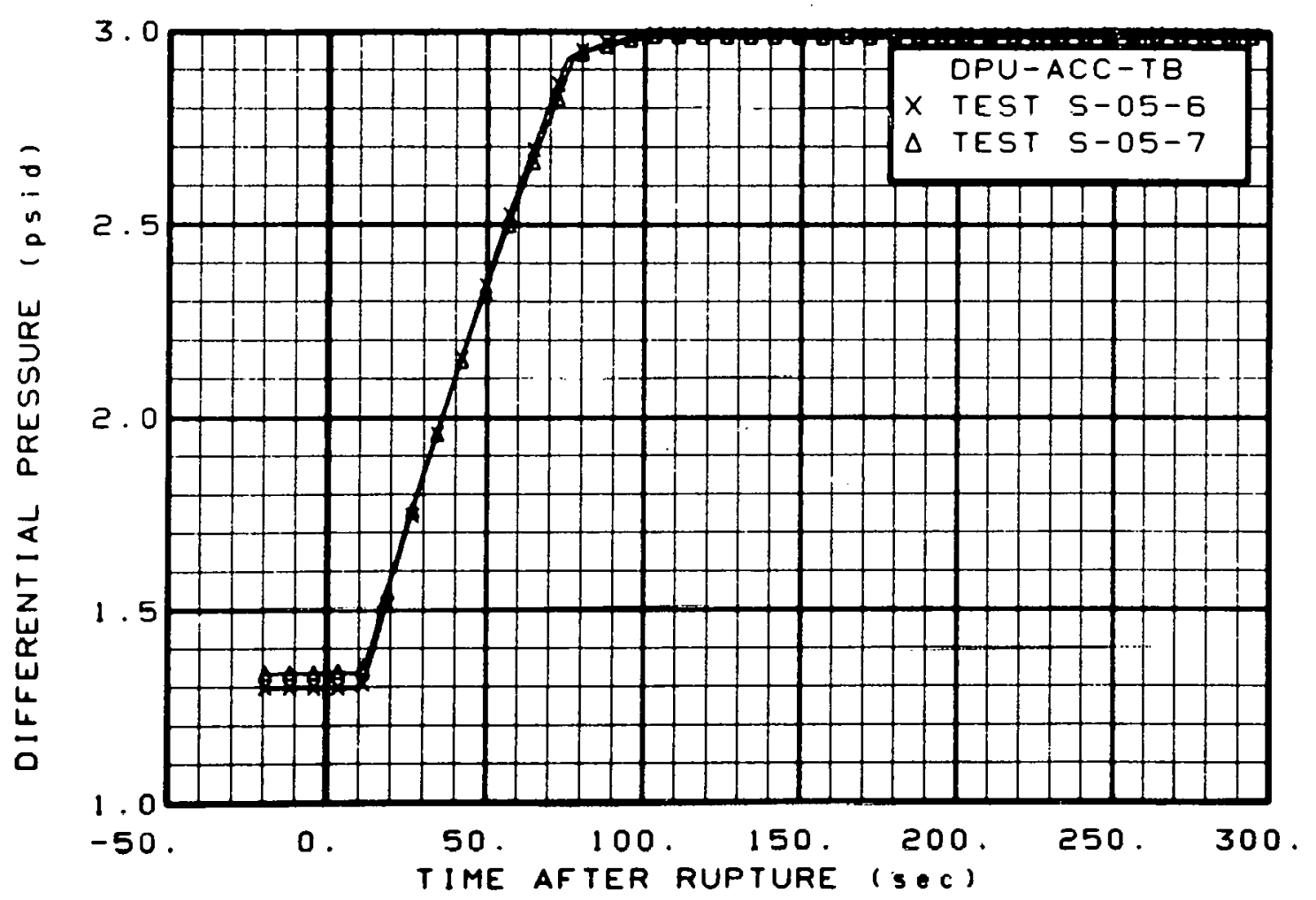

Fig. 364 Differential pressure in intact loop accumulator (DPU-ACC-TB), from -20 to $300 \mathrm{sec}$.

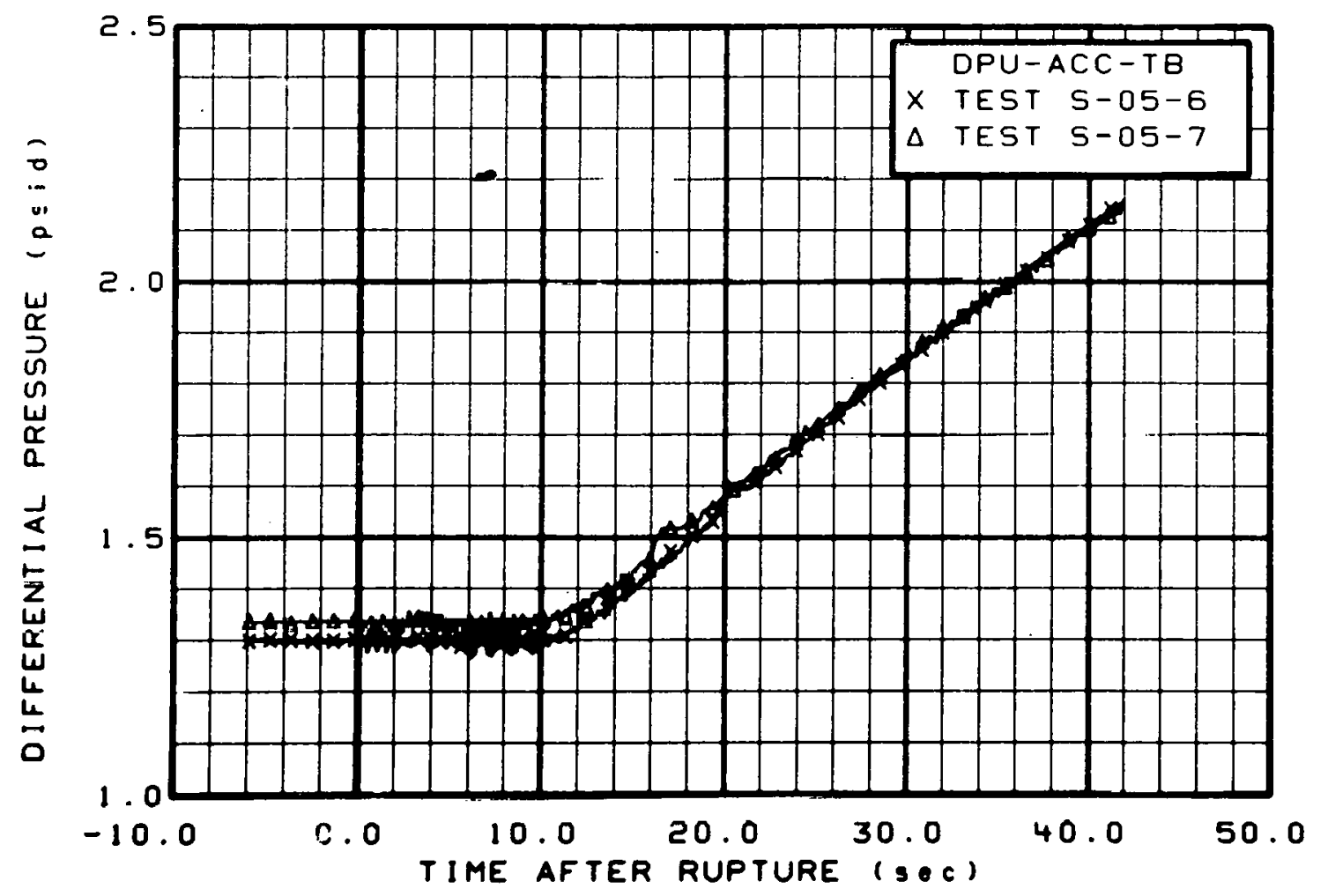

Fig. 365 Differential pressure in intact loop accumulator (DPU-ACC-TB), from -6 to $42 \mathrm{sec}$. 


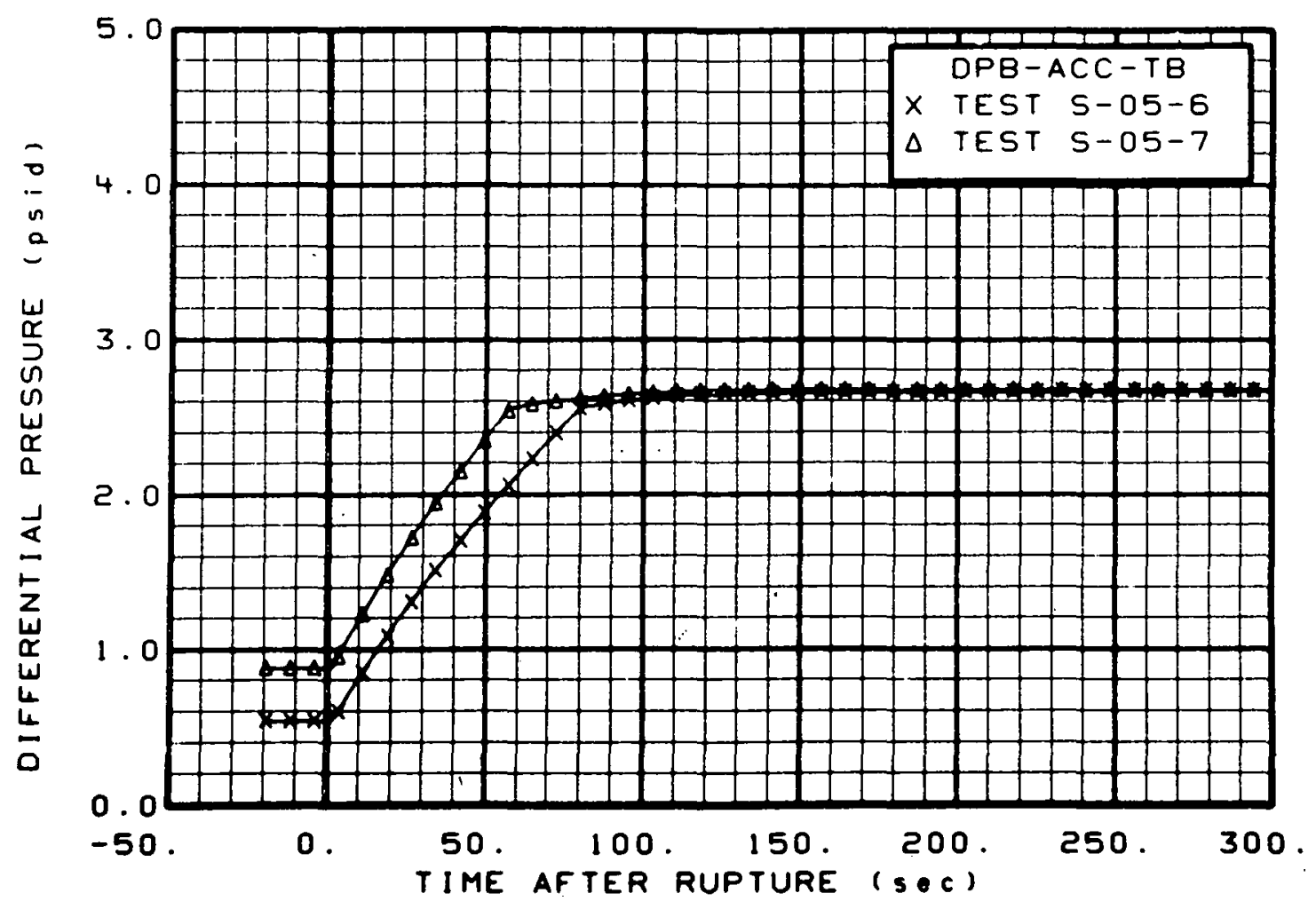

Fig. 366 Differential pressure in broken loop accumulator (DPB-ACC-TB), from -20 to $300 \mathrm{sec}$.

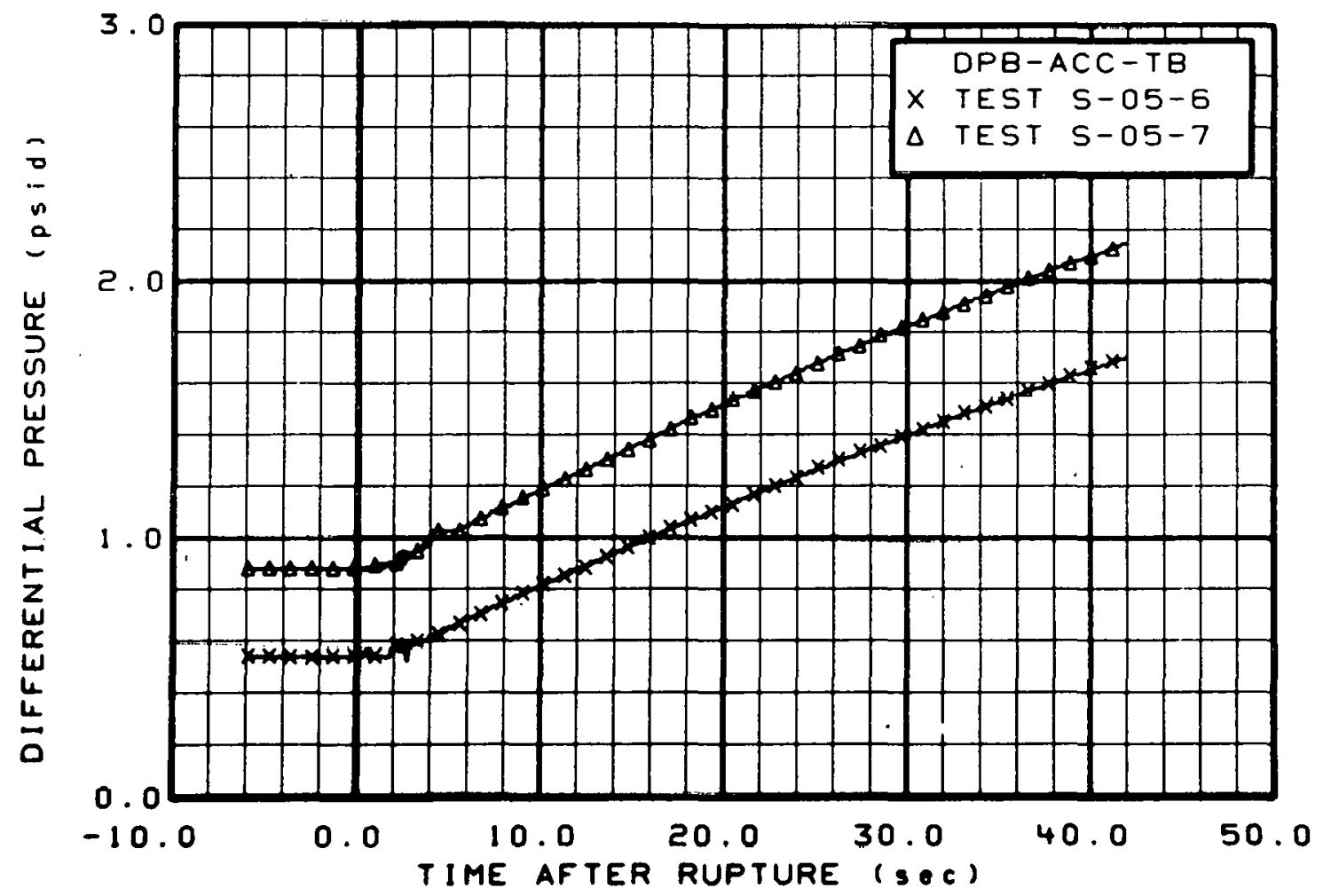

Fig, 367 Differential pressure in broken loop accumulator (DPB-ACC-TB), from -6 to $42 \mathrm{sec}$. 


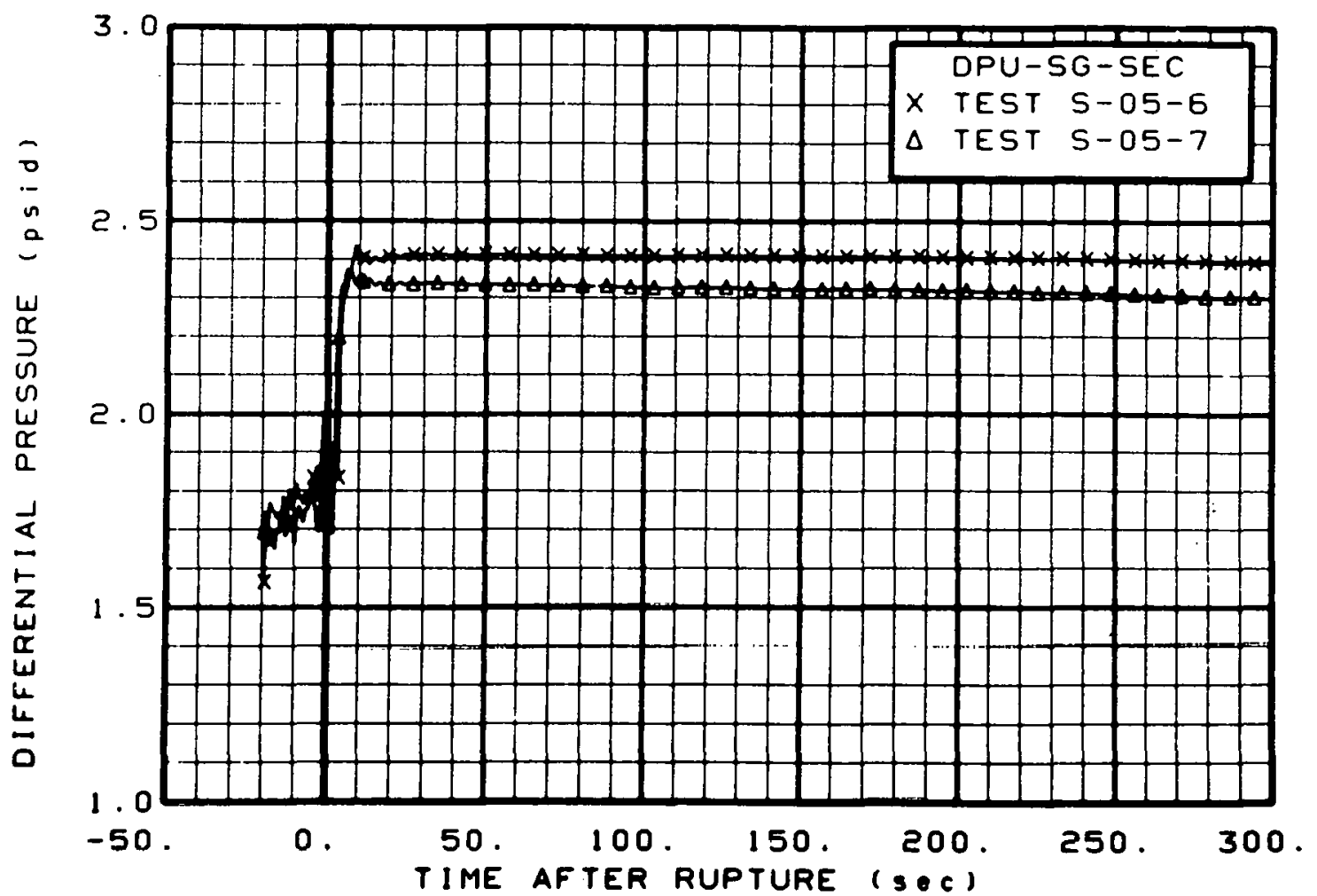

Fig. 368 Differential pressure in steam generator secondary (DPU-SG-SEC), from -20 to $300 \mathrm{sec}$.

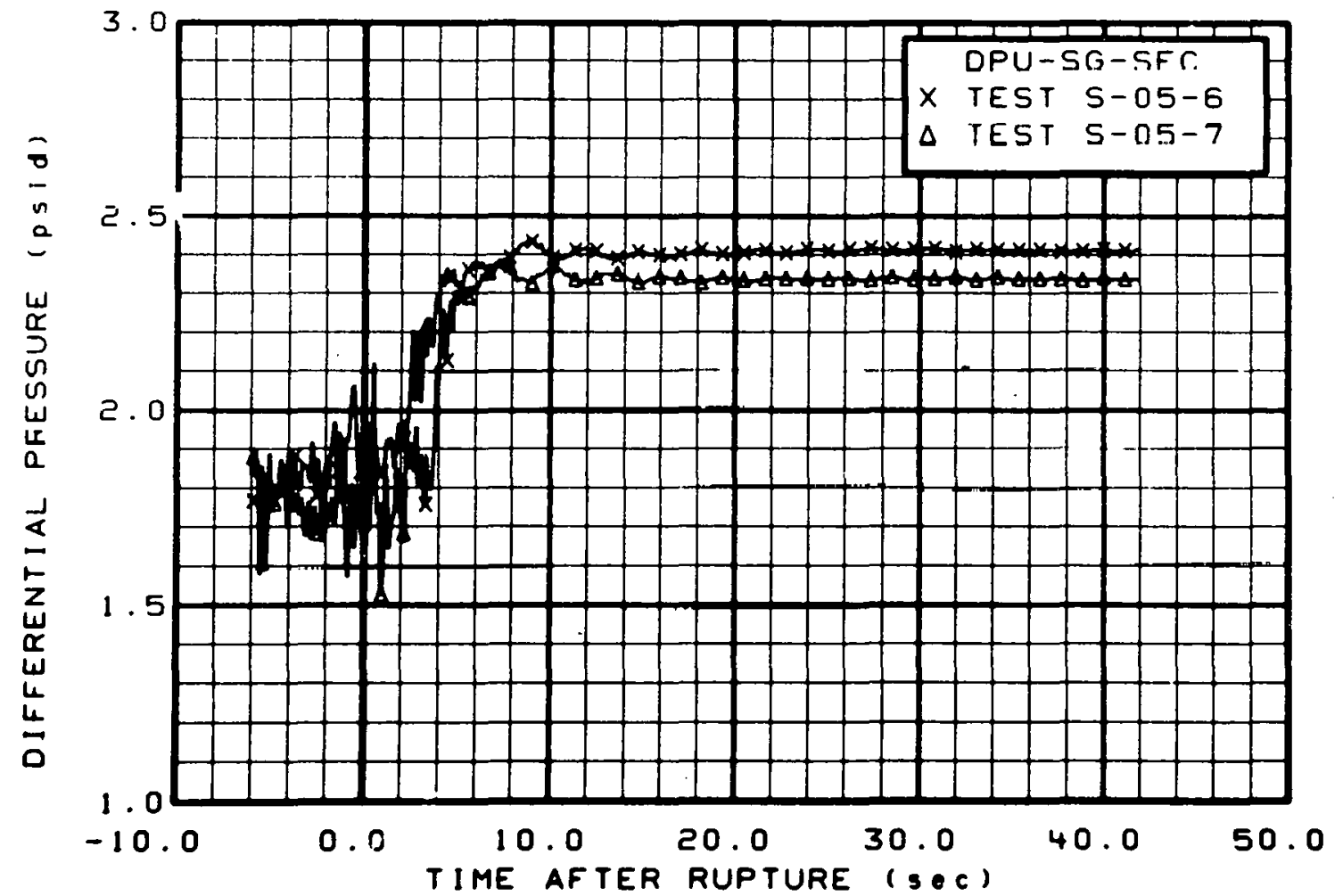

Fig. 369 Differential pressure in steam generator secondary (DPU-SG-SEC), from -6 to $42 \mathrm{sec}$. 


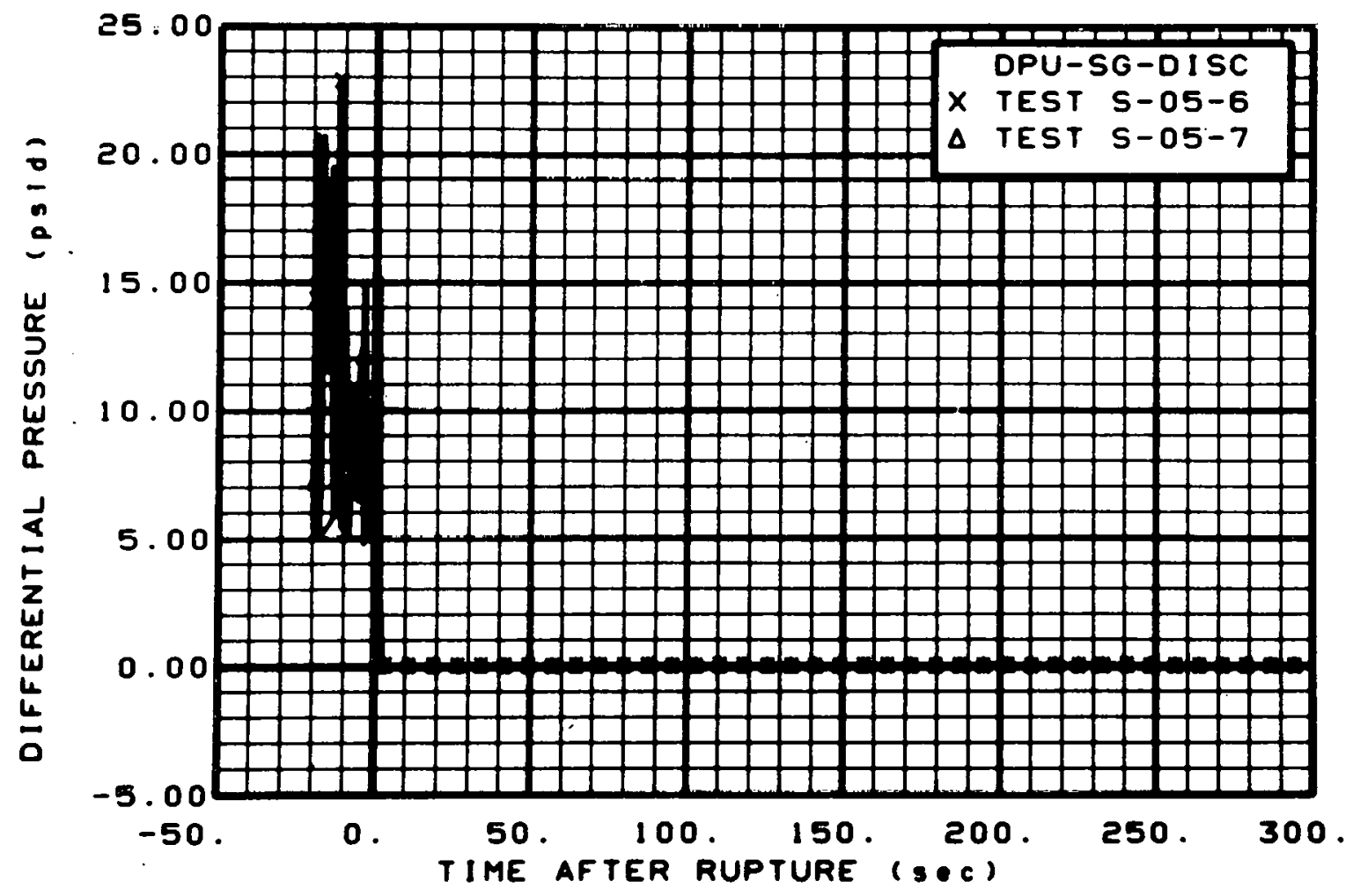

Fig. 370 Differential pressure across steam generator outlet orifice (DPU-SG-DISC), from -20 to $300 \mathrm{sec}$.

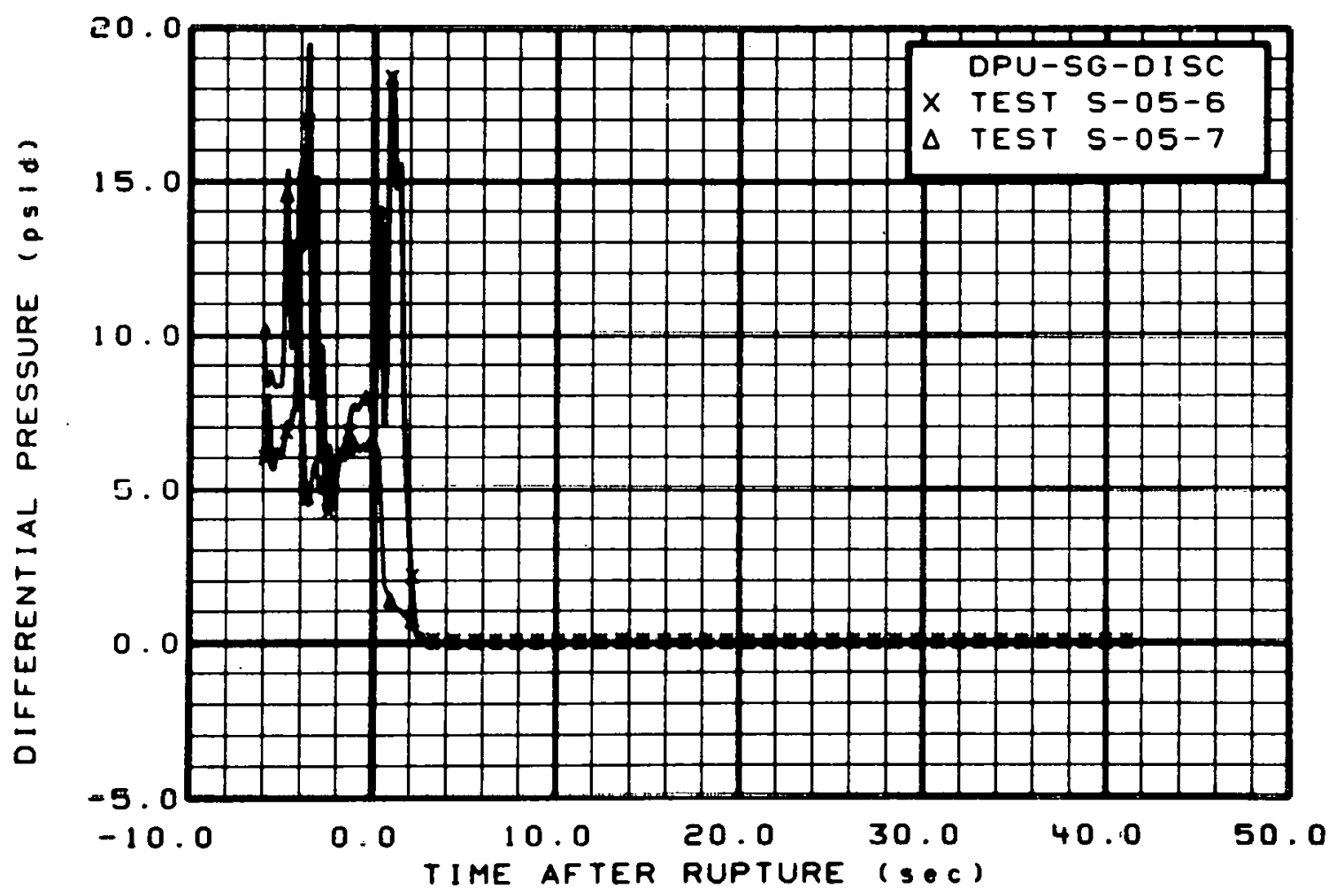

Fig. 371 Differentiàl pressure across steam generator out let orifice (DPU.SG .DISC), from -6 to 42 sec. 


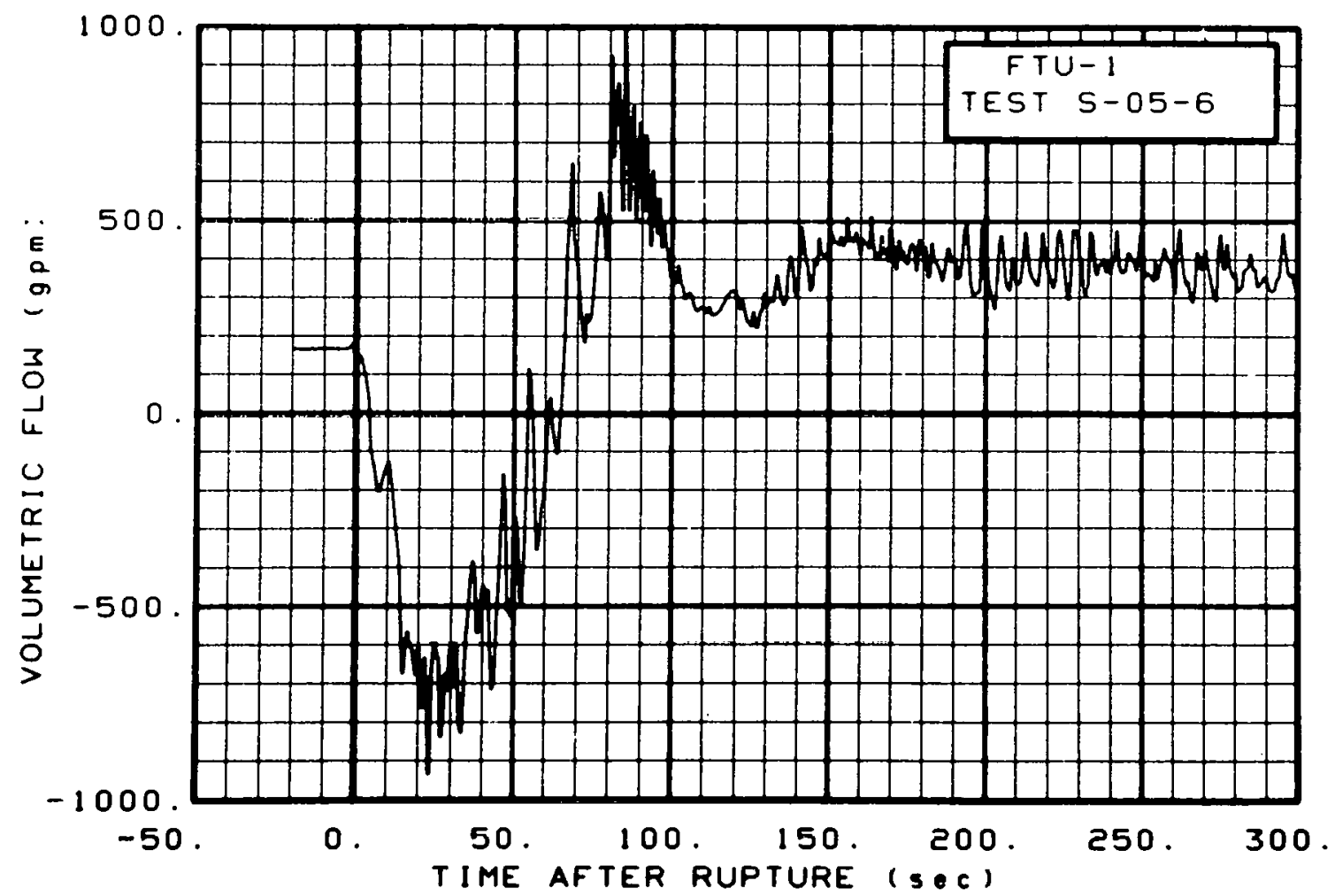

Fig. 372 Volumetric flow in intact loop, Test S-05-6 (FTU-1), from -20 to $300 \mathrm{sec}$.

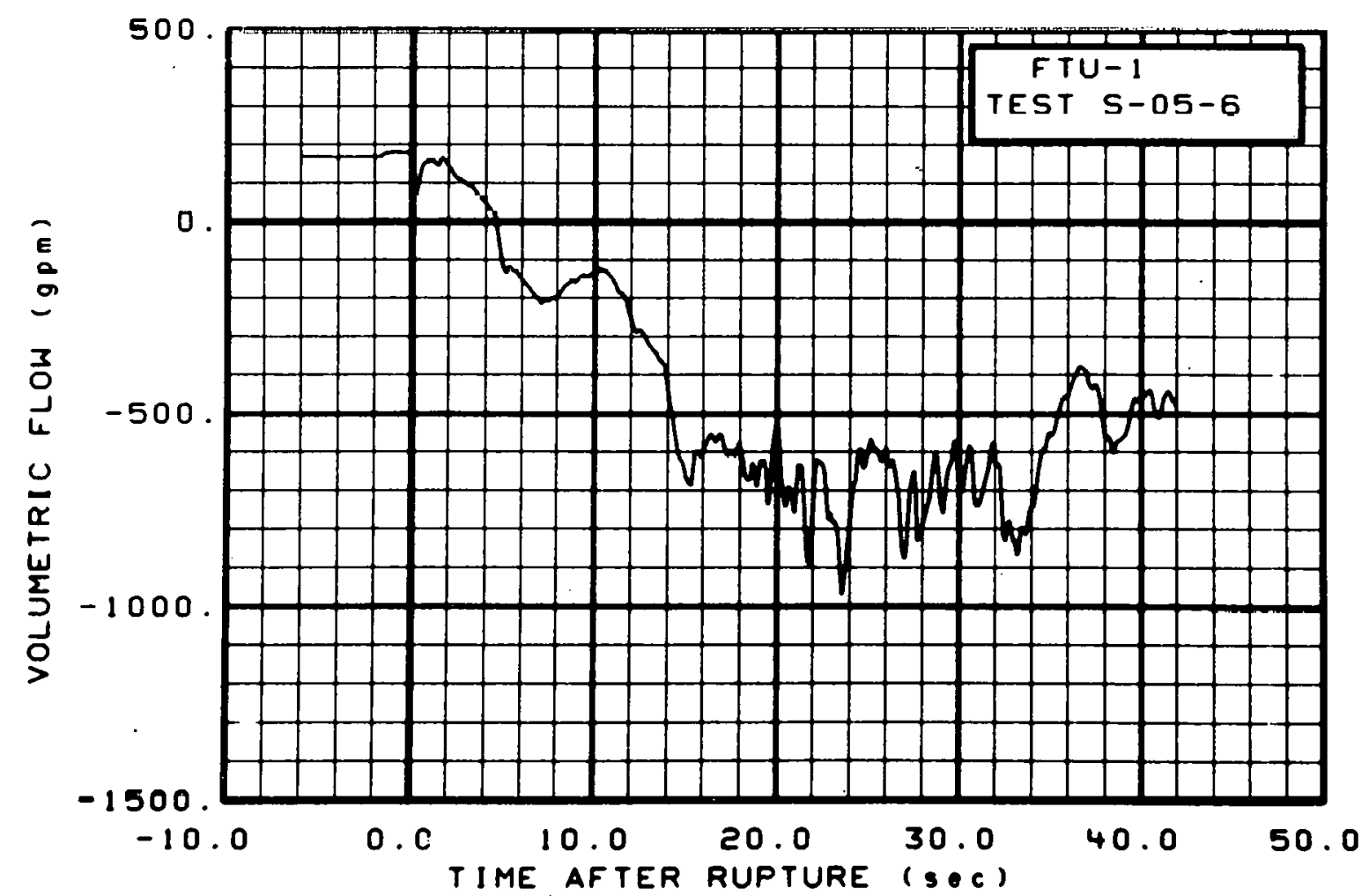

Fig. 373 Volumetric flow in intact 10op, Test S-05-6 (FTU-1), from -6 to $42 \mathrm{sec}$. 


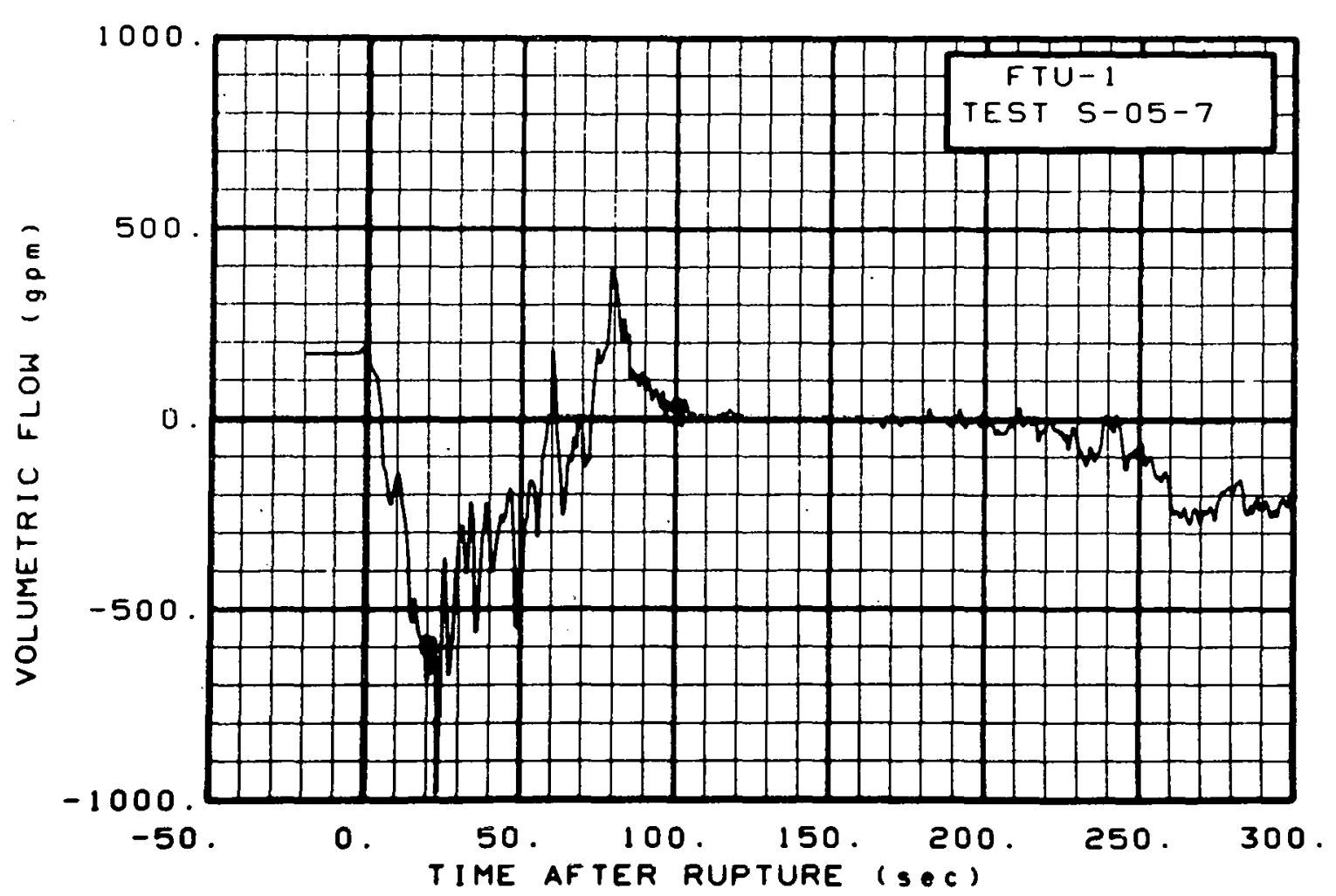

Fig. 374 Volumetric flow in intact 1oop, Test S-05-7 (FTU-1), from -20 to $300 \mathrm{sec}$.

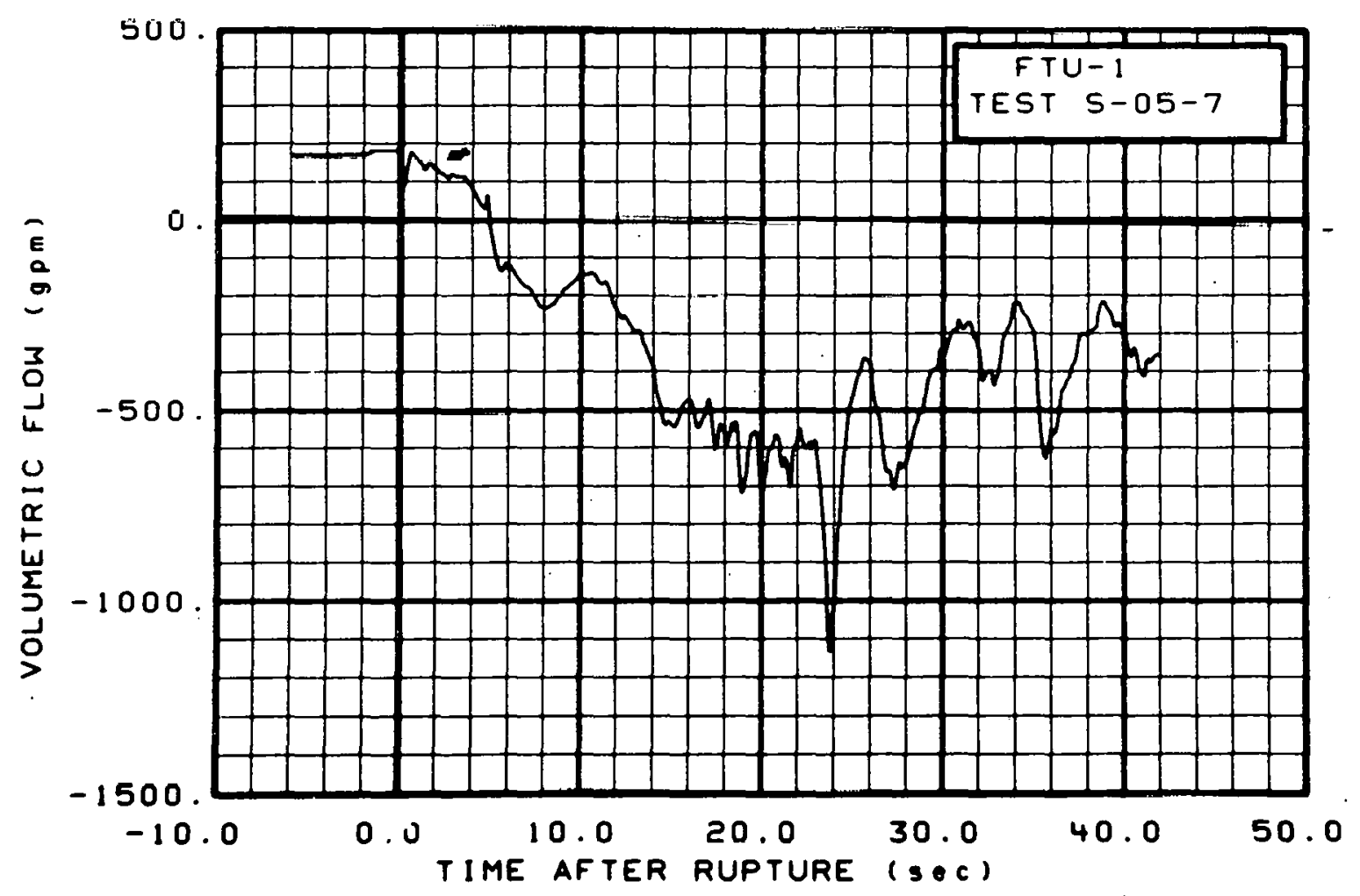

Fig. 375 Volumetric flow in intact 1oop, Test S-05-7 (FTU-1), from -6 to 42 sec. 


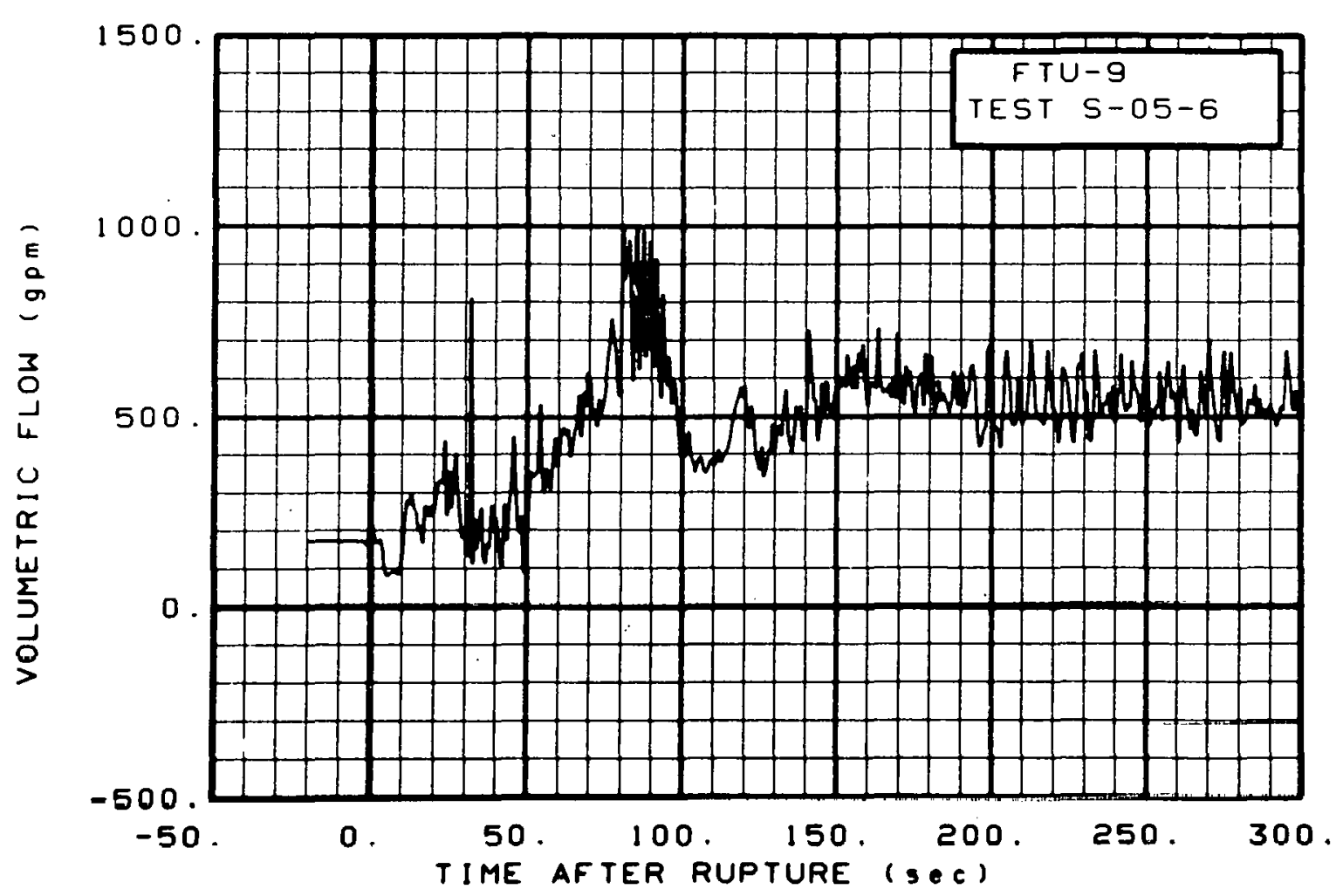

Fig. 376 Volumetric flow in intact loop, Test S-05-6 (FTU-9), from -20 to $300 \mathrm{sec}$.

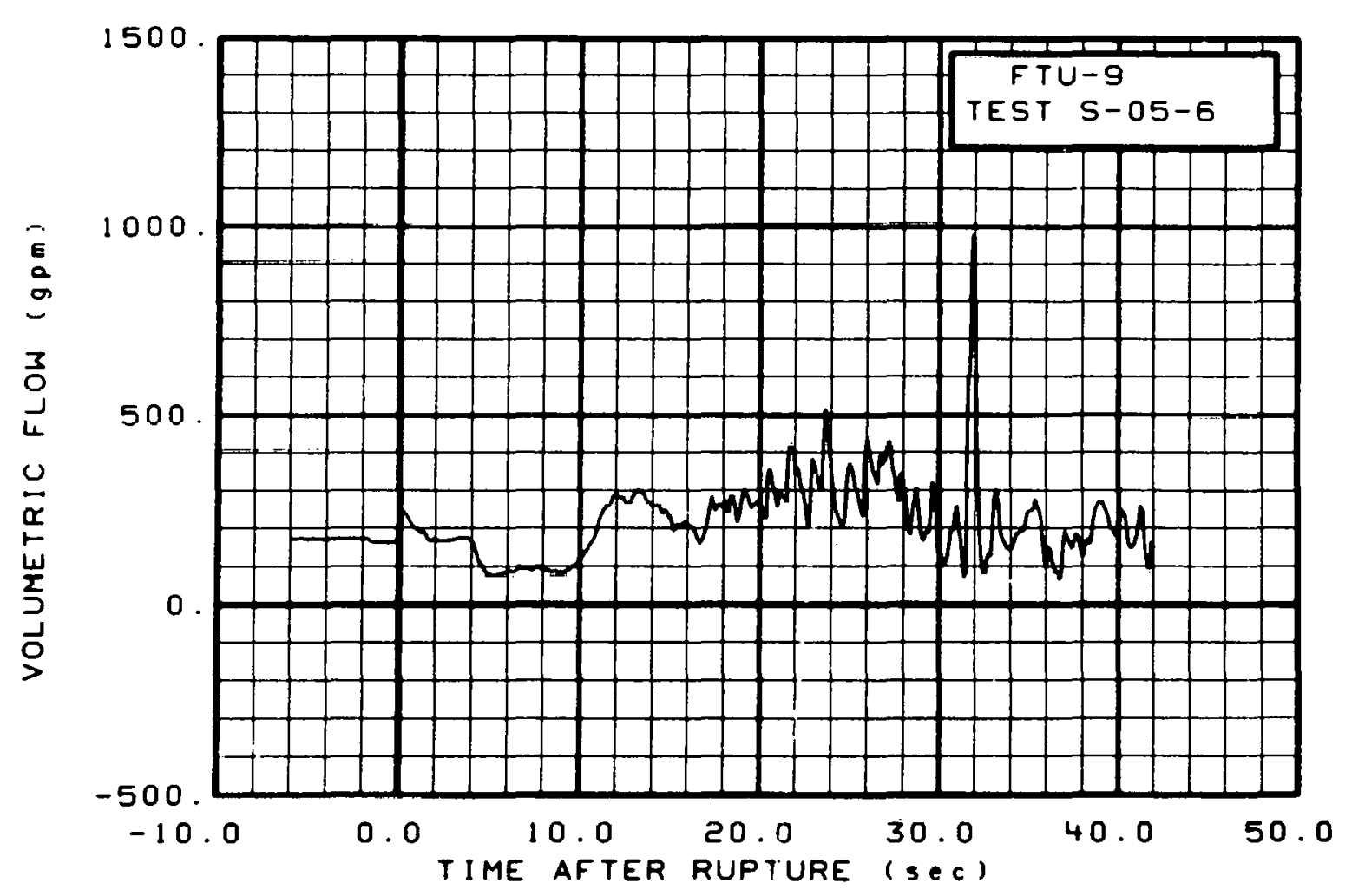

Fig. 377 Volumetric flow in intact loop, Test S-05-6 (FTU-9), from -6 to $42 \mathrm{sec}$. 


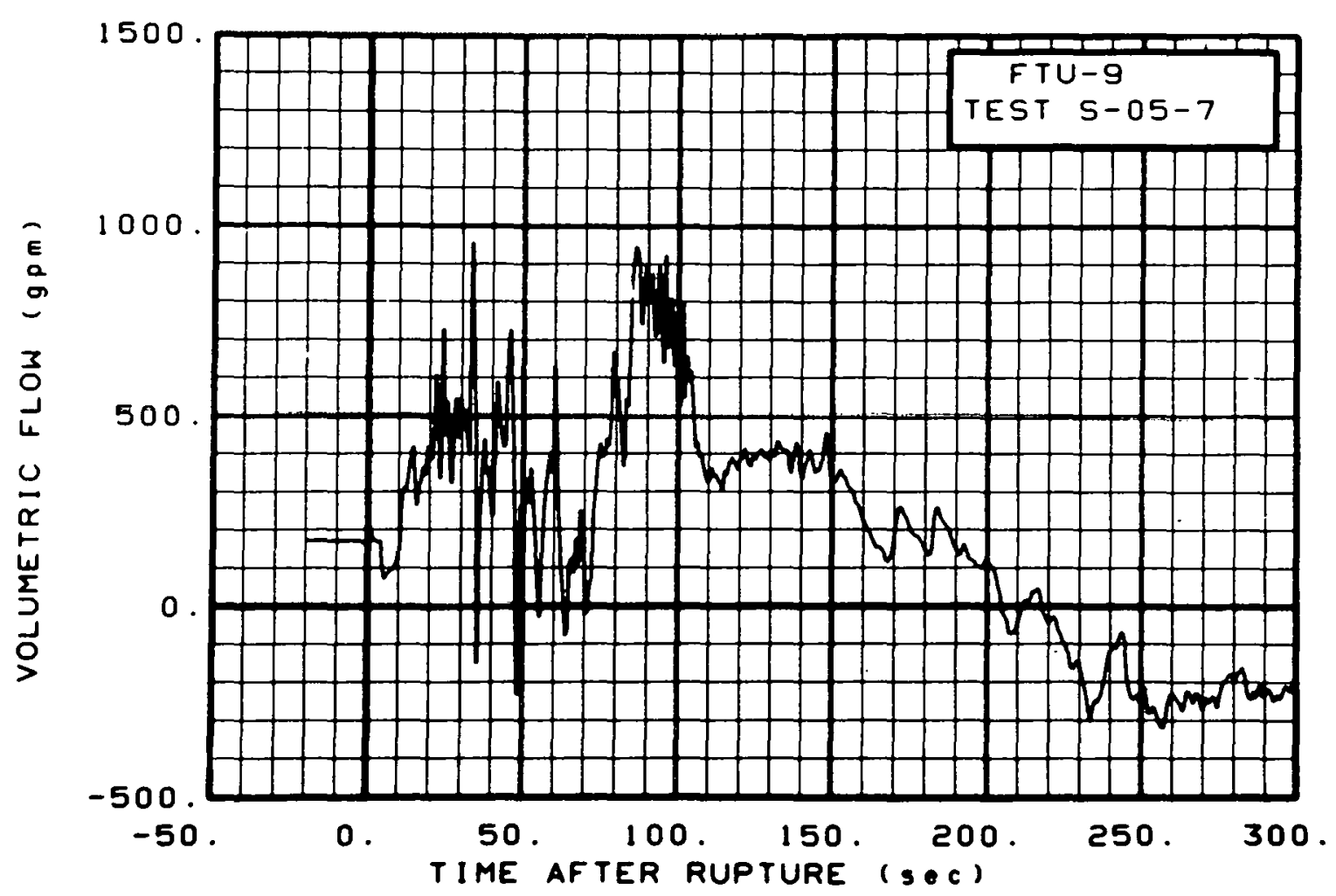

Fig. 378 Volumetric flow in intact loop, Test S-05-7 (FTU-9), from -20 to $300 \mathrm{sec}$.

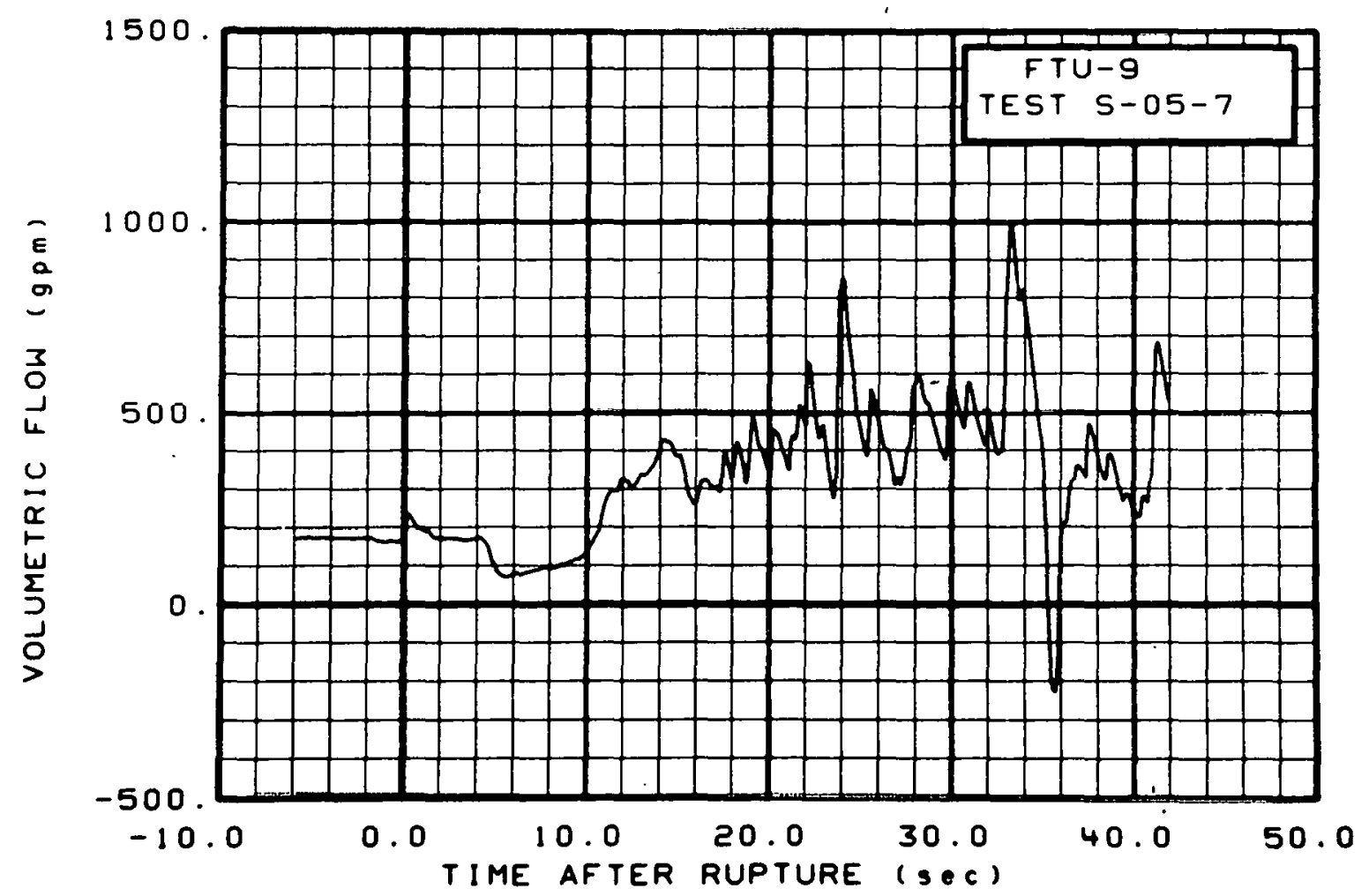

Fig. 379 Volumetric flow in intact 1oop, Test S-05-7 (FTU-9), from -6 to 42 sec. 


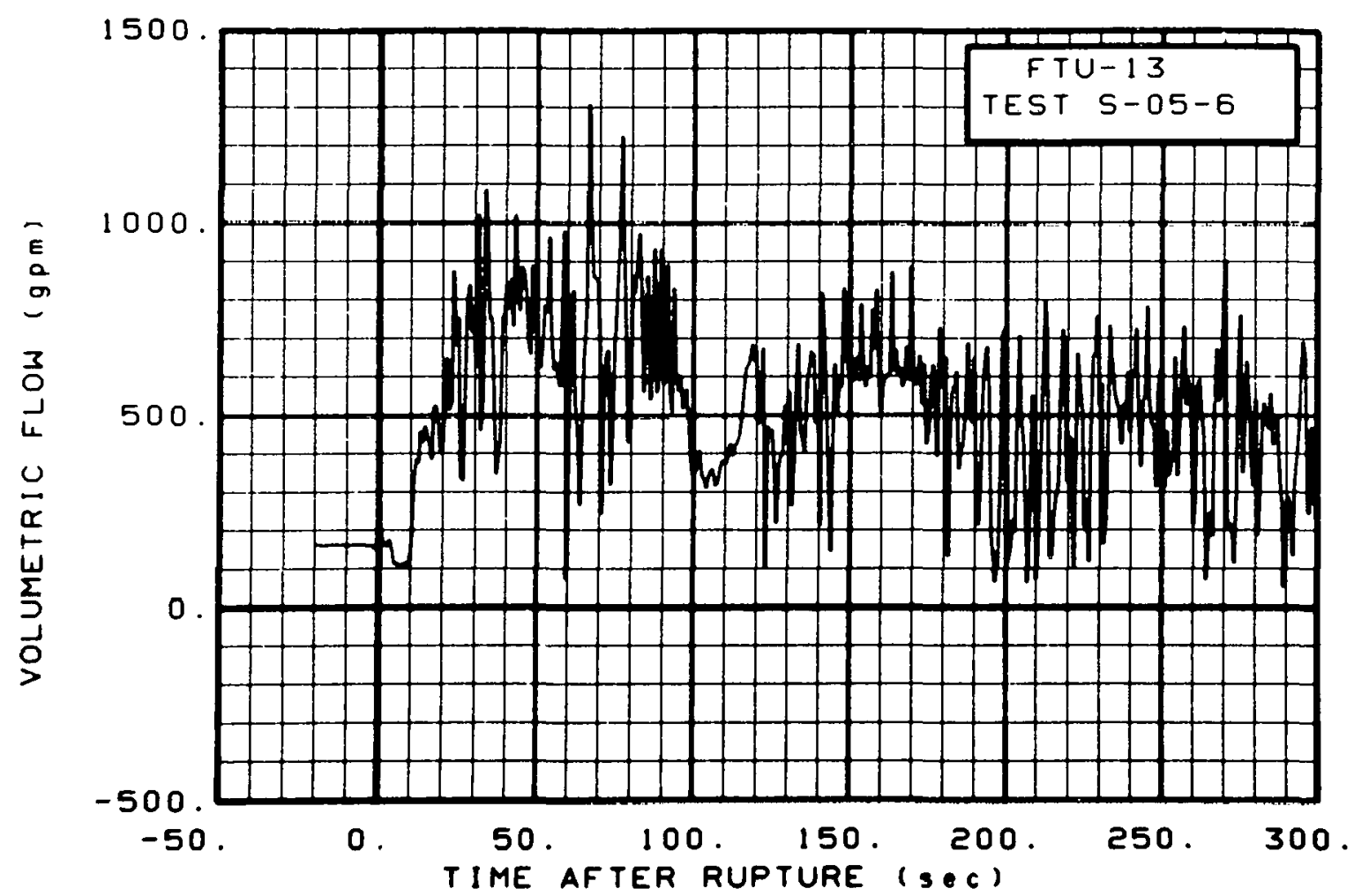

Fig. 380 Volumetric flow in intact 10op, Test S-05-6 (FTU-13), from -20 to $300 \mathrm{sec}$.

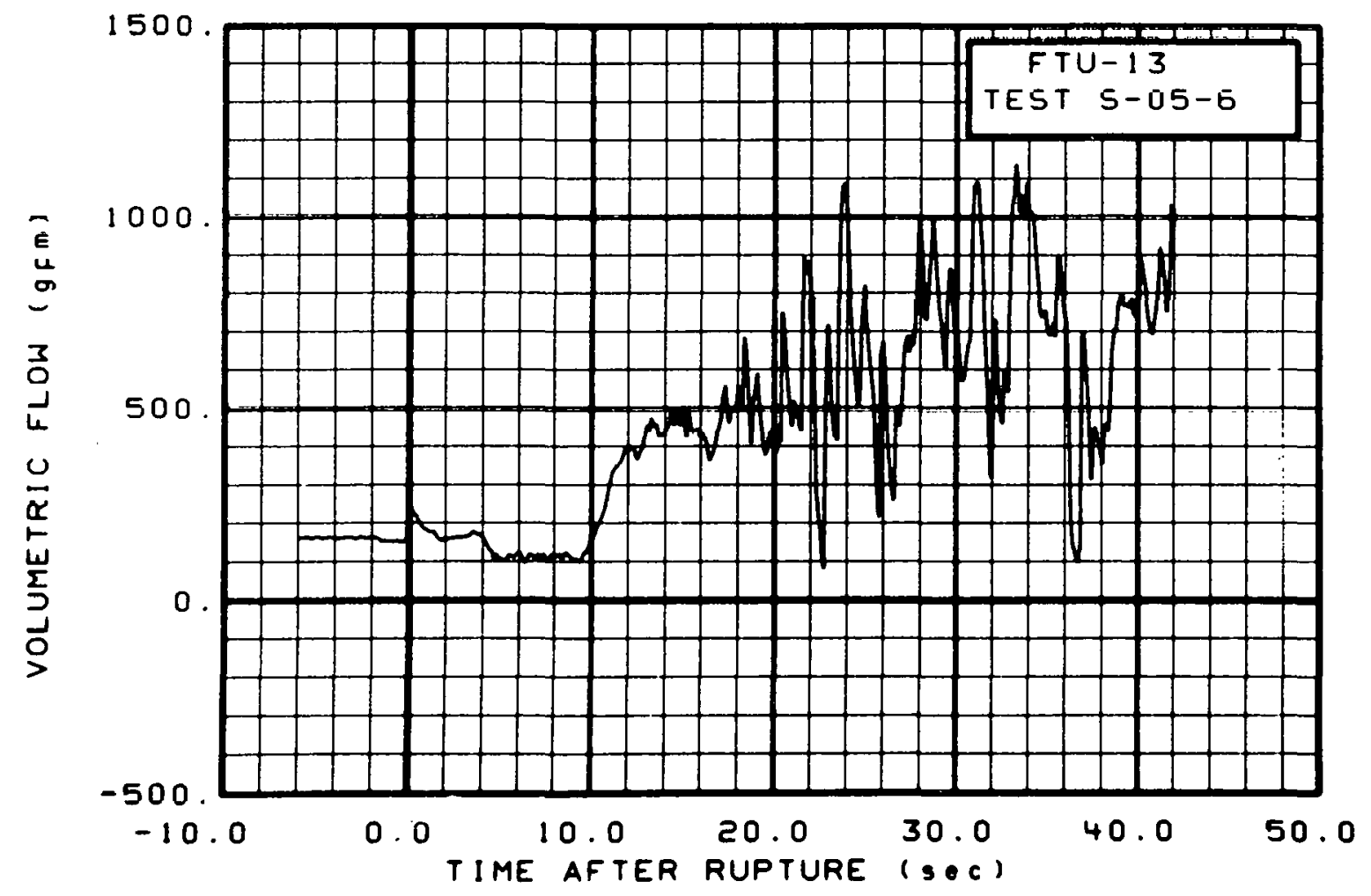

Fig. 381 Volumetric flow in intact 10op, Test S-05-6 (FTU-13), from -6 to $42 \mathrm{sec}$. 


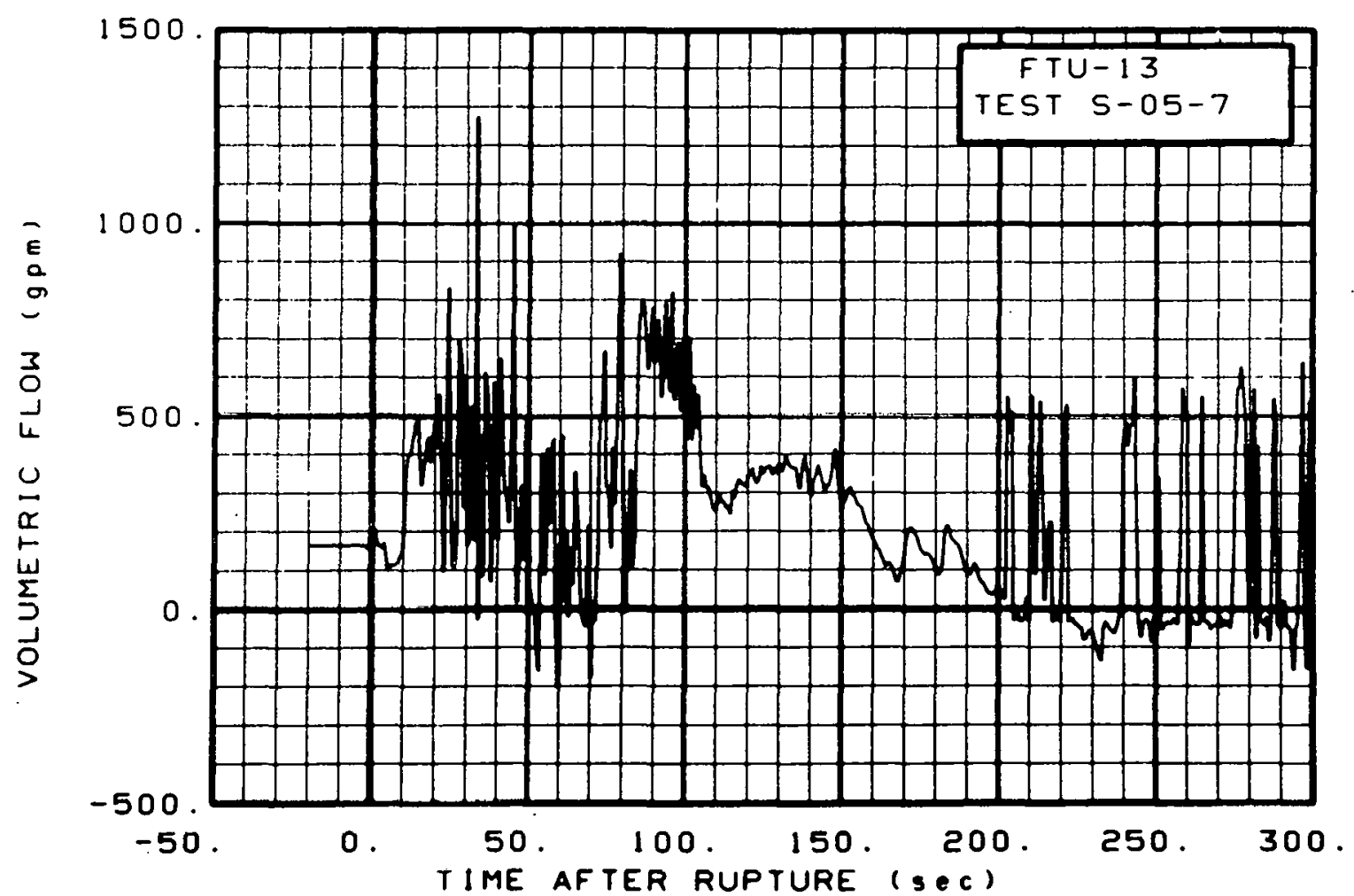

Fig. 382 Volumetric flow in intact loop, Test S-05-7 (FTU-13), from -20 to $300 \mathrm{sec}$.

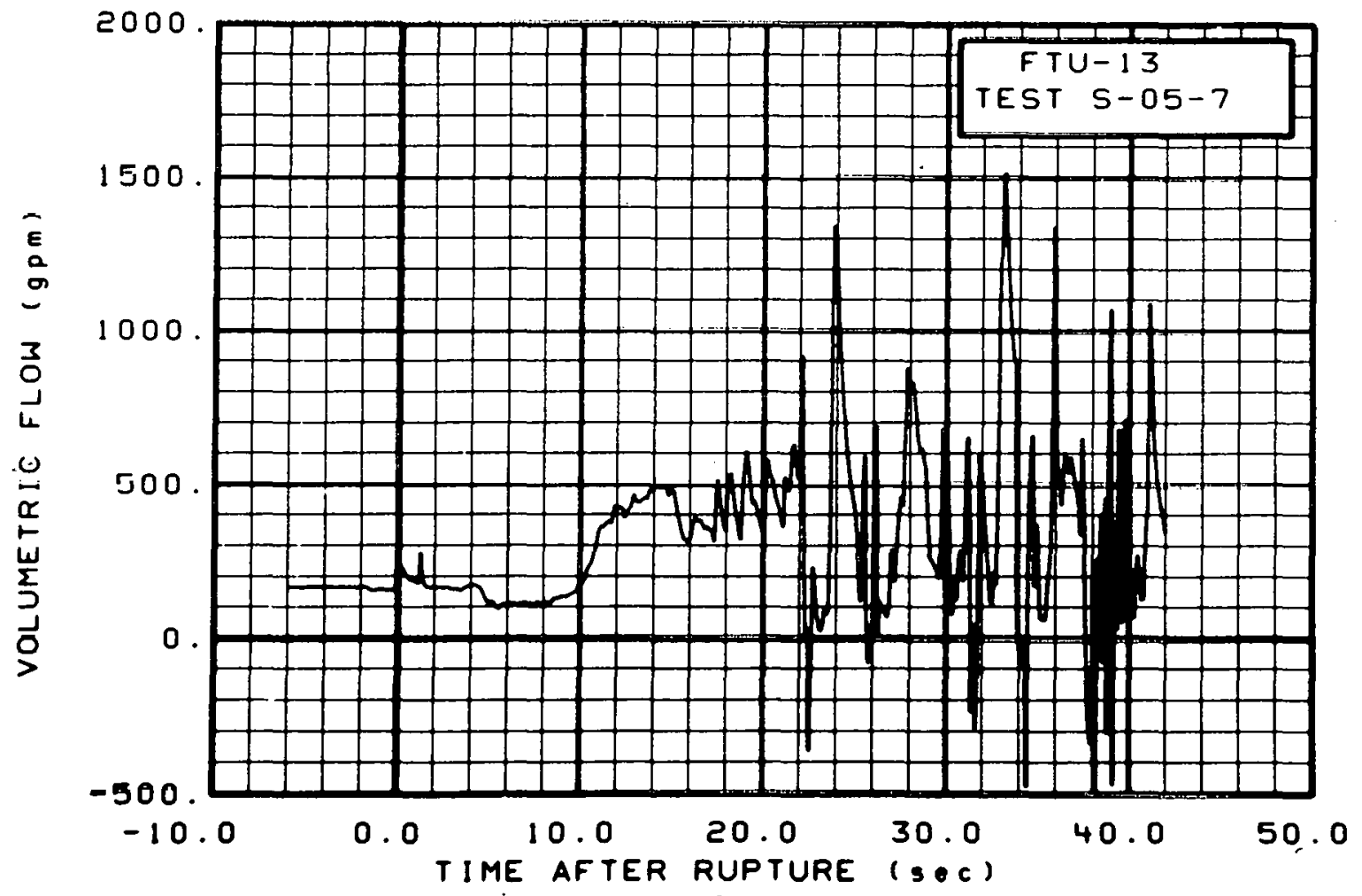

Fig. 383 Volumetric flow in intact 1oop, Test S-05-7 (FTU-13), from -6 to 42 sec. 


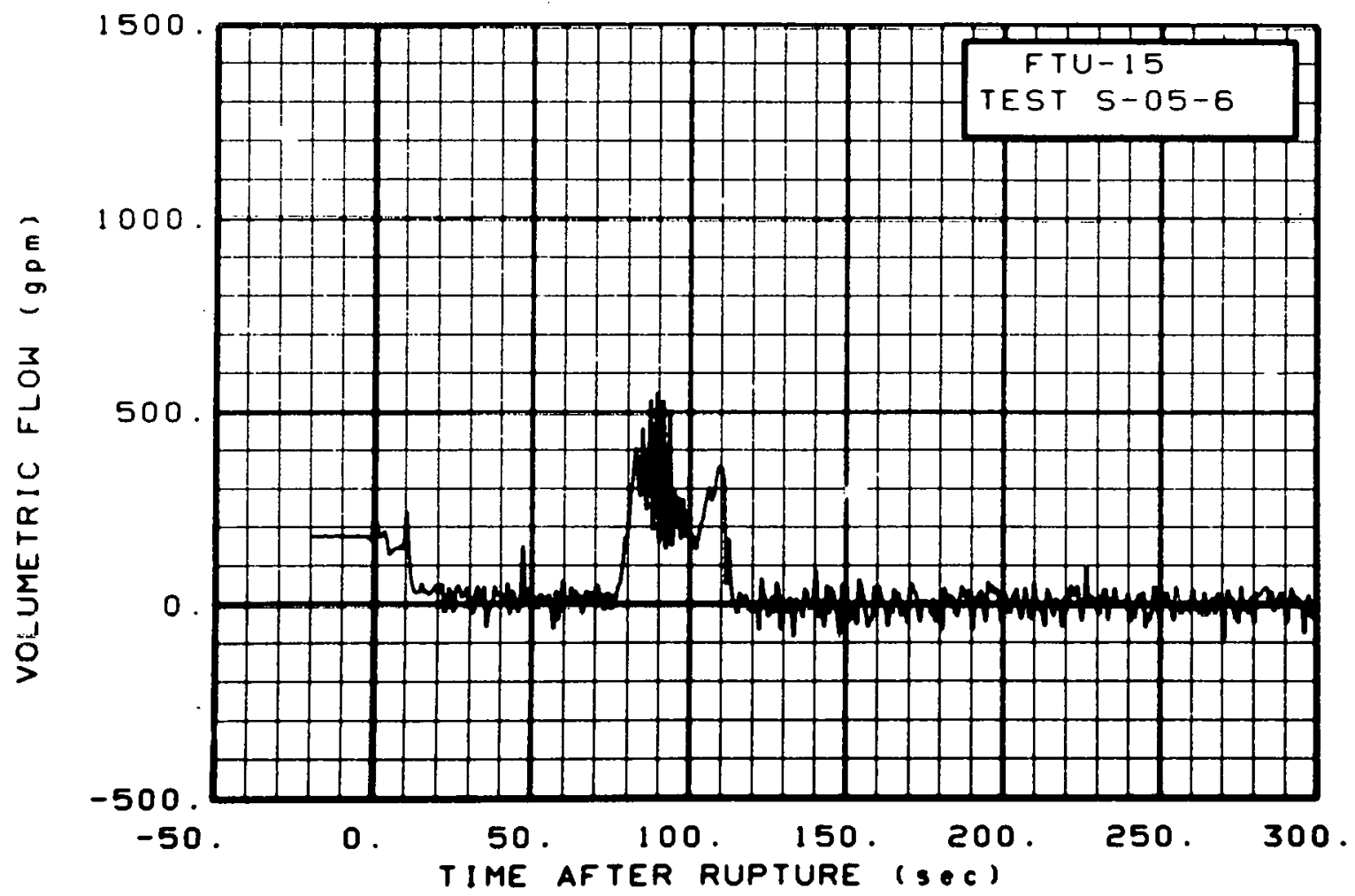

Fig. 384 Volumetric flow in intact loop, Test S-05-6 (FTU-15), from -20 to $300 \mathrm{sec}$.

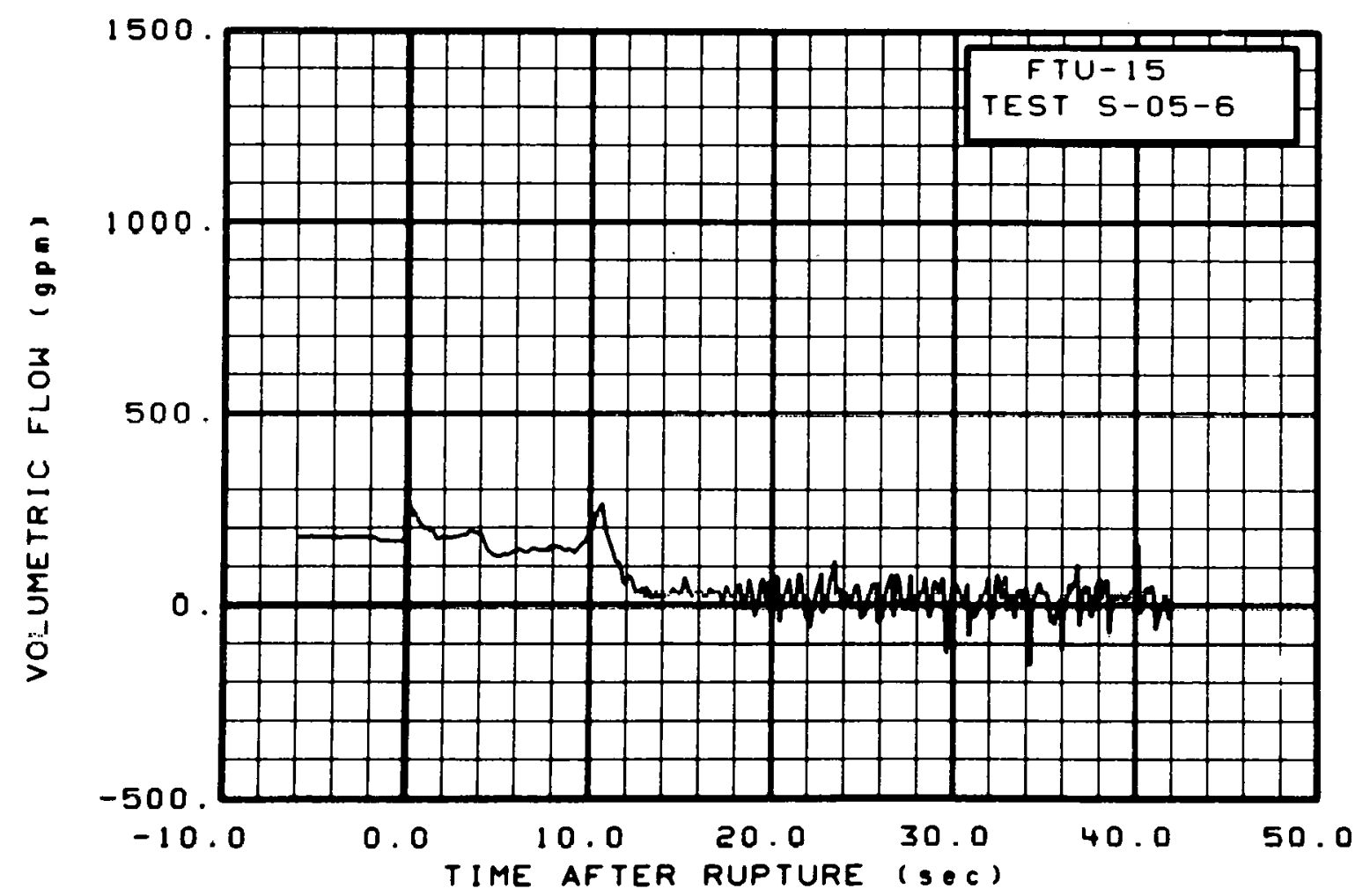

Fig. 385 Volumetric flow in intact loop, Test S-05-6 (FTU-15), from -6 to $42 \mathrm{sec}$. 


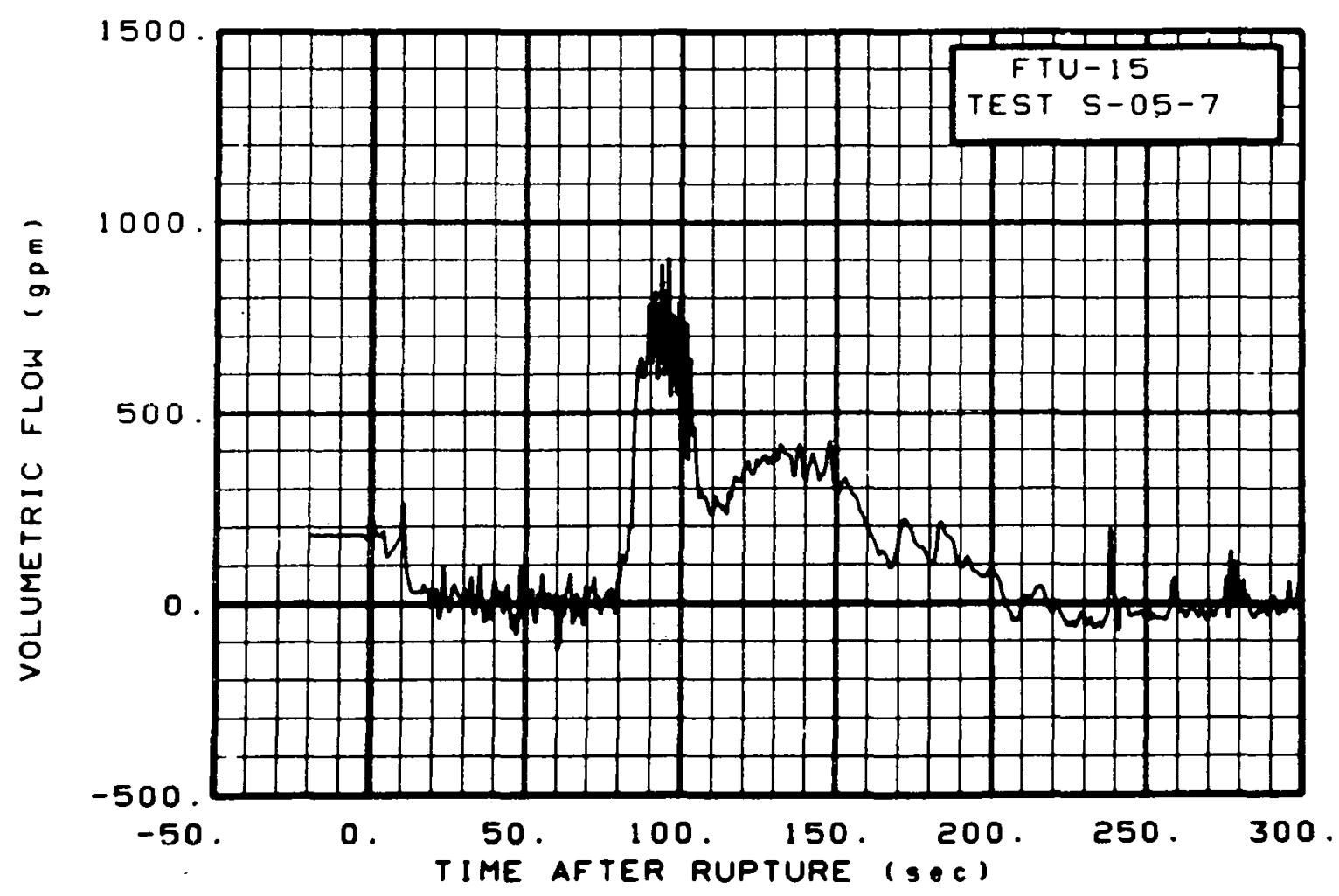

Fig. 386 Volumetric flow in intact 1oop, Test S-05-7 (FTU-15), from -20 to $300 \mathrm{sec}$.

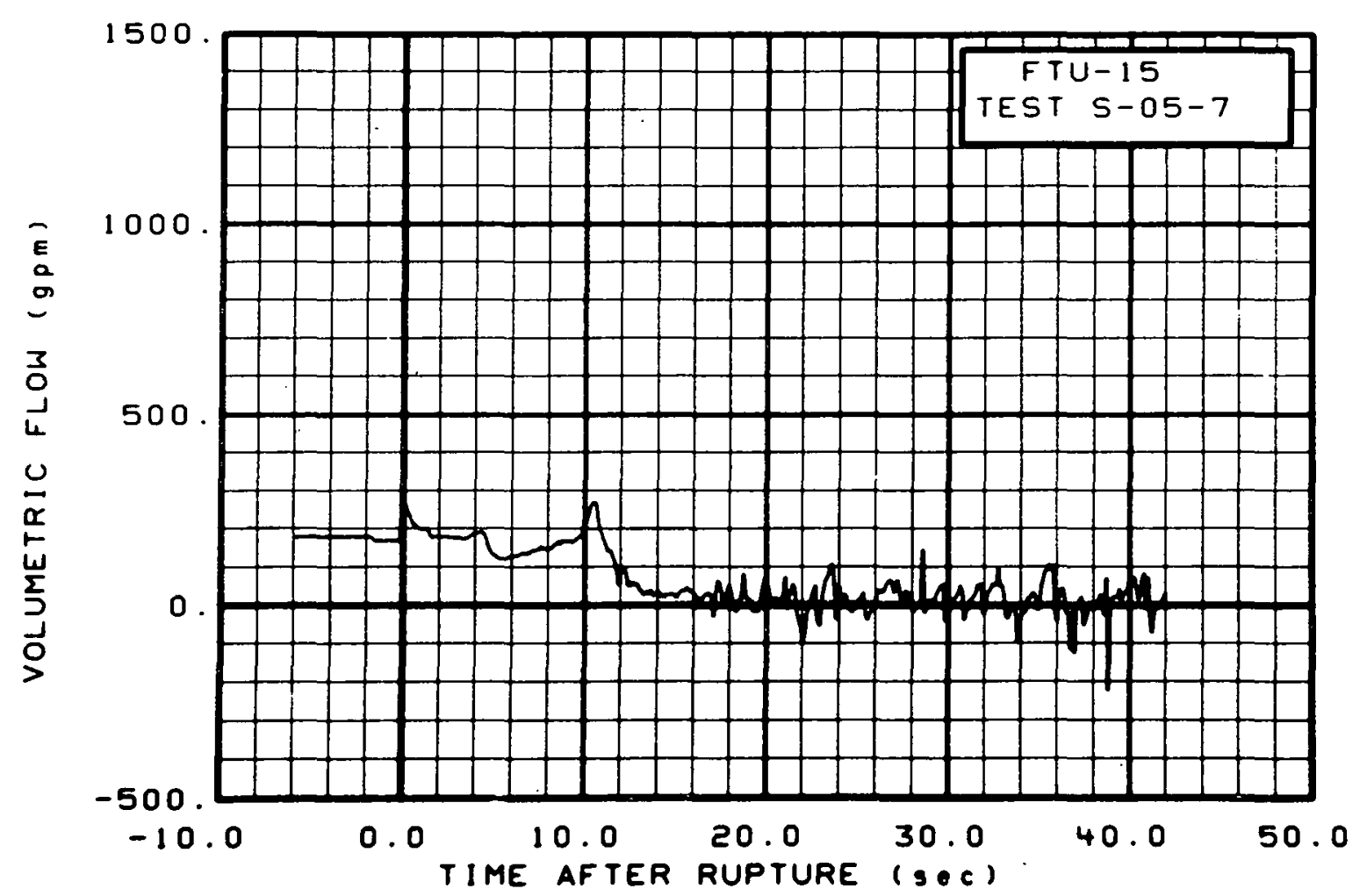

Fig. 387 Volumetric flow in intact 10op, Test S-05-7 (FTU-15), from -6 to $42 \mathrm{sec}$. 


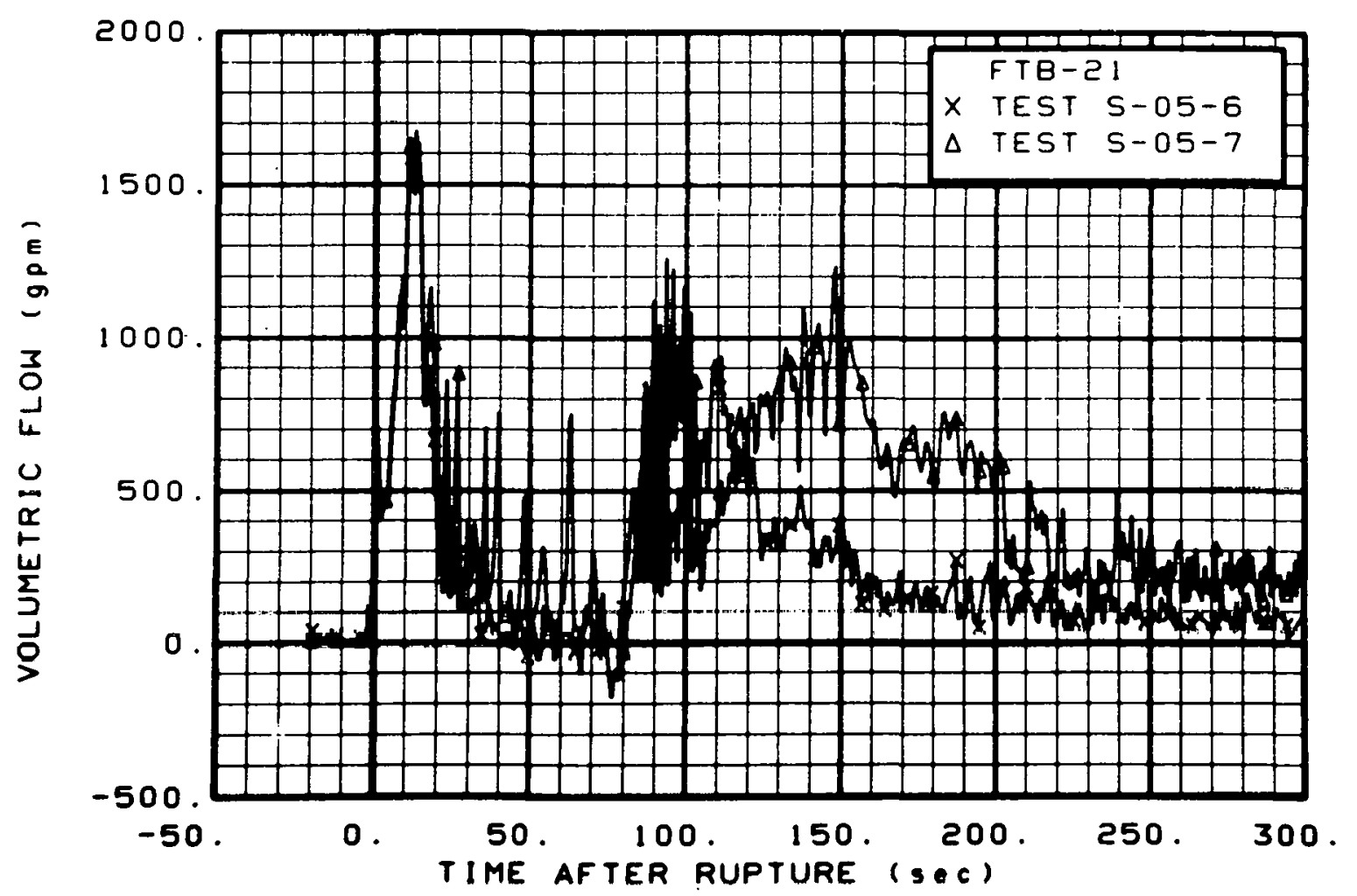

Fig. 388 Volumetric flow in broken loop (FTB-21), from -20 to $300 \mathrm{sec}$.

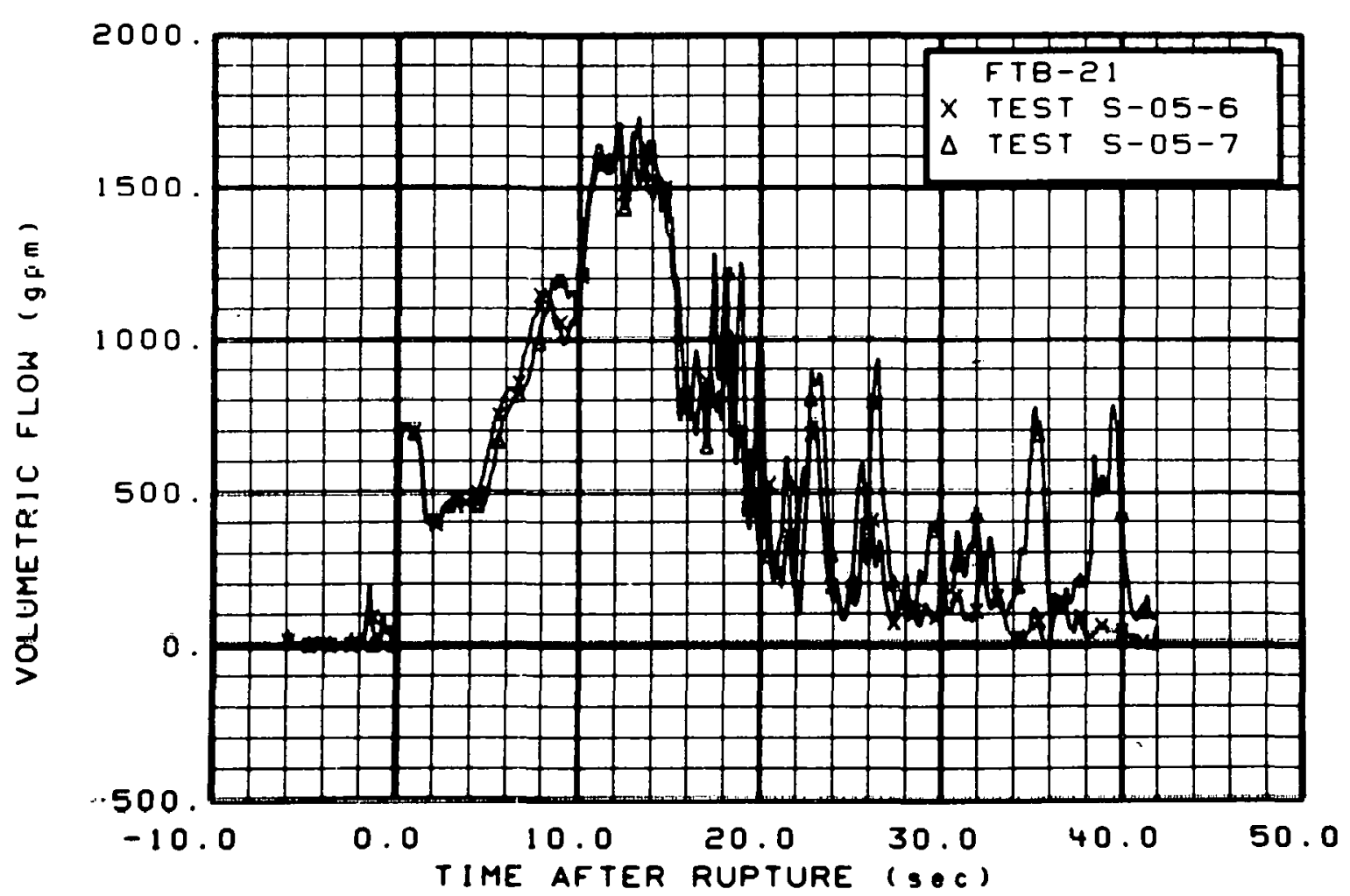

Fig. 389 Volumetric flow in broken 10op (FTB-21), from -6 to $42 \mathrm{sec}$. 


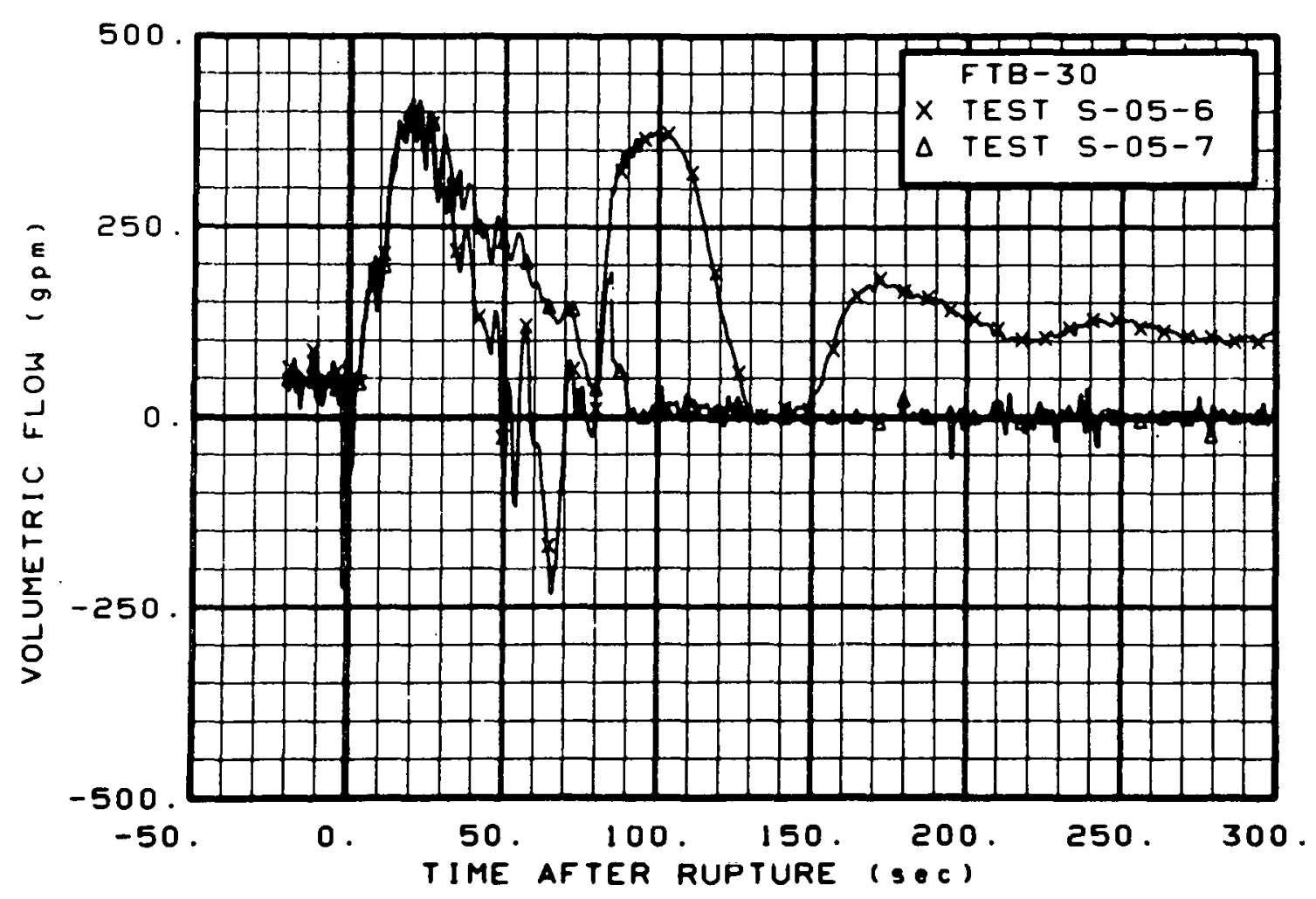

Fig. 390 Volumetric flow in broken loop (FTB-30), from -20 to $300 \mathrm{sec}$.

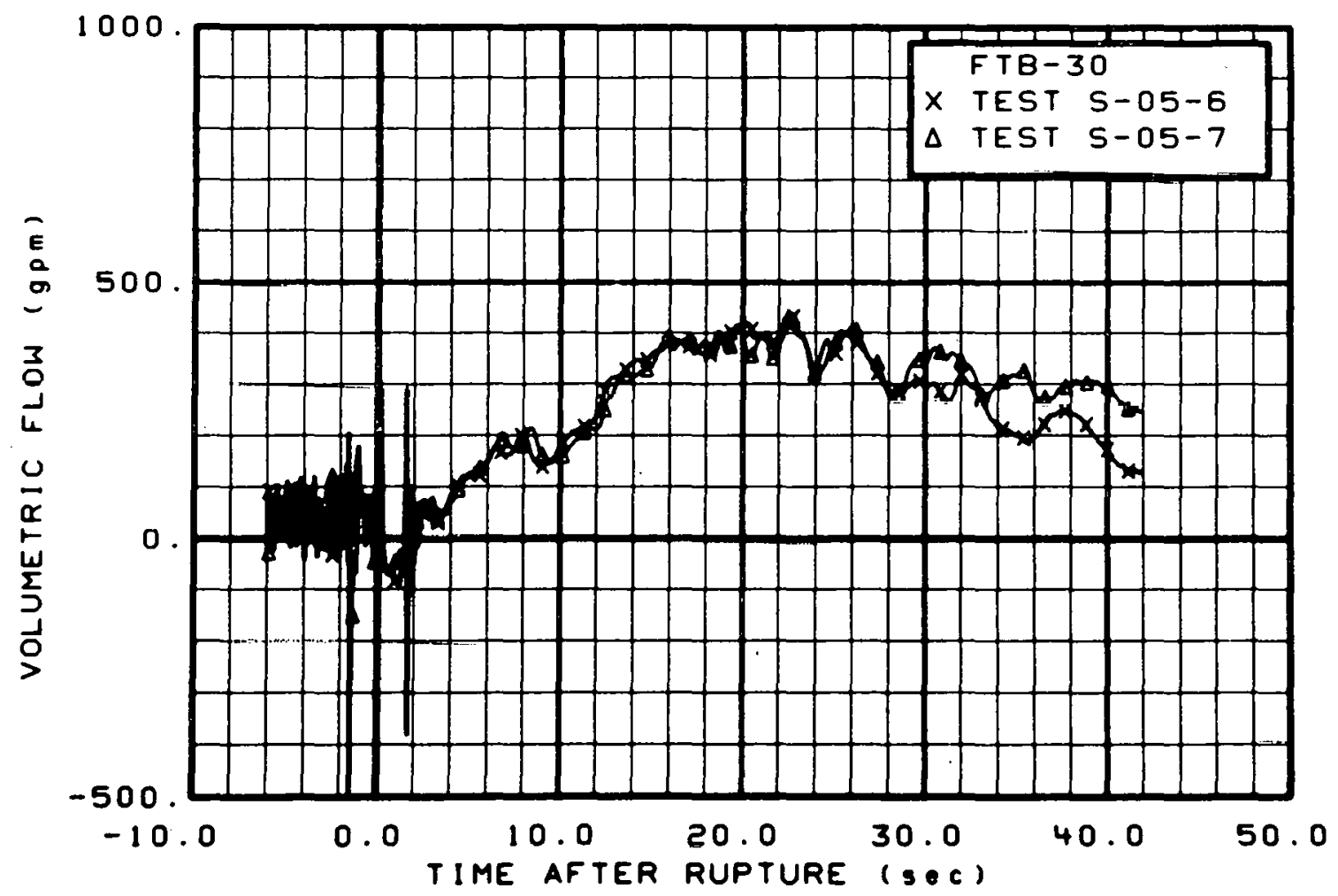

Fig. 391 Volumetric flow in broken loop (FTB-30), from -6 to $42 \mathrm{sec}$. 


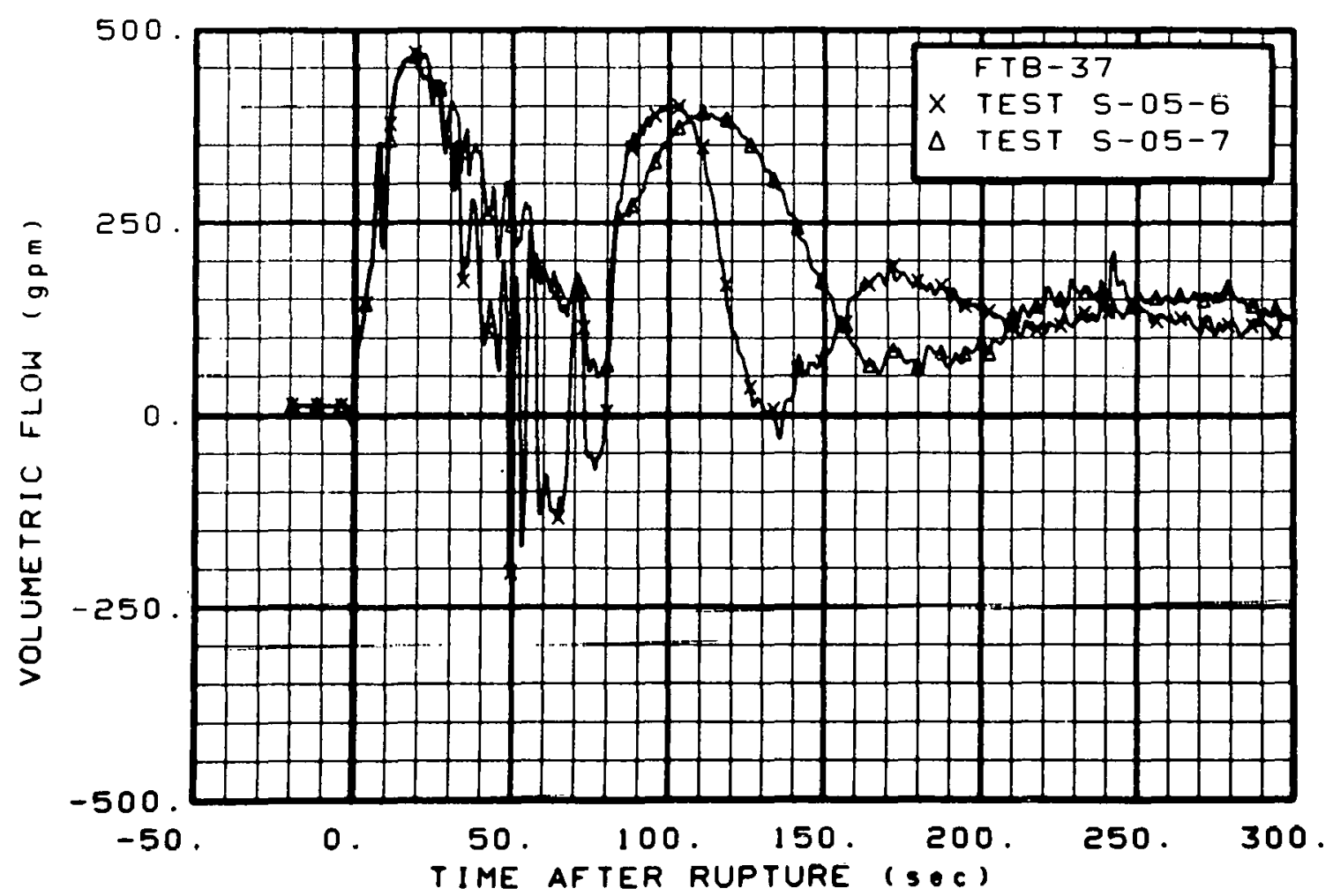

Fig. 392 Volumetric flow in broken loop (FTB-37), from -20 to $300 \mathrm{sec}$.

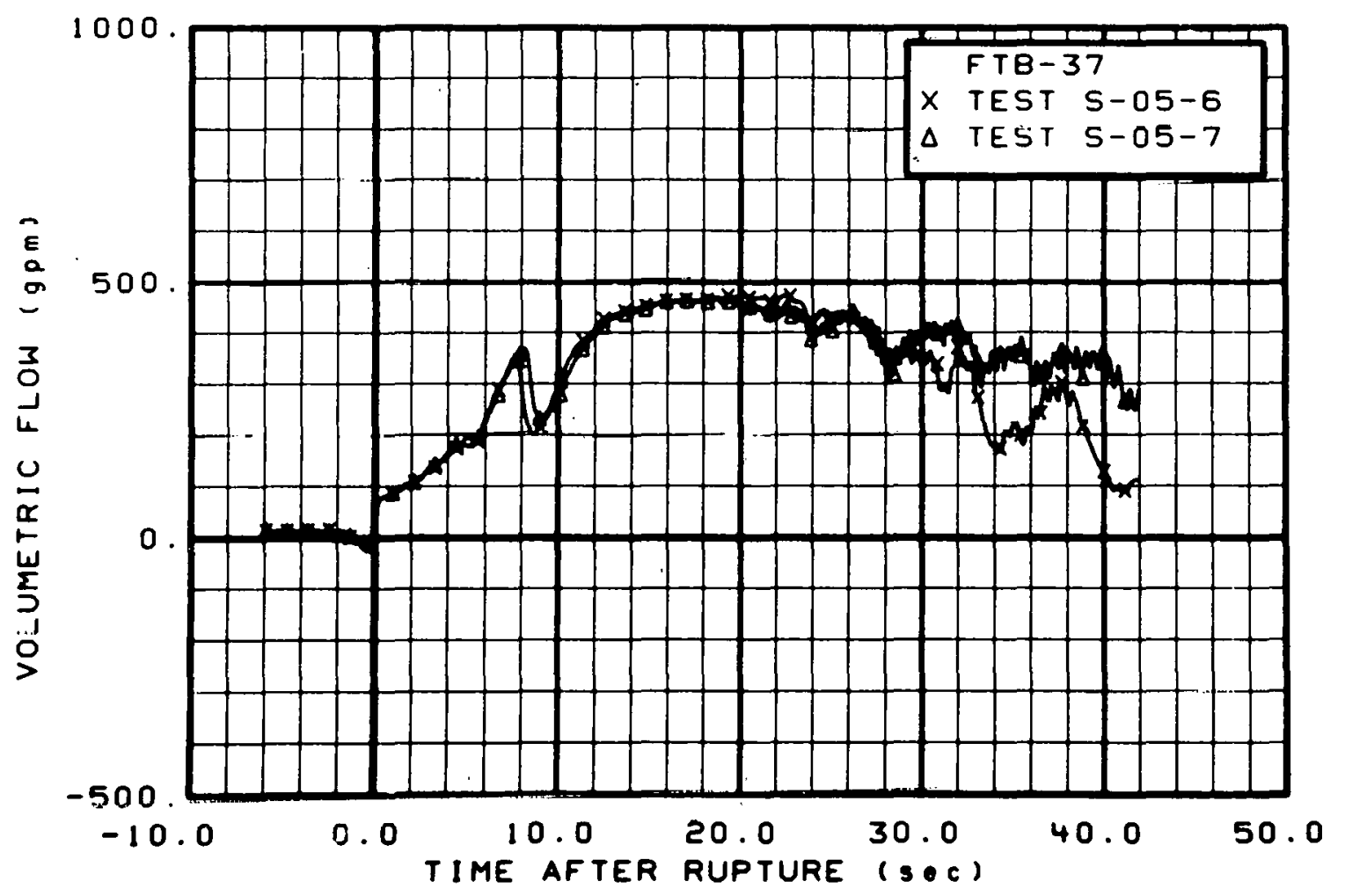

Fig. 393 Volumetric flow in broken loop (FTB-37), from -6 to $42 \mathrm{sec}$. 


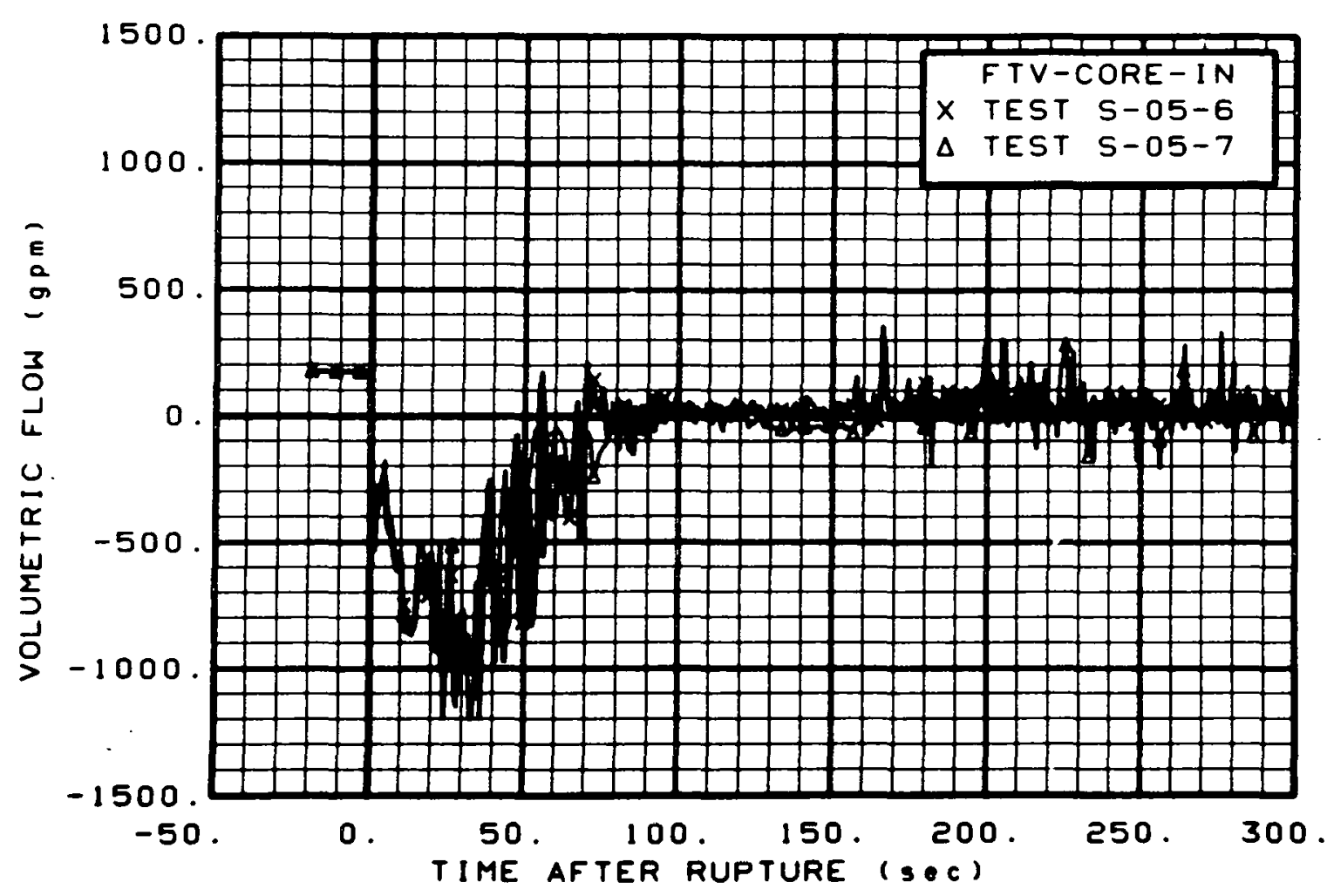

Fig. 394 Volumetric flow in core entrance (FTV-CORE-IN), from -20 to $300 \mathrm{sec}$.

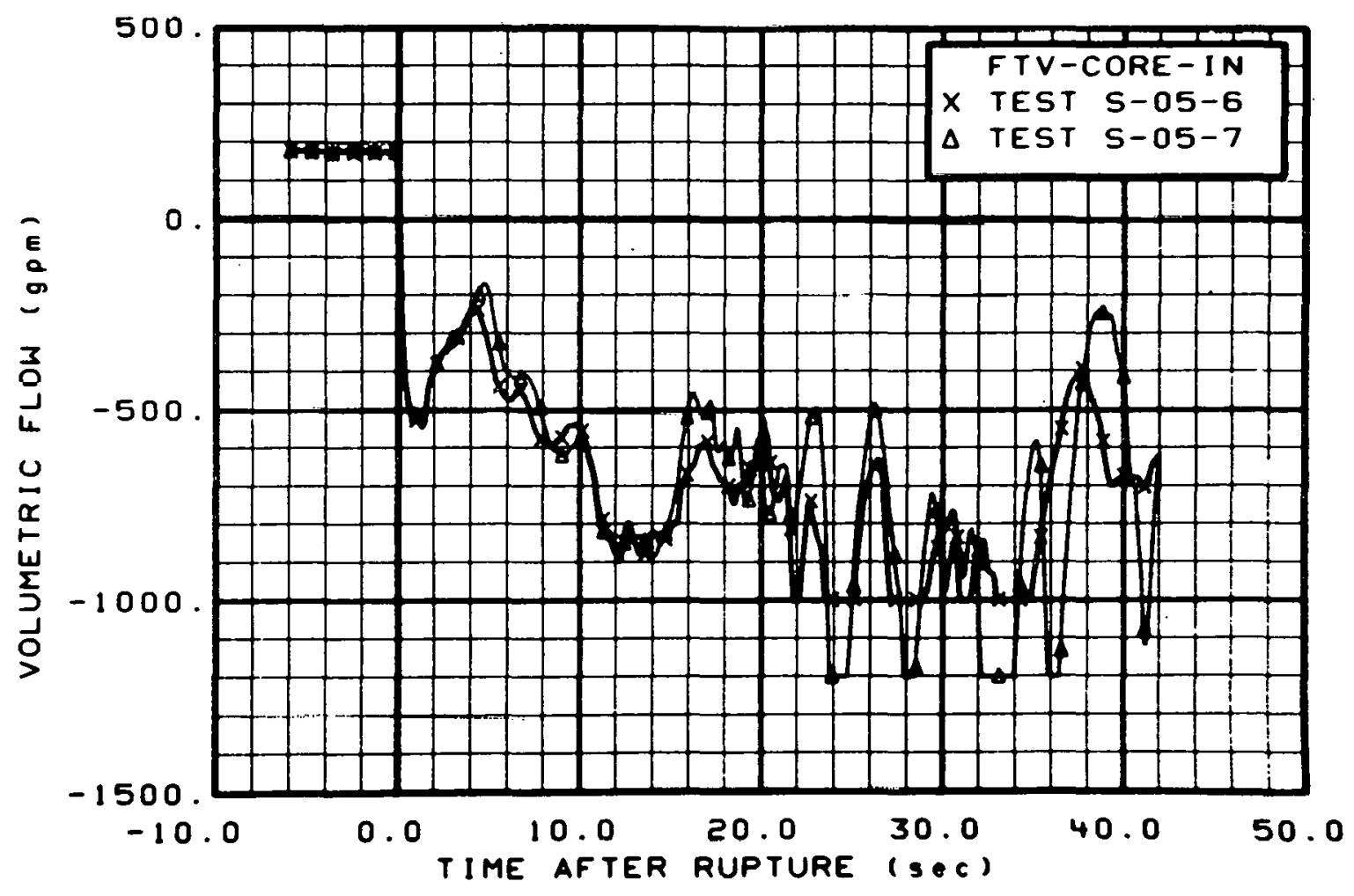

Fig. 395 Volumetric. flow in core entrance (FTV-CORE-IN), from -6 to $42 \mathrm{sec}$. 


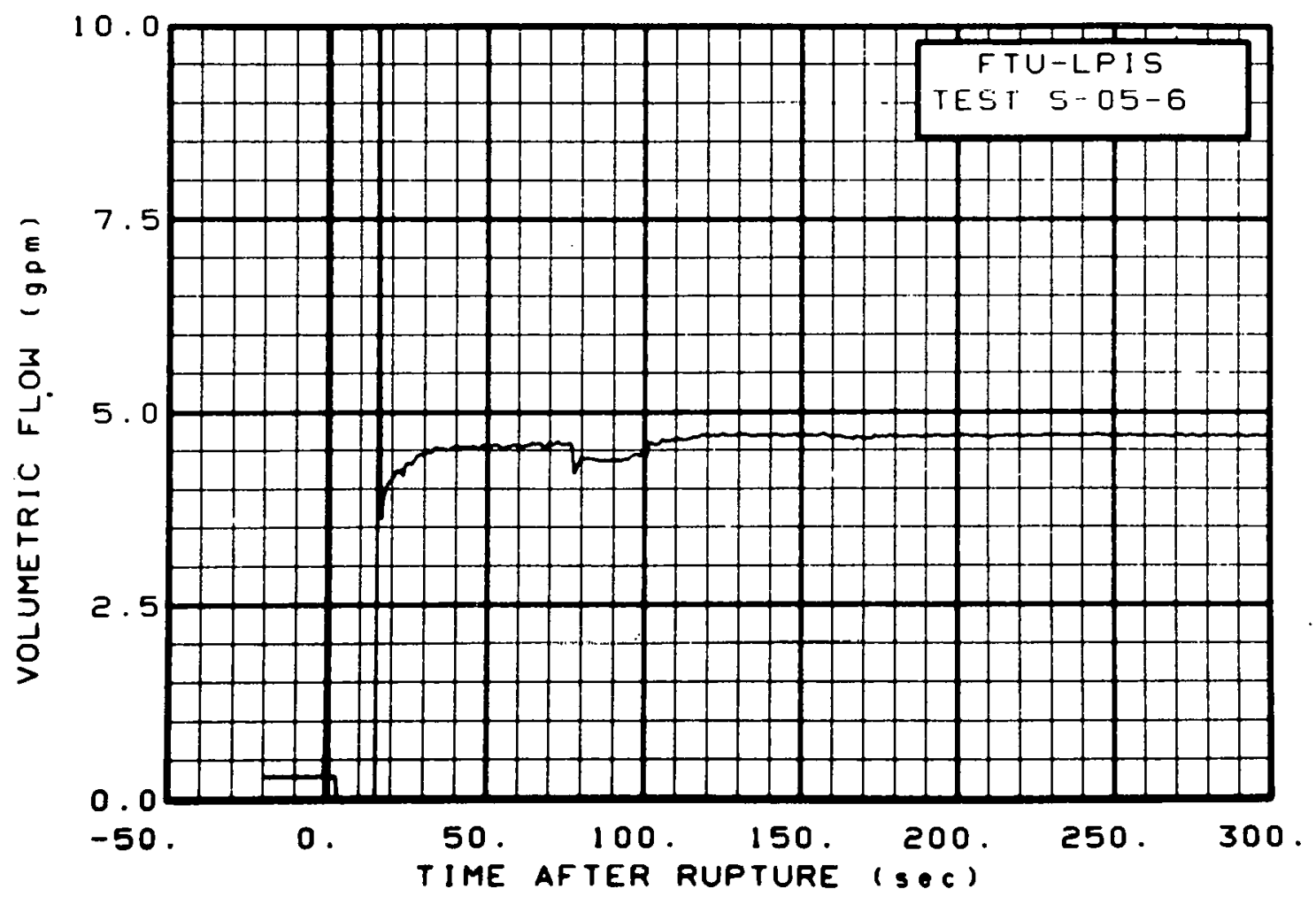

Fig. 396 Volumetric flow in intact loop low pressure injection line, Test S-05-6 (FTU-LPIS), from -20 to $300 \mathrm{sec}$.

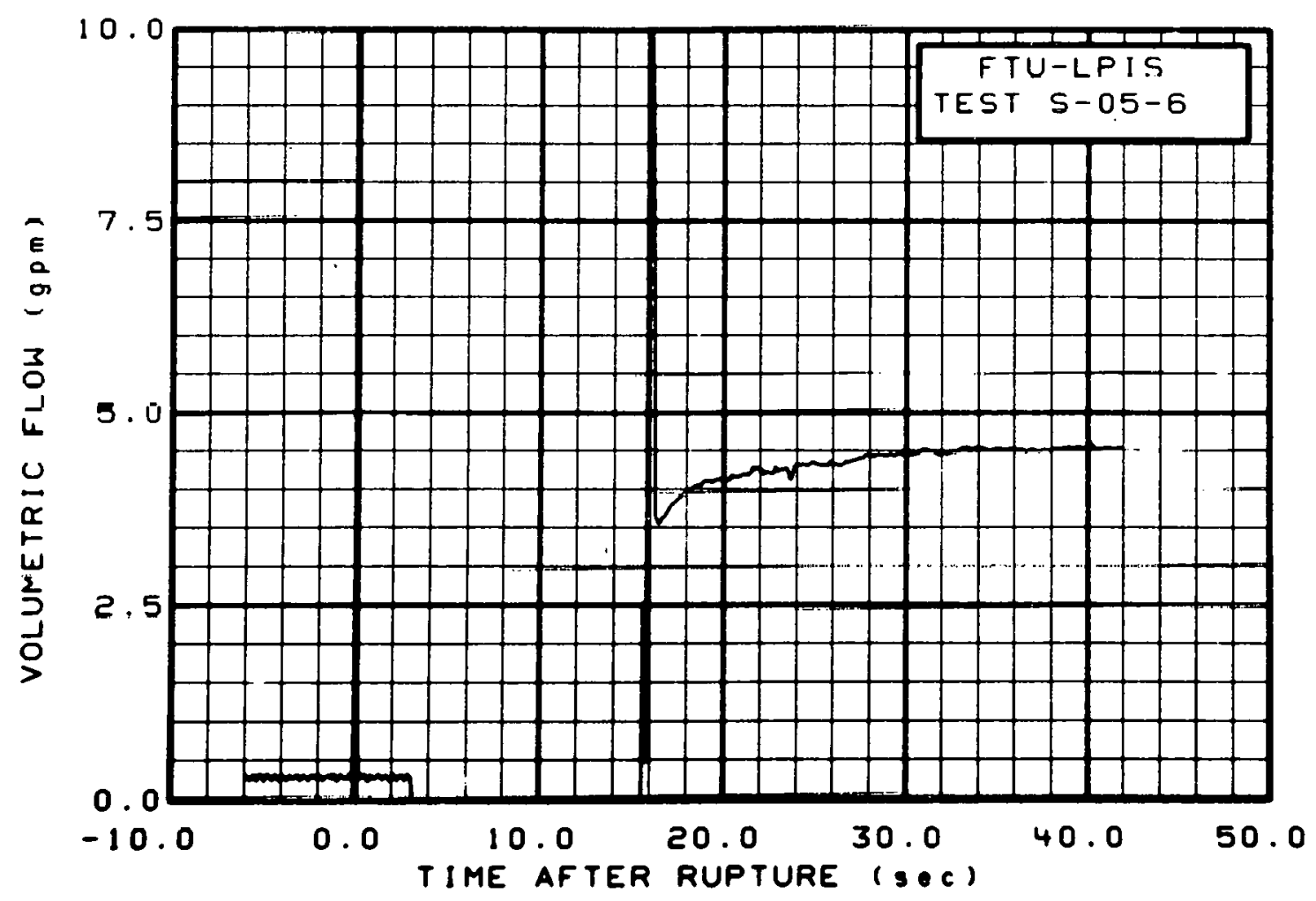

Fig. 397 Volumetric flow in intact loop low pressure injection line, Test S-05-6 (FTU-LPIS), from -6 to $42 \mathrm{sec}$. 


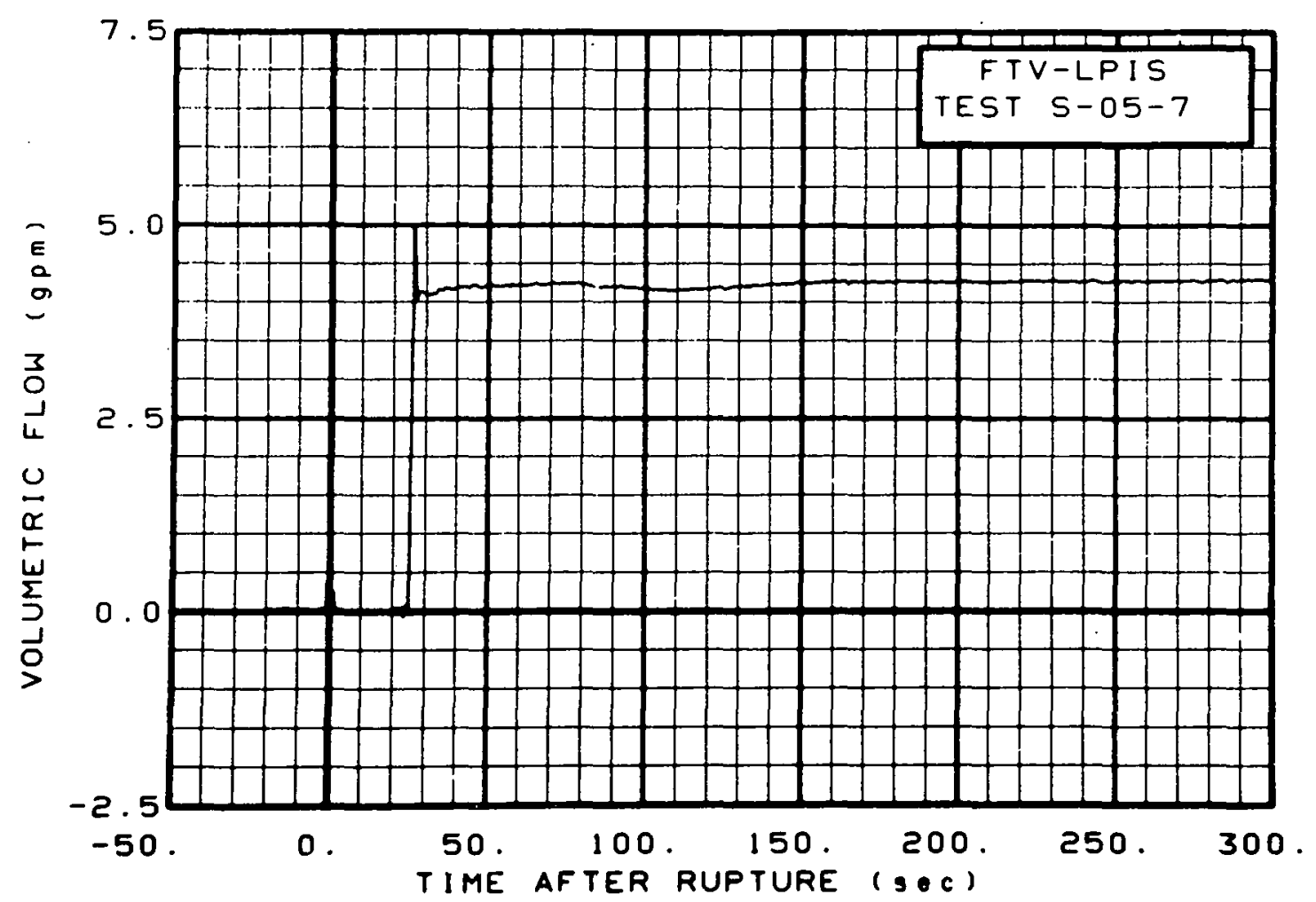

Fig. 398 Volumetric flow in vessel low pressure injection line, Test S-05-7 (FTV-LPIS), from -20 to $300 \mathrm{sec}$.

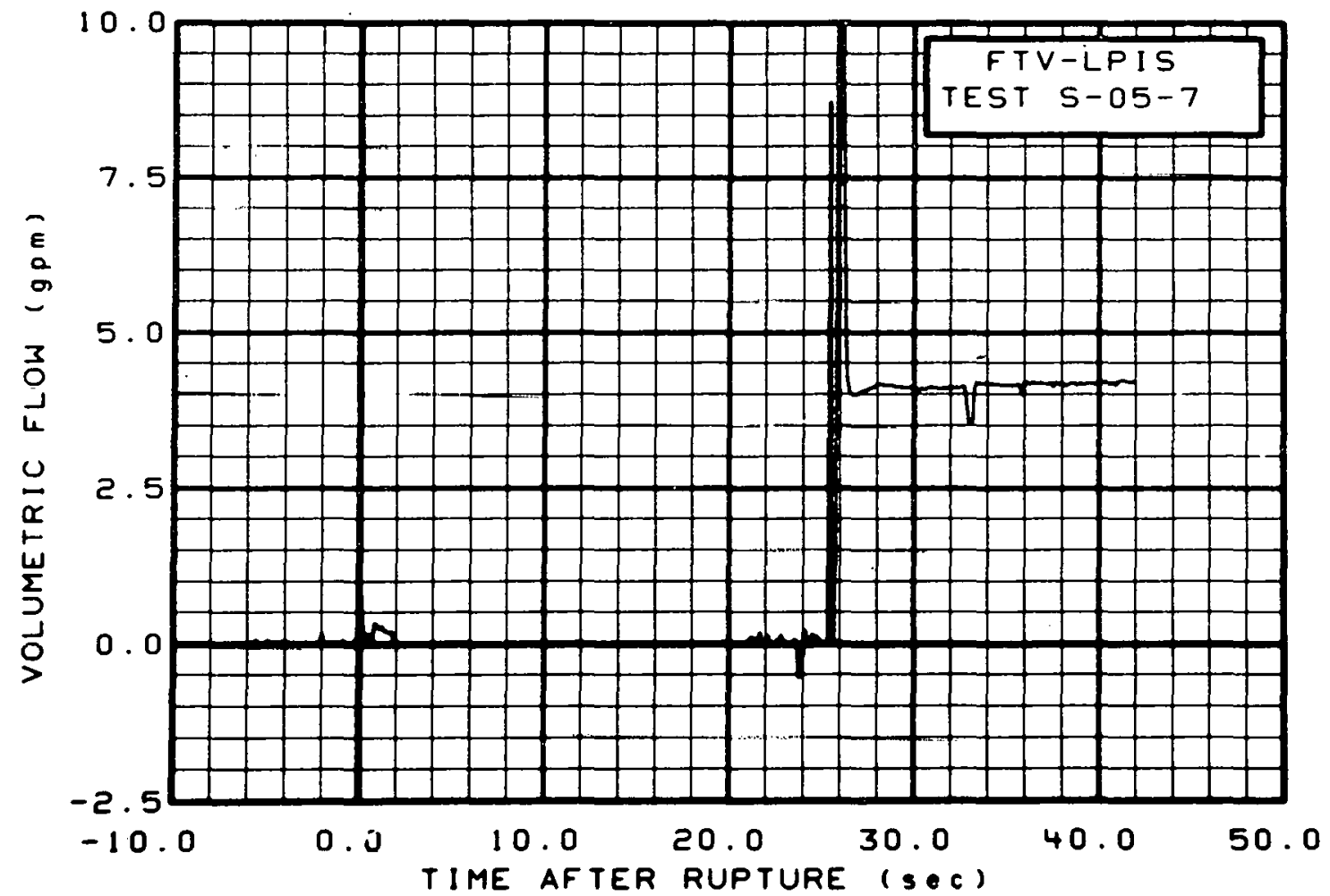

Fig. 399 Volumetric flow in vessel low pressure injection line, Test S-05-7 (FTV-LPIS), from -6 to 42 sec. 


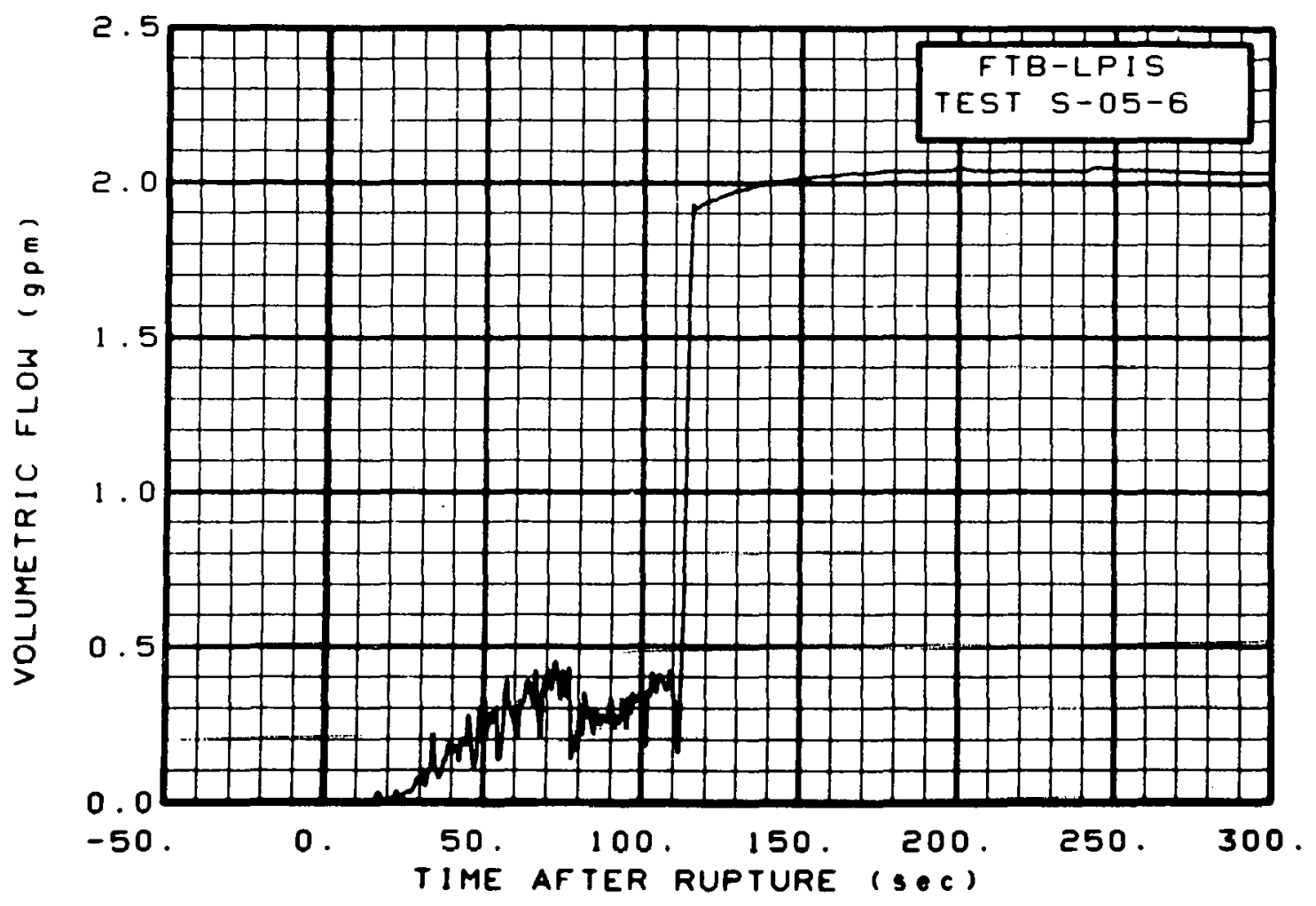

Fig. 400 Volumetric flow in broken loop low pressure injection line, Test S-05-6 (FTB-LPIS), from -20 to $300 \mathrm{sec}$.

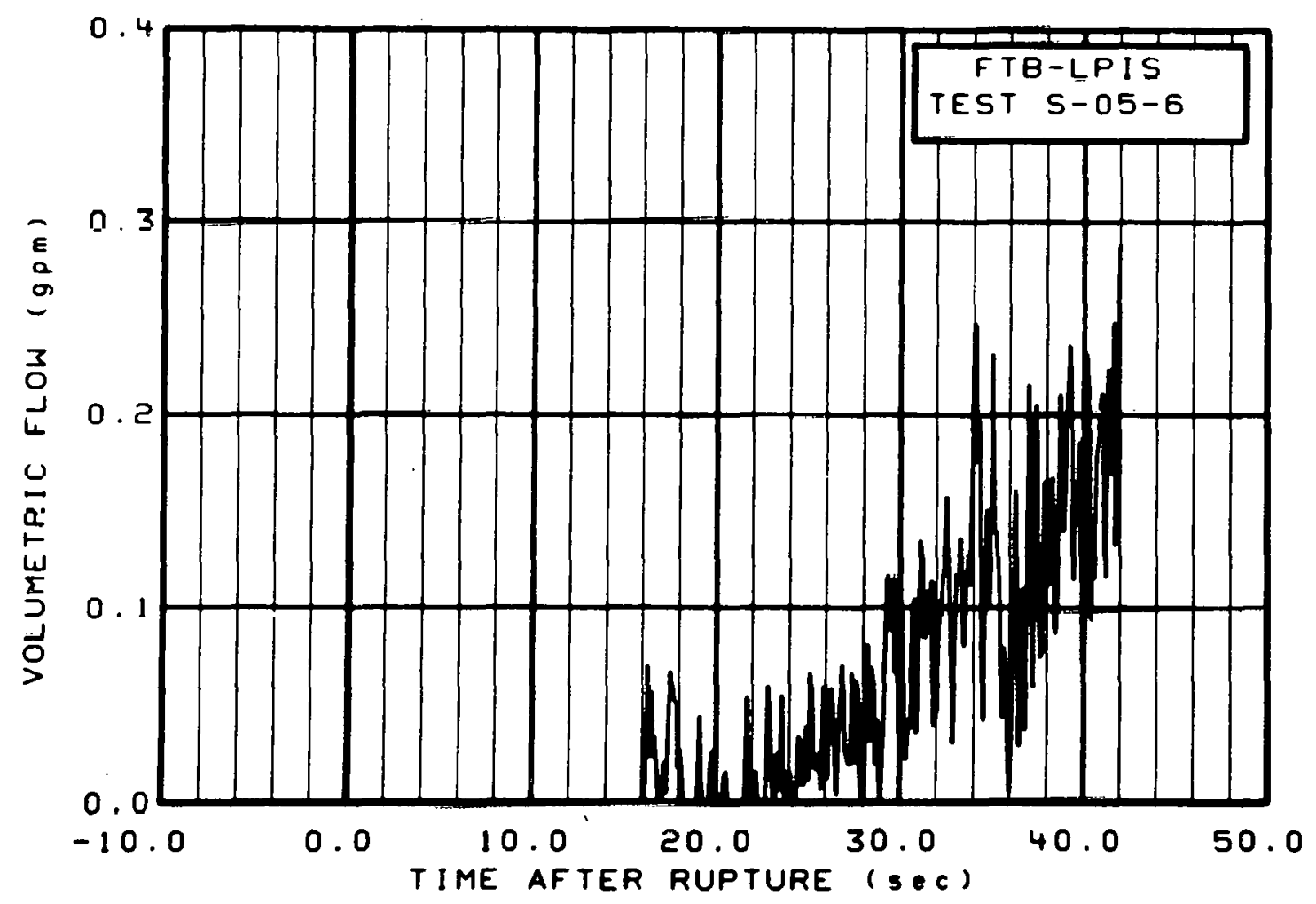

Fig. 401 Volumetric flow in broken loop low pressure injection line, Test S-05-6 (FTB-LPIS), from -6 to $42 \mathrm{sec}$. 


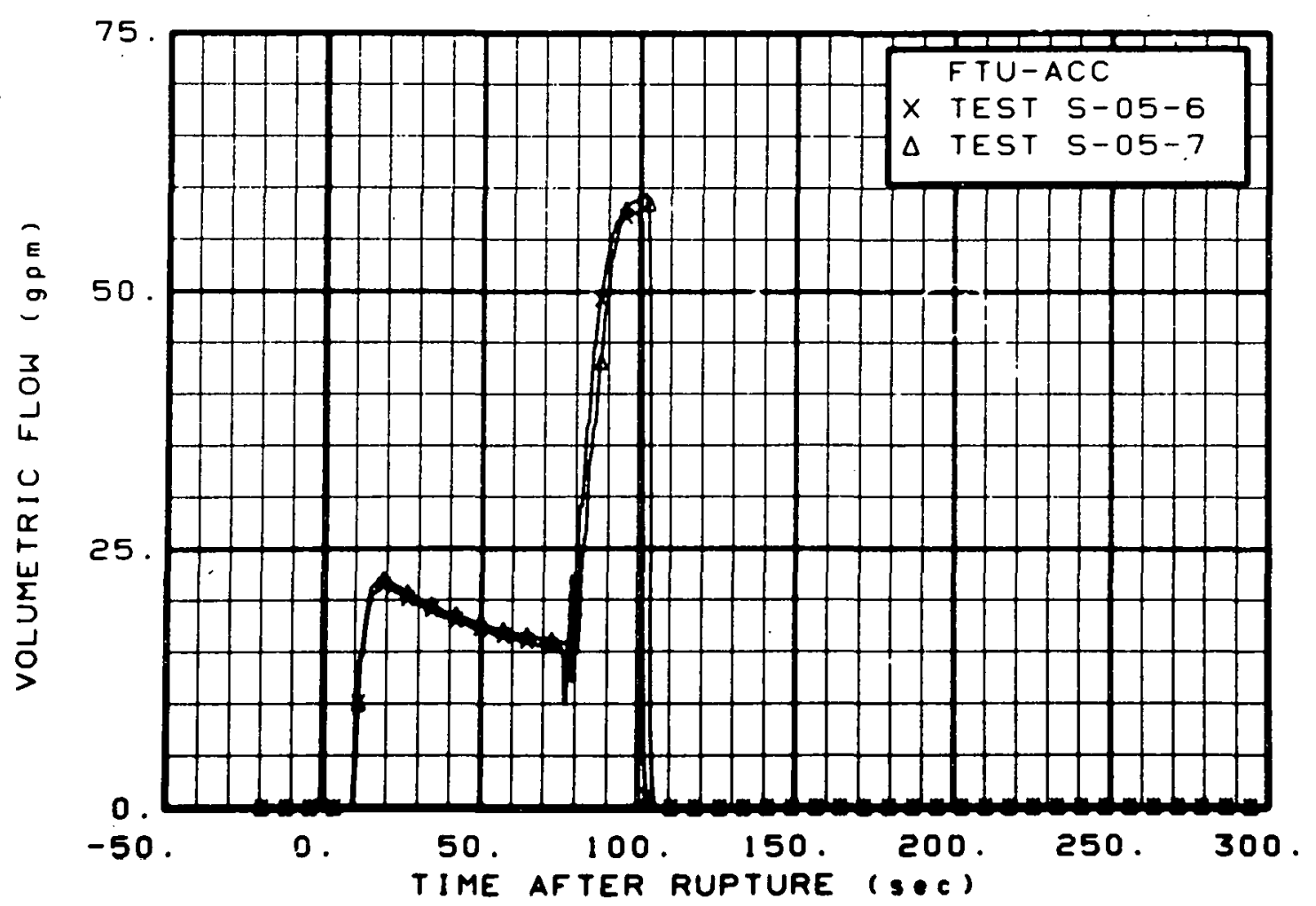

Fig. 402 Volumetric flow in intact loop accumulator discharge line (FTU-ACC), from -20 to $300 \mathrm{sec}$.

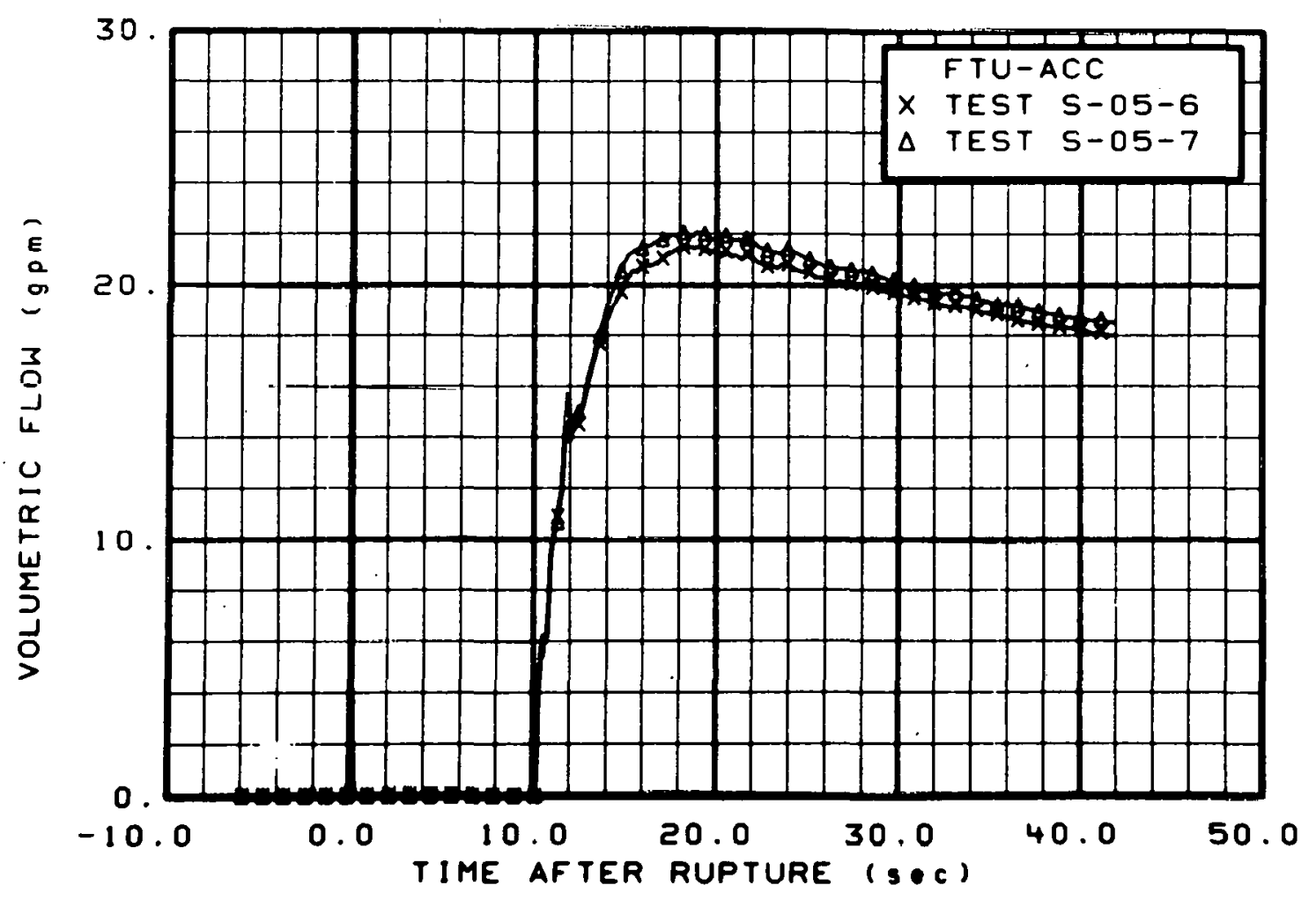

Fig. 403 Volumetric flow in intact loop accumulator discharge line (FTU-ACC), from -6 to $42 \mathrm{sec}$. 


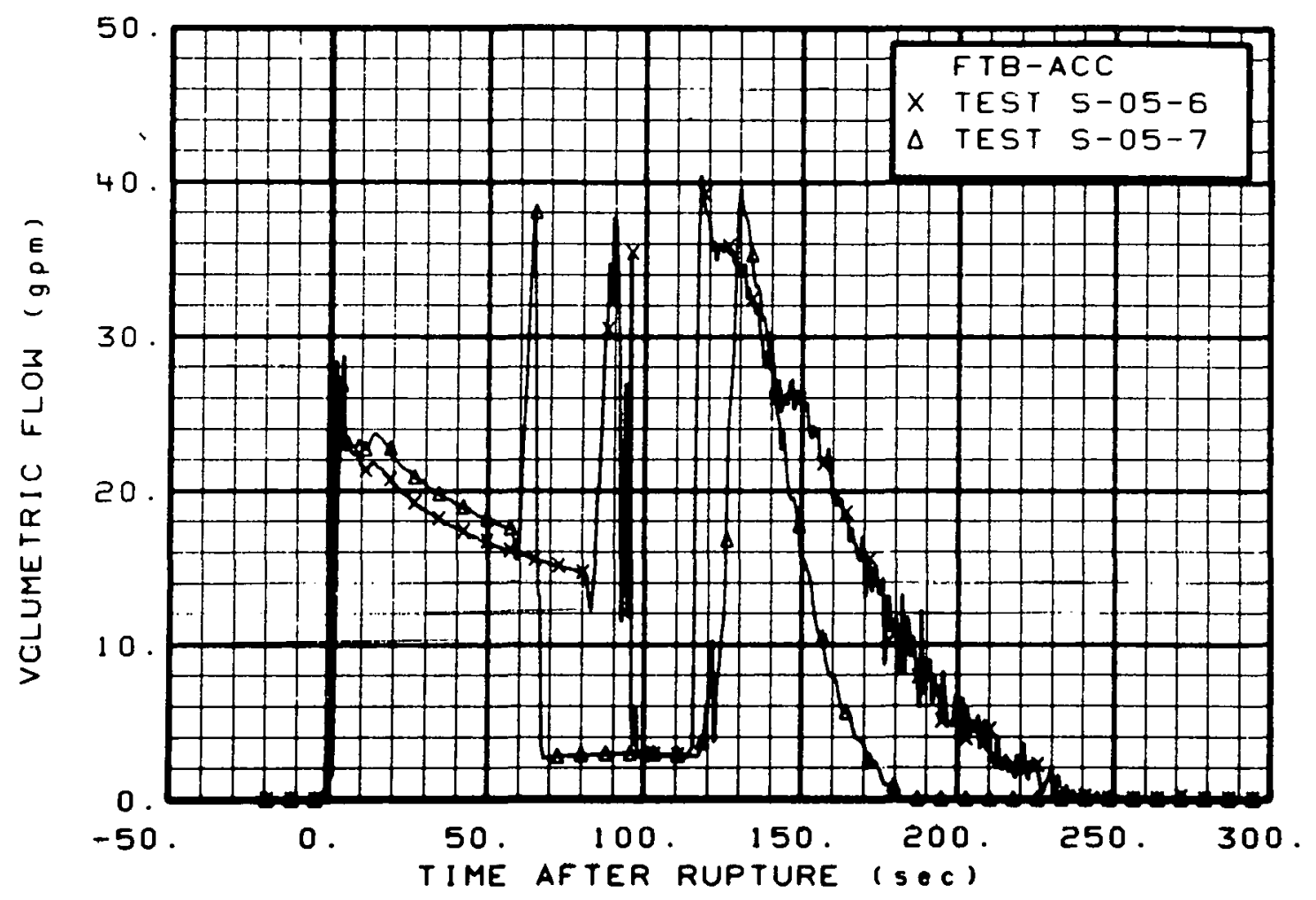

Fig. 404 Volumetric flow in broken loop accumulator discharge line (FTB-ACC), from -20 to $300 \mathrm{sec}$.

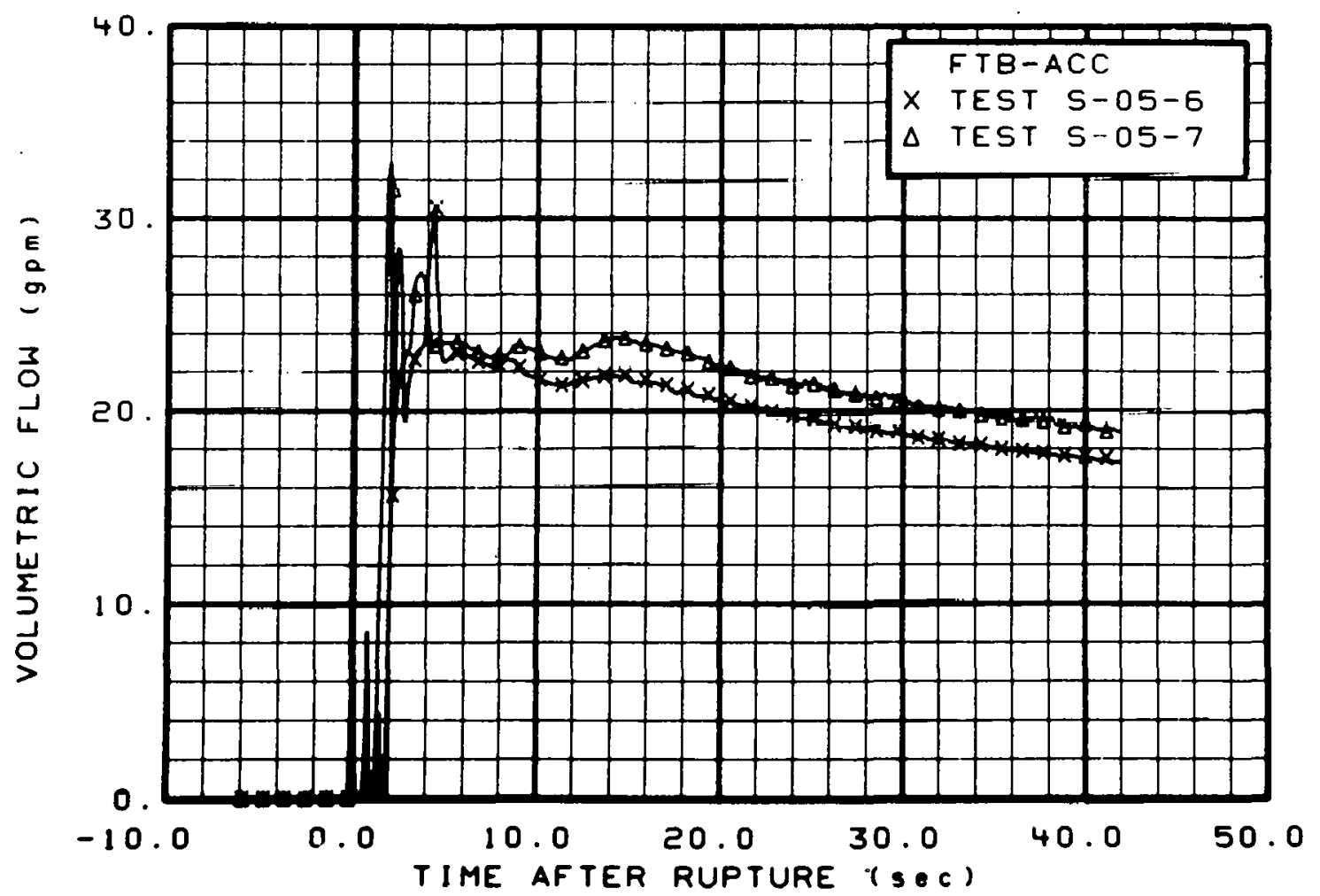

Fig. 405 Volumetric flow in broken loop accumulator discharge line (FTB-ACC), from -6 to $42 \mathrm{sec}$. 


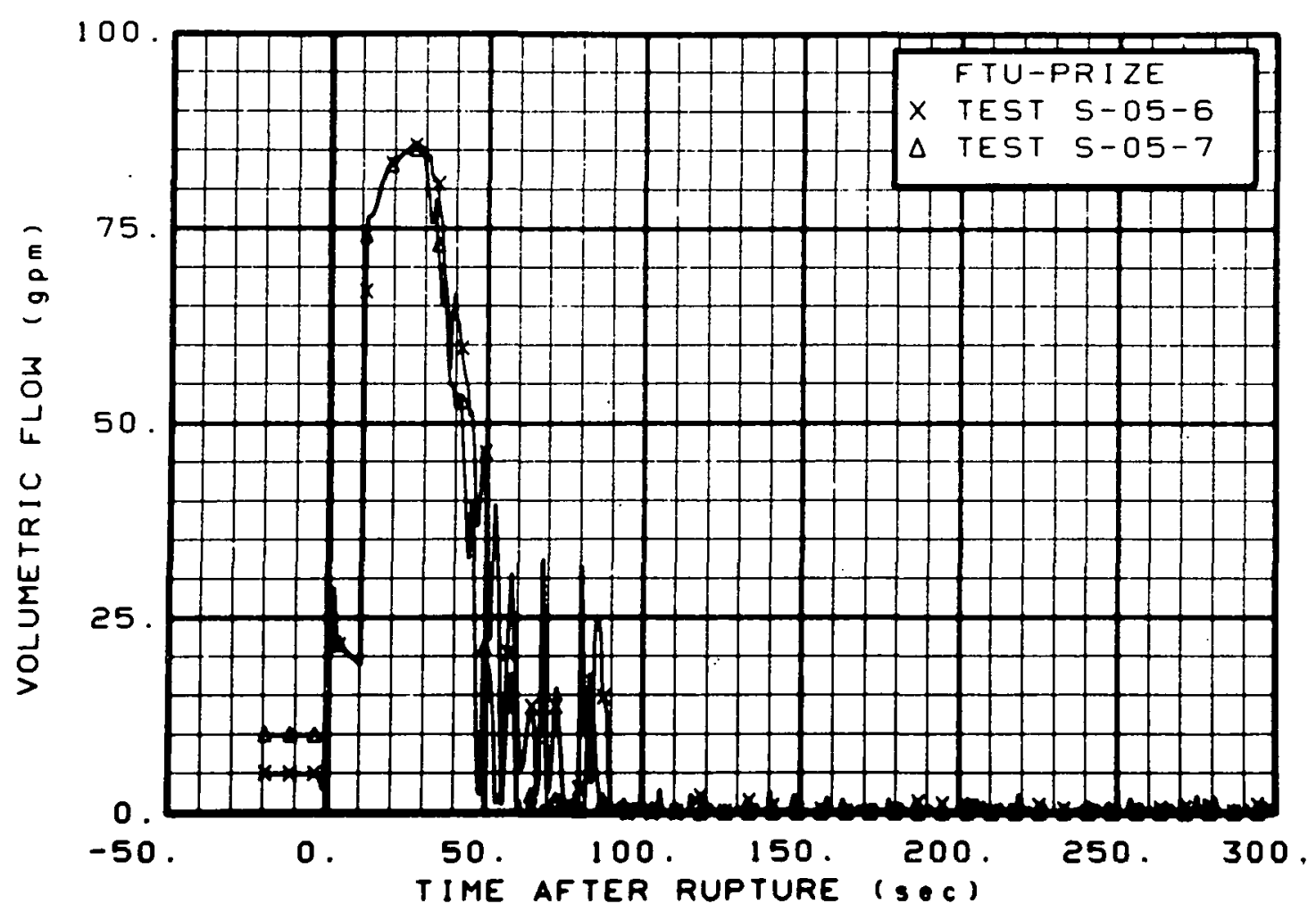

Fig. 406 Volumetric flow from pressurizer (FTU-PRIZE), from -20 to $300 \mathrm{sec}$.

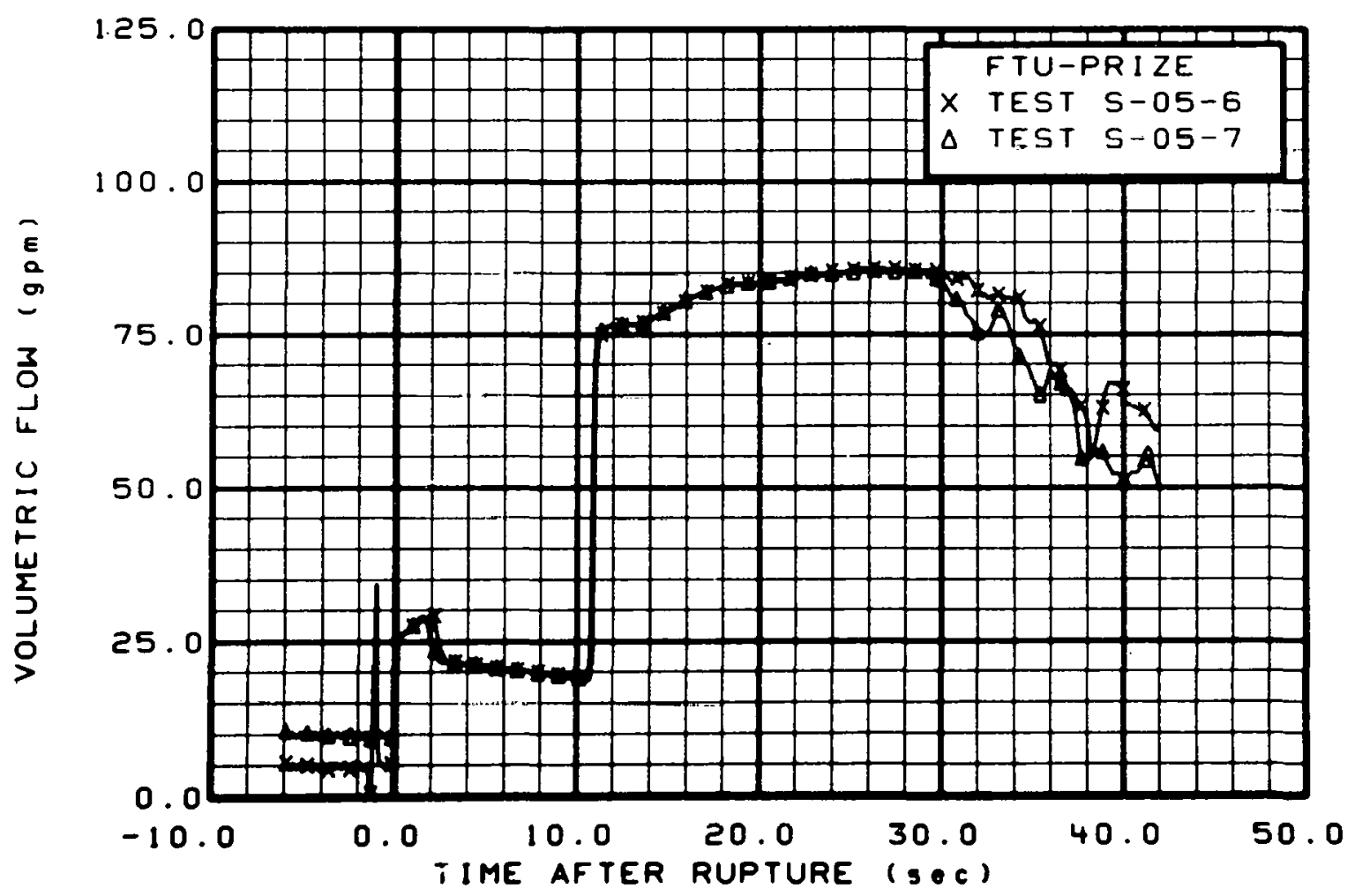

Fig. 407 Vulumetric flow from pressurizer (FTU-PRIZE), from -6 to $42 \mathrm{sec}$. 


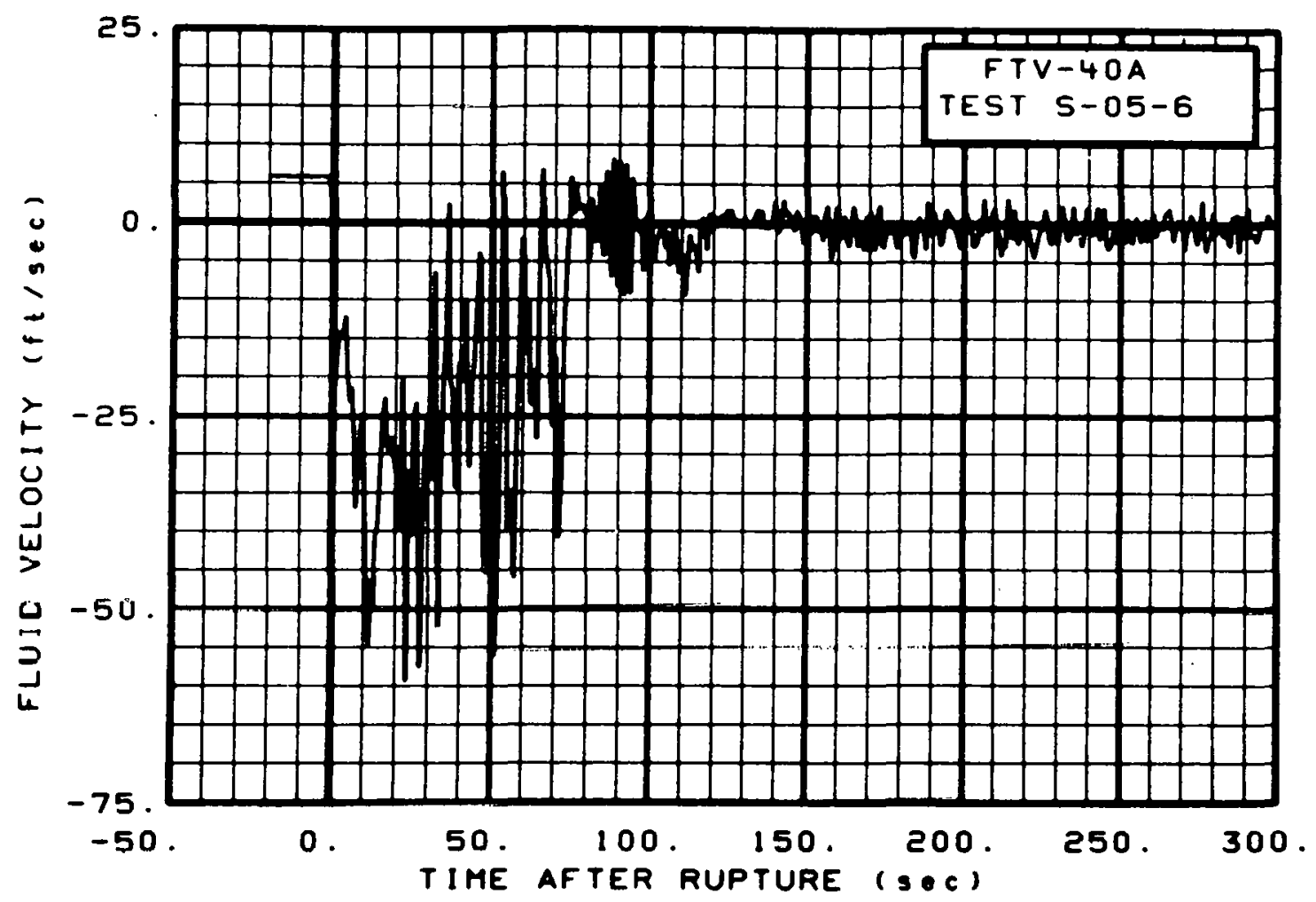

Fig. 408 Fluid velocity in vessel, Test S-05-6 (FTV-40A), from -20 to $300 \mathrm{sec}$.

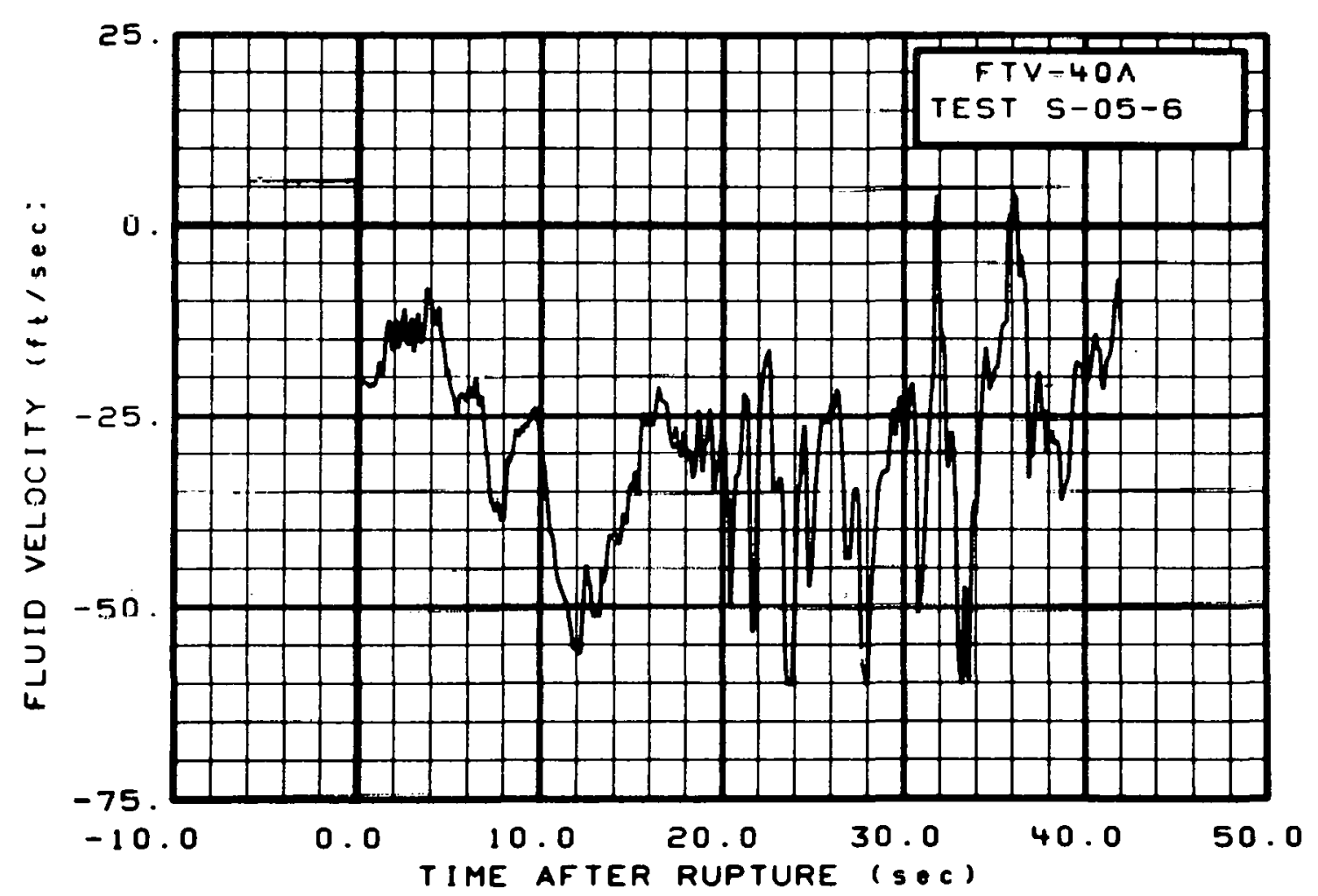

Fig. 409 Fluid velocity in vessel, Test S-05-6 (FTV-40A), from -6 to $42 \mathrm{sec}$. 


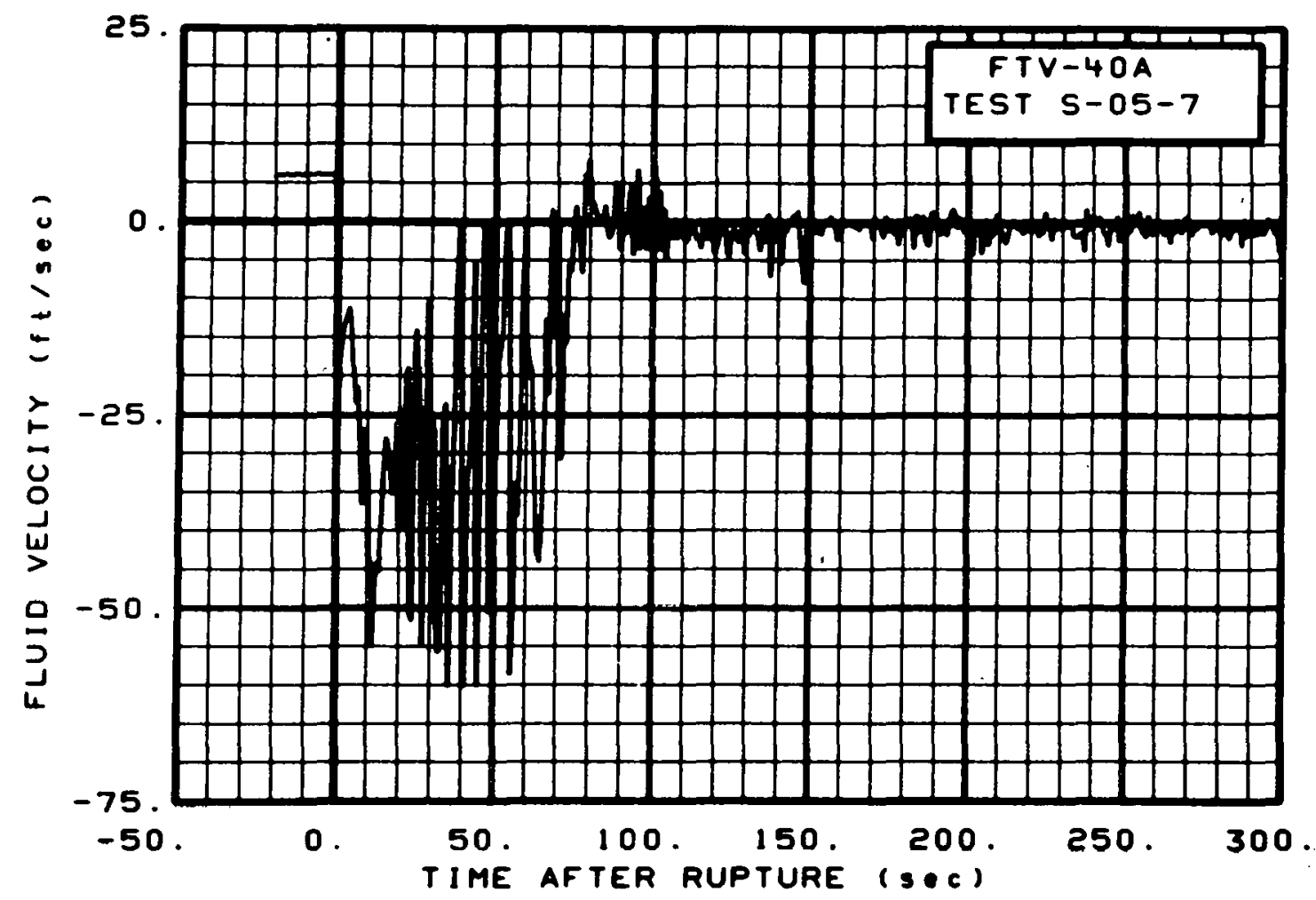

Fig. 410 Fluid velocity in vesse1, Test S-05-7 (FTV-40A), from -20 to 300 sec.

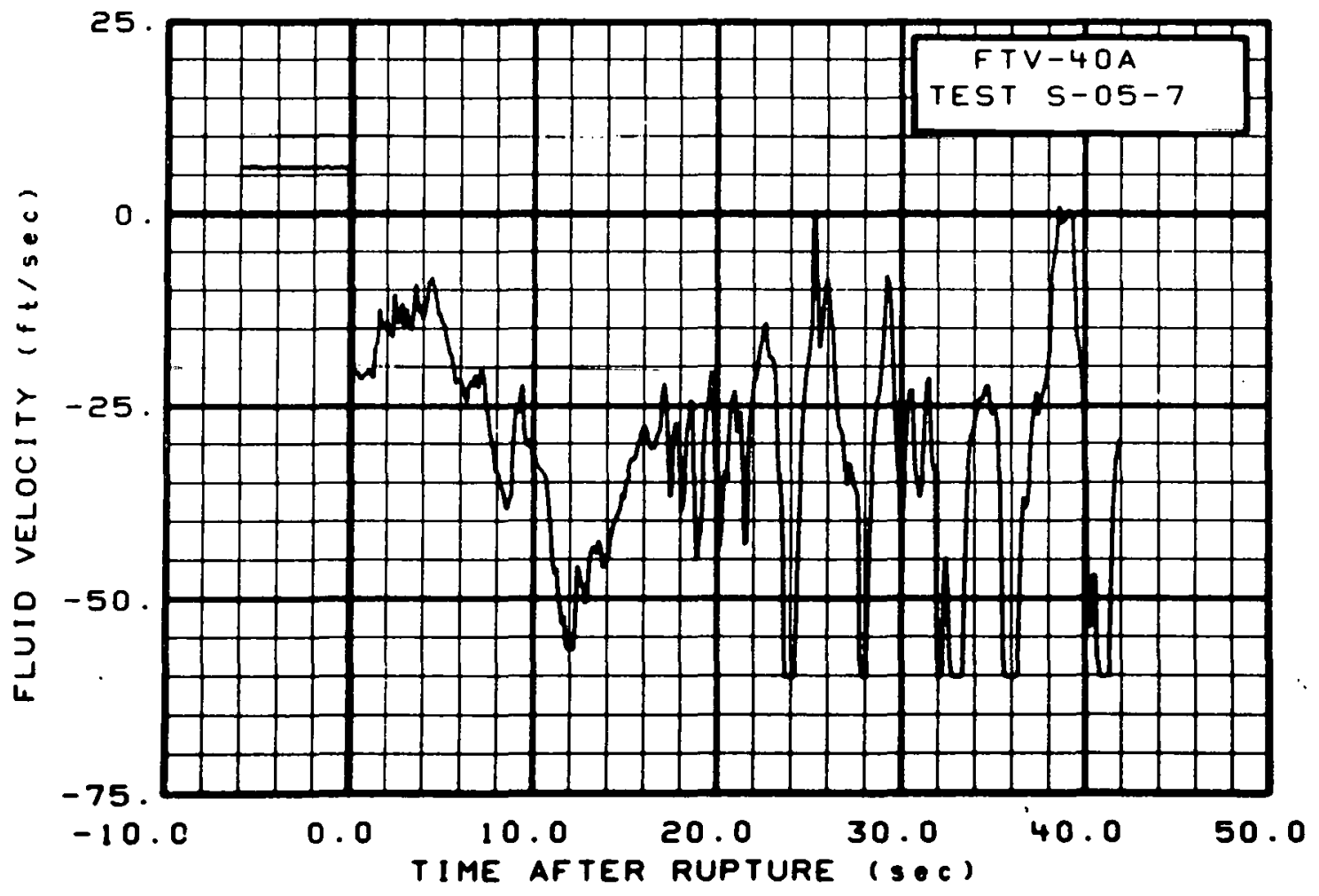

Fig. 411 Fluid velocity in vessel, Test S-05-7 (FTV-40A), from -6 to $42 \mathrm{sec}$. 


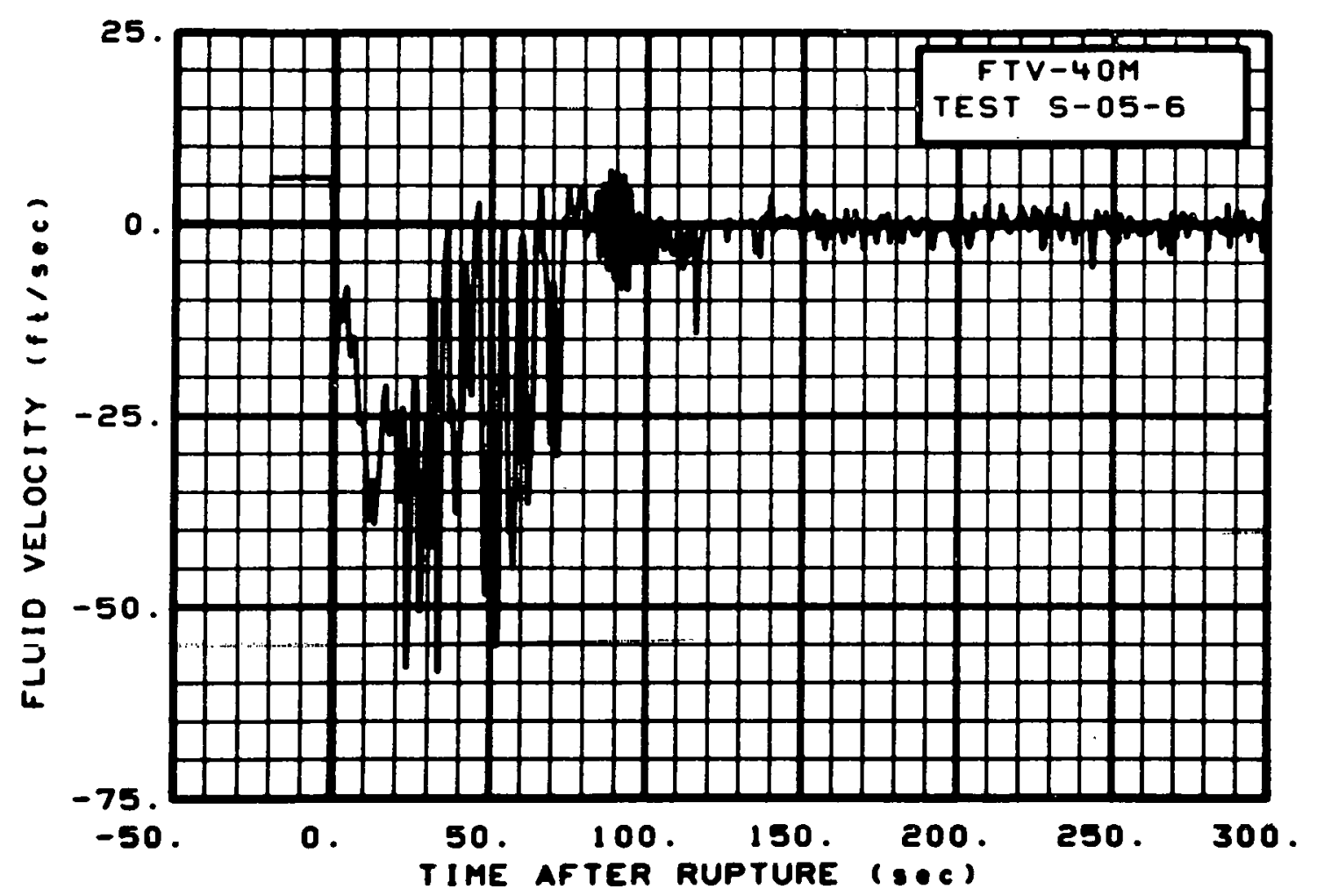

Fig. 412 Fluid velocity in vessel, Test S-05-6 (FTV-40M), from -20 to $300 \mathrm{sec}$.

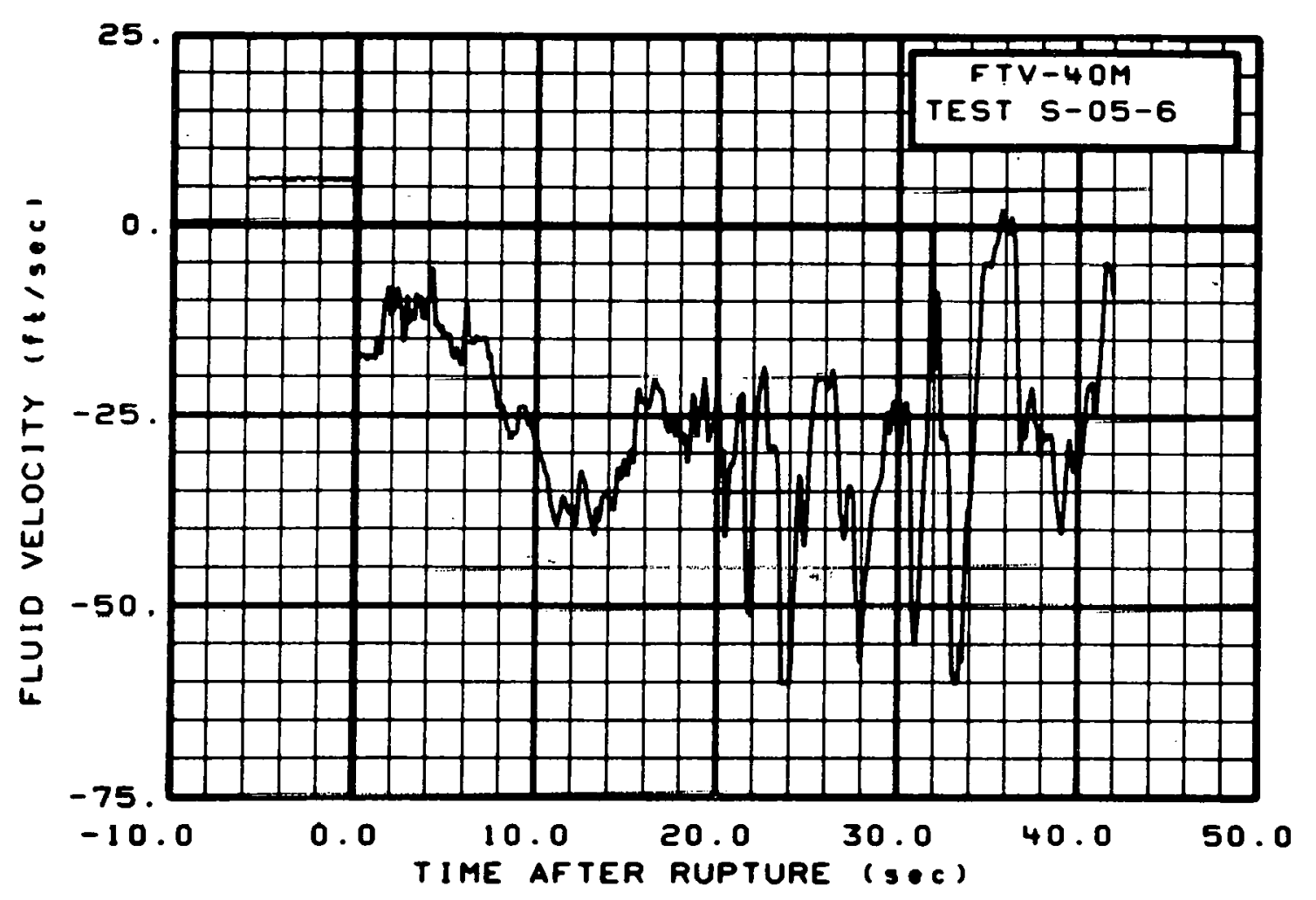

Fig. 413 Fluid velocity in vesse1, Test S-05-6 (FTV-40M), from -6 to $42 \mathrm{sec}$. 


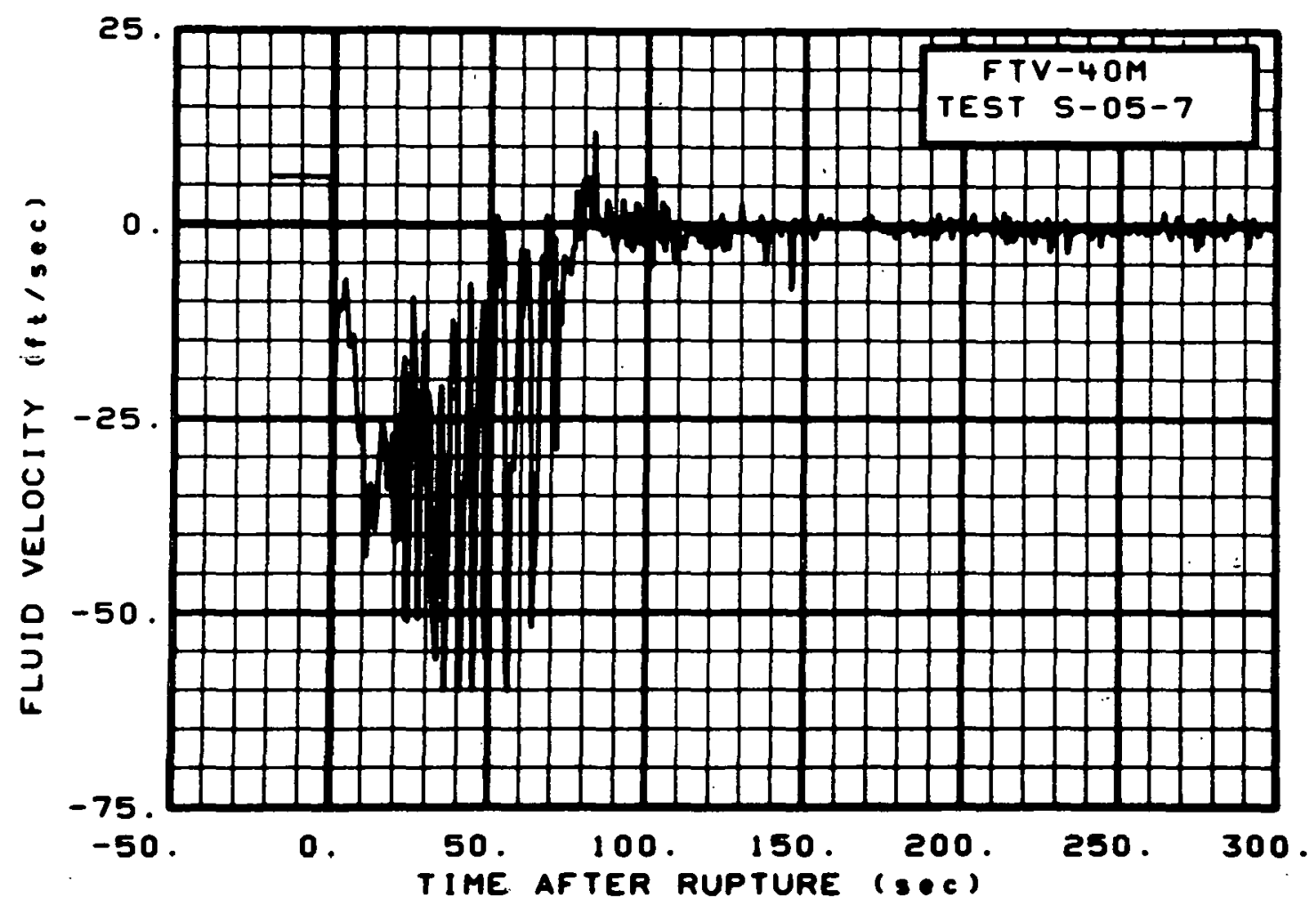

Fig. 414 Fluid velocity in vessel, Test S-05-7 (FTV-40M), from -20 to $300 \mathrm{sec}$.

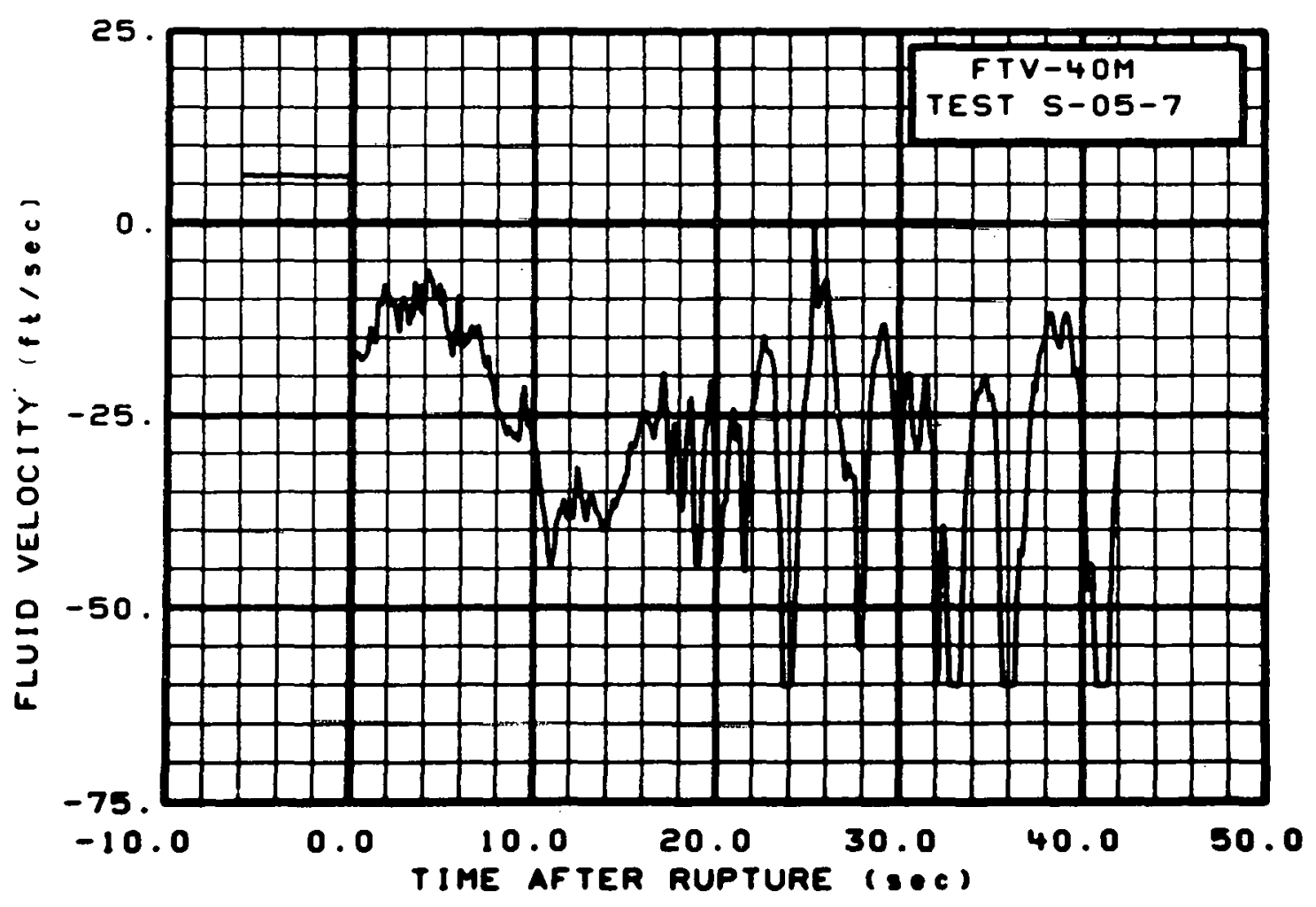

Fig. 415 Fluid velocity in vessel, Test S-05-7 (FTV-40M), from -6 to $42 \mathrm{sec}$. 


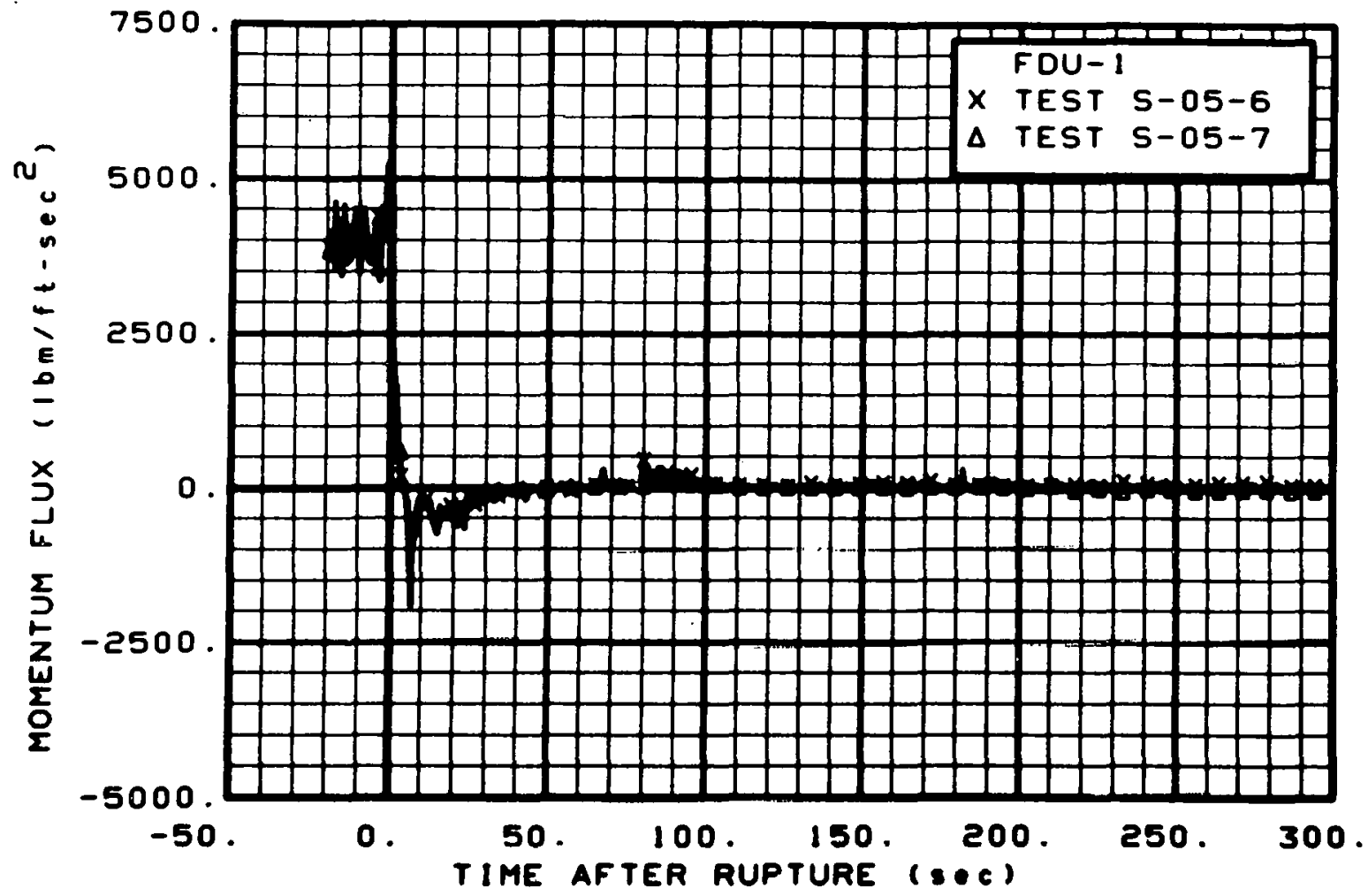

Fig. 416 Momentum flux in intact loop (FDU-1), from -20 to $300 \mathrm{sec}$.

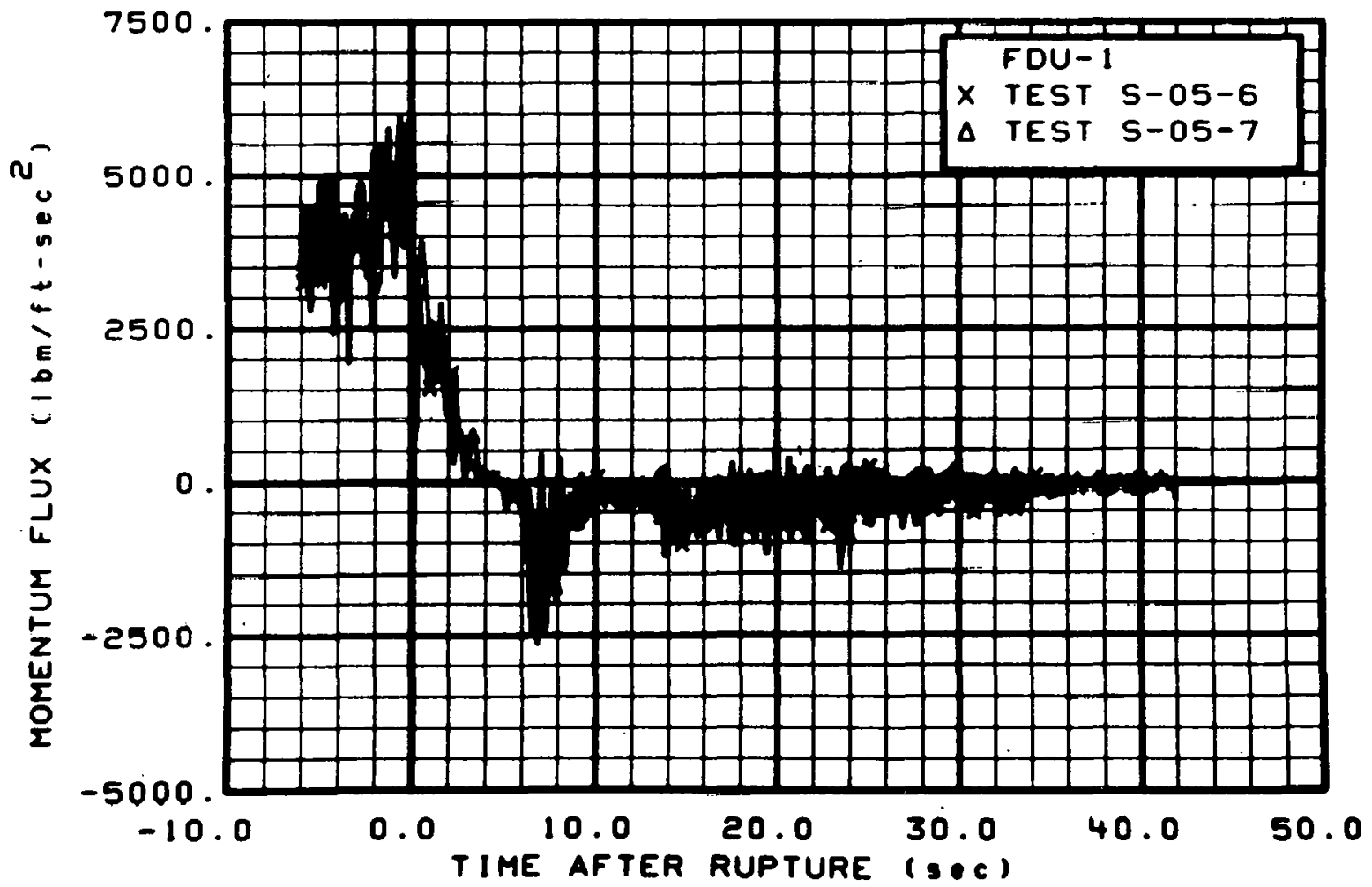

Fig. 417 Momentum flux in intact loop (FDU-1), from -6 to $42 \mathrm{sec}$. 


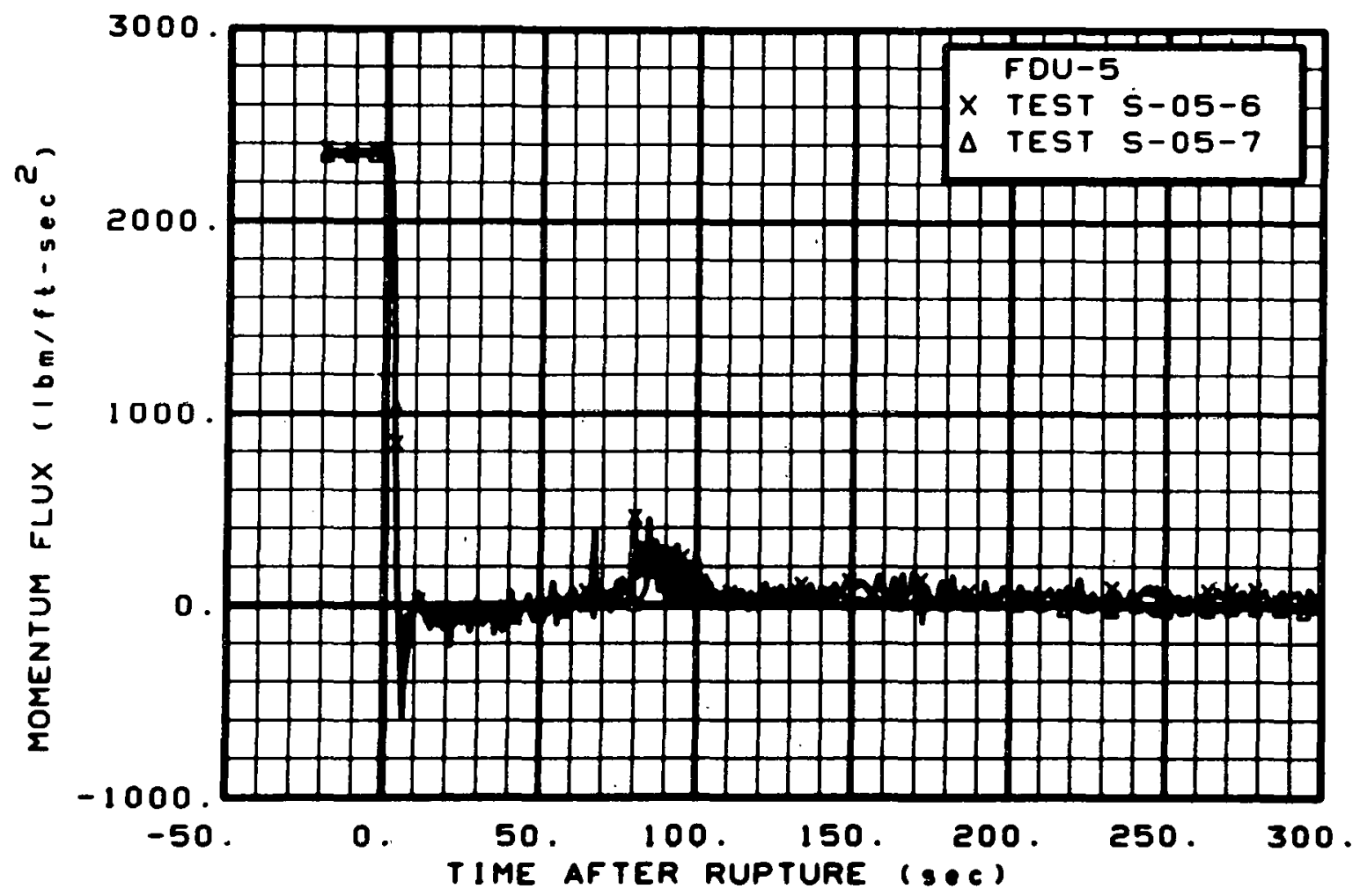

Fig. 418 Momentum flux in intact loop (FDU-5), from -20 to $300 \mathrm{sec}$.

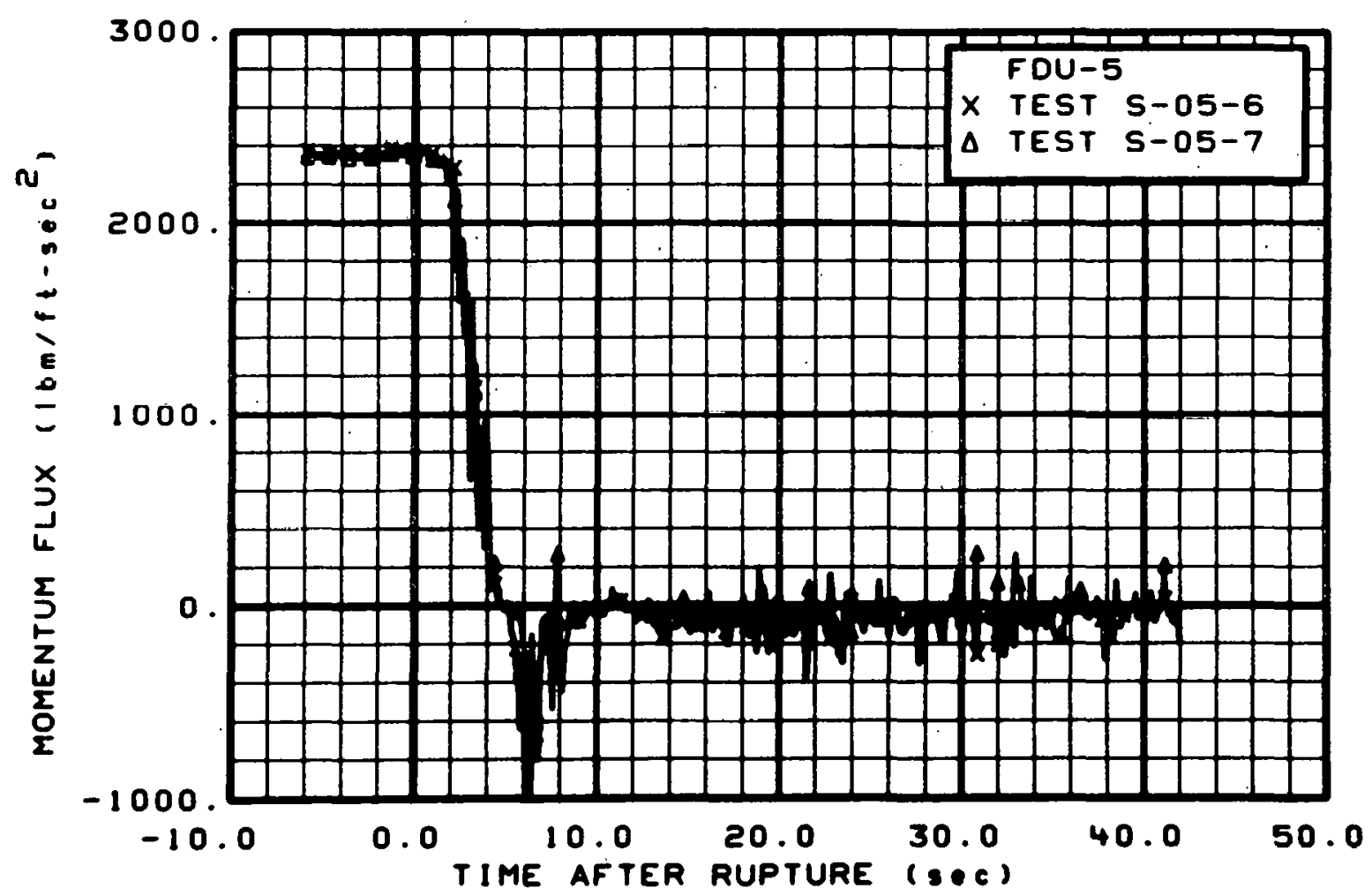

Fig. 419 Momentum flux in intact loop (FDU-5), from -6 to 42 sec. 


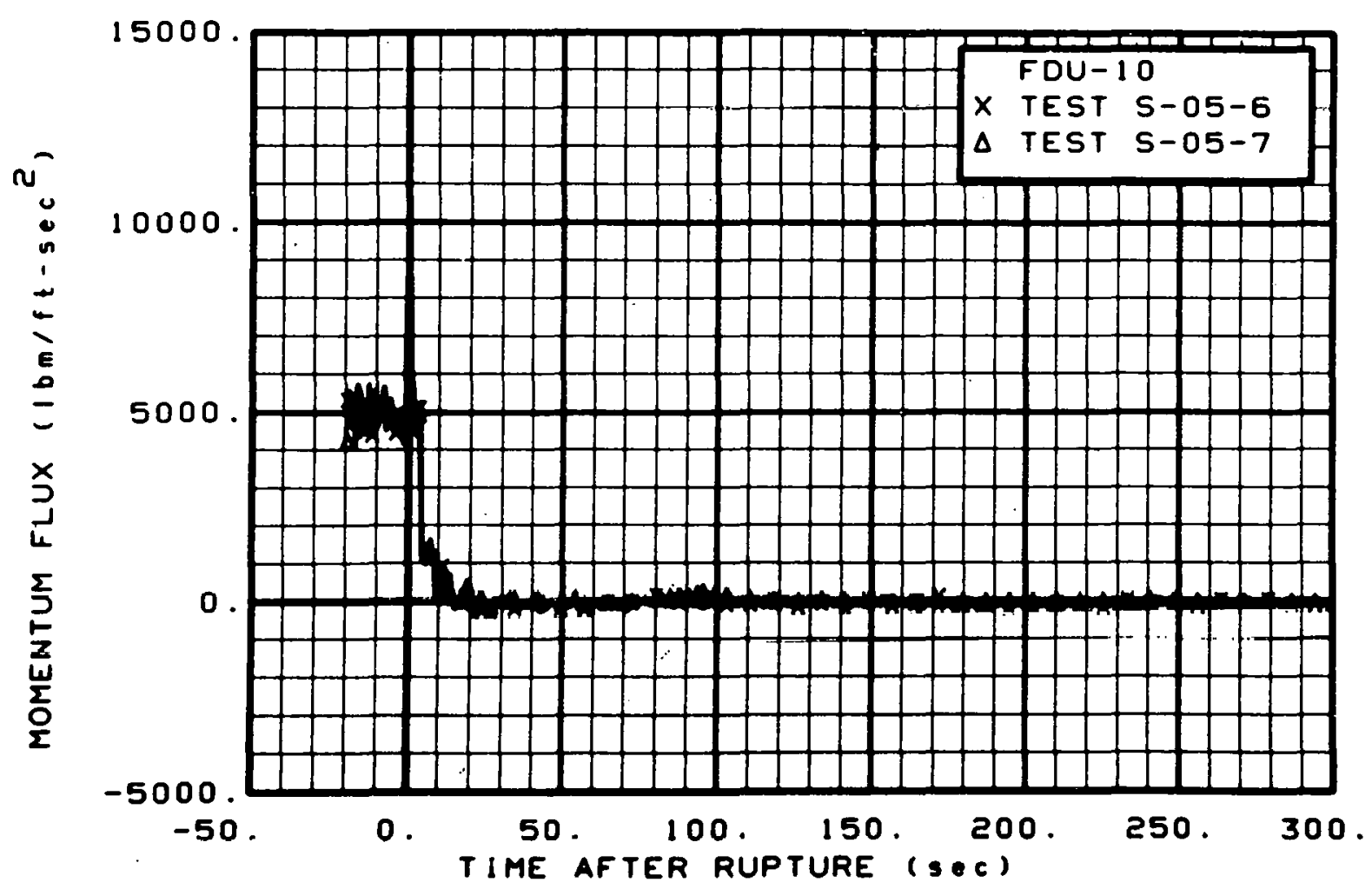

Fig. 420 Momentum flux in intact loop (FDU-10), from -20 to $300 \mathrm{sec}$.

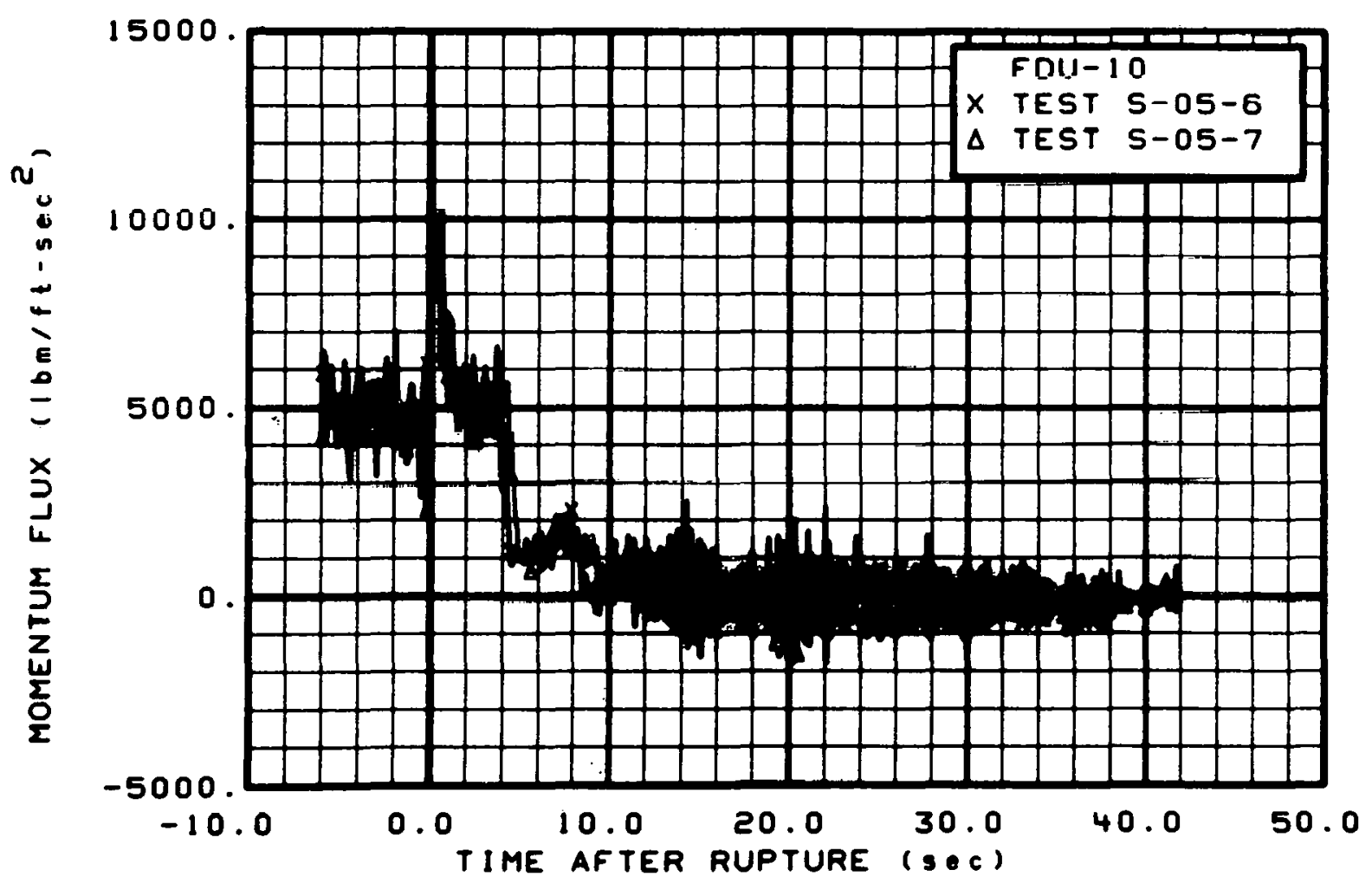

Fig. 421 Momentum flux in intact loop (FDU-10), from -6 to $42 \mathrm{sec}$. 


\section{THIS PAGE}

\section{WAS INTENTIONALLY \\ LEFT BLANK}




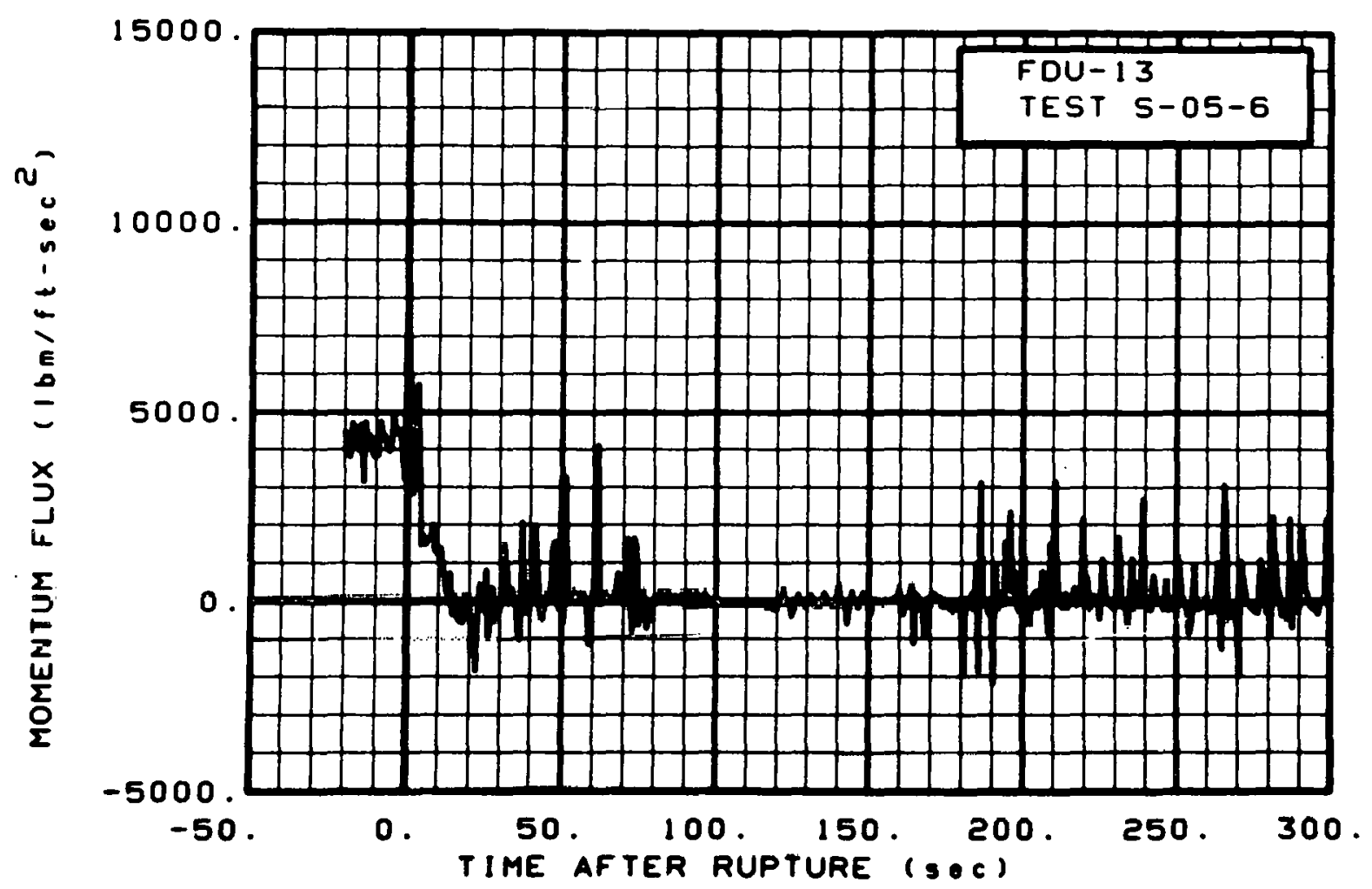

Fig. 422 Momentum filux in intact loop, Test S-05-6. (FDU-13), from -20 to $300 \mathrm{sec}$.

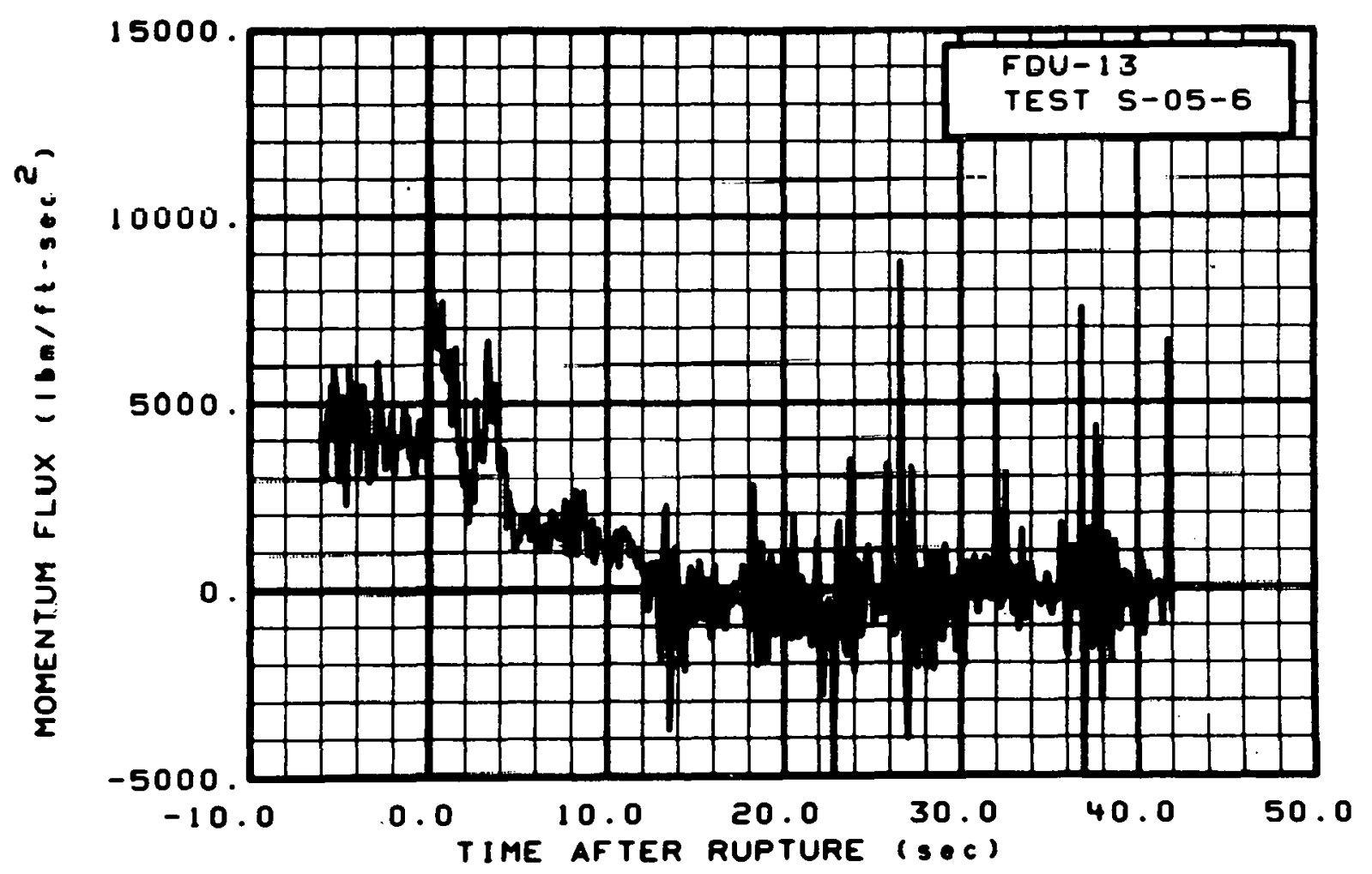

Fig. 423 Momentum flux in intact loop, Test S-05-6 (FDU-13), from -6 to 42 sec. 


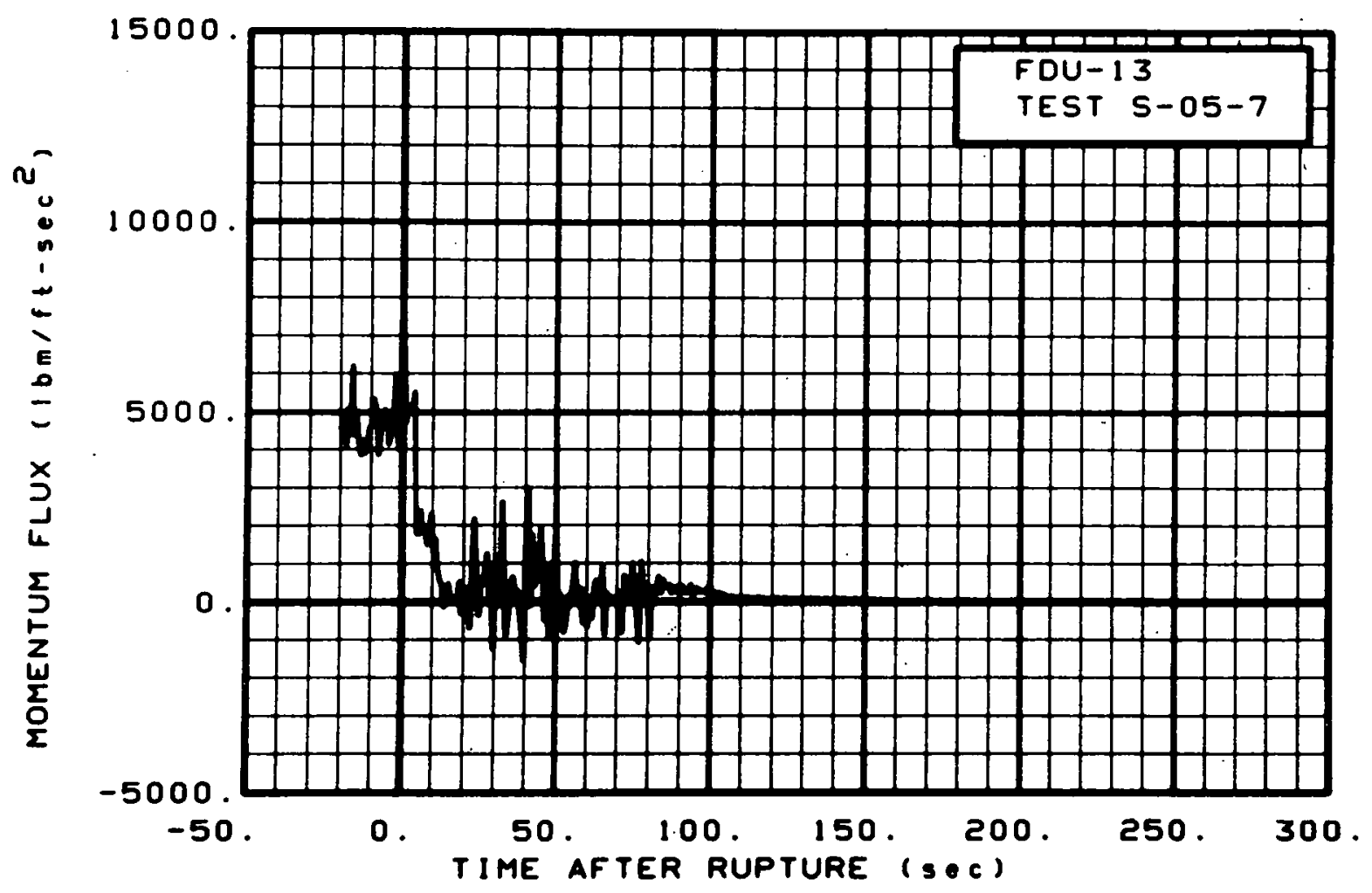

Fig. 424 Momentum flux in intact loop. Test S-05-7 (FDU-13), from -20 to 300 sec.

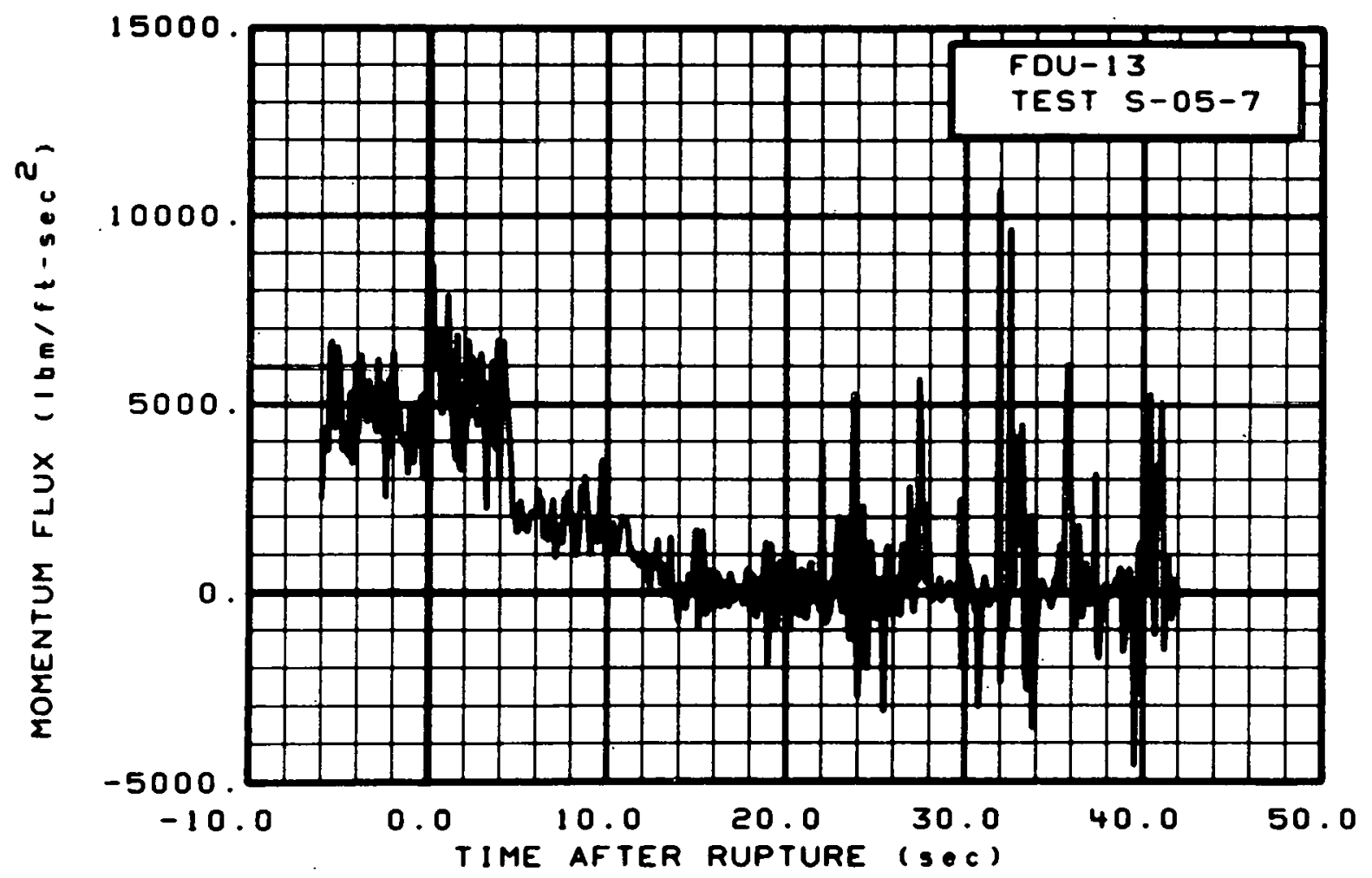

Fig. 425 Momentum flux in intact loop. Test S-05-7 (FDU-13), from -6 to $42 \mathrm{sec}$. 


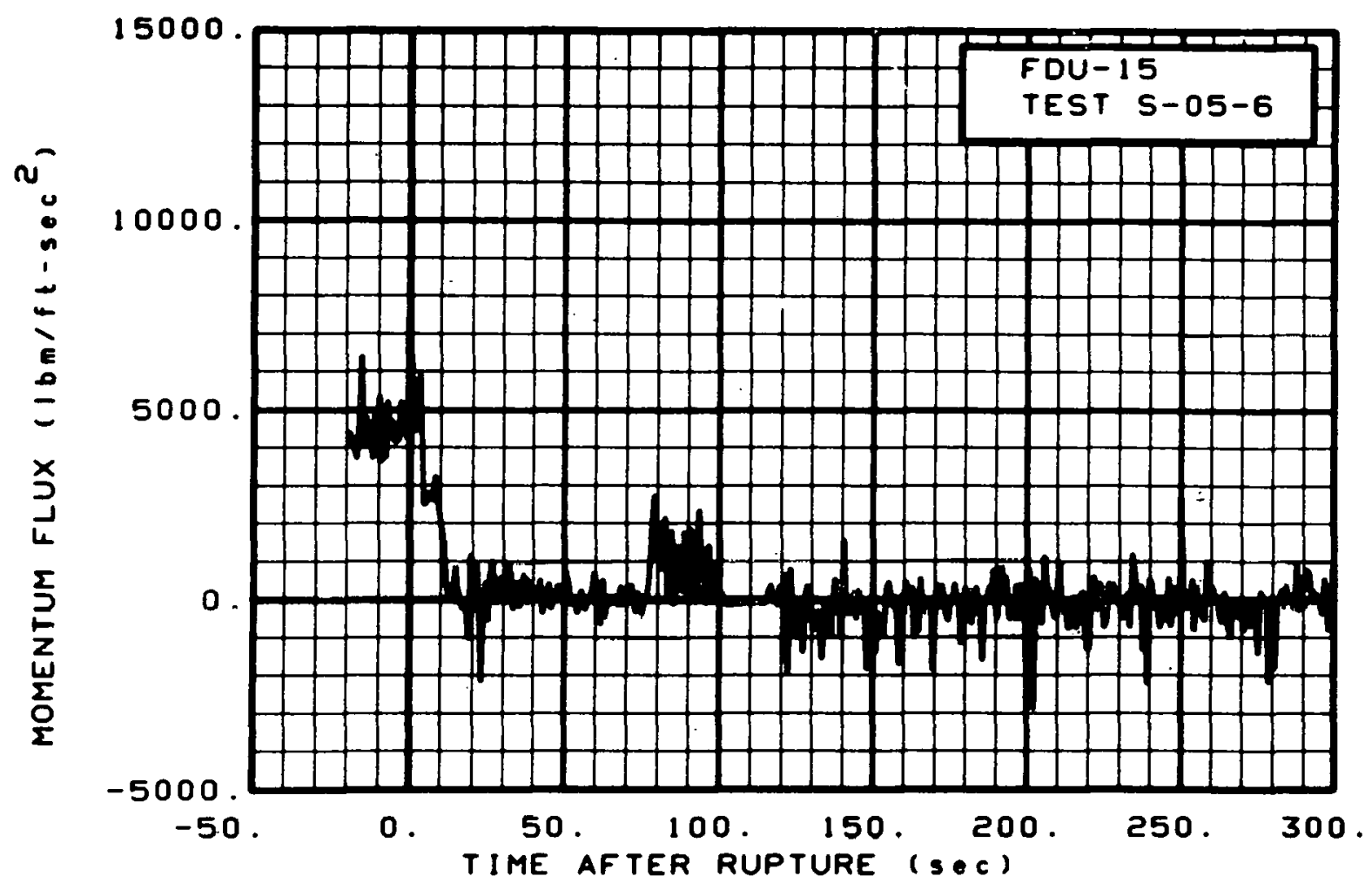

Fig. 426 Momentum flux in intact 10op, Test S-05-6 (FDU-15), from -20 to $300 \mathrm{sec}$.

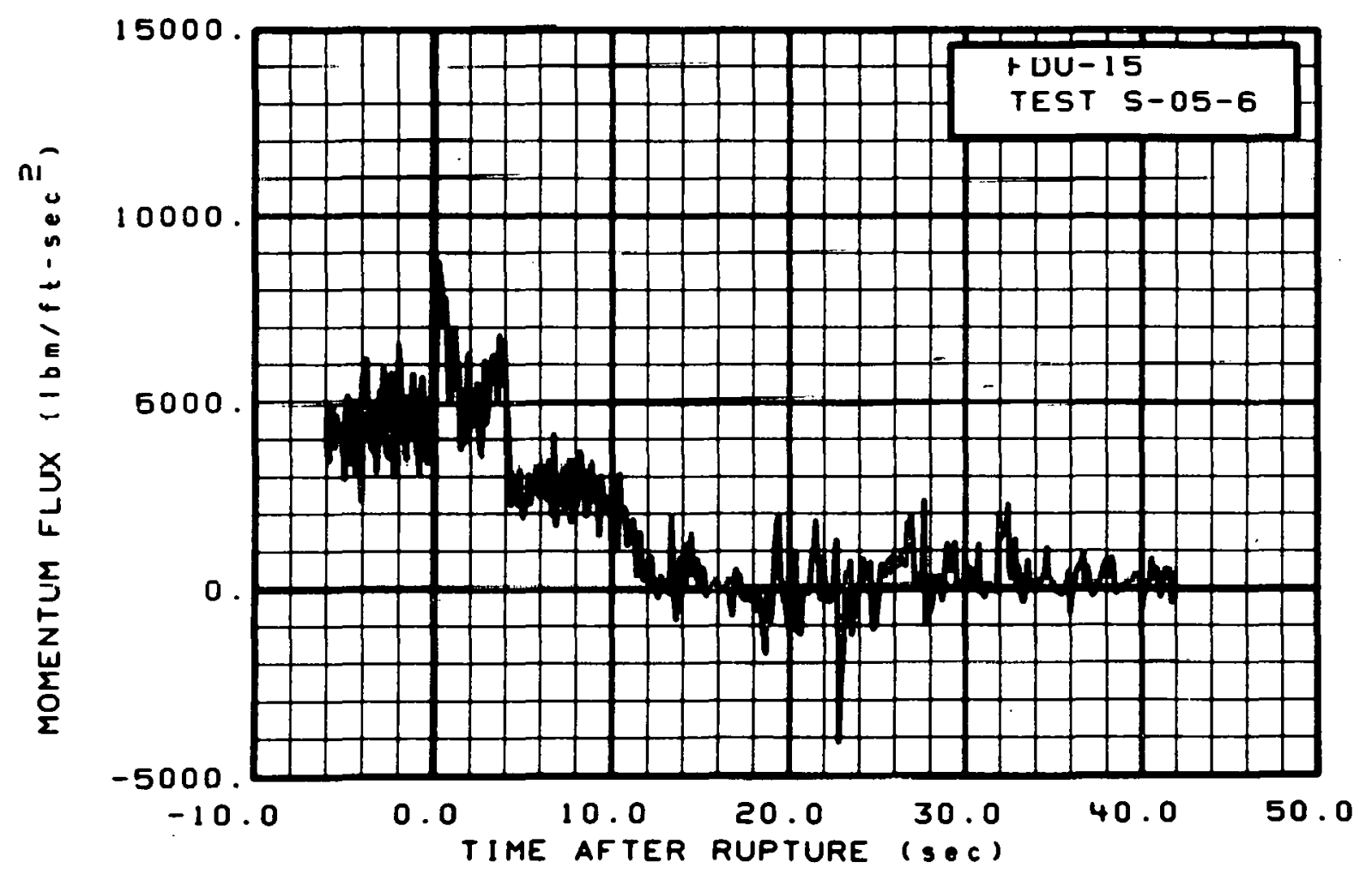

Fig. 427 Momentum flux in intact loop, Test S-05-6 (FDU-15), from -6 to $42 \mathrm{sec}$. 


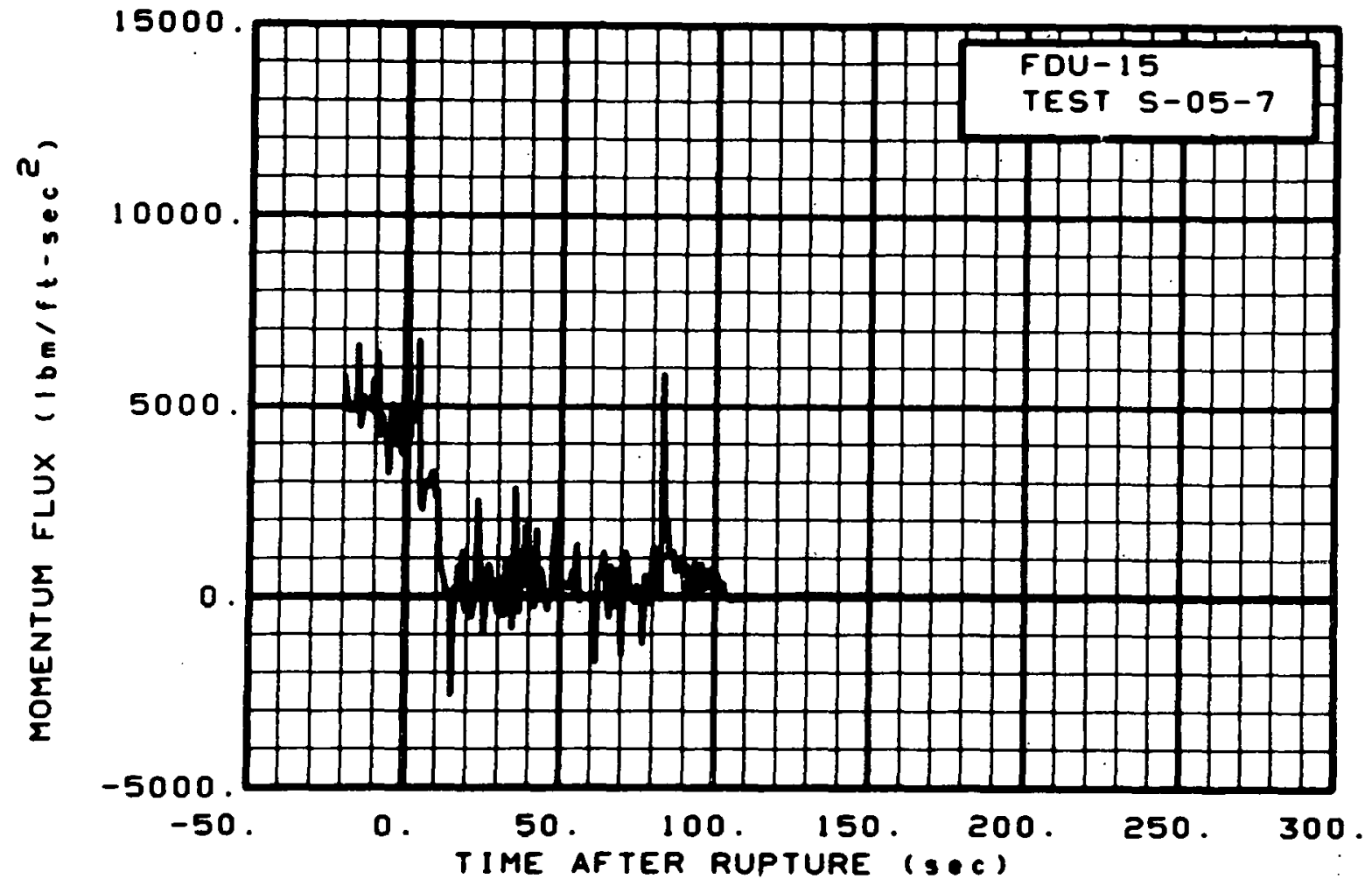

Fig. 428 Momentum flux in intact loop, Test S-05-7 (FDU-15), from -20 to $300 \mathrm{sec}$.

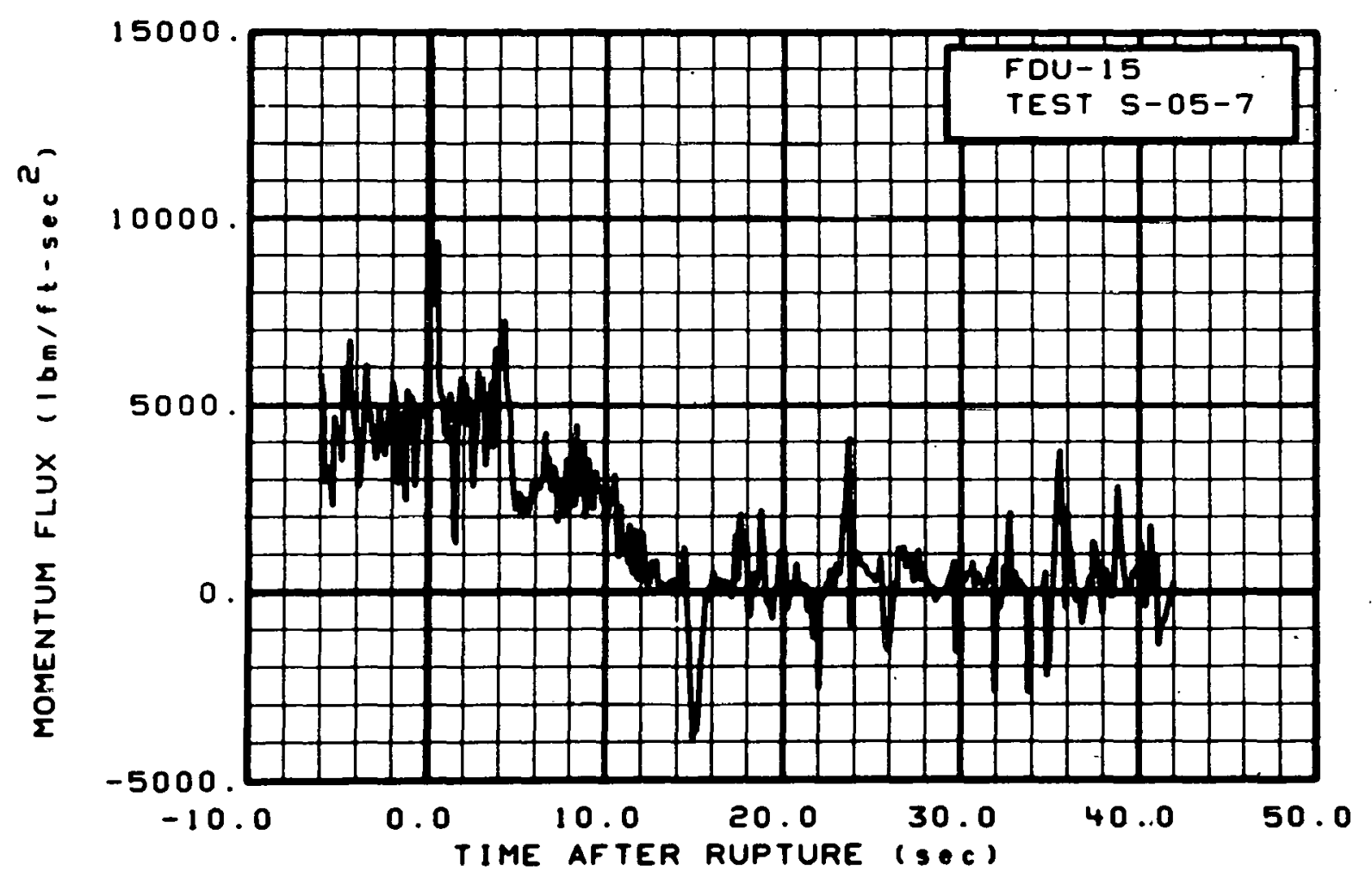

Fig. 429 Momentum flux in intact loop, Test S-05-7 (FDU-15), from -6 to $42 \mathrm{sec}$. 


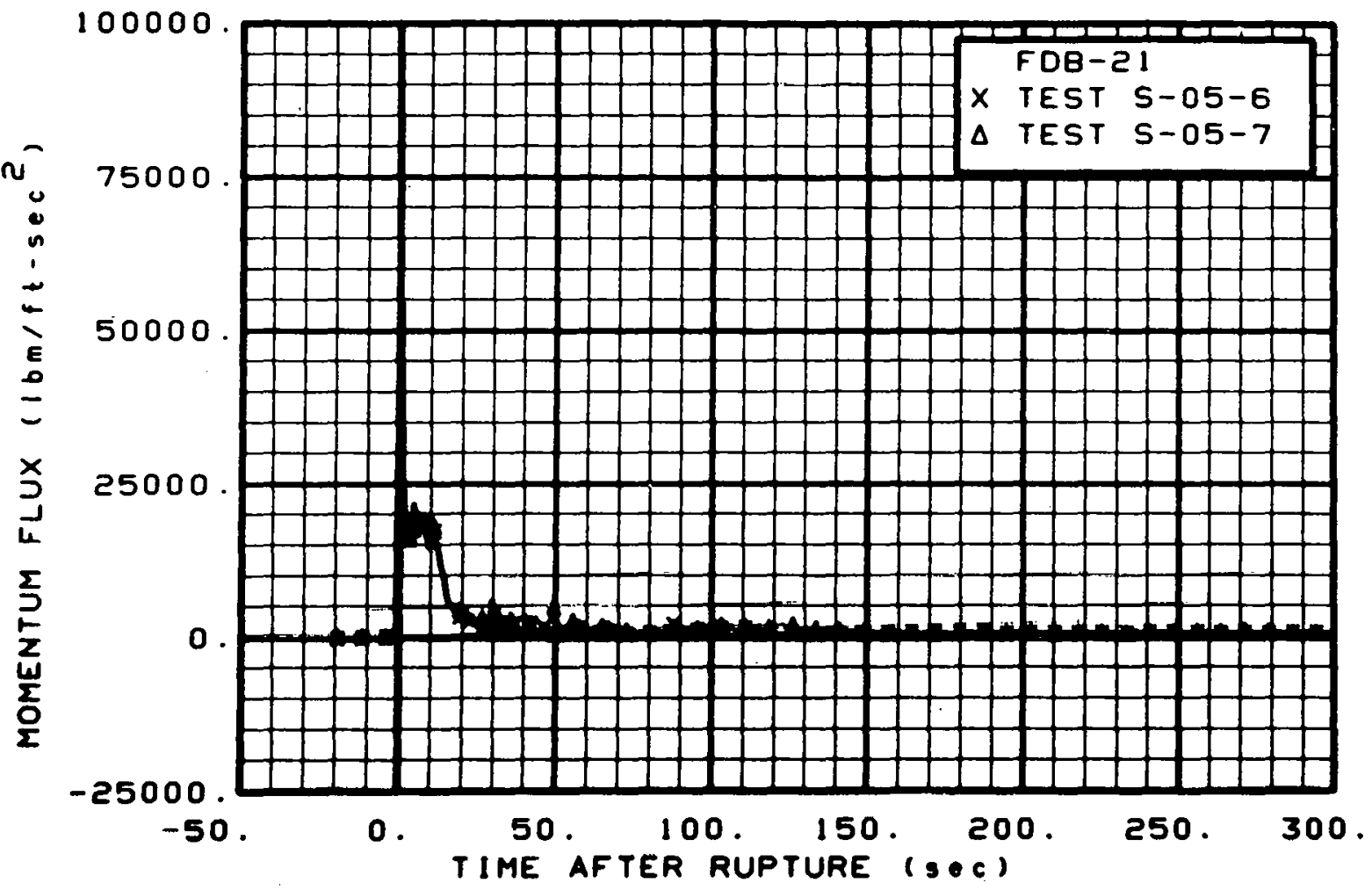

Fig. 430 Momentum flux in broken loop (FDB-21), from -20 to $300 \mathrm{sec}$.

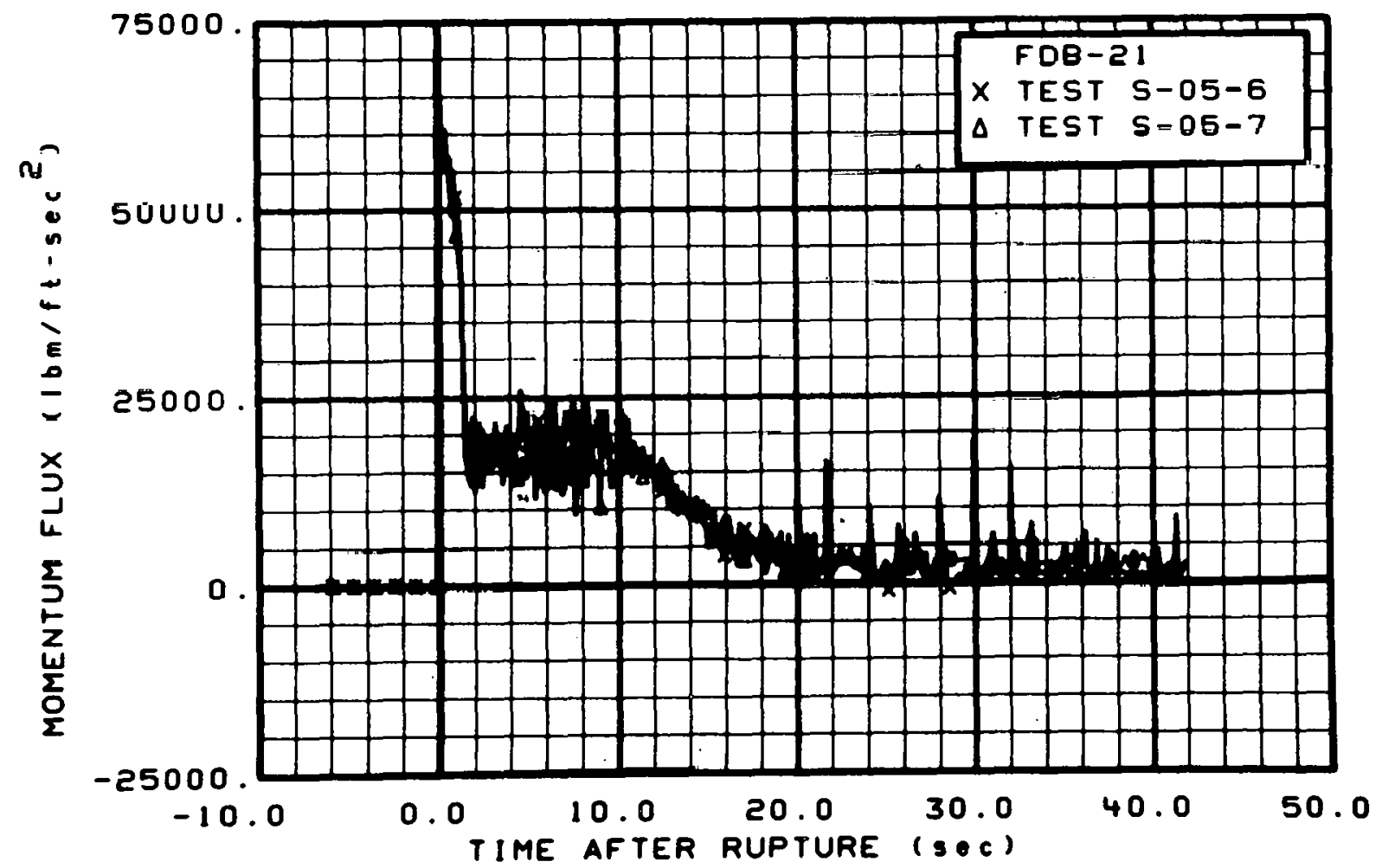

Fig. 431 Momentum flux in broken loop (FDB-21), from -6 to $42 \mathrm{sec}$. 


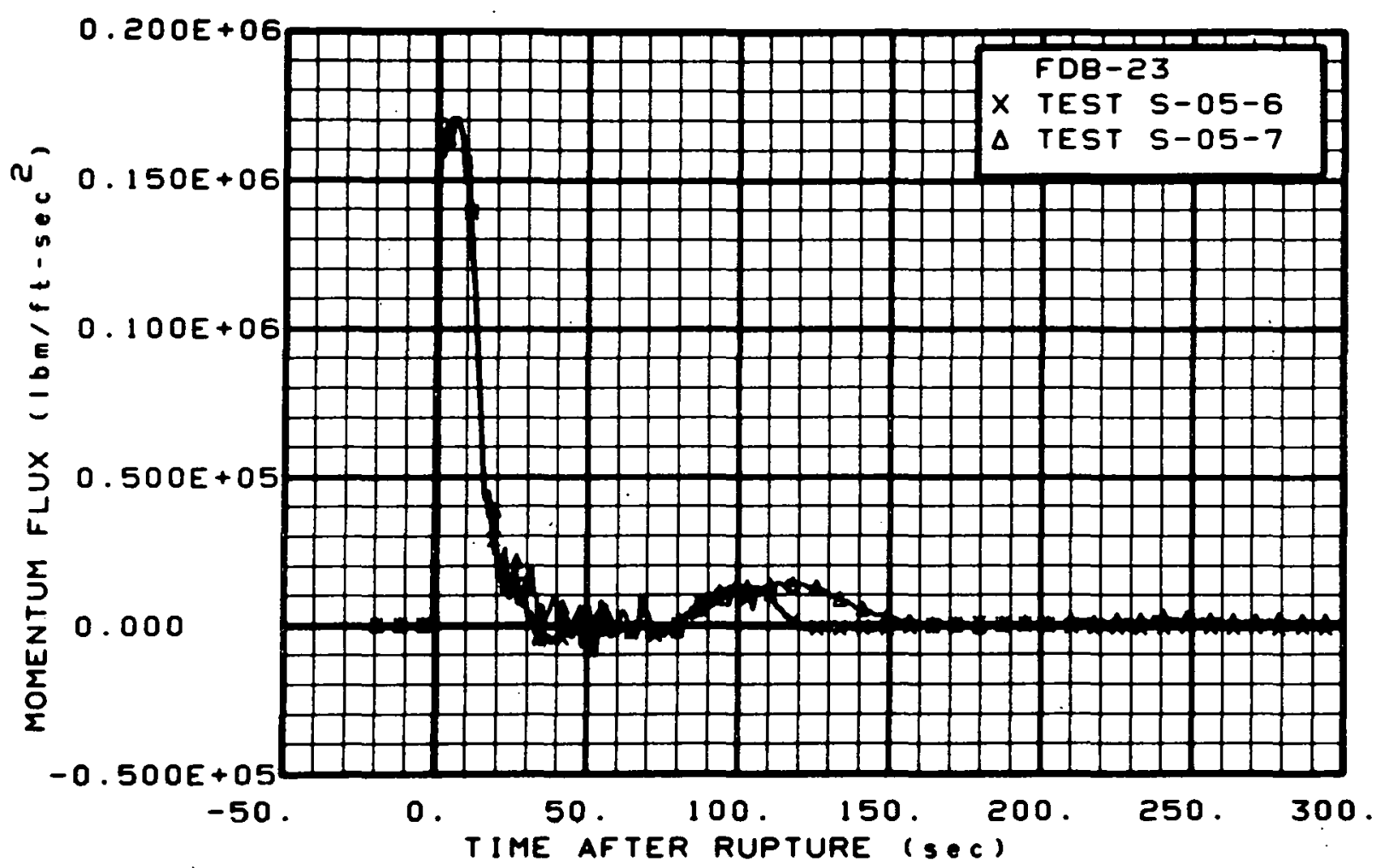

Fig. 432 Momentum flux in broken loop (FDB-23), from -20 to $300 \mathrm{sec}$.

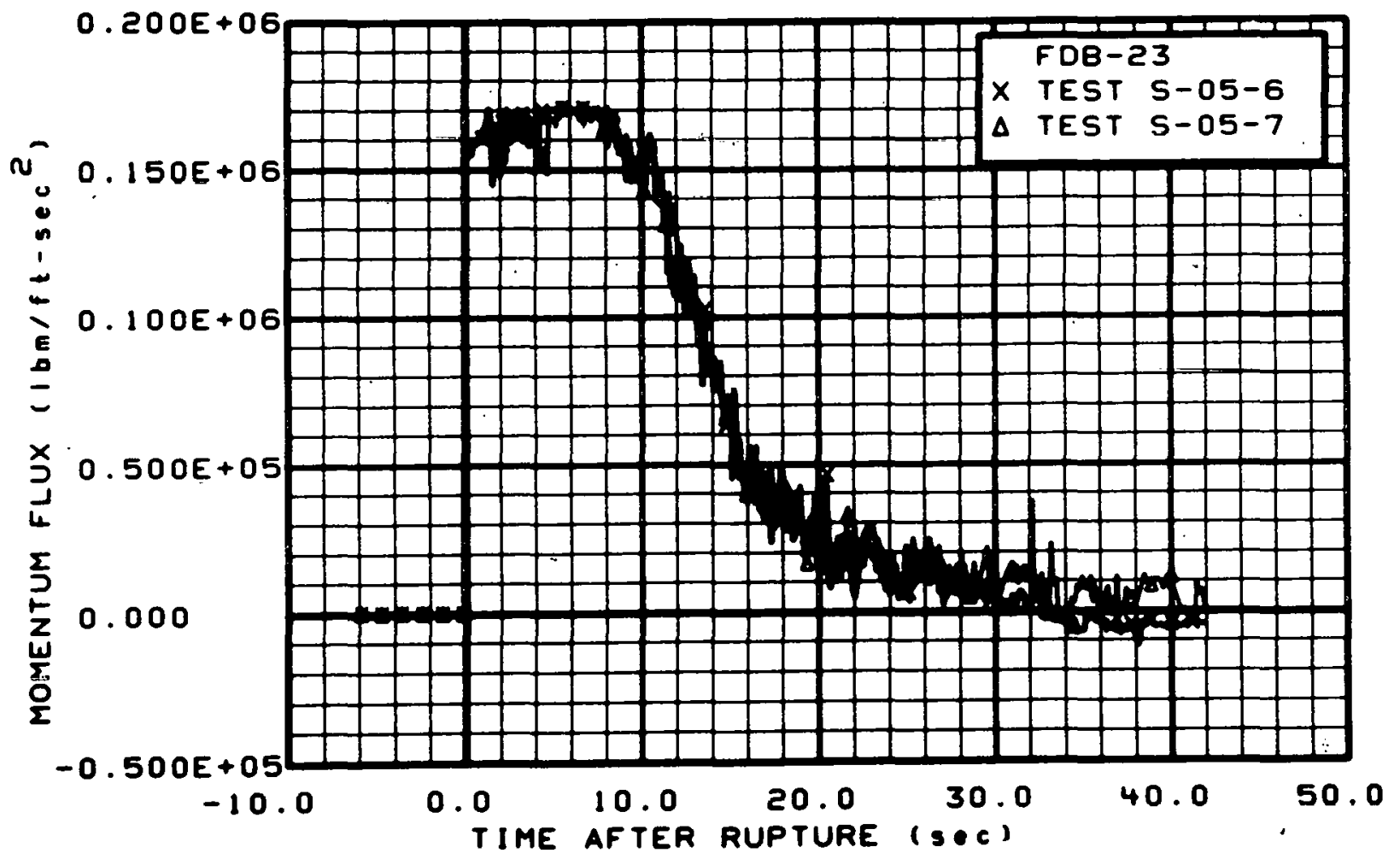

Fig. 433 Momentum flux in broken loop (FDB-23), from -6 to $42 \mathrm{sec}$. 


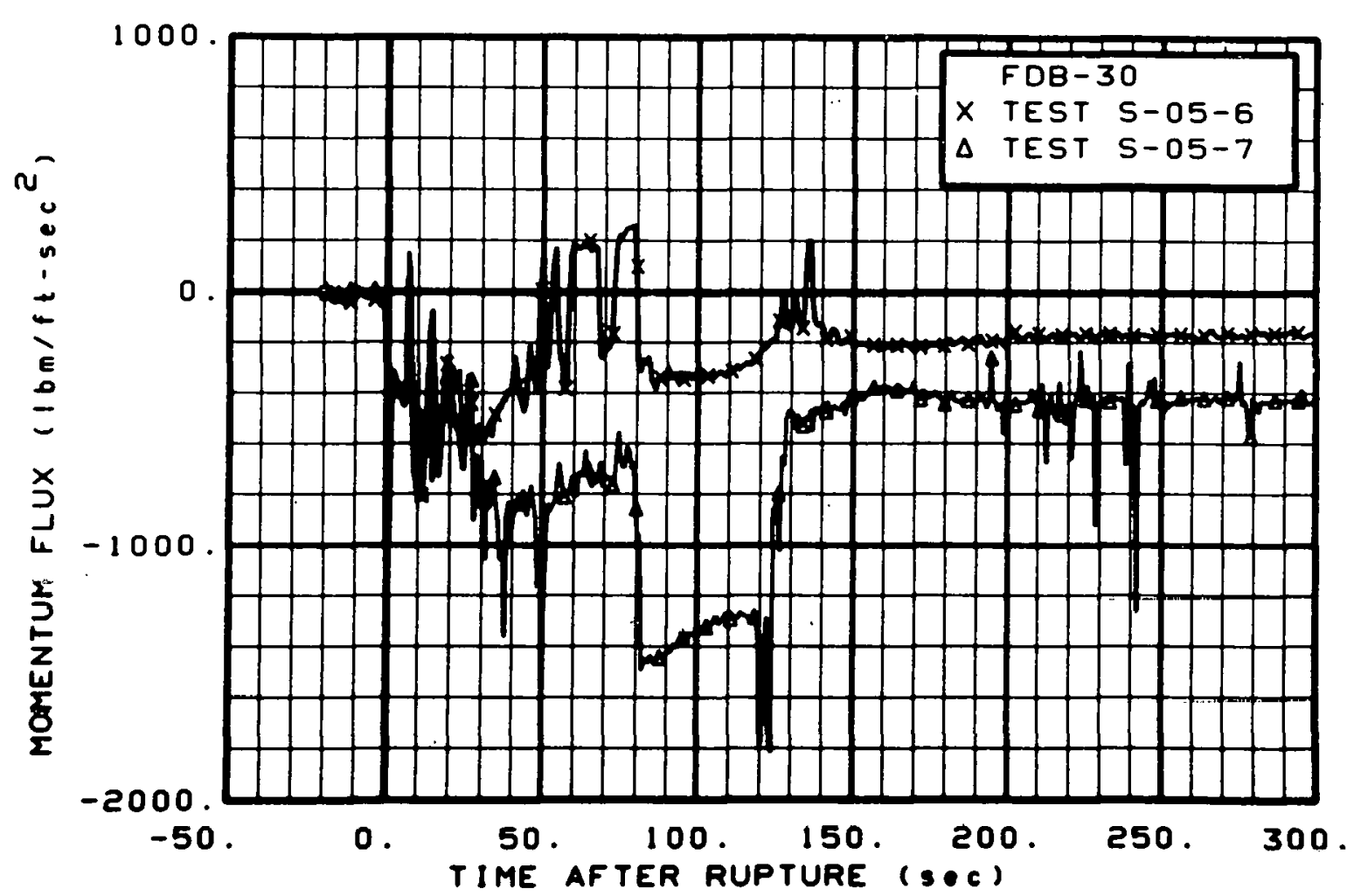

Fig. 434 Momentum flux in broken loop (FDB-30), from -20 to $300 \mathrm{sec}$.

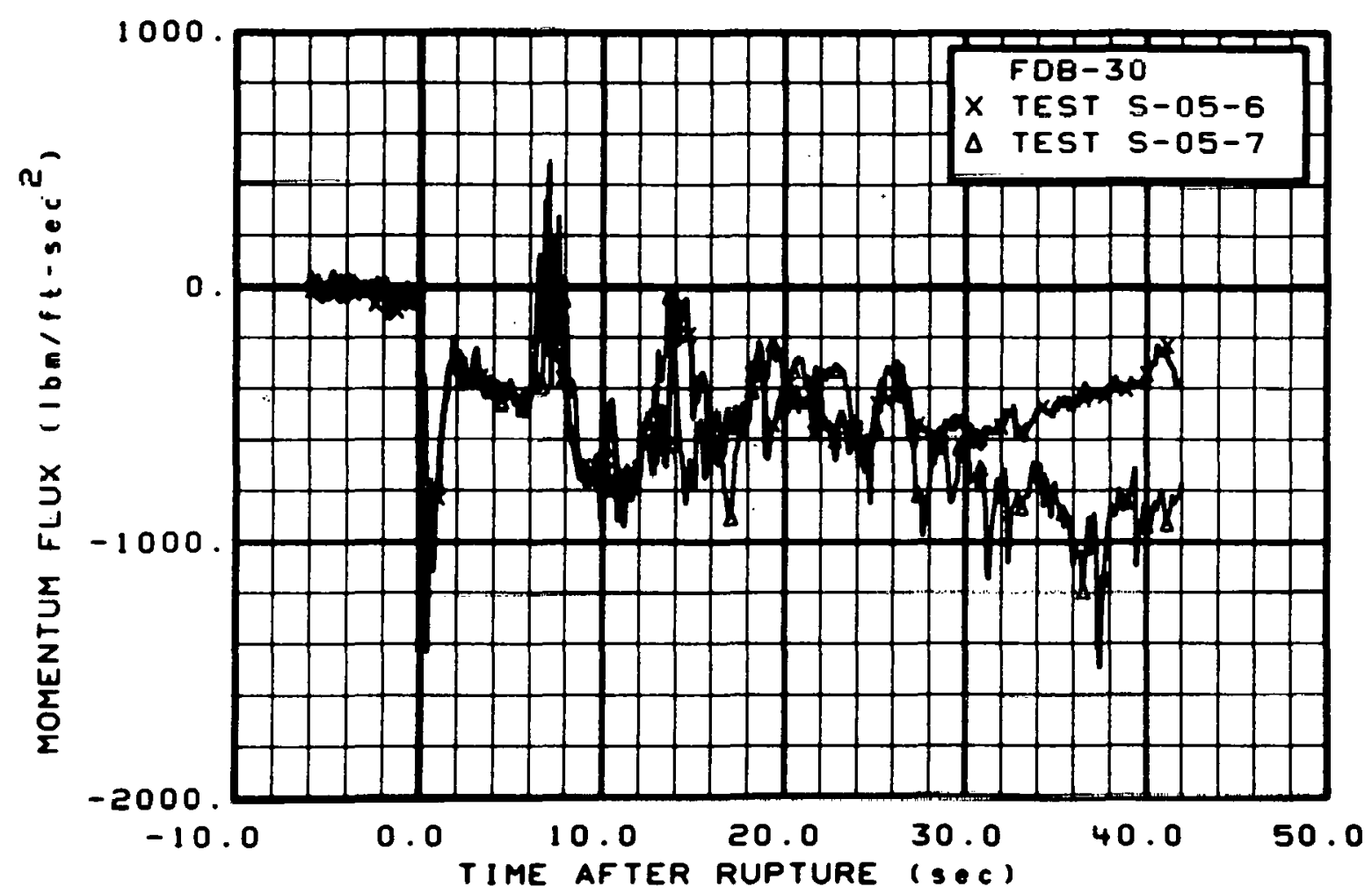

Fig. 435 Momentum flux in broken loop (FDB-30), from -6 to $42 \mathrm{sec}$. 


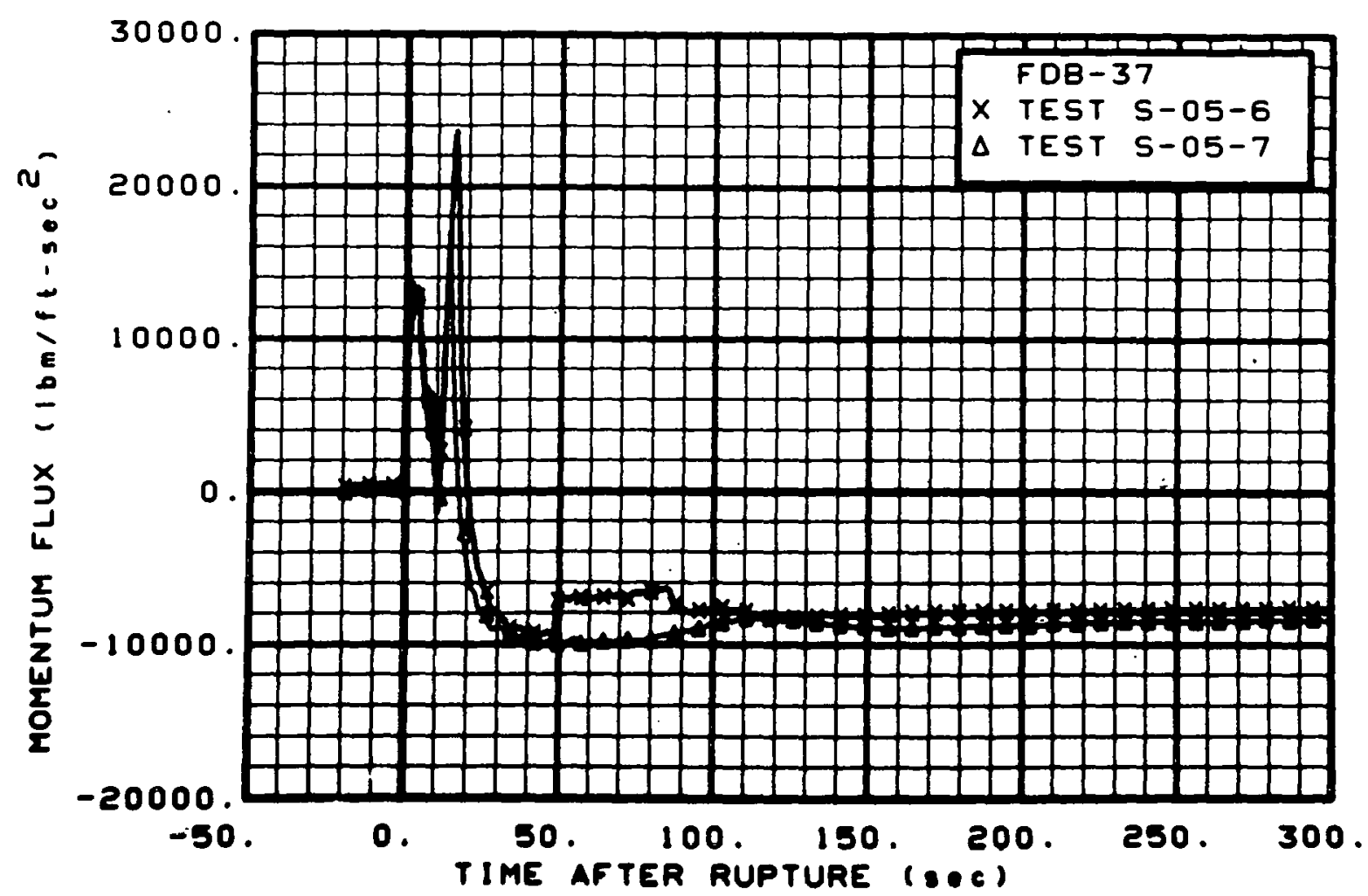

Fig. 436 Momentum flux in broken loop (FDB-37), from -20 to $300 \mathrm{sec}$.

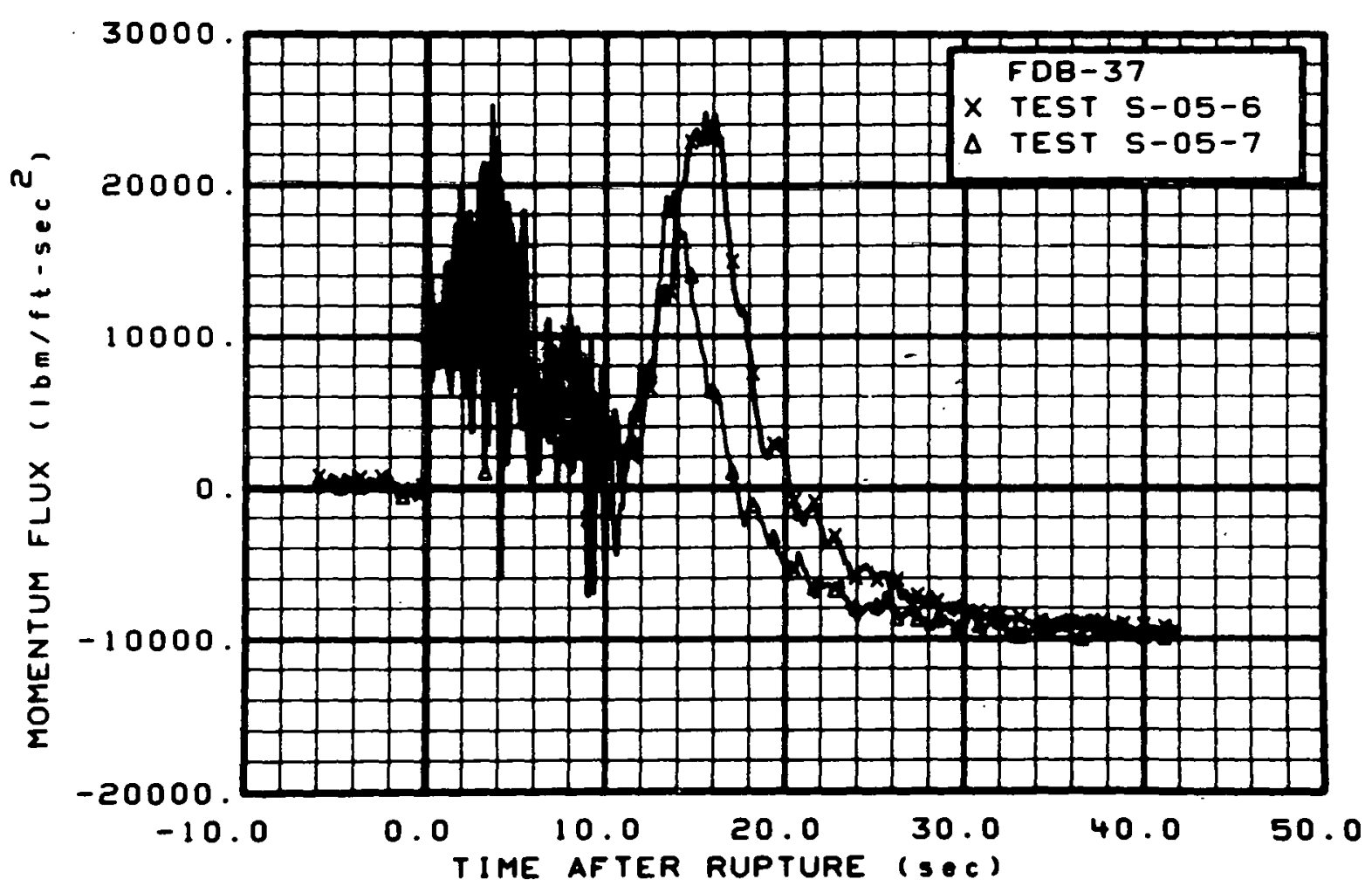

Fig. 437 Momentum flux in broken loop (FDB-37), from -6 to $42 \mathrm{sec}$. 


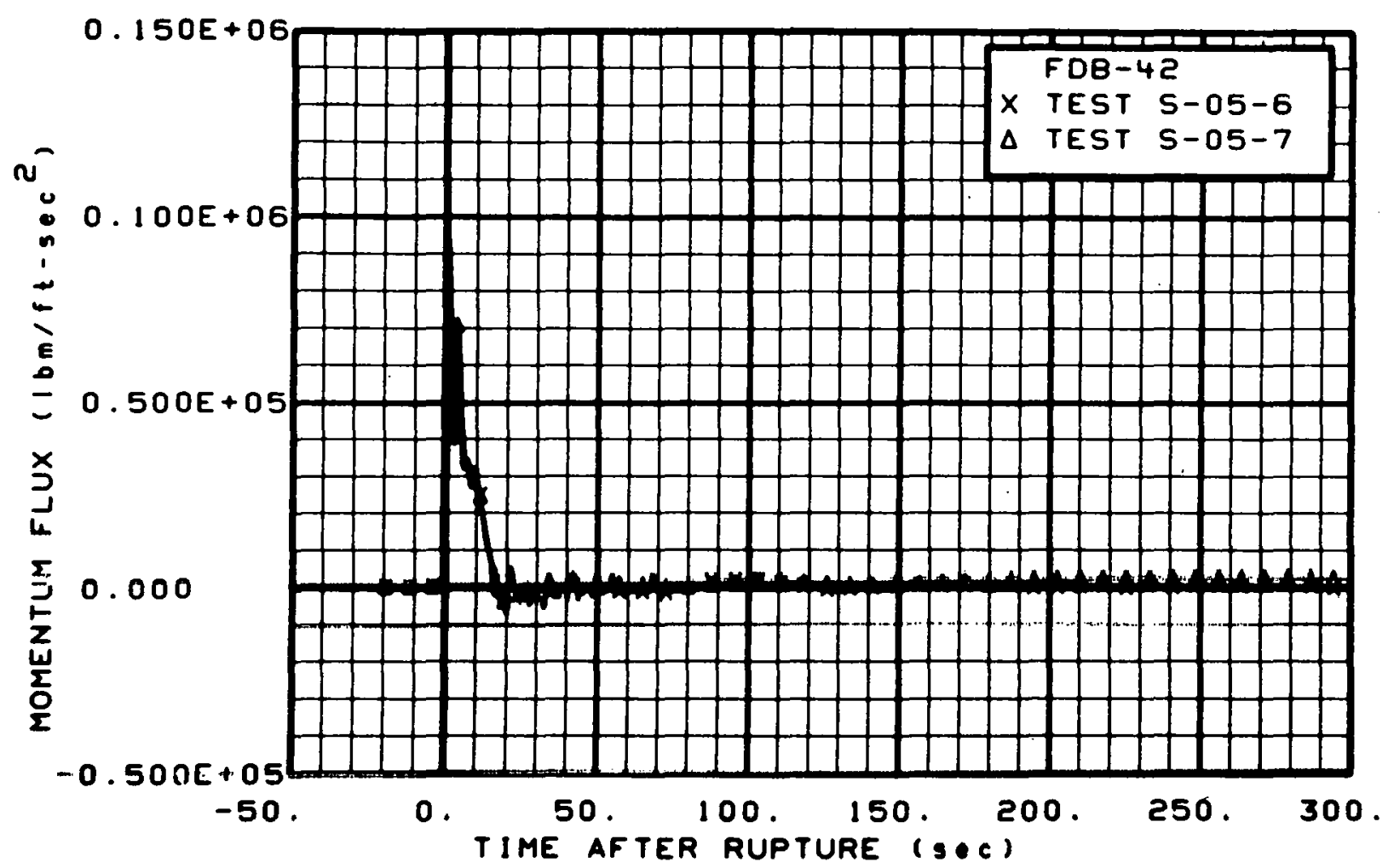

Fig. 438 Momentum flux in broken loop (FDB-42), from -20 to $300 \mathrm{sec}$.

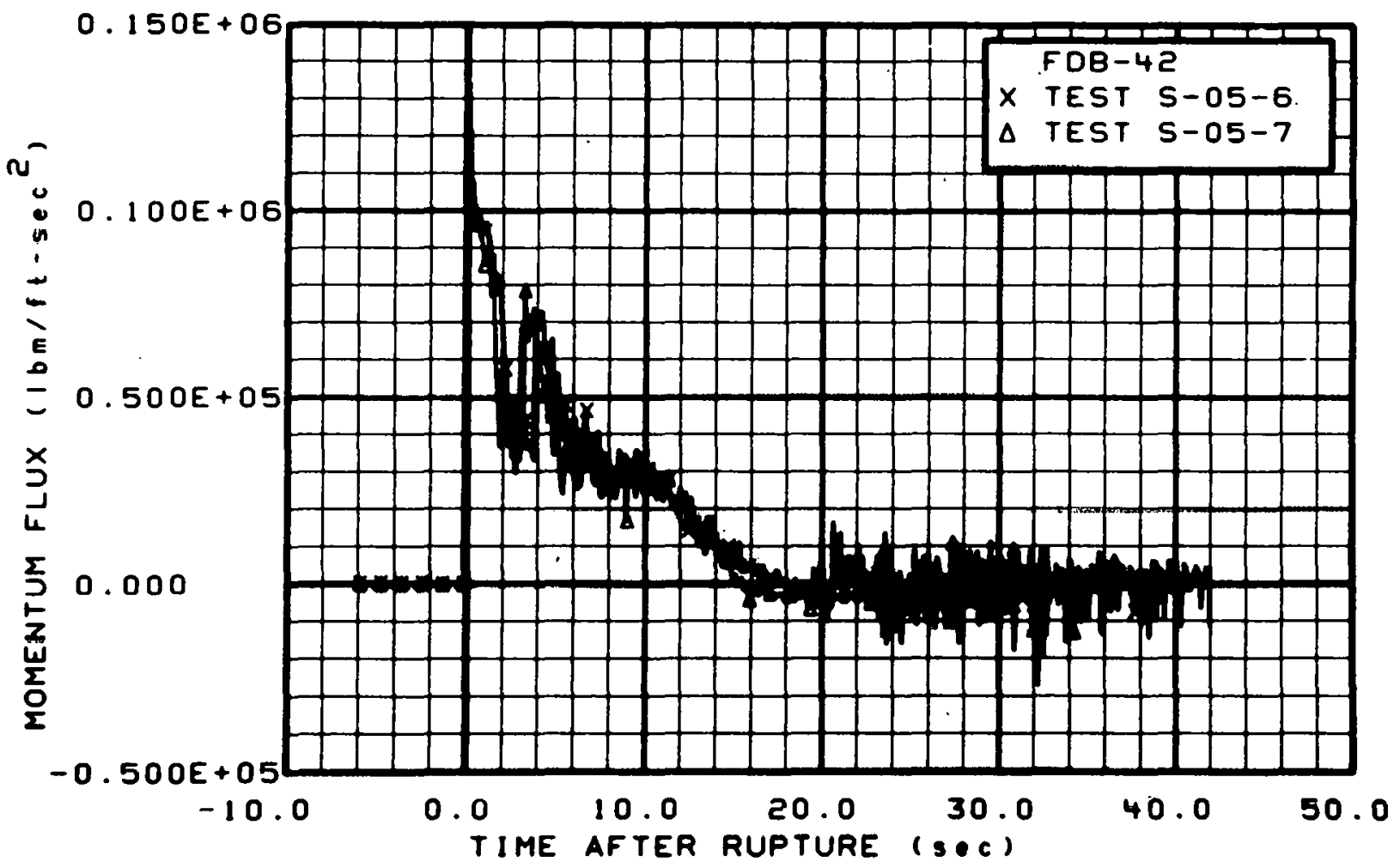

Fig. 439 Momentum flux in broken loop (FDB-42), from -6 to $42 \mathrm{sec}$. 


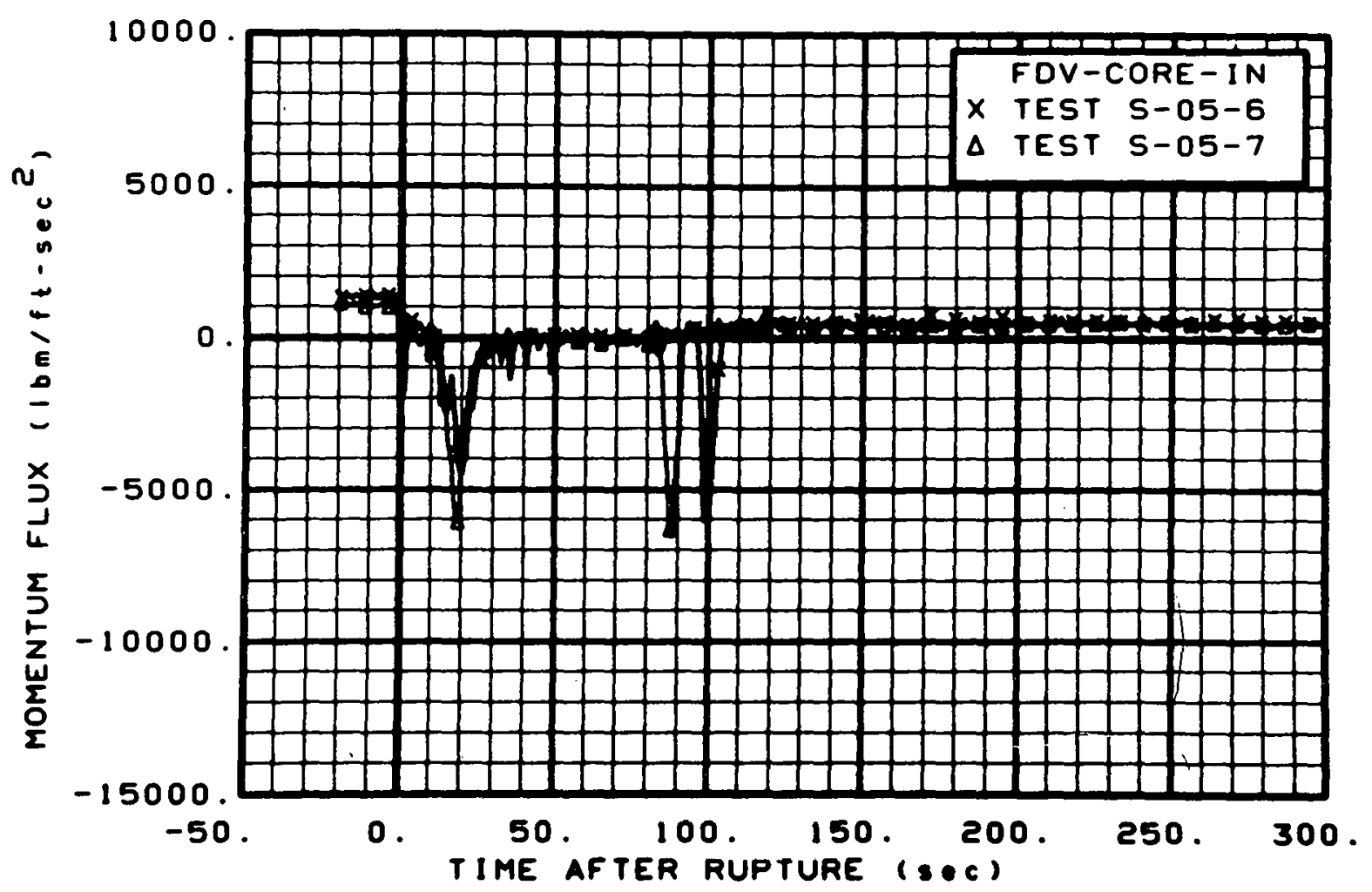

Fig. 440 Momentum flux in core entrance (FDV-CORE-IN), from -20 to 300 sec.

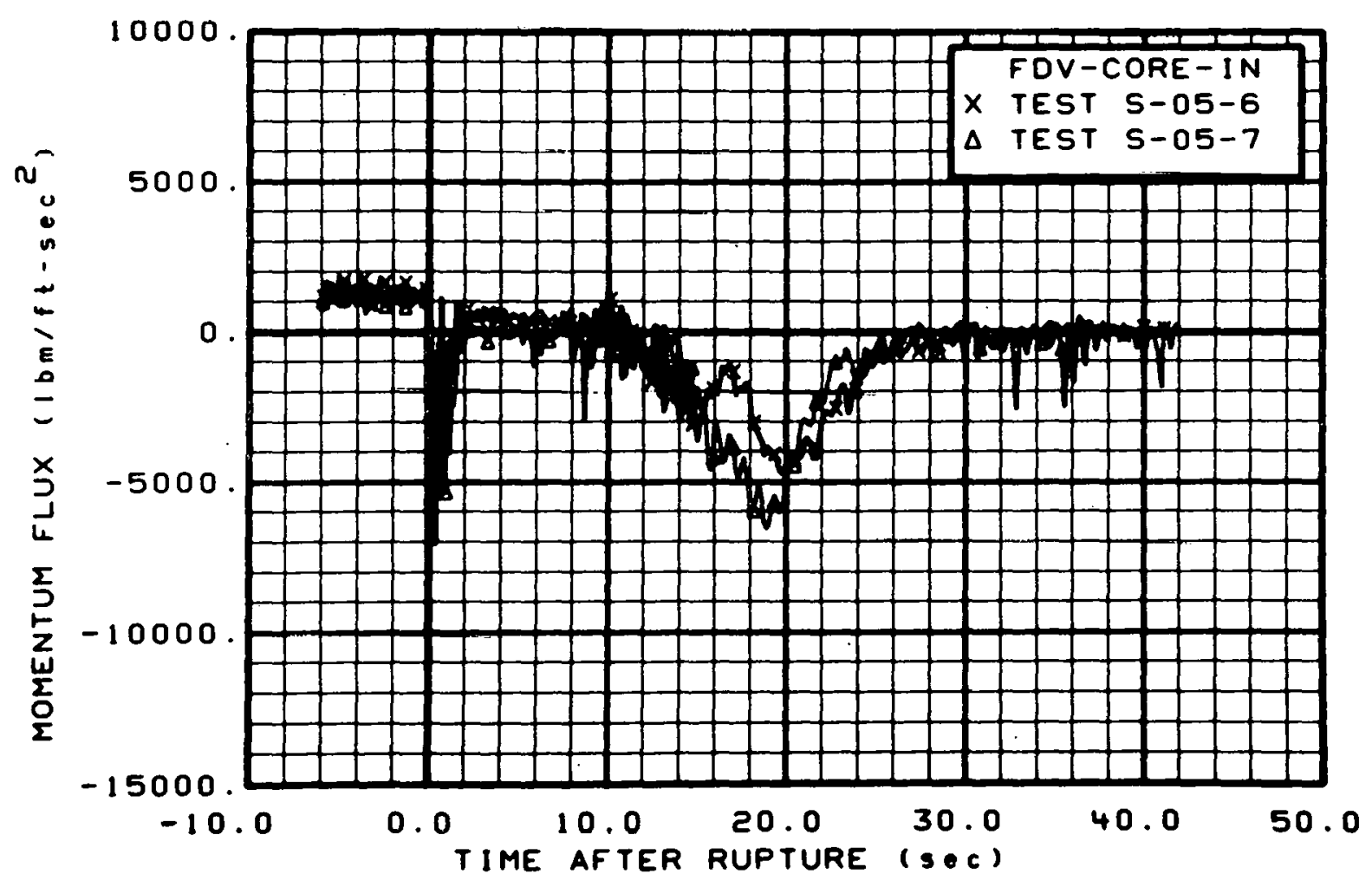

Fig. 441 Momentum flux in core entrance (FDV-CORE-IN), from -6 to $42 \mathrm{sec}$. 


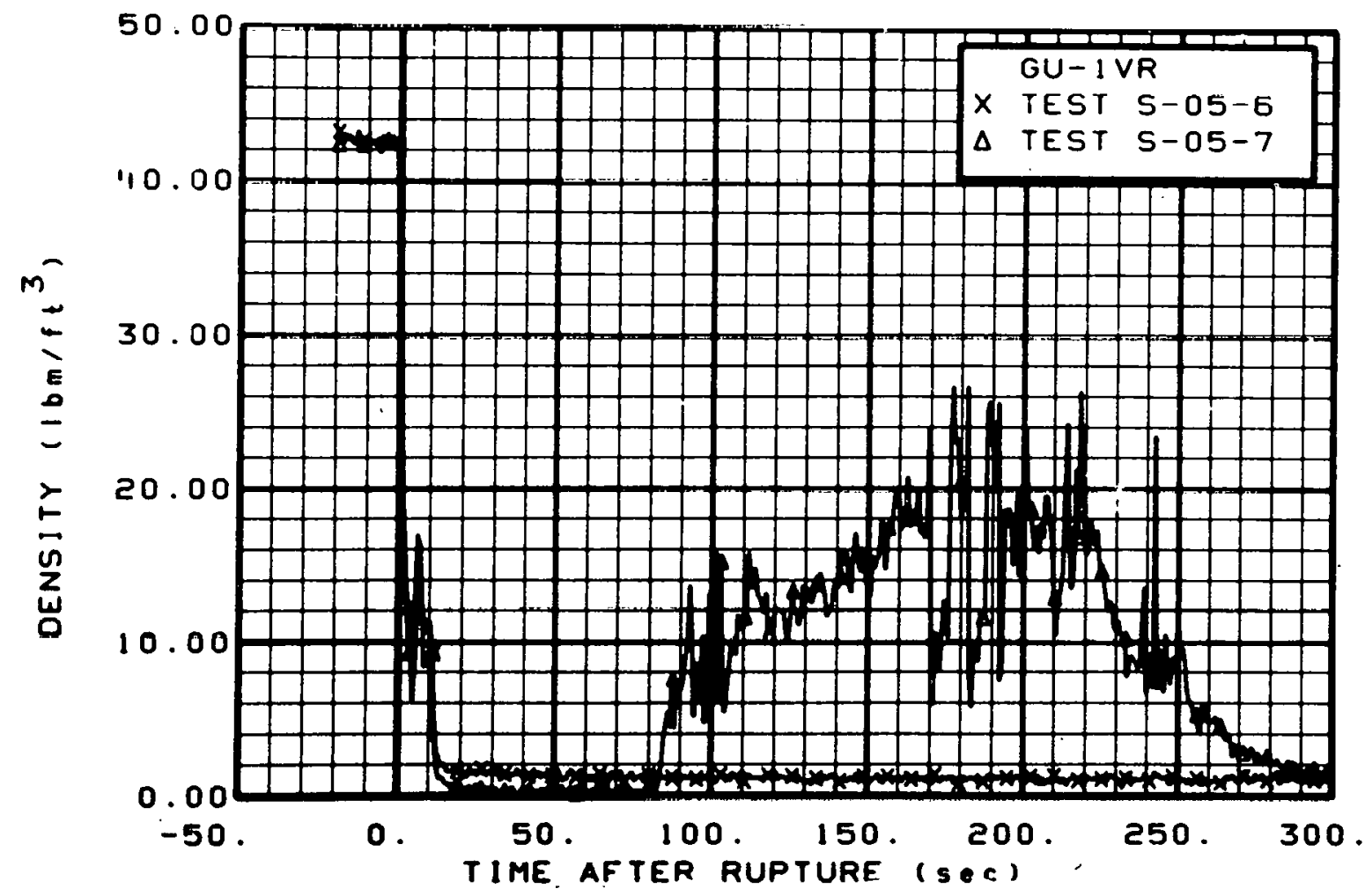

Fig. 442 Density in intact loop (GU-lVR), from -20 to $300 \mathrm{sec}$.

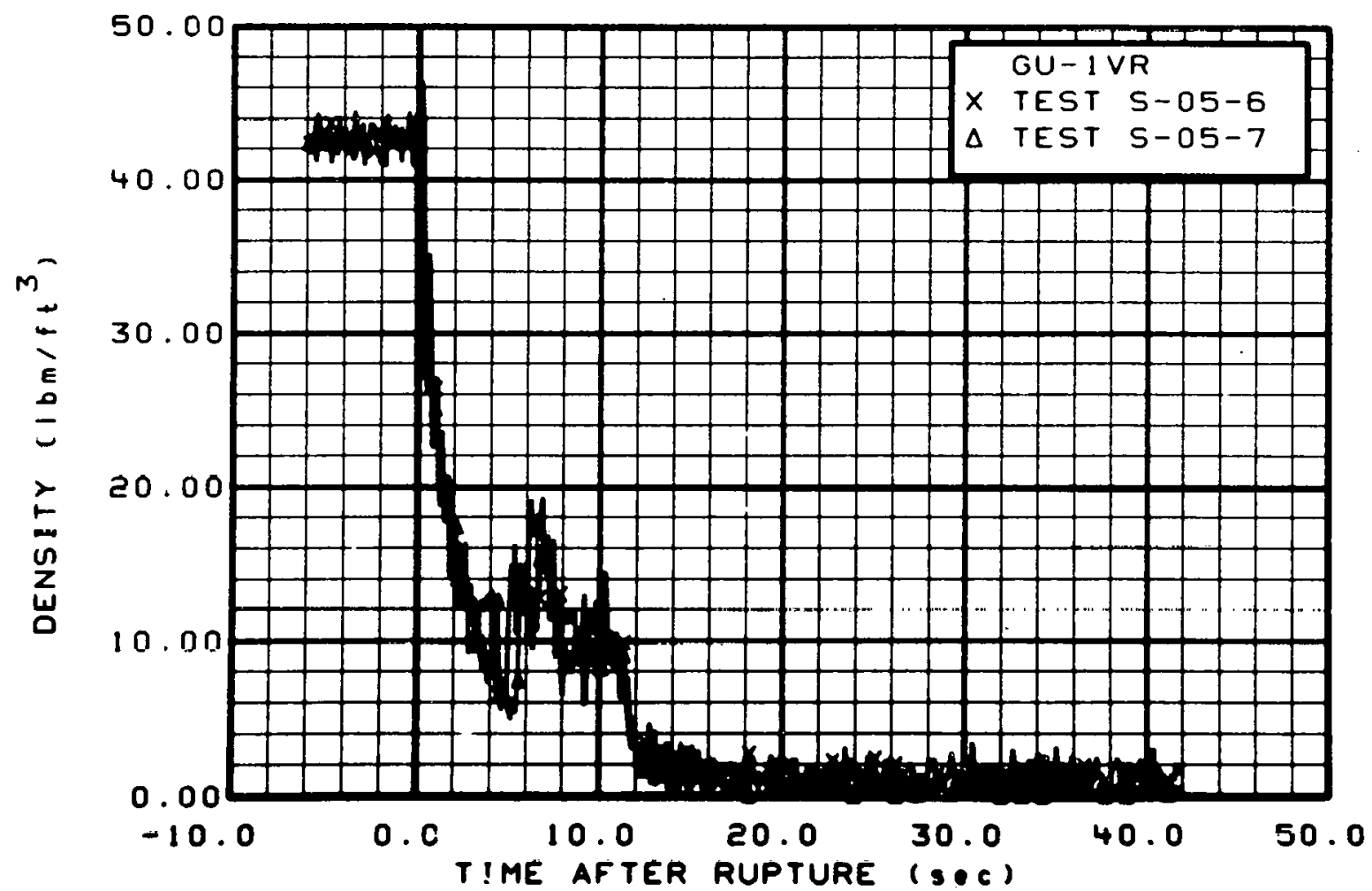

Fig. 443 Density in intact loop (GU-1VR), from -6 to $42 \mathrm{sec}$. 


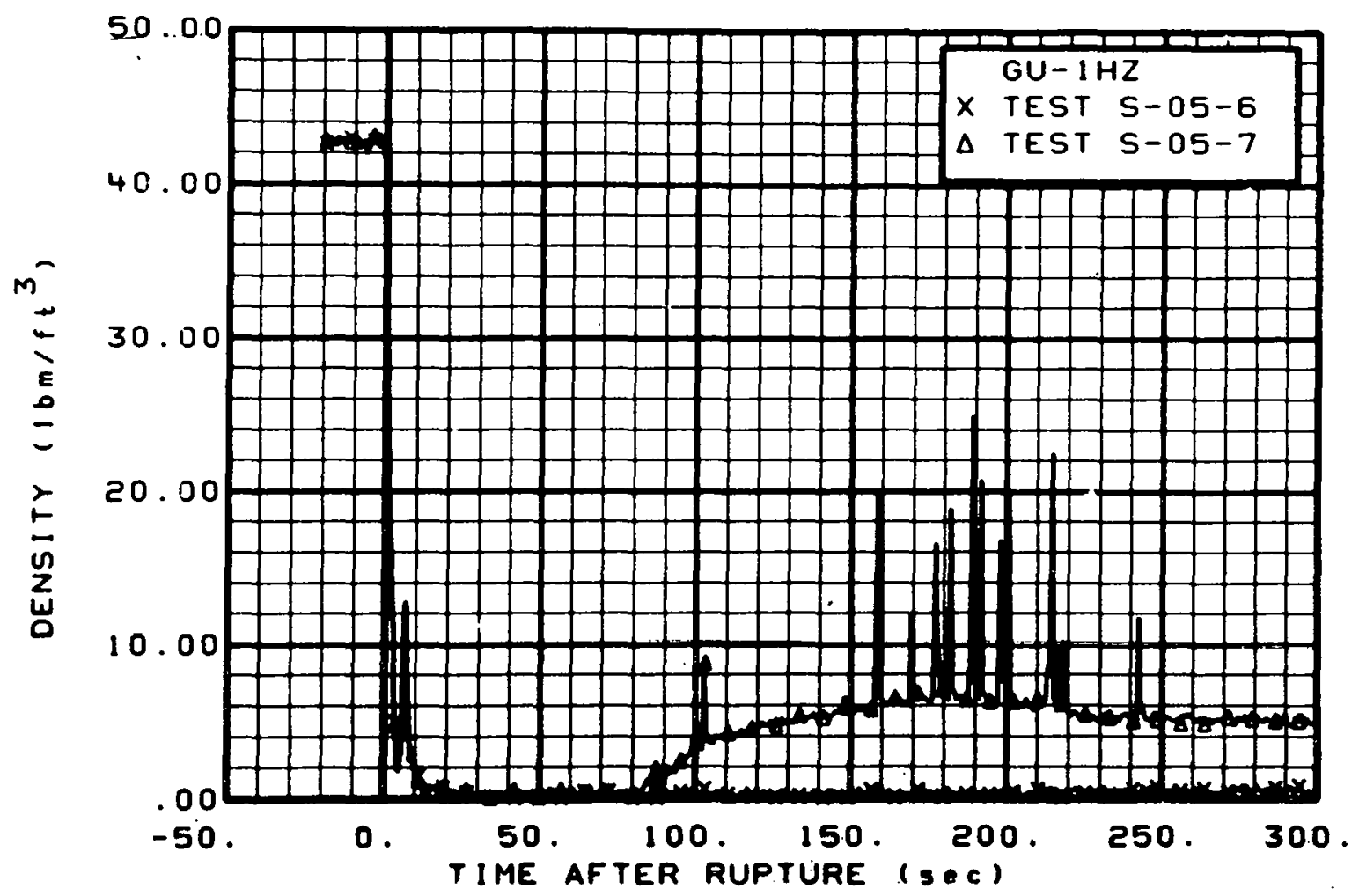

Fig. 444 Density in intact loop (GU- $1 \mathrm{HZ}$ ), from -20 to $300 \mathrm{sec}$.

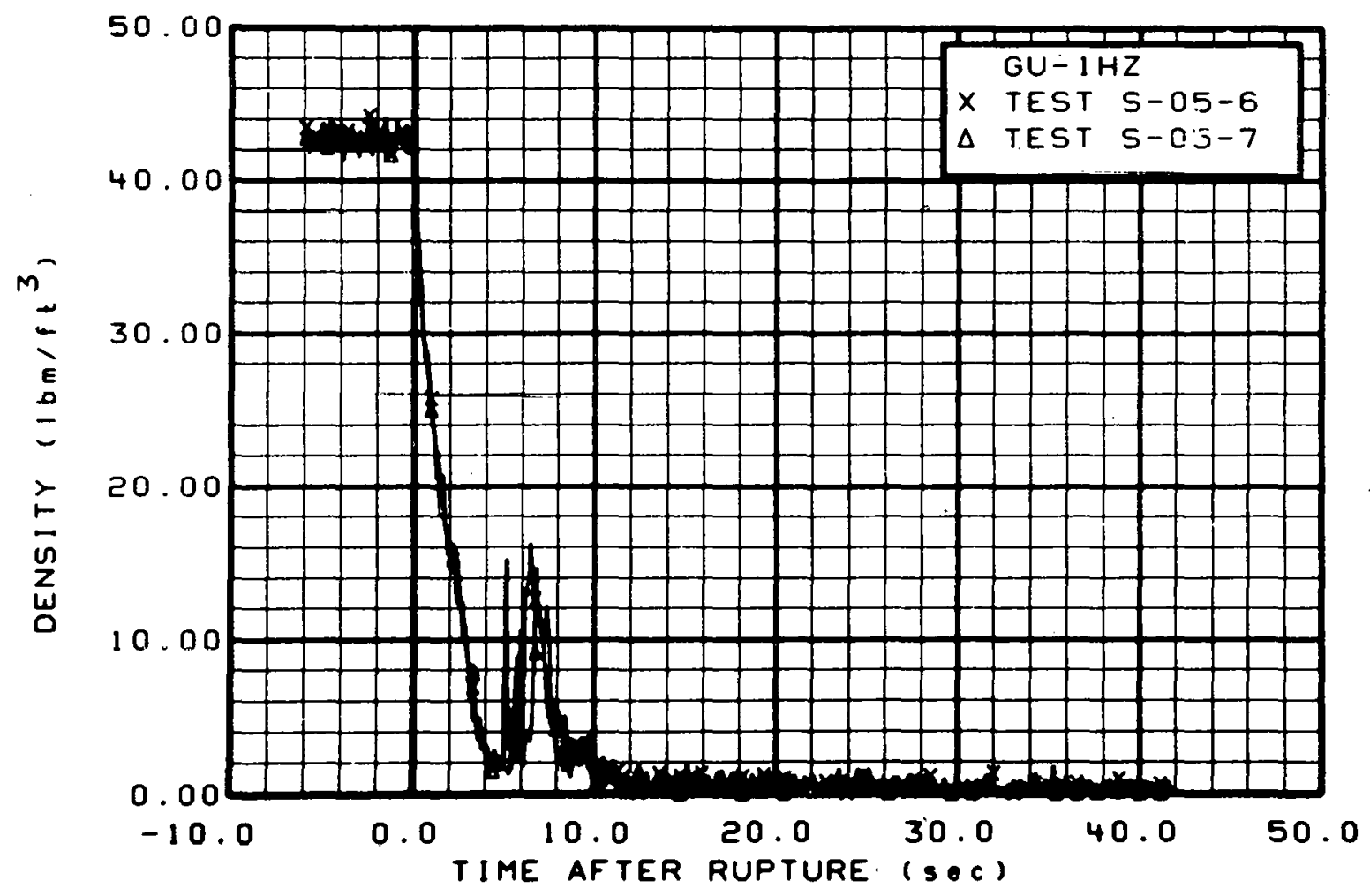

Fig. 445 Density in intact loop (GU-1HZ), from -6 to $42 \mathrm{sec}$. 


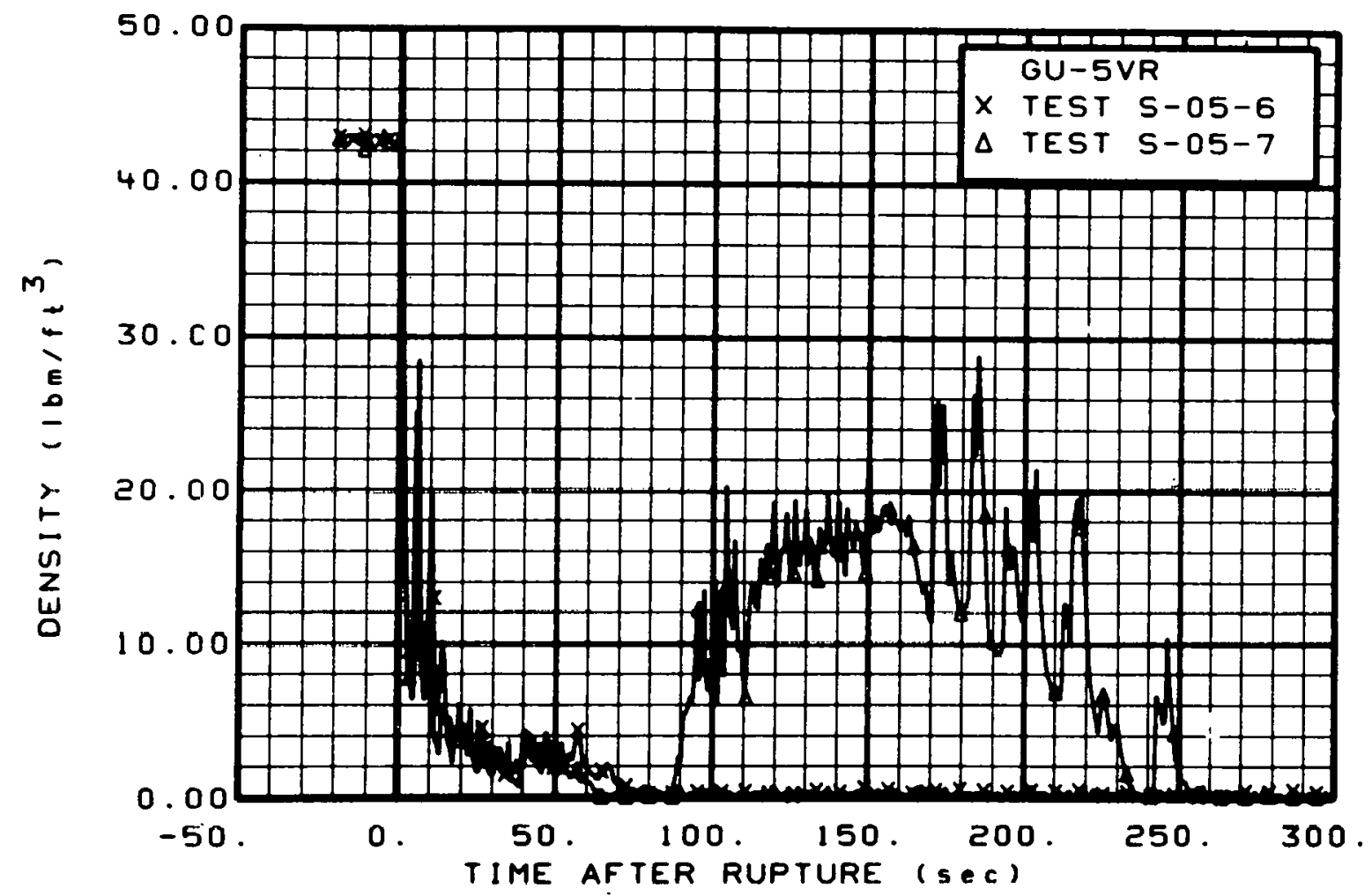

Fig. 446 Density in intact 10op (GU-5VR), from -20 to $300 \mathrm{sec}$.

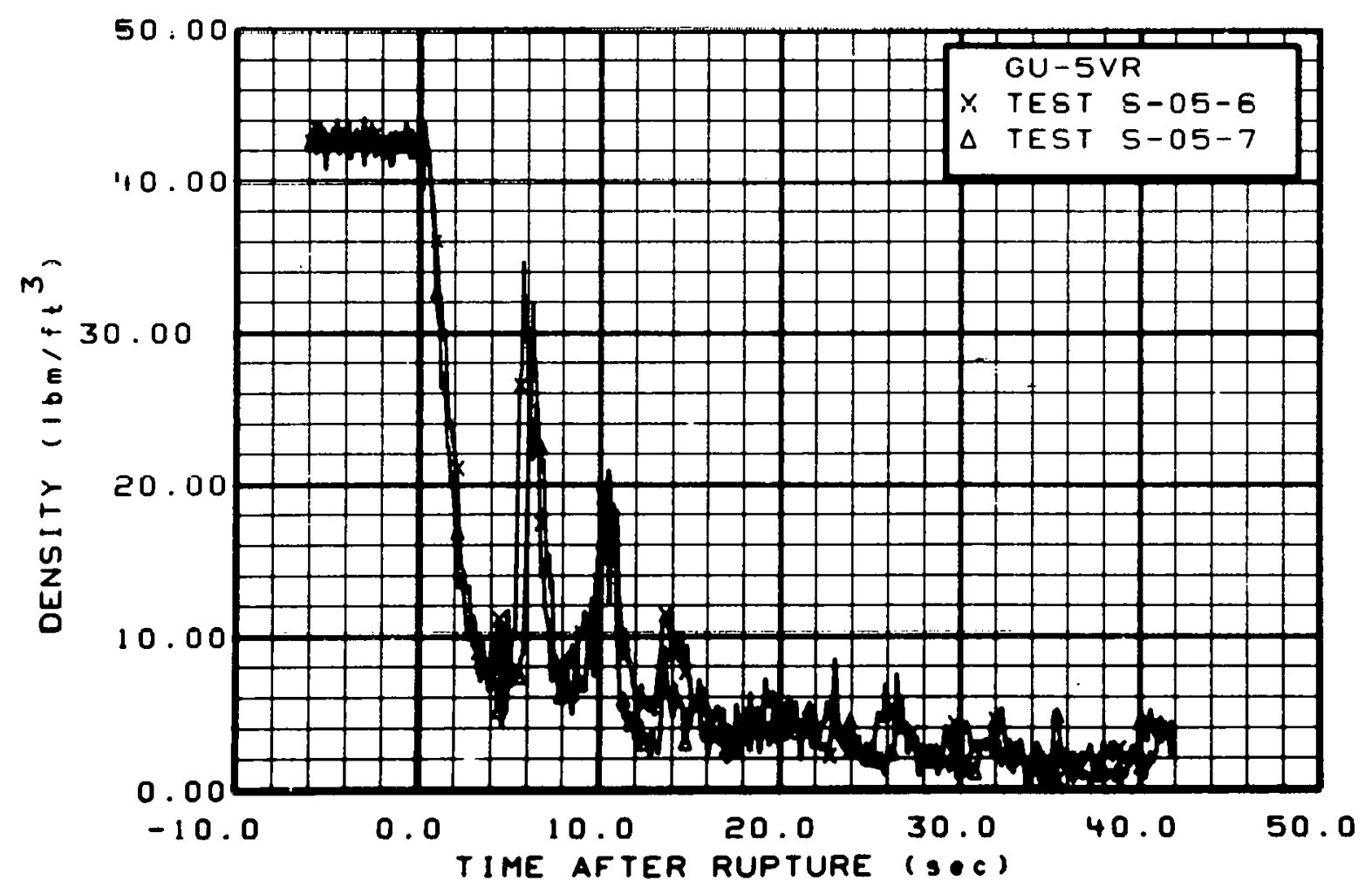

Fig. 447 Density in intact loop (GU-5VR), from -6 to $42 \mathrm{sec}$. 


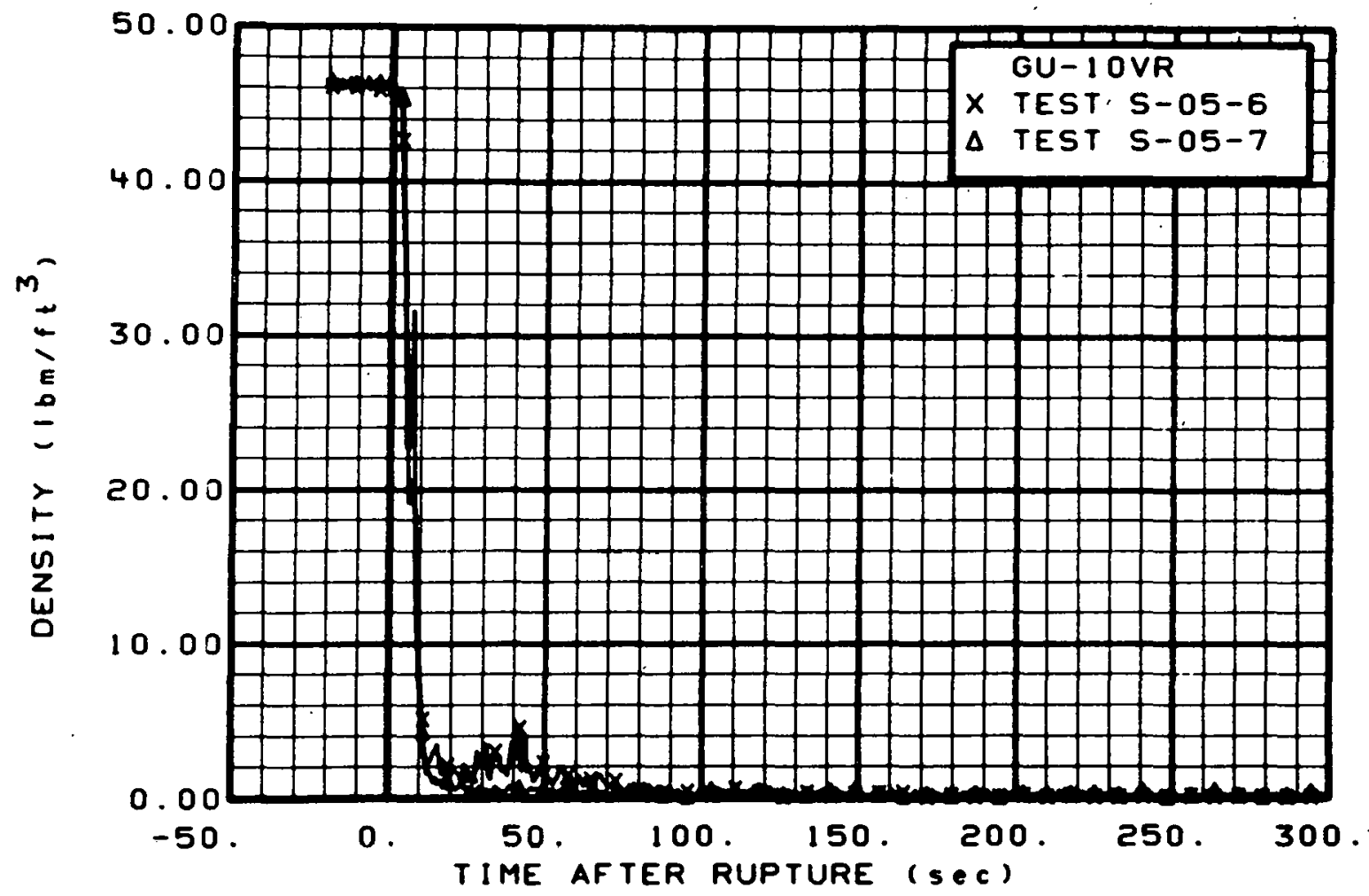

Fig. 448 Density in intact 10op (GU-10VR), from -20 to $300 \mathrm{sec}$.

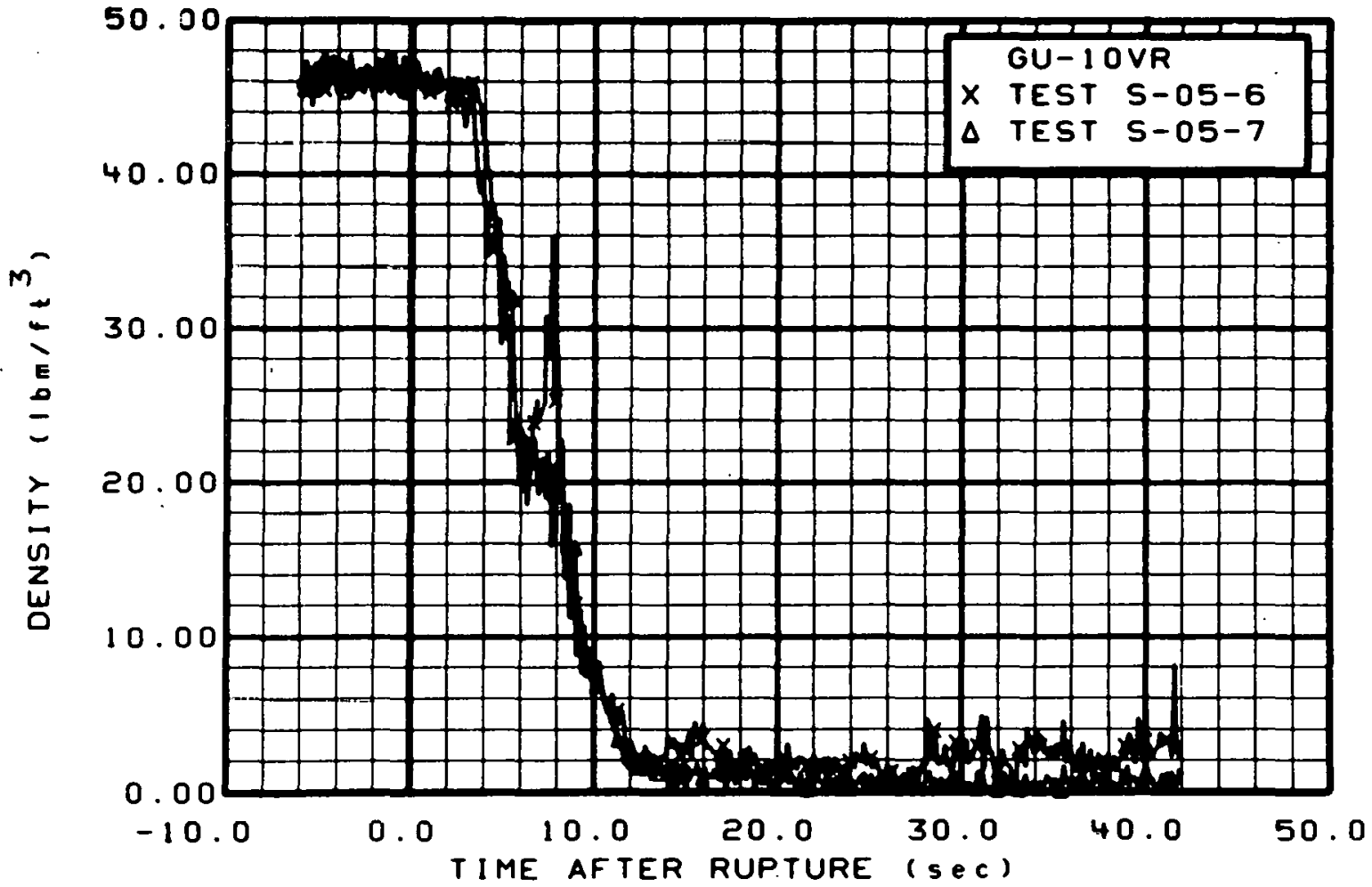

Fig. 449 Density in intart. 10op (GU-10VR), from -6 to $42 \mathrm{sec}$. 


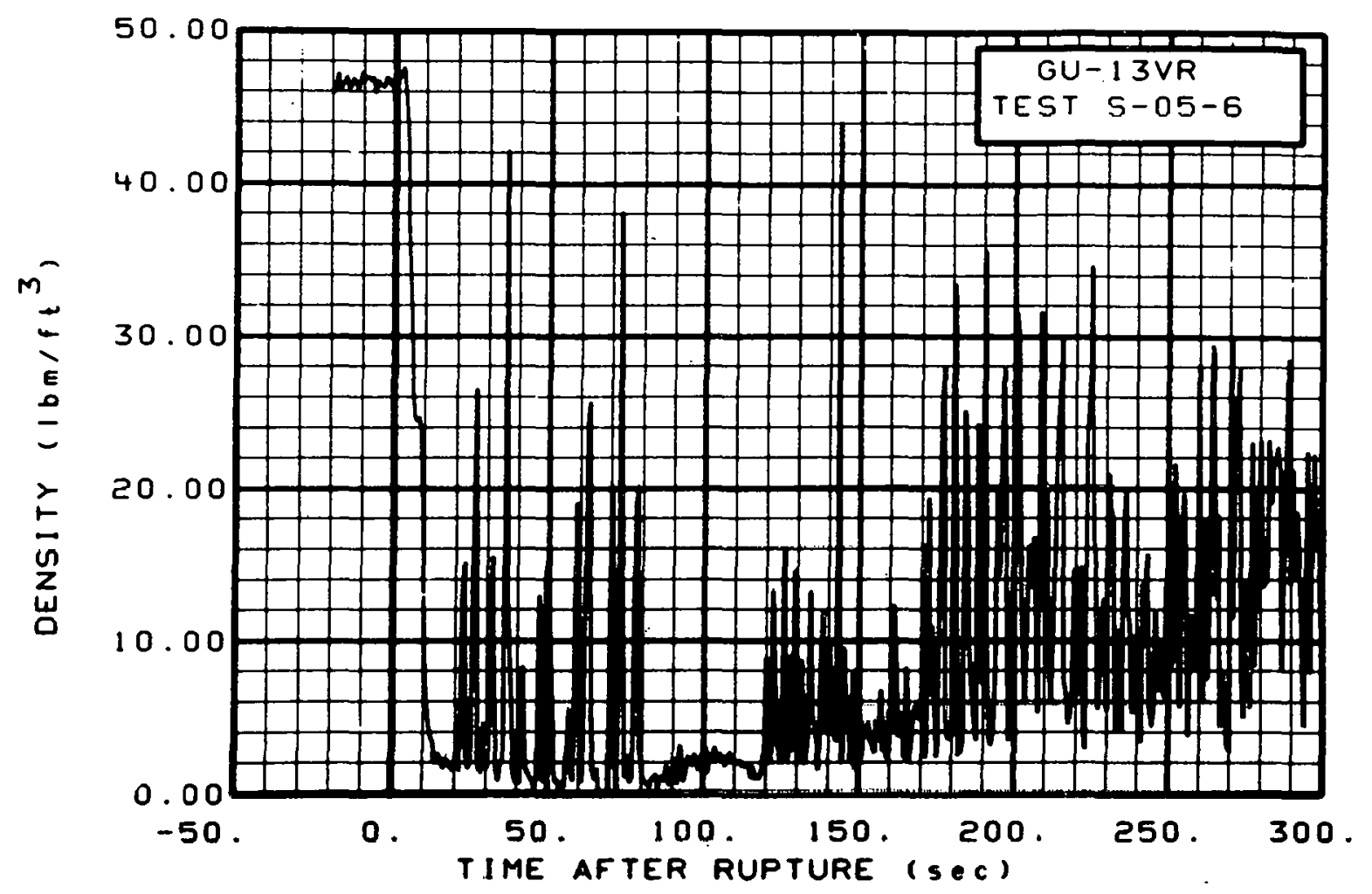

Fig. 450 verisity in intact 10op, Test S-05-6 (GU-13VR), from -20 to $300 \mathrm{sec}$.

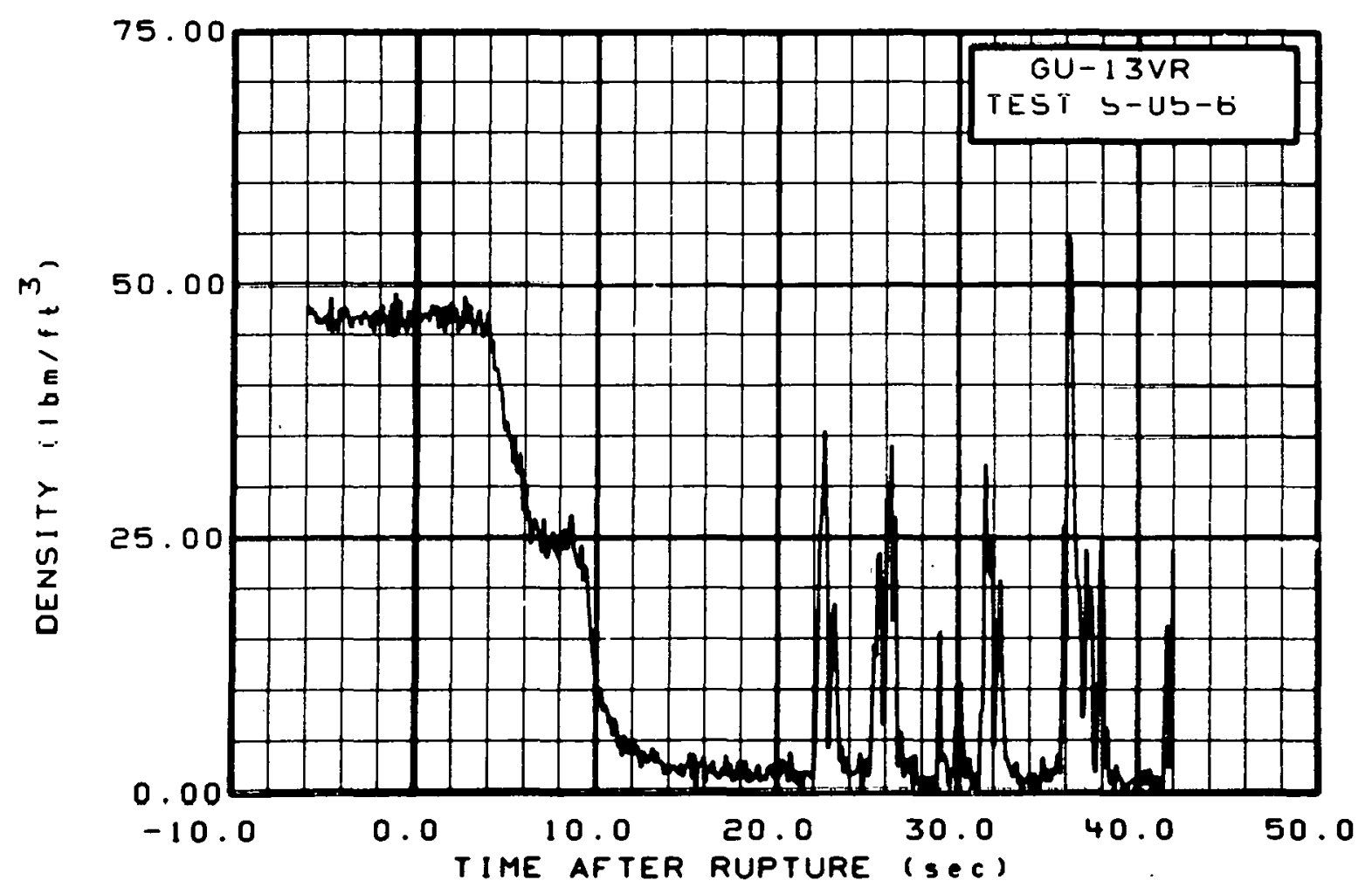

Fig. 451 Density in intact 10op, Test S-05-6 (GU-13VR), from -6 to $42 \mathrm{sec}$. 


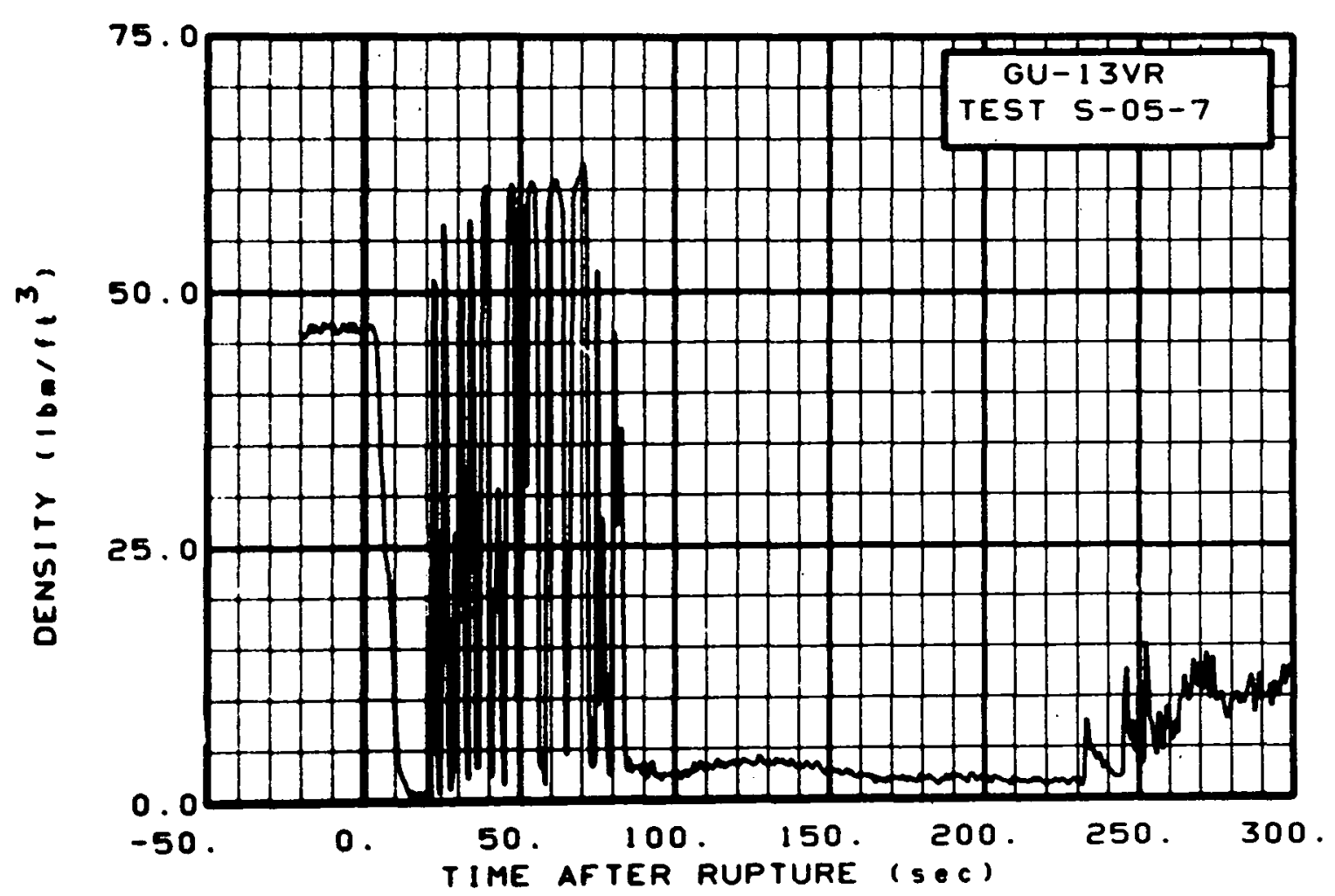

Fig. 452 Density in intact 10op, Test $S-05-7$ (GU-13VR), from -20 to $300 \mathrm{sec}$.

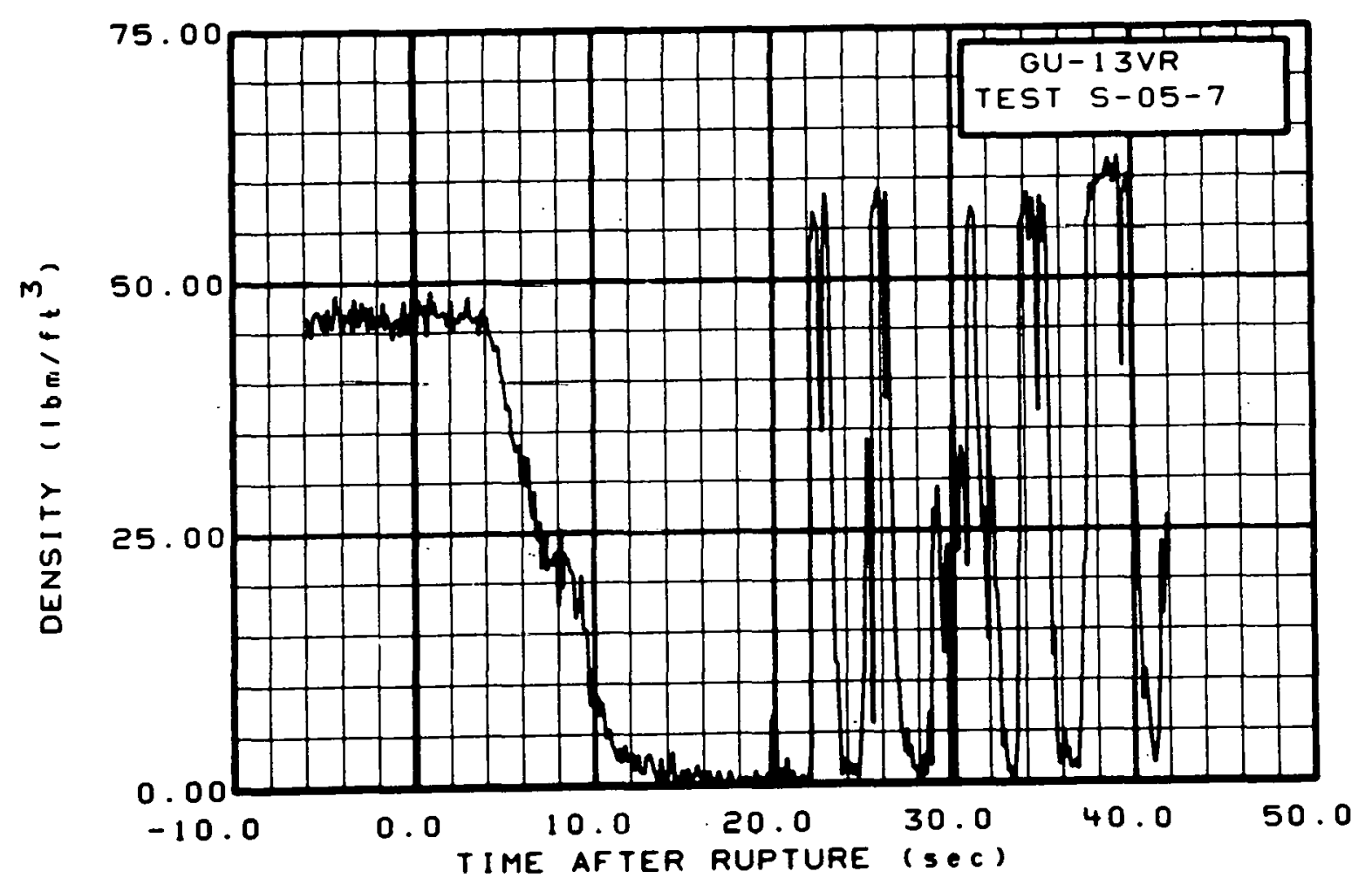

Fig. 453 Density in intact 10op, Test S-05-7 (GU-13VR), from -6 to $42 \mathrm{sec}$. 


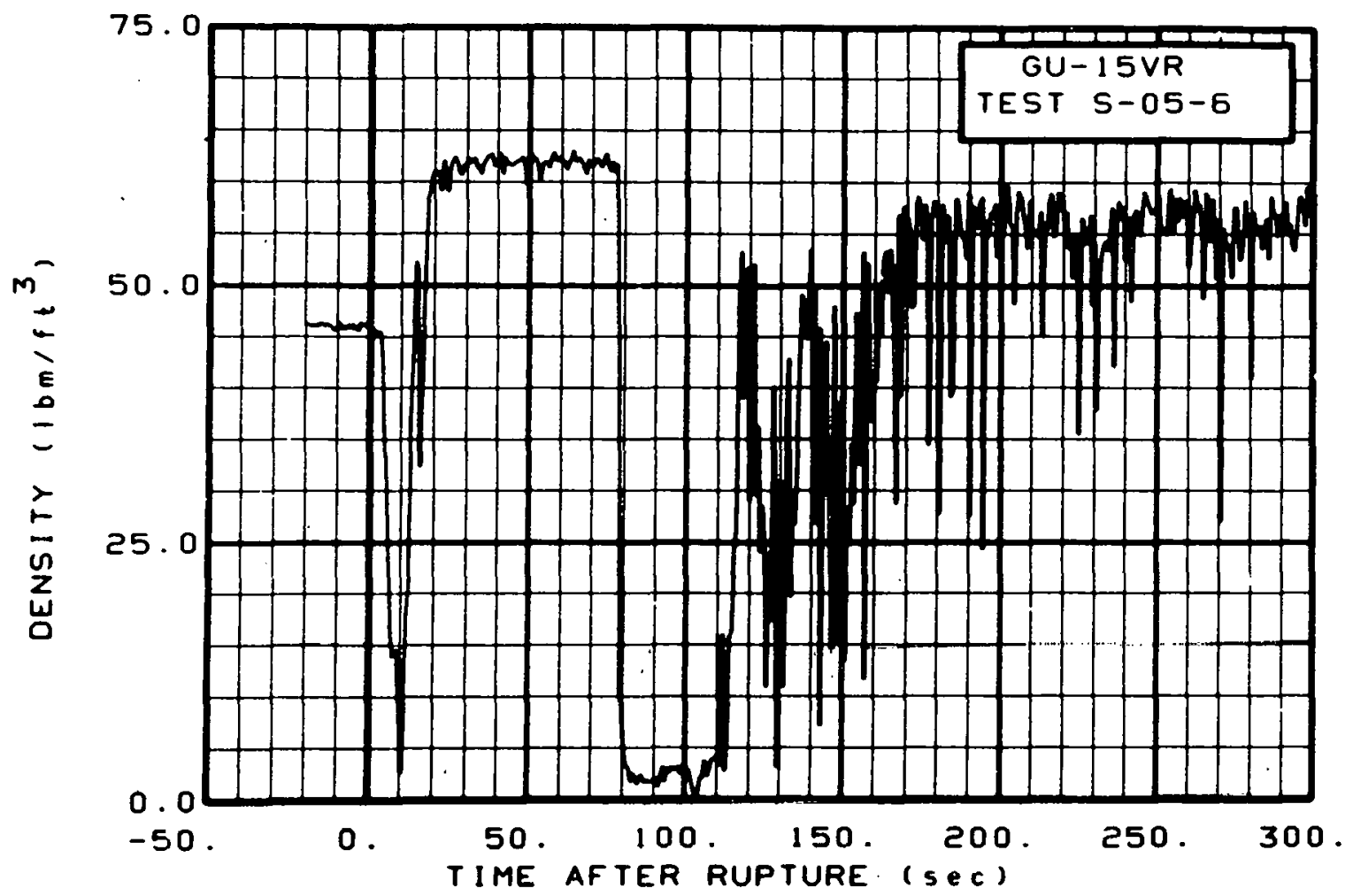

Fig. 454 Density in intact 10op, Test S-05-6 (GU-15VR), from -20 to 300 sec.

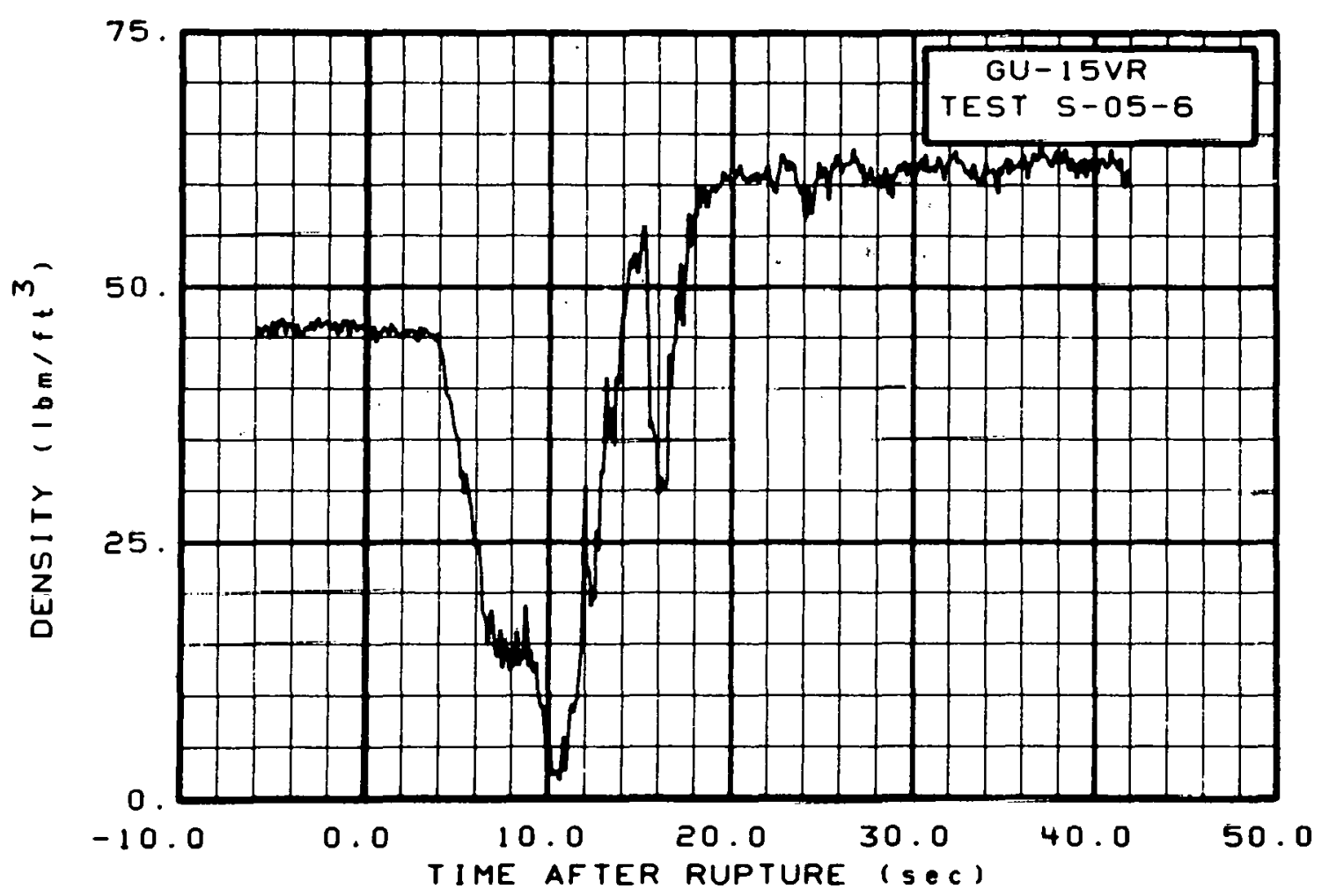

Fig. 455 Density in intact 10op, Test S-05-6 (GU-15VR), from -6 to 42 sec. 


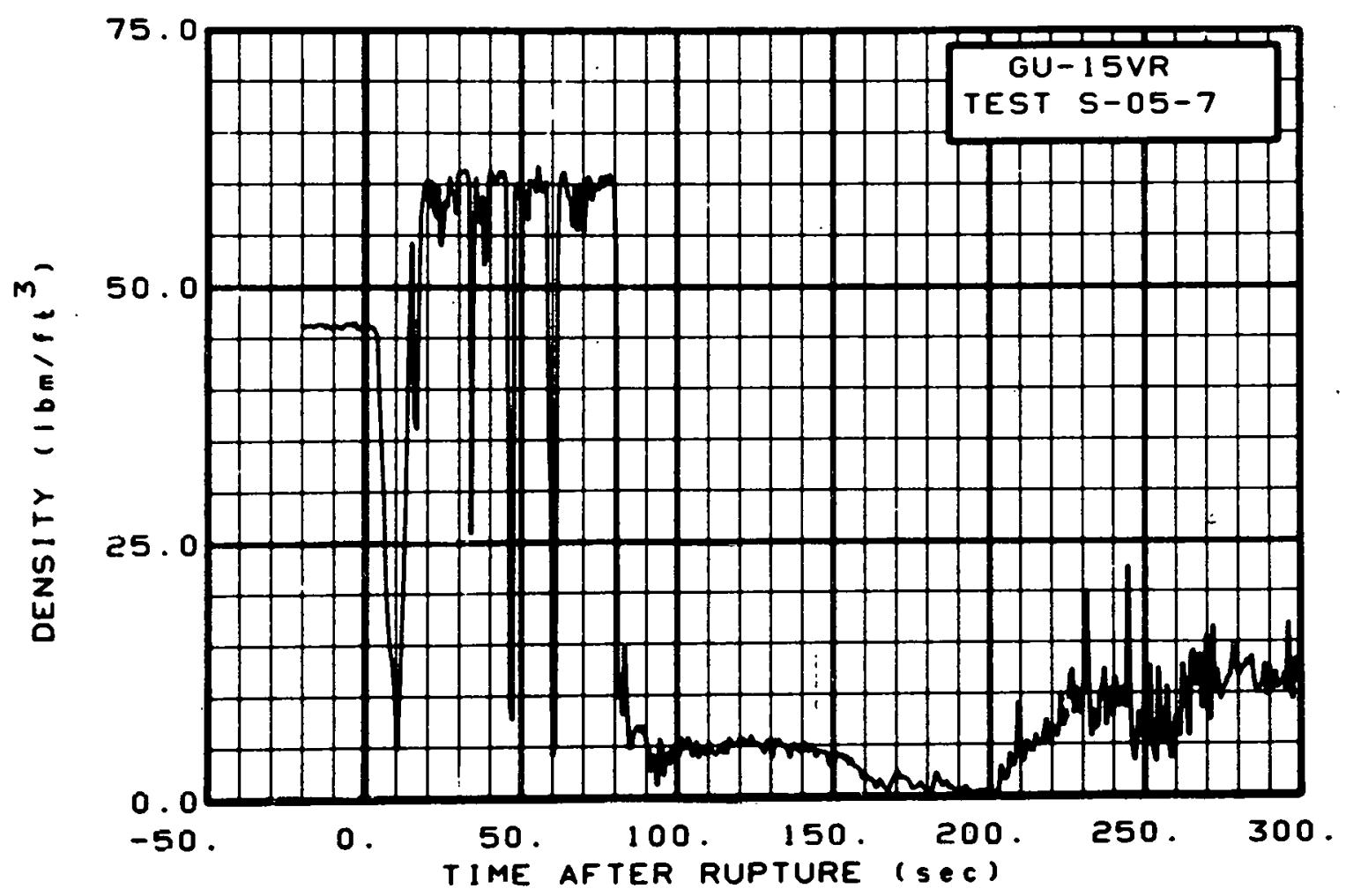

Fig. 456 Density in intact 10op, Test S-05-7 (GU-15VR), from -20 to $300 \mathrm{sec}$.

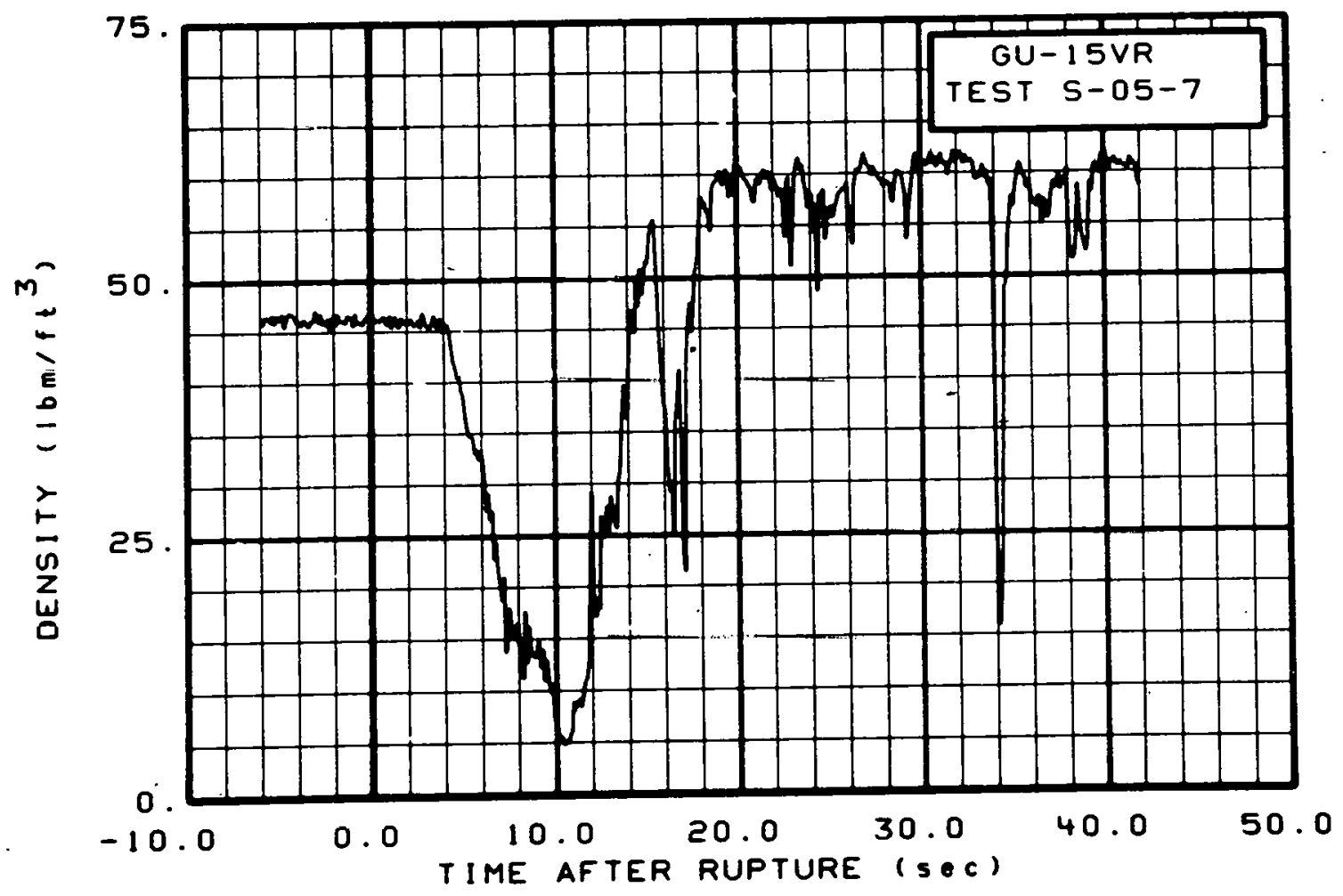

Fig. 457 Density in intact 10op, Test S-05-7 (GU-15VR), from -6 to $42 \mathrm{sec}$. 


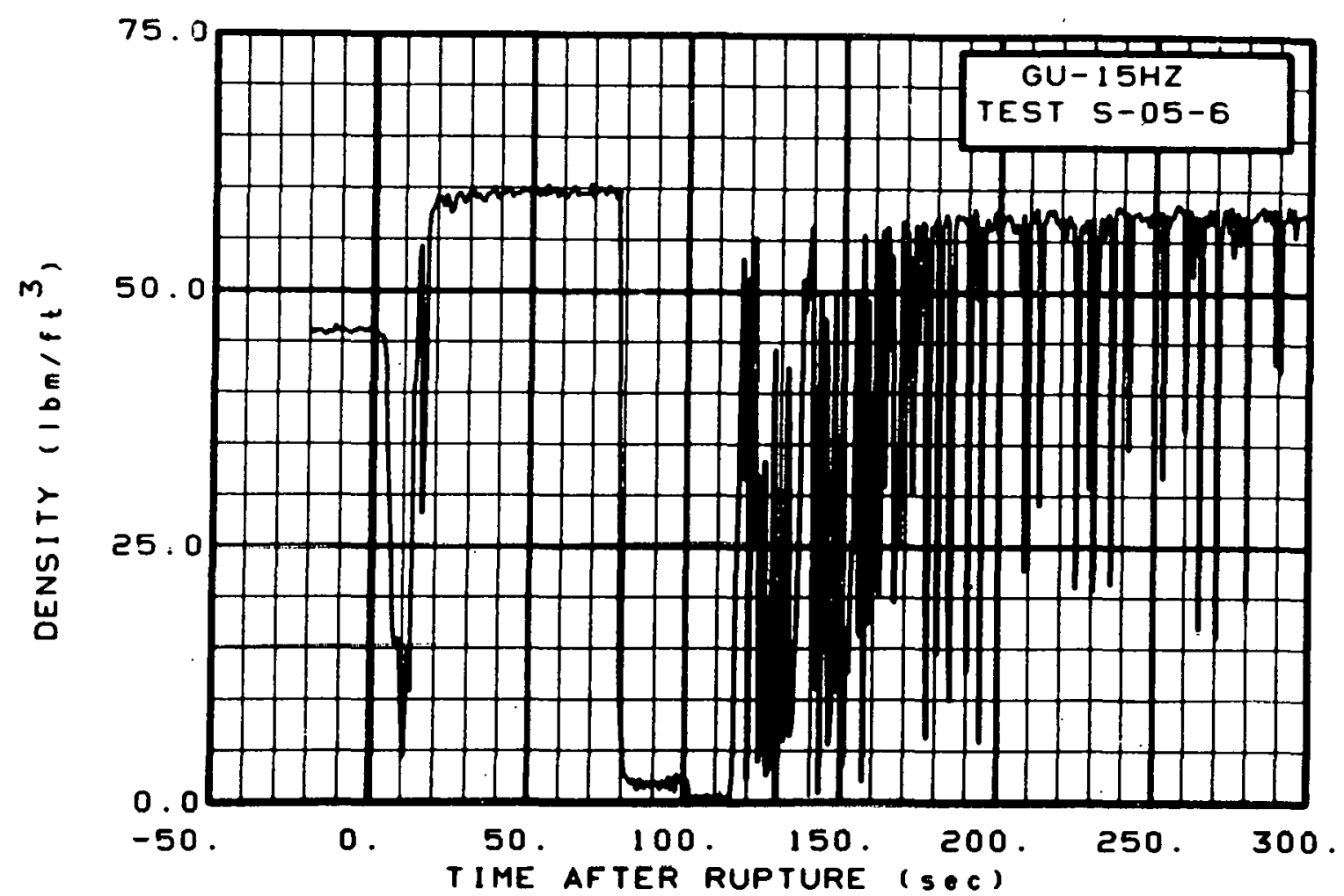

Fig. 458 Density in intact 1oop, Test S-05-6 (GU-15HZ), from -20 to $300 \mathrm{sec}$.

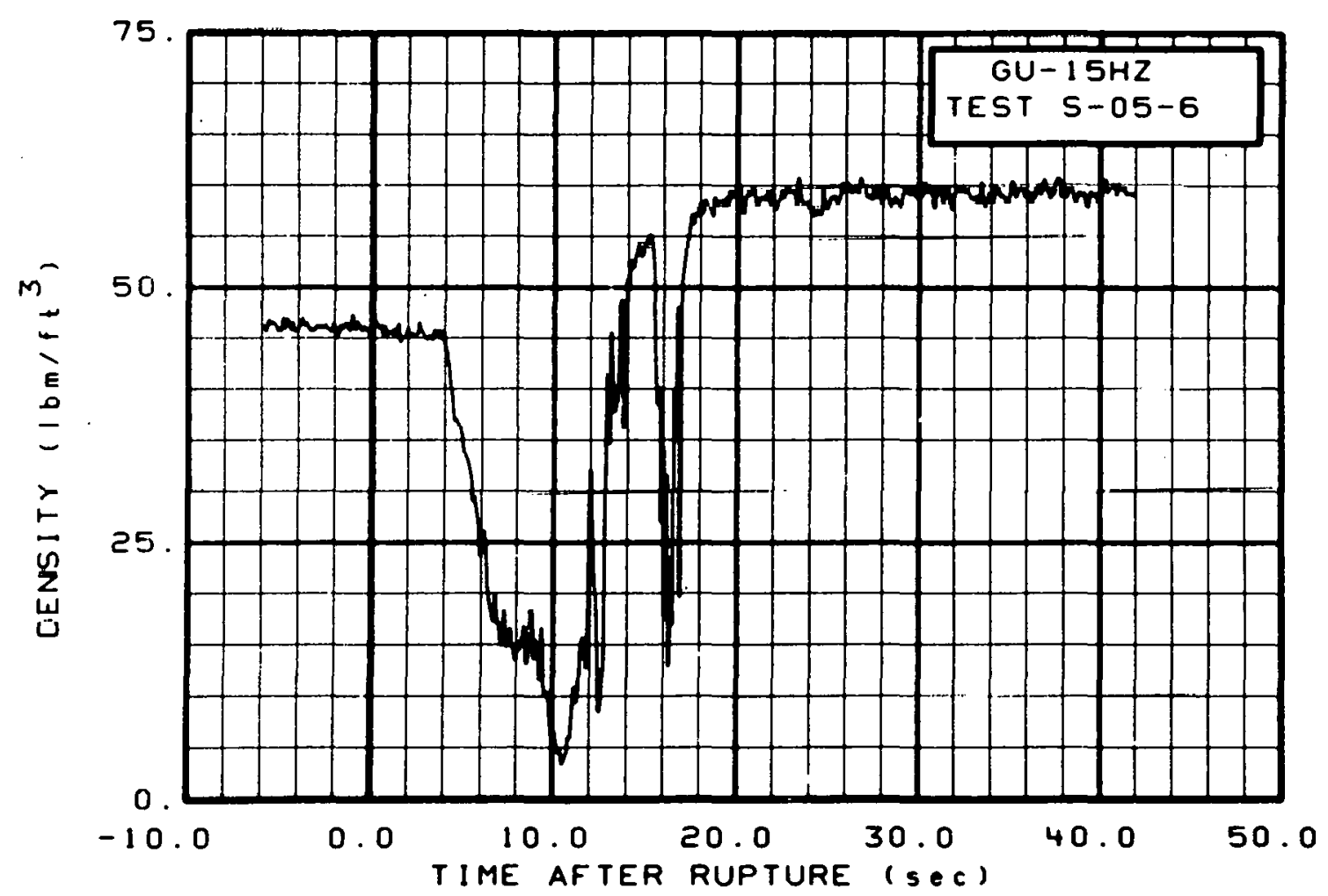

Fig. 459 Density in intact 1oop, Test S-05-6 (GU-15HZ), from -6 to $42 \mathrm{sec}$. 


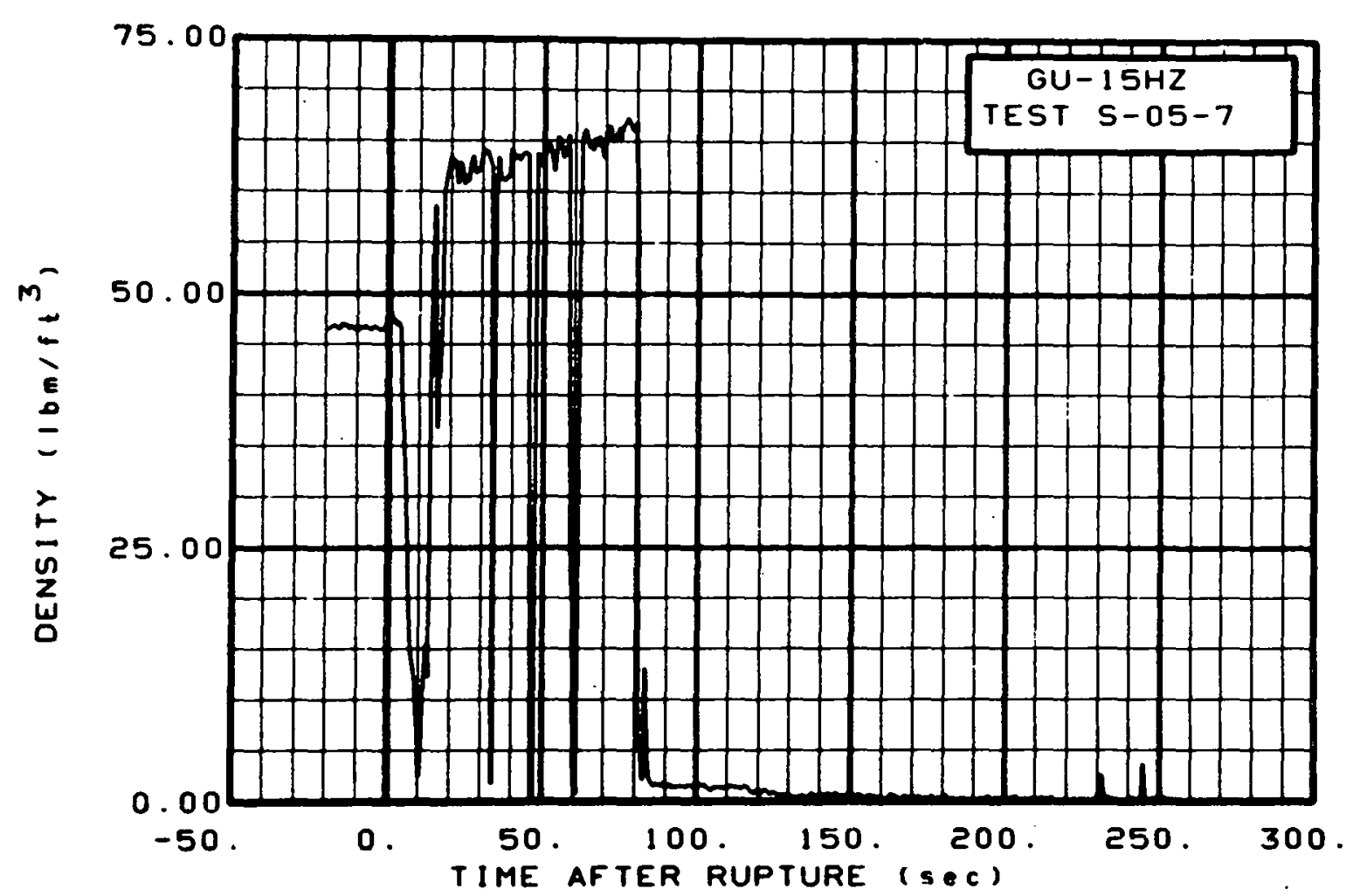

Fig. 460 Density in intact 1oop, Test S-05-7 (GU-15HZ), from -20 to $300 \mathrm{sec}$.

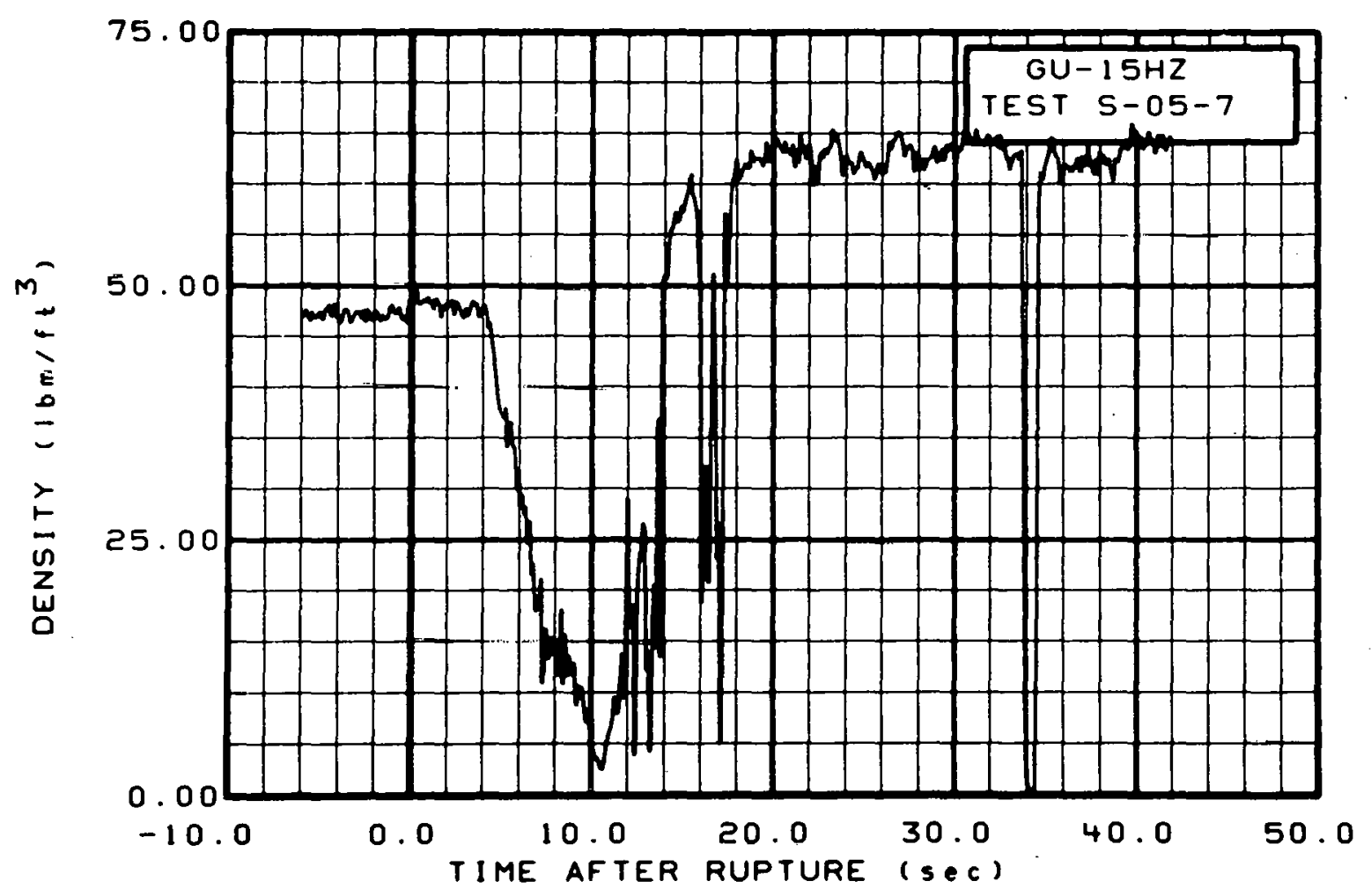

Fig. 461 Density in intact 1oop, Test S-05-7 (GU-15HZ), from -6 to $42 \mathrm{sec}$. 


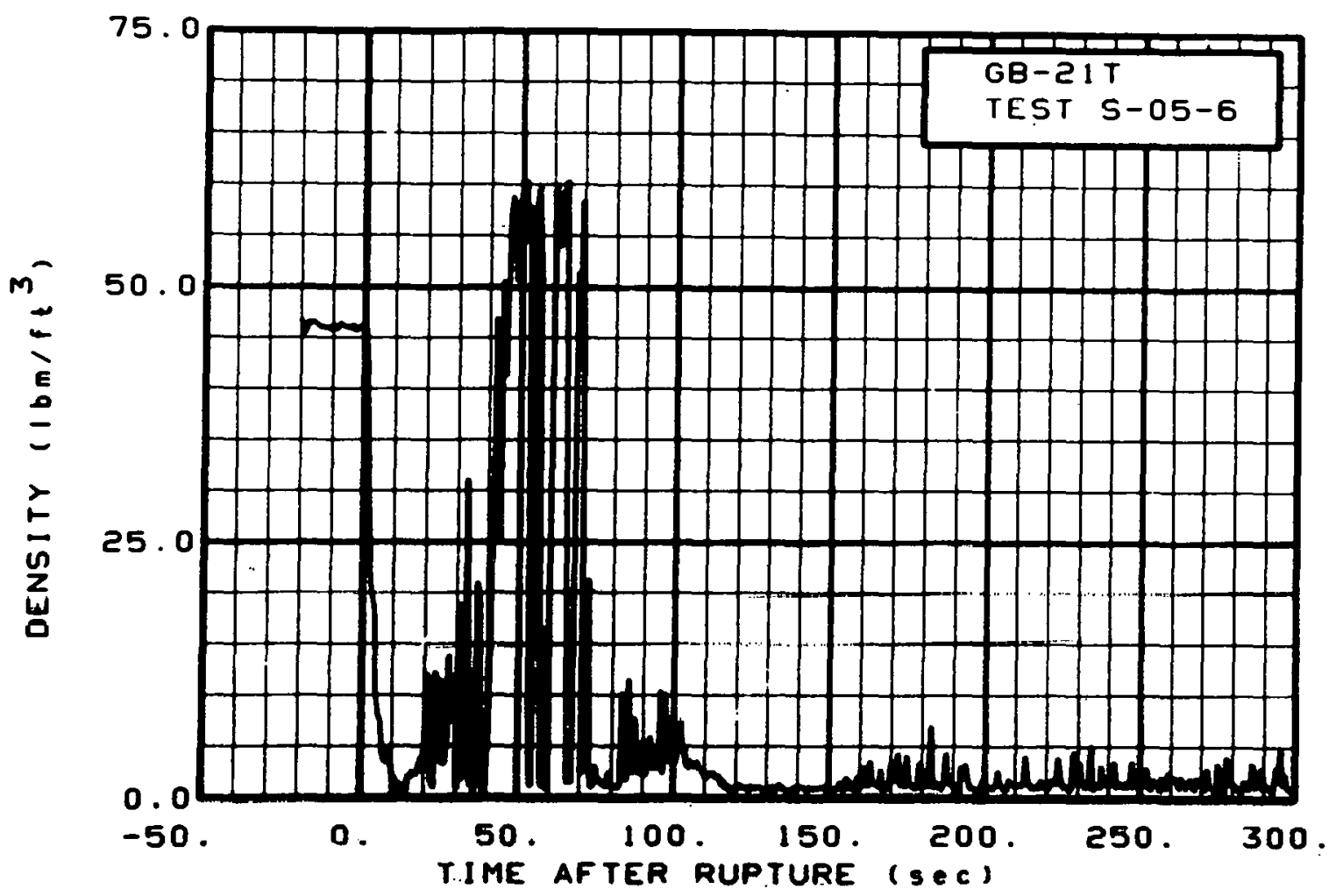

Fig. 462 Density in broken 1oop, Test S-05-6 (GB-21T), from -20 to $300 \mathrm{sec}$.

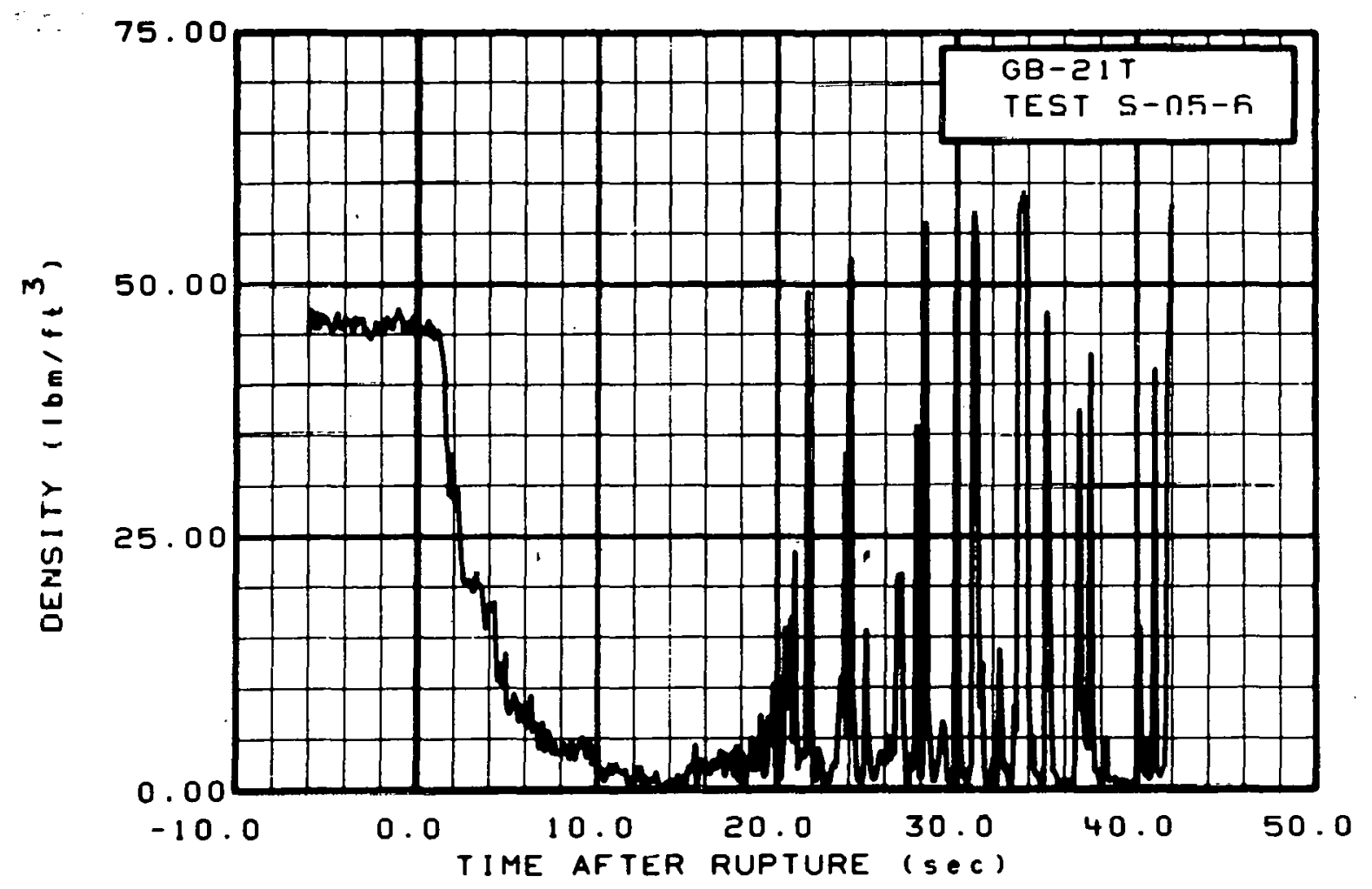

Fig. 463 Density in broken 10op, Test S-05-6 (GB-21T), from -6 to $42 \mathrm{sec}$. 


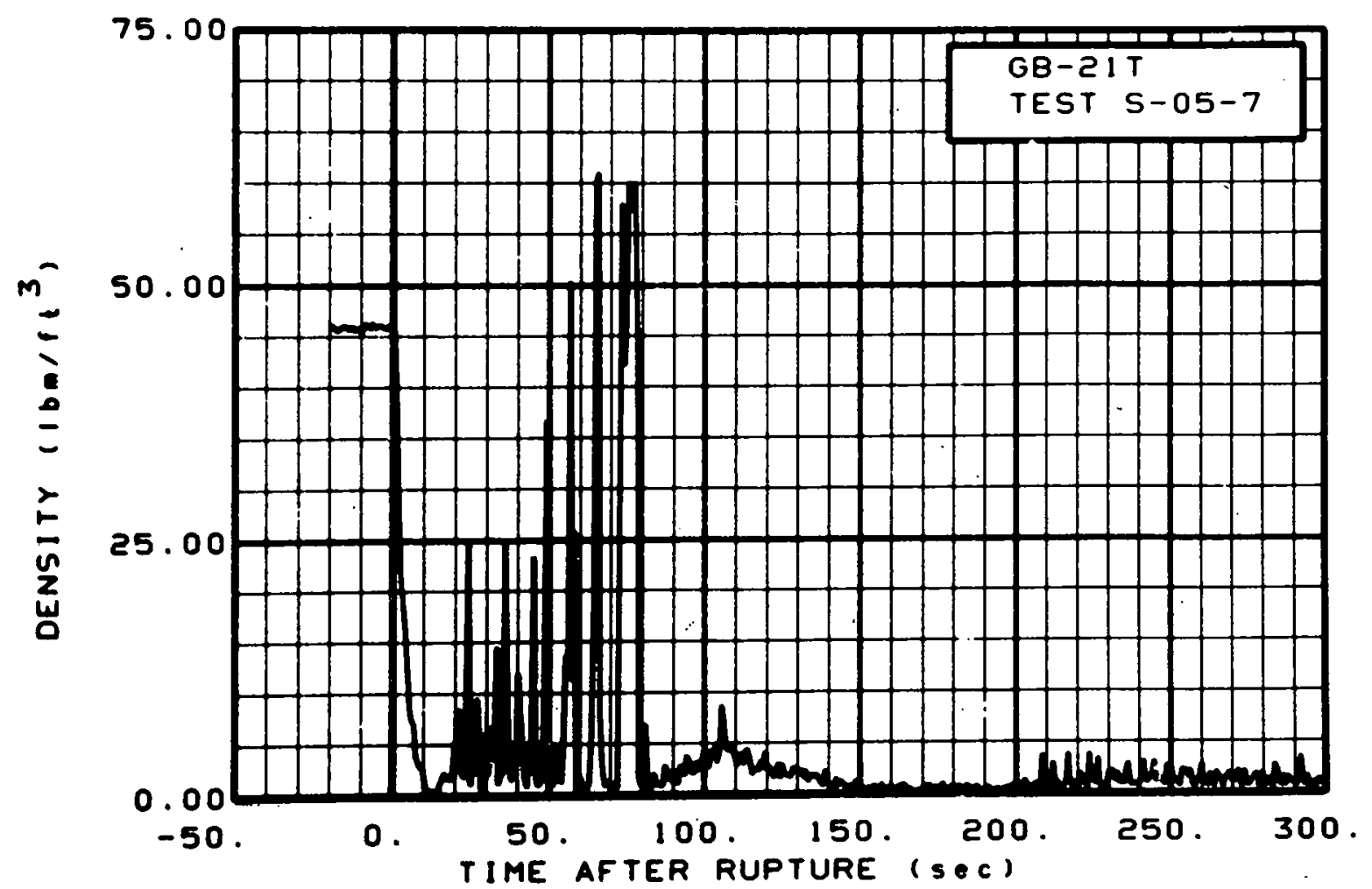

Fig. 464 Density in broken 10op. Test S-05-7 (GB-21T), from -20 to 300 sec.

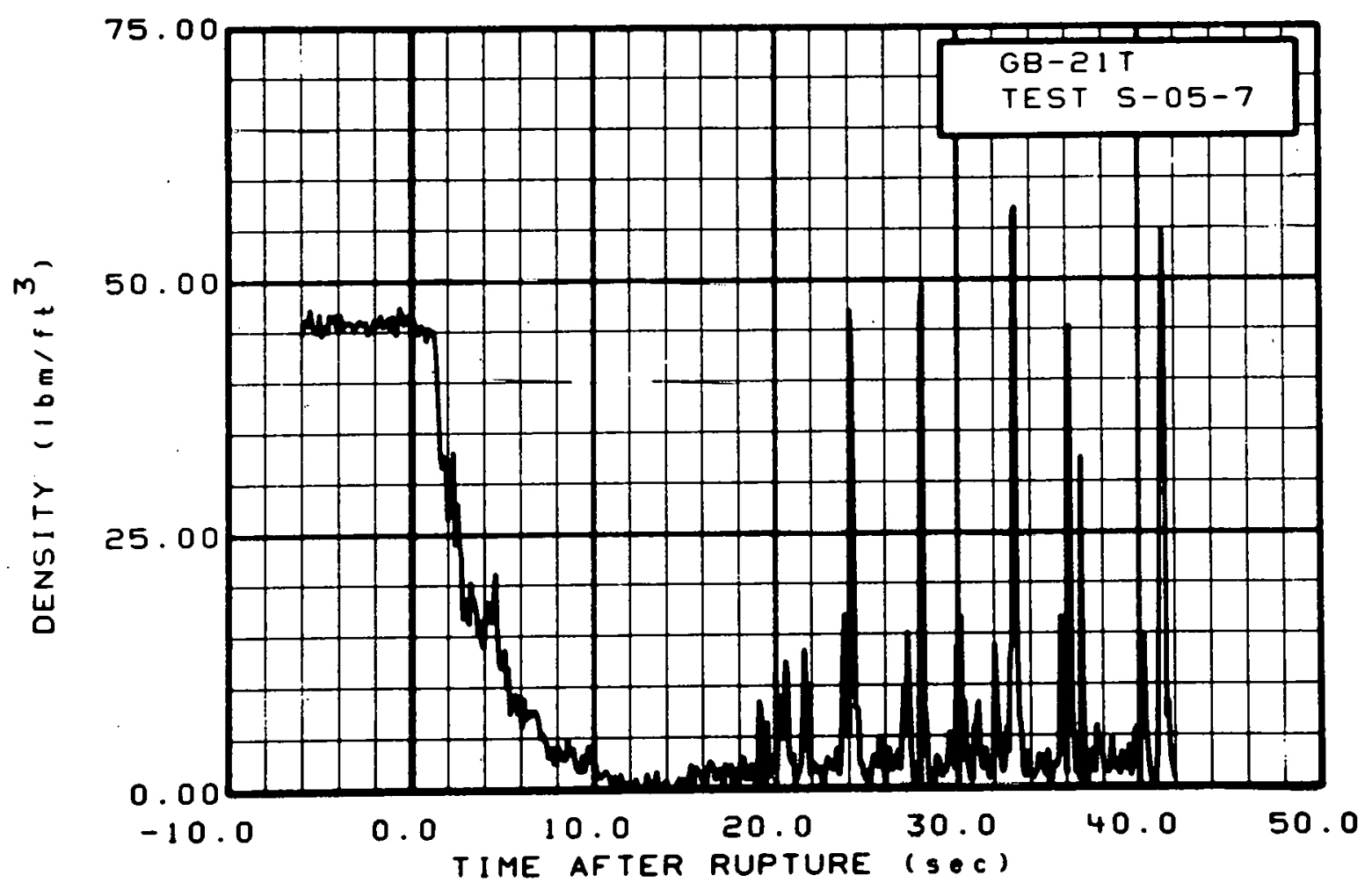

Fig. 465 Density in broken loop, Test S-05-7 (GB-21T), from -6 to $42 \mathrm{sec}$. 


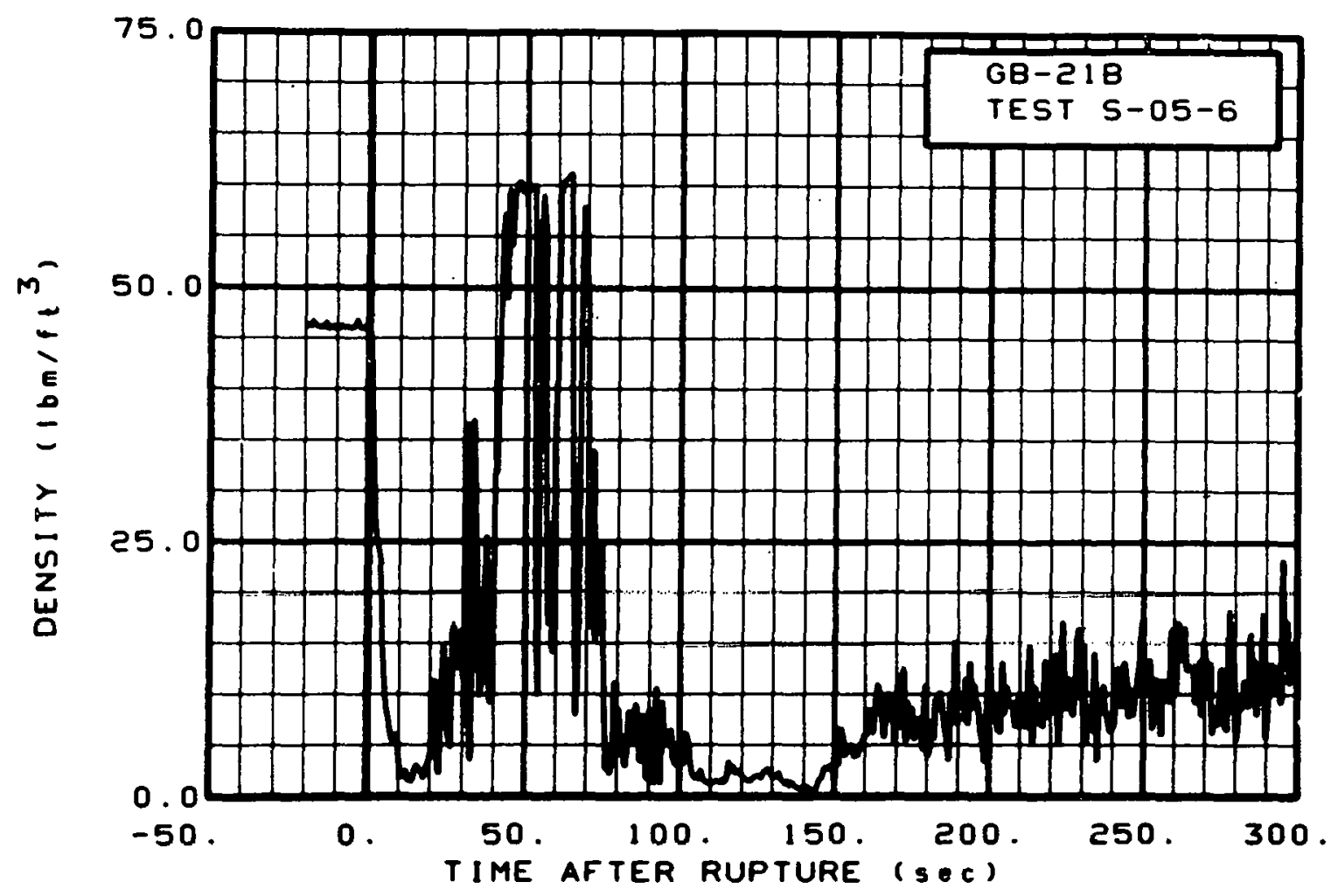

Fig. 466 Density in broken 1oop, Test S-05-6 (GB-21B), from -20 to $300 \mathrm{sec}$.

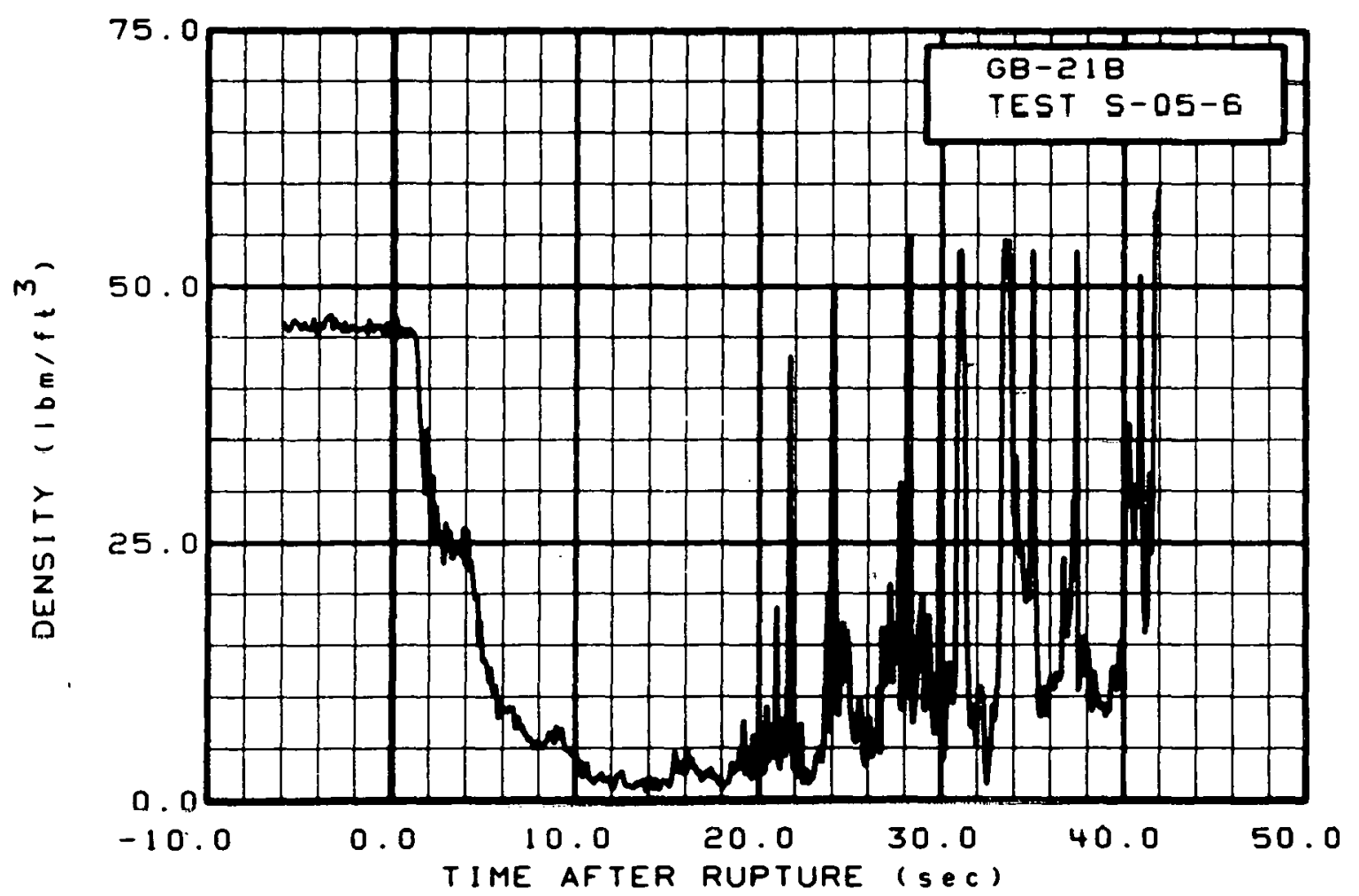

Fig. 467 Density in broken 1oop, Test $S-05-6(G B-21 B)$, from -6 to $42 \mathrm{sec}$. 


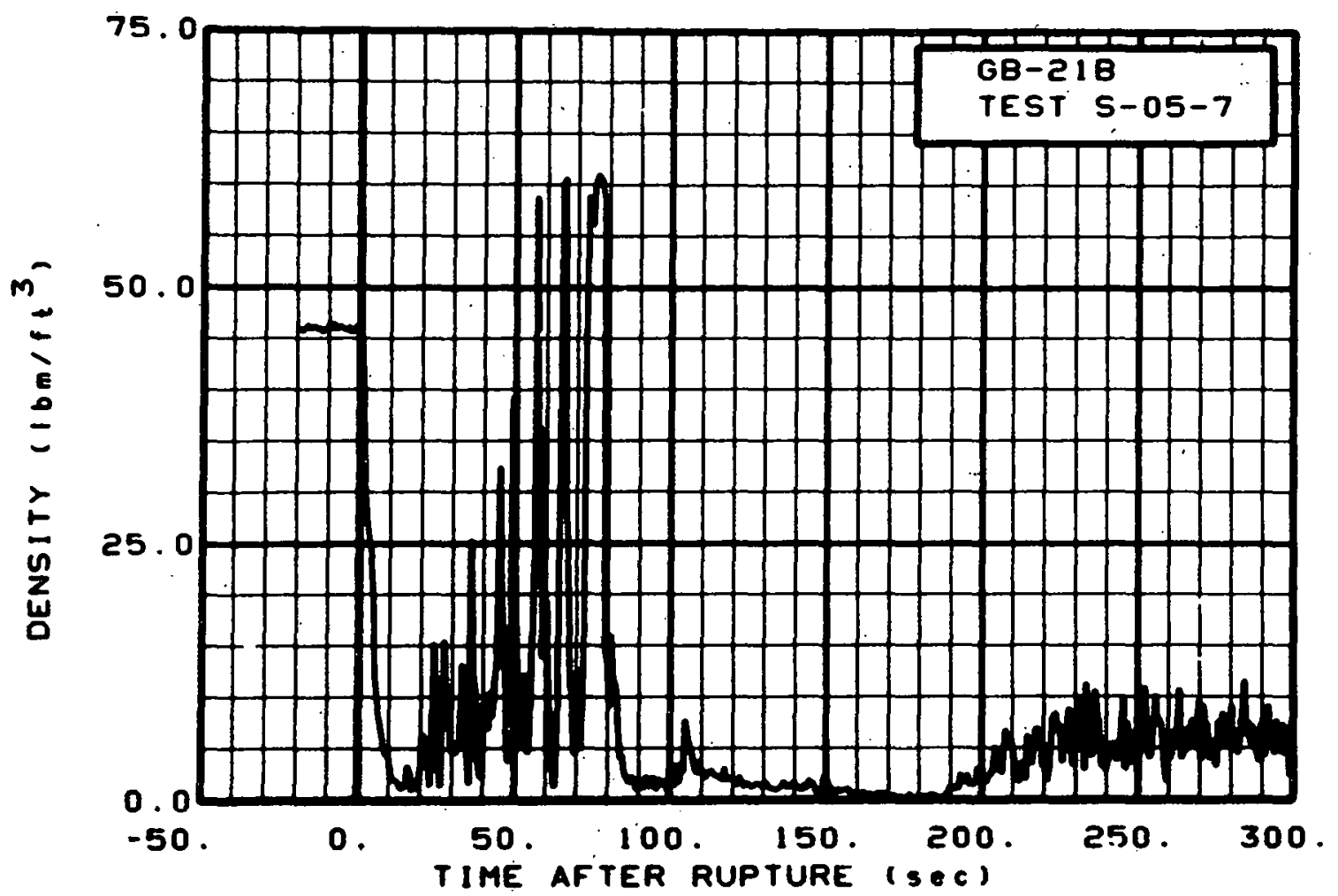

Fig. 468 Density in broken loop, Test S-05-7 (GB-21B), from -20 to $300 \mathrm{sec}$.

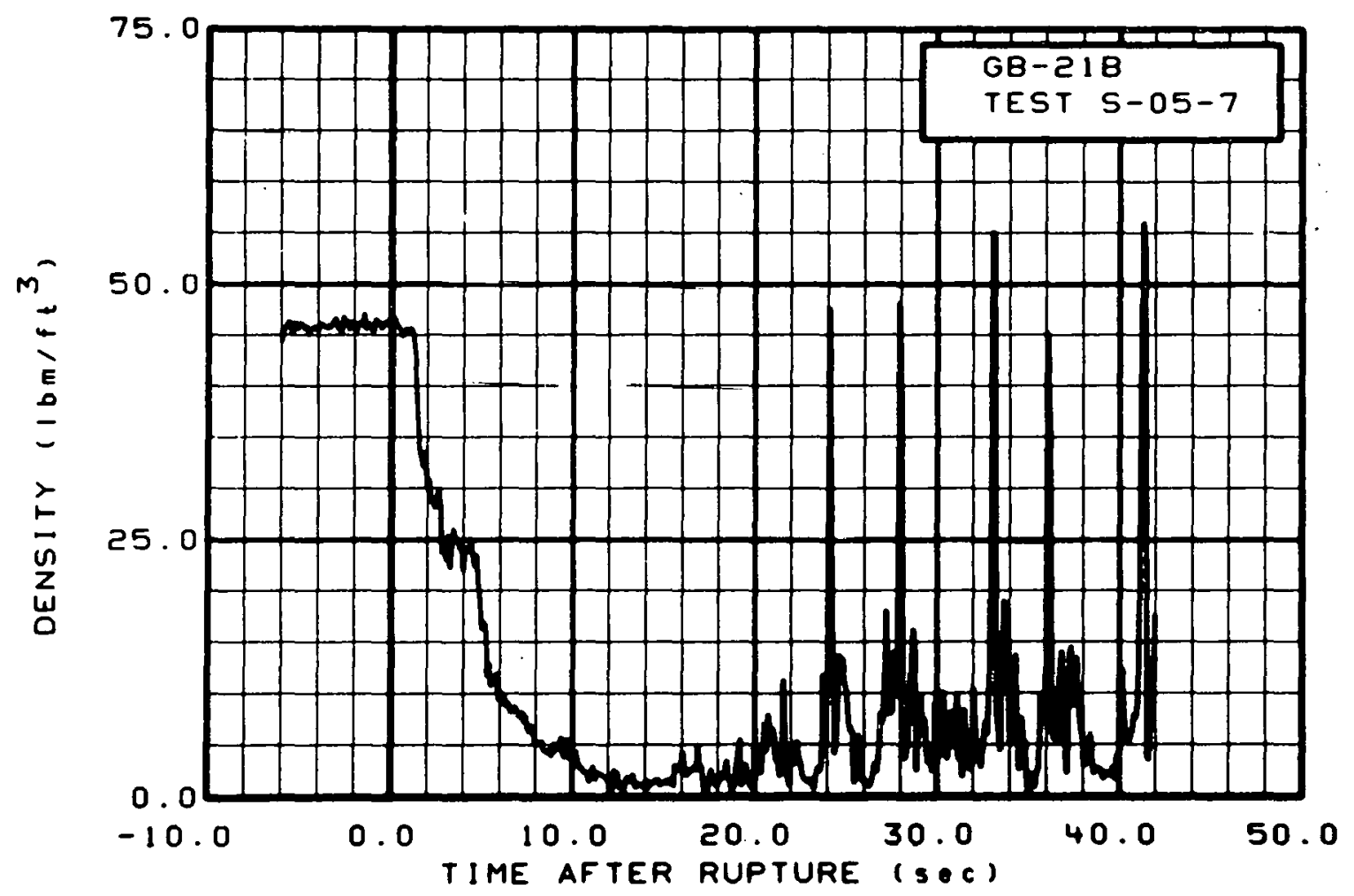

Fig. 469 Density in broken 1oop, Test S-05-7 (GB-21B), from -6 to 42 sec. 


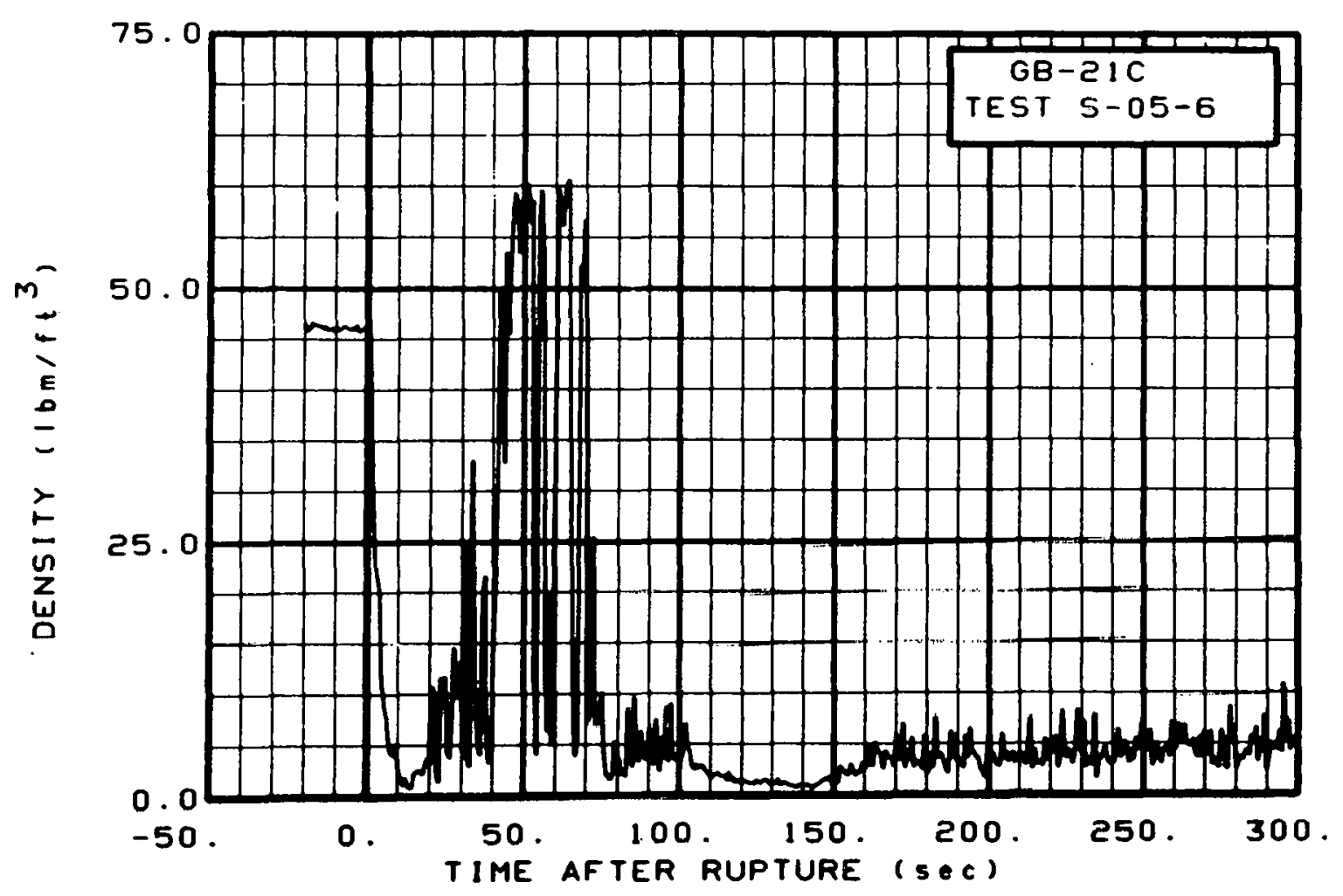

Fig. 470 Density in broken loop, Test S-05-6 (GB-27C), from -20 to $300 \mathrm{sec}$.

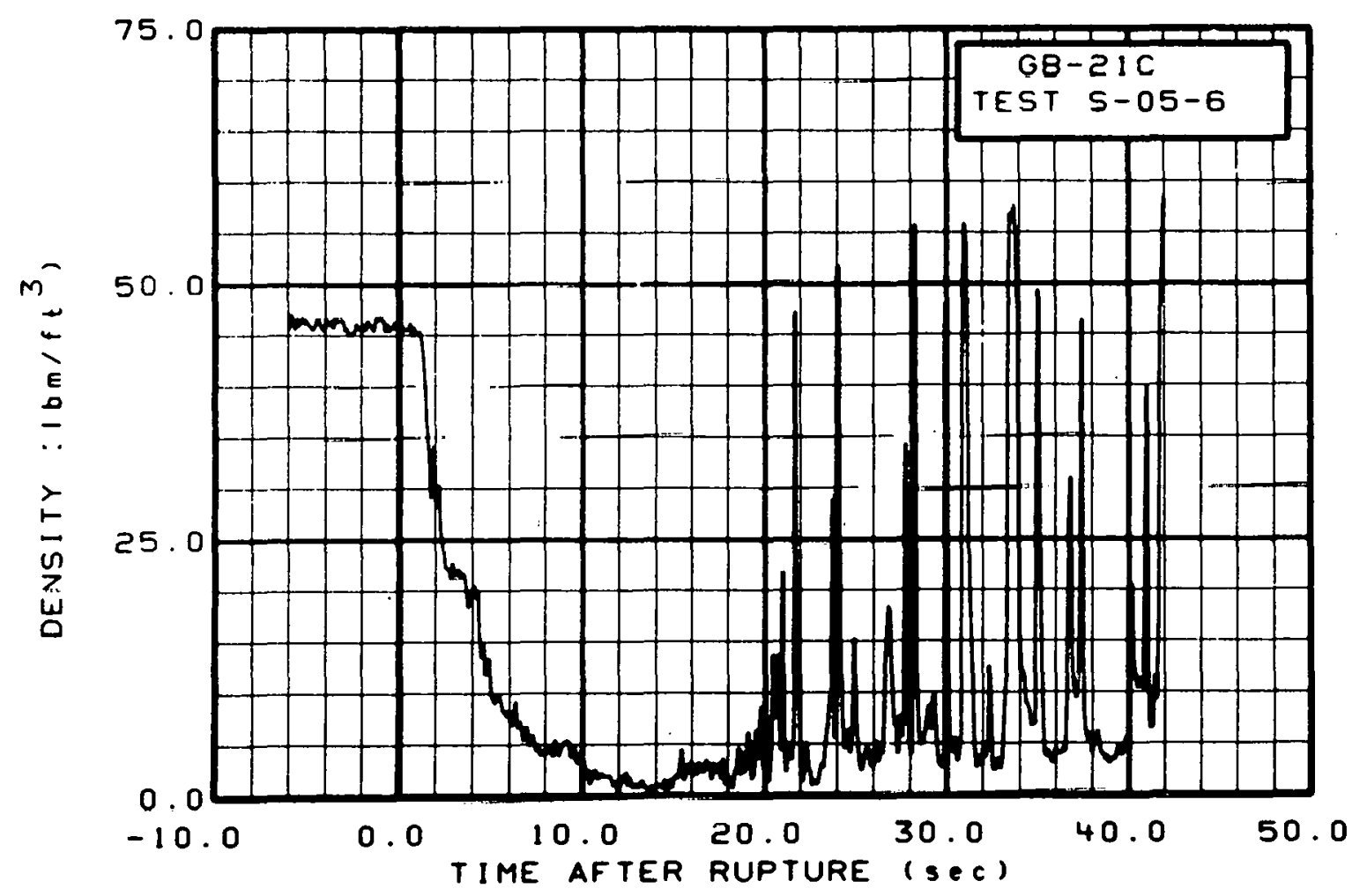

Fig. 471 Density in broken 10op. Test S-05-6 (GB-21C), from -6 to $42 \mathrm{sec}$. 


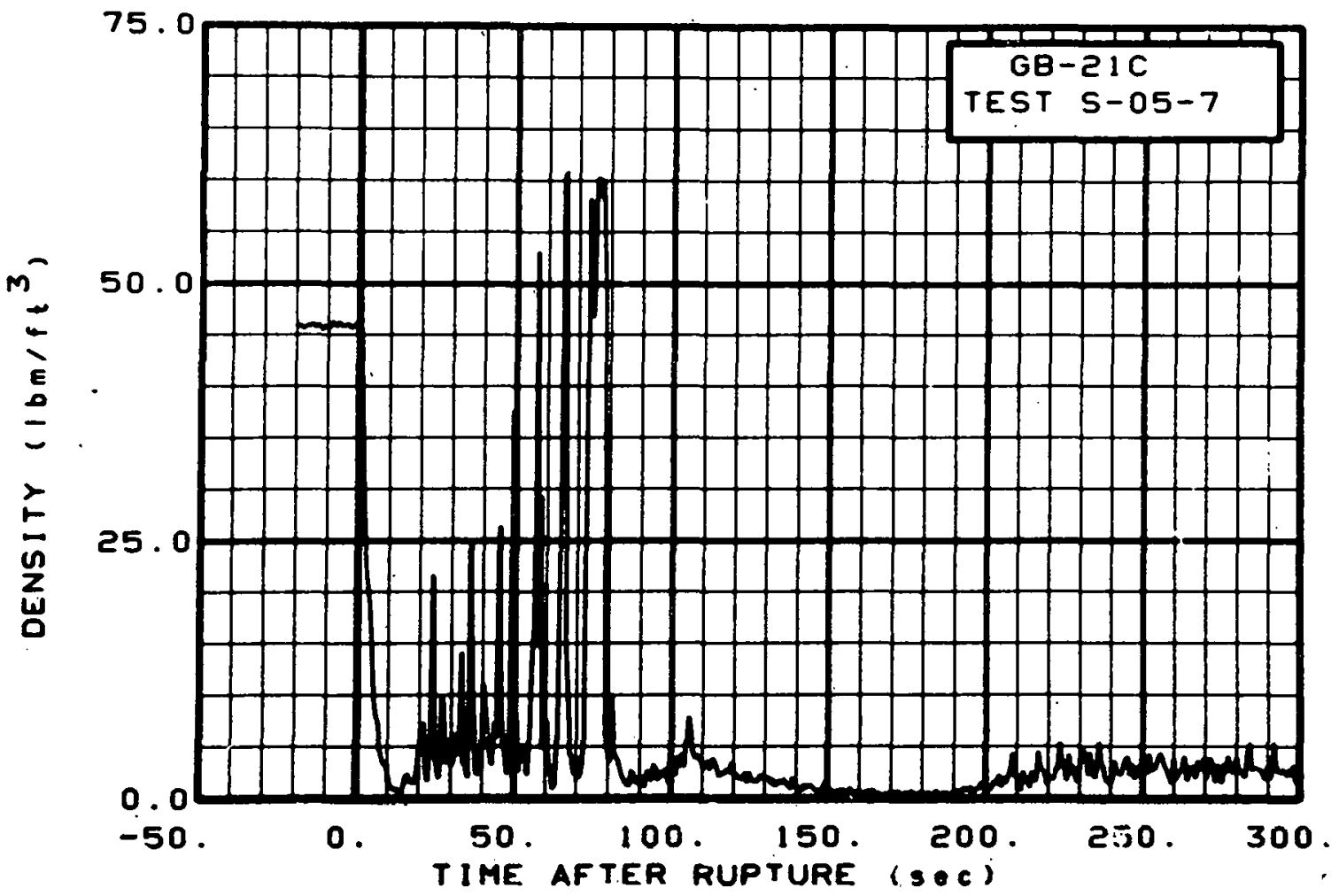

Fig. 472 Density in broken 1oop, Test $\$-05-7$ (GB-21C), from -20 to $300 \mathrm{sec}$.

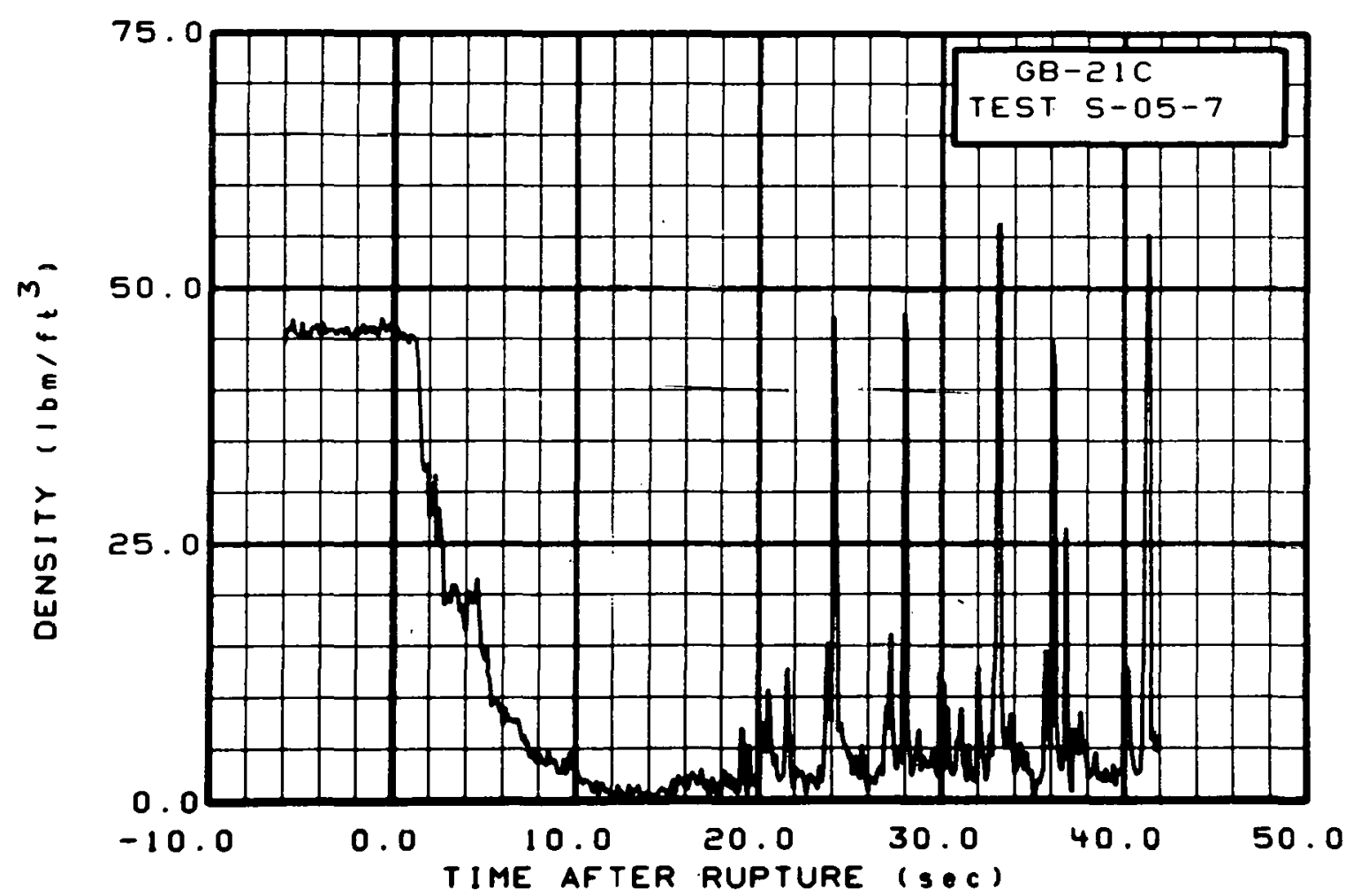

Fig. 473 Density in broken loop, Test S-05-7 (GB-2]C), from -6 to 42 sec. 


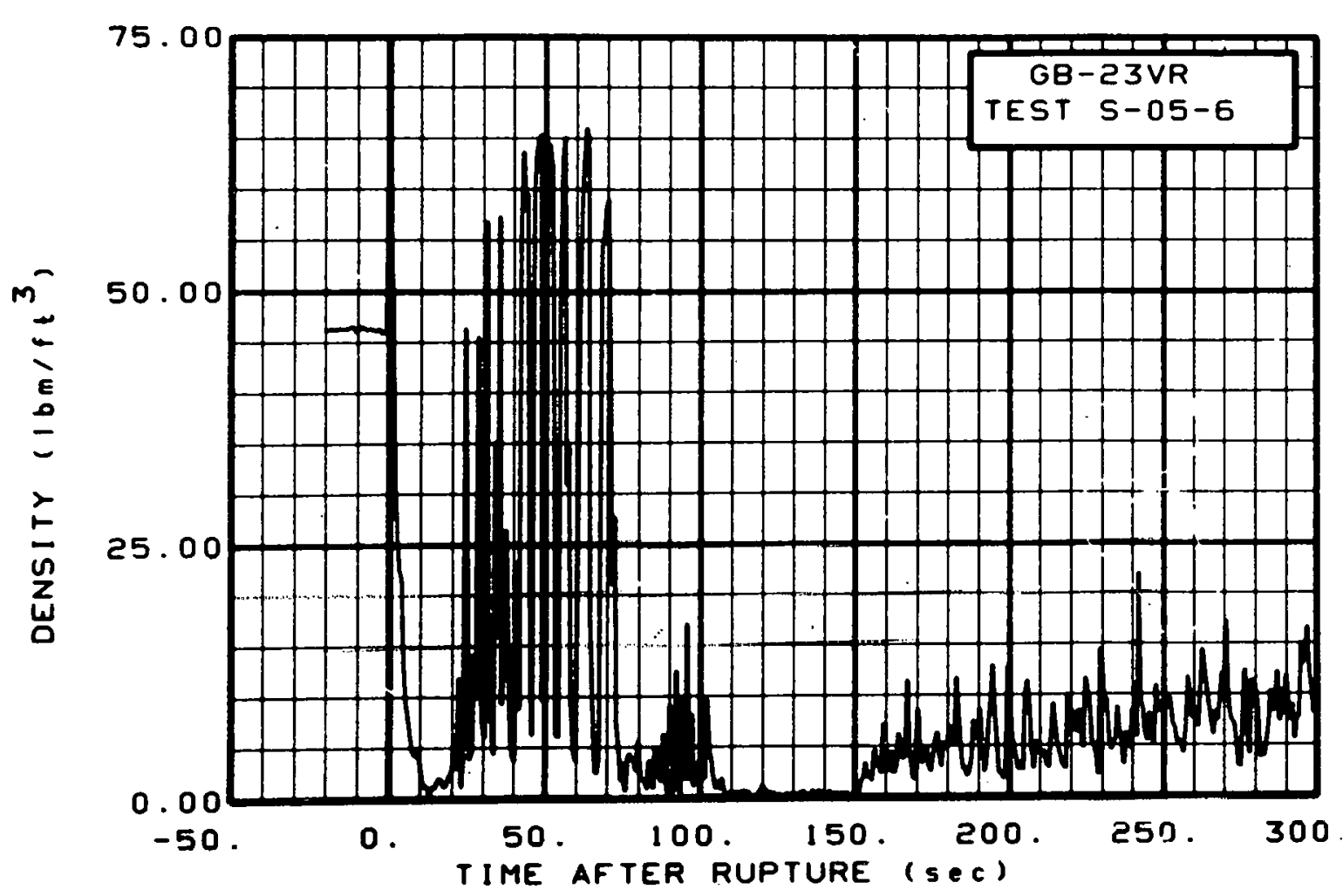

Fig. 474 Density in broken loop, Test S-05-6 (GB-23VR), from -20 to $300 \mathrm{sec}$.

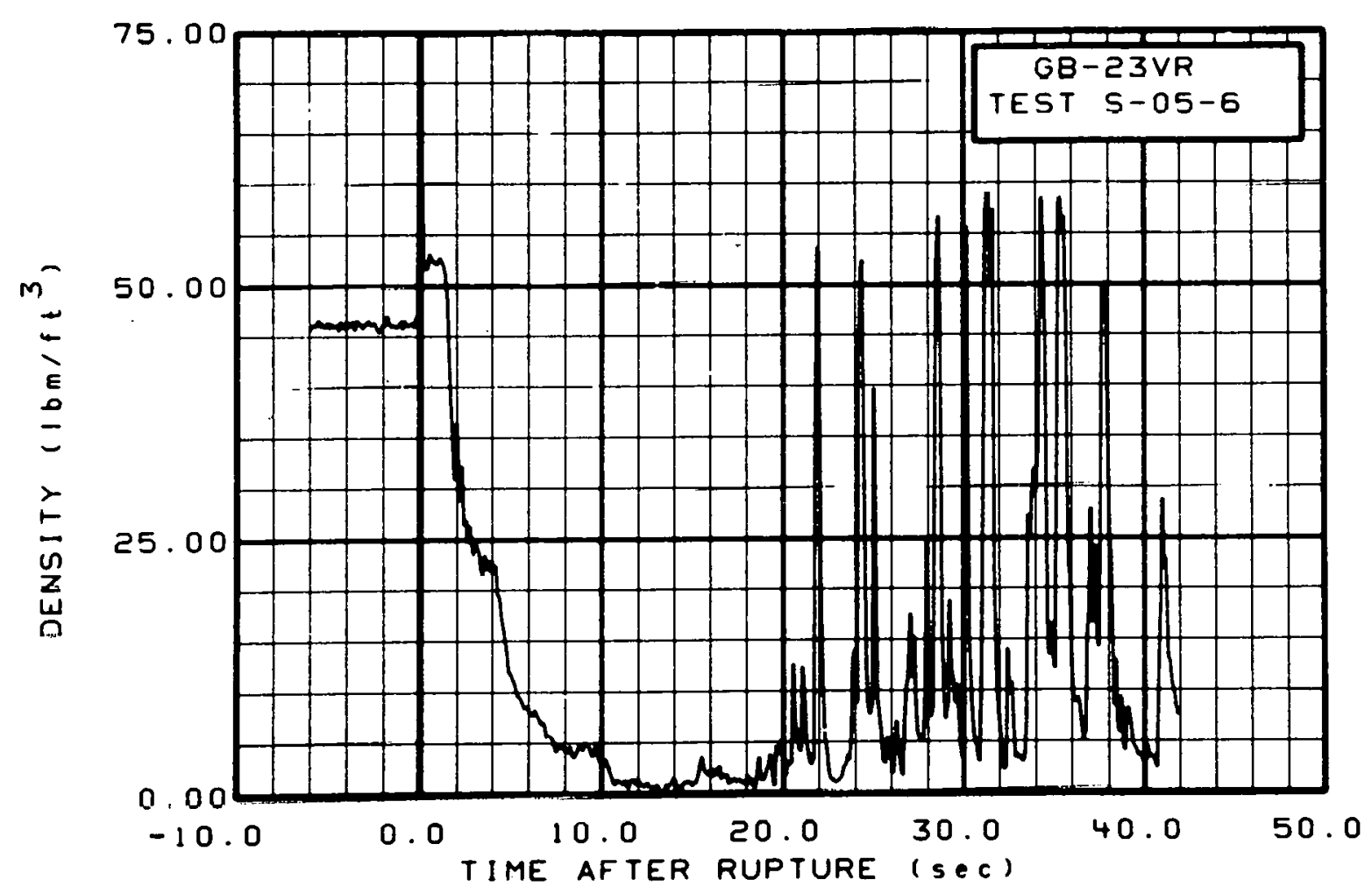

Fig. 475 Density in broken loop, Test S-05-6 (GB-23VR), from -6 to $42 \mathrm{sec}$. 


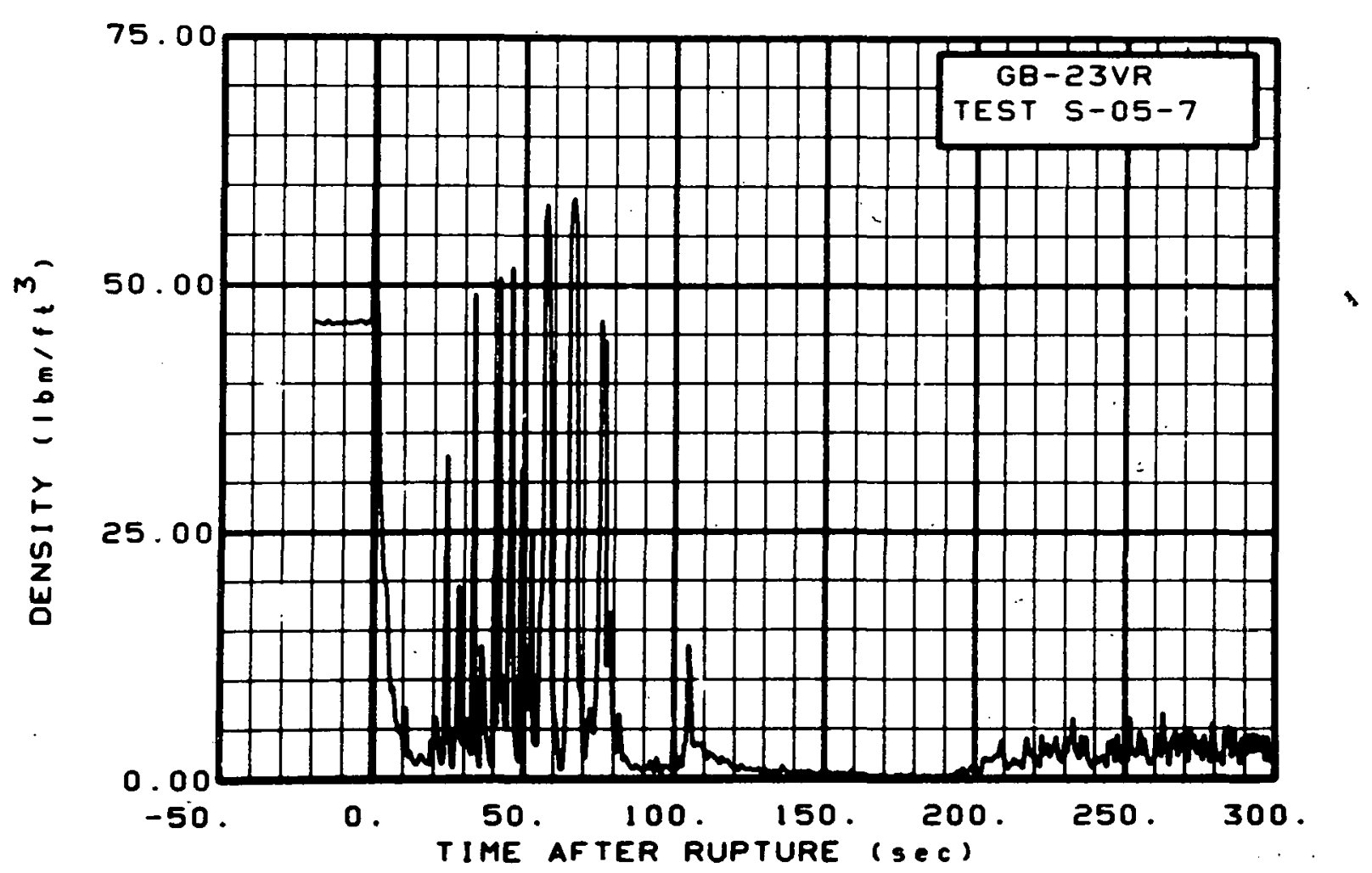

Fig. 476 Density in broken 10op, Test S-05-7 (GB-23VR), from -20 to: $300 \mathrm{sec}$.

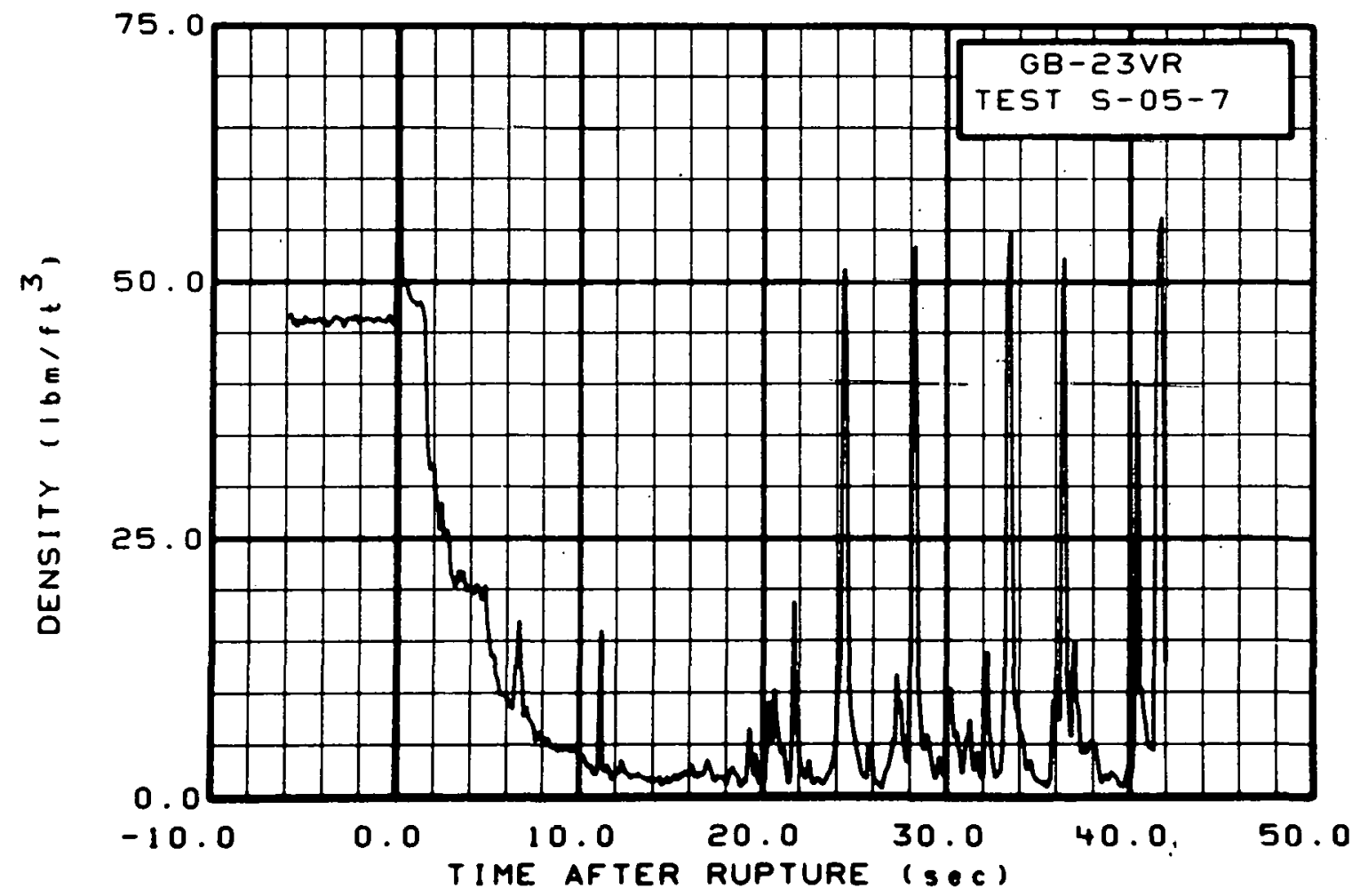

Fig. 477 Density in broken 1oop, Test. S-05-7 (GB-23VR), from -6 to 42 sec. 


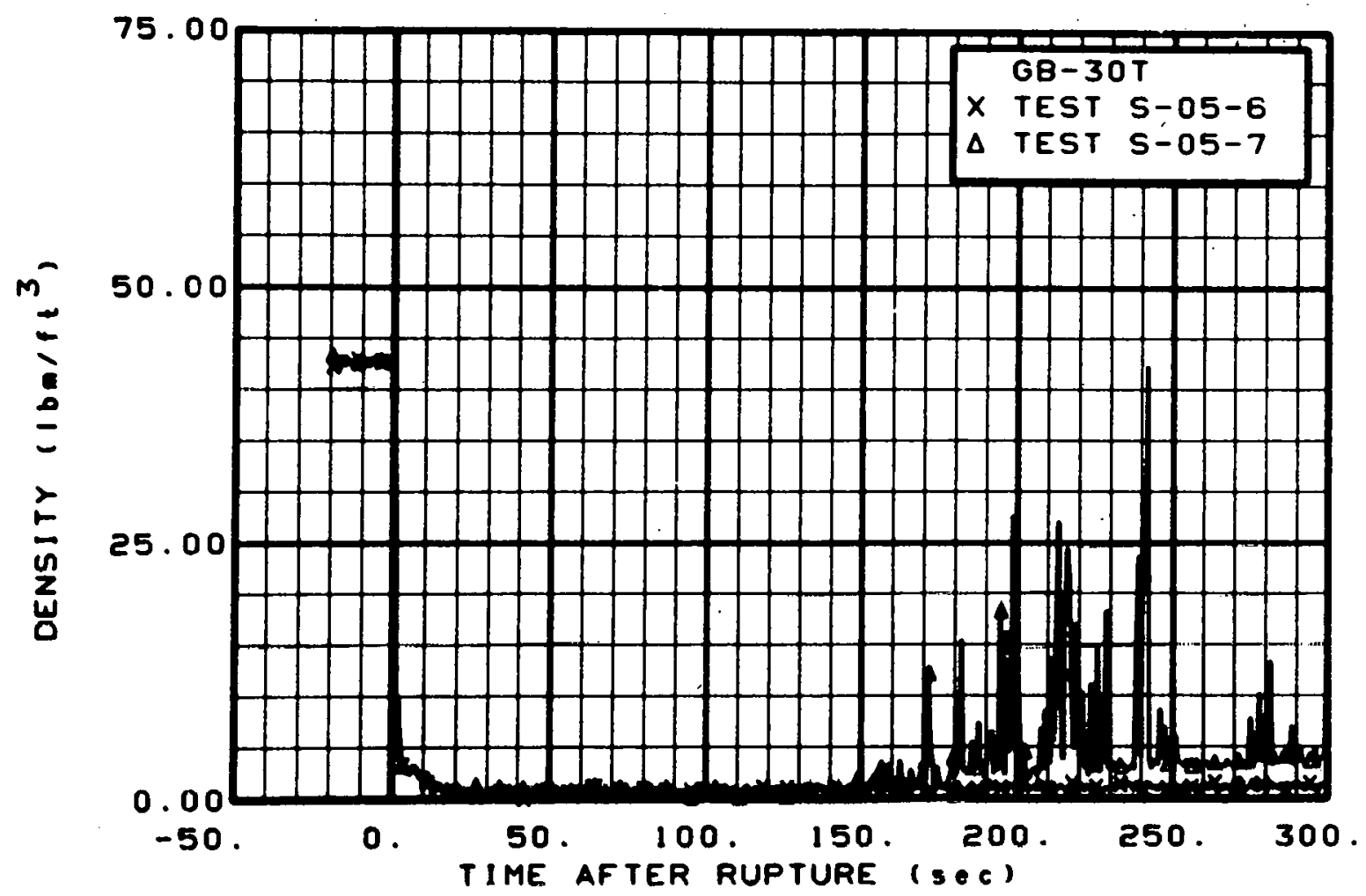

Fig. 478 Density in broken loop (GB-30T), from -20 to $300 \mathrm{sec}$.

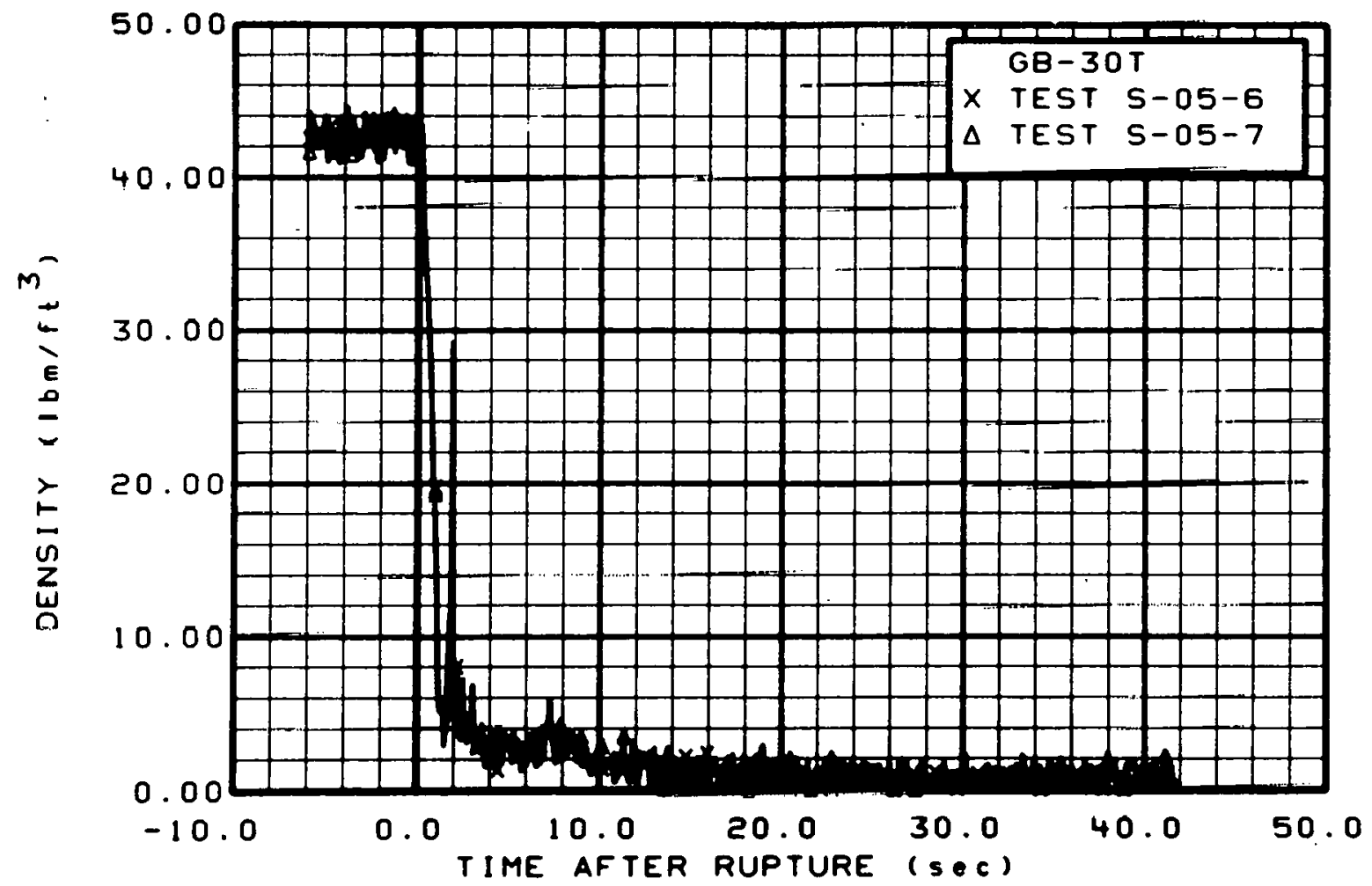

Fig. 479 Density in broken loop (GB-30T), from -6 to $42 \mathrm{sec}$. 


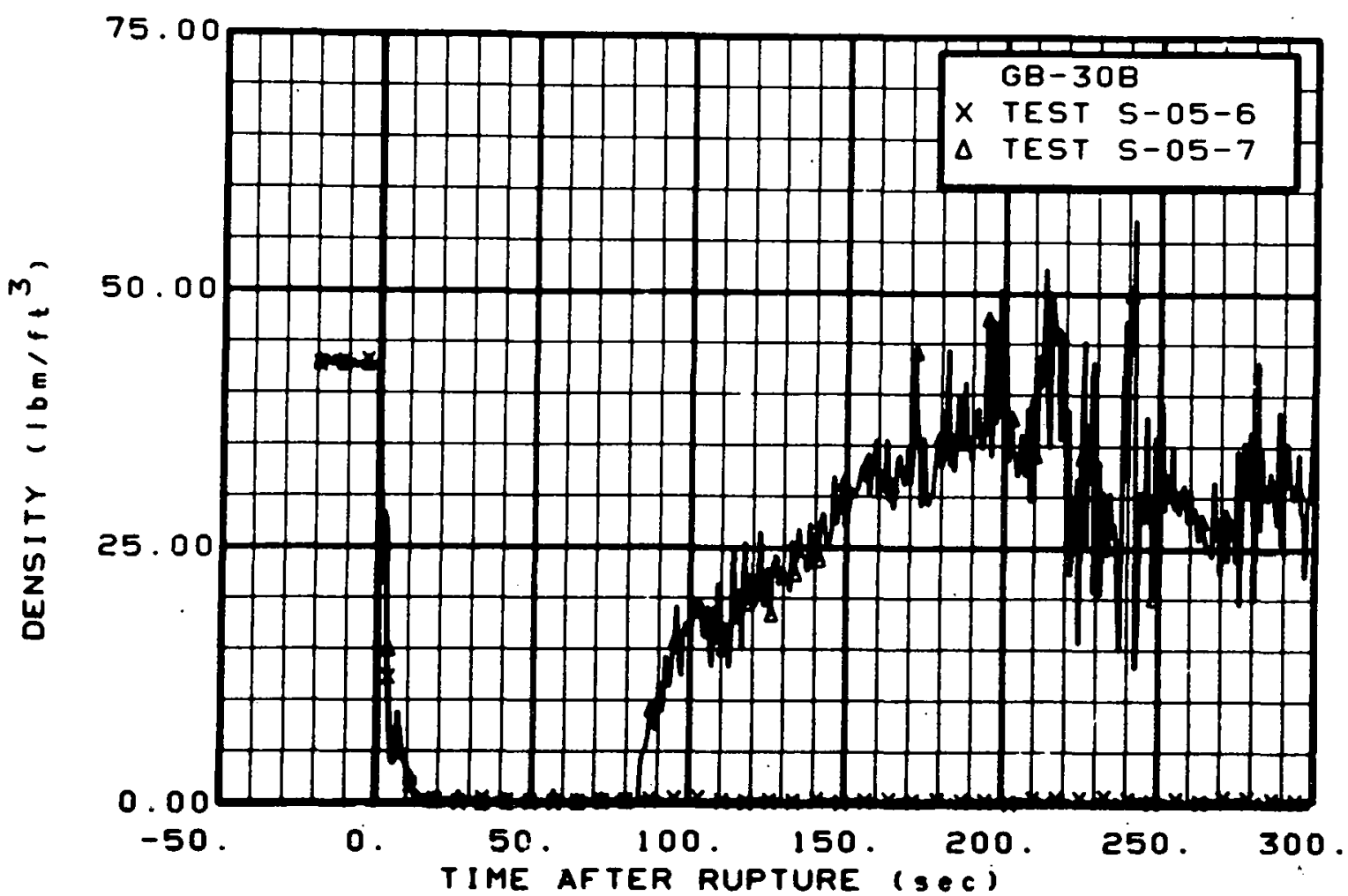

Fig. 480 Density in broken loop (GB-30B), from -20 to $300 \mathrm{sec}$.

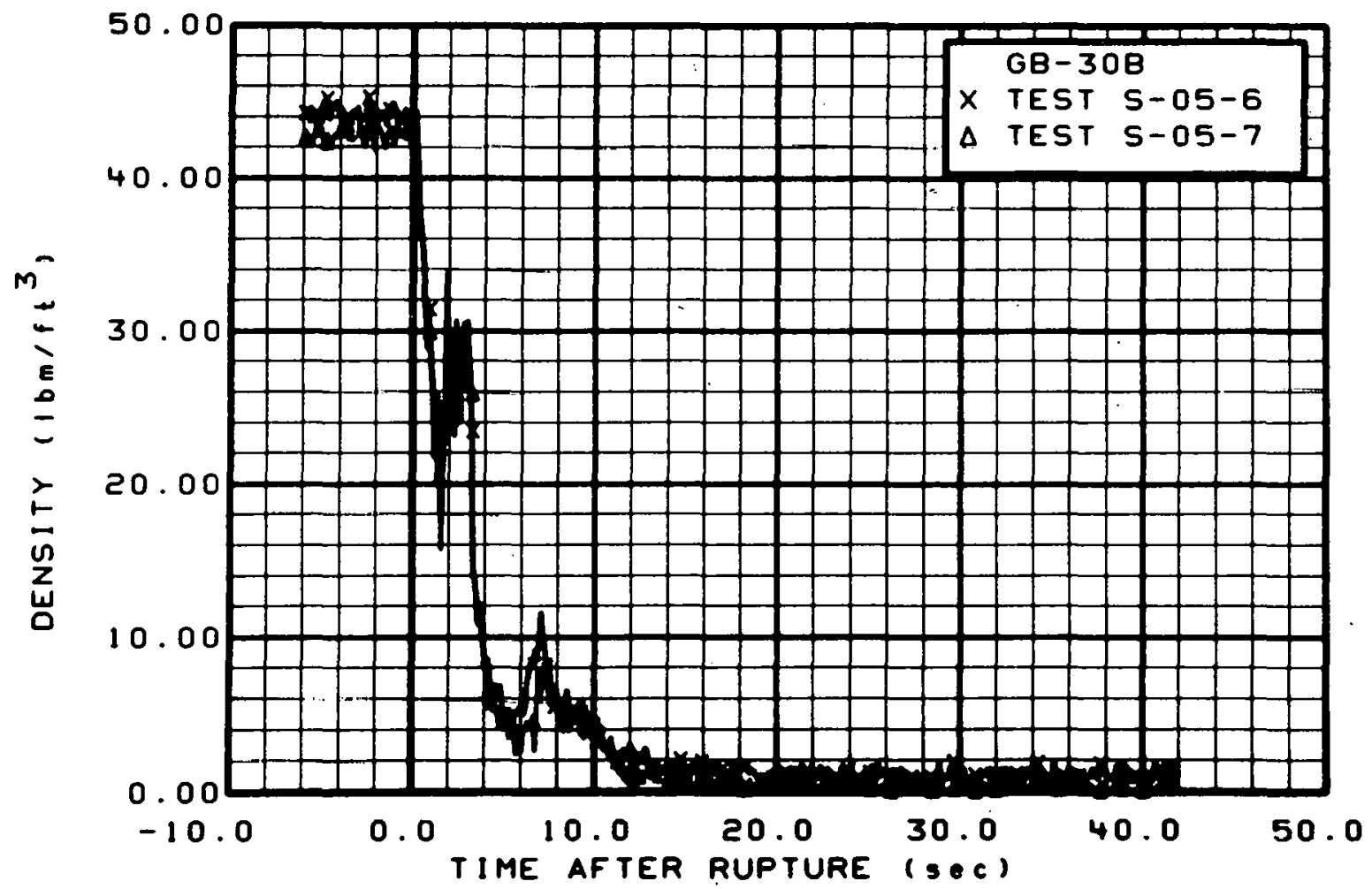

Fig. 481 Density in broken loop (GB-30B), from -6 to $42 \mathrm{sec}$. 


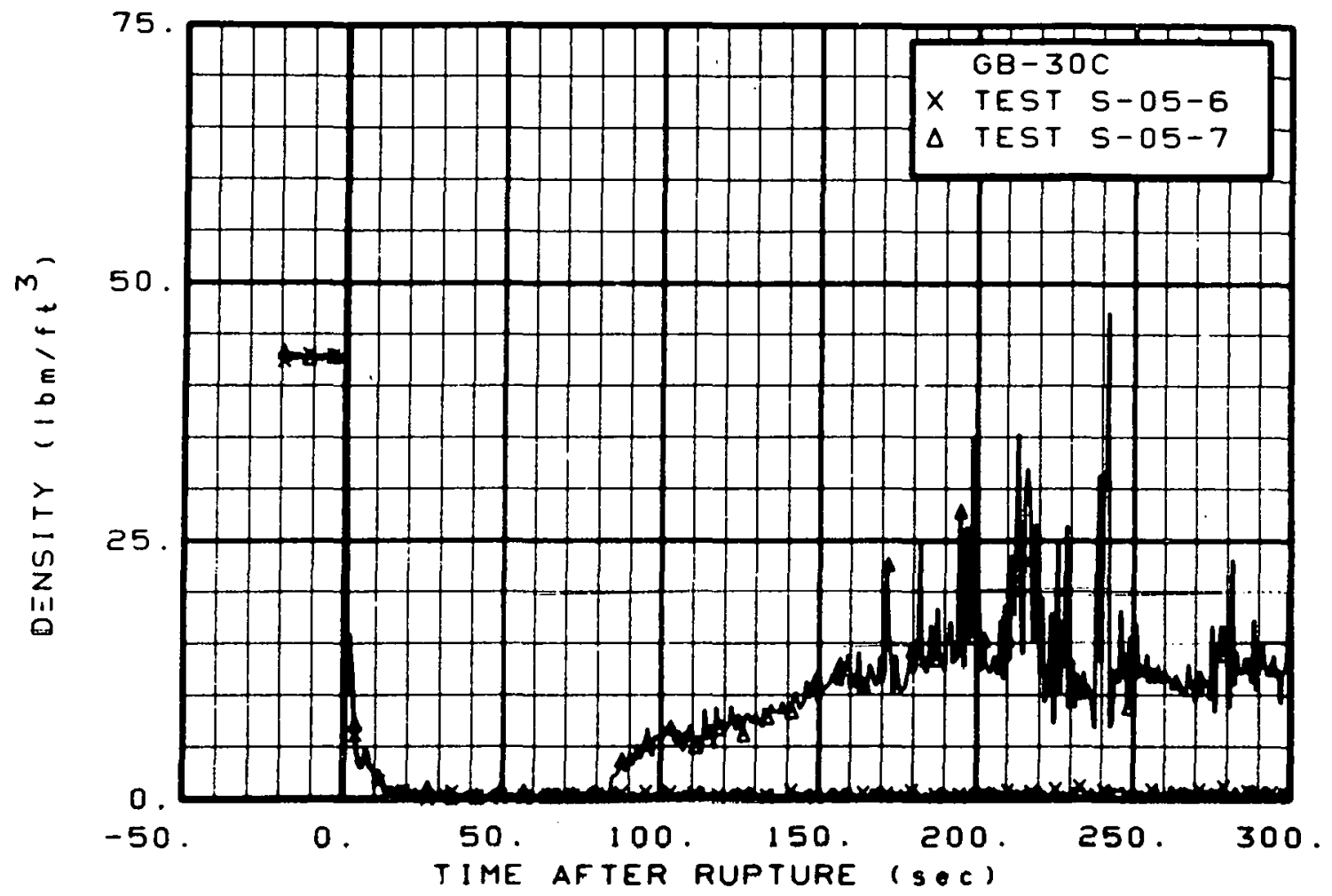

Fig. 482 Density in broken 100p (GB-30C), from -20 to $300 \mathrm{sec}$.

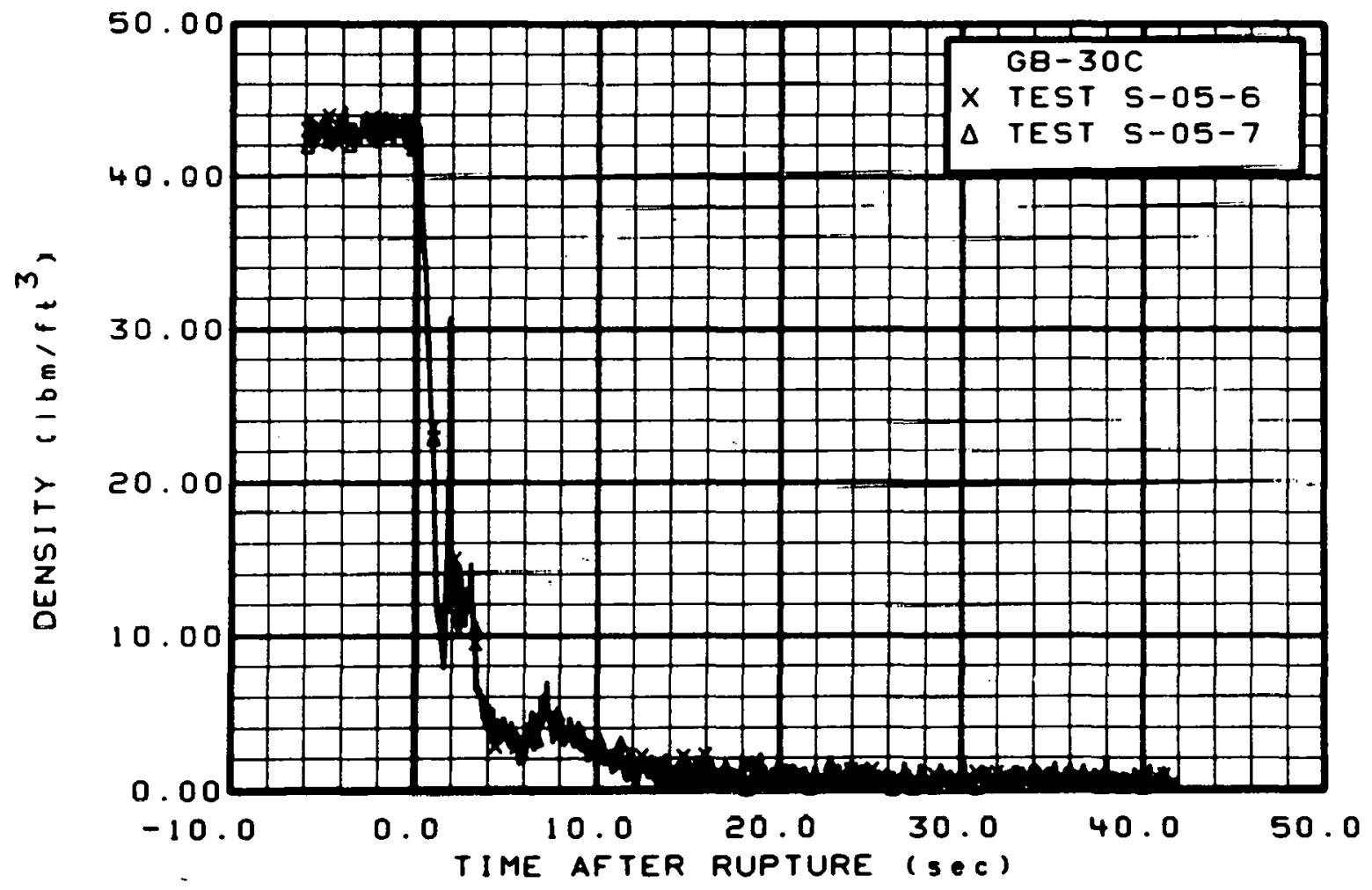

Fig. 483 Density in broken loop (GB-30C), from -6 to $42 \mathrm{sec}$. 


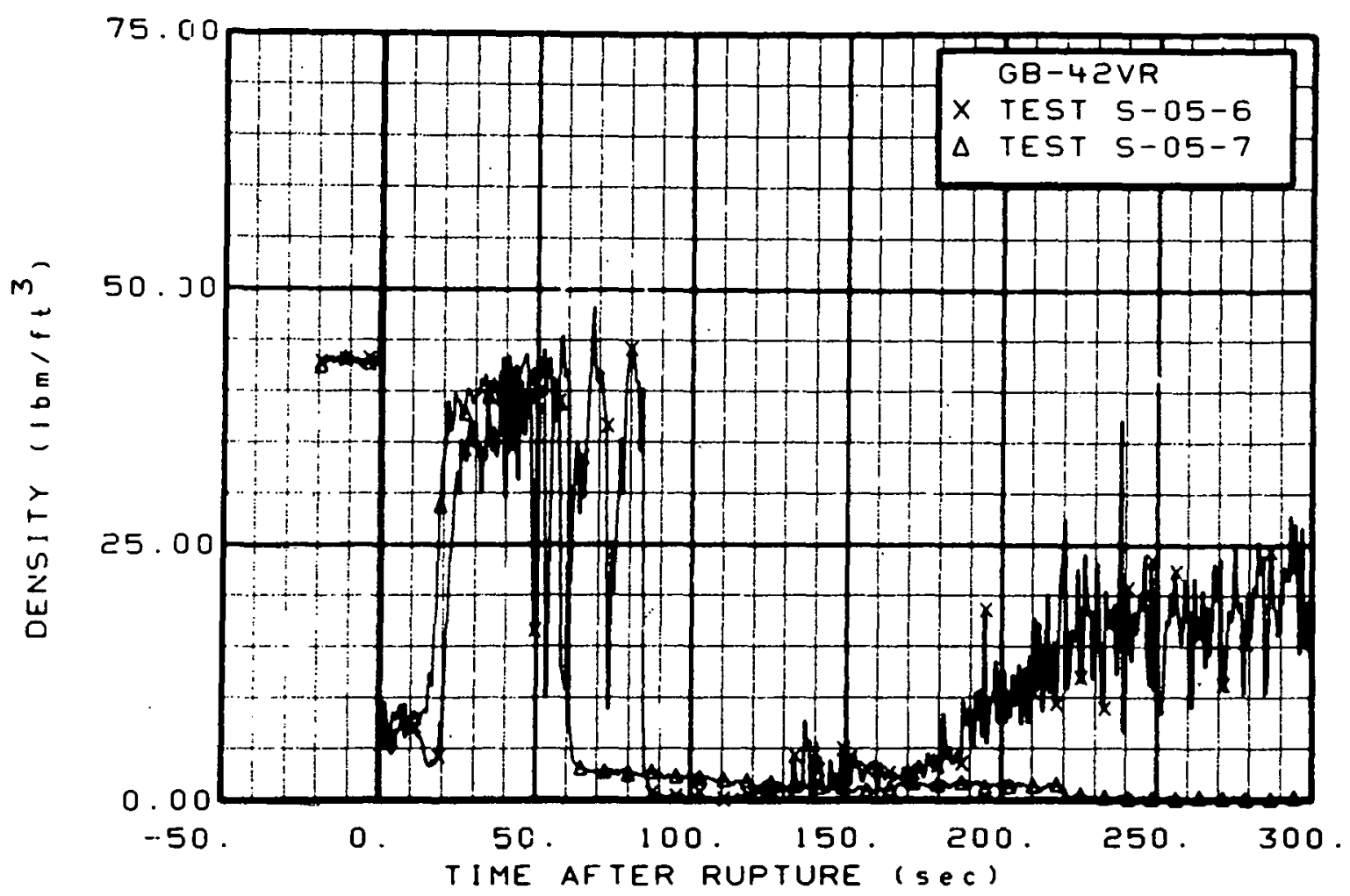

Fig. 484 Density in broken loop (GB-42VR), from -20 to $300 \mathrm{sec}$.

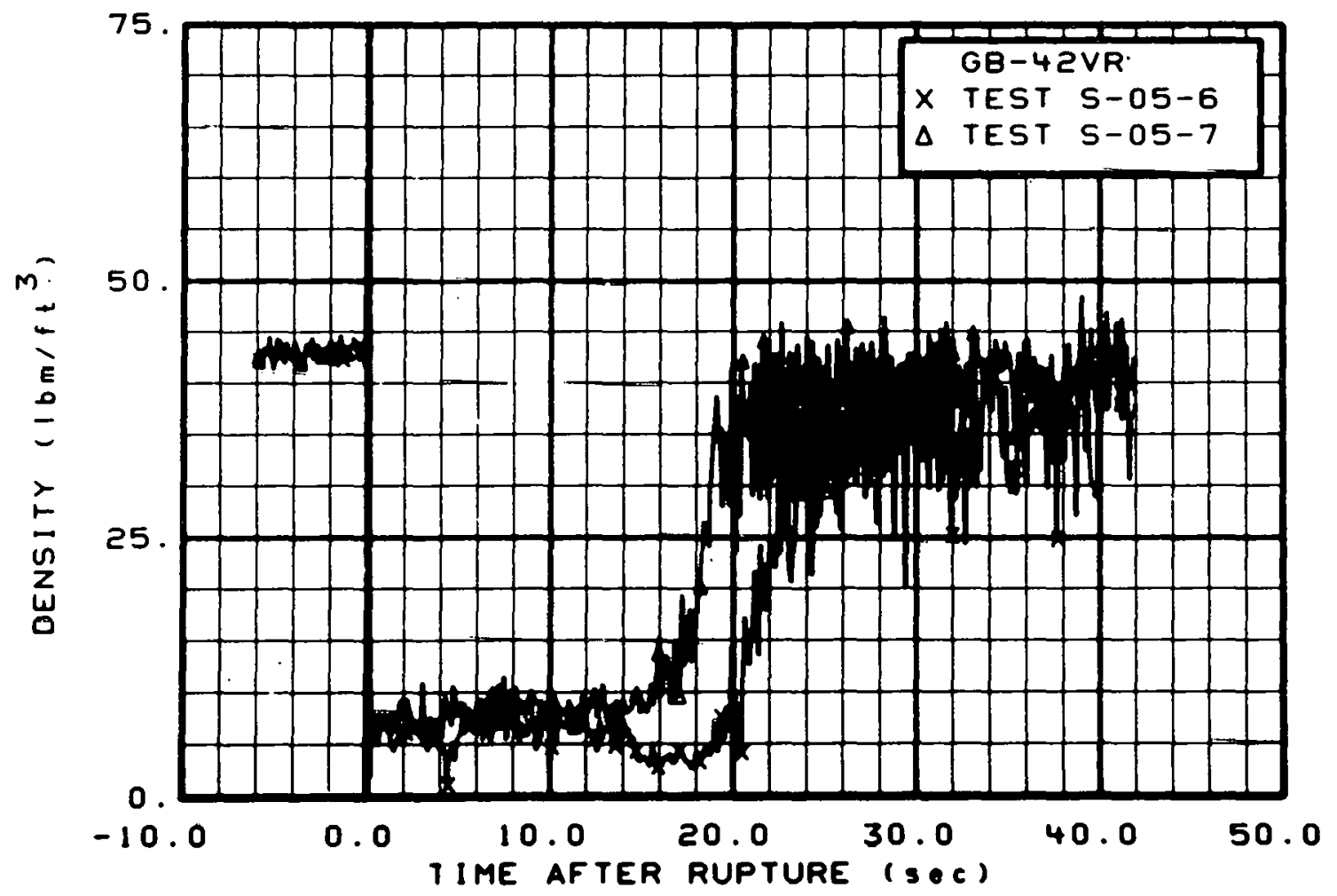

Fig. 485 Density in broken 10op (GB-42VR), from -6 to $42 \mathrm{sec}$. 


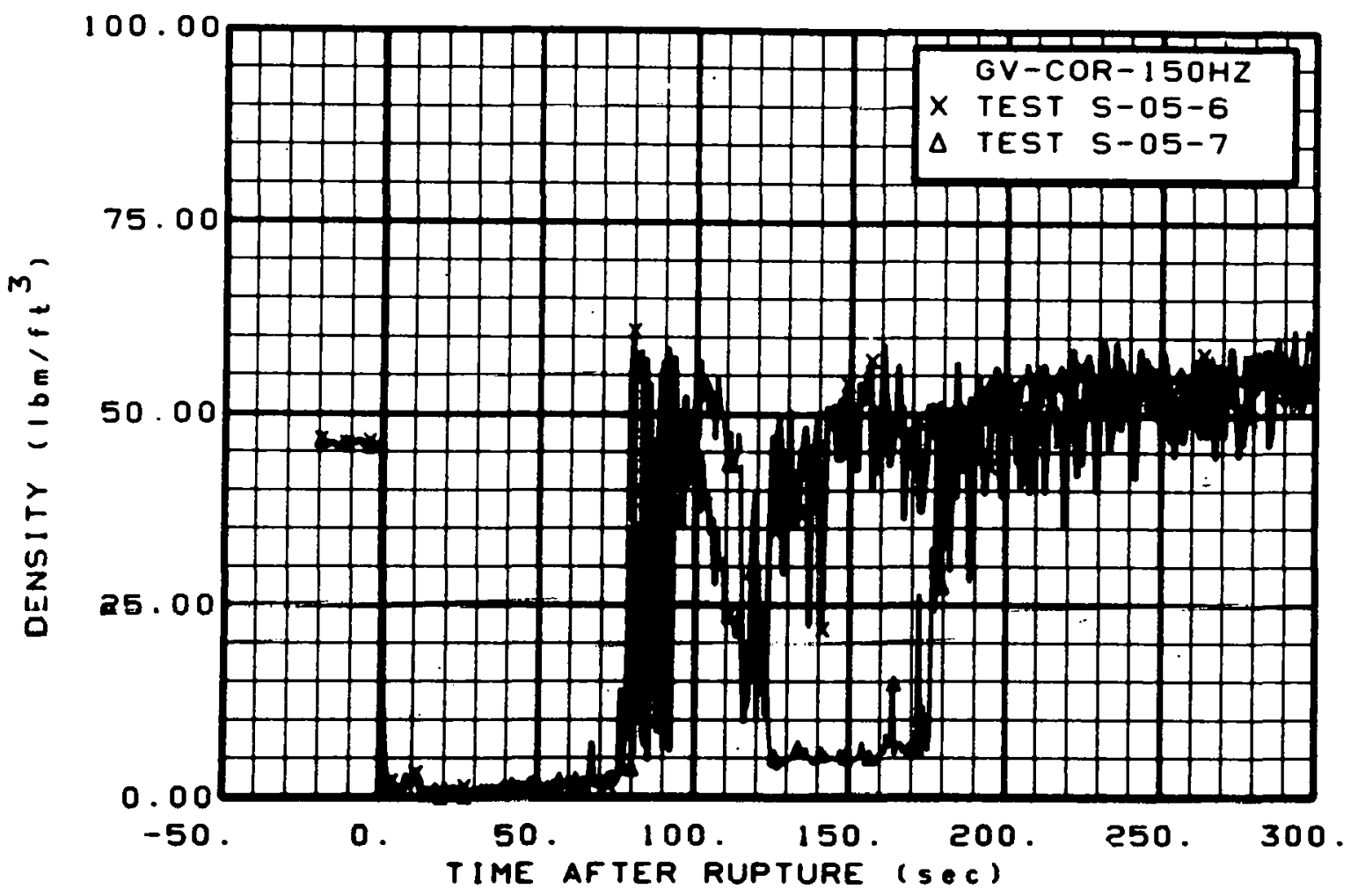

Fig. 486 Density in vessel (GV-COR-150HZ), from -20 to $300 \mathrm{sec}$.

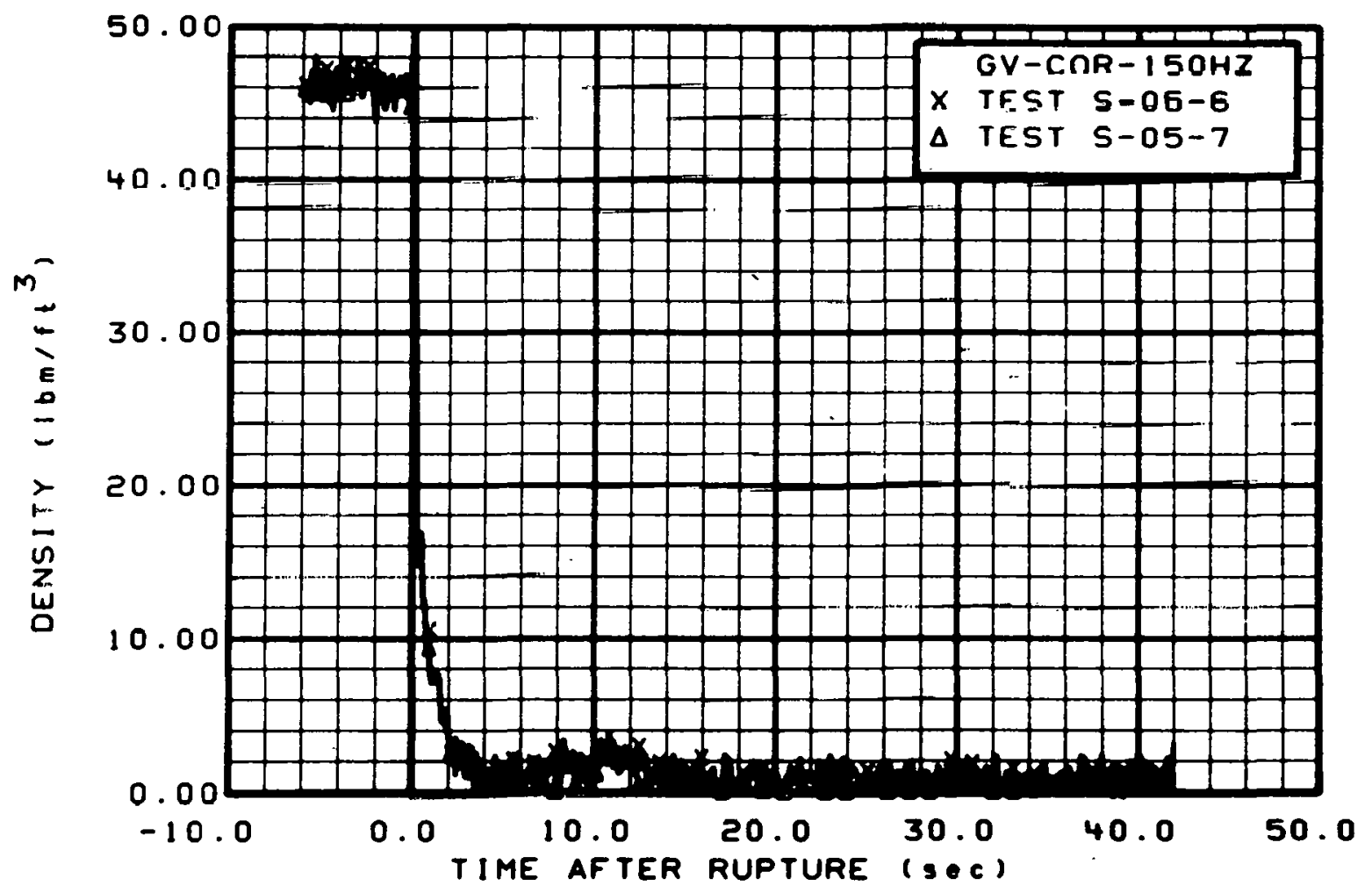

Fig. 487 Density in vessel (GV-COR-150HZ), from -6 to $42 \mathrm{sec}$. 


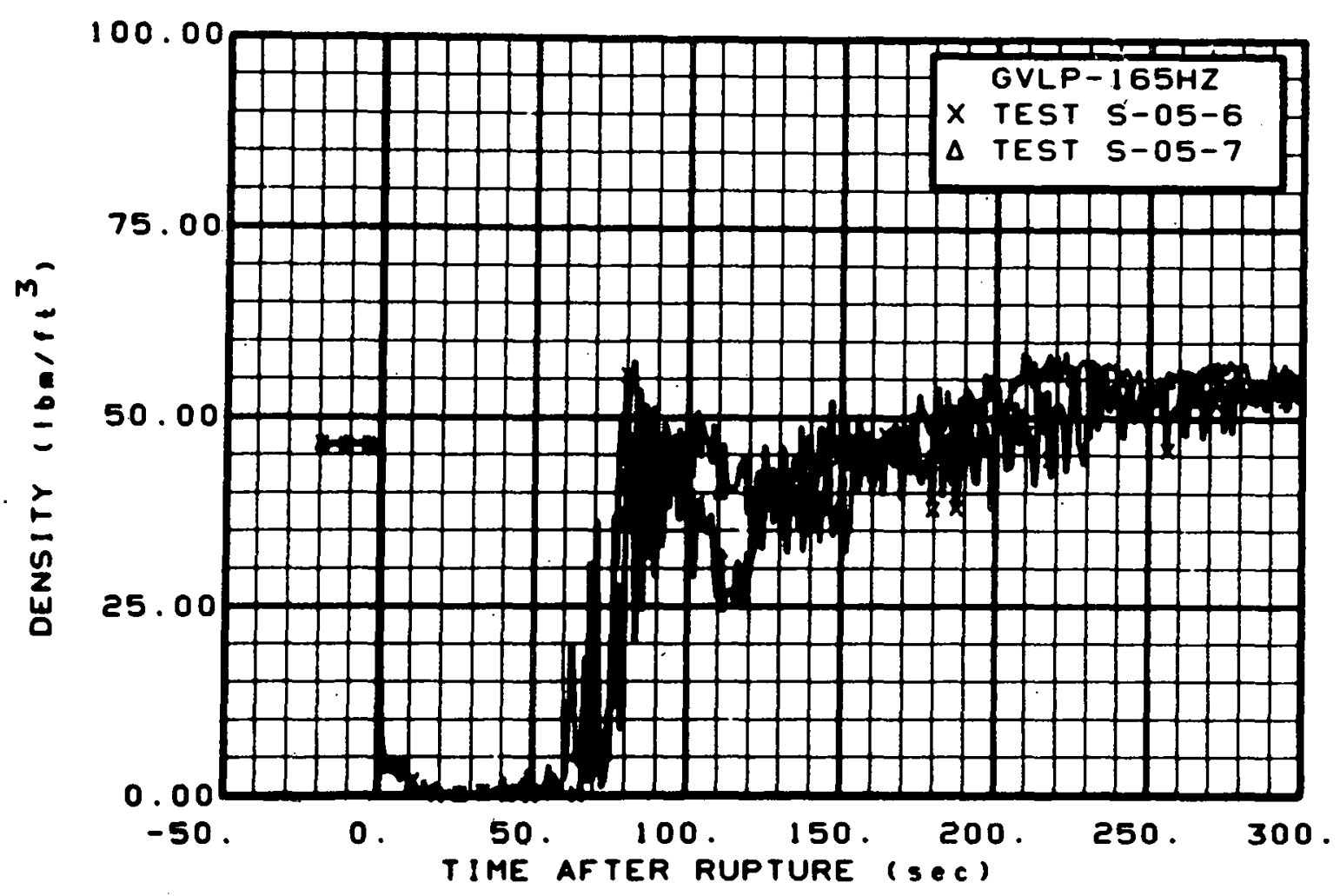

Fig. 488 Density in vesse 1 (GVLP-165HZ), from -20 to $300 \mathrm{sec}$.

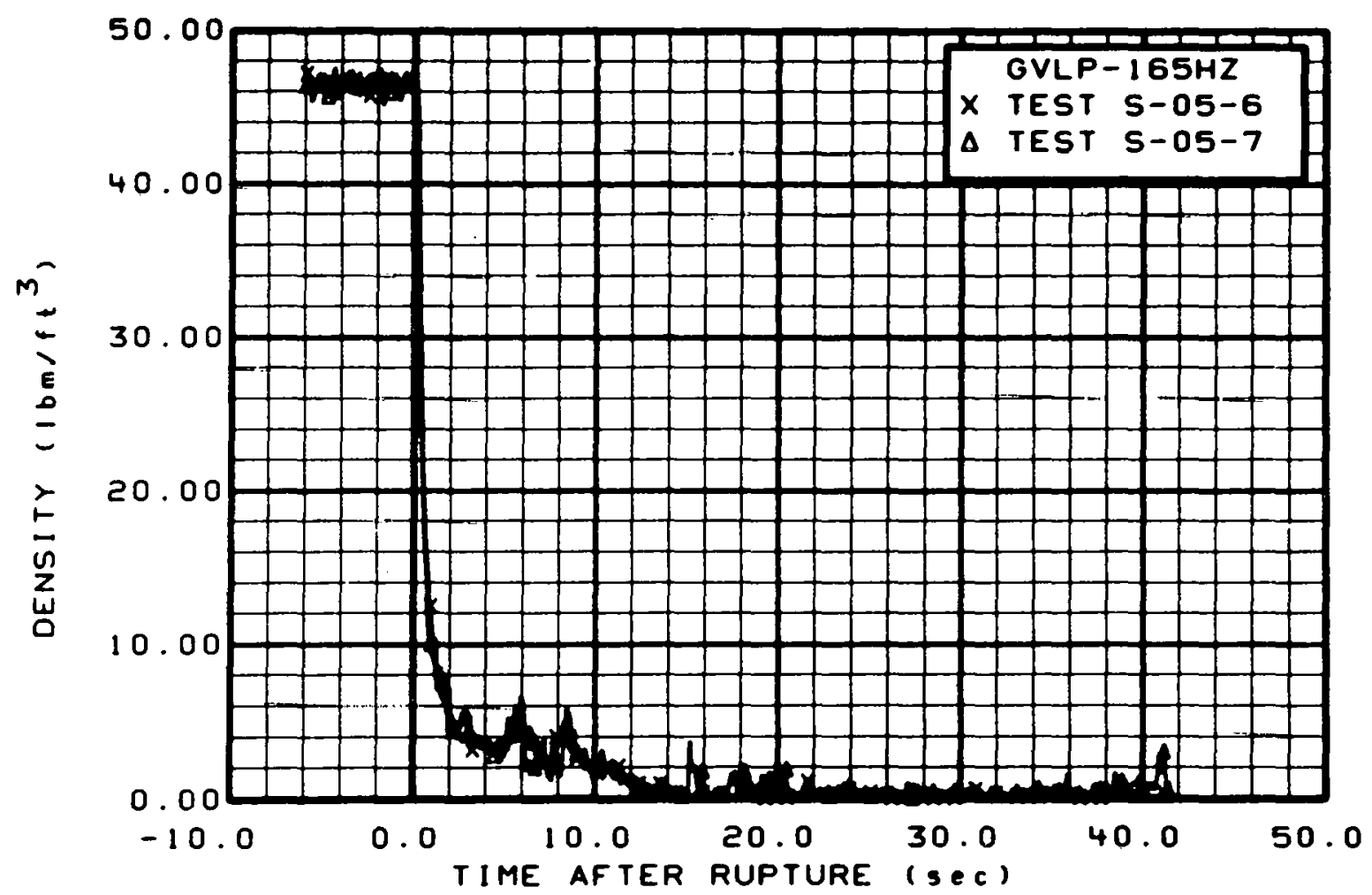

Fig. 489 Density in vessel (GVLP-165HZ), from -6 to 42 sec. 


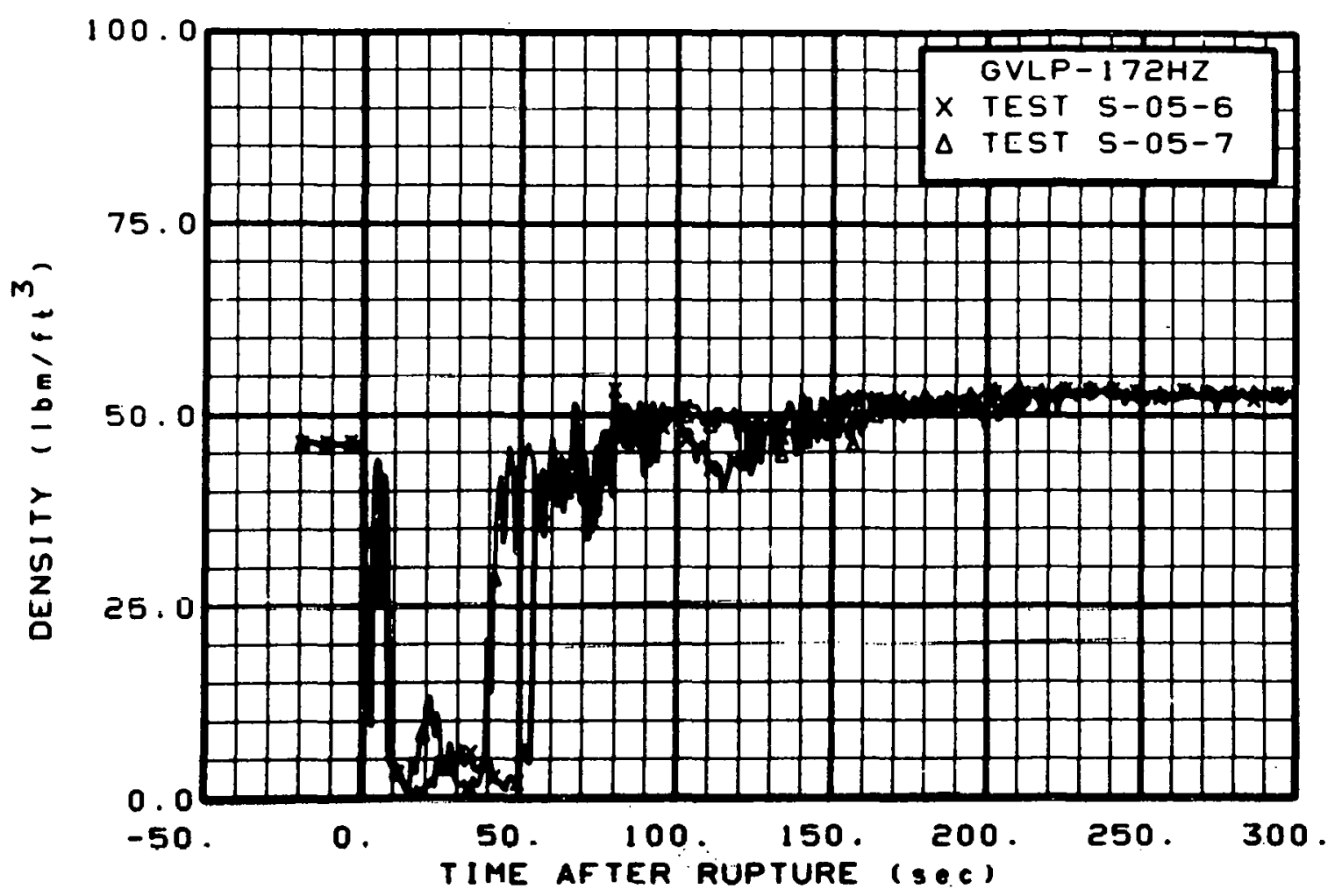

Fig. 490 Density in vessel (GVLP-172HZ), from -20 to $300 \mathrm{sec}$.

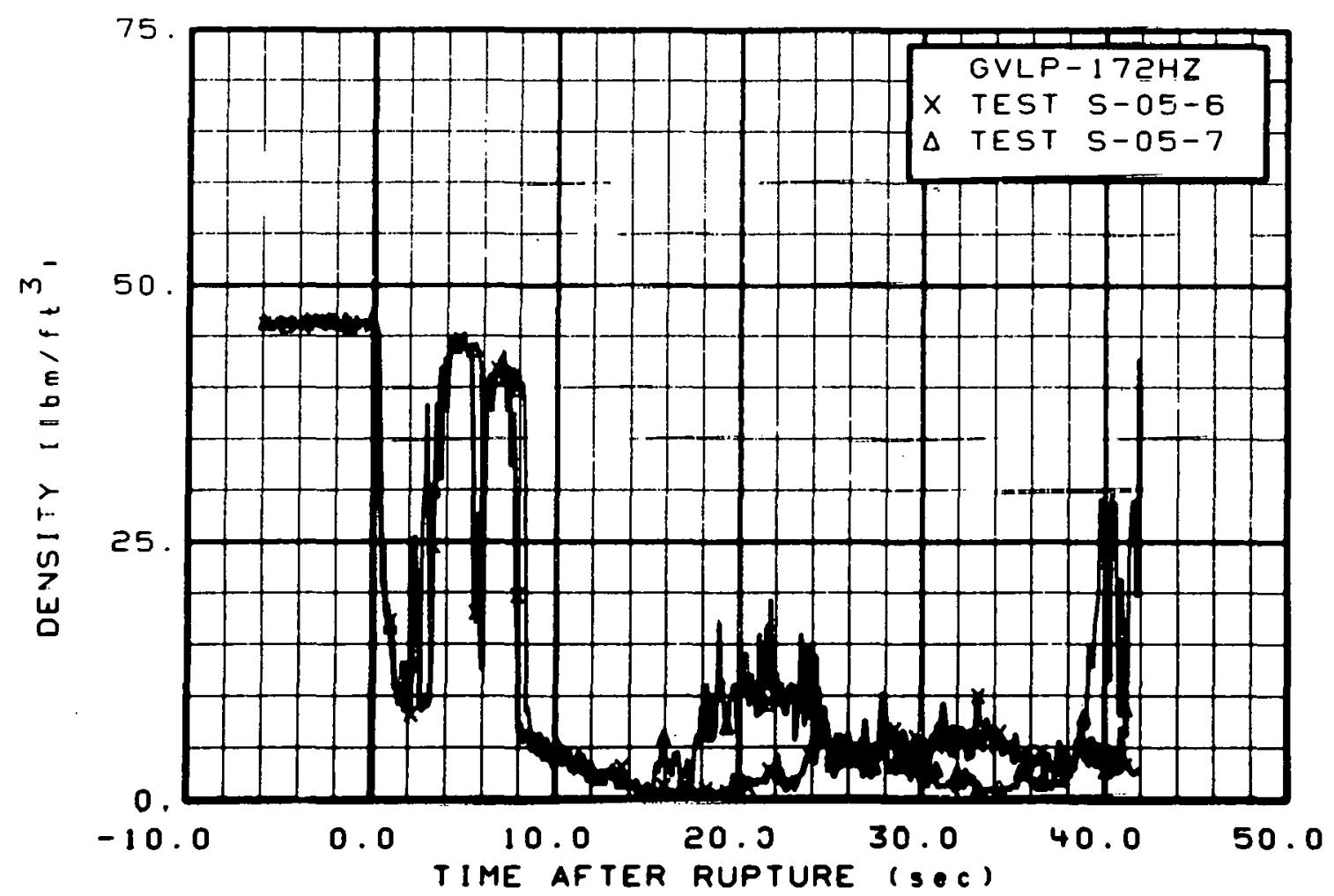

Fig. 491 Density in vessel (GVLP-172HZ), from -6 to $42 \mathrm{sec}$. 


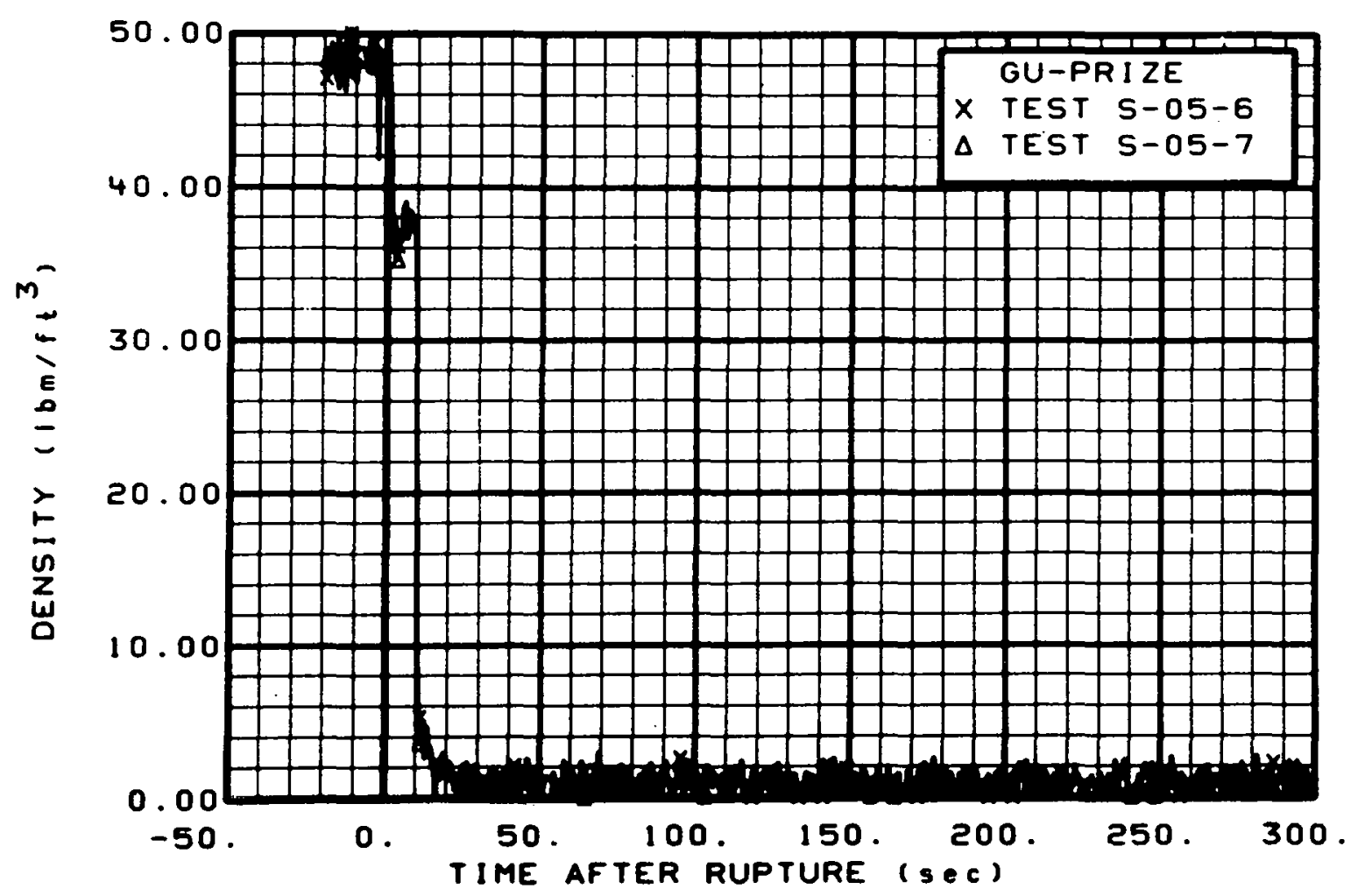

Fig. 492 Density in pressurizer (GU-PRIZE), from -20 to $300 \mathrm{sec}$.

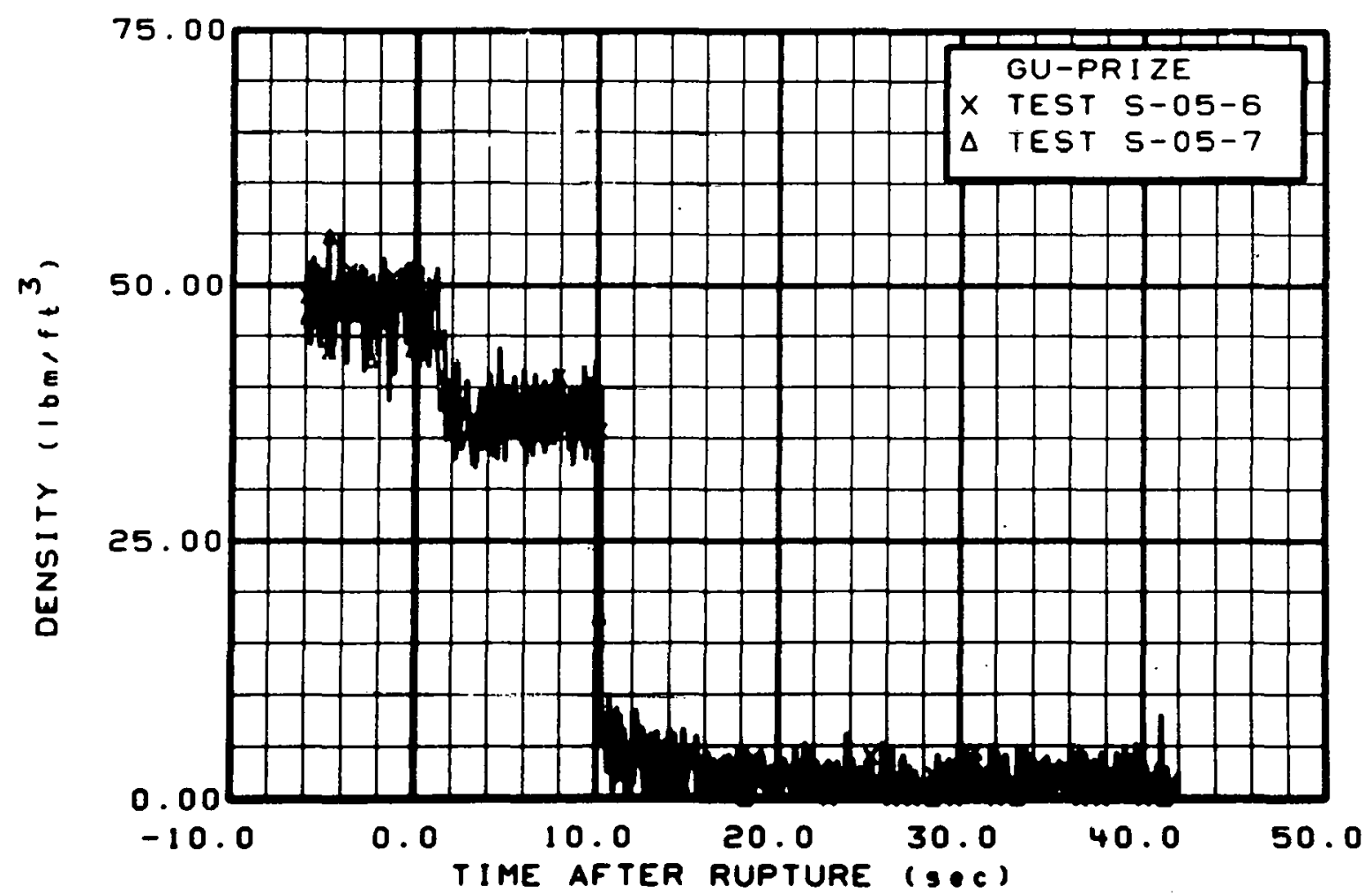

Fig. 493 Density in pressurizer (GU-PRIZE), from -6 to $42 \mathrm{sec}$. 


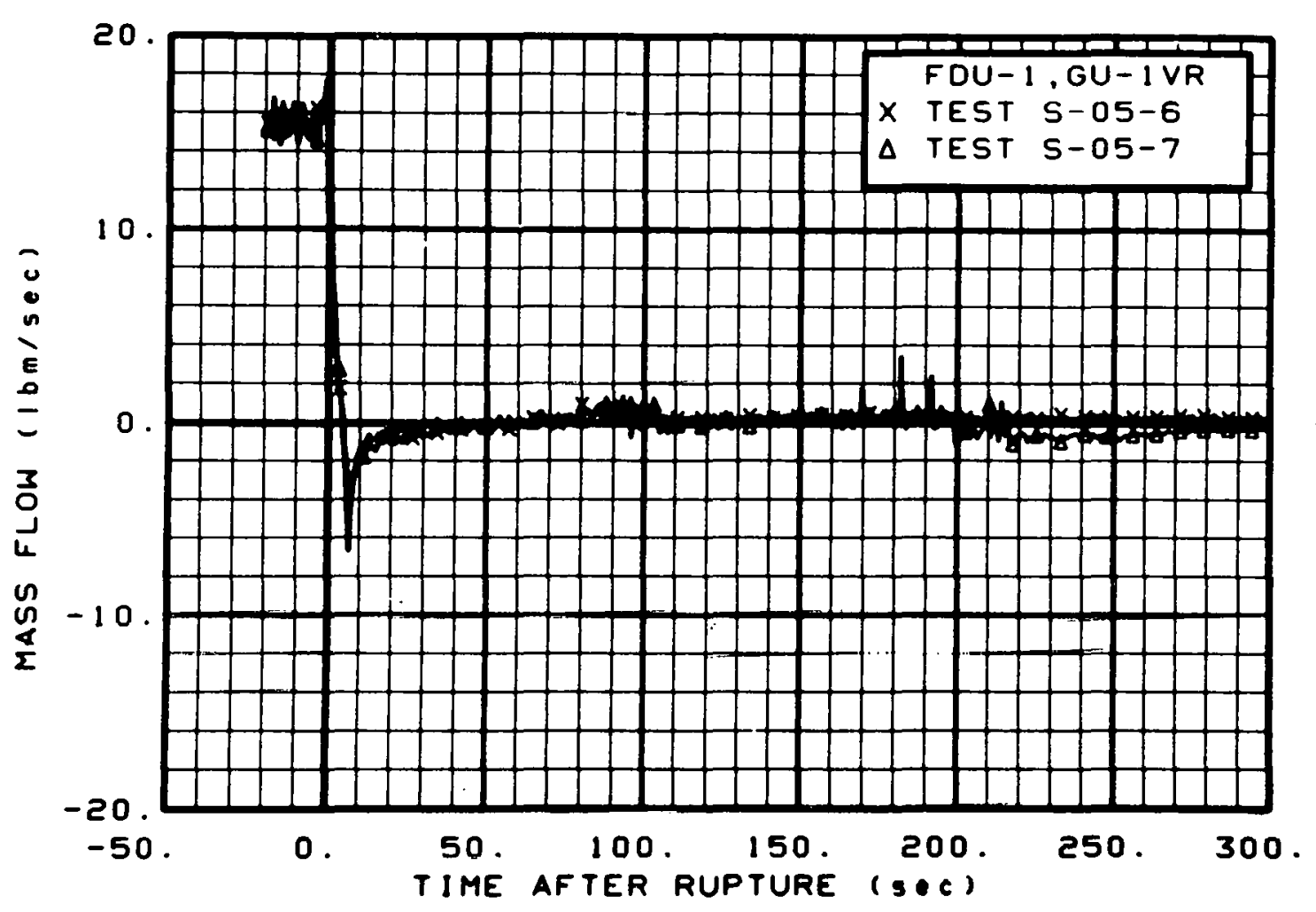

Fig. 494 Mass flow in intact loop (FDU-1, GU-1VR), from -20 to $300 \mathrm{sec}$.

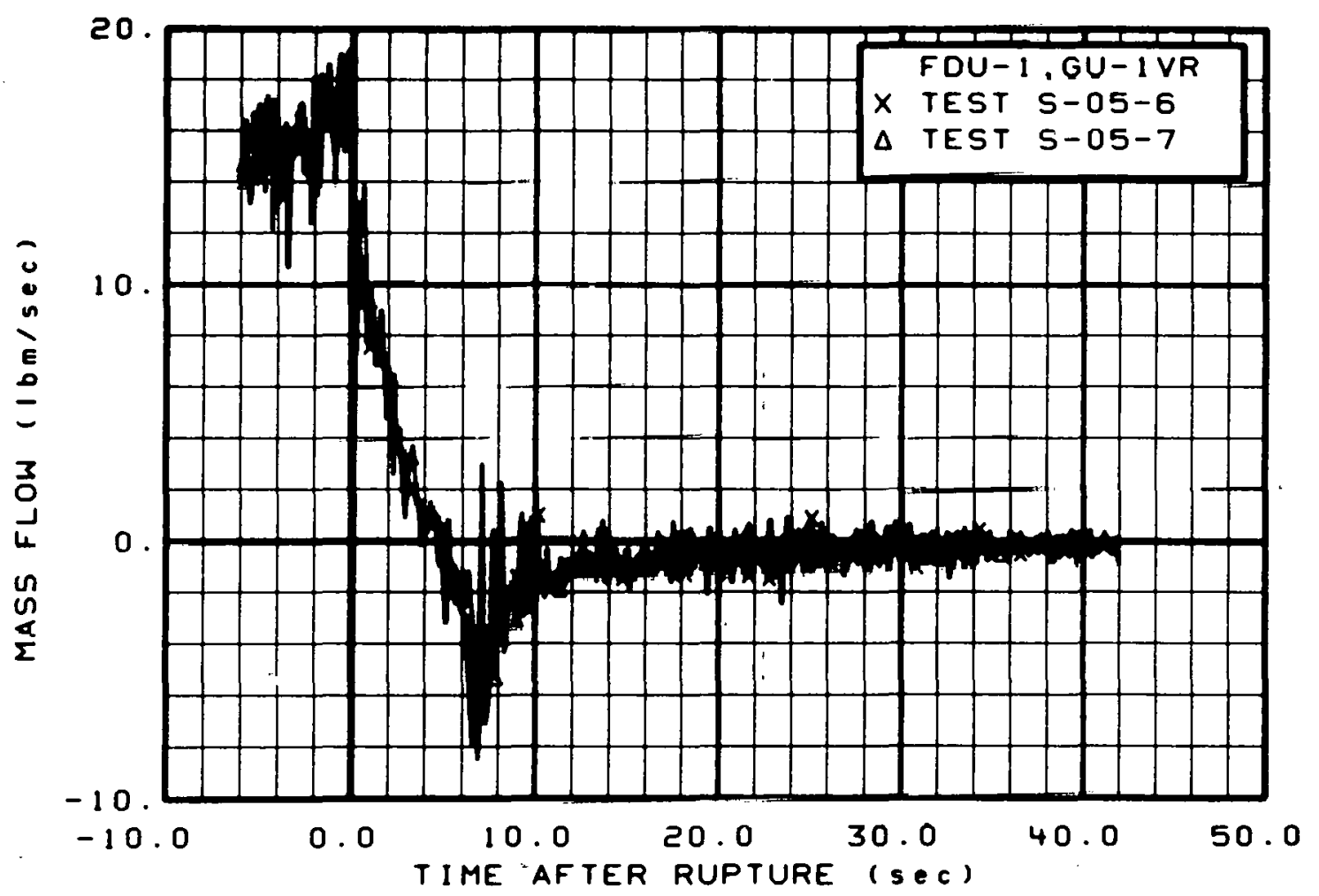

Fig. 495 Mass flow in intact loop (FDU-1, GU-1VR), from -6 to $42 \mathrm{sec}$. 
THIS PAGE

\section{WAS INTENTIONALLY LEFT BLANK}




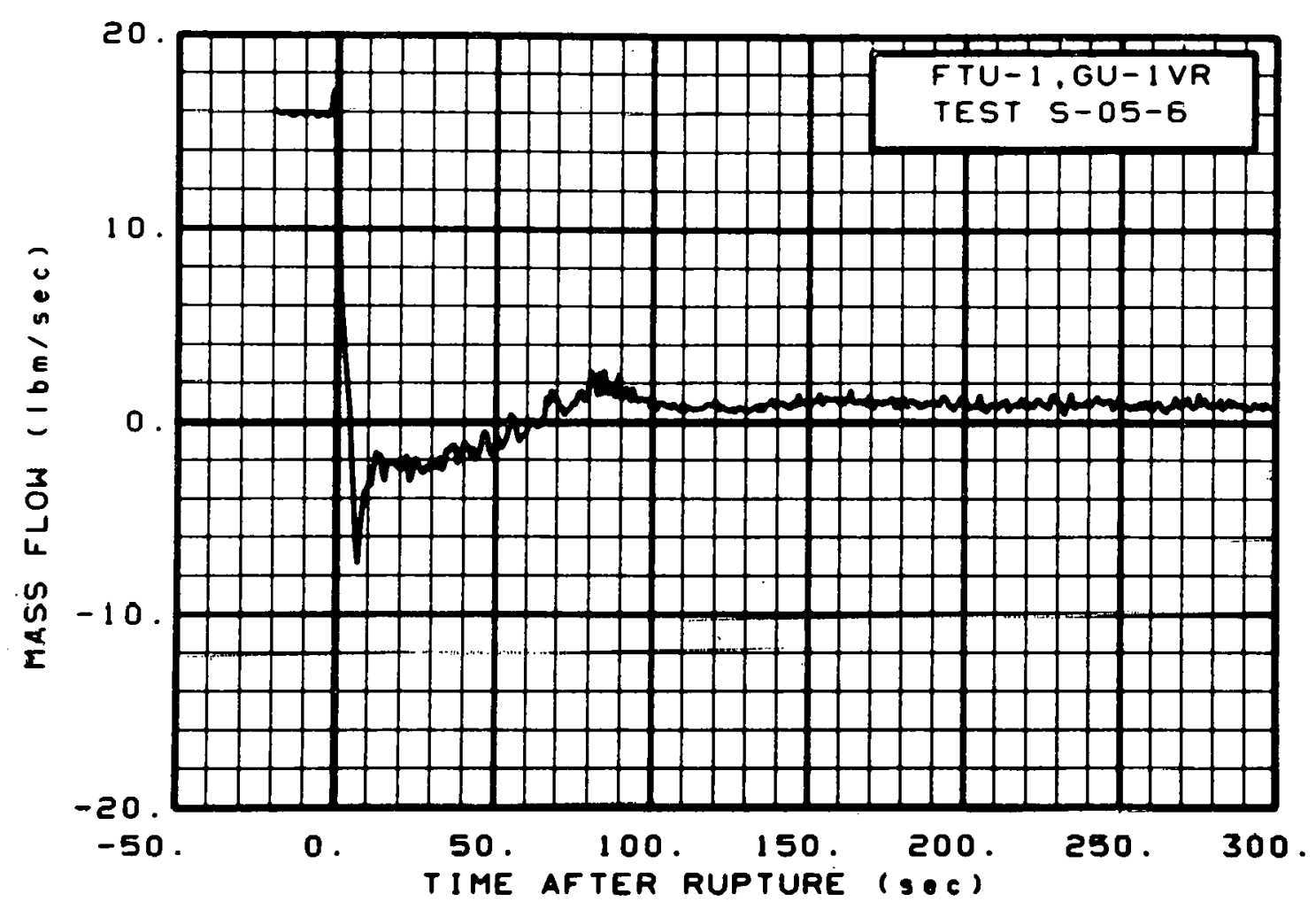

Fig. 496 Mass flow in intact 1oop, Test S-05-6 (FTU-1, GU-1VR), from -20 to $300 \mathrm{sec}$.

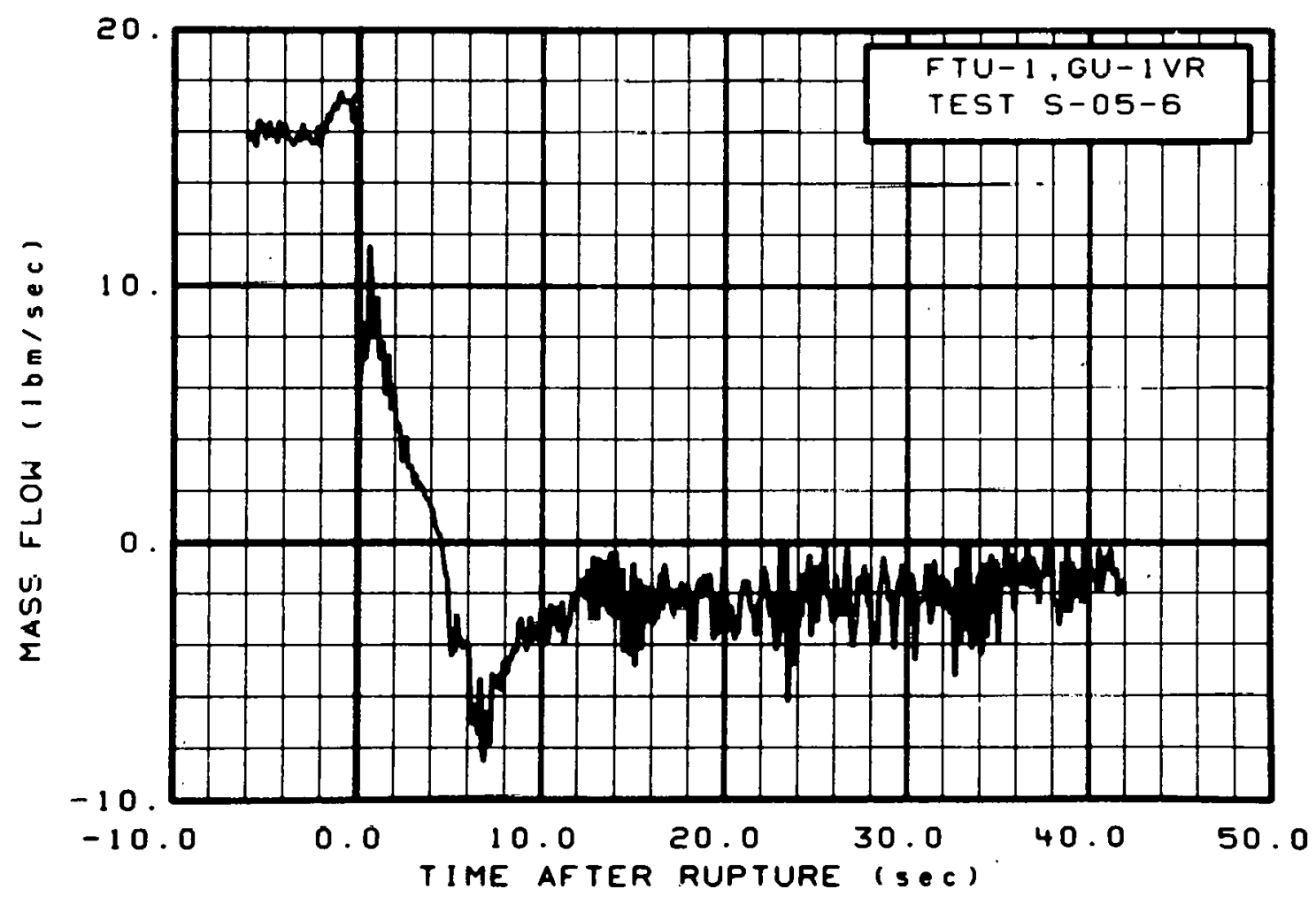

Fig. 497 Mass flow in intact loop, Test S-05-6 (FTU-1, GU-1VR), from -6 to $42 \mathrm{sec}$. 


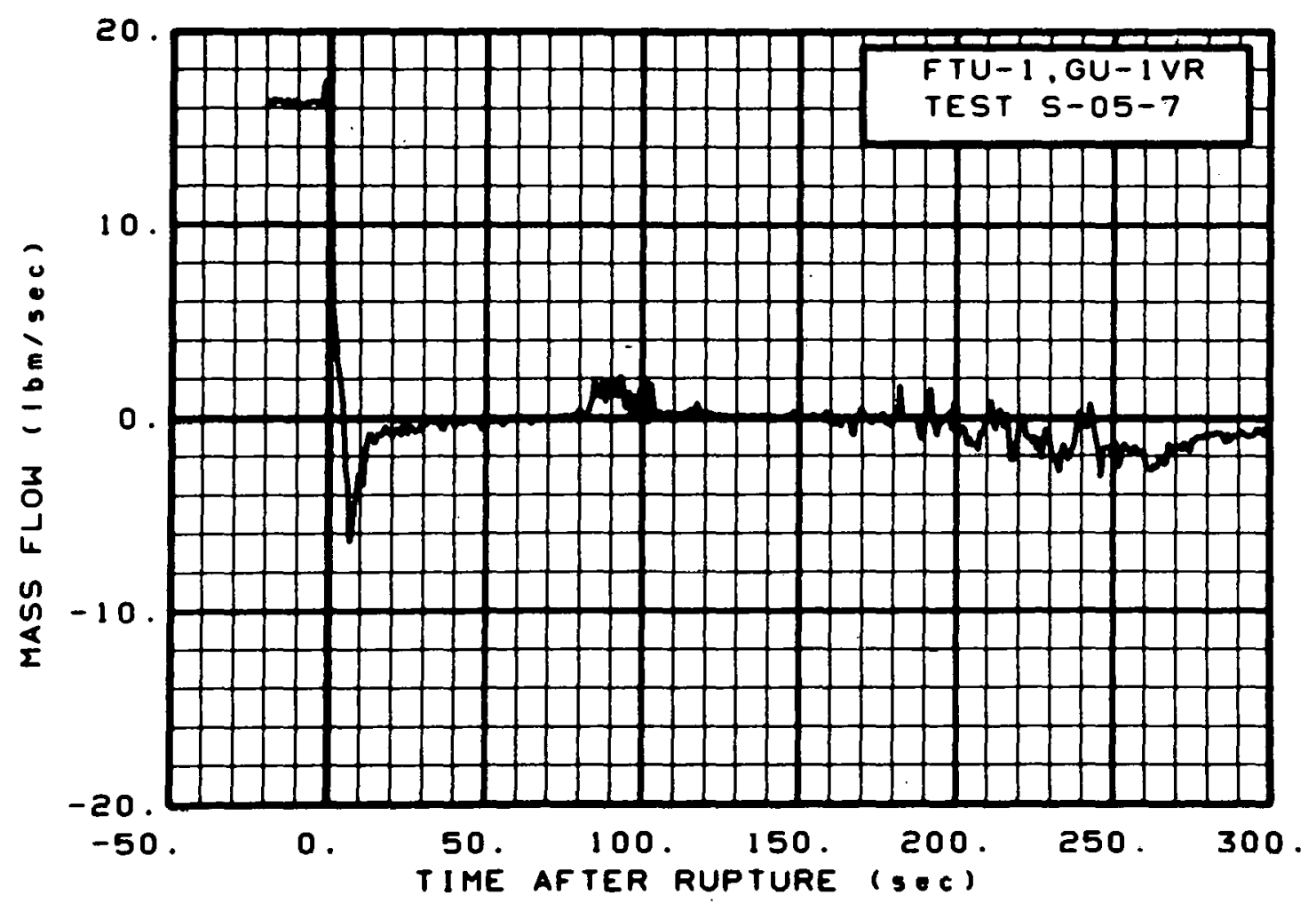

Fig. 498 Mass flow in intact loop, Test S-05-7 (FTU-1, GU-1VR), from -20 to $300 \mathrm{sec}$.

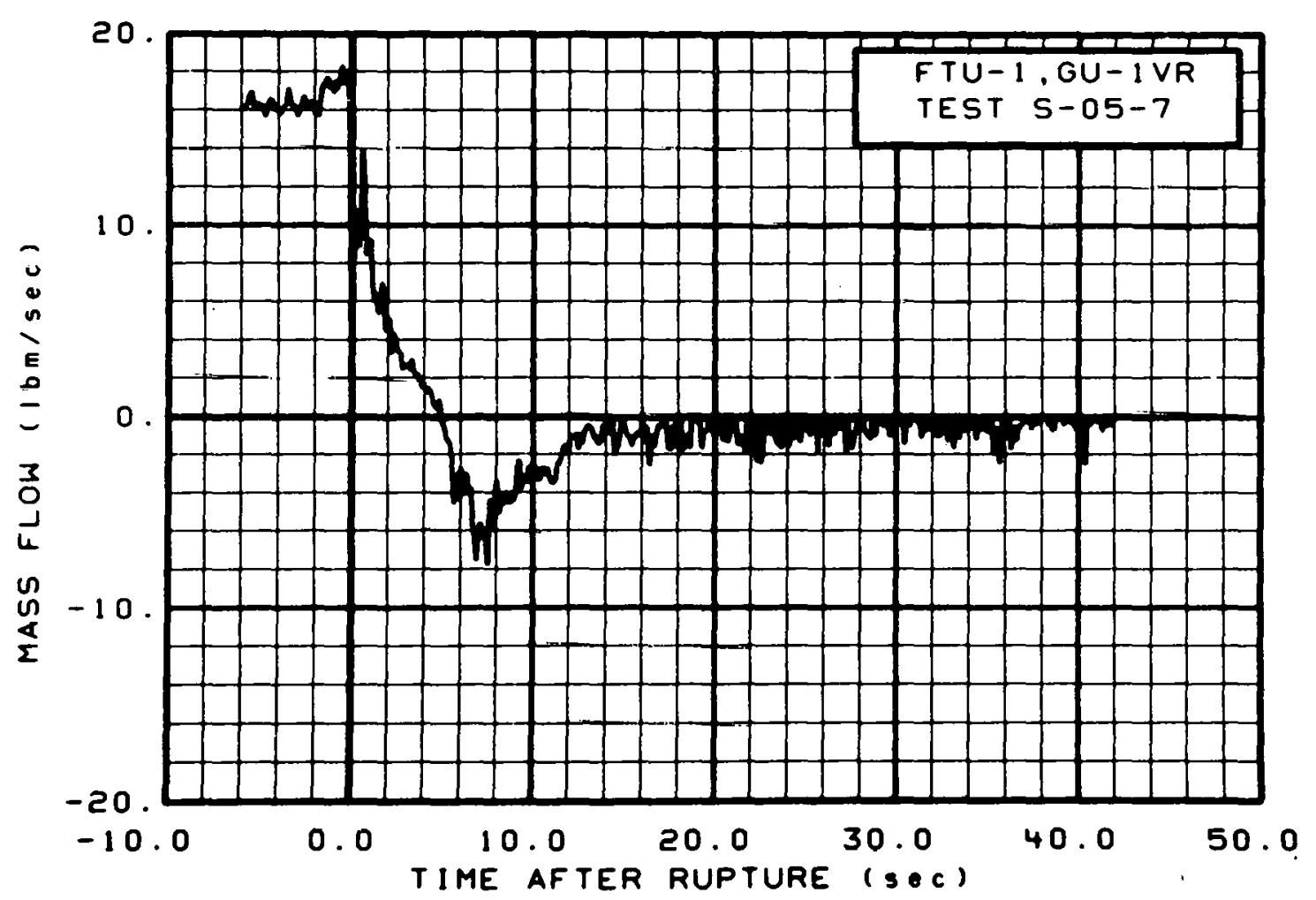

Fig. 499 Mass flow in intact 10op, Test S-05-7 (FTU-1, GU-1VR), from -6 to $42 \mathrm{sec}$. 


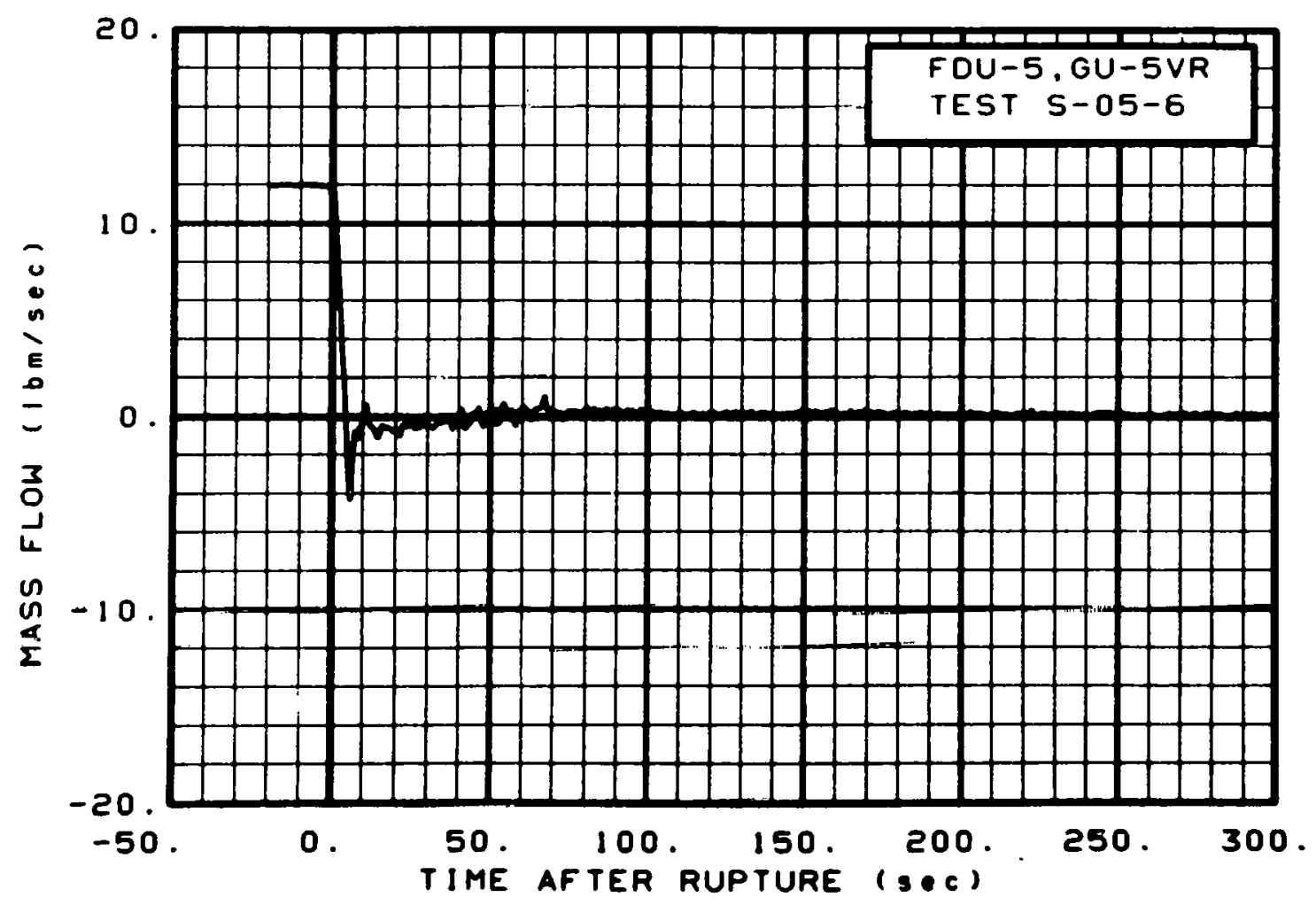

Fig. 500 Mass flow in intact loop, Test S-05-6 (FDU-5, GU-5VR), from -20 to $300 \mathrm{sec}$.

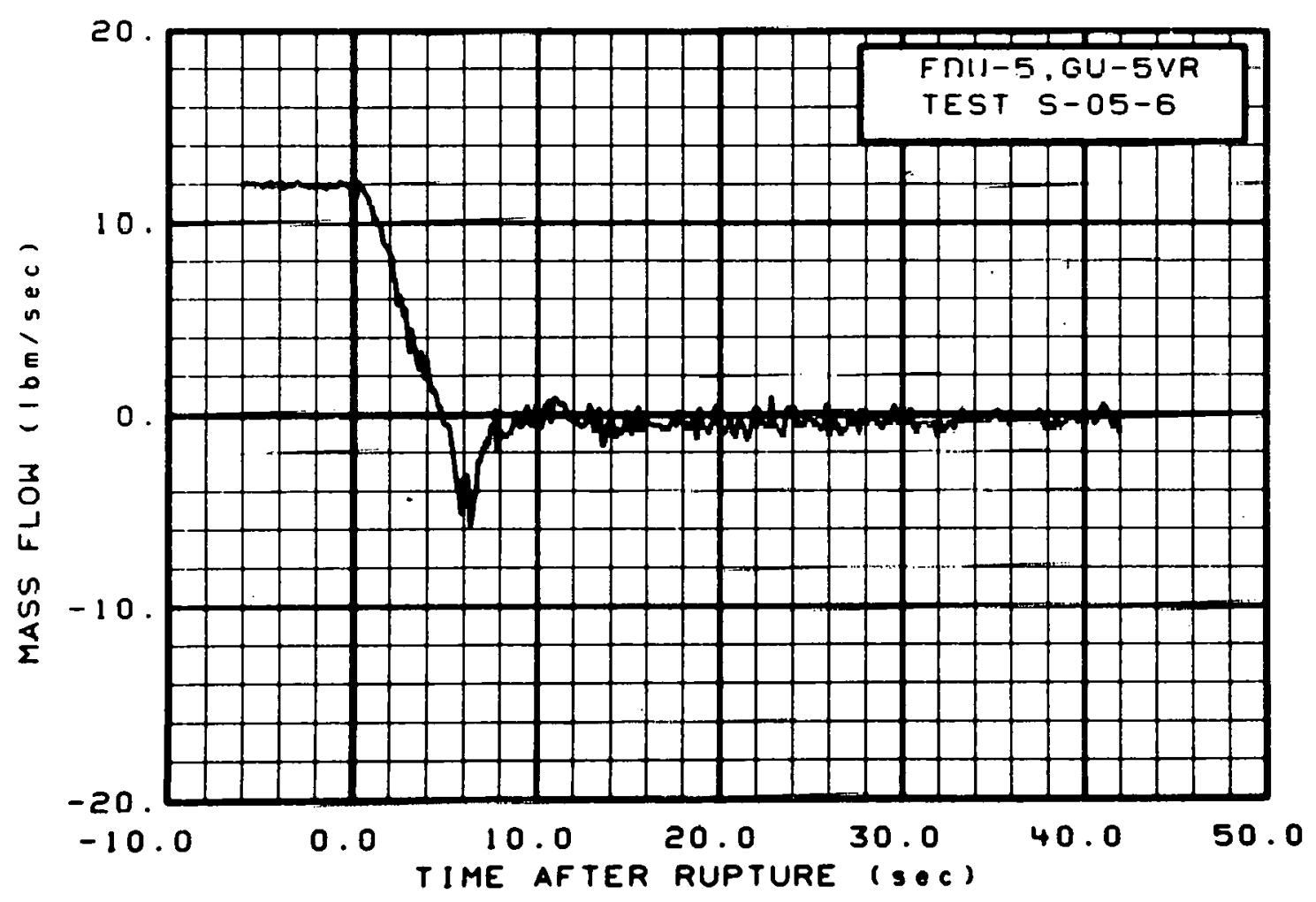

Fig. 501 Mass flow in intact 1oop, Test S-05-6 (FDU-5, GU-5VR), from -6 to $42 \mathrm{sec}$. 


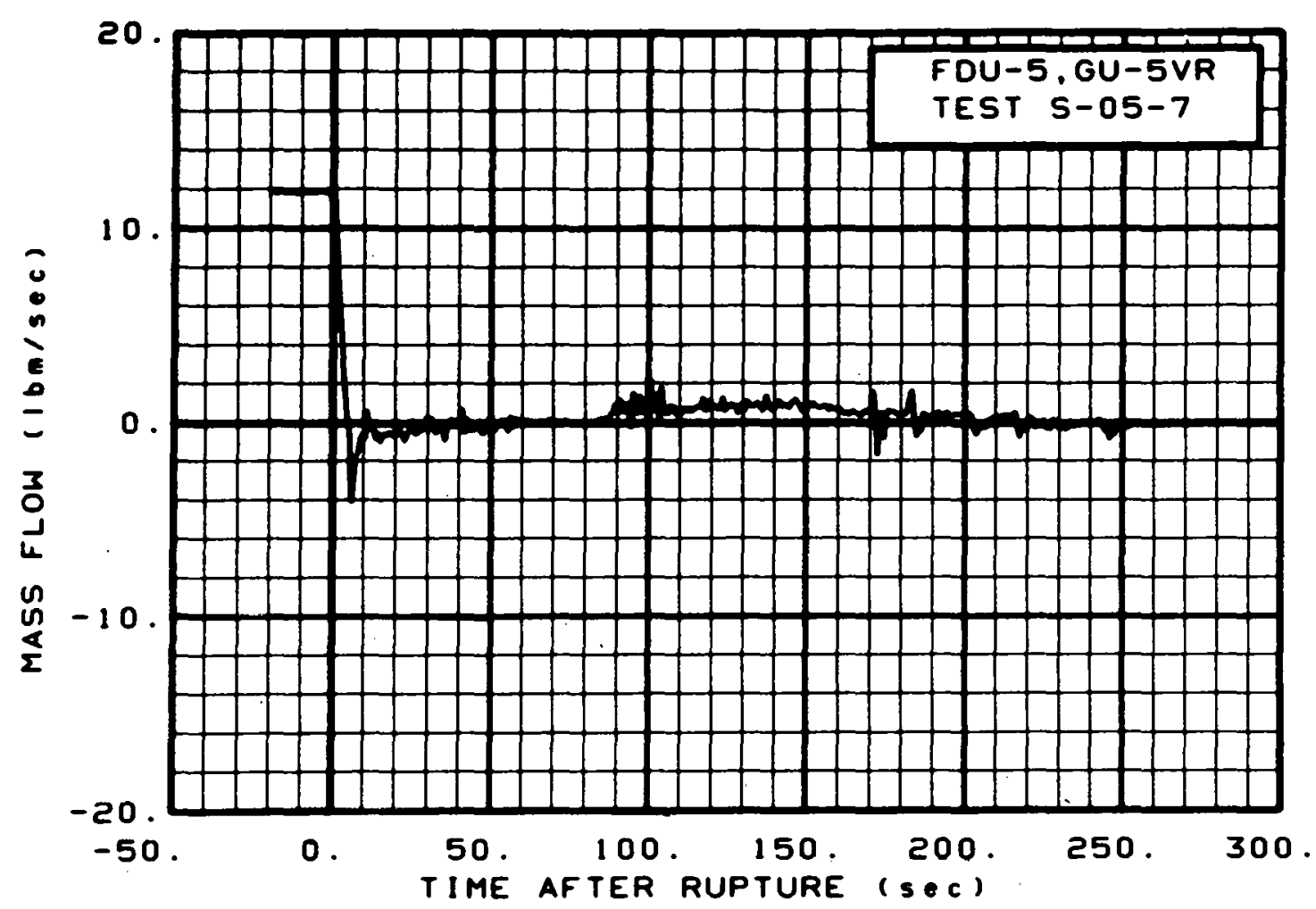

Fig. 502 Mass flow in intact 1oop, Test S-05-7 (FDU-5, GU-5VR), from -20 to $300 \mathrm{sec}$.



Fig. 503 Mass flow in intact 1oop, Test S-05-7 (FDU-5, GU-5VR), from -6 to $42 \mathrm{sec}$. 


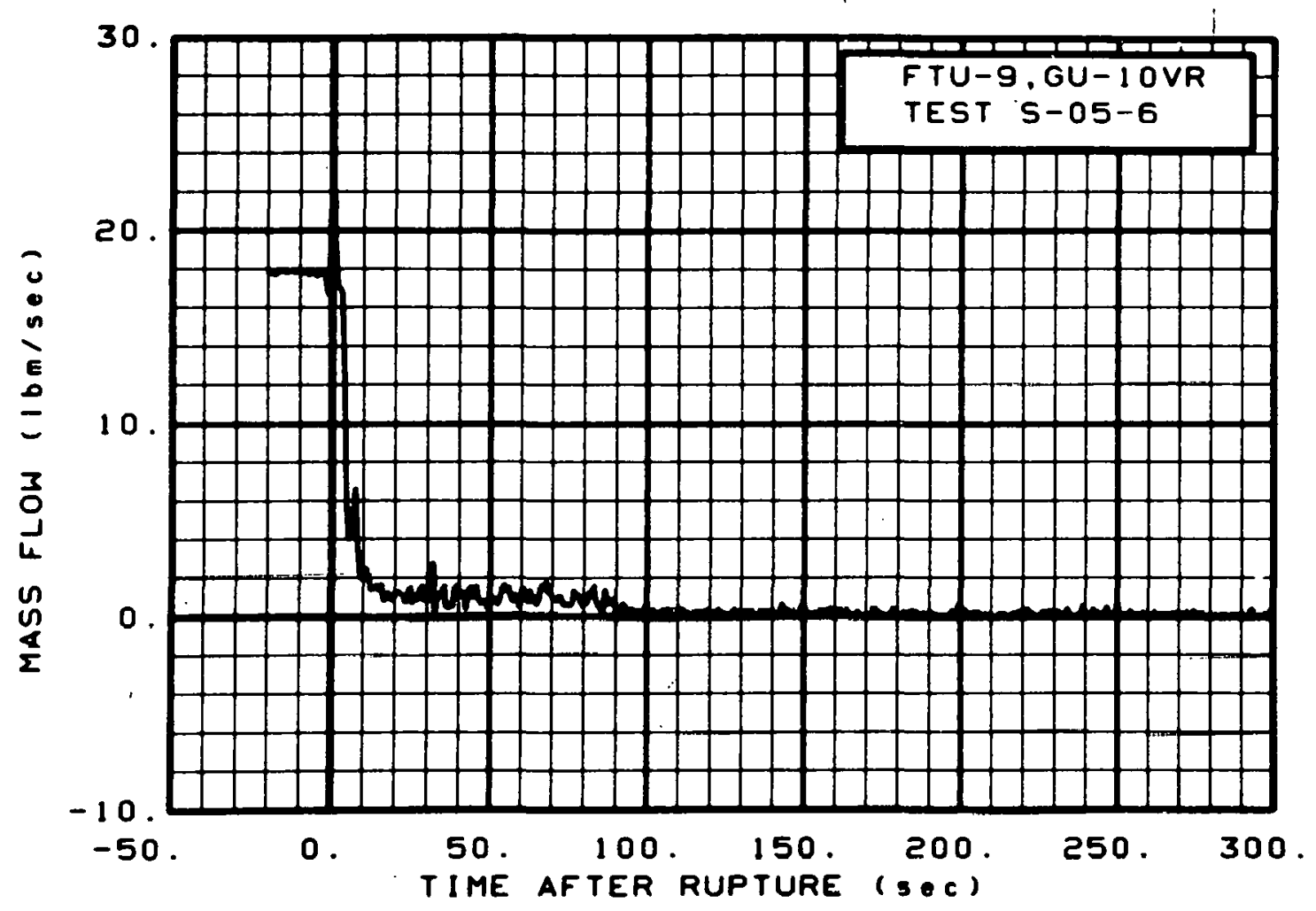

Fig. 504 Mass flow in intact 1oop, Test S-05-6 (FTU-9, GU-10VR), from -20 to $300 \mathrm{sec}$.

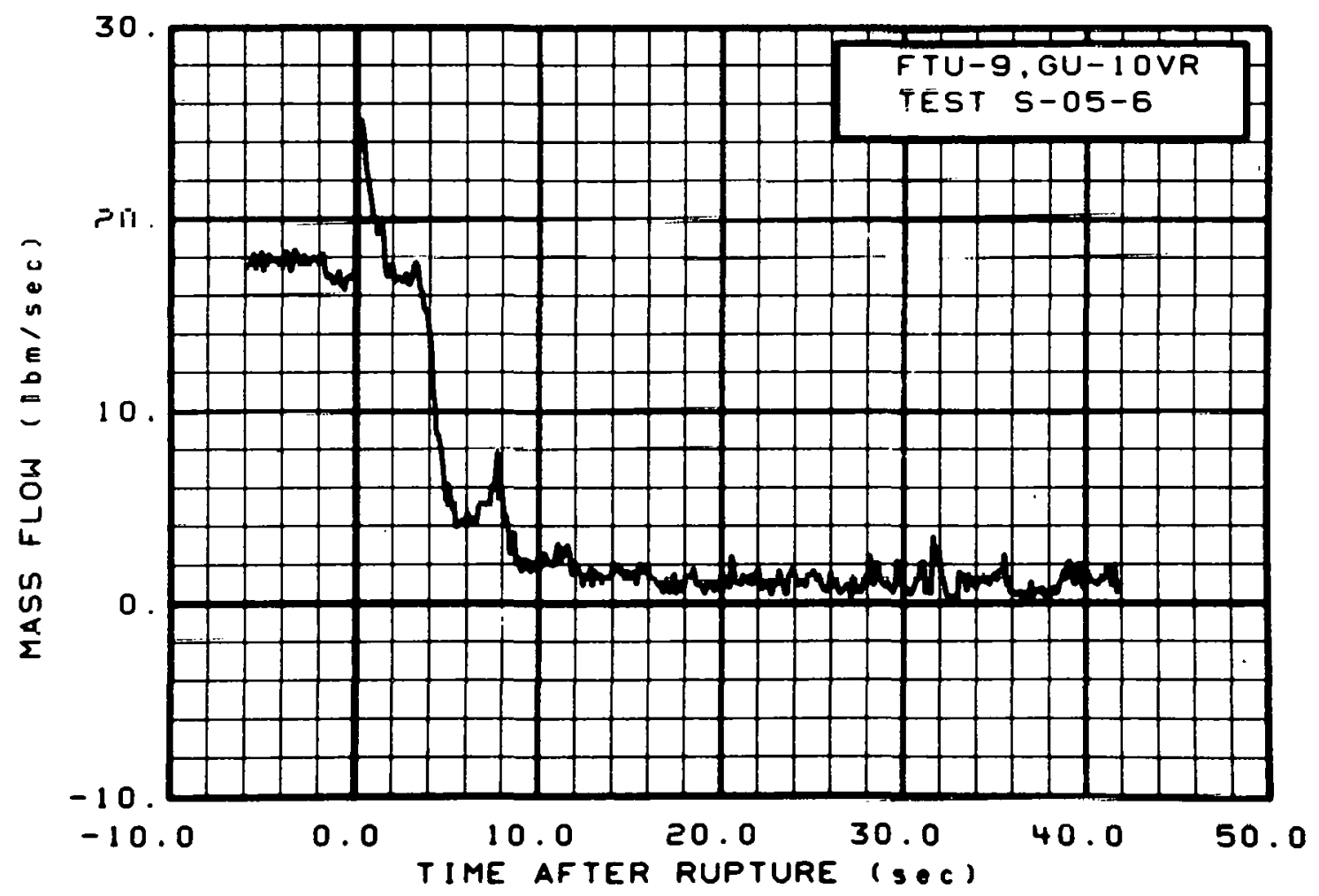

Fig. 505 Mass flow in intact 10op, Tes't S-05-6 (FTU-9, GU-10VR), from -6 to $42 \mathrm{sec}$. 


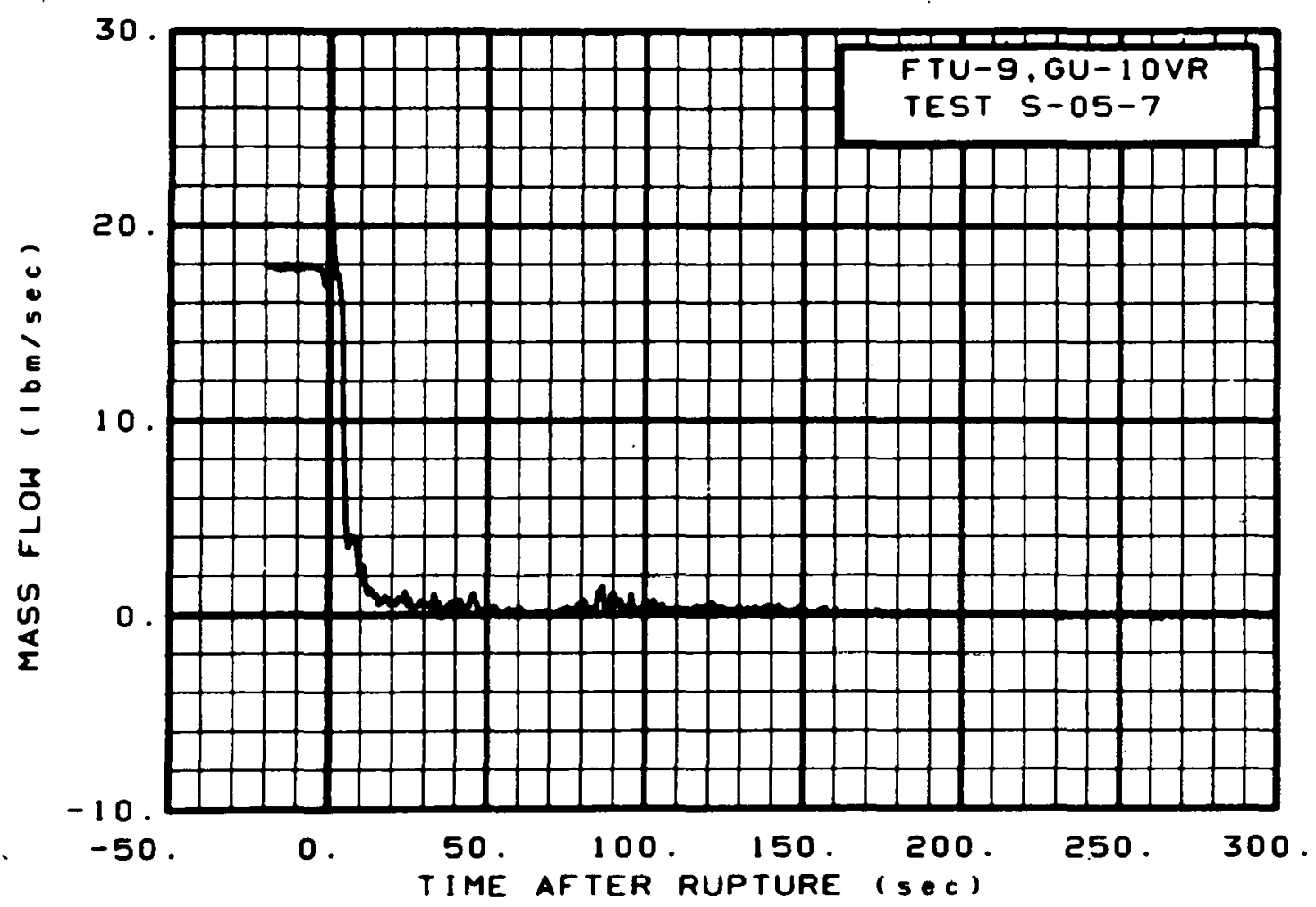

Fig. 506 Mass flow in intact 1oop, Test S-05-7 (FTU-9, GU-10VR), from -20 to $300 \mathrm{sec}$.

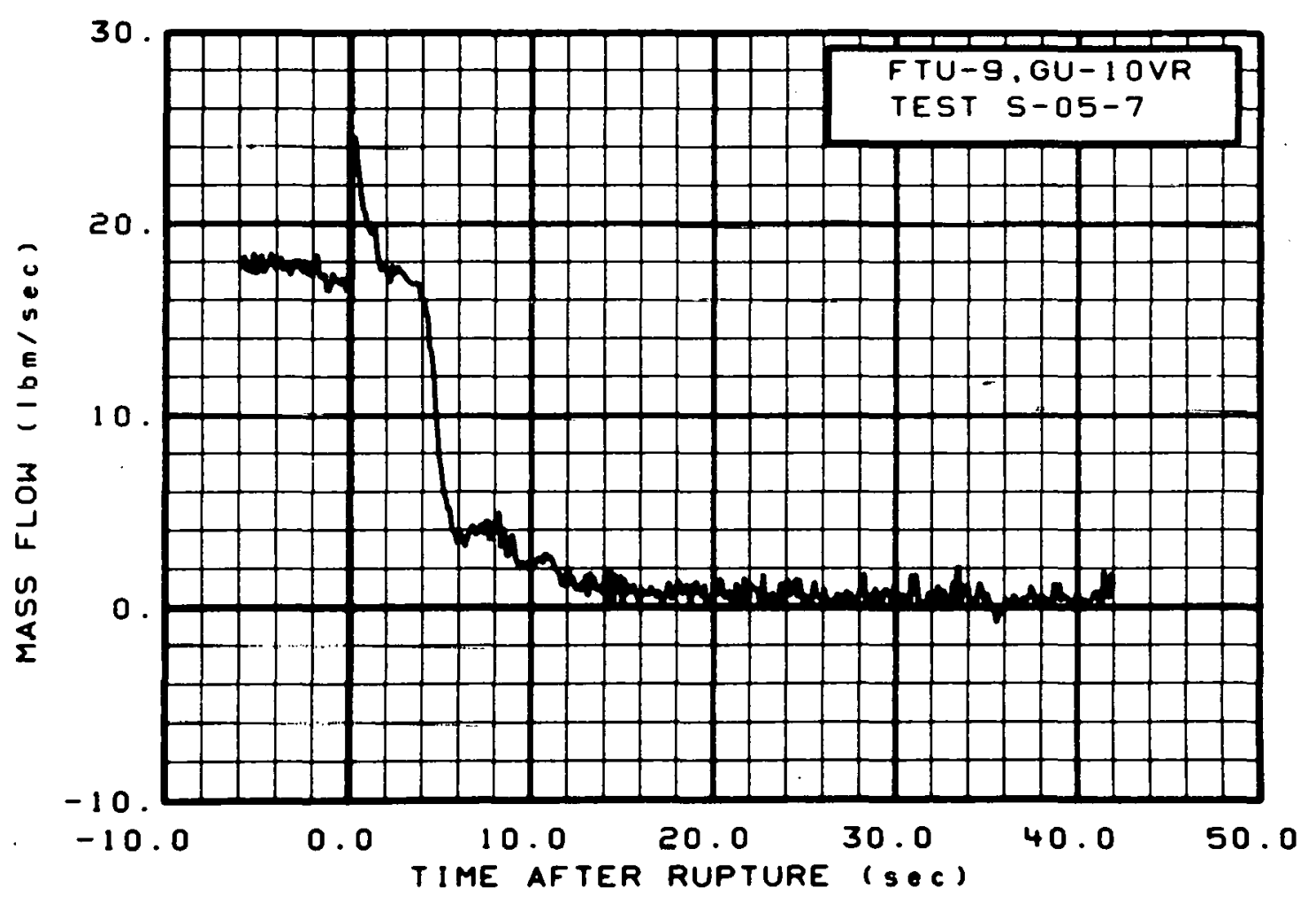

Fig. 507 Mass flow in intact loop, Test S-05-7 (FTU-9, GU-10VR), from -6 to 42 sec. 


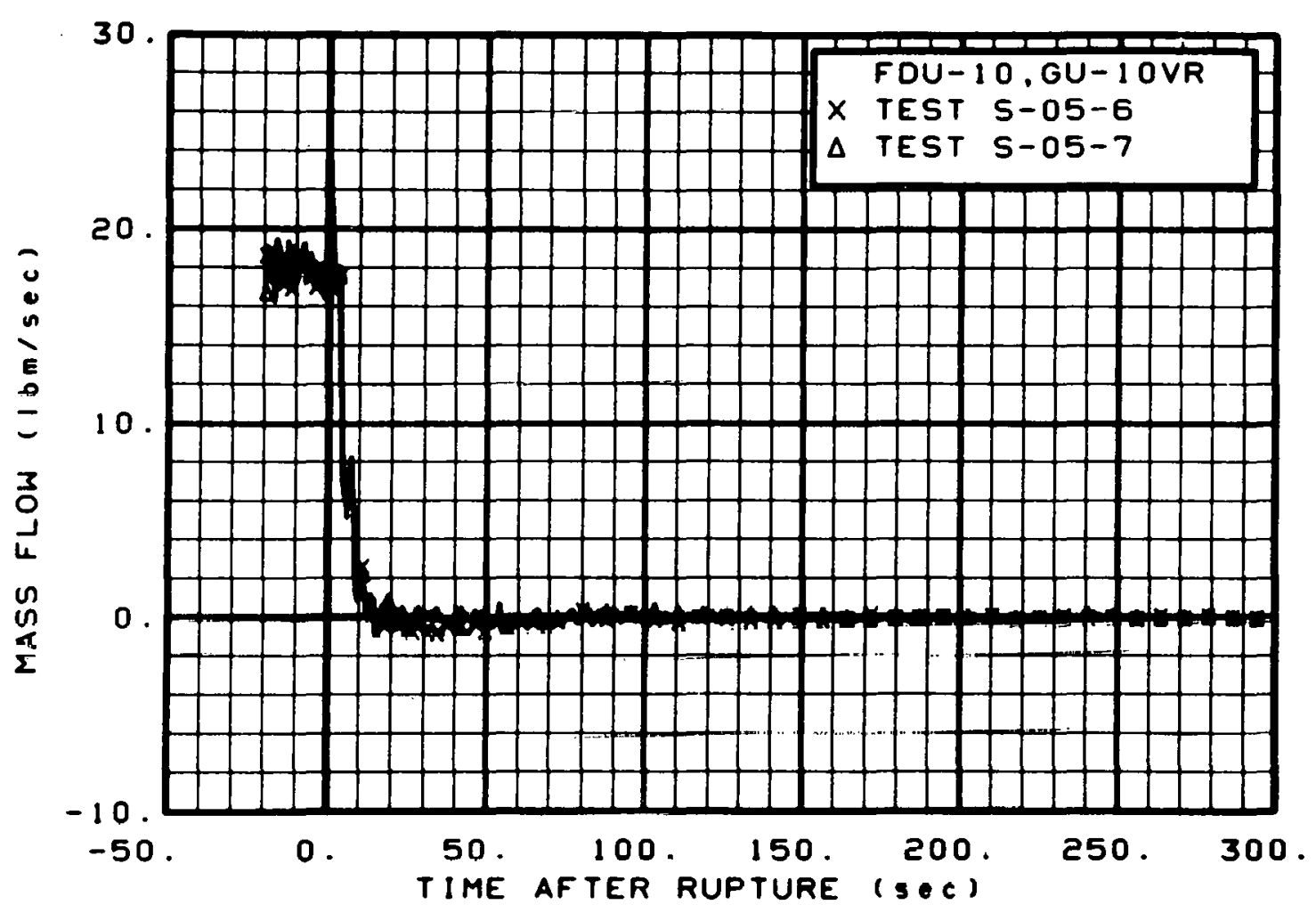

Fig. 508 Mass flow in intact loop (FDU-10, GU-10VR), from -20 to $300 \mathrm{sec}$.

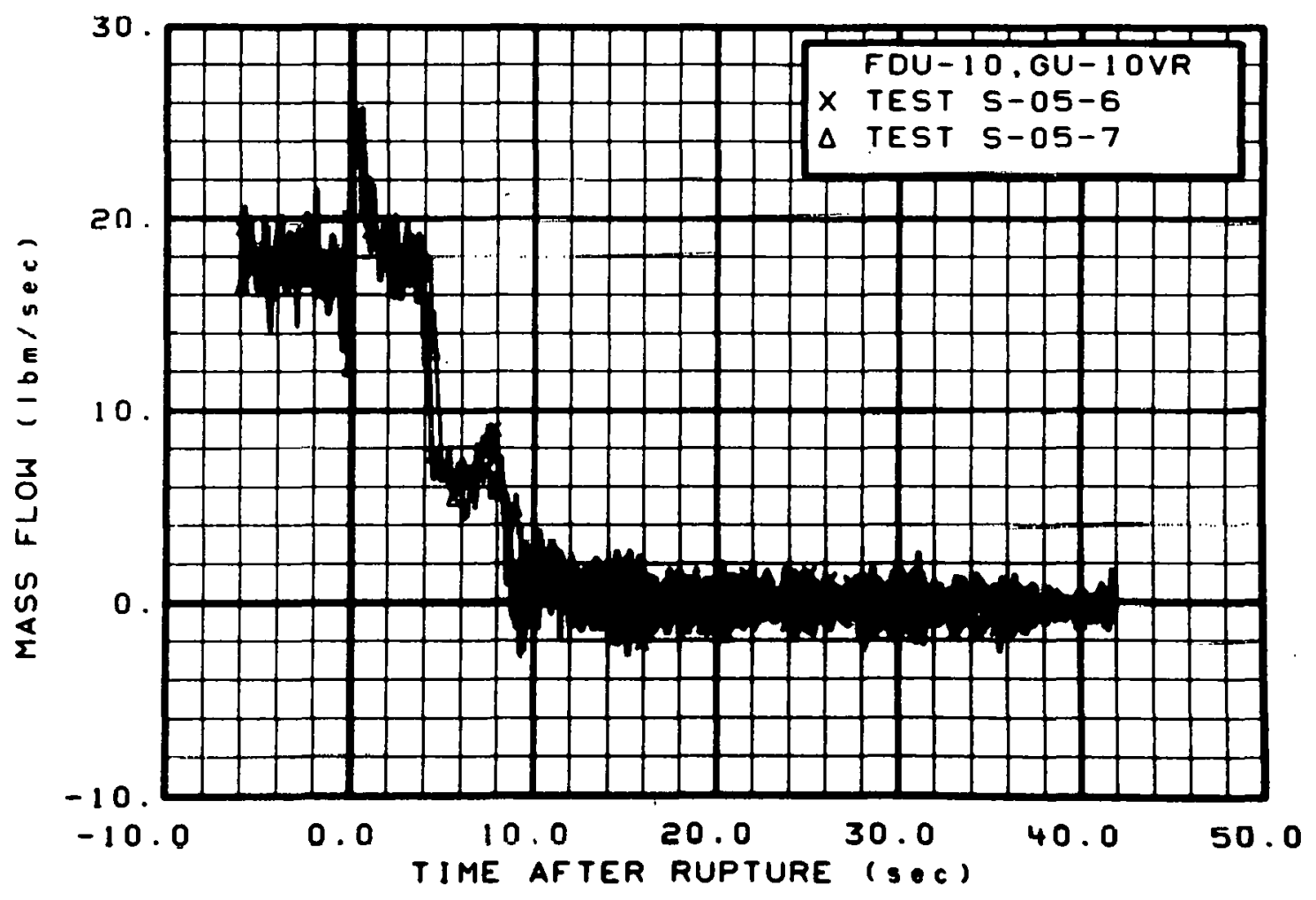

Fig. 509 Mass flow in intact loop (FDU-10, GU-10VR), from -6 to $42 \mathrm{sec}$. 


\section{THIS PAGE}

\section{WAS INTENTIONALLY \\ LEFT BLANK}




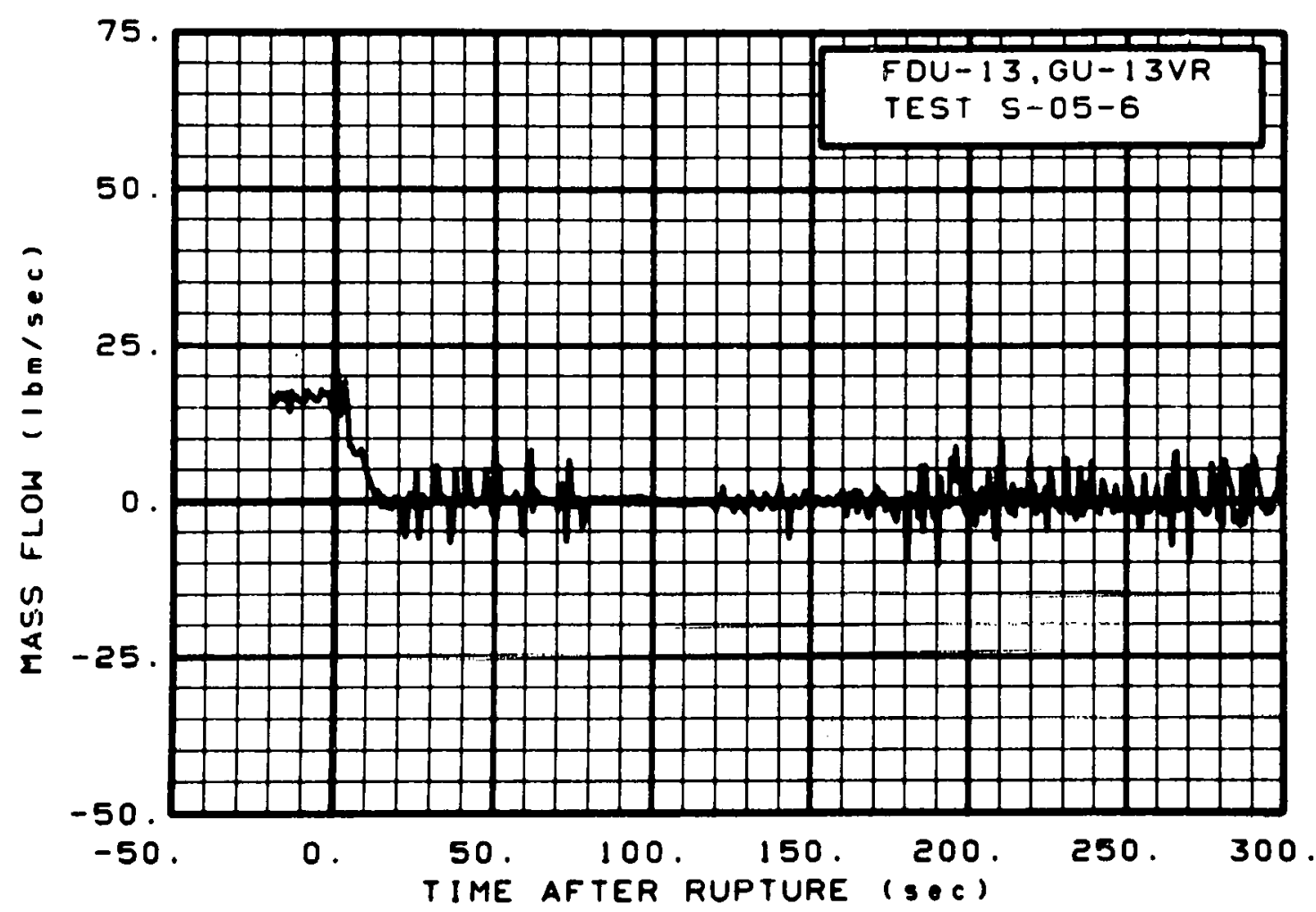

Fig. 510 Mass flow in intact loop, Test S-05-6 (FDU-13, GU-13VR), from -20 to $300 \mathrm{sec}$.

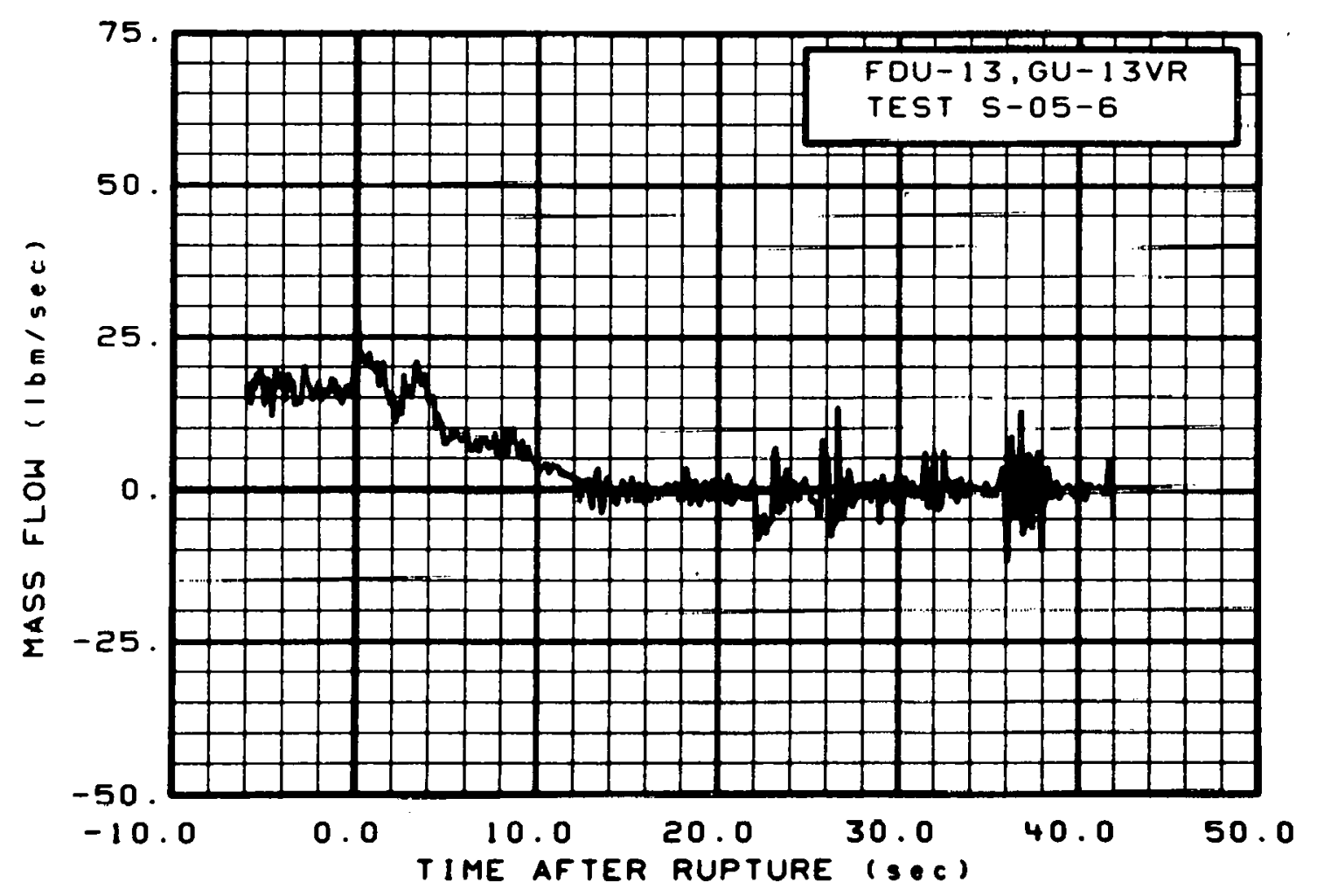

Fig. 511 Mass flow in intact 10op, Test S-05-6 (FDU-13, GU-13VR), from -6 to $42 \mathrm{sec}$. 


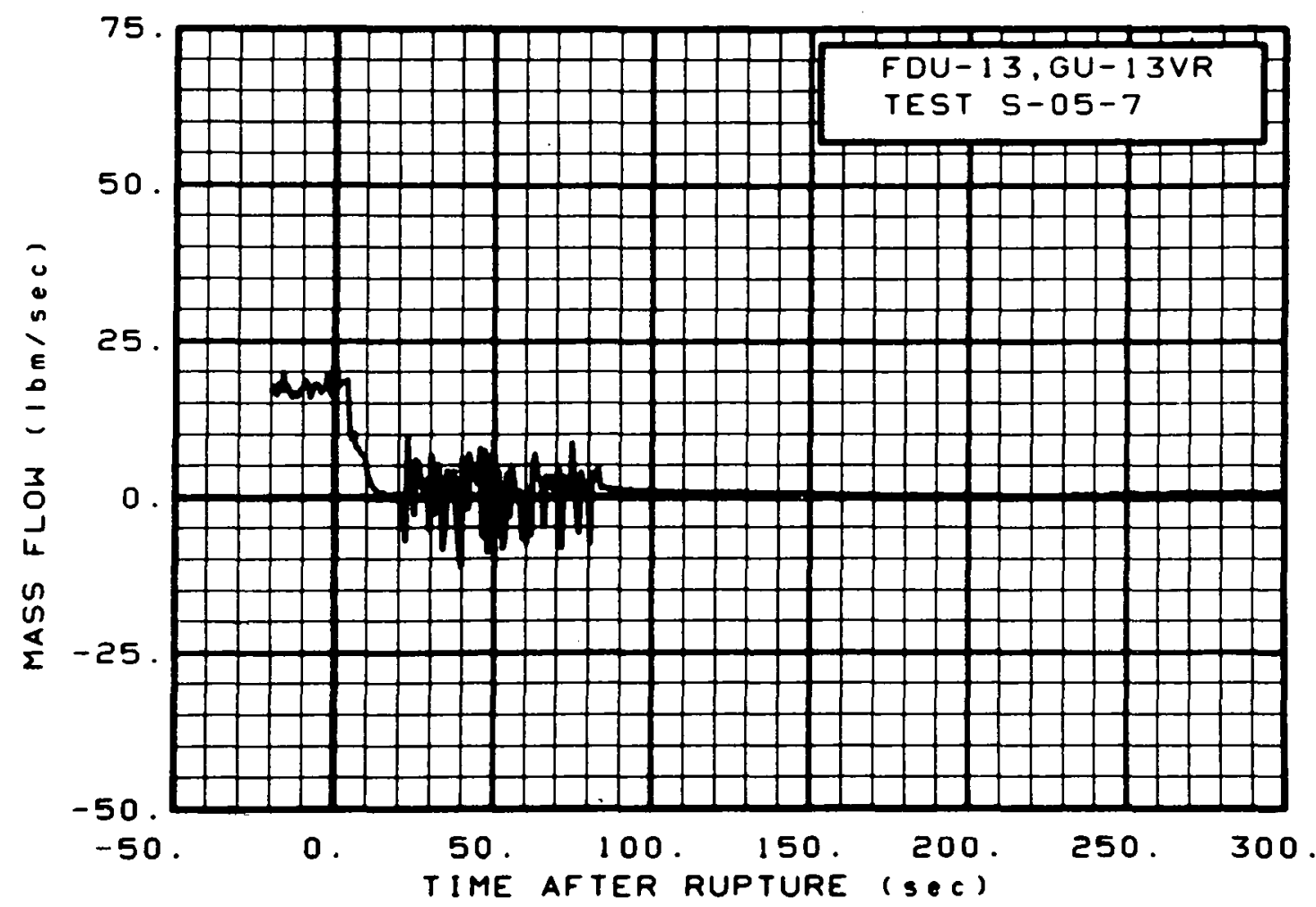

Fig. 512 Mass flow in intact loop, Test S-05-7 (FDU-13, GU-13VR), from -20 to $300 \mathrm{sec}$.

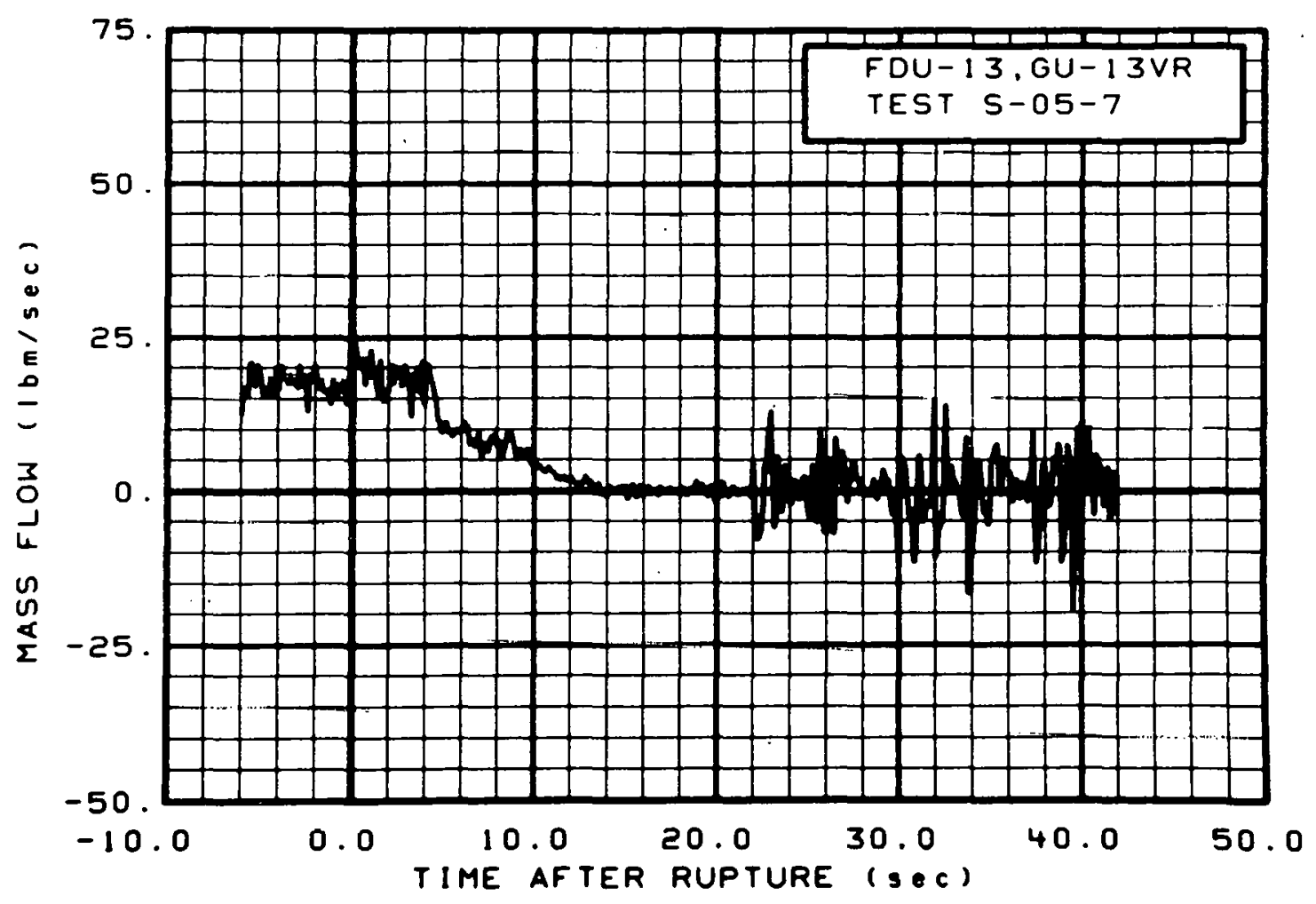

F1g. 513 Mass flow in intact 1nop. Test S-05-7 (FDU-13, GU-13VR), from -6 to 42 sec. 


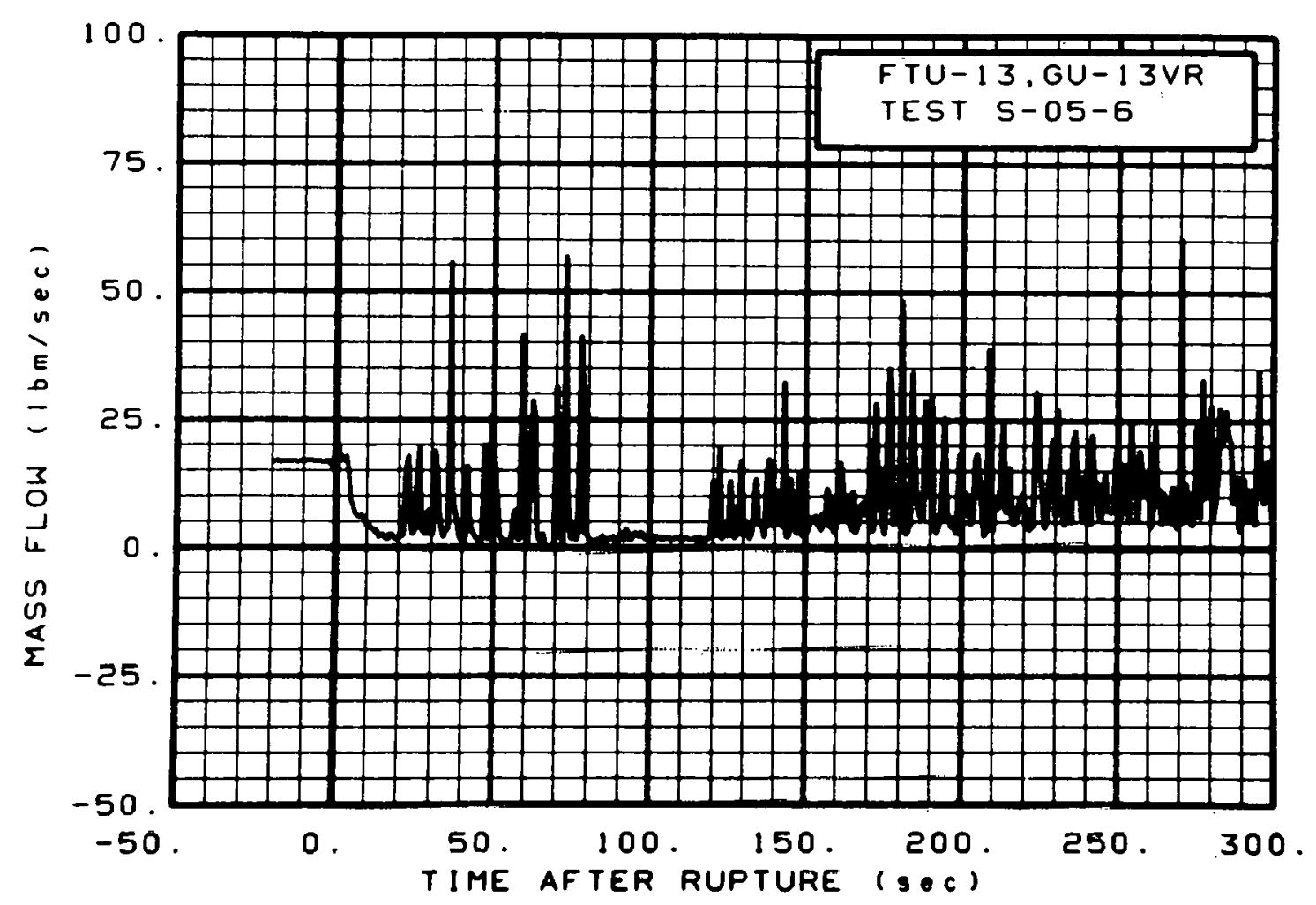

Fig. 514 Mass flow in intact loop, Test S-05-6 (FTU-13, GU-13VR), from -20 to $300 \mathrm{sec}$.

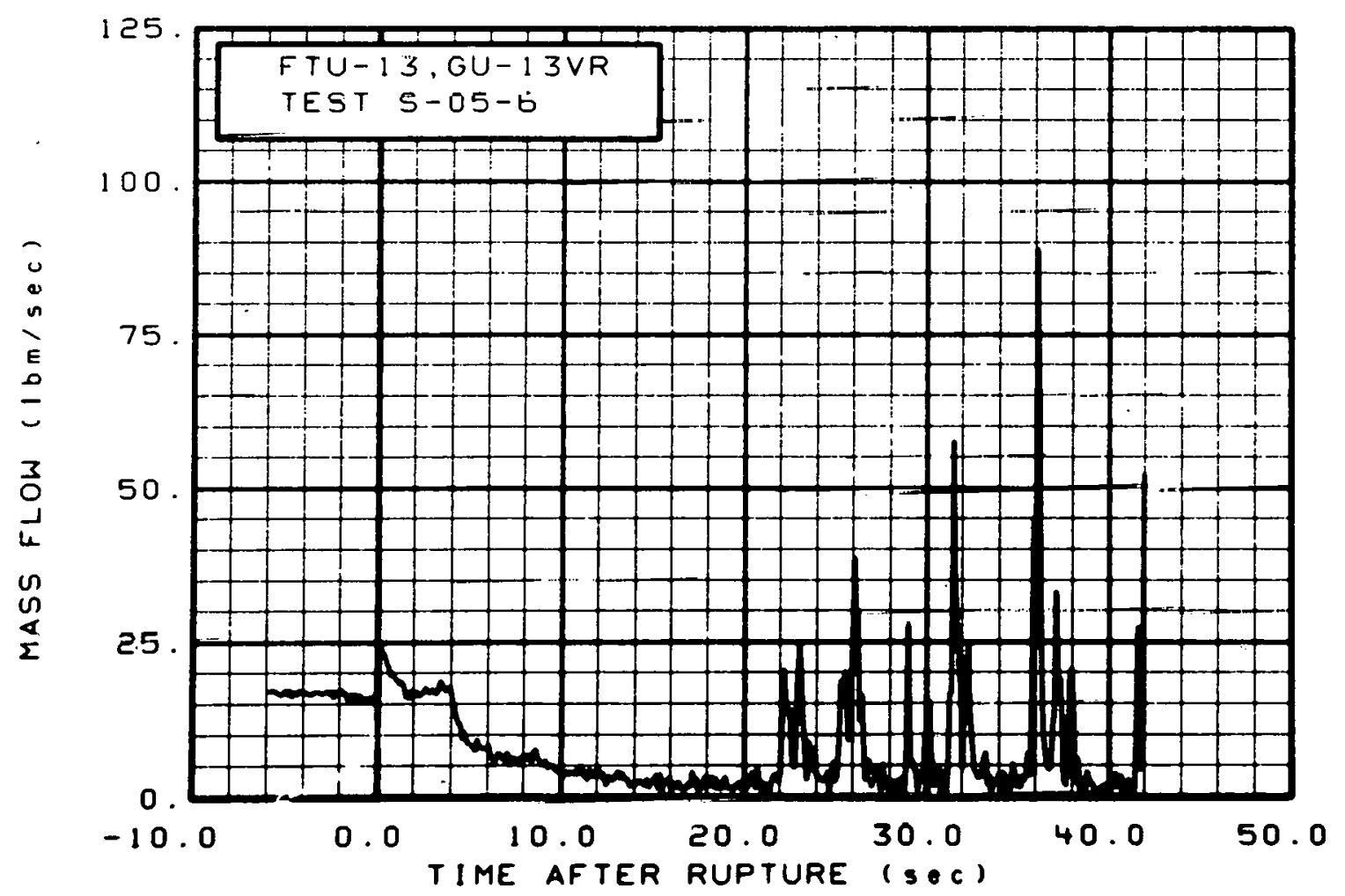

Fig. 515 Mass flow in intact 10op, Test S-05-6 (FTU-13, GU-13VR), from -6 to 42 sec. 


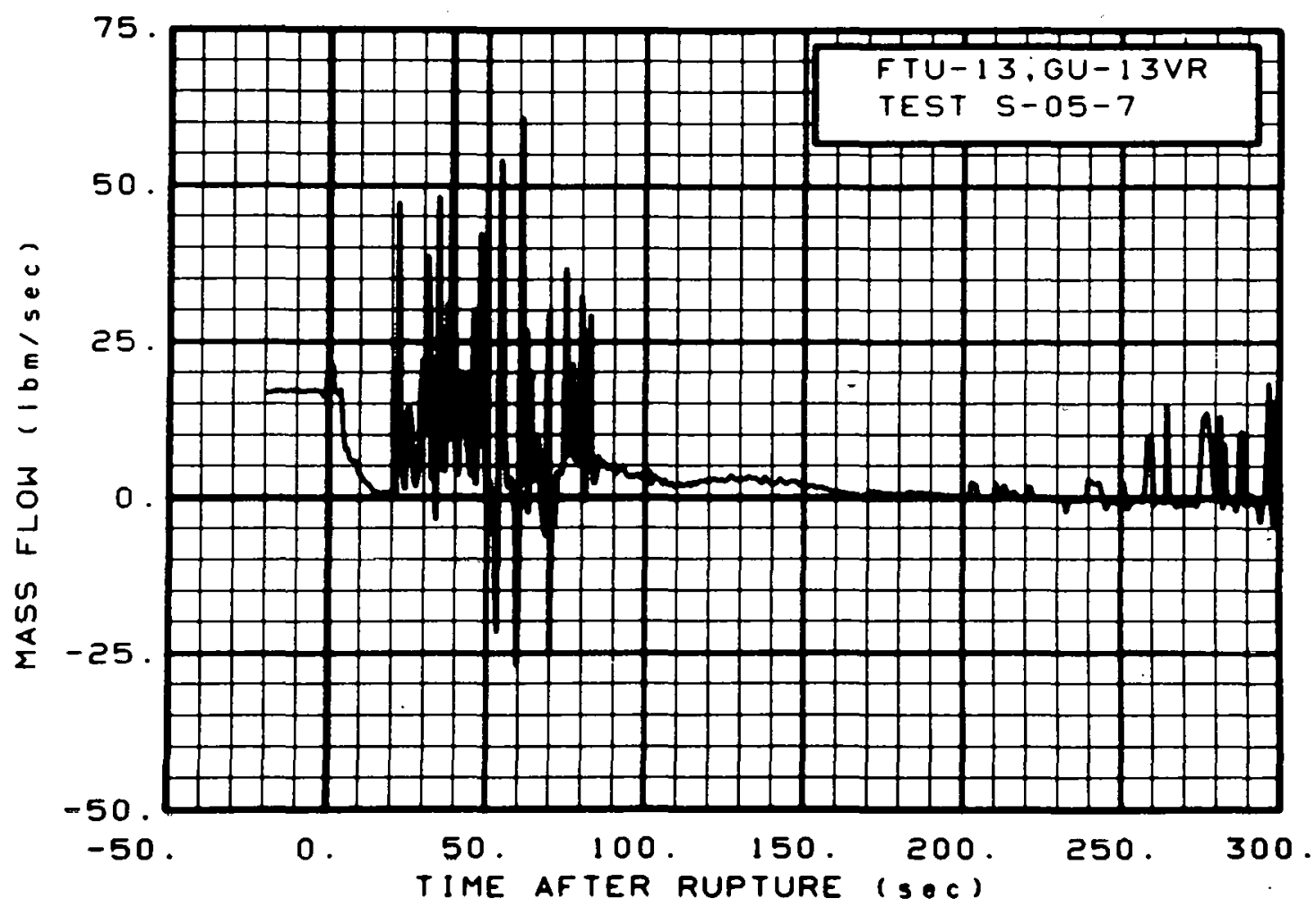

Fig. 516 Mass flow in intact 10op, Test S-05-7 (FTU-13, GU-13VR), from -20 to $300 \mathrm{sec}$.

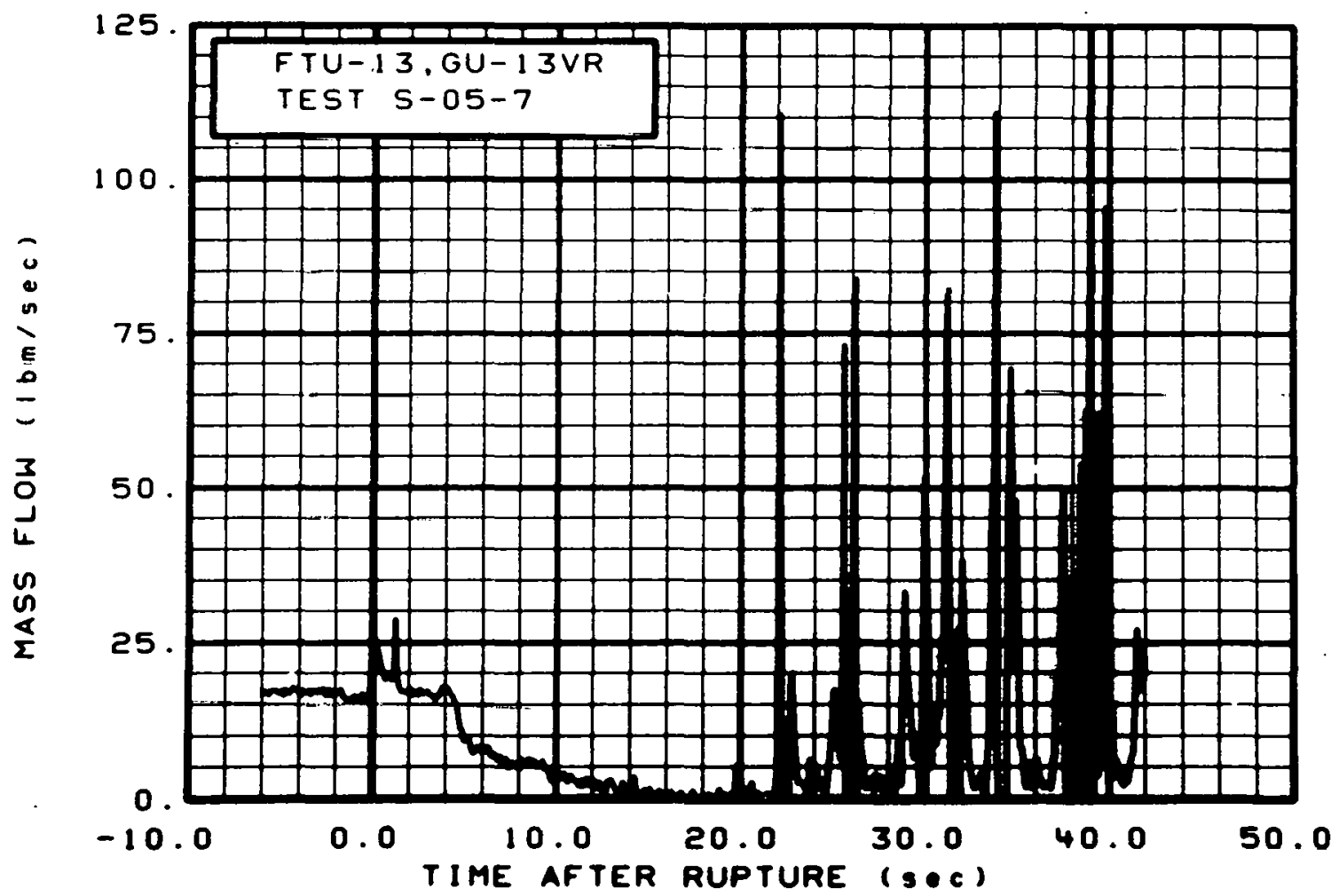

Fig. 517 Mass flow in intact. loop, Test S-05-7 (FTU-13, GU-13VR), from -6 to 42 sec. 


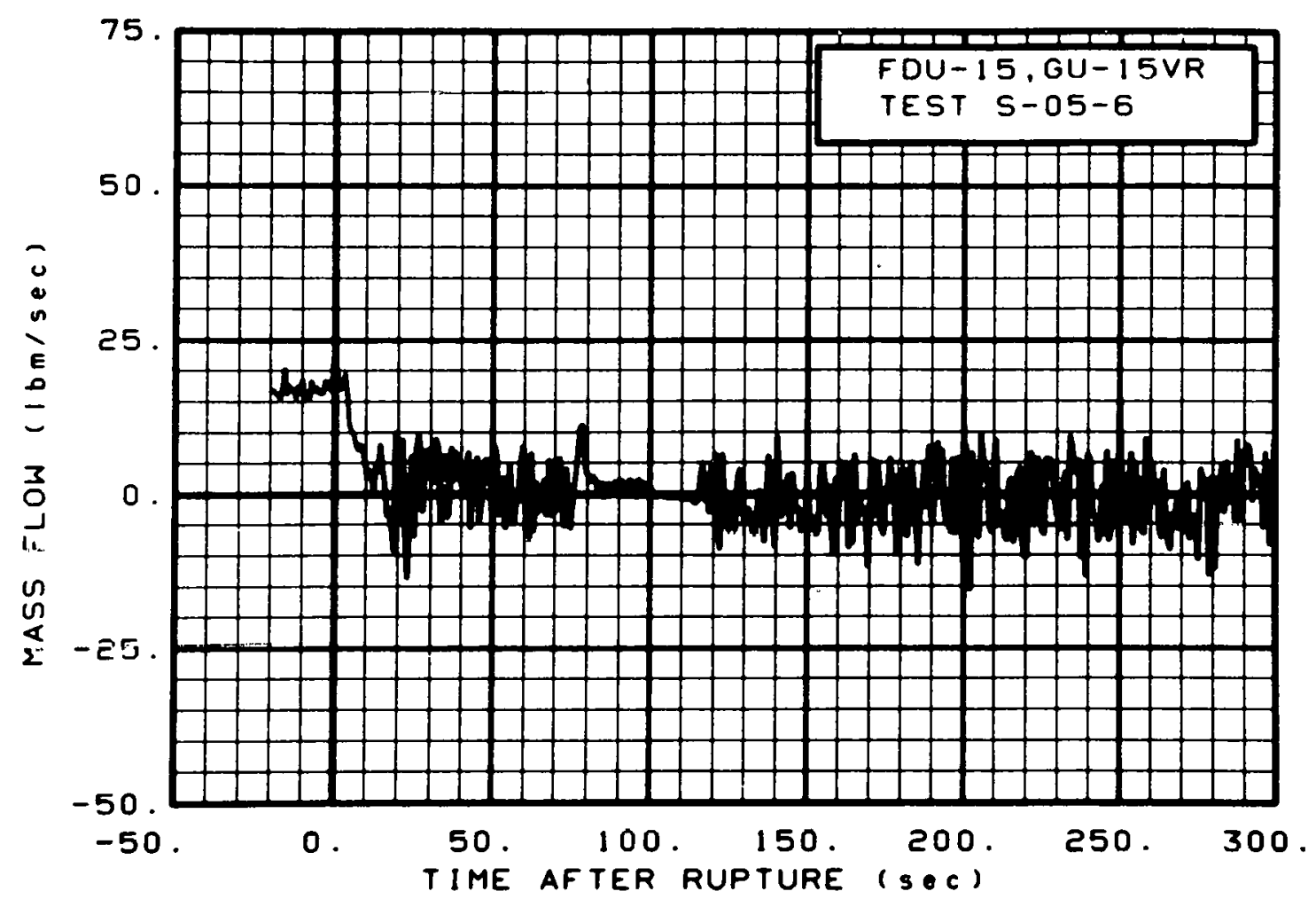

Fig. 518 Mass flow in intact 10op, Test S-05-6 (FDU-15, GU-15VR), from -20 to $300 \mathrm{sec}$.

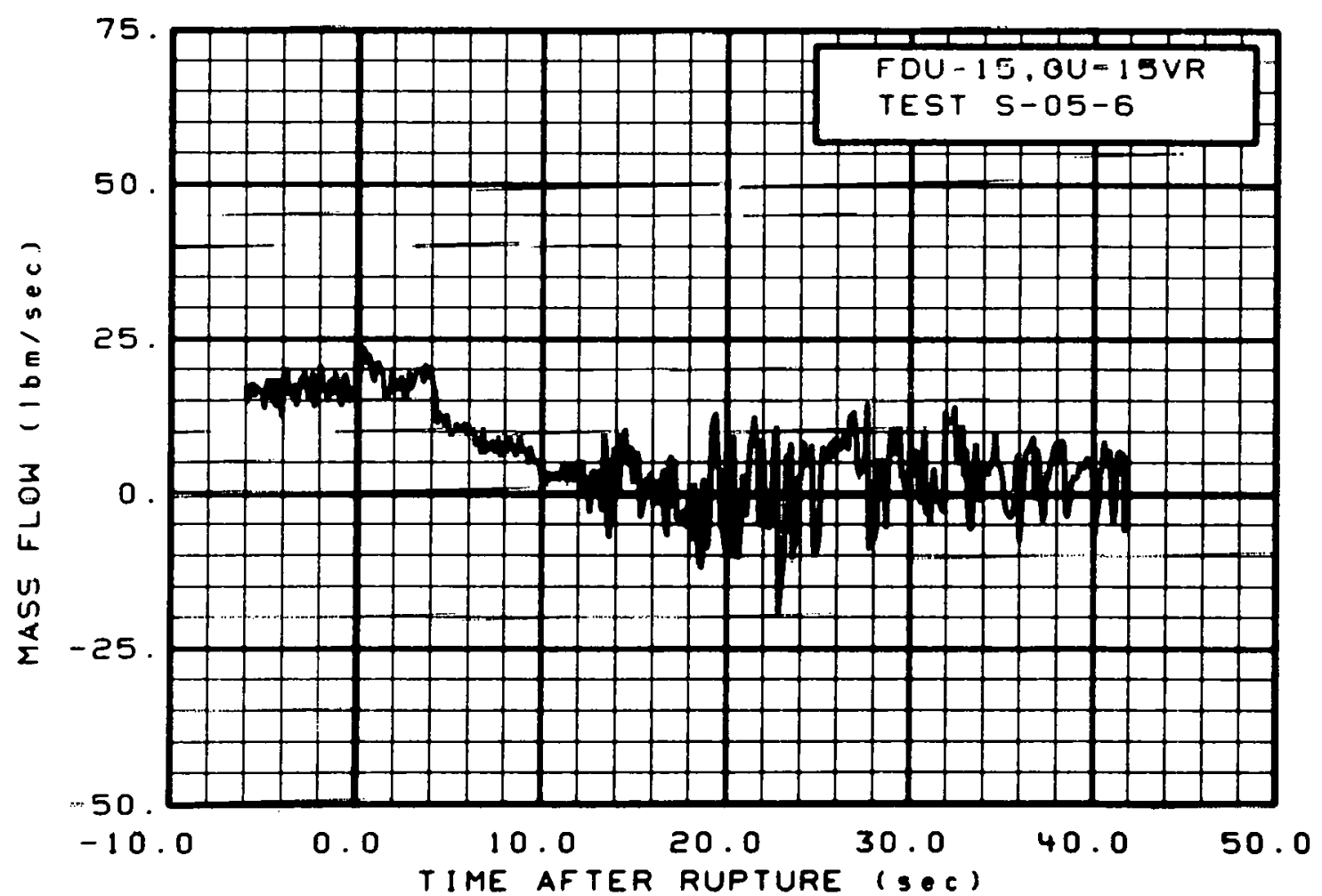

Fig. 519 Mass flow in intact 10op, Test S-05-6 (FDU-15, GU-T5VR), from -6 to 42 sec. 


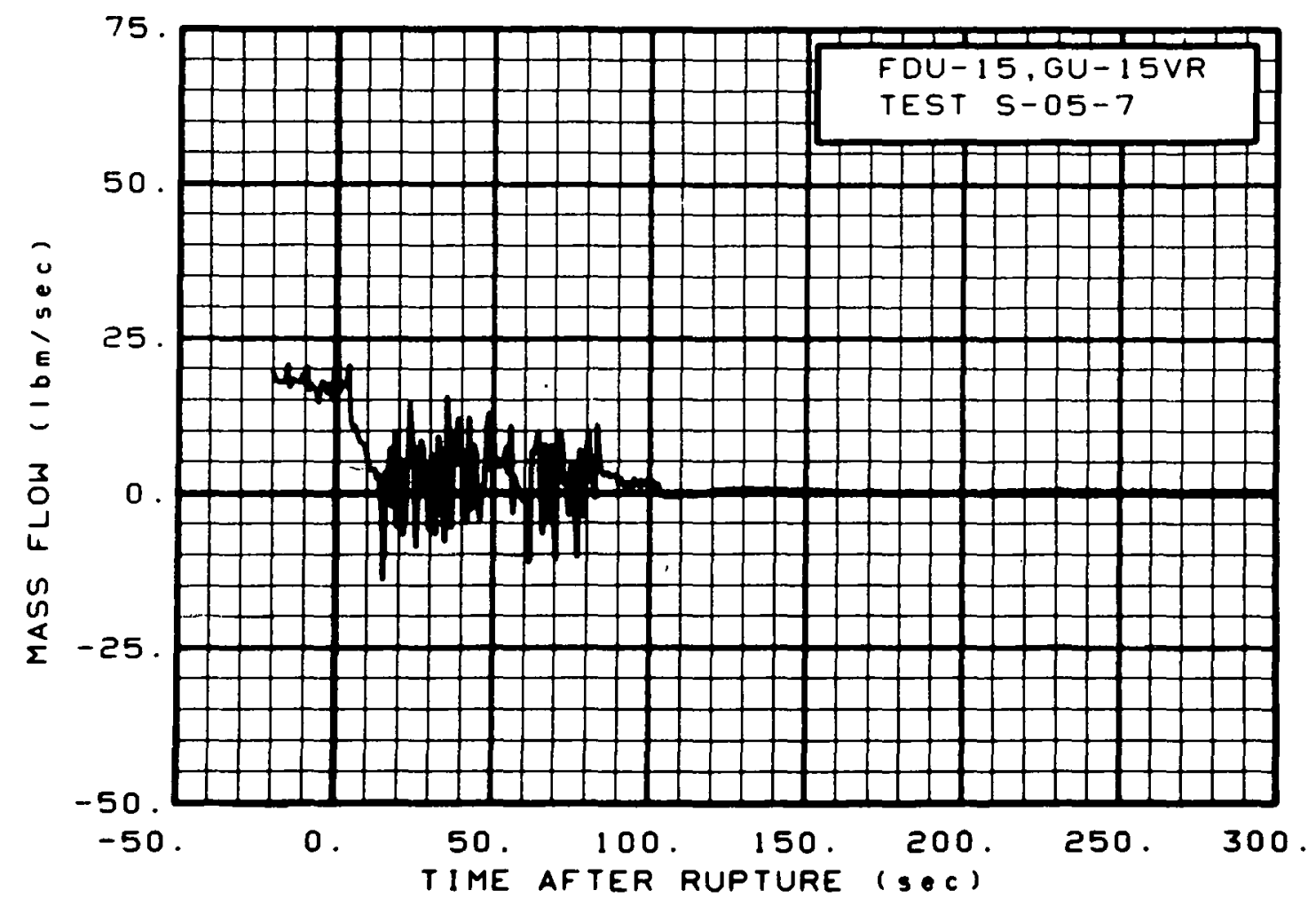

Fig. 520 Mass flow in intact 10op, Test S-05-7 (FDU-15, GU-15VR), from -20 to $300 \mathrm{sec}$.

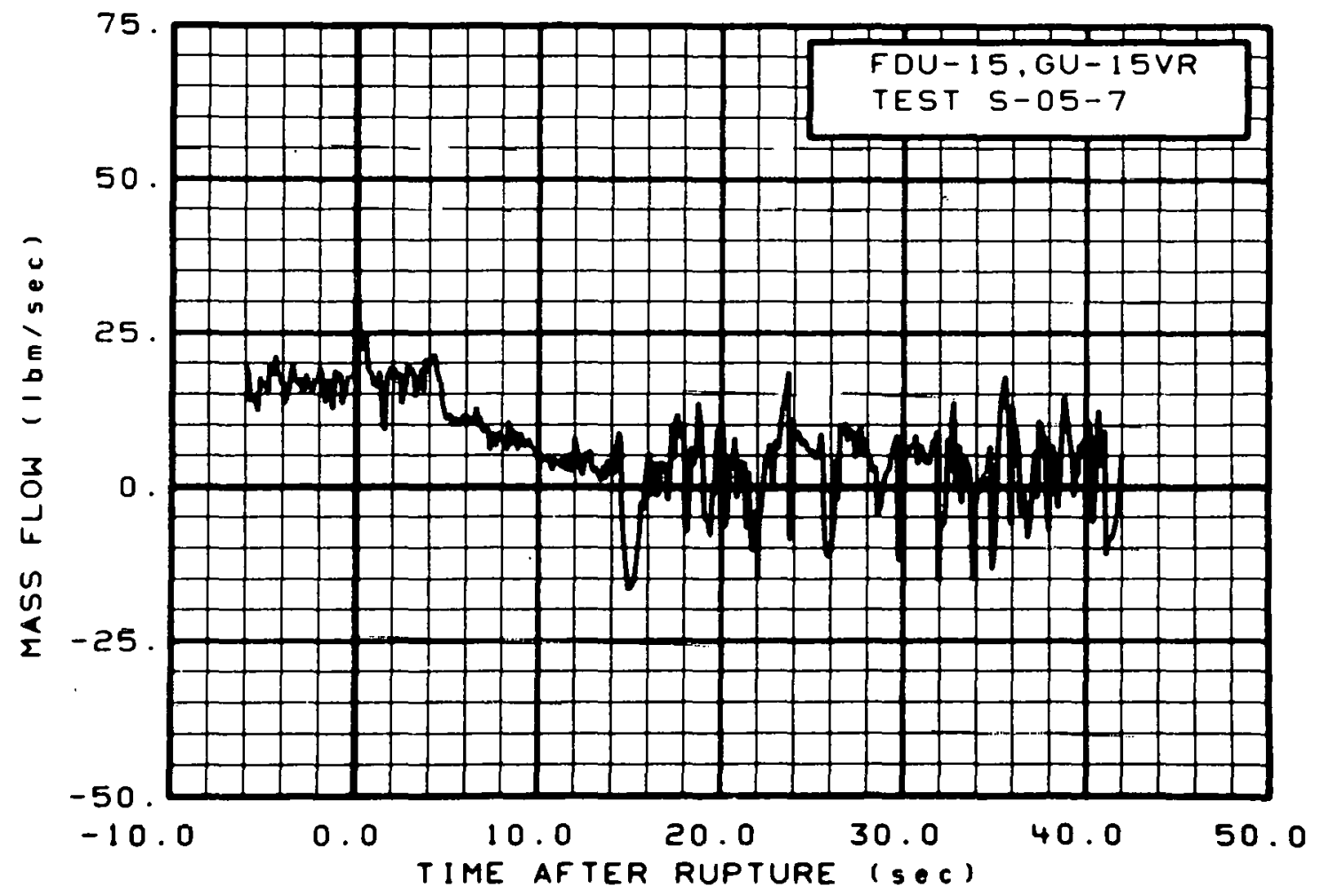

Fig. 521 Mass flow in intact 1oop, Test S-05-7 (FDU-15, GU-15VR), from -6 to 42 sec. 


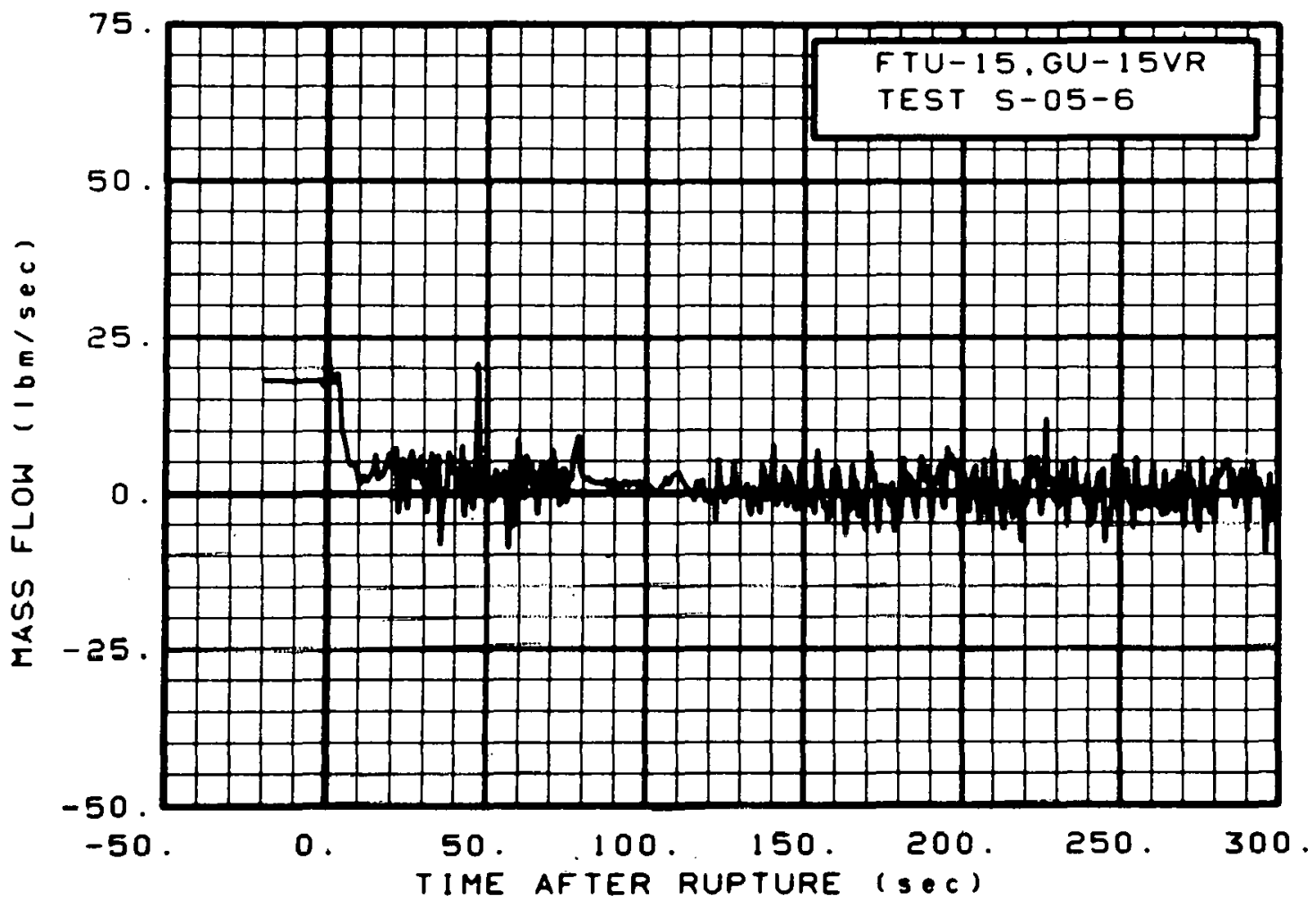

Fig. 522 Mass flow in intact loop, Test S-05-6 (FTU-15, GU-15VR), from -20 to $300 \mathrm{sec}$.

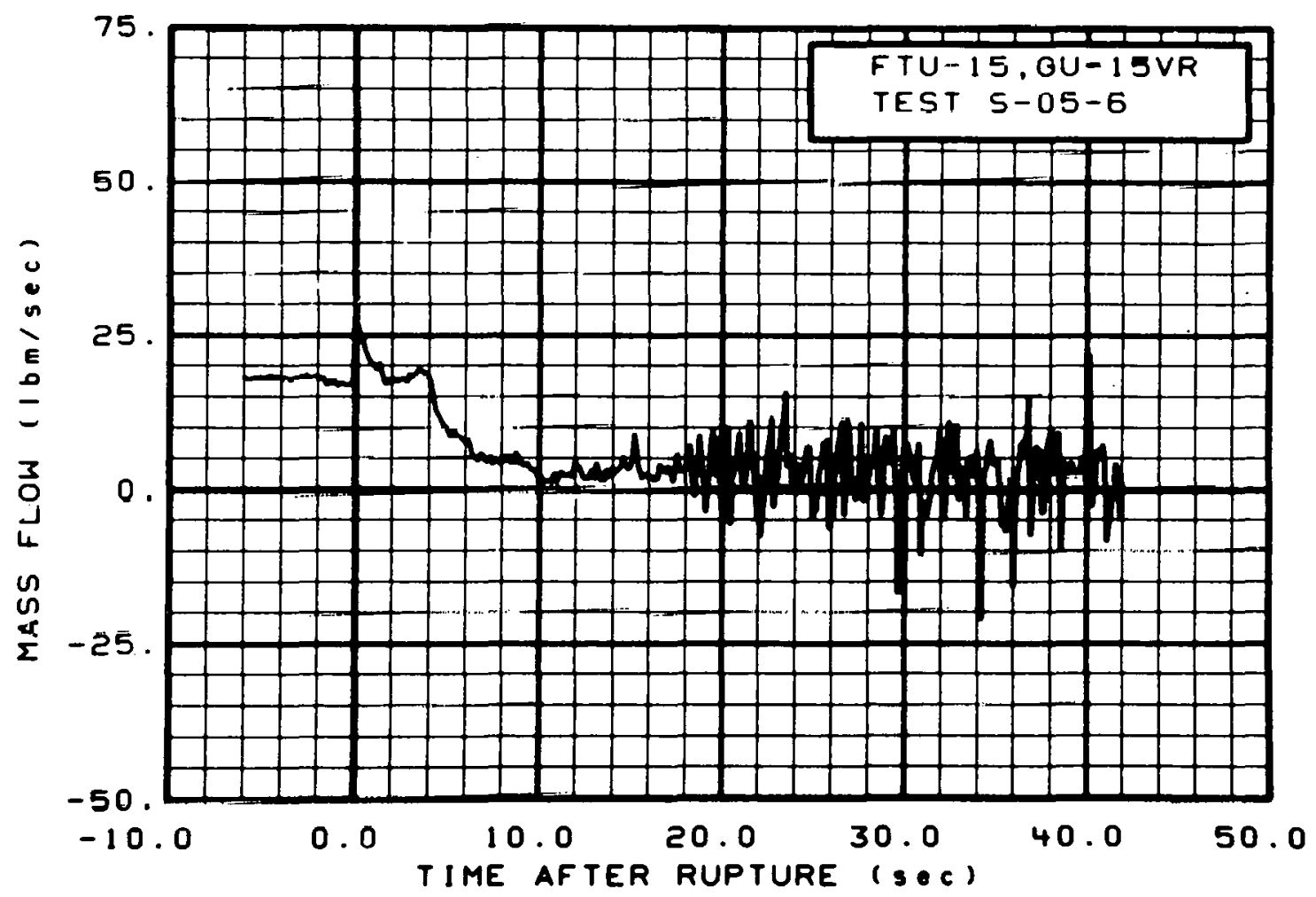

Fig. 523 Mass flow in intact 10op, Test S-05-6 (FTU-15, GU-15VR), from -6 to $42 \mathrm{sec}$. 


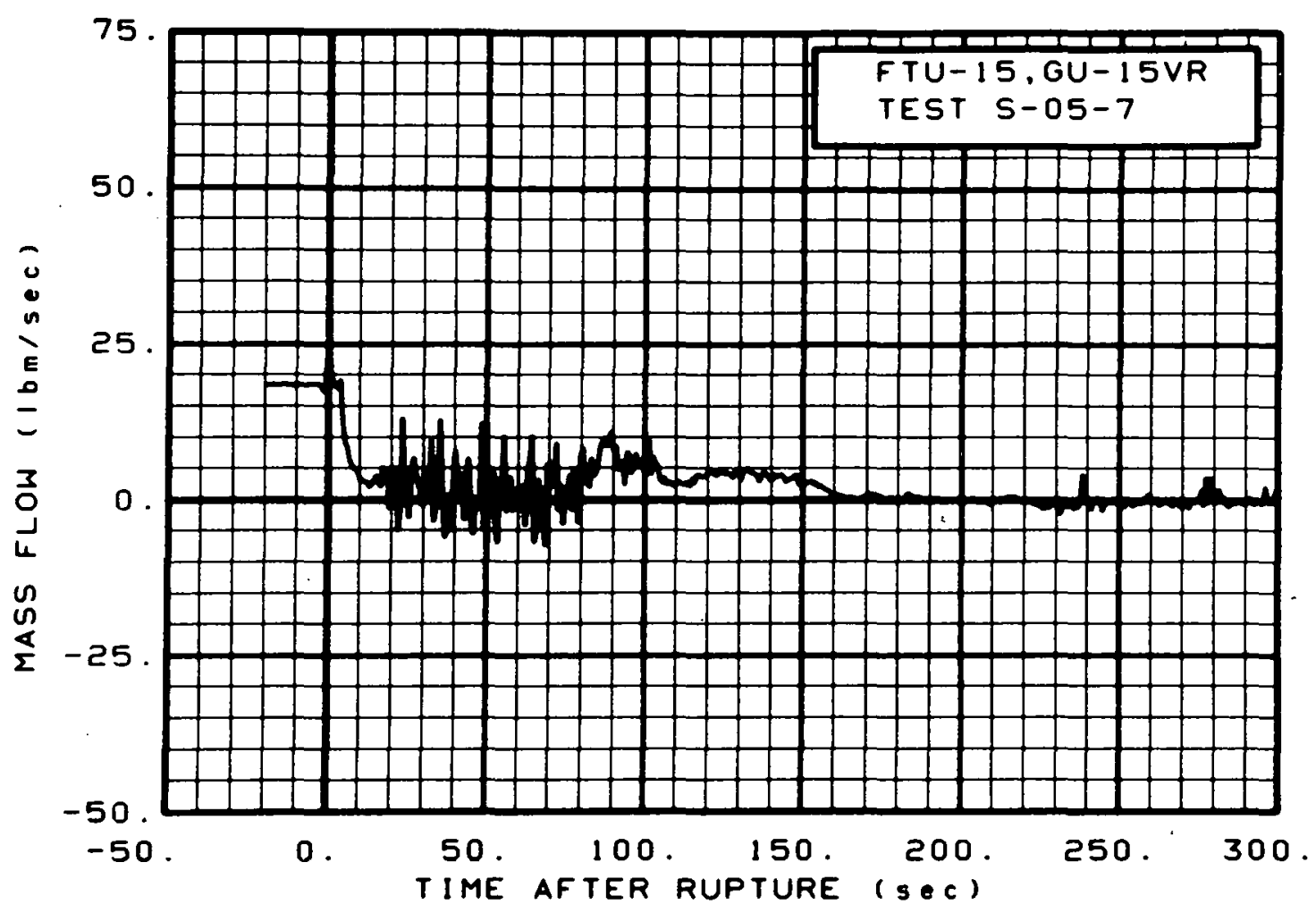

Fig. 524 Mass flow in intact 1oop, Test S-05-7 (FTU-15, Gll-15VR), from -20 to $300 \mathrm{sec}$.

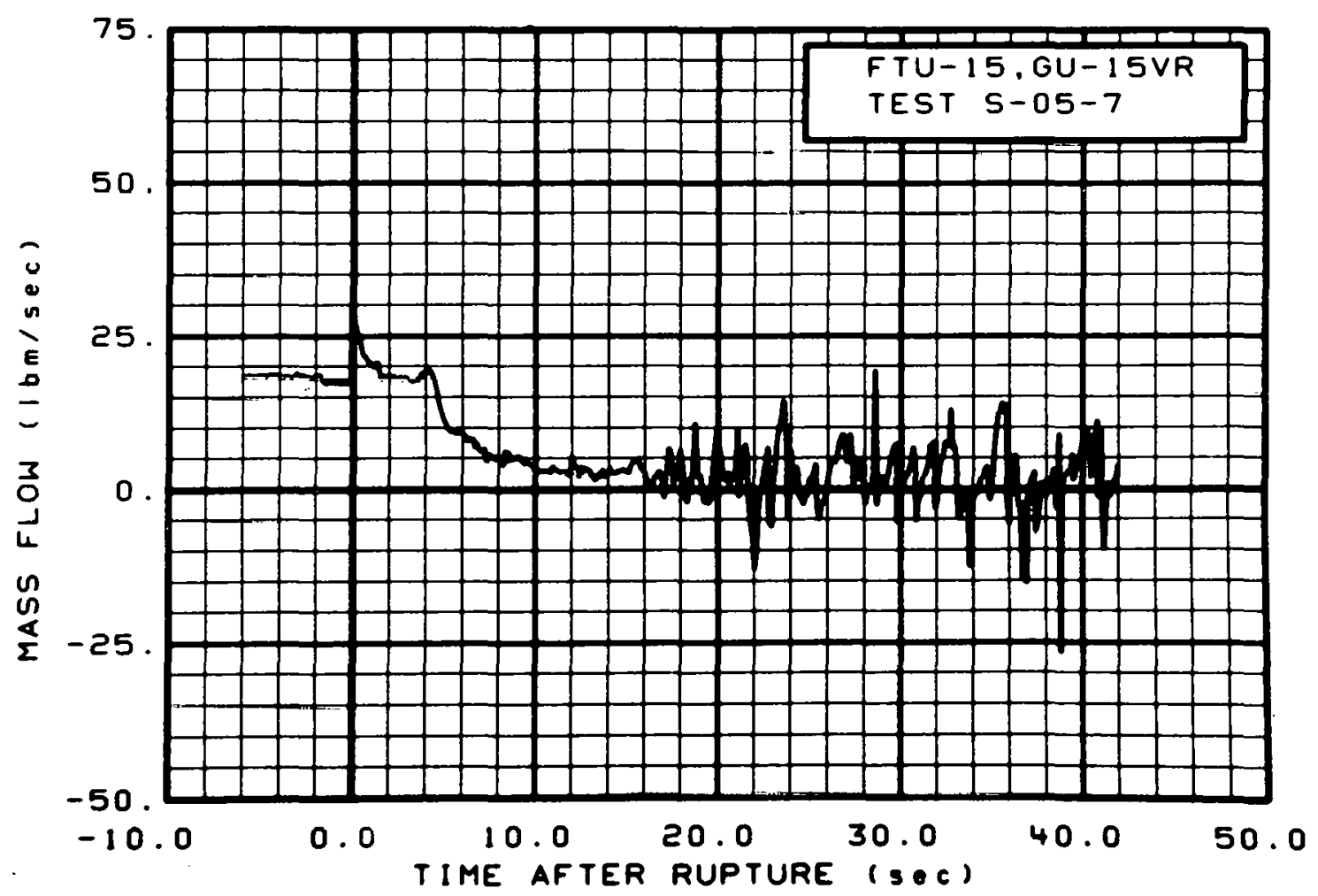

Fig. 525 Mass flow in intact 10op, Test S-05-7 (FTU-15, GU-15VR), from -6 to $42 \mathrm{sec}$. 


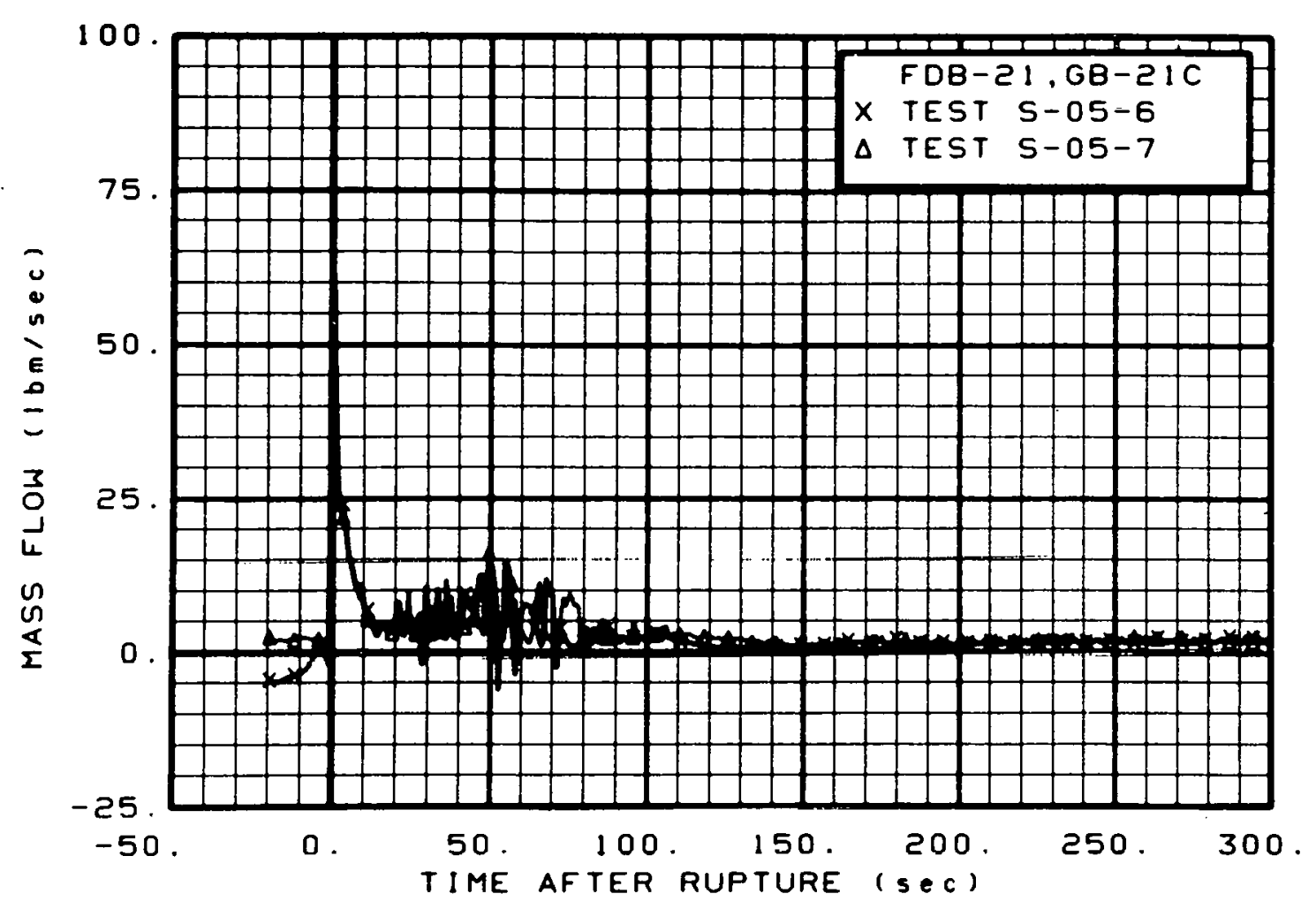

Fig. 526 Mass flow in broken loop (FDB-21, GB-21C), from -20 to $300 \mathrm{sec}$.

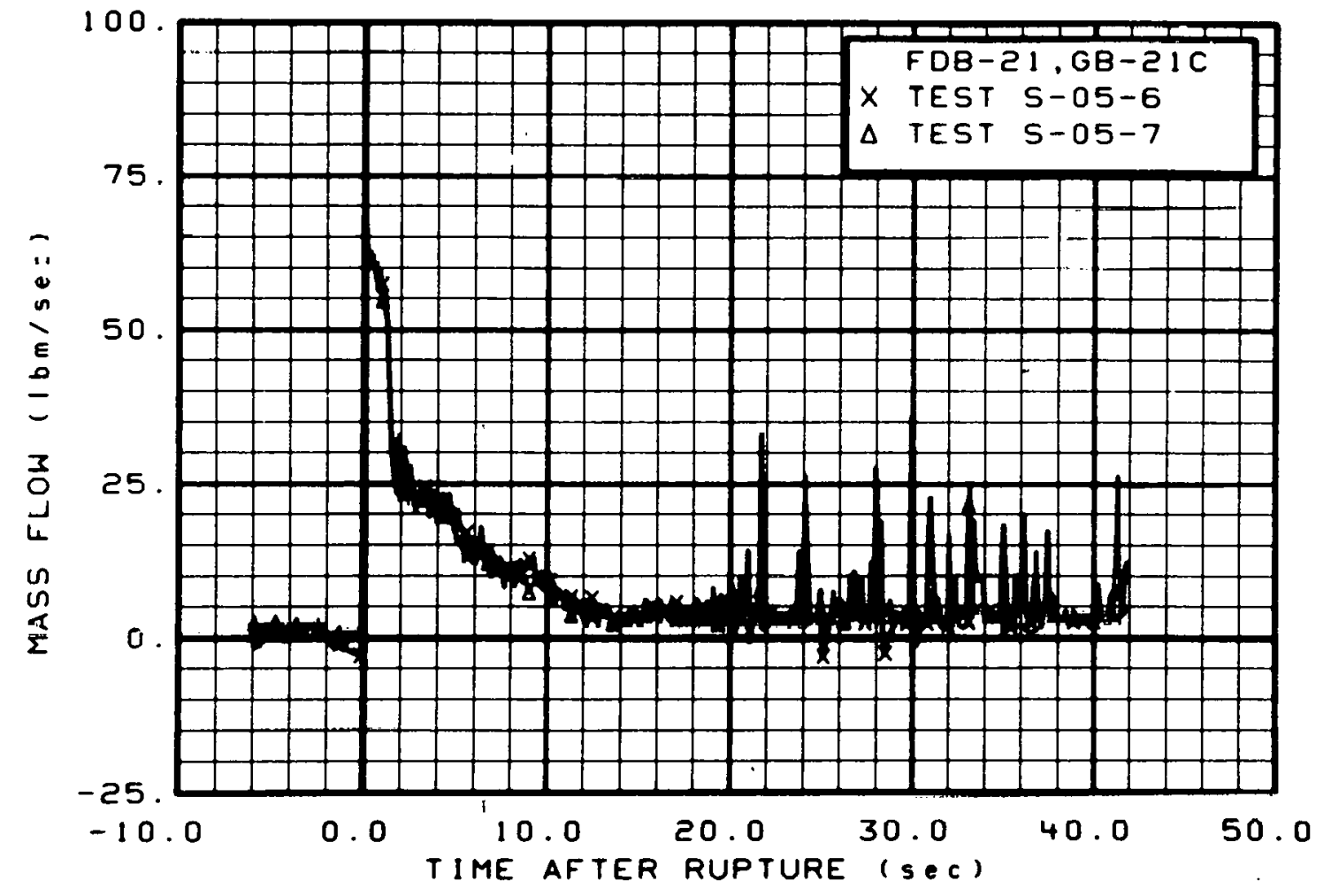

Fig. 527 Mass flow in broken loop (FDB-21, GB-21C), from -6 to $42 \mathrm{sec}$. 


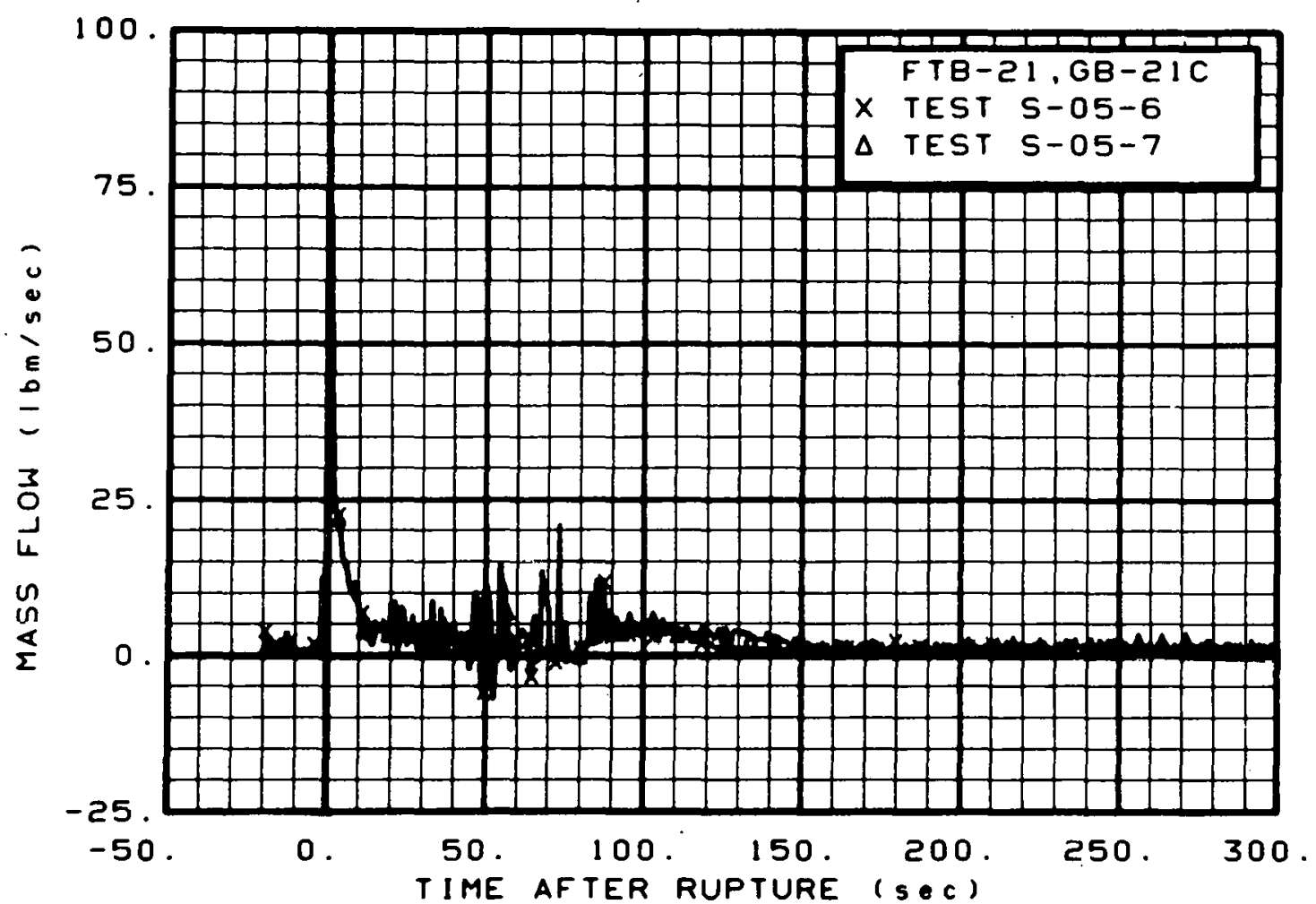

Fig. 528 Mass flow in broken loop (FTB-21, GB-21C), from -20 to $300 \mathrm{sec}$.

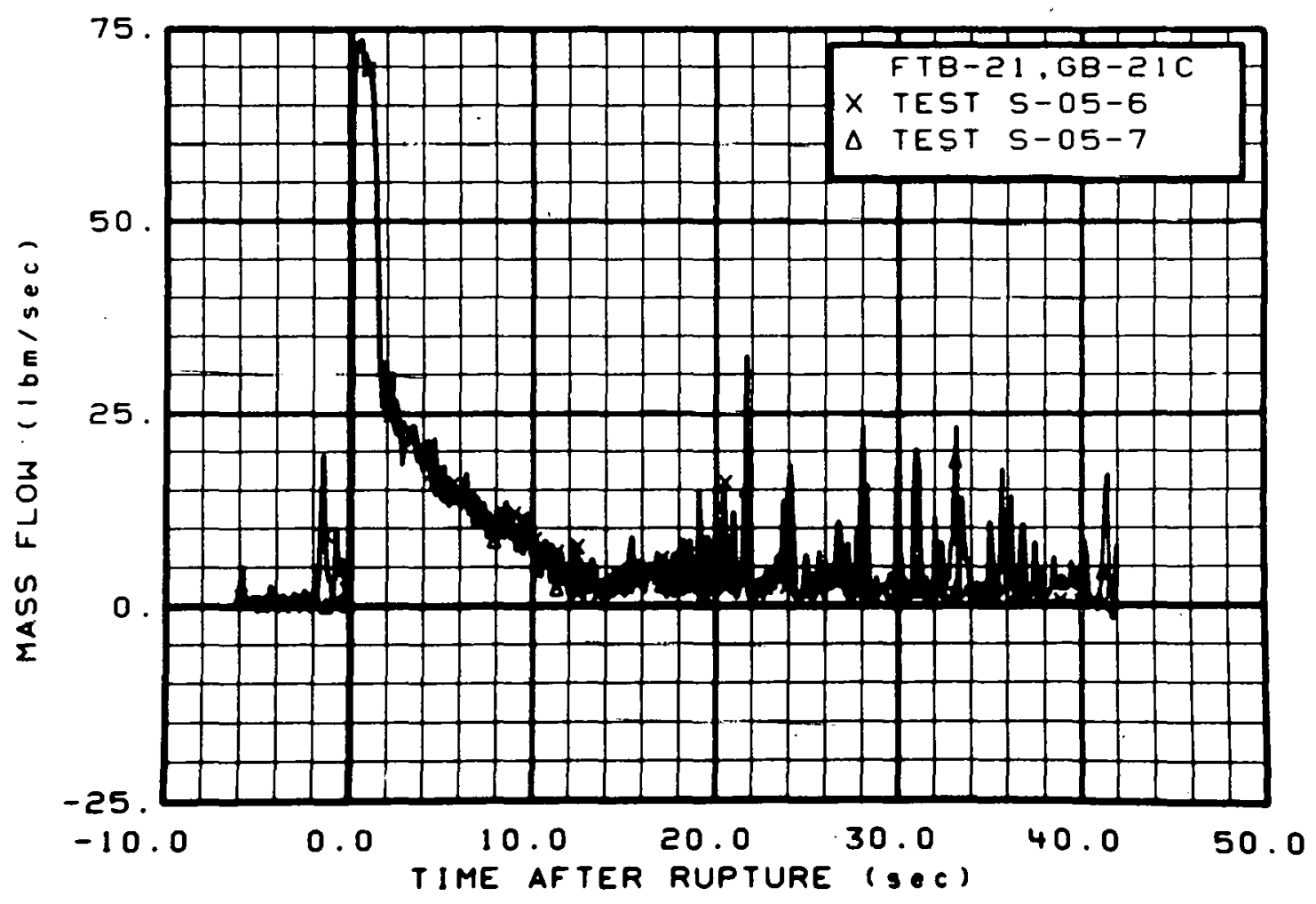

Fig. 529 Mass flow in broken loop (FTB-21, GB-21C), from -6 to $42 \mathrm{sec}$. 


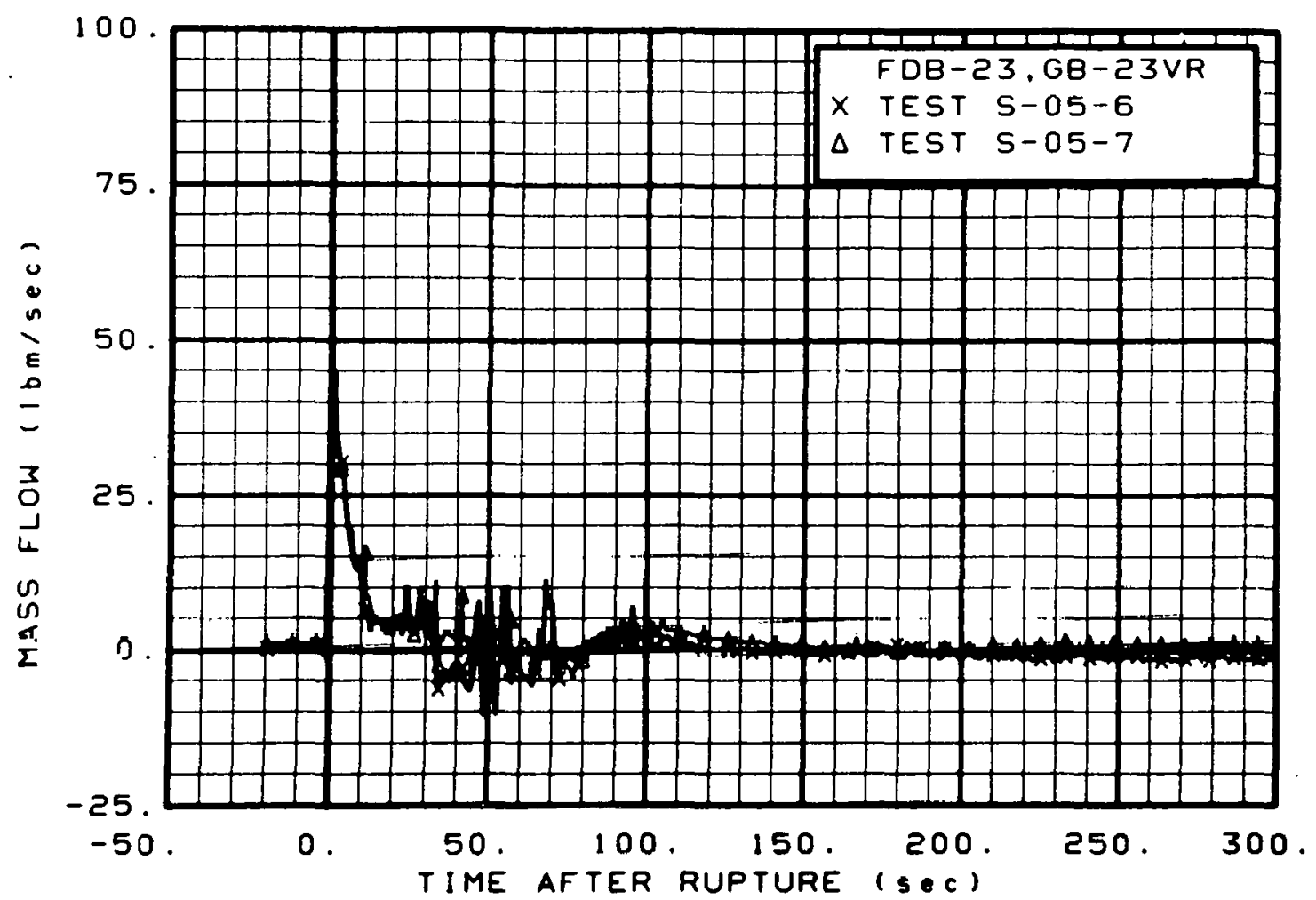

Fig. 530 Mass flow in broken loop (FDB-23, GB-23VR), from -20 to $300 \mathrm{sec}$.

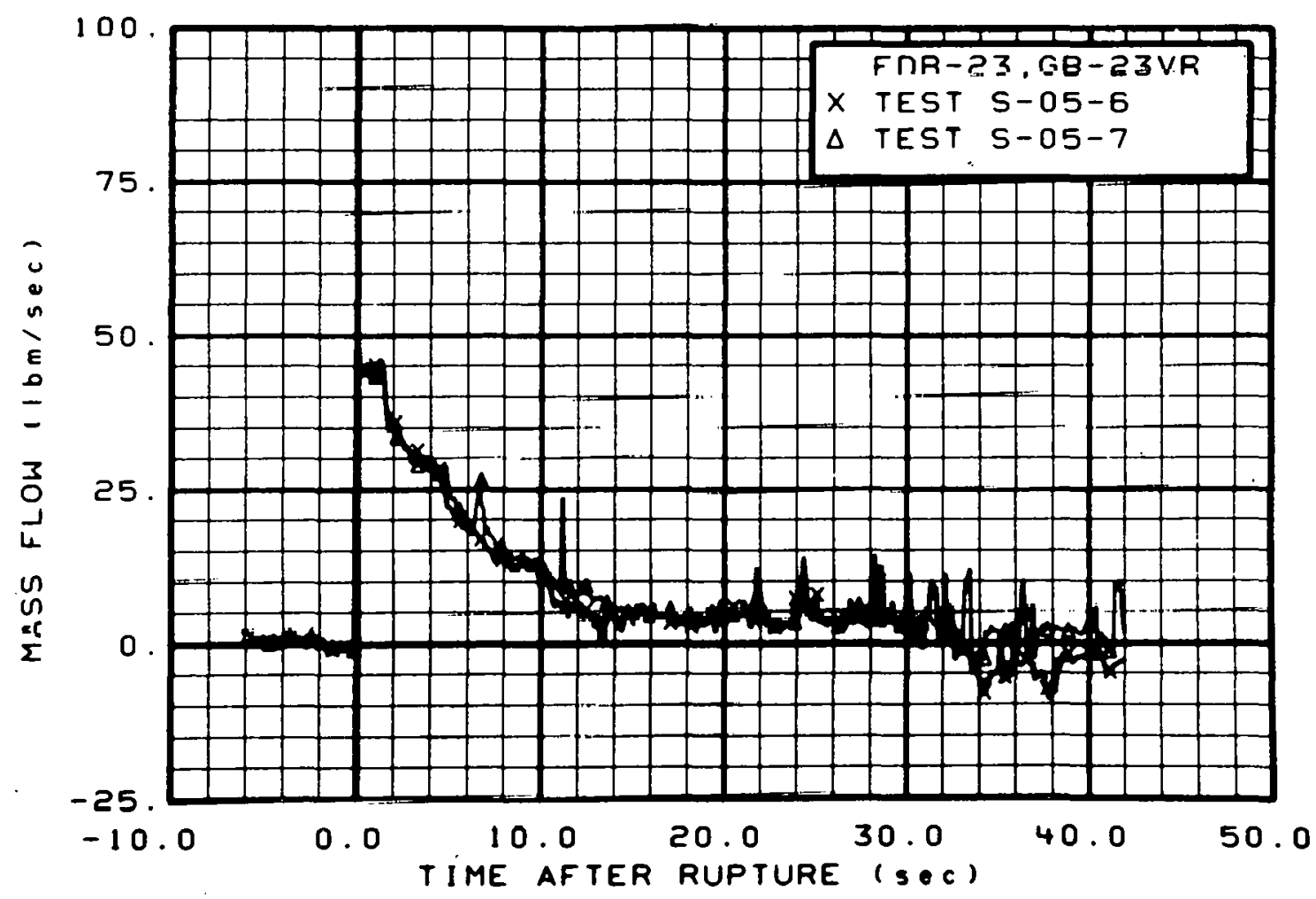

Fig. 531 Mass flow in broken 10op (FDB-23, GB-23VR), from -6 to $42 \mathrm{sec}$. 


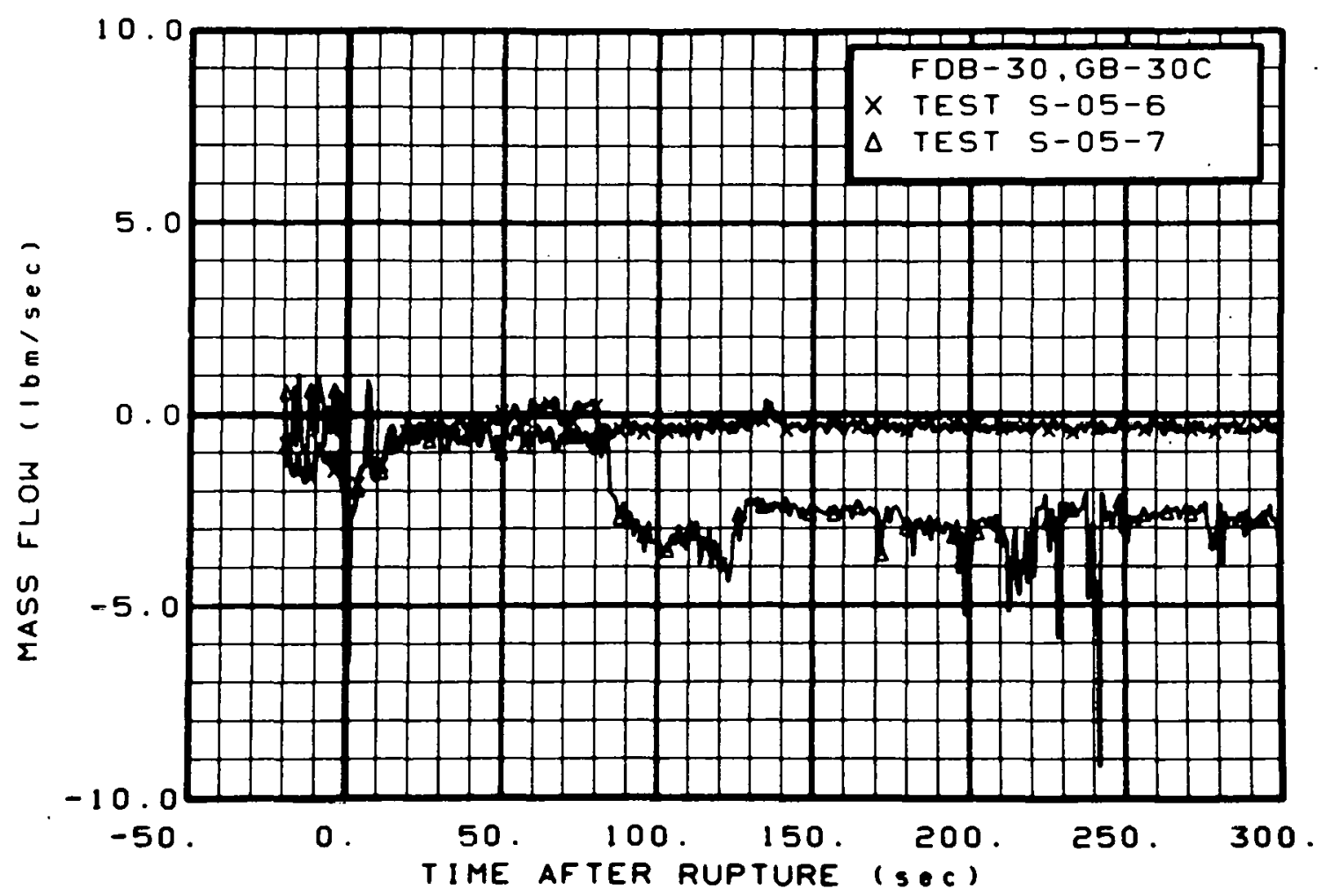

Fig. 532 Mass flow in broken loop (FDB-30, GB-30C), from -20 to $300 \mathrm{sec}$.



Fig. 533 Mass flow in broken loop (FDB-30, GB-30C), from -6 to $42 \mathrm{sec}$. 


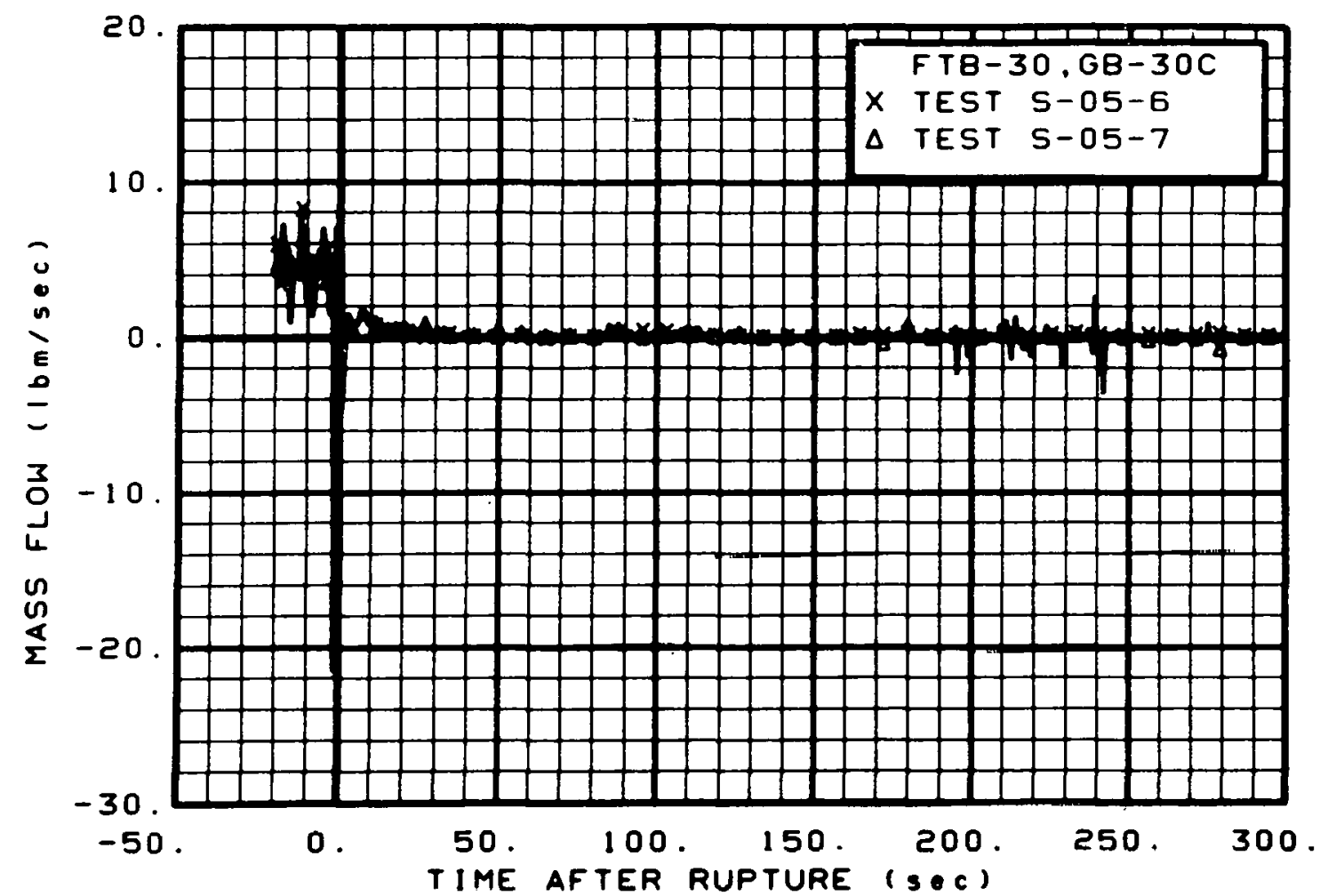

Fig. 534 Mass flow in broken 10op (FTB-30, GB-30C), from -20 to $300 \mathrm{sec}$.

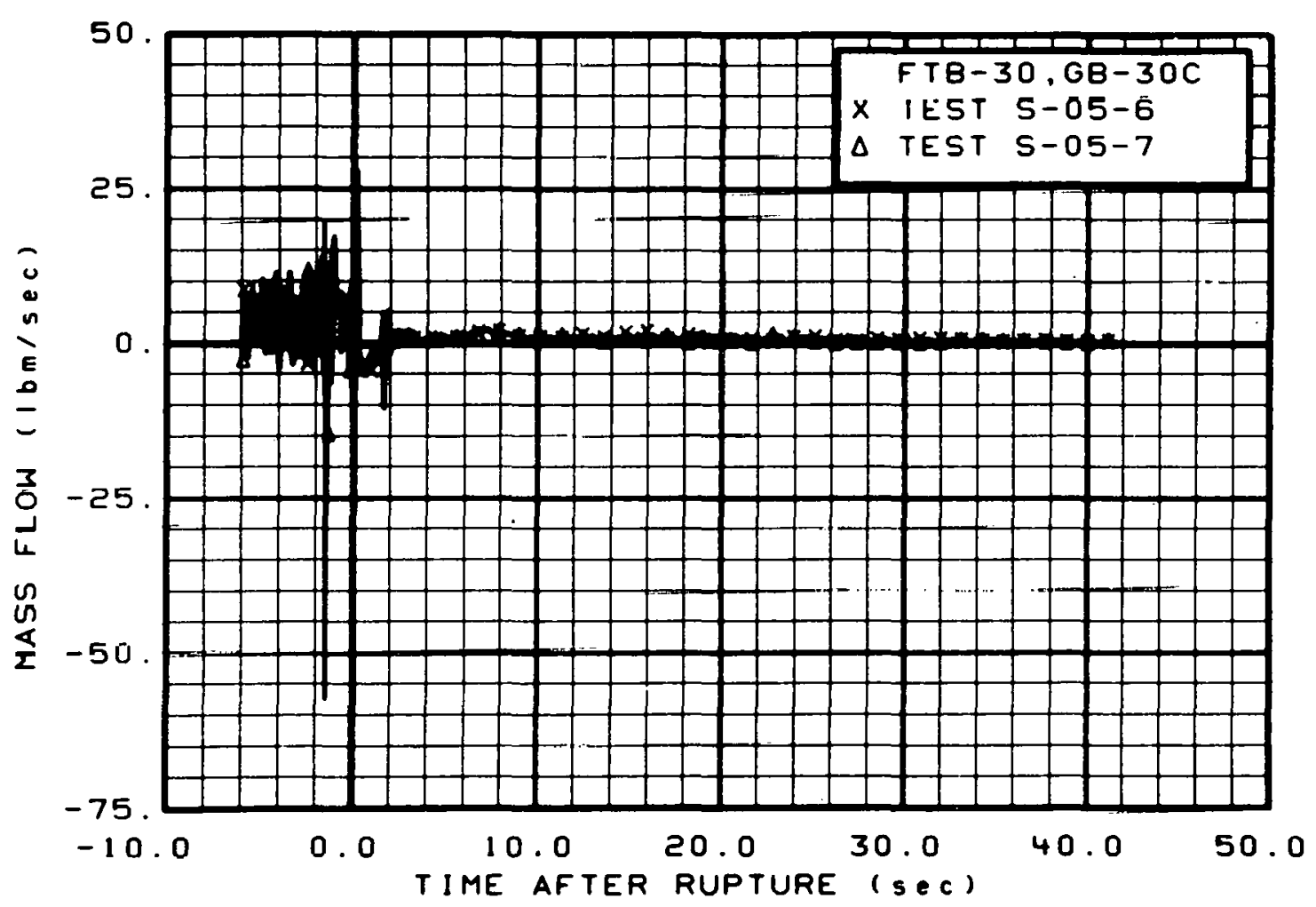

Fig. 535 Mass flow in broken loop (FTB-30, GB-30C), from -6 to $42 \mathrm{sec}$. 


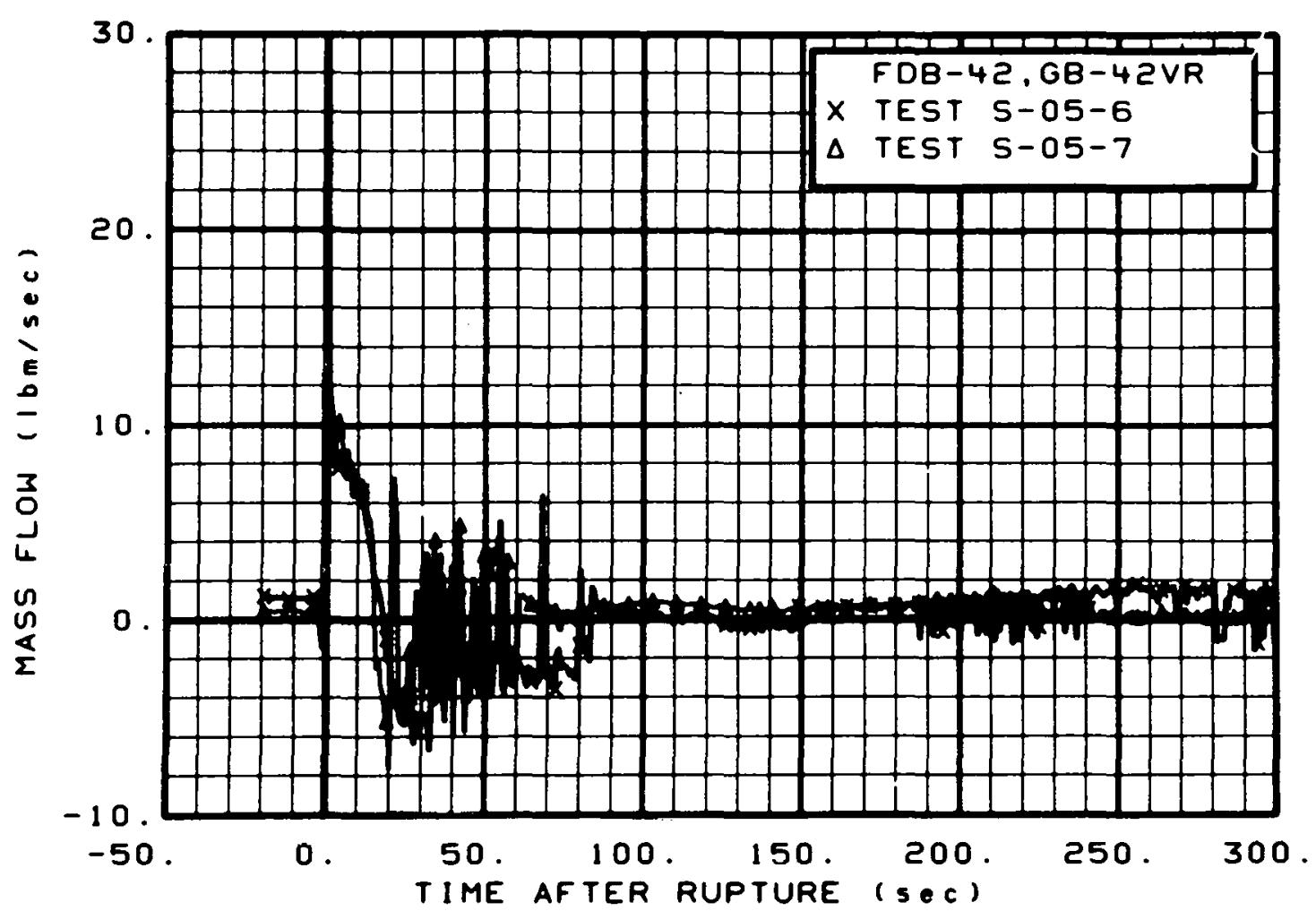

Fig. 536 Mass flow in broken loop (FDB-42, GB-42VR), from -20 to $300 \mathrm{sec}$.

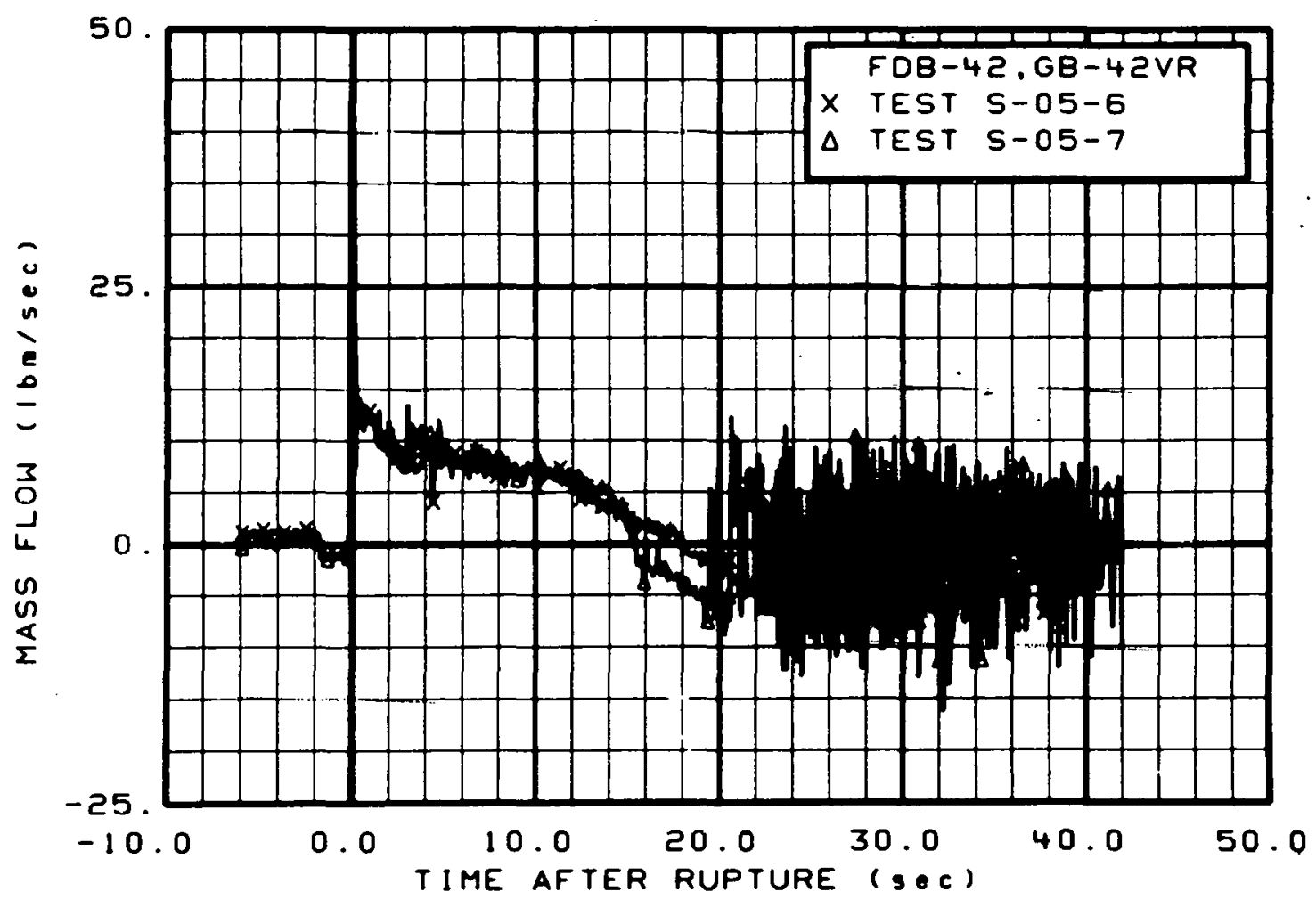

Fig. 537 Mass flow in broken loop (FDB-42, GB-42VR), from -6 to $42 \mathrm{sec}$. 


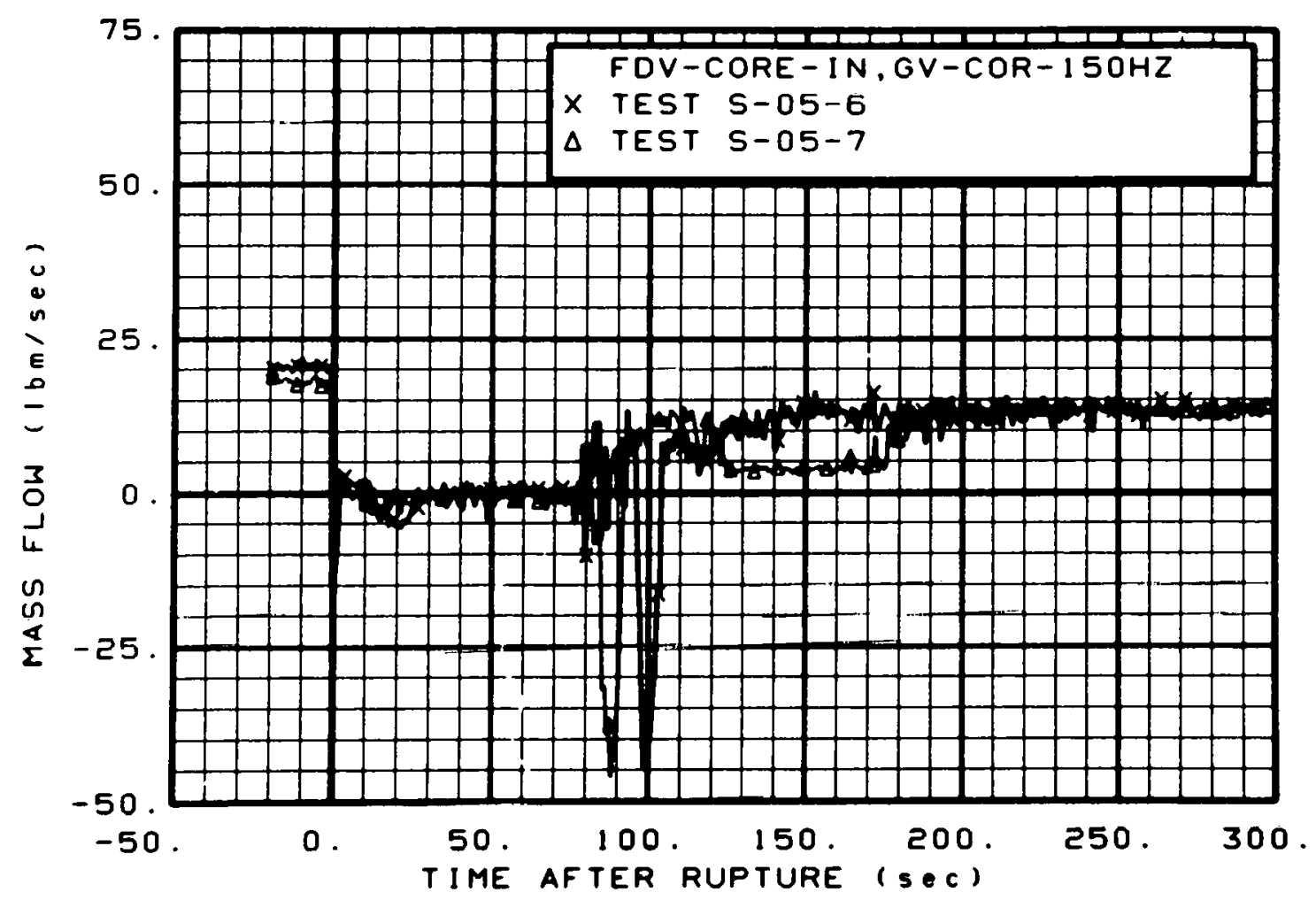

Fig. 538 Mass flow in vessel (FDV-CORE-IN, GV-COR-150HZ), from -20 to $300 \mathrm{sec}$.

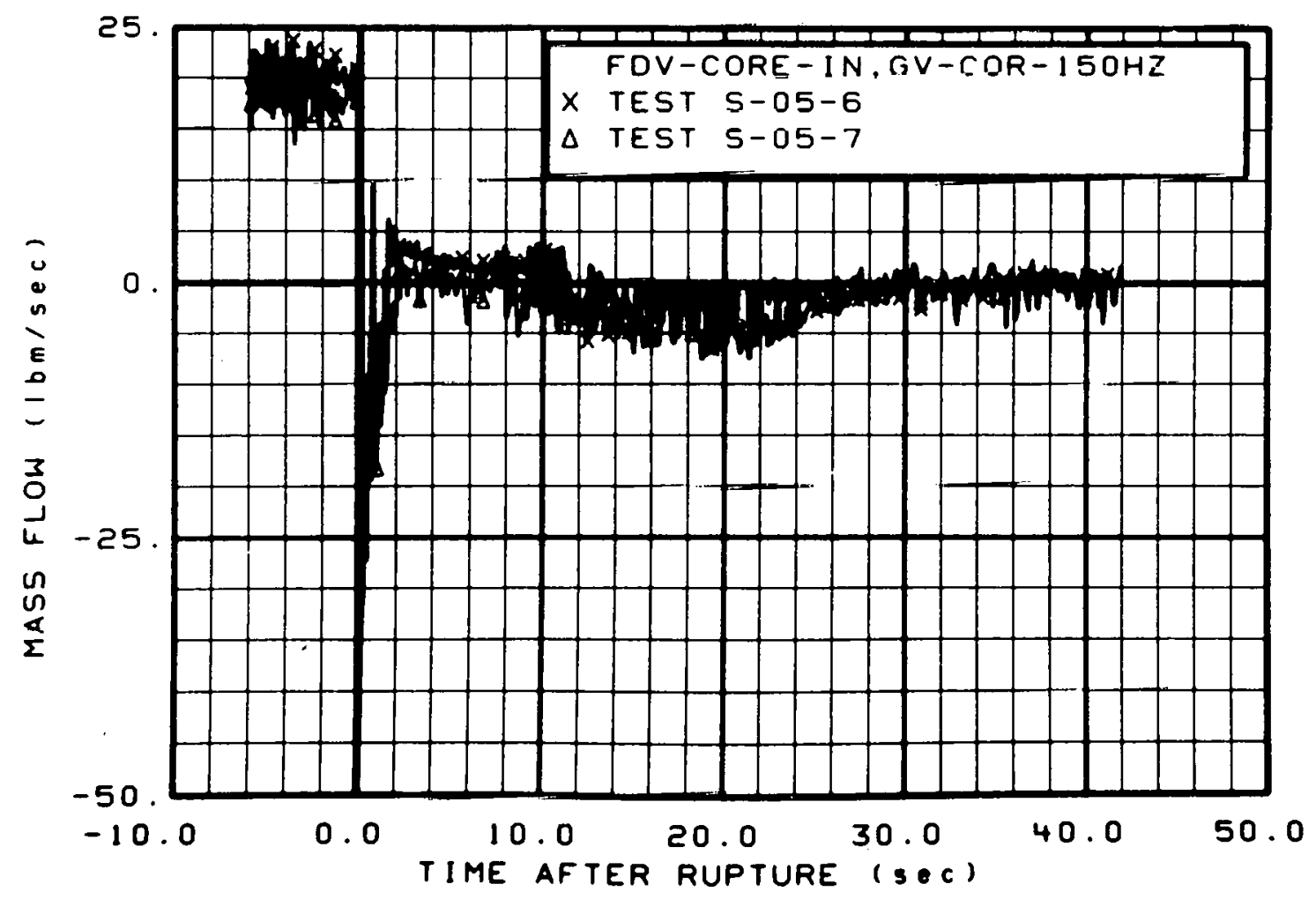

Fig. 539 Mass flow in vessel (FDV-CORE-IN, GV-COR-150HZ), from -6 to 42 sec. 


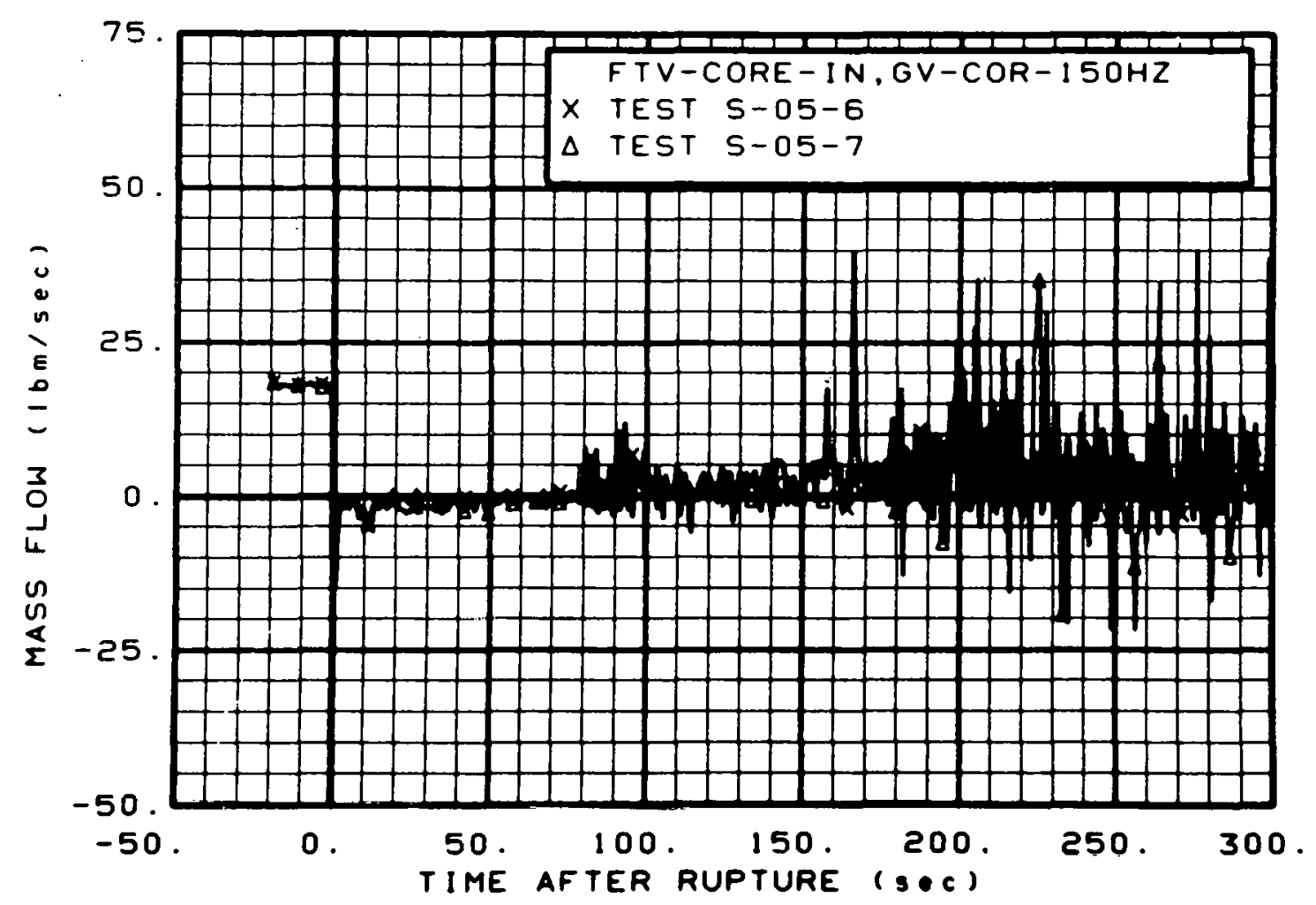

Fig. 540 Mass flow in vessel (FTV-CORE-IN, GV-COR-150HZ), from -20 to $300 \mathrm{sec}$.

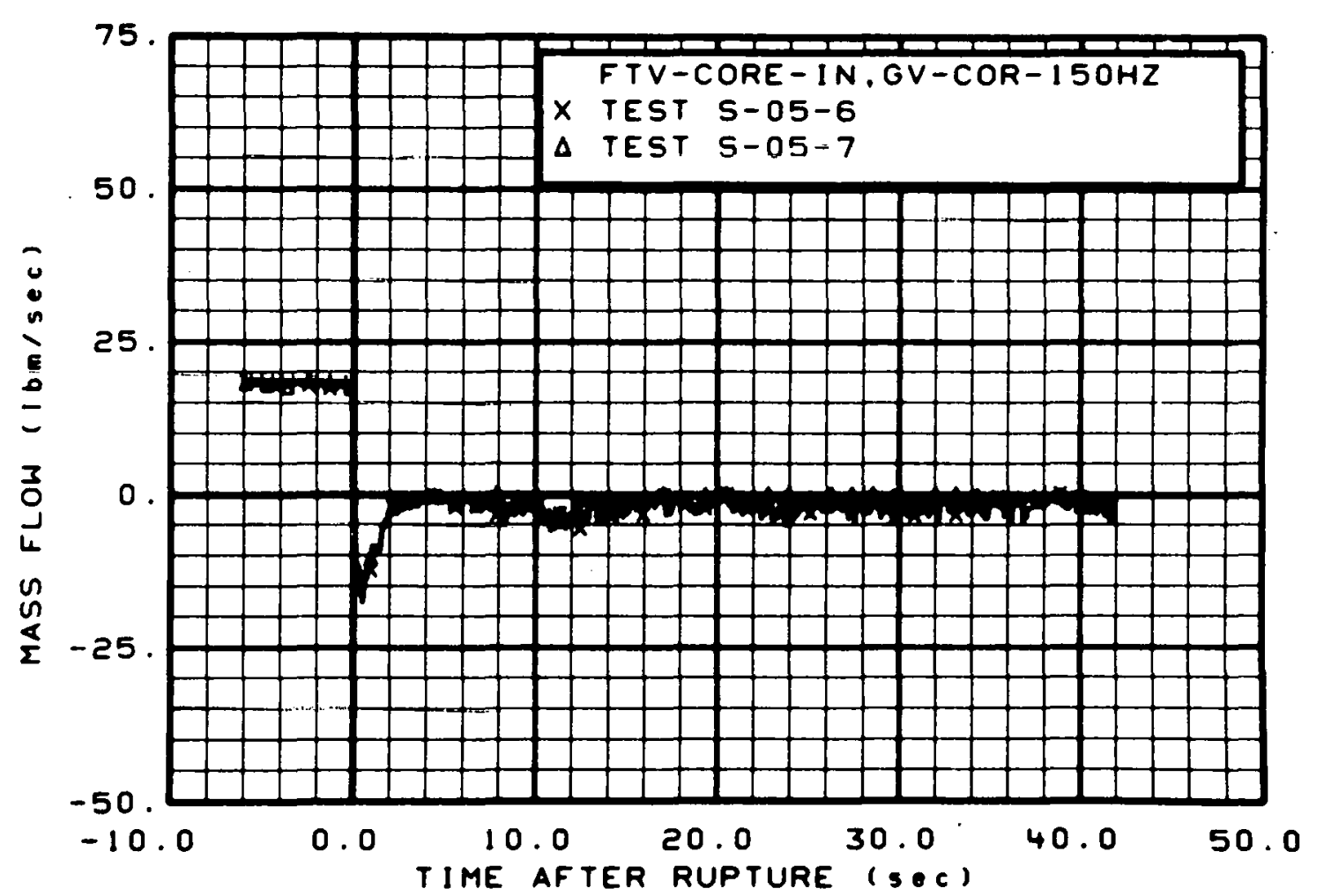

F1g. 541 Mass flow in vessel (FTV-CORE-IN, GV-C.OR-150HZ), from -6 to $42 \mathrm{sec}$. 


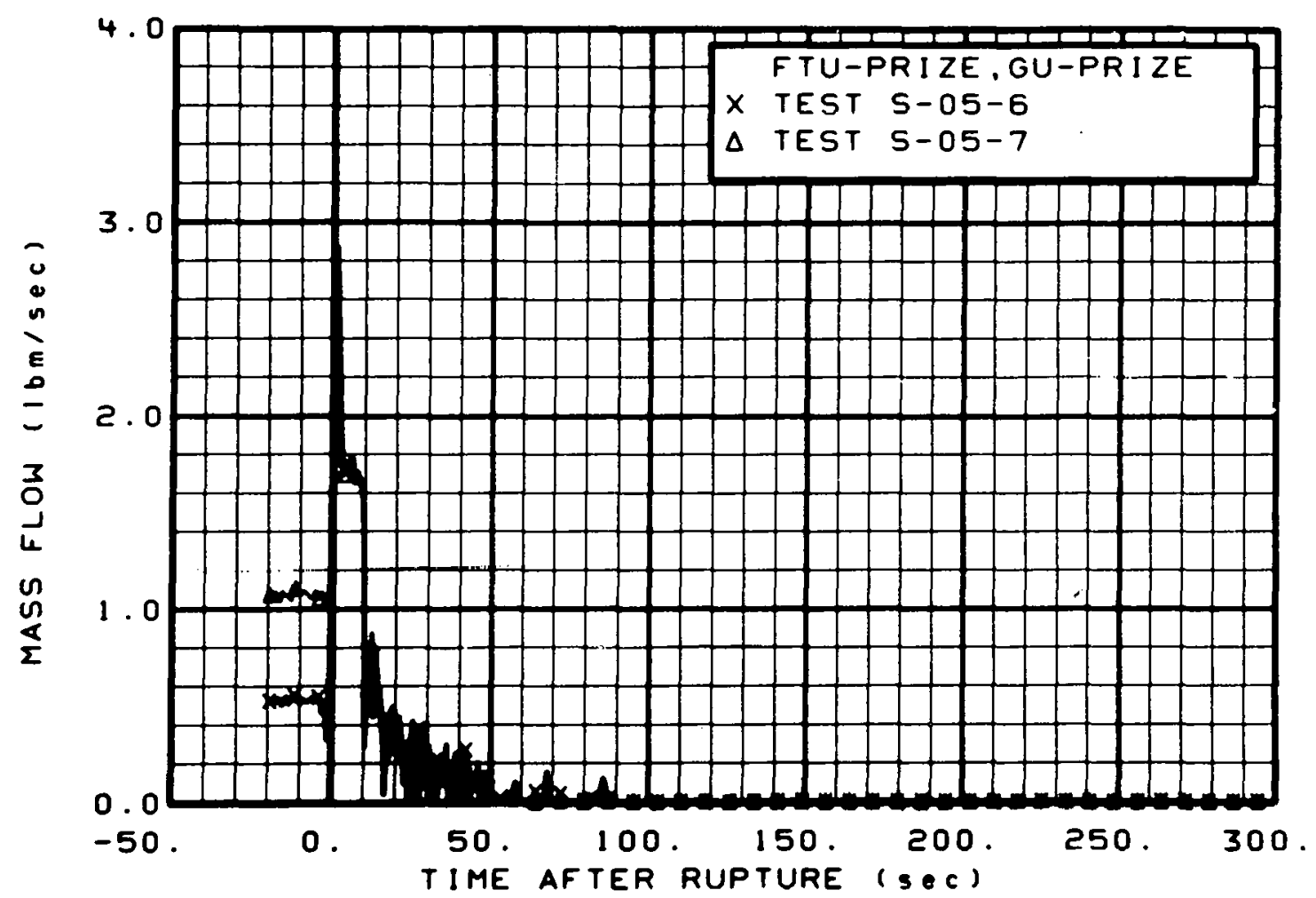

Fig. 542 Mass flow in pressurizer surge line (FTU-PRIZE, GU-PRIZE), from -20 to $300 \mathrm{sec}$.

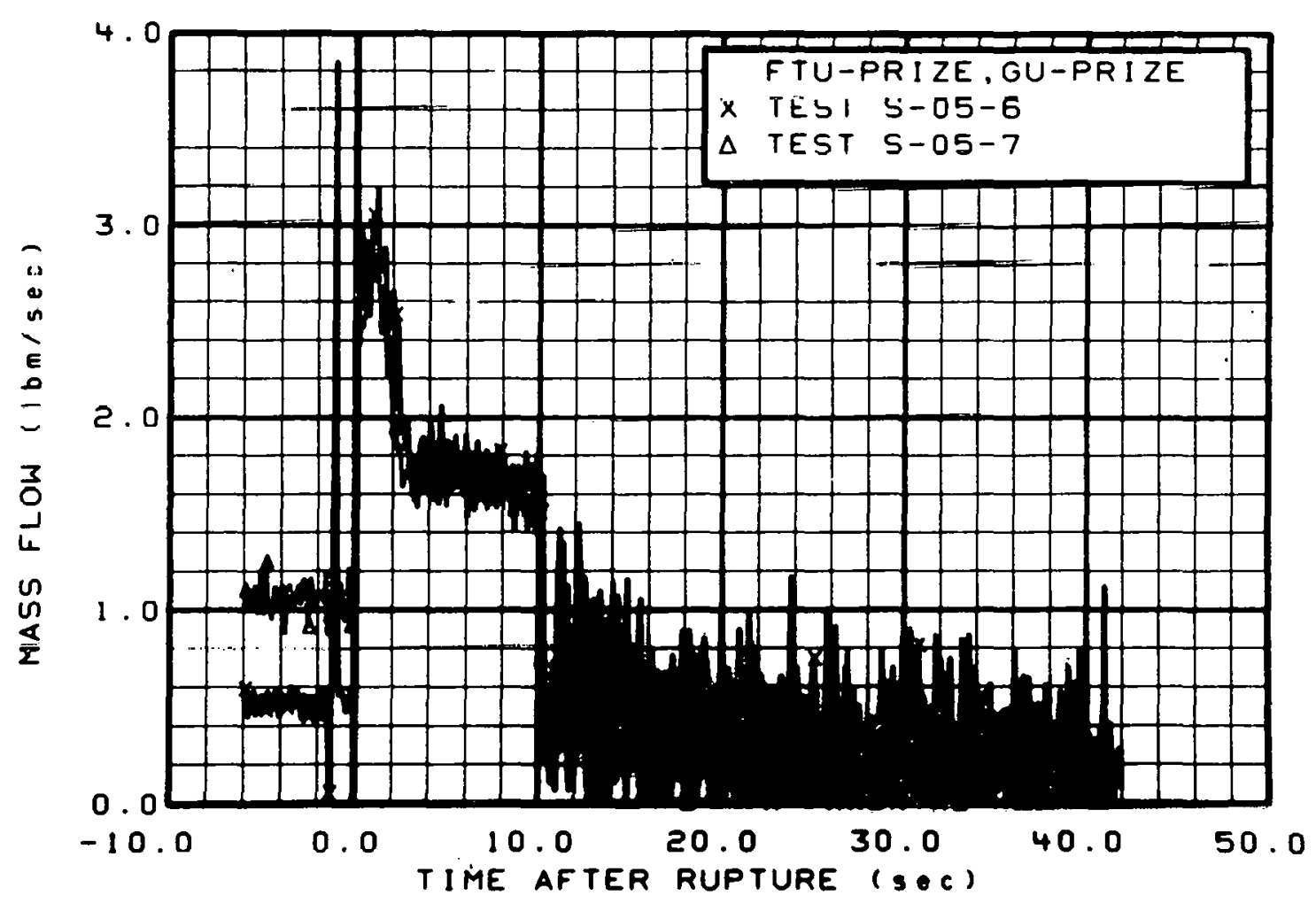

Fig. 543 Mass flow in pressurizer surge line (FTU-PRIZE, GU-PRIZE), from -6 to $42 \mathrm{sec}$. 


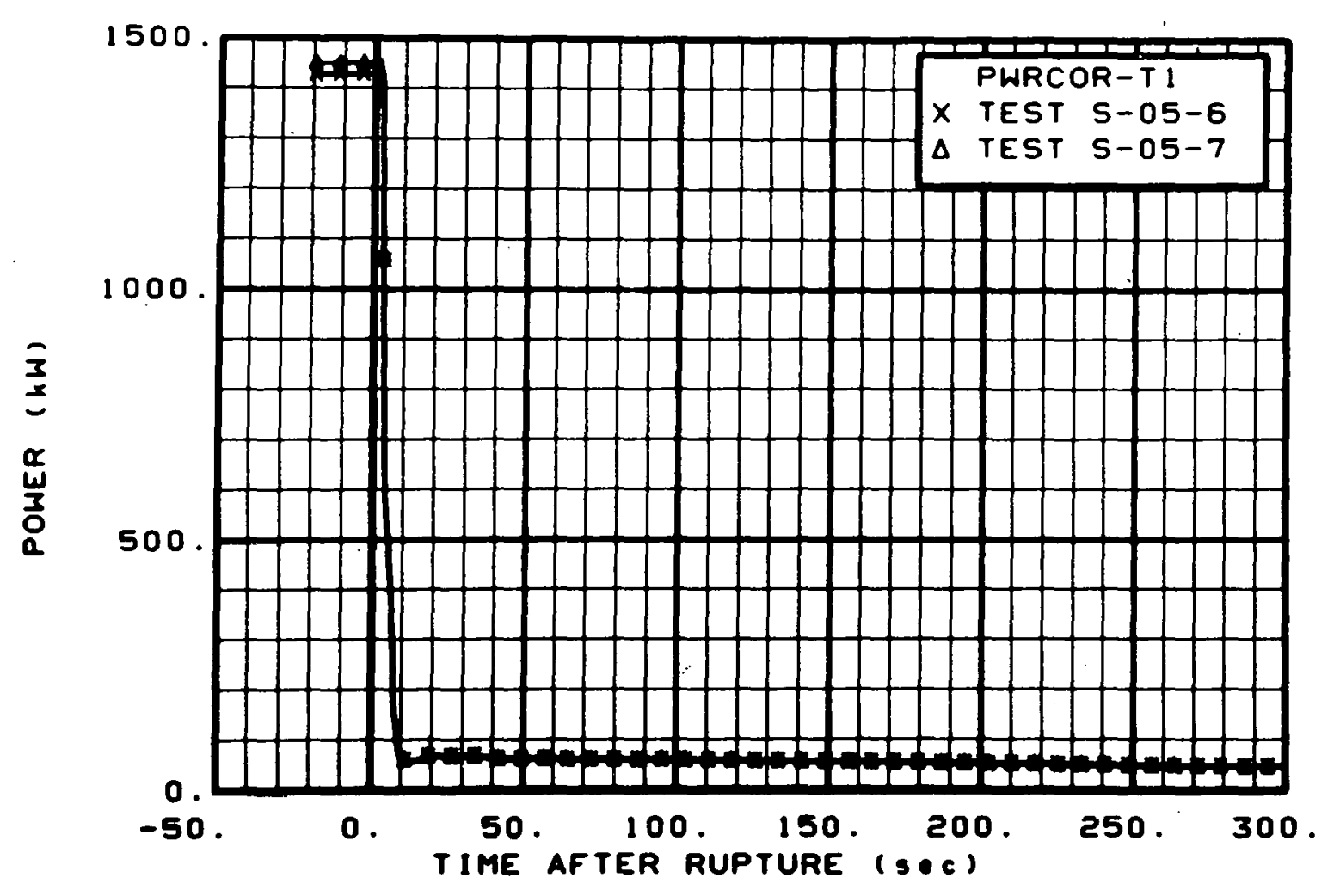

Fig. 544 Core heater rod total power (PWRCOR T-1), from -20 to $300 \mathrm{sec}$.

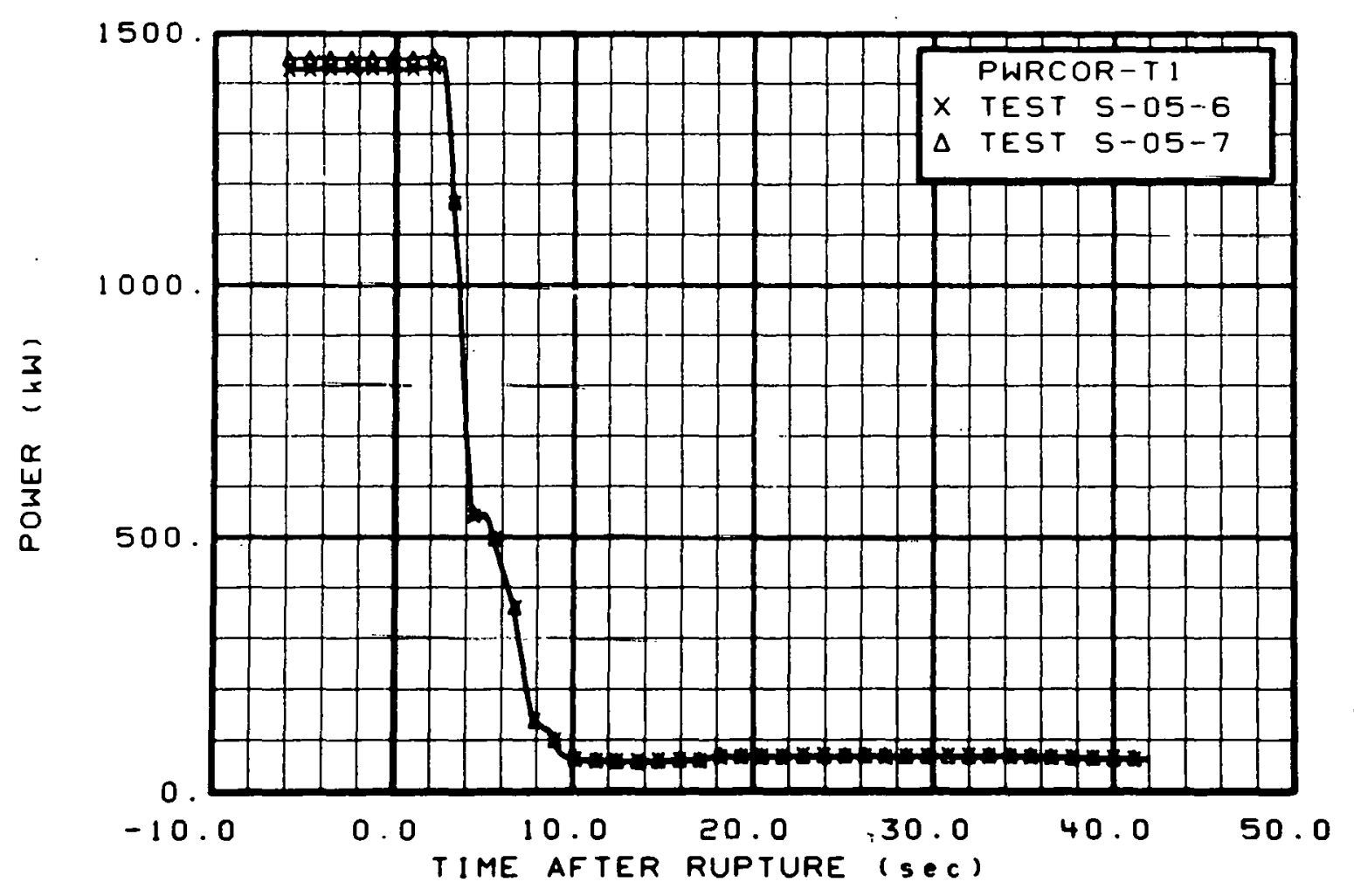

Fig. 545 Core heater rod total power (PWRCOR T-1), from -6 to $42 \mathrm{sec}$. 


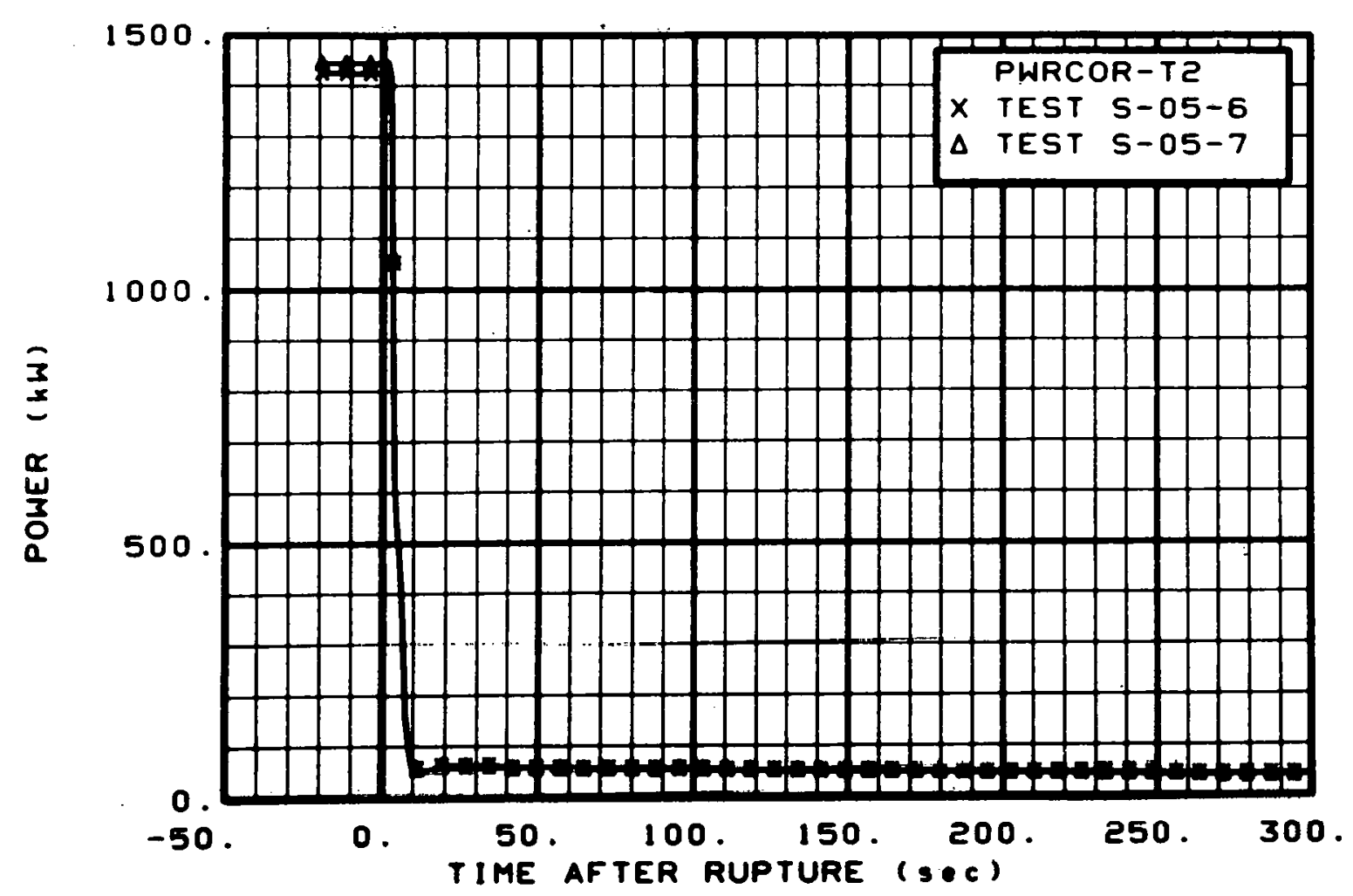

Fig. 546 Core heater rod total power (PWRCOR T-2), from -20 to $300 \mathrm{sec}$.

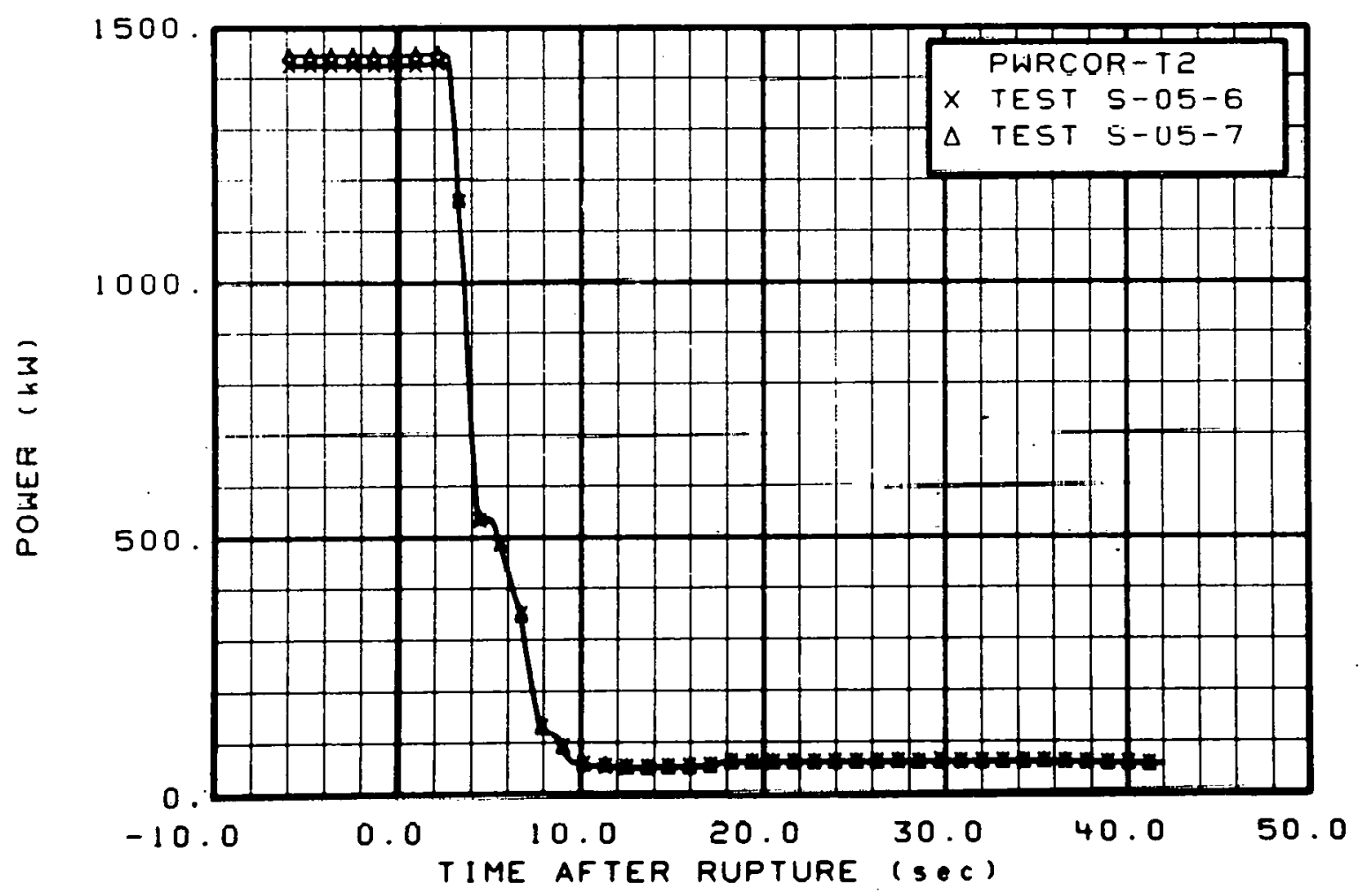

Fig. 547 Core heater rod total power (PWRCOR T-2), from -6 to 42 sec. 


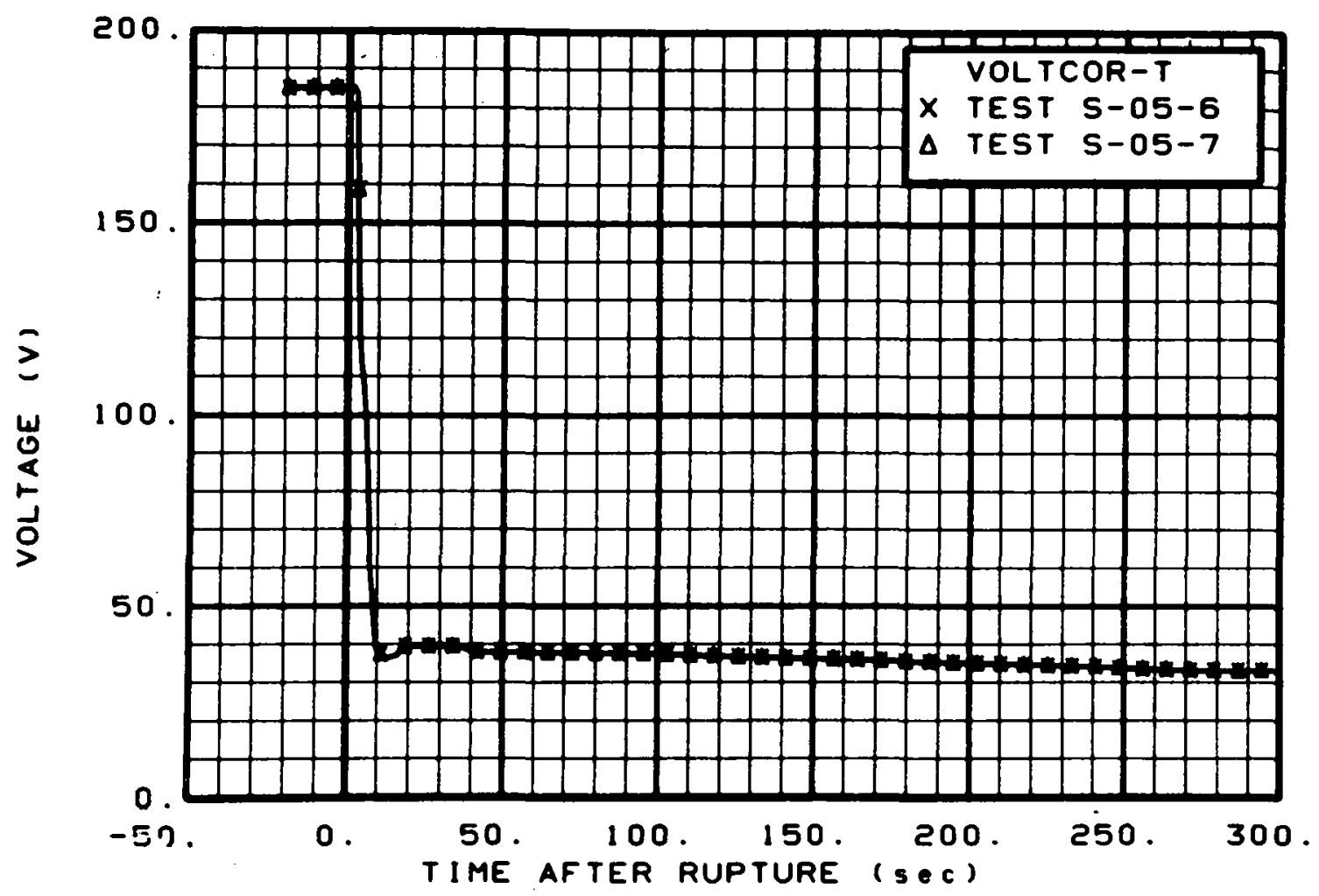

Fig. 548 Core heater voltage (VOLTCOR-T), from -20 to $300 \mathrm{sec}$.

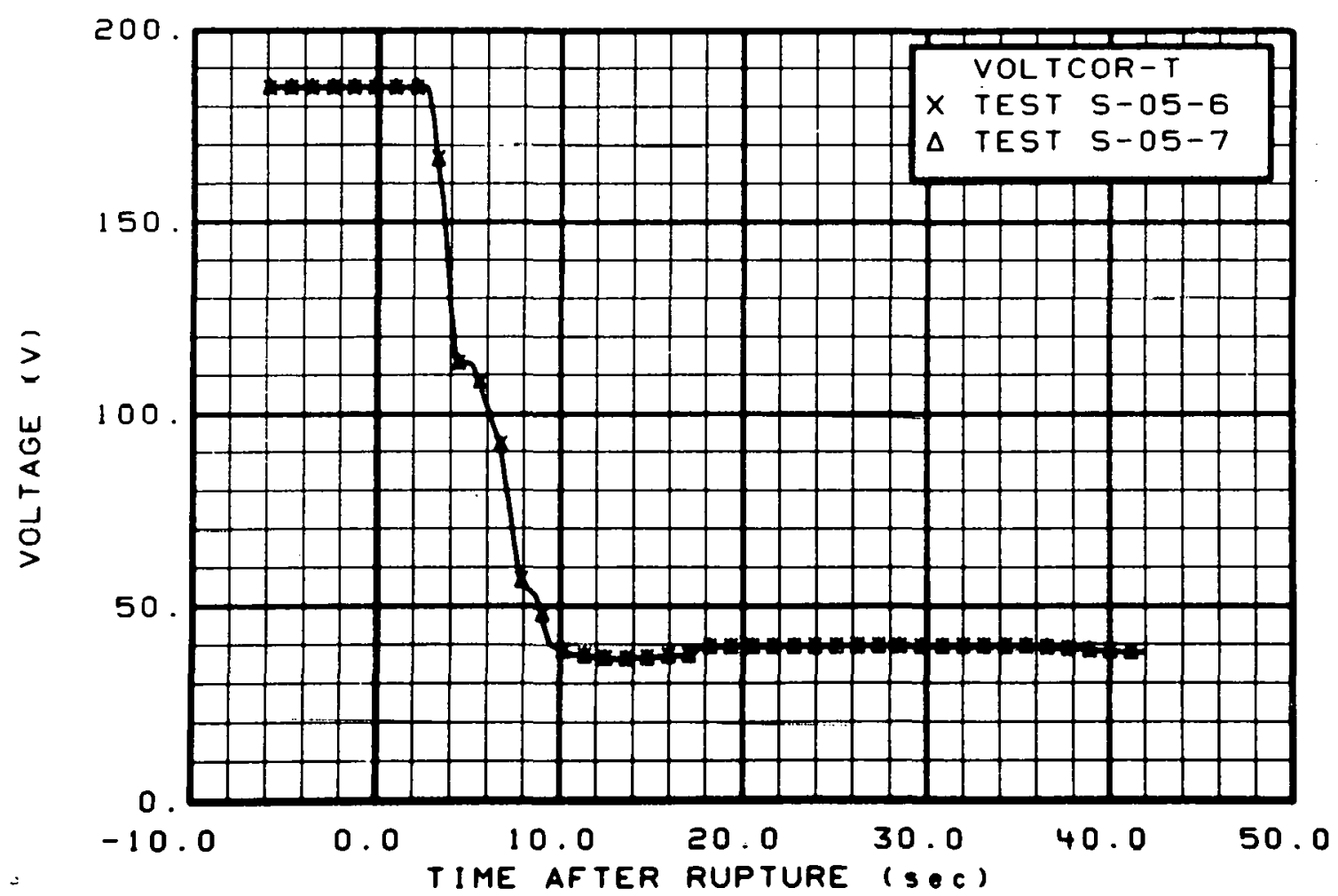

Fig. 549 Core heater voltage (VOLTCOR-T), from -6 to $42 \mathrm{sec}$. 


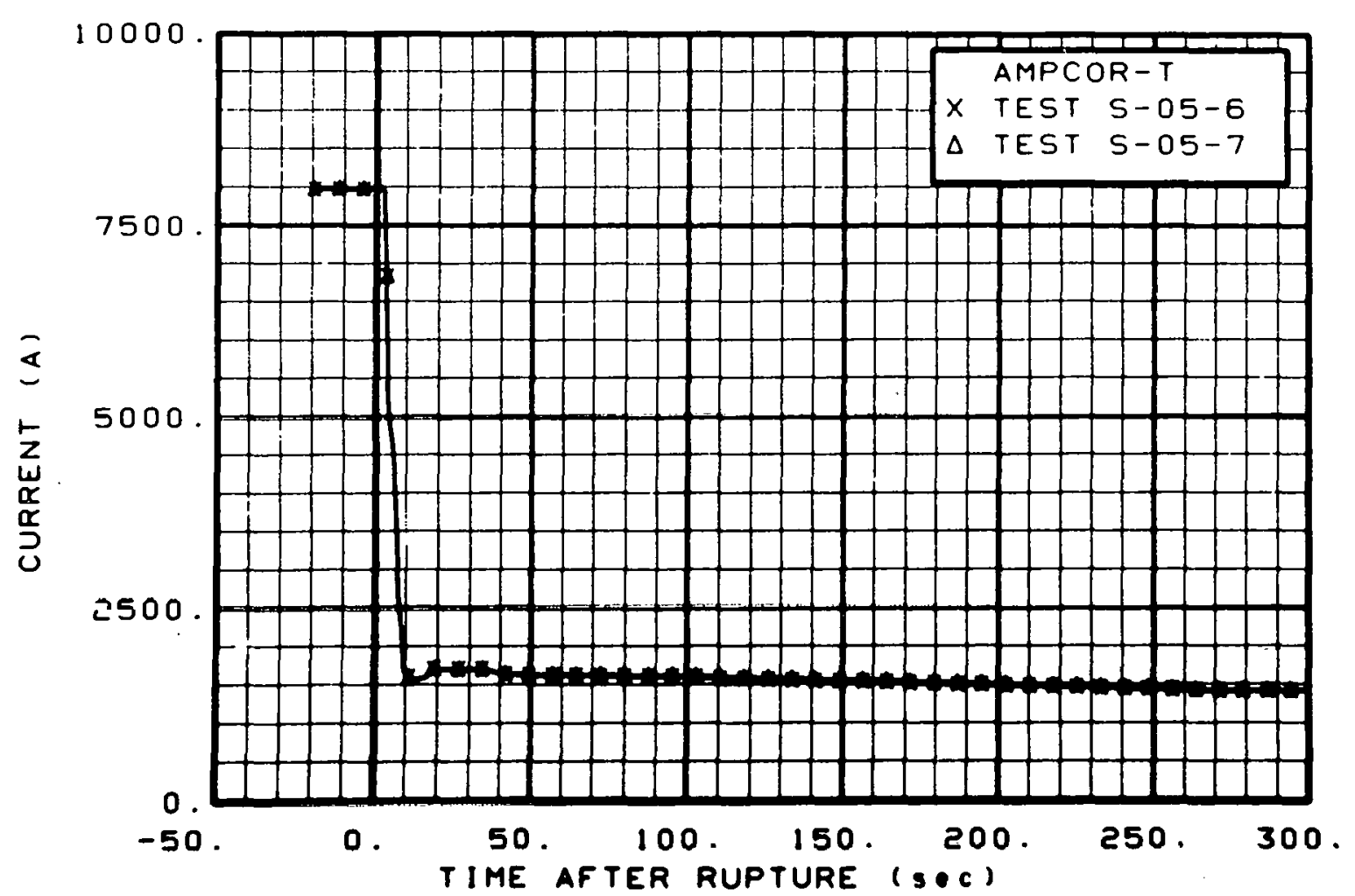

Fig. 550 Core heater current (AMPCOR-T), from -20 to $300 \mathrm{sec}$.

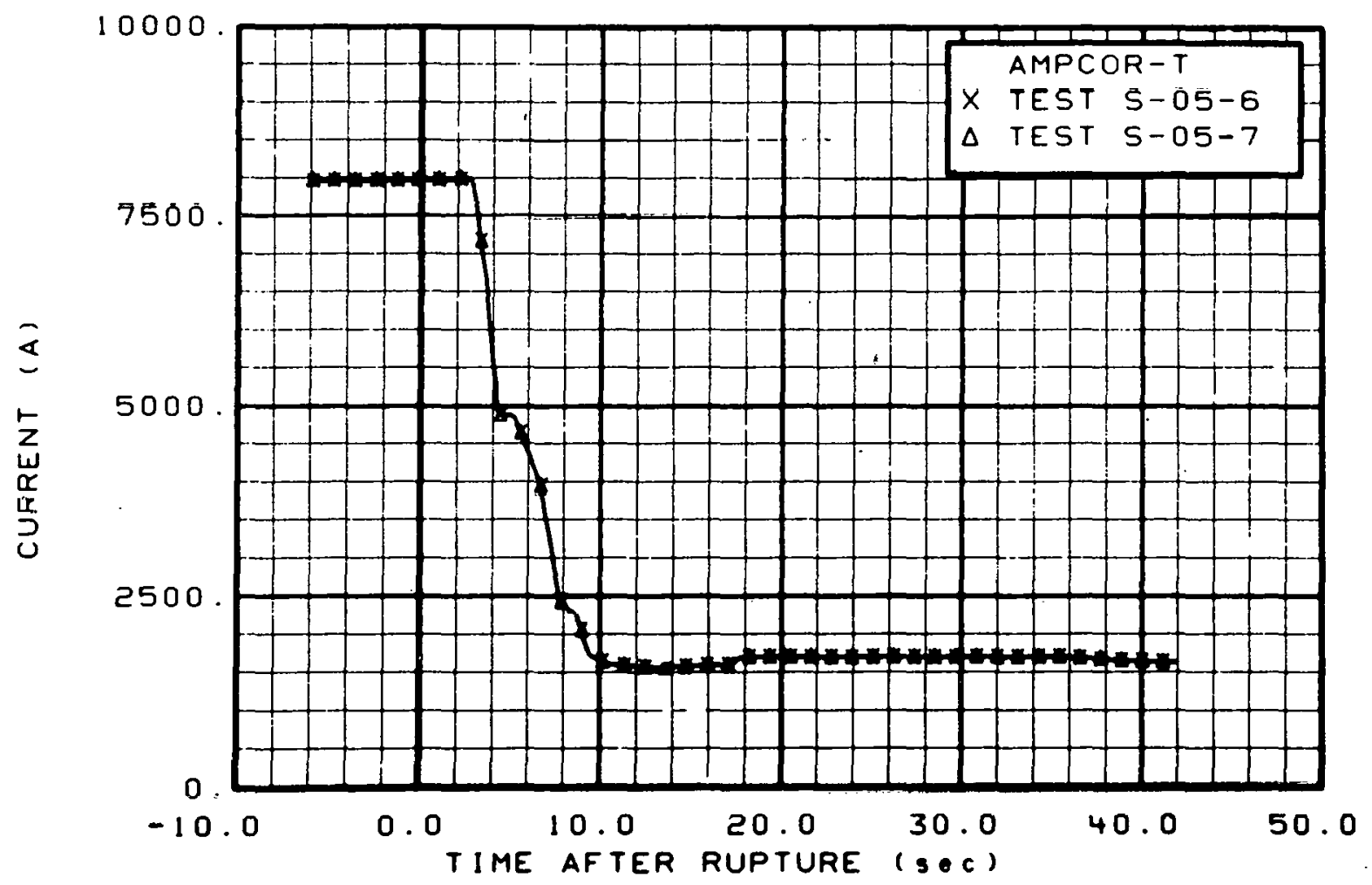

Fig. 551 Core heater current (AMPCOR-T), from -6 to $42 \mathrm{sec}$. 


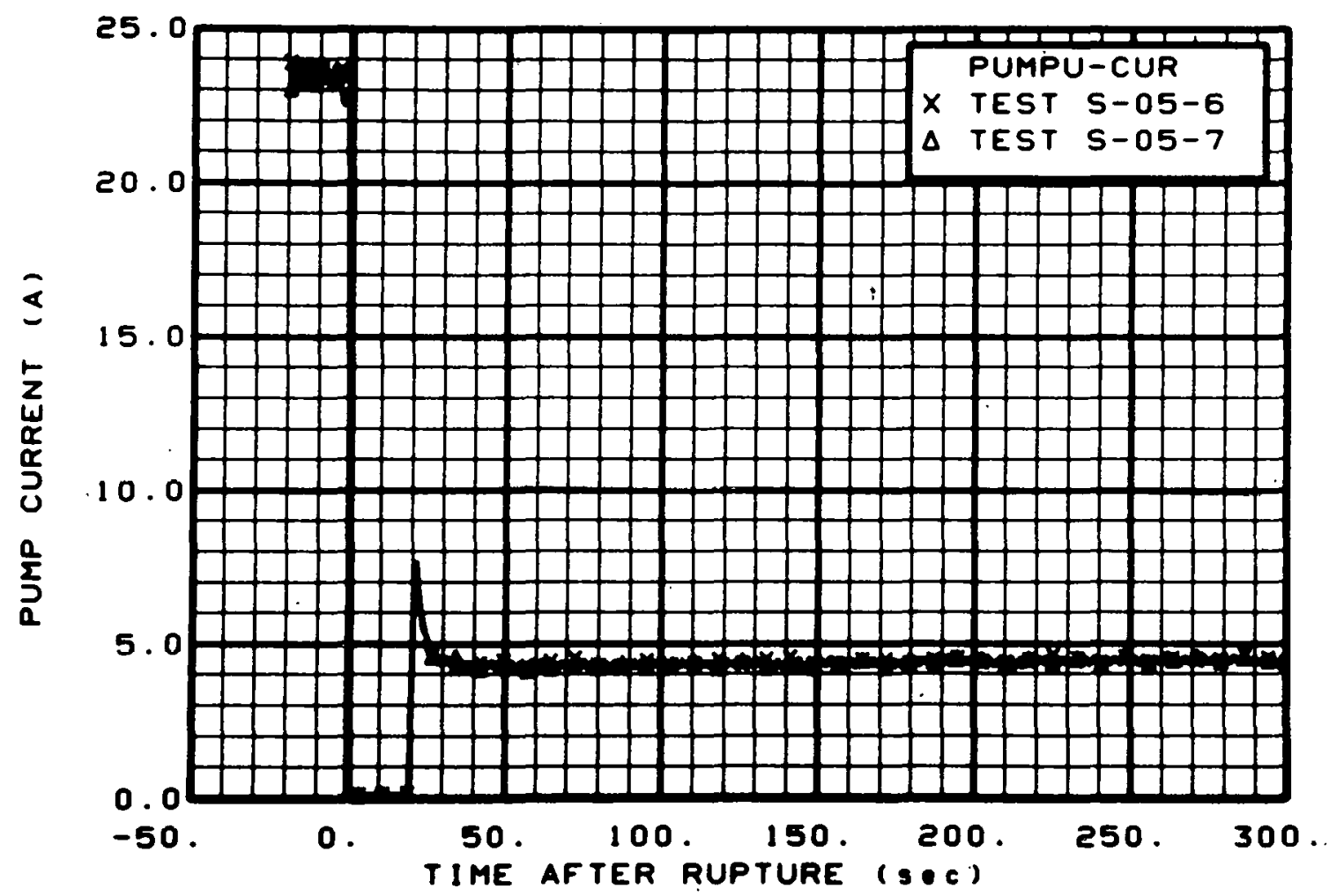

Fig. 552 Primary pump current (PUMPU-CUR), from -20 to $300 \mathrm{sec}$.

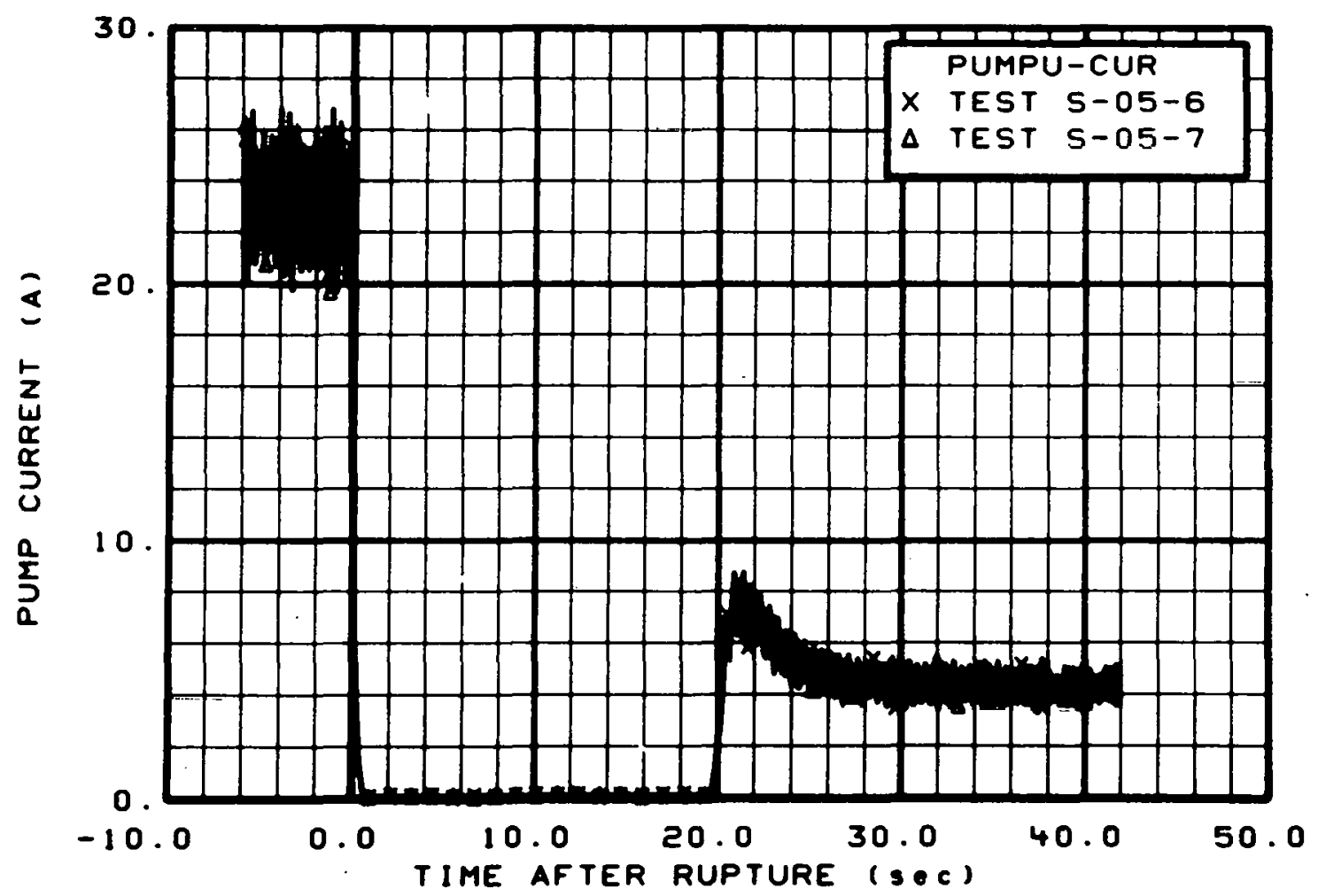

Fig. 553 Primary pump current (PUMPU-CUR), from -6 to 42 sec. 


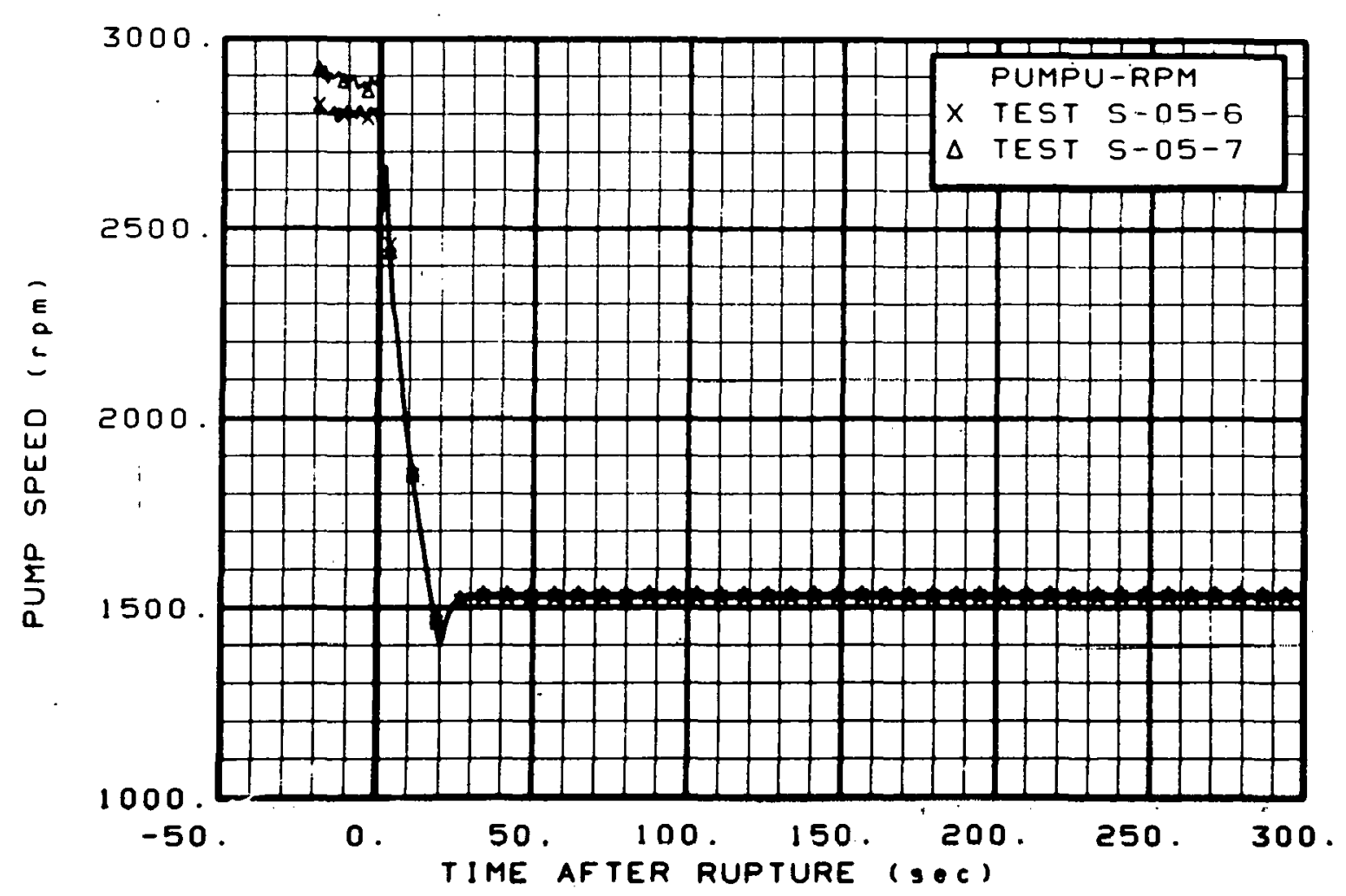

Fig. 554 Primary pump speed (PUMPU-RPM), from -20 to $300 \mathrm{sec}$.

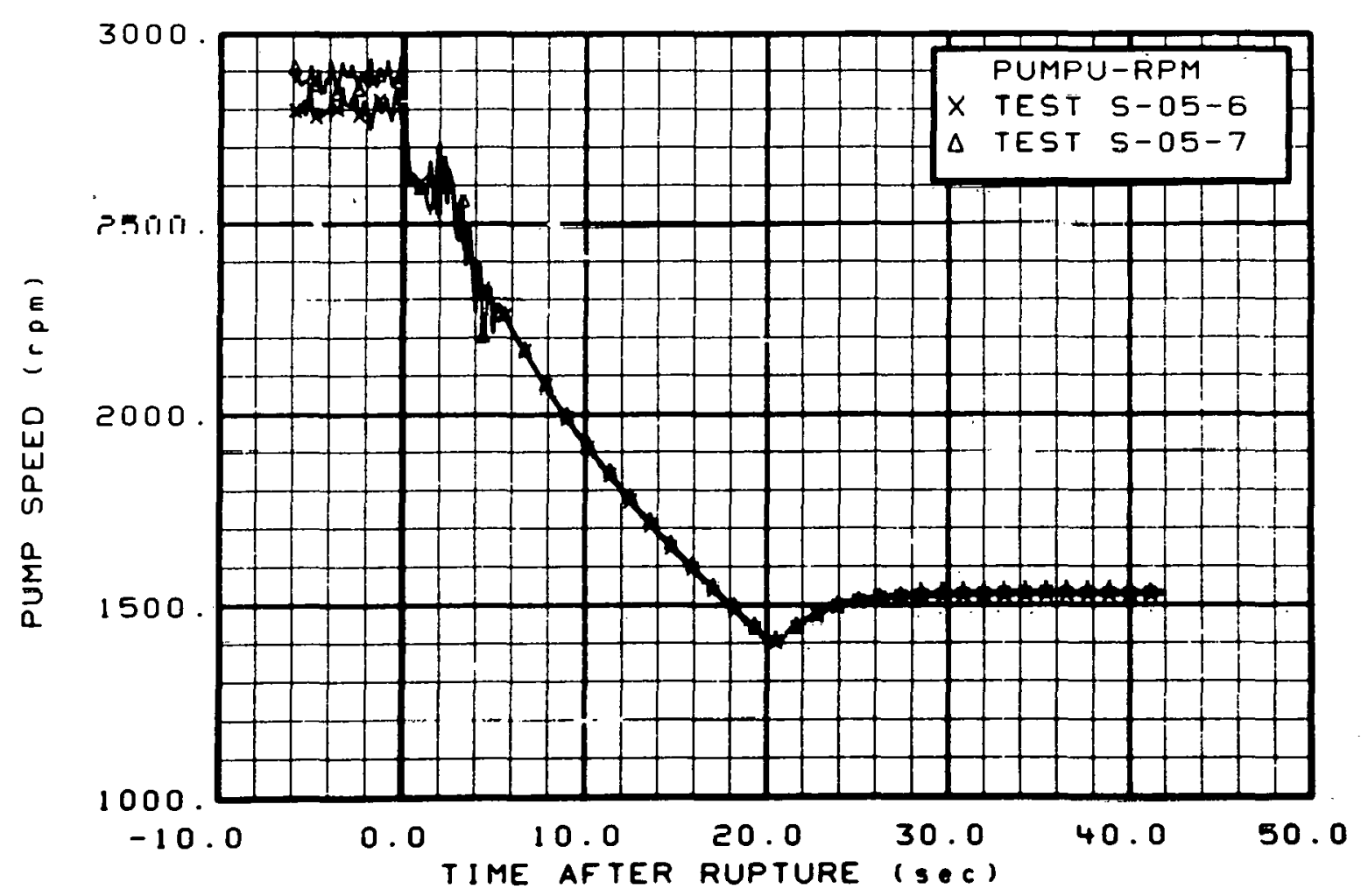

Fig. 555 Primary pump speed (PUMPU-RPM), from -6 to $42 \mathrm{sec}$. 


\section{REFERENCE}

1. E. M. Feldman and D. J. Olson, Semiscale Mod-1 Program and System Description for the Blowdown Heat Transfer Tests (Test Series 2), ANCR-1230 (August 1975). 
THIS PAGE

\section{WAS INTENTIONALLY LEFT BLANK}




\section{APPENDIX A}

POSTTEST ADJUSTMENTS TO DATA FROM SEMISCALE MOD-1 TESTS S-05-6 AND S-05-7 
THIS PAGE

\section{WAS INTENTIONALLY LEFT BLANK}




\section{APPENDIX A \\ POSTTEST ADJUSTMENTS TO DATA FROM SEMISCALE MOD-1 TESTS S-05-6 AND S-05-7}

Many of the transducers used in the Semiscale Mod-1 system exhibit significant sensitivity to one or more spurious inputs. Strain gage bridge circuits used in pressure transducers, differential pressure transducers, and drag discs are sensitive to changes in ambient temperature. Differential pressure cells are also sensitive to changes in system pressure. Photomultiplier tubes used as gamma-ray detectors.in the density transducers are sensitive to temperature changes, as well as to random variations in the locations of the radiation sources. Core power measurements depend on a calibrated resistor, which changes in value as a function of time and power level as it heats up.

Although the errors introduced into the data by spurious secondary inputs generally do not exceed the specified error ranges of the transducers, significant improvement in measurement accuracy can be achieved if the secondary sensitivity can be identified and removed. In the case of the drag discs, corrections are absolutely necessary since the signal due to temperature fluctuations can exceed that due to flow by several hundred percent. Since the exact values of the spurious inputs to which different transducers might be sensitive cannot often be easily predicted and are sometimes inconvenient to measure, secondary effects have been accounted for by correcting the data after the test rather than by using elaborate real time programs in the data acquisition system computer. The methods and results of the posttest data correction analysis for Tests S-05-6 and S-05-7 are presented in the following paragraphs and tables.

\section{PRESSURE MEASUREMENTS}

Corrections to pressure transducer measurements in the main system loop are based on data taken from the standard reference (Heise) gauge at Spool 4, taken $15 \mathrm{sec}$ before initiation of blowdown and at $300 \mathrm{sec}$ after initiation of blowdown. The pressure readings are adjusted to account for pressure variations around the main loop, using the readings of nearby differential pressure cells. A linear correction is then applied to the pressure data to match the data to the reference data at the two specified time points.

Correction of the steam generator secondary pressure (PU-SGSD) measurement is done in the same manner as for the main loop pressures using a Heise gauge installed expressly for this purpose.

Pressure measurement corrections are performed using the data acquisition system (DAS) computer using the following equation: 
where

$$
F^{\prime}(t)=c_{0}+c_{1}[F(t)]
$$

$$
\begin{aligned}
& F^{\prime}(t)=\text { corrected data } \\
& F(t)=\text { raw data } \\
& C_{0}=\text { offset } \\
& C_{1}=\text { scaling factor. }
\end{aligned}
$$

\begin{tabular}{|c|c|c|c|c|}
\hline \multirow[b]{2}{*}{$\begin{array}{c}\text { Detector } \\
\text { Identification }\end{array}$} & \multicolumn{2}{|c|}{ Test $5-05-6$} & \multicolumn{2}{|c|}{ Test $\mathrm{S}-05-7$} \\
\hline & $\mathrm{C}_{\mathrm{O}}$ & $c_{1}$ & $\mathrm{C}_{0}$ & $c_{1}$ \\
\hline PU-PRIZE & --- & --- & -16.0 & 1.0140 \\
\hline PU-SGSD & -5.9 & .0 .9949 & -36.8 & 1.0579 \\
\hline$P B^{\circ}-37$ & -- & -- & 23.0 & 0.9955 \\
\hline$P B-32$ & -9.2 & 0.9512 & -91.5 & 1.0554 \\
\hline PB-HN1 & -- & --- & -12.5 & 1.0159 \\
\hline$P B-C N 2$ & 55.5 & 0.9708 & --- & $= \pm 0$ \\
\hline $\mathrm{PB}-\mathrm{CN} 3$ & 75.4 & 0.9565 &.- & --- \\
\hline $\mathrm{PB}-\mathrm{CN} 4$ & -11.2 & 1.0036 & -21.4 & 1.0160 \\
\hline$P V=U P+10$ & 35.2 & 0.0564 & -51.0 & 1.0130 \\
\hline$P V-L P-166$ & -- & --- & -30.4 & 1.0187 \\
\hline
\end{tabular}

The values of the offset and scaling factor are given in Table A-I.

\section{TABL[ A-I}

CONSTANTS FOR PRESSURE MEASUREMENT CORRECTIONS 


\section{DIFFERENTIAL PRESSURE MEASUREMENTS}

Pressure sensitivity in the differential pressure cells in the main system loop is determined from the pretest system pressure check. Digital data are recorded for all measurements.at ambient temperature, with no system flow, at pressures of ambient, 200 , $500,1000,1500,2000$, and 2250 psig. The output of the differential pressure cells is plotted against system pressure, with the resulting plots used to describe the pressure sensitivity of the transducers.

The response of the differential pressure cells due to ambient pressure and temperature is determined from a digital data scan taken at $500^{\circ} \mathrm{F}$ and $1750 \mathrm{psig}$, with no system flow. The measured transducer outputs are compared with the values calculated due only to the density difference between the water inside the loop (500\%) and outside the loop in the sense lines ( 80 to $100^{\circ} \mathrm{F}$ ).

The difference between the measured value and the calculated value is considered to be the result of pressure sensitivity and thermal drift. On-line processing of the data in the computer data acquisition system applies this difference automatically to the measured data. After the data scan at $500^{\circ} \mathrm{F}$ is made, no more opportunities exist to obtain data with the pump stopped and the system full of liquid; therefore, for lack of later data, the thermal drift calculated from the $500^{\circ} \mathrm{F}$ data is assumed to be constant throughout the test. However, posttest pressure sensitivity corrections are applied to the data according to system pressure.

In correcting differential pressure data for pressure sensitivity, the data are initially corrected for errors in amplification and ambient offsets. The pressure sensitivity is then subtracted from these corrected data to arrive at the final values. Corrections were made using the following equations:

$$
\begin{aligned}
& F^{\prime}(t)=C_{1}[F(t)]+C_{0} \\
& F^{\prime \prime}(t)=F^{\prime}(t)-P_{1}[P(t)]
\end{aligned}
$$

where

$$
\begin{aligned}
& \mathrm{C}_{0}=\text { ambient offset } \\
& \mathrm{C}_{1}=\text { amplification factor } \\
& F(t)=\text { raw data } \\
& F^{\prime}(t)=\text { first data correction } \\
& P(t)=\text { pressure data }
\end{aligned}
$$




$$
\begin{aligned}
& P_{1}=\text { pressure sensitivity } \\
& F^{\prime \prime}(t)=\text { final result. }
\end{aligned}
$$

The values for $\mathrm{C}_{0}, \mathrm{C}_{1}$, and $\mathrm{P}_{1}$ are given in Table A-II.

For some differential pressure measurements, the data scan at $500^{\circ} \mathrm{F}$ cannot be used as a reference for thermal drift; so other references are used. The liquid level measurements in the intact loop accumulator (DPU-ACC-TB), the broken loop accumulator (DPB-ACC-TB), the pressurizer (DPU-PRESLL), and the intact loop steam generator (DPU-SG-SEC) are referenced to calculated values based on geometrical considerations at the time when gas flow from the respective vessel is first noted, or when the system is completely drained. The reading from the steam generator discharge venturi (DPU-SG-DISC,)

$\underline{\text { TABLE A-I I }}$

CONSTTANTS FOR DIFFERENTIAL PRESSURE

\begin{tabular}{|c|c|c|c|c|}
\hline \multirow{2}{*}{$\begin{array}{c}\text { Detector } \\
\text { Identification } \\
\end{array}$} & \multicolumn{4}{|c|}{ Test S-05-6 } \\
\hline & $c_{1}$ & $\mathrm{C}_{0}$ & $P_{1}$ & $P(t)$ \\
\hline DPV-9-166QQ & 1.0 & 0.330 & 0.0001886 & PV-LP-166 \\
\hline DPV-26-55QM & 1.0 & -0.066 & 0.0000832 & PV-LP-166 \\
\hline \multirow[t]{2}{*}{$D F V=110=15 G M Q$} & 1.0 & 0.501 & 0.0002884 & $P V-L P-166^{\circ}$ \\
\hline & \multicolumn{4}{|c|}{ Test S-05-7: } \\
\hline $\begin{array}{c}\text { Detector } \\
\text { Identification } \\
\end{array}$ & $c_{1}$ & $\mathrm{C}_{0}$ & $\mathrm{P}_{1}$ & $P(t)$ \\
\hline DPU-UP.-3 & 1 & 0.0398 & 0.0000227 & $P V-U P+10$ \\
\hline DPU-SGOP-7 & 1 & 0.3980 & 0.0002274 & $P U=13$ \\
\hline DPU-7-10 & 1 & 0.0653 & -0.0000373 & PU-13 \\
\hline DPB-37-38 & 1 & 0.0978 & 0.0000525 & $P B-37$ \\
\hline DPV-9-166QQ & 1 & -0.3520 & -0.0002012 & PV-LP-166 \\
\hline$D P V-26-55 Q M$ & 1 & 0.0671 & 0.0000956 & $P V-U P+10$ \\
\hline
\end{tabular}
MEASUREMENT CORRECTIONS 
is shifted to read zero after flow is stopped. For these detectors, and those having nonlinear pressure sensitivities, the corrections are performed according to the following equations:

$$
\begin{aligned}
& F^{\prime}(t)=K F(t)+C_{1} \text { for } t<t_{1} \text { or when to } t_{i} \text { are listed } \\
& \text { for time points } t \text {, where } t_{1} \leq t \leq t_{n} \text {. } \\
& F^{\prime}(t)=K F(t)+c_{i}+\frac{t_{-} t_{i}}{t_{i}+1-t_{i}}\left(c_{i}+1-c_{i}\right) \text { for } t_{i} \leq t \leq t_{i}+1 \\
& \text { where } i \text { takes on values } 1 \text { to } n-1 \\
& F^{\prime}(t)=K F(t)+C_{n} \text { for } t>t_{n}
\end{aligned}
$$

where

$$
\begin{array}{lll}
\cdot \mathrm{t} & = & \text { time } \\
\mathrm{F}^{\prime}(\mathrm{t}) & = & \text { corrected data } \\
\mathrm{F}(\mathrm{t}) & = & \text { raw data } \\
\mathrm{K} & = & \text { scaling factor } \\
\mathrm{C}_{\mathrm{i}} \text { and } \mathrm{t}_{\mathrm{i}}= & \text { corrections and time points. }
\end{array}
$$

The values of the constants are given in Table $\Lambda$-III. 
TABLE A-III

CONSTANTS FOR IRREGULAR DIFFERENTIAL

PRESSURE MEASUREMENT CORRECTIONS

\begin{tabular}{|c|c|c|c|c|c|c|c|}
\hline \multirow[b]{2}{*}{$\begin{array}{c}\text { Detector } \\
\text { Identification } \\
\end{array}$} & \multicolumn{7}{|c|}{ Test S-05-6 } \\
\hline & $k$ & $c_{1}$ & $t_{1}$ & $\mathrm{C}_{2}$ & $t_{2}$ & $c_{3}$ & $t_{3}$ \\
\hline DPU-SG-DISC & 1 & 0.6 & -- & -- & --- & --- & -- \\
\hline DPU-ACC-TB & 1 & -0.093 & -- & -- & --- & --- & -- \\
\hline DPB-23-CN1 & 100 & $m=-$ & $=-$ & -- & --- & $==$ & --- \\
\hline$D P B-32 U-36 L$ & 1 & 0.371 & 0 & -0.122 & 0.01 & -3.080 & 12.00 \\
\hline$D P B-37-38$ & 1 & 0 & 0.01 & 0.14 & 18.0 & --- & -- \\
\hline DPB-CN1-PSS-63 & 1 & 49 & -- & --- & --- & --- & -- \\
\hline \multirow[t]{2}{*}{ DPB-ACC-TB } & 1 & 0.635 & -- & --- & $\cdots-$ & -- & -- \\
\hline & \multicolumn{7}{|c|}{ Test S-05-7 } \\
\hline $\begin{array}{c}\text { Detector } \\
\text { Identirication }\end{array}$ & $K$ & $\mathrm{C}_{1}$ & $t_{1}$ & $c_{2}$ & $t_{2}$ & $c_{3}$ & $t_{3}$ \\
\hline DPU-PRESLL & 1 & 0.103 & --- & --- & --- & --- & --- \\
\hline DPU-SG-DISC & 1 & 1.6 & --- & --- & $-\div-$ & --- & -- \\
\hline DPU-SG-SEC & 1 & 3.298 & -- & -- & --- & -- & $\because-$ \\
\hline DPU-ACC-TB & 1 & 1.517 & $\ldots-$ & --- & -- & -- & -- \\
\hline $\mathrm{DPB}-32 \mathrm{U}-36$ & 1 & 0.371 & 0 & -0.380 & 0.01 & -3.080 & 12.00 \\
\hline $\mathrm{DPB}-\mathrm{ACC}-\mathrm{TB}$ & 7 & 1.025 & -- & -- & $-\cdots$ & $-=-$ & $==-$ \\
\hline
\end{tabular}




\section{MOMENTUM FLUX MEASUREMENTS}

The temperature sensitivity of drag discs is determined from pretest warmup data taken at 200 and $500^{\circ} \mathrm{F}$ with no system flow. The temperature sensitivity is removed before the data are converted to momentum flux. The temperature of each transducer is taken from the signal of a nearby fluid or metal temperature thermocouple. Slight corrections for errors in setting the transducer output to zero at ambient conditions are also made at this time. Corrections are made using the following equation:

$$
F^{\prime}(t)=F(t)+D_{0}-D_{1} T(t)
$$

where

$$
\begin{aligned}
& F^{\prime}(t)=\quad \text { corrected data } \\
& \mathrm{F}(\mathrm{t})=\text { raw data } \\
& T(t)=\text { temperature data from the transducer used for temperature correction } \\
& \text { sensitivity } \\
& \mathrm{D}_{\mathrm{O}}=\text { ambient offset } \\
& \mathrm{D}_{1}=\text { temperature sensitivity. }
\end{aligned}
$$

Values of the constants are given in Table A-IV. 
TABLE A-IV

CONSTANTS FOR MOMENTUM FLUX

MEASUREMENT CORRECTIONS

\begin{tabular}{|c|c|c|c|}
\hline \multirow[b]{2}{*}{$\begin{array}{c}\text { Detector } \\
\text { Identification } \\
\end{array}$} & \multicolumn{3}{|c|}{ Test $\mathrm{S}-05-6$} \\
\hline & $\mathrm{D}_{0}$ & $\mathrm{D}_{1}$ & $T(t)^{[a]}$ \\
\hline FDU- 1 & -0.065 & 0.000550 & TMU-1T16 \\
\hline FDU-5 & -0.016 & -0.000247 & TMU-1T16 \\
\hline FDU- 10 & -0.041 & 0.000223 & TMU-1T16 \\
\hline FDU-13 & -0.025 & 0.000942 & TMU-15T16 \\
\hline คUU-15 & -0.261 & 0.001194 & TMII-15T16 \\
\hline FDB-2I & -0.004 & -0.000503 & $T M Q=2 \cap R 16$ \\
\hline FDB -23 & 0.044 & 0.000582 & TMD-20்̄16 \\
\hline FDB $-30^{[\mathrm{b}]}$ & -0.146 & -0.000755 & TFB-30 \\
\hline $\mathrm{FDB}-37^{[\mathrm{b}]}$ & -0.048 & 0.000329 & TFB -37 \\
\hline$F D B-42$ & -0.119 & 0.000831 & $T F B-42$ \\
\hline \multirow[t]{2}{*}{ FDV-CORE-IN } & -1.027 & -0.002958 & TFV-LP-7 \\
\hline & \multicolumn{3}{|c|}{ Test S-05-7 } \\
\hline $\begin{array}{c}\text { Detector } \\
\text { Identification } \\
\end{array}$ & $\mathrm{D}_{0}$ & $D_{1}$ & $T(t)^{[a]}$ \\
\hline FDU $=1$ & -0.064 & -0.000562 & TMU-1T16 \\
\hline FDU -5 & 0.031 & -0.000178 & $T M U=1 T 16$ \\
\hline FDU- 10 & 0.023 & 0.000250 & TMU-1T16 \\
\hline FDU- 13 & 0.195 & 0.000964 & TMU-15T16 \\
\hline FDU- 15 & -0.258 & -0.001275 & TMU-15.T.16 \\
\hline FDB-21 & -0.042 & -0.000824 & TMB $-20 B 16$ \\
\hline FDB -23 & 0.050 & 0.000616 & TMB-20B 16 \\
\hline $\mathrm{FDB}-30^{[\mathrm{b}]}$ & -0.142 & -0.000764 & TFB 30 \\
\hline FDB $-37^{[\mathrm{b}]}$ & -0.120 & 0.000263 & TFB-37 \\
\hline$F U B-42$ & -0.107 & .0 .000812 & TFB-42 \\
\hline FOV-CORE-IN & -0.883 & -0.002004 & TFV-LP-7 \\
\hline
\end{tabular}

[a] $T(t)$ is the temperature data used for temperature sensitivity correction. The symbols listed identify the thermocouples from which the data were obtained.

[b] FDB-30 and FDB-37 are mounted horizontally and during blowdown were partially filled with subcooled water which affected the temperature sensitivity. 


\section{DENSITY MEASUREMENTS}

Density calculations are based on the voltage output of the photomultiplier tubes in the gamma-attenuation densitometer assemblies. The equation used for converting voltage to density is as follows:

$$
\rho=(1 / C) \ln \{D /[F(t)+B]\}
$$

where

$$
\begin{aligned}
& \rho=\text { the density in } \mathrm{lbm} / \mathrm{ft}^{3} \\
& \mathrm{C}=\text { a constant based on the length of the gamma beam path } \\
& \mathrm{D}=\text { a theoretical voltage for zero attenuation inside the vessel } \\
& \mathrm{A}=\text { an amplification factor } \\
& \mathrm{B}=\text { a biasing factor } \\
& \mathrm{F}(\mathrm{t})=\text { the transducer voltage output. }
\end{aligned}
$$

Constants $\mathrm{A}$ and $\mathrm{B}$ are adjusted to match the final data to density values calculated from measured pressure and temperature values at the preblowdown and postdrain conditions, effectively giving the data an in-place calibration. The values of the constants for various transducers are given in Tablc $A-V$.

An amplifier which precalculates the logarithm function is used for some density measurements and hence, a simpler conversion formula is uscd:

$$
p=c_{0}+c_{1} F(t)
$$

where

$$
\begin{aligned}
& \mathrm{C}_{\mathrm{O}}=\text { offset } \\
& \mathrm{C}_{1}=\text { scaling factor } \\
& \mathrm{F}(\mathrm{t})=\text { the transducer voltage output. }
\end{aligned}
$$

The values for constants $\mathrm{C}_{0}$ and $\mathrm{C}_{1}$ are given in Table $\mathrm{A}-\mathrm{VI}$.

. Some density measurements are obtained using a two-beam gamma densitometer which operates on the same basic principle of gamma attenuation as does the single-beam gamma densitometer. Each beam originates from the same gamma source and is allowed to 
TABLE A-V

CONSTANTS FOR DENSITY MEASUREMENT

CONVERSIONS TO ENGINEERING UNITS

Test S-05-6

\begin{tabular}{|c|c|c|c|c|}
\hline $\begin{array}{c}\text { Detector } \\
\text { Identification } \\
\end{array}$ & A & B & $C$ & $D$ \\
\hline GU-IVR & 1.093 & -0.189 & 0.0095 & 3.26 \\
\hline GU- $1 \mathrm{HZ}$ & 1.071 & -0.282 & 0.0095 & 7.39 \\
\hline GU-5VR & 1.168 & -0.791 & 0.0095 & 6.12 \\
\hline GU-10VR & 1.112 & -0.542 & 0.0095 & 7.02 \\
\hline GU-13VR & 1.252 & -0.591 & 0.0095 & 2.83 \\
\hline GU-15VR & 1.147 & -0.819 & 0.0095 & 7.36 \\
\hline GU- $15 \mathrm{HZ}$ & 1.164 & -0.364 & 0.0095 & 2.83 \\
\hline$G B-21 B$ & 1.105 & $=0.572$ & 0.008 & 8.28 \\
\hline$G B-21 T$ & 1.060 & -0.174 & 0.0057 & 7.89 \\
\hline GU-23VR & 1.115 & -0.750 & ก. กก95 & 7.28 \\
\hline$G B-30 B$ & 1.011 & 0.181 & 0.008 & 8.18 \\
\hline$G B-30 T$ & 1.159 & -0.899 & 0.0057 & 7.78 \\
\hline$G B-42 V R$ & 0.931 & $0.491^{\circ}$ & 0.006 & 4.86 \\
\hline GV-COR-1.5OHZ & 1.006 & 0.040 & 0.014 & 2.44 \\
\hline GVLP-165HZ & 1.034 & -0.117 & 0.024 & 5.60 \\
\hline GU-PRIZE & 1.098 & -0.059 & 0.0095 & 0.87 \\
\hline
\end{tabular}




\begin{tabular}{lccccc}
$\begin{array}{c}\text { Detector } \\
\text { Identification }\end{array}$ & $\mathrm{A}$ & & $\mathrm{B}$ & $\mathrm{C}$ & $\mathrm{D}$ \\
\cline { 2 - 3 } GU-13VR & 1.263 & -0.632 & 0.0095 & 2.82 \\
GU-15VR & 1.089 & -0.438 & 0.0095 & 7.82 \\
GU-15HZ & 1.223 & -0.524 & 0.0095 & 2.70 \\
GB-21B & 1.107 & -0.582 & 0.008 & 8.27 \\
GB-21T & 1.061 & -0.180 & 0.0057 & 7.91 \\
GU-23VR & 1.033 & 0.023 & 0.0095 & 7.28 \\
GB-30B & 1.006 & 0.214 & 0.008 & 8.17 \\
GB-30T & 1.158 & -0.892 & 0.0057 & 7.77 \\
GB-42VR & 0.889 & 0.656 & 0.006 & 4.65 \\
GVLP-165HZ & 1.046 & -0.181 & 0.024 & 5.70 \\
GU-PRIZE & 1.082 & -0.042 & 0.0095 & 0.88 \\
& & & & \\
\hline
\end{tabular}

pass through separate portions of the piping cross-sectional flow area to obtain an average density measurement in that particular region. The geometrical relationship of the gamma beam path through the piping and geometrically related variables used for processing of data from a two-beam gamma densitometer are shown in Figure A-1.

The average density measured by each individual gamma beam is obtained using the same equation as is used for the single-beam gamma densitometers:

$$
\rho=(1 / C) \ln \{D /[A F(t)+B]\} \text {. }
$$

Values for the constants for the single-beam density measurements obtained with the two-beam gamma densitometers are presented in Table A-V along with the constants for single-beam gamma densitometers.

In the Semiscale Mod-1 system, two-beam gamma densitometers provide added information which allows the calculation of a better average density than that obtained from a single beam. A mathematical model is used for processing the two-beam data to obtain the improved average density information. The processing method used is based on a 
TABLE. A-VI

CONSTANTS FOR UENSITY MEASUREMENT

CONVERSIONS TO ENGINEERING UNITS FOR DETECTORS USING LOG AMPLIFIERS

\begin{tabular}{|c|c|c|c|c|}
\hline \multirow[b]{2}{*}{$\begin{array}{l}\text { Detector } \\
\text { Identification }\end{array}$} & \multicolumn{2}{|c|}{ Test S-05-6 } & \multicolumn{2}{|c|}{ Test S-05-7 } \\
\hline & $C_{0}$ & $c_{7}$ & $c_{0}$ & $c_{1}$ \\
\hline GV-COR- $1.50 \mathrm{HZ}$ & -- & -- & -168.8 & -36.26 \\
\hline GULP $=172 \mathrm{HZ}$ & -26 & -1.336 & -26.0 & -1.327 \\
\hline
\end{tabular}

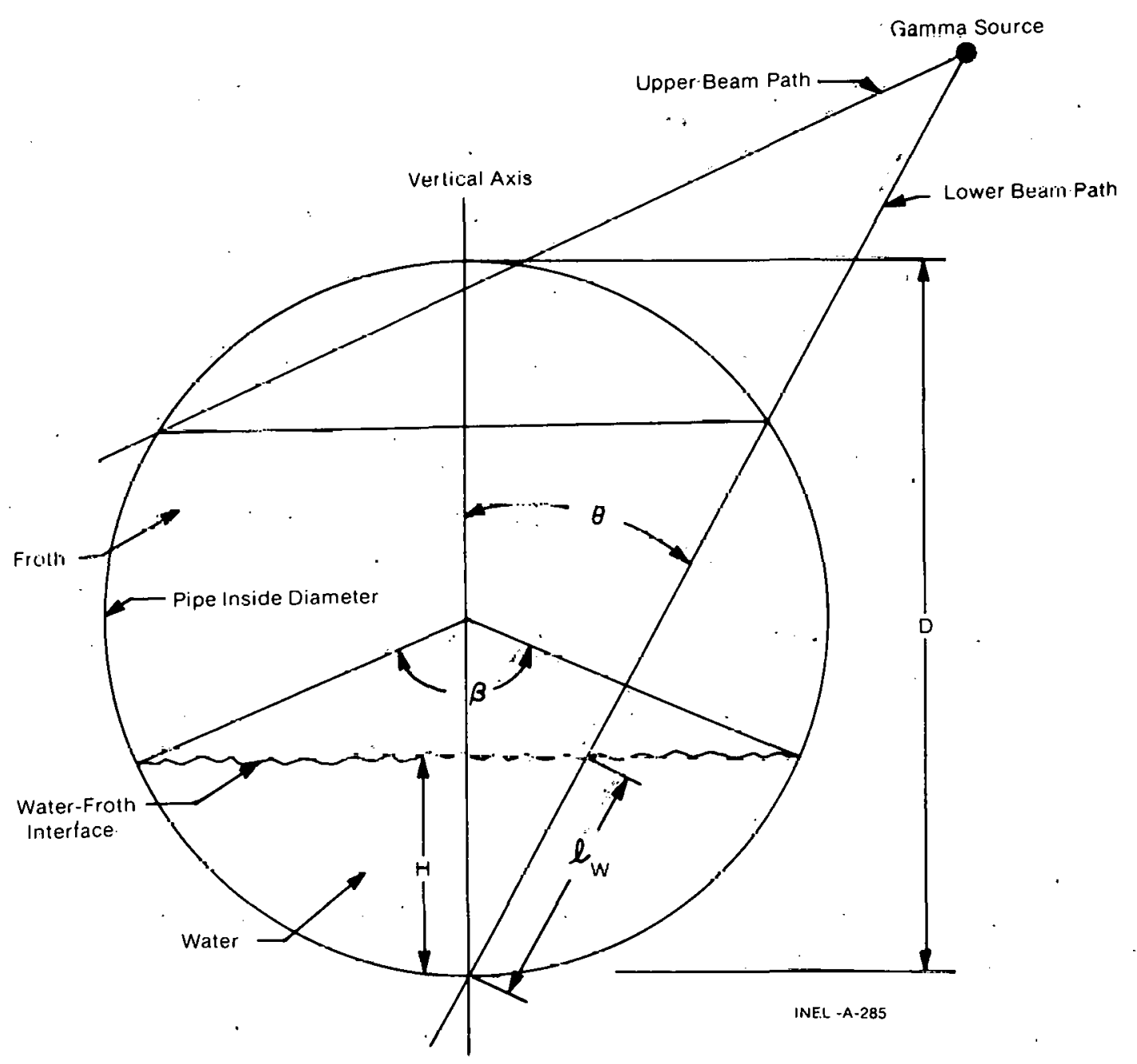

Fig. A-l Geometry used for processing of density data obtained from two-beam gamma densitometers. 
froth-water model coupled with information from the two individual gamma beams and related beam path and piping cross-sectional geometry. The resulting information is recorded and reported under the density measurement identification ending with a " $\mathrm{C}$ ", for example, GB-21C.

The use of the froth-water model for obtaining average density from a two-beam gamma densitometer is based on observations indicating that flow regimes in the Semiscale Mod-1 system can be modeled by a layer of water on the bottom of the pipe with a degree of froth on the surface. For homogeneous flow conditions such as all froth or all liquid the model remains valid. At any point in time, slug flow is also modeled. The froth-water model does not model annular or inverted annular flows very well. However, these flows are not expected to exist for significant portions of a Semiscale Mod-1 system blowdown in horizontal piping. Density gradients from the top to the bottom of the pipe may exist showing no distinct location change from water to froth. This flow is neither totally homogeneous nor stratified, but the froth-water model does provide an adequate approximation of the average density characteristic of this flow pattern.

The average density obtained by using the gamma beam geometry shown in Figure A-1 and by applying the froth-water model is given by

$$
\bar{\rho}=\alpha_{f} \rho_{1}+\left(1-\alpha_{f}\right) \rho_{w} 1 b m / f t^{3}
$$

where

$$
\begin{aligned}
& \bar{\rho}=\text { average cross-sectional density } \\
& \rho_{1}=\begin{array}{l}
\text { average density measured by the upper gamma beam (measures the froth } \\
\text { density) }
\end{array} \\
& \rho_{\mathrm{W}}=\text { density of liquid water (at local system conditions) } \\
& \alpha_{\mathrm{f}}=1+(1 / 2 \pi)(\sin \beta-\beta)=\text { froth fraction. }
\end{aligned}
$$

The angle which $\beta$ represents is shown in Figure A-1. Values for $\beta$ are obtained as follows:

$$
B=2 \cos ^{-1}(1-2 h)
$$

where

$$
h=\frac{H}{D}=\cos ^{2} \theta\left(\frac{\rho_{2}-\rho_{1}}{\rho_{w}^{-\rho_{1}}}\right)
$$

where

$$
\begin{aligned}
& \mathrm{H}=\ell_{\mathrm{W}} \cos \theta \cdot\left(\ell_{\mathrm{W}} \text { and } \theta \text { are defined in Figure } \mathrm{A}-1\right) \\
& \mathrm{D}=\text { piping inside diameter } \\
& \rho_{2}=\text { the average density measured by the lower gamma beam. }
\end{aligned}
$$


DISTRIBUTION RECORD FOR TREE-NUREG 1055

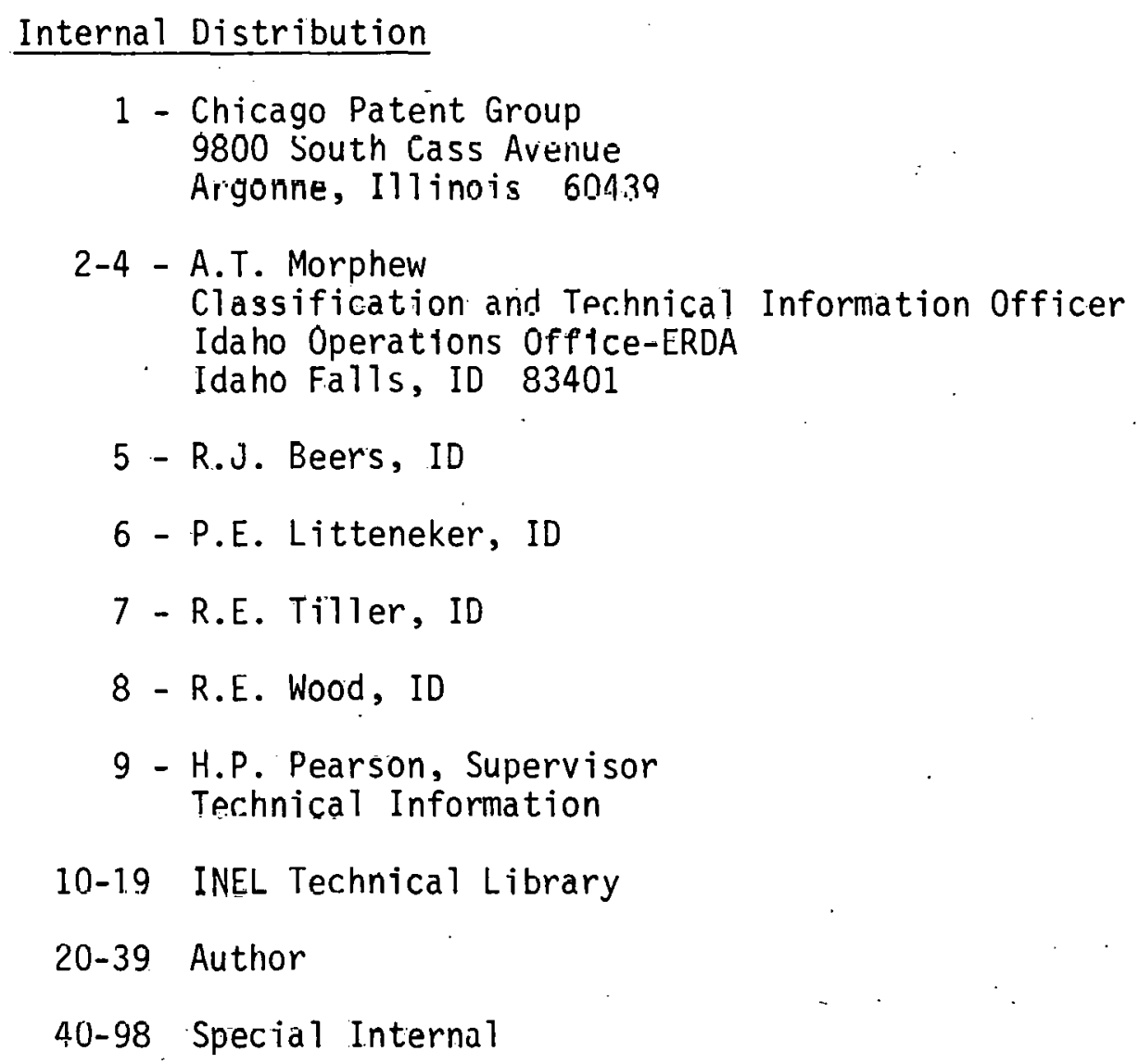

External Distribution

99-100 Sau1 Levine, Director Office of Nuclear Regulatury Research, NRC Washington, DC 20555

101-405 Distribution under NRC-2, Water Reactor Safety Research Systems Engineering 